\title{
Publieke netwerken : een theoretische en empirische analyse van het functioneren van overheidsinstellingen
}

Citation for published version (APA):

Koers, J. F. (1998). Publieke netwerken : een theoretische en empirische analyse van het functioneren van overheidsinstellingen. [Doctoral Thesis, Maastricht University]. Universiteit Maastricht. https://doi.org/10.26481/dis.19980313jk

Document status and date:

Published: 01/01/1998

DOI:

10.26481/dis.19980313jk

Document Version:

Publisher's PDF, also known as Version of record

Please check the document version of this publication:

- A submitted manuscript is the version of the article upon submission and before peer-review. There can be important differences between the submitted version and the official published version of record.

People interested in the research are advised to contact the author for the final version of the publication, or visit the DOI to the publisher's website.

- The final author version and the galley proof are versions of the publication after peer review.

- The final published version features the final layout of the paper including the volume, issue and page numbers.

Link to publication

\footnotetext{
General rights rights.

- You may freely distribute the URL identifying the publication in the public portal. please follow below link for the End User Agreement:

www.umlib.nl/taverne-license

Take down policy

If you believe that this document breaches copyright please contact us at:

repository@maastrichtuniversity.nl

providing details and we will investigate your claim.
}

Copyright and moral rights for the publications made accessible in the public portal are retained by the authors and/or other copyright owners and it is a condition of accessing publications that users recognise and abide by the legal requirements associated with these

- Users may download and print one copy of any publication from the public portal for the purpose of private study or research.

- You may not further distribute the material or use it for any profit-making activity or commercial gain

If the publication is distributed under the terms of Article $25 \mathrm{fa}$ of the Dutch Copyright Act, indicated by the "Taverne" license above, 


\section{PUBLIEKE NETWERKEN}

\section{Een theoretische en empirische analyse van het functioneren van overheidsinstellingen}

\section{PROEFSCHRIFT}

ter verkrijging vam

de graad van doctor aan de Universiteit Maastricht, op gezag van de Rector Magnificus,

Prof. dr. A.C. Nieuwenhuijzen Kruseman, volgens het besluit van het College van Decanen, in het openbaar te verdedigen

op vrijdag 13 maart 1998 om 12.00 uur

door

Jan Frank Koers 


\section{Promotor:}

Prof. dr. J.G. Backhaus

\section{Co-promotor:}

Dr. G. Meijer

Leden van de beoordelingscommissie:

Prof. dr. W.F.J. Buijink (voorzitter)

Prof. dr. P.B. Boorsma (Technische Universiteit Twente)

Dr. J.G.A. van Mierlo

CIP-gegevens Koninklijke Bibliotheek, Den Haag

Koers, Jan Frank

Publieke Netwerken: een theoretische en empirische analyse van het functioneren van overheidsinstellingen/ Jan Frank Koers

Proefschrift Universiteit Maastricht - Met lit. opg. - Met samenvarting in het engels. ISBN 90-9011405-X

Trefw.: overheidsorganisaties; Nederland, onderzoek.

Copyright 1998, J.F. Koers, Utrecht

Druk: Brouwer Uithof, Utrecht 




\section{Voorwoord}

Deze dissentatie over het functioneren van de publieke sector is geschreven op grond van mijn belangstelling voor de (economische) politiek. De overheid geeft elk jaar vele miljarden guldens uit en beïnvloedt vergaand de allocatie. Veel van de activiteiten van de publieke sector worden verricht door overheidsinstellingen. De mate waarin deze overheidsorganisaties goed functioneren beïnvloedt dan ook in hoge mate de nationale welvaart.

Teneinde meer inzicht te krijgen in het functioneren van de overheid is in dit proefschrift een eclectische benadering gevolgd. Verschillende economische theorieën en benaderingen zijn gebruikt, voor zover relevant voor het onderwerp. Voor een econoom geschoold in de openbare financiën is deze aanpak gebruikelijk. De openbare financiën bestaat immers uit verschillende deelwetenschappen zoals de micro-economie, de macro-economie en de bestuurskunde die elk licht werpen op bepaalde facetten van het functioneren van de publieke sector. Naast de eclectische werkwijze wordt aangesloten bij de traditie dat theoretisch onderzoek wordt gecombineerd met empirisch onderzoek. In het empirische deel wordt bezien in hoeverre de ontwikkelde theorie inzicht geeft in de werkelijkheid. Vanuit een positieve anallyse wordt aangegeven in hoeverre instituties goed functioneren. In de loop der tijd doen er zich binnen een netwerk allerlei veranderingen voor waarop overheidsinstellingen vaak slechts tot bepaalde hoogte kunnen inspelen. Het is aan economen om dan alternatieve instituties te analyseren en zo een belangrijke bijdrage te leveren aan het verbeteren van de welvaart. Dit is dan ook het doel van de netwerkbenadering en de gevolgde kwalitatieve benadering.

Rest mij tenslotte iedereen die aan de totstandkoming van dit proefschrift heeft bijgedragen te bedanken. In de eerste plaats dank ik de onderzochte instellingen voor de verleende medlewerking. Verder ben ik mijn promotor Prof. dr. Jürgen Backhaus zeer erkentelijk voor zijn goede en positieve begeleiding en mijn co-promotor dr. Gerrit Meijer voor zijn raad en bemoedigende woorden. Dank gaat voorts uit naar dr. Bob Jansen woor de door hem verstrekte adviezen met betrekking tot het onderzoek. Verder dank ik dr. Simon Duindam voor zijn commentaar op delen van het proefschrift, dr. Hans van Mierlo voor zijn commentaar op hoofdstuk 5, dr. Aggie Paulus voor de in de loop der jaren verstrekte adviezen en Prof. dr. Chuck Powers voor het geleverde commentaar op de summary. Verder dank ik jedereen die gedurende de laatste jaren de Brown-Bag-Groep heeft bijgewoond en voorts dank ik de studenten van mijn onderwijsgroepen voor de stimulerende gedachtenwisseling.

Verder ben ik veel dank verschuldigd aan mijn familie die mij op alle mogelijke manieren bij het schrijven van deze dissertatie heeft gesteund. Meer in het bijzonder dank ik Linda voor haar begrip tijdens het schrijven en bedank ik mijn zoontje Fabian voor zijn aanwezigheid tijdens het afronden van het proefschrift. Tenslotte will ik dit proefschrift opdragen aan de Nederlandse belastingbetaler.

Utrecht, 1 december 1997. 

Inhoudsopgave

DEEL 1. DOEL VAN HET ONDERZOEK

$1 \quad$ De probleemstelling $\ldots \ldots \ldots \ldots \ldots \ldots \ldots \ldots \ldots$

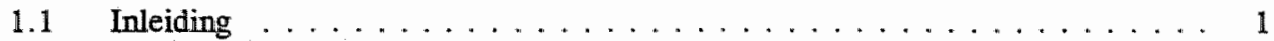

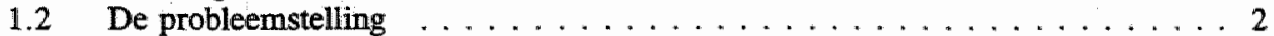

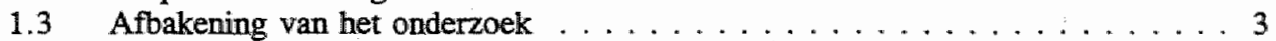

1.3.1 Hoe belangrijk zijn deze overheidsinstellingen? . . . . . . . . . 5

1.4 Economische theorie en onderzoeksmethoden . . . . . . . . . . . 9

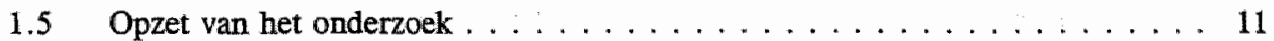

DEEL 2. DE THEORIE VAN OVERHEDSINSTELLINGEN $\ldots \ldots \ldots \ldots 15$

2 Waarom bestaan er orerheidsinstellingen $\ldots \ldots \ldots \ldots$

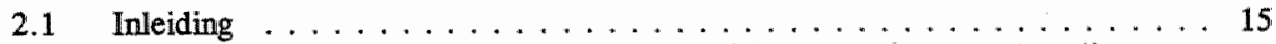

2.2 Waarom worden overheidsinstellingen opgericht en waarom worden zij

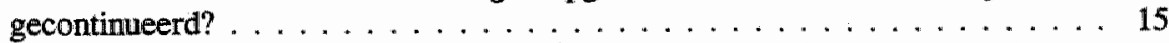

2.2.1 Kan het bestaan van overheidsinstellingen verklaard worden door de

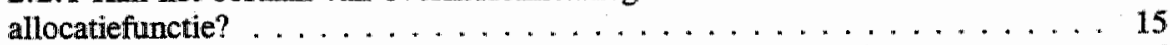

2.2.1.1 Het natuurlijke monopolie . . . . . . . . . . . . . . 16

2.2.1.2 Collectieve goederen . . . . . . . . . . . . . . . 22

2.2.1.3 Externe effecten ... . . . . . . . . . . . . . . . 28

2.2.1.4 Het onvoldoende aanwezig zijn van informatie . . . . . . 32

2.2.1.5 Belastingheffing . . . . . . . . . . . . . . . . . 33

2.2.2 Kan het bestaan van overheidsinstellingen worden verklaard door de

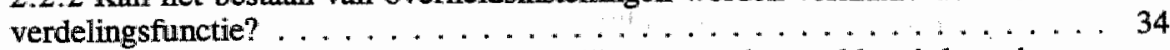

2.2.3 Kan het bestaan van overheidsinstellingen worden verklaard door de

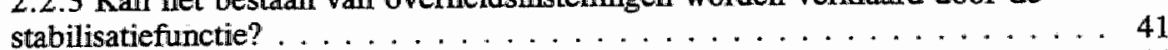

2.2.4 Interactie van functies . . . . . . . . . . . . . . . . . . . . 44

2.3 Waarom kiest de overheid ervoor gebruik te maken van een overheidsinstelling en waarom gebruikt zij geen ander

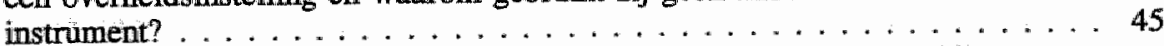

2.3.1 Omstandigheden waaronder overheidsinstellingen vooral geschikt zijn om in een goed of dienst te voorzien . . . . . . . . . . . . . . 45

2.3.2 De benadering van de comparatieve kosten ............... . . 51

2.3.3 Een afweging van kosten en baten van elk instrument . . . . . . . . . 54

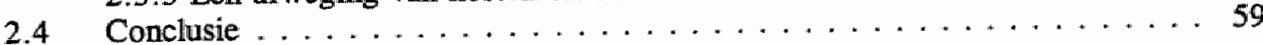

3 De theorie van overheidsinstellingen, een netwerkbenadering .......61

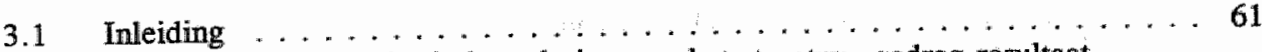

3.2 industriële organisatie-benadering van het structurur-gedrag-resultaat- $\ldots \ldots 63$
paradigma $\ldots \ldots \ldots \ldots \ldots$

3.2.1 Hoe ziet het op overheidsinstellingen toegepaste structuur-gedragresultaat-paradigma-schema eruit? 
3.2.2 In hoeverre kan het schema de "performance" van een

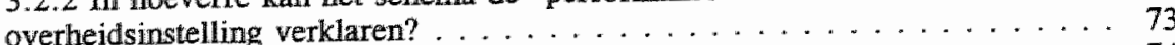

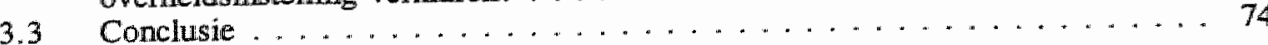

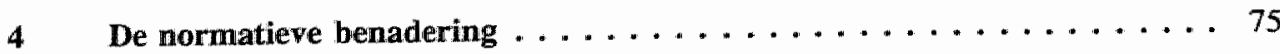

4.1 Inleiding: kan het gedrag van een overheidsinstelling worden verklaard door de welvaartseconomie?

4.2 Op welke wijzen kan de overheid het gedrag van een overheidsinstelling beinvloeden?

4.3 In hoeverre kunnen dergelijke normatieve prijssregels het gedrag van

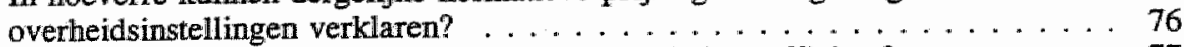

4.3.1 In hoeverre zijn overheidsinstellingen technisch efficiënt? . . . . . . . 77

4.3 .2 In hoeverre zijn overheidsinstellingen Pareto-efficiënt? . . . . . . . . 78

4.3.3 Hoe moet een overheidsinstelling dan wel worden gezien? . . . . . . . . 80

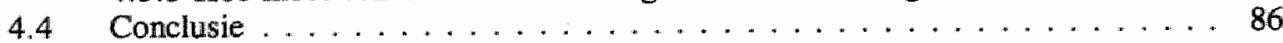

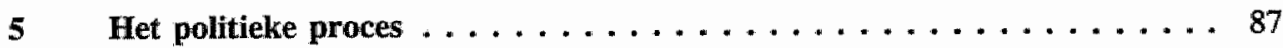

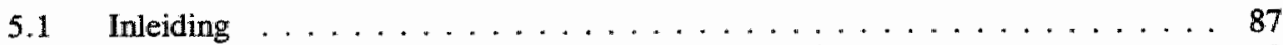

5.2 Hoe kan het politieke proces worden weergegeven? . . . . . . . . 88

5.3. In hoeverre streeft de overheid in een overlegdemocratie de doelen van de kiezer en daarmee een efficiënte uitkomst na? . . . . . . . . . . . . . 89

5.4 In hoeverre streeft de overheid in een referendumdemocratie de doelen van de kièzer en daarmee een efficiënte uitkomst na? . . . . . . . . . . . 91

5.5 In hoeverre streeft de overheid in het Nederlandse democratische systeem de doelen van de kiezer en daarmee een efficiënte uitkomst na? . . . . . . . . . 93

5.6 Hoe beinvloedt het politieke proces de "performance" van overheidsinstel-

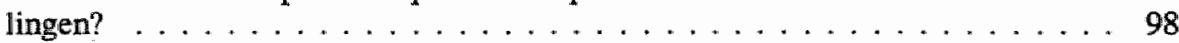

5.6 .1 Welk beleid streven de politici na? . . . . . . . . . . . . . . 98

5.6 .2 Wordt het beleid van politici uitgevoerd? . . . . . . . . . . . . 99

5.7 Conclusie . . . . . . . . . . . . . . . . . . . . . . . 100

6 De overheidsinstelling als netwerk $\ldots \ldots \ldots \ldots 10 \ldots \ldots$

6.1 Inleiding: hoe kan het gedrag van overheidsinstellingen dan wel worden verklaard? . . . . . . . . . . . . . . . . . . . . . . . 101

6.2 Hoe kan het netwerkconcept worden toegepast op overheïdsinstellingen? . . . 101

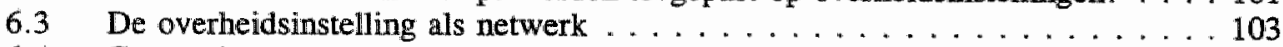

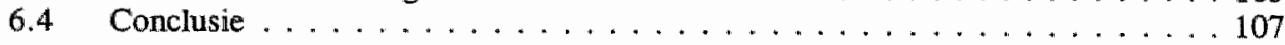

7 Welke actoren bepalen de doelen van het netwerk? . . . . . . . . . . 109

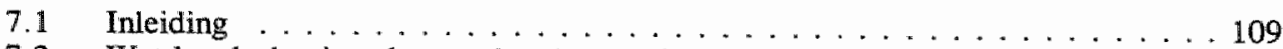

7.2 Wat houdt de eigendomsrechtenbenadering in? $\ldots \ldots \ldots \ldots \ldots$

7.3 Hoe beinvloedt de verdeling van eigendomsrechten het gedrag en de "performance" van overheidsinstellingen? . . . . . . . . . . . . . 113

7.4 Hoe verhoudt de verdeling van eigendomsrechten in een netwerk zich met het machtsvraagstuk uit de organisatietheorie? 
8 Hoe ziet het besluitvormingsproces binnen het netwerk eruit? . . . . 123

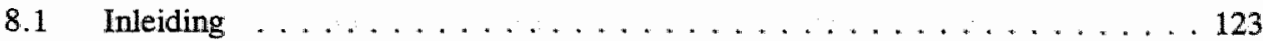

8.2 Wat moet worden verstaan onder het besluitvormingsproces? . . . . . . 123

8.3 Welke wijzen van besluitvorming kunnen worden onderscheiden binnen een netwerk? . . . . . . . . . . . . . . . . . . . . . . . . 124

8.4 Welke besluitvormingsstrategieën worden gevolgd? . . . . . . . . . . . . 127

8.5 Hoe beînvloedt het besluitvormingsproces het gedrag en de "performance" van een overheidsinstelling? . . . . . . . . . . . . 128

8.6 Conclusie . . . . . . . . . . . . . . . . . . . . . . . . . . . . . . . . . . 129

9 Wat voor relaties bestaan er tussen de actoren binnen een netwerk en wat zijn de gevolgen hiervan voor het gedrag van een overheidsinstelling? $\ldots \ldots \ldots \ldots \ldots \ldots \ldots \ldots \ldots \ldots \ldots \ldots \ldots$

9.1 Inleiding: relaties binnen het netwerk $\ldots \ldots \ldots \ldots \ldots \ldots \ldots 131$

9.2 Wat wordt verstaan onder een principaal-agent-relatie? . . . . . . . . 132

9.3 Hoe beïnvloeden de betrekkingen tussen actoren het gedrag en de "performance" van overheidsinstellingen? . . . . . . . . . . . 136

9.4 Welke doelen worden door de principalen nagestreefd? . . . . . . . . . 138

9.5 De culturur binnen het netwerk . . . . . . . . . . . . . . . . 140

9.6 Conclusie . . . . . . . . . . . . . . . . . . 141

10 In hoeverre kan het bureaucratiemodel van Niskanen worden gebruikt om de relaties tussen de actoren binnen het netwerk te verklaren? . . . . . . . . . . . . . . . . . 143

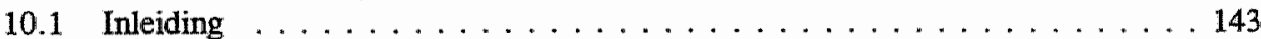

10.2 Het bureaucratiemodel van Niskanen . . . . . . . . . . . . . . . 144

10.3 In hoeverre kan het bureaucratiemodel van Niskanen worden gebruikt om de relaties tussen de actoren binnen het netwerk te verklaren? . . . . . . . 148

10.4 Kan speltheorie worden gebruikt om de relaties binnen het netwerk te onderzoeken? . . . . . . . . . . . . . . . . . . . . 157

11 Hoe beïnvloeden de transacties tussen de actoren het gedrag en de "performance" van een netwerk? . . . . . . . . . . . . 161

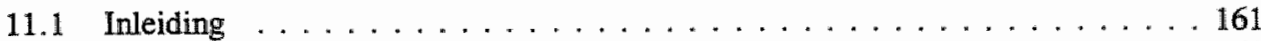

11.2 Wat wordt verstaan onder de transactiekostenbenadering? . . . . . . . . 162

11.3 Hoe verhoudt de transactiekostenbenadering zich tot de netwerkbenadering? . 171

11.4 In hoeverre kan de transactiekostenbenadering worden gebruikt voor het verklaren van het gedrag van het netwerk? . . . . . . . . . 177

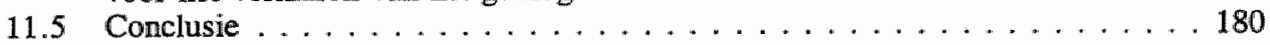


12.1 Inleiding . . . . . . . . . . . . . . . . . 183

12.2 In hoeverre zijn de doelen van het opstellen van een politiek-economische theorie, zoals aangegeven in paragraaf 3.1 , bereikt?

12.3 Hoe verhoudt de ontwikkelde theorie zich met recente voorstellen om de publieke sector te reorganiseren?

DEEL 3. "PERFORMANCE ANALYSE" EN CASE-STUDIES

13 Doel-onafhankelijke en doel-afhankelijke benaderingen $\ldots \ldots \ldots \ldots 195$

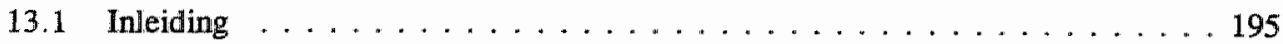

13.2 Kan de "performance" worden bepaald met de "indicatoren"-methode? . . . . 195

13.3 In hoeverre kan de "performance" van een overheidsinstelling worden verklaard door de "performance approach"? . . . . . . . . . . . . . . . . . 197

13.3.1 Is de kwantitatieve benadering goed genoeg? . . . . . . . . . . 200

13.4 In hoeverre kan de doelbenadering worden gebruikt? . . . . . . . . 200

13.5 Evaluatie en de beleidsnetwerkbenadering . . . . . . . . . 201

13.6 Wat wordt verstaan onder de kwalitatieve benadering? . . . . . . . . 202

13.7 In hoeverre biedt de kwalitatieve benadering een antwoord op de tegen de doell-benadering gerezen bezwaren? . . . . . . . . . . . 204

13.8 In hoeverre zijn de bezwaren die zijn gerezen tegen de kwalitatieve benadering van belang? . . . . . . . . . . . . 205

13.9 In hoeverre is het wenselijk de door Jansen voorgestelde

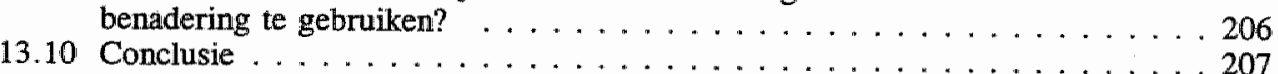

14 Onderzoeksprotocol . . . . . . . . . . . . . . . . . . 209

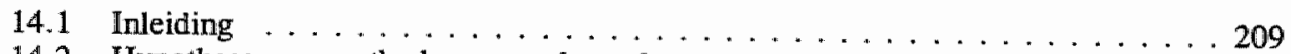

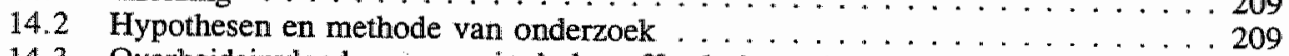

14.3 Overheidsinvloed: waarom is de betreffende instelling een overheidsinstelling? . . . . . . . . . . . . . . . . . . 210

14.4 Structuur-analyse: welke doelen kunnen worden bereikt? $\ldots \ldots \ldots \ldots \ldots 211$

14.5 Hoe kan de ontsluierde "performance" van een overheidsinstelling worden

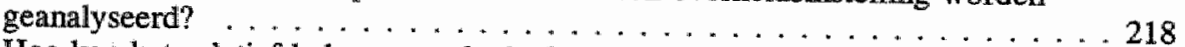

14.6 Hoe kan het relatief belang van de doelen worden vastgesteld? . . . . . . 222

14.7 Hoe kan de "performance" van een overheidsinstelling worden samengevat?". 225

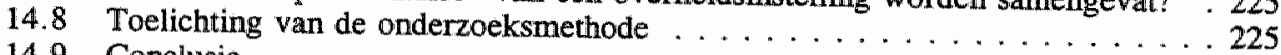

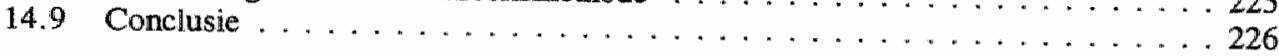

Sectorstudies . . . . . . . . . . . . . . . . . . . . . . 229

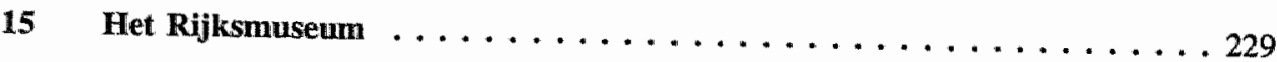

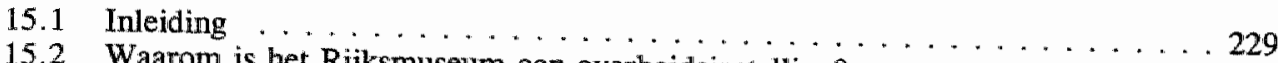

15.2 Waarom is het Rijksmuseum een overheidsinstelling? . . . . . . . . . . . 2229

15.3 De organisatie van het Rijksmuseum _. . . . . . . . . . . . . . . . 2229

15.4 Structuur-analyse; welke doelen kunnen worden bereikt? $\ldots \ldots \ldots \ldots \ldots 236$ 
15.5 Het recht op vruchtgebruik (usus fructus)

15.6 Wie had het recht om de organisatie van het Rijksmuseum te wijzigen, te verkopen of te liquideren?

15.7 Welke doelen kunnen wit de verdeling van eigendomsrechten worden afgeleid?

15.8 Het analyseren van de ontsluierde "performance"

van het Rijksmuseum . . . . . . . . . . . . . . . . . . . . 259

15.9 Het bepalen van de reeks van doelen $\ldots \ldots \ldots \ldots \ldots . \ldots \ldots$

15.10 In hoeverre zijn deze doelen verwezenlijkt en is deze verwezenlijking

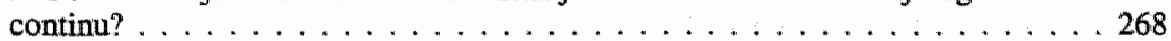

15.11 Wat zijn de kosten van de doelen van het Rijksmuseum? . . . . . . . 276

15.12 Wat is het relatieve belang van de doelen? . . . . . . . . . . . 280

15.13 Vaststellen van de "performance" in termen van baten en kosten . . . . . . . 291

15.14 Conclusie . . . . . . . . . . . . . . . . . . . . . . . 296

16 Het elektriciteitsbedrijf N.V. MEGA-Limburg (N.V. Provinciale

Limburgse Elektriciteitsmaatschappij) . . . . . . . . . . . . . 297

16.1 Inleiding . . . . . . . . . . . . . . . . . . . . . 297

16.2 De ontwikkeling van N.V. SVM naar N.V. PLEM . . . . . . . . . 297

16.3 De organisatie van de elektriciteitssector in Nederland en van de PLEM . . . . 297

16.4 Structuur-analyse: welke doelen kunnen worden bereikt? . . . . . . . . . . 306

16.5 Het recht op vruchtgebruik (usus fructus) . . . . . . . . . . . . . . . 320

16.6 Wie had het recht om de vorm of inhoud van een zaak te veranderen of te verhandelen (abusus)? . . . . . . . . . . . . . . . . . 325

16.7 Welke doelen kunnen uit de verdeling van eigendomsrechten worden afgeleid? . . . . . . . . . . . . . . . . . . . . . . . . 327

16.8 Het analyseren van de ontsluierde "performance" van de NV PLEM . . . . 331

16.9 In hoeverre zijn deze doelen verwezenlijkt en is deze

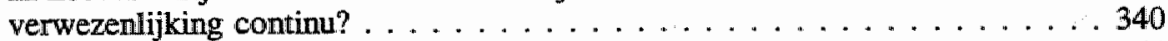

16.10 Wat zijn de kosten van de doelen van de NV PLEM? . . . . . . . . . . 364

16.11 Wat is het relatieve belang van de doelen? . . . . . . . . . . . . 367

16.12 Het vaststellen van de "performance" in termen van baten en kosten . . . . 375

16.13 Conclusie . . . . . . . . . . . . . . . . . . . . 386

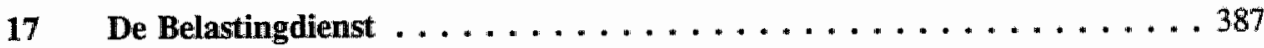

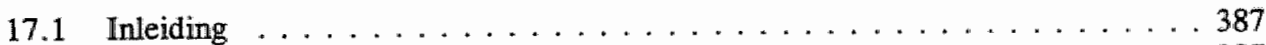

17.2 Waarom is de Belastingdienst een overheidsinstelling? . . . . . . . . . . 387

17.3 De Belastingdienst als netwerk . . . . . . . . . . . . . . . . . . . . . . . . . . . . . . . . . . . . .

17.4 De interne organisatie van de Belastingdienst . . . . . . . . . . . . . 392

17.5 Structuur-analyse: welke doelen kunnen worden bereikt? . . . . . . . . . 396

17.6 Het recht op vruchtgebruik, wie maakt aanspraak op de winst? . . . . . . . 410

17.7 Wie heeft het recht de organisatie van de Rijksbelastingdienst te wijzigen, te verkopen of te liquideren? . . . . . . . . . . . . . . . . 410

17.8 Wellke doelen kunnen uit de verdelling van eigendomsrechten worden afgeleid?

17.9 Het analyseren van de ontsluierde "performance" van de Rijksbelastingdienst . . . . . . . . . . . . . . . . . . . . . 413

17.10 In hoeverre zijn deze doelen verwezenlijkt en is deze verwezenlijking 


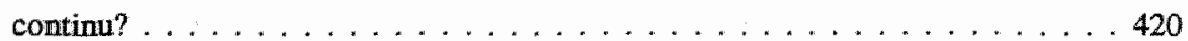

17.11 Wat zijn de kosten van de doelen van de Rijksbelastingdienst? . . . . . . . . 454

17.12 Wat is het relatieve belang van de doelen? . . . . . . . . . . . . 463

17.13 Het vaststellen van de "performance" in termen van baten en

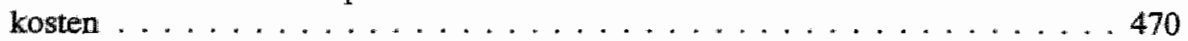

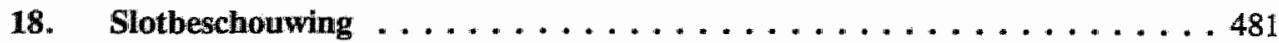

18.1 Samenvatting van het onderzoek .................... 481

18.2 Welke conclusies kunnen uit het onderzoek worden getrokken? . . . . . . . 484

18.3 Een toepassing: privatisering en privatiseringsschema's . . . . . . . . . 489

Appendix 1. De normatieve benadering . . . . . . . . . . . . . . . . . 497

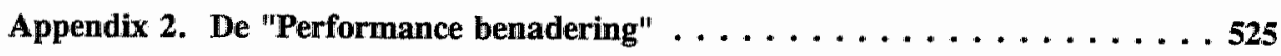

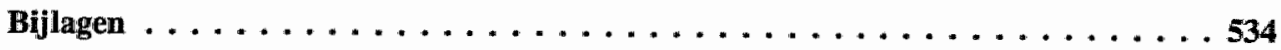

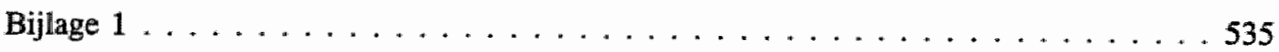

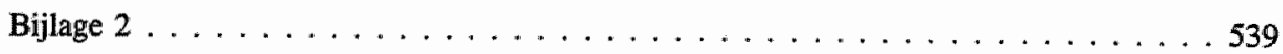

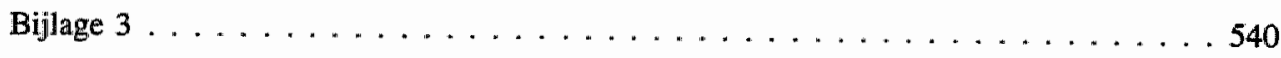

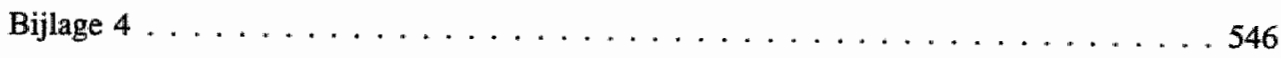

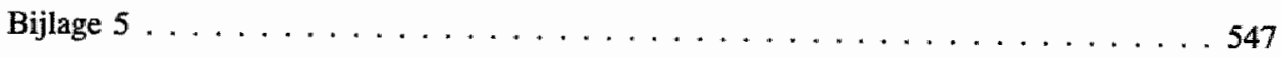

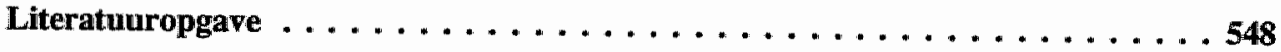

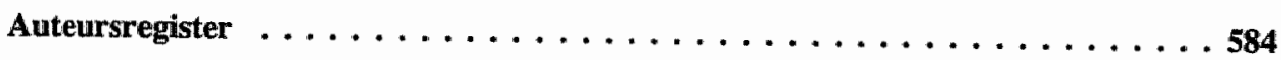

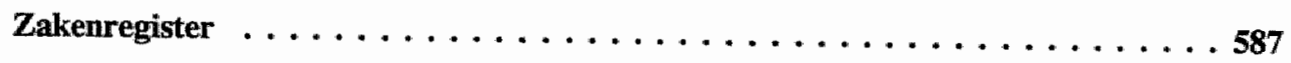

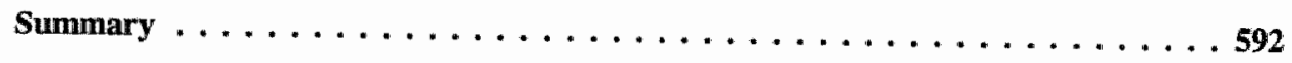

Curriculum Vitae $\ldots \ldots \ldots \ldots \ldots \ldots$ 
: 
. 


\section{DEEL 1. DOEL VAN HET ONDERZOEK}

\section{Hoofdstuk 1. De probleemstelling}

\subsection{Inleiding}

Rond de eeuwwisseling vormden overheidsorganisaties zoals overheidsbedrijven, met name in Midden-Europa, een belangrijke inkomstenbron voor de overheid. Hoewel de bijdragen van dergelijke overheidsbedrijven aan de begroting sindsdien sterk zijn afgenomen en op dit moment in West-Europa relatief onbelangrijk zijn, hebben andere overheidsinstellingen juist een grote vlucht genomen. Hierbij kan er op worden gewezen dat zij werk verschaffen aan een aanzienlijk deel van de beroepsbevolking. Belangrijk is verder dat door overheidsinstellingen in de yorm van "off-budget"-activiteiten allerlei bijkomende doelen worden nagestreefd. De mate waarin overheidsinstellingen dergelijke bijkomende doelen nastreven varieert aanzienlijk en lijkt slechts beperkt te worden door de creativiteit van het management en van de politici die de activiteiten van de instellingen sponsoren.

De mate waarin dit mogelijk is en de mate waarin dit feitelijk gebeurt kan slechts te weten worden gekomen door het analyseren van het gedrag en meer in het bijzonder van de "performance" van deze overheidsinstellingen. Hierbij dient beseft te worden dat er geen algemeen aanvaarde economische theorie van hun gedrag bestaat. Eén reden hiervoor is dat de openbare financiën, voor zover zij gericht is op het beleid, vooral gebaseerd is op een macro-economische in plaats van op een micro-economische analyse. Verder heeft de micro-economische theorie van het bedrijf zich vooral gericht op het modelleren van het gedrag van particuliere ondernemingen. In de theorie van de openbare financiën is de laatste decennia relatief weinig aandacht besteed aan overheidsbedrijven, mede omdat hun belangrijkheid is afgenomen in vergelijking met andere inkomstenbronmen van de overheid, zoals belastingen. Wel is in de openbare financiën aandacht geschonken aan de belangrijkste organisatievorm in de publieke sector, namelijk het bureau. $^{1}$

Het is opvallend dat overheidsbedrijven/instellingen steeds meer worden gezien als overbodig, hetgeen de roep om privatisering door economen, vooral ook geschoold in de neo-klassieke traditie, verklaart. Hierbij wordt echter dikwijls voorbij gegaan aan wezenlijke verschillen tussen publieke en particuliere instellingen. Het verschil in gedrag is namelijk niet automatisch een indicatie voor een slechtere "performance" maar weerspiegelt eerder de verschillende doelen van hun eigenaren en de verschillen in organisatiestructuur. Particuliere ondernemingen vormen geen geschikte vergelijkingsmaatstaf voor overheidsinstellingen aangezien de eigenaren van private ondernemingen veelal ander gedrag van het management eisen dan de tijdelijke eigenaren van overheidsinstellingen, te weten de politici die controle uitoefenen op het management van publieke ondernemingen. Wat deze eigenaren nu werkelijk verwachten en hoe zij met het oog hierop de overheidsbedrijven controleren is nog weinig duidelijk.

Er zijn een aantal redenen waarom gekozen is voor dit onderwerp. Zoals opgemerkt is het onderwerp maatschappelijk van groot belang. Het beter begrijpen van het gedrag en de

${ }^{1}$ Vergelijk bijvoorbeeld: Niskanen $(1971$, pp. 14-15). 
"performance" van overheidsinstellingen en vooral het in staal zijn op een adequate wijze de "performance" van een specifieke overheidsinstelling te bepalen, is niet alleen noodzakelijk voor het verklaren van het resultaat van overheidsinstellingen (in de zin van "performance"), maar is ook noodzakelijk teneinde te kunnen verklaren in hoeverre de overheid en de overheidsinstellingen al dan niet te groot zijn. Miller en Moe merken. bijvoorbeeld op: "Some recent theories have blamed the growth of government on budgetmaximizing bureaucrats who are assumedly capable of imposing their most preferred budget-output combination on legislatures, subject to cost and demand constraints. However, theoretical examination of the range of bargaining outcomes that might occur between bureau and legislature shows that budget-maximizing behavior does not necessarily lead to super-optimal levels of production, nor do the suggested reforms of competition and privatization necessarily improve the situation". 2

Om zinvol een uitspraak te kunnen doen over de wenselijkheid van privatisering, het introduceren van meer mededinging in de publieke sector, het wijzigen van de eigendomsrechtenstructuur en het weranderen van de bestaande prikkels binnen de publieke sector en overheidsinstellingen is meer onderzoek vereist.

\subsection{De probleemstelling}

Gezien het grote beslag dat de collectieve sector legt op het nationale inkomen is het van groot belang te weten in hoeverre deze middelen efficiënt worden besteed. Onderzoek naar de "performance" is een belangrijk hulpmiddel om na te gaan of dit het geval is. Dit geldt zowel voor het bedrijfsleven als voor de collectieve sector. In de collectieve sector wordt de "performance"-meting bemoeilijkt door het veelal afwezig zijn van directe prikkels voor een efficiënte besteding van middelen. Dit komt onder andere doordat publieke instellingen vaak een monopolie hebben, collectieve goederen aanbieden en niet failliet gaan.

Het doel van deze dissertatie is dan ook enerzijds om te komen tot een theoretisch beter onderbouwde analyse van de "performance" van overheidsinstellingen en anderzijds om met behulp van deze theoretische kennis de "performance" van een aantal overheidsinstellingen in de werkelijkheid te onderzoeken. Het onderzoek is dienovereenkomstig gebaseerd op een tweetal centrale vragen, te weten:

1. Hoe kan de "performance" van een overheidsinstelling op theoretische wijze worden verklaard?

2. Hoe kan de "performance" van een specifieke overheidsinstelling worden bepaald?

Het onderzoek bestaat dan ook uit een theoretisch en een empirisch deel. Het gaat met andere woorden om de vragen: wat doen overheidsinstellingen nu werkelijk, hoe doen zij dat en hoe goed doen zij dat. ${ }^{3}$ Door middel van empirisch onderzoek wordt een meer algemene theorie over het functioneren van overheidsorganisaties afgeleid. Vervolgens wordt de ontwikkelde methodiek door middel van case studie-onderzoek op een drietal bedrijven toegepast.

\footnotetext{
${ }^{2}$ Miller en Moe (1983, p. 297).

${ }^{3}$ Backhaus (1994, p. 285).
} 


\subsection{Afbakening van het onderzoek}

Dit onderzoek is gericht op de "performance"-analyse van overheidsinstellingen. Wat nu precies onder "performance" verstaan moet worden kan worden geillustreerd met de werking van het productieproces. Het productieproces kan als volgt worden ontleed:

ingerette middelen
inputs $\rightarrow\left[\begin{array}{l}\text { activiteiten } \\ \text { throughputs }\end{array} \rightarrow\right.$ prestaties $\begin{array}{l}\text { prouts } \\ \text { outputs }\end{array} \rightarrow \begin{array}{l}\text { effecten } \\ \text { outcomes }\end{array}$

De verschillende onderdelen van het productieproces kumnen gemeten worden met behulp van respectievelijk middelenindicatoren, procesindicatoren, prestatie-indicatoren en effectindicatoren. ${ }^{4}$ Het is in het kader van dit onderzoek belangrijk dat ingezien wordt dat de "performance" niet gelijk gesteld mag worden aan de in het productieproces gereedgekomen goederen en diensten, de prestatie. "Performance" is een veel ruimer begrip. Hieronder wordt verstaan: de in het productieproces verrichte activiteiten, de in het productieproces gereedgekomen produkten en de effecten. Met andere woorden hoe doen overheidsinstellingen het? De overheid beoogt met het in het leven roepen van een overheidsbedrijf aan de ene kant bepaalde prestaties te realiseren en aan de andere kant bepaalde effecten te bereiken. Vooral deze beoogde effecten zijn vaak een reden voor de overheid om bepaalde overheidsinstellingen op te richten. Daarnaast zijn de in het productieproces verrichte activiteiten van belang voor het bepalen van de "performance". "Performance" en efficiëntie hangen in die zin naww met elkaar samen." Een confrontatie van de ingezette middelen met de geleverde prestaties geeft een beeld van de doelmatigheid van het productieproces. Vaak wordt gesteld dat overheidsinstellingen niet efficiënt werken. Het is in dit verband van belang een onderscheid te maken tussen technische (Xinefficiëntie), allocatieve (A-inefficiëntie) en kwaliteitsinefficiëntie ( $Q$-inefficiëntie) ${ }^{6}$ In het geval van allocatieve inefficiëntie worden inputs in verkeerde verhoudingen gecombineerd, gegeven de omvang van de productie, de prijzen van de imputs en de stand van de techniek. Van technische inefficiëntie is sprake indien met de gegeven inputs een lagere productie wordt gehaald dan op zich mogelijk zou zijn. ${ }^{7}$ Dit impliceert dat niet op het minimale kostemniveau wordt geopereerd. Een andere benaming voor technische inefficientie is X-inefficiëntie. In het geval van volkomen mededinging impliceert Pareto-efficiëntie technische efficiëntie. Van kwaliteitsinefficiëntie wordt gesproken indien de kwalitatieve eigenschappen van de goederen de preferenties van de consumenten niet goed weerspiegelen. Indien nu in dit onderzoek gesproken wordt over "performance" gaat het derhalve niet alleen om technische maar ook om Pareto-efficièntie. Aangezien de factor tijd in dit onderzoek niet van groot belang is wordt hier voomamelijk gesproken over statische efficiëntie. Hierbij wordt uitgegaan van de benadering van de Virginia School.

\footnotetext{
4 Baeten (1993, p. 73).

${ }^{5}$ Goudriaan et al. (1986, pp. 24-27).

${ }^{6}$ Huther (1991, pp. 260 ev.)

${ }^{7}$ De Groot en Goudriaan (1991, pp. 26 ev).
} 
Deze stelt dat gegeven de beperkingen die bestaan er geen betere oplossing mogelijk is. ${ }^{8}$ Hierop wordt in hoofdstuk 4 en appendix 1 verder ingegaan. Dit uitgangspunt ligt eveneens ten grondslag aan de in dit onderzoek toegepaste kwalitatieve benadering. De reden dat deze benadering wordt gevolgd is dat het hierdoor mogelijk is een "revealed preference" analyse te gebruiken voor de analyse van de "performance" van overheidsinstellingen. Getracht wordt de bezwaren verbonden aan het opstellen van welvaartsfuncties van overheidsbedrijyen door aggregatie van individuele nutsfuncties (is nut meetbaar) te omzeilen. Een soortgelijke benadering ten aanzien van efficiëntie wordt gevolgd door Hayek. Hij stelt dat indien een institutie blijft voortbestaan niet gesteld kan worden dat deze efficienter is dan een andere gelijksoortige institutie, omdat elke institutie functioneert in een andere context en onder andere eigendomsverhoudingen. ${ }^{9}$

Het is belangrijk op te merken dat het in dit proefschrift niet alleen gaat om de efficiëntie maar ook om de doeltreffendheid van overheidsinstellingen. Een confrontatie van ingezette middelen met de effecten op de gebruiker geeft cen beeld van de doeltreffendheid wan het productieproces. Een analytisch onderscheid tussen doelmatigheid en doeltreffendheid is van belang omdat een voorziening op zichzelf zeer doelmatig kan werken zonder daarbij doeltreffend te zijn. Een voorziening produceert dan op doelmatige wijze zinloze activiteiten. De motieven van de overheid om bepaalde voorzieningen te financieren en middels overheidsinstellingen te verrichten zijn voor een groot deel gericht op de door de overheid beoogde effecten (bijvoorbeeld een goede gezondheidstoestand van de bevolking, veiligheid etc.). Het gaat dus niet alleen om doelmatigheid maar ook om de doeltreffendheid van de betrokken voorziening. Het gaat dan bijvoorbeeld niet alleen om de hoeveelheid gedistribueerde elektriciteit maar ook om de invloed op de werkgelegenheid en de economische ontwikkeling van de regio etc.. Dit is ook de reden waarom in dit onderzoek gebruik wordt gemaakt van een "doel-afhankelijke-benadering", de kwalitatieve benadering, waarbij de doelen van groot belang zijn. Voorts is het voor deze benadering van groot belang te weten in hoeverre de doelen zijn gerealiseerd en wat de kosten daarvan zijn.

Zoals aangegeven richt het onderzoek zich op overheidsinstellingen. Daarnaast werd in het voorgaande ook gesproken over overheidsbedrijven en bureaus. Het verband tussen deze drie categorieën is als volgt. Ten aanzien van overheidsbedrijven kan een juridische en een economische benadering worden onderscheiden. Juridisch gezien kan onderscheid worden gemaakt tussen directe en indirecte overheidsbedrijven. ${ }^{10}$ Directe overheidsbedrijven zijn bedrijven die rechtstreeks door een openbaar lichaam en veelal in de vorm van een min of meer autonoom administratief onderdeel daarvan, worden uitgeoefend. Deze categorie vormen de staatsbedrijven. Indirecte overheidsbedrijven zijn N.V.'s en andere rechtspersonen waarvan uitsluitend openbare lichamen aandeelhouder, deelgenoten of leden zijn. Het betreft hier dus $100 \%$ deelnemingen." Voor dit onderzoek is deze juridische definitie niet zozeer van belang omdat het ons niet gaat om de formele juridische verschillen tussen overheidsbedrijven en particuliere ondernemingen, maar om de

${ }^{8}$ Crew en Rowley (1988, p. 54)

9 Zie ook: Hayek (1990, Hoofdstuk 2).

to Handelingen 2, Bijl. 1954/55 en 1955/56, 3816, Wet van 28 juni 1956 houdende belastingheffing van overheidsbedrijuen.

11 N.J., 1982, nr. 266 met noot Ten Kate. 
feitelijke economische verschillen. In dit onderzoek wordt daarom een economisch criterium gevolgd waarbij van een overheidsbedrijf kan worden gesproken indien voldaan wordt aan het Popitz-criterium. ${ }^{12}$ Dit criterium houdt in dat de door een overheidsbedrijf voortgebrachte goederen en diensten ook door een particuliere onderneming kan worden voortgebracht. Overheidsbedrijven worden in dit proefschrift dan ook gedefinieerd als: instellingen die goederen en diensten voortbrengen die ook door particuliere bedrijven kunnen worden voortgebracht en waarin de overheid dominante invloed heeft. Uitgaande van deze omschrijving kan een belangrijke conclusie worden getrokken. Publieke ondernemingen verschillen in die zin van particuliere ondernemingen dat het beschikkingsrecht van korte duur is. ${ }^{13}$ Afgezien van dit verschil hoeven publieke en particuliere bedrijven niet van elkaar te verschillen. Overheidsbedrijven kumnen dan ook groot of klein zijn, arbeids- of kapitaalintensief, multinationaal of meer regionaal en zij kunnen voorkomen in vrijwel alle handels- en industriesectoren. ${ }^{14}$ Deze verscheidenheid blijkt ook uit de verschillende juridische vormen die overheidsbedrijven kunnen aannemen. Zij verschijnen in grote variatie zowel in het publiekrecht als in het privaatrecht. Het Nederlandse overheidsbedrijf kan onder andere de vorm aannemen van een staatsbedrij $\mathrm{f}^{15}$, een N.V., een stichting of een zelfstandig bestuursorgaan. Het is in dit verband belangrijk te onderkennen dat ook bureaus, zoals gedefinieerd door Niskanen, onder deze definitie vallen. ${ }^{16}$ De overheidsinstellingen zoals die in dit onderzoek aan de orde komen bestrijken dan ook een breed gebied, varièrend van overheidsinstellingen die vrijwel alleen publieke taken uitvoeren en die vrijwel volledig bekostigd worden met subsidies verstrekt door de overheid en anderzijds overheidsinstellingen die een privaatrechtelijk karakter hebben en hun inkomen vrijwel volledig genereren via de markt. Om verwarring te voorkomen zal in het vervolg dan ook gesproken worden van overheidsinstellingen, waarmee dus zowel (directe en indirecte) overheidsbedrijven als bureaus worden bedoeld.

\subsubsection{Hoe belangrijk zijn deze overheidsinstellingen?}

In paragraaf 1.1 is reeds gewezen op het grote economische belang van de in dit proefschrift onderzochte overheidsinstellingen. Tal van uiteenlopende overheidsorganisaties voldoen aan de vermelde omschrijving van een overheidsinstelling. Daarbij gaat het globaal om een vijftal categorieën.

De eerste categorie wordt gevormd door de zogenaamde publiekgeorienteerde ondernemingen. Bij deze ondernemingen is de bedrijfsmatige activiteit onderdeel van een openbaar lichaam. Hierbij kan gedacht worden aan een afdeling van een Ministerie, een agentschap of aan een tak van dienst bij een gemeente. Voorbeelden van dergelijke bedrijven zijn de Rijksbelastingdienst en het Rijksmuseum (gedurende de periode 19701990). Verschillende overheidsinstellingen waren oorspronkelijk departementale diensten

\footnotetext{
12 Popitz (1932, p. 49).

13 Rees $(1984$, pp. 368 e.w.).

14. Vergelijk ook: Savas $(1987$, P. 3-4),

${ }^{15}$ Tot de $6^{e}$ wijziging van de Comptabiliteitswet.
}

16 Niskanen omschrijft een burean als een non-profit-organisatie die ten minste voor een dieel door de overheid gefinamcierd wordt, bijwoorbeeld door een periodieke subsidie, vergelijk: Niskanen, 1971, p. 15 . 
en zijn later omgevormd tot staatsbedrijven of overheidsdeelnemingen. Een voorbeeld hiervan is de PTT die historisch gegroeid is uit een dergelijke departementale dienst. Er is weinig onderzoek verricht naar het totale economische belang van dit soort orgamisaties. Met behulp van de Staatsalmanak kan hiervan wel een indruk worden gekregen. In Bijlage 1 is een overzicht gegeven van de hierin genoemde diensten. ${ }^{17}$ Ook tal van andere onderdelen van de diverse Ministeries kunnen echter worden opgevat als overheidsinstellingen, zoals gedefinieerd in dit onderzoek. Hierbij kan gedacht worden aan de Departementale Accountantsdiensten en bijvoorbeeld aan de Dienst Gebouwen Buitenland (DGB) en de Facultaire Dienst Telecommunicatie (FDT) op het Ministerie van Buitenlandse Zaken. Verder kunnen ook tall van inspecties worden opgevat als overheidsinstellingen. De overheid heeft overwegende invloed en de betreffende activiteiten zouden ook door particuliere bedrjyen verricht kunnen worden. Benadinukt moet worden dat naast de departementale diensten ook de wele gemeentelijke en provinciale diensten van belang zijn. Zoals aangegeven in bijlage 1 zijn er vanaf 1994 een aantal agentschappen ingesteld. Omdat een agentschap onderdeel is van een ministerie gelden voor deze orgamisaties geen aparte begrotingswetten.

Een tweede categorie werd tot de $6^{e}$ wijziging van de Comptabiliteitswet gevormd door de staatsbedrijven, zoals gedefinieerd in de Bedrijvenwet. ${ }^{19}$ Deze bedrijven waren ook onderdeel van het openbaar lichaam maar waren administratief afgescheiden ten behoeve van een bedrijfseconomisch beheer. Voor deze bedrijven gold een aparte begrotingswet. ${ }^{20}$ Eind 1984 bedroeg de intrinsieke waarde van de Nederlandse staatsbedrijven nog F. 32,129 miljard. Hiervan kwam ruim 28 miljard voor rekening van de PTT. ${ }^{21}$ In de jaren ' 80 en ' 90 zijjn de bestaande staatsbedrijven zoals de Rijkspostspaarbank, de Staatsdrukkerij en uitgeverijbedrijf en het Staatsvissershavenbedrijf omgevormd tot particuliere rechtspersonen, waarbij de overheid door middel van haar aandelenkapitaal overwegende invloed behield.

In de derde plaats bezit de overheid eigendomsrechten in een groot aantal particuliere rechtspersonen. 22 Deze particuliere rechtspersoon kan verschillen al naargelang het type overheid en de aard van de zelfstandigheid. Voor instellingen zoals musea en ziekenhuilzen wordt vaak de stichtingsvorm gebruikt. Tezamen met de gemeentelijke energiebedrijven zijn dit voorbeelden van publieke goederen die doorgaans door lagere overheden (gemeente/prowincie) worden beheerd. Een ander voorbeeld van stichtingen waarin de overheid invloed uitoefent zijn de rijksmusea na 1995. De publieke onderneming kan ook in de vorm zijn gegoten van een NV of een BV waarvan de aandelen in handen zijn van de staat (directe staatsdeelnemingen). Of de overheid inderdaad dominante invloed heeft

\footnotetext{
17 Ministerie van Binnenlandse Zaken, (1996, pp. 13 e.v.).

18 Artikel $71_{2}, 71_{3}$ Comptabiliteitswet, zile ook: Algemeen deel Memorie van toelichting bij de $6^{\circ}$ wijziging van de Compitabuliteitswet, Hafir, september 1995, A $1.2 \mathrm{~h}$ en A 1.2b, p. 105.
} 19 Stb. 1928, 249. De intrekking van de Bedrijwenwet is geeffectueerd bij Koninklijk Besluit van 15 juni
$1994,5 t b .460$.

\footnotetext{
20 Hafir, A $1.2 f$ sept. 1992, algemeen deel van de Memorie van toelichting bij de $4^{\circ}$ wijziging van de
Comptabiliteitswet 1976 .

21. Van Oijen (1986, p. 8).

22: Schreuder (1994, Hoofdlstuk 10).
} 
binnen dit soort instellingen hangt niet alleen af van het aandelenkapitaal maar ook van de wijze waarop het toezicht is geregeld en van de restricties waar deze bedrijven mee te maken hebben. Van de omvang van deze categorie kan een indruk gekregen worden door te kijken naar de staatsbalans die is opgenomen in de Miljoenennota. In de jaren ' $80 \mathrm{ging}$ het om ongeveer 40 bedrijven, waarin de overheid alle of een deel van de aandelen bezat. De intrinsieke of voor zover van toepassing de beurswaarde van deze bedrijven bedroeg in 1984 F. 45,335 miljard. ${ }^{23}$ Per 31 december 1985 werden $21 \%$ van alle bezittingen van de staat gevormd door enerzijds de staatsbedrijven en anderzijds deze deelnemingen. Op de staatsbalans van 31 december 1994 staat vermeld dat de waarde van deelnemingen F. 47,613 miljard bedroeg op een totaal bedrag aan activa van F. 330,831 miljard. In Bijlage 2 is hiervan een overzicht opgenomen. ${ }^{24}$ Eind 1996 bedroeg de waarde van de deelnemingen $F .57,402$ miljard. Daarnaast is ook het netwerk van dochters en kleindochters van bovengenoemde ondernemingen van belang. Zo participeert de overheid via bijvoorbeeld de Nationale Investeringsbank (NIB) en de regionale ontwikkelingsmaatschappijen, waarin de overheid aandelen bezit (Limburgs Instituut voor Ontwikkeling en Financiering (LIOF) en N.V. Noordelijke Ontwikkelingsmaatschappij (NOM)) in een groot aantal bedrijven. Bij andere regionale ontwikkelingsmaatschappijen zoals de Gelderse, Brabantse en Overijsselse ontwikkelingsmaatschappijen zijn de provincies de belangrijkste aandeelhouders.

In de vierde plaats zijn de zelfstandige bestuursorganen van belang. In het verslag van de Algemene Rekenkamer over 1994 worden deze organen omschreven als: "publiekrechtelijke organen waaraan de uitoefening van een publieke taak is opgedragen zonder dat sprake is wan (volledige) hïrrarchische ondergeschiktheid aan de minister, alsmede privaatrechtelijk vormgegeven organen die met openbaar gezag zijn bekleed ". ${ }^{25}$ Verder wordt opgemerkt: Voorbeelden van openbaar-gezagstaken zijn vergunningverlening, keuring en certificering, registratie, het houden van toezicht, het toekennen van uitkeringen of subsidies en het innen van heffingen". Deze zelfstandige besturursorganen zijn voorbeelden van functionele decentralisatie. ${ }^{26}$ Overheidstaken zoals het verstrekken van uitkeringen en subsidies, worden door dergelijke organen uitgevoerd waarbij de ministeriële verantwoordelijkheid tot bepaalde hoogte is beperkt. Hoewel er vaak niet of slechts beperkt sprake is van een hièrarchisch ondergeschikte positie is de betreffende minister er wel verantwoordelijk voor dat de inrichting en vormgeving van en vooral ook het toezicht op zelfstandige bestuursorganen goed is geregeld. ${ }^{27}$ In principe kunnen deze zelfstandige bestuursorganen dan ook als overheidsinstellingen, zoals gedefinieerd in deze paragraf, worden opgevat. Of dit het geval is hangt echter ook af van de in de instellingswet overgedragen bevoegdheden. Volgens de Algemene Rekenkamer dienen de Ministers

${ }^{23}$ T.a.p., p. 13.

24 Tweede Kamer der Staten-Generaal, (1995) Nota over de toestand van's Rijksfinancien, bijlage 10.

25. Tweede Kamer der Staten-Generaal (yergaderjaar 1994-1995), Versiag wan de Algemene Rekenkamer over 1994, pp. 7-8. Vergelijk ook de Algennene Wet Bestuursrecht (Awb), artikel 1. Mede als gevolg van dit onderzoek van de Algemene Rekenkamer zijn Aanwijzigingen inzake zbo's totstandgekomen die zijn opgenomen in de Aanwijzingen voor de regelgeving. Volgens aanwijzimg $124^{2}$ is een zbo cen bestuursorgaan op het niveau van de centrale overheid dat niet hiërarchisch ondergeschilkt is aan een minister en geem adviescollege is zoalls omschreven in de Kaderwet adviescolleges.

26 Schreuder (1994, pp. 377-380.)

27 Vergelijk ook: Tweede Kamer, vergaderjaar 1992-1993, 21427, nrs , 40-41, pp. 53-54. 
naast andere bevoegdheden tenminste de mogelijkheid te hebben om invloed uit te oefenen op de prestaties van het orgaan. Bovendien moet de minister aanwijzingen kunnen geven ten aanzien van de uitvoering van de publiekstaak. Regering en parlement behouden in principe dan ook overwegende invloed, ook al laat het toezicht van het Ministerie in de praktijk veel te wensen over. ${ }^{28}$ Bovendien hebben ambtenaren van de Ministeries soms zitting in het bestuur, de directie of een toezichthoudend orgaan. Tenslotte moeten zelfstandige besturursorganen op grond van het regeringsstandpunt functionele decentralisatie steeds worden ingesteld bij een formele wet. ${ }^{29} \mathrm{Bij}$ overdracht van taken door de Minister aan een (op te richten) zelfstandig bestuwrsorgaan dient in ieder geval de StatenGeneraal te worden geïnformeerd. Dit impliceert ook dat regering en parlement de mogelijkheid houden om eventueel de rechtsvorm op een later tijdstip weer te veranderen. Overigens zijn er zoals de Algemene Rekenkamer aangeeft ook verschillende zelfstandige bestuursorganen ingesteld zonder een wettelijke basis. ${ }^{30}$

Uit dit onderzoek van de Algemene Rekenkamer bleek dat er per september 1993189 zelfstandige bestuursorganen of clusters van dergellijke organen waren. Hiervan hebben zij er uiteindelijk 162 onderzocht die verbonden zijn met 12 ministeries. In totaal ging het daarbij om 545 afzonderlijke organisaties. ${ }^{31}$ Deze zelfstandige bestuursorganen verschillen wat de rechtsvorm betreft sterk van elkaar. Zo waren er 93 publiekrechtelijke organen, 58 stichtingen, 4 verenigingen, $5 \mathrm{~N}$.V.'s en $4 \mathrm{~B}$.V.'s. Hierbij moet well bedacht worden dat een aantal instellingen ook genoemd zijn bij de categorie van de publiek georiẻnteerde ondernemingen of de deelnemingen. ${ }^{32}$ De genoemde N.V.'s en B.V. 's zijn bijvoorbeeld niet alleen zelfstandige bestuursorganen maar kunnen ook worden aangemerkt als staatsdeelneming, zoals hier omschreven. Het belangrijkste voorbeeld hiervan is De Nederlandsche Bank N.V. (DNB). Andere voorbeelden van zelfstandige bestuursorganen zijn de Universiteit Utrecht, de Open Universiteit, de Raden voor de Kinderbescherming, de Openbare Hogescholen en het Algemeen Burgerlijk Pensioenfonds. ${ }^{33}$ Overigens is het ABP per 1 januari 1996 formeel geen zelfstandig bestuursorgaan meer. De Algemene Rekenkamer schatte de totale uitgaven en de ontvangsten van de zelfstandige bestuursorganen in 1992 op F. 160 miljard. Voorts vloeide er ongeveer F. 38 miljard aan begrotingsgelden naar deze organen, oftewel ongeveer $18 \%$ van de totale uitgaven in 1992 van het Rijk. In 1992 waren er ongeveer 130.000 werknemers werkzaam bij deze zelfstandige bestuursorganen, terwijl ongeveer 309 departementale ambtenaren ondersteuning verleen284 Tweede Kamer der Staten-Generaal (vergaderjaar 1994-1995), Verslag van de Algemene Rekenkamer
over 1994, 24130, nr. 3 paragraaf 4.7.

29 Tweede Kamer (vergaderjaar 1990-1991), Regeringsstandpunt functionele decentralisatie, 19042, nir. 4, p. 17 e.v.

30 Tweede Kamer der Staten-Generaal (vergaderjaar 1994-1995), 24130, nr. 3, Verslag van de Algemene Rekenkamer ower 1994 , p. 20.

${ }^{31}$ T.a.p. P. 10.

${ }^{32}$ Belangrijk is te onderkennen dat agentschappen ondergeschikt zijn aan de minister en dus geen zbo zijn, terwijl ook privaatrechtelijke instellingen die geen openbaar gezag uitoefenen geen zbo zijn.

33: Hierbij moet wel bedacht worden dat er verschil van mening bestaat over wat verstaan moet worden onder zelfstandige bestuursorgamen en onder de publieke taak. Zo meende de Minister van Onderwijs, Cultuur en Wetenschappen dat openbare universiteiten en hogescholen geen zelfstandige bestuursorganen zijn, aangezien de kerntaken van deze instellingen geen typische overheidstaak zijn. Ook ten aanzien van andere instellingen bestond verschil van inzicht. T.a.p., pp. 15-17. 
den bij de uitvoering van de door de organen uitgevoerde publiekstaak. ${ }^{34}$

Tenslotte moeten de lagere overheden worden genoemd. De provincies en gemeenten maakten van oudsher gebruik van publiekgeoriënteerde ondernemingen zoals takken van dienst. Een ander instrument waarvan op lokaal niveau veel gebruik wordt gemaakt is de publiek-private samenwerking. Een aantal voorbeelden zijn genoemd in bijlage 4 . Verschillende bestuurlijk-juridische vormen zijn daarbij mogelijk. Ten aanzien van de publiekrechtelijke sfeer kan gedacht wordien aan een gemeenschappelijke regeling of een commissie op grond van artikel 63 van de Gemeentewet. In de privaatrechtelijke sfeer kan gedacht worden aan een overeenkomst of een privaatrechtelijke rechtspersoon. Een besluit van een gemeente om een privaatrechtelijke rechtspersoon zoals een stichting of een vennootschap op te richten of hierin deel te nemen moet op grond van artikel 228 lid 1 sub a van de Gemeentewet worden goedgekeurd door Gedeputeerde Staten. Gedeputeerde Staten zal akkoord gaan met het oprichten van een rechtspersoon door de gemeente indien dit gebeurt overeenkomstig het in artikel 234 neergelegde criterium. Dat will zeggen dat de keuze voor een vennootschap of een stichting bijzonder aangewezen moet worden geacht. Gemeenten moeten dit ook aantonen, aangezien in principe de publiekrechtelijke weg de voorkeur heeft bij samenwerking tussen overheid en particulieren. Wel is het zo dat Gedeputeerde Staten dit in de praktijk veelal marginaal toetsen. De laatste decennia is het aantal opgerichte privaatrechtelijke rechtspersonen sterk toegenomen. Dijkstra en Iedema merken op: "Ondanks" de belemmeringen die art. 234 opwerpt is er na 1931 sprake van een enorme toename van het aantal gemeentelijke privaatrechtelijke instellingen. Het gebruik dat gemeentelijke overheden de afgelopen jaren van PPS (PubliekPrivate Samenwerking JFK) hebben gemaakt heeft deze ontwikkeling versterkt" " ${ }^{35}$ Veel overheidsinstellingen zijn in het verleden opgericht door lagere overheden. Hierbij kan gedacht worden aan elektriciteits- en gasbedrijven en waterleidingsbedrijwen. Dit gebeurde vaak als onderdeel van de gemeentelijke organisatie maar ook dikwijls in de vorm van een privaatrechtelijke rechtspersoon. Een goed voorbeeld hiervan is de N.V. PLEM. Voor zover het bier gaat om aandelen van lagere overheden in vennootschappen kunnen deze vormen van Publiek-Private Samenwerking eventueell ook als deelneming worden opgevat.

\subsection{Economische theorie en onderzoeksmethoden}

In deze paragraaf zal worden ingegaan op de platsbepaling van het onderzoek binnen de economische theorie. Aangegeven wordt in hoeverre het onderzoek bijdraagt aan theorievorming. Over het begrip theorie bestaan tal van interpretaties. Aangezien in dit onderzoek wordt getracht de theorie te verbinden met de empirie rijst de vraag wat nu precies onder theorie moet worden verstaan. Om die vraag te kunnen beantwoorden wordt kort te rade gegaan bij de methodologie en wetenschapsfilosofie.

Lakatos stelt dat een economische theorie bestaat uit een harde kern en een beschermende laag. ${ }^{36}$ In het proces van toetsing van theorieën aan de empirie wordt de harde kern niet of nauwelijks gewijzigd. De laag van beweringen rond de harde kern kan wel worden aangepast. De harde kern kan volgens Lakatos worden gezien als een instrument. ${ }^{\text {? }}$

${ }^{34}$ T.a.p., p. 13.

${ }^{35}$ Dijkstra en ledema (1990, p. 500).

${ }^{36}$ Lakatos (1970) in: Lakatos en Musgrave (1970, p. 133).

${ }^{37}$ T.a.p., p. 135 . 
Putnam gaat verder in op de rol van de harde kern. Hij verstaat onder theorie een harde kern met daaromheen uitbreidingshypothesen. ${ }^{38}$ Uitbreidingshypothesen zijn aanvillingen op en operationaliseringen van de harde kern. Hij onderscheidt in dit verband een tweetal schema's, te weten:

\begin{tabular}{|l||}
\hline SCHEMA 1: DEDUCTIE \\
HARDE KERN \\
UTBREIDINGSHYPOTHESEN \\
??? (juist of onjuist) \\
SCHEMA 2: INDUCTIE \\
HARDE KERN \\
T?? \\
\hline
\end{tabular}

Figuur 1.1. Schema's ter oplossing van wetenschappelijke problemen ${ }^{39}$

Schema 1 houdt in dat de theorie wordt getoetst aan de empirie. Er is dan sprake van deductie. In het geval van schema 2 worden uit de empirie met behulp van de harde kern bepaalde uitbreidingshypothesen afgeleid. ${ }^{40}$. Toegepast op dit onderzoek kan het volgende worden opgemerkt. Op dit moment is er zoals vermeld nog niet een algemeen geaccepteerde theorie van het gedrag en meer in de bijzonder de "performance" van overheidsinstellingen. De micro-economische "Theory of the Firm" heeft zich voornamelijk gericht op het modelleren van het gedrag van particuliere ondernemingen. Zo is de "Theory of the Firm"-als productiefunctie een nuttige constructie voor het onderzoeken van een grote varièteit van prijzen en productievraagstukken. Het is echter niet een algemene theorie van het bedrijf. $\mathrm{Zij}$ is niet of nawwelijks bruikbaar voor de analyse van onderwerpen als werkgelegenheidsverhoudingen en de juiste keuze van financiële instrumenten. Evenmin is deze benadering erg bruikbaar voor het verklaren van het gedrag en de "performance" van overheidsinstellingen. Het blijven volhouden dat het productiefunctieconcept van het bedrijf universele toepasbaarheid heeft, leidt ertoe dat veel relevante activiteiten binnen organisaties, meer in het bijzonder van overheidsinstellingen, buiten beschouwing blijven. Ook in de theorie van de openbare financiën zijn overheidsinstellingen sinds de Tweede Wereldoorlog enigszins veronachtzaamd, onder meer omdat hun belangrijkheid is achtergebleven bij andere inkomstenbronnen, waaronder belastingen.

Teneinde het inzicht in organisaties, met name ten aanzien van de "performance" te

\footnotetext{
38 Putnam (1979, p. 261).

${ }^{39}$ Broni: T.a.p., pp. 261-262.

${ }^{40}$ T.A.p., pp. 262.
} 
vergroten vormen verschillende "theories of the firm" vooralsnog een betere benadering om verder te komen dan een algemene theorie van het bedrijf, geschikt voor alle soorten analyse. In dit onderzoek wordt dan ook geprobeerd, mede op grond van empirisch onderzoek ("case studies"), om alsnog tot een theorie van overheidsinstellingen ten aanzien van de "performance" te komen. De uiteenzetting over overheidsinstellingen zoals weergegeven in Deel 2 kan dan ook worden opgevat als de harde kern.

Als uitbreidingshypothese kan bijwoorbeeld gedacht worden aan een specifieke doelfunctie. Deze doelfuncties worden geschat door middel van empirisch onderzoek bij een drietal overheidsinstellingen (hoofdstuk 15, 16 en 17). In dit onderzoek beperkt de analyse zich verder tot het onderzoeken van acht hypothesen. Deze benadering sluit aan bij de opvatting van onder andere Coase, te weten:

"It is impossible to undertake good empirical work without a theory and difficult to formulate theories without good empirical work. Empirical work and the improwement of our theories have to go on simultaneously". ${ }^{41}$

Naast een plaatsbepaling van het onderzoek binnen de economische theorie is een nadere indeling van het onderzoek van belang. De economie kan op een positieve en een normatieve wijze worden bedreven. In de literatuur bestaat hierover geen énduidigheid. In dit onderzoek wordt hieronder het volgende verstaan. Van positief of beschrijvend wordt gesproken indien economen menen te weten hoe economische subjecten zich in de werkelijkheid gedragen. Voor overheidsinstellingen betekent dit dat onderzocht moet worden welke activiteiten dergelijke instellingen succesvol kunnen verrichten. Van normatief of voorschrijvend is sprake indien economen menen te weten hoe economische subjecten zich zouden moeten gedragen om bepaalde doelen te bereiken, bijvoorbeeld om hun winst of hun nut te maximaliseren. ${ }^{42}$ Gecombineerd met de omschrijving van de economische theorie kan de conclusie getrokken worden dat de economie bedreven kan worden op een deductief voorschrijvende en deductief beschrijvende wijze en op een inductief beschrijvende manier. In dit onderzoek wordt het feitelijke functioneren van een drietal overheidsinstellingen onderzocht. Deel 2 van het onderzoek zal dan ook voornamelijk deductief beschrijvend zijn terwijl Deel 3 inductief beschrijvend is. Eén en ander wordt in hoofdstuk 4 en verder uitgewerkt.

\subsection{Opzet van het onderzoek}

Voorts wordt in dit onderzoek de lijn gevolgd van algemeen naar specifiek. Uitgaande van een institutioneel kader wordt uiteindelijk het functioneren van afzonderlijke overheidsinstellingen onderzocht. In deze dissertatie wordt een theorie van het gedrag en de "performance" van overheidsinstellingen ontwikkeld. Het doell van deze theorie is om een algemeen kader te ontwikkelen waarmee de "performance" van overheidsinstellingen kan worden onderzocht. De twee centrale vragen worden daartoe aan de hand van een aamtal deelvragen onderzocht. Deze deelvragen zijn:

1. Waarom bestaan er overheidsinstellingen?

2. In hoeverre kan het gedrag van een overheidsinstelling worden verklaard door de normatieve welvaartstheorie?

41 Coase (1993, pp. 360-361).

${ }^{42}$ Russell en Wilkinson (1979, paragraaf 17.1). Vgl. ook: Soeteman (1981, pp. 31-35 en p. 495). 
3. In hoeverre kan het gedrag en de "performance" worden verklaard door het politieke proces?

4. In hoeverre kan het gedrag worden verklaard door een netwerkbenadering?

5. In hoeverre kan het gedrag worden verklaard door de theorie van de eigendomsrechten?

6. In hoeverre kan het gedrag en de "performance" worden verklaard door het beshuitvormingsproces?

7. In hoeverre kan het gedrag worden verklaard door de principaal-agent-theorie?

8. In hoeverre kan het gedrag worden verklaard door de transactiekostentheorie?

9. Welke methoden bestaan ex in het algemeen om de "performance" van een overheidsinstelling te onderzoeken?

10. Hoe kan het gedrag en de "performance" van een concrete overheidsinstelling in de praktijk worden onderzocht?

Deze vragen worden in een drietal delen beantwoord. Deel 1 omvat een introductie en afbakening van het onderzoek. In Deel 2 wordt dieper ingegaan op de theorieën met betrekking tot overheidsinstellingen en de "performance" van deze overheidsinstellingen. Allereerst wordt in hoofdstuk 2 aangegeven waarom overheidsinstellingen eigenlijk worden opgericht. Zijn, zoals nogal eens wordt gesteld, vooral marktfalenoverwegingen van belang of spelen ook andere factoren een rol? Overheidsinstellingen zullen vaak zijn opgericht in verband met het toekomstige gedrag en de toekomstige "performance" van die instellingen. Aangezien het in dit onderzoek met name om die "performance" gaat, wordt in hoofdstuk 3 begonnen met het ontwikkelen van een theorie van overheidsinstellingen. Daarbij wordt onderzocht of gebruik kan worden gemaakt van kennis die is opgedaan binnen het vakgebied van de industriële organisatie. Verder is het van belang te weten welke en vooral wiens doelen een overheidsinstelling nastreeft. $\mathrm{Zijn}$ dat de doelen van de kiezers, de politici of bijvoorbeeld van het management? Indien overheidsinstellingen de doelen van de kiezers nastreven zou het voldoende zijn om deze te onderzoeken. In hoofdstuk 4 wordt in dit verband ingegaan op de normatieve theorie van overheidsinstellingen. Bezien wordt in hoeverre deze benadering kan worden gebruikt om het feitelijke gedrag van een overheidsinstelling te verklaren. Gedragen overheidsinstellingen zich overeenkomstig de normatieve benadering? De conclusie is dat dit niet waarschijnlijk is. Derhalve wordt vervolgens een positieve theorie van overheidsinstellingen ontwikkeld. Uitgaande van de veronderstelling dat de overheidsinstelling al bestaat, worden verscheidene positieve theorieën bezien, voor zover relevant voor de verklaring van het gedrag en de "performance" van overheidsinstellingen. In de literatuur is vanuit verschillende hoek ("public choice", neo-institutionele economie) getracht te komen tot een analyse van het gedrag van overheidsinstellingen. Hoewel deze benaderingen ons inzicht in belangrijke facetten van het gedrag van overheidsinstellingen aanzienlijk hebben vergroot rijst toch de vraag naar de samenhang van de verschillende benaderingen. Dit probleem laat zich oplossen door de "public choice" en de neo-institutionele benadering te integreren in het uit de organisatiekunde bekende netwerkconcept. Dit sluit aan bij recente ontwikkelingen waarbij getracht wordt de organisatietheorie en transactiekosteneconomie te integreren in een netwerk. Elk van de genoemde benaderingen belicht bepaalde facetten van een overheidsinstelling. Naar verwachting zal een combinatie van deze benaderingen het gedrag 
van overheidsinstellingen (met het oog op de "perfomance") in de praktijk beter verklaren dan de vele economische en organisatiekundige benaderingen afzonderlijk. In hoofdstuk 6 wordt dan ook aangegeven in hoeverre een overheidsinstelling kan worden gezien als een hybride organisatie.

Dit algemene concept wordt vervolgens in de hoofdstukken 6 tot en met 12 gepreciseerd. Dit gebeurt in de eerste plaats door het met behulp van de theorie van de eigendomsrechten beschrijven van de relevante actoren binnen dit algemene kader, waarbij voor zover relevant een verbinding wordt gelegd met de organisatietheorie en -sociologie, waarbinnen zij het in een ander verband, tevens an dergelijke vraagstukken de nodige aandacht is besteed. Verder wordt ingegaan op de besluitworming binnen een netwerk. Verschillende modellen zijn beschreven in de literatuur. Kort wordt aangegeven hoe de besluitvorming binnen een netwerk plaatsvindt en welk model hiervoor het best kan worden gebruikt. Vervolgens worden de interacties tussen deze actoren beschreven, waarbij gebruik wordt gemaakt wan de principaal-agent-theorie en meer in het bijzonder van de theorie van de bureaucratie van Niskanen. Aangegeven wordt in hoeverre deze theorie gebruikt kan worden voor het verklaren van het gedrag van overheidsinstellingen. In dit verband wordt tevens ingegaan op de rol van asymmetrische informatie binnen het netwerk. Voorts wordt ingegaan op de transactiekostentheorie. Tenslotte volgt een conclusie. Aangegeven wordt in hoeverre de doelen van de theorie zijn behaald, in hoeverre nader onderzoek nodig is en voorts wordt samengevat in hoeverre de theorie een goede verklaring biedt voor belangrijke factoren als het gedrag en de "performance" van overheidsinstellingen, voor het vraagstuk van privatisering en in hoeverre bijvoorbeeld een wijziging van de "incentive structure" binnen het netwerk hierop van invloed kan zijn.

In Deel 3 volgt het empirische deel. In hoofdstuk 13 en in appendix 2 worden een aantal benaderingen uiteengezet waarmee economen proberen om de "performance" van een overheidsinstelling te analyseren. De nadruk zal daarbij liggen op de positieve en empirische benaderingen. Vervolgens wordt aangegeven welke benadering de meeste kans op succes biedt. In hoofdstuk 14 volgt een onderzoeksprotocol waarin een achttal hypothesen worden geformuleerd ten aanzien van de netwerkbenadering en de manier waarop het functioneren van een netwerk in de praktijk kan worden onderzocht. Deze hypothesen worden vervolgens in hoofdstuk 15,16 en 17 voor een drietal instellingen aan de hand van 16 vragen onderzocht. Gekozen is voor het Rijksmuseum, de N.V. PLEM en de Belastingdienst. In hoofdstuk 18 volgt een samenvatting en volgen conclusies en aanbevelingen. 


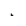




\section{DEEL 2. DE THEORIE VAN OVERHELSINSTELLINGEN}

\section{Hoofdstuk 2. Waarom bestaan er overheidsinstellingen?}

\subsection{Inleiding}

Voordat in de volgende hoofdstukken wordt ingegaan op die vraag waarom overheidsinstellingen zich op een bepaalde wijze gedragen is het essentieel te weten waarom deze instellingen eigenlijk bestaan. Om deze vraag te beantwoorden moet worden verklaard waarom de overheid ingrijpt in de economie. Aangegeven moet worden wanneer overheidsinstellingen vooral geschikt zijn, terwijl ook de kosten van de verschillende instrumenten in overweging moeten worden genomen. Hierbij gaat het niet alleen om de redenen voor het oprichten van overheidsinstellingen maar ook om de redenen voor nationalisering en privatisering van bestaande instellingen. Dit hoofdstuk sluit aan bij de opzet zoals die gevolgd wordt door Dieter Bôs. ${ }^{43}$ Er kan onderscheid worden gemaakt tussen ideologische en economische redenen. In paragraf $2.2 \mathrm{komt}$ alleen de laatste categorie aan de orde. Onder meer wordt ingegaan op de bestaansredenen die verband houden met het corrigeren van marktgebreken, terwijl voorts wordt ingegaan op de "public choice"-benadering. In paragraaf 2.3 wordt onderzocht waarom de overheid nu precies kiest voor een overheidsinstelling en niet voor een ander instrument. In dit verband wordt onderscheid gemaakt tussen enerzijds de geschiktheid van overheidsinstellingen om onder bepaalde omstandigheden bepaalde goederen en diensten voort te brengen en anderzijds de kosten en baten van de verschillende instrumenten. In paragraaf 2.4 volgt een conclusie.

\subsection{Waarom worden overheidsinstellingen opgericht en waarom worden zij geconti- nueerd?}

Ingrijpen van de overheid in de economie door het oprichten van overheidsinstellingen houdt verband met de functies van de overheid. Musgrave en Musgrave vermelden een drietal functies, te weten: ${ }^{44}$
A. De allocatiefunctie.
B. De verdelingsfunctie.
C. De stabilisatiefunctie.

\subsubsection{Kan het bestaan van overheidsinstellingen worden verklaard door de allocatie- functie?}

Op grond van de allocatiefunctie worden in de literatuur een aantal redenen onderscheiden waarom de overheid ingrijpt in de economie, onder meer door middel van overheidsinstellingen. Deze redenen houden allen verband met efficiëntie-overwegingen. ${ }^{45}$ Bij deze categorie kan worden gedacht aan het zoveel mogelijk bevorderen van een Pareto-

\footnotetext{
${ }^{43}$ Bōs (1986, p. 27), vergelijk ook: Bäs (1991, pp. 6 e.v.).

44 Musgrave en Musgrave (1984, Hoofdstuk 1).

${ }^{45}$ Schram, Verbon en Var Winden (1991, pp. 186 ev.).
} 
efficiënte allocatie. In een "first best" economie is het marktevenwicht dat resulteert Pareto-efficiënt en zijn de prijzen gelijk aan de marginale kosten. Voorts geldt dat elke Pareto-efficiënte allocatie bereikt kan worden gegeven de oorspronkelijke distributie.

De reden dat er geen Pareto-efficiènte allocatie tot stand komt is gelegen in een onvoldoende functioneren van de markt (performance failure) of in het niet totstandkomen van de betreffende markten (market absence) ${ }^{46}$ Een aantal in de literatuur veel genoemde redenen voor marktfalen zijn: ${ }^{4 \pi}$

1. de aanwezigheid van een monopolie;

2. de voorziening in collectieve goederen;

3. het bestaan van externe effecten;

4. het niet bestaan van markten, onder andere door gebrek aan informatie;

5. het heffen van belastingen.

Elk van deze factoren kan een reden zijn dat de allocatie inefficiënt is. In deze gevallen kan gesproken worden van een "first-best"-oplossing als bestaansreden voor overheidsinstellingen. Aangezien deze redenen in de literatuur vaak vermeld worden als zijnde belangrijke redenen waarom overheidsinstellingen worden opgericht worden deze hier nader onderzocht. Aan de hand van een aantal belangrijke bedrijfstakken en overheidsinstellingen wordt uiteengezet in hoeverre het waarschijnlijk is dat overwegingen met betrekking tot marktfalen een rol spelen of hebben gespeell.

\subsubsection{Het natuurlijke monopolie}

In de normatieve benadering van het marktfalen wordt vaak het bestaan van een monopolie genoemd als argument voor het instellen en continueren van een overheidsinstelling. ${ }^{48}$ In de literatuur worden een aantal redenen voor het bestaan van een monopolie genoemd. In de eerste plaats kan een monopolie ontstaan door het bezit van schaarse productiefactoren. Een tweede reden voor het bestaan van een monopolie kan gelegen zijn in het bestaan van wettelijke regelingen, octrooien, etc. Hierbij kan gedacht worden aan veel nutsbedrijwen zoals elektriciteits- en waterleidingsbedrijven. Uit de micro-economie is het bekend dat in het geval van een monopolie de prijs hoger wordt dan de marginale kosten. Er wordt dus relatief minder ângeboden tergen een högere prijs. Eén en ander leidt tot een inefficiënte allocatie. ${ }^{49}$ Overheidsingrijpen door prijsregulering of door het produceren door middel van overheidsinstellingen kan een efficiënte allocatie bevorderen. In de derde plaats kan een monopolie verband houden met een dalende gemiddelde kostencurve, een zogenaamd natuurlijk monopolie ("increasing returns to scale" ${ }^{\text {s0 }}{ }^{50}$ Het gaat hierbij om voorzieningen waarbij interne schaalvoordelen optreden bij uitbreiding van de produc-

\footnotetext{
46 Vergelijk voor het onderscheid tussen beide bijwoorbeeld: OECD, Group on economic and emvironmental policy integration, Integrating Environment and Economics, Parijs, 24 mei 1993.

${ }^{47}$ F. Bator (1958, p. 351 e.v.).

48 T.a.p., p. 55 .

${ }^{49}$ Curwen (1986, p. 135).

${ }^{50}$ Russell en Wilkinson (1979, pp. 356 e.v.)
} 
tie, zodat de gemiddelde kosten van de productie dalen als de productie stijgt. ${ }^{51}$ Efficiêntie vereist dat de productiekosten zo laag mogelijk worden gehouden. Indien de schaalvoordelen zodanig zijn dat efficiëntie slechts éen bedrijf toelaat wordt gesproken van een natuurlijk monopolie. In tegenstelling tot een homogeen polypolist kan een monopolist wel winst maken. Vanuit een statische analyse bezien gaat de door een monopolist voortgebrachte hoeveelheid gepaard met verlies aan consumptie- en productiemogelijkheden en daarmee met allocatieve inefficiëntie. De overheid kan van mening zijn dat deze winst te hoog is. Op grond daarvan kan zij besluiten door het inschakelen van overheidsinstellingen zelf de betreffende produkten voort te brengen. De overheidsinstelling kan de prijs gelijkstellen aan de marginale kosten. In principe leidt dit tot een efficiënte allocatie, onder de voorwaarde dat op andere markten eveneens een allocatief efficiente allocatie tot stand komt. Het is overigens maar de vraag of de overheid de relevante marginale kosten wel kent. De overheid beschikt in werkelijkheid vaak niet over perfecte informatie over productietechnologieën en prijzen van productiefactoren. Bovendien zou zij dan de vraag naar het produkt moeten kennen in huidige en toekomstige perioden. ${ }^{52}$ Indien op andere markten geen Pareto-efficiënte allocatie tot stand komt kan de overheid kiezen voor een "second-best" -oplossing en de prijzen ongelijk aan de marginale kosten stellen. In appendix 1 wordt hier verder op ingegaan. Ook kan zij er voor kiezen de voordelen van productie op grote schaal binnen de overheidsinstelling te combimeren met een redelijk winstniveau. De gerealiseerde winst komt dan toe aan de staat. Voorts kan gebruik worden gemaakt van interne subsidiëring, aangezien een over heidsinstelling vrijwel altija meer dan één goed of dienst zal aanbieden. ${ }^{53}$

Vamuit een normatief perspectief bezien zal overheidsingrijpen niet steeds modig zijn. Het is namelijk ook mogelijk dat een particulier bedrijf de prijs gelijk stelt aan de gemiddelde kosten. Het bedrijf maakt dan geen winst. Er is dan sprake van een beperkt (constrained) efficiënte oplossing. Dit zal met name het geval zijn indien er sprake is van een penfecte "contestable market", waarbij er geen entreebarrières zoals omschreven door Stigler zijn. Dat wil zeggen: geen kostenasymmetrieèn tussen toetreder en bestaande producenten en geen toe- en uittredingskosten. Door de dreiging van entree kan het bedrijf dan geen hogere prijs vast stellen. De prijs wordt dan vastgesteld in de buirt van de "first-best"oplossing $\mathrm{p}=\mathrm{mk}$. In de experimentele economie is veel onderzoek verricht naar zogenaamde "double auction" monopolies. In het geval van een "single auction" monopolie is er één verkoper die een bod ontvangt van meerdere potentiële kopers. Uiteindelijk ontstaat een evenwichtsprijs waarbij de gevraagde en aangeboden hoeveelheid gelijk zijn. De nadruk ligt daarbij dus op de aanbodkant. In dat geval kan een monopolieprijs ontstaan. Indien evenwel sprake is van een "double auction" monopolist wordt elk bod en elk aanbod centraal bijgehouden en openbaar gemaakt. Indien een dergelijke monopolist gebruik maakt van prijsdiscriminatie kan dat voor de kopers een signaal zijn dat de prijs omlaag kan. Davis en Holt merken op: "Once again, buyers, upon seeing that sellers could afford to sell at lower prices, would refuse to accept higher prices in subsequent

\footnotetext{
51. T.a.p., p. 252. Zie ook: Sharkey (1982, p. 20). Het is van belang op te merken dat met het meten van de mate van schaalvoordelen, hetgeen relatief eenwoudig is, niet automatisch bepaald kan wordem of er sprake is van een natuurlijk monopolie. Ook andere factoren zijn relevant waaronder de marktstructuur en de aard van de vraag op de betreffende markt.
}

52 Mamuth (1993, p. 159).

53 Vergelijk ook: De Jong (1958, p. 10). 
periods" ".4 Uit onderzoek blijkt dat in dat geval de handel plaatsvindt tegen een prijs die ergens tussen het oorspronkelijke bod en het aanbod van de monopolist in ligt. ${ }^{55}$

Niet alleen natuurlijke momopolies maar ook naturlijke oligopolies kunnen voor de overheid een reden zijn om zelf de productie te verzorgen. In dat geval kunnen een beperkt aantal bedrijven de optimale productie van een bedrijfstak goedkoper voortbrengen ${ }^{56}$ Het is ook in dit geval niet altijd nodig om een overheidsmonopolie te vestigen. Vogelsang merkt bijvoorbeeld op dat een overheidsinstelling als prijsleider zou kunnen optreden, waardoor eveneens de beoogde welvaartswinst gerealiseerd kan worden.

Het argument dat het bestaan van een natuurlijk monopolie een reden is voor het oprichten en continueren van een overheidsinstelling heeft een tweetal belangrijke bezwaren. Net zoals bij veel andere op de theorie van het marktfalen gebaseerde bestaansredenen is het onduidelijk waarom in het geval van een natuurlijk monopolie een overheidsinstelling wordt opgericht en niet gekozen wordt voor allerlei andere instrumenten zoals regulering en subsidiëring. Een tweede belangrijk bezwaar betreft het volgende. Vaak wordt gesteld dat veel openbare nutsbedrijven de eigenschap van een matuurlijk monopolie hebben omdat zij hun produkten leveren door middel van een kostbaar netwerk. Het in het leven roepen van nog zo'n netwerk zou te veel kosten met zich meebrengen. Hierbij wordt veelal gewezen op lokale gasleverantie, telefoonnetwerken, kabeltelevisie en levering van elektriciteit via een elektriciteitsnet. In werkelijkheid komen overheidsinstellingen die functioneren op grond van het natuurlijke monopolie-motief, in Nederland niet of nauwelijks voor.

Als voorbeeld wordt kort ingegaan op de Nederlandse elektriciteitssektor. Vaak wordt gesteld dat de elektriciteitssector gekenmerkt wordt door dalende gemiddelde kosten. Ten aanzien van de vraag of dit een reden is voor overheidsinvloed in de elektriciteitssector kan allereerst de vraag worden gesteld of de overheid zich door dit soort overwegingen laat leiden. Dat het economisch verstandig zou zijn om een bepaald beleid te voeren betekent geenszins dat de overheid dat ook daadwerkelijk doet. Voorts kunnen er de nodige vraagtekens gezet worden bij het natuurlijke monopolie-karakter van nutsbedrijven in de elektriciteitssector. Onderscheid kan worden gemaakt tussen de productie- en distributiesector. Voor de productie van elektriciteit moet veel geïnvesteerd worden in productiemiddelen. Bedrijven in deze sector worden gekenmerkt door hoge vaste kosten. Tot een bepaalde hoogte is hierbij sprake van dalende gemiddelde kosten en derhalve van toenemende schaalopbrengsten. Indien de productie stijgt nemen de kosten af. Bij de elektriciteitsproductie kan onderscheid gemaakt worden tussen een drietal niveaus, te weten het niveau van de generator, het niveau van de centrale en het niveau van het productiebedrijf. Künneke geeft aan dat schaalopbrengsten op het niveau van de generator zijn uitgeput bij ca. $400 \mathrm{MW} .{ }^{57}$ Aangezien de omvang van moderne conventionele generatoren hoger ligt zijn hier geen schaalvoordelen meer te behalen. Hij constateert verder dat er geen onderzoeksgegevens beschikbaar zijn over de optimale ormvang van de opwekkingscentralle, die bestaat uit eén of meerdere generatoren. Wel is het waarschijnilijk dat hier kostenvoordelen gerealiseerd kunnen worden door bijvoorbeeld kostenbesparing

\footnotetext{
${ }^{54}$ Davis en Holt (1993, p. 152).

${ }^{55}$ Zie ook: Hey (1994, p. 207).

56 Vogelsang (1990, p. 28).

${ }^{57}$ Künneke (1992, p. 11).
} 
bij bediening en onderhoud. Met betrekking tot de minimale schaalomvang van het productiebedrijf lopen de resultaten uiteen. Deze variëren van ongeveer $1600 \mathrm{MW}$ tot $4000 \mathrm{MW} .{ }^{58} \mathrm{Bij}$ het totstandkomen van de Elektriciteitswet van 1989 in Nederland is ook ingegaan op de vraag wat de optimale bedrijfsomvang is van een productiebedrijf: Deze werd geschat op ongeveer $3500 \mathrm{MW}$. Dit zou betekenen dat er in Nederland in dat geval ongeveer 4 productiebedrijven zouden overblijven. Het is duidelijk dat er dan geen sprake is van een natuurlijk monopolie.

Met betrekking tot de distributiesector is er weinig onderzoek verricht naar de optimale schaal. Het is waarschijnlijk dat bij de opbouw van een elektriciteitsnet voordelen zijn te behalen bij de uitbreiding daarvan. $\mathrm{Nu}$ vrijwel iedereen is aangesloten op het elektriciteitsnet is het echter waarschijnlijk dat er geen belangrijke schaalvoordelen meer te behalen zijn bij uitbreiding van de productie. Daartoe zullen opnieuw kosten gemaakt moeten worden. Neuberg concludeerde naar aanleiding van een onderzoek maar Amerikaanse distributiebedrijven dat de meeste schaalvoordelen al bij 1000 aansluitingen gerealiseerd zijn, terwijl vanaf ongeveer 2,8 miljoen aansluitingen zich schaalnadelen voordoen. ${ }^{59}$ In de Memorie van Toelichting bij het Wetsontwerp Energiedistributie werd de minimale omvang gelegd bij ongeveer 100.000 verbruikersadressen, uitgaande van horizontaal geüntegreerde distributiebedrijven. ${ }^{60} \mathrm{De}$ optimale schaal werd dus hoger ingeschat dan de genoemde 1000 verbruikersadressen. Gegeven dit aantal zouden er in Nederland enige tientallen distributiebedrijven overblijven. Ook in deze sector is derhalve niet: zozeer sprake van een natuurlijk monopolie als wel van een wettelijk monopolie. Vogelsang merkt op dat het natuurlijke monopolie-kenmerk afhangt van het niveau van de vraag, dat vervolgens weer afhangt van de bevolkingsdichtheid en de economische ontwikkeling. ${ }^{61}$ Hoewel in Europees verband gewerkt wordt aan deregulering is de elektriciteitsmarkt in de jaren' 70 en '80 een voornamelijk nationale markt. Binnen de Nederlandse markt kan onderscheid gemaakt worden tussen een vijftal regio"s, die elk gekenmerkt worden door hoge entreebarrières (met name door het aanhouden van overcapaciteit en door het bestaan van een wettelijk momopolie). Voor elektriciteitsbedrijven is het niet mogelijk te produceren of te distribueren in een ander voorzieningsgebied. Ook voor afnemers geldt dat elektriciteit niet van een bedrijf in een ander voorzieningsgebied gekocht mag worden, hoewel hier eind jaren '80 geleidelijk verandering in kwam. Door deze segmentering van de Nederlandse markt is het niveau van de vraag sterk gereduceerd. Het zal vrijwel altijd zo zijn dat indien de markt steeds kleiner wordt gemaakt één bedrijf in de gehele (resterende) marktvraag kan voorzien. Dit heeft evenwel weinig te maken met een natuurlijk monopolie. $\mathrm{Er}$ is hier sprake van een wettelijk monopolie. Om meer inzicht te krijgen in de redenen van het bestaan van deze publieke elektriciteitsbedrijven dienen dan ook de factoren die geleid hebben tot dit wettelijke monopolie geanalyseerd te worden. Een normatieve benadering schiet dan ook tekort.

Ook de telecommunicatiesector wordt vaak gezien als een schoolvoorbeeld van een

58 Vergelijk, T.a.p.s pp. 11-12. Hij baseert zich op onderzoek van Christensen en Greene (1976) en Huettmer en Landon (1978).

59 Neuberg (1977, pp. 303-323).

60 Tweede Kamer der Staten-Generaal (vergaderjaar 1990-1991), Memorie yan Toelichting, "22160, nr. 3. p. 6.

61 Vogelsang (1990, p. 28). 
natururlijk monopolie. De PTT is in 1989 verzelfstandigd. ${ }^{62}$ Vooralsnog behield de Nederlandse PTT/KPN het wettelijke monopolie op de verzorging en het beheer van de transmissielijnen op het Nederlandse grondgebied. Dit monopolie wordt door de snelle ontwikkelingen op het gebied van glasvezel- en satellietverbindingen echter steeds meer uitgehold, terwijl bovendien de regelgeving op telecommunicatiegebied zich in Europees verband steeds meer ontwikkelt in de richting van volledige liberalisatie, die uiteindelijk ook voor het gewone vaste (in de zin van niet-mobiele) telefoonverkeer moet gaan gelden. ${ }^{63}$ In de Memorie van Toelichting bij de wijziging van de Machtigingwet PTT Nedertand N.V. werd opgemerkt." "Het is namelijk met ingang van I januari 1993 een ieder toegestaan deze gehuurde vaste verbindingen (concessiehouder is PTT Telecom B.V.) te gebruiken voor het verrichten van bepaalde telecommunicatiediensten " ${ }^{4}$ De exclusieve tak van PTT Telecom B.V. beperkt zich dan ook zoals hiervoor opgemerkt, tot de aanleg, instandhouding en het beheer van de vaste verbindingen en heeft geen betrekking op de exploitatie ervan.

Vaak wordt volgehouden dat de PTT een monopolie had inzake het beheer en de exploitatie van het netwerk op grond van de genoemde schaalvoordelen. Gewezen wordt dan op de hoge kosten van het aanleggen van een tweede telecommunicatie-infrastructuur indien er meerdere PTT's naast elkaar in dezelfde markt opereren. Ten aanzien van de exploitatie gaat dat duidelijk veel minder op. Met toenemende verkeersintensiteit kan de capaciteit van het netwerk verhoogd worden zonder dat de investeringskosten in dezelfde mate toenemen. In Nederland is weinig onderzoek gedaan naar de mate waarin schaalvoordelen bestaan. De commissie Steenbergen en de commissie Swarttouw hebben in de jaren 80 onderzoek verricht naar de wenselijkheid om de aanleg, instandhouding en exploitatie van de telecommunicatie-infrastructuur in éen hand te leggen. ${ }^{65}$ In beide rapporten werd geconcludeerd dat het mede met het oog op schaalvoordelen niet wenselijk was om concurrentie toe te staan op de Nederlandse infrastructurur. ${ }^{66}$ Gesteld werd verder: "Om zich te kunnen handhaven op de telecommunicatiemarkt zijn voor PTT Telecom B.V. voldoende schaalgrootte en gewicht absolute vereisten". ${ }^{7}$ Met name in de VS. en Canada hebben tellefoonmaatschappijen als AT\&T en Bell Canada het laatste decennium onderzoek verricht naar het meten van de aanwezigheid van schaalvoordelen in de telecommunicatiesector door middel van econometrisch onderzoek. De resultaten van dergelijk onderzoek zijn niet éenduidig en variëren van schaalvoordelen tot schaalnadelen, afhankelijk van de gekozen specificatie van de technische vooruitgang. De werkelijke mate van schaalvoordelen in de telecommunicatiesector is dan ook onduidelijk. Veel van

\footnotetext{
62 Wet van 26 oktober 1988 , houdende regels met betrekking tot de oprichting van de naamloze vennootschap PTT Nederland N.V. (Machtigingswet PTT Nederland N.V.).
}

63 Vergelijk: Commissie van de Europese Gemeenschappen, Richtlijn nr. 90/388, EEG, 28 juni 1990 (dienstenrichtlijn).

64 Tweede Kamer der Staten-Generaal (vergaderjaar 1992-1993), kamerstuk 23192, nr. 3, p. 3. Vergelijk ook: Staatscourant van 22 december 1992, nr. 248.

${ }^{65}$ Commissie Steenbergen (1985-1986), Signalen voor straks. Een nieuwe richting voor de PTT, kamerstukken 17370, nrs. 30-31 en Rapport van de Commissie Swartouw, maart 1982, kamerstukken, 17370, nr. 1.

66 Eerste Kamer der Staten-Generaal (1988), Memorie van Antwoord Regels met betrekking tor de voorzieningen voor telecommunicatie (Wet op de telecommunicatievoorzieningen), 20369 , nr. 226 b. p. 3 .

${ }^{67}$ Tweede Kamer der Staten-Generaal (vergaderjaar 1992-1993), Memorie van Toelichting bij de wijziging van de Machtigingswet PTT Nederlland N.V., 23192, mr. 3, p. 5. 
dergelijk onderzoek wordt gekenmerkt door een hoge mate van aggregatie. Indien wordt aangetoond dat er sprake is van toememende schaalopbrengscen in een sector weten we niet waar deze voordelen zich voordoen. Denkbaar is dat er in sommige gebieden schaalvoordelen zijn terwijl deze elders al benut zijn of niet meer bestaan. Indien beweerd wordt dat overheidsinterventie nodig is in verband met het bestaan van een natuurlijk monopolie is het van belang te weten wat de kleinste eenheid is met dalende gemiddelde kosten. Blankart en Knieps stellen: 6 "Economies of scale may be relevant in local areas, but they are certainly not widespread enough to justify the traditional regulation of long distance telecommunications networks".

Tegenwoordig is vrijwel iedereen aangesloten op het telefoonnetwerk. Nog een extra aansluiting levert geen dalende gemiddelde kosten meer op, maar mogelijk zelfs stijgende kosten omdat dure investeringen nodig zijn om het netwerk uit te breiden. Hetzelfde geldt overigens voor de spoorwegen. Tot een bepaalde hoogte zal een toenemend gebruik van het bestaande spoorwegnet leiden tot lagere kosten per eenheid treinvervoer. Na dit punt is dit evenwel niet langer het geval. Neemt het gebruik nog meer toe dan zijn kostbare investeringen nodig. Een voorbeeld hiervan is de introductie van de OV-jaarkaart, waardoor het gebruik van het openbaar vervoer is toegenomen. Het bestaande spoorwegnetwerk is hier echter nog onvoldoende op berekend.

In de telecommunicatiesector zijn er voorts, met name door de stijgende vraag zowel in Europa als in de VS, steeds meer parallelsystemen, met name bij de lange afstandscommunicatie. Door de toenemende vraag daalt het belang van schaalvoordelen in de lange afstandstelecommunicatie. Tenslotte moet bij het beantwoorden van de vraag of er al dan niet sprake is van een natuurlijk monopolie ingegaan worden op de omvang van de relevante markt. In de telecommunicatiesector is de minimaal efficiënte schaal (MES) vaak groter dan de nationale markt (bijvoorbeeld bij de productie van schakelcentrales). Indien zoals in het verleden gebeurd is de markt eerst beperkt wordt tot de nationale markt komt er een moment waarop eèn bedrijf de gehele markt kan voorzien. Indien er ook nog een tweede bedrijf in de markt zou opereren zou dat inderdaad hoge kosten met zich meebrengen. Evenals in de elektriciteitssector is ook hier niet zozeer sprake van een natuurlijk monopolie alswel van hoge entreebarrières in de vorm van een wettelijk monopolie. Om te weten te komen waarom de overheid een overheidsinstelling in het leven heeft geroepen moet ook hier onderzocht worden waarom de overheid deze entreebarrières heeft opgericht.

Ten aanzien van kunst wordt wel gesteld dat kunst eveneens gemaakt wordt onder omstandigheden van dalende gemiddelde kosten. Hierbij moet ook gedacht worden aan het bevorderen, conserveren en instandhouden van kunst als onderdeel van het culturele erfgoed. Ook het tentoonstellen van kunst in musea en het geven van theatershows zou gekenmerkt worden door dalende gemiddelde kosten. Musea zijn relatief groot. Indien musea volledig gebruilkt worden moet de toegangsprijs laag zijn. Maar bij een dergelijke lage prijs is het museum verliesgevend, hetgeen betekent dat subsidies van de overheid nodig zijn. Dit kan worden geillustreerd met een voorbeeld. ${ }^{69}$ Veronderstel dat een museum 100 bezoekers kan ontvangen voor een rondleiding. Elke rondleiding kost F. 100,-, inclusief de kosten van het museum. De entreeprijs moet dan f. 1, zijn, wil het museum haar kosten volledig dekken. Om te zorgen dat er 100 mensen komen moet de prijs echter $f$. 0,75 zijn. In dat geval worden evenwel niet alle kosten goed gemaakt. Indien de prijs $f$. 2 ,- is komen er 50 bezoekers. Dan maakt het museum geen verlies. Een

${ }^{68}$ Blankart en Knieps (1989, p. 580).

${ }^{69}$ Dit voorbeeld is ontleend aan: Grampp (1989, p. 260). 
belangrijk deel van de capaciteit wordt dan evenwel niet benut. Er is sprake van verspil-

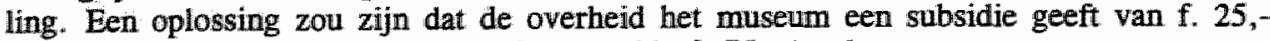
zodat er dan 100 bezoekers komen die per saldo f. 75 ,- betalen.

Bij de beantwoording van de vraag of hier overheidsinmenging nodig is staat centraal of de rondleiding voor de één meer dan f. 1,- waard is en voor de nader minder, en of dir per saldo f: 100 , - oplevert. Indien dat niet het geval is zou de rondleiding moeten worden afgeschaft in plaats van te worden gesubsidieerd. Voorts is het belangrijk te weten wat de kosten zijn van een alternatief dat de mensen evenveel waard is. Indien de kosten van cen alternatief lager zijn moet het alternatief gekozen worden. Het niet meenemen van dit soort informatie is dan ook de zwakte van het argument dat de overheid invloed heeft in musea omdat deze gekenmerkt worden door dalende gemiddelde kosten. Een subsidie aan een museum op grond van dalende gemiddelde kosten moet alleen gebruikt worden voor verlaging van de entreeprijs van het museum. In werkelijkheid wordt de subsidie evenwel vaak gebruikt voor vergroting van de uitgaven van het museum en ter vergroting van de capaciteit, hetgeen het probleem van de dalende gemiddelde kosten nog groter maakt.

Heyndels en Vuchelen hebben onderzocht in hoeverre er bij de belastingadministratie/belastingdienst sprake is van een positief verband tussen de hoogte van de productie en het niveau van de produktiviteit (de Wet van Verdoorn). ${ }^{70}$ Zij benaderen de productie van de Belastingdienst door het niveau van de belastingopbrengst en de produktiviteit door de opbrengst per ambtenaar. Hun onderzoek bevestigt dat er een positief verband bestaat tussen het niveau van de belastingopbrengst en de produktiviteit, hetgeen wijst op aanzienlijke statische schaalvoordelen. $\mathrm{Zij}$ vinden geen bewijs voor de aanwezigheid van dynamische schaalvoordellen. Een snelle toename van de belastingopbrengst gaat miet gepaard met een snelle groei van de produktiviteit. Dat de statische relatie wel geldt maar de dynamische niet verklaren zij door te wijzen op de relatieve onbelangrijkheid van de wijzigingen ten opzichte van het absolute niveau. Deze dalende gemiddelde kosten zouden een reden kunnen zijn waarom de belastinginning in Nederland verzorgd wordt door de overheid. De gedachte is dan dat de verzorging van de inning door een particullier bedrijf zou kunnen leiden tot een hogere prijs van de inning, analoog aan de analyse van een natuurlijk monopolie. Er zouden dan middelen worden overgeheveld van de belastingbetaler naar dit bedrijf. Ook hier is het echter maar de vraag in hoeverre deze schaalvoordelen slechts ến bedrijf bestaansrecht zouden geven. Het is denkbaar dat de belastingadministratie wordt opgezet als een verplichte ziektekostenverzekering. Deze kan in Nederland bij verschillende maatschappijen worden afgesloten. Er is geen sprake van een monopolie. Het is waarschijnlijk dat er ook bij de belastingadministratie ruimte zou zijn voor meerdere bedrijiven.

\subsubsection{Collectieve goederen}

Een tweede reden voor de overheid om door middel van een overheidsinstelling bepaalde activiteiten te verrichten houdt verband met de voortbrenging van collectieve goederen. Collectieve goederen zijn goederen die niet geschikt zijn voor splitsing in individueel leverbare eenheden. ${ }^{71}$ ledereen moet het goed gebruiken of heeft er mee te maken, ongeacht of een individu dit prefereert. Voor sommigen is het een publiek goed, voor anderen een "public bad". Verder zijn deze goederen niet-exclusief. Niemand kan van het

${ }^{70}$ Heyndels en Vuchelen (1987, pp. 295-301).

${ }^{71}$ Cullis en Jones (1987, pp. 21-22). 
gebruik van het goed worden uitgesloten. Voorts zijn collectieve goederen niet-rivaliserend. Wat de ene persoon gebruikt kan een ander ook nog tegelijk gebruiken. Private goederen en collectieve goederen kunnen beschouwd worden als twee uitersten. Om de kJoof tussen deze twee uitersten te dichten stelt Buchanan een theorie van clubs woor. Hij omschrijft deze theorie als "a theory of co-operative membership, a theory that will include as a variable to be determined the extension of ownership-consumption rights over differing numbers of persons ".72 Een club is het aantal mensen waarmee de voordelen van goederen en diensten gedeeld moeten worden. Anderen kunnen worden uitgesloten van het gebruik van een goed. Dit hoeft volgens Buchanan geen ernstige beperking wan de theorie te zijn omdat indien de eigendomsrechtenstructurur variabel genoeg is, maar weinig goederen en diensten niet exclusief zijn. De theorie van clubs is in die zin een theorie van het optimale aantal personen in de club. ${ }^{73}$ Demsetz onderscheidt collectieve en publieke goederen. Het begrip collectieve goederen komt overeen met wat hiervoor is aangeduid als collectieve goederen. Onder publieke goederen verstaat hij goederen die niet-rivaliserend maar wel exclusief zijn. ${ }^{74}$ In paragraaf 2.3.1 worden deze goederen overeenkomstig de benadering van Savas aangeduid als tolgoederen.

In het geval van een efficiënte allocatie van een collectief goed wordt die hoeveelheid voortgebracht waarbij de gesommeerde bereidheid van de verschillende consumenten te betalen voor een aanvullende eenheid gelijk is aan de marginale kosten. ${ }^{75}$ De vraag is nu of deze efficiënte voorziening van een collectief goed ook tot stand komt. ${ }^{76}$ Het kernprobleem hierbij is of consumenten bereid zijn hun preferenties te uiten. Bij marktgoederen is er geen aanleiding voor hen dat niet te doen. In het geval van collectieve goederen ligt dat veelal anders.

Soms is het in theorie wel mogelijk dat in de marktsector een efficiënte allocatie van collectieve goederen of quasi-collectieve goederen wordt bereikt. Zoals opgemerkt zijn er allerlei varianten van collectieve goederen mogelijk. Grossekettler geeft aan dat voor deelbare collectieve goederen die wel exclusief zijn enerzijds de mate van rivaliteit kan verschillen en dat anderzijds een bepaalde doelgroep kan worden aangewezen. De mate van rivaliteit kan worden bepaald met een elasticiteit, de zogenaamde rivaliteitsgraad. Deze geeft aan in welke mate de kosten van voortbrenging van het collectieve goed veranderen indien het aantal mensen dat dit goed consumeren toeneemt. De rivaliteitsgraad is het produkt van de elasticiteit van het gebruik (hoeveel moet er meer worden aangeboden indien het aantal gebruikers met $1 \%$ stijgt) en de elasticiteit van het beschikbaar stellen van een hoeveelheid collectief goed (toename van de kosten van voortbrenging indien de productie met $1 \%$ verhoogd wordt). Indien een prijs gelijk gesteld wordt aan de marginale kosten dekt deze alleen de kosten indien de rivaliteitsgraad groter is dan 1. Indien dat niet het geval is moet de prijs hoger zijn dan de marginale kosten. Het tarief

${ }^{72}$ Buchanan (1965, p. 1..)

${ }^{73}$ T.a.p., p. 13.

${ }^{74}$ Demsetz (1970, p. 295).

75 Samuelson (1954, pp. 387-389). Vergelijk ook: Samuelson (1955). Dan geldt dat de gesommeerde marginale substitutieverhouding (MSV) van de verschillende consumenten gelijk is aan de marginale transformatievoet (MTV) (MSVa + MSVb + MSVc + .. + MSVn = MTV).

76 Vergelijk: Vicary (1996, p. 430). 
moet overeenkomen met de rivaliteitsgraad: ${ }^{77}$ De doelgroep waarwoor het collectieve goed is bestemd dient (in theorie) zoveel mogelijk deze hogere prijs te betalen. In dat geval is het in principe mogelijk om een efficiënte allocatie te bereiken.

Omdat collectieve goederen echter niet-exclusief zijn, zijn consumenten zoals vaak wordt gesteld, niet geneigd hun preferenties weer te geven. Iedereen probeert het goed voor niets te krijgen ("free rider"-effect) met als gevolg dat de markt het betreffende goed niet produceert. $^{78}$ Ten aanzien van het "free rider"-probleem kan worden opgemerkt dat dit geen feilt is maar een gevolg van de hypothese dat mensen een nutsfiunctie maximaliseren die alleen afhangt van hun eigen consumptie van goederen. ${ }^{79}$ Ook in de marktsector worden collectieve goederen voortgebracht. Hierbij kan gedacht worden aan ziekenhuizen. Er is vooral in de experimentele economie veel onderzoek verricht naar het belang van het "free rider" effect en naar de mate waarin de markt zelf zorgt voor een efficiênte voorziening van collectieve goederen. De resultaten van dit soort onderzoek lopen uiteen. Schneider en Pommerehne concludeerden op grond van een in 1981 uitgevoerd experiment dat er zich wel enig "free-rider"-gedrag voordoet, maar minder dan op grond van de theorie verwacht zou worden. ${ }^{80}$ De resultaten van een experiment dat werd uitgevoerd door Marwell en. Ames gingen iets verder en gaven aan dat individuen bijdragen aan de voorziening in collectieve goederen en zeker niet allemaal "free rider" gedrag vertonen. ${ }^{81}$ Ander onderzoek laat zien dat na hethaling wel "free rider"-gedrag kan worden waargenomen. Er worden dan aanzienlijik minder collectieve goederen voortgebracht dan

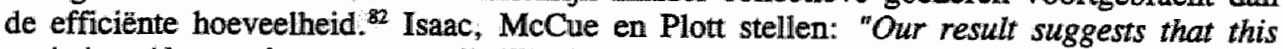
optimism (d.w.z. dat mensen vrijwillig bijdragen aan de voortbrenging van een collectief goed, JFK) is unwarranted for cases in which contributions must be obtained repeatedly over time. Contributions quickly erode to low levels after two or so periods"." ${ }^{33}$ Ook Andreoni onderzocht de invloed van herhaling op de bijdrage van individuen aan de voortbrenging van collectieve goederen. ${ }^{84}$ Deze en andere onderzoeken suggereren dat "free riding" weliswaar voorkomt maar dat dit niet zodanig is dat er geen collectieve goederen worden voortgebracht door de particuliere sector. Verschillende andere onderzoeken maken duidelijk dat het "free-rider" gedrag zich kan voordoen maar dat dit niet altijd zo is. Om deze onbepaaldheid tegen te gaan proberen economen te onderzoeken welke factoren vooral invloed hebben op de voortbrenging van collectieve goederen. Hagel en Roth onderscheiden op grond van de verschillende verschenen onderzoeken een negentiental factoren. ${ }^{85}$ Deze factoren delen zij in een drietal groepen in, namelijk omge-

77 Grossekettler in: Boetteher (ed.) (1991, p. 130).

${ }^{78}$ Hiardin (1968, pp. 1243 e.v.) en Olson jr. (1968). Vergelijk echter ook: Tullock (1996, pp. 221-224).

${ }^{79}$ Stiglitz (1988, p. 120).

Schneider en Pommerehne (1981, pp. 689-704).

81 Marwell en Ames (1981, p. 307).

Isaac, McCue en Plott (1985, pp. 67-68).

83. T.a.p., p. 69.

Andreoni (1988, paragraaf 3, pp. 296 ev.).

${ }^{85}$ Hagel en Roth (eds) (1995, p. 143). 
vingsfactoren (aantal mensen, geslacht e.d.), systematische variabelen (zoals rechtvaardigheidsoverwegingen en altruisme) en ontwerpvariabelen (zoals unanimiteitsregels en gestructureerde communicatie). Een aantal factoren hebben vooral duidelijke effecten. Zoals hiervoor opgemerkt suggereren de data dat de bijdragen van individuen aan de voortbrenging van collectieve goedieren afnemen indien herhaling als factor in het onderzoek wordt meegenomen. ${ }^{86}$ Ook communicatie is een belangrijke variabele. Uit verschillende onderzoeken blijkt dat het "free rider" gedrag zich in gestructureerde groepen nauwelijks voordoet. ${ }^{87}$ Hierbij moeten wel steeds zoveel mogelijk variabelen bezien worden. Mancur Olson ${ }^{88}$ stelde bijwoorbeeld eind jaren '60 al dat de kans op cen miet-optimale voorziening van collectieve goederen toeneemt naarmate de groep groter is, waardoor de kans kleiner wordt dat individuen vrijwillig een deel van de kosten van een collectief goed zullen dragen. Naar het verband mussen groepsgrootte (het aantal mensen dat het collectieve goed wil gebruiken) en vrijwillige bijdrage aan het collectieve goed is in de experimentele economie veel onderzoek verricht. Ledyard stelt in dit verband: "Clearly, subjects appear to respond positively to increases in their MCPR (marginal per capita return JFK) although the effect is diluted in large groups" " Omdat er naast de groepsgrootte zoals genoemd andere factoren meespelen (Olson noemde bijvoorbeeld eind jaren ' 60 al de belangen die op het spel staan als een belangrijke factor) hoeft een grote groepsomvang niet te leiden tot "free rider" gedrag, zoals ook onderzoek van Pommerehne, Feld en Hart laat zien. ${ }^{90}$ Ook volgens Lipford neemt het free-rider-gedrag niet toe indien het aantal betrokkenen toeneemt. ${ }^{91}$ Anderen zoals Zaleski en Zech vinden wel een positief verband. ${ }^{92}$

Vaak wordt gesteld dat voor zover de marktsector onvoldoende van een collectief goed voortbrengt de overheid een taak heeft om hier voor te zorgen. $\mathrm{Zij}$ zou dan de preferenties van de consumenten moeten ontdekken. ${ }^{93}$ Vervolgens zou zij iedereen overeenkomstig die preferenties moeten laten betalen. Tenslotte zou zij de betreffende collectieve goederen moeten voortbrengen, bijvoorbeeld door middel van overheidsinstellingen. Nïet zelden wordt echter de conclusie getrokken dat het in verband met de niet-exclusiviteit niet mogelijk is om deze preferenties van de burgers ten aanzien van collectieve goederen te bepalen. Pommerehne geeft aan dat dit wel mogelijk is. Hij stelt: "Es gibt,..., eine Reihe von Ansatzpunkte und Möglichkeiten, die Präferenzen für öffentliche Güter zu erfas$\operatorname{sen}^{\prime \prime}{ }^{4}$ Hij onderscheidt elf methoden waarmee de preferenties van burgers ten aanzien

T.a.p., p. 148.

${ }^{87}$ T.a.p., p. 143. Vergelijk ook Davis en Holt (1993, p. 337).

88 Olson (1971, hoofdstuk 2).

89 Ledlyard in: Hagel en Roth (eds) (1995), p. 154.

${ }^{90}$ Pommerehne, Feld en Hart (1994, pp. 514-516).

${ }^{91}$ Lipford (1995, pp. 301 e.v.)

92 Zaleski en Zech (1996, p. 410). Vergelijk ook: Tullock (1996, p. 185), Lipford (1996a, pp. 187-188) en Lipford (1996b, pp. 413-416).

${ }^{93}$ Pommerehne (1987, paragraaf 1.2.).

94 T.a.p., p. 7. 
van collectieve goederen of ten minste de vraag naar een collectief goed bepaald kunnen worden. ${ }^{95}$ Er is evenwel geen standaardmethode. Afhankelijk van onder meer de specifieke kenmerken van het collectieve goed komen meerdere methoden in aanmerking. Dat neemt niet weg dat in de praktijk dergelijk empirisch onderzoek door de overheid niet wordt verricht. Enerzijds omdat de benodigde kennis van de openbare financièn bij de overheid in onvoldoende mate aanwezig is en anderzijds omdat de preferenties van de burgers bij het handelen van de overheid blijkbaar miet doorslaggevend zijn. Er is dan ook weinig reden om aan te nemen dat overheidsinstellingen uitsluitend zijn opgericht op grond van het collectieve goed-argument.

Thebout geeft overigens aan dat voor een belangrijk deel van de collectieve goederen, namelijk die goederen die lokaal worden aangeboden, er wel een te realiseren oplossing mogelijk is ${ }^{96}$ De lokale gemeenten (en overheidsinstellingen) bieden een bepaald voorzieningenniveau (in de betekenis van goederenpakket) aan. De burgers wegen de voor- en nadelen van dit voorzieningenniveau af tegen de kosten van verhuizen en tegen de voor-en nadelen van voorzieningenniveaus in andere gemeenten. All naar gelang de uitkomst van deze afweging zullen zij verhuizen (stemmen met de voeten). ${ }^{97}$ Het model van Tiebout is gebaseerd op een zevental veronderstellingen, te weten de veronderstelling van mobiliteit, volledige informatie, het bestaan van een groot aantal gemeenschappen, afwezigheid van beperikingen op het gebied van werkgelegenheid, afwezigheid van externe effecten, het bestaan van een optimale omvang van een gemeente en tenslotte de veronderstelling dat gemeenten mensen proberen aan te trekken indien zij onder de optimale omvang zitten en zullen "afstoten" indien zij boven de optimale omvang zitten. Onder deze veronderstellingen $\mathrm{kan}$, indien wordt afgezien van transactiekosten, een efficiënte uitkomst worden gerealiseerd. Dowding en John stellen: "(..) we show a multivariate model is able to demonstrate Tiebout-moving (...). This provides further corroboration for the Tiebout model ${ }^{\prime \prime} .{ }^{98}$ In Nederland is de mogelijkheid van lokale gemeenten om af te wijken van nationale regelingen vergeleken met andere landen zoals de V.S. relatief gering. Toch hebben ook Nederlandse gemeenten de mogelijkheid om aan de aanbodkant speciale voorzieningen in het leven te roepen. Hierbij kan gedacht worden aan de voortbrenging van collectieve goederen en de vrijheid om tot bepaalde hoogte de tarieven voor gemeentelijke milieuheffingen voor bedrijven en gezinnen vast te stellen. Met name ten aanzien van de riool- en reinigingsrechten zijn er belangrijke verschillen. Gemeenten kunnen proberen door middel van overheidsinstellingen zoals scholen bepaalde goederen aan te bieden. Een ander voorbeeld hiervan is het opzetten van gemeentelijke musea met als doel de aantrekkingskracht van de gemeente te vergroten. Ook bestaan er belangrijke verschillen in de mate waarin minima worden gesubsidieerd.

Een voorbeeld van een sector die gesubsidieerd wordt is de kunst. Als reden voor deze subsidiëring wordt veelal aangevoerd dat kunst een publiek goed is. Omdat de voordelen verbonden aan kunst zo groot zijn en omdat het anderzijds zo moeilijk is om de prijs van kunst te bepalen, wordt wel gesteld dat kunst niet aan de markt overgelaten kan worden. Indien er voldoende kunst beschikbaar dient te zijn moet het worden gesubsidieerd, bijvoorbeeld door het verlenen van subsidies aan musea. Valt kunst, tentoongesteld in

\footnotetext{
95 T.a.p.,p. 11.

96 Tiebout (1956, p. 424).

${ }^{97}$ Dowding en John $(1996$, p. 393).

${ }^{98}$ T.a.p.,p. 403.
} 
musea, nu te beschouwen als een publiek goed? In de literatuur worden verschillende redenen genoemd waarom het een publiek goed zou zijn. ${ }^{99} \mathrm{Zo}$ is wel gesteld dat kunst een onderdeel is van het culturele erfgoed. Iedere burger ontvangt de baten van het behoud van het erfgoed ongeacht of hij daar nu prijs op stelt of niet. Bovendien is er in dat geval een free rider effect. Iedereen denkt dat de voordelen toeh wel ontwangen worden en heeft daarom een prikkel om niet te betalen. Een ander argument waarom kunst kan worden beschouwd als een publiek goed is dat kunst iets is wat de mensen waarderen, ook all hebben ze er niet constant mee te maken. Je kunt een museum waarderen omdat het aanwezig is, een keuzemogelijkheid biedt om er al dan niet heen te gaan. De bewoners van Amsterdam en toeristen denken positief over het Rijksmuseum omdat zij, indien zij dat wensen, de mogelijkheid hebben om er heen te gaan. Als argument waarom kunst een publiek goed is wordt ook wel genoemd dat kunst, bijvoorbeeld gehouden in musea, een bron van nationale trots is. Nederlanders waarderen het Rijksmuseum niet omdat ze er ooit heen zullen gaan mar omdat het wereldwijd bekend is. De redenering is $\mathrm{mu}$ dat kunst, omdat het $\mathrm{kan}$ worden beschouwd als een publiek goed, gesubsidieerd moet worden door de overheid. Door de voorziening in dit goed aan de markt over te laten zou de totale productie van de economie minder zijn dan op zich mogelijk is. Het Rijksmuseum zou derhalve zijn opgericht en worden gecontinueerd omdat het voorziet in een publiek goed (bewaren van het nationale erfgoed). Er is zoals dan wordt opgemerkt wel een prijs voor kunstvoorwerpen, maar deze weerspiegelt onvoldoende het algemene belang ervan.

Het lijkt evenwel niet waarschijnlijk dat dit inderdaad de reden is van het bestaan van het Rijksmuseum. In de eerste plaats is het maar de vraag of er in het geval van kunst die wordt tentoongesteld in musea, sprake is van een publiek goed. Duidelijk is dat er in dat geval sprake is van exclusiviteit. Ook indien kunst wordt gezien als onderdeel van het culturele erfgoed is het niet meteen duidelijk dat het gesubsidieerd moet worden. Dat het culturele erfgoed woordelen heeft voor iedereen zegt weinig. Dit geldt immers voor veel zaken, variërend van wetenschap en technologie tot religie en morele waarden. De kernvragen moeten dan ook zijn: Wat is het voordeel, hoeveel moet worden voortgebracht en wat zijn de kosten. Netzer stelt: ${ }^{100}$ "We as a nation agree not only that the arts are good for us but also that government intervention is necessary to assure more and better artistic production and consumption than would result from unaided pursuit of "narrower commercial purposes" by artists and artistic organizations":

Het probleem is mu echter juist dat niet bewezen is dat bijvoorbeeld het subsidiëren van kunst in musea, omdat het een publiek goed is, evenveel voordeel oplevert als het subsidieren van iets anders of het in het geheel niet subsidiëren van musea. Er moet met andere woorden worden uitgezocht wat de geaggregeerde bereidheid om te betalen is voor het tentoonstellen van kunst in musea als onderdeel van het nationale erfgoed en wat de kosten zijn. Voorts moet onderzocht worden of er alternatieven zijn waarbij de bereidheid om te betalen nog meer boven de kosten ligt. ${ }^{10 \%}$ Voorstanders van het publieke goed karakter van kunst hebben nog steeds niet duidelijk gemaakt dat de bereidheid om te betalen werkelijk boven de kosten ligt. Hierbij komt dat zij de kosten aanzienlijk onderschatten. De kosten zijn het inkomen dat ontvangen zou zijn indien het kapitaal, waaronder de waarde van de collectie, op een andere wijze was geïnvesteerd. Dit is dan ook de reden waarom musea veelal groter zijn dan ze op economische gronden zouden moeten zijn. De conclusie is dat de bereidheid om te betalen door de overheid veelal niet

\footnotetext{
99 Vergelijk bijvoorbeeld: Netzer (1978, pp. 12 e.... $)$.

${ }^{100}$ T.a.p., p. 16.

101 Zje ook: Heilbrun (1996, p. 73).
} 
wordt onderzocht. Frey en Pommerehne stellen in dit verband: "There exists no such thing as the "welfare of society" in any area, and least of all in the cultural field. There are only interpretations by public decision-makers of what kind of ant should be supported. There is a large subjective element in such interpretations, without thase involved necessarily being aware of it. Thus, even if politicians and administrators were inclined to pursue the common good in the case of art, they would do so in a quite personal way". 102 Musea kunnen dan ook nooit alleen om deze reden zijn opgericht.

\subsubsection{Externe effecten}

Een derde reden houdt verband met externe effecten. Er bestaan verschillende opvattingen over wat nu precies verstaan moet worden onder externe effecten. Bator interpreteert externe effecten bijwoorbeeld dermate nuim dat de meeste corzaken van marktfalen hieronder gebracht kunnen worden. ${ }^{103}$ De meeste schrijvers volgen een meer beperkte benadering wan externe effecten omdat oorzaken van marktfalen zoals monopolie aanzienlijk verschillen van de comventionele externe effecten. Hier wordt onder externe effecten verstaan: de invloeden die van bepaalde economische handelingen uitgaan op niet bij deze handellingen betrokken ondernemingen en huishoudingen, dus invloeden die buiten de markt omgaan. ${ }^{104}$ Externe effecten kunnen van technische en van financiële aard zijn. Technische externe effecten beinvloeden de input-output combinaties en de marginale kosten van derden. ${ }^{105}$ Deze externe effecten maken derhalve deel uit van de productieof nutsfunctie. Financiële exterme effecten leiden niet tot veranderingen in input-outputcombinaties. $\mathrm{Zij}$ ontstaan indien externe effecten worden overgebracht door hogere prijzen. De activiteiten van de één hebben financiële consequenties voor een ander maar leiden niet tot een verkeerde allocatie van middelen, uitgaande van volkomen mededinging. ${ }^{106}$ Baumol en Oates noemen als voorbeeld van financiële extèrne effecten het effect dat een toename van de vraag naar schoenen heeft op de prijs van leer en daarmee op de welvaart van de kopers van leren tassen. ${ }^{10 T}$ Anders dan in het geval van technische externe effecten zou dit geen verschuiving van de productiefunctie van leren tassen tot gevolg hebben. Deze financiële externe effecten veroorzaken geen marktfalen maar weerspiegelen de grotere schaarste van een bepaald goed. Bij technische externe effecten is dit juist niet het geval. Effecten worden dan niet weerspiegeld in hogere of lagere prijzen. ${ }^{108}$ Overigens blijkt een duidelijk onderscheid tussen technische en financiële externe effecten in de praktijk niet altijd mogelijk.

${ }^{102}$ Frey en Pommerehne (1989, p. 28).

${ }^{103}$ Baumol en Oates (1988, p. 29).

${ }^{104}$ Rosen (1988, pp. 124-126). Zle voor een overzicht van de literatuur: Papandreou (1994).

105 Bator (1958; p. 357).

106 Zie voor de kenmerken van de marktvorm volkomen mededinging: Mamuth (1990, pp. 0.4.-0.5). De marktvorm volkomen mededinging ("perfect competition") combineert de marktvorm volledige mededinging ("pure, competition", dat wil zeggen, veel marktpartijen, homogene goederen en geen toetredingsbelemmeringen) met marktperfectie en vrije prijsvorming.

${ }^{107}$ Baumol en Oates (1988, pp. 30-31).

${ }^{108}$ Tietenberg (1992, pp. 52-54). 
Er zijn verschillende oorzaken voor het ontstaan van externe effecten. De eerste oorzaak houdt verband met het bestaan van non-convexiteit. Ondanks dat het maatschappelijk wenselijk kan zijn een bepaalde hoeveelheid te produceren produceert een individuele producent miet. Dit kan zich voordoen indien, voordat enige productie mogelijk is, aanzienlijke hoeveelheden inputs nodig zijn om het productieproces op te zetten. De hoge aanvangskosten leiden entoe dat de productiemogelijkhedencurve niet convex is. Hierdoor zou een individuele producent een verlies lijden. Het is daamaast mogelijk dat de eigendomsrechten goed geformuleerd zijn maar dat de transactiekosten dermate hoog zijn dat een markt voor bepaalde goederen niet actief is. Ondanks de afwezigheid van een markt wordt het betreffende goed samen met eventuele externe effecten in positieve hoeveelheden voortgebracht. De consument consumeert een hoeveelheid die hij niet kan controleren. Dat geldt zowel voor het eigenlijke goed als voor de externe effecten daarvan. ${ }^{10}$ In de derde plaats ontstaan externe effecten veelal omdat niemand eigenaar is van het betreffende goed (water, lucht e.d.). De eigendomsrechtenstructurur is niet exclusief. Indien de rook van een fabriek bijvoorbeeld onderdeel zou zijn van een markttransactie zodat de eigenaar van een aangrenzend perceel het efficiènte niveau van de rook kan weergeven, zou het externe effect niet leiden tot inefficiëntie. Vaak wordt gestell dat indien een dergelijke markt ontbreekt en indien er geen equivalente institutionele voorziening is , zoals bijvoorbeeld onderhandelen in het geval van het Coase-theorema, de uitkomst waarschijnlijk inefficiënt zal zijn. "Hi Hiertegen kan worden aangevoerd dat indien er geen oplossing bestaat, er geen sprake zou zijn van inefficiëntie.

Voor een privaat goed (vergelijk paragraaf 2.2.1.2) geldt dat de marginale sociale kosten gelijk zijn aan de marginale private kosten en wordt in principe een efficiënte hoeveelheid geproduceerd. Indien er zich externe effecten voordoen is dat niet het geval, ${ }^{112}$ In het geval van een negatief extern effect geldt dat de marginale sociale kosten hoger zijn dan de marginale private kosten. Er wordt te veel geproduceerd $\mathrm{Bij}$ een positief extern effect zijn de marginale sociale kosten lager dan de marginale private kosten met als gevolg dat er te weinig geproduceerd wordt. Nemen wij bijwoorbeeld een elektriciteitscentrale dan kan geconstateerd worden dat een aantal externe effecten zoals vervuiling, de effecten van warm koelwater e.d. niet of onvoldoende in de prijzen zijn opgenomen. De prijs is lager dan de marginale sociale kosten. Evenals bij de voortbrenging van collectieve goederen en de aanwezigheid van een natuurlijk monopolie als bestaansreden voor overheidsinstellingen kan ook hier weer het bezwaar worden aangevoerd dat er tal van andere mogelijkheden zijn om externe effecten te internaliseren. De overheid kan onder meer kiezen voor een Pigoviaanse belasting, voor subsidies, het verhandelen van vervuilingsrechten, regulering en onderhandelen in het kader van het Coase-theorema. Het Coase-theorema impliceert dat indien eigendomsrechten eenmaal zijn vastgesteld, er geen overheidsinsterventie meer nodig is om negatieve externe effecten tegen te gaan ${ }^{113}$ Een meer is dan bijvoorbeeld niet langer publiek eigendom maar wordt overgedragen in particuliere eigendom. Indien de nieuwe eigenaar streeft naar winstmaximalisatie zal de uitkomst in

${ }^{109}$ Comes en Sandler (1986, p. 34).

${ }^{110}$ T.a.p., pp. $39-41$.

${ }^{111}$ Newberry (1989, Hoofdstuk. 10, p. 215).

${ }^{112}$ Rosen (1988, p. 127).

${ }^{113}$ Cornes en Sandler (1986, p. 33). 
een situatie van particuliere eigendom maatschappelijk efficiènt zijn. ${ }^{114}$ Toch zullen door de introductie van eigendomsrechten externe effecten lang niet altijd opgelost worden. Indien de onderhandelingskosten hoog zijn is het onwaarschijnlijk dat de betrokkenen met elkaar gaan onderhandelen en tot een overeenkomst komen. Denk bijvoorbeeld aan luchtvervuiling waarbij miljoenen mensen betrokken kannen zijn. Bovendien suggereert het theorema dat eigenaren de vervillingsbron gemakkelijk kunnen opsporen. Vaak is dat niet het geval maar zijn er duizenden mogelijke bronnen. Het is voor de eigenaar dan ondoenlijk om langs juridische weg de vervuiling te voorkomen. Tenslotte kan de overheid met behulp van overheidsinstellingen zelf de juiste hoeveelheid voortbrengen. Een voordeel hiervan is dat de overheid dan zeker weet dat een maatschappelijk efficiënte productie wordt gerealiseerd. Het is waarschijnlijk dat een overheidsinstelling gemakkelijker gecontroleerd kan worden dan particuliere bedrijven waaraan emissierechten zijn toegekend. Productie door overheidsinstellingen kan in dit verband ook een goed alternatief zijn voor een milieuheffing. Een verhoging van de prijs van bijwoorbeeld elektriciteit door een overheidselektriciteitsbedrijf zou voor een belangrijk deel hetzelfde effect hebben als een heffing op de gebruiker, evenwel zonder de extra administratieve last en kosten van een dergelijke Pigoviaanse belasting.

Op grond van de theorie van het marktfalen is het niet altijd duidelijk welke van de genoemde mogelijkheden om negatieve externe effecten tegen te gaan gekozen moeten worden. Noch is het gezegd dat voor zover dat wel duidelijk is, dit in de praktijk gebeurt. Tenslotte kan ook hier worden opgemerkt dat in de praktijk nauwelijks overheidsinstellingen zijn te vinden die (uitsluitend) op grond van deze reden in het leven zijn geroepen en: worden gecontinueerd.

Als voorbeeld van overheidsinstellingen die mede gecontinueend worden in verband met de door hen voontgebrachte externe effecten wordt vaak gewezen op musea. Hierbij kan gedacht worden aan de Nederlandse rijksmusea, die in de jaren ' 80 onderdeel uitmaakten van het Ministerie van WVC. ${ }^{115}$ Allereerst kan ook hier weer de vraag worden gesteld waarom de overheid zich door allocatie-overwegingen zou laten leiden. Om te weten te komen of deze musea werkelijk zijn opgericht en worden gecontimueerd op grond van de voortgebrachte positieve externe effecten is het essentieel te weten of er bij het bewaren en tentoonstellen van kunst in musea inderdaad sprake is van externe effecten. ${ }^{116}$ Allereerst rijst de vraag of de externe effecten die worden toegeschreven aan de kunst reële externe effecten zijn. Netzer beschrijft een viertal externe effecten, namelijk:"117

1. Kunst is beter naarmate de hoeveelheid andere kunst groter is. Verschillende kunstvormen als opera, concerten en populaire muziek vergroten de kennis, vaardigheden en werkgelegenheidsmogelijkheden en ondersteunen in die zin elkaar.

2. Eir zal in de toekomst meer kunst zijn en deze kunst zal beter zijn naarmate er in het heden meer kunst is. Toekomstige generaties kunnen profiteren van de kunst die nu gemaakt wordt. Deze kunst moet echter nu worden betaald.

3. Hoe groter de hoeveelheid kunst op een bepaald moment is, hoe waarschijnlijker het is dat een deel hiervan experimenteel is.

\footnotetext{
${ }^{114}$ Baumol en Oates (1988, p. 28).

11: Tegemwoordig ressortenen deze musea onder hel ministerie van Onderwijs, Cultuur en Wetenschappem (OCW).

116 Vergelijk Klamer (1995, p. 301). Zie ook: Klamer (1996).

117 Netzer $(1978$, pp. 22-24).
} 
4. Kunst en cultuur zijn belangrijk voor steden om bezoekers aan te trekken, hetgeen inkomsten oplevert voor onder meer hotels en restaurants.

Hoewel deze argumenten op zich juist zijn wijst Grampp erop dat dat voor veel goederen geldt. ${ }^{18}$ "The more automobiles there are, the greater will be the demand and output of tires and the greater will be there durability". In de literatuur worden ten aanzien van kunst meerdere mogelijke reële externe effecten genoemd. Bij nader inzien blijken de meeste van deze vermeende reële effecten geen reële maar financiële externe effecten of helemaal geen externe effecten te zijn. Voor zover het wel gaat om positieve reële externe effecten rijst de vraag of de overheid deze effecten niet goedkoper op een andere wijze kan realiseren. Grampp noemt als voorbeeld het door Australische economen genoemde reële externe effect dat mensen die kunst waarderen zich meer aan de wet houden. Indien dit effect al zou bestaan zou bewezen moeten worden dat een uitgave door de overheid aan musea de criminaliteit meer zou verminderen dan het zelfde bedrag besteed aan cellen of politieagenten. Voorts zou vanzelfsprekend bewezen moeten worden dat de overheid zich ook inderdaad door dit soort overwegingen laat leiden.

De meeste externe effecten die aan kunst worden toegeschreven zijn evenwel van financiële aard. Het financiële externe effect ten gevolge van kunst houdt in dat kunst in musea mensen aantrekt waardoor er meer wordt uitgegeven in een gemeente en waardoor het inkomen van een gemeente toeneemt. Grampp vermeldt als voorbeeld de studie naar de effecten op New Orleans van de tentoonstelling van de schatten van Toetanchamon. Uit deze studie bleek dat voor elke dollar die aan de kunst besteed wordt ongeveer drie dollar elders wordt besteed, waardoor er een multipliereffect is van drie. ${ }^{119}$ Hiertegen kan worden aangevoerd dat wat de ene gemeente wint door de subsidie aan het museum door een andere gemeente verloren wordt doordat zij minder bezoekers ontvangt en doordat zij waarschijnlijk hogere belastingen moet betalen om de subsidie te kunnen financieren. Hetzelfde geldt voor landen. Indien het ene land subsidieert en het andere niet valt te verwachten dat mensen musea in het subsidiërende land gaan bezoeken. Overigens dient wel bedacht te worden dat musea tot bepaalde hoogte complementair zijn. Twee musea naast elkaar zullen elkaar niet alleen beconcurreren maar zullen elkaar ook aanvullen. Denk bijvoorbeeld aan musea in Brussel, Amsterdam en Berlijn. Het is denkbaar dat deze samen meer toeristen trekken uit bijvoorbeeld de VS en Japan dan ze ieder afzonderlijk zouden doen. Musea zijn dus gedeeltelijk complementair en zullen tot bepaalde hoogte met elkaar concurreren. Samenvattend zijn er echter al met al toch weinig redenen om aan te nemen dat de rijksmusea vanwege positieve externe effecten zijn opgericht en worden gecontinueerd. Ook indien aangenomen wordt dat kunst externe effecten voortbrengt, rechtvaardigt dit geenszins de subsidiëring van musea door de overheid. We moeten ook weten hoeveel waarde de mensen ontlenen aan de externe effecten. Dit komt tot uiting in hun bereidheid om te betalen. Hieronder wordt het bedrag verstaan dat een individu zou willen betalen voor het externe effect, ervan uitgaande dat zonder zijn bijdrage het museum niet zou kunnen voortbestaan. Het probleem is nu te weten te komen hoeveel de positieve externe effecten waard zijn voor menisen die deze baten ontvangen en wat de mensen dienovereenkomstig bereid zijn te betalen voor deze externe effecten. Voorts moeten de kosten van het betreffende beleidsinstrument (museum, subsidie, etc.) bepaald worden en tegen elkaar worden afgewogen.

Een ander voorbeeld van een overheidsinstelling die is opgericht in verband met het

118 Grampp (1989. pp. 249-250).

119 T.a.p., p. 247. 
bestaan van positieve externe effecten is de PTT (KPN). De toegang tot een groot telecommunicatienetwerk is veelal van meer waarde dan de toegang tot een klein netwerk. Elke aanvullende cliënt van het netwerk creëert een voordeel voor andere gebruikers van het netwerk. In die zin is er sprake van een positief extern effect. Het is ook mogelijk dat het toevoegen van extra gebruikers aan een netwerk negatieve externe effecten met zich meebrengt. Hierbij kan gedacht worden aan langere wachttijden en overbelasting van het net. Het lijkt warschijinlijk dat positieve externe effecten zullen afnemen indien het netwerk een bepaalde omvang heeft bereikt. Nu in Nederland zo ongeveer iedereen op het telefoonnet is aangesloten lijken dergelijke positieve externe effecten te zijn uitgeput. Mogelijk is wel dat het bestaan van positieve externe effecten destijds een rol heeft gespeeld bij de oprichting van de PTT als overheidsinstelling. In paragraaf 2.2 .2 wordt aangegeven dat vooral andere redenen van belang zijn geweest.

Bij de Spoorwegen geldt eveneens dat aanvankelijk de uitbreiding van het spoorwegnet gunstig is voor al bestaande gebruikers. Stel bijwoorbeeld dat in het begin alleen gereisd kan worden tussen Maastricht en Heerlen. Door de toename van het aantal gebnikers kan het spoorwegnetwerk worden uitgebreid, bijvoorbeeld naar Utrecht, hetgeen positieve externe effecten voor de bestaande gebruikers met zich meebrengt. Tegenwoordig zijn de positieve externe effecten voor een belangrijk deel uitgeput. Nog meer reizigers leidt tot minder comfort en langere wachttijden voor de bestaande reizigers. Overigens kan binnen het bestaande netwerk de opbrengst sterk vergroot worden. Dit is mogelijk door meer gebruik te maken van marktsegmentering. In Nederland is het onderscheid tussen de eerste en tweede klas altijd zeer beperkt geweest. Door dit onderscheid te vergroten, meer eerste klas rijtuigen in te voeren en de prijzen te verhogen zou de opbrengst kunnen toenemen. Wellicht kunnen dan ook bepaalde lijnen rendabel blijven die nu dreigen te verdwijnen.

\subsubsection{Het onvoldoende aanwezig zijn van informatie}

Een vierde argument voor het oprichten van overheidsinstellingen heeft betrekking op het niet totstandkomen van markten voor bepaalde goederen en diensten, waamaar op zich wel vraag is en die tegen een prijs lager dan de marktprijs kunmen worden voortgebracht. De reden hiervoor is het onvoldoende aanwezig zijn van informatie bij bedrijven. 120 Dit verschijnsel doet zich onder meer voor bij bepaalde verzekeringen en in de bancaire. sector. Problemen die zich hierbij voordoen zijn averechtse selectie ("adverse selection") en zedelijk risico ("moral hazard"): Bij averechtse selectie ontstaat voor bepaalde goederen geen markt omdat alleen mensen die waarschijnlijk in de toekomst ook een claïm op de verzekeringsmaatschappij zouden leggen, zich zouden verzekeren. ${ }^{121} \mathrm{Bij}$ averechtse selectie wordt het gedrag als gegeven beschouwd. Cliènten zijn dan evenwel in staat om zich vooraf anders voor te doen. ${ }^{122}$ Indien sprake is van zedelijk risico kan de waarschijnlijkheid dat iemand een beroep doet op de verzekering beinvloed worden door individueell gedrag. ${ }^{123}$ Na het sluiten van het contract past de agent zijn gedrag zodanig

\footnotetext{
120 Vergelijk: Stiglitz (1994, pp. 33-36).

${ }^{121}$ Coles en Malcomson (1989, Hoofidstuk 5, p. 138).

122 T.a.p., p. 145.

123 T.a.p., p 136.
} 
aan dat het anders is dan de principaal verwacht. ${ }^{124}$ Indien dergelijke redenen ertoe leiden dat er geen markten tot stand komen leidt dat tot een inefficiënte allocatie. De overheid kan proberen door middel van overheidsinstellingen de niet op markten tot stand gekomen diensten alsnog voort te brengen teneinde deze inefficiëntie ongedaan te maken. Particuliere banken verrichten bijwoorbeeld bepaalde diensten niet, omdat zij het risico van voortbrenging van deze diensten te groot achten en omdat zij over onvoldoende informatie over de vraag naar die diensten beschikken. Kredietverlening aan verlieslijdende (overheids)instellingen kan dermate grote risico's met zich meebrengen dat een particuliere bank hier niet toe zal overgaan. Vaak wordt gesteld dat de overheid daarom de Nationale Investeringsbank (N.I.B.) in het leven heeft geroepen. ${ }^{125}$ De N.I.B. werd vooral opgericht met het doel kredieten te verlenen aan kleine en middelgrote ondernemingen met een risico dat dermate hoog was dat particuliere banken daar niet toe bereid waren. Tot de N.I.B. zullen zich met name die bedrijuen wenden die elders geen leningen ontvangen en dus een verhoogd risico hebben (averechtse selectie). Indien het bedrijf geleend heeft van de overheid via de N.I.B. wordt de kans kleiner dat de overheid het bedrijf failliet zal laten gaan. Dit schept een moral hazard probleem. Het bedrijf kan stellen niet in de gelegenheid te zijn om terug te betalen omdat dit de bedrijfswoering en bijvoorbeeld de werkgelegenheid in gevaar kan brengen.

Ook bij dit marktfalenargument voor het oprichten van overheidsinstellingen, l.c. de N.I.B., kunnen een aantal kanttekeningen worden geplaatst. Het lenen aan minder efficiënte bedrijven kan leiden tot een inefficiënte allocatie. Het is niet altijd bekend of een bedrijf op de lange termijn wel rendabel zal zijn. Voorts is het niet duidelijk hoeveel geleend moet worden op grond van deze overwegingen. Hoe bereken je het uit te lenen bedrag dat op grond van marktfalen gerechtvaardigd is? Het is onwaarschijnlijk dat de overheid over deze informatie beschikt. Bovendien zijn er mogelijk alternatieven die meer van een eventuele tekortkoming wegnemen tegen lagere kosten.

\subsubsection{Belastingheffing}

Een vijfde reden waarom marktwerking inefficiënt zou kunnen zijn houdt verband met de wijze van inkomstenverwerving door de overheid. De overheid dekt haar inkomsten voornamelijk door belastingen, welke belangrijke welvaartsverliezen tot gevollg kunnen hebben. Naarmate de belastingdruk toeneemt leiden belastingen tot hogere welvaartsverliezen ("excess burdens"). Dit kan verduidelijkt worden met de Laffercurve, waarbij na een bepaald belastingtarief de belastingopbrengst afneemt, tengevolge van deze toenemende welvaartsverliezen. De vervanging van belastingen door de opbrengsten van overheidsinstellingen kan leiden tot lagere welvaartsverliezen, vanzelfsprekend alleen voor zover overheidsinstellingen zich aan de marktwerking houden. 26 Een voordeel hiervan zou zijn dat burgers zelf een keuze zouden kumnen maken tussen het al dan niet kopen van de goederen van de overheidsinstelling. Het kopen van de goederen van de overheidsinstelling gaat op basis van vrijwilligheid in tegenstelling tot belastingen die juist een gedwongen karakter hebben. Dit zou betekenen dat de overheid voor een deel zou terugkeren naar het oude concept van de ondernemingsstaat van de Kameralisten, waarbij het voor de overheid geeligend was deel te nemen aan het marktproces.

124 T.a.p.., p. 141.

125 Vgl. Van Gool (1988, p. 2).

126 Backchaus (1980, pp. 19-20). 


\section{Conclusie}

De "public interest"-theorie ging ervan uit dat de overheid intervenieert om het algemeen belang te bevorderen en om daarmee een inefficiënte allocatie te bestrijden. ${ }^{127}$

In de voorgaande paragrafen zijn de nodige kanttekeningen geplaatst bij het belang van marktfalen als verklaring woor het bestaan en oprichten van overheidsinstellingen. Overheidsinstellingen kunnen in verband met het falen van markten zijw opgericht en kunnen ora deze redenen worden gecontinueerd, maar het is onwaarschijnlijk dat dit in de praktijk op grond hiervan gebeurt. Vaak zal de overheid zich niet laten leiden door marktfalenoverwegingen. Veelal is het erg moeilijk de bereidheid om te betalen van de mensen te bepalen. Musea en dergelijke kunnen dan ook nooit alleen om deze redenen zijn opgericht. In ieder geval kan de omvang van de betreffende overheidsinstelling niet alleen bepaald zijn op grond van dergelijke overwegingen. Indien het vanuit nommatief oogpunt wenselijk is om een overheidsinstelling op te richten maar dit gebeurt in de werkelijkheid niet of indien het in de praktijk onmogelijk blijkt om met behulp van een overheidsinstelling de betreffende gebreken te corrigeren, is deze benadering van weinig belang. In feite is er dan ook geen sprake van marktfalen. De markt kan niet gebruikt worden voor zaken waarvoor zij niet geschikt is. Een eventueel op grond van een marktfalenbenadering nagestreefde allocatie zou slechts "Nirvana-beleid" zijn. Andere redenen moeten een rol hebben gespeeld. In de volgende paragrafen wordt nader op deze redenen ingegaan.

\subsubsection{Kan het bestaan van overheïdsinstellingen worden verklaard door de verde- lingsfunctie?}

Vaak wordt gedacht dat vooral progressieve belastingen leiden tot herverdeling. Overheidsinstellingen kunnen door een bepaalde prijsstelling en door de voortbrenging van bepaalde diensten hetzelfde bereiken. Indien herverdeling plaatsvindt via overheidsinstellingen zullen bepaalde groepen hiervan immers meer profiteren dan andere. Hochman en Rodgers stellen dat een gedeelte van de herverdeling door de overheid de politieke macht van de ontvangers weerspiegelt (een politiek proces). ${ }^{128}$ Daarnaast achten zij het geloofwaardig dat een deel van deze herverdeling niet alleen voordelig is voor de ontvangers maar ook voor de (belasting-)betaler (die indirect geld verstrekt aan overheidsinstellingen). Dat ook betalers voordeel ontlenen aan de betaling verklaren zij enerzijds door te wijzen op de preferenties van individuen ten aanzien van zekerheid en anderzijds door het benadrukken van de onderlinge afhankelijkheid van individuele nutsfuncties. Gegeven een dergelijke afhankelijkheid tussen nutsfuncties is het mogelijk dat enige herverdeling tedereen beter af maakt, op voorwaarde zoals zij stellen dat deze afhankelijkheid de vorm aanneemt van een extern effect. In dat geval is het mogelijk dat Pareto-optimale verdeling, in tegenstelling tot wat de orthodoxe leer van de openbare financièn leert, nilet alleen spoort met inkomensherverdeling maar deze zelfs vereist. Indien een onderlinge afhankelijkheid van mutsfuncties bestaat is het mogelijk door middel van herverdeling door middel van overheidsinstellingen (bijvoorbeeld via lage elektriciteitsprijzen) de welvaart van iedereen te vergroten.

\footnotetext{
${ }^{127}$ Posner (1976, pp. 334 e.v. $)$

128 Hochman en Rodgers (1969, pp. 542-544). Vergelijpk ook: Hochman en Rodgers (1970, pp. 997-1002) en Hochman en Rodgers (1974, pp. 752-757).
} 
De verdelingsfunctie wordt door Musgrave en Musgrave in enge zin uitgelegd. In feite beperken zij zich tot inkomensherverdeling op grond van rechtvaardigheidsoverwegingen. Het is evenwel ook mogelijk de inkomensverdeling ruimer op te vatten. ${ }^{129}$ In dat geval wordt het gebruik van de "public enterprise rent" gezien als een vorm van inkomensverdeling. Bij deze verdeling sluit een andere benadering aan, te weten de "public choice" benadering. ${ }^{130}$ Volgens deze benadering zijn overheidsinstellingen het resultaat van een continu onderhandelingsproces tussen belangengroepen, de overheidsbureaucratie en politici. Hierbij moet worden opgemerkt dat deze vorm van "rentseeking" nauw samenhangt met de allocatiefunctie en ook hieronder kan en misschien wel moet worden gebracht. De overheid streeft doelen ma en maakt daarvoor een afweging van de te gebruiken middelen. Het kan zijn dat het doel het goedkoopst nagestreefd kan worden met behulp van een overheidsinstelling. In paragraaf 2.3 wordt hier verder op ingegaan. Hoewel vaak gesteld wordt dat overheidsinstellingen worden opgericht om bepaalde marktgebreken te corrigeren en om bepaalde macro-economische doelen te bereiken, kunnen hierbij zoals vermeld, de nodige vraagtekens gezet worden. In het kader van de theorie van het marktfalen is het gewenst dat de overheid optreedt teneinde een Paretooptimale allocatie te bevorderen. Het is echter niet gezegd dat de overheid dit ook werkelijk kan. Eén en ander is namelijk afhankelijk van de hoeveelheid relevante informatie waarover de overheid beschikt en dit is vaak een probleem aangezien er geen markt is waarop deze informatie tot uitdrukking kan komen. Voorts is het mogelijk dat het betreffende marktgebrek reeds op een andere wiize, bijvoorbeeld door de instelling van een institutie (grotendeels) is opgelost. ${ }^{131}$

Tenslotte is het zo dat overheidsingrijpen bepaalde kosten met zich mee zal brengen. Derhalve moet een kosten-baten-analyse opgesteld worden om te bezien of de allocatieve efficiëntie tegen redelijke kosten kan worden bereikt. Voorts is het mogelijk dat er in het geheel geen informatie is.

Naast het corrigeren van marktimperfecties zijn andere factoren van belang. Het lijkt onwaarschijnlijk dat bijvoorbeeld het Rijksmuseum alleen is opgericht om een allocatieve inefficiëntie te corrigeren en hoewel bij de oprichting van een elektriciteitsbedrijf in de vorm van een overheidsbedrijf efficiëntie-overwegingen een rol zullen hebben gespeeld, zijn veelal ook andere overwegingen van belang. Deze overwegingen houden veeleer verband met een "public-choice" proces. ${ }^{132}$ De overgang van particuliere naar publieke bedrijven beïnvioedt de winststructuur in een economie. Dit zall met name het geval zijn indien een overheidsinstelling technisch inefficiënt produceert en derhalve veel "rents" voortbrengt. Bij een particulier bedrijf zullen middelen veelal worden uitgekeerd an de aandeelhouders. Bij een overheidsinstelling worden middelen vaak overgeheveld naar de overheid, personeel, management en consumenten. De overheidsinstelling kan dan ook gezien worden als een verzameling actoren die beschikken over een bundel eigendomsrechten. Uitgangspunt van de "public choice" benadering is dat al deze actoren bepaalde doelen nastreven. In het geval van overheidsinstellingen zullen zij proberen zich zo veel mogelijk van de gederfde winst ("public enterprise rent") toe te eigenen. Deze "rentsee-

${ }^{129}$ Zie ook: Ramanadham (1995, p. 2).

${ }^{130}$ Posner (1971, pp. 341-342). Vergelijk ook: Tollison en Tullock (eds) (1987).

${ }^{131}$ Newberry in: Hahn (1989, Hoofdstuk 10, pp. 215 e.w. $)$.

132 McLean (1987, pp. 1-3). 
king" is dan de voornaamste reden voor het bestaan van overheidsinstellingen. ${ }^{133}$ Indien politieke actoren hun doelen beter kunnen bereiken door het oprichten van een overheidsinstelling of door middel van nationalisering, zullen zij hiertoe overgaan. Het omgekeerde is ook mogelijk. Menen de actoren dat overheidsinstellingen de door hen beoogde doelen in de weg staan, dan zallen zij geneigd zijn tot privatisering. ${ }^{134}$ Dit verklaart ook waarom overheidsinstellingen vaak verliesgevend zijn of gekenmerkt worden door een relatief laag rendement. Overheidsinstellingen worden dan niet gebruikt om inkomsten te genereren voor de overheid, bijvoorbeeld door produkten aan te bieden die goed in de smaak vallen, maar om bijkomende doelen te realiseren. Er kan dan ook worden gesteld dat het voor de tegenwoordige overheid kenmerkend is dat zij gefinancierd wordt door belastingen, hetgeen door Schumpeter wordt aangeduid als de belastingstaat, en miet door zich als ondernemer te begeven op markten, de zogenaamde ondernemingsstaat. ${ }^{135}$ Indien het welvaartssysteem van een land weinig ontwikkeld is kan de prijsstelling door overheidsinstellingen gebrukt worden om een herverdeling tot stand te brengen. Indien het belasting-en sociale zekerheidsstelsel wan een land anderzijds hoog ontwikkeld is kan prijsstelling door overheidsinstellingen gebruikt worden als een minder zichtbare vorm van herverdeling van inkomen en vermogen dan verkregen zoli kunnen worden door regulering en belastingen. ${ }^{136}$ Belastingwetgeving is onderworpen aan intensieve parlementaire controle. Aharoni geeft aan dat door de veelheid van doelen van overheidsinstellingen de controle op overheidsinstellingen verloren gaat. ${ }^{137}$ Een mindere prestatie ten aanzien van het eigenlijke doel kan immers veroorzaakt worden door een betere prestatie ten aanzien van de andere nagestreefde doelen, die vaak minder zichtbaar zijn. Bovendien zijn de geldstromen binnen een overheidsinstelling vaak geen onderdeel van de overheidsbegroting, een andere reden waarom de allocatie onzichtbaar is.

De herverdeling door overheidsinstellingen lijkt in eerste instantie beperkt te zijn. Indien de herverdeling te ver gaat zal dat immers gepaard gaan met verliezen en zal de overheid moeten bijspringen. Aharoni ${ }^{138}$ merkt op dat het publiek deze verliezen zal zien als het gevolg van inefficiënt opereren van overheidsinstellingen en niet als gevolg van het nastreven van bijkomende doelen. Desalniettemin kunmen de effecten van overheidsinstellingen, zeker indien er veel overheidsinstellingen zijn, op de herverdeling aanzienlijk zijn. De herverdelende activiteit van een overheidsinstelling hoeft niet te leiden tot verlies indien de overheidsinstelling gebruik maakt van kruiselingse subsidiëring of indien de herverdelende activiteit ten koste gaat van investeringen in kapitaalgoederen en bijvoorbeeld onderzoek en ontwikkeling. Daar komt bij dat overheidsinstellingen veelal een bevoorrechte positie genieten. Zo ontvangen zij vaak leningen tegen lagere tarieven en kunnen zij, mede op grond van eventuele monopolieposities, goederen aan afnemers leveren tegen lagere tarieven (tegenover deze voordelen staan evenwel ook nadelen, bijvoorbeeld in de vorm van politieke interventiemogelijkheden en restricties: vergelijk hoofdstuk 9). Overheidsinstellingen hoeven deze voordelen niet te gebruiken om te

133 Zie over "rent-seeking" verder: Crew en Rowley (1988, pp. 49-67).

${ }^{134}$ Backhaus (1989, pp. 364-366 e.v.).

${ }^{135}$ Schumpeter in: Schumpeter $(1953$, pp. $1-71$, p. 22, p. 35$)$.

136 Vogelsang $(1990$, p. 17).

137 Aharoni (1986, Preface).

138 T.a.p., pp. 169 e.v. 
concurreren met particuliere ondernemingen. Vaak worden zij gebruikt om een reeks van doelen, zoals nagestreefd door een coalitie van politieke actoren, te realiseren. De prijs die wordt gerekend ligt veelal beneden de lange termijn marginale kosten. Shapiro en Sheiton $^{139}$ verklaren de prijsstelling beneden de marginale kosten van overheidsinstellingen door te benadrukken dat lage prijzen kunnen zorgen voor aanvaarding van het project, terwijl prijsstijging na aanvaarding van het project ertoe kan leiden dat er oppositie ontstalat van gebruikers. De managers van de bedrijven worden hier rechtstreeks door geraakt en bovendien zullen politici met het $00 \mathrm{~g}$ op herverkiezing prijsstijging tegengaan. Politici proberen methoden te vinden om de constitutionele beperkingen op het lenen aan overheidsinstellingen te verminderen. Dit zal veelal verband houden met de financiering van activiteiten buiten de begroting om ("off-budgetactiviteiten") waardoor het financieringstekort van de overheid kleiner lijkt. Aharoni ${ }^{140}$ geeft aan dat in het geval van een coalitie-regering overheidsinstellingen door afzonderlijke ministers gebruikt kunnen worden om zonder medeweten of expliciete instemming van andere ministers en meer expliciet de minister van Financiën, de fondsen binnen deze bedrijven te gebruiken voor eigen doelen. De overheid kan overheidsinstellingen gebnuiken voor doelen waarvoor waarschijnlijk geen parlementaire meerderheid zou worden gehaald, verder kan zij politiek verwante personen benoemen en voordelen geven aan hen die de betreffende partijen steunen. Ook de werknemers trachten zoveel mogelijk voordelen te behalen bijvoorbeeld door het streven naar het verwijderen van beloningsplafonds. Tenslotte hebben ook andere actoren doelen die zij in het interactieproces proberen te realiseren. Een belangrijke verklaring voor het bestaan van overheidsinstellingen vormit dan ook het bestaan van interne subsidiëring. Interne subsidiëring kan worden beschouwd als ëen van de belangrijkste vormen van "rent-seeking" en verklaart voor een belangrijk deel waarom veel goederen en diensten in een gereguleerde bedrijfstak tegen lagere tarieven en in grotere hoeveelheden worden voortgebracht dan in een niet gereguleerde bedrijfstak. Een belangrijk kenmerk van interne subsidiëring is dat overheidsinstellingen uniforme tarieven gebruiken die gebaseerd zijn op de totale gemiddelde kosten van verschillende diensten. Hierbij kan gedacht worden aan elektriciteitstarieven voor klein-gebruikers, die in principe niet verschillen voor klamten die verder van het distributiebedrijf zijn gevestigd. Bepaalde diensten worden geleverd beneden de marktprijs. Deze diensten worden betaald door middel van interne subsidiëring, hetzij door toekomstige generaties (bijvoorbeeld een gasbedrijf in handen van de overheid dat een prijs rekent zonder rekening te houden met de "scarcity rent"), hetzij door aandeelhouders, schuldeisers van het bedrijf of door andere klanten van het bedrijf die een prijs betalen die hoger ligt dan de kosten die gemaakt moeten worden om hen te bedienen. Hoewel dit in de praktijk vaak moeilijk is moet interne subsidiëring onderscheiden worden van andere vormen van prijsstelling. Prijsstelling op grond van de Ramsey-regel, zoals behandeld zal worden in hoofdstuk 4, is geen interne subsidiëring, aangezien de prijs niet beneden de marginalle kosten wordt gesteld. Ook "predatory pricing", een tijdelijke tactiek om concurrenten uit de markt te drijven, en "peak-load pricing" moeten niet als zodanig worden beschouwd. Hetzelfde geldt tenslotte voor prijsdiscriminatie.

Posner stelt dat interne subsidiëring dezelfde functies heeft als belastingheffing, namelijk om te betalen voor de goederen en diensten die de politiek wil voortbrengen en die door de markt niet of onvoldoende zouden zijn voortgebracht, om geld over te dragen van de ene naar de andere groep of om een combinatie van deze beide functies te realiseren. Derhalve kan interne subsidiëring en in een ruimer verband "rent-seeking" gezien worden

${ }^{139}$ Shapiro en Shelton (1981, pp. 96-108).

${ }^{140}$ Aharoni (1986, hoofdstuk 4). 
als een onderdeel van de openbare financiën. ${ }^{141}$ Interne subsidiëring is alleen mogelijk indien een regulerende instantie/de overheid de markt afschermt door middel van entreebarriêres. Indien de markt niet zou worden afgeschermd zou een bedrijf de verliesgevende activiteiten eenvoudigweg niet verrichten. Daarnaast valt te verwachten dat andere bedrijven zouden gaan opereren in de winstgevende markten, waardoor de prijs en dienovereenkomstig de winst zouden dalen. Met een "interne subsidiëring"-benadering (door Posner aangeduid als "taxation by regulation" of de openbare financiën-benadering van regulering) kan het gebruik van interne subsidiëring en de aanwezigheid van entreebarrières bij overheidsinstellingen worden verklaard. Voorts kan ook worden verklaard waarom een overheidsinstelling vaak toestemming nodig heeft van een regulerende instantie om nieuwe activiteiten te ontplooien en waarom overheidsinstellingen de voortbrenging van bepaalde diensten niet mogen beëindigen zonder toestemming van de overheid. De reden hiervan is dat én en ander het beleid van interne subsidiëring zou kumnen doorbreken. Deze benadering levert eveneens een verklaring op waarom er overheidsinstellingen bestaan die geen monopolistische structuur hebben. Dit is mogelijk indien de vraag in een dergelijke markt niet perfect elastisch is en indien de verplichting van interne subsidiëring op alle bedrijven in een markt wordt gelegd.

Duidelijk is dat er tal van redenen kunnen zijn waarom actoren die participeren in het onderhandelingsproces kunnen kiezen voor overheidsinstellingen. Voorts verschillen de politieke en sociale instituties waarbinnen dergelijke onderhandelingsprocessen plaatsvinden onder andere op grond van verschillen in taal, cultuur en historische ontwikkeling van land tot land, hetgeen kan resulteren in verschillende keuzes. Ook uit het velle empirische onderzoek, veelal verricht in de vorm van case studies, blijkt duidelijk deze verscheidenheid aan redenen waarom overheidsinstellingen in de praktijk worden opgericht.

Bij het Rijksmuseum zagen we dat overwegingen ten aanzien van marktfalen niet of onvoldoende konden verklaren waarom het is opgericht: De vraag rijst hoe de overheidsinviloed dan kan worden verklaard. De reden waarom de overheid de kunst ondersteunt houdt vooral verband met "rent-seeking". De musea vragen en ontvangen subsidies. ${ }^{142} \mathrm{De}$ overheidssteum is im het voordeel van degenen die daarom vragen en veel minder voor anderen. Individuen en groepen halen de overheid over om - bijvoorbeeld regels uit te vaardigen, belasting te heffen of uitgaven te doen die uiteindelijk leiden tot herverdeling van inkomen. ${ }^{143} \mathrm{De}$ "rent" is dan het verschil tussen het werkelijke inkomen of vermogen van het individu en wat de markt hem zou opleveren. "Rent-seeking" leidt naast inkomensherverdeling tot, naar vaak wordt gesteld, een lager nationaal inkomen. Zij is waarschijnlijk meer effectief indien het aantal "rent-seekers" beperkt is in verhouding met het aantal mensen dat de kosten moet dragen in de vorm van hogere belastingen. Bovendien leent de structuur van de kunstsector zich voor "rent-seeking". De vraag naar kunst is inkomenselastisch $(\geq 1)$. Om een toename in de vraag te bewerkstelligen hoeft een museum relatief weinig moeite te doen, hetgeen de kosten van "rentseeking" vermindert en dienovereenkomstig de mate van "rent-seeking" vermeerdert. De mensen die baat hebben bij musea, waaronder het management, belangengroepen en bezoekers, zijn relatief geringer in aantal dan de bevolking. De voorstanders kunnen gemakkelijker hun krachten bundelen en hun wensen kenbaar maken dan de gehele bevolking, te meer daar de voordelen voor de "rent-seekers" aanzienlijk kunnen zijn,

\footnotetext{
${ }^{141}$ Posner (1971, p. 29).

${ }^{142}$ Grampp (1989, pp. 113-121).

${ }^{143}$ T.a.p., 120. Zie ook: Klamer (1995, p. 301).
} 
terwijl de nadelen voor iedere burger relatief gering zijn. Het totale bedrag dat door de Nederlandse overheid aan kunst wordt besteed bedroeg in 1994 F. 2,244 miljard ${ }^{144}$ Op een bevolking van 15,5 milljoen betekent dit dat iedere inwoner $\mathrm{F}, 144,80$ betaalt. Al deze individuen hadden zich kunnen bundelen teneinde de subsidiëring ongedaan te maken en teneinde op deze wijze F, 144,8 te besparen. Waarschijnijjk zouden ze hiervoor elk echter aanzienlijk meer moeten betalen dan deze F. 144,80. Zou het bedrag groot genoeg zijn dan valt te verwachten dat er inderdaad een zekere bundeling van belangen zal ontstaan. Aangezien het aantal mensen dat voordeel heeft van de overheidssteun aanzienlijk geringer is hebben zij elk een voordeel dat aanzienlijk groter is dan F. 144,80. Daarmee hebben zij een grotere prikkel om de overheid over te hallen musea te subsidiëren. Mensen die musea bezoeken en het management van het museum krijgen door de subsidies aan het museum steun van de overheid. Ook degenen die binnen de overheid werken en "rents" overhevelen aan bezoekers en management kunnen een deel van de "rent" voor zich zelf bestemmen. Indien geen "rents" zouden worden toegekend aan het management en bezoekers zou het aantal mensen bij de overheid dat zich bezighoudt met het controleren van het museum aanzienlijk geringer zijn. $\mathrm{Zij}$ zouden dan andere activiteiten moeten ontplooien waarvoor zij waarschijnlijk een lagere beloning zouden ontvangen.

Ook voor andere sectoren kan worden onderzocht of er sprake is van een dergelijk "rent seekingsproces". Een goed voorbeeld van een dergelijk "public choice" proces geven Blankart en Knieps ten aanzien van de telecommunicatiesector. ${ }^{145} \mathrm{Zij}$ menen dat de verschillen in deregulering in Duitsland en de V.S. niet door economische motieven, zoals verschillen in schaalvoordelen, verklaard kunnen worden maar door een institutionele analyse waarbij met name politiek-economische factoren van belang zijn. Het verschil in overheidsbemoeienis met de telecommunicatiesector in beide landen verklaren zij enerzijds aan de hand van verschillen in de belangengroepenstructurur en anderzijds met behulp van verschillen in organisatie van het besluitvormingsproces in beide landen. Het prijsbeleid in de telecommunicatiesector was er op gericht de kosten te dekken en bij te dragen aan de expansie van het netwerk. Mede in verband met de in paragraaf 2.2 .1 .3 reeds vermelde positieve externe effecten werd er gebruik gemaakt van interne subsidiering. Lange afstandstelecommunicatiegebruikers subsidieerden lokale gebruikers waardoor het netwerk kon worden uitgebreid. De politieke actoren bestonden in zowel de V.S. als Duitsland vooral uit het telecommunicatiemonopolie en de kleine en grote gebruikers van het netwerk (consumenten, bedrijven). In Duitsland is het besluitvormingsproces relatief gecentraliseerd. De federale minister van Post en Telecommunicatie is als enige competent ten aanzien van alle telecommunicatievraagstukken. Blankart en Knieps geven aan dat in een dergelijk besluitvormingsproces de uitkomst waarschijnlijk een compromis is van de belangen van alle groepen, dus zowel lokale als lange afstandsgebruikers. ${ }^{146}$ De Deutsche Bundespost was voor het behoud van een monopolie. Zij probeerde hiervoor steun te verwerven door interne subsidiëring aan kleine lokale gebruikers, hetgeen ten koste ging van de lange afstandsgebruikers. In de V.S. zijn er een tweetal instanties die betrokken zijn bij de telecommunicatiesector, namelijk de Federal Communications Commision (FCC) voor de telecommunicatie tussen staten en de Public. Utility Commissions (PUC's) met bevoegdheden ten aanzien van de lokale telecommunicatie. Gebruikers van lange afstandverbindingen, met name bedrijven, dienden zich te richten tot de FCC terwijl de lokale gebruikers zich richten tot de PUC's. Zolang het netwerk werd opge-

${ }^{144}$ Ministerie van Financiën (1995), Miljoenennota 1995, p. 76, bijlage 2.

${ }^{145}$ Blankart en Knieps (1989, pp. 579-598).

${ }^{146}$ T.a.p., pp. $584 \mathrm{ew}$. 
bouwd stemden de belangen van beide instanties overeen. Naarmate geen positieve externe effecten meer te behalen vielen begonnen de belangen van FCC en PUC's uiteen te lopen. Dit had tot gevolg dat de FCC haar doelen doorzette hetgeen leidde tot de deregulering van de lange afstandscommunicatie in de V.S. . Ook in Nederland was "rentseeking" in de jaren "70 en '80 erg belangrijk. Bij de behandeling van de verzelfstandiging wan de PTT en van de Wet op de telecommunicatie in het parlement werd vooral veel alandacht besteed aan de mogelijke effecten op kruisellingse subsidiëring. Feitelijk werd hier veel meer over gesproken dan over de vraag hoe belangrijk de schaalvoordelen in deze sector nu precies waren. ${ }^{147}$. Twee soorten kruiselingse subsidiëring werden onderscheiden. Enerzijds de subsidiëring van mationale telefoongebruikers door lange afstandgebruikers en anderzijds de subsidiëring van de post door de winstgevende telecommunicatiesector. Door de toenemende concurrentie op de markt voor lange afstandsgebruikers zouden deze tarieven dalen. In de jaren ' 90 werden daarom de binnemlandse tarieven verhoogd. Bij de behandeling van de verzelfstandiging van de PTT in het parlement werd benadrukt dat verliezen van de post niet gedekt mochten worden door winsten behaald in de telecommunicatiesector. Kruiselingse subsidiëring moest verder voorkomen worden.

Ook in de elektricitejtssector is er sprake van "rent-seeking". Ten aanzien van de elektriciteitssector in Nederland hebben we de nodige kanttekeningen geplaatst bij het natuurlijk monopolie-argument voor het bestaan van overheidsinvloed in deze sector. De Braekeleer en Hartog hebben onderzoek verricht naar de elektriciteitsprijzen in Nederland en Belgie. ${ }^{148}$ Op grond van hun onderzoek lijkt het waarschijnlijk dat er in Nederland sprake is van kruiselingse subsidiëring van grote afnemers ten behoeve van kleine afnemers. In Nederland betalen kleine afnemers een lagere "mark-up" dan overeenkomt met de prijselasticiteit van de vraag. Grote gebruikers worden gediscrimineerd ten behoeve van kleine consumenten. Dit houdt in dat ook hier de ene groep erin slaagt voordeel te behalen ten koste van een andere groep, hetgeen betekent dat er sprake is van "rent-seeking". Dit blijkt ook uit de berekeningen van de "public enterprise rent" van veel elektriciteitsbedrijven, waaronder MEGA-Limburg, die veelal aanzienlijk was. In hoofdstuk 17 wordt hier verder op ingegaan.

Jansen toont in zijn onderzoek naar DSM, TNO en de NS aan dat ook in het verleden herverdeling van inkomen door middel van overheidsinstellingen een grote rol speelde. ${ }^{149}$ Hoewell bij de Staatsmijnen geen sprake was van gederfde winst maakte zij na de Tweede Wereldoorlog wel gebruik van kruiselingse subsidiëring. De winst behaalt bij de cokesproductie en de chemische bedrijven compenseerde de verliezen van de mijnbouw, gasdistributie en woningexploitatie. Ook bij de N.S. was sprake van het gebruik van middelen voor bijkomende doelen. Jansen beschrijft dat de "public enterprise rent" bij de NS na de Tweede Wereldoorlog steeds verder opliep en in 1970 reeds F. 91,6 miljoen bedroeg. Deze middelen werden onder meer besteed aan het reizigersvervoer, bijvoorbeeld voor het in gebruik houden van onrendabele lijnen, het goederenvervoer maar ook aan bijwoorbeeld de arbeidswoorwaarden van het personeel, zoals vergeleken met de werknemers in de metaalnijverheid relatief betere pensioenvoorzieningen, doorbetaling

\footnotetext{
147 Vergelijk bijwoorbeeld: Tweede Kamer der Staten-Generaal (vergaderjaar 1985-1986), Kabinetsstandpunt taak en functie van de PTT met betrekking tot informatie- en telecommunicatietechnologie, 17370, nrs. 3031, p. 17.

${ }^{1418}$ De Braekeleer en Hartog (1992, p. 16).

149 Jansen (1993, pp. 72, 74, 127 en 178).
} 
van volledige lonen bij ziekte, wachtgeld bij ontslag wegens dienstinkrimping en het niet hoeven te betalen van premies voor de ziektewet en het ziekenfonds. Ook bij T.N.O. nam de gederfde winst na de Tweede Wereldoorlog toe, van F. 2,765 miljoen in 1960 tot F. 20,083 miljoen in 1970 . Deze "public enterprise rent" is voor een belangrijk deel besteed aan het inhalen van de wetenschappelijke achterstand en de financiering van de salarissen van bestuurders van T.N.O.-instituten. Voorts is een deel waarschijnlijk gebruikt voor commerciële activiteiten die werden ontplooid in concurrentie met andere onderzoeksbureaus:

Mellink toont aan dat ook bij de Nationale Investeringsbank (N.I.B.) de "public enterprise rent" na de Tweede Wereldoorlog steeds meer toeneemt, namelijk van -F.0,33 miljoen in 1950 tot F. 12,33 miljoen in 1970. Dit is een bevestiging van het vermoeden dat overwegingen ten aanzien van marktfalen slechts gedeeltelijk een rol hebben gespeeld bij het oprichten en continueren van de N.I.B.. De N.I.B. is zelfs bij uitstek in de gelegenheid om middelen over te hevelen naar bepaalde sectoren en bedrijven. Na 1984 werd getracht de N.I.B. om te vormen tot een meer commerciële klantgerichte investeringsbank. De "public enterprise rent" vertoont dan ook een forse afname en wordt uiteindelijk zelfs negatief. ${ }^{150}$

Deze en andiere onderzoeken suggereren dat de "public enterprise rent" van veel overheidsinstellingen vlak na de Tweede Wereldoorlog relatief gering was en tot de jaren " 70 is toegenomen, waarna enige daling is ingetreden. Toen in de jaren ' 70 de economische situatie slechter werd en de financieringstekorten steeds groter werden, werden er meer bezuinigingen doorgevoerd. Dit betekende dat ook de bijkomende doelen die de politieke actoren via overheidsimstellingen trachten te realiseren (bekostigd uit de "public enterprise rent $^{\text {") }}$ ) tegen het licht werden gehouden. Bepaalde bijkomende doelen werden beperkt terwij1 ook meer en meer bezien werd of er alternatieve mogelijkheden waren om de resterende bijkomende doelen te realiseren. De roep om allerlei privatiseringsvarianten nam toe, al dan niet in combinatie met allerlei subsidies, zoals bijwoorbeeld bij de N.S.. Naarmate de "public enterprise rent" en dienovereenkomstig de bijkomende doelen relatief minder belangrijk werden geacht werd het ook aantrekkelijker om overheidsinstellingen te verkopen of anderszins te verzelfstandigen. De voor de pollitieke actoren relevante contante waarde van de "public enterprise rent" (over de periode die de politieke actoren verwachten nog in die functie te zullen meemaken) is dan kdeiner dan de opbrengst bij verkoop. Het is dan rationeel om het bedrijf te privatiseren teneinde op deze wijze zich de "rent" toe te eigenen. ${ }^{151}$ Ook Van Mierlo wijst op de veranderingen binnen de publieke sector, die onder meer worden gekenmerkt door toenemende verzelfstandiging van publieke instellingen. ${ }^{152}$ In paragraf 12.3 wordt hier verder op ingegaan.

2.2.3 Kan het bestaan van overheidsinstellingen worden verklaard door de stabilisatilefunctie?

De stabilisatiefunctie is gericht op het handhaven van een hoog niveau van bezetting van de productiecapaciteit en van een stabiele waarde van geld. ${ }^{153}$ Met de overheidsinstel-

\footnotetext{
150 Van Gooll (1988, pp. 23 e... . .

15]. Vergelijk ook: Backhaus (1989, pp. 368 e.v.).

152. Van Mierlo $(1995$, pp. 3 e....).

${ }^{153}$ Musgrave (1959, p. 22).
} 
ling kan bijwoorbeeld gestreefa worden naar verbetering van de werkgelegenheidssituatie of de economische ontwikkeling van een regio, terwijl met het investeringsbeleid van de onderneming een anti-cyclisch beleid gevoerd kan worden. Een in de literaturur genoemde bestaansreden voor overheidsinstellingen heeft in dit verband betrekking op de mate waarin een land aanitrekkingskracht heeft op nieuw kapitaal. Als argument voor nationalisering of het oprichten van overheidsinstellingen wordt wel gesteld dat particuliere bedrijven te weinig investeren in nieuwe fabrieken en machines. Duidelijk is dat de mogelijkheid van nationalisering het risico voor bedrijven ten aanzien van nieuwe investeringen aanzieniljk vergroot, waardoor allerlei investeringsprojecten niet worden uitgevoerd.

Een hiermee verwante bestaansreden voor overheidsinstellingen is gelegen in de bevordering van de industriële ontwikkeling. Met name in ontwikkelingslanden zijn kapitaalmarkten niet altijd goed ontwikkeld en kan de bereidheid van ondernemers om risico te dragen onvoldoende zijn. De mogelijkheid is dan aanwezig dat de investeringen door de particuliere sector beneden de door de overheid gewenste investeringen en economische groei ligt. Regeringen van ontwikkelingslanden zullen de gewenste economische groei en de daarbij behorende investeringswoet en de voor de uiteindelijke uitkomst benodigde investeringen in de afzonderlijke regio"s en sectoren veelal neerleggen in een plan. Indien de door de overheid beoogde groei boven de door de markt te realiseren groei ligt kunnen overheidsinstellingen een rol gaan spelen. Ramanadham noemt drie situaties waarin de overheden van ontwikkelingslanden een roll kunnen spelen, te weten: ${ }^{154}$

1. De geplande investeringen zijn hoger dan gerealiseerd kunnen worden door de particuliere sector. Er zijn extra middelen van de overheid en uit het buitenland nodig om de beoogde groei te kunnen realiseren.

2. In ontwikkelingslanden zullen particuliere investeerders vooral geneigd zijn te investeren in de lichte industrie em in de handels- en dienstensector. Door het lenen van geld op de financiële markten kan de overheid fondsen herverdelen en deze door middel van. overheidsinstellingen heralloceren naar andere sectoren.

3. Hetzelfde geldt voor de allocatie van middelen tussen consumptie en investeringen in een economie. Door middel van belastingen en leningen kan de overheid besparingen heralloceren naar investeringen, in plaats dat deze middelen voor consumptieve uitgaven gebruikt worden.

Ramanadham zet uiteen dat de omvang van de publieke productie en investeringen nauw samenhangen met het gewenste en verwachte rendement in de marktsector. Dit kan worden verduidelijkt met figuur 2.1 . Op de $x$-as stal het mogelijke rendement van een investering vermeld en op de $\mathrm{y}$-as het door de overheid toegestane rendement. Binnen rechthoek PQRO is het rendement dermate laag dat particuliere investeerders niet zullen investeren.

${ }^{154}$ Ramanadham (1991, pp. 5 e.v.). 


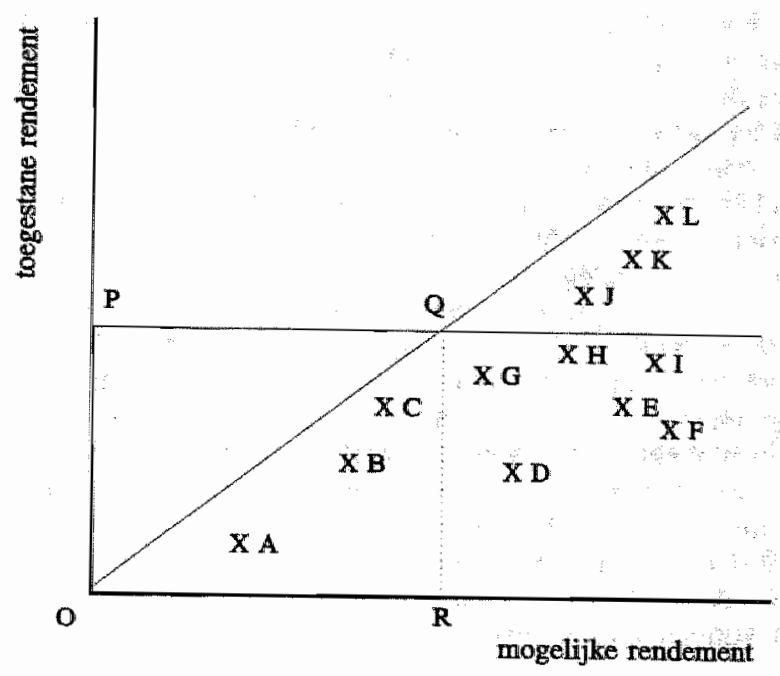

Figuur 2.1 Overheidssector en rendement op investeringen ${ }^{155}$

Het volgende onderscheid is nu mogelijk. Ramanadham wijst erop dat het rendement op investeringen in veel door de overheid geprefereerde sectoren gedurende langere perioden relatief laag zal zijn. Hierbij kan bijvoorbeeld gedacht worden aan sectoren in de zware industrie. Indien een investering een aammerkelijk lager rendement heeft dan het rendement zoals dat verlangd wordt door particuliere investeerders, in Figuur 2.1 de punten $A, B$ en $C$, zijn overheidsinstellingen benodigd om de betreffende projecten alsnog te realiseren. Indien het rendement slechts weinig lager is dan het door de markt verlangde rendement, punten G, $\mathrm{H}$ en I, kan door de overheid ook andere instrumenten zoals subsidies gebruikt worden. Door subsidieverlening wordt in dat geval het rendement op investeringen verhoogd waardoor particuliere investeerders alsnog bereid zullen zijn deze projecten te financieren. De projecten $\mathrm{J}, \mathrm{K}$ en $\mathrm{L}$ zouden tenslotte door de particuliere sector zelf gefinancierd kunnen worden.

Ramanadham constateert dat de relatieve omvang van de publieke en particuliere sector nu bepaald wordt door:

-Het mogelijke rendement op investeringen

- Het toegestane rendement

-Het rendement dat bereikbaar is voor de particuliere sector

Deze rendementen kunnen van land tot land verschillen, temeer daar ook het beleid van de overheid hierop van invloed is. Derhalve zal ook de omvang van de publieke productie van land tot land verschillen.

Een ander doel van overheidsinstellingen kan verband houden met het vergemakkelijken van de lange termijn gecentraliseerde planning in een economie. Indien de overheid beschikt over een beperkt aantal sleutelindustrieën kan dat de planning van de economie vereenvoudigen. Daarnaast beschikt de overheid door middel van overheidsinstellingen over meer concrete informatie over de markt. Een ander voordeel van overheidsinstel-

${ }^{155}$ Ramanadham (1991, p. 9). 
lingen is dat de overheid kan bepalen in welke sector er wordt geinvesteerd en er op kan toezien dat investeringen niet in het buitenland plaatsvinden. Zoals Monsen en Walters het stellen: "A state-owned firm, can be told to keep investments at home, purchase from domestic suppliers, hire a nation's workers, and behaviour in an overtly nationalistic fashion so as to make the government look good ${ }^{15}{ }^{156}$ Een andere reden woor het oprichten van overheidsinstellingen of het nationaliseren van bestaande bedrijven houdt verband met de steunverlening aan slecht draaiende bedrijven, vooral met het oog op bescherming van de productie en werkgelegenheid, veelal om politieke redenen. Dit vond vooral in het begin van de jaren tachtig plaats en belemmerde, naar wel wordt gesteld, voor een deel de noodzakelijke herstructurering. Als argument voor nationalisering wordt daarentegen ook wel de behoefte aan rationalisering en herstructurering van reeds ontwikkelde bedrijfstakken genoemd. Hierbij kan bijvoorbeeld gedacht worden aan de nationalisaties in het Verenigd Koninkrijk gedurende de periode 1945-1951. ${ }^{157}$ Tenslotte kan gewezen worden op de beoogde socialisatie van de productie als mogelijke bestaansreden. ${ }^{158}$ Overheidsinstellingen worden dan opgezet teneinde de economische structuur te wijzigen van kapitalistisch naar socialistisch. Het concept van een socialistische maatschappij heeft met name gedurende het laatste decennium sterk aan kracht ingeboet. Dit zou dan een van de verklaringen kunnen zijn waarom steeds meer overheidsinstellingen worden geprivatiseerd.

\subsubsection{Interactie van functies.}

Het is van belang zich te realiseren dat de drie vermelde functies interacties kunnen vertonen. ${ }^{159}$ Musgrave vermeldt een drietal mogelijke interacties, namelijk allocatie versus stabilisatie, allocatie versus inkomensverdeling en inkomensverdeling versus stabilisatie. De ene doelstelling kan worden opgeofferd voor een andere. Er is zoals vrijwel steeds in de economie een duidelijke afweging van efficiëntie en verdeling/rechtvaardigheid. Met een elektriciteitsbedrijf kan bijvoorbeeld gestreefd worden naar bestrijding van de werkloosheid door extra personeel in dienst te nemen, maar ook naar zo laag mogelijke tarieven door efficiëntiebevordering. Centraal staat hier het functioneren van overheidsinstellingen en de redenen waarom overheidsinstellingen worden opgericht. Daarom is deze interactie van functies voor ons bijzonder relevant, aangezien overheidsinstellingen om een combinatie van deze redemen zijn opgericht. ${ }^{160}$. We kennen nu de redenen waarom overheidsinstellingen worden opgericht en worden gecontinueerd. In veel gevallen is het nog niet duidelijk waarom de overheid gebruik maakt van een overheidsinstelling en niet van een ander instrument. Hierop wordt in de volgende paragraaf ingegaan.

2.3 Waarom kiest de overheid ervoor gebruik te maken van een overheidsinstelling en waarom gebruikt zij geen ander instrument?

In de voorgaande paragrafen zijn tal van redenen genoemd waarom een overheidsinstel-

\footnotetext{
156 Monsen en Walters (1983, p. 25).

157 Ramanadham (1991, p. 5).

158 Rees (1984, p. 5).

${ }^{159}$ Musgrave (1986, Hoofdstuk 1).

160 Abaroni (1986, p 127).
} 
ling wordt opgericht. Vaak zijn er echter alternatieven voor overheidsinstellingen waardoor het niet meteen duidelijk is waarom de overbeid niet hiervoor kiest. Indien de overheid bijvoorbeeld lagere entreeprijzen voor musea wil realiseren, om er voor te zorgen dat iedereen toegang heeft tot de kunst, kan zij ook aan een particulier bedrijf subsidie verlenen. Naast de subsidie brengt dit kosten met zich mee die de overheid moet maken om te controleren of de overheidsinstelling deze doelen, waaronder bijvoorbeeld inkomensherverdeling ook werkelijk probeert te bereiken ("monitoring").

Teneinde de vraag te beantwoorden waarom de overheid kiest voor een overheidsinstelling en niet voor een ander instrument moet op een tweetal factoren worden ingegaan. Enerzijds zijn er omstandigheden waaronder een overheidsinstelling, in éen van de vele verschillende vormen, als instrument geschilkt is, terwijl dat in andere omstandigheden minder of niet het geval is. Anderzijds moeten de baten en kosten voor de politieke actoren in overweging worden genomen.

\subsubsection{Omstandigheden waaronder owerheidsinstellingen vooral geschikt zijn om in een goed of dienst te roorzien}

Om deze vraag te beantwoorden kan het best worden aangesloten bij de vele privatiseringsliteratuur die hierover is verschenen. Savas gaat hier uitgebreid op in. Hij maakt een onderscheid tussen enerzijds de verschillende soorten goederen en anderzijds de wijzen waarop deze goederen kumnen worden voortgebracht. Hij onderscheidt de volgende besturingsstructuren:

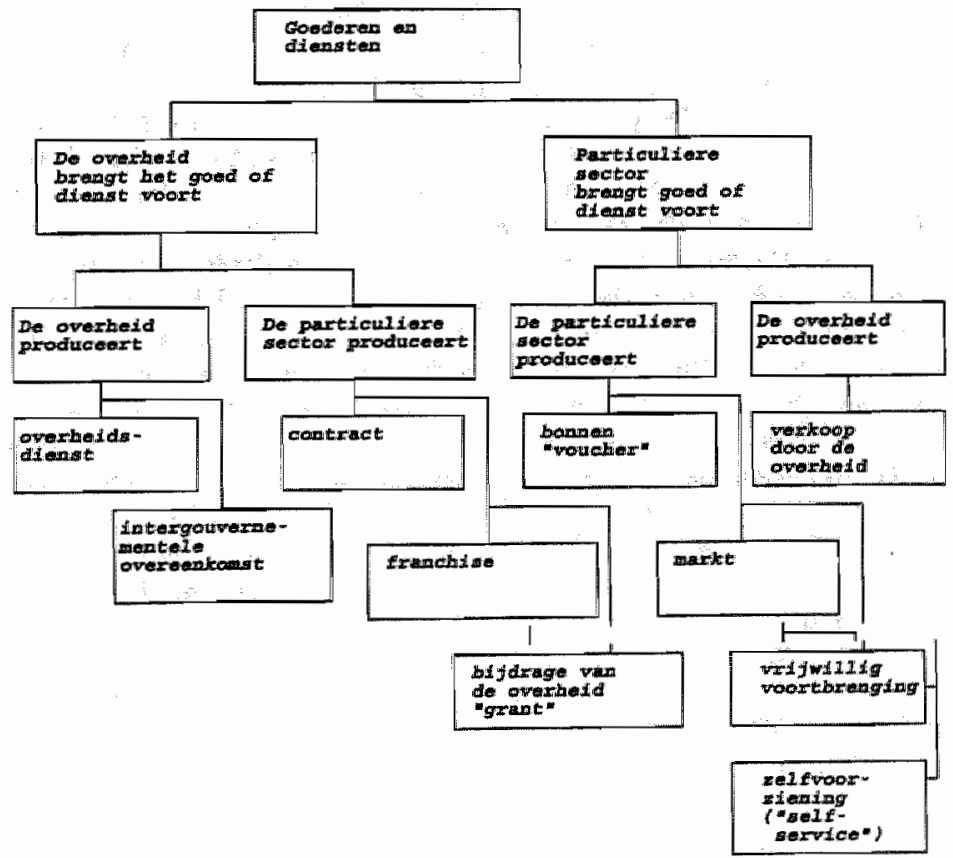

Figuur 2.2 Tien alternatieve besturingsstructuren om goederen en diensten voort te brengen ${ }^{161}$

${ }^{161}$ Bron: Savas (1987, p. 63). 
Onderscheid kan worden gemaakt tussen degene die het goed of de dienst produceert, degene die het consumeert en degene die optreedt als de "arranger" of "provider" ${ }^{\text {"162 }}$ Dit is degene die het goed voortbrengt. In het geval van een intergouvernementele overeenkomst wordt een andere overheidsdienst gecontracteerd. Een voorbeeld hiervan is de brandweer. De organisationele vom blijft de bureaucratie. De overheid brengt het goed voort ("arranger") en treedt ook op als producent. Indien de overheid gebruik maakt van een contract sluit zij een overeenkomst met een particulier of publiek bedrijf om de goederen of diensten te leveren. De overheid regelt de voortbrenging, terwijl het bedrijf produceert. De overheid betaalt voor deze goederen. Hierbij kan gedacht worden aan de levering van militaire uitrusting, papier etc. Van der Bij noemt als bijzondere vorm van deze besturingsstructuur de zogenaamde uitbesteding van dienstverlening. ${ }^{163}$ De overheid sluit in dat geval een contract met een particuliere onderneming of non-profitinstelling. Deze particuliere organisatie produceent vervolgens het betreffende goed en levert dit aan de consument, terwijl de overheid hiervoor betaalt. In de V.S. Wordt deze vorm van uitbesteding aangeduid als "purchase of service contracting" (POSC). Indien gebruik wordt gemaakt van franchising kunnen bepaalde privileges, bijvoorbeeld een monopolie, worden verleend aan het bedrijf dat de goederen of diensten levert. Vaak is er tevens sprake van prijsregulering. Het verschil met een contract is dat bij een contract de overheid betaalt, terwijl bij franchising de goederen en diensten worden betaald door de consument. Hierbij kan gedacht worden aan het monopolie van elektriciteitsbedrijven als de N.V. PLEM in de jaren ' 80 of het monopolie van de Belastingdienst. Indien gebruik wordt gemaakt van een bijdrage van de overheid ("grant") kan gedacht worden aan een subsidie, aan leningen tegen lage rente en belastingvrijstellingen. Deze bijdragen worden gegeven aan de producent. Het doel van een bijdrage is het verlagen van de prijs van een goed of dienst. Een voorbeeld hiervan zijn de overheidsbijdragen aan culturele instellingen zoals het Rijksmuseum. In het geval van het "voucher"-systeem worden bonnen gegeven aan de consument. De consument kan min of meer vrij kiezen tussen de verschillende aanbieders van het goed waar de bonnen voor bestemd zijn. ${ }^{164}$ Hierbij kan gedacht worden aan voedselbonnen. De goederen en diensten worden door een particuliere onderneming voortgebracht en de overheid betaalt indirect, door de verstrekte bonnen, voor de betreffende dienst. Een andere wijze waarop goederen en diensten voortgebracht kunnen worden is door de vrijwillige voortbrenging ervan. Een voorbeeld hiervan is de vrijwillige brandweer. Een organisatie regelt de voorziening en "produceert" door de inzet van zijn leden of werknemers of betaalt een particulier bedrijf om het goed voort te brengen. De meest gebnikte besturingsstructuur is het contract waarbij de consument optreedt als "arranger" en waarbij een bedrijf het betreffende goed of de betreffende dient voortbrengt. De overheid staat hier in principe buiten. Bij overheidsverkoop treedt de consument op als de "arranger". Goederen en dienst worden dan gekocht van de overheid, bijwoorbeeld door het kopen van het recht hout te mogen kappen of naar olie te mogen boren. Tenslotte kan "self-service" genoemd worden. Het gezin kan gezien worden als een "self-service"-eenheid die een reeks van belangrijke goederen en diensten voortbrengt.

Savas geeft aan dat deze structuren afzonderlijk maar ook in combinatie met andere gebruikt kunnen worden. Ook kunnen verschillende voorzieningen gebruikt worden voor

\footnotetext{
162 Vergelijk ook: Van Kesteren en Vos (1996, p. 125).

${ }^{163}$ Van der Bij (1992, pp. 15-17).

164 Waring $(1996$, p. 63$)$.
} 
Voor de vraag die in dit hoofdstuk centraal staat is het van belang een stap verder te gaan. Zoals reeds is aangestipt in paragraaf 2.2 .1 .2 kunnen verschillende goederen worden onderscheiden. Niet alle instrumenten lenen zich om alle soorten goederen voort te brengen. Wel is het zo dat private goederen door middel van alle genoemde structuren voortgebracht kunnen worden. Afhankelijk van de mate waarin goederen exclusief en niet-rivaliserend zijn kan een onderscheid worden gemaakt tussen private goederen, collectieve goederen, "common-pool" goederen en tolgoederen. Het onderscheid tussen deze goederen kan als volgt worden weergegeven:

\begin{tabular}{|c|c|c|c|}
\hline \multicolumn{2}{|c|}{ Kenmerk van het goed } & \multicolumn{2}{|c|}{ mate van exclusiviteit } \\
\hline & & - & + \\
\hline \multirow[t]{2}{*}{ mate van rivaliteit } & - & $\begin{array}{l}\text { collectieve goede- } \\
\text { ren }\end{array}$ & tolgoederen \\
\hline & + & $\begin{array}{l}\text { "common-pool" } \\
\text { goederen }\end{array}$ & private goederen \\
\hline
\end{tabular}

Tabel 2.1 Vier soorten goederen onderscheiden op grond van hun kenmerken ${ }^{166}$

Collectieve goederen zijn aan de orde gekomen in paragraaf 2.2.1.2. Opgemerkt is dat deze niet-rivaliserend zijn en dat niemand van het gebruik ervan kan worden uitgesloten. Als voorbeeld is een vuurtoren genoemd, terwijl ook defensie als een voorbeeld hiervan kan worden beschouwd. In het geval van een "common-pool" goed is er geen sprake van exclusiviteit, het goed is echter wel rivaliserend. Een voorbeeld hiervan is de vis in de zee. Een vis kan door iedereen gevangen worden, maar een vis die eenmaal gevangen is kan maar door één persoon worden genuttigd. Tolgoederen zijn goederen waarvan mensen wel uitgesloten kunnen worden, maar die niet-rivaliserend zijn. Een voorbeeld is een film uitgezonden in een bioscoop of een voetbalwedstrijd. Savas merkt op: "Unlike commonpool goods, toll goods can be supplied by the marketplace. Because exclusion is readily possible, users will pay and therefore suppliers will supply the goods". ${ }^{167}$ Op zich zouden deze goederen geen problemen hoeven op te leveren. Er zijn echter uitzonderingen, te weten de tolgoederen die worden voortgebracht onder condities van dalende gemiddelde kosten.

Vervolgens geeft Savas aan welke goederen door middel van welke besturingsstructuur kunnen worden voortgebracht. Dit kan worden samengevat met de volgende tabel.

\footnotetext{
${ }^{165}$ Savas $(1987$, p. 83$)$.

${ }^{166}$ T.a.p., pp. 36 e.v. en p. 56.

167 T. 稙.P , p. 56.
} 


\begin{tabular}{|c|c|c|c|c|}
\hline $\begin{array}{l}\text { Besturings- } \\
\text { structurur }\end{array}$ & private goederen & tolgoederen & $\begin{array}{l}\text { collectieve } \\
\text { goederen }\end{array}$ & $\begin{array}{l}\text { "common pool" } \\
\text { goederen }\end{array}$ \\
\hline $\begin{array}{l}1 \text {. } \\
\text { overheids- } \\
\text { dienst }\end{array}$ & $\mathrm{x}$ & $x$ & $\mathrm{x}$ & $x$ \\
\hline $\begin{array}{l}2 . \\
\text { intergouverne- } \\
\text { mentele over- } \\
\text { eenkomst }\end{array}$ & $\mathrm{x}$ & $x$ & $\mathrm{x}$ & $\mathrm{x}$ \\
\hline $\begin{array}{l}3 . \\
\text { contract }\end{array}$ & $\mathrm{x}$ & $\mathrm{x}$ & $x$ & $\mathrm{x}$ \\
\hline $\begin{array}{l}4 . \\
\text { franchise }\end{array}$ & $\mathrm{x}$ & $\mathrm{x}$ & & \\
\hline $\begin{array}{l}5 . \\
\text { overheidsbij- } \\
\text { drage } \\
\text { ("grant") }\end{array}$ & $\mathrm{x}$ & $\mathrm{x}$ & & $x$ \\
\hline $\begin{array}{l}6 . \\
\text { bonnen } \\
\text { ("voucher") }\end{array}$ & $\mathrm{x}$ & $x$ & & $\mathrm{x}$ \\
\hline $\begin{array}{l}7 . \\
\text { markt } \\
\end{array}$ & $\mathrm{x}$ & $\mathrm{x}$ & & \\
\hline $\begin{array}{l}8 . \\
\text { vrijwillige } \\
\text { voortbrenging }\end{array}$ & $\mathrm{x}$ & $\mathrm{x}$ & $x$ & $\mathrm{x}$ \\
\hline $\begin{array}{l}9 . \\
\text { zelfvoorziening } \\
\text { (self-service) }\end{array}$ & $x$ & & & \\
\hline $\begin{array}{l}10 . \\
\text { overheidsver- } \\
\text { koop }\end{array}$ & $x$ & $\mathrm{x}$ & & \\
\hline
\end{tabular}

Tabel 2.2 Soorten goederen en wijzen waarop het kan worden voortgebracht ${ }^{168}$

Zoals gesteld kunnen private goederen door middel van elke besturingsstructuur worden voortgebracht. Collectieve goederen kunnen niet worden voortgebracht door een bijdrage, franchising, een bonnensysteem en de markt omdat ze niet-exclusief zijn, waardoor zoals opgemerkt ten gevolge van het "free-rider"-effect er geen efficiënte allocatie hoeft te ontstaan. Tolgoederen kunnen door middel van elke structuur worden voortgebracht, behalve zelfvoorziening. "Common-pool" goederen kunnen niet worden voortgebracht door middel van franchising, overheidsverkoop, de markt en via zelfvoorziening.

Uit Tabel 2.2 blijkt dat een overheidsdienst/-instelling alle vier soorten goederen kan voortbrengen. Door middel van franchising kunnen alleen private goederen en tolgoederen

160 T.a.p., p. 94. 
worden voortgebracht. De vraag blijft dus waarom de overheid gebruik maakt van een overheidsinstelling. Om deze vraag te beantwoorden moet worden opgemerkt dat de eigenschappen van de genoemde besturingsstructuren in de praktijk nogal kunnen verschillen. Savas geeft hiervan het volgende overzicht.

\begin{tabular}{|c|c|c|c|c|c|c|c|c|c|c|}
\hline Keternerta & $\begin{array}{l}\text { overheids- } \\
\text { dienes: }\end{array}$ & $\begin{array}{l}\text { Tintergotiveme- } \\
\text { mentele over- } \\
\text { enkorwast }\end{array}$ & sontract & framelaise & $\begin{array}{l}\text { bijelrage } \\
\text { ("grant) }\end{array}$ & boungen & maikikt & $\begin{array}{l}\text { vrijowllige } \\
\text { woont- } \\
\text { binenging }\end{array}$ & $\begin{array}{l}\text { Whoors } \\
\text { neminge. }\end{array}$ & $\begin{array}{l}\text { aweritids- } \\
\text { vertoops }\end{array}$ \\
\hline 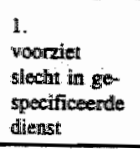 & $t+$ & 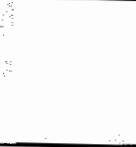 & & & & $+t$ & $t+$ & + & $+t$ & 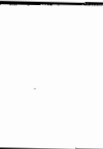 \\
\hline $\begin{array}{l}2 . \\
\text { werpist } \\
\text { meerdente } \\
\text { producenten }\end{array}$ & & $\therefore$ & +4 & & $\because:$ & $\begin{array}{l}+4 \\
\therefore \quad \\
\therefore \quad \therefore\end{array}$ & +4 & . & 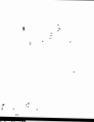 & \\
\hline $\begin{array}{l}3 . \\
\text { bevandert } \\
\text { efferutio en } \\
\text { effectivite: }\end{array}$ & & 3 & ++ & + & + & +4 & +4 & + & - & \\
\hline $\begin{array}{l}4 . \\
\text { bereilkt } \\
\text { schush } \\
\text { voondielen }\end{array}$ & $\therefore$ & $\frac{+}{4}$ & ++ & ++ & + & ++ & $+*$ & ++ & $\because$ & \\
\hline $\begin{array}{l}5 . \\
\text { relateert de } \\
\text { kosten and de } \\
\text { baten }\end{array}$ & & + & $4+$ & + & ++ & ++ & +4 & +4 & ++ & + \\
\hline $\begin{array}{l}6 . \\
\text { is klamage } \\
\text { rimlat }\end{array}$ & & $\therefore$ & & $t+$ & + & +7 & $+\div$ & +4 & +4 & $+t$ \\
\hline $\begin{array}{l}7 . \\
\text { relatiliaf } \\
\text { ongevoelig } \\
\text { voor thatude }\end{array}$ & $\therefore \quad ;$ & $\begin{array}{c}+4 \\
\vdots\end{array}$ & $\because \because$ & 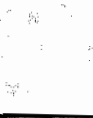 & : & & $\therefore$ & +4 & $t+$ & \\
\hline $\begin{array}{l}8 . \\
\text { Hewordert } \\
\text { hervendeling }\end{array}$ & ++ & +1 & ++ & & $+\infty$ & $t+$ & & + & & \\
\hline $\begin{array}{l}9 . \\
\text { streft } \\
\text { nos }\end{array}$ & $+t$ & $t^{4}$ & + & 4 & 4 & + & + & & & \\
\hline 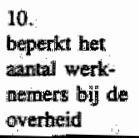 & 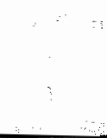 & & $\begin{array}{l}+4 \\
\because \therefore:\end{array}$ & ++ & ++ & ++ & ++ & +4 & +4 & \\
\hline
\end{tabular}

$++\quad=$ indien de besturingsstructurur het betreffende kenmerk duidelijk bezit

$+\quad=$ indien de betreffende eigenschap in enige mate aanwezig is Indien er in de tabel geen enkel teken verschijnt betekent dit dat de besturingsstructuur deze eigenschap niet bezit.

Tabel 2.3 Karakteristieken van verschillende besturingsstructuren ${ }^{169}$

Sommige diensten kunnen gemakkelijker worden gespecificeerd dan andere. Het aanleg- 
gen van een weg laat zich bijvoorbeeld duidelijk omschrijven aan de hand van allerlei technische specificaties. Onderwijs daarentegen leent zich daar veel minder voor. Diensten die zich slecht laten specificeren kumnen niet gemakkelijk worden voortgebracht door middel van intergouvernementele overeenkomst, contract, overheidsbijdrage en franchise. Bij de woortbrenging van deze goederen is duidelijke supervisie nodig en constante feedback tussen producent en consument. Dit kan het best worden bereikt indien de consument of eventueel de producent optreedt als "arranger" dat een structuur als een contract, een bonnensysteem en de markt het best werkt indien er sprake is van competitie. Met betrekking tot de efficiëntie en effectiviteit merkt Savas op: "One of the mast fundamental determinants of the efficiency and effectiveness of any arrangement is competition; that is, the degree of competition that an arrangement permits will, to a major extent, determine how efficiently that arrangement will supply a servi$\mathrm{ce}^{\prime \prime}{ }^{170}$ Schaalvoordelen worden vooral benut, afhankelijk van de kenmerken van het productieproces. Overheidsdiensten zullen vaak niet efficiënt zijn omdat de optimale schaal van de voorziening van de betreffende dienst bijvoorbeeld 5.000 is terwijl er maar 100 mensen in een dorp wonen. Andere besturingsinstrumenten bieden meer mogelijkheden. Punt 5 houdt in dat de efficiëntie bevorderd wordt indien er een directe band bestaat tussen het betalen voor een dienst en het ontvangen van de voordelen ervan. Deze band bestaat alleen voor private en tolgoederen. Belangrijk is dat er geen tussenschakel is tussen de consument en de producent. In het geval van een overheidsdienst is de band tussen betalen (belastingbetaling) en ontvangen minimaal. Intergouvernementele overeenkomsten en franchising (overheidsmonopolies) scoren hier duidelijk hoger. Punt 6 houdt in dat direct contact tussen de consument en de producent de klantgerichtheid vergroot. Dit is vooral het geval indien de consument zelf kan kiezen. Dit is niet het geval bij intergouvernementele contracten en overheidsdiensten. Met betrekking tot fraude meent Savas dat bij de verdeling van contracten, bijdragen en monopolies door de overheid fraude kan worden gepleegd. Overheidsdiensten zijn wel relatief ongevoelig voor fraude. Bij punt $8 \mathrm{kan}$ worden opgemerkt dat de verschillende structuren verschillen in de mate waarin zij de herverdeling van goederen en diensten bevorderen. Overheidsdiensten en intergouvernementele contracten scoren hier hoog. Bij punt 9 gaat het om de realisering van bijkomende doelen zoals de ontwikkeling van een regio. Volgens Savas is echter geen van deze structuren meer gevoelig voor het beleid van de overheid, met uitzondering van de markt, vrijwillige voontbrenging en zelfvoorziening. Punt 10 geeft tenslotte aan dat structuren zoals contracten, de markt en zelfs intergouvemementele contracten en franchising het aantal werknemers bij de overheid beperken.

Tabel 2.3 zou eventueel nog kunnen worden uitgebreid. Zij maakt duidelijk dat bepaalde besturingsstructuren bepaalde kenmerken hebben. Geconstateerd kan worden dat de aard van de goederen in combinatie met de genoemde kenmerken, zoals in hoeverre is de dienst gespecificeerd, in hoeverre is er behoefte aan klantgerichtheid en is er sprake van fraudegevoeligheid, voor een groot deel bepalen welk instrument wordt gekozen. ${ }^{171}$ Voortbrenging door de overheid door middel van overheidsinstellingen lijkt meer voor de hand te liggen bij collectieve goederen, aangezien er dan minder alternatieve voortbrengingsmogelijkheden zijn. Ook bij tolgoederen is het aantal altermatieven zoals weergegeven in tabel 2.2 beperkt, terwijl dat bij private goederen juist zeer groot is. Hierbij moet well bedacht worden dat geen enkel instrument ideaal is. Savas merkt op: "Many arrangements share each desirable feature. The conclusion to be drawn is that there is generally

${ }^{170}$ T.a.p., p. 96.

171 Vergelijk in dit verband ook: Van Kesteren en Vos (1996, pp. 126 e.v.). 
mare than one good way to provide a service". 172

Toch schiet voorgaande benadering voor het verklaren van het bestaan van overheidsinstellingen nog tekort. $\mathrm{Zij}$ geeft aan dat overheidsinstellingen, in de vorm van overheids diensten en franchising onder bepaalde omstandigheden meer of juist minder geschikt zijn dan andere instrumenten. Naast de geschiktheid van een instrument speelt mee wat de kosten en baten van het gebnuik ervan zijn voor de politieke actoren. Hierop wordt in de volgende paragrafen ingegaan.

\subsubsection{De benadering van de comparatieve kosten}

Ramanadham heeft een theorie ontwikkeld van de comparatieve voordelen als aanvullende reden voor het bestaan van overheidsinstellingen. In deze paragraaf wordt hier op ingegaan.

De argumenten voor het oprichten van een overheidsinstelling en het instandhouden ervan kunnen in de woorden van Ramanadham als volgt worden samengevat: "(..) the case for establishing or retaining an enterprise in the public sector is strong when (and as long as) there is a comparative advantage in organising given transactions within a public enterprise. The basic assumption is that being a public enterprise enables it to make the maximum possible contibution to national well-being $(\ldots)^{* 173}$ Ramanadham vermeldt dat er veel pleit voor het oprichten van een overheidsinstelling indien er een comparatief voordeel is om bepaalde activiteiten te organiseren binnen overheidsinstellingen. Het voordeel bestaat uit enerzijds het verwachte financiële rendement en anderzijds het verwachte maatschappelijke rendement. Ramanadham beschrijft dat er verschillende combinaties van particulier en maatschappelijk rendement bestaan waaruit de overheid kan kiezen.

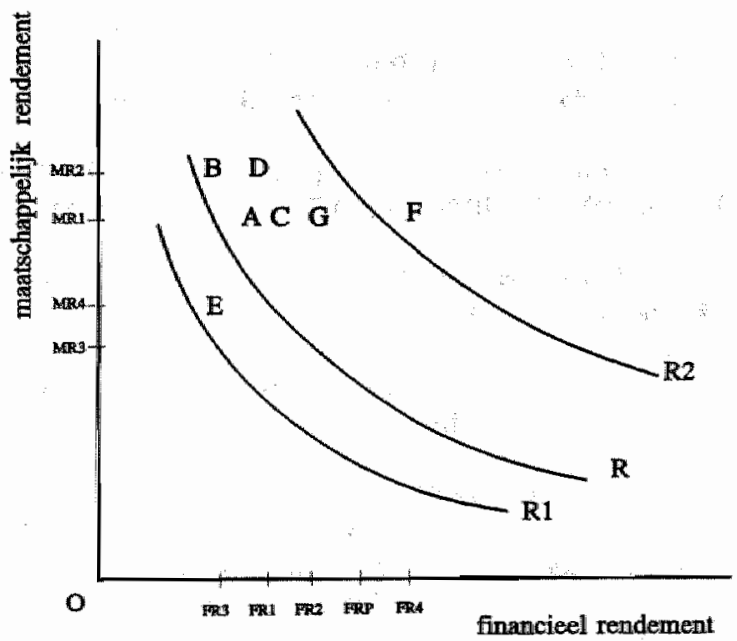

Figuur 2.3 Comparatieve voordelen van overheidsinstellingen ${ }^{174}$

\footnotetext{
172 T.a.p. p. 115

173 Ramanadham (1991, p. 16).

${ }^{174}$ Bron: T.a.p., p. 17.
} 
De curves $\mathrm{R} 1, \mathrm{R}$ en $\mathrm{R2}$ geven mogelijke combinaties van particulier en maatschappelijk rendement weer. Stel dat een bepaalde combinatie van sociaal en financieel rendement, i.c. A, geprefereerd wordt door de overheid. Uitgangspunt is dat de financiële opbrengst niet varieert met de sociale opbrengst. Indien FRp het rendement is dat door particuliere bedrijven gewenst wordt en Mr1 het door de overheid gewenste maatschappelijke rendement, is het de vraag of een particulier bedrijf een combinatie van rendementen kan realiseren met een hogere particuliere en maatschappelijke opbrengst dan $A$. In dat geval zou een particulier bedrijf middelen opofferen ter bereiking van maatschappelijk rendement aangezien zij in plaats van Mr1 FRp ook Mr3 FRp kan realiseren. Het is miet waarschijnlijk dat een particulier bedrijf dit zal doen. Indien een particulier bedrijf FRp nastreeft wordt evenwel slechts $\mathrm{Mr} 3$ gerealiseerd, hetgeen impliceert dat het door de overheid geprefereerde punt A niet gerealiseerd wordt. In principe zijn ook andere instrumenten dan overheidsinstellingen mogelijk om punt $A$ te bereiken, bijvoorbeeld subsidieverlening. Indien de subsidie die verstrekt moet worden om $A$ te bereiken kleiner is dan FR1 FRp is het denkbaar dat het comparatieve voordeel van een subsidie groter is dan dat van een overheidsinstelling of een eventueel ander instrument.

Ramanadham vermeldt een zevental situaties waarin het waarschijnlijk is dat een overheidsinstelling een comparatief voordeel heeft, namelijk: ${ }^{175}$

1. Indien de activiteit, op grond van bepaalde doelen van de overheid, plaatsvindt als een monopolie, maar de overheidscontrole op de particuliere sector niet effectief zou zijn.

2. Indien de levensvatbaarheid gering is vanwege redenen die het management van thet bedrijf niet kan overwinnen.

3. Indien de technologie alleen te importeren is. Dit kan overheidsinterventie aanmoedigen ten einde de buitenlandse controle over het bedrijf te minimaliseren.

4. Indien kapitaal alleen geïmporteerd kan worden en de overheid probeert om managementcontrole door buitenlandse kapitaalverschaffers te verminderen.

5. Indien de invloed van het bedrijf op de concentratie van inkomen en welvaart hoog is en derhalve overheidsinterventie nodig geacht wordt.

6. Indien de preferenties van de overheid met betrekking tot het sociale beleid grote invloed hebben op het bedrijf en het (producenten)surplus negatief beïnloeden.

7. Indien de organisatie van activiteiten binnen de publieke sector geen aanvullende kosten met zich meebrengt boven de kosten van voortbrenging in de particuliere sector.

Ramanadham wijst erop dat met name de laatste factor cruciaal is. Hij benadrukt dat de bijkomende kosten in de praktijk het comparatieve voordeel van overheidsinstellingen aanzienlijk kunnen verminderen, ongeacht de voordelen inzake bijvoorbeeld marktfalen. Het is denkbaar dat niet FR1 maar FR3 gerealiseerd wordt, hetgeen impliceent dat niet R maar slechts R1 bereikt wordt. Ramanadham vermeldt woorts dat er ook factoren zijn die kunnen leiden tot een verschuiving van $R$ naar $R 2$, bijvoorbeeld omdat markten na verloop van tijd minder imperfect kunnen worden en in verband met positieve externe effecten. Bij iedere $\mathrm{Sr}$ is een hoger financieel rendement haalbaar. Vanaf een bepaald stadium zullen particuliere bedrijven de bedrijfstak binnentreden. Er vanuitgaande dat

${ }^{175}$ Ramanadham (1991, p. 18). 
particuliere bedrijven minimaal een rendement eisen van FRp zullen zij pas in de markt gaan opereren vanaf de combinatie $\mathrm{G}$ in Figurur 2.3. Indien de overheid een rendement van Mr1 beoogt heeft een overheidsinstelling dan geen comparatief voordeel Het is dan denkbaar dat de betreffende activiteiten aan particuliere bedrijwen worden overgelaten of dat het instrument van overheidsinstellingen vervangen wordt door een ander instrument. De conclusie is dan ook dat de comparatieve yoordelen verschillen per overheidsinstelling of ander instrument en tevens per periode.

In de praktijk bleken er zich ten aanzien van de benadering van comparatieve voordelen een aantal problemen voor te doen.

In de eerste plaats werd bij het opzetten van overheidsinstellingen veelal voorbijgegaan aan bepaalde intrinsieke kosten van deze instellingen. De voortbrenging van activiteiten door overheidsinstellingen heeft naast voordelen ook nadelen. Zo zal het orgamiseren van activiteiten binnen overheidsinstellingen kosten met zich meebrengen, waarmee particuliere bedrijven zich niet geconfronteerd zien. Ramanadham onderscheidt een vijftal van dit soort kosten, namelijk:

1. De kosten van betrokkenheid van de overheid bij de oprichting van overheidsinstellingen en de periode daarna. Hierbij kan gedacht worden aan een reeks wan factoren waaronder de valak trage goedkeuring van investeringswoorstellen van het management.

2. De kosten van excessieve unificatie. Tegenover de voordelen van integratie staan bijwoorbeeld nadelen door overcentralisatie van het beslissingsproces.

3. De kosten van politieke en parlementaire controle en kritisch onderzoek. De controle van het parlement kan dermate ver gaan dat eigen initiatief en het nemen van risico's door managers zoveel mogelijk vervangen wordt door vaste procedures. Dit zal zich des temeer voordoen naarmate de politieke actoren meer de neiging hebben op grond van politieke redenen te interveniëren, hetgeen aanzienlijke kosten met zich mee kan brengen.

4. De kosten van de publieke verslaglegging. De verslaglegging aan de overheid leidt er vooral toe dat de politieke actoren tal van mogelijkheden hebben om te interveniëren. Het is mogelijk dat door een intensieve controle de nadruk wordt gelegd op genomen risico's die tot fouten hebben gelleid terwijl genomen risico's die tot successen hebben geleid buiten beschouwing blijven. Dit kan ertoe leiden dat enerzijds managers zoveel mogelijk trachten risico's en fouten te voorkomen en zich dienovereenkomstig zoveel mogelijk zullen conformeren an politieke pressie terwijl anderzijds hierdoor een prikkel ontstaat om zoveel mogelijk overheidsinstellingen en actoren bij beslissingen te betrekken, zodat het niet mogelijk is afzonderlijke actoren verantwoordelijk te stellen.

5. Tenslotte zijn ook de kosten van het gedrag van het management in de publieke sector van belang.

In de tweede plaats bleven de maatschappelijke opbrengsten in de praktijk veelal achter bij de verwachte maatschappelijke opbrengsten. Een ernstig probleem hierbij is het op juiste wijze meten van deze maatschappelijke opbrengsten. Geillustreerd met Figuur 2.3 is het denkbaar dat miet punt A maar punt $\mathrm{E}$ gerealiseerd wordt.

In de derde plaats is ook de "leercurve" van belang. Met name ontwikkelingslanden hebben in het verleden nogal eens te maken gehad met een leercurve die een veel langere periode besloeg dan vooraf verwacht was. Vaak kwam dit door de te ambitieuze doelen van deze ontwikkelingslanden. 
De benadering van de comparatieve voordelen gaat er vanuit dat politici de sociale welvaart maximaliseren. In werkelijkheid is er weinig aanleiding dit te veronderstellen. Politici zullen een afweging maken van de politieke baten en kosten, die aanzienlijk kunnen afwijken van de maatschappelijke opbrengsten en kosten. Het beschermen van de werkgelegenheid en het voortbestaan van zwakke bedrijven kan dan prioriteit krijgen terwijl dit vamuit strikt economisch gezichtspunt niet wenselijk zou zijn. Daar komt bij dat indien de benadering die uitgaat van marktfalen wordt gevolgd, overheidsinstellingen vaak worden voorgesteld als rationele actoren die door de overheid bepaalde doelen nastreven. De overheid controleert deze bedrijven vervolgens volledig. In werkelijkheid is de situatie evenwel veel meer gecompliceerd. Landen bereiken zelden consensus over nationale doelen terwijl er voorts in de geschiedenis voldoende voorbeelden bestaan van conflicten tussen regeringen en overheidsinstellingen en overheidsinstellingen onderling. $\mathrm{De}$ vaak geschetste situatie dat de overheid de strategie uitstippelt van een overheidsinstelling terwijl de overheidsinstelling zelf zich voornamelijk bezighoudt met de uitvoering lijkt in werkelijkheid niet te bestaan. Aharoni geeft aan dat de overheid vaak geen strategie aangeeft, terwijl zij wel intervenileert bij de uitvoering. Deze interventie wordt gerechtvaardigd met het argument dat de overheid uiteindelijk voor de eventuele verliezen opdraait. Verder is het van belang te onderkennen dat de benadering van een overheid die zijn netto baten maximaliseert moet worden aangevuld met het concept van een polycentrische overheid. Er zijn tal van actoren die beslissen over het verticaal integeren van de overheid. Hierbij kan gedacht worden aan de verschillende departementen die toezien op overheidsinstellingen, de verschillende actoren binnen deze departementen en voorts ministers en kamerleden. Daarnaast zijn ook actoren buiten de overheid van belang. Het is mogelijk dat bijvoorbeeld consumenten, afnemers, leveranciers en vakbonden invloed hebben op de keuze van het door de overheid gekozen instrument. Op grond van een "public choice"-benadering zouden overheidsinstellingen eveneens actief zijn in de door Jones genoemde sectoren met sterk geconcentreerde industrieën met onvolkomen mededinging. De reden hierwoor is evenwel een andere dan de door Jones genoemde en is hierin gelegen dat zich in deze sectoren technische inefficiëntie ("slack") kan voordoen, hetgeen veelal miet mogelijk is in een markt met veel concurrentie. ${ }^{176}$ De technische inefficiëntie en de hiermee nagestreefde doelen, kan verschillen van instelling tot instelling en van periode tot periode. De overheidsinstellingen, met name de belangrijke overheidsinstellingen als de elektriciteitsbedrijven en de waterleidingbedrijven, worden door de politici gebruikt om doelen na te streven teneinde herverkiezing te realiseren. Het management zou vervolgens de overheidsinstelling moeten afschermen tegen deze politieke inmenging. In werkelijkheid zijn de bestuurders van overheidsinstellingen vaak benoemd als vertegenwoordiger van een bepaalde groep, wiens belangen zij moeten bewaken. Managers van overheidsinstellingen kumen na verloop van tijd in belangrijke mate politieke macht verwerven. Dit neemt niet weg dat zij zich zullen realiseren dat er belangrijke restricties bestaan die niet overschreden dienen te worden. Indien managers dit wel zouden doen kan dit leiden tot meer controle en minder discretionaire bevoegdheden
voor de managers in de toekomst.

In een democratie zullen regeerders trachten herkozen te worden. $\mathrm{Zij}$ zullen hierbij gebruik maken van alle mogelijke middelen waaronder overheidsinstellingen. Politieke actoren hebben daardoor een prikkel om met name de belangrijke overheidsinstellingen te prijsstijgingen zoveel mogelijk te beperken teneinde werkloosheid tegen te gaan en de afhangen van de tijd die resteert tot de verkiezingen en van dit gebeurt zal onder andere

${ }^{176}$ Jones et al. (1982, pp. 24 e.v.). 


\subsubsection{Een afweging van kosten en baten van elk instrument}

Dat de politieke actoren redenen hebben om in te grijpen in de economie en een overheidsinstelling een geschikt instrument hiervoor zou zijn is op zich niet voldoende. Andere factoren zijn van belang. In de vorige paragraaf is ingegaan op de comparatieve voordelen. Aangegeven is dat deze benadering op een aantal punten uitgebreid moest worden. Naast de redenen van de politieke actoren en de geschiktheid van een overheidsinstelling als instrument zijn vooral de kosten van het instrument in vergelijking met andere instrumenten van belang. Bovendien gaat het om de baten voor alle actoren. Hierop wordt in deze paragraaf verder ingegaan.

Een overheidsinstelling kan worden opgevat als een bedrijfshuishouding, waarin de overheid overwegende invloed uitoefent, of zoals Ramanadham stelt: "The concept of public enterprise,..., is that it refers to an organization which combines in itself elements of "publicness" and "enterprise" ". ${ }^{177}$ Coase maakt een onderscheid tussen marktcoördinatie en het afstemmen van activiteiten binnen een onderneming. De beslissing om een bedrijf op te zetten of voor een bedrijf om al dan niet verticaal te integreren is uiteindelijk een beslissing over het al dan niet gebruik maken van markttransacties. ${ }^{178}$ Hierbij zal de winstgevendheid van beide methoden tegen elkaar moeten worden afgewogen. De reden voor het bestaan van een organisatie is dan dat de kosten van markttransacties vermeden of beperkt kunnen worden door het afstemmen van activiteiten binnen een organisatie. Indien de kosten van markttransacties hoog zijn faalt de markt en dienen transacties geïnternaliseerd te worden in een bedrijf. Factoren die derhalve het ontstaan van organisaties en verticale integratie bevorderen zijn bijvoorbeeld de kosten van het bepalen van marktprijzen en de onderhandelingskosten om tot marktcontracten te komen. Een factor die de uitbreiding van een bedrijf tegengaat is bijvoorbeeld de grotere kans op fouten indien meer activiteiten worden geinternaliseerd. Uiteindelijk zal er een evenwicht tot stand komen waarbij de kosten van het voortbrengen van een volgende actie binnen een bedrijf gelijk zijn aan de kosten van marktcoördinatie van die volgende actie.

Williamson heeft onderzoek verricht naar factoren die leiden tot hoge transactiekosten en daarmee tot het ontstaan van bedrijven. Hij stelt dat de interactie tussen menselijke factoren (opportunisme, beperkte rationaliteit) en omgevingsfactoren (onzekerheid, klein aantal partijen bij transacties, specificiteit van de activa) uiteindelijk de mate van internalisering in bedrijven bepaalt. Indien gekozen wordt voor coördinatie via de markt kan dit bijvoorbeeld gerealiseerd worden door het opstellen van lange termijn contracten. Door gebrek aan informatie en beperkte rationaliteit van de contractanten kan het specificeren van de toekomstige ontwikkelingen moeilijk zijn, waardoor het opstellen van een compleet contract erg moeizaam en kostbaar wordt. Een contract zal in dat geval dan ook vrijwel steeds incompleet zijn en dit schept vervolgens ruimte voor opportunisme. Marktpartijen kunnen ook kiezen voor korte termijn contracten. Een belangrijk voordeel is dat minder eisen gesteld hoeven te worden aan de rationaliteit vam contractanten. Een nadeel is dat indien de eerste contractant woordelen behaalt ("first mover strategy") dit aanleiding kan geven tot kostbare heronderhandelingen die dienen om het contract te vernieuwen. In het geval van onzekerheid en in een situatie van onderhandelingen tussen een beperkt aantal partijen kan het wenselijk zijn activiteiten af te stemmen binnen een organisatie. Binnen een organisatie kan de onzekerheid beperkt blijven (in verhouding tot bijvoorbeeld lange termijncontracten) waardoor minder eisen gesteld hoeven te worden aan de mate van

in Ramanadham (1991, p. 3).

${ }^{178}$ Coase (1937, pp. 386 e.w.)., herdrukt in Stigler and Boulding (eds) (1953, pp. 331-352). 
rationaliteit. De kans op opportumisme is geringer en de onderhandelingen zullen onder andere door de institutionalisering van controlemechanismen onder omstandigheden minder kostbaar zijn. De interactie tussen menselijke factoren en omgevingsfactoren bepaalt derhalve uiteindelijk of coôrdinatie plaatsvindt via de markt of dat activiteiten worden afgestemd binnen een bedrijfshuishouding, waarbij een afweging van de kosten centraal zal staan. ${ }^{179}$

In het voorgaande is aangegeven waarom overheidsinstellingen organisaties zijn. Analoog aan de gevolgde gedachtengang kan ook geanalyseerd worden waarom de overheid overwegende invloed in deze instellingen heeft. Van Helden geeft aan dat de keuze tussen de verschillende varianten en dus ook of productie plaats zal vinden door middel van overheidsinstellingen, afhangt van de mate van "asset specificity". ${ }^{180}$ Ook Borcherding merkt op dat de beslissing van de overheid om al dan niet een overheidsinstelling op te richten veel weg heeft van de door Williamson geanalyseerde verticale integratie van een bedrijf. Evenals een particulier bedrijf zal ook de overheid een afweging maken tussen de kosten en opbrengsten van het zelf produceren en het overlaten van de productie aan de markt ${ }^{181}$ In hoofdstuk 11 wordt hier verder op ingegaan.

Het is duidelijk dat de keuze voor de meest wenselijke organisatievorm binnen de publieke sector niet alleen bepaald wordt door de mate van "asset specificity". Tal van andere factoren zijn denkbaar. Demsetz merkt op: "There is much more to the problem of economic arganization than is plausibly subsumed under transaction and monitoring cost. Perhaps the transaction and monitoring approaches to the theory of the firm have confined our research too much. Firms would exist in a world in which transaction and monitoring cost are zero, although their organization might be considerably different" ${ }^{182}$ Dienovereenkomstig gaan Alchian en Demsetz niet nit van transactiekosten maar van eigendomsrechten. ${ }^{183}$ Het al dan niet oprichten van een overheidsinstelling hangt dan naww samen met de verdeling van eigendomsrechten. Op grond van hun eigendomsrechten kumnen politieke actoren trachten door -een "rent-seekings"-proces zoveel mogelijk van de gederfde winst ("public enterprise rent") te bemachtigen. Philips stelt: "When efficiency requires large-scale, highly idiosyncratic investments in capital with long pay-back periods, when information is incomplete, asymmetrically distributed, and costly to gain or transfer, when bargaining is among small numbers, and when noncongruent and conflicting objectives are operative, then market-mediated transactions are likely to yield suboptimal results". ${ }^{184}$ Ook anderen stellen dat naast transactiekosten andere verklaringen denkbaar zijn. Hofstede stelt bijvoorbeeld dat onder meer de identificeerbaarheid van de doelstellingen en de meetbaarheid van de productie relevant zijn voor de keuze van de besturingsstructuur. ${ }^{185}$ Voorts is het niet gezegd dat indien op grond van de transactie-

\footnotetext{
${ }^{179}$ Clarke (1990, pp. 175 e.v.).

${ }^{180}$ Vam Helden in: Mol en Verbon (1993, pp. 61-63).

${ }^{181}$ Borcherding in: Prichard (ed.) (1983, pp. 104 e.v.).

${ }^{182}$ Demsetz (1988, p. 157).

${ }^{183}$ Alchian en Dermsetz (1972, p. 780).

${ }^{184}$ Philips (1987, p. 585).

${ }^{18.5}$ Hofstede (1981, pp. 193-211).
} 
kostentheorie overheidsinvloed in een bedrijf wenselijk is, de overheid in de praktijk hier ook voor zal kiezen.

De centrale vraag in dit hoofdstuk was waarom overheidsinstellingen worden opgericht en worden gecontinueerd. Op grond van voorgaande overwegingen blijken naast de redenen voor de overheid (allocatie, stabilisatie en herverdeling) de geschiktheid van een overheidsinstelling als instrument en de kosten van het bereiken van de doelen een rol te spelen. Hierbij sluit de benadering van Jones en Mason aan. Zij menen dat een overheidsinstelling moet worden opgericht indien enerzijds de nationale baten groter zijn dan de kosten en anderzijds deze netto baten voor overheidsinstellingen groter zijn dan voor alternatieve institutionele vormen zoals gereguleerde particuliere ondernemingen en subsidies. ${ }^{186}$ De baten die vooral bestaan uit de welvaartswinsten ten gevolge van het verwijderen van marktgebreken moeten worden afgewogen tegen de kosten van het falen van overheidsinstellingen. Dit falen binnen overheidsorganisaties kan ontstaan door een afwijkende "incentive-structuur" en door informatieproblemen. Volgens Jomes en Mason zouden de baten van een overheidsinstelling vooral groot zijn indien het alternatief voor een overheidsinstelling een particulier monopolie, geen bedrijf of een oligopolie is of indien er sprake is van aanzienlijke externe effecten. Deze omstandigheden zullen zich met name voordoen indien sectoren gekenmerkt worden door kapitaal-intensieve bedrijven. De kosten van overheidsinstellingen ten opzichte van particuliere organisaties zullen daarentegen hoog zijn indien activiteiten plaatsvinden op een kleine schaal en indien verkopen bijvoorbeeld plaatsvinden in snel veranderende en competitieve markten. Indien in dergelijke sectoren, zoals bijvoorbeeld in de landbouw, toch nationalisatie plaatsvindt dreigen grote "monitoring" - en organisatiekosten om managers te laten functioneren in het publieke belang.

Een bezwaar van deze benadering is dat zij, net als de benadering van Ramanadham, normatief is. Dat het maatschappelijk gezien goed zou zijn een overheidsinstelling op te richten betekent nog niet dat dit ook werkelijk gebeurt. Bovendien zijn er allerlei actoren binnen de overheid die bepaalde doelen hebben en die proberen te realiseren. In het algemeen zullen al deze actoren bepaalde belangen hebben en proberen deze tegen

minimale kosten te bereiken. Tal van factoren bepalen of de overheid uiteindelijk voor een overheidsinstelling kiest of op een andere wijze haar doelen probeert na te streven. Dit verklaart waarom er een grote diversiteit van overheidsinstellingen bestaat, op verschillende wijze juridisch vormgegeven, en opererend op verschillende allocatieve efficięntie-niveaus. Een overheidsinstelling is bovendien zoals ook in de vorige paragrafen benadrukt slechts één van de vele instrumenten. Of zoals Jones en Mason het stellen: "Public enterprise is ... one among many tools avallable for achieving the government's goals, and the choice of this tool is a function of the costs and benefits associated with its use as compared to those of other institutional forms"

De conclusie is dan ook dat alle relevante actoren (vergelijk hoofdstuk 6 e.v.) overeenkomstig de drie functies bepaalde doelen hebben. Fen overheidsinstelling zal soms zeer geschikt zijn om de doelen van een bepaalde actor te realiseren, soms juist niet. Daarnaast zal een actor kijken naar de kosten van elk instrument, zoals weergegeven in tabel 2.4.

186 Jones (1982, pp. 25 e.Y.).

187 Jones en Mason in: Jones et all. (1982, p. 24). Vergelijk ook: Jones en Vogelsang (1982). 


\begin{tabular}{|c|c|c|c|c|}
\hline Aiternatieven: & $\begin{array}{l}\text { Conitante waarde van } \\
\text { de kosten (in geld) }\end{array}$ & $\begin{array}{l}\text { Atternatieve } \\
\text { kosten }\end{array}$ & $\begin{array}{l}\text { Transactiekosten } \\
\text { en } \\
\text { "agency costs" } \\
\text { ("monitoring } \\
\text { costs"), als } \\
\text { onderdeel van de } \\
\text { alternatiewe kos- } \\
\text { ten }\end{array}$ & $\begin{array}{l}\text { Totale contante } \\
\text { wrarde van de } \\
\text { kosten. }\end{array}$ \\
\hline $\begin{array}{l}\text { Overheids instelling met } \\
\text { "unitaire" structiuir } \\
\text { (franchise) }\end{array}$ & & & & A \\
\hline $\begin{array}{l}\text { Overheidsinstelling met } \\
\text { beperkte externe } \\
\text { verzelfstandiging }\end{array}$ & & & & B \\
\hline $\begin{array}{l}\text { Overheidsinstelling met } \\
\text { volledige externe verzelfst- } \\
\text { andiging, waarbij de over- } \\
\text { heid nog wel in het bezit is } \\
\text { van aandelen van het bedrijf }\end{array}$ & & & & c \\
\hline $\begin{array}{l}\text { Particuliere organisatie met } \\
\text { bijdrage ("grant") door de } \\
\text { owerheid, bekostigd uit the- } \\
\text { lastingen en heffingen }\end{array}$ & & & & $\mathbb{D}$ \\
\hline $\begin{array}{l}\text { Belastingheffing en subsidie- } \\
\text { werstrekking, bijvoorbeeld } \\
\text { aan consumenten door mid- } \\
\text { del van bonnensysteem } \\
\text { ("voucher") }\end{array}$ & & & & $\mathrm{E}$ \\
\hline $\begin{array}{l}\text { Belastingen en heffingen } \\
\text { (bijwoorbeeld ter bereiking } \\
\text { van inkomenswerdeling) }\end{array}$ & & & & F \\
\hline Regulering & & & & $\mathbf{G}$ \\
\hline $\begin{array}{l}\text { Publiel/Private samenwer- } \\
\text { kingsvormen }\end{array}$ & & & & $\mathbf{H}$ \\
\hline Overheidscontracten & & & & 1 \\
\hline Overheidsverkoop & & & & J \\
\hline \multirow[t]{2}{*}{$\begin{array}{l}\text { Intergouvernementele } \\
\text { overeenkomsten }\end{array}$} & & & & $\mathbf{x}$ \\
\hline & Allocatiefunctie & $\begin{array}{l}\text { Stabilisatie- } \\
\text { functie }\end{array}$ & $\begin{array}{l}\text { Herverdelings: } \\
\text { functie }\end{array}$ & $\begin{array}{l}\text { Opbrengsten: } \\
\text { (contante } \\
\text { waarde van de } \\
\text { opbrengsten) }\end{array}$ \\
\hline
\end{tabular}

\section{Tabel 2.4 Redenen voor het bestaan van overheidsinstellingen}

Actoren zullen het totale pakket aan inkomsten en uitgaven per besturingsstructuur tegen elkaar afwegen, gegeven hun doelen en de geschiktheid van het instrument. De verwerving van inkomsten door de overheid door middel van overheidsinstellingen valt onder de 
allocatiefunctie. Doel is de kosten te minimaliseren. Dit zijn niet alleen de kosten van het realiseren van de doelen maar ook de inningskosten, de "excess burden". Zijn bijvoorbeeld de belastingen hoog dan wordt het aantrekkelijker om een ander inningsinstrument te kiezen. De interactie van de verschillende actoren leidt uiteindelijk tot het all dan niet kiezen voor een overheidsinstelling of voor het continueren ervan.

\subsection{Conclusie}

Sinds de Tweede Wereldoorlog is het belang van publieke instellingen sterk toegenomen. Hoewel het aantal staats- en overheidsbedrijven (in enge zin geformuleerd) in Nederland het laatste decennium is afgenomen, is, zoals in hoofdstuk 1 is aangegeven, het aantal overheidsinstellingen (in ruime zin), indien het Popitz-criterium wordt gevolgd, nog steeds aanzienlijk. Het is van groot belang te weten waarom dergelijke publieke instellingen worden opgericht en blijven voortbestaan. Uit empirisch onderzoek is duidelijk geworden dat het aantal redenen waarom owerheidsinstellingen in de praktijk worden opgericht vrijwel onbeperkt is. Sommige overheidsinstellingen maken winst terwijl andere verlies lijden. Sommige overheidsinstellingen hebben zelfstandig toegamg tot de kapitaalmarkt terwijl andere volledig zijn aangewezen op leningen verstrekt door de overheid. Deze variatie is belangrijk om te begrijpen waarom overheidsinstellingen bestaan. Uitgaande van een theoretische analyse is aangegeven dat er tal van redenen kunnen zijn voor het bestaan van dergelijke bedrijven. In dit hoofdistuk zijn evenwel een aantal kanttekeningen geplaatst bij het belang van overwegingen die verband houden met marktgebreken. Van groot belang voor het verklaren van het bestaan van overheidsinstellingen en de vorm van deze instellingen zijn "public choice" processen. Naast de redenen voor politieke actoren om een overheidsimstelling op te richten is de mate van geschiktheid daarvan van belang. Indien bijvoorbeeld een bijdrage ("grant") van de overheid in de betreffende situatie meer geschikt is zullen de politici geneigd zijn hiervoor te kiezen. Daarnaast zijn ook de kosten van elk instrument van belang. Met behulp van Tabel 2.4. kan tenslotte in samenhang met Tabel 2.3 worden beredeneerd of een overheidsinstelling zal worden opgericht of dat de politieke actoren kiezen voor een alternatief. Niet alleen het oprichten en continueren van overheidsinstellingen kan met deze analyse worden verklaard maar ook de eventuele keuze voor privatisering. Volgens de in dit hoofdstuk geschetste benadering zal een overheidsinstelling geprivatiseerd worden indien de redenen voor de politieke actoren zijn veranderd, indien het instrument minder geschikt is geworden in vergelijking met andere instrumenten of indien de (alternatieve) kosten van andere instrumenten (in relatie met de baten) relatief zijn gedaald.

In dit onderzoek wordt vervolgens een stap verder gegaan. Ervan uitgaande dat een overheidsinstelling eenmaal is opgericht rijst de vraag naar" het gedrag en de "performan$\mathrm{ce}^{\text {"i }}$ ervan. Geconstateerd kan worden dat de redenen voor het oprichten van overheidsinstellingen ten nauwste samenhangen met de verschillen in gedrag van overheidsinstellingen en particuliere bedrijven, aangezien overheidsinstellingen veelal in verband met deze beoogde verschillen in gedrag zijn opgericht. De politiek-economische theorie die in de komende hoofdstukken wordt uitgewerkt bouwt hier op voort. 


$$
\text { . }
$$




\section{Hoofdstuk 3. De theorie van overheidsinstellingen, een netwerkbenade- ring}

\subsection{Inleiding: een politiek-economisch-organisatiekundige theorie van overheidsinstel- lingen}

Er bestaat een uitgebreide literatuur waarin ingegaan wordt op de vraag waarom overheidsinstellingen worden opgericht. In het verlengde hiervan ligt de vraag boe een overbeidsinstelling zich in de praktijk gedraagt en wat de reden is van dit gedrag. Het is duidelijk dat deze vraagstukken samenhangen. Overheidsinstellingen zullen vaak zijn opgericht met het oog op een bepaald toekomstig resultaat. De centrale vraag die in dit hoofdstuk en de volgende hoofdstukken wordt beantwoord luidt dan ook: door welke factoren kan de "performance" van een overheidsinstelling worden verklaard.

Het doel van de komende hoofdstukken is om een theorie te ontwikkelen van overheidsinstellingen. Allereerst moet worden aangegeven wat met een dergelijke theorie wordt beoogd. Backhaus stelt dat een politiek-economische theorie van overheidsinstellingen: $:^{188}$

1. Het gedrag van een overheidsinstelling moet verklaren, voor zover het zich van het gedrag van andere bedrijven onderscheidt.

2. Moet bijdragen aan de beantwoording van een aantal vragen, zoals:

-welke economische functies kunnen overheidsinstellingen vervullen?

-welke organisatievormen zijn daarvoor geschikt?

-in hoeverre is het verstandig in bepaalde sectoren van de economie overheidsinstellingen te privatiseren dan wel de overheidsinvloed in bedrijven en instellingen te vergroten?

In dit deel wordt ten aanzien van het eerste punt een iets ruimere benadering gevolgd. Het accent ligt op het verklaren van de "performance" van een overheidsinsteiling. Hierbij wordt ervan uitgegaan dat het gedrag één van de factoren is die het resultaat beinnloedt. Naast het gedrag zijn echter ook andere factoren van belang zoals de marktstructuur en de politieke factoren. Met behulp van de ontwikkelde theorie kan vervolgens inzicht verworven worden in een reeks van vraagstukken met betrekking tot overheidsinstellingen, zoals de functie van overheidsinstellingen, de daarvoor geschikte organisatievormen en de vraag wanneer overgegaan zal en/of moet worden tot privatisering.

De theorie over het gedrag van overheidsinstellingen zoals die in het theoretische deel van dit proefschrift wordt uiteengezet bestaat dienovereenkomstig uit een tweetal onderdelen. Zoals in het vorige hoofdstuk is aangegeven worden overheidsinstellingen enerzijds gekenmerkt door min of meer bedrijfsmatige activiteiten en anderzijds door de overheidsinvloed. Voor een verklaring van het gedrag dienen beide facetten in de theorie te worden geîntegreerd. $\mathrm{Er}$ is derhalve een politiek-economische theorie van het gedrag van overheidsinstellingen nodig.

Overheidsinstellingen functioneren in markten. Dit betekent dat zij te maken hebben met de factoren die ook invloed uitoefenen op particuliere bedrijven, zoals de ard van de markt, de mogelijkheid van entree en dergelijke. Dit sluit aan bij het structurur-gedragresultaat-paradigma, dat dan ook dient als uitgangspunt. Zo zal een overheidsinstelling waak de vorm aannemen van een wettelijk monopolie, hetgeen vanzelfsprekend gevolgen heeft voor de marktstructuur. Belangrijker voor ons zijn de verschillen in gedrag tussen

${ }^{188}$ Backhaus (1980, p. 1). 
een overheidsinstelling en een particulier bedrijf. In het kader van het structuur-gedragresultaat-paradigma wordt ten aanzien van het gedrag veelal ingegaan op oligopolistische concurrentie. Er zijn theoretische en empirische redenen om aan te nemen dat particuliere ondernemingen in monopolies en gereguleerde markten minder kostenefficiënt zijn dan particuliere bedrijven in markten van volkomen mededinging. ${ }^{189}$ De vraag is dan ook of de specifieke kenmerken die aan overheidsinstellingen worden toegeschreven niet voornamelijk veroorzaakt worden doordat overheidsinstellingen vaak opereren in imperfecte markten. Ook bij een overheidsinstelling kunnen oligopolistische factoren een rol spelen. Toch zullen deze factoren veelal slechts een gedeeltelijke verklaring voor het gedrag van overheidsinstellingen vormen. Dit komt omdat overheidsinstellingen onderdeel witmaken van het politieke proces. Dit politieke proces is van invloed op het gedrag van overheidsinstellingen en dient dan ook geanalyseerd te worden, waarbij gekeken dient te worden naar ministers, parlementsleden, bureaucraten en pressiegroepen. De analyse van de externe organisatie is behoorlijk ontwikkeld. Het kader voor het analyseren van politieke factoren is evenwel minder ontwikkeld. Hiermee is niet gezegd dat er geen snelle ontwikkeling is van allerlei vaak met elkaar verwant werk dat onder verschillende titels verschijnt, zoals theorie van de eigendomsrechten, transactiekosten-economie, "public choice" en "x-efficiency" theorie. Elke tak van deze literatuur kan belangrijk bijdragen aan een beter inzicht in het gedrag van overheidsinstellingen. De wijze van functioneren van een overheidsinstelling kan schematisch als volgt worden weergegeven:

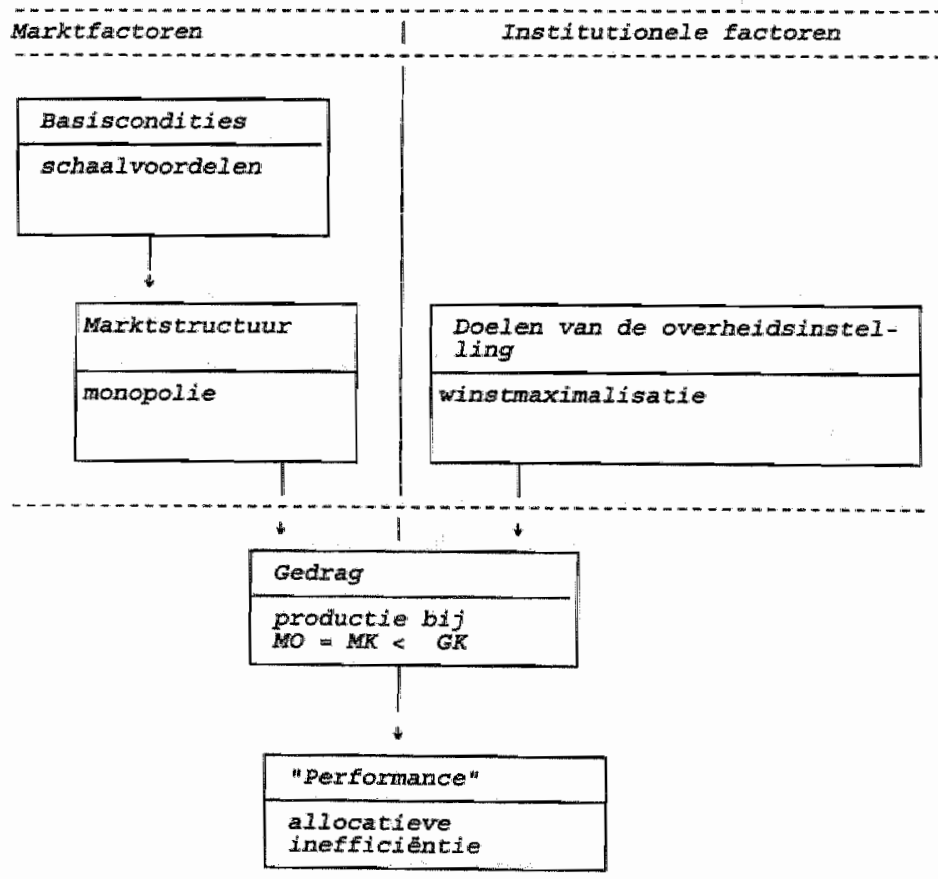

Figuur 3.1 De "performance" van een overheidsinstelling

${ }^{189}$ Leibenstein (1966, pp. 392-415) en Leibenstein (1978, pp. 203-211).

1907 Bron: Vogelsang (1990, p. 17). 
Indien wij het gedrag van een overheidsinstelling willen verklaren dienen verschillende vragen beantwoord te worden, waaronder de vraag wie nu in werkelijkheid de doelen van de overheidsinstelling bepaalt. Daarnaast kan het gedrag van overheidsinstellingen geanalyseerd worden door meer specifiek aandacht te besteden aan de vraag hoe de verdeling van eigendomsrechten er uitziet, wie de principaal en wie de agent is, en voorts zijn de hoogte van transactiekosten en de integratie van dergelijke factoren in één omvattend kader van belang. Al deze factoren leiden ertoe dat de "incentive-structuur" en het gedrag van een overheidsinstelling aanzienlijk kan afwijken van die van een particulier bedrijf. Dit heeft ook gevolgen voor het besluitvormingsproces en kan uiteindelijk grote gevolgen hebben voor de "performance". Vervolgens kan deze "performance" weer invloed hebben op de marktstructurur, het marktgedrag en het politieke proces.

In de linkerhelft van Figuur 3.1 is de traditionele benadering van de industriële organisatie, het zogenaamde structurur-gedrag-resultaat-schema weergegeven. Hoewel het gedrag van overheidsinstellingen van instelling tot instelling kan verschillen is het van belang naar parallellen te zoeken teneinde te komen tot een politiek-economische theorie van overheidsinstellingen. Deze theorie zal op grond van voorgaande gedachtengang ontwikkeld worden door uit te gaan van het structuur-gedrag-resultat-paradigma, door vervolgens te onderzoeken wiens doelen worden nagestreefd in het politieke proces en door tenslotte de neo-institutionele en "public choice" benadering toe te passen. In paragraaf 3.2 zal worden ingegaan op de industriêle organisatie benadering en de consequenties hiervan voor de overheidsinstelling. In hoofdstuk 5 en verder wordt ingegaan op de rechterkant van het schema, te weten de institutionele of politieke factoren.

\subsection{De industriële organisatie-benadering van het structuur-gedrag-resultaat-paradig- ma}

Uitgangspunt bij het opstellen van een theorie van overheidsinstellingen is het raamwerk zoals dat in de industriële organisatie gebruikt wordt, te weten het gematigde structuurgedrag-resultaat-paradigma ${ }^{191}$ Hoewel de nieuwe industriële economie aanzienlijk afwijkt van de structuur-gedrag-resultaat-benadering vloeit zij bier ook logisch uit voort. Het belangrijkste verschil is in feite dat de nieuwe industriële organisatie gebruik maakt van de speltheorie. ${ }^{192}$ De eenvoudige causale relaties in het traditionele structurur-gedrag-resultaat-schema zijn vervangen door een hele reeks van mogelijke verbanden. Norman en La Manna geven als voorbeeld het verschil in de amalyse van een bovennormaal winstniveau. Volgens hen zou dit in de traditionele industriële organisatie verklaard worden door collusie (gedrag) ten gevolge van hoge concentratie, bijvoorbeeld door exogene entreebarrières. Op grond van de nieuwe industriële organisatie wordt de structuur, het gedrag en de "performance" in een speltheoretisch model gelijktijdig bepaald. Zij geven aan dat entreebarrières nu variabelen zijn waarover besloten moet worden en die endogeen bepaald worden door de strategische beslissingen van bedrijven.

De nieuwe industriële organisatiebenadering laat evenwel onverlet dat het gematigde structuur-gedrag-resultaat-paradigma nog steeds bruikbaar is, mits maar beseft wordt dat er geen eenduidige causale relaties bestaan. Dit schema wordt om een aantal redenen als uitgangspunt genomen. In de eerste plaats omdat het gematigde structuur-gedrag-resultaatschema nog steeds als een belangrijke benadering in de industriële organisatie beschouwd

191 Schmidt en Rittaler (1989, pp. 114 e.v.).

${ }^{192} \mathrm{Vgl}$. Norman en La Manna $(1992$, p. 3). 
kan worden, in de tweede plaats omdat het een algemeen kader schetst waarbinnen andere factoren gemakkelijk kunnen worden geïntegreerd, in de derde plaats omdat het schema zich leent als uitgangspunt voor een positieve theorie en in de vierde plaats omdat het sterk gericht is op het verklaren van het uiteindelijk marktresultaat, waarbij niet uitsluitend technische efficiëntie centraal staat. Tenslotte kan worden opgemerkt dat het strucnur-gedrag-resultaat-schema in dit deel op zich geen onderwerp van onderzoek is, maar slechts als uitgangspunt dient om duidelijk te maken hoe het politieke proces, de microeconomie, de "public choice" theorie, en de neo-institutionele economie met elkaar samenhangen en waarmee aangegeven $\mathrm{kan}$ worden in hoeverre het functioneren van een overheidsinstelling afwijkt van het gedrag van een particulier bedrijf.

\subsubsection{Hoe ziet het op overheidsinstellingen toegepaste structuur-gedrag-resultaat- schema eruit?}

Bimen het structuur-gedrag-resultaat-schema kunmen een viertal blokken worden onderscheiden. Het eerste blok heeft betrekking op de algemene marktcondities, het tweede op de marktstructuur, het derde op het gedrag van bedrijven in een bepaalde bedrijfstak en het vierde blok betreft het resultaat van de bedrijven in een sector, waarbij verschillende resultaatvariabelen onderscheiden kunnen worden. In deze paragraaf zullen we kort het schema weergeven, teneinde duidelijk te maken in hoeverre dit schema gebruikt kan worden voor overheidsinstellingen.

\section{Basiscondities}

\section{De aanbodkant}

\section{- Kosten}

Het is van belang te weten hoe groot de vaste kosten van een overheidsinstelling zijn in relatie tot de totale kosten. Voorts is het van belang te weten hoe groot de capaciteit van de sector is en hoe nieuw de productiecapaciteit is. Toegepast op de elektriciteitssector moet onderscheid gemaakt worden tussen de productie- en distributiesector. Voor de productie van elektriciteit moet veel geinvesteerd worden in productiemiddelen. Bedrijven in deze sector worden gekenmerkt door hoge vaste kosten. Tot een bepaalde hoogte zal hierbij sprake zijn van dalende gemiddelde kosten en derhalve van schaalvoordelen. Indien de productie stijgt nemen de kosten af. In hoofdstuk 2 is hier meer uitgebreid op ingegaan. In de productiesector is sprake van overcapaciteit. Een belangrijk deel van de vaste kosten bestaat uit verzonken kosten ("sunk costs"), kosten die niet meer ongedaan gemaakt kunnen worden door het verkopen van machines e.d. op de tweedehandsmarkt. Voor de distributiesector moeten met name kosten gemaakt worden voor het elektriciteitsnet en het op spanning brengen van elektriciteit. Bij het Rijksmuseum en de Belastingdienst zijn de arbeidskosten de belangrijkste kostenpost. Het probleem van "sunk costs" zoals hiervoor beschreven doet zich daar niet of veel minder voor. Bij de Bellastingdienst kunnen de investeringen in opleidling van het personeel eventueel als zodanig worden
beschouwd.

\section{-Technologie}

Bellangrijk is voorts in hoeverre de betreffende bedrijfstak kapitaal- of arbeidsintensief is en de mate waarin de activiteiten van de sector veel technische kennis vereisen. Verder is 
het van belang of er zich leereffecten voordoen en of de verrichte activiteiten een specialistisch karakter hebben. In hoofdstuk 11, dat gewijd is aan de transactiekostenbenadering, wordt hierop teruggekomen. Voorts is het relevant te weten of er op voorraad of op order geproduceerd wordt, hoe groot de productiecapaciteit is en of het gaat om een produkt of een dienst. Ten aanzien van de elektriciteitssector kan worden opgemerkt dat deze wordt gekenmerkt door grote eenheden. Voor de productie en distributie van elektriciteit is veel technologie nodig. Ook het Rijksmuseum beschikt over specifieke kennis over de wijze waarop kunstwerken gerestaureerd moeten worden en over kunstwerken met name uit bepaalde perioden. De Belastingdienst verricht veel werkzaamheden waarvoor veel met name fiscaal-juridische kennis nodig is. Het productieproces van de Belastingdienst is zeer arbeidsintensief. Dit blijkt ook uit het grote aandeel van het personeelsbudget in het totale budget.

\section{-Overheidsbemoeienis}

De overheid kan op verschillende wijzen een rol spelen, bijvoorbeeld door het aankopen van goederen of door regulering van de bedrijfstak. Verder kan de overheid invloed uitoefenen door de heffing van belastingen en het verstrekken van subsidies: Denkbaar is voorts dat de overheid door middel van een "second-best" beleid met behulp van overheidsinstellingen invloed tracht uit te oefenen. In hoofdstuk 4 , gewijd aan de nomatieve benadering, zullen deze aspecten verder aan bod komen. In de elektriciteitssector was de invloed van de owerheid groot. De elektriciteitsbedrijven waren in de periode 1970-1990 N.V."s met overheersende invloed van de overheid. Dat gold zowel voor de productie- als. distributiesector, die in de jaren "70 en ' 80 verticaal geïntegreerd waren. Het was voor andere bedrijven niet mogelijk toe te treden. In de jaren " 80 is de elektriciteitssector gedereguleerd. Elektriciteitsbedrijven zijn gesplitst in productie- en distributiebedrijven. Voorts is er een horizontale integratie doorgevoerd. Geleidelijk aan wordt de overheidsinvloed verminderd. De Nederlandse markt is ingedeeld in een aantal districten. Het is voor bedrijven nog niet mogelijk te leveren aan andere regio's. Ook is het niet mogelijk te concurreren op buitenlandse markten. In Europees verband bestaat nog steeds regulering. Het Rijksmuseum was gedurende de jaren ' 80 onderdeel van bet Ministerie van W.V.C.. Zoals beschreven in hoofdstuk 15 is het Rijksmuseum halverwege de jaren " 90 geprivatiseerd, waardoor de overheidsinvloed afnam. Ook bij MEGA Limburg en de Belastingdienst had de overheid grote invloed. Bij MEGA Limburg kwam dit onder andere tot uiting door de benoeming van commissarissen. Bij de Belastingdienst is dit meteen al duidelijk aangezien deze dienst onderdeel is van het Ministerie van Financiën. De Directeur-Generaal der Belastingen staat aan het hoofd van de dienst en is verantwoording schuldig aan met name de Staatssecretaris en Minister van Financiën.

\section{De vraagkant}

\section{-Aantal vragers}

Is het aantal vagers groot of relatief beperkt. Verder is het van belang hoe de ruil plaatsvindt. Gebeurt dit door middel van mededinging of is er een prijsreguleringssysteem. Het aantal verbruikers van elektriciteit is zeer groot, aangezien vrijwel iedereen op het elektriciteitsnet is aangesloten. Ook het aantal bezoekers van het Rijksmuseum is groot, namelijk ongeveer 1 miljoen aan het einde van de jaren ' 80 en het begin van de jaren ' 90 . Wie bij de Belastingdienst de klanten zijn hangt ervam af of de Belastingdienst wordt gezien als een intermediaire producent of een finale producent. Indien deze dienst wordt opgevat als een intermediaire producent zijn er in feite twee soorten klanten. 
Enerzijds worden diensten verleend aan de overheid en andere onderdielen van de kwartaire sector, anderzijds worden diensten verricht aan burgers en bedrijven. Het is echter ook mogelijk de Belastingdienst op te vatten als finale producent. De belastingbetalers kunnen dan worden opgevat als de vragers, aangezien de Belastingdienst als het ware een dienst verleent door het geld te innen. Dit aantal is zeer groot, in feite iedereen met een sofi-nummer.

\section{-(verwachte) vraag}

De vraag rijst in welke fase van de levenscychus het produkt zich bevindt en in hoeverre er groeimogelijkheden zijn. Gaat het bij de toekomstige groei om vervanging van de bestaande capaciteit of om uitbreiding daarvan. In de elektriciteitsmarkt leefde in de jaren '70 de verwachting dat de vraag naar elektriciteit sterk zou stijgen. Door allerlei ontwikkelingen is dit niet in die mate gebeurd. Hierbij kan gedacht aan de beide oliecrises, aan de recessie en de voortgaande energiebesparing. Voor de sector Limburg is het verbruik van elektriciteit gestegen van 2.566.398 MWh in 1970 tot $6.205 .444 \mathrm{MWh}$ in 1989. Ter vergelijking, van 1965 tot 1974 steeg het verbruik van elektriciteit in de regio Limburg van 1.511.787 tot 3.473.292 MWh. Bij de Belastingdienst hangt de verwachte vraag sterk af van de economische groei en de hoogte van de belastingtarieven. Voor de totale belastingopbrengst geldt een macro-economische progressiefactor van ongeveer 1,1 . Dit betekent dat indien de economische groei met $1 \%$ toeneemt, de belastingopbrengst met ongeveer $1,1 \%$ stijgt.

\section{-Prijselasticiteit van de vraag}

Is de vraag prijselastisch of juist ongevoelig voor prijswijzigingen. Indien de vraag prijsinelastisch is zullen zelfs grote prijswijzigingen geen grote invloed hebben op de benutte capaciteit.

\section{-Tijdelijkheid van de vraag}

Is de vraag éénmalig of is er sprake van een terugkerende dienst. In de elektriciteitssector is de vraag niet tijdelijk. Hetzelfde geldt voor de Belastingdienst.

\section{-Conjunctuur- en seizoensinvloeden}

In welke mate is de bedrijfstak gevoelig voor conjuncturele schommelingen? Indien een overheidsinstelling hoge vaste lasten heeft zal een wijziging van de vraag een relatief grotere invloed hebben op het bedrijfsresultaat. Verder is het belangrijk te weten of de bedrijfstak erg afhankelijk is van overheidsopdrachten. Indien het slecht gaat met de economie zal ook de overheid geneigd zijn minder te besteden waardoor in dat geval een recessie extra hard aan kan komen. Andere belangrijke factoren zijn bijwoorbeeld de olieprijzen en de dollarkoers. De vraag naar elektriciteit is conjunctuurgevoelig, in de zin dat in tijden van een recessie de vraag naar elektriciteit zal dalen. Aangezien elektriciteit als een eerste levensbehoefte opgevat kan worden zullen consumenten het verbruik niet veel matigen. De fluctuatie in het verbruik van elektriciteit door bedrijven kan wel van invloed zijn. Ook de dienstverlening door de Belastingdienst is gevoelig voor conjunctuuren seizoensinvloeden. De conjunctuurgevoeligheid blijkt uit de genoemde macro-economische progressiefactor. De seizoensinvloed heeft te maken met het door de Belastingdienst gehanteerde principe van "pay as you earn". 


\section{Marktstructuur}

\section{-Relevante markt}

Bij het bepalen van de relevante markt waarbinnen de overheidsinstelling opereert kan onderscheìd gemaakt worden tussen geografische en technische criteria, Op grond van geografische criteria kan bijvoorbeeid onderscheid gemaakt worden tussen regionale/nationale en internationale markten. Onderscheidende criteria zijn verder kenmerken van de goederen zoals bederfelijkheid, transportmogelijkheden en preferenties van de consument. Hoewel in Europees verband gewerkt wordt aan deregulering is de elektriciteitsmarkt in de jaren '70 en '80 een voornamelijk nationale markt. Binnen de Nederlandse markt kan onderscheid gemaakt worden tussen een vijftal regio"s, die elk gekenmerkt worden door hoge entreebarrières. Voor elektriciteitsbedrijven is het niet mogelijk te produceren of te distribueren in een andere sector. Ook voor afnemers geldt dat het niet mogelijk is om elektriciteit van een bedrijf in een andere sector te kopen. Aan het eind van de jaren '80 kwam hier langzamerhand verandering in. Grote bedrijven zouden elektriciteit in het buitenland kunnen kopen. Voorts zijn entreebarrières zoals bestaande handelstarieven van belang voor het afbakenen van de geografisch relevante markt. Op grond van technische criteria is het vaak mogelijk door de bedrijfstak woortgebrachte goederen in te delen in verschillende categorieên. Van belang daarbij zijn produktkarakteristieken, overeenkomsten in productietechnologie, mogelijkheden voor de producenten om andere produkten voort te brengen, de hoogte van de kruiselingse substitutie-elasticiteit en de mate van prijsparallellisme. Ten aanzien van elektriciteit kan zoals opgemerkt onderscheid gemaakt worden tussen productie van elektriciteit en de feitelijke distributie van elektriciteit aan de afnemers. Samenvattend is de relevante markt voor een regionaal bedrijf als MEGALimburg de markt voor distributie van elektriciteit in de regio Limburg.

\section{- Marktaandelen}

Zijn er veel even grote bedrijven of zijn er weinig aanbieders en hebben juist enkele bedrijven een groot aandeel in de relevante markt? Indien dat laatste het geval is impliceert dat een relatief hoge concentratie. Om de concentratie te meten zijn verschillende criteria mogelijk, waaronder de Hirschmann-Herfindahl-index. Voorts is het van belang hoe groot het marktaandeel van de overheidsinstelling is. Van Witteloostuijn merkt op dat de omvang en aard van de verzonken kosten de concentratie en dichtheid van een markt. bepalen. ${ }^{193}$ Bij overheidsinstellingen zal dit veelal bepaald zijn door de overheid, bijvoorbeeld door het opleggen van een juridisch monopolie. Het aantal aanbieders in de elektriciteitsmarkt is laag. Voor de deregulering was er én bedrijf dat zorgde voor de productie en distributie van elektriciteit. $\mathrm{Na}$ de deregulering is er voor elke sector een productiebedrijf en een distributiebedrijf, een zogenaamd bilateraal monopolie. Een competitieve situatie waarbij elk bedrijf zowel in andere sectoren als op buitenlandse markten kan concurreren is nog ver weg. Net zoals in de telecommunicatiesector is gekozen voor een geleidelijke deregulering. In de markt van de belastinginning in Nederland is sprake van één bedrijf, namelijk de Belastingdienst. Er is dus sprake van een wettelijk monopolie. Dit neemt niet weg dat in principe meerdere bedrijven denkbaar zouden zijn.

${ }^{193}$ Van Witteloostuijn $\left(1994, p_{n} 771\right)$ 
Is het aantal vragers erg groot of daarentegen beperkt. Worden er standaardprodukten verkocht of betreft het produkten die op maat worden gemaakt. In de elektriciteitsmarkt wordt via het distributiebedrijf geleverd aan klein- en grootverbruikers. De uiteindelijke vraag is niet geconcentreerd. Bij de Belastingdienst is sprake van een groot aantal belastingplichtigen. De Belastingdienst draagt de belastingen af aan de rijksoverheid. Ook worden middelen ten behoeve van derden geind, zoals sociale zekerheidspremies en tot het begin van de jaren "90 onroerend goed belastingen.

\section{-Produktdifferentiatie}

Is er sprake van een standaarddienst of -goed of verschillen de produkten in de ogen van de consumenten. Of er sprake is van produktdifferentiatie is ook van belang voor het onderzoeken van het bestaan van entreebarrières in de betreffende markt. Opgemerkt kan worden dat er verschillende soorten elektriciteit bestaan. De spanning van de elektriciteit kan verschillen. Aan grote bedrijven kan elektriciteit worden geleverd met een andere spanning, die zij vervolgens zelf op het vereiste niveau brengen. De prijzen van deze vormen van elektriciteit kunnen verschillen. Afgezien van deze vormen van elektriciteit bestaat de markt echter uit elektriciteit met de normale spanning. Deze elektriciteit kan worden beschouwd als een homogeen goed. Bij de Belastingdienst is het moeilijker om te spreken van produkten. Dit kan nog wel indien de dienst wordt opgevat als finale producent. ${ }^{194}$ In dat geval kunnen verschillende produkten onderscheiden worden. Het gaat daarbij om de verschillende soorten aanslagen en aangiften maar ook om hulp-bijaangifte, zogenaamde rulings (afspraken), informatieverstrekking en berekeningen en tenuitvoerleggingen. Volgens de Kam en Van den Berg kan voorts burgerzin ("compliance") op fiscaal terrein als een produkt worden opgevat. ${ }^{195}$

\section{- Toetredingsbarrières}

Verschillende benaderingen ten aanzien van toetredingsbarrières kunnen worden onderscheiden. ${ }^{196}$ Zo gaat Stigler er vanuit dat in het geval van entreebarrières er kostenasymmetrieën moeten bestaan tussen zittende producenten en potentiële toetreders. Demsetz en Brozen bezien met name de overheidsreguleringen en -interventie, terwijl Bain alle factoren die ertoe leiden dat de prijs niet daalt tot het niveau tot de marginale kosten beschouwt als entreebarrières. Hij beziet niet alleen structuur- maar ook gedragsvariabelen. Verschillende factoren kunnen een rol spelen bij de vraag in hoeverre een overheidsinstelling zich geconfronteerd ziet met toetredingsbarrières. Indien de sector kapitaalintensief is, zijn relatief meer financiële middelen nodig bij toetreding. De verwerving van vreemd vermogen is dan extra belangrijk. In verband met de onzekerheid die verbonden is aan de toetreding is het denkbaar dat nieuwkomers meer moeite hebben vermogen aan te trekken. Ook "sunk costs" kunnen een belemmering vormen voor nieuwe toetreding. Verder is het relevant in welke mate er schaalvoordelen zijn, hoe groot de minimaal efficiënte schaal (MES) is ten opzichte van de marktomvang en in welke mate

194 Vergelijk ook: De Kam en Van den Berg (1992, p. 24).

${ }^{195}$ T.a.p., p. 24.

1966 Vergelijk: Baim (1954), Stigler (1968, pp. 67-70), Demzetz (1981, p. 56) en Brozen in: Goldschmid (et al.) (1974). 
er zich leereffecten voordoen. Tenslotte zijn factoren als het beleid van de overheid en de reputatie van de overheidsinstelling belangrijk om te beoordelen of er entreebarrières bestaan. Vaak zal een overheidsinstelling de vorm aannemen van een wettelijk monopolie. Bain onderscheidt een aantal entreebarrières. Naast schaalvoordelen vermeldt hij produktdifferentiatie en absolute kostenvoordelen. Deze factoren zijn eveneens voor een overheidsinstelling van belang. In de elektriciteitssector waren de entreebarrières hoog. Door de overheidsregulering is toetreding niet mogelijk. Bovendien is de schaal van de productie groot. Tot bepaalde hoogte zullen zich schaalvoordelen voordoen, waardoor het voor andere bedrijven moeilijk is om de elektriciteitsmarkt te betreden. Ook voor de Belastingdienst was dit het geval. De Belastingdienst is als enige instelling belast met de uitvoering van de fiscale wetgeving. $\mathrm{Zij}$ is belast met de inning van grote bedragen belastinggelden. Deze inning gaat; zoals is aangegeven in hoofdstuk 2 , tot bepaalde hoogte gepaard met dalende gemiddelde kosten. Wel lijkt het mogelijk dat particuliere instellingen zich richten op de inning van bepaalde heffingen, zoals bepaalde sociale verzekeringen en milieuheffingen.

\section{-Uittredingsbarrières}

In hoeverre is het mogelijk zonder veel kosten uit te treden. Indien er sprake is van "sunk costs" of indien de bedrijfstak een erg specifiek karakter heeft is uittreding kostbaar. Bestaande bedrijven zullen in dat geval niet snel uittreden terwijl andere bedrijven niet snel zullen toetreden.

\section{- Mate van verticale integratie en conglomeratie}

Zijn de bedrijwen in de bedrijfstak sterk verticaal geïntegreerd of daarentegen sterk gespecialiseerd en in welke mate maken bedrijven deel uit van grote conglomeraten.

Elektriciteitsbedrijven waren verticaal geïntegreerd. In de jaren ' 80 hebben bedrijven zich gespecialiseerd. Sindsilien is productie en distributie feitelijk niet meer in één hand, hoewel distributiebedrijwen vaak nog wel aandelen hebben in productiebedrijven.

\section{Marktgedrag}

\section{-Prijsbeleid}

Ten aanzien van het prijsbeleid van ondernemingen in een bedrijfstak is het bij de analyse van een overheidsinstelling belangrijk te weten in welke mate het marktgedrag gekenmerkt wordt door concurrentie en in hoeverre er coördinatie plaatsvindt. Scherer noemt. een aantal factoren die oligopolistische coördinatie beïnvloeden. Indien bijvoorbeeld de kosten en de produkten gekenmerkt worden door heterogeniteit kan dit de coördinatie belemmeren, aangezien het moeilijker wordt een gemeenschappelijke optimale prijs vast te stellen. Andere belangrijke factoren zijn het bestaan van prijsleiderschap, het hanteren van bepaalde "full-cost" prijsregels ("rules of thumb") en de mate waarin gebruik gemaakt wordt van "focal points". 197 Tal van andere factoren kunnen van belang zijn. Indien er veel vaste kosten zijn kan dat een prikkel vormen om sterk te concurreren met de prijs in de hoop in een recessie tenminste een deel van de vaste lasten te dekken. ${ }^{198}$

${ }^{197}$ Scherer en Ross (1990, hoofdstuk 7 en 8).

198 Vergelijk ook: Tirole (1988, paragraaf 6.3-6.5) over supergames, prijsrigiditeiten en reputatie-effecten. 
Voor het verklaren van het resultaat van overheidsinstellingen is het essentieel om het gedrag en meer in het bijzonder het prijsbeleid te analyseren. In appendix 1 wordt hierop uitvoeriger op ingegaan.

In de elektriciteitssector zouden de elektriciteitsbedrijven gelet op de entreebarrières en de monopolistische marktworm monopolieprijzen kunnen vaststellen. Dit is in de werkelijkheid maar ten dele gebeurd. Twee belangrijke ontwikkelingen zijn hierbij van belang.

1. De gemiddelde kosten zijn hoger dan strikt noodzakelijk. Dit duidt op technische inefficiêntie en wordt veroorzaakt door het nastreven van bijkomende doelen als voorlichting, millieu en inkomensherverdeling.

2. $\mathrm{Er}$ is sprake van interne subsidiêring. Grootverbruikers betalen een relatief lagere prijs terwijl kleinverbruikers een iets hogere prijs betalen.

Minder duidelijk was het prijsbeleid van de Belastingdienst. Voor haar produkten werden veelal geen prijzen gerekend. De door haar gemaakte kosten werden via de begroting door de overheid betaald. Indirect betalen de burgers dus wel voor deze produkten.

\section{- Opwerpen van strategische toetredingsbelemmeringen}

Bedrijven hebben tal van mogelijkheden om door hun gedrag entree tegen te gaan. ${ }^{199}$ $\mathrm{Zij}$ kunnen bijvoorbeeld zorgen voor overcapaciteit. Indien potentiële toetreders het waarschijnilijk achten dat bestaande bedrijven die capaciteit ook zullen gebruiken (Spence hypothese) kan dit entree tegen gaan. ${ }^{200}$ Bedrijven leggen zich dan vast op een bepaalde strategie. Voorts kan gedacht worden aan investeringen in R\&D. Door innovatie kunnen potentiële toetreders een achterstand oplopen waardoor zij niet zullen toetreden. Ook kan een bedrijf proberen door produktdifferentiatie (merk, adverteren) een sterke positie te verwerven. Bedrijven kummen ook proberen door "predatory pricing" entree tegen te gaan. Door overheidsregulering beschermde bedrijfstakken hebben minder prikkels te innoveren teneinde derden buiten de markt te houden. Voorts kan gebruik worden gemaakt van lange termijn-contracten. ${ }^{201}$ In de elektriciteitsmarkt was het opwerpen van entreebarrières niet nodig. Elektriciteitsbedrijven hielden in deze periode overcapaciteit aan. Deze overcapaciteit diende niet als entreebarrière maar was veeleer het gevolg van enerzijds het inzakken van de markt en anderzijds het niet snel genoeg beperken van de capaciteit, onder andere door te hoge afzetverwachtingen.

\section{- Bedrijfsstrategie ten aanzien van horizontale en verticale integratie}

Overheidsinstellingen kunnen proberen door integratie voordelen te behalen. Denkbaar is dat er schaalvoordelen te behalen zijn. Ook is het mogelijk dat bedrijven op deze wijze relatief goedkoop overcapaciteit kunnen overnemen, waardoor hun positie versterkt wordt. Het "naileve trade-off model" van Williamson stelt dat reële kostenbesparingen een oorzaak kunnen zijn van horizontale integratie. ${ }^{202}$ Door rationalisatie en schaalvoordelen

\footnotetext{
199 Clarke (1990, paragraaf 4.1).

200 Tirole (1988, pp. 306 e.w.).

201 Ziss (1996. pp. 672 e.v.).

202 Williamson $(1986$, p. 238$)$.
} 
zouden dergelijke voordelen kunnen ontstaan. Het is in dit geval mogelijk dat de consumenten er niet op achteruitgaan terwijl de producenten aanvullende voordelen behalen. Leibenstein daarentegen stelt dat de kosten door gebrek aan mededinging juist kunnen stijgen ( $\mathrm{X}$-inefficiëntie). Met betrekking tot verticale integratie stelt Williamson dat de interactie van "human" en "environmental factors" de hoogte van de transactiekosten bepaalt en daarmee of er sprake zal zijn van verticale integratie. Ook wordt wel gesteld dat integratie veroorzaakt wordt door onderlinge technologische aflhankelijkheid en onzekerheid (ten aanzien van bijvoorbeeld grondstoffen). Een andere verklaring is de levenscyclushypothese van Stigler. Volgens deze benadering zall de arbeidsverdeling in een bedrijfstak variëren met de omvang daarvan. Voorts kunnen er monopolistische motieven zijn voor verticale integratie. In hoofdstuk 6 en volgende wordt verder ingegaan op verticale integratie en het ontstaan van (overheids)netwerken. Toegespitst op de elektriciteitssector kan worden opgemerkt dat elektriciteitsbedrijven in de jaren ' 80 gedwongen werden om zich te specialiseren. Voorts streefden zij naar horizontale integratie, zoals het integreren van de elektriciteits- en gasdistributie.

\section{-R\&D-beleid}

In hoeverre voert de bedrijfstak innovaties door. Of dit het geval is zal ook bepaald worden door de marktstructuur. Er bestaan verschillende theorieèn over het verband tussen marktstructuur en innovatie/research. Arrow constateent dat door de onzekerheid verbonden aan research en door de collectief goed eigenschap er zich problemen kunnen voordoen met betrekking tot de voorziening van research in yrije markteconomieèn. ${ }^{203}$ Arrow stelt dat de prikkeis om uit te vinden sterker zijn voor een competitieve dan voor een monopolistische bedrijifstak. Demsetz daarentegen stelt dat er weliswaar een grotere prikkel is om uit te vinden bij een competitieve bedrijfstak, maar dat dit slechts veroorzaakt wordt door de lagere productie van een monopolie. ${ }^{204}$ Indien bedrijfstakken van gelijke omvang worden bekeken is er geen verschil. Schumpeter meent dat monopoliemacht en grote bedrijfsomvang innovatie en technologische vooruitgang meer stimuleren dan bij volkomen mededinging het geval is. ${ }^{205}$ Grotere bedrijven kumnen research gemakkelijker intern financieren, er kunnen zich schaalvoordelen voordoen ten aanzien van de ontwikkeling en toepassing van nieuwe produkten en productietechnieken terwijl grote bedrijven ook meer geprikkeld zouden zijn de entree tegen te gaan door innovatie. Hoewel meer empirisch onderzoek nodig is zijn er redenen om aan te nemen dat een oligopolistische structuur waarschijnlijk tot de meeste innovatie zal leiden.206

\section{Resultaat ("Performance")}

Met resultaat wordt bedoeld hoe een bedrijf of verschillende bedrijven in een bedrijfstak het doen. Het is derhalve een ruim begrip. Er bestaan verschillende "performance"indicatoren zoals winst, productie en efficiëntie. Bij de in de bedrijfstak gemaakte winst rijst de vraag of deze hoog of laag is vergeleken met andere gelijksoortige bedrijfstakken of eerdere periodes. Verder is van belang of de productie hoog is en wat de groeimogelijkheden van de sector zijn. Voorts is het belangrijk te weten of de bedrijven technisch

\footnotetext{
203 Arrow in: Lamberton (1962, pp. 152-156).

204 Demsetz (1965), in Lamberton (1971, pp. 176-178).

205 Schumpeter, (1965, Pp. 87-106).

206 Vergelijk: Rosenberg (1976, PP. 101-112) en bijwoorbeeld: Shrieves (1978, pp. 329 e.V.).
} 
efficiënt zijn en of er allocatieve verbeteringen te behalen zijn. Tenslotte is het voor de beoordeling van de "performance" van belang te weten hoe de innovatiegezindheid van een overheidsinstelling is.

\section{Winst}

In de elektriciteitssector werd gedurende de tachtiger jaren winst gemaakt. Hierbij is geen sprake van monopoliewinst. De winst van MEGA-Limburg/PLEM is bijwoorbeeld lager dan het rendement op staatsobligaties. Dit duidt op winstderving en technische inefficientie ten aanzien van het eigenlijke doel.

\section{Groei/Productie}

Bij de productie en distributie van elektriciteit gaat het om grote hoeveelheden. De groei is gematigd. Gedurende de periode 1970-1990 was er overcapaciteit. Bezien we de productie van de Belastingdienst dan rijst de vraag wat hieronder precies verstaan moet worden. Vervolgens moet dan worden bepaald hoe deze in de praktijk gemeten kan worden en hoe de verschillende produkten gewogen dienen te worden. De Belastingdienst meet sinds het begin van de jaren ' 90 haar eigen productie. Hienuit blijkt dat de productie simds de jaren " 80 fors is toegenomen.

\section{Allocatieve/Technische efficiëntie}

Borcherding stelt dat de productie van een goed binnen de publieke sector gemiddeld ongeveer tweemaal zo duur is als de private productie van dat goed zou zijn. ${ }^{207}$ Ook anderen komen tot de conclusie dat publieke voortbrenging veelal duurder is dan particuliere. ${ }^{208}$ De vraag waar in dit onderzoek verder op in wordt gegaan is waardoor dit veroorzaakt wordt.

\section{Innovatiebereidheid}

De theorie ten aanzien van marktvorm en innovatiebereidheid is niet eenduidig. Toch lijkt het zoals opgemerkt waarschijnlijk dat een oligopolistische marktvorm tussen monopolie en volkomen mededinging in de innovatie het meest zal bevorderen. Gesteld kan worden: "(...) dat volkomen mededinging zich niet goed verdraagt met innovaties, en dat grotere ondernemingen, met grotere marktaandelen in een gunstige positie lijken te verkeren voor het creëren van procesinnovatie. Voor produktinnovaties hebben kleinere (maar niet te klein) de betere papieren indien er veel technologische mogelijkheden zijn" ${ }^{\text {th }}{ }^{209}$ Gezien de hoge entreebarrières is het doorvoeren van innowatie minder van belang. Dit zal pas echt toenemen bij meer concurrentie op de energiemarkt. Een eerste stap is gezet met het splitsen van elektriciteitsbedrijven in productie en distributie.

Samenvattend kan gesteld worden dat het traditionele structurur-gedrag-resultaat-paradigma de relatie tussen marktstructurur en winst benadrukt. Indien een bedrijfstak gekenmerkt. wordt door een hoge mate van concentratie en er tevens entreebarrières zijn zullen de prijzen boven de marginalle kosten liggen en zal er dienovereenkomstig winst gemaakt

\footnotetext{
207 Borcherding $(1977$, p. 62$)$.

308 Vergelijk: Van der Bij (1992, p. 15).

209 Mamuth (1990, paragraaif 9.6).
} 
worden. Duidelijk is dat niet alleen de marktstructuur maar met name ook het marktgedrag bepalend is voor de "performance" van een overheidsinstelling in een bedrijfstak. Tevens kan het marktgedrag de marktstructuur beinvloeden. Ook voor overheidsinstellingen geldt dat de marktstructuur en het marktgedrag bepalend zijn voor de "performance" die vervalgens weer de structuur en het gedrag beïnvloedt.

\subsubsection{In hoeverre kan het schema de "performance" van een overheidsinstelling verklaren?}

Vergeleken met particuliere bedrijven zijn er een aantal belangrijke verschillen. Deze hebben niet zozeer betrekking op de marktstructuur alswel op de inwloed van het politieke proces op het gedrag van overheidsinstellingen. Een en ander kan als volgt worden weergegeven:

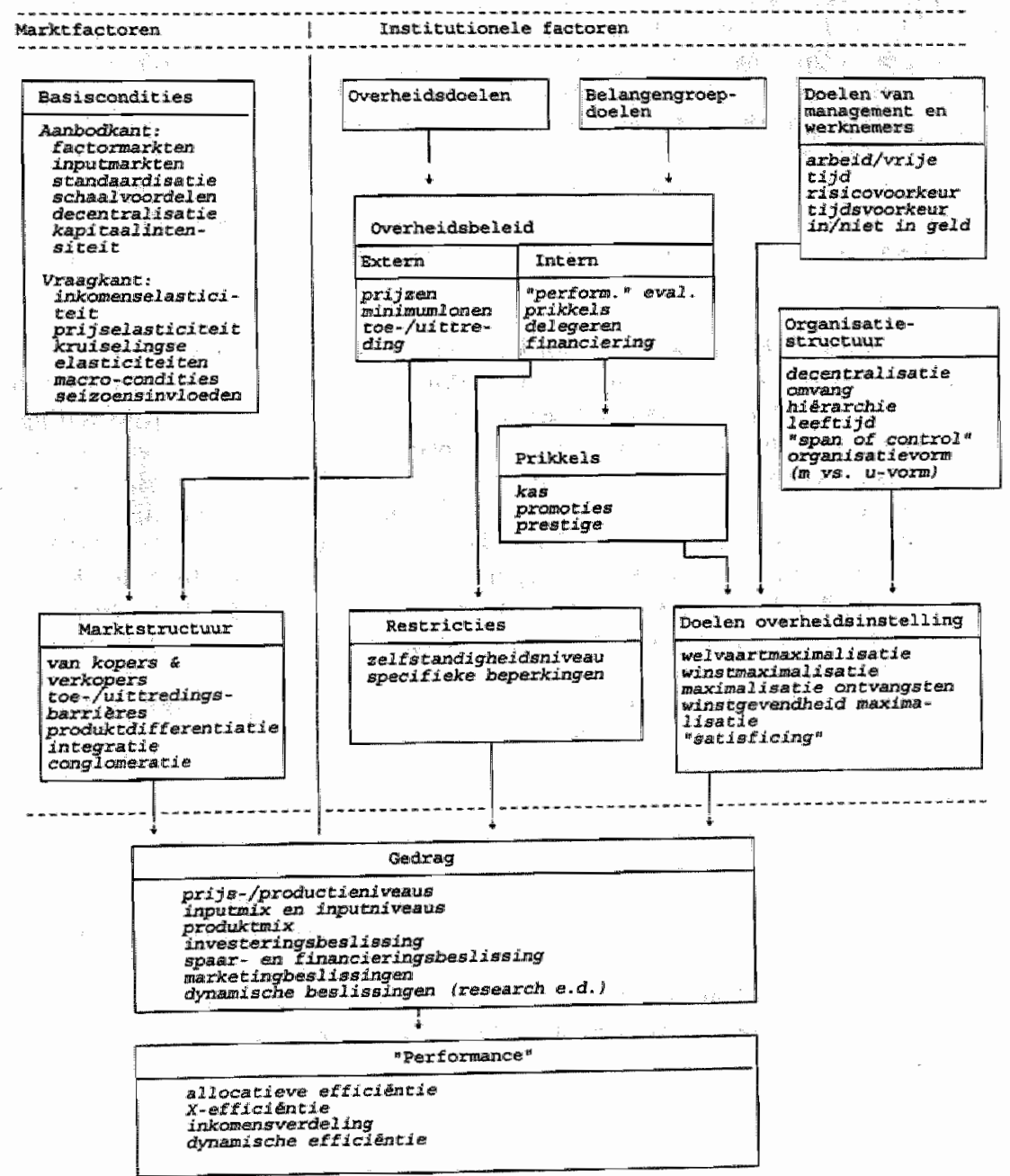

Figuur 3.2 Het uitgewerkte analyse schema 
In het voorgaande is ingegaan op het verband tussen basiscondities, marktstructurur, -gedrag en resultaat. Cruciaall is de veronderstelling van winstmaximalisatie. Indien managers bijvoorbeeld niet streven naar winstmaximalisatie maar naar omzetmaximalisatie of het zoveel mogelijk ten eigen bate gebruilken van de discretionaire bevoegdheden, verandert, uitgaande van een bepaalde marktstructuur en de basiscondities, het gedrag van de overheidsinstelling en het resultaat aanzienlijk. Dit is belangrijk aangezien bij overheidsinstellingen meestal geen sprake is van winstmaximalisatie als doelstelling. Hierbij dient bedacht te worden dat niet alleen de doelen van de managers binnen de overheidsinstelling van belang zijn maar ook de doelen van voor de overheidsinstelling rellevante actoren als ambtenaren en ministers. De tijdelijke eigenaren van de overheidsinstelling leggen hun doelen vast in bepaalde restricties (regels of randvoorwaarden), die worden opgelegd aan de overheidsinstelling. Doelen en restricties zijn van invloed op het gedrag van de organisatie. ${ }^{210}$ Het is dan ook niet voldoende alleen naar marktfactoren te kijken. Ook het politieke proces heeft invloed op het gedrag en het resultaat van een overheidsinstelling. ${ }^{211} \mathrm{De}$ invloed van het politieke proces leidt ertoe dat de eigendomsrechtenstructuur, de principaal-agentverhouding en de transactiekostenstructuur belangrijk kunnen afwijken van die van een particulier bedrijf, waardoor het structuur-gedragresultaat-paradigma onvoldoende aanknopingspunten biedt voor de verklaring van het gedrag en de "performance" van overheidsinstellingen. De interacties tussen de verschillende variabelen, bijvoorbeeld de "performance" die de structuur beïnloedt is bij overheidsinstellingen nog van extra belang omdat de "performance" door de overheid geanalyseerd zal worden en via overheidsbeleid haar weerslag zal hebben op de overheidsinstelling.

De doelen van een overheidsinstelling worden bepaald door tal van actoren. In de eerste plaats zijn de doelen van de managers en werknemers van de overheidsinstelling van belang. Daarnaast worden de doelen bepaald door een aantal overheidsinstellingen die zich bezighouden met het controleren van de instelling. Voorts zijn andere belangengroepen waaronder vakbonden en politieke partijen van belang. ${ }^{212}$ De belangen van deze verschillende groepen zullen veelal met elkaar in strijd zijn. De uiteindelijke invloed van verschillende individuen/groepen op de feitelijke doelen van de overheidsinstelling hangt af van de relatieve macht van deze groepen om beslissingen te beinvloeden. In het vervolg van dit deel zal dan ook op het gedrag en de factoren die het gedrag van een overheidsinstelling bepalen worden ingegaan, aangezien dit gedrag het belangrijkste verschil is met particuliere bedrijven. De overheid kan op verschillende wijzen het gedrag en het resultaat van de overheidsinstelling beînvloeden. Hierop wordt in hoofdstuk 4 ingegaan.

\subsection{Conclusie}

In dit boofdstuk is een aanzet gegeven tot een netwerkmodel van overheidsinstellingen. Daartoe is, uitgaande van het Structuur-Gedrag-Resultaat-paradigma, ingegaan op een aantal factoren die van invloed zijn op het resultaat. Benadrukt is dat er sprake is van wederzijdse beïnvioeding van de verschillende factoren. Uiteindelijk bleek vooral het gedrag van belang als belangrijk verschil met particuliere bedrijven.

\footnotetext{
${ }^{210}$ Vergelijk ook: Tullock (1992, Hoofdstuk 4).

211 Vogelsang (1990, p. 13).

212 T.a.p., p. 14.
} 


\section{Hoofdstuk 4. De normatieve benadering}

4.1 Inleiding: kan het gedrag van een overheidsinstelling worden verklaard door de welvaartseconomie?

In dit deel wordt verklaard waarom overheidsbedrijven en -bureaus zich op een bepaalde wijze gedragen. Veel van de literatuur is evenwel niet gewijd aan het feitelijke gedrag van overheidsinstellingen maar aan de vraag hoe zij zich in allerlei uiteenlopende omstandigheden zouden moeten gedragen. In markten die gekenmerkt worden door volkomen mededinging zullen producenten en consumenten onder de bekende restricties uit de welvaartseconomie een Pareto-efficiënte allocatie trachten te bereiken. Met betrekking tot overheidsinstellingen kan volgens de normatieve benadering evenwel niet verwacht worden dat zij zich op een Pareto-allocatieve wijze zullen gedragen. ${ }^{213}$ Dit houdt onder meer verband met het gebrek aan mededinging en het feit dat overheidsinstellingen vaak geen recht hebben op de winst die zij maken. Derhalve dienen volgens de normatieve benadering regels te worden opgelegd aan overheidsinstellingen omtrent hoe zij zich in werkelijkheid dienen te gedragen. In dit hoofdstuk wordt aangegeven in hoeverre deze normatieve theorie het feitelijke gedrag van overheidsinstellingen kan verklaren.

4.2 Op welke wijzen kan de overheid het gedrag van een overheidsinstelling beïnvloeden?

Er kunnen verschillende wijzen onderscheiden worden waarop de overheid het gedrag en de prestatie van een overheidsinstelling kan beïnvloeden. Eén en ander is geillustreerd in Figuur 4.1:

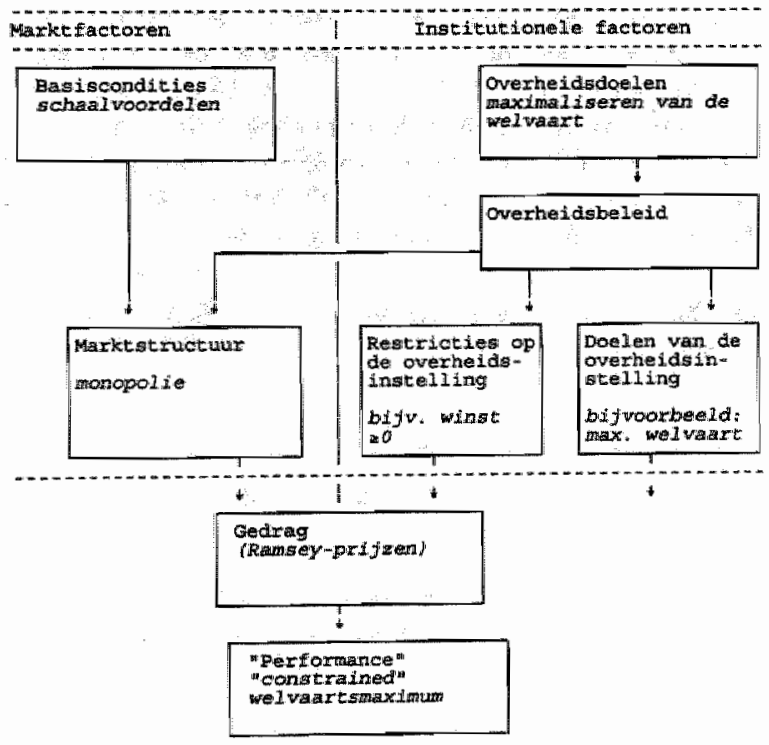

Figuur 4.1 De normatieve benadering van de overheidsinstelling ${ }^{214}$

\footnotetext{
${ }^{213}$ Blankart (1980, p. 21).

214 Vogelsang (1990, p. 19).
} 
Het bovenstaande schema kan dienen als uitgangspunt voor zowel een normatieve als een positieve benadering. Op grond van de normatieve benadering kan de overheid op een drietal manieren het gedrag van een overheidsinstelling beïnvloeden.

In de eerste plaats is het mogelijk dat de overheid de marktstructunur beinvlcedt, bijvoorbeeld door het instellen van een monopolie. Vervolgens kan zij dit monopolie toekennen aan een overheidsinstelling. Hierbij kan gedacht worden aan de in hoofdstuk 2 behandelde overheidsmonopolies in de elektriciteitssector of in de telecommunicatie ("switching equipment"). Het instellen van een juridisch monopolie impliceert het opwerpen van entreebarrières. Politieke actoren zullen dan grote invloed uit kunnen oefenen door restricties op te leggen en door de vrijkomende discretionaire bevoegdheid in te vullen.

In de tweede plaats kan de overheid (externe) restricties opleggen aan de overheidsinstelling. In het kader van de eigendomsrechtembenadering en de principaal-agenttheorie zal op deze sturingsinstrumenten worden teruggekomen. Er zijn tal van restricties denkbaar, bijwoorbeeld restricties op het prijsgedrag van de overheidsinstelling of op het investeringsgedrag. Ook kunnen restricties worden opgelegd ten aanzien van de mate waarin de overheidsinstelling eigen vermogen mag aanhouden en met betrekking tot de mate waarin de instelling zelf de personeelsformatie mag uitbreiden.

Een derde wijze waarop de overheid kan ingrijpen is door het bepalen van de doelen van de overheidsinstelling en door ervoor te zorgen dat de overheidsinstelling deze doelen ook nastreeft. $\mathrm{Zij} \mathrm{kan} \mathrm{dit} \mathrm{proberen} \mathrm{te} \mathrm{realiseren} \mathrm{door} \mathrm{het} \mathrm{gebruiken} \mathrm{van} \mathrm{allerlei} \mathrm{sturings-} \mathrm{en}$ controlemechanismen. Deze categorie vormt eveneens een restrictie van de overheid. $\mathrm{Zij}$ wordt wel aangeduid als interne restrictie.

De combinatie van doelen, restricties en prikkels die de overheid in het leven roept heeft (onder de veronderstelling van "satisficing" van de betrokkenen) gevolgen voor het gedrag en de "performance" van een overheidsinstelling. Indien bijwoorbeeld de overheid prijsregulering vaststelt op een wijze dat het bedrijf een redelijke vergoeding ontvangt is het mogelijk dat het management minder aandacht besteedt aan kostenminimalisatie en meer aan bijkomende doelen zoals een aangenaam werktempo. Dit kan in die zin leiden tot zowel allocatieve als technische inefficiëntie. ${ }^{215}$ In appendix 1 wordt ingegaan op de twee voor het gedrag van de overheidsinstelling (zoals dat in dit onderzoek geanalyseerd wordt) belangrijkste categorieën, te weten de vraag welke doelen de overheidsinstelling zou moeten nastreven en de vraag welke prijzen een overheidsinstelling zou moeten rekenen.

\subsection{In hoeverre kunnen dergelijke normatieve (prijs)regels het gedrag van overheids- instellingen verklaren?}

Mede op grond van de normatieve benadering worden overbeidsinstellingen dikwijls bekritiseerd als zijinde organisaties die niet goed functioneren. Vaak wordt daarbij gesproken over inefficiëntie, waarbij het niet altijd duidelijk wordt welke soort efficiëntie wordt bedoeld. Ook worden vaak andere criteria aangelegd zoals de mate van winst- of verliesgevendheid, rendement op kapitaal en produktiviteitsratio's. Vooral deze laatste criteria geven, zoals in hoofdstuk 13 en verder uiteen wordt gezet, veelal slechts een zeer beperkt beeld van de "performance" van een overheidsinstelling. De normatieve benadering gaat er verder vanuit dat de overheidsinstelling ook daadwerkelijk handelt overeen-

215 Vergelijk ook: Koers (1995, pp. 28 e.v.). 
komstig de normatieve regels. Dat het economisch gezien wenselijk is om zich op een bepaalde wijze te gedragen betekent echter niet dat dit in werkelijkheid gebeurt of nog belangrijker dat dit in werkelijkheid ook mogelijk is. Vaak zijn er allerlei restricties die ertoe leiden dat het normatief voorgestelde beleid in werkelijkheid niet te realiseren valt. Indien dan toch op grond van de gebruikte abstracte modellen wordt volgehouden dat overheidsinstellingen niet efficiënt zijn dient dit te worden gezien als weinig realistisch. Zoals in appendix 1 is uitgewerkt zijn bestaande situaties waarin geen verandering optreedt voor de betrokkenen blijkbaar efficiënt. ${ }^{216}$ Voorts streven overheidsinstellingen vaak tal van bijkomende doelen na waaraan de normatieve regels onvoldoende recht doen. In deze paragraaf wordt getracht één en ander te verduidelijken door de beeldvorming van de overheidsinstelling, zoals die veelal in normatieve onderzoeken (impliciet) wordt gehanteerd, te verbreden. Hiertoe zal worden ingegaan op de x-efficiëntie, statische en dynamische efficiëntie van overheidsinstellingen.

\subsubsection{In hoeverre zijn overheidsinstellingen technisch efficiënt?}

In beginsel zijn alle Nederlanders gezamenlijk eigenaar van een overheidsinstelling. Dit eigendom is in het politieke proces gedelegeerd aan de regering en het parlement. De politici kunnen dan ook gezien worden als de tijdelijke eigenaren van de overheidsinstelling. Een belangrijk kenmerk van hedendaagse overheidsinstellingen is dat deze instellingen, zoals vaak wordt opgemerkt, veelal technisch inefficiënt zijn. Dit geldt niet alleen voor overheidsbedrijven maar ook voor bureaus in het algemeen. Conybeare stelt bijvoorbeeld: "Lack of competition is a major cause of technical inefficiency in production, and there appears to be much evidence that public bureaus are less technically efficient than private firms ${ }^{12}{ }^{217}$ Dit hangt nauw samen met het concept van de belastingstaat. Overheidsinstellingen dienen tegenwoordig niet meer alls inkomensbron maar zijn in het leven geroepen om allerlei (bijkomende) doelen te realiseren cq. goederen voort te brengen. ${ }^{218}$ Van belang is te constateren dat indien gesproken wordt van $x$-inefficiëntie van overheidsinstellingen, hiermee bedoeld wordt dat het eigenlijke doel van de overheidsinstelling (bijv. een museum: tentoonstellingen e.d.) niet tegen minimale kosten wordt voortgebracht. Tal van redenen zijn hiervoor aan te voeren. De inkoop kan bijvoorbeeld te duur zijn door een gebrek aan competitief bieden. De absentie in verband met ziekte is veelal hoger. Ook is het denkbaar dat verouderde machines, computers en dergelijke worden gebruikt. Voorts kan er sprake zijn van een inefficiënt voorraadmanagement-systeem op het departement. Tenslotte is ook het aantal personeelsleden relatief vaak hoger dan bij bedrijven in de marktsector. Een andere reden waarom overheidsinstellingen vaak inefficiënt zijn houdt verband met de specifieke kenmerken van veel overheidsproductie. Het gaat hierbij vaak om de voortbrenging van collectieve goederen en zoals Olson al opmerkte zal de productie van deze goederen vaak inefficiënt zijn. 2119 De resultaten van empirisch vergelijkend onderzoek naar de efficiëntie van overheidsinstellingen en particuliere bedrijven zijn overigens niet eenduidig. Volgens Bokkes zullen in het geval van bijkomende doelen de discretionaire bevoegdheden van het management van de overheidsinstelling toenemen, onder meer omdat de bijkomende doelen van de principalen

\footnotetext{
216 Zie ook: Bokkes (1989, p. 60).

217 Conybeare (1983, p. 496).

218 Vergelijk: Koers (1995, pp. 45 e.v.).

219 Olson, in Moss, ed. $(1973$, p. 359$)$.
} 
kunnen wisselen en door de beperkte rationaliteit van de principalen. 20 Daar staat tegenover dat principalen zich meer bewust zullen zijn van de discretionaire doelstellingen en deze door allerlei beperkende regels zullen proberen te beperken en ook rechtstreeks zullen ingrijpen. Het is waarschijnlijk dat hierdoor de technische efficiëntie van de overheidsinstelling vermindert.

In het algemeen wordt de vermeende technische inefficiëntie van overheidsinstellingen als negatief ervaren en wordt daarbij gewezen op wachtrijen, "red tape" en bureaucratie.

Door de $x$-inefficiëntie liggen de kosten hoger dan strikt noodzakelijk, hetgeen blijkt uit het naar boven verschuiven van de gemiddelde en marginale kostencurve. Hieruit wordt veelal de conclusie getrokken dat de welvaart vermindert, aangezien er sprake is van vermindering van het consumenten- en producentensurplus.

$\mathrm{Na}$ de constatering dat overheidsinstellingen veelal technisch inefficiënt zijn wordt vervolgens vaak gesteld dat overheidsinstellingen Pareto-inefficiënt zijn. Vervolgens wordt een normatieve analyse uitgevoerd om de Pareto- en technische efficiëntie te verbeteren. ${ }^{221}$ Dit verduidelijkt waarom veel literatuur gericht is op de berekening van de optimale prijs van een overheidsinstelling. Ten aanzien van het verband tussen Paretoefficiêntie en productieniveau van een overheidsinstelling kunnen zich allerlei mogelijkheden voordoen.

\subsubsection{In hoeverre zijn overheidsinstellingen Pareto-efficiënt?}

Friedrich onderscheidt een viertal typen overheidsbedrijven. ${ }^{222}$ Het eerste type beoogt de productiehoeveelheid en het aantal werknemers te maximaliseren, het tweede type tracht alleen de hoeveelheid te maximaliseren, het derde alleen het aantal personeelsleden en het vierde tenslotte probeert het aantal personeelsleden te maximaliseren, zonder daarbij te streven naar een grotere productie-omvang. De door hem genoemde onderscheiding is voor ons minder van belang omdat dit onderzoek zich miet beperkt tot overheidsbedrijven in enge zin en omdat hier een andere invalshoek wordt gekozen. Hier wordt aangeven dat de normatieve benadering gebaseerd is op een onjuist beeld (in ieder geval in de praktijk van het empirische onderzoek) van de overheidsinstelling. Daarom wordt hier een enigszins afwijkend onderscheid gemaakt. In deze paragraaf worden een viertal typen overheidsinstellingen onderscheiden en wordt aangegeven in hoeverre voor een bepaald type al clan niet een Pareto-efficiënte uitkomst verwacht kan worden.

\section{Type 1.}

In de eerste plaats is het mogelijk dat een overheidsinstelling de vorm heeft van een monopolie. Zij kan gezien worden als een inkomstenbron voor de overheid. Het bedrijf is in dit geval technisch efficiënt aangezien wel tegen minimale kosten wordt geproduceerd. De gemiddelde kosten-curve blijft dan gelijk. Dit is natuurlijk niet het geval indien de gemiddelde kostencurve hoger ligt dan noodzakelijk. Vaak wordt nu opgemerkt dat de overheidsinstelling Pareto-inefficiënt is. Zoals nog zal worden aangegeven is dit alleen juist indien alleen gekeken wordt naar het eigenlijke goed. Als voorbeeld van een type 1overheidsinstelling kan een elektriciteitsbedrijf genoemd worden, hoewel het vaak zo zal

\footnotetext{
${ }^{220}$ Bokkes (1989, p. 59).

${ }^{221}$ Schram, Verbon en Van Winden (1991, pp. 189 e.v).

222 Vgl. Friedrich, in: Thiemeyer (et al. $)$ (1987, p. 39).
} 
zijn dat dergelijke bedrijven technisch inefficiênt zijn ten aanzien van het eigenlijke doel. De kostencurves komen dan hoger te liggen.

Type 2.

Daarnaast is het mogelijk dat de overheidsinstelling produceert op een punt tussen de monopolie- en volkomen mededingingshoeveelheid in. Ten aanzien van het eigenlijke doel wordt geconstateerd dat hier een welvaartsverlies optreedt. Belangrijk is op te merken dat veelall een gedeelte van de winst, subsidies van de overheid en de "gederfde welvaart" worden gebruikt voor bijkomende doelen. Het bedrijf kan redelijk winstgevend zijn.

\section{Type 3.}

Een derde mogelijkheid is dat de overheidsinstelling produceert op het productieniveau van volkomen mededinging. Ook hier zullen de kostencurves vaak hoger liggen dan noodzakelijk en zal ook dit bedrijf veelal technisch en Pareto-inefficiënt geacht worden, in de zin dat niet tegen minimale kosten geproduceerd wordt. Hierdoor wordt winst gederfd die op grond van een "rent-seekingsproces" wordt aangewend voor bijkomende doelen.

\section{Type 4.}

Een andere mogelijkheid houdt in dat de overheidsinstelling erg veel voortbrengt van het eigenlijke doel, meer nog dan de volkomen mededinging-hoeveelheid, tegen een prijs die lager is dan de volkomen mededingings-prijs. Dit komt qua hoeveelheid overeen met het Niskanen-model. Dit gaat gepaard met een verlies. Dit verlies zal veelal gedekt worden door subsidies verstrekt door de overheid en wordt in feite gebruikt voor doelen alls werkgelegenheid, hoge productie van een goed, bijvoorbeeld omdat consumptie van dit goed positief beoordeeld wordt door de overheid, lage prijzen ter herverdeling van inkomen etc. Vaak zal worden opgemerkt dat ook hier sprake is van een Pareto-inefficiente allocatie. Dit hoeft echter niet het geval te zijn. Het verlies wordt woor de bijkomende doelen gebruikt. Vaak is hierbij sprake van interne subsidiëring. De winst die gemaakt wordt met de voortbrenging van bepaalde goederen wordt gebruikt om de voortbrenging van het verliesgevende goed mogelijk te maken. De diverse onderscheiden mogelijkheden illustreren eveneens dat interne subsidiëring slechts één van de mogelijke vormen van "rent-seeking" is. Een voorbeeld is het Rijksmuseum, zoals dat in de jaren "70 en '80 opereerde. Gedurende deze periode moest er geld van de overheid bij. De gederfde winst van de onderneming is de "public enterprise rent". Deze kan gezien worden als opportuniteitskosten en kan, zoals nog zal worden uitgewerkt, worden berekend door de waarde van een alternatief, te weten het rendement op staatsobligaties.

\section{Overheidsinstelling, meerdere doelen en welvaart}

In het voorgaande werden een aantal uiteenlopende situaties beschreven die op grond van een standaardanalyse vrijwel allemaal gekarakteriseerd worden als Pareto-inefficiënt. In de praktijk zijn veel van deze owerheidsinstellingen verlieslijdend. De conclusie die dan ook veelal uit dergelijk empirisch onderzoek wordt getrokken is dat deze situatie verbetering behoeft, bijvoorbeeld door het opleggen van specifieke prijsregels zoals behandeld in paragraaf A.2.3.1 (appendix), of door het door middel van privatisering verbeteren van de technische efficiëntie. ${ }^{223}$ Deze normatieve analyse is onvolledig, zo niet onjuist. In de eerste plaats is het niet waarschijnlijk dat een overheidsinstelling zich in de praktijk door dergelijke regels (zoals de "Ramsey nule") zall laten leiden. In de tweede plaats wordt er volledig voorbijgegaan aan de werkelijke aard van een overheidsinstelling, namelijk het

223 Vergelijk bijwoarbeeld: Huibers (1995, Pp. 430-431). 
realiseren van een reeks van doelen ten behoeve van de eigenaren. ${ }^{224}$ Veel van de onderzoeken naar overheidsinstellingen zijn kostenvergelijkingsstudies die zich richten op de wraag of een instelling relatief technisch efficient is. Gezien het specifieke karakter van een overheidsinstelling leveren dergelijke onderzoeken, zoals aangegeven is in paragraaf 4.3.1, evenwel slechts een beperkt inzicht op in het functioneren van dergelijke instellingen. Badaüs stelt in dit verband." "Diese Kostenvergleichsstudien tragen allerdings weniger zur Klärung von Effizienzaussagen bei, als eher zur Venwirrung und Verfachung der notwendigen Diskussion". 225

Uit allerlei onderzoeken blijkt dat overheidsinstellingen veelal meerdere doelen nastreven, doelen die een particulier bedrijf miet zal proberen te realiseren. Spyros Lioukas constateert bijvoorbeeld op grond van zijn onderzoek naar Griekse overheidsinstellingen dat verschillende categorieèn overheildsinstellingen in deze kunnen worden onderscheiden. Zo onderscheidt hij overheidsinstellingen die topprioriteit geven aan winst terwijl andere meer in het bijzonder omzetmaximalisatie en expansie of een reeks van kwaliteitsdoelen benadrukken. ${ }^{226}$ Hiermee is niet gezegd dat particuliere ondernemingen niet te maken hebben met een veelvoud van doelen. Cyert en March gaven in 1963 al aan dat het bestaan van meerdere doelen eigen is aan zowel publieke als particuliere bedrijven. ${ }^{227}$ In de volgende hoofdstukken wordt aangegeven dat er evenwel belangrijke verschillen bestaan tussen overheidsinstellingen en particuliere bedrijven met betrekking tot de invloed van het politieke proces en de eigendomsrechtenstructuur. Dientengevolge bestaan er belangrijke verschillen in "incentive-structure" tussen een publiek en een particulier bedrijf. Dit kan ertoe leiden dat andere, niet winstgevende doelen worden nagestreefd, waaronder de voortbrenging van collectieve goederen en bijwoorbeeld inkomensherverdeling.

\subsubsection{Hoe moet een overheidsinstelling dan wel worden gezien?}

Uitgangspunt voor onze analyse zal daarbij de volgende overheidsinstelling van het vierde type zijn die gekenmerkt wordt door technische inefficiëntie:

\footnotetext{
224 Vergelijk bijvoorbeeld: Bramn (1988, pp. 93 ev.).

225 Badauls, in: Thitemeyer (et al.) (1987, p. 187).

22.6 Lioukas (1991).

${ }^{227}$ Cyert en March (1992), vergelijk ook: Ivancevich en Matteson (1987, p. 26).
} 


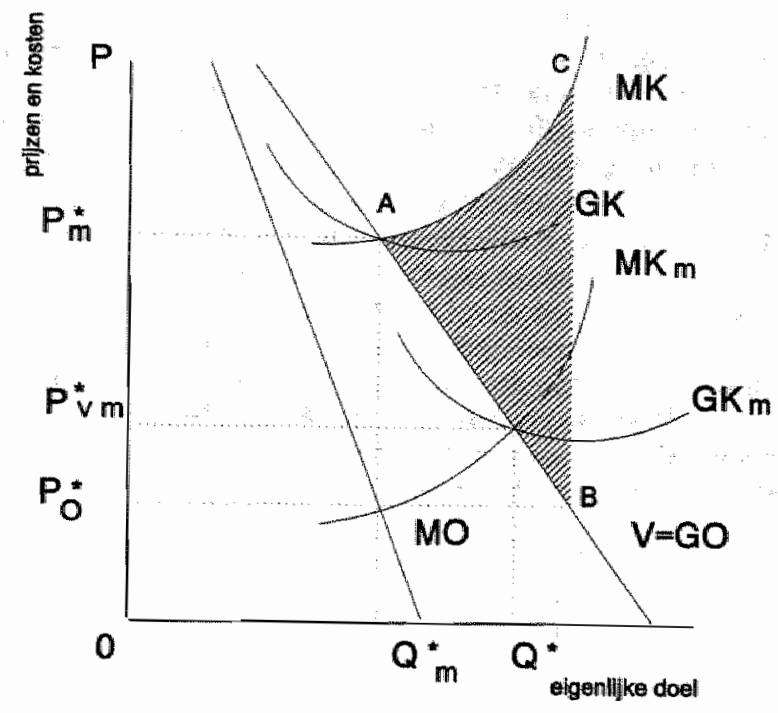

Figuur 4.2 Voorbeeld van een overheidsinstelling/museum

Uitgegaan wordt van een overheidsinstelling, bijvoorbeeld een museum, die technisch inefficiënt produceert en een lagere prijs rekent dan de volkomen mededingingsprijs. Hierbij kan gedacht worden aan factoren als te veel personeel, verouderde uitrusting, machines, computers e.d. en te hoge beloningen. De kostencurves liggen in de figuur dan ook hoger dan bij een $\mathrm{X}$-efficiënt bedrijf (mk versus $\mathrm{mk}_{\mathrm{p}}$ ). Daarnaast is de overheidsinstelling Pareto-inefficiënt door de technische inefficiëntie en de lage prijs en te grote geproduceerde hoeveelheid. Uit Figuur 4.2 blijkt immers dat de overheidsinstelling meer kunstwerken tentoonstelt tegen een lagere entreeprijs dan de volkomen mededingingssituatie zou rechtvaardigen. Onderscheid kan worden gemaakt tussen enerzijds de effecten van de hogere kostencurves en anderzijds de effecten van de grotere gesubsidieerde productie. Door de technische inefficiëntie ten gevolge van de bogere kosteneurves treedt er een welvaartsverlies op. Zowel het consumenten- als het producentensurplus nemen af. Door de lagere prijs die gerekend wordt en de relatief grote voortgebrachte hoeveelheid neemt het producentensurplus af, terwijl het consumentensurplus toeneemt. $\mathrm{Er}$ treedt een welvaartsverlies op ter grootte van het gebied rechts van de vraagcurve, onder de marginale kostencurve 1 en boven $\mathrm{p}^{*} \mathrm{o}$ (gebied $\mathrm{abc}$ ). De instelling lijdt een verlies, namelijk het gebied onder de gemiddelde kostencurve en boven de prijs. Hier geldt immers dat de kosten per eenheid hoger liggen dan de prijs op de markt. De verliezen van de overheidsinstelling moeten worden gedekt door subsidies van de overheid of door interne subsidiëring. Opvallend is dat in veel moderne overheidsinstellingen winst gederfd wordt. De vraag die rijst is waarom overheidsinstellingen veelal verlieslijdend zijn. Wordt het structuur-gedrag-resultaat-paradigma nader bezien dan kan het gebrek aan winst bijvoorbeeld te maken hebben met allerlei kenmerken van de marktstnuctuur. Belangrijker zijn evenwel de specifieke kenmerken van het politieke proces en van de overheidsinstelling die vaak tot specifiek gedrag leiden. Dit zal vaak samenhangen met een afwijkende eigendomsrechtenstructurur, bijzondere principaal agent-verhoudingen en transactiekosten, waarop in hoofdstuk 6 en verder, zal worden ingegaan.

In het voorgaande is een aantal keren gesuggereerd dat een welvaartsverlies gebruikt zou 
kumnen worden woor een ander doel. Hoewel deze omschrijving wel ongeveer weergeeft wat er gebeurt is zij te onnauwkeurig. De inefficiënties die optreden ten aanzien van het eigenlijke doel geven namelijk een vertekend beeld. Zij vertegenwoordigen de kosten die gemaakt worden voor de andere doelen en zijn in die zin dus geen werkelijke welvaartsverliezen. Dit verdient nadere uitleg. Stel dat ons museum een tweetal doelen heeft, bijvoorbeeld de voortbrenging van museale diensten en de bevordering van de werkgelegenheid in de regio. Derhalve stelt zij 500 extra werknemers aan die zij ook nog eens extra beloont. Is het bedrijf mu inefficiënt? ${ }^{228}$ Zoals in het voorgaande is aangegeven zal dat op grond van standaard economische berekeningen/analyse inderdaad gesteld worden. In werkelijkheid hoeft dit niet het geval te zijn. We moeten het bedrijf in dit geval zien als een organisatie die een tweetal goederen voortbrengt, namelijk museale diensten en werkgelegenheid. Een deel van de hulpbronnen wordt voor het ene goed, museale diensten, gebruikt, terwijl eveneens een deel van de hulpbronnen voor het doel werkgelegenheid wordt aangewend. Ten aanzien van die verschillende goederen is de instelling dan niet technisch inefficiẻnt! De overheidsinstelling kan dan ook als volgt worden voorgesteld":

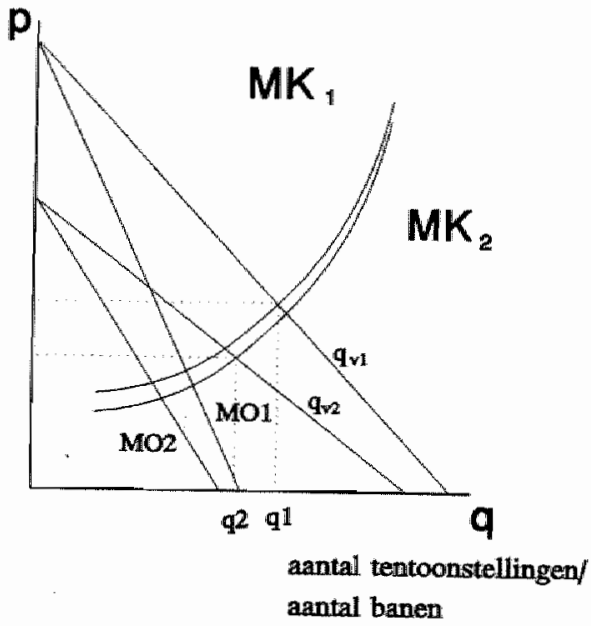

$q 1=$ tentoonstellingen

$\mathbf{q} 2=$ werkgelegenheid

\section{Figuur 4.3 Overheidsinstelling en de productie van twee goederen}

Voor het werkgelegenheidsdoel zullen de marginale opbrengsten en marginale kosten voor de maatschappij als geheel tegen elkaar worden afgewogen.

Indien beide produkten gecombineerd worden kan het volgende worden opgemerkt. Zoals gemeld kunnen de politici worden gezien als de tijdelijke eigenaren van de overheidsinstelling. Omdat zij slechts de tijdelijke eigenaren zijn, hebben zij een prikkel om de marginale baten en marginale kosten aan elkaar gellijk te stellen zonder rekening te houden met factoren als tijd en schaarste. De eigenaren zullen met andere woorden zoveel mogelijk de netto baten proberen te maximaliseren. Dit betekent dat een overheidsinstelling veelal statisch (Pareto)efficiënt is met betrekking tot alle goederen/doelen. Dit is een redelijk uitgangspunt. De overheild en de relevante politieke actoren kunmen al deze

\footnotetext{
${ }^{228}$ Clarke (1990, p. 226). Eén en ander is gebaseerd op een Harberger-analyse van welvaartsverliezen.
} 
doelen op verschillende wijze proberen te bereiken. Indien zij kiest voor overheidsinstellingen is dit de relatief meest efficiënte wijze. Gegeven de aanwezige beperkingen is het niet bekend hoe het beter zou kunnen. Dus hoewel vaak technisch inefficient ten aanzien van het eigenlijke doel is de overheidsinstelling wel Pareto-efficiënt met betrekking tot alle doelen. Ten aanzien van alle doelen is het niet mogelijk de welvaart van de een te verhogen zonder die van een ander te verlagen. Omdat elke overheidsinstelling verschilt (ten aanzien van de verschillende doelen) is het niet mogelijk deze bedrijven qua (technische en Pareto-) efficiëntie te vergelijken. Dit is nog wel mogelijk met betrekking tot de technische efficiëntie ten aanzien van het eigenlijke doel. Met andere woorden, het is niet bekend of het beter kan omdat we geen vergelijkingsmateriaal hebben. Een particulier bedrijf zou daarentegen in dit voorbeeld wel technisch efficiënt zijn maar niet Pareto-efficüënt (denk aan collectieve goederen en externe effecten). Daarom is er ten aanzien van alle doelen in dat geval in principe een Pareto-verbetering mogelijk.

Dat een overheidsinstelling als allocatief efficiënt ten aanzien van alle doelen beschouwd kan worden, kan als volgt met een woorbeeld worden geillustreerd. Het uitgangspunt van dit voorbeeld is dat de overheid/politieke actoren een bepaald doel willen bereiken. Dit doel kost F. 100 miljoen. De overheid heeft bij de realisering van dit doel meerdere keuzes, onder andere:

\section{*Belastingheffing:}

-de belastingheffing zal, zeker indien de belastingen al hoog zijn, gepaard gaan met "excess burdens". Indien de "excess burden" $10 \%$ bedraagt zijn de totale kosten F. 110 miljoen.

-Stel dat de overheid het doel probeert te bereiken met een subsidie. Evenals aan de belastingheffing zijn ook aan de subsidiëring bepaalde kosten verbonden. Neem aan dat er ook hier een "excess burden" van $10 \%$ van de totale uitgaven van F. 100 miljoen is. Totaal zijn de kosten van de subsidie dus F. 110 miljoen.

De totale kosten voor de economie van het pakket van overheidsuitgaven en -inkomsten bedragen derhalve 120 miljoen. waarvan F. 20 miljoen welvaartsverliezen.

\section{* Overheidsinstelling}

De overheid kan ook het doel proberen te realiseren door gebruik te maken van interne subsidierring door overheidsinstellingen zelf. Er bestaat de nodige kritiek op het gebruik van interne subsidiëring. Thiemeyer stelt in dit verband: "In der Allgemeinen (Deregulierungs- JFK) Diskussion scheint sich die Verhinderung der intemen Subventionierung sogar als das Hauptziel der ganzen Bewegung zu zeigen" ${ }^{229}$ Toch kan interne subsidiëring ook voordelen hebben, zoals hierna wordt aangegeven. De overheidsinstelling streeft een aantal doelen na. Daar wordt nu dit doel aan toegevoegd. Indien er van wordt uitgegaan dat de overheidsinstelling voor het nieuwe doel een winst maakte van F. 100 miljoen, dan kan de nieuwe situatie worden bezien:

In plaats van de winst uit te keren aan bijwoorbeeld de aandeelhouders of deze te reserveren wordt de winst nu gebruikt voor een aanvullend doel. De winst die behaald wordt met de bestaande doelen verandert niet. De kosten van die doelen nemen niet toe.'

229 Thiemeyer, in: Thiemeyer (et al.) (1987, pp. 111-112). 
De overheidsinstelling zal nu extra middelen inzetten om het nieuwe doel te bereiken. Hiertoe zal zij nieuwe productiefactoren inschakelen. Het is waarschijnlijk dat zij voor een deel gebruik kan maken van de bestaande faciliteiten van het bedrijf, waaronder bijwoorbeeld het verkoopnetwerk, het inkoopsysteem en dergelijke. Omdat het bedrijf er al is evenals de benodigde specifieke kennils en opgeleid personeel kunnen er, afhankelijk van allerlei omstandigheden, belangrijke synergie-effecten zijn. ${ }^{230}$ Dit is ook bij de behandeling van de zogenaamde "Verbundproduktion" in paragraaf A.2.3 aangegeven. De overheidsinstelling kan het doel dan tegen lagere kosten dan F. 100 miljoen bereiken, bijwoorbeeld F, 90 miljoen. De gederfde winst van 90 miljoen vormen nu de alternatieve kosten van het bijkomende doel. Per saldo bedraagt het voordeel voor de maatschappij/owerheid F. 120 miljoen $-\mathbb{F} .90$ miljoen $=$ F. 30 miljoen. De winst van de overheidsinstelling is nu echter nog slechts $F_{*} 10$ miljoen. Een analyse van de overheidsinstelling zou nu ten onrechte laten zien dat de instelling technisch inefficiënt is.

Of dit voordeel zich in de praktijk zal voordoen hangt er onder meer vanaf in hoeverre het doel verband houdt met de reguliere taken van de overheidsinstelling, in hoeverre de vereiste kennis en de wil om het doel voort te brengen aanwezig zijn en tenslotte of er schaalvoordelen te behalen zijn. Indien binnen het bedrijf werknemers elkaar in de weg lopen, er geen goede coördinatie is tussen de verschillende afdelingen en er te weinig ruimte is om iedereen te behuizen is het onwaarschijnlijk dat dergelijke synergie-effecten zich zullen voordoen. De kosten zullen dan hoger zijn dan F. 100 miljoen. De overheid zal dan geneigd zijn het doel op een andere wijze te bereiken.

Voorts dient bedacht te worden dat het niet juist is om te spreken van één overheid aangezien er tal van actoren van belang zijn, zowel binnen als buiten de overheid, die allen een dergelijke afweging maken. In dit verband is het dan ook zinvoller een netwerkbenadering toe te passen, waarbij ook dergelijke synergie-effecten een rol kunnen spelen.

Het is nu interessant te bekijken wanneer de overheid kiest voor belastingen en wanneer voor een overheidsinstelling.

Een eerste reden houdt verband met de specifieke eigendomsrechtenverdeling binnen een overheidsinstelling. De regering streeft bepaalde doelen na en kan als tijdelijke eigenaar van de overheidsinstelling onder andere deze overheidsinstelling daarvoor gebruiken. Gebruikt zij de overheidsinstelling niet voor het bereiken van bijkomende doelen dan zullen de door de overheidsinstelling behaalde winsten terechtkomen op de begroting. Het parlement zal meebeslissen over de besteding van deze middelen. De discretionaire bevoegdheid van de regering wordt hiermee verminderd.

Daarnaast moeten de kosten van inning van middelen tegen elkaar worden afgewogen. De overheid kan haar uitgaven financieren door belastingen en quasi-belastingen (regulering en opleggen van verplichtingen) maar ook door overheidsinstellingen. Al deze drie categorieên brengen kosten met zich mee, variërend van inningskosten tot welvaartsverliezen. Inning van belastingen kan gepaard gaan met welvaartsverliezen maar dat geldt ook voor de inning door middel van overheidsinstellingen, bijvoorbeeld indien hiervoor een overheidsmonopolie is gecreëerd. Het is denkbaar dat met name indien de belastingen hoog zijn, het voordelig is doelen na te streven door middel van overheidsinstellingen. De collectieve lasten lijken lager terwijl bovendien de welvaartsverliezen beperkt kunnen blijven. Met name indien een economie dicht bij het omslagpunt op de Laffercurve zit is het aantrekkelijk extra doelen te realiseren door middel van overheidsinstellingen.

Ten derde kunnen de genoemde synergie-effecten een rol spelen. De overheidsinstelling is

${ }^{230}$ Vergelijk: Caves (1989, p. 155). 
er al terwijl het doel anders wellicht alleen gerealiseerd kan worden door het in het leven roepen van een nieuwe organisatie, hetgeen extra kosten met zich mee kan brengen.

In het algemeen kan gesteld worden dat een overheidsinstelling er op deze wijze taken bij krijgt. Soms zullen deze taken of goederen betrekking hebben op dezelfde fase van de bedrijfskolom of op een opvolgende of voorgaande fase van de bedrijfskolom. Vaak zullen deze taken echter betrekking hebben op activiteiten uit een andere branche of een andere markt, hetgeen $\mathrm{kan}$ worden opgevat als diversificatie. Belangrijk is in te zien dat tegenover de bijkomende activiteiten van een overheidsinstelling vaak geen prijs staat. Vaak gaat het hierbij om collectieve goederen en exterme effecten. Redenen voor particuliere bedrijven om over te gaan tot diversificatie houden allereerst verband met het effectiever kunnen gebruiken van activa. Om allerlei redenen is het mogelijk dat een bedrijf activa niet volledig gebruikt, waaronder hoge vaste kosten die over zoveel mogelijk produkten gespreid moeten worden, fluctuaties in de vraag en bestaande managementcapaciteit. Het bedrijf zou de onvoldoende gebruikte activa kunnen verkopen of leasen aan een ander bedrijf. In het geval van transactiekosten is het mogelijk dat diversificatie door het bedrijf zelf aantrekkelijker is. Ook voor een overheidsinstelling kan dit een reden zijn aanvullende doelen na te streven en in die zin over te gaan tot diversificatie.

Een weede reden voor diversificatie houdt verband met financièle voordelen die behaald kunnen worden door reductie van financiële risico's. Een gediversificeerd bedrijf zal relatief groter zijn waardoor er schaalvoordelen kunnen ontstaan bij het verwerven van kapitaal. Door de diversificatie kan het risico minder zijn waardoor gemakkelijker vreemd vermogen kan worden aangetrokken. Aangezien een overheidsinstelling veelal niet in een positie is zelfstandig vermogen aan te trekken zal het verminderen van financiële risico's als argument voor diversificatie minder van belang zijn. Wel van belang is het onderscheid tussen eigenaar en "management control" in het bedrijf"231. Het management streeft voor een deel eigen doelen na, zoals inkomen en werkgelegenheid. Het is in haar belang om het risico van werkloosheid te verminderen door bijwoorbeeld diversificatie of het nastreven van andere doelen. Hoewel deze redenen voor een deel kunmen verklaren waarom een overheidsinstelling bijkomende doelen nastreeft zijn ook andere factoren van belang.

Posner noemt een aantal voordelen van interne (kruiselingse) subsidiëring als vorm van "rent-seeking" ${ }^{\text {"232 }}$ De administratiekosten, waronder het invullen van allerlei aanvraagfor-mulieren zullen lager zijn. Indien een uniform tarief wordt gehanteerd hoeven er geen kosten te worden gemaakt voor het ontdekken van de kosten van de diverse groepen. Voorts kan interne subsidiëring ertoe leiden dat de tijd van de wetgever zo efficiènt mogelijk wordt gebruikt, aangezien allerlei regulerende instanties zich met deze interne subsidiering kumen bezighouden. Posner noemt verder dat mensen het wellicht meer rechtvaardig zullen achten indien andere klanten de kosten dragen van een subsidie, dan indien de belastingbetaler dit moet doen. Crew en Rowley merken ten aanzien van knuiselingse subsidiêring op: "Cross-subsidies are a powerful, non-transparant mechanism for wealth redistribution in a rent-seeking society, and regulation provides an outstandingby effective device for operating cross-subsidization".233 "Zij menen dat kruiselingse subsidiëring, gegeven de restricties in de economie, waarschijnlijk efficiënt is. Zij stellen in dit verband: "Given the regulatory environment, a case can be made that cross-

\footnotetext{
${ }^{2311}$ Clarke (1990, paragraaf 9.2.).

232 Posner (1971, pp. 45-47).

${ }^{233}$ Crew en Rowley (1988, p. 63).
} 
subsidization is efficiënt in the sense of Virginia political economy". ${ }^{234}$

Indien de politieke actoren een (impliciete) kosten/batenanalyse maken, zoals weergegeven in paragraaf 2.3.3, kunnen zij tot de conclusie komen dat de meest efficiënte wijze om het doel te bereiken is dit te laten verzorgen door overheidsinstellingen. Hoewel standaard/normatieve analyses vaak zullen wijzen op inefficiëntie is dat feitelijk niet het geval. De politieke actoren kijken niet alleen naar de kosten van de overheidsinstelling maar zij plaatsen deze ook in een ruimer kader. $\mathrm{Zij}$ maken een afweging met andere inkomstenbronnen en bezien op welke wijze het doel het goedkoopst bereikt kan worden: De ene keer zal dit afwegingsproces resulteren in het gebruiken van een overheidsinstelling terwijl een andere keer gekozen zal worden voor belastingheffing en bijvoorbeeld subsidiëring of door voortbrenging door een particulier bedrijf. Bij voortbrenging door een particulier bedrijf zullen zoals vermeld, de verschillen in kosten van "monitoring" van beide bedrijven moeten worden afgewogen. Hieruit kan ook geconcludeerd worden dat de verschillen tussen ondernemingsstaat en belastingstaat ten aanzien van overheidsinstellingen gerelativeerd dienen te worden. In een ondernemingsstaat zou de winst van de overheidsinstelling naar het parlement vloeien. Vervolgens worden met deze winsten doelen nagestreefd. In een belastingstaat worden de winsten niet uitgekeerd aan het parlement maar worden direct doelen hiermee nagestreefd. Zoals aangegeven zal dit veelal geschieden op grond van een afweging van kosten en baten. Dit leidt tot de suggestie dat het in de periode dat overheidsinstellingen voornamelijk als inkomstenbron werden gebruikt, niet aantrekkelijk was bijkomende doelen door dergelijke instellingen na te streven. Blijkbaar waren er betere alternatieven.

\subsection{Conclusie}

De normatieve benadering geeft, op basis van modellen, aan hoe overheidsinstellingen zich zouden moeten gedragen. Zoals is opgemerkt zegt zij weinig over het feitelijke gedrag van overheidsinstellingen. In werkelijkheid blijkt het opstellen van een welvaartsfunctie niet haalbaar te zijn, terwijl het al helemaal niet mogelijk is door middel van een welvaarts-functie concrete doelen te attribueren aan een specifieke overheidsinstelling. Het is dan ook niet mogelijk dat een overheidsinstelling in de praktijk opereert op grond van dergelijke normatieve doelen. Voorts schiet een normatieve analyse tekort bij de beoordeling van de efficièntie/"performance" van een overheidsinstelling. Veelal wordt geconstateerd dat een overheidsinstelling technisch inefficiënt is en dus een lagere "performance" heeft dan een particulier bedrijf, terwijl hiermee voorbijgegaan wordt aan de werkelijke aard en de werkelijke wijze van functioneren van een overheidsinstelling. Overheidsinstellingen streven een groot aantal doelen na. Gegeven de restricties in de economie, zoals de verdeling van eigendomsrechten binnen de overheidsinstelling, zijn deze instellingen Pareto-efficiënt. Geanalyseerd moet dan worden in hoeverre een alternatieve institutie tot efficiëntie-winst kan leiden. Een dergelijke analyse kan slechts succesvol zijn indien bekend is waarom overheidsinstellingen zich in de praktijk op een bepaalde wijze gedragen en hoe de "performance" in de praktijk onderzocht kan worden. De vraag rijst in dit verband of dit gedrag en de doelen die overheidsinstellingen nastreven via het politieke proces niet eenvoudigweg bepaald worden door de kiezers. Zijn het niet de kiezers die bepalen welke goederen een overheidsinstelling voortbrengt en tegen welke kosten dat gebeurt? Vaak wordt immers gesteld dat de overheid en overheidsinstellingen de preferenties van de kiezers zullen nastreven. In het volgende hoofdstuk wordt aangegeven in hoeverre dit waarschijnlijk is.

${ }^{234}$ T.a.p.p. p. 64 


\section{Hoofdstuk 5. Het politieke proces}

\subsection{Inleiding}

In het theoretische deel van dit proefschrift staat de vraag centraal waarom overheidsinstellingen zich op een bepaalde wijze gedragen. In hoofdstuk 4 is uiteengezet dat de welvaartstheorie als normatieve theorie de "performance" van een overheidsinstelling in de praktijk onvoldoende kan verklaren. Op grond van welvaartseconomische overwegingen zou het verstandig kunnen zijn om een "third-best" beleid te voeren. Het is echter niet gezegd dat dit werkelijk gebeurt. De normatieve theorie van de overheidsuitgaven veronderstelt dat de goederen en diensten die door de overheid worden voortgebracht ook inderdaad corresponderen met de preferenties van individuen ${ }^{230}$ Peirce merkt op dat dit onder meer door de werking van het politieke proces niet het geval hoeft te zijn. ${ }^{231}$

In dit hoofdstuk wordt onderzocht of het gedrag, de doelen en de "performance" van overheidsinstellingen verklaard kunnen worden door het politieke proces. Dit wordt gedaan door de welvaartstheorie, overeenkomstig de benadering van Van den Doel, op te vatten als een positieve theorie. De relatie wordt bezien tussen "de feitelijk bestaande organisatie van een samenleving en de mate van behoeftenbevrediging van de leden van die samenleving die daarvan het feitelijk gevolg is ${ }^{11232}$ Om deze vraag te beantwoorden wordt allereerst geanalyseerd wat precies verstaan moet worden onder het politieke proces. Het politieke stelsel kan worden voorgesteld als een principaal-agent-verhouding. De kiezers streven bepaalde doeien na, die door vertegenwoordigers al dan niet worden uitgevoerd. Daarnaast bestaat er een principaal-agent-verhouding tussen parlement en regering. Tenslotte bestaat er een principaal-agent-verhouding tussen het departement en de betreffende overheidsinstelling. Bezien wordt hoe dit proces overeenkomstig de benadering van Van den Doel kan worden weergegeven als een productieproces.

Om te analyseren welke invloed het politieke proces heeft op het gedrag en de "performance" van overheidsinstellingen is het vervolgens van belang in te gaan op de vraag welk beleid door het politieke proces wordt aanvaard. ${ }^{233}$ Kan een efficiënte uitkomst, waarbij het gezamenlijke nut van alle burgers gemaximaliseerd wordt; verwacht worden? Daarbij wordt onderscheid gemaakt tussen onder meer de directe democratie en de representatieve democratie zoals Nederland die kent. Wordt in dergelijke besluitvormingsstelsels een efficiënte uitkomst gerealiseerd? Streven met andere woorden overheidsinstellingen en de overheid in het algemeen inderdaad slechts doelen $c_{\mathrm{n}} \mathrm{q}$. de voortbrenging van een hoeveelheid collectieve goederen na overeenkomstig de preferenties van de consument/kiezer of streeft de overheid eigen doeien na? Indien de kiezers soeverein zijn en volledig bepalen welke goederen de overheid moet voortbrengen en welke doelen zij moet nastreven zijn de doelen van de politici en bureaucraten niet van invloed op het gedrag van overheidsinstellingen. Slechts indien de overheid en overheidsinstellingen (gedeeltelijk) soeverein zijn bepalen actoren aan de aanbodkant de voorziening in collectieve

\footnotetext{
230 Pommerehne (1987, pp. 1-4).

23i Peirce (1981, p. 14).

22 Van den Doel (1988, p. 10).

239 Dunleavy (1991, Hoofdstuk 4).
} 
goederen. Indien dat het geval is dienen wij de doelen van politici en actoren binnen overheidsinstellingen te onderzoeken. Hierbij dient te worden opgemerkt dat nog veel onderzoek op dit gebied nodig is. ${ }^{234}$ Volstaan wordt dan ook met het aangeven of het waarschijnlijk is dat de politieke actoren zelf in enigerlei mate eigen voorkeuren kunnen inbrengen en eigen doelen kunnen nastreven.

De voorgaande besluitvormingsmodellen van de overlegdemocratie, de referendumdemocratie en de representatieve democratie gingen ervan uit dat er geen uitvoerende bureaucratie of overheidsinstellingen zijn. Indien dat well het geval is rijst de vraag in hoeverre het waarschijnlijk is dat het door de kiezers en politici voorgestane beleid door overheidsinstellingen ook daadwerkelijk zal worden uitgevoerd.

\subsection{Hoe kan het politieke proces worden weergegeven?}

In gedachten moet worden gehouden dat efficiëntie kan worden bereikt door marktwerking maar ook door niet-markt-middelen. ${ }^{235} \mathrm{Bij}$ dit laatste kan gedacht worden aan de functie van thal van instituties in een economie. Een voorbeeld hiervan is het onderhandelingsproces zoals dat tussen eigenaren gevoerd kan worden. Volgens Coase zou een adequate toewijzing van eigendomsrechten leiden tot een efficiënte allocatie. Veelal wordt gesteld dat deze vorm van bilateraal onderhandelen goede diensten kan bieden in het geval van externe effecten waar weinig individuen bij zijn betrokken, maar tekortschiet in het geval van collectieve goederen en externe effecten waar veel personen bij zijn betrokken, onder andere in verband met de hoge onderhandelingskosten. ${ }^{236}$

Voor publieke goederen en externe effecten waarbij veel personen zijn betrokken is er een alternatieve institutie voor de markt en bilateraal onderhandelen, te weten het politieke systeem. ${ }^{237}$ Een politiek systeem bestaat uit de cultuur, zoals de doelen van individuen, en de structuur, zoals de machtsverhoudingen binnen dat systeem. Tenslotte kan binnen een dergelijk politiek systeem het politieke proces worden onderscheiden. Door middel van een dergelijk politiek proces worden beslissingen genomen. Easton beschrijft het politieke proces als ziljnde de bindende waardentoedeling voor en namens de samenleving als geheel ${ }^{238}$ Het is belangrijk te onderkennen dat het daarbij niet alleen om economische waarden gaat. Volgens Grondsma en Van den Doel kan het politieke proces als volgt worden weergegeven:

\footnotetext{
${ }^{204}$ Zie ook: Van Winden (1989, pp. 1075-1076).

tass Newbery, in: Hahn (ed.) (1989, p. 215).

226 Vgl. Coase (1960, pp. 1-44), hendrukt in: Coase (1988, pp. 116 e.v.).

${ }^{237}$ Downs (1957, p. 144).

${ }^{238}$ Eastom (1979, p. 3, pp. 47 e.v. $)$.
} 


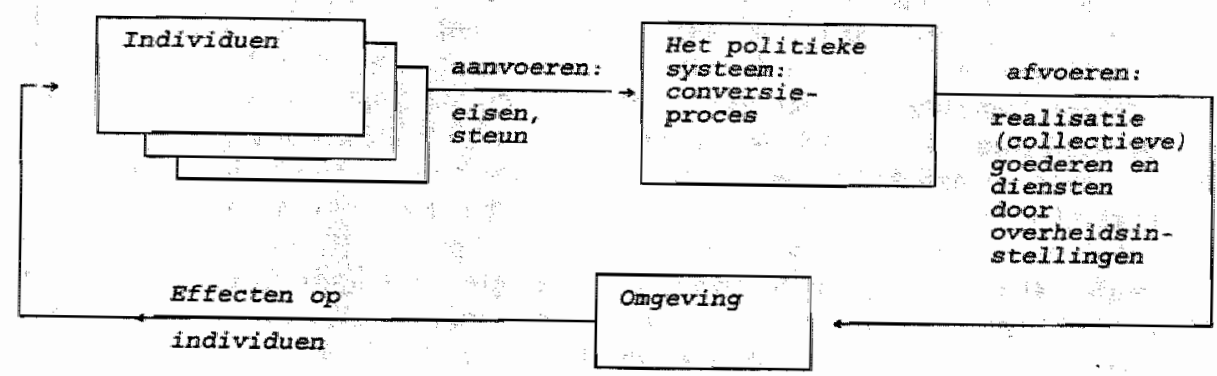

\section{Figuur 5.1 Het politieke proces ${ }^{239}$}

In het politieke proces worden de preferenties van de burgers omgezet in beslissingen over goederen en diensten die zullen worden voortgebracht. Op deze wijze beschreven kan het politieke proces worden opgevat als een bedrijfstak. In de omgeving van het politieke proces, te weten de samenleving, hebben deze beslissingen vervolgens invloed. Tenslotte heeft het door het politieke proces gerealiseerde beleid effecten op de individuen, die op grond daarvan hun preferenties zullen aanpassen. ${ }^{240}$ Elk van deze fasen kan weer worden onderverdeeld in verschillende deelfasen. Van den Doel geeft aan dat ten aanzien van het conversieproces in elk geval een viertal deelfasen onderscheiden kunnen worden, te weten het overleg, de meerderheidsbeslissing, de representatie en de uitvoering. ${ }^{241}$ Deze vier deelfasen kunnen worden opgevat als de verschillende geledingen binnen een bedrijfskolom. Van den Doel merkt dienaangaande op: "Evenals in het bedrijfsleven mogelijk is kunnen ook hier afzonderlijke geledingen worden overgeslagen, bijwoorbeeld wanneer de resultaten van overleg in een aktiegroep niet naar de politici maar direkt naar de ambtenaren worden doorgespeeld". ${ }^{242}$ Alleen indien er een uitvoerende bureaucratie is zijn er overheidsinstellingen. In de overige gevallen wordt de uitvoerende taak door de overlegdemocratie, de referendumdemocratie of de representatieve democratie verricht.

\subsection{In hoeverre streeft de overheid in een overlegdemocratie de doelen van de kiezer en daarmee een efficiënte uitkomst na?}

Allereerst kan de vraag worden gesteid in hoeverre groepen, waarvan de leden vrijwillig met elkaar overleggen en waarbij niemand gebonden is aan de groepsbeslissingen, inderdaad in staat zijn om een beleid te voeren dat voor de totale welvaart van de leden van de groep optimaal is.

Ten aanzien van het unaniem beslissen over de voortbrenging van collectieve goederen en de heffing van middelen is meer in het bijzonder Wicksell van belang. Hij stelt dat de

239 Bron: Grondsma en Van den Doel (1975, p. 201). Vergelijk ook: Van den Doel (1978, p. 31).

2400 Van den Doel (1978, p. 32).

${ }^{241}$ T.a.p.x p. 32.

${ }^{242}$ T.a.p., p. 34. 
gehele samenleving samenkomt en stemt over begrotingsvoorstellen. Deze voorstellen omvatten zowel het niveau waarop collectieve goederen zullen worden voortgebracht als het pakket heffingen en belastingen dat dient ter financiering van het collectieve goed. ${ }^{243}$ ledereen mag een begrotingswoorstel doen en elk individu heeft een vetorecht. Vervolgens wordt er gestemd over elk voorstel. Indien een veto wordt uitgesproken wordt er gestemd over een volgend altermatief. Er wordt net zolang gestemd tot er sprake is van unanimiteit. In dat geval is de allocatie efficiënt aangezien er geen alternatief is waarbij de éen er op wooruit kan gaan zonder dat een ander er op achteruitgaat. ${ }^{244}$ Essentieel hierbij is dat er geen transactiekosten zijn, dat iedereen complete informatie heeft over de gewenste allocatie en deze gewenste allocatie ook in stemming brengt en voorts dat de voorstellen unaniem worden aanvaard. ${ }^{245}$ Lindahl laat zien dat in het geval van unanimiteit er een niveau van publieke voorziening bestaat dat aanvaardbaar is voor alle leden van de samenleving. Door strategisch gedrag van de verschillende individuen en door hoge besluitvormingskosten is het evenwel mogelijk dat een dergelijk (Lindahl)evenwicht niet berelkt wordt. Tullock en Buchanan laten zien dat de vraag of de unamimiteitsregel gebruikt moet worden kan worden geanalyseerd met behulp van een afweging van de marginale kosten en baten. ${ }^{246}$ De onderhandelingskosten die nodig zijn om unanimiteit te bereiken moeten worden afgewogen tegen de kosten van het niet gebruiken van een unanimiteitsregel. Op grond van de benadering van Lindahl, Tullock, Buchanan en ook Johansen kan dan ook gesteld worden dat voor het bereiken van een optimale uitkomst in een overlegdemocratie aan een vijftal voorwaarden moet zijn voldaan. ${ }^{247}$ In de eerste plaats opereert iedereen op een Pareto-efficiënte wijze. Indien een Pareto-verbetering gerealiseerd kan worden wordt hier ook inderdaad voor gekozen. Verder zijn de partijen ongeveer even sterk, hetgeen betekent dat er sprake is van een democratisch onderhandelingsproces, terwijl voorts gelijktijdig wordt onderhandeld over het voorzieningenpakket en de verdeling van de kosten daarvan over de verschillende individuen. Bovendien worden de kosten zodanig verdeeld over de individuen in de groep dat een laag aandeel in de kosten voor de één leidt tot een hoog kostenaandeel voor een ander. Tenslotte heeft de vraagcurve naar collectieve goederen van ieder individu een dalend verloop. Van den Doel geeft aan dat in dat geval de vraag naar een collectieve voorziening groter wordt naarmate het aandeel in de kosten per eenheid van een individu lager is. ${ }^{248}$ In de werkelijkheid wordt veelal niet aan meerdere van deze veronderstellingen voldaan. Zoals aangegeven in hoofdstuk $2 \mathrm{kan}$ zich met name in grote groepen het "free rider"-probleem voordoen. Er ontstaat dan geen optimale uitkomst. Een oplossing hiervoor kan zijn dat de individuen in een groep op democratische wijze collectieve dwang aanvaarden. ${ }^{249}$ Daarmee wordt echter aan éen van de kenmerken van de overlegdemocratie, namelijk dat niemand aan de genomen besluiten gebonden is, niet meer voldaan.

\footnotetext{
${ }^{243}$ Vergelijk: Mueller (1989, pp. 43-44).

244 Wicksell (1896), vertaald Musgrave and Peacock (1958, pp. 92 e.v v $_{\text {) }}$.

245 Buchanan en Brennan (1980, pp. 6-8).

246. Buchanan en Tullock (1983, p. 86).

247 Johansen (1965, pp. 126 e.v.).

248 Van den Doel (1978, p. 69).

249 T.a.p., p. 92 .
} 
5.4 In hoeverre streeft de overheid in een referendumdemocratie de doelen van de kiezer en daarmee een efficiënte uitkomst na?

Een referendumdemocratie verschilt op een drietal punten van de overlegdemocratie. ${ }^{250}$ In de eerste plaats is de unanieme besluitvorming vervangen door meerderheidsstemming (in een directe democratie). Goedhart geeft aan dat meerderheidsbeslissingen onontkomelijk zijn. Hij stelt: "Meerderheidsbeslissingen zijn nodig bij wijze van "second-best"benadering, $(\ldots)^{m .}{ }^{251}$ In de tweede plaats kent de groep in dit besluitvormingsmodel een overheid die genomen beslissingen ook inderdaad afdwingt. Er is niet langer sprake van vrijblijvendheid en vrijwilligheid. Verder noemt Van den Doel alls derde verschil: "(...) zowel die meerderheid als die minderheid kan bestaan uit individuen met een verschillende doelstellingsfunctie" ${ }^{252}$

Het aanvaarden van meerderheidsstemming levert uiteindelijk, uitgaande van ééntoppige preferenties, de keus van de mediane kiezer op. Deze eigenschap van meerderheidsstemming maakt het veelal mogelijk de doelen van de overheid te verklaren door het verklaren van de keus van de mediane kiezer. Indien preferenties symmetrisch zijn verdeeld, kan dit een goede benadering zijn van de efficiênte oplossing. 253 Dit is met mame het geval indien ervan wordt uitgegaan dat preferenties slechts ordinaal kunnen worden geordend. Er wordt dan geen rekening gehouden met de relationele intensiteit van de voorkeuren van individuen. Indien er particuliere substituten zijn voor een collectief aangeboden goed of indien de vraagstukken niet eenduidig op een schaal weergegeven kunnen worden kunnen echter al snel meertoppige-preferenties ontstaan. Het mediane kiezermodel is dan ook nogal bekritiseerd. ${ }^{254}$ Het bestaan van meerdere dimensies kan eenvoudig worden weergegeven. Musea verschillen niet alleen in de hoeveelheid kunst die tentoongesteld en bewaard wordt maar ook ten anzien van verschillende soorten kunst. Zo kan bijvoorbeeld een onderscheid worden gemaakt tussen een museum bestemd voor historische $(\mathrm{H})$, moderne (M) en naïeve kunst $(\mathrm{N})$. In plaats van te kiezen voor een bepaalde omvang van een museum moet gekozen worden wat voor soort museum zal worden gebouwd. Stel de preferentie-ordening kan als volgt worden weergegeven:

\begin{tabular}{|c|c|c|}
\hline \hline kiezer 1 & kiezer 2 & kiezer 3 \\
\hline H & M & N \\
\hline M & N & H \\
\hline N & H & M \\
\hline
\end{tabular}

Tabel 5.1: Preferentie-ordening: drie kiezers en drie voorstellen

\footnotetext{
360 Van den Doell (1978, p. 106).

251 Goedhart (1975, p. 340).

202 T.a.p., p. 106.

${ }^{253}$ Buchanan en Tallock (1983, pp. 125-130). Vergelijk ook: Black (1971, pp. 14 e.v.).

254 Enelow en Hinich (1984, hoofdstuk 2 en 3).
} 
Kiezer 1 prefereert een museum voor historische kunst boven een museum voor moderne of maieve kunst. Een meerderheidsvoorstel bestaat in deze situatie niet omdat elk voorstel kan worden verworpen door een alternatief voorstel. Indien gekozen wordt tussen $\mathrm{H}$ en $\mathrm{M}$ zal $N$ winnen. Indien gekozen wordt tussen $H$ en $N$ wint $M$. Daarmee is de stemvolgorde en de agendavorming een belangrijk middel om uitkomsten te beïnvloeden. Er is in het geval van tweetoppigheid ("double peaked preferences") derhalve sprake van een cyclisehe meerderheid. In dat geval en indien er veel collectieve goederen zijn, kan het politieke proces minder bevredigend zijn. ${ }^{255}$ Het kan in dat geval namelijk leiden tot inconsistente beslissingen over collectieve goederen (stemparadox). Daar komt nog bij dat collectieve beslissingen veelal moeten worden genomen over meerdere vraagstukken. Arrow heeft nu aangetoond dat indien de stemprocedure rechtvaardig is, in de zin dat er bijvoorbeeld geen sprake is van een dictatuur en de individuele vrijheid van individuen niet is beperkt, er geen efficiënte uitkomst tot stand hoeft te komen ("Arrow's impossibility theorema"). ${ }^{256}$ Een efficiente uitkomst kan in principe slechts dan worden gegarandeerd indien één van de door Arrow genoemde criteria wordt losgelaten. ${ }^{257}$ Van den Doel geeft dan ook aan dat een tweetal problemen moeten worden opgelost wil een efficiënte uitkomst gerealiseerd worden. Enerzijds moet rekening worden gehouden met de intensiteit van de preferenties van de burgers en anderzijds moet de collectieve transitiviteit gewaarborgd worden. ${ }^{258}$ Met de intensiteilt van de voorkeuren van de burgers zou rekening gehouden kunnen worden door middel van stemmenruil ("'logrolling ${ }^{\text {t1 }}$ ). In dat geval is onderlinge ruil van steun voor bepaalde voorstellen mogelijk, hetgeen onder omstandigheden kan leiden tot een optimale maatschappelijke welvaart. ${ }^{259}$ In een dergelijke situatie kunnen echter ook uitkomsten gerealiseerd worden die aanzienlijk afwijken van de preferenties van de mediane kiezer. ${ }^{260}$ Teneinde beide door Van den Doel genoemde problemen gelijktijdigg op te lossen is een wijziging van het kiessyteem evenwel onontkomelijk. Daarbij moet gedacht worden aan een kiessysteem waarbij een individu aan elk alternatief een verschillend aantal punten mag toekennen. Vervolgens worden alle punten opgeteld. Het alternatief met de meeste stemmen wordt vervolgens gekozen. ${ }^{261}$ Een nadeel hiervan is dat kiezers niet langer hoeven te stemmen overeenkomstig hun voorkeuren (één van de criteria van Arrow) betgeen kan leiden tot strategisch gedrag en manipulatie van de einduitslag door het in stemming brengen van een kansloos beleidsalternatief, hetgeen invloed kan hebben op het uiteindelijk gekozen alternatief. Tot slot moet nog worden opgemerkt dat veel empirisch onderzoek is verricht naar de vraag of het probleem van cyclische meerderheden zich bij meerderheidsstemming daadwerkelijk voordoet. ${ }^{262}$ Stratmann geeft bijvoorbeeld aan dat het voorkomen van cyclische meerderheden mogelijk niet zo belangrijk is als vaak wordt gedacht, tenminste in het gevall van een "zero-sum-game". Het probleem van dit soort onderzoek is dat het valak

\footnotetext{
135 Rosen (1988, p. 89).

${ }^{256}$ Arrow (1963, pp. 96 e.v.).

${ }^{257}$ Vergelijk ook: Blair en Pollak (1983, pp. 88-95).

w8 Van den Doel (1978, paragraaf 4.3.).

599 Mueller (1976, p. 407).

260 Buchanan en Tullock (1983, pp. 134-135). Zij onderscheiden twee soorten logrolling.

261 Black (1971, pp. 59. e.r.).

262 Zile bijwoorbeeld Stratmann (1996, p. 16)
} 
geen algemene uitspraken toelaat, omdat het gericht is op de beshitworming binnen bepaalde instellingen gedurende een bepaalde periode (Stratmann onderzoekt bijvoorbeeld de besluitvorming in het Amerikaanse Congres).

Het beeld van de overheid tot zover is in die zin onrealistisch dat de overheid wordt voorgesteld als zijnde neutraal en zonder eigen interesses. In werkelijkheid bestaat de overheid, zoals ook in hoofdstuk 2 is benadrukt, uit mensen (politici, bureaucraten etc.) die doelen nastreven. Teneinde het politieke proces in representatieve democratieèn te kunnen weergeven dienen eveneens het gedrag en de doelen van degenen die regeren te worden belicht. Bovendien is er in de praktijk veelal geen sprake van een directe democratie met meerderheidsstemming maar van een representatieve democratie waarin burgers vertegen-woordigers kiezen die namens hen beslissingen nemen.

5.5 In hoeverre streeft de operheid in het Nederlandse democratische systeem de doelen/preferenties van de kiezer en daarmee een efficiënte uitkomst na?

Het voorgaande is op zich zowel van toepassing op het stemgedrag bimmen wetgevende vergaderingen als op het stemgedrag van kiezers. Er zijn echter een aantal kenmerken die uniek zijn voor de representatieve democratie.

Easton geeft aan dat in representatieve democratieen er een politieke arbeidsverdeling bestaat ten aanzien van het politieke gedrag. ${ }^{263}$ Burgers zijn enerzijds kiezers maar fungeren anderzijds ook als politici, ambtenaren en voorts als lid van belangengroepen. $^{264}$ Het politieke productieproces van collectieve goederen en diensten wordt aanzienlijk beïnvloed door deze politieke arbeidsverdeling. Dit houdt namelijk in dat individuele kiezers alleen een beslissing nemen over wie then zal vertegenwoordigen, terwijl de gekozen vertegenwoordigers vervolgens stemmen over allerlei beleidsalternatieven.

Het politieke productieproces kan dienovereenkomstig worden voorgesteld als een politiek stroommodel waarin politieke actoren, instituties en organisaties met elkaar worden verbonden door politieke vraag-en aanbodprocessen. Het politieke stroommodel van het politieke proces in representatieve democratieën levert een conceptueel kader warbinnen overheidsinstellingen functioneren. ${ }^{265}$ Het vormt een uitwerking van Figuur 5.1 en kan als volgt worden weergegeven:

\footnotetext{
263 Easton (1965, pp. 21 e.v.).

264 Van Mierlo (1984, Pp. 258.259).

265 Van Mierlo $\left(1990^{n}\right.$ p. 5).
} 


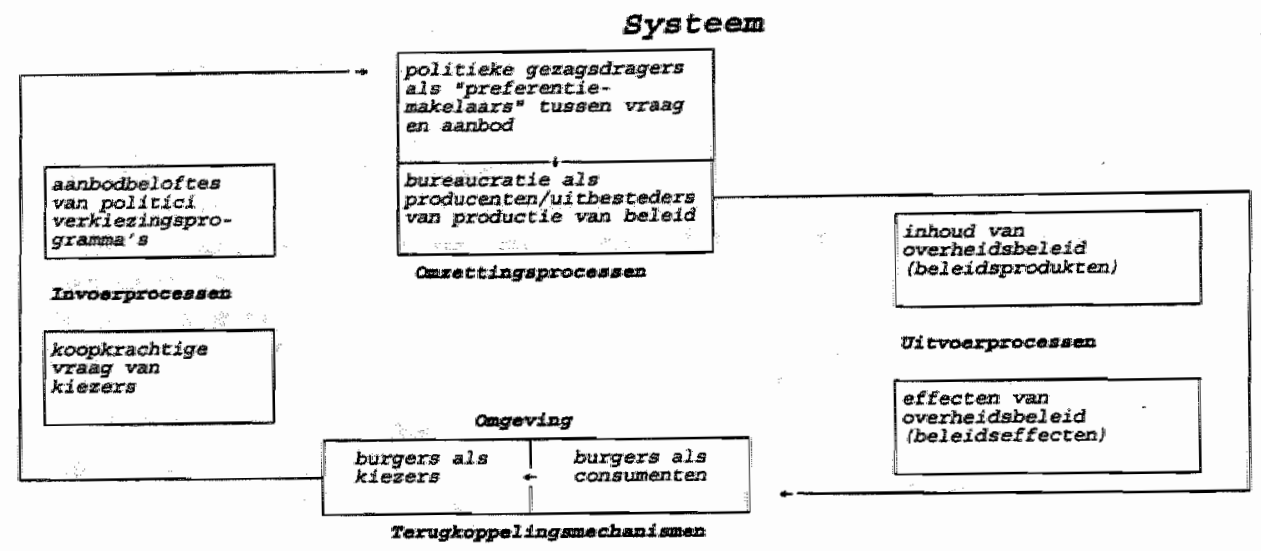

Figuur 5.2 De politieke kringloop ${ }^{266}$

Een voorbeeld van een dergelijke benadering is de ruimtelijke theorie van electoraie concurrentie ("spatial theory of electoral competition"). Deze theorie maakt deel uit van de "public choice" theorie.267 "Spatial theory of electoral competition" zoals geinntroduceerd door Downs heeft betrekking op modellen van de representatieve democratie en is meer in het bijzonder gericht op de dynamiek van het partijgedrag in een dergelijke democratie. $\mathrm{Zij}$ is verder ontwikkeld door onder meer Davis, Hinich, Ordeshook en Riker. ${ }^{268}$ Deze benadering wordt hier om een aantal redenen gevolgd. In de eerste plaats sluit een public choice-benadering van het politieke proces goed aan bij de netwerkbenadering van overheidsinstellingen zoals die in hoofdstuk 6 en verder wordt uiteengezet. Daarnaast is het model in de literatuur verder uitgewerkt. Verscheidene hypotheses afgeleid van het Downsiaanse kiezermodel alsook het complete model zelf zijn in empirisch onderzoek getest. ${ }^{269}$ Verschillende elementen van het Downsiaanse kiezermodel zijn ook voor Nederland bevestigd. Zo tonen kiezers toenemende beleidsrationaliteit en voorts is de "smallest distance-hypothese" bevestigd. ${ }^{270}$ Ten derde is dit model specifiek uitgewerkt voor Nederland.

Zoals vermeld dient in representatieve democratieën een onderscheid gemaakt te worden tussen kiezers aan de vraagzijde van de politieke markt en poltici aan de aanbodzijde. De kiezers prefereren een bepaald beleid en bepaalde collectieve goederen. Politici beloven een bepaald type overheidsbeleid voort te brengen zodra zij eenmaal in de regering zitten.

De vraag naar overheidsbeleid en meer in het bijzonder naar collectieve goederen wordt uitgeoefend door de kiezer door het verrichten van bepaalde politieke activiteiten,

\footnotetext{
${ }^{266}$ Bron: Van Mierlo (1984, p. 266).

267 Downs (1957, pp. 11 e.v.).

24ie bijvoorbeeld: Riker en Ordeshook (1973, hoofdstuk 12) en Hinich en Ordeshook (1970, pp. 772 791).
}

259 Zie bijvoorbeeld Hinich en Ordeshook (1970, pp. 773 e.v.).

$2 \pi 0$ Van Mierlo $(1990$, p.7). 
waaronder meer in het bijzonder het uitbrengen van stemmen bij verkiezingen. Kiezers laten zich leiden door nutsmaximalisatie en evalueren op grond daarvan verschillende politieke alternatieven. Zij stemmen op de partij die een politiek alternatief biedt dat het dichtst bij het door hen geprefereerde alternatief komt ("smallest distance-hypothesis"). Voorts nemen kiezers een positie in in een n-dimensionale politieke ruimte, die de ndimensies van overheidsbeleid weergeven. ${ }^{271}$

Aan de aanbodkant beloven partijkandidaten tijdens verkiezingen een bepaald aanbod van regeringsbeleid te zullen realiseren. Politici laten zich leiden door stemmenmaximalisatie. Dit komt omdat zij, zelfs indien zij hun eigen politieke preferenties proberen te realiseren door een bepaald overheidsbeleid aan te bieden, eerst een positie in de regering zullen moeten veroveren. Teneinde ministersposten te winnen zullen zij verkiezingsoverwinningen moeten behalen en om dat te bereiken dienen zij hun stemmen te maximaliseren. ${ }^{272}$ Daarom wordt in het Downsiaanse model stemmenmaximalisatie beschouwd als de "regulating motive" voor het partijgedrag ten aanzien van het aanbod van overheidsbeleid. ${ }^{273}$ Dit leidt ertoe dat kandidaten hun beleidsvoorstellen gebruiken om de kiezers in de richting van een electoraal optimum te dirigeren. De kiezers beschouwen een beleid als optimaal indien dat hun nut maximaliseert. Daarentegen zal een kandidaat een electoraal resultaat optimaal achten indien hij voldoende steun krijgt om zo effectief mogelijk te participeren in de regering. Op deze manier worden het kiesgedrag van het electoraat en partijgedrag van de politici aan elkaar gekoppeld. Deze confrontatie van vraag en aanbod resulteert in de partijdynamiek die varieert met het specifieke partijsysteem. Hierbij dient wel bedacht te worden dat partijprogramma's door interne partijpolitiek tot stand komen. Leden en dus kiezers participeren in dit partijproces en bepalen dus mede de doelen!

In een twee-partijensysteem zullen concurrerende kandidaten, uitgaande van éêntoppige preferenties, in hun beleidsaanbod (analoog aan het "median-voter"-theorema) convergeren naar de preferenties van de mediane kiezer en zullen zij vergelijkbare beleidsalternatieven aandragen. ${ }^{274}$ Stemmenmaximalisatie dwingt politici er toe de eigen politieke preferenties los te laten en de politieke preferenties van de (meerderheid van de) kiezers te benadrukken. Deze kiezers kunnen beschouwd worden als soevereine consumenten in het politieke proces. Indien echter kiezers wel informatie hebben over de meningen van de politieke partijen maar niet over de kosten en baten van die meningen wordt bij een tweepartijenstelsel geen maatschappelijk efficiënte situatie bereikt.

In een meerpartijenstelsel is coalitievorming tussen minderheidspartijen noodzakelijk om een meerderheidsregering te vormen, aangezien het zelden voorkomt dat één partij de meerderheid weet te behalen. In Nederland is dit bijvoorbeeld nog nooit voorgekomen. In een veelpartijenstelsel als het Nederlandse bestaan er overeenkomstig de stelling van Hinich en Ordeshook, onder de voorwaarde dat politieke partijen streven naar stemmenmaximalisatie en de beleidsvoorkeuren van de kiezers een symmetrische, eéntoppige verdeling hebben, in een politiek evenwicht drie verschillende vestigingsplaatsen voor

\footnotetext{
27. Riker en Ordeshook (1973, pp. 341 e.v. $)$

$2 \pi$ Easton (1965, p. 28).

${ }^{273}$ Stevers, in: Brugmans, et al. (1968, pp. 37-70).

274. Vergelijk: Mueller (1989, pp. 179 e.v.). Dit hoeft niet het geval te zijn indien voldaan wordt aan vergaande symmetrie-eisen.
} 
politieke partijen. ${ }^{275}$ Hierbij wordt aangenomen dat de politieke ruimte ëéndimensionaral is. Van Mierlo geeft in zijn proefschrift aan dat coalitievorming als nadeel heeft dat het voor kiezers vrijwel onmogelijk wordt om rationeel hun stem uit te brengen. ${ }^{276}$ Dit wordt veroorzaakt door de onvoorspelbaarheid van de coalitievorming en daardoor van het uiteindelijk nagestreefde beleid, zoals nog eens duidelijk bleek bij de in 1994 in Nederland gevoerde kabinetsformatie. Voor de verkiezingen lag een kabinet bestaande uit CDA en VVD meer voor de hand, terwijl na de verkiezingen toch gekozen werd voor een regering bestaande uit VVD, PvdA en D'66. Politieke partijen zullen na de verkiezingen gedwongen zijn compromissen te sluiten. Coalitievorming is derhalve complex en brengt kosten met zich mee voor de deeinemers aan het proces van coalitievorming, waaronder overredingskosten, informatie- en tijdskosten. ${ }^{277} \mathrm{Zij}$ kan worden opgevat als een "nonzero-sum-game" ${ }^{n}$ met meerdere spelers, waarbij de winst voor de eên niet het verlies van een ander betekent. Politieke onzekerheid over coalitiegedrag van politieke partijen leidt uiteindelijk volgens Van Mierlo tot politieke inconsistentie en onbetrouwbaarheid van partijkandidaten, in de zin dat kiezers van te voren niet weten waar ze aan toe zijn. Onder deze omstandigheden kunnen stemmenmaximalisatie en beleidsmaximalisatie door politici in evenwicht worden gebracht. In die zin worden carrièregedrag, hetgeen inhoudt dat de preferenties van de kiezers worden nagestreefd, en paternalistisch gedrag, waarbij het streven naar de eigen persoonlijke politieke preferenties centraal staat, met elkaar gecombineerd. ${ }^{278}$ De opstelling van de politieke partijen convergeert niet automatisch naar de positie van de mediane kiezer. Van Mierlo concludeert daaruit dat in een veelpartijenstelsel de voorwaarden voor consumentensoevereiniteit in de politiek niet volledig worden vervald. Onder consumentensoevereiniteit wordt de situatie verstaan dat kiezersvoorkeuren de leidraad vormen voor de voorziening in collectieve goederen, terwijl de producenten zich hierbij aansluiten. Naast de consumentensoevereiniteit van de kiezers wordt het productieproces van collectieve goederen echter voor een belangrijk deel beheerst door producentensoevereiniteit van de politici. ${ }^{279}$ Voor een belangrijk deel omdat kiezers participeren in politieke partijen en op die manier de beleidsvoorkeuren bepalen. Een en ander leidt volgens deze theorie tot een dynamisch proces van politieke concurrentie, waarvan de resultaten afhankelijk zijn van het bestaande partijenstelsel, de doelstellingen van de politieke partijen, de verdeling van de beleidsvoorkeuren over het electoraat en het stemonthoudingsgedrag van de kiezers.

Het Downsiaanse model is gebaseerd op een groot aantal veronderstellingen, waarvan Ordeshook een uitgebreide opsomming geeft. ${ }^{280}$ De optima van de individuele kiezers zijn bijvoorbeeld gelijkmatig over de politieke ruimte verdeeld, terwijl politici door de kiezers slechts op grond van hun beleidsvoorkeuren worden beoordeeld. Verder is er tussen de partijen bijvoorbeeld sprake van volkomen concurrentie. Op elk van deze veronderstellingen kan, zoals vrijwel altijd bij modellen, kritiek worden geuit. Hierbij dient bedacht te worden dat de veronderstellingen van een model op zich niet hoeven te kloppen. Het gaat er veeleer om dat de hypotheses die de theorie oplevert empirische

\footnotetext{
Trs Hinich en Ordeshook (1970, pp. 787-788).

276 Van Mierlo (1989, p. 39).

277 Adrian en Press (1968, p. 556).

278 Van den Doel (1979, pp. 18-23).

${ }^{279}$ Van Mierlo (1989, p. 295).

250 Ordeshook in: Budge (et al.) (1976, pp. 285 e.v.).
} 
toetsing kunnen doorstaan. Belangrijker is dan ook de kritiek die is geleverd op de benadering van Van Mierlo, aangezien het hier niet alleen om de veronderstellingen gaat. Van Velthoven noemt een aantal bezwaren van deze benadering. ${ }^{281}$ Zo merkt hij op dat Van Mierlo zich beperkt tot drie partijen, namelijk het CDA, de PvdA en de VVD zonder dit verder te motiveren. Verder merkt hij op dat Van Mierlo suggereert dat kiezers in een veelpartijenstelsel niet rationeel kunnen stemmen en dat partijen een grote vrijheid hebben om eigen doelen na te streven, zonder hier evenwel verder op in te gaan. Belangrijker is de kritiek dat Van Mierlo soms uitgaat van een ééndimensionale en in andere hoofdstukken van een meerdimensionale politieke ruimte in Nederland. Aangezien de stelling van Hinich en Ordeshook bij Van Mierlo centraal staat is dit verschil van groot belang. Downs ging in zijn model uit van één dimensie en de vraag rijst of dit realistisch is. Stokes en Converse geven aan dat dit miet het geval is. ${ }^{282}$ Anderen waaronder Van der Eijk en Niemöller menen dat de veronderstelling van é̉n dimensie wel geloofwaardig is.

Gezien de vraagstelling van dit hoofdstuk, namelijk in hoeverre beïnvloedt het politieke proces het gedrag en de "performance" van een overheidsinstelling, is het belangrijk te weten of er sprake is van consumentensoevereiniteit of dat politici eigen doelen kunnen nastreven. Indien dat het geval is, is een efficiënte uitkomst niet gegarandeerd. Het is nu van belang te weten in hoeverre het antwoord verschilt indien er wel wordt uitgegaan van meerdere dimensies. Riker en Ordeshook geven aan dat de analyse van competitie van meerdere politieke partijen in een politieke ruimte met meerdere dimensies soortgelijke resultaten oplevert als de analyse bij een politieke ruimte met slechts één dimensie. ${ }^{283}$ Ook McKelvey en Schofield hebben hier onderzoek naar verricht. De (chaos)theorema's van McKelvey en Schofield stellen dat indien twee of meer dimensies van beleid bellangrijk zijn, het waarschijnlijk is dat er een continue stroom van beleidsvoorstellen is, waarbij er steeds beleidswoorstellen bestaan die door een meerderheïd worden geprefereeerd boven het laatste voorstel. ${ }^{284}$ Dit impliceert dat ò elk beleidsvoorstel zal worden verslagen door een ander òf dat een beleidsvoorstel op een arbitraire wijze zal worden geselecteerd uit de stroom van mogelijke beleidsvoorstellen, of zoals zij het stellen: "The Theorem (...) shows, at least for the Euclidian case, either the majority rule social order is completely transitive, or it is involved in a single cycle set". Verder stellen zij: "The existence of a single cycle set implies that it is possible for majority nule to wander anywhere in the space of alternatives ${ }^{\prime 2}{ }^{285}$ Belangrijk is te constateren dat dit probleem alleen bestaat indien verondersteld wordt dat het wetgevingsorgaan ook in staat is direct het verkozen beleid uit te voeren. In de praktijk geschiedt dit slechts indirect via de formatie van een kabinet. De vraag is dan ook hoe het formatieproces de beleidspreferenties van een wetgevende vergadering transformeert in beleid zoals dat door een kabinet wordt uitgevoerd. Laver geeft met behulp van zijn portfolio allocatie model aan dat ook in het geval dat verscheidene beleidsdimensies belangrijk zijn de besluitvorming neigt naar het midden. ${ }^{286}$ Dit zou een algemene generalisatie betekenen van het unidimensionele model

281 Van Velthowen (1990, p. 851).

282 Zie: Stokes (1963, pp. 368-377) en Converse, in: Jennings en Zeigler (1966, pp. 9 e.v.).

283 Riker en Ordeshook (1973, pp. 309 e.w.).

28. McKelvey (1976, pp. 472-482).

$28 s$ T.a.p., pp. $479-480$.

Laver (1993, p. 9). Zie ook: Laver, Schofield en Schmidt (1992, p. 175), Laver en Hunt (1992) en Laver en Shepsle (1996). 
naar meerdere dimensies. Aangezien er echter een aantal verstoringen kunnen optreden (nog afgezien van de veronderstellingen waarvan wordt uitgegaan), lijkt vooralsnog de conclusie gerechtvaardigd dat er tot bepaalde hoogte sprake is van producentensouvereiniteit en dat binnen de aanbodkant van het politieke proces (bestaande uit de regering plus het parlement) de regering eigen doelen kan nastreven. Zoals Laver aangeeft is de mate: van producentensoevereiniteit in die zin beperkt dat een regering bij het voeren van beleid daarbiy wel zal neigen naar een centrumpositie.

\subsection{Hoe beïnvloedt het politieke proces de "performance" van overheidsinstellingen?}

\subsubsection{Welk beleid streven de politici na?}

Uit het voorgaande blijkt dat het politieke proces veelal niet zal leiden tot een welvaartsoptimum. Gegeven de constatering dat er tot een bepaalde hoogte sprake is van producentensoevereiniteit, kan vervolgens de vraag worden gesteld welke doelen politici, meer in het bijzonder de uitvoerende macht, onder meer met behulp van overheidsinstellingen, zullen nastreven. In de literatuur worden in dit opzicht een tweetal theorieën onderscheiden. De politieke conjunctuurcyclustheorie stelt dat politici zich rationeel zullen gedragen en een economisch beleid zullen voeren waarmee de waarschijnlijkheid van herverkiezing zal worden gemaximaliseerd. ${ }^{287}$ Rogoff benadrukt dat politici vooral geneigd zullen zijn om in verkiezingsjaren de uitgaven met een hoge "attentiewaarde" te vergroten. ${ }^{288} \mathrm{De}$ "partisan"-theorie voorspelt dat politici streven naar het zoveel mogelijk realiseren van de eigen verkiezingsprogramma's. Van Dalen en Swank hebben onderzoek verricht naar de geldigheid van de collectieve vraagtheorie van de mediane kiezer, de theorie van de politieke conjunctuurcyclus en de "partisan"-theorie voor Nederland ${ }^{289}$ In hun onderzoek vinden zij dat geplande verkiezingen een opdrijvend effect hebben op alle uitgaven, met uitzondering van de sociale zekerheid. Zij stellen: "Op zich zelf is deze uitkomst zeer opvallend omdat deze impliceent dat politici meer uitgeven dan door de mediane kiezer. gevraagd wordt". 290 . Dit sluit aan bij de hiervoor gegeven constatering dat er tot op zekere hoogte sprake is van producentensoevereiniteit. Van Dalen en Swank merken verder op dat hun bevindingen in strijd zijn met de stelling van Rogoff, in die zin dat ook overheidsuitgaven met een lage "attentiewaarde" zoals defensie en uitgaven voor infrastructurele werken, worden verhoogd. Voorts menen zij dat de resultaten van hun onderzoek een bevestiging inhouden van de "partisan"-theorie. Zij concluderen: "Wij interpreteren de gevonden coefficiënten als volgt. De Nederlandse minister heeft een dienende taak, maar laat ook electorale en ideologische motieven een rol spelen bij de
bepaling van de overheidsuitgaven".

In de meeste parlementaire democratieèn is getracht grenzen te stellen aan de bevoegdheden van de uitvoerende macht, onder andere door de constitutionele bepaling dat de uitvoerende macht de steun van de meerderheid van het parlement nodig heeft. Ondanks deze constintionele verantwoordelijkheid van de uitvoerende instantie aan het wetgevende

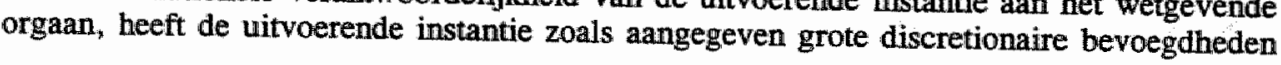

\footnotetext{
287 Vergelijk: Nordhaus (1975, pp. 169-190).

289 Rogoff (1990, pp. 21-36).

'Van Dalen en Swank (1995, pp. 374-375).

200 T.a.p., p. 373 .
} 
waarmee zij eigen doelen kan nastreven. Deze bevoegdheid heeft zij in de eerste plaats omdat zij grote invloed heeft op het gehele wetgevingsproces (de meeste wetten komen tot stand op voordracht van de regering). Daamaast kan de regering het parlement ontbinden en nieuwe verkiezingen uitschrijven. ${ }^{291}$

\subsubsection{Wordt het beleid van politici uitgevoerd?}

Van den Doel noemt naast de besluitvormingsmodellen van de overlegdemocratie, de referendumdemocratie en de representatieve democratie het beslluitvormingsmodel van de uitvoerende democratie. ${ }^{292}$ In theorie zou het door de politici aangenomen beleid door overheidsinstellingen moeten worden uitgevoerd. De invloed van het politieke proces op een overheidsinstelling kan als volgt worden weergegeven:

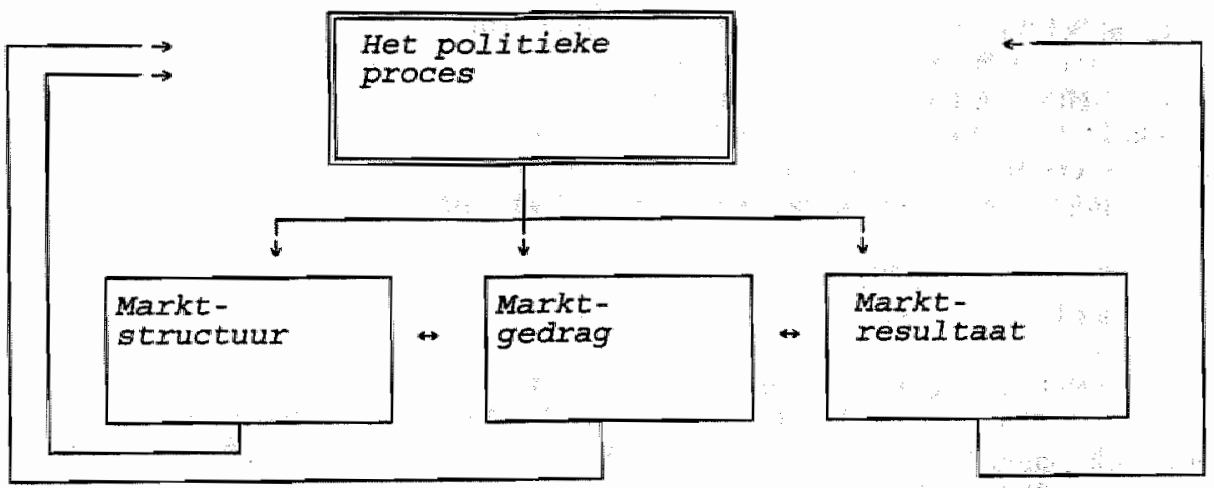

Figuur 5.3 De invloed van het politieke proces op de "performance"

Het beleid zoals dat door politici is aangenomen kan invloed hebben op de marktstructuur en het gedrag van de overheidsinstellingen en daarmee op de "performance". De klassieke benadering ging ervan uit dat het beleid van gekozen politici automatisch door het ambtenarenapparaat werd uitgevoerd. Peirce merkt op: "Most economic analysis presupposes that the bureaucracy implements exactly the program specified in the law. This is equivalent to the classical approach in political science (..... Unitil recently, political science also has ignored implementation almost completely".293

In werkelijkheid wordt het beleid niet automatisch uitgevoerd. Peirce geeft aan dat de modeme politieke wetenschap de klassieke opvatting madrukkelijk afwijst. De uitvoering van het beleid kan ook worden gezien als een politiek proces. Dit kan ertoe leiden dat de uitvoering andere resultaten oplevert dan beoogd door de wetgevende macht. Van den Doel merkt in dit verband op: "Niet alleen de burgers en de politici, maar ook de ambtenaren beschikken over ekonamische beslissingsmacht". ${ }^{294}$ Onder economische

\footnotetext{
291 Laver (1993, pp. 2-3).

292. Van den Doel (1978, hoofistuk 6$)$.

Peirce $(1981$, p. 55).

294 Van den Doel (1978, p. 167).
} 
beslissingsmacht van een individu verstaat hij: "(..) een specifieke vorm van invloed, namelijk die welke wordt aangewend in overeenstemming met zijn doeleinden en wordt ondersteund door de mogelijkheid tot toepassing van negatieve economische sankties". Aan de ene kant geven politici opdrachten aan overheidsinstellingen en verstrekken zij budgetten aan deze instellingen. Maar aan de andere kant beschikken ambtenaren over specifieke kennis en vaardigheden. Tot bepaalde hoogte is er sprake van asymmetrische informatie, waardoor werknemers binnen overheidsinstellingen een eigen beleid kunnen voeren.

Peirce gaat verder in op de vraag wanneer de resultaten van de uitvoering van overheidsbeleid voorall zullen verschillen van de doelen die de politici voor ogen stonden. Hij stelt vervolgens een aantal stellingen op. Zo stelt hij bijvoorbeeld dat de kans dat het beleid van de politici mislukt groter is indien een overheidsinstelling weinig publieke belangstelling trekt, naarmate een overheidsinstelling onafhankelijker is van het begrotingsproces, indien de instelling goederen levert aan sommigen voor minder dan de marktprijs, of indien de wetgeving zeer gecompliceerd is. ${ }^{295}$ "Teneinde de "performance" van "een overheidsinstelling te kunnen verklaren is het dan ook niet voldoende te weten wat voor een beleid door politici gevoerd wordt. Het is essentieel om inzicht te hebben in het functioneren van individuen binnen overheidsinstellingen en de interactie tussen hen en de gekozen politici. Hierop wordt in de volgende hoofdstukken ingegaan.

\subsection{Conclusie}

In dit hoofdstuk is ingegaan op de vraag hoe het politieke proces het gedrag en de "performance" van overheidsinstellingen beïnloedt. Daartoe is ingegaan op een aantal besluitvormingsmodellen, te weten de overlegdemocratie, de referendumdemocratie en de representatieve democratie. De conclusie is dat het politieke proces niet automatisch een efficiènte uitkomst verzekert. De aanbodkant van het politieke proces kan tot bepaalde hoogte een eigen beleid voeren en eigen doelen nastreven. Vervolgens rijst de vraag wat het effect is indien een uitvoerende bureaucratie c.q. overheidsinstellingen worden toegevoegd. Het uitgangspunt is dam dat overheidsinstellingen deel uitmaken van het politieke stelsel, terwijl het politieke stelsel deel uitmaakt van de publieke sector van het bedrijfsleven. De politici voeren dan een beleid dat van invloed is op de marktstructurur, het gedrag en de "performance" van overheidsinstellingen. Het blijkt nu dat het waarschijnlijk toch al niet efficiènte beleid van de politici door overheidsinstellingen bovendien slechts tot bepaalde hoogte wordt uitgevoerd. Daarnaast kunnen actoren binnen overheidsinstellingen zoals managers en werknemers een eigen beleid voeren.

De conclusie die uit dit hoofdstuk getrokken kan worden is dan ook dat het politieke proces weliswaar grote invloed heeft op het gedrag en de "performance van overheidsinstellingen maar dat ook andere factoren van belang zijn. Teneinde de "performance" te kunnen verklaren is het essentieel dat ook het beleid van de actoren binnen deze overheidsinstellingen en de interactie van dit beleid met het beleid van politici geanalyseerd wordt. In de volgende hoofdstukken wordt dan ook verder ingegaan op de factoren die dit
gedrag beïnvloeden.

${ }^{258}$ Peirce (1981, pp. 68 e.v.). 


\section{Hoofdstuk 6. De overheidsinstelling als netwerk}

6.1 Inleiding: hoe kan het gedrag van overheidsinstellingen dan wel worden verklaard?

Verklaringen voor het bestaan van overheidsinstellingen en het gedrag van overheidsinstellingen hebben veel gemeen. Overheidsinstellingen worden veelal opgericht met het oog op bepaald toekomstig gedrag ervan. Indien bijvoorbeeld politieke actoren een overheidsinstelling oprichten ter bestrijding van de werkloosheid in een bepaalde regio, dan zal het toekomstige prijsgedrag van de overheidsinstelling navenant zijn. Dit neemt niet weg dat door het ontstaan van de overheidsinstelling nieuwe belangengroepen in het leven worden geroepen, waaronder het management en de werknemers van het bedrijf, die grote invloed kunnen uitoefenen op het gedrag van de overheidsinstelling. In de komende paragrafen worden, uitgaande van de veronderstelling dat de overheidsinstelling al bestaat, verscheidene positieve theorieën bezien, voor zover relevant voor de verklaring van het gedrag van overheidsinstellingen. In de literatuur is vanuit verschillende hoek ("public choice", neo-institutionele economie) geprobeerd om te komen tot een analyse van het feitelijke gedrag van overheidsinstellingen. Hoewel deze benaderingen het inzicht in belangrijke facetten van het gedrag van overheidsinstellingen aanzienlijk hebben vergroot, rijst toch de vraag naar de samenhang ervan. Dit probleem laat zich oplossen door de "public choice" en de neo-institutionele benadering te integreren in het uit de organisatiekunde bekende netwerkconcept. Dit sluit aan bij recente ontwikkelingen waarbij getracht wordt de organisatietheorie en transactiekosteneconomie te integreren in een netwerk, waarbij het gaat om een netwerk als instituut. ${ }^{296}$ In de volgende paragrafen wordt getracht tot een dergelijke integratie van theorieën te komen.

\subsection{Hoe kan het netwerkconcept worden toegepast op orerheidsinstellingen?}

Uit het voorgaande bleek reeds dat de overheidsinstelling een complexe organisatie is. ${ }^{297}$ Complexe organisaties zijn organisaties die gekenmerkt worden door een grote mate van differentiatie, als structurele vormgeving van vergaande arbeidsdeling. De benadering in deze paragraaf heeft als uitgangspunt het structuur-gedrag-resultaat-schema en de analyse van het politieke proces, zoals uiteengezet in de hoofdstukken 3 en $\mathbf{5}$ en zoals is samengevat in Figuut 6.1.

${ }^{236}$ Buxbaum (1993, pp. 698-700). Zie ook: Mattsson (1995, p. 760).

Perrow (1979, p. 55). 


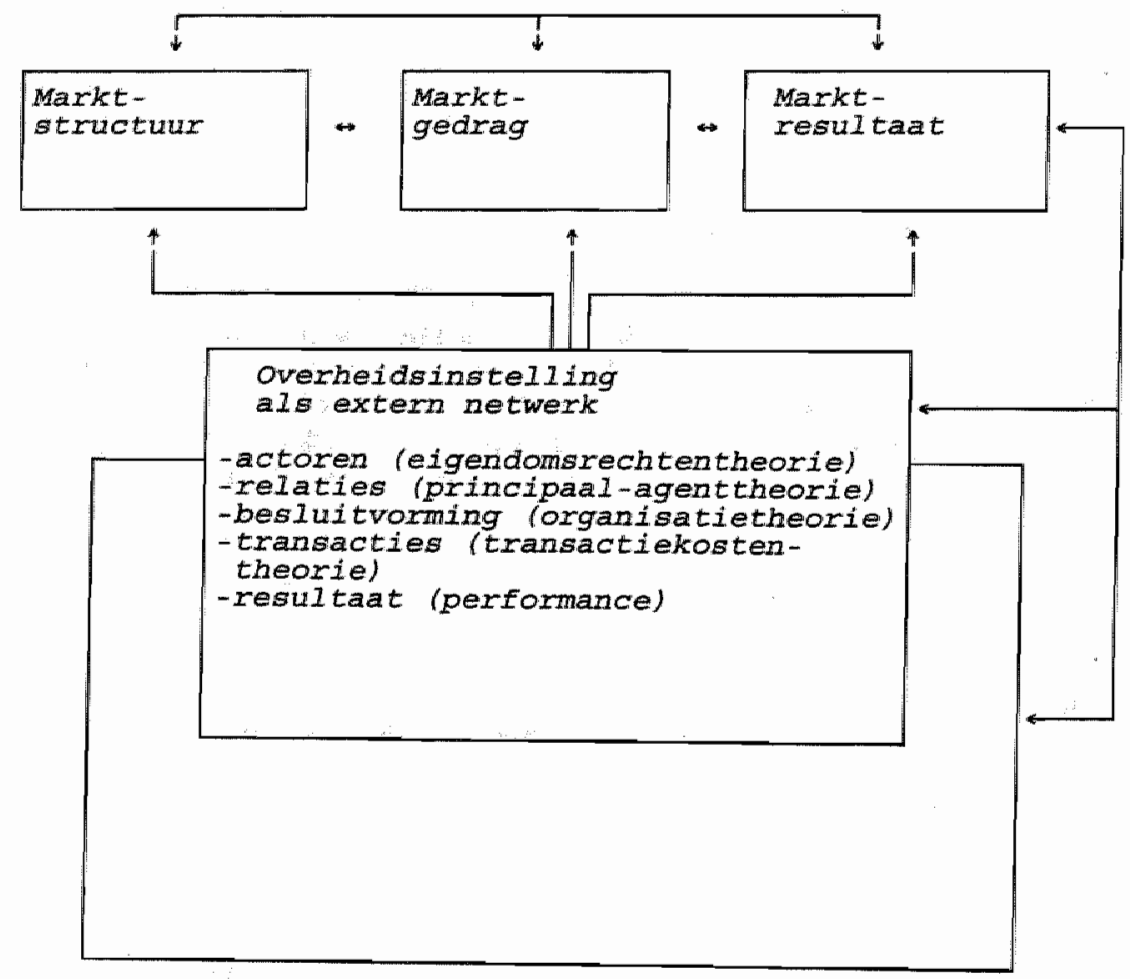

\section{Figuur 6.1 De overheidsinstelling als netwerk}

Teneinde meer inzicht te krijgen in de wijze van functioneren van overheidsinstellingen wordt een theorie van overheidsinstellingen opgesteld. Er kunnen verschillende soorten modellen worden onderscheiden. Bertels en Nauta noemen 6 soorten waaronder het ideaalmodel, het analogiemodel, het structurele model en het abstracte model. Het beoogde model is een combinatie van een analogie- en een structureel - model. Een analogiemodel benadrukt een (veronderstelde) overeenstemming in de functie of werking van het beeldsysteem met dat van het origineel. ${ }^{298}$ Het dient ter verklaring van een bepaalde werking van het originele afgebeelde systeem. Een structureel model tracht kennis over structurele verschijnselen betreffende het origineel te ordenen en overdraagbaar te maken. Het model kan vervolgens gebruikt worden bij de ontwikkeling van een strategie voor verder onderzoek.

De ontwikkelde theorie wordt in hoofdstuk 14 en verder gebruikt voor een aantal doelen:

1. Een analyse van de structurur van een overheidsinstelling;

2. Een analyse van de doelen van een overheidsinstelling;

3. Een analyse van de processen die plaatsvinden tussen onderdelen van een overheidsinstelling;

4. Een analyse van processen van verandering van een overheidsinstelling;

5. Een analyse van de resulterende "performance" van de overheidsinstelling.

Bertels en Nauta (1974, hoofdstuk 7). 
Uitgaande van deze verschillende functies van het model wordt getracht een aantal uiteenlopende theorieen en benaderingen met elkaar te combineren, zoals de public choice-benadering, waarbij de nadruk zal liggen op de atomistische organisatie-opvatting, de benadering van de eigendomsrechten en de principaal-agent-benadering. Voortbouwend op de "public choice"-benadering wordt gekozen voor de netwerk-benadering, waarin overheidsinstelling wordt opgevat als een samenstel van actoren. ${ }^{299}$. Deze netwerken zijn instituties die noch te typeren zijn als markt, noch als hiërarchie. In die zin is een overheidsinstelling te beschouwen als een (onderdeel) van een netwerk. ${ }^{300}$ Zoals Hutter en Teubner het omschrijven: "Hybrids are no more than "discrete structures" on a sliding scale between spot-market contracts and full-fledged formal organizations" 301

Analoog aan de benadering van Van Mierlo kunnen een drietal redenen genoemd worden waarom overheidsinstellingen kunnen worden opgevat als een (onderdeel van een) netwerk. ${ }^{302}$ In de eerste plaats hebben overheidsinstellingen vaak een private rechtsvorm, terwijl zij publieke taken uitoefenen. Deze organisaties worden veelal gekenmerkt door een zekere mate van zelfstandigheid, terwijl zij vaak in markten opereren. Overheidsinstellingen zijn door de invloed van het politieke proces onderdeel van een netwerk. In de tweede plaats verwerven zij inkomsten uit meerdere bronnen. Enerzijds ontvangen zij dikwijls (verkapt) subsidie van de overheid, anderzijds verkopen zij veelal goederen tegen prijzen op een markt. In de derde plaats worden de productiebeslissingen binnen dergelijke instellingen enerzijds gecoördineerd via de markt en anderzijds door de overheid via het budgetmechanisme. De overheidsinstellingen zoals die in dit onderzoek aan de orde komen bestrijken dan ook een breed gebied, variërend van overheidsinstellingen die vrijwel alleen publieke taken uitvoeren en die vrijwel volledig bekostigd worden door subsidies verstrekt door de overheid en anderzijds overheidsinstellingen die een privaatrechtelijk karakter hebben en hun inkomen vrijwel volledig genereren via de markt.

\subsection{De overheidsinstelling als netwerk.}

Het model wordt gespecificeerd met behulp van de volgende begrippen. ${ }^{303}$

netwerk:

extern netwerk:

een geheel van actoren en betrekkingen tussen die actoren.

een overheidsinstelling en toezichthoudende organen.

intern netwerk: het geheel van actoren binnen een overheidsinstelling.

instantie: actor in het netwerk van de overheidsinstelling. Elke persoon die een beleid voent of tracht te voeren en daarbij eigen doelstellingen nastreeft. Binnen het netwerk overheidsinstelling zijn een groot aantal actoren te onderscheiden, zoals ministers, kamerleden, ambtenaren, managers, werknemers, vakbonden, etc.

betrekking: een verbinding tussen instanties in het netwerk; een min of meer duurzaam patroon van min of meer gelijksoortige interacties tussen

\footnotetext{
299 Het is in dit verband van belang op te merken dat het hier gaat om een netwerk-benadering waarbij het metwerk wordt opgevat als instituut en niet on de netwerkbenadering als methode! Vergelijk ook:

O'Toole (1997).

300 Vergelijk ook: Jones (ed.) (1982, p. 1).

${ }^{301}$ Hutter en Teubner (1993, p. 707).

302 Van Mierlo in: Mol en Verbon (1993, p. 19).

${ }^{309}$ De Ridder, in: Fleurke (1983, Hoofdstuk 4).
} 
interactie:

twee instanties. Hierbij kan gedacht worden aan de verhoudingen tussen managers en werknemers, subsidiestromen van departementen naar het bedrijf, de verhoudingen met vakbonden e.d. .

éenzijdige op de andere of wederzijds op elkaar gerichte activiteiten van meerdere instanties.

Er kan onderscheid gemaakt worden tussen een extern en een intern netwerk. Binnen een extern netwerk zijn zowel actoren binnen als buiten de overheidsinstelling opgenomen. Boycko, Shleifer en Vishny merken in dit verband op: "(...) the government is at best an approximate concept. In many transitions as well as developing countries, "the government" consists of a number of ministries, each of which has its own specific abjectives different from those of other ministries in the "government". ${ }^{304}$ Vaak wordt gesproken over de overheid, terwijl ook binnen de overheid een groot aantal verschillende actoren onderscheiden kunnen worden. Binnen een intern netwerk gaat het tenslotte alleen om de personen binnen de overheidsinstelling zelf. Ook deze actoren kunnen verschillende belangen en doelen hebben.

Met het netwerk-model wordt meer in het bijzonder de structuur van een overheidsinstelling weergegeven. Het netwerkmodel is al veel langer in gebruik bij antropologen en sociometristen. Zij analyseren netwerken van personen, zogenaamde sociale netwerken. Ook in de bestuurskunde en de politicologie worden de laatste jaren beleidsprocessen steeds meer met behulp van een netwerkbenadering geanalyseerd ${ }^{305}$ Veel aandacht wordt bijvoorbeeld besteed aan de analyse van beleidsnetwerken. ${ }^{306}$ Deze inzichten kunnen, naar analogie gebruikt, behulpzaam zijn bij het construeren van een model van een overheidsinstelling. Ook in de organisatietheorie en de economische wetenschap is het netwerkconcept tegenwoordig een bellangrijk onderzoeksveld. ${ }^{307}$. Buxbaum stelt bijvoorbeeld: "(This) "fits within an important if recent trend towards bringing organization theory and transaction cost economic theory into a discourse nenwork". ${ }^{308}$

De elementen van een netwerk worden aangeduid als actoren. De verbindingen tussen de elementen worden betrekkingen genoemd. Een netwerk kan worden gezien als een "symbiotic arrangement", waarbij ongelijke partners deelnemen in een wederzijds voordelig arrangement. ${ }^{309}$ Schanze vermeldt een aantal kenmerken van de transacties die als "symbiotic arrangements" kunnen worden aangeduid. Zo noemt hij als kenmerk dat er impliciet of expliciet sprake is van asymmetrie tussen partners, dat de mogelijkheden en rechten inzake de controle ("monitoring") en sanctiemogelijkheden van elkaars gedrag zijn

\footnotetext{
304 Boycko, Shleifer en Vishny (1996, pp. 767-768).

${ }^{300}$ Klijn en Koppenjan (1997, p. 144).

306 Vergelijk: Kickert, Klijn en Koppenjan (1997), Klijn (1996) en De Bruijn en Ten Heuvelhof (1995). Indlien netwerken zijn gericht op de ontwikkeling of uitvoering van beleid worden deze aangeduid als beleidsnetwerk. In dit onderzoek gaat het met name om een netwerk als samenwerkingsverband. Zile ook: Godfroig en Nelissen (1993).
} 307 Vergelijk ook: Menard (1996, pp. 154-183), Schäfer (1996, pp. 184-187) en Lindenberg (1996, pp. 188-
196).

300 Buxbaum (1993, p. 698). Vergelijk ook: Bulder, Leeuw en Flap (1996, p. 263).

309 Schanze (1993, p. 691) 
vastgelegd en voorts dat het gaat het om vrijwillige samenwerking door bedrijven. ${ }^{310}$ Indien een overheidsinstelling wordt voorgesteld als een netwerk gaat het evenwel niet alleen om de samenwerking van bedrijven en instellingen, maar ook van individuen. De overheidsinstelling kan worden gezien als een intern netwerk met tal van actoren, dat deel uitmaakt van een veel groter extern netwerk, eveneens met een groot aantal actoren, waaronder ambtenaren, ministers en kamerleden. In dit onderzoek wordt derhalve een ruime omschrijving van het begrip netwerken gehanteerd overeenkomstig de benadering van Powell. Hij omschrijft netwerken als "Reciprocal pautems of communication and exchange".31 Deze omschrijving geeft tevens een inzicht in de omvang van een netwerk. Mattsson merkt in dit verband op: "A nerwork structure can be envisaged where actors are directly or indirectly connected to each other (...). Exchange in one relationship is conditioned by exchange in other relationships. This is the reason why analyses of seperate individual relationships are very restricted in their ability to explain performance and dynamics in economic systems ${ }^{13}$. ${ }^{2}$ Verder merkt hij op: "The bounderies and the degree of authority may change over time. In fact, the dynamics of bounderies and of the degree of authority are important policy issues both at actor level and at societal level ${ }^{m} .{ }^{313}$

Tenslotte is het van belang te onderkennen dat er in een netwerk een groot aantal actoren opereren, terwijl voorts actoren lid kunnen zijn van meerdere netwerken. In de loop der tijd $\mathrm{kan}$ dit bovendien veranderen. Binnen een dergelijk netwerk vinden een tweetal soorten evolutieprocessen plaats. ${ }^{314}$ In het geval van natuurlijke selectieprocessen ontstaan instituties spontaan zonder dat iemand bewust veranderingen doorzet. Kunstmatige selectieprocessen ontstaan door het bewust creëren van nieuwe instituties. ${ }^{315}$ Duidelijk is dat veel selectieprocessen binnen een netwerk een kunstmatig karakter hebben, in de zin dat er een orde ontstaat ten gevolge van menselijk handelen. Iedere actor streeft een bepaald doel na en probeert daarmee bewust bepaalde wijzigingen door te voeren of de bestaande situatie te handhaven. In deze paragraaf zal verder een netwerkmodel van de overheidsinstelling worden ontwikkeld. Het aanvankelijk nog eenvoudige model zal steeds verder worden uitgewerkt door de structuur en de interacties binnen die structuur nader te karakteriseren. Een aantal van de aangrijpingspunten van Mitchell zullen daarbij, zij het aangepast, terugkeren.

Mitcheli noemt twee soorten kenmerken van het netwerk, namelijk morfologische, waarmee de structuur van het netwerk kan worden gekarakteriseerd en interactionele, waarmee de culturur en de aard van de verbindingen in het netwerk getypeerd worden. ${ }^{316}$ De structuur is het objectieve patroon van afhankelijkheidsrelaties. ${ }^{317}$ De mate waarin

310 T.a.p., p. 693 .

${ }^{31}$ Powell $(1990$, p. 295).

312 Mattsson (1995, p. 761).

313 T.a.p., p. 762.

i4 Vgl. Biddle (1991, p. 19).

315 Zie verder: Vanberg (1996, p. 690). Vergelijk ook: Commons (1924) en (1934), Hodgson (1996, paragraaf 1), Witt (1996, paragraaf 2), Kubon-Gilke (1996) en Basu (1996).

${ }^{315}$ Mitchell (1969, p. 296).

317 Wassenberg (1980. p. 20). 
een netwerk een sterke of zwakke structuur heeft is afhankelijk van een tweetal kenmerken. In de eerste plaats is dit afhankelijk van de organisatiegraad. In het geval van de organisatiegraad gaat het om de intensiteit van de relaties in een netwerk. Een tweede kenmerk is de symmetriegraad. Hierbij gaat het om de mate van scheefheid van de relaties. Met de mate van scheefheid wordt bedoeld de mate waarin de verschillende actoren gelijkwaardig zijn of elkaar juist domineren.

Onder de culturur van een netwerk verstaan wij de verwachtingen die de verschillende actoren van elkaars gedrag hebben. ${ }^{318}$ Tenslotte wordt de mate waarin de leden van een. netwerk vaste en gedeelde verwachtingen omtrent elkaars gedrag hebben aangeduid als kristallisatiegraad.

Culturur en structuur bepalen samen de institutionaliseringsgraad van het netwerk. Hiermee wordt gedoeld op de mate warin objectieve afhankelijkheidsrelaties en de corresponderende subjectieve verwachtingen vastgelegd zijn. Het gaat hierbij om de principaal-agentverhoudingen binnen het netwerk. Eén en ander kan als volgt worden weergegeven:

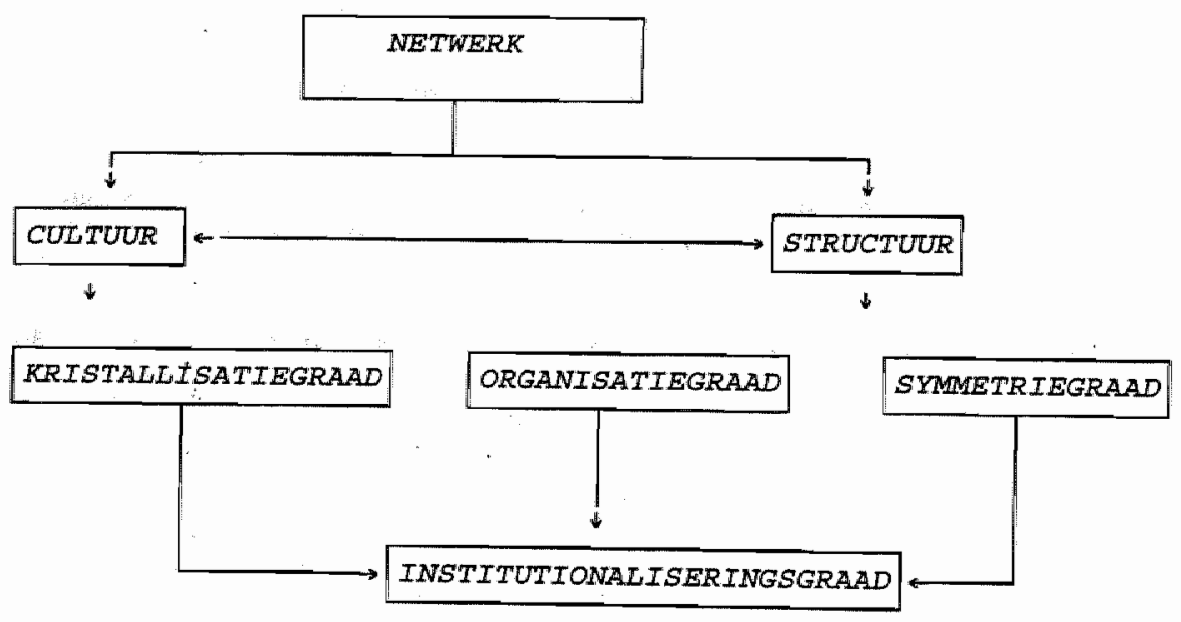

Figuur 6.2 De institutionaliseringsgraad van een netwerk

Netwerken kunnen in het algemeen ontstaan indien de sector inputs nodig heeft die noch de markt noch een bedrijf overeenkomstig hun wensen kan leveren, of zoals weergegeven door Buxbaum: "These imputs may be of a quality that the market may not be able to price well, or of a quality that permits their opportunistic capture under existing rules of contract law, leading over time to underinvestment in them. They may be of a quality that typical styles of hierarchical processing within firms also do not handle well; for example, technological information that only speedy processing, difficult to obtain within the firm Het is waarschijnlijk dat ook de in hoofdstuk 4 genoemde synergie-effecten kunnen bijdragen tot het ontstaan van dergelijke netwerken. In het kader van de transacties binnen het netwerk wordt verder op de transactiekosten en het ontstaan van netwerken ingegaan.

\footnotetext{
${ }^{318 .}$ T.a.p., p. 22.

\$19 Buxbaum (1993, Pp. 708-709).
} 
Vanuit een netwerkbenadering kan worden geconstateerd dat het aantal actoren zeer groot is. Indien onderzocht wordt wat de doeleinden zijn van een overheidsinstelling en wat de "performance" is gaat het ons om doeleinden van het netwerk. Het gaat ons derhalve om de actoren die een beleid voeren of trachten te voeren en die ook in staat zijn invloed uit te oefenen op de doelen van de overheidsinstelling. Peirce geeft aan dat de doelen van een overheidsinstelling onderscheiden kunnen worden in een drietal categorieën. Naast het doel van het voortbestaan van de organisatie zijn de doelen van de werknemers en die van de principalen van belang. ${ }^{320}$ Teneinde het onderzoek zo concreet mogelijk te maken is een criterium nodig om het aantal relevante actoren in te perken. Bij de definiëring van overheidsinstellingen hebben we gezien dat deze van particuliere bedrijven verschillen met betrekking tot het houderschap van de eigendomsrechten. De verdeling van deze eigendomsrechten binnen het netwerk wordt dan ook gebruikt om het aantal actoren te beperken. De netwerkbenadering is van belang omdat zij duidelijk maakt dat niet alleen de actoren binnen de overheidsinstelling voor het onderzoek naar het gedrag en de "performance" relevant zijn. Het gaat om alle dragers van eigendomsrechten binnen het gehele externe netwerk.

\subsection{Conclusie}

In dit hoofdstuk is een netwerkmodel geïntroduceerd. Overheidsinstellingen moeten worden gezien als netwerken van actoren. Teneinde het gedrag en de "performance" te kunnen verklaren is het $\mathrm{nu}$ van belang dit model verder uit te werken. Het is belangrijk hierbij steeds te bedenken dat een institutionele analyse wordt gevolgd.

520 Peirce (1981, p. 10). 



\section{Hoofdstuk 7. Welke actoren bepalen de doelen van het netwerk?}

\subsection{Inleiding}

In dit hoofdstuk zal worden ingegaan op de vraag welke actoren binnen het netwerk van belang zijn. Daartoe zal in het kader van de eigendomsrechtenbenadering worden ingegaan op de vraag welke actoren binnen het netwerk invloed kunnen uitoefenen op de doelen en op het besluitvormingsproces.

\subsection{Wat houdt de eigendomsrechtenbenadering in?}

Zoals in het vorige hoofdstuk reeds is opgemerkt is het aantal actoren in een overheidsinstelling, beschouwd als netwerk, zeer groot. Teneinde het gedrag van een overheidsinstelling in de praktijk te verklaren dient een selectie gemaakt te worden van de voor het gedrag van de instelling relevante actoren. Hiertoe kan gebruik gemaakt worden van de eigendomsrechtenbenadering. Deze benadering is goed in te passen in de netwerkbenadering. Evenals bij de netwerkbenadering staat ook bij de eigendomsrechtenbenadering niet meer de organisatie centraal. Het gaat veel meer om individuen die hun eigen belangen nastreven, gegeven de beperkingen van de bestaande organisatie en eigendomsrechtenstructuur. ${ }^{321}$ In de nutsfunctie van individuen is ook het nut dat ontleend wordt aan goederen als bijvoorbeeld vrije tijd en aantrekkelijk werk opgenomen. Vooruitlopend op de transacties binnen het netwerk, zoals die in hoofdstuk 11 aan de orde komen, kan worden opgemerkt dat de verdeling van eigendomsrechten en het bestaan van transactiekosten samenhangen. Coase stelt dat indien er geen transactiekosten zijn de verdeling van eigendomsrechten geen invloed heeft op de allocatie. ${ }^{322}$ Indien er wel positieve transactiekosten zijn leidt een bepaalde verdeling van eigendomsrechten tot andere transacties dan een andere verdeling van eigendomsrechten.

De eigendomsrechtentheorie gaat verder uit van het methodologisch individualisme. Hieraan liggen een tweetal veronderstellingen ten grondslag. In de eerste plaats wordt verondersteld dat alle activiteiten betekenisvol zijn en doelgericht. Individuen zijn volledig dan wel beperkt rationeel en proberen hun mit te maximaliseren. Hierbij gaat het niet alleen om het nut dat ontleend wordt aan het goed zelf zoals in de neo-klassieke theorie maar ook om het nut dat ontleend wordt aan de verschillende gebruiksmogelijkheden van het goed. Daarnaast wordt verondersteld dat alle activiteiten kunnen worden verklaard als resultaat van individueel doelgerichte acties. Dit concept verandert miet door de integratie van deze theorie in een netwerkbenadering. Individuen streven binnen het netwerk naar "satisficing". In de kern komt het erop neer dat de politieke eigenaar (eigenaren) en de managers op grond van hun doelfunctie een afweging maken van de baten van het nastreven van eigen doelen en ondernemingsdoelen en van de daarbij behorende kosten. Deze benadering van overheidsinstellingen kan in een figuur als volgt worden voorgesteld:

\footnotetext{
321 Furubotn en Pejovich (1972, p. 1137).

Coase $(1960$, pp. 1-44)
} 


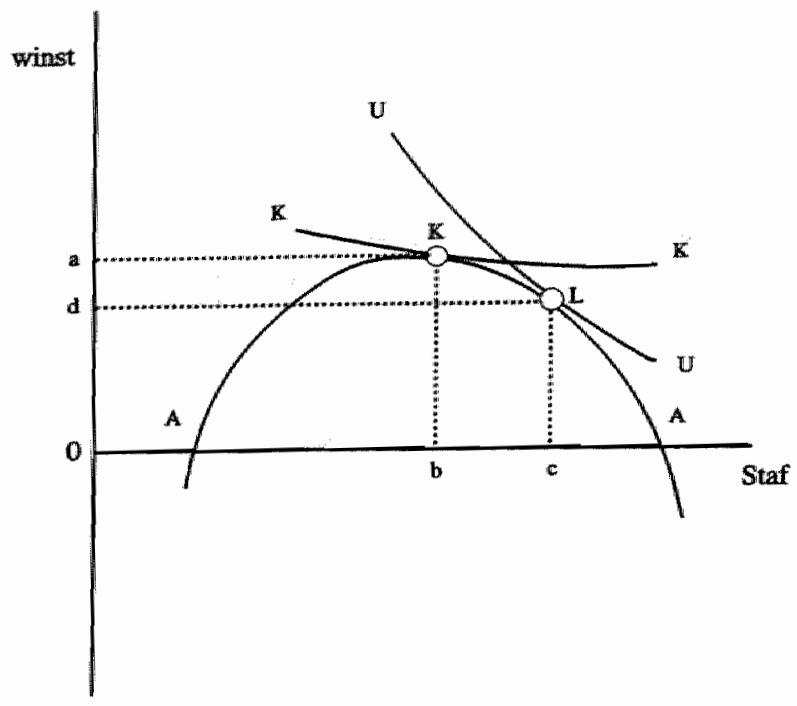

Figuur 7.1 De eigendomsrechtenbenadering toegepast op een overheidsinstelling ${ }^{323}$

De politieke eigenaren (indifferentiecurve $\mathrm{K}$ ) en het management (indifferentiecurve $\mathrm{U}$ ) proberen op grond van hun nutsfunctie hun nut te maximaliseren gegeven de restrictie van de "opportunity set" AKLA. In tegenstelling tot de aandeellhouders van een private onderneming streven de eigenaren van een overheidsinstelling niet zozeer naar maximalisatie van de waarde van de onderneming maar naar allerlei bijkomende doelen, gegeven een bepaald winstniveau. Ook de managers streven naar bepaalde bijkomende doelen, waaronder bijvoorbeeld de omvang van de staf, gegeven een bepaalde winst. De mate waarin zowel de politieke eigenaren als de managers bijkomende doelen en winst nastreven hangt af van de afweging van de baten van beide tegen de kosten.

Duidelijk is dat de doelen van beide groepen actoren verschillen. De politieke actoren leggen hier meer de nadruk op winst dan de managers. Belangrijk is dat er niet één politieke eigenaar is maar dat er tal van actoren zijn die over eigendomsrechten kunnen beschikken, met name indien het eigendomsrecht sterk gespreid is. Ook de doelfuncties van de verschillende actoren zullen verschillen. In de praktijk zullen er evenveel doelfuncties als politieke eigenaren en managers zijn. De vraag rijst welke uitkomst nu bereikt wordt. Dit hangt voor een belangrijk deel af van de institutionele structuur. Zoals zal worden uitgewerkt worden in een klassiek kapitalistische onderneming de doelen van de eigenaar nagestreefd. In een overheidsinstelling/netwerk hangt dit af van de verdeling van eigendomsrechten over de diverse actoren. In het navolgende wordt op de verschillende eigendomsrechten in een klassieke onderneming ingegaan en wordt een aantal verschillen aangegeven met overheidsinstellingen, teneinde een aantal gedragsverschillen van een overheidsinstelling/nerwerk te kunnen analyseren.

\section{Eigendomsrechten}

Aan economische goederen zijn verschillende categorieën eigendomsrechten verbonden

323 Bewerking van: Furubotn en Pejovich (1972, p. 1152). 
die door verschillende actoren kunnen worden uitgeoefend. De wijze waarop de eigendomsrechten zijn verdeeld beïnvloedt het keuzegedrag van individuen.

De economische theorie van de beschikkingsrechten maakt het mogelijk een aantal "eigendomsrechten" te onderscheiden. Volgens deze benadering wordt onder eigendomsrechten een bundel van beschikkingsrechten verstaan die de eigenaarsrechten, privileges en beperkingen in het gebruik omschrijven. Het hier gebruikte begrip eigendomsrechten moet nadrukkelijk van het juridische begrip worden onderscheiden. ${ }^{324}$ Het is van groot belang zich te realiseren dat economen onder eigendomsrechten alle bevoegdheden begrijpen. ${ }^{325}$ Een belastinginspecteur die de bevoegdheid heeft een aanslag op te leggen beschikt met betrekking tot die bevoegdheid over een eigendomsrecht. De bevoegdheid is overdraagbaar en anderen kunnen van het gebruik van die bevoegdheid worden uitgesloten. Belangrijk is dat verschillende eigendomsrechten c.q. bevoegdheden op elkaar inspelen. De belastinginspecteur legt bijvoorbeeld een aanslag op, de burger kan bijvoorbeeld zijn bankrekening opheffen (de bevoegdheid om een bankrekening op te theffen is een eigendomsrecht). Bevoegdheden c.q. eigendomsrechten kunnen worden afgeleid van tall van wettelijke regelingen, bijvoorbeeld veiligheids- en milieuregelingen, arbeidsrechtelijke bepalingen en statuten. Juridische regelingen vormen randvoorwaarden voor het verrichten van economische activiteiten. Dergelijke randvoorwaarden kunnen voortkomen uit alle normatieve regelingen die de economische transacties tussen personen beïnvloeden. Het begrip eigendomsrechten in de zin van de "property rights" theorie moet dan ook ruimer wordien opgevat dan alleen het juridische eigendom. Bij private ondememingen kan ook gedacht worden aan bepalingen die de inbreng van eigenaars en managers bij het besluitvormingsproces van ondernemingen regelen. ${ }^{326}$ Alchian en Demsetz geven aan dat een onderneming bezien vanuit de eigendomsrechtenbenadering kan worden opgevat als een bundel van vijf eigendomsrechten, die in drie groepen kunnen worden onderscheiden: ${ }^{327}$

\section{Groep A. het recht op gebruik van een zaak (usus)}

1.: Controle over inputs en outputs.

2. Controle over de samenstelling van de leden van het productieteam (aannemen en ontslaan).

3. Partij te zijn bij alle contracten over inputs (in de handen van één contracterende agent).

\section{Groep B: het recht op vruchtgebruik (usus fructus)}

4. Aanspraak te maken op de residuele winst nadat alle kosten hiervan zijn afgetrokken

\footnotetext{
324 Künneke, in: Moll en Verbon (1993, p. 36).

325 Backhaus en Nutzinger (eds.) (1982, p. 53).

326 Künneke, in: Mol en Verbon (1993, p. 36), vgll. ook: De Alessi (1969, pp. 16-17).

327 Alchian en Demsetz (1972, pp. 780 e.v.).
} 

(abusus)

5. Het recht de betreffende rechten over te dragen, oftewel het recht om de organisatie te wijzigen, te verkopen of te liquideren

Deze verschillende categorieên beinvloeden elk op een verschillende manier het economische allocatieproces. Zo zal bijvoorbeeld een actor die uitsluitend het recht op gebruik van een zaak heeft weinig geneigd zijn om in het goed te investeren, aangezien hij niet zal profiteren van deze investeringen. ${ }^{328}$

Bij een klassieke onderneming zijn de zeggenschap, het recht op de resuduele inkomsten en het ondermemingsrisico geconcentreerd in de handen van één persoon. Alchian en Demsetz geven aan dat de klassieke onderneming, die door de genoemde bundeling van beschikkingsrechten wordt gekenmerkt, ontstaat indien aan twee noodzakelijke voorwaarden is voldaan:

a. De produktiviteit laat zich door teamproductie verhogen. Dit impliceert dat de individuele bijdragen aan de totale productie niet is te determineren en dat er dientengevolge een meetprobleem bestaat ten aanzien van het bepalen van de individuele marginale produktiviteit van de teamleden.

b. De marginale produktiviteit van de individuele productiefactoren kan het best worden bepaald door het registreren van het inputgedrag en de "performance" van de productiefactoren (inputs).

Indien aan deze twee voorwaarden is voldaan is de kans groot dat een klassieke onderneming ontstaat, die gekenmerkt wordt door deze bundeling van beschikkingsrechten ${ }^{329}$ De reden hiervoor is dat het dan wenselijk is de verschillende inputs in een productieproces samen te voegen. Dit laatste is dan ook de reden waarom de contracten met de inputeigenaren alle in éen hand moeten samenkomen. Het eigendomsrecht van een klassiek kapitalistische onderneming wordt volgens Alchian en Demsetz dan ook gekenmerkt door:

1. De ondernemer beschikt over de genoemde eigendomsrechten.

2. Elke beslisser tracht zijn nut te maximaliseren en gedraagt zich dienovereenkomstig.

3. De vraag naar de produkten van het bedrijf is oneindig elastisch.

4. De kosten van het toezien op het gedrag van de samenwerkende inputs is nul.

In dat geval zall de onderneming streven naar winstmaximalisatie. De samenwerkende inputs (arbeid, kapitaal) menen dat de verwerving van niet-financiële doelen door "shirking" erg kostbaar is. Zij zullen dan ook niet dergelijke goederen/bijkomende doelen verwerven. Ook de eigenalar meent dat het nastreven van niet-financiële doelen voor hem zelf te kostbaar is en zal hier dan ook niet toe overgaan. In de klassiek kapitalistische onderneming heeft één persoon (de "monitor") het recht toe te zien op de "performance" van teamleden terwijl hij zelf geen prikkel heeft over te gaan tot "shirking".

\footnotetext{
${ }^{328}$ Künneke, in: Mol en Verbon (1993, pp. 36-37).

329 Moerland (1997, p. 168).
} 

ce"! van overheidsinstellingen?

Volgens de eigendomsrechtenbenadering wordt het gedrag van overheidsinstellingen voornamelijk bepaald door het ontbreken van private eigendomsrechten, c.q. het bestaan van een incomplete eigendomsrechtenstructuur. ${ }^{330}$ Volgens Alchian en Demsetz ontstaat er door de niet scheidbaarheid van de totale productie van het team, belangrijke problemen ten aanzien van het meten van de prestatie van teamleden en dienovereenkomstig ten aanzien van het bepalen van de beloning. Door de kosten die gemaakt moeten worden om de marginale produktiviteit van de inputs te bepalen is het waarschijnlijk dat deze produktiviteit niet wordt vastgesteld en is er ook geen beloningssysteem overeenkomstig de prestatie mogelijk. Door de afwezigheid van een dergelijk beloningssysteem zal de produktiviteit van de teamleden (samenwerkende inputs) lager zijn dan in principe mogelijk is. Dit zal ook invloed hebben op het gedrag van een overheidsinstelling:

Een ander voorbeeld is dat een bedrijf beschikt over het vruchtgebruik maar niet over het recht om goederen te verbandelen. In dat geval heeft zij geen prikkel om rekening te houden met de toekomstige waarde van het goed, hetgeen de efficiëntie kan verminderen en hetgeen kan leiden tot overexploitatie. Indien het bedrijf aan de andere kant wel recht heeft op het gebruik van een goed, maar niet op de winst, heeft het bedrijf geen prikkel om de winst te verhogen, hetgeen kan leiden tot een technisch inefficiënte wijze van produceren. In die zin richt de eigendomsrechtenbenadering zich vooral op de beperkingen die de overheid oplegt aan een overheidsinstelling. Samenvattend kan gesteld worden dat elke eigendomsrechtenstructuur invloed heeft op het gebruik van hulpbronnen en de uiteindelijke combinatie van geproduceerde goederen en diensten. Elke specifieke eigendomsrechtenstructuur impliceert een andere omvang van de transactiekosten.

In het navolgende worden een aantal verschillen ten aanzien van de eigendomsrechtenstructuur tussen particuliere bedrijven en overheidsinstellingen geanalyseerd en wordt ingegaan op de consequenties daarvan. Niet alleen zijn er verschillen tussen particuliere ondernemingen en overheidsinstellingen. Ook tussen overheidsinstellingen onderling bestaan er belangrijke verschillen. Er kan bijvoorbeeld sprake zijn van een N.V. of van de door Alchian en Demsetz genoemde gereguleerde onderneming, zoals bijvoorbeeld een nutsbedrijf. Dergelijke verschillen in eigendomsrechtenstructuur beinvioeden het gedrag van actoren in het netwerk en daarmee het feitelijke gedrag van de overheidsinstelling. Derhalve zal ook worden ingegaan op de invloed van dergelijke verschillende eigendomsrechtenstructuren binnen overheidsinstellingen.

1. De eigenaren van een particuliere onderneming hebben een prikkel om hun winst te maximaliseren en om te controleren of het management hier ook inderdaad naar streeft. Hierdoor zullen particuliere bedrijven relatief meer gedwongen worden om hun kosten te minimaliseren en om zoveel mogelijk te streven naar innovatie. Bij overheidsinstellingen is het eigendom vaak erg gespreid (dit zal overigens ook bij particuliere ondernemingen vaak voorkomen). De doelen van de eigenaren hoeven niet zo zeer winstmaximalisatie te zijn, maar kunnen ook op andere gebieden liggen. Door de gespreidheid van het eigendom van een overheidsinstelling kan een free rider-effect ontstaan ten aanzien van het controleren van het management. Op grond van een kosten/baten-analyse is het voor iedere actor aantrekkelijk geen kosten te maken en de controle van het management aan andere eigenaren over te Iaten.

Een nadeel van de spreiding van eigendomsrechten is voorts dat de beloning van

${ }^{330}$ Zie: Alchian (1965, pp. 816-829). 
het management duurder wordt. Pejovich geeft aan dat een toename in de consumptie van doelen als vergroting van de staf en dergelijke, inferieur is aan een gelijke stijging van het geldinkomen, omdat een inkomen in geld een grotere reeks keuzemogelijkheden oplevert. ${ }^{331}$ Door de spreiding van het eigendom slaagt bet management er bijvoorbeeld in 1000 gulden aan eigen discretionaire doelen te bereiken, die hem echter slechts 100 gulden waard is. Dit betekent dat er een verlies aan welvaart optreedt. Tegenover dit nadeel van spreiding van eigendomsrechten staat als voordeel dat het mogelijk is dat de produktiviteit hoger wordt. Alchian geeft aan dat een eventuele hogere produktiviteit samenhangt met het: bestaan van interne kapital- en arbeidsmarkten. Het bestaan van dergelijke markten kan leiden tot relatief goedkope informatie. ${ }^{332}$

Op grond van het paradigma van Berle en Means uit 1932 kan er een scheiding tussen eigendom en bestuur optreden indien een groot aantal eigenaren eigendomsrechten verwerven. ${ }^{333}$ Bestuur ("control") heeft in deze betekenis betrekking op de mogelijkheid van een bepaald individu of een groep van individuen om het besluitvormingsproces in een bedrijf te bepalen. Hierbij gaat het met name om de fundamentele beslissingen waaronder bijvoorbeeld de selectie van managers en directeuren. ${ }^{334}$ Eigenaren hevelen om allerlei redenen eigendomsrechten over naar het management. In de empirische literatuur wordt in dit verband wel onderscheid gemaakt tussen door de eigenaar gecontroleerde bedrijven ("ownercontrolled firms" OC) en door het management gecontroleerde bedrijven ("management-controlled firms" $\mathrm{MC}$ ), met als criterium de spreiding van de eigendom. In de literatuur worden allerlei criteria gehanteerd ter onderscheiding van beide soorten ondernemingen. Monsen definieert een door de eigenaar gecontroleerde onderneming bijvoorbeeld als een bedrijf waarvan tenminste $10 \%$ van de aandelen in handen is van étn aandeelhouder en er aanvullend bewijs is van actieve controle of indien één partij eigenaar is van $20 \%$ van de aandelen. Van een manager gecontroleerde onderneming spreekt hij indien geen enkele aandeelhouder meer dan $5 \%$ van de aandelen in handen heeft. ${ }^{335}$ Indien deze benadering gevolgd wordt lijkt op het eerste gezicht een overheidsinstelling vaak een eigenaar gecontroleerde onderneming, aangezien de overheid bijvoorbeeld in de vorm van een provincie, gemeente of een departement veelal meer dan $20 \%$ van de aandelen in handen heeft. Het paradigma lijkt dan niet van toepassing te zijn op een overheidsinstelling. Bedacht moet echter worden, zoals ook is uitgewerkt in het vorige hoofdstuk, dat de overheid niet gezien moet worden alls é̂n afzonderlijke actor. Bimnen de overheid zijn er tal van actoren en derhalve tal van eigenaren waardoor een overheidsinstelling gezien moet worden als een door het management gecontroleerde onderneming. ${ }^{336}$ Indien het eigendom meer gespreid is kan er een "free rider" effect ontstaan ten aanzien van het controleren van het management. Het

331 Pejovich, in: Furubarn en Pejovich (1974, pp. 146-150).

332. Alchisn, in: Manne et al. (1969).

${ }^{333}$ Berle en Means (1982, pp. 48 e.v. en pp. 352-357).

334 Leech en Leahy (1991, pp. 1423-1428).

33. Monsen, Chiu en Cooley (1968, pp. 435-451).

336 Vergelijk ook paragraaf 10.2, het bureaucratiemodel van Niskanen. Zie ook: Steuneaberg (1996, pp. 309
e.v.). 
management verkrijgt meer zelfstandigheid, hetgeen kan leiden tot lagere efficientie, met name indien tegenover de vergrote bevoegdheden van het management geen grotere verantwoordelijkheid staat. Daarnaast kunnen verschillende eigenaren verschillende opvattingen over de doelen van een overheidsinstelling hebben (heterogene preferenties). Indien geen van de eigenaren in staat is zijn wil op te leggen moet er onderhandeld worden. Dit zal leiden tot compromissen en kan leiden tot meer discretionaire vrijheid voor het management, dat daarmee in de voorbereiding en uitvoering rekening zal houden. Overigens is het niet per definitie zo dat de "monitoring" van een overheidsinstelling minder zall zijn in verband met de spreiding van het eigendom. Wagner merkt op dat het mogelijk is dat een politieke actor teneinde herkozen te worden, de taak op zich neemt om een overheidsinstelling te controleren. ${ }^{337}$ In het geval van particuliere ondernemingen wordt door sommigen, waaronder bijvoorbeeld Fama, wel gesteld dat mamagers door de aanwezigheid van allerlei disciplinerende mechanismen ervan zullen worden weerhouden om acties te ondernemen die niet in het belang zijn van de aandeelhouders. ${ }^{33}$ Hierbij kan gedacht worden aan het gevaar van faillissement, de dreiging van een overmame en de mededinging op de arbeidsmarkt voor managers. Fama meent dat de mededinging op de arbeidsmarkt voor managers bijvoorbeeld een rem vormt op het mastreven van eigen doelen door het management. Duidelijk is dat dergelijke disciplinerende mechanismen bij overheidsinstellingen veel minder een rol spelen.

2. Aandelen in overheidsinstellingen worden in de praktijk, afgezien van privatisering, niet verhandeld. Overdraagbararheid van aandelen $\mathrm{kan}$ ertoe leiden dat bedrijven efficiënt geleid worden. Door overname van een slecht geleid bedrijf en vervanging van het management heeft een overnemend bedrijf de mogelijkheid vermogenswinst te boeken. ${ }^{339}$ De Alesssi benadrukt dat de niet-overdraagbaarheid van eigendom van overheidsinstellingen ertoe leidt dat individuen zich niet kunnen specialiseren op deze actiwiteit. ${ }^{340}$ Hierdoor hebben zij weinig prikkels om de "performance". van een overheidsinstelling te controleren. Dit leidt ertoe dat de grenzen die gesteld worden aan de groei van de discretionaire bevoegdheden van het management beperkt zijn en in elk geval minder stringent zullen zijn dan bij particuliere bedrijven. Gegeven deze grotere discretionaire bevoegdheden en de veronderstelling dat managers in bedrijven nut ontlenen aan het controleren van de hulpbronnen zal het management geneigd zijn zijn uitgaven te vergroten. ${ }^{341}$

Alchian geeft aan dat het transfereren van eigendomsrechten in publieke organisaties op zich wel mogelijk is maar relatief meer kosten met zich meebrengt. In het geval van particuliere organisaties kan de portefeuille van eigendomsrechten (aandelen en dergelijke) relatief eenwoudig worden gewijzigd. In een publieke organisatie is de verandering van eigendomsrechten moeilijker door te voeren. Dit kan slechts gerealiseerd worden door een wijziging van de structuur van een organisatie, de wijziging van de inhoud van een functie of doordat het individu in de organisatie een andere functie aameemt. Voorts is de controle op de inputs

\footnotetext{
337 Wagner, in: Tullock (ed.) (1966, pp. 161-170).

3is Fama (1980, 88, pp. 292-296).

399 Vogeisang $(1990$, p. 55$)$.

340 De Allessi (1969, p. 22),

34: De Alessi (1973, pp. 64-81).
} 
veelal minder en is het vaak ook minder duidelijk wie aanspraak kan maken op de winst.

3. Op zich zijn faillissementen van overheidsinstellingen altijd mogelijk geweest. Slechts in uitzonderingsgevallen is de overheid op grond van de statuten of de wet verplicht een faillissement van een overheidsinstelling te voorkomen. Desalniettemin gaan overheidsinstellingen in de praktijk niet of slechts zelden failliet. Het management en de werknemers lopen daardoor relatief minder risico hun baan te verliezen indien de overheidsinstelling slecht presteert. Dit heeft als gevolg dat het management en de werknemers meer gelegenheid hebben om eigen doelen na te streven, waardoor de technische efficiëntie kan verminderen.

4. Een vierde belangrijk verschil betreft het recht op vruchtgebruik Overheidsinstellingen mogen lang niet altijd zelfstandig beschikken over hun vermogen. De centrale vraag luidt in hoeverre winsten aan de publiekrechtelijke eigenaar moeten worden afgedragen. Indien de winst moet worden afgedragen kan dat ertoe leiden dat de bedrijfsvoering minder efficiënt is. Bedrijven hebben in dat geval geen belang bij het verhogen van de winst en het verlagen van de kosten.

Künneke bepleit dan ook de exploitatiewinsten geheel of gedeeltelijk binnen het bedrijf te reserveren. Indien de eigenaar op deze wijze het recht van vruchtgebruik en eventueel ook het gebruiksrecht overdraagt, kan hij worden aangeduid als de zogenaamde "dispossessed owner". ${ }^{342}$ De agent die nu het recht van vruchtgebruik krijgt overgedragen, veelal het management van de overheidsinstelling, kan dan worden aangeduid als de vruchtgebruiker. De overheidsinstelling is dan zelf verantwoordelijk voor eventuele tekorten en voor het voortbestaan van de instelling. Dit levert een prikkel op om zonder inmenging van de publiekrechtelijke eigenaren een zekere mate van efficiëntie te realiseren, De efficiëntie zou het meest worden gestimuleerd indien een overheidsinstelling een onbeperkt recht heeft op het eigen vermogen. In de praktijk is het recht op de winst en het eigen vermogen veelal aan beperkingen onderhevig.

5. In het kader van het abusus gebruiksrecht moet de vraag worden gesteld in hoeverre een overheidsinstelling zelf bevoegd is kapitaalgoederen en andere goederen te verhandelen. Indien dit alleen mogelijk is via de Dienst der Domeinen zal de opbrengst van deze goederen toekomen aan de overheid. Toekenning van dit recht kan de efficiëntie verhogen, omdat in dat geval het bedrijf een prikkel heeft om de opbrengst uit het gebruilk van kapitaalgoederen af te wegen tegen de opbrengst bij verkoop. Indien economische actoren dit recht hebben zullen zij niet alleen rekening houden met de huidige maar ook met de toekomstige opbrengsten en kosten, omdat zij deze door verkoop kunnen kapitaliseren. Het leidt ertoe dat economische actoren ook de efficiëntie op lange termijn zullen nastreven. Indien zij het betreffende recht niet hebben zullen individuen geneigd zijn hun winst op de korte termijn te maximaliseren door hoge exploitatie van de goederen.

Een ander facet van dit recht is de mogelijkheid om zelfstandig vreemd vermogen aan te trekken op de kapitaalmarkt. Volgens Künneke kan deze bevoegdheid de efficiëntie van een overheidsinstelling vergroten. ${ }^{343}$ Een overheidsinstelling die

\footnotetext{
${ }^{342}$ Minkler $(1989, \mathrm{P}, 343)$.

343. Künmeke, in: Mol en Verbon (1993, p. 40).
} 
zelfstandig zonder garantieverlening door een publiekrechtelijke instelling leent op de kapitaalmarkt, geeft kređietverstrekkers delen van de onderneming in onderpand. Dit impliceert een wijziging van de eigendomsrechtenstructuur van een overheidsinstelling. Indien particuliere bedrijven leningen aangaan dienen zij een vergoeding over het geleende vermogen te betalen. Doen zij dit niet dan bestaat de mogelijkheid van een faillissement. Kredietverleners zien toe op de efficièntie van het bedrijf. Indien de prestaties van het bedrijf tegenvallen is het mogelijk dat leningen worden ingetrokken, hetgeen voor bedrijven die lenen op de kapitaalmarkt een prikkel kan zijn de efficiëntie te vergroten. Hetzelfde geldat voor overheidsinstellingen die zelfstandig en zonder garantieverlening door publiekrechtelijke instanties vreemd vermogen kunnen aantrekken, zij het dat overheidsinstellingen in de praktijk niet failliet zullen gaan. Overheidsinstellingen die geen bevoegdheid hebben zelfstandig te lenen op de kapitaalmarkt zijn aangewezen op verstrekking door publiekrechtelijke instellingen. In de praktijk kijken deze instellingen niet alleen naar de winstgevendheid maar ook naar bijkomende doelen als werkgelegenheid en herverdeling van inkomen. De technische inefficiëntie is dan het gevolg van het gebrek aan controle door kredietverstrekkers en de nadruk op bijkomende doelen van publiekrechtelijke instanties.

Op grond van de eigendomsrechtenbenadering wordt vaak gesteld dat de (klassieke) particuliere onderneming, gegeven de bundeling van beschikkingsrechten, technisch efficiënt is terwijl overheidsinstellingen in verband met de afwijkende eigendomsrechtenstructuur minder efficiënt zijn. Geillustreerd met Figuur 7.1 betekent dit dat niet het punt van maximale winst $(K)$ bereikt wordt, maar bijvoorbeeld punt $L$. In dat geval is er sprake van een gederfde winst ter grootte van oppervlakte DLOC - oppervlakte OBAK. Vogelsang wijst erop dat de efficiëntie van overheidsinstellingen door allerlei factoren kan meevallen ${ }^{344}$ Hij wijst bijvoorbeeld op de mogelijkheid dat er verschillende overheidsbedrijven en/of bureaus bestaan die met elkaar concurreren om de beschikbare financiële middelen, hetgeen de efficiëntie kan verbeteren. Verder wijst hij erop dat managers in overheidsinstellingen doelen kunnen hebben als prestige en filantropie, hetgeen eveneens zou kunnen leiden tot efficiënt gedrag van een overheidsinstelling. Wagner stelt dat het mogelijk is dat een politicus de taak van het controleren van een overheidsinstelling op zich kan nemen om herkozen te worden. ${ }^{345}$

Naast de redenen waarom overheidsinstellingen relatief mogelijk meer efficiënt zijn dan vaak wordt verwacht, noemt Vogelsang een aantal redenen waarom particuliere bedrijven wellicht minder efficięnt zijn dan vaak wordt aangenomen. Met betrekking tot overheidsinstellingen werd opgemerkt dat de spreiding van eigendomsrechten over tal van actoren kan leiden tot een vermindering van de "monitoring"' van een overheidsinstellingen. Ook ten aanzien van particuliere ondernemingen met veel aandeelhouders kan zich een dergelijke spreiding voordoen, hetgeen eveneens kan leiden tot de genoemde "free rider"-effecten. In punt 2 werd gesteld dat in het geval van particuliere ondernemingen de mogelijkheid van overname er toe kan leiden dat de efficiëntie toeneemt. Vogelsang wijst erop dat dit in de praktijk tegen kan vallen aangezien enerzijds financiële markten kosten met zich meebrengen en anderzijds de bestaande aandeelhouders de overname kunnen zien

\footnotetext{
344 Vogelsang (1990, p. 56).

34S Wagner (1966, pp. 167-169).
} 
als een signaal van beter management in de toekomst. ${ }^{346} \mathrm{Zij}$ zullen dan ook hun aandelen niet verkopen tenzili de prijs van deze aandelen de hogere verwachte waarde van de inkomsten weerspiegelt. Ten aanzien van het argument dat overheidsinstellingen in de praktijk niet failliet gaan is wel opgemerkt dat ook grote bedrijven niet snel failliet zullen gaan, bijwoorbeeld omdat ze van groot belang zijn voor de economie van een land en de overheid zich geroepen zal voelen eventueel het bedrijf te subsidiëren.

Tenslotte zijn de resultaten van empirisch onderzoek naar de effecten van de eigendomsrechtenstructuur op de "performance" van een bedrijf niet eenduidig en leveren niet een duidelijke conclusie op. Veel studies wijzen er op dat door de eigenaar gecontroleerde bedrijven een hogere winst hebben dan door het management gecontroleerde bedrijven. De resultaten van deze onderzoeken zijn evenwel vaak niet statistisch significant ${ }^{347}$ Voorts zijn er veel onderzoeken die wijzen op een grotere winstgevendheid van door het management gecontroleerde bedrijven. ${ }^{348}$ Meer recente onderzoeken hebben gebruik gemaakt van continue variabelen als maatstaven voor aandeelhouderconcentratie. ${ }^{349}$ Veel onderzoeken gingen er vanuit dat de concentratie van aandeelhouders op een lineaire rechtstreekse wijze invloed heeft op de "performance" van een bedrijf. Verschillende onderzoeken weerspreken deze veronderstelling, waaronder het onderzoek van Morck et al. waarbij Tobin's q als indicator voor de "performance" wordt gehanteerd en het percentage van de aandelen in handen van de directie als een indicator voor de eigendom wordt genomen. $\mathrm{Zij}$ constateren dat het verband tussen eigendom en "performance" nietlineair is. ${ }^{350}$ Dit komt door een combinatie van factoren. Enerzijds stemt dit overeen met de benadering van Jensen en Meckling dat naarmate het eigendom van een manager toeneemt de "performance" toeneemt aangezien managers in dat geval meer geneigd zullen zijn om te streven naar maximalisatie van de waarde van de onderneming. Dit laat zich anderzijds combineren met de benadering van Demsetz. ${ }^{351}$ Hij meent dat de disciplinerende werking van de markt er voor zal zorgen dat managers naar maximalisatie van de winst van de onderneming zullen streven ook al beschikken zij over een zeer beperkt deel van de eigendomsrechten. Indien managers daarentegen over een belangrijk deel van de eigendomsrechten beschikken kan dit de controle door andere eigenaren juist bemoeilijken, waardoor de "performance" negatief in plaats van positief beïnvloed wordt (hetgeen slechts gedeeltelijk overeenkomt met de benadering van Morck, Schleifer en Vishing). Hoewel managers bij overheidsinstellingen zelden over aandelen in de instelling zullen beschikken zullen zij wel over bepaalde eigendomsrechten beschikken. In die zin is dit soort onderzoek ook relevant voor overheidsinstellingen.

Overigens zijn niet alleen verschillen in eigendomsrechten binnen de overheidsinstelling van belang. Owen en Braeutigum stellen dat burgers in een democratie het recht hebben administratieve acties langs juridische weg aan te vechten. Toegepast op overheidsinstel-

\footnotetext{
346 Vogelsang $(1990$, p. 56).

347 Zie bijvoorbeeld: Holl (1975, pp. 257-262).

348 Zie ook: Ware (1975, pp. 81-95) en woorts Thonet en Poensgen (1979, pp. 25-29).

3*t Leech en Leahy (1991, p. 1419).

36\% Morck, Schleifer en Vishing (1988, pp. 311-314). Zij vinden dat er een positieve verhouding is tussen management en eigendom en performance bij $0-5 \%$ eigendom, een negatief verband er bovendien minder duidelijk bij 5-25\% eigendom in handen van het management en een positief maar eveneens minder duidelijk verband bij een eigendom in handen van het management van meer dan $25 \%$.
}

35il. Demsetz (1983, pp. 378-381). 
lingen betekent dit dat overheidsinstellingen die activiteiten verrichten die onderworpen zijn aan dergelijke procesregels minder snel op verandering zullen inspelen dan particuliere bedrijven of overheidsinstellingen die activiteiten verrichten die minder aan dit soort procesrecht zijn onderworpen. Dit kan een reden zijn waarom overheidsinstellingen minder flexibel zijn dan particuliere bedrijven. Het maakt in dit verband ook uit hoe een overheidsinstelling juridisch is vorm gegeven. Een overheidsinstelling die deel uitmaakt van een departement is aan andere regels onderworpen dan een overheidsinstelling in de NV-vorm, die aan dezelfde regels onderworpen zal zijn als particuliere bedrijven. De verwachting is dat er minder interventie zal zijn met overheidsinstellingen die opereren in dynamische markten, die gekenmerkt worden door onder andere snel fluctuerende vraag en "hoge sunk costs". Indien die interventie er wel is door de publiekrechtelijke eigenaar zullen deze bedrijven minder efficiënt zijn.

\subsection{Hoe verhoudt de verdeling van eigendomsrechten in een netwerk zich met het machtsvraagstuk uit de organisatietheorie?}

De organisatietheorie heeft zich in het verleden voornamelijk beziggehouden met de interne organisatie. Williamson stelt: "The preoccupation of organization theory specialists with internal organization is a potentially useful corrective", in die zin dat de organisatietheorie een aanvulling zou kunnen zijn op de neo-klassieke benadering waarbij het bedrijf wordt opgevat als een productiefunctie en waarbij aan hiërarchische verhoudingen geen aandacht wordt besteed. ${ }^{352}$ Williamson noemt als én van de redenen waarom de organisatietheorie slechts in beperkte mate heeft bijgedragen aan de economische theorievorming, dat zij weinig aandacht besteedt aan efficiëntie-analyse en veel meer de nadruk legt op het machtsvraagstuk. Desalniettemin kan dit onderdeel van de organisatietheorie geïntegreerd worden in een theorie van overheidsinstellingen.

Er bestaat namelijk een verband tussen de economische theorie van de verdeling van eigendomsrechten in organisaties en het uit de organisatiekunde en -sociologie bekende vraagstuk van macht van actoren in een organisatie. In de organisatiekunde wordt van macht gesproken indien een actor voor het bereiken van een bepaald doel is aangewezen op andere actoren of groepen van actoren in de organisatie. ${ }^{353}$ Macht kan verkregen worden door enerzijds het in bezit krijgen van middelen, anderzijds het effectief inzetten van die middelen in ruilrelaties en voorts door het vormen van coalities om eigen doelen te bereiken en om het realiseren van gewenste uitkomsten voor anderen te verkleinen.

Met betrekking tot de machtsbronnen kan een onderscheid worden gemaakt tussen positiemacht en legitieme macht. Van positiemacht is sprake indien degene die een formele rechtspositie in de organisatie bekleedt het recht heeft bepaalde dingen van andere actoren te vragen. ${ }^{354}$ Positiemacht heeft een drietal aspecten die van invloed zijn op de hoeveelheid macht. In de eerste plaats heeft de positie invloed op de mate waarin de actor toegang heeft tot informatie. De toegankelijkheid van informatie en personen voor een actor bepalen voor een groot deel de invloed die een actor kan uitoefenen op beslissingen die op verschillende plaatsen en verschillende niveaus in de organisatie genomen worden. Daarnaast brengt het bekleden van een bepaalde positie bepaalde bevoegdheden c.q. eigendomsrechten met zich mee. Ten derde hebben de aard van de positie en de bijbeho-

35I Williamson (1981, p. 1539).

353 Veen $(1992$, p. 147).

T.a.p., p. 155. 
rende bevoegdheden invloed op de mate van vrijheid en zelfstandigheid waarmee bepaalde zaken afgehandeld kunnen worden en op de mate waarin een actor zelf initiatieven kan nemen.

De positiemacht kan worden ondersteund door door de leden van de organisatie aanvaarde regels. In dat geval is er sprake van legitieme macht. ${ }^{355}$ Ook deze regels kunnen bepaalde eigendomsrechten impliceren. Uit het voorgaande kan worden opgemaakt dat de eigendomsrechten als één van de machtsbromen kunnen worden aangemerkt. De totale hoeveelheid macht in een organisatie is overigens niet absolunt. ${ }^{356}$ Indien de invloed van het uitvoerend personeel groeit hoeft dit niet altijd ten koste te gaan van de invloed van toezichthoudende actoren. Indien de wederzijdse afhankelijkheid van actoren in een organisatie toeneemt neemt ook de totale macht toe.

In dit verband wordt in de sociologie veelal gewezen op het verschil tussen de officiele en inofficiële hiërarchie, mede omdat het aangeeft dat een organisatie niet zozeer als een mechanisch alswel als een natuurlijk systeem moet worden opgevat. Dit impliceert dat het mogelijk is dat personen in een organisatie een bepaalde macht hebben los van de officiele hiërarchie en derhalve wellicht invloed kunnen uitoefenen op de doelen. Dalton geeft bijvoorbeeld aan dat het mogelijk is dat managers aan de top nauwelijks macht hebben terwijl mensen drie of vier niveaus lager over aanzienlijke macht beschikken. ${ }^{357}$ Voor zover een persoon op grond van deze macht beschikt over bepaalde bevoegdheden kan ook in dit geval gesproken worden van eigendomsrechten. Uit de verdeling van macht en eigendomsrechten in een organisatie kumen vervolgens doelen worden afgeleid.

De actoren die beschikken over bepaalde machtsbromnen zullen proberen de opvatting, de gevoelens en/of het gedrag van andere actoren zodanig te beinvloeden dat hun doelen zoveel mogelijk worden gerealiseerd. Daartoe zullen zij diverse machtsmiddelen gebruiken, zoals economische middelen waaronder geld, goederen en diensten en informationele middelen. Door het bezit van bepaalde informatie kan het gedrag van andere actoren beinvloed worden. Voorts kan gedacht worden aan deskundigheidsmiddelen, meer in het bijzonder aan het beschikken over specifieke deskundigheden waardoor informatie verwerkt en gebruikt kan worden.

Tenslotte zal de macht waarover een actor beschikt gebruikt worden. De machtsmiddelen worden ingezet. In de literatuur kunnen een tweetal dimensies van machtsgebruik worden onderscheiden. ${ }^{358}$ De eerste dimensie is de mate van rationaliteit. Machtsgebruik is meer rationeel naarmate meer gebruik gemaakt wordt van argumenten en meer gestreefd wordt naar oplossingen die voor de verschillende actoren bevredigend zijn. De tweede dimensie heeft betrekking op de mate waarin sprake is van expliciet machtsgebruik, oftewel de mate waarin openlijk gebruik gemaakt wordt van macht. Machtsgebruik is meer expliciet indien belangentegenstellingen duidelijker zijn. Op grond van beide dimensies zijn een viertal strategieën van machtsgebruik mogelijk. Eén en ander kan in een schema worden weergegeven.

\footnotetext{
13ss T.a.P., p. 156

356 Tannenbaum (et al.) (1974, pp. 218-219).

357 Dalton (1959, Hoofdstuk 2).

${ }^{338}$ Falbo (1977).
} 


\begin{tabular}{|c|c|c|}
\hline $\begin{array}{l}\text { Beinvloeding } \\
\text { Machtsgebruik }\end{array}$ & Rationeel & Niet-rationeel \\
\hline Expliciet & $\begin{array}{l}\text { Probleem-oplossende benade- } \\
\text { ring }\end{array}$ & $\begin{array}{l}\text { Confronterende } \\
\text { benadering }\end{array}$ \\
\hline Irmpliciet & $\begin{array}{l}\text { Situationeel- } \\
\text { manipulatieve } \\
\text { benadering }\end{array}$ & $\begin{array}{l}\text { Psychologisch- } \\
\text { manipulatieve } \\
\text { benadering }\end{array}$ \\
\hline
\end{tabular}

Tabel 7.1: Machtsgebruikstrategieën binnen een netwerk

Een actor kan in de eerste plaats proberen om zijn doelen te bereiken op een probleemoplossende wijze. Het machtsgebruik is dan rationeel en expliciet en gericht op het zoveel mogelijk bereiken van een voor ieder bevredigende oplossing. Ook is het mogelijk dat een actor juist veelmeer een situationeel manipulatieve benadering volgt. Een actor probeert dan op een min of meer verborgen wijze tot voor iedereen acceptabele oplossingen te komen. Indien een actor een psychologisch manipulatieve benadering volgt probeert hij heimelijk voordelen te behalen ten koste van een ander. Tenslotte kan een actor door middel van een confronterende benadering op een open wijze zoveel mogelijk van zijn eigen doelen proberen te behalen. Ook combinaties van deze strategieën zijn mogelijk. Uit onderzoek blijkt dat actoren zoveel mogelijk een rationele strategie volgen. ${ }^{359}$

Deze uiteenzetting over de verhouding tussen macht en eigendomsrechten heeft een aantal belangrijke consequenties. Eigendomsrechten zijn één van de machtsbronnen waarover actoren kunnen beschikken. Indien uitgegaan wordt van een ruime opvatting van eigendomsrechten kunnen eventueel alle machtsbronnen waaraan bevoegdheden kunnen worden ontleend tot de eigendomsrechten worden gerekend. Verder geldt dat actoren verschillende strategieën hebben om hun macht te gebruiken voor het realiseren van doelen. Het bezit van machtsbronnen/eigendomsrechten alleen is dan ook niet doorslaggevend. Moene stelt: "The allocation of formal decision-making power does not necessarily identify the real influence on decision making ${ }{ }^{360}$

Afhankelijk van een combinatie van machtsbronnen c.q. eigendomsrechten (als machtsbron kan ook de toegang tot informatie beschouwd worden en derhalve ook het voorkomen van asymmetrische informatie), de beschikking over en de inzet van machtsmiddelen en de wijze van machtsgebruik slagen actoren erin hun doelen te bereiken.

Hierbij dient bedacht te worden dat een actor die een bepaald eigendomsrecht heeft er niet altijd in zal slagen zijn doelen te bereiken. Er zijn allerlei redenen waarom dit het geval kan zijn, bijwoorbeeld:

* De aanwezigheid van verschillende machtsmiddelen, deskundigheid en het voorkomen van asymmetrische informatie.

* De machtsgebruikstrategie die een actor hanteert. Indien een actor bijvoorbeeld altijd geneigd is toe te geven zal hij er ondanks zijn hulpbronnen niet in slagen zijn doelen te bereiken.

* Besluitvormingsproces: een actor met veel machtsbronnen kan er bijvoorbeeld toch niet in slagen de agenda te bepalen. Het is waarschijnlijk dat met name kleinere actoren hiermee geconfronteerd zullen worden.

25s Patchen (1974, p. 216).

360 Moene (1986, p. 336). 
Op deze factoren wordt in de volgende hoofdstukken dieper ingegaan.

\subsection{Conclusie}

In het voorgaande is aangegeven dat een overheidsinstelling bestaat uit tal van actoren. Omdat het aantal actoren zeer groot is, is dit aantal beperkt tot die actoren die dragers zijn van eigendomsrechten. De nadruk lag hierbij op de structuur van een overheidsinstelling. Teneinde de "performance" van de onderneming te schatten is het verder van belang de doelen van de overheidsinstelling te kennen. De doelen van een overheidsinstelling worden bepaald door de eigenaren van de onderneming, namelijk de houders van de eigendomsrechten binnen het netwerk, die zoals in het voorgaande is aangegeven en in het volgende hoofdstuk verder zal worden uitgewerkt, streven naar "satisficing". In het volgende hoofdstuk wordt verder ingegaan op de besluitvorming binnen overheidsinstellingen. Daarbij wordt er van uitgegaan dat de interactie tussen tal van houders van eigendomsrechten leidt tot een bepaalde realisatie van de doelen. 


\section{Hoofdstuk 8. Hoe ziet het besluitvormingsproces binnen het netwerk eruit?}

\subsection{Inleiding}

In hoofdstuk 6 is, uitgaande van een "public choice"-benadering, een overheidsinstelling voorgesteld als een netwerk van een groot aantal actoren. ${ }^{361}$ Dit grote aantal actoren is vervolgens in hoofdstuk 6 beperkt tot de voor het onderzoek meest relevante actoren. Als selectiecriterium werd de theorie van de eigendomsrechten gebruikt. ${ }^{362}$ Op grond van deze redenering werden alleen die actoren die dragers zijn van eigendomsrechten (dat wil zeggen bepaalde bevoegdheden hebben) geselecteerd. Verder is uiteengezet dat actoren met behulp van deze eigendomsrechten en uitgaande van bepaalde strategieën hun doelen trachten te realiseren. Voorts geldt dat het machtsgebruik door deze actoren plaatsvindt in een besluitvormingsproces. In dit hoofdstuk wordt hier dan ook verder op ingegaan. In het besluitvormingsproces vinden onderhandelingen plaats tussen actoren die allen binnen het netwerk in een afhankelijkheidsrelatie verkeren. Binnen netwerken kunnen afhankelijk van de besluitvormingscontext zeer verschillende besluitvormingsprocessen onderscheiden worden. De vraag met het oog op het verklaren van de "performance" is nu welke besluitvormingsprocessen binnen een bepaald netwerk zich vooral zullen voordoen en hoe dit de "performance" beïnvloedt.

\subsection{Wat moet worden verstaan onder het beshuitvormingsproces?}

Het besluitvormingsproces voltrekt zich in achtereenvolgende fasen. Het proces start op het moment dat informatie die op een probleem wijst ter beschikking komt en het proces eindigt indien een gekozen oplossing in de praktijk is gebracht. Het besluitvormingsproces kan als volgt worden weergegeven.

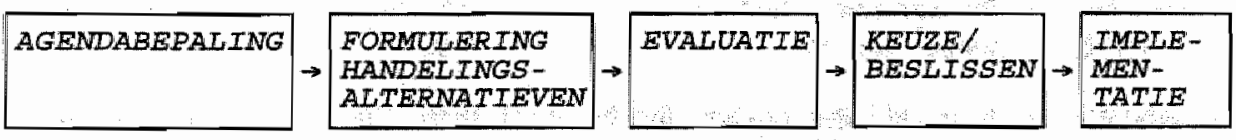

\section{Figuur 8.1 Het besluitvormingsproces binnen een netwerk ${ }^{363}$}

De actor kan, afhankelijk van zijn verhouding met andere actoren en met behulp van zijn machtsbronnen (eigendomsrechten), machtsmiddelen en machtsgebruikstrategieën op verschillende plaatsen in het besluitvormingsproces invloed uitoefenen. Indien hij er bijvoorbeeld in slaagt het probleem te definiëren kan dat zeer belangrijk zijn voor de uiteindelijke doelrealisering. De totale combinatie van machtsbronnen, machtsmiddelen, machtsgebruik en besluitvormingsprocessen leidt, afhankelijk van de "state of the world" die zich voordoet, uiteindelijk tot een realisering van doelen en bepaalde beleidsuitkomsten. Het is daarom belangrijk in te zien dat de doelen van de houders van de

${ }^{361}$ Mitchell (1969, pp. 64 e.v.).

362 Kuinneke, in: Mol en Verbon (1993, pp. 31 e.v.).

363 In de literatuur bestaan er verschillende visies op de vormgeving van het besluitvormingsproces. Simon. noemt als besluirvormingsfasen bijvoorbeeld: de fase van de "intelligence" activiteiten, die van de "dlesign" activiteiten, de "choice" activiteiten en tenslotte noemt hij de "review" activiteiten, waarbij de in het verleden gemaakte keuzen en uitgevoerde alternatieven worden geëvalueerd. Eventueel kan deze fase in Figuur 8.1 ma de implementatiefase worden toegevoegd. Vergelijk: Simon (1977, p. 41). 
eigendomsrechten/machtsbronnen weliswaar de doelen van een overheidsinstelling zijn, maar dat deze door de verschillende processen en strategieën niet per definitie gerealiseerd hoeven te worden, nog afgezien van de ontwikkelingen in de omgeving. Wel is het, zoals opgemerkt in hoofdstuk 4, waarschijnlijk dat gegeven de restricties een optimaal resultaat tot stand komt.

Paul merkt ten aanzien van het besluitvormingsproces op: "De worm die de besluitvorming aanneemt kan variëren wan economisch-rekenkundig ("besluitvorming is als het oplossen van een rekenprobleem") tot politiek respectievelijk ongestructureerd ${ }^{\text {"t }}{ }^{364}$ In het eerste geval zijn de doelen e.d. van de actoren bekend. Het is dan van te voren duidelijk welke oplossing er gekozen wordt. Beheersing door de principalen is dan mogelijk. Paul merkt verder op: "Ingeval doelen en technologie van een systeem echter onduidelijk zijn, falen rekenkundige methoden. In plaats van systeem-rationaliteit staat de maximering van deelbelangen voorop. Sturing en beheersing zijn dan veelal moeilijk te realiseren". In paragraaf 8.3 worden de belangrijkste vormen die het besluitvormingsproces kan aannemen behandeld.

\subsection{Welke wijzen van besluitvorming kunnen worden onderscheiden binnen een netwerk?}

In dit hoofdstuk worden, voorzover relevant voor dit onderzoek, een aantal besluitvormings- en beslissingsmodellen behandeld, die in de literatuur worden onderscheiden, namelijk:

* Het rationele actormodel

* Het model van Simon

* Het bureaucratische model

* Het vuinisvat- ("garbage can") model

* Het politieke of arenamodel

Deze modellen geven tevens de ontwikkelling weer van het denken over besluitvorming in organisaties. Dit denken wordt gekenmerkt door de ontwikkeling van een gesloten systeem benadering naar open systeem benaderingen met wederzijdse interactie en tal van actoren. In het navolgende wordt kort ingegaan op de verschillende varianten.

In de holistische benadering wordt elke actor beschouwd als een ondeelbare actor. Een voorbeeld hiervan is het rationele actormodel. Hierin wordt de besluitvormer voorgesteld als een "black box". Het bedrijf wordt geconfronteerd met bepaalde problemen en streeft bepaalde doelen na. De actor formuleert bepaalde handelingsalternatieven en analyseert de bijbehorende consequenties. De alternatieven die de actor het meeste voordeel opleveren en het minste kosten worden gekozen.

Het gedrag van een overheidsinstelling kan volgens deze benadering verklaard worden door de doelen van een overheidsinstelling en de dienovereenkomstige acties te analyseren. ${ }^{365}$ Deze holistische organisatieopwatting gaat mogelijk nog op voor kleine organisaties die actief zijn op markten van volkomen mededinging. $Z$ iij is veel minder bruikbaar voor grote organisaties waarbij verschillende actoren over belangrijke eigendomsrechten beschikken. Als reactie hierop wordt in de atomistische organisatie-benadering de

\footnotetext{
364 Paul, in: Van Gemerden (et all.), Herweyer en Van Selm (red) (1987, p. 28).

${ }_{365}$ Veen $(1992$, pp. 178 e.v.).
} 
organisatie voorgesteld als een samenstel van groepen en individuen. Gemeenschappelijk uitgangspunt van deze benadering is dat de bureaucratische functionaris niet een afhankelijk organisatie-onderdeel is maar daarentegen eigen doelen nastreeft.

Een alternatief model dat het rationele model aanpast is het "bounded rationality model" of "administrative man model" van Simon. ${ }^{366}$ Dit model verschilt op twee manieren van het rationele actor model. In de eerste plaats impliceert het niet dat er sprake is van individuele rationaliteit in het besluitvormingsproces en het stelt voorts dat individuen welliswaar streven naar de beste oplossing maar veelal genoegen zullen nemen met minder, omdat de besluiten waarmee zij geconfronteerd worden een grotere informatieverwerkingscapaciteit vergen dan zij bezitten. ${ }^{367}$ De rationaliteit van het individu wordt volgens Simon op drie punten begrensd, namelijk door:

1. de waarden en normen die het individu hanteert (religie etc.);

2. de reflexen, gewoonten en vaardigheden van een individu;

3. de mate van kennis en de hoeveelheid informatie waarover een individu beschikt.

Op grond van punt 3 is er sprake van subjectieve rationaliteit. Het individu beschikt niet over volledige informatie en in die zin is de rationaliteit beperkt,

Een tweede verschil met het rationele actor model is dat een individu in het "bounded rationality model" niet streeft naar maximalisatie maar naar bevrediging van doelen. "Satisficing" betekent dat een individu het zoekproces beeindigt indien een alternatief is gevonden dat voldoet aan een bepaalde subjectieve minimumstandaard van een individu ten aanzien van de mate waarin het alternatief bijdraagt aan het bereiken van een doel. $^{368}$ Volgens Simon streeft een individu om een drietal redenen parar bevredigend gedrag. In de eerste plaats moeten beslissingen genomen worden op grond van verschillende al dan niet tegengestelde waarden. In de tweede plaats is het waardensysteem van een individu waarschijnlijk meer subjectief en impliciet dan objectief en expliciet. Tenslotte stelt hij dat een beslisser niet in staat is een groot aantal waarden te vergelijken en in een rangorde te plaatsen.

Wat nu precies bevredigend wordt gevonden door een individu wordt bepaald door zijn aspiratieniveau. Dit aspiratieniveau heeft een dynamisch karakter en kan veranderen door de ervaringen die individuen opdoen. Herhaaldelijke successen kunnen leiden tot een stijging van het aspiratieniveau terwijl herhaaldelijke mislukkingen het aspiratieniveau kunnen doen dalen. ${ }^{369}$

Als representant van de atomistische benadering kan het bureaucratische model (niet te verwarren met het bureaucratiemodel van Niskanen) worden genoemd. De besluitvormer

\footnotetext{
356 Steers (1984, p. 281), vgl. ook: Pugh en Hlickson (1989: p, 138). Tegenover het concept wan de "Economic Man" stelt Simon een model van de "Administrative Man". "While "Economic Man" maximizes "Administrative Man" satisfices" en: Simon et al. (1992, p. 50).

367 Vergelijk: Conlisk (1996, pp. 669 e.v.).

368. Simon (1957, pp. 196 e.v.). Simon geeft aan dat "satisficing" een essentielle stap is in de toepassing van het principe van "bounded rationality". Hieronder verstaat Simon: "The capacity of the human mind for formulating and solving complex problems is very small comparing with the size af the problems whose solution is reguired for abjectiveby rational behavior in the real world - or even for a reasonable approximation to such objective rationality" ${ }^{\prime}$, p. 198.
}

${ }^{36 s}$ Simon (1960, pp. 1 e.v.). 
wordt in deze benadering gezien als een hiërarchisch en functioneel geordend geheel van actoren. Een overheidsinstelling wordt niet opgevat als een "black box" maar als een samenstel van organisaties, deelorganisaties en afdelingen. Het handelen van deelorganisaties zal veelal niet gericht zijn op het bereiken van bepaalde doelen maar op het vergroten van de belangrijkheid van de eigen organisatie. Dit zal zij onder andere proberen te bereiken door allerlei zaken te vermijden, waaronder bijvoorbeeld vermindering van personeel en vermindering van het toegewezen budget. De deelorganisaties krijgen delen van problemen te verwerken waar zij vervolgens slechts beperkte invloed op kunnen vitoefenen. Elke deelorganisatie bekijkt problemen vanuit een bepaalde invalshoek en stelt bepaalde prioriteiten. ${ }^{370}$

De organisatie werkt aan de hand van procedures. Gedrag van de organisatie is voorgeprogrammeerd. Voorts tracht de organisatie onzekerheid zoveel mogelijk te vermijden door onder andere het maken van marktverdelingsafspraken en in het algemeen door het streven om tot een zogenaamde "onderhandelde omgeving" te komen. ${ }^{311}$

Een ander besluitvormingsmodel is het "garbage cam" model. ${ }^{372}$ Organisaties gedragen zich volgens dit model als georganiseerde anarchieën. De doelen zijn onduidelijk en inconsistent, terwijl de participatie door de leden zeer wisselend is. Cohen, March en Olson geven aan dat een organisatie beschouwd kan worden als een verzameling van problemen, oplossingen, participanten en keuzesituaties. Participanten zullen beslissingen moeten nemen. Het kenmerkende van dit model is nu dat deze vier elementen in een min of meer willekeurig patroon voorkomen. Het is niet zo dat eerst een probleem wordit geïdentificeerd, dat vervolgens oplossingen worden geformuleerd en dat alternatieven tegen elkaar worden afgewogen. In het "garbage can" model is deze volgorde willekeurig. Als voorbeeld kan gedacht worden aan de besluitvorming bimen universiteilten. In de besluitvorming binnen dit soort organisaties is overigens wel een structuur te ontdekken. Dit systeem vormt een redelijk antwoord op de grote omgevingsonzekerheid waarin de participanten verkeren.

De duidelijkste exponent van de atomistische benadering is tenslotte het arenamodel. Volgens dit model kan de besluitvormer worden gezien als een ongeordend geheel van actoren. Bij de besluitvorming tussen organisaties en in het geval van besluitvorming binnen grote overheidsorganisaties is er geen ultieme beslisser. Elke actie van een organisatie is het resultaat van een politiek onderhandelingsproces, in die zin dat tal van actoren het resultaat hebben beinvloed. Geen enkele actor is in staat de uitkomst volledig te bepalen. Posities bepalen wat een actor mag en moet doen. Het besluitvormingsproces kan dan ook verklaard worden door in de eerste plaats de standpunten van de verschillende spelers te analyseren. Deze standpunten worden voor een belangrijk deel bepaald door subjectieve inschattingen en prioriteiten van actoren. Het primaire criterium is niet zozeer een juiste beslissing alswel een acceptabele beslissing. In de tweede plaats moeten de belangen van de verschillende actoren onderzocht worden. Standpunten worden bepaald door belangen van spelers. Deze bellangen kunnen zowell organisationeel als persoonilik zijn. Vervolgens kan het beshuitvormingsproces verklaard worden door de machtsverhoudingen tussen de actoren. Tenslotte zijn de actiekanalen van belang. Een actiekanaal is een organisatie of bedrijfsonderdeel dat actie onderneemt op een bepaald probleem. Het actiekanaal waarin het probleem aan de orde komt is bepalend voor het karakter van het

\footnotetext{
370 Wassenberg, (1980, p. 10).

37? T.a.p., p. 23.

${ }^{3 n}$ Cohen, March en Olson (1972, pp. 1-25), March en Olson (1976).
} 
probleem.

Geconcludeerd kan dan ook worden dat de actie van een organisatie het gevolg is van onderhandelingen tussen de verschillende actoren. De uiteindelijke beslissing is het resultaat van de actiekanalen, de spelers, de positie van die spelers, bun belangen en voorkeuren en het onderhandelingsproces. ${ }^{373}$ Moene stelt het, uitgaande van zijn analyse van de bureaucratietheorie van Niskanen als volgt: "Depending on the distribution of the decision-making power and of relevant information, different kinds of interaction between sponsors and bureaus may result". ${ }^{374}$ De in dit onderzoek gevolgde netwerkbenadering bouwt sterk voort op dit concept. Binnen deze benadering wordt eveneens de nadruk gelegd op de interactieprocessen tussen actoren en de resulterende strategieen en complexe doelen. De gevolgde benadering gaat echter verder aangezien veel aandacht besteed wordt aan de institutionele context van de interactieprocessen tussen actoren: ${ }^{375}$

\subsection{Welke besluitvormingsstrategieën worden gevolgd?}

In de vorige paragraaf zijn verschillende besluitvormingsstrategieën behandeld. In navolging van Thompson en Tuden geeft Paul aan wanneer bepaalde besluitvormingsstrategieën met name zullen worden gebruikt. Eén en ander kan worden geillustreerd met de volgende tabel:

\begin{tabular}{|l|l|l|l|}
\hline \multicolumn{2}{|l|}{} & \multicolumn{2}{|l|}{ preferenties ten aanzien van de doelen } \\
\cline { 2 - 4 } & bekend & onbekend \\
\hline $\begin{array}{l}\text { oorzaak-gevolg- } \\
\text { relaties } \\
l \text { technologie }\end{array}$ & bekend & rekenkundig & compromis \\
\cline { 2 - 4 } & onbekend & beoordeling & inspiratie \\
\hline
\end{tabular}

\section{Tabel 8.1 Besluitvormingsstrategieën en besluitvormingscontext ${ }^{376}$}

De wijze waarop de besluitworming binnen een netwerk plaatsvindt is afhankelijk van een aantal factoren. Allereerst zijn de doelen van belang. Vooral indien er binnen het netwerk geen actor is die voldoende macht heeft om een bepaald besluit af te dwingen kan er gebrek aan consensus ontstaan over de na te streven doelen. Ook de mate waarin de omgeving verandert is hierbij van belang. Indien de omgeving snel verandert zullen ook de doelen moeten wijzigen. Hierover kan verschil van mening bestaan. Beheersing van de organisatie is dan moeilijk. Naast de mate waarin doelen worden gedeeld is de meetbaarheid van de outputs van belang voor de vraag wat voor besluitvormingsproces zich voordoet binnen een netwerk. Paul merkt op: "Het niet meetbaar zijn van outputs bemoeilijkt vaak de besluitvorming over de doelen, zeker waar sprake is wan meer doelen die

\footnotetext{
3 T.a.p., P. 18.

374 Moene (1986* p. 334).

375 Kilijn en Koppenjan (1997, p. 148).

376 Paul, in: Van Gemerden (et al.), Herweyer en Van Selm (red) (1987, p. 30).
} 
tegelijkertijd worden nagestreefd en wartoe middelen dienen te worden gealloceerd" 3 m Tenslotte is het voor de aard van het besluitvormingsproces van belang in hoeverre tussen verschillende actoren overeenstemming bestaat over de wijze waarop outputs worden gerealiseerd. De vraag daarbij is of het duidelijk is hoe doelen bereikt kunnen worden.

Indien de doelen eenduidig zijn en de gebruikte technologie duidelijk is, is een rekenkundige wijze van besluitworming mogelijk. Hierbij kan gedacht worden aan het in de vorige paragraaf behandelde rationele actor-model en in mindere mate aan bet begrensde ratiomalliteit-model. Beheersing van de organisatie als onderdeel vain het netwerk is dan (in meer of mindere mate) mogelijk. Indien er geen duidelijkheid is met betrekking tot de preferenties zal besluitvorming moeten plaatsvinden via compromis of op inspiratie. Zoals is weergegeven in Tabel 8.1 . is, indien de doelen niet algemeen gedeeld worden en de gebruikte technologie niet duidelijk is, beoordeling door experts nodig.

Indien de doelen niet worden gedeeld door alle actoren en er een belangenstrijd bestaat, kunnen allerlei sociale processen grote invloed krijgen in het beslluitvormingsproces. Economische argumenten zijn niet meer doorslaggevend maar subjectieve belangen, onderhandelingsprocessen en machtsstructuren. Economische argumenten worden wel gebruikt maar dienen vooral ter onderbouwing van reeds op andere gronden genomen besluiten. De besluitvorming zal dan meer de vorm aannemen zoals geschetst in het genoemde arenamodel. Het "garbage can"-model kan worden gezien als een extreme vorm van dit soort besluitvorming. Tenslotte merkt Paul op dat naast de mate waarin er consensus over de doelen bestaat, de outputs gemeten kunnen worden en de mate waarin het duidelijk is hoe die outputs kunnen worden voortgebracht (technologie) de verdeling: van eigendomsrechten van belang is ${ }^{378}$ Het gaat er daarbij vooral om hoe de diverse taken binnen een netwerk en meer in het bijzonder binnen een organisatie worden gedelegeerd. Deze verdeling beinvloedt het besluitvormingsproces. $\mathrm{Zij}$ heeft daarmee eveneens invloed op de effectiviteit van beheersingssystemen en de uiteindelijke "performance".

\subsection{Hoe beinvloedt het besluitvormingsproces het gedrag en de "performance" van een overheidsinstelling?}

Het paradoxale verschijnsel dat de dynamiek van een netwerk soms aanzienlijk afwijkt van de strategische bedoelingen en tactieken van de verschillende actoren laat zich bijvoorbeeld duidelijk ilustreren met de gang van zaken ten aanzien van het Rijn-ScheldeVerolme-(R.S.V.-) concern in de jaren tachtig. Destijds waren er een drietal redenen dat er een dergelijke kloof bestond. In de eerste plaats werd het verschil tussen doelen en beleidsuitkonsten veroorzaakt door turbulente sociale, techmologische en economische ontwikkelingen in de omgeving waardoor de concermleiding er niet in slaagde de uitgestippelde koers te volgen. In de tweede plaats zorgden niet alleen omgevingsfactoren maar ook interne rivaliteiten, gebrekkige informatiestromen en een ondoorzichtige organisatiestructuur ervoor dat de Raad van Bestuur er niet in slaagde de beoogde doelen te bereiken. ${ }^{379}$ Een derde reden hield verband met de verschillende doelen van de verschil-

\footnotetext{
m.a.p., p. 29.

37. T. a.p., 11.
}

Parlementaire enquëtecommissie RSV, Verslag van de werkzaamheden, deal 13, Den Hag, Staatsdruk-
kerij, 1984 , p. 48 . 
lende actoren, waaronder politieke actoren, concernieiding, parlementsleden, etc, die veelal dermate uiteenliepen dat ze moeilijk met elkaar te verenigen waren. De besluitvorming vond niet op een rekenkundige wijze plaats maar veelmeer op een manier zoals weergegeven met het arenamodel of zelfs het "garbage can"-model. Deze wijze van besluitvorming leidde ertoe dat de prestatie van het concern veel te wensen overliet. Met de in dit onderzoek geschetste benadering had op deze problemen ten aanzien van de "performance" met betrekking tot alle doelen en de relevante actoren gewezen kumnen worden. De politiek kan in dergelijke gevallen tijdig actie ondernemen, bijvoorbeeld door het beperken van het aamtal houders van eigendomsrechten of door het zodanig wijzigen van de betreffende bewoegdheden dat de doelen van het betreffende bedrijf meer overeenkomen met die van de politieke actoren. Hieruit volgt dat een onderscheid gemaakst kan worden tussen de doelen die de principalen als houders van eigendomsrechten mastreven en de doelen zoals die door een overheidsinstelling in de praktijk worden gerealiseerd (en nagestreefd). Hiertussen kan een aanzienlijk verschil bestaan.

Een kanttekening is hierbij op zijn plaats. Veen stelt dat er veelall een hoge correlatie bestaat tussen de hiërarchische positie die iemand inneemt (macht) en de hoeveelheid waargenomen invloed en daarmee tussen doelen van eigenaren en de nagestreefde en gerealiseerde doelen in een metwerk. Hij steit: "De kappeling van macht van de organisatorische positie en de legitimiteit van de structuur doet verwachten, dat er een duidelijke samenhang gevonden zal worden tussen de structuurkenmerken van de organisatie en de invloedsverdeling in de organisatie. Dit is slechts gedeeltelijk het geval. Er wordt een duidelijke en consistente samenhang gewonden tussen de hiërarchische positie in de organisatie en de hoeveelheid waargenomen invloed. Tussen allerlei andere structuurkenmerken en de waargenomen invloed is de overeenkomst aanzienlijk minder duidelijk" ${ }^{380}$ Indien er in een organisatie een hoge correlatie tussen macht en invloed bestaat, is het goed mogelijk om door middel van de "revealed preference methode" de doelen af te leiden. De veronderstelling dat overheidsinstellingen allocatief efficiënt zijn is in dat geval redelijk. Doelen van de houders van eigendomsrechten worden dan immers ook geëffectueerd. Een probleem hierbij is dat het niet van te voren zeker is of er met betrekking tot de actoren binnen de betreffende overheidsinstelling sprake is van een hoge correlatie. Indien er geen sprake is van een dergelijke hoge correlatie hoeft de "revealled prefe-

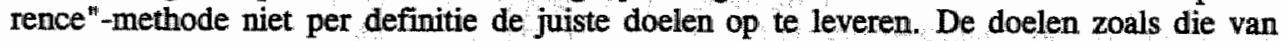
het gedrag van een overheidsinstelling worden afgeleid weerspiegelen slechts gedeeltelijk de doelen van de houders van eigendomsrechten. In dat geval is de interviewmethode, als middel voor aanvullende informatie, geëigend. Reden waarom zoveel mogelijk beide methodes, revealed preference- en interviewmethode, gecombineerd moeten worden teneinde de doelen van de houders van eigendomsrechten te achterhalen. In paragraaf $14.5 \mathrm{zal}$ nader op beide methoden worden teruggekomen.

Uit het voorgaande blijkt dat er verschil kan bestaan tussen de doelen van de principalen en de feitelijke doelrealisering. Naast de genoemde redenen is bet denkbaar dat dit verschil veroorzaakt wordt doordat actoren beschikken over asymmetrische informatie en door het bestaan van transactiekosten. Derhalve zal in de volgende paragrafen meer concreet worden ingegaan op de relaties tussen diverse actoren binnen het netwerk en op de transactiekosten.

\subsection{Conclusie}

In voorgaande hoofdstukken is aangegeven dat een overheidsinstelling gezien kan worden als een samenstel van actoren (vgl. hoofdstuk 6) waarin de verschillende actoren in het

380 Veen (et al.) (1.992) 
besluitvormingsproces de doelen en het beleid bepalen. De mate waarin beheersing van de organisatie mogelijk is, is-voor een belangrijk deel afhankelijk van de aard van de besluitvormingsprocessen. In dit hoofdstuk zijn dan ook verschillende besluitvormingsprocessen onderscheiden. De vraag is welke besluitvormingsprocessen zich bimnen een netwerk wooral zullen voordoen. Aangegeven is dat dit afhankelijk is van een aantal factoren. In de eerste plaats gaat het erom in hoeverre de doelen door de belangrijkste actoren worden gedeeld. Daarnaast is het van belang in hoeverre de outputs gemeten kunnen worden. Indien de outputs niet meetbaar zijn wordt het moeilijker om beslissingen te nemen over de doelen. Voorts maakt het voor de wijze van besluitvorming uit in hoeverre actoren het eens zijn over de wijze waarop de outputs worden voortgebracht. Tenslotte is de organisatiestructuur en de delegatie van taken binnen de organisatie belangrijk. De aard van de besluitvormingsprocessen en de daarmee gepaard gaande beheersingsmogelijkheden voor de principalen hebben vervolgens grote invloed op de "performance". 


\section{Hoofdstuk 9. Wat voor relaties bestaan er tussen de actoren binnen een netwerk en wat zijn de gevolgen hiervan voor het gedrag van een overheidsinstelling?}

\subsection{Inleiding: relaties binnen het netwerk}

Eén van de kenmerken van een netwerk is dat hierin verschillende principaal-agentrelaties kunnen voorkomen tussen de afzonderlijke actoren. ${ }^{381}$. Powell stelt. "The properties of the parts of this system are defined by the kinds of interaction that take place among them. The behaviors and interests of individual actors are shaped by these patterns of interaction ". ${ }^{382}$ Hoewel hij het niet alleen over netwerk-organisaties heeft kan dit hier wel op worden toegepast. Verder stelt hij: "(...) an exclusive focus on the transactionrather than the relationship-as the primary unit of analysis is misplaced" ${ }^{383}$

In deze paragraaf zal verder worden ingegaan op de ontwikkelde theorie. Met behulp van de principaal-agent-benadering wordt de aard van de relaties tussen de geselecteerde actoren nader bepaald. ${ }^{384}$ Daartoe zal in dit hoofdstuk worden ingegaan op de principaal-agent-theorie, terwijl in hoofdstuk 10 het bureaucratiemodel van Niskanen wordt onderzocht. Dit model kan worden opgevat als een toepassing van een principaal-agent model.

Het is nu van belang onze aandacht te richten op de ard van de betrekkingen tussen de actoren. Hess onderscheidt een aantal soorten relaties in organisaties, die zich ook bimen netwerken voordoen ${ }^{385}$ In de eerste plaats is er de autoritaire relatie waarbij de ondergeschikte een arbeidsovereenkomst tekent en op grond waarvan hij accepteert dat een leidinggevende bepaalde taken vaststelt. Dit is vooral kenmerkend voor organisaties. In de tweede plaats is er het door Hess aangeduide "contingency contract", waarin precies is aangegeven welke werkzaamheden de werknemer zal verrichten indien zich bepaalde omstandigheden voordoen. In dit geval is er dan ook geen sprake van een hiërarchische verhouding. Tenslotte is er de principaal-agent-verhouding.

Elk van deze drie relaties kan transactiekosten met zich meebrengen. Hierbij zijn vooral de principaal-agent-relaties van belang, mede omdat de transactiekosten van de eerste twee relatievormen hierin zijn opgenomen en anderzijds omdat dit soort relaties vanuit de netwerkbenadering het meest belangwekkend is. In dit hoofdstuk zullen dan ook alle relaties tussen twee actoren, waarbij de ene actor bet doel van de ander nastreeft worden opgevat als principaal-agent-relaties, ongeacht of dit tussen bijvoorbeeld een departement en een overheidsinstelling of binnen en overheidsinstelling plaatsvindt.

\footnotetext{
36. Schanze (1993, p. 693).

32 Powell (1990, p. 301).

30 Powell (1990, p. 323).

3at. Backhaus en Nutzinger (eds.) (1982, p. 53).

3 Hess (1983, pp. 99 e.v.).
} 


\subsection{Wat wordt verstaan onder een principaal-agent-relatie?}

De "agency"-theorie is afgeleid van het werk van Jensen en Meckling en Fama en Jensen. ${ }^{386}$ Binnen de principaal-agent-literatuur kanmen een tweetal stromingen onderscheiden worden. ${ }^{387}$ De eerste stroming is van wiskundige aard en houdt zich met name bezig met formele modelleringen van principaal-agent-verhoudingen, waarbij wordt uitgegaan van bepaalde veronderstellingen. Uitgaande van dergelijke veronderstellingen vraagt zij zich af welke contracten optimaal zijn. De stroming die voor ons meer relevant is, is die van de positieve "agency"-theorie. Deze stroming is meer beschrijvend. Hierbij wordt er vanuit gegaan dat een organisatie bestaat uit een verzameling contracten, hetgeen goed aansluit bij de hier gevolgde netwerkbenadering. Het gaat daarbij vooral om de kosten van de in de werkelijkheid wargenomen relaties tussen principalen en agenten. Verschillende eigendoms- en bestuurstructuren leiden tot een ander gedrag en een andere "performance" van een (overheids)instelling. Dit wijkt af van de neo-klassieke theorie die een bedrijf ziet als een "black box" en waarbij het gedrag van de participanten in een bedrijf buiten beschouwing blijf. ${ }^{388} \mathrm{Er}$ bestaat overigens verschil van mening over de mate waarin een scheiding van eigendom en bestuur (en daarmee de relaties van principalen en agenter) invloed heeft op het gedrag en de "performance" van een bedrijf. Demsetz en Lehn stellen bijvoorbeeld dat de eigendoms-/bestuursstructuur geen invloed heeft op de "performance", aangezien die structuur zich aanpast aan de kenmerken en "performance" van een bedrijf. ${ }^{\text {"89 }}$ Indien een en ander gecombineerd wordt met het schema van hoofdstuk 3 , dan kan de conclusie getrokken worden dat het enerzijds waarschijnilik is dat de eigendomsrechtenstructuur binnen een overheidsinstelling het gedrag van een overheidsinstelling beimvloedt en daarmee de "performance" van dat bedrijf, terwijl anderzijds de "performance" van een overheidsinstelling weer invloed heeft op het gedrag van dat bedrijf, onder andere doordat de eigendomsrechtenstructuur zich hieraan aampast.

Op grond van de toepassing van de principaal-agent-theorie op een overheidsinstelling kan geconstateerd worden dat met name de politieke eigenaren en managers van belang zijn, aangezien deze veelal dragers zijn van eigendomsrechten.

Zoals in paragraaf 3.2 is uiteengezet zijn naast de eigendomsrechtenstructuur en de principaal-agentrelaties ook andere factoren van belang waaronder de marktstructuur die eveneens van invloed is op de prestaties. De marktstructuur is van invloed op het proces van formulering van doelen en op de principaal-agent-relatie. Indien een overheidsinstelling functioneert op een markt van volkomen mededinging heeft dit onder andere tot gevolg dat het stimuleringssysteem meer zal worden gericht op het bereiken van technische efficientie. Er zal dan ook minder ruimte zijn voor het bereiken van politieke doelen door de principalen en de agenten. Zoals in paragraaf 3.2 is aangegeven wordt de marktstructuur waar de betreffende overheidsinstelling in opereert, mede bepaald door de aard van de goederen die het bedrijf voortbrengt. Indien het bedrijf collectieve goederen voortbrengt als hoofddoelstelling zal het bedrijf zelden op een markt die gekenmerkt wordt door volkomen mededinging opereren. De marktstructurur kan dan ook de invloed van de structuur van eigendomsrechten doen verminderen. In hoofdstuk 3 is reeds gewezen op de

\footnotetext{
386 Jensen en Meckling (1976, pp. 305-360), Fama en Jensen (1983, pp. 301-326) en (1983, pp. 327-350).

387 Jensen (1983, pp. 334-336).

Jensen en Meckling (1976, pp. 306-307).

${ }^{3 *}$ Demsetz en Lehn (1985, pp. 1155-1159).
} 
interactie van de verschillende voor de verklaring van de "performance" rellevante actoren. In deze paragraaf wordt verder ingegaan op de relaties binnen het netwerk.

In een principaal-agent model worden twee (groepen) individuen onderscheiden $\mathrm{De}$ verhouding tussen hen laat zich beschrijven als een verhouding tussen een principaal en een agent waarbij de principaal wil dat de agent zoveel mogelijk de doelen van de principaal nastreeft door het uitvoeren van bepaalde taken. ${ }^{390}$

Het principaal-agent-model is gebaseerd op een aantal veronderstellingen ${ }^{391}$ In de eerste plaats wordt verondersteld dat beide actoren hun nutsfunctie maximaliseren, gegeven bepaalde restricties en institutionele randvoorwaarden (waaronder het politieke stelsel zoals dat in hoofdstuk 5 is behandeld). Deze nutsfuncties verschillen van elkaar. In de tweede plaats is de verhouding tussen een principaal en een agent gebaseerd op een expliciete of impliciete overeenkomst tussen beide actoren. Ten derde is er voor de principaal sprake van imperfecte "monitoring". Dit betekent aan de ene kant dat er sprake is van asymmetrische informatie in die zin dat de principaal niet alle beslissingen en activiteiten van de agent kan waarnemen en dit betekent aan de andere kant dat deze beslissingen en activiteiten ook miet rechtstreeks uit de resultaten van de agent kunnen worden afgeleid. Dit komt omdat deze beslissingen niet per definitie het betreffende resultaat hoeft te hebben veroorzaakt. Andere factoren kunnen hebben meegespeeld.

De laatste veronderstelling heeft betrekking op de aanwezigheid van transactiekosten, waarvan in de neo-klassieke theorie veelal wordt geabstraheerd. Wat precies onder transactiekosten verstaan dient te worden is enigszins vaag. De volgende categorieën zijn belangrijk:

In de eerste plaats de kosten voor elke partij van het anticiperen op eventualiteiten. In de tweede plaats de kosten van het beslissen over en het tot overeenstemming komen over hoe met deze eventualiteiten om te gaan. Ten derde de kosten van het opstellen van een voldoende duidelijk contract en tenslotte de kosten van het juridisch afdwingen van dit contract. $^{392}$

In het kader van het principaal-agent-model beschilkt de principaal over een bundel eigendomsrechten. Op grond hiervan wil de principaal een aantal doelen realiseren. Cubbin en Leech geven aan dat indien managers zelf over het eigendom beschikken de belangen van aandeelhouders en managers samenvallen ${ }^{393}$ Indien dit echter niet het geval is, bijwoorbeeld omdat er sprake is van spreiding van eigendom, ontstaat er een verschil tussen de welvaart van de principaal of eigenaar en de belangen van het management of de agenten. De principaal schakelt agenten in voor het bereiken van zijn doelen omdat hij zelf niet in staat is alle taken te verrichten en omdat hij over onvoldoende informatie beschikt. ${ }^{394}$ De agenten zullen het nastreven van winst afwegen tegen het behalen van eigen voordielen als salaris en aangename werkomstandigheden.

Eén en ander leidt tot een tweetal met elkaar samenhangende problemen, namelijk het

\footnotetext{
390 Blankart (1980, Pp. 84 e.w.).

391. Neelen, in: Mol en Verbon (1993, p. 79).

392 Hart en Holmstrom, in: Bewly (1987, hoofdstuk 3.3, p. 132).

39 Cubbin en Leech (1983, Pp. 351-354).

394. Wgi. Mellink (1992, pp. 2-3).
} 
probleem van verborgen actie en het probleem van verborgen informatie. ${ }^{395}$ De agent beschikt over specifieke informatie, zodat hij de mogelljkheid heeft om door middel van "moral hazard" de transactie naar zijn hand te zetten. De agent probeert op grond van zijn bijzondere deskindigheid een deel van zijn kosten af te schuiven op de principaal. Hierbij kan bijwoorbeeld gedacht worden aan de verhouding tussen departement en de managers van een overheidsinstelling. Het probleem van verborgen informatie heeft betrekking op de specifieke informatie met betrekking tot zijn eigen deskundigheid, kennis en voorkeuren waarover een agent beschikt:

Beide problemen leiden ertoe dat een agent opereert in een omgeving van onzekerheid. Dit impliceert dat indien het doel van de principaal niet bereikt wordt, het niet zeker is dat dit de schuld is van de agent. ${ }^{396}$ Dit verschil in belangen wussen de eigenaren en het management is van geen belang indien de eigenaren het management kunnen dwingen hun welvaart te maximaliseren. Om ervoor te zorgen dat de agent toch de doelen van de principaal nastreeft hanteert de principaal aan de ene kant een stimuleringssysteem en aan de andere kant een controlesysteem. ${ }^{397}$

Het stimuleringssysteem houdt in dat de agent positief geprikkeld wordt om gegeven de eigen wensen en doelen zoveel mogelijk de doelen vam de principaal na te streven.

In de literatuur wordt een drietal sturingsmechanismen onderscheiden. Allereerst kan de principaal sturen door het overdragen van informatie aan de agent en door overreding. Ten tweede kan hij proberen te sturen door het geven van financieje prikkels. Prestatieen beloningssystemen zijn voorbeelden van dergelijke systemen. ${ }^{398}$ Tenslotte kan hij trachten te sturen door het geven van regels en voorschriften.

Daarnaast is een controlesysteem nodig om te controleren of de agenten inderdaad de doelen van de principaal nastreven. Dit controlesysteem kan bijvoorbeeld bestaan uit het opleggen van regels of uit het direct ingrijpen.

Indien de principaal kiest voor het sturingsmechanisme van overdracht van informatie of voor bet geven van financiële prikkels houdt de agent de mogelijkheid zelf te kiezen. Het gaat er dan vooral om een situatie te creeren van "incentive compatibility". In dat geval hebben de principaal en de agent gedeeltelijk dezelfde belangen. In het geval van het geven van regels probeert de principaal haar doelstellingen vast te leggen in op te leggen randvoorwaarden. Voor de analyse van het gedrag van overheidsinstellingen zijn vooral deze regels/randvoorwaarden van belang, aangezien in de publieke sector het hanteren van financiele prikkels nog niet algemeen voorkomt, hoewel bijvoorbeeld het toekennen van een recht op de winst aan een overheidsbedrijf of-bureau steeds meer wordt doorgevoerd. Ook het geven van informatie is van belang. Dit is echter veelal moeilijk theoretisch en empirisch te onderzoeken.

Bij het opzetten van deze systemen moet rekening worden gehouden met de kosten. De kosten die door de principaal gemaakt moeten worden om er voor te zorgen dat de uitkomsten van de handelingen van de agent overeenkomstig de doelen van de principaal zijn kunnen worden aangeduid als "agency-kosten" "399 In de literatuur kunnen een

\footnotetext{
395 Arrow, in: Pratt en Zeckhauser (edls.) (1985, pp. 37-51).

396 Furubotn en Pejovich (1974, pp. 1-9).

397 Vergelijk ook: Pratt en Zeckhauser in: Pratt en Zeckhauser (eds.) (1985, p. 17).

39. Robbins (1995, pp, 258-264).

39x Jensen en Meckling (1976, p. 308).
} 
drietal soorten agencykosten worden onderscheiden. In de eerste plaats zijn er "monitoring costs". Dit zijn alle kosten die de principaal maakt om er voor te zorgen dat de agent overeenkomstig de doelen van de principaal handelt. De kosten die het stimuleringssysteem en het controlesysteem met zich meebrengen kunnen worden beschouwd als "monitoring costs". Een tweede kostencategorie vormen de "bonding costs". Dit zijn de kosten die de agent maakt om te voorkomen dat hij (te veel) afwijkt van de doelen van de principaal. Een derde kostencategorie vormt de "residual loss". Dit is het welvaartsverlies voor de principaal als gevolg van het eigen afwijkende beleid van de agent.

Jensen en Meckling stellen dat alle kosten worden gedragen door de actor die de principaal-agent verhouding in het leven heeft geroepen. ${ }^{400}$ In de meeste gevallen zal dit de principaal zijn. Zoals bij de behandeling van de veronderstellingen van het principaalagent-model reeds is opgemerkt streeft de principaal naar nutsmaximalisatie. Hij zal dan ook proberen de agencykosten te minimaliseren.

Neelen geeft aan dat deze indeling van de "agency kosten" voor overheidsinstellingen minder bruikbaar is, aangezien beide door dezelfde actor worden voldaan. ${ }^{\text {t01 }}$ Hij geeft een alternatieve indeling van de agency kosten in preventiekosten, inspectiekosten en consequentiekosten. Een principaal zal de overheidsinstelling vooral ook proberen te sturen door het opleggen van randvoorwaarden. Hierdoor wordt de discretionaire bevoegdheid van het management beperkt. In dit verband zijn de preventiekosten de kosten verbonden aan het begrenzen van de handelingsruimte van de agent door het geven van regels en voorschriften. Deze kosten bestaan uit het ontwikkelen van randvoorwaarden en het kenbaar maken van die randvoorwaarden aan het management. Inspectiekosten zijn de kosten verbonden aan het controleren door de principaal of de overheidsinstelling zich ook aan deze regels en voorschriften heeft gehouden. De consequentiekosten zijn gelijk aan de welvaartsverliezen, de genoemde "residual loss".

De vraag rijst wat het effect is van een vermindering van de randvoorwaarden door de principaal. Een eerste effect zal zijn dat de preventiekosten zullen verminderen. De kosten van het ontwerpen en kenbaar maken van minder vergaande randvoorwaarden zullen minder zijn dan indien de randvoorwaarden meer gedetailleerd zijn. Ook de inspectiekosten zullen afnemen omdat de naleving van minder gedetailleerde randvoorwaarden veelal minder kostbaar zal zijn. Het management krijgt meer vrijheid zelf een beleid te bepalen. Hoewel dit zou kunnen leiden tot meer efficiëntie ligt het meer voor de hand dat het management meer eigen doelen zal gaan nastreven, te meer daar niet alle doelen in de randvoorwaarden even duidelijk omschreven zullen zijn en het management meer interpretatievrijheid en daarmee mogelijkheden om de randvoorwaarden te ontduiken krijgt ("shirking"): 402 Bovendien zijn de consequentiekosten minder zichtbaar dan de inspectie- en preventiekosten, waardoor relatief meer vrijheid zal worden gelaten an de overheidsinstelling. Het totale resultaat van een vermindering van de randvoorwaarden zal dan ook veelal zijn dat de preventie- en inspectiekosten zullen afnemen terwijl de consequentiekosten zullen toenemen. Alchian en Demsetz stellen in dit verband: "But since costs must be incurred to monitor each other, each input owner will have more incentive to shirk when he works as part of a team, then if his performance could be monitored easily or if he did not work as a team". ${ }^{403}$ De overheid streeft door middel van overheidsinstellingen vaak bijkomende doelen na. De huidige trend van interne en

two Jensen en Meckling (1976, p. 328).

401 Neelen, in: Mol en Verbon (1993, p. 78).

402 Alchian en Demsetz (1972, p. 780).

403 T.a.p., p. 780 . 
externe verzelfstandiging hoeft niet per definitie te leiden tot lagere agencykosten en in die zin tot grotere efficièntie. Dit hangt ervan af of tegenover de lagere preventie- en inspectiekosten al dan niet hogere kosten staan om het bijkomende doel op een andere wijze te realiseren, bijvoorbeeld door subsidièring of regulering. Van geval tot geval zal bezien moeten worden of efficiëntie-winsten te behalen zijn door wijziging van de randwoorwaarden.

Voorts dient gerealiseerd te worden dat naarmate de besluitvorming verder van de principaal af plaatsvindt, meer aandacht zal moeten worden besteed aan de doelen en wensen van de agenten. De afstand tussen principaal en agent wordt niet alleen beinvloed door dè agencykosten maar ook door het soort organisatie, de hiërarchische structunr, de plaats van de principaal in die structuur en de aard van de activiteiten die de betreffende onderneming verricht.

\subsection{Hoe beinvloeden de betrekkingen tussen actoren het gedrag en de "performance" van overheidsinstellingen?}

Met betrekking tot overheidsinstellingen zijn meerdere principaal-agent-relaties van belang. Meer specifiek kunnen een drietal vormen van principaal-agent-relaties worden onderscheiden.

In de eerste plaats de verhouding tussen kiezer en politici, waarbij de kiezers de principalen en de politici de agenten zijn. De tweede principaal-agent-relatie is die tussen politici en managers van overheidsinstellingen, waarbij de politici de principalen zijn en de managers van overheidsinstellingen de agenten. Een derde principaal-agent-verhouding betreft die tussen managers van overheidsinstellingen, de principalen, en werknemers, de agenten.

In hoofdstuk 5 is uiteengezet dat de eerste principaal-agent-verhouding in een meerpartifenstelsel minder van belang is voor het begrijpen van het gedrag van overheidsinstellingen. Er is tot bepaalde hoogte sprake van producentensoevereiniteit. Bovendien zal de kiezer weinig invloed hebben op het functioneren van overheidsinstellingen omdat kiezers op cen politieke partij stemmen op grond van andere overwegingen dan het functioneren van een overheidsinstelling en omdat het niet aannemelijk is dat kiezers die silechts eens in de vier jaar hun stem uitbrengen wezenlijk invloed uitoefenen op het gedrag van overheidsinstellingen. Ook de derde verhouding is relatief minder belangrijk. De invloed van de werknemers op de doelen en het gedrag van een overheidsinstelling is veelal beperkt. Gesteld kan worden dat de principaal-agent-verhouding die bij overheidsinstellingen vooral ook van belang is, die is tussen politici en managers van de bedrijven. De politici zijn vanuit deze optiek de tijdelijke eigenaren die het eigendomsrecht vitoefenen namens de kiezer. De vraag rijst hoe dit valt te combineren met hetgeen Alchilan opmerkt. ${ }^{404}$ Hij stelt dat alleen individuen eigendomsrechten kunnen hebben. Dit impliceert dat beschikkingsirechten binnen een organisatie beschilkingsrechten zijn van de eigenaren van die organisatie. Hieruit vloeit voort dat een organisatie/bedrijf zelf geen eigendomsrechten heeft. Wel krijgt zij eigendomsrechten gedelegeerd van de eigenaren die zij vervolgens mamens hen uitoefent. In dit onderzoek wordt evenwel aangesloten bij Furubotn en Pejovich, en bij meer recentelijk Bokkes, die stellen dat ook organisaties en de staat houders van eigendomsrechten kunnen zijn. ${ }^{405}$ Vervolgens rijst de vraag wie in

\footnotetext{
Vergelijk: Alchian (1965, pp. 816-829).

405 Vergelijk bijvoorbeeld: Furubotn en Pejovich (1972 w pp. 1139-1140).
} 
het geval van overheidsinstellingen de principaal is. Fama en Jensen menen dat de principaal degene is die recht heeft op de winst (de residuele claim). Dit is datgene wat overblijft nadat de leveranciers van inputs, die recht hebben op een vaste vergoeding, zijn betaald. ${ }^{406} \mathrm{Bij}$ overheidsinstellingen zal er echter vaak geen residuele claim in deze zin zijin. Zoals in het begin van dit hoofdstulk is opgemerkt wordt er hier vanuitgegaan dat er sprake is van een principaal-agent relatie indien de ene actor de doelen van de ander uitvoert. Ook bij overheidsinstellingen is er dan sprake van een principaal. Bokkes merkt op dat de donateurs van non-profit- en overheidsinstellingen de rol van principaal vervullen. ${ }^{407}$ Belangrijk is volgens hem wat het doel van de organisatie is. Is het doel het maximaliseren van de winst dan vormt de residuele claim een recht op de winst. Is het doel het verzorgen van onrendabele elektriciteitsaansluitingen dan zijn dit de resultaten die uiteindelijk toevloeien aan de principalen. De vraag rijst vervolgens wie mu precies de principaal is. Was dit in het geval van het Rijksmuseum het Ministerie van OCW of bijvoorbeeld de Directeur-Generaal? Het is mogelijk het departement als geheel op te vatten als principaal, mits gerealiseerd wordt dat binnen het departement tal van actoren werkzaam zijn. Per geval moet dan geanalyseerd worden wie precies de principaal is. Bokkes stelt: "Zinvoller lijkt het om voor concrete situaties en specifieke relaties, de relaties in beeld te brengen" ${ }^{408}$ Voorts kan geconstateerd worden dat er niet eén principaal-agent-verhouding is maar een veelvoud hiervan. De benadering dat er bij een overheidsinstelling meerdere primcipalen en agenten zijn sluit aan bij de benadering van Aharoni. ${ }^{409}$ Tenslotte kan worden opgemerkt dat ook de interactie tussen principalen en agenten onderling transactiekosten met zich mee kan brengen (vergelijk hoofdstuk 11).

Een iets andere invalshoek van de principaal-agent-benadering binnen overheidsinstellingen heeft betrekking op de verdeling van taakstellende bevoegdheden. Fama en Jensen onderscheiden het productie-/beslissingsproces in een viertal stappen, namelijk de voorbereiding van de besluitvorming, de vaststelling van het beleid, de uitvoering en tenslotte de controle van de prestaties van de agenten, hetgeen global overeenkomt met het besluitvormingsproces binnen het netwerk, zoals uiteengezet in hoofdstuk 8.410 De beleidsvoorbereiding en -uitwoering wordt aangeduid als "decision management" terwijl de actoren die verantwoordelijk zijn voor de "decision control belast worden met de beleidsbepaling en de controle op de uitvoering van het beleid door het management van de overheidsinstelling. Een effectief systeem van "decision management" impliceert dat het controleren van beslissingen gescheiden is van het management. Deze verdeling van taken ontstaat voornamelijk omdat de informatie die nodig is voor het sturen van het productieproces over tal van actoren verspreid is en omdat deze informatie niet kosteloos overgedragen kan worden. Doordat de organisatie die over de meeste informatie beschikt de voorbereiding en de uitvoering verzorgt worden de transactiekosten geminimaliseerd. De principaal behoudt toezicht in de vorm "van het "decision control", waardoor ongewenste dienstontduiking zoveel mogelijk voorkomen kan worden. De "control" beslissingen worden veelal genomen door toezichthoudende organen terwijl managementsbeslis-

Fama en Jensen (1983, pp. 302-303).

Bokkes (1989, pp. 51-52).

Bokkes (1989, p. 54).

409 Aharoni (1986, p. 129).

4:0 Fama en Jensen (1983, p. 303). 
singen worden genomen door het besturur van de organisatie. ${ }^{411}$ Dit is ook bij overheidsinstellingen het geval waar veelal een onderscheid bestaat mussen enerzijds de strategische beslissingen (bijwoorbeeld door een departement genomen) en anderzijds de meer operatieve en tactische beslissingen die door het management van de overheidsinstelling worden genomen. De verdeling van deze eigendomsrechten zall echter per overheidsinstelling verschillen. Het gedrag van een overheidsinstelling $\mathrm{kan}$ nu verklaard worden door te kijken naar de afweging van "enforcing costs" en "residual loss". De principaal ziet toe dat de overheidsinstelling haar doelen nastreeft. Tot bepaalde hoogte zal zij in de praktijk op grond van deze kostenafweging dienstontduiking toestaan.

\subsection{Welke doelen worden door de principalen nagestreefd?}

Op grond van de in hoofdstuk 5 gevolgde redenering zijn mede de doelen van actoren aan de aanbodkant van belang. In het kader van de principaal-agent-verhouding wordt hier in het kort op ingaan. De vraag rijst wat mu precies de doelen zijn van de principalen. Het is duidelijk dat er op zich een groot aantal doelen mogelijk zijn. Zoals in hoofdstuk 2 is aangegeven worden overheidsinstellingen geacht een variëteit van doelen na te streven en te voldoen aan een variëteit van verwachtingen. ${ }^{412}$ In dit onderzoek zullen wij deze doelen in een viertal categorieën samenvatten:

- basisdoelstelling;

- werkgelegenheidsdoelstelling;

- beleidswrijheid;

- winst.

Het eerste doel omvat de eigenlijke taken van het bedrijf, bijvoorbeeld in het geval van de N.S. transport etc.. Zoals hierboven gesteld worden deze activiteiten verricht op een politiek bepaald aanvaardbaarheidsniveau. Voor de ontwikkelde theorie is het tweede doel belangrijker, te weten de werkgelegenheidsdoelstelling. Publieke ondernemingen zijn belast met het verschaffen van werkgelegenheid, met name daar waar particuliere bedrijven niet voldoende werkgelegenheid hebben gecreëerd. Wanneer overheidsinstellingen worden gebruikt om werkgelegenheid te scheppen, geschiedt dit veelal op basis van het patronage-beginsel, hetgeen inhoudt dat werkgelegenheid wordt gecreëerd voor diegenen die de regerende partij hebben gesteund. ${ }^{413}$ Backhaus noemt een drietal redenen waarom volgens hem een regerende partij overgaat tot politieke benoemingen. Allereerst zal de regerende partij personen benoemen om benoemingen van voorgangers ongedaan te maken en om door andere politieke partijen benoemde personen te vervangen door politiek verwante personen. De reden daarvoor is dat van de door de tegenstander benoemde managers kan worden verwacht dat zij de doelen nastreven van de politieke tegenstander, hetgeen impliceert dat zij de realisering van doelen door de huidige principalen zullen tegenwerken. Daarnaast zal de regerende partij zoveel mogelijk politiek verwante personen benoemen om in de toekomst zoveel mogelijk hun steun te verwerven. Tenslotte is het verschil in loon van een bepaalde functie bij een overheidsinstelling en wat anders verdiend zou zijn in de marktsector een onderdeel van de "public enterprise rent", die de regerende partij zich probeert toe te eigenen. Voor zover zij er in slaagt zich deze "rent" toe te eigenen behaalt zij een voordeel. Het ligt voor de hand dat de regeren-

${ }^{411}$ T.a.p., Pp. 301-325.

412 Aharoni (1986, p. 128).

41. Haririan (1989, p. 48). 
de partij, door het koppelen van zoveel mogelijk voordelen aan de betreffende functie, zal proberen dit voordeel te maximaliseren. Door het benoemen van zoveel mogelijk personen, bij voorkeur in een vast dienstverband, verzekert zij zich ook in de toekomst van deze voordelen. ${ }^{414}$ Dit proces van politieke benoemingen bij overheidsinstellingen leidt veelal tot een overbezetting van personeel. Dit geldt vooral voor het management, omdat het voor de principaal van groot belang is dat het management, als agent, zoveel mogelijk de door de principaal opgedragen taken en de gestelde doelen uitvoert. Het nastreven van werkgelegenheid is een van de redenen dat de kwaliteit van de produkten en de geleverde diensten en de netto-winst achter zullen blijven bij vergelijkbare ondernemingen in de marktsector. ${ }^{415}$

Een derde doelstelling heeft betrekking op de verscheidenheid van aanwendingsmogelijkheden waarvoor publieke ondernemingen kunnen worden benut. Deze categorie kan onder één noemer worden gebracht, te weten het verkrijgen van beleidsvrijheid. Hierbij valt te denken aan zaken als het zorgen voor het bestellen van post in heel Nederland, ook in afgelegen gemeenten en het zorgen voor elektriciteitsaansluitingen voor elke regio, ook al is dit economisch gezien niet rendabel. De verschillen in partijprogramma's weerspiegelen zich in het beleid zoals dat door de verschillende ministeries gevoerd wordt. Machtswisselingen kunnen, met name in een meerpartijenstelsel, leiden tot relatief grote veranderingen in het te voeren beleid en in de beleidsdoelen die worden nagestreefd. Overheidsinstellingen hebben dan ook niet alleen te maken met de plotselinge veranderingen waarmee een markteconomie geconfronteerd wordt, zij zullen zich ook moeten aanpassen aan het herhaaldelijk wisselen van eigenaar. Backhaus merkt op dat alleen de lange termijn doelen waarover de politieke partijen niet noemenswaardig van mening verschillen als leidraad gebruikt kunnen worden voor het investeringsbeleid en de langere termijnplanning. De overige doelen kunnen slechts gedurende de veel kortere periode dat politieke partijen aan de macht zijn worden nagestreefd. Iedere partij zal daarom proberen om de niet door andere partijen gedeelde doelen vast te leggen in de vorm van beleidsdocumenten, statuten en wettelijke en grondwettelijke bepalingen. Ook kunnen de regerende politieke partijen proberen om het beleid van overheidsinstellingen voor een langere periode vast te leggen door het sluiten van langlopende contracten. Een nadeel van dit verankeren van doelen in de onderneming is dat de structuur van de onderneming verstart. Dit is nadelig omdat het netwerk met het oog op de continuïteit, voldoende flexibel moet zijn om verschillende beleidsdoeleinden na te kunnen streven.

Een vierde doel dat de principalen kunnen nastreven is het maken van winst. De inkomsten uit publieke ondernemingen zijn van oudsher van belang. ${ }^{416}$ De winst wordt geind door de tijdelijke eigenaar van de overheidsinstelling. Om zijn inkomsten zoveel mogelijk te maximaliseren kan hij een beleid voeren dat erop gericht is om de investeringen van de overheidsinstelling te beperken. Een belangrijke reden hiervoor is dat de investeringen voor de huidige principaal kosten zijn en pas in de toekomst inkomsten zullen opleveren. Het is mogelijk dat dan de politieke tegenstander de principaal is die profiteert van de inkomsten. Zo bezien is het voor de huidige principaal niet aantrekkelijk op grote schaal te gaan investeren. Door het zoveel mogelijk onttrekken van winst en het relatief weinig investeren worden middelen aan de overheidsinstelling onttrokken. Hierdoor ontstaat een ongunstige arbeid/kapitalverhouding. Dit is een derde reden waarom overheidsinstellingen vaak minder zullen presteren dan vergelijkbare bedrijven in de marktsector.

414 Backhaus (1989, p. 368).

415 Monsen en Walters (1983, pp. 45-47).

${ }^{4 i 6}$ Backhaus (1989, pp. 369 e.v.). 
De verschillende bijkomende doelen zijn veelal met elkaar in strijd. Indien er meer aandacht besteed wordt aan een bijkomend beleidsdoel, bijwoorbeeld meer treinverbindingen op onrendabele trajecten, zal dit leiden tot minder winst etc.. De bijkomende doelen zijn veelal gekoppeld aan de eigenlijke doelen. Ook dit levert een verklaring op waarom de productie van overheidsinstellingen veelal niet technisch efficiënt is. Naast de doelen van de principaal zijn de doelen van de agent(en) van groot belang. Hierop wordt in het volgende hoofdstuk verder ingegaan.

\subsection{De cultuur binnen het netwerk}

Sinds de jaren tachtig wordt in de organisatietheorie steeds meer belang gehecht aan de cultuur binnen een organisatie. 417 Vanuit de antropologie, de psychologie, de sociologie en de economie zijn verschillende opvattingen ten aamzien van het begrip cultuur en het belang daarvan voor organisaties ontwikkeld. Hier wordt onder organisatieculturur verstaan een verzameling vastgelegde opvattingen, waarden en normen over het werk, over elkaar, over zichzelf en over de organisatie. Daarbij hoort een geleidelijk gegroeid gedragsrepertoire dat aan nieuwe leden wordt overgedragen. ${ }^{418}$ Van Doorn en Lammers ontleden het begrip culturur (vanuit een sociologische en functionalistische invalshoek) in een viertal facetten, namelijk: 419

1. De normen: het gaat daarbij om opvattingen over hoe men zich dient te gedragen of hoe men zich juist niet dient te gedragen;

2. De verwachtingen: hoe zal een ander zich gedragen?

3. De doeleinden van de verschillende actoren;

4. De waarden: het gaat hierbij om de maatstaven die mensen aanleggen om eigen en andermans gedrag te beoordelen.

Anderen zoals Bate richten zich vooral op het functioneren van de groep. Bate behandelt de organisatiecultuur als een reeks van groepsoriëntaties. Zo noemt hij onder meer de mate van affiniteit, dat wil zeggen de mate waarin mensen emotioneel bij elkaar betrokken raken, en hiërarchie in de zin van de manier waarop organisatieleden reageren op verschillen in positie, macht en verantwoording. Verder wijst hij op de mate waarin organisatieleden bereid zijn om met anderen nieuwe projecten te beginnen en de mate waarin organisatieleden ervoor kiezen om samen of juist alleen te werken. ${ }^{420}$

Al deze verschillende benaderingen laten onverlet dat het de fumctie van een organisatiecultuur is om verschillende individuen in $\mathrm{min}$ of meer stabiele sociale structuren te verenigen. De culturur wordt dan gezien als een aanvulling van de formele organisatiestructuur. In de economische wetenschap wordt de organisatiecultuur ook wel aangeduid als socialal kapitaal. Onder sociaal kapitaal wordt verstaan: "The informal social structure within and on top of the official bureaucratic hierarchy within governments made up of

\footnotetext{
4i.7 Vergelijk in dit verband bijwoorbeeld: Frey en Schuster (1996, pp. 29-33), Visser (1995, pp. 41 e.v.), Koene (1996), Van Reenen en Waisfisz (1995), Van der Krogt en Vroom (1991, hoofdstuk 3) en Schein (1985).

418 Ontleend aan Schein (1985, pp. 17 e.y.)

119 Van Doom en Lammers (1959, pp. 89 e.v.).

420 Bate (1984, pp. 43 e.v.).
} 
De vraag is nu hoe de cultuur van een netwerk van belang is voor de "performance". In de neo-institutionele economie wordt de organisatiecultuur meestal niet expliciet genoemd. Toch wordt in de neo-institutionele economie en ook in dit onderzoek impliciet veel aandacht besteed aan de cultuur. De cultuur wordt voor een groot deel bepaald door de verdeling van eigendomsrechten, de aard van het besluitvormingsproces en de relaties tussen de verschillende actoren. Met name in paragraaf 7.4 bij de behandeling van macht in organisaties is hierop reeds ingegaan. Aangegeven is dat actoren ook op grond van informele organisatiestructuren eigendomsrechten kunnen bezitten. Eigendomsrechten die formeel niet aan hen hoeven te zijn toegekend. Verder kunnen actoren bepaalde gedeelde waarden en normen hebben. Deze normen zijn van invloed op de wijze waarop de betreffende actoren binnen een netwerk hun doelen proberen te bereiken. In die zin wordt de organisatiecultuur in de neo-institutionele economie en de public choice geincorporeerd. Dit laat onverlet dat sociale netwerken van invloed zijn op de "performance". Bulder, Leeuw en Flap hebben onderzoek verricht naar de effecten van reorganisaties van publieke netwerken op het sociale kapitaal en de prestatie. ${ }^{422}$ Indien een reorganisatie er toe leidt dat deze sociale netwerken uit elkaar vallen is het mogelijk dat de "performance" verslechtert in plaats van verbetert. Bulder, Leeuw en Flap merken in dit verband op: "Thus the unintended outcome of an organizational reform that focuses on increasing efficiency, effectiveness and customer satisfaction, may be that these in fact deteriora$t e^{n}{ }^{423}$ Waarden en normen kunnen veranderen evenals de eigendomsrechten. Hierdoor kunnen ook de doelen die in de organisatie worden nagestreefd veranderen. De conclusie van deze paragraaf is dan ook dat de waarden en opvattingen van organisatieleden invloed hebben op het gedrag en de uiteindelijke "performance" van een netwerk. De cultuur wordt echter voor een belangrijk deel gevormd door factoren die in dit onderzoek reeds aan de orde zijn gekomen.

\subsection{Conclusie}

In dit hoofdstuk is ingegaan op de relaties binnen een publiek netwerk. Aangegeven is dat met name principaal-agent-relaties van belang zijn. Verder is ingegaan op het belang van deze relaties en de doelen van de principalen. Tenslotte is aansluitend op paragraaf 7.4 aangestipt dat ook de cultuur van een netwerk van belang is voor het verklaren van de "performance". In dit onderzoek wordt de cultuur niet behandeld als een afzonderlijke factor, maar wordt zij gezien als een resultante van andere factoren zoals de verdeling van bevoegdheden en de relaties tussen actoren. Derhalve wordt in het volgende hoofdstuk verder ingegaan op de relaties binnen het netwerk.

\footnotetext{
421 Bulder, Leeuw en Flap (1996, p. 261).

42 Bulder, Leeuw en Flap (1996, pp. 261 e.v.).

42 T.a.p., p. 262.
} 


\section{Hoofdstuk 10. In hoeverre kan het bureaucratiemodel van Niskanen worden gebruikt voor het verklaren van de relaties binmen het net- werk?}

\subsection{Inleidìng}

De laatste twintig jaar is er een nieuw onderzoeksterrein ontstaan dat probeert de politieke besluitvorming zoals die plaatsvindt in democratieèn vorm te geven op een manier die veel overeenkomst vertoont met de conventionele analyse van het gedrag van consumenten en bedrijven in de private markten. ${ }^{424}$ Deze benadering staat bekend als politieke economie of "public choice" theorie. ${ }^{425}$

De "public choice-benadering" onderzoekt publieke keuzes, die gemaakt worden als een resultaat van individuen die hun belangen nastreven, zoals dat in feite ook in de particuliere sector gebeurt. Buchanan stelt in dit verband: "As emphasized throughour modern public-choice theory, persons who act in agency roles, as "govemors", are not basically different from their fellow citizens, and methodological consistency suggests that the same motivations for behavior be imputed to persons in public and private choices". ${ }^{426} \mathrm{Er}$ kan binnen de public choice theorie onderscheid gemaakt worden tussen aan de ene kant de meer abstracte literatuur, door Dunleavy aangeduid met "first principles" literatuur en daarnaast de meer toegepaste literanur die door hem wordt angeduid met de term "institutional public choice". ${ }^{427}$ De "first principles" analyse maakt onder andere gebruik van technieken als de speltheorie teneinde vraagstukken met betrekking tot het gedrag van individuen en groepen te onderzoeken, In verband met het abstracte karakter is deze benadering voor dit onderzoek minder relevant. In dit hoofdstuk wordt met name de benadering van de institutionele "public choice" gevolgd. De literaturur die binnen deze benadering past biedt een overzicht van de vele aspecten van het politieke proces en van overheidsinstellingen Hierbij kan gedacht worden aan schrijvers als Mancur Olson, Anthony Downs, William Niskanen en James Buchanan. ${ }^{428} \mathrm{Zij}$ hebben een aantal theorieën ontwikkeld die ingaan op de wijze waarop de kernprocessen van de liberaal democratische politiek functioneren.

Zoals hierboven weergegeven wordt de tweede benadering gevolgd, te weten die van de institutionele public choice theorie. Er zijn tal van institutionele kaders mogeiljk. Zoals in hoofdstuk 5 is weergegeven wordt als institutioneel kader het model van het Nederlandse

${ }^{434}$ Dunleavy $(1991, \mathrm{p}, 2)$.

Hemerijck (1995, p. 231). Binnen de politieke economie kunnen de economie van de politiek (de "public choice"), waarbij de nadruk ligt op het geven van economische verklaring van overheidsbemoeienis en de politiek van de economie, waarbij het accent ligt op de invloed vam politieke factoren op bet economische beleid, worden onderscheiden.

${ }^{428}$ Buchanan en Brennan (1980, p. 5).

${ }^{427}$ Dunleavy (1991, p. 1).

428 Hierbij moet bedacht worden dat de wijze waarop in de literatur binnen de "public choice" theorie werschillende stromingen worden onderscheiden, niet eenduidig is. Buchanan onderscheidt een drietal stromingen binnen de "public choice" theorie. In de eerste plaats onderscheidt bij de stroming die de economische wetenschap wil toepassen op de politiek, daarnaast de stroming van de "social choice" en tenslotte de constirutionele economie. De derde stroming komt in feite overeen met de biervoor genoemde institutionele "public choice", Vergelijk: Buchanan en Brennan (1987, preface xi). 
democratische politieke stelsel geschetst. Zoals in dat hoofdstuk is uiteengezet is er tot bepaalde hoogte sprake van producentensoevereiniteit, in die zin dat de overheid en overheidsinstellingen eigen doelen kunnen nastreven. Indien deze benadering wordt gevolgd, kan een overheidsinstelling worden beschouwd als een netwerk, waarin verschillende actoren (zowel binnen de owerheidsinstelling, management, werknemers etc. als buiten bet bedrijf, politici, vakbonden en dergelijke) met elkaar "onderhandelen" om eigen doelstellingen te bereiken en waarbij de verschillende belangengroepen allen invloed uitoefenen op het bedrijf en de doelen van het bedrijf. ${ }^{42}$ Overheidsinstellingen hebben ofincileel opgelegde doelen die veelal zijn neergellegd in statuten. Vaak zijn deze breed en vaag geformuleerd. Veelal zijn de officieel geformuleerde doelen in statuten en beleidsdocumenten van ministeries de doelen van de politieke actoren. Daarnaast hebben ook actoren binnen de overheidsinstelling bepaalde doelstellingen. Het is dan ook niet gezegd dat de formele doelen van een overheidsinstelling ook werkelijk worden nagestreefd. Of dat all dan niet het geval is hangt grotendeels af van het totale onderhandelingsproces en van de verschillende actoren die op elkaar inwerken. Braun heeft uitgebreid onderzoek verricht naar de doelen van overheidsinstellingen en constateent onder meer dat hoe meer een overheidsinstelling zich bezig houdt met de voortbrenging van collectieve goederen des te minder duidelijk de doelen zullen zijn geformuleerd. ${ }^{430}$ Er is in dat gevall meer ruimte voor eigen interpretatie..$^{431}$

\subsection{Het bureaucratiemodel van Niskanen}

In deze paragraaf wordt, ter verdere specificering van de betrekkingen binnen het netwerk, ingegaan op de relatie tussen de overheidsinstelling en het institurut dat de overheidsinstelling sponsort. Moene merkt op dat de interactie tussen beiden kan verschillen afhankelijk van de verspreiding van besluitvormingsmacht en van de relevante informatie waarover beide partijen beschikken. ${ }^{432}$ In deze paragraaf wordt verder ingegaan op het bureaucratiemodel van Niskanen. Het budgetmaximaliseringsmodel kan worden gezien als één van de antwoorden op de kritiek zoals die geleverd wordt op het bureaucratiemodel van Weber. ${ }^{433}$ De Weberiaanse bureaucratie is een formele verticale en hiërarchische organisatiestructuur met arbeidsverdeling en posities die gebaseerd zijn op deskundigheid. Dergelijke modellen veronderstellen dat rationele bureaucratische structuren automatisch leiden tot rationeel individueel gedrag. ${ }^{434}$ In werkelijkheid hoeft dit niet het geval te zijn, aangezien het gedrag dat goed is voor de organisatie in haar geheel niet optimaal hoeft te zijn voor individuen binnen de organisatie. Van Mierlo stelt in dit verband: "The bureaucratic model of Weber has structural as well as behavioural characteristics. Behavioural characteristics are present in various devices of discipline and control. Formalisation and objectivisation of rules and regulations result in bureaucratic behaviour. The bureaucrat does his job precisely and consistently. Citizens are treated

\footnotetext{
Aharoni (1986, pp. 134-141).

Braun (1987, pp. 161 e.v.).

*31 Backhaus (1994, p. 284).

432 Noene $(1986, p, 333)$. 433 Weber (1947). Voor een overzicht van de bezwaren van het bureaucratiemodel van Weber, zie: Hekman,
$(1983$, hoofdstuk 3 en 4$)$.

434 Peirce (1981, p. 9).
} 
anonymously and impartially, "sine ina et stwdio". In this model structural features are the most important. As structural features become more dominant, the bureaucratic organisation becomes more rational.

However, this does not hold for behavioural characteristics. Preciseness, consistency and impersonality may at a certain point prevent the realisation of formal objectives of the organisation; structural characteristics as differentiation, hierarchy and recruitment on basis of expertise may coincide with imprecise, inconsistent and personal behaviour of the bureaucrat". 435

Het is dan ook juister om, zoals veelal ook gebeurt in de moderne literatuur, het gedrag van een bureaucratische organisatie te verklaren door "rent-seekingsgedrag" van individuen en groepen van individuen binnen en buiten de organisatie. Een belangrijke exponent van deze literatumr vormt het bureaucratiemodel van Niskanen, dat de bron vormt van een reeks van budgetmaximaliseringsmodellen. ${ }^{436}$ Het Niskanen-model kan als een verbijzondering worden gezien van het principaal-agent-model en zal om die reden dan ook worden gebruikt ter nadere specificering van de relaties binnen het netwerk. Het Niskanen-model gaat ervan uit dat het bureau niet over expliciete eigendomsrechten beschikt, bijvoorbeeld in de vorm van de mogelijkbeid van het inhouden van winst. Zoals in hoofdstuk 7 is opgemerkt beschikt het bureau wel impliciet over bepalde eigendomsrechten, in de zin van toegang tot informatie waarover de sponsor in principe niet beschikt. Dit model lijkt goed toepasbaar op overheidsinstellingen, aangezien het hier vaak gaat om organisaties met een relatief grote zelfstandigheid. Daar komt nog bij dat het gebruikte Popitz-criterium dermate ruim is dat dit, zoals reeds is opgemerkt, ook van toepassing is op veel organisaties die Niskanen zou aanduiden als bureaus, ${ }^{437}$ die hij omschrijft als non profit-organisaties die temminste voor een deel door de overheid gefinancierd worden, bijvoorbeeld door middel van een periodieke subsidie. ${ }^{438}$ In hoeverre dergelijke modellen inderdaad gebruikt kunnen worden voor het verklaren van de relaties binnen het netwerk wordt in paragraaf 10.3 nader aangegeven. De financierende organisatie wordt door hem sponsor genoemd. Uitgangspunt van de analyse van Niskanen is dat een bureau de te leveren voorziening in haar geheel tegen een vast budget aanbiedt, terwijl bedrijven in de marktsector produkten per stuk verkopen. De verklaring hiervoor is dat de sponsor nergens anders terecht kan. Dit leidt ertoe dat bureaus zich anders gedragen dan particuliere ondernemingen.

Niskanen veronderstelt dat er sprake is van informatie-asymmetrie. De sponsor kent de kostenfunctie van de bureaucraat niet terwijl de bureaucraat wel op de hoogte is van de waardering van de output door de sponsor. ${ }^{439}$ Daardoor is de bureaucraat in staat om zijin aanbodmonopoliepositie beter uit te buiten dan de regerende partijen hun vraagmonopoliepositie (de wetgever is monopsonist) en is hij in staat de door hem gewenste productie-omvang te realiseren. Niskanen typeerde de relatie tussen sponsor en bureau als een bilateraal monopolie. De sponsor is afhankelijk van de bureaus voor de productie van

435. Van Mierlo (1995, p. 2).

436 Deze modellen hebben met elkaar gemeen dat ze bepaalde veronderstellingen loslaten of andere toevoegen en de gevolgen daarvan bezien. Vergelijk bijvoorbeeld: Miller en Moe (1983, pp. 297-322).

437 Vergelijk: Niskanen (1971, pp. 2 e.v.).

438. Niskamen (1971, p. 15) en Thompson, (1973, pp. 950-953).

439 Niskanen (1971, pp. 50-51).

400 Meijdam en Verbon, in: Mol en Verbon (1993, p. 89). 
goederen en diensten, terwijl de bureaus van de sponsor afhankelijk zijn voor de financiering. Door de informatie-asymmetrie is er feitelijk echter sprake van een monopolie. Vertaald in termen van de principaal-agent-benadering betekent dit dat de politicus ten gevolge van de informatie-asymmetrie miet in staat is een zodanig contract op te stellen dat de bureaucraat zich overeenkomstig de preferenties van de politicus gedraagt. De vraag rijst welke productie-omvang de bureaucraat zal nastreven. Niskanen veronderstelt dat de door de bureaucraat gewenste productie-omvang gelijk is aan de omvang waarbij hij zijn budget maximaliseert, onder de restrictie dat bij dat productieniveau het budget niet kleiner mag zijn dan de totale kosten. Volgens Niskanen is budgetmaximalisatie het middel voor de bureaucraat om zijn uiteindelijke doelen te realiseren waaronder bijvoorbeeld een goed salaris en goede werkomstandigheden. ${ }^{441}$ Eén en ander kan worden geillustreerd aan de hand van Fuguur 10.1.

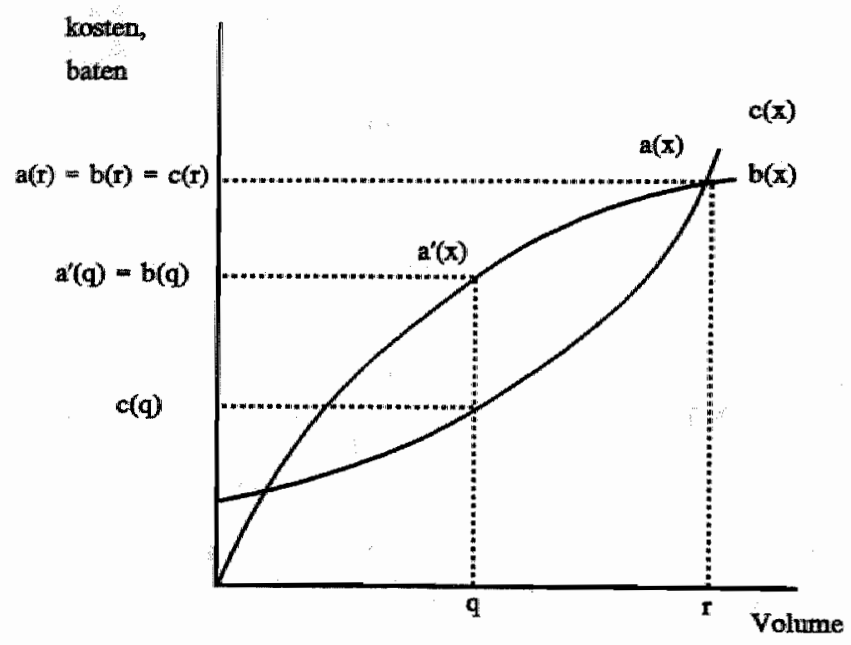

$c(x)=$ kosten van de bureancraat

$b(x)=$ budgetproductiefunctie

\section{Figuur 10.1 Het bureaucratiemodel van Niskanen ${ }^{422}$}

De $x$-as geeft in het geval van een collectief goed de omvang van de dienstverlening per gebruiker weer. Op de $y$-as zijo de in geld uitgedrukte kosten en baten weergegeven. $c(x)$ zijn de kosten die de bureaucraat moet maken en $b(x)$ zijn de in geld uitgedrukte baten voor de politicus. De voorkeur van de politici ten aanzien van een bepaalde hoeveelheid overheidsvoorzieningen kan worden weergegeven met een budget-productiefunctie $(b(x))$. Deze functie geeft aan hoeveel de principaal maximaal wil betalen voor een bepaald voorzieningenniveau. Indien wordt afgezien van inkomenseffecten valt dit budget samen met de marginale baten zoals de politici deze opvatten. In het geval van allocatieve efficiëntie zou de hoeveelheid $q$ moeten worden voortgebracht, waar de marginale baten gelijk zijn aan de marginale kosten. Hierbij wordt uitgegaan van de veronderstelling dat de preferen-

\footnotetext{
Breton en Wintrobe (1975).

442 Bron: Kraan, in: Mol en Verbon (1993, p. 110).
} 
ties van de regerende politici de preferenties van alle burgers weerspiegelen. Hierbij wordt er verder vanuitgegaan dat er sprake is van een zero-sum game, of zoals Conybeare opmerkt: "The thrust of the model suggests that bureaucratic rents are most likeby to have a zero-sum relationship to the welfare of the rest of society.

Aangezien de bureaucraat er in slaagt zijn wil op te leggen zal in werkelijkheid de hoeveelheid $\mathbf{r}$ worden voortgebracht. Er is derhalve sprake van allocatieve inefficiëntie, hoewel er well kostenefficiënt of $\mathrm{X}$-efficiënt wordt geproduceerd. Kostenefficiëntie wil zeggen dat de al dan niet allocatief efficiënte hoeveelheid met minimale inzet van middelen tot stand komt. De totale kosten zijn dan gelijk aan het budget. Hierbij dient te worden opgemerkt dat in de figuur ervan is uitgegaan dat de totale kosten meer dan evenredig toenemen met de uitbreiding van de totale hoeveelheid diensten, hetgeen overeenkomt met de ideeën van Tullock hieromtrent. ${ }^{44}$ Het is echter niet gezegd dat de productiekosten van collectieve goederen in werkelijkheid meer dan evenredig toenemen. Gezien het collectieve goed karakter is het niet onwaarschijnlijk dat de totale kosten afnemen of evenredig met de productie stijgen. Voor een markt met volkomen mededinging geldt dat kosteninefficiënte bedrijven door de marktwerking worden weggeconcurreerd. Bedrijven zullen op dergelijke markten dan ook kostenefficiënt handelen. Indien er sprake is van een markt met monopolistische elementen is het mogelijk dat een manager niet altijd de meest optimale inputbeslissing neemt en dat de onderneming opereert op een hogere kostenfunctie. Er is in dat geval sprake van kosteninefficiëntie. In Figuur 10.1 is dat het geval bij bijvoorbeeld een productieomvang tussen $q$ en $\mathrm{r}$ in. ${ }^{445}$

Een interessant verschijnsel doet zich hierbij voor. Budgetmaximalisatie zal veelal gepaard gaan met kostenefficiëntie: Het niet kostenefficiënt produceren kan onder omstandigheden ook voordelen opleveren voor de bureaucraat. 46 Hierbij kan gedacht worden aan een verminderde werkdruk. Bureaucraten streven dan niet alleen naar budgetmaximalisatie maar ook naar "slack". Onder "slack" wordt het verschil verstaan tussen ontvangsten (het budget) en minimale kosten (technische efficiëntie) ${ }^{47}$ Migué en Bélangêr stellen: "The basic idea behind the managerial discretion approach to the analysis of bureaus and non profit institutions is that managers are assumed to derive personal satisfaction from allocating resources of their firm to other than productivity increasing expenses". $48 \mathrm{Zij}$ geven aan dat een bureaucraat zal kiezen voor productie met slack, hetgeen zij aanduiden als discretionaire winst (productieomvang tussen $q$ en $r$ in Figuur 10.1). Het slackbedrag wordt besteed aan zaken als extra personeel en staf, betalingen aan belangengroepen die het bureau steunen etc. De productie is dan kleiner dan in het geval van budgetmaximalisatie tegen een budget dat hoger is dan de kosten. Dit impliceert dat de kostenefficièntie afneemt terwijl de allocatieve efficiëntie toeneemt. Niskanen erkende later overigens dat overproductie en efficiêntie substituten konden zijn. ${ }^{449}$

Conybeare (1983, p. 482).

44 Tullock (1965, pp. 149-150).

${ }^{445}$ Heit bureau produceert dan tegen een budget dat hoger is dan de kosten.

T.a.p., p. 91

4⿻7乛 Migué en Bélangér (1974, pp. 29 e.v.). Zie voor verdere uitwerkingen van het model van Niskanen ook: Williamson (1964), Bush en Span (1977), De Alessi (1969) en Orzechowski (1977).

4 T.a.p., p. 27.

4a9 Niskanen (1975, p. 635). 
Indien een parallel wordt getrokken met de principaal-agent-theorie dan kan worden geconstateerd dat het bureaucratiemodel van Niskanen beschouwd moet worden als een extreme variant van deze theorie. De principaal heeft geen enkele informatie over de verhouding tussen imput en output. Deze theorie kan beschouwd worden als vergaand omdat, zoals in het vorige hoofdstuk reeds is opgemerkt, er veelal een afweging zal worden gemaakt van informatie en kosten. De principaal kan wel aan informatie komen maar daar staan kosten tegenover. Meijdam en Verbon merken op dat de principaal wel allijd een informatie-achterstand zal houden in de vele gevallen dat de overheidsproductie niet in meetbare eenheden plaatsvindt. ${ }^{450}$ Breton en Wintrobe merken op dat politici, indien zij niet over informatie over de kostenfunctie van de bureaucraat beschikken, de betreffende informatie kunnen kopen. Politici kunnen hun preferenties opleggen door allerlei beheersinstrumenten. De uiteindelijke uitkomst is politiek bepaald en wordt dan vermeerderd met het bedrag dat zich niet laat verminderen door controles, aangezien deze teveel kosten met zich mee zouden brengen. ${ }^{45 !}$

\subsection{In hoeverre kan het bureaucratiemodel van Niskanen worden gebruikt om de relaties tussen de actoren binnen het netwerk te verklaren?}

Kraan vermeldt een viertal kritiekpunten op het oorspronkelijke model van Niskanen. Het eerste bezwaar is dat de bureaucraat de politicus kan dwingen om een alles-of-niets beslissing te nemen. De politicus zou dan worden gedwongen om of het door de bureaucraat gewenste productieniveau voort te brengen of om in het geheel niet te produceren. Een tweede kritiek is de veronderstelling dat de bureaucraat alleen zou streven naar budgetmaximalisatie (waarbij met dat budget uiteindelijke doelen als prestige, invloed en salaris gerealiseerd kunnen worden). Migué en Bélangér stellen dat het voorzieningenvolume en de discretionaire beheerswinst de noodzakelijke middelen $z$ ijn om de uiteindelijke bureaucratische doelen af te leiden. ${ }^{452}$ Zij stellen dat de bureaucraat een afweging maakt tussen voorzieningenniveau en discretionaire beheerswinst en dat hij zijn onderhandelingsgedrag afstemt op de gewenste combinatie. ${ }^{453}$

Ook andere vraagtekens kunnen gezet worden bij de maximaliseringsdoelstelling van bureaucraten. Downs onderscheidde een negental motieven van agenten, op grond waarvan zij op een bepaalde manier zullen handelen. Afhankelijk van het gewicht dat een agent aan een bepaald motief toekent kunnen een vijftal persoonlijkheidstypen worden afgeleid. Of de instelling daadwerkelijk streeft naar budgetmaximalisatie hangt dan ook af van aanwezige persoonlijkheidstypen binnen de instelling. ${ }^{454}$ Meer in het algemeen kan gestell dat het voordeel van een groot bureau wordt tegengegalan door het verlies aan controle over het bureau door de manager. Er zal zich een situatie voordoen waarbij nutsmaximaliserende bureaucraten geen verdere budgetmaximalisatie zullen nastreven. ${ }^{455}$

Voorts kumnen op grond van empirisch onderzoek vraagtekens bij de veronderstelling van

\footnotetext{
${ }^{459}$ Meijdam en Verbon, in: Mol en Verbon (1993, p. 94).

451 Vergelijk: Breton en Wintrobe (1975).

${ }^{422}$ Migué en Bélangér (1974, pp. 28-29).

${ }^{453}$ Vgl, ook: Niskanen, in: Blais en Dion (1991).

.454 Downs (1967, p. 143).

*ss Breton en Wintrobe $(1975$, p. 198).
} 
budgetmaximalisatie gezet worden. Deze veronderstelling kan juist zijn binnen een bureau maar lijkt onjuist te zijn tussen bureaus. ${ }^{456}$ De voordelen voor een bureaucraat kunnen in een klein bureau groter zijn dan in een groot bureau. Voorts komt het herhaaldelijk voor dat managers die werkzaam zijn in grote bureaus gaan werken voor een relatief klein bureau. Een en ander suggereert dat de doelstelling van de bureaucraat ongelijk is aan budgetmaximalisatie.

Een derde kritiek betreft de mogelijkheid dat de bureaucraat slechts een beperkte dominantie verwerft of dat de politicus dominant is. Dit laatste impliceert dat de politicus over voldoende informatie beschikt en een zodanig contract kan opstellen dat de bureaucraat zich overeenkomstig de preferenties van de politicus zal gedragen. In de literatuur is veel aandacht besteed aan onderzoek naar het loslaten van de veronderstelling van een passieve sponsor. ${ }^{457}$ Hiertoe is onder meer gebruik gemaakt van speltheorie en van allerlei modellen, zoals bijvoorbeeld het prijsleider-volger-model De uiteindelijke uitkomst hangt vanzelfsprekend sterk af van de gehanteerde modellen en de bijbehorende veronderstellingen. Moene onderzoekt bijvoorbeeld wat het effect is indien de sponsor eencuidig de vaste kosten kent. Hierbij wordt er vanuitgegaan dat de variabele kosten proportioneel zijn met de productie-uitbreiding en dat de spomsor niet exact op de hoogte is van deze variabele kosten. Het is dan mogelijk dat er sprake is van een onderexpansie van het bureau. ${ }^{458}$

Breton en Wintrobe merken op dat bureaumaximalisatie leidt tot een inefficiěnte situatie waarbij de marginale opbrengsten ongelijk zijn aan de marginale kosten. De burgers zullen hierop reageren door bij de verkiezingen op partijen te stemmen die beloven de voorziening in het publieke goed en dienovereenkomstig de belastingen te verminderen. Ook deze partij heeft evenwel te maken met informatieasymmetrie, zodat zij ook weer zal worden weggestemd. Dit impliceert wel, zoals ook Wagner stelt, dat politici een sterke prikkel hebben om gebruik te maken van hun monopoliemacht aan de vraagkant en zich niet passief zullen opstellen. ${ }^{459}$ Of en in welke mate dit het geval is hangt dan ook af van de aard van het kiessysteem. 460

Miller en Moe merken op dat een bilateraal monopoliespel in feite onbepaald is. "Depending upon their relative skills and resources, rational behavior may lead to outcomes falling anywhere between (or including) two extremes: one at which the monopolist gains. maximum advantage by acting with full knowledge of the monopolist's reaction curve, and one at which such adwantages accrue only to the monopsonist" 461 Ten aanzien van de vraag waar precies de uitkomst bereikt wordt merken zij op dat dit vooral afhangt van de mate waarin de ene actor leert over de reactiecurve van de andere.

Een vierde kritiekpunt heeft betrekking op de relatie tussen beide partijen ${ }^{462}$ Kraan

496 Breton en Wintrobe (1975, p. 204).

457 Zie bijwoorbeeld: Miller (1977, pp. 37-51), Miller en Moe, (1983, pp. 297-322), Moene (1986, pp. 333-

345) en Hassapis (1996, pp. 157-174).

458 Moene (1986, paragraaf 3).

$4 \leqslant 9$ Vergelijk hoofdstuk 7 over de spreiding van eigendomsrechten.

460. Vergelijk paragraaf 4.

${ }_{461}$ Miller en Moe (1983, p. 308).

4 Kriz Kraan, in: Mol en Verbon (1993, paragraaf 7.3). 
merkt op dat indien er sprake is van effectieve hiërarchie (in de betekenis dat de politicus eventueel kan ingrijpen in het productieproces) er in feite al geen sprake meer is van een bilateraal monopolie. Informatie kan dan gebruikt worden om de ander te dwingen tot een bepaalde handeling: Dit is niet het geval bij onafhankelijke partijen.

Vervolgens zal worden ingegaan op een aantal andere punten van kritiek. Onder meer wordt onderzocht hoe de netwerkbenadering zich verhoudt met imperfecte informatie en meer in het bijzonder met het bureaucratiemodel van Niskanen met asymmetrische informatie.

\section{Imperfecte Informatie}

Van imperfecte informatie is sprake indien niet alle informatie die relevant is voor de actoren voorhanden is. Imperfecte informatie kan onder andere veroorzaakt worden door de complexiteit van het (markt)systeem, door het bestaan van onzekerheid, door ondoorzichtigheid van het besluitvormingsproces van andere actoren of door incompleetheid van de informatie. De vraag rijst in hoeverre actoren incomplete informatie hebben. Van incomplete informatie is sprake indien spelers sommige elementen van de spelregels niet kennen. ${ }^{463}$ Niet alle randvoorwaarden van het (markt)proces zijn in dat geval bekend. Met betrekking tot de ontwikkelde netwerkbenadering kan de vraag worden gesteld in hoeverre de actoren elkaars doelfuncties kennen. In het in dit deel ontwikkelde model lijkt het redelijk om ervan uit te gaan dat de actoren inderdaad op de hoogte zijn van elkaars waarderingen van de doelen of in elk geval een waarschijnlijkheidsverdeling daarvan kunnen opstellen. Een groter probleem levert aanwezigheid van imperfecte informatie op. In het geval van imperfecte informatie gaat het er vooral om dat actoren het feitelijke gedrag van anderen niet volledig kunnen inschatten. Een belangrijke vorm van imperfecte informatie heeft betrekking op de aanwezigheid van asymmetrische informatie. Onder asymmetrische informatie wordt de situatie verstaan waarin de ene kant van de markt complete informatie heeft en de andere gekarakteriseerd wordit door incomplete informatie of de situatie dat sommige actoren informatie hebben waarover andere actoren aan dezelfde kant van de markt niet beschikken. ${ }^{464}$ Zoals in het kader van de principaalagent benadering is aangegeven betekent dit dat de informatie niet kosteloos beschikbaar is voor de sponsor. De sponsor zal een afweging moeten maken van de marginale kosten en baten van het verwerven van extra informatie. In het navolgende wordt verder ingegaan op het bureaucratiemodel van Niskanen en zal een link gelegd worden met het probleem van asymmetrische informatie.

Het model van Niskanen kan gezien worden als een bijzonder geval van ons gedragsmodel. In werkelijkheid is er niet een situatie van twee monopolisten (c.q. twee groepen) maar zijn er tal van actoren die elk een beleid voeren of trachten te voeren. Peirce merkt in dit verband op: "Since hierarchical control breaks down and incentive systems are applied sporadically, the bureaucrat's behavior will often be determined by his own preferences". 465 "Deze actoren kunnen zich als groep gedragen als een monopolist maar het is niet gezegd dat zij dat doen. Dit zal vooral het geval zijn indien er relatief weinig actoren zijn en de organisatie relatief klein is. Niskanen behandelt de verschillende groepen actoren in feite als een "black box". Teneinde te ontdekken hoe een overheidsinstel-

\footnotetext{
Arrow en Scitovsky (1969, p. 384).

4 McKenna (1986, p. 19).

45. Peirce (1981, p. 37).
} 
ling functioneert is het juist ook belangrijk hoe deze actoren binnen deze "black box" zich gedragen en is het onjuist van te voren een bilateraal monopolie te veronderstellen. Breton en Wintrobe stellen in dit verband. "A bureaw may be a monopoly, but individual bureaucrats are not monopolists, (...)." Zij merken verder op dat competitieve "rent-seeking" tussen de bureaucraten binnen een bureau ertoe kan leiden dat het bureau niet streeft naar budgetmaximalisatie. ${ }^{466}$ Daarnaast kan er potentieel of feitelijk concurrentie zijn tussen verschillende bureaucraten en verschillende sponsors en tussen verschillende actoren binnen de sponsor. Niskanen ziet dit blijkbaar ook in, aangezien hij in het laatste deel van zijn boek ingaat op "committees" binnen de sponsor en onderzoekt in hoeverre de belangen van de wetgever, "committee" en bureau met elkaar overeenstemmen. ${ }^{467}$ Voorts benadrukken veel studies die gewijd zijn aan de invloed van concurrentie, dat de technische efficiëntie van overheidsinstellingen verbetert indien deze gedwongen worden te concurreren met particuliere bedrijven. ${ }^{468}$ Hierbij moet benadrukt worden dat, aangezien nut niet opgeteld kan worden, het in de praktijk ook niet mogelijk is een geaggregeerde nutsfunctie op te stellen. Onder stringente voorwaarden is het slechts mogelijk om een schatting te maken van de preferenties van de principaal of het bureau.

Voorts dient beseft te worden dat politici, zoals in hoofdstuk 5 is aangegeven, in een politiek systeem met coalitieregeringen niet per definitie de preferenties van de consumenten naar bijvoorbeeld collectieve goederen nastreven. $\mathrm{Zij}$ streven ook eigen doelen na, in die zin is er sprake van producentensoevereiniteit. Voor zover dat het geval is lijkt het dan ook onjuist de politieke optimale situatie aan te duiden als allocatief efficiênt:

Het Niskanen-model houdt zoals vermeld rekening met imperfecte informatie, meer in het bijzonder met asymmetrische informatie. Niskanen realiseert dit door invoering van de veronderstelling dat de sponsor de kostenfunctie van de bureaucraat niet kent terwijl de bureaucraat de waardering van de output door de politicus wel kent. Deze informatieasymmetrie leidt ertoe dat de doelfunctie van de bureaucraat gerealiseerd wordt. Hoewel het onwaarschijnlijk lijkt dat een van beiden zijn doelfunctie volledig kan realiseren, ${ }^{4}$ kan informatie-asymmetrie er wel toe leiden dat een van de partijen in werkeliikheid belangrijker is voor de doelbepaling van de overheidsinstelling. Ook in dit geval is het mogelijk dat een verschil wordt gevonden tussen de doelen van de eigenaren en de doelrealisatie. Dit verschil hoeft zich niet voor te doen indien de toegang tot specifieke informatie ook als een eigendomsrecht wordt beschouwd. Voorts kan worden opgemerkt dat indien in het Niskanenmodel de "performance" van een overheidsoverheidsinstelling wordt gemeten, uitgegaan zal worden van de doelen die de politicus heeft ten aanzien van het bedrijf. Vaak zal dan worden geconstateerd dat de "performance" tekortschiet omdat de bureaucraat tegenwerkt. In de in dit onderzoek geformuleerde benadering is er evenwel vanuitgegaan dat ook actoren binnen een owerheidsinstelling dragers kunnen zijn van (gedelegeerde) eigendomsrechten (bijwoorbeeld het recht op de winst, het recht om zelf personeel aan te stellen en te ontslaan) en dat zij in die hoedanigheid mede de doelen van een overheidsinstelling bepalen. Indien de politicus slechts gedeeltelijk erin slaagt de bureaucraat overeenkomstig zijn preferenties te laten gedragen betekent dit geenszins dat de

Breton en Wintrobe $(1982$, p. 198).

4 Niskanen (1971, pp. 219 e.v.).

468 Vergelijk ten aanzien van de Canadese spoorwegen: Caves en Christenson (1975, pp. 64-92).

4* Miller en Moe stellen in dit verband: "Budgets and service levels, after all, are not really bureaucratic decisions-they are joint decisional outcomes that arise from bureau-legislature interaction, and they showld be modelled as such." Miller en Moe (1983, p. 298). 
"performance" van de overheidsinstelling tekortschiet. Er kan dan toch sprake zijn van een efficiënte allocatie, aangezien de politicus wellicht slechts over een (aanzienlijk) deel van de eigendomsrechten zall beschikken. De doelen van de eigenaren worden dan wellicht wel bereikt. Hierbij dient voorts te worden gerefereerd aan hetgeen in het begin van dit hoofdstuk werd opgemerkt, inhoudende dat het bureau, zoals voorgesteld in het bureaucratiemodel van Niskanen, geen eigendomsrechten heeft op een eventueel exploitatie-overschot/winst (recht van vruchtgebruik). Dit leidt, volgens Niskanen, de bureaucraat ertoe zijn onderhandelingspositie uit te buiten en te streven naar budgetmaximalisatie. Indien evenwel de bureaucraat zich de voordelen van het bureau ook op andere wijze kan toeëigenen, bijvoorbeeld door de winst in te houden en te gebruiken voor zijn doelen, verdwijnt de prikkel om te streven naar budgetmaximalisatie. Dit komt overeen met hoofdstuk 7, waarin in het kader van de verdeling van eigendomsrechten, werd opgemerkt dat het toekennen van het recht op vruchtgebruik onder omstandigheden kan leiden tot: efficiëntieverbetering. Het is dan veel minder in het belang van de bureaucraat om naar budgetmaximalisatie te streven, aangezien de winst dan verdwijnt.

Verder kan nog worden opgemerkt dat de passieve rol van de sponsor voomamelijk wordt veroorzaakt door de informatieasymmetrie. In werkelijkheid heeft de sponsor echter tal van instrumenten om het gedrag van de bureaucraat te beïnvloeden en informatie te verwerven. ${ }^{470}$ Downs noemt bijvoorbeeld de mogelijkheid van het instellen van meerdere gedeeltelijk met elkaar concurrerende bureaus en het verwerven van informatie via alternatieve bronnen. ${ }^{471}$ Deze instrumenten gaan evenwel gepaard met kosten. De sponsor zal dan ook een afweging moeten maken tussen enerzijds de baten van de instrumenten en anderzijds de kosten ervan. Het gaat daarbij om de afweging van de toename van het consumentensurplus versus de kosten van de instrumenten. Het voor de sponsor optimale budget van het bureau is nu het allocatief efficiënte budget vermeerderd met het bedrag van het budget dat voor hem te duur zou zijn om door middel van allerlei instrumenten te elimineren. Het zal zich mogelijk ergens tussen beide evenwichten (voor politicus en bureaucraat) in bevinden, afhankelijk van de hoogte van de kosten van de instrumenten. Indien de marginale kostencurve bijvoorbeeld boven de marginale opbrengstencurve van het gebruik van deze instrumenten ligt, zall de budgetmaximaliserende situatie bereikt worden. Breton en Wintrobe merken op dat voor het elimineren van overproductie de sponsor informatie moet hebben over de werkelijke kostenfunctie van het bureau, terwijl zij voor het verminderen van $\mathrm{X}$-inefficiëntie informatie moet hebben over de werkelijke minimumkosten van de voorziening in het betreffende goed/dienst. Aangezien het duurder is om $X$-inefficiëntie te reduceren zou de voornaamste bron van inefficiëntie binnen bureaus $X$-inefficiëntie zijn en niet een overaanbod van cen bepaalde voorziening.

Overigens moet hierbij worden opgemerkt dat sommige economen menen dat het gebruik van controle-instrumenten door de sponsor in feite een verspilling van hulpbronnen vormt. ${ }^{472}$

Hierbij moet worden opgemerkt dat het te eenvoudig is om te stellen dat in het geval van allocatief efficiënte productie een bepaalde hoeveelheid, in Figuur 10.2 hoeveelheid w, moet worden gerealiseerd en dat overige geproduceerde hoeveelheden inefficiënt zijn. In dat punt geldi dat de marginale baten voor de politicus en de marginale kosten voor de

\footnotetext{
470 Vergelijk in dit verband ook: Hassapis (1996, paragraaf 3).

${ }^{471}$ Downs (1967, p. 193, zie ook Hoofdstuk 22).

472 Vergellijk ook: Thompson en Zumenta (1981, pp. 25-50).
} 
bureaucraat aan elkaar gelijk zijn. Het betreft hier immers alleen het eigenlijke doel. Zoals opgemerkt streeft een overheidsinstelling in werkelijkheid meerdere doelen na met hetzelfde budget. Dit betekent dat op grond van allocatieve efficiëntie-overwegingen wellicht niet punt $\mathrm{w}$ bereikt wordt maar voor een ander goederenpakket moet worden gekozen. Er moet gekeken worden naar de totale marginale baten en marginale kosten voor alle relevante actoren en van alle doelen en niet alleen van de politicus. Dit kan worden geillustreerd met de volgende figuur:

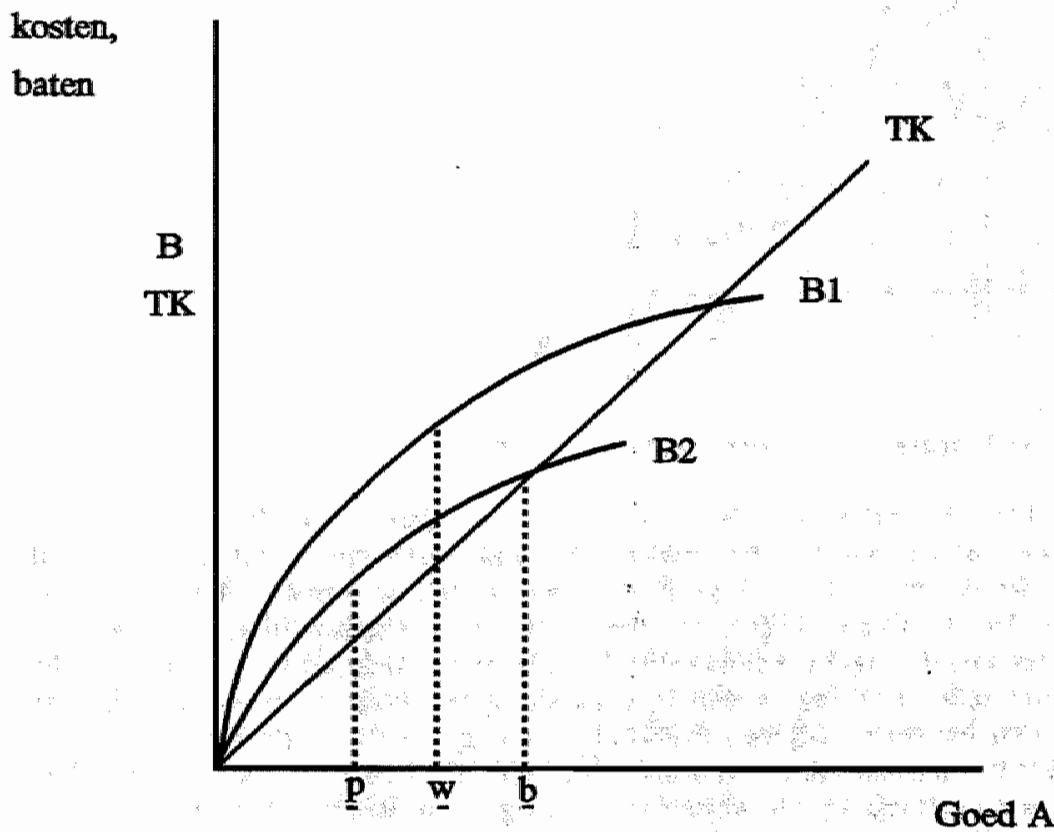

Figuur 10.2 Niskanenmodel en overheidsinstellingen.

Voor het betreffende goed wordt slechts een deel van het budget gebruikt. In werkelijkheid is zoals weergegeven in de grafiek, voor het goed niet budget 1 maar budget 2 beschikbaar. De rest van het budget is bestemd voor allerlei bijkomende doelen. Nu zou op de $\mathrm{x}$-as de voorziening in alle goederen/doelen kunnen worden geplaatst. Probleem hierbij is evenwel dat veel van de bijkomende doelen (externe effecten e.d.) zich in de praktijk nauwelijks laten waarderen. Anders dan de bureaucratietheorie veronderstelt is niet alleen het productieproces voor de sponsor niet waarneembaar maar is ook de output voor de sponsor in het geval van bijkomende doelen erg moeilijk te bepalen.

Een en ander kan ook worden weergegeven met behulp van de analyse zoals uitgevoerd door Wyckoff met behulp van indifferentiecurven. 


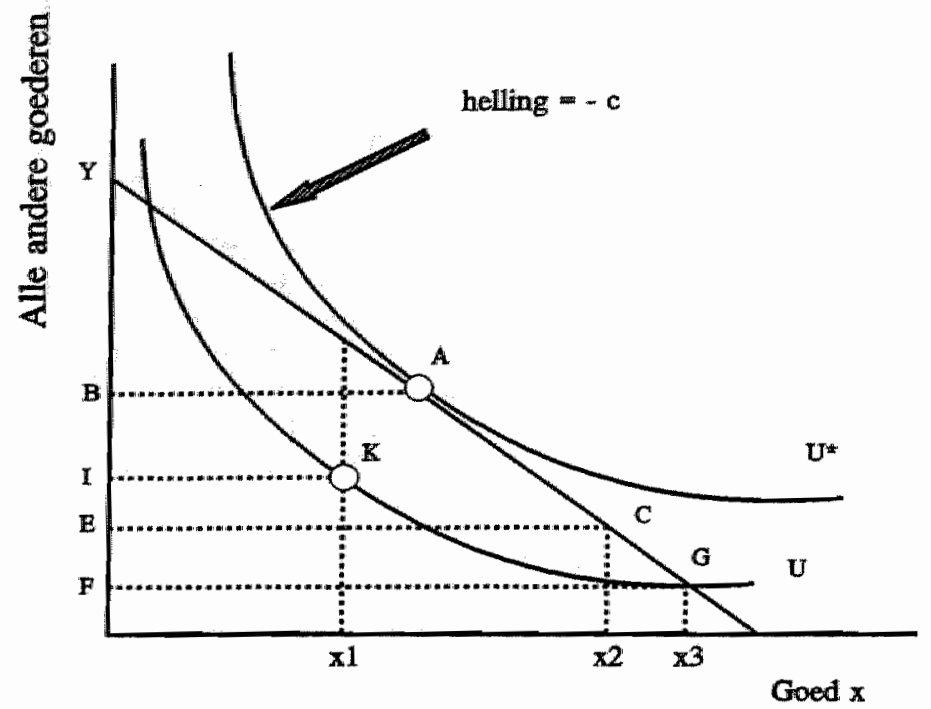

Figuur 10.3 Evenwichtscondities en overheidsinstellingen ${ }^{473}$

Hierbij is u de indifferentiecurve van de principaal, de politicus en is de curve YG het budget waarover de bureaucraat kan beschikken. Verondersteld wordt dat de principaal een keuze maakt tussen het goed dat door de overheidsinstelling wordt geleverd en alle andere goederen. Uit de figuur blijkt dat indien de overheidsinstelling een punt $\mathbb{K}$ realiseert, er een maximaal mogelijke hoeveelheid slack optreedt, in de zin van technische inefficiëntie. De overheidsinstelling is dan in staat de sponsor meer te rekenen dan de werkelijke kosten van het goed. Bij een overheidsinstelling zal dit in de regel het geval zijn. De slack wordt nu niet alleen gebruikt door de agenten om allerlei voor hen relevante doelen na te streven (zoals gesteld door Migué en Bélangér) alswel door de eigenaren om hun doelen na te streven. Hierbij gaat het om allerlei bijkomende doelen als de werkgelegenheid en de ontwikkeling van een regio. Het is dan waarschijnlijk dat er bij een overheidsinstelling die opereert in een competitieve markt of die dient als inkomstenbron voor de overheid niet of nauwelijks "slack" optreedt.

Uit verschillende empirische studies blijkt dat de productie van bureaus veelal groter is dan de productie die een budgetmaximaliserende bureaucraat zou voortbrengen. 774 Dit lijkt paradoxaal en moeilijk verklaarbaar, maar is goed te verenigen met de in dit deel geschetste benadering. Bijkomende doelen zoals in hoofdstuk 2 uiteengezet zijn vaak verbonden aan de productie van het eigenlijke doel, waarbij de externe effecten belangrijke neveneffecten vormen. Doel van de grote productie van het goed is dan niet zozeer de voorziening van het eigenlijke goed (bijvoorbeeld elektriciteit) alswel bijvoorbeeld inkomensverdeling. Bijkomende doelen zijn dan gekoppeld aan het eigenlijke doel. Figuur 10.3 moet dan zodanig worden geînterpreteerd dat de "slack" gebruikt wordt voor bijvoorbeeld herverdeling of de voortbrenging van externe effecten. In de figuur wordt het budget gebruikt voor de voortbrenging van bijkomende doelen, door middel van de

\footnotetext{
${ }^{473}$ Deze figuur is ontleend aan Wyckoff $(1990$, p. 37).

476 Vergelijk ook: McGuire (1981, pp. 316-318).
} 
productie van goed $\mathrm{x}$. Dat er in dat geval erg veel van een goed wordt voortgebracht is niet verwonderlijk. ${ }^{475}$

Verder geldt voor een overheidsinstelling dat de sponsor slechts eén van de financieringsbrommen van het bedrijf is. Het verstrekken van subsidies laat zich in Figuur 10.2 illustreren met een evenwijdige verschuiving omhoog van de budgetlijn. ${ }^{46}$ Indien de bureaucraat naar budgetmaximalisatie streeft zou een punt rechts van $G$ bereikt worden, in het geval van "slack" maximalisatie blijft punt $\mathbf{K}$ de uitkomst. De "slack" neemt evenwel toe wan punt $\mathbf{K}$ tot een punt op de hogere budgetlijn, gesteld dat de principaal nog steeds een mutsniveau ter grootte van u nastreeft. In feite betekent dit niets anders dan dat het bedrag dat beschikbaar is voor bijkomende doelen toeneent. Naast subsidies door de overheid, veelall verwerkt in een begroting, raamt de overheidsinstelling de inkomsten van het verkopen van het produkt aan klanten. Soms worden deze tevens in de begroting van een overheidsinstelling opgenomen. Vaak zal dit evenwel niet het geval zijn (collegegelden worden bijwoorbeeld geind door de universiteit, maar zijn eigendom van de overheid). Een overheidsinstelling in BV- of NV-vorm verwerft meestal eigen inkomsten en is dan ook slechts beperkt aangewezen op de sponsor. Hierbij kan bijvoorbeeld gedacht worden aan de NS, die door de overheid wordt betaald om bepaalde onrendabele lijnen te exploiteren. Als een derde financieringsbron voor overheidsinstellingen is de public enterprise rent van belang. Het totale budget van een overheidsinstelling bestaat dan ook in feite uit deze drie bronnen, waarvan dus slechts een gedeelte van de overheid afkomstig is. De bijkomende doelen worden dan gefinancierd door de subsidies van de overheid en de public enterprise rent.

Tenslotte kan als laatste aanvulling worden opgemerkt dat hoewel het wel mogelijk is om met behulp van een algemene theorie een aantal verbanden ten aanzien van het gedrag van overheidsinstellingen in het algemeen weer te geven, het niet mogelijk is om op grond van een theorie uitspraken te doen over het specifieke gedrag van een overheidsinstelling, aangezien in werkelijkheid overheidsinstellingen van instelling tot instelling verschillen. Dit gedrag dient dan ook van bedrijf tot bedrijf nader te worden onderzocht door het analyseren van de "performance" ervan. Miller en Moe merken in dit verband op: "The interesting question, then, is not whether we have a "bureaucracy problem" but where and to what extent the problem surfaces". ${ }^{477}$. Dit sluit aan bij de ontwikkeling van de laatste decennia waarbij het onderzoek naar het functioneren en de prestatie van overheidsinstellingen steeds meer verschoven is van normatief en theoretisch naar positief en empirisch onderzoek. Dit komt ook overeen met hetgeen organisatiedeskundigen veelal stellen, namelijk dat het meestal niet mogelijk is standaardgedragskenmerken af te leiden van de mutsfuncties van individuen. De doelfuncties van de relevante actoren zullen steeds per geval onderzocht moeten worden, waarbij de in dit deel ontwikkelde theorie als analyseschema kan dienen.

Indien deze overwegingen worden gecombineerd met de standaardbezwaren die tegen het Niskanenmodel worden aangevoerd, dan blijkt dat dit model slechts beperkt bruikbaar is voor het verklaren van de relaties binnen een netwerk. Voorts kan de vraag worden

475 T.a.p., pp. 312-322.

476 Niskanen duidt een bureau die gedeeltelijk door sponsors en gedeeltelijk door verkopen wordi gefinancierd aan met "mixed bureau". Hij stelt: "In effect, a mixed bureau sells the same output to two groups of customers-one group represented by the collective sponsor of the bureau; and the other the group that directly purchases a service at a per-unit rate". Niskanen (1971, p. 87).

47 Miller en Moe (1983, p. 32i). 
gestell in hoeverre het waarschijnlijk is dat een overheidsinstelling in de praktijk veel te groot zall zijn. Bureaucraten zullen vaak niet (alleen) naar budgetmaximalisatie streven. Een overheidsinstelling zal in een aantal gevallen met een zekere mate van concurrentie geconfronteerd worden met andere overheidsinstellingen en particuliere bedrijwen, terwijl de sponsor een redelijke schatting kan maken van de kosten van het eigenlijke doel en daarmee in feite ook van de bijkomende doelen. Dit komt voor een deel omdat de sponsor over allerlei instrumenten beschikt om informatie te verwerven. Indien de principalen het idee krijgen dat op een andere wijze de bijkomende doelen goedkoper kunnen worden voortgebracht hebben zij een sterke prikkel om hiertoe over te gaan. De alternatieve mogelijkheden van de overheid om de doelen te realiseren vormen waarschijnlijk de belangrijkste restrictie op eventueell budgetmaximaliserend of slackmaximaliserend gedrag van het management van de overheidsinstelling.

Voorts zijn er tal van principaal-agent-verhoudingen binnen een netwerk, waarbij vaak geen symmetrische monopoliepositie zal ontstaan. Daar komt mog bij dat de eigenaren de "slack" gebruiken voor het nastreven van bijkomende doelen. Zij proberen zoveel mogelijk van de "public enterprise rent" te bestemmen voor groepen en individuen die zij willen steunen (leveranciers, consumenten e.d.), omdat zij daar later een tegenprestatie van verwachten, bijvoorbeeld in de vorm van steun bij verkiezingen. Het zal door deze factoren dan ook meevallen met de mate warin overheidsinstellingen te groot worden in verhouding tot de preferenties van de sponsors. Op grond van de tot dusver ontwikkelde theorie kan tevens worden opgemerkt dat privatisering niet noodzakelijk tot een efficiëntere situatie leidt. ${ }^{478}$ Hetzelfde geldt voor de introductie van meer competitie binnen de publieke sector. Het voornaamste effect hiervan zal zijn, zoals we bijvoorbeeld kunnen zien bij de NS, dat het nastreven van bijkomende doelen sterk zal worden verminderd. Ook in het geval van dergelijke maatregelen is er derhalve sprake van "rent-seeking" en is het vooral de vraag wie er op vooruit en wie er op achteruitgaat gaat en niet zozeer in hoeverre de technische efficiëntie verbeterd: Dat de technische efficiëntie verbetert lijkt waarschijnlijk. Zoals eerder is aangegeven hoeft dit evenwel geen Pareto-verbetering te zijn, aangezien sommigen er op wooruit gaan terwijl anderen erop achteruit gaan. Voorts zal het niet altijd mogelijk zijn om uit de efficiëntieverbetering degenen die er op achteruit gaan te compenseren overeenkomstig het compensatieprincipe van Kaldor. ${ }^{479}$

Of dit al dan niet het geval is kan uiteindelijk alleen worden onderzocht door de kosten van de bijkomende doelen te analyseren en door te bezien in hoeverre hier efficiëntieverbeteringen zijn te behalen.

Eén en ander overziend is het met name de wetgever die verantwoordelijk is voor een eventuele te grote overheid, aangezien zij de bestaande eigendomsrechtenstructuur, de besluitvormingsprocessen en de bijbehorende "incentive structuur" in het leven heeft geroepen en niet zozeer de overheidsinstellingen. ${ }^{480}$

\footnotetext{
21. Vergelijk: Miller en Moe (1983, p. 297, en pp. 320 e.v.), Zie ook Ministerie van Financiën (1997), p.
$47 \%$ Indien een bepaalde staat van de wereld zoveel beter is dan een andere dat degenen die er op acheruit gaan gecompenseerd kunnen worden, moet deze staat worden gekozen, zelfs als de feitelijke compensatie niet pllaatsvindt. Kaldor (1939, Pp. 550-551). Scitovsky voert een aantal bezwaren aan tegen dit criterium. Afgezien van ethische problemen is het mogelijk dat $x$ geprefereerd wordt boven $y$ en $y$ boven $x$. Dit hoef zich niet voor te doen. Het is echter mogelijk dat de preferenties van individuen zodanig zijn dat de sociale keuzes inconsistent worden. Vgl. Scitovsky, opgenomen in: Arrow en Scitovsky (1969, p. 400).

40rgelijk ook: Barzel (1989, pp. 102-103). 

ken?

In hoofdstuk 9 is in het kader van de principaal-agent-theorie opgemerkt dat een beschrijvende benadering zal worden gevolgd. $\mathrm{Na}$ behandeling van de principaal-agent-theorie en het model van Niskanen kan verder worden ingegaan op de strategische interacties van actoren binnen het netwerk. De vraag rijst in hoeverre de speltheorie meer inzicht hierin kan geven en daarmee in het gedrag van overheidsinstellingen: ${ }^{481}$ Het gedrag van de eigenaren zou gemodelleerd kunnen worden door middel van een speltheoretisch model, waarbij de behandelde theorie over de relaties binnen het netwerk als uitgangspunt kan dienen. Opgemerkt dient te worden dat het niet de bedoeling van deze paragraaf is om een volledige uitwerking te geven van de speltheorie. Doel is slechts om een globaal overzicht te geven van de bijdrage die de speltheorie kan leveren bij het verklaren van de interacties binnen het netwerk.

Harsanyi omschrijft de speltheorie als: "a theory of strategic interaction". ${ }^{482}$ Als grondlegger van de speltheorie kunnen Von Neumann en Morgenstern worden beschouwd. ${ }^{483}$

De wettelijke regelingen, statuten en richtlijnen van het netwerk vormen de spelregels, de structuur van het spel. Binnen dit kader is er sprake van strategische interactie tussen spelers. De spelers verschillen qua macht en invloed en onderling zijn er bepaalde relaties. Spelers doen bepaalde zetten, verwachten bepaalde tegenzetten en anticiperen hierop. Als uitgangspunt kan een netwerk/spel met een tweetal spelers genomen worden, hetgeen aansluit bij de in hoofdstuk 9 uiteengezette principaal-agent-benadering. Hierbij wordt er vanuit gegaan dat er sprake is van een non-coöperatief spel. Dit betekent dat spelers niet samen kunnen werken, ook al zouden zij dit willen. Ordeshook geeft aan dat het vaak niet eenvoudig is te kiezen tussen een coöperatief of non-coöperatief spel omdat het veelal moeilijk is om de vraag te beantwoorden of actoren de wijze waarop zij zullen stemmen van te voren met andere actoren bespreken. Voorts is het dikwijls moeilijk om bijvoorbeeld de vraag te beantwoorden of tegenstanders gezamenlijk actie hebben ondernomen. Ordeshook stelt in dit verband: 484 "Answering such questions may be difficult. Thus, any choice between a noncooperative and cooperative formulation of a situation may be debatable. Indeed much recent theorizing about coalition formation proposes adapting noncooperative concepts to cooperative solutions. Leaming to walk before we run, however, we define a noncooperative game as a situation in which people must choose without the opportunity for explicitly coordinating their actions". Derhalve zal het netwerk vooralsnog worden geanalyseerd als zijnde een non-coöperatief spel.

Binnen het netwerk bestaan er verschillende typen spelers 1 en 2 . Speler 2 weet niet precies welk type speler 1 is en vice versa. Elk type verschilt bijvoorbeeld ten aanzien van de verwachtingen die hij over de andere speler heeft. De gevolgde veronderstelling is dan ook dat niet zozeer de actor het onderwerp van analyse is (de "player centered" benadering) alswel het type speler ("type centered benadering"). ${ }^{45}$ Stel dat nu een bepaald type speler 1 en een bepaald type speler 2 actief zijn. Dit zijn in dat geval de actieve typen. Harsanyi merkt op dat de "pay off" van een actieve speler afhangt van zijn

\footnotetext{
431 Vergelijk in dit verband: Lynn (1993) en Pappi, Knoke en Bisson (1993).

4 Harsanyi (1995, p. 292).

48i Von Neumann en Morgenstern (1947).

484 Ordeshook (1986, p. 99).

Harsanyi (1995, p. 295).
} 
strategie en van het type speller dat hij is. ${ }^{486}$ De veronderstelling is nu dat elke speler de vorm van zijn "pay off" functie kent, zij het dat hij niet weet hoe de "pay off" functie van een andere speler eruit ziet. Hij weet ook niet wat voor type speler de andere speler vertegenwoordigt. De informatie is dus niet alleen incompleet maar ook imperfect. ${ }^{487}$. Een speler heeft slechts beperkte informatie over de zetten die een andere speler zal doen.

Analoog aan de benadering van Harsanyi kan mu een loterij worden toegevoegd. ${ }^{48}$ Tijdens het begin van het spel wordt door middel van een loterij een bepaald type speler gekozen. Er is een bepaalde waarschijnlijkheid dat dit bepaalde type speler in een dergelijke loterij gekozen wordt en dus operationeel is. Deze waarschijnlijkheid kan worden weergegeven in een waarschijnlijkheidsmatrix. Elke speler maakt een schatting van de waarschijnlijkheidsverdeling met behulp van de informatie waarover hij beschikt: Door het toevoegen van een loterij ontstaat er een spel met complete informatie. Enerzijds omdat nu gedurende het spel met behulp van de loterij bepaalde typen spelers gekozen wordt. Aangezien dit gedurende het spel gebeurt vormt de selectie van spelers niet langer een onderdeel van de mathematische structuur van het spel. Anderzijds zijn de waarschijnlijkheden bekend aan iedere speler. De informatie is nog wel imperfect aangezien spelers slechts tot bepaalde hoogte weten welke typen spelers door middel van de loterij worden gekozen. Hoe weet speler 1 nu dat speler 2 van een bepaald type is? Speler 1 kan eem schatting maken van de kans dat speler 2 van een bepaald type is, gegeven het feit dat hij zelf van een bepaald type is (waarvan bij op de hoogte is). Met behulp van deze waarschijnlijkheid probeert speler 1 de verwachte waarde van de "pay off" te maximaliseren. Hetzelfde geldt voor speler 2. Met behulp van deze "pay off" functie (de zogenaamde semi-conditionele "pay off" functie) is het mogelijk een serie Nash-evenwichten te formuleren. Harsanyi merkt op dat met een relevante evenwichtsheorie een van deze evenwichten als de oplossing van het spel geselecteerd kan worden. Dit resulteert in een bepaald gedrag van het netwerk.

Het is natururlijk mogelijk dit spel uit te breiden tot een spel met meerdere spelers (" $n$ game"). De analyse verandert hierdoor in feite niet. In plaats van een actieve speler is er nu een actieve set van spelers. Elke set met deze spelers is een "appropriate set". Zo resulteert een familie van "appropriate sets". Met behulp van een loterij wordt ook hier weer een selectie aangebracht en resulteent een bepaalde "appropriate set", de zogenaamde actieve set. Binnen deze set zijn de actieve typen spelers opgenomen. Ook hier is weer de waarschijnlijkheid dat een actieve set gekozen wordt bekend ("conditional probability"). De analyse is verder hetzelfde als in het geval van een netwerkspel met 2 spellers.

Een semiconditionele "pay off" functie kan worden afgeleid. Ook nu gelld dat er sprake is van een spel met complete informatie, zij het dat de informatie nog steeds imperfect is. Spelers maximaliseren hun (semi conditionele) "pay off" functie. Dit resulteert wederom in een serie Nash evenwichten, waarvan met behulp van een geschikte theorie één evenwicht gekozen kan worden. Dit is de oplossing van de interactie van spelers binnen het netwerk. De oplossing van een spel wordt door Ordeshook omschreven als. "We consider the nature of equilibria, some of the conditions under which equilibria exist, and the sense in which we can say that equilibria "solve" games, by which we mean: predict choices and outcomes" Hierdoor resulteert een bepaald gedrag en gegeven de overige

\footnotetext{
486 T.a.p., p. 296.

Repullo (1986, pp. 179-180).

Harsanyi (1995, p. 297).

499 Ordeshook (1986, pp. 97-98).
} 
beperkingen (marktgedrag, transactiekosten e.d.) een bepaalde "performance" .

In deze paragraaf is uitgegaan van een noncoöperatief spel en is derhalve voorbijgegaan aan de vorming van bepaalde coalities van actoren. Ordeshook omschrijft een coalitie als: " (...) an agreement among two or more persons to coordinate their actions (choices or strategies). ${ }^{490}$ Coalities kunnen formeel zijn vastgelegd maar kunnen ook een informeel karakter hebben. Het is denkbaar dat in dat laatste geval coalitievorming zelfs niet waar te nemen is. In deze paragraaf zal verder niet worden ingegaan op de coalitievorming, aangezien deze vanuit theoretisch perspectief weinig toevoegt aan het behandelde spel. Ordeshook merkt in dit verband op." "Despite the importance of the concept of a coalition to politics, in a theoretical sense communication and the coordination that communication makes possible add nothing new to game theory". ${ }^{491}$ Verder stelt hij dat elk evenwicht dat bereikt wordt, of dit nu op een coöperatieve wijze bereilkt wordt of niet, een noncoöperatief evenwicht moet zijn omdat een coalitie alleen stabiel is indien geen van de leden van de coalitie een prikkel heeft om naar een andere situatie te streven.

Nu kan met behulp van de behandeling van de speltheorie en het geschetste spel (zonder expliciet in te gaan op coalitievorming binnen het netwerk) een antwoord gegeven worden op de vraag of speltheorie gebruikt kan worden bij het verder analyseren van de relaties binnen het netwerk. Duidelijk is dat speltheorie een nuttig hulpmiddel kan zijn om de interactie van actoren te modelleren en vooral om de uitkomst daarvan te analyseren. Een probleem van veel modellen is dat meestal niet één evenwicht resulteert. Screpanti en Zamagani verwoorden dit bezwaar als volgt: "The modern theory, although it has pushed the original ideas of Von Neumann and Morgenstern far forward, has encountered formidable problems. For example, even in the field of ca-operative games there is usually a multiplicity of possible equilibria. The number and the nature of the equilibria associated with a certain game will thus be determined by the particular interpretation of the game, the set of strategies available to the players, and the rationality criteria to which they adhere. There is no universally valid criterion of choice". ${ }^{492}$

Een belangrijke beperking is echter de empirische toepasbaarheid, ondermeer omdat veel speltheorie normatief is. ${ }^{493}$ Daar komt bij dat een speltheoretisch model weinig waarde heeft zonder een solide theoretische achtergrond.

400 Harsanyi (1995, p. 302).

49 T.a.p., p. 303.

492 Screpanti en Zamagni (1993, p. 394).

493 Vergelijk: Sugden (1995, pp. 534-535). Hij stelt in dit verband: "My approach, like that of classical gane theory, will be normative". 
8 


\section{Hoofdstuk 11. Hoe beinvloeden de transacties tussen de actoren het ge- drag en de "performance" van een netwerk?}

\subsection{Inleiding}

In dit hoofdstuk zal verder worden ingegaan op de (ruil)transacties tussen de houders van de eigendomsrechten binnen het netwerk. Allereerst wordt de transactiekostenbenadering uiteengezet voor zover deze van belang is voor een overheidsinstelling. Vervolgens wordt bezien in hoeverre deze benadering in de netwerkbenadering van overheidsinstellingen kan worden geïntegreerd. Tenslotte worden de effecten van de transactiekosten op het gedrag van een overheidsinstelling geanalyseerd.

De neo-klassieke theorie abstraheert van het bestaan van transactiekosten en onderscheidt slechts de productiekosten. Transactiekosten ontstaan indien een aantal veronderstellingen wordt losgelaten. In de eerste plaats brengt het verzamelen van informatie over potentiële contractpartners kosten met zich mee, in de tweede plaats zijn onderhandelingen niet kosteloos en tenslotte kunnen er zich na het sluiten van het contract meningsverschillen voordoen. Teneinde de uitvoering van een transactie zo goed mogelijk te laten verlopen zullen voor en na het afsluiten van transacties kosten moeten worden gemaakt.

Coase stelde dat transactiekosten dermate groot kunnen worden dat transacties binnen organisaties voordelen opleveren ten opzichte van transacties via markten. ${ }^{494}$ Hij maakt onderscheid tussen marktcoördinatie en het afstemmen van activiteiten binnen een onderneming.

De beslissing om een bedrijf op te zetten of voor een bedrijf om al dan miet verticaal te integreren is uiteindelijk een beslissing over het al dan niet gebruik maken van markttransacties. ${ }^{495}$ Williamson stelt: "The usual study of economizing in a production function framework is thus extended to include an examination of the comparative costs of planning, adapting, and monitoring task completion under alternative governance structures". 496

In het kader van de transactiekostenbenadering staan de mate waarin transacties en de afspraken omtrent transacties efficiënt zijn centraal. Transactiekosten zijn dan ook niet alleen de kosten van transacties maar ook de kosten van wijziging van de eigendomsrechtenstructuur. Een transactie is in dit verband de overdracht van een goed of dienst via een technisch scheidbare verbindingsschakel, die de overgang van de ene fase van het productieproces naar de andere inhoudt. Bokkes definieert transacties als: "Economische handelingen waarbij minimaal twee actoren vrijwillig overeenkomen om een verandering aan te brengen in hun set van beschikkingsrechten, en wel zodanig dat de nieuwe set van beschikkingsrechten van iedere betrokken actor mede afhankelijk is van beschikkingsrechten die voor die handeling in bezit waren van minstens één van de andere actoren". ${ }^{497}$ Bokkes meent dat transacties niet alleen een ruil van beschikkingsrechten vormen maar dat ook nieuwe beschikkingsrechten kunnen ontstaan.

\footnotetext{
494 Coase (1937, pp. 390-391).

495 T.a.p., pp. 390-392.

Williamson $(1981$, p. 1544).

${ }^{4977}$ Bokkes (1989, p. 25).
} 
Transacties kunnen via de markt alsook binnen organisaties plaatsvinden. In dit verband wordt gesproken van een besturingsstructuur of coördinatiemechanisme ("governance structure"). Coördinatie betekent dat de activiteiten zoals die uit de verdeling van eigendomsrechten en het gebruik daarvan voortvloeien, op elkaar moeten worden afgestemd. Bokkes stelt: "Een coördinatiemechanisme kan daarom beschreven worden in temen wan de verdeling van beschikkingsrechten en wat daarmee gedaan wordt" ${ }^{498}$ Hierbij kan gedlacht worden aan marktprijzen, interne verrekenprijzen en interne processen van planning en "monitoring". Hierbij zal de winstgevendheid van beide methoden moeten worden afgewogen. De reden voor het bestaan van een bedrijf is dan dat de kosten van markttransacties vermeden of beperkt kunnen worden door coördinatie van activiteiten binmen een bedrijf. Indien de kosten van markttransacties hoog zijn faalt de markt en dienen tramsacties geinternaliseerd te worden in een bedrijf. Factoren die derhalve het: ontstaan van bedrijven en verticale integratie bevorderen zijn bijvoorbeeld de kosten van het ontdekken van marktprijzen en onderbandelingskosten om tot marktcontracten te komen. Een factor die de vitbreiding van een bedrijf tegengaat is bijvoorbeeld de grotere kans op fouten indien meer activiteiten worden geïnternaliseerd. Uiteindelijk zal er een evenwicht tot stand komen waarbij de kosten van het intern coördineren van een volgende actie gelijk zijn aan de kosten van marktcoördinatie van die volgende actie. Ook de interne organisatie binnen een bedrijf wordt volgens deze benadering door dergelijke factoren bepaald.

De kernvraag is welke besturingsstructuur tot de laagste som van productie- en transactiekosten leidt, gegeven de verschillende kenmerken van een transactie.

\subsection{Wat wordt verstaan onder de transactiekostenbenadering?}

Grossekettler stelt dat bepaalde transactiekosten een verstorende werking hebben. Deze transactiekosten zijn duidelijk ongewenst. Andere transactiekosten kunnen evenwel een duidelijke functie hebben in een economie en zijn dan ook volgens hem gewenste transactiekosten. "Transaktionskosten stellen in Wirtschaftssystemen nicht nur "Reibung" dar, sondern sind Soziokatalysatoren, die enwïnschte Prozesse wie z.B. das Gewinnen won Markttransparenz aktivieren (niedrige Transaktionskosten) und unenwïnschte Prozesse wie z.B. die Bildung von Preiskartellen inhibieren (hohe Transaktionskosten) ". ${ }^{99}$ Hij gaat er vamuit dat bepaalde transactiekosten een gegeven vormen dat zich niet laat veranderen. Hij noemt het voorbeeld van een verwarmingsinstallatie. Stel dat een bepaalde verwarmingsinstallatie optimaal functioneert indien het 20 graden onder 0 is. Deze temperatuur kan gezien worden als een verstoring en kan worden opgevat als transactiekosten. Deze $-20^{\circ} \mathrm{C}$ in bijvoorbeeld Siberie vormt een gegeven waar niets aan te doen is. Het is nu van belang dat de transactiekosten niet te laag zijn (bijvoorbeeld een temperatuur van $10{ }^{\circ} \mathrm{C}$ ) aangezien de verwarmingsinstallatie dan niet goed werkt. Grossekettler kijkt derhalve vooral naar de constitutionele aspecten, de spelregels en niet zozeer naar de activiteiten binnen die institutie. Wordt één en ander toegepast op netwerken dan is het denkbaar dat bepaalde transactiekosten gegeven zijn, in de zin dat er weinig aan te doen valt. Het is dan mogelijk dat een netwerk beter werkt en een hogere "performance" haalt, indien de transactiekosten hoger zijn. In het navolgende wordt hier aan voorbij gegaan. Centraal staan immers, gegeven de instiutionele structuur, de transacties binnen het netwerk. Transactiekosten zijn dan, zoals zal worden aangegeven, negatief.

\footnotetext{
${ }^{49 \%}$ T.a.p., p. 23.

${ }^{499}$ Grossekettler (1996).
} 
In het navolgende zal worden ingegaan op de transactiekostenbenadering. In het algemeen kunnen binnen de transactiekostenbenadering een tweetal takken worden onderscheiden. Enerzijds de transactiekosten ten gevolge van investeringen in gespecialiseerde inputs, zoals die door Williamson worden benadrukt en anderzijds de transactiekosten die veroorzaakt worden door het niet altijd even goed meetbaar zijn van activiteiten binnen de organisatie. ${ }^{500}$

Allereerst zal ingegaan worden op de eerste stroming. In dit verband zijn de factoren die leiden tot hoge transactiekosten en tot het ontstaan van bedrijven van belang. Willamson onderscheidt ex ante en ex post transactiekosten. Ex ante kosten zijn de werkelijke kosten voor het tekenen van een contract terwijl ex post kosten de werkelijke kosten zijn na het tekenen van het contract. Williamson merkt verder op dat de ex ante kosten mede afhankelijk zijn van de verwachte ex post kosten. ${ }^{501}$ Verschillende soorten ex post kosten worden onderscheiden. In de eerste plaats zijn er de onderhandelingskosten die nodig zijn om bestaande contracten aan te passen, in de tweede plaats de kosten van het opzetten van een beheersstructuur waaraan meningsverschillen kumnen worden voorgelegd, in de derde plaats de kosten van het gebonden zijn aan een contract, terwijl tussentijds de situatie verandert en tenslotte de kosten die nodig zijn om de tegenpartij zodanig aan zich te binden dat zij de verplichtingen nakomt.

De ex ante kosten die betrekking hebben op het beperken van ex post kosten bestaan uit de kosten die nodig zijn voor het overeenkomen van een beheers- en controlesysteem zoals dat aan de orde is gekomen in hoofdstuk 9, dat gewijd was aan de principaal-agentrelaties in het netwerk. Voor de hoogte van deze kosten is het essentieel in hoeverre de prestaties gemeten kunnen worden en of partijen er belang bij hebben om hun verplichtingen na te komen. Deze opvatting van transactiekosten is dermate ruim dat ook het totstandkomen van een verdeling van eigendomsrechten, de kosten van het beheers- en controlesysteem in het kader van de principaal-agent-verhouding en de besluitvormingskosten binnen het netwerk, tot de transactiekosten moeten worden gerekend.

De transactiekostenbenadering maakt onderscheid tussen aan de ene kant een tweetal kenmerken van menselijk gedrag ("human factors") en aan de andere kant een drietal kenmerken van transacties ("environmental factors")..$^{502}$ Dit kan als volgt worden weergegeven:

\footnotetext{
sto Williamson (1985, paragraaf 2.2.).

501 "T.a.p., pp. 28-29.

sog Dietrich (1994, deel 1).
} 


\begin{tabular}{|l|l|}
\hline $\begin{array}{l}\text { Veronderstellingen ten aanzien van het } \\
\text { menselijk gedrag }\end{array}$ & Kenmerken van transacties \\
\hline $\begin{array}{l}\text { Begrensde rationaliteit } \\
\text { (Bounded Rationality) }\end{array}$ & $\begin{array}{l}\text { Specificiteit van activa } \\
\text { (Asset Specificity) }\end{array}$ \\
Opportunisme & $\begin{array}{l}\text { Onzekerheid } \\
\text { Schaal en Frequentie van Transacties }\end{array}$ \\
\hline
\end{tabular}

\section{Tabel 11.1 Transactiekosten, menselijk gedrag en kenmerken van transacties. ${ }^{503}$}

Ten aanzien van het menselijke gedrag gaat de transactiekostentheorie in de eerste plaats uit van opportunisme. 504 Individuen streven naar eigen belang. Dit kan gebeuren met min of meer geoorloofde middelen maar ook met middelen als list en bedrog en het achterhouden van informatie. Onzekerheid en asymmetrische informatie kunnen aanleiding geven tot opportunistisch gedrag. In de tweede plaats gaat de transactiekostenbenadering uit van "begrensde rationaliteit". Een rationaliteitsbegrip is nodig om voorspellingen te kunnen doen over het gedrag van actoren. Begrensde rationaliteit houdt in dat individuen weliswraar naar kostenminimalisatie streven, maar dat dit, aangezien zij niet alle alternatieven kennen noch alle aspecten van wel bekende alternatieven tegen elkaar af kunnen wegen, niet betekent dat de situatie waarbij de kosten minimaal zijn wordt gerealiseerd. Bokkes stelt dat het nodig kan zijn te weten wat voor (bepaalde) actoren rationeel is. Om dat te bepalen zou kunnen worden uitgegaan van een gemiddelde actor in een dergelijke situatie, terwijl het voorts mogelijk is gebruik te maken van vuistregels. ${ }^{505}$

Voorts zijn er een drietal kenmerken van transacties die invloed uitoefenen op de uiteindelijke besturingsstructuur. Een belangrijk kenmerk is dat van de "asset specificity". Activa kunnen onderscheiden worden in activa met een algemeen en een specifiek doel. Activa met een algemeen doel kunnen relatief gemakkelijk, in de zin van zonder veel waardeverlies, gebruikt worden voor andere aanwendingsmogelijkheden, terwijl dat voor specifieke activa veel minder het geval is. Williamson onderscheidt vier soorten van specifieke activa.

In de eerste plaats kunnen de plaatsgebonden activa ("site specificity") worden onderscheiden. Indien de plaats eenmaal gekozen is, zijn de activa immobiel. Hierbij kan gedacht worden aan een elektriciteitscentrale of een hoogoven. In de tweede plaats zijn er specifieke fysieke activa ("physical asset specificity"). Hiervan is sprake indien de partijen of één van de partijen investeren in machines die kenmerken hebben die specifiek zijn voor de transactie en een lagere waarde hebben voor alternatieve aanwendingen. In de derde plaats zijn er menselijke activa die specifiek zijn ("human asset specificity"). Hiervan is sprake indien investeringen in "human capital" nodig zijn. Specifieke vaardigheden ontstaan vaak door een "learning-by-doing" proces. Hierbij kan gedacht worden aan de Belastingdienst. Personeel wordt intern opgeleid en verwerft specifieke (belastingtechnische) vaardigheden en kennis. Tenslotte noemt Williamson de categorie van "bestemmings"-activa ("dedicated assets"). Hiervan is sprake indien de verkoper ten

\footnotetext{
501 Bron: Helden, in: Mol en Verbom (1993, p. 56).

so4 Williamson (1985, Appendix, pp. 64-67).

sor Bokkes (1989, p. 27).
} 
behoeve van een bepaald contract bepaalde investeringen doet, die anders niet zouden zijn verricht. Indien het contract niet wordt nageleefd zou de verkoper geconfronteerd worden met overcapaciteit. ${ }^{506}$

In het geval van een hoge mate van "asset specificity" zullen partijen meer met elkaar verbonden zijn. Dit kan tot uiting komen in de keuze voor lange termijn contracten of eventueel voor verticale integratie. Dit hangt ook af van andere kenmerken van transacties. Een tweede kenmerk van transacties is dat deze transacties onzekerheid met zich meebrengen. Naarmate de onzekerheid groter is zullen transacties via de markt met meer transactiekosten gepaard gaan. Een derde kenmerk van transacties is dat van de frequentie en schaal. Indien een transactie herhaaldelijk voorkomt en er meer personen bij betrokken zijn is de mogelijkheid aanwezig dat ruil via de markt niet tot minimalisatie van de transactiekosten zal leiden. Met het oog op die transactiekosten kan het dan ook wenselijk zijn te kiezen voor meer uitgewerkte contracten.

Williamson meent dat het marktmechanisme veelal de meest efficiënte besturingsstructuur oplevert. Hij legt de nadruk op opportunisme, begrensde rationaliteit en specificiteit van activa. Pas indien deze drie zich gezamenlijk voordoen komen andere meer gecompliceerde besturingsstructuren zoals bijvoorbeeld coördinatie binnen een organisatie in aanmerking. ${ }^{507}$ Indien er geen sprake is van opportunisme kunnen partijen elkaar eenvoudig beloven zich aan de afspraken te zullen houden. Indien individuen zoals de klassieke benadering stelt onbeperkt rationeel zijn kunnen zij alle eventualiteiten voorzien en hiermee in het contract rekening houden. De mogelijkheid van opportunistisch handelen ontbreekt dan. Ook indien er geen sprake is van "asset specificity" is het gevaar van opportunistisch gedrag gering. Activa kunnen onmiddellijk voor andere aanwendingen worden gebruikt. Williamson verondersteit dat de twee gedragskenmerken opportunisme en "bounded rationality" allijd in meer of mindere mate aanwezig zullen zijn en dat derhalve de mate van "asset specificity" doorslaggevend is. $\$$.

Indien gekozen wordt voor coördinatie via de markt kan dit bijvoorbeeld gerealiseerd worden door het opstellen van lange termijn contracten. Door onzekerheid en bounded rationality van de contractanten kan het specificeren van de toekomstige ontwikkelingen

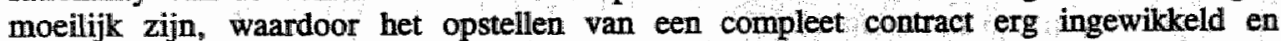
kostbaar wordt. Een contract zal in dat geval dan ook vrijwel steeds incompleet zijn en dit schept vervolgens ruimte voor opportunisme.

Marktpartijen kunnen ook kiezen voor korte termijn contracten. Een belangrijk voordeel is dat minder eisen gesteld hoeven te worden aan de rationaliteit van contractanten. Een madeel is dat indien de eerste contractant voordelen behaait ("first mover strategy") dit aanleiding kan geven tot kostbare heronderhandelingen die nodig zijn om het contract te vernieuwen. In het geval van onzekerheid en in een situatie wan onderhandelingen tussen een beperkt aantal partijen kan het wenselijk zijn activiteiten te coördineren binnen een bedrijf.

Tenslotte kan de organisatie worden bezien. Indien er zich positieve transactiekosten voordoen wordt het netto-resuitaat van een besturingsstructurir negatief beinvloed. De schade die dan optreedt kan worden uitgedrukt in alternatieve kosten. Dit zijn de kosten

\footnotetext{
s06 Williamson $(1973$, p. 519).

son Williamson (1985, pp. 30-32).

sos Vergelijk: Conlisk (1996, pp. 669-668).
} 
van het niet kumnen gebruiken van de imputs voor een andere aanwending. Indien gekeken wordt maar organisaties kan in dit opzicht een onderscheid worden gemaakt tussen de externe en interne organisatie.

\section{Externe Organisatie}

In het kader van de externe organisatie gaat het om de verticale integratie van organisaties. Zoals in hoofdstuk 2 is opgemerkt is er sprake van verticale integratie indien meerdere fases van de bedrijfskolom worden geintegreerd binnen een bedrijf. ${ }^{509} \mathrm{Er}$ bestaan verschillende theorieên die trachten te verklaren waarom verticale integratie plaatsvindt, waaronder bijvoorbeeld de levenscychushypothese van Stigler. ${ }^{510}$ Williamson meent dat de transactiekostenbenadering de beste verklaring biedt, waarbij de interactie tussen human factors en environmental factors uiteindelijk de mate en wijze van internalisering in bedrijven bepaalt. Zoals is aangegeven legt hij daarbij de nadruk op de mate van "asset specificity". Riordan en Williamson trachten de twee uitersten, namelijk neoklassieke markten en hiërarchische bedrijven te integreren in een algemeen kader. ${ }^{511}$ Indien de mate van "asset specificity" gering is zal het voor een bedrijf vanuit transactiekostenoverwegingen veelal efficient zijn deze goederen via de markt te verwerven. Indien de "asset specificity" toeneemt nemen ook de transactiekosten van transacties via de markt toe, terwijl de kosten van transacties binnen bedrijven affemen. In dit verband dienen verschillende soorten transactiekosten te worden onderscheiden. In de eerste plaats de kosten van aanpassing die afhankelijk zijn van de mate van "asset specificity". Daamaast zijn er nog andere transactiekosten die een bedrijf onderscheiden van de markt, namelijk de verschillende prikkels en de verschillen in bureaucratische kosten van bedrijfs- en marktorganisatie. Beide laatste categorieën zijn relatief onafhankelijk van de mate van asset specificity. Vergeleken met de "high powered incentives" in de markt zijn de "low powered incentives ${ }^{\text {" binnen en bedrijf minder effectief. }}{ }^{512}$ Daarnaast vertoont een bedrijf een aantal bureaucratische verstoringen, waaronder de verstoringen zoals die in het kader van de principaal-agent-benadering aan de orde zujn gekomen en bijvoorbeeld ten aanzien van de afweging van investeringen. Indien de "asset specificity" laag is zal dit er toe leiden dat de transactiekosten van een bedrijf hoger zijn dan die van de markt. Dit is als volgt geillustreerd in Figuur 11.1.

\footnotetext{
sos Clarke (1990, pp. 172-173).

910 Stigler (1951, pp. 185-193).

sil Riordan en Williamson (1985, p. 366).

st: T,a.p., D. 368.
} 
Produltiekosten,

Transactiekosten

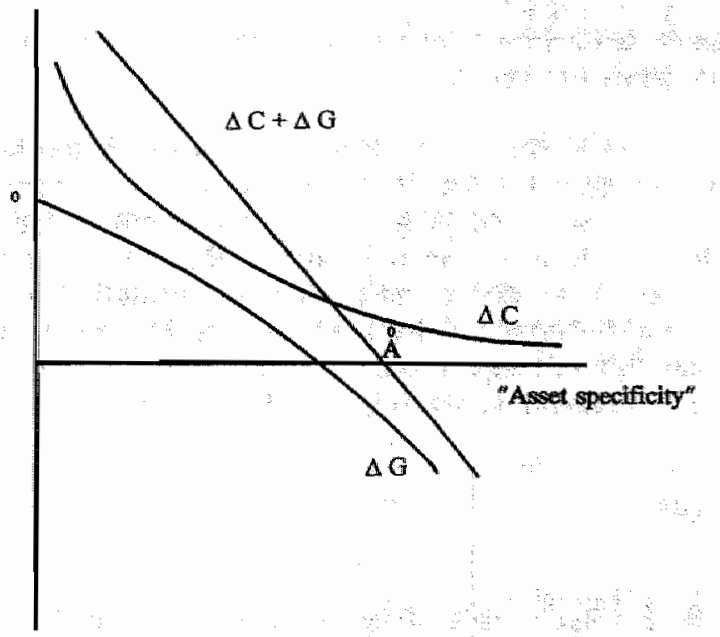

Figuur 11.1 Productiekosten, transactiekosten en "asset specificity"ss

Hierbij staat $\Delta \mathrm{G}$ voor het verschil in transactiekosten tussen onderneming en markt, terwijl A staat voor de mate van "asset specificity". Bij de gegeven analyse dient bedacht te worden dat in het algemeen gesteld kan worden dat transactiekosten positief zijn, omdat enerzijds actoren niet volledig rationeel zijn en anderzijds omdat zij niet over volledige informatie beschikken. Indien de "asset specificity" toeneemt worden de verschillen in transactiekosten van transacties via de markt en onderneming steeds kleiner, terwijl zij na een bepaald stadium negatief worden. De transactiekosten van transacties door middel van een onderneming zijn dan lager dan die via de markt. Zoals in het begin van dit hoofdstuk reeds werd benadrukt zijn echter niet alleen de transactiekosten maar ook de productiekosten yan belang. Van der Bij stelt in dit verband: "Het is dus heel goed mogelijk dat de agent tegen de laagste productiekosten de diensten kan voortbrengen, maar dat deze agent vervolgens bovencontractuele voordelen in de wacht sleept door een inferieure prestatie te leveren. Uiteindelijk zal de som van productie- en transactiekosten de doorslag moeten geven bij de beslissing of de overheid dient over te gaan tot (bijvoorbeeld JFK) uitbesteding van de productie" ${ }^{\prime \prime 4}$ De produetiekosten van goederen die voortgebracht worden met activa met een lage specificiteit en die op de markt verhandeld worden zullen relatief laag zijn, onder andere door de bij de productie behaalde schaalvoordelen. Indien sprake is van een hoge mate van "asset specificity" zullen zich veel minder schaalvoordelen voordoen en zullen de transactiekosten relatief hoog zijn In Figuur 11,1, zijn de verschillen in productiekosten tussen voortbrenging door een bedrijf en via de markt weergegeven door curve $\Delta \mathrm{C}$. Indien de "asset specificity" laag is zijn de productiekosten van een bedrijf hoger dan die in de markt, terwijl indien de asset specificity toeneemt de verschillen in productiekosten naderen naar nul.

De verschillen in productie- en transactiekosten kunnen gezamenlijk worden weergegeven door curve $\Delta \mathrm{C}+\Delta \mathrm{G}$. Hieruit trekken Williamson en Riordon de conclusie dat:

1. De organisatie van transacties via de markt de laagste kosten met zich meebrengt indien de "asset specificity" gering is.

\footnotetext{
513 Bron: t.a.p., p. 366.

${ }^{514}$ Van der Bij (1992, p. 16).
} 
2. Interne organisatie de laagste kosten met zich meebrengt indien de "asset specificity" hoog is.

3. Geen van beide besturingssystemen een aanzienlijk voordeel hebben indien de "asset specificity" in de buurt ligt van $A^{\circ}$.

Naast de mate wan "asset specificity" kan het gebruik van een bedrijf als besturingsstructuur ook andere voordelen hebben. Binnen een bedrijf kan de onzekerheid beperkt blijven (in verhouding tot bijvoorbeeld lange termijncontracten) waardoor minder eisen gesteld hoeven te worden aan de mate van rationaliteit. De kans op opportunisme is geringer en de onderhandelingen zullen onder andere door de institutionalisering van controlemechanismen onder omstandigheden minder kostbaar zijn. De interactie tussen "human factors" en "environmental factors" bepaalt derhalve uiteindelijk of coördinatie plaatsvindt via de markt of via een onderneming, waarbij een afweging van de kosten centraal zall staan. ${ }^{515}$

\section{Interne Organisatie}

Analoog aan de gevolgde gedachtengang kan ook geanalyseerd worden waarom de overheid overwegende invloed in deze bedrijven heeft. Met betrekking tot overheidsinstellingen kan een onderscheid gemaakt worden tussen verschillende interne organisatiestructuren. Zo kan een onderscheid gemaakt worden tussen een overheidsorganisatie met een unitaire structuur (U-vorm), met een divisiestructuur (M-vorm), een overheidsorganusatie met beperkte externe verzelfstandiging en een overheidsorganisatie met volledige externe verzelfstandiging. In het geval yan een unitaire structurur (U-vorm) is er enerzijds een gecentraliseerd hierrarchisch gezag en anderzijds dikwijls een functionele afdelingsvorming. 516 Bij de multidivisionele organisatiestructurur is er sprake van een verdeling van bevoegdheden tussen de centrale directie en de verschillende divisies. De divisies zijn relatief zelfstandig. Het centrale niveau houdt zich vooral bezig met de grote lijnen. Redenen voor de ontwikkeling van een multidivisionele structuur uit een unitaire structur (interne verzelfstandiging) houden vooral verband met de informatieproblemen die ontstaan bij unitaire organisaties. Door het grote aantal hiërarchische schakels kan de informatievoorziening bij een unitaire organisatie traag verlopen en kan het centrale niveau te maken krijgen met te veel detailinformatie, terwijl bij de formulering van subdoelstellingen van afdelingen binnen de U-vormige organisatie het risico van opportunisme zich voordoet. Het voordeel van de $\mathrm{M}$-vormige organisatie is dat het management zich weer meer met de hoofdlijnen kan bezighouden en dat de afzonderlijke divisies gemakkelijker te controlerem zijn, met name indien deze gerund worden als winstcentra. Hierdoor wordt het risico van opportunisme kleiner. Door de zelfstandigheid van de divisies kunnen de verticale informatiestromen in de organisatie verminderen, hetgeen eveneens minder kosten met zich mee zal brengen. Door controle en beloningssystemen is het voor het centrale gezag mogelijk de divisies zodanig te laten opereren dat de kans op opportunisme wordt tegengegaan. Vaak wordt bij interne verzelfstandiging gebruik gemaakt van een dienstbegroting en managementcontracten. Veelal wordt door de overheid niet langer op taken en middelen gestuurd maar op output. Met de directeur van de betreffende dienst worden dan afspraken gemaakt over welke prestaties de instelling tegen welke kosten zal

sis Clarke (1990, pp 175 e.v.).

516 Williamson (1985, hoofdstuk 11, met name pp. 278, 280, 283-285). 
vombrengen. ${ }^{517}$ Van beperkte exteme verzelfstandiging is sprake indien de supervisie door het centrale gezag vermindert en de inwloed van prijsafspraken groter wordt. De beperkt extern verzelfstandigde organisatie kan zelf klanten werven, maar het overheidslichaam is belast met de goedkeuring van de begroting en is voorts verantwoordelijk voor eventuele tekorten.

In geval van een volledig extern verzelfstandigde overheidsinstelling is de betreffende organisatie geen overheldsinstelling meer. De overheid is niet langer toezichthouder naar slechts marktpartij. De ovenheid kan bijvoorbeeld langlopende contracten sluiten on een bepaalde dienst wate worgen.

Van Helden geeft an dat de keuze tussen de verschillende varianten en dus ook of productie plaats zal vinden door middel van overheidsinstellingen of particuliere bedrijven, afhangt van de mate van "asset specificity", vergelijk Tabel 11.2:

\begin{tabular}{|c|c|c|}
\hline Specificiteit van activa & $\begin{array}{l}\text { Organisatievorm verzelf- } \\
\text { standiging }\end{array}$ & Contractworm: \\
\hline hoog & unitair & "relational contracting" \\
\hline maiddel-hoog & $\begin{array}{l}\text { multidivisionele structuur } \\
\text { of beperkte externe verzelf- } \\
\text { standiging }\end{array}$ & $\begin{array}{l}\text { "relational contracting / } \\
\text { neo-classical contract } \\
\text { law" }\end{array}$ \\
\hline laag & $\begin{array}{l}\text { volledige externe verzelf- } \\
\text { standiging }\end{array}$ & $\begin{array}{l}\text { "neoclassical contract } \\
\text { law / classical } \\
\text { contract law" }\end{array}$ \\
\hline
\end{tabular}

Tabel 11.2 Specificiteit van activa en organisatiestructuur ${ }^{518}$

Hierbij moet bedacht worden dat de keuze voor een bepaalde besturingsstructuur niet alleen het gedrag en de transacties tussen actoren beinvloedt, maar ook de eigendomsrechtenstructur en de relaties tussen actoren.

Ter illustratie van een transactiekostenanalyse kan de elektriciteitssector worden geanalyseerd. In de eerste plaats kan een elektriciteitsbedrijf de vorm aannemen van een Uvormige organisatie. Dit zal met name het geval zijn indien de mate van "asset specificity" hoog is. Hierbij zal het vooral gaan om plaatsgebonden en specifieke fysieke activa. De elektriciteitsproductie maakt bijvoorbeeld in de vorm van een tak van dienst deel uit van een gemeente. In dit geval is de planning en beheersing van de door de overheidsinstelling verrichte activiteiten in hamden van het college van $B \& W$. De verslaglegging verloopt via de gemeente, er is een intensieve vorm van supervisie door de verantwoordelijke wethouder, terwijl prijsafspraken van ondergeschikt belang zijn. Er is sprake van "relational contracting".

In de tweede plaats kan het elektriciteitsbedrijf intern verzelfstandigd zijn. Dit zal zich met name voordoen indien de mate van "asset specificity" noch hoog noch laag is. Planning, beheersing en supervisie door B\&W zijn nog wel aanwezig, maar zullen minder

517 Berkenbosch en Helleman (1995, pp. 23-24).

s.18 Bron: Van Helden, in: Mol en Verbon (1993, p. 64). 
belangrijk zijn dan in het geval van een $\mathbf{u}$-vormige organisatie-structuur. Veelal is er sprake van een dienstbegroting met managementcontracten. Het belang van prijsafspraken kan toenemen, bijwoorbeeld door het gebruik van een prestatiebegroting. In de derde plaats kan het elektriciteitsbedrijf beperkt extern zijn verzelfstandigd. Dit zal zich met name voordoen indien de "asset specificity" beperkt is. Er is dan sprake van een externe organisatie, terwijl planming, beheersing en supervisie door de overheidsinstantie van minder belang zijn. Voorts neemt de rol van prijsafspraken toe. De zelfstandigheid van het elektriciteitsbedrijf is groter, zij kan bijvoorbeeld zelfstandig klanten werven en veelal zullen bepaalde eigendomsrechten gedeeltelijk zijn gedelegeerd, bijvoorbeeld het recht om personeelsleden aan te stellen (samenstelling van het team van producenten). De begroting van het elektriciteitsbedrijf moet echter nog steeds worden goedgekeurd door de gemeente. Prijsafspraken met de overheidsinstelling nemen een meer belangrijke plaats in. Indien er sprake is van interne verzelfstandiging (situatie 2) en indien er sprake is van beperkte externe verzelfstandiging (situatie 3 ) zijn waarschijnlijk eveneens relationele contracten nodig. Het is echter denkbaar dat ook neoklassieke contractvormen worden gebruikt.

Tenslotte kan het elektriciteitsbedrijf volledig extern verzelfstandigd zijn. De overheidsinstantie houdt zich niet langer bezig met planning en beheersing, noch met supervisie. De overheid sluit een contract af met het bedrijf, waarin prijsafspraken zijn opgenomen. Meer eenvoudige contractvormen zoals neoklassieke of klassieke contractvormen ("classical en neo-classical contract law") zijn denkbaar.

Indien de mate van "asset specificity" beperkt is zal de vierde variant het meest efficiënt zijn. Hierbij is het ook van belang in hoeverre er sprake is van concurrentie met andere bedrijven. In het geval van elektriciteitsbedrijven is de mate van "asset specificity" relatief hoog, terwijl de concurrentie (door de door de politiek bepaalde monopolistische markt-vorm) vooralsnog beperkt is. Dit maakt het waarschijnlijk dat op grond van transactiekostenoverwegingen wordt gekozen voor bijvoorbeeld de tweede of derde variant en niet voor volledige externe verzelfstandiging. In het algemeen geldt dat hoe beperkter de "asset specificity", hoe waarschijnlijker het is dat verzelfstandiging de som van productie- en transactiekosten minimaliseert. In het algemeen kan gesteld worden dat de eerste drie varianten kunnen worden beschouwd als hybride organisaties, zoals uiteengezet in hoofdstuk 6 en 7.

Naast de door Williamson benadrukte "stroming" waarbij transactiekosten veroorzaakt worden door "asset specificity" kunnen transactiekosten ook veroorzaakt worden doordat prestaties en activiteiten niet goed gemeten kunnen worden. Williamson neemt deze benadering slechts zijdelings op in zijn analyse, mede omdat de voortgang ervan volgens hem niet zo groot is. ${ }^{519}$ Voor de toepassing van de transactiekostenbenadering op overheidsinstellingen is deze benadering evenwel juist wel van groot belang. Het is dan mogelijk dat de drie door Williamson genoemde kenmerken van transacties tekortschieten. Meetproblemen kunnen leiden tot belangrijke transactiekosten en kunnen dienovereenkomstig leiden tot specifieke coördinatiemechanismen. Indien de prestaties of de activiteiten in het productieproces moeilijk te meten zijn is het zoals in het kader van de principaal-agent-benadering is opgemerkt, mogelijk dat een actor/agent minder presteert dan hij zou moeten doen. Dit is mogelijk omdat het niet kunnen bepalen van de prestaties ruimte schept voor opportunistisch gedrag en/of omdat de agent zelf de prestatie ook niet of slechts tegen zeer hoge kosten kan meten. Het ex post controleren van organisaties kan zeer kostbaar zijn. Het is wellicht goedkoper hiermee reeds in de ex ante sfeer rekening te houden. Dit lijkt een belangrijke reden orn dergelijke activiteiten door middel van een overheidsinstelling te regelen. De overheid kan ervoor zorgen dat zij mogelijkheden heeft

s19 Vergelijk: Williamson (1985). 
om in te grijpen in het productieproces, bijwoorbeeld door accountantscontrole, goedkeuring van begrotingen, rechtstreeks toezicht op de output en input e.d., waardoor de transactiekosten lager kunnen blijven dan indien het goed wordt voortgebracht door een particulier bedrijf. Hierbij dient bedacht te worden dat eventuele reguleringskosten van voorziening door een particulier bedrijf eveneens als transactiekosten beschouwd moeten worden. Het is dan ook onjuist te stellen dat privatisering altijd de transactiekosten zal verlagen. Dit is pas juist indien de overheid de bijkomende doelen wegbezuinigt of indien een zodanig coördinatiemechanisme mogelijk is dat meetproblemen voorkomen worden, bijwoorbeeld door het gebruiken van merkartikelen of bepaalde standaarden. ${ }^{520}$

\subsection{Hoe verhoudt de transactiekostenbenadering zich met de netwerkbenadering?}

Op grond van beide invalshoeken van de transactiekostenbenadering kan een overheidsinstelling gezien worden als een verzameling contractuele relaties. Dit sluit goed aan bij de netwerkbenadering.

Williamson stelt: "Hybrid arrangements are chosen at a point on the scale between market and hierarchy where market controls are week because of the asset specificity of the transaction, and the transaction costs of a fully integrated organization are too hig $h^{\prime \prime}$. 521 Hutter en Teubner zetten vraagtekens bij de verklaring gegeven door de transactiekostenbenadering voor het bestaan van netwerken. $\mathrm{Zij}$ ontwikkelen een verklaring voor het bestaan van netwerken binnen het kader van de "social systems"-theorie. ${ }^{522}$ Allereerst menen zij dat het concept van de transactiekosten onduidelijk is, onder andere omdat deze kosten niet bepaald kunnen worden door gebruik te maken van prijzen die op een markt tot stand komen. Daarnaast heeft de keus tussen een tweetal institutionele alternatieven (markt of hiërarchie) alleen zin indien de resulterende "performance" hetzelfde is. In werkelijkheid is die "performance" echter juist erg verschillend voor overheidsinstellingen en alleriei alternatieve besturingsstructuren. Zij suggereren dat acties in een netwerk zowel aan de eisen van de individuele actoren als van de organisatie moeten voldoen. Hutter en Teubner benadrukken de rol van netwerk-organisaties als een eigen sociaal systeem. Hierbij sluit aan dat het voor de overheid vanuit transactiekostenoverwegingen weliswaar onverstandig zou kunnen zijn om een overheidsinstelling/netwerk in het leven te roepen, maar dat dit in de praktijk toch gebeurt. ${ }^{523}$ Een belangrijke reden hiervoor kan zijn dat politieke actoren door het instellen van een overheidsinstelling proberen zich een bepaald deel van een eventuele "public enterprise rent" toe te eigenen (all dan niet indirect door het bevoordelen van bepaaldle cliënten).

Stephen en Gillanders geven verder aan dat niet alleen de "monitoring" nadat het contract is gesloten van belang is maar ook de selectie van het team/netwerk. Williamson erkent naast het bestaan van ex post transactiekosten weliswaar het bestaan van ex ante transactiekosten, dit neemt echter niet weg dat relatief weinig onderzoek is verricht naar de invloed van het selecteren van een team van actoren en de sociale context van

520 Zie met betrekking tot dergelijke mechanismen: Kenney en Klein (Journal of Law and Economics, Vol. 26, pp. 497-540).

sal Williamson (1985, p. 83).

522 Hutter en Teubner (1993, p. 708).

523 Koers (1995, paragraaf 2).

5234 Stephen en Gillanders (1993, pp. 726-727) 
transacties op de toe- of afname van opportunisme.

Powell geeft aan dat netwerken op een aantal punten afwijken van markttransacties en hiërarchische "governance" structurur, hetgeen is weergegeven in Tabel 11.3.

\begin{tabular}{|c|c|c|c|}
\hline \multirow[t]{2}{*}{ Kenmerken } & \multicolumn{3}{|c|}{ Besturingsstructuur } \\
\hline & Markt & Hiërarchie & Netwerk \\
\hline Normatieve basis & $\begin{array}{l}\text { Contract - eigen- } \\
\text { domsrechten }\end{array}$ & Dienstverband & $\begin{array}{l}\text { Complementair, } \\
\text { elkaar aanvullend }\end{array}$ \\
\hline Communicatiemiddel & Prijzen & Routines & Relationeel \\
\hline $\begin{array}{l}\text { Methoden van con- } \\
\text { flicthantering }\end{array}$ & $\begin{array}{l}\text { Via procedures, af- } \\
\text { dwingen via de rech- } \\
\text { ter }\end{array}$ & $\begin{array}{l}\text { Administratieve } \\
\text { goedkeuring, super- } \\
\text { visie }\end{array}$ & $\begin{array}{l}\text { Wederkerigheid, } \\
\text { reputatie-effecten }\end{array}$ \\
\hline Mate van flexibiliteit & Hoog & Laag & Middel \\
\hline $\begin{array}{l}\text { Mate van betrokken- } \\
\text { heid en binding tus- } \\
\text { sen partijen }\end{array}$ & Laag & Middel tot hoog & Middel tot hoog \\
\hline Klimaat/sfeer & $\begin{array}{l}\text { Nauwkeurig en/of } \\
\text { achterdochtig }\end{array}$ & $\begin{array}{l}\text { Formeel, bureaucra- } \\
\text { tisch }\end{array}$ & $\begin{array}{l}\text { Wederzijdse voor- } \\
\text { delen, open einde }\end{array}$ \\
\hline $\begin{array}{l}\text { Preferenties van } \\
\text { actoren of keuzes }\end{array}$ & Onafhankelijk & Afhankelijjk & Interafhankelijk \\
\hline Mengvormen & $\begin{array}{l}\text { Herhaalde transacties } \\
\text { (Geertz, 1978) } \\
\text { Contracten als } \\
\text { hiërarchische docu- } \\
\text { menten } \\
\text { (Stinchcombe, 1985) }\end{array}$ & $\begin{array}{l}\text { Informele organisatie } \\
\text { (Dalton 1957) } \\
\text { Marktachtige vor- } \\
\text { men: } \\
\text { winstcentra, reken- } \\
\text { prijzen } \\
\text { (Eccles, 1985) }\end{array}$ & $\begin{array}{l}\text { Status hièrarchieën } \\
\text { Meerdere partners } \\
\text { Formele regels }\end{array}$ \\
\hline
\end{tabular}

\section{Tabel 11.3 Marktcoördinatie, hierarchie en netwerk ${ }^{525}$}

Hij onderscheidt eveneens markttransacties, hiërarchie en de netwerkstructuur. Indien gebruik wordt gemaakt van markttransacties zijn de uitgewisselde voordelen duidelijk omschreven, is er geen onderling vertrouwen vereist en zijn er juridische sanctiemogelijkheden. In een organisatie is vooral iemands hiërarchische positie binnen de organisatie van belang. In het geval van uitwisseling binnen een netwerk zijn vooral de verhoudingen tussen de actoren van belang. De onderlinge transacties zijn in beginsel onbeperkt en worden verricht binnen het kader van het netwerk. Sancties zijn niet zozeer juridisch als wel normatief van aard. Dat wil zeggen dat vooral ook de door de verschillende actoren gedeelde normen en waarden van belang zijin.

Powell stelt dat slechts in een relatief klein aantal gevallen het bestaan van netwerken verklaard kan worden door de minimalisatie van transactiekosten. ${ }^{526}$ Volgens hem zijn strategische overwegingen, waaronder bijvoorbeeld de toegang tot belangrijke hulpbron-

s2s Bron: Powell (1990, p. 300).

${ }^{526}$ T.a.p., p. 322. 
nen en het verwerven van vaardigheden die niet intern eigen gemaakt kunnen worden van veel groter belang. Hij stelt:

"The absence of a clear developmental pattern and the recognition that network forms have multiple causes and varied historical trajectories suggest that no simple explanation ties all the cases together. Economizing is obviousty a relevant concem in many instances, especially in infant industries where competitive preserves are strong. But it alone is not a particularly robust story, it is but one among a number of theoretically possible motives for action-all of which are consonant with a broad view of self-interest. Clearly many of the arrangements discussed above actually increase transaction costs, but in return they provide concrete benefits or intangible assets that are far more valuable. The reduction of uncertainty, fast access to information, reliability, and responsiveness are anong the paramount concerns that motivate the participants in exchange networks". 527

Powell geeft aan dat drie factoren essentieel zijn voor het bestaan en de evolutie van netwerken, ${ }^{528}$ namelijk:

\section{- know how"}

Netwerken zijn vooral nuttig woor de ruil van goederen waarvan de waarde niet gemakkelijk te meten is. Hierbij kan gedacht worden aan zaken als "know how", een bepaalde wijze van productie of een innovatieve ondernemingsgezind heid.

Veel kennisintensieve activiteiten zoals wetenschappelijk onderzoek, culturele productie en computerprogrammering vereisen weinig fysiek kapitaal. Williamson heeft duidelijk gemaakt dat naarmate activiteiten meer algemeen zijn en naarmate deze gemakkelijker te substitueren zijn markttransacties waarschijnlijker zijn. In het geval van kennisintensieve activiteiten zijn netwerkorganisaties bijzonder geschikt in verband met de nadruk op communicatie en wederzijdse verplichtingen. Netwerkorganisaties/overheidsinstellingen zijn dan ook meer waarschijnlijk indien kennis en vaardigheden zich niet lenen voor hiërarchische controle in organisaties of verkoop op een markt (patenten en uitrusting kunnen bijvoorbeeld wel verhandeld worden op een markt). Voor veel overheidsactiviteiten geidl dat de waarde van de voortgebrachte goederen moeilijk bepaald kan worden. Dit geldt bijvoorbeeld voor de voortbrenging van collectieve goederen en externe effecten.

\section{-vraag naar snelheid}

Dit houdt in dat het aangaan van coalities een snellere en goedkopere manier is om zich aan te passen aan veranderde omstandigheden, dan bijvoorbeeld fusie. Voordelen van netwerken zouden dan ook zijn de snelle toegang tot informatie, flexibiliteit en aanpassing. Of dit in de werkelijkheid ook zo is zal afhangen van het karakter van het netwerk. Wel is het aannemelijk dat indien deze voordelen niet (meer) aanwezig zijn, het netwerk uiteen zal vallen. Hierbij kan bij wijze van voorbeeld gedacht worden aan het uiteenvallen van het R.S.V.-concern. Ten aanzien van de overheid kan worden opgemerkt dat overheidsinstellingen/netwerken het vormen van coalities mogelijk maakt. Binnen dergelijke netwerken kunnen activiteiten zich sneller aanpassen aan gewijzigde omstandigheden. ${ }^{59}$ Hierbij speelt de "public enterprise rent" een centrale rol, aangezien de verschillende actoren zich zoveel mogelijk van deze "public enterprise rent" zullen

\footnotetext{
5.2. T.a.p. p. 323.

s218 T.a.p., pp. 323-327.

529 Vergelijk ook: Van Mierlo (1995, pp. 18-19).
} 
tranisacties op de toe- of afname van opportunisme.

Powell geeft aan dat netwerken op een aantal punten afwijken van markttransacties en hiërarchische "governance" structuur, hetgeen is weergegeven in Tabel 11.3.

\begin{tabular}{|c|c|c|c|}
\hline \multirow[t]{2}{*}{ Kenmerken } & \multicolumn{3}{|c|}{ Besturingsstructuur } \\
\hline & Markt & Hiërarchie & Netwerk \\
\hline Normatieve basis & $\begin{array}{l}\text { Contract - eigen- } \\
\text { domsrechten }\end{array}$ & Dienstverband & $\begin{array}{l}\text { Complementair, } \\
\text { elkaar aanvullend }\end{array}$ \\
\hline Communicatiemiddel & Prijzen & Routines & Relationeel \\
\hline $\begin{array}{l}\text { Methoden van con- } \\
\text { flicthantering }\end{array}$ & $\begin{array}{l}\text { Via procedures, af- } \\
\text { dwingen via de rech- } \\
\text { ter }\end{array}$ & $\begin{array}{l}\text { Administratieve } \\
\text { goedkeuring, super- } \\
\text { visie }\end{array}$ & $\begin{array}{l}\text { Wederkerigheid, } \\
\text { reputatie-effecten }\end{array}$ \\
\hline Mate van flexibilliteit & Hoog & Laag & Middel \\
\hline $\begin{array}{l}\text { Mate van betrokken- } \\
\text { heid en binding tus- } \\
\text { sen partijen }\end{array}$ & Laag & Middel tot hoog & Middel tot hoog \\
\hline Klimaat/sfeer & $\begin{array}{l}\text { Nauwkeurig en/of } \\
\text { achterdochtig }\end{array}$ & $\begin{array}{l}\text { Formeel, bureaucra- } \\
\text { tisch }\end{array}$ & $\begin{array}{l}\text { Wederzijdse voor- } \\
\text { delen, open einde }\end{array}$ \\
\hline $\begin{array}{l}\text { Preferenties van } \\
\text { actoren of keuzes }\end{array}$ & Onafhankelijk & Afhankelijk & Interafhankelijk \\
\hline Mengvormen & $\begin{array}{l}\text { Herhaalde transacties } \\
\text { (Geertz, 1978) } \\
\text { Contracten als } \\
\text { hiërarchische docu- } \\
\text { menten } \\
\text { (Stinchcombe, 1985) }\end{array}$ & $\begin{array}{l}\text { Informele organisatie } \\
\text { (Dalton 1957) } \\
\text { Marktachtige vor- } \\
\text { men: } \\
\text { winstcentra, reken- } \\
\text { prijzen } \\
\text { (Eccles, 1985) }\end{array}$ & $\begin{array}{l}\text { Starus hiërarchieèn } \\
\text { Meerdere partners } \\
\text { Formele regels }\end{array}$ \\
\hline
\end{tabular}

\section{Tabel 11.3 Marktcoördinatie, hierarchie en netwerk ${ }^{525}$}

Hij onderscheidt eveneens markttransacties, hierarchie en de netwerkstructuur. Indien gebruik wordt gemaakt van markttransacties zijn de uitgewisselde voordelen duidelijk omschreven, is er geen onderling vertrouwen vereist en zijn er juridische sanctiemogelijkheden. In een organisatie is vooral iemands hiërarchische positie binnen de organisatie van belang. In het geval van uitwisseling binnen een netwerk zijn vooral de verhoudingen tussen de actoren van belang. De onderlinge transacties zijn in beginsel onbeperkt en worden verricht binnen het kader van het netwerk. Sancties zijn niet zozeer juridisch als well normatief van aard. Dat wil zeggen dat vooral ook de door de verschillende actoren gedeelde normen en waarden van belang zijn.

Powell stelt dat slechts in een relatief klein aantal gevallen het bestaan van netwerken verklaard kan worden door de minimalisatie van transactiekosten. ${ }^{526}$ Volgens hem zijn strategische overwegingen, waaronder bijwoorbeeld de toegang tot belangrijke hulpbron-

'ss Bron: Powell (1990, p. 300).

$\$ 26$ T.a.p., p. 322. 
nen en het verwerven van vaardigheden die niet intern eigen gemaakt kunnen worden van veel groter belang. Hij stell:

"The absence of a clear developmental pattern and the recognition that network forms have multiple causes and varied historical trajectories suggest that no simple explanation ries all the cases together. Economizing is obviously a relevant concem in many instances, especially in infant industries where competitive preserves are strong. But at alone is not a particularly robust story, it is but one among a number of theoretically possible monives for action- all of which are consonant with a broad view of self-interest. Clearly many of the arrangements discussed above actually increase transaction costs, but in return they provide concrete benefits or intangible assets that are far more valuable. The reduction of uncertainty, fast access to information, reliability, and responsiveness are among the paramount concerns that motivate the participants in exchange networks". 527

Powell geeft aan dat drie factoren essentieel zijn voor het bestaan en de evolutie van netwerken, ${ }^{528}$ namelijk:

\section{- "know how"}

Netwerken zijn vooral nuttig voor de ruil van goederen waarvan de waarde niet gemakkelijk te meten is. Hierbij kan gedacht worden aan zaken als "know how", een bepaalde wijze van productie of een innovatieve ondernemingsgezindheid.

Veel kennisintensieve activiteiten zoals wetenschappelijk onderzoek, culturele productie en computerprogrammering vereisen weinig fysiek kapitaal. Williamson heeft duidelijk gemaakt dat naarmate activiteiten meer algemeen zijn en naarmate deze gemakkelijker te substitueren zijn markttransacties waarschijnlijker zijn. In het geval van kennisintensieve activiteiten zijn netwerkorganisaties bijzonder geschikt in verband met de nadruk op communicatie en wederzijdse verplichtingen. Netwerkorganisaties/overheidsinstellingen zijn dan ook meer waarschijnlijk indien kennis en vaardigheden zich niet lenen voor hiërarchische controle in organisaties of verkoop op een markt (patenten en uitrusting kunnen bijwoorbeeld wel verhandeld worden op een markt). Voor veel overheidsactiviteiten geldt dat de waarde van de voortgebrachte goederen moeilijk bepaald kan worden. Dit geldt bijwoorbeeld voor de voortbrenging van collectieve goederen en externe effecten.

\section{-vraag naar snelheid}

Dit houdt in dat het aangaan van coalities een snellere en goedkopere manier is om zich aan te passen aan veranderde omstandigheden, dan bijvoorbeeld fusie. Voordelen van netwerken zouden dan ook zijn de snelle toegang tot informatie, flexibiliteit en aanpassing. Of dit in de werkelijkheid ook zo is zal afhangen van het karakter van het netwerk. Wel is het aannemelijk dat indien deze voordelen niet (meer) aanwezig zijn, het netwerk uiteen zal vallen. Hierbily kan bij wijze van voorbeeld gedacht worden aan het uiteenvallen. van het R.S.V.-concern. Ten aanzien van de overheid kan worden opgemerkt dat overheidsinstellingen/netwerken het vormen van coalities mogelijk maakt. Binnen dergelijke netwerken kunnen activiteiten zich sneller aanpassen aan gewijzigde omstandigheden. $^{\text {s29 }}$ Hierbij speelt de "public enterprise rent" een centrale rol, aangezien de verschillende actoren zich zoveel mogelijk van deze "public enterprise rent" zullen

\footnotetext{
S.a.p. T., p. 323.

52 T.a.p., pp. 323-327.

5200 Vergelijk aok: Van Mierlo (1995, pp. 18-19).
} 
proberen toe te eigenen.

\section{-vertrouwen}

Een belangrijke factor die samenwerking binnen een netwerk bevordert houdt verband met de aanwezigheid van vertrouwen tussen actoren. De mate van vertrowwen wordt positief beinvloed door onder meer de herhaalde interacties tussen actoren en daarmee samenhangend door een hoge waarschijnlijkheid van toekomstige interacties. Vertrouwen zal ook beïmloed worden door de mate waarin het hebben van een bepaalde reputatie van belang is. Bijvoorbeeld indien het contact in de ene situatie invloed heeft op contacten in een andere situatie, onder meer omdat actoren elkaar in allerlei commissies weer tegenkomen.

De organisatietheorie onderzoekt in hoeverre deze drie factoren voldoende ontwikkeld zijn om bij te kunnen dragen aan de ontwikkeling van netwerken. Snelheid en know how zijp (ook well te zien als "asset specificity") essentieel voor het ontstaan van een netwerk, terwijl vertrouwen een noodzakelijke voorwaarde is voor het voortbestaan van een netwerk.

Volgens Picot zijn er een viertal factoren van belang voor de vraag of netwerken zullen ontstaan. Naast "asset specificity" op grond van de transactiekostenbenadering, zijn andere factoren van belang zoals technologie, onzekerheid en entreebarrières. Het verband: tussen specificiteit en besturingsstructuur kan als volgt worden geillustreerd.

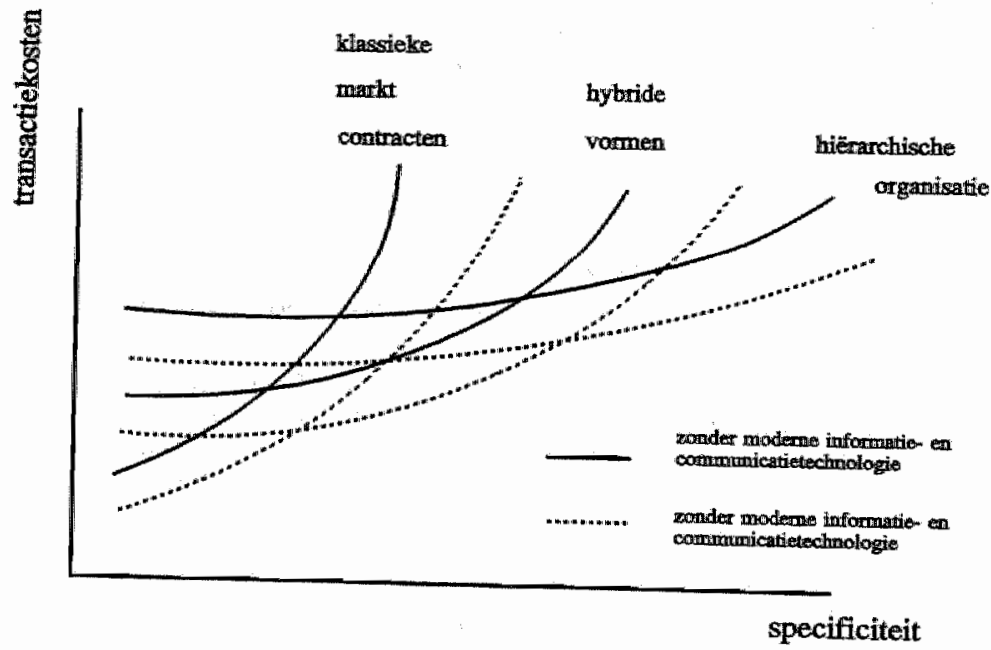

Figuur 11.2 Asset specificity, transactiekosten en besturingsstructuur ${ }^{530}$

530 Bron: Picot (1993, p. 733). Zie ook: Lindenberg (1996, p. 188). 
Naarmate de specificiteit toeneemt nemen eveneens de transactiekosten toe. Voorts geldt dat naarmate de integratie in een organisatie groter is de kosten van het management van "asset specificity" minder wordt. ${ }^{531}$ In paragraaf 2.3 .3 is uiteengezet dat de mate van "asset specificity" ook één van de verklaringen kan zijn voor het ontstaan van overheidsinstellingen. ${ }^{532}$ Dit kan nu vanuit een netwerkperspectief nader worden uitgewerkt.

\section{Technologie}

Transactiekosten zijn de kosten van communicatie en informatie, die gemaakt moeten worden om een ruil te realiseren. Door toename van de technologische kennis is het mogelijk dat de transactiekosten dalen. Picot merkt in dit verband op: "Costs of information and communication relate to all activities wirhin a transaction such as search for alternatives, negotiation of conditions, management of task performance and exchange, checking of qualities, quantities and prices, as well as adaptation to changes during fulfilment of the transaction. To the extent that information and communication technologies can economize on exchange related costs, transaction costs will decrease with adoption of such technologies" ${ }^{533}$ Hierbij kan gedacht worden aan telecommunicatie en informatietechnologieën. Hierdoor verschuiven de curves in de figurur naar rechts waardoor een wijziging van de besturingsstructuur kan ontstaan. Het is dan mogelijk dat de overheid niet kiest voor het opzetten van een activiteit in de vorm van een tak van dienst maar als overheidsinstelling in bijvoorbeeld de N.V.-vorm. Een verandering van de technologie leidt in die zin tot veranderingen in het netwerk.

\section{Omzekerheid}

Toename van de onzekerheid in de omgeving maakt samenwerking tussen organisatie en actoren belangrijker. Volgens Picot heeft de toename van de onzekerheid in de omgeving van organisaties en daarmee de verhoogde dynamiek, samen met verkorting van de produktlevenscyclus in het recente verleden tot een toename van netwerkorganisaties geleid.

\section{Entreebarrières}

In verband met de toenemende dynamiek van de omgeving is aanpassing van organisaties nodig. Vaak is het te kostbaar om kennis zelf te verwerven (intern door opleidingsprojecten en dergelijke). Volgens Picot zijn de entreebarrières voor kennis altijd hoog. Deze entreebarrières zijn vaak lager indien samengewerkt wordt met andere actoren in een netwerk.

Picot geeft aan dat deze vier factoren, waaronder dus "asset specificity" de "belangrijkste determinanten zijn voor het ontstaan van "symbiotic arrangements". De vraag is nu echter welk soort "symbiotic arrangement" zal ontstaan. Hoe zullen de actoren zich tot elkaar verhouden binnen het netwerk van de overheidsinstelling? Om deze vraag te beantwoorden wordt teruggekeerd naar relaties binnen het netwerk. Indien de transactiekosten positief zijn is het van groot belang om deze relaties tussen verschillende actoren te

\footnotetext{
531 Picot (1993, pp. 732, 736).

532 Vergelijk ook: Koers (1995, paragraaf 4).

$\$ 33$ Pícot $(1993$, p. 733).
} 
analyseren. Hieruit blikt ook het verband tussen enerzijds de transacties en anderzijds de relaties binnen het netwerk. Picot noemt een drietal kenmerken van het patroon var de onderlinge afhankelijkheid van elkaars hulpbronnen die bepalend zijn voor het ontstans wan een bepaald soort "symbiotic arrangement". ${ }^{34}$ Dit sluit aan bij de benadering van Powell die stelt: "(the) basic assumption of network relationships is that one party is dependent on resources controlled by another, and that there are gains to be had by the pooling of resources" 535 Allereerst noemt Picot "dependency of resources". Hiervan is sprake indien een hulpbron betere resultaten oplevert in combinatie met hulpbronnen van een ander bedrijf of een andere actor. Een tweede factor is "potency". Hiervan kan worden gesproken indien een hulpbron niet van een andere hulpbron afhankelijk is terwijl de andere hulpbronnen wel van deze hulpbron afhankelijk zijn. Een derde factor is plasticiteit van hulpbronnen. Dit houdt in dat het soort gebraik van een bepaalde hulporon nauwelijks voorspeld kan worden, bijvoorbeeld de kennis van werknemers. Picot geeft dit in een schema als volgt weer:

\begin{tabular}{|l|l|l|l|l|}
\hline \multicolumn{2}{|c|}{} & \multicolumn{3}{|c|}{ A's hulpbronnen } \\
\cline { 2 - 5 } & Afhankelijk & $\begin{array}{l}\text { Potent en met } \\
\text { lage plasticiteit }\end{array}$ & $\begin{array}{l}\text { Potent en met } \\
\text { hoge plastici- } \\
\text { teit. }\end{array}$ \\
\hline $\begin{array}{l}\text { B's hulpbron- } \\
\text { nen }\end{array}$ & $\begin{array}{l}\text { Potent met } \\
\text { hoge plastici- } \\
\text { teit }\end{array}$ & $\begin{array}{l}\text { Integratie van } \\
\text { hulpbromnen } \\
\text { (overname of } \\
\text { fusie) }\end{array}$ & $\begin{array}{l}\text { B houdt een } \\
\text { (minderheids-) } \\
\text { aandeel in A }\end{array}$ & $\begin{array}{l}\text { "Joint ventu- } \\
\text { re" }\end{array}$ \\
\cline { 2 - 6 } & $\begin{array}{l}\text { Potent met lage } \\
\text { plasticiteit }\end{array}$ & Licentie & Consortium & $\begin{array}{l}\text { A houdt een } \\
\text { (minderheids-) } \\
\text { aandeel in B }\end{array}$ \\
\hline
\end{tabular}

\section{Figuur 11.3 Een kader voor efficiēnte "symbiotic arrangements"}

Indien een tweetal actoren nu een symbiotic arrangement aangaan kumen op grond van deze drie kenmerken, uitgaande van "dependent resources", een zestal soorten "symbiotic arrangements" worden onderscheiden. In het eerste geval is actor A afhankelijk van hulpbronnen van actor B, welke potent en plastisch zijn. Actor A heeft moeite om het gebruik van kennis door B waar te nemen en te controleren waardoor een "moral hazard"probleem ontstaat. A kan de "performance" van B niet waarnemen. Derhalve is integratie (voor A) de efficiënte strategie. In geval twee beschikt B over potente hulpbronnen met lage plasticiteit waarvan actor $A$ afhankelijk is. Door middel van een contract in de vorm van een licentie kan de economische kern van de "symbiotic arrangement" mu worden vastgelegd. In de derde en zesde situatie zij̄n beide in het bezit van potente hulpbronnen en zijn zij derhalve afhankelijk van elkaar. De actor met de relatief meer plastische hulpbronmen is in het voordeel. Het is moeilijker om zijn bijdragen te controleren,

\footnotetext{
5o. Picot (1993, pp. 736 e.v.).

sis Powell (1990, F)...303).

536. Bron: Picot (1993, p. 737).
} 
hetgeen leidt tot een "moral hazard" risico. De efficiënte situatie zou zijn dat de actor met de hoge plasticiteit aandelen (in de zin van eigendomsrechten) zou moeten aanhouden in actor $\mathrm{A}$. In de vierde situatie zijn de actoren wederzijds afhankelijk van elkaar, terwijl beide actoren over hulpbronnen beschikken met een lage plasticiteit. Het oprichten van een consortium zou mu een efficiënte oplossing zijn aangezien voordelen van synergie kunnen ontstaan en het risico door de bundeling van hulpbronnen kan dalen. De vijfde situatie heeft als kenmerk dat beide actoren beschilkken over potente hulpbronnen die gekenmerkt worden door een hoge mate van plasticiteit. Hierdoor ontstaat, indien de "performance" van de ander niet geregistreerd kan worden, voor beiden de mogelijkheid van "moral hazard" - gedrag. Een gezamenlijke onderneming is dan het meest efficiènt. Hierbij kan gedacht worden aan een overheidsinstelling als onderdeel van een departement, zoals het Rijksmuseum. Dit vergemakkelijkt de "monitoring" en het nastreven van gemeenschappelijke doelen. In Tabel 11.3 is uitgegaan van een tweetal actoren. In werkelijkheid kunnen dat er natuurlijk veel meer zijn.

\subsection{In hoeverre kan de transactiekostenbenadering worden gebruikt voor het verklaren van het gedrag van het netwerk?}

Op grond van de bovenstaande overwegingen over de transactiekosten in een netwerk kunnen een aantal conclusies over de bruikbaarheid van de transactiekostenbenadering voor de verklaring van het gedrag en de "performance" van een overheidsinstelling/netwerk worden getrokken.

\section{Overheidsinstellingen kunnen in de praktijk niet met elkaar vergeleken worden}

De transactiekostenbenadering gaat veelal niet uit van de absolute hoogte van transactiekosten maar onderzoekt de verschillende besturingsstructuren, uitgaande van verschillen in transactiekosten. Dit is omslachtig indien voor een overheidsinstelling tal van alternatieve besturingsstructuren denkbaar zijn (andere overheidsinstellingen, markt, regulering etc.). Dit zal zich vooral voordoen indien een overheidsinstelling bijkomende doelen nastreeft. Het is in het geval van meerdere vage doelen of éen vaag doel moeilijk om de transactiekosten van meerdere verschillende besturingsstructuren met elkaar te vergelijken. Onderzoek naar de instelling op grond van de transactiekostenbenadering zou weinig opleveren indien niet alle alternatieven onderzocht zouden worden. Een betere strategie is te onderzoeken wat de kosten zijn van de bijkomende doelen en te bezien (eventueel in relatie met andere aanwendingsmogelijkheden) of deze kosten al dan niet hoog zijn.

Overheveling naar de private sector kan de transactiekosten verlagen maar zoals ook Bokkes benadrukt is dat niet per definitie het geval. ${ }^{537}$ Zoals in dit deell is aangegeven hangt dit grotendeels af van de wijze waarop de verschillende onderdelen van het netwerk worden beinvloed. Of een verbetering ontstaat kan slechts van geval tot geval worden geanalyseerd.

\section{Transactiekosten en meerdere doelen}

Zoals reeds herhaaldelijk is aangegeven streven overheidsinstellingen veelal niet naar winstmaximalisatie en streven zij meerdere doelen na. Indien het niet mogelijk is de realisering van die doelen weer te geven in éên dimensie, dan kunnen de baten en kosten van die transactie moeilijk worden bepaald en tegen elkaar worden afgewogen. Voorts is

s37 Zie ook: Dietrich (1994, pp. 40 e.v.). 
het van belang om te weten of de principalen een homogene groep miet gelijke doelstellingen vormen of een heterogene groep vormen met verschillende doelen.

Indien een organisatie meerdere doelen nastreeft zullen de transactiekosten veelal groter zijn. Dit zal met name het geval zijn indien de verschillende doelen mauwelijks samenhangen. Overeenkomstig de benadering van Borcherding kan worden opgemerkt dat het wiet: mogelijk is om in het geval van andere doelstellingen dan winstmaximalisatie, de relatieve efficiëntie van overheids- en particuliere productie te vergelijken. Hij merkt op dat de transactiekosten van andere besturingsmechamismen mogelijk de technische inefficiëntie van overheidsinstellingen overtreffen. ${ }^{538}$ Politici kumnen de indruk hebben dat een overheidsinstelling transactiekosteninefficiênt is. Vaak is het in de praktijk niet mogelijk de bijkomende doelen adequaat te meten of gebeurt dit eenvoudig niet In hoofdstuk 4 is aangegeven dat in het geval van de technische inefficiëntie veelal alleen naar het eigenlijke doel gekeken wordt. Dit nu kan zich dat ook bij toepassing van de transactiekostenbenadering voordoen. De transactiekosten lijken dan erg hoog omdat alle transactiekosten aan het eigenlijke goed worden toegerekend. De overheid/politieke actoren kunnen mu in de verleiding komen om te privatiseren om:

1. de transactiekosten te verminderen;

2. de $\mathrm{X}$-efficiëntie te verbeteren;

3. te bezuinigen op bijkomende doelen.

Of het vamuit transactiekostenoverwegingen en gelet op alle doelen aantrekkelijk is om te privatiseren kan slechts bepaald worden door een grondige analyse van de diverse besturingsstructuren. Onderzocht moet dan worden hoe groot de alternatieve kosten zijn van die doelen.

3. Bij overheidsinstellingen moet de doelstelling minimalisatie van de transactiekosten worden verruimd, ook politieke doelen spelen een rol.

Van Helden geeft aan dat de transactiekostenbenadering aangevuld dient te worden. Indien de overheid moet beslissen over het al dan niet overgaan tot verzelfstandiging of juist het beperken van de zelfstandigheid van een overheidsinstelling zullen niet alleen economische overwegingen maar ook politieke doelen een rol spelen. Op grond van de theorie zoals die in de vorige paragrafen is uiteengezet, is het inmiddels duidelijk dat "rentseekings"processen van groot belang zijn en voor een belangrijk deel het gedrag van overheidsinstellingen verklaren. Zoals in het kader van het structuur-gedrag-resultaatschema is aangegeven zal de overheid bij verzelfstandiging rekening houden met de markt- en concurrentiefactoren. Indien een monopolie ontstaat kan dit voor de overheid leiden tot hoge prijzen voor de te leveren goederen. Hierbij kan verwezen worden naar hoofdstuk 2, waarin werd aangegeven dat kosten en baten van verschillende (overheidsjinstrumenten tegen elkaar afgewogen dienen te worden. Voorts is opgemerkt dat de idemtificeerbaarheid van de doelen en de meetbaarheid van outputs van groot belang is. Indien de output niet of tegen hoge kosten gemeten kan worden kan dit voor de overheid een reden zijn om deze goederen via overheidsinstellingen voort te brengen. Hierbij is niet zozeer de asset specificity alswel de controleerbaarheid van de overheidsinstelling van belang.

538 Borcherding (1983, pp. 99-184). 

zijn.

De centrale vraag was hoe overheidsinstellingen zich in de praktijk gedragen. Dit hangt voor een belangrijk deel af van de aard van de gekozen besturingsstructuur. Indien door gewijzigde omstandigheden een besturingsstructuur vanuit transactiekostenoogpunt niet goed meer functioneert kan gekozen worden voor een nieuwe structuur. In principe leidt een tijdelijk inefficiëmte besturingsstruetuur tot ontevredenheid bij de eigenaren en leidt in die zin tot een prikkel om wijzigingen door te voeren. De vraag is echter of dit ook gebeurt. De transactiekostenbenadering gaat ervan uit dat actoren beperkt rationeel zijn. Dit betekent dat ook politieke actoren slechts in beperkte mate een afweging zullen maken van de efficiëntie (transactiekosten) van alternatieve besturingsstructuren. Gegeven het kenmerk van "bounded rationality" is het denkbaar dat de overheid de bestaande organisatiestructuur aanvaardbaar acht en niet zoekt naar alternatieven. In de marktsector kunnen marktprikkels zorgen voor een aanpassing van de organisatiestructuur. Bij overheidsinstellingen zullen marktprikkels veel minder van belang zijn. Het is dan de vraag of deze marktprikkels vervangen worden door andere redenen om te zoeken naar alternatieven. Hierbij kan gedacht worden aan pressie van belangengroepen en het politieke proces (verkiezingen) en de op grond hiervan geïnitieerde bezuinigingsoperaties. Politieke actoren streven wellicht naar kostenminimalisatie, maar het is niet gezegd dat dit ook bereikt wordt. Denkbaar is dat politici tevreden zijn met bijwoorbeeld een elektriciteitsbedrijf met een $\mathbf{M}$-vormige structuur terwijl een beperkte externe verzelfstandiging (transactie-)kostenefficiënter zou zijn. Gegeven de beperkingen zou dit dan wel efficiënt zijn.

\section{Naast "asset specificity" zijn andere factoren van belang.}

Zoals opgemerkt hebben kunnen naast "asset specificity" andere factoren van belang zijn, zoals de identificeerbaarheid van doelen en de meetbaarheid van de outputs. Indien bijvoorbeeld de output moeilijk is an te wijzen zal de overheid minder geneigd zijn over te gaan tot verzelfstandiging. Tenslotte kunnen ook de kenmerken van bepaalde goederen een rol spelen bij de keuze van de overheid voor de mate van zelfstandigheid van een overheidsinstelling, bijvoorbeeld indien zich externe effecten voordoen die verbonden zijn aan de voortgebrachte produkten of indien het gaat om de voortbrenging van goederen met een publiek karakter. ${ }^{539}$

\section{Transactiekosten efficiënt voor wie?}

Politieke actoren streven zoals in hoofdstuk 2 is opgemerkt niet zozeer naar allocatieve efficiëntie, alswel naar hun eigen belang. Dit kan met name in een politiek systeem met coalitieregeringen een ander belang zijn dan dat van de samenleving in haar geheel. Wellicht dat op grond van een transactiekostenbenadering een efficiëntere besturingsstructuur mogelijk is, maar dat dit op grond van hun doelen voor hen niet optimaal is.

Voorts kan nog het volgende worden opgemerkt. Aangegeven is dat overheidsinstellingen (opgevat als een netwerk) kunnen worden gezien als een onderdeel van het politieke proces en voor een belangrijk deel het aanbod van onder andere collectieve goederen bepalen. Daarnaast kunnen tal van overheidsorganisaties beschouwd worden als overheidsinstellingen. Hierbij kan gedacht worden aan departementen, Rijksbelastingdienst, Rekenkamer etc. Dit politieke proces wordt in die zin beschouwd als een netwerk overheidsinstelling. Daarbij zijn sommige actoren belangrijker dan andere. Indien de prefe-

s39 Vam Helden, in Moll en verbon (1993, Paragraaf 4.3.2. en 4.3.3.). 
renties van alle overheidsinstellingen zouden worden onderzocht is het mogelijk een aanbodcurve van collectieve goederen af te leiden. De aanbodkant van het Downsian modell zou dan verwangen kunnen worden door bovengenoemde aanbodfunctie. Waarschijnlijk geeft dit een beter beeld wan de werkelijkheid dan een analyse van partijprogramma's.

Owerigens is er sprake van een wisselwerking tussen vraag en aanbodkant. De productie van de overheid kan onderscheiden worden van de effecten ("outcomes") van dat beleid. De burgers reageren in hun politieke gedrag op deze effecten van overheidsbeleid. Deze reacties zouden kunnen worden weergegeven in een beleids reactie-functie. Van Mierlo vermeldt nog een aantal mogelijke wijzigingen. Omdat deze vooral ook gaan over de vraagkant van het pollitieke proces zal hiler verder niet op worden ingegaan. ${ }^{540}$

\section{Relaties binnen het netwerk en transactiekosten}

De principaal zall proberen de agent in het gareel te houden. Voor zover hij hiervoor kosten maakt leidt dat tot een verschuiving van de kostenfunctie, die kan worden gezien als het budget van de overheidsinstelling. Hierdoor verschuift ook het optimale doelenpakket. Dit effect laat zich onderscheiden in een "inkomens-" effect en een substitutieeffekt op de diverse doelen. Door de transactiekosten verschuift de budgetcurve naar beneden, in die zin dat minder van het budget beschikbaar is voor het bereiken van de verschillende bijkomende doelen. Hierbij wordt er vanuit gegaan dat op korte termijn de kostencurve vastligt. Dit betekent dat meer van het totale kostenbudget besteed moet worden aan transactiekosten. Alleen met behulp van specifiek onderzoek kan bepaald worden hoe groot deze transactiekosten zijn, voor zover dit tenminste in de praktijk mogelijk is. De vraag rijst vervolgens of de kostencurve ook qua richting verschuift. Deze verschuift alleen als de transactiekosten van bepaalde doelen meer toenemen dan van andere. Dit is slechts waarschijnlijk indien alleen bepaalde principaal-agent-verhoudingen hoge transactiekosten met zich meebrengen en andere niet of indien agenten stelselmatig een aversie vertonen ten opzichte van bepaalde doelen. Wil dit zich voordoen dan moeten de preferenties van principalen en actoren met betrekking tot bepaalde doelen aanzienlijk verschillen.

\subsection{Conclusie}

Transactiekosten vormen eén van de verkllaringen voor de specifieke organisatiestructuur. Op grond van de transactiekosten wordt in theorie door de actoren/ eigenaren voor een bepaalde structurur gekozen. Dit hoeft niet het geval te zijn. Gebeurt dit wel dan beinvloedt dit ook de overige onderdelen van het netwerk zoals de verdeling van eigendomsrechten, de relaties tussen actoren en het besluitvormingsproces. Ook dit zal weer invloed hebben op het gedrag en de "performance" van de overheidsinstelling.

Indien activa specifiek zijn zal een overheidsinstelling slechts beperkt extern zelfstandig zijn. Het bedrijf zal in beperkte mate eigen vermogen mogen aanhouden. In principe bevordert dit de efficientie, zoals in hoofdstuk 7 bij de behandeling van de eigendomsrechtenstructuur is aangegeven, terwijl de transactiekosten minimaal zijn. Is dit nu optimaal? Op grond van efficièntieoverwegingen wel, maar zoals in paragraaf 2.2 .2 is uiteengezet is de herverdeling van inkomen door een overheidsinstelling erg belangrijk. Het impliceert dat er minder bijkomende doelen nagestreefd kunnen worden. Ten aanzien van het eigenlijke doel mag dit efficiënt zijn, dit wil nog niet zeggen dat er vooruitgang mogelijk is ten aanzien van alle bijkomende doelen. Of dit het geval is kan slechts van

Van Mierlo (1989, pp. 209-210). 
geval tot geval anderzocht worden. 


\section{Hoofdstuk 12. Samenvatting en conclusie Deel 2: hoe kan de "performance" van een overheidsinstelling worden verklaard?}

\subsection{Inleiding}

Op grond van het verklaringsmodel van het gedrag van overheidsinstellingen, zoals dat in dit theoretische deel ontwikkeld is, kunnen nu de volgende conclusies worden getrokken over het gedrag en de "performance" van overheidsinstellingen.

Het structuur-gedrag-resultaat-schema is uitgewerkt door de toepassing van een netwerkbenadering. Een overheidsinstelling kan worden opgevat als een samenstel van actoren, die allemaal proberen om hun doelen te bereiken. In hoofdstuk 6 is uitgewerkt dat de verdeling van eigendomsrechten invloed heeft op de "performance", hoewel verschillen in eigendomsrechten niet automatisch hoeven te leiden tot een mindere efficièntie. ${ }^{541} \mathrm{De}$ eigenaren streven bepaalde doelen $\mathrm{na}$, relevante actoren staan in bepaalde verhoudingen tot elkaar en trachten in een besluitvormingsproces zoveel mogelijk van hun doelen te realiseren. Ook de transactiekosten binnen een overheidsinstelling als besturingsstructurur kunnen daarbij een rol spelen. Belangrijke verschillen tussen overheidsinstellingen en particuliere bedrijven bestaan uit de invloed van het politieke proces. Dit resulteert in verschillen in organisationele en individuele prikkels tussen overheidsinstellingen en particuliere bedrijven. Borcherding merkt op dat de beslissing van de overheid om al dan niet een overheidsinstelling op te richten veel weg heeft van de door Williamson geanalyseerde verticale integratie van een bedrijf. Evenals een particulier bedrijf zal ook de overheid een afweging maken tussen de kosten en opbrengsten van het zelf produceren en het overlaten van de productie aan de markt. ${ }^{542}$ Indien de overheid een bepaald doel wenst te bereiken zal zij een afweging maken tussen de kosten en baten van particuliere of publieke voortbrenging. In hoofdstuk 2 is aangegeven dat elk van de genoemde besturingsstructuren specifieke kenmerken beeft, $Z$ ij zullen in bepaalde omstandigheden beter functioneren dan in andere. Daamaast moet gelet worden op de kosten. Een subsidie brengt naast de subsidie kosten met zich mee. De overheid moet kosten maken om te controleren of het particuliere bedrijf deze doelen, waaronder bijvoorbeeld inkomensherverdeling, ook werkelijk probeert te bereiken ("monitoring"). Indien de "monitoring costs" voor een particulier bedrijf hoger zijn dan voor een even efficiènte overheidsinstel ling en én van de bovengenoemde argumenten voor een overheidsinstelling doet zich voor, is het waarschijnlijk dat de owerheid er voor kiest de productie te verzorgen door middel van overheidsinstellingen. De in dit deel ontwikkelde theorie van overheidsinstellingen kan mu als volgt worden weergegeven:

s4l Zie: Daves en Christensen (1980, pp. 458-476).

s4: Borcherding (1983, pp. 99-184). 


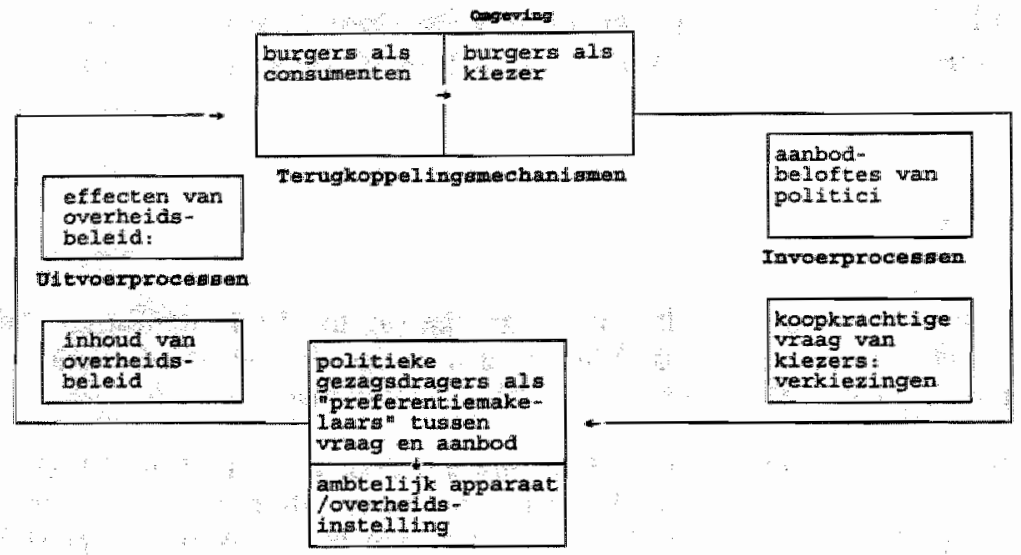

onzeting aprocersen

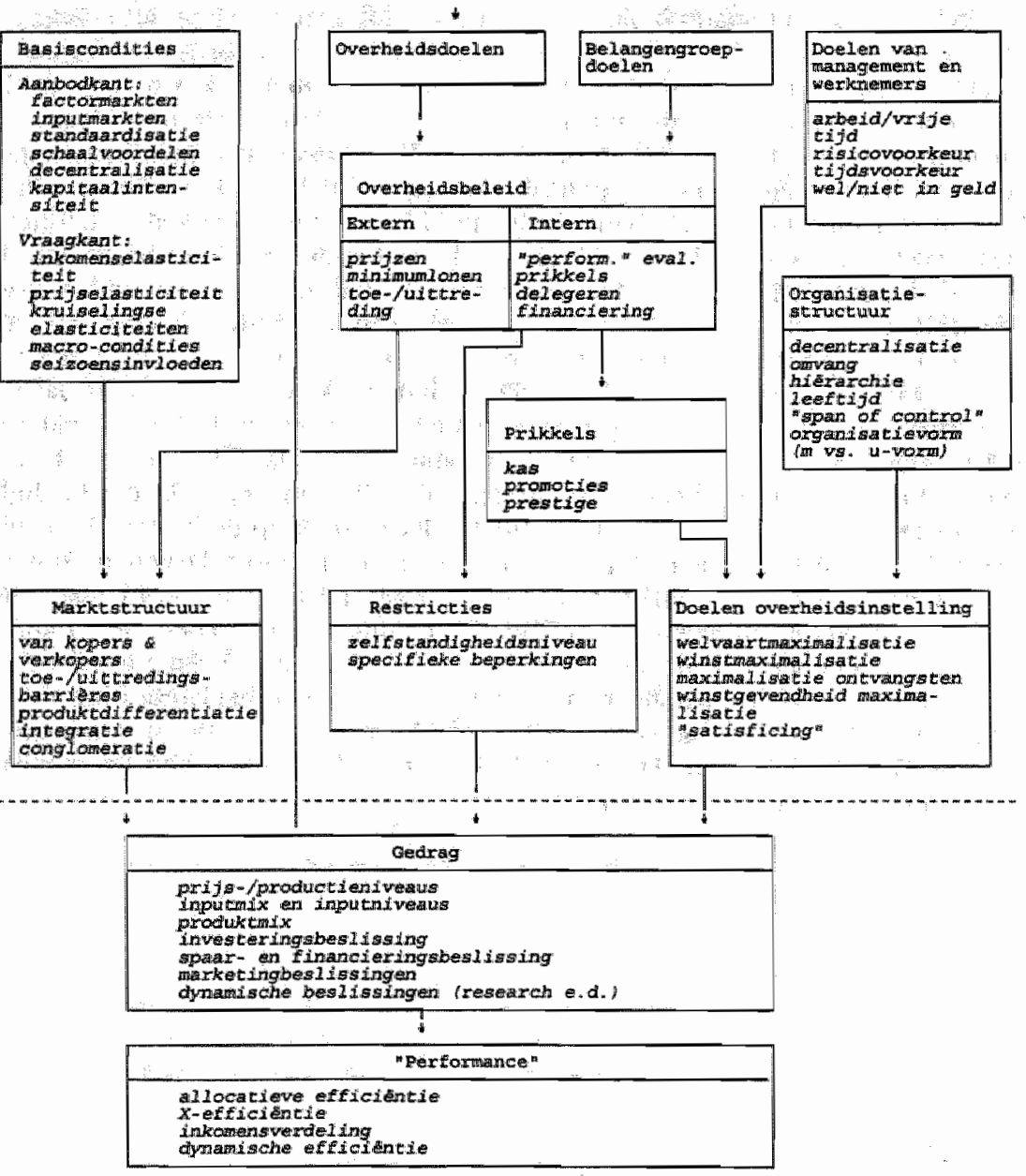

Figuur 12.1 Resultaat en gedrag van een overheidsinstelling 
Hieruit vloeien een aantal belangrijke factoren voort die het gedrag vain een overheidsinstelling kunnen verklaren. In Figuir 12.1 valt op dat er allerlei (externe en interne) restricties zijn waar een overheidsinstelling mee te maken heeft. In het kader van de principaal-agentheorie is op een aantal sturingsinstrumenten ingegaan. Er zijn tal van restricties denkbaar, bijvoorbeeld restricties op het prijsgedrag van een overheidsimstelling of op het investeringsgedrag. Ook kunnen restricties worden opgelegd ten aanzien van de mate waarin een overheidsinstelling eigen vermogen mag aanhouden en met betrekking tot de mate waarin de instelling zelf de formatie van personeel mag uitbreiden. Hierbij kan onderscheid gemaakt worden tussen verschillende soorten prikkels en verschillende soorten overheidsinstellingen.

\section{Organisationele prikkels}

Op grond van de structurur-gedrag-resultaat-benadering zoals die in hoofdstuk 3 is toegepast op overheidsinstellingen is het duidelijk dat de marktstructuur ook voor de "performance" van overheidsinstellingen van groot belang is. Samenvattend kan gesteld worden dat er een aantal belangrijke verschillen tussen overheidsinstellingen en particuliere bedrijven bestaan. In het kader van de eigendomsrechtenbenadering zagen we dat overheidsinstellingen in de praktijk niet geconfronteend worden met faillissementen en dat overheidsinstellingen veelal niet te maken hebben met mededinging, in die zin dat overheidsinstellingen vaak opereren als wettelijk monopolie.

In de eerste plaats is het mogelijk dat de overheid de marktstructuur en daardoor het gedrag en de "performance" van een overheidsinstelling beinvloedt. Hierbij kan gedacht worden aan de instelling van overheidsmonopolies in de elektriciteitssector of in de telecommunicatie. Het instellen van een juridisch monopolie impliceert het opwerpen van entreebarrières. Politieke actoren zullen dan grote invloed uit kunnen oefenen door restricties op te leggen en door de vrijkomende discretionaire bevoegdheid in te vullen. Indien door privatisering de marktstructuur wordt gewijzigd is het mogelijk dat de technische efficiëntie toeneemt. Uit de literatuur blijkt bijvoorbeeld dat privatisering geen effectief instrument is om de efficiëntie van een overheidsinstelling te verbeteren, indien de instelling voor privatisering reeds concurrentie ondervond in de afzetmarkt. ${ }^{543}$ Dit is eenvoudig te begrijpen indien de benadering gevolgd wordt die in dit deel is weergegeven. Hoewel de verdeling van eigendomsrechten, het besluitvormingsproces, de princlpaal-agent-relaties en de transacties en transactiekosten zullen veranderen door privatise-m ring is dat in dit geval blijkbaar niet dusdanig dat de efficiëntie verandert. Dit sliuit aan bij hoofdstuk 4 over de normatieve analyse, waarin werd uiteengezet dat indien een overheidsinstelling concurreert op een competitieve markt er weinig ruimte is bijkomende doelen na te streven. Er is nauwelijks sprake van "rent-seeking" en de "public enterprise rent $^{\text {" }}$ zal gering zijn. In het geval van privatisering zal de technische efficièntie dan ook maar beperkt toenemen.

Vaak worden overheidsinstellingen mimder met concurrentie geconfronteerd. Gebrek aan competitie kan belangrijke invloed hebben op het keuzegedrag van individuen zowel binnen als buiten de organisatie. Consumenten hebben in het geval van een wettelijk monopolie geen keus en moeten de produkten van de overheidsinstelling als netwerk wel afnemen. Particuliere bedrijven moeten, voor zover er sprake is yan mededinging; wel

sut Vergelijk: Huibers (1995, pp. 430-431) en Borcherding, Pommerehne en Schneider, in: Baker en Elliott (1990, pp. 397 e.v.). 
rekening houden met de last die ze opleggen aan de cliëmten in de vorm van wachtrijen en administratieve rompslomp: In het geval van verminderde competitie zal dat weel minder het geval zijn. Bij een overheidsinstelling bestaat in dat geval geen prikkel om rekening te houden met de kosten die gemaakt worden door de consumenten. Particuliere bedrijven zullen ook zo veel mogelijk streven naar efficiëntie teneinde beter in staat te zijn de door de consumenten gewenste goederen te leveren, terwijl dat bij (monopolistische) overheidsinstellingen minder het geval kan zijn Genoemde argumenten komen overeen met de kritiek die veelal geuit wordt op monopolies in de marktsector. Ten aanzien van particuliere monopolies wordt vaak gesteld dat deze statisch inefficiënt zijn maar mogelijk dynamisch efficiënt indien zij meer innovaties weten te realiseren waardoor de kosten zullen dalen. Het is niet waarschijnilik dat overheidsinstellingen meer innovaties zullen realiseren dan particuliere competitieve bedrijven. Dit zou technische inefficiëntie impliceren.

Overigens valt er binnen de publieke sector een belangrijke ontwikkeling te onderkennen. Door veranderingen in de samenleving, met name door de ontzuiling en door veranderingen binnen de publieke sector, zoals de grote groei na de Tweede Wereldoorlog en de toenemende kritiek in de jaren ' 80 wordt steeds meer geprobeerd de zelfstandigheid van overheidsinstellingen te vergroten. Dit leidt ertoe dat de overheidsinstellingen meer dan vroeger worden geconfronteerd met concurrentie en dat de invloed van de omgeving op de overheidsinstelling steeds meer toeneemt. Deze invloed bestaat niet alleen uit de invloed van het politieke proces maar dus ook steeds meer uit de feedback door het marktproces. De cliënten van de overheidsinstelling worden steeds belangrijker.

De mogelijkheid van fallissement vormt een budgettaire beperking voor particuliere bedrijven. Te grote verliezen kunnen voor particuliere bedrijven het einde betekenen. De mogelijkheid om allerlei doelen na te streven naast de productie van het eigenlijke goed, waaronder bijwoorbeeld het extra belonen van medewerkers, is derhalve beperkt. Overheidsinstellingen daarentegen worden vaak, zij het lang niet altijd, gekenmerkt door lage winstniveaus of zelfs aanzienlijke verliezen. In dat laatste geval wordt er geld overgehevelld van de belastingbetaler naar de overheidsinstelling, waarmee vervolgens allerlei doelen worden nagestreefd. Managers van overheidsinstellingen hebben in het algemeen meer mogelijkheden discretionailre doelen na te streven.

\section{Individuele prikkels}

Een tweede belangrijk verschil tussen publieke en particuliere bedrijven heeft, zoals in het kader van de principaal-agent benadering is aangegeven, betrekking op de prikkels waarmee werknemers bij overheidsinstellingen geconfronteerd worden. : Hierbij kan gedacht worden aan het beloningssysteem, de salarisstructuur en de kans op ontslag.

Beloningsstructuren (salarissen) van managers in overheidsinstellingen zijn veelal minder gekoppeld aan de winst. Bovendien zijn salarissen veelal meer beperkt. Het zal vaak niet acceptabel worden geacht aan managers in overheidsinstellingen topsalarissen uit te betalen, terwijl dat in het bedrijfsleven wel gebeurt. Dit kan ertoe leiden dat niet de beste mensen worden ingehuurd of dat managers/individuen minder geprikkeld zullen worden om zich in te spannen. Indien er sprake is van vaste ambtelijke salarisschalen is het voorts waarschijnlijk dat de arbeidskosten ongelijk zijn aan de marginale opbrengsten van een extra werknemer, hetgeen inefficiënt is:

Hierbij is het voorts van belang zich te realiseren dat veel publieke instellingen niet zo zeer goederen produceren alswel een administratief dienstenkarakter hebben. Ook deze activiteiten brengen een aantal verschillen met zich mee.

In het kader van productie-activiteiten verricht door een overheidsinstelling wordt vaak 
uitgegaan van observeerbare inputs en outputs, duidelijk omschreven doelen etc.. Mede door het administratieve/diensten karakter van veel overheidsinstellingen wordt hier in de

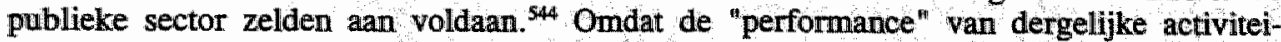
ten moeilijk te bepalen is en ook de kosten moeilijk te bepalen zijn kunnen problemen ontstaan ten aanzien van de verhouding tussen principalen en agenten. Het administratieve karakter van de activiteiten leidt er ook toe dat de beloningsstructurur moeilijk te koppelen is aan de prestatie. Bovendien worden dergelijke organisaties zoals opgemerkt vaak gekenmerkt door een veelvoud van doelen. Een ander kenmerk van dergelijke organisaties, zoals bij de behandeling van eigendomsrechten in hoofdstuk 7 is aangegeven, is dat de band tussen inputs en outputs beperkt is. Extra inzet van personeel leidt nilet automatisch tot meer productie en andersom leidt een lagere productie niet automatisch tot minder personeel. ${ }^{545}$ In hoofdstuk 4 is uiteengezet dat deze wijze van analyseren van een overheidsinstelling slechts een beperkt beeld geeft. Minder van het eigenlijke doel wil niet zeggen dat er ook minder bijkomende doelen worden nagestreefd.

In het kader van de bureaucratietheorie van Niskanen en een aantal aanvullingen hierop is meer in het bijzonder ingegaan op het gedrag van dit soort overheidsinstellingen. Indien de bureaucraat de enige instelling is die bepaalde diensten aanbiedt zal zij proberen om de ormvang van de instelling te maximaliseren. Bureaucraten hebben belangrijke informatievoordelen vergeleken met wetgevers, met name ten aanzien van de kosten van overheidsdiensten. De bureaucraat kan de baten en kosten bijwoorbeeld anders voorstellen dan ze werkelijk zijn. Soms zal de bureaucraat de kosten te laag weergegeven. Dit zal met name het geval zijn indien er sprake is van competitie en in het geval van hoge kosten. De bureaucraten proberen dan in een later stadium aanvullende budgetten te verwerven.

Soms zullen de bureaucraten de kosten te hoog weergeven. De ontvangen middelen kunnen aan andere doelen besteed worden. De bureaucraat is bang dat anderen de indruk hebben dat de dienst met minder kosten voortgebracht kan worden en dat hij dienovereenkomstig volgend jaar minder zal ontwangen. Daarom heeft de bureaucraat een prikkel het totale budget aan het eind van het jaar op te maken. Bovendien kan de bureaucraat acties ondernemen die de baten en kosten beïnvloeden.

Een en ander leidt tot de conclusie dat de conventionele "incentive structure" slecht bruikbaar is voor dergelijke organisaties. In hoofdstuk 10 zijn een aantal kanttekeningen bij deze benadering geplaatst. Bureaucraten concurreren met elkaar om middelen. In die zin is het marktconcept tot bepaalde hoogte vervangen door bureaucratische mededinging. Bureaucraten hebben bovendien veelal een reeks van doelen. Zij streven niẹt alleen naar een toename van de omvang van hun afdeling maar zij streven met behulp van hun discretionaire bevoegdheden ook allerlei andere doelen na. Voorts is het mogelijk dat zij risico's zoveel mogelijk proberen te vermijden. Bureaucraten proberen hun budget te vergroten en concurreren om dat te bereiken met andere bureaucraten. Zij zullen proberen zoveel mogelijk te voldoen aan de wensen van de politici/parlementariers die zitting hebben in lichamen die de instelling controleren. Bepaalde inefficiënties van de instelling zijn dan ook vaak hieraan te wijten. De instelling probeert zo goed mogelijk aan allerleil met name distributieve doelen en wensen te voldoen.

Daar staat tegenover dat indien de concurrentie om middelen beperkt is, bijvoorbeeld omdat er slechts één overheidsinstelling is die de betreffende activiteit verricht, bureaucraten meer eigen doelen kunnen gaan nastreven. De belangen van bureaucraten en het publieke belang kumnen dan ver uit elkaar gaan lopen. Indien de instelling een algemeen

Zie: Tullock (1992, Hoofdstuk 4 en 5).

S4s Vergelijk ook: Parkinson, herdrukt in Mansfield (1980). 
budget krijgt is dit het belangrijkste controle-instrument ten aanzien van de instelling. De instelling kan enige discretionaire bevoegdheden hebben binnen het budget. Ze kan met die bevoegdheden eigen doelen nastreven. Ze kan $\mathrm{mu}$ dreigen te bezuimigen op een onderdeel om het algemene budget te vergroten. Een bureau kan bijvoorbeeld slechts een beperkt aantal alternatieven presenteren.

Een ander belangrijk verschill tussen owerheidsinstellingen en particuliere ondernemingen heeft betrekking op de kans op ontslag. De mogelijkheid werknemers te ontslaan is bij owerheidsinstellingen niet zozeer juridisch alswel feitelijk meer beperkt. Dit leidt ertoe dat incompetente werknemers moeilijker ontslagen kunnen worden, hetgeen eveneens kan leiden tot inefficiêntie.

Tenslotte zijn de transacties tussen de actoren, zoals die voortvloeien uit de verdeling van eigendomsrechten van belang. Hierbij zijn niet alleen de transactiekosten zoals die voortvloeien uit specificiteit van activa relevant maar zijn ook de transactiekosten ten gevolge van de installatie van de eigendomsrechtenstructiur, de verandering daarvan en de controlemechanismen in het kader van de principaal-agentverhouding van belang. Vooral "agencykosten" zijn belangrijk indien de transacties binnen overheidsinstellingen worden geanalyseerd.

Een derde wijze waarop de politieke actoren invloed hebben op een overheidsinstelling is door het bepalen van de doelen van de overheidsinstelling en door ervoor te zorgen dat de overheidsinstelling deze doelen ook nastreeft. Zij kan dit proberen te realiseren door het gebruiken van allerlei sturings- (prikkels) en controlemechanismen. Deze categorie vormt eveneens een restrictie van de overheid. $\mathrm{Zij}$ wordt wel aangeduid als interne restrictie.

De interactie tussen al deze variabelen verklaart het uiteindelijk resulterende gedrag vam een overheidsinstelling. Inmiddels zal duidelijk zijn dat het gedrag van vrijwel elke overheidsinstelling zal verschillen. Ook indien twee elektriciteitsbedrijven in Nederland of bijwoorbeeld de Belastingdienst in Nederland en Duitsland vergeleken worden zullen belangrijke verschillen gevonden worden. Zelfs het intertemporeel vergelijken van eenzelfde overheidsinstelling zal slechts de conclusie opleveren dat de vergelijking weinig zinvol is indien daarmee beoogd wordt het gedrag of belangrijker de "performance" te verklaren. Zoals eerder gememoreerd is het beter casuistisch te werk te gaan en overheidsinstellingen afzonderlijk te onderzoeken. Tenslotte moet nog worden benadrukt dat het veelal zo zal zijn dat het netwerk als geheel ander gedrag vertoont dan het door de afzonderlijke actoren/de politiek nagestreefde gedrag.

12.2 In hoeverre zijn de doelen van het opstellen van een politiek-economische theorie, zoals aangegeven in paragraaf 3.1 , bereikt?

\section{Gedrag van het netwerk}

Uit de ontwikkelde theorie blijkt dat het voor het analyseren van het gedrag en de "performance" nodig is om precies te weten welke doelen/goederen een overheidsinstelling nastreeft en wat de kosten hiervan zijn. De overheid moet derthalve weten wat de "performance" is van een overheidsinstelling, waarbij niet zozeer naar de technische inefficiëntie ten aanzien van het eigenlijke doel alswel naar de kosten van de bijkomende doelen gekeken moet worden. Indien de "performance" bekend is kunmen maatregelen genomen worden. Dit is mogelijk door de verschillende factoren die invloed hebben op de "performance" te wijzigen. Dit is bijwoorbeeld mogelijk door het wijzigen van de 
marktstructuur, door het wijzigen van de eigendomsrechtenstructuur (bijvoorbeeld door het toekennen van bet recht op eigen vermogen), door het wijzigen van het beloningsstelsel en door het beînvloeden van de na te streven bijkomende doelen. Indien de overheid constateert dat de kosten van de bijkomende doelen erg hoog zijn, kan zij overwegen om deze over te hevelen naar andere overheidsinstellingen of naar de marktsector (bijvoorbeeld door het verstrekken van subsidies).

\section{De functie van overheidsinstellingen}

Met betrekking tot de functie van overheidsinstellingen kan op grond van hoofdstuk 4, gewijd aan de normatieve theorie, worden geconcludeerd dat een belangrijke functie van overheidsinstellingen het nastreven van bijkomende doelen is en dat er in die zin vrijwel steeds sprake is van "rent-seeking". Een probleem van deze bijkomende doelen is dat deze vaak moeilijk te meten zijn en in de praktijk veelal nauwelijks gemeten worden. Dit in relatie met de relatief zelfstandige positie van veel overheidsinstellingen (ten opzichte van bijvoorbeeld departementen) biedt het management de mogelijkheid de geboden vrijheid te benutten voor eigen doelen als budgetmaximalisatie en het nastreven van "slack". De sponsor zal in dat geval nog minder informatie hebben over wat er zich binnen een overheidsinstelling afspeeit. Een belangrijke restrictie hierop is de mogelijkheid voor politieke actoren om de baten en de kosten van het voortbrengen van de bijkomende doelen door de overheidsinstelling af te wegen tegen de baten en de kosten van alternatieve voortbrengingsmogelijkheden als belastingheffing, andere overheidsinstellingen of subsidiëring van particuliere bedrijven of tegen het in het geheel niet voortbrengen van de bijkomende doelen. De mogelijke voordelen van synergie moeten dan ook worden afgewogen tegen de mogelijke kosten van het niet goed kunnen controleren van het management ten gevolge van de gesignaleerde informatie-asymmetrie. De kosten/batenafweging kan alleen plaatsvinden door een "performance"-analyse van de betreffende overheidsinstelling.

\section{Organisatievormen}

In het theoretische deel zijn een aantal organisatievormen genoemd die een overheidsinstelling als netwerk kan aannemen. De organisatievorm hangt af van een reeks van factoren, waaronder de verdeling van eigendomsrechten en de efficiëntie daarvan, de relaties tussen de eigenaren, de transactiekosten en het besluitvormingsproces. Het netwerk en de interacties tussen actoren bepalen het gedrag van een overheidsinstelling. Per geval moeten de doelen van de actoren, de eigendomsrechten c.q. macht waarover ze beschikken, het besluitvormingsproces en de transactiekostenstructuur geanalyseerd worden. In het geval van het Rijksmuseum legden de principalen bijvoorbeeld meer de nadruk op verzelfstandiging en minder de nadruk op bijkomende doelen. Ze beschikten over de eigendomsrechten om een wijziging door te voeren en voorts zijn zij in staat gebleken om in het besluitvormingsproces hun doelen te realiseren. Een belangrijke reden voor de principalen om te streven naar verzelfstandiging kan verband hebben gehouden met de afweging van transactiekosten en de diverse beloningsstructuren en de macroeconomische situatie die noodzaakte tot bezuinigingen. Zoals aangegeven in hoofdstuk 2 moet privatisering dan ook gezien worden als gevolg van een afwegings- en "rentseekings" -proces van de actoren in het netwerk, waarbij deze actoren (tevens dragers van eigendomsrechten) zich voornamelijk zullen laten leiden door een afweging van baten en kosten. 
12.3 Hoe verhoudt de ontwikkelde theorie zich met recente voorstellen om de publieke sector te reorganiseren?

Van Mierlo vermeldt een viertal veranderingen die zich in het praktische functioneren van publieke bureaucratieen hebben voorgedaan. ${ }^{546}$ Het klassieke onderscheid tussen beleid en uitvoering verdwijnt steeds meer, de overheid is qua omvang met name sinds 1945 sterk gegroeid, de overheidsorganisatie heeft steeds meer een eigen dynamiek ontwikkeld en tenslotte werd in de jaren tachtig de overheid zelf meer en meer onderwerp van kritiek. De nadruk kwam steeds meer te liggen op een kleinere maar betere overheid. De huidige organisatievormen in de publieke sector hebben zich onvoldoende aangepast aan de ontwikkelingen die zich in de overheidssector maar vooral ook in haar omgeving (cliënten, politici) hebben voorgedaan. Van den Doel en Van Velthoven stellen dat de kern van het probleem van de overheidsorganisatie ligt in de hiërarchische structurur en de monopolistische marktvorm. ${ }^{547}$ Op grond daarvan zou de monopolistische marktvorm vervangen moeten worden door mededinging terwijl de hiërarchie vervangen zou moeten worden door democratie. Het concept van publiek ondernemerschap, afkomstig van David Osborne en Ted Gaebler, probeert dit te realiseren en biedt in die zin mogelijkheden voor een radicale hervorming van de publieke organisatievorm. ${ }^{548}$ De bureaucratische organisaties binnen de publieke sector zouden omgevormd moeten worden tot meer ondernemingsgerichte organisaties. Een nieuwe vorm van overheid is nodig op alle niveaus van de overheidsorganisatie en dus ook op het niveau van de in deze dissertatie onderzochte overheidsinstellingen. Deze ideeën zijn zeer actueel, ook gelet op de ontwikkelingen in de V.S., waar onder supervisie van Al Gore getracht wordt tot een zodanige reorganisatie van de overheid te komen dat deze flexibel, efficiënt en effectief is. ${ }^{549}$ De heruitgevonden overheid dient goederen van een hoge kwaliteit te leveren en dient sterk klantgericht te zijn. Osborne en Gaebler menen dat deze overgang naar een ondernemingsgezinde publieke sector gerealiseerd kan worden door de toepassing van een tiental principes:

1. De overheid moet nauwkeurig onderzoeken of er alternatieven zijn voor levering via eigen organisaties.

2. Bestuurders zouden cliënten moeten laten participeren in het management door hen op te nemen in managementteams e.d.

3. Meer concurrentie in de publieke sector door rivaliteit tussen verschillende afdelingen, concurrentie tussen verschillende overheidsinstellingen om aan de preferenties van de cliënt te voldoen:

4. Instellingen moeten het aantal regels op grond waarvan zij opereren minimaliseren.

5. Onderzoek naar de "performance" van overheidsinstellingen moet niet gebeuren door te kijken naar de inputs die benodigd zijn voor de programma's maar door te kijken naar de effecten van beleid.

6. Gebruikers van overheidsdiensten moeten gezien worden als cliënten. Hun preferenties moeten onderzocht worden, de overheidsinstelling moet hen keuzes bieden, etc.

7. De overheid moet niet alleen geld uitgeven, maar het ook zelf verdienen. Onder meer door het rekenen van prijzen voor de door haar geleverde goederen en diensten en het opzetten van winstcentra.

\footnotetext{
546 Van Mierio (1995, p. 2).

547 Van den Doel en Van Velthoven (1993, pp. 148-174).

sas Osborne en Gaebler (1992, hoofdstuk 11).

${ }^{\$ 499}$ Gore (1993). Vergelijk ook: Wilson (1994, pp. 667-668) en Kamensky (1996, pp. 248-249).
} 
8. De overheid moet niet alleen goederen en diensten aanbieden om bepaalde doelen te bereiken maar moet ook proberen om te voorkomen dat bepaalde behoeften ontstaan. Denk aan inbraakpreventie, brandpreventie e.d. .

9. Gecentraliseerde instellingen moet gedecentraliseerd worden. De hiërarchische controle moet vervangen worden door onder meer teamwerk, participatief management en een grotere participatie van de werknemers.

10. Overheden moeten niet alleen proberen doelen te bereiken door opdrachten en hiërarchische controle maar ook door hervorming van markten. De overheid zou bepaalde activiteiten kunnen subsidièren in plaats van ze zelf voort te brengen.

Volgens Osborne en Gaebler zou dit pakket een belangrijke uitweg kunnen vormen uit het oude dilemma overheid of markt, tussen enerzijds de inefficiënte bureaucratische organisatievorm en anderzijds de markt (met als belangrijk bezwaar: marktfalen). Van Mierlo merkt op dat een ondernemende overheid niet alleen een oplossing zou kunnen zijn voor de problemen waarmee de overheidsorganisaties in Westerse landen te maken hebben, maar ook voor de reorganisatie van de economieën in Oost-Europa. ${ }^{550}$

De vraag rijst in hoeverre dit aansluit bij de conclusies die uit dit deel getrokken kunnen worden. Hierin zijn overheidsinstellingen beschreven als netwerken van actoren. Aangegeven werd dat overheidsinstellingen veelal organisaties tussen de overheid en de markt in betroffen. De principes van Osborne en Gaebler houden in feite in dat dergelijke netwerken aan bepaalde eisen moeten voldoen. Niet per definitie meer markt is nodig alswel aanpassing van overheidsnetwerken aan veranderde omstandigheden. Dit geldt bijvoorbeeld voor veranderingen in eigendomsrechten, transactiekosten, relaties binnen het netwerk en de verhoudingen met de omgeving, met name met cliënten en politici. Punt 1 en 10 houden bijvoorbeeld in dat de eigenaren beter moeten onderzoeken of er alternatieven zijn voor eigen voortbrenging. Dit correspondeert met hetgeen daarover is opgemerkt in hoofdstuk 2 . In dit hoofdstuk werd aangegeven dat de overheid tot bepaalde hoogte prikkels heeft om te onderzoeken of de voortbrenging van bepaalde goederen en diensten op een goedkopere wijze mogelijk is. Punt 2 en 9 houdt in dat de eigendomsrechtenstructuur van overheidsinstellingen gewijzigd moet worden. Meer eigendomsrechten moeten door de huidige eigenaren worden overgedragen aan de actoren binnen de overheidsinstelling en aan de cliënten van de organisatie. Ook de relaties tussen actoren in de publieke sector moeten volgens Osbome en Gaebler gewijzigd worden, zoals blijkt uit punt 3. Uit punt 5 en 6 blijkt dat meer nadruk moet worden gelegd op de klanten en daarmee waarschijnlijk vooral ook op het eigenlijke doel. Indien meer het accent moet worden gelegd op de realisering van het eigenlijke doel en minder op de bijkomende doelen, zoals ook blijkt uit punt 7 , betekent dat in feite dat de eigenaren hun doelen moeten aanpassen. Zoals we gezien hebben beïnvloeden al deze factoren de "performan-

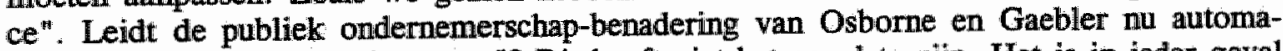
tisch tot de hoogste "performance"? Dit hoeft niet het geval te zijn. Het is in ieder geval onjuist dit in zijn algemeenheid zo te stellen. De invoering van het publieke ondernemerschap lijkt in te houden dat een bepaald soort netwerkorganisatie wordt voorgesteld voor alle overheidsinstellingen. Dit kan leiden tot een hogere "performance" maar dit hoeft niet het geval te zijn. Of zoals Backhaus stelt: "Unless there are identical political circumstances, the best practice of one (public) enterprise is not likely to be the best practice of another ${ }^{n}{ }^{551}$ De "performance" zal van netwerk tot netwerk verschillen. Overheidsinstellingen zijn immers sterk verschillend, onder meer qua eigendomsrechtenstructurur en de

\footnotetext{
5so Van Mierlo (1995, p. 5).

55I Backhaus (1994, pp. 283 e.v.).
} 
aard van de goederen en diensten die worden voortgebracht en zij zullen dan ook sterk verschillende doelen nastreven. De kosten, in de vorm van alternatieve kosten, moeten meegewogen worden. De conclusie is dan ook dat de "performance" per instelling onderzocht moet worden en dat pas op grond van dergelijk onderzoek kan worden aangegeven of een wijziging van het netwerk bijvoorbeeld door veranderingen in de eigendomsrechtenstructuur de "performance" kan verbeteren. De vraag is dan hoe de "performance" van overheidsinstellingen bepaald kan worden. 


\section{DEEL 3. "PERFORMANCE" ANALYSE EN CASE-STUDIES}

In deel 2 is onderzocht waarom overheidsinstellingen zich op een bepaalde manier gedragen. Meer specifiek ging het om het verklaren van de "performance" van overheidsinstellingen. Vervolgens wordt in dit deel geanalyseerd hoe de "performance" van overheidsinstellingen in de praktijk kan worden bepaald. Aangezien overheidsinstellingen en particuliere ondernemingen op zich niet yerschillen ligt het op het eerste gezicht voor de hand om de bedrijfseconomische prestatie-analyse hiervoor te gebruiken. Winstcijfers en allerlei financiële ratio's (rentabiliteit van het eigen vermogen e.d.) kunnen dan een redelijk beeld geven van het prestatieniveau van de onderneming. Dit blijkt in de praktijk echter niet haalbaar en vaak ook niet gewenst. De reden hiervoor is dat overheidsinstellingen veelal geheel andere doelen nastreven dan particuliere ondernemingen. ${ }^{552}$ Hiervoor zijn een aantal redenen.

1) Uit de definitie van overheidsinstellingen zoals die in dit onderzoek wordt gehanteerd kan worden afgeleid dat overheidsinstellingen niet per definitie naar winst streven. Hieruit volgt dat kennelijk allerlei andere doelen dan maximalisatie van de waarde van de onderneming van belang zijn. ${ }^{553}$ Doelen die veelal in particuliere ondernemingen geen rol spelen en ook niet met behulp van ondernemingsfinanciering/berichtgeving geanalyseerd kunnen worden. Hiermee is niet gezegd dat particuliere bedrijven naast of in plaats van hun winstdoelstelling niet ook andere doelstellingen kunnen hebben.

2) Zoals in hoofdstuk 2 is aangegeven vindt overheidsingrijpen door middel van overheidsinstellingen plaats op grond van de allocatie-, stabilisatie- of herverdelingsfunctie. Deze functies kunnen interacties vertonen. Dit impliceert dat overheidsinstellingen en dan met name de politieke actoren tal van doelen kunnen nastreven die een particulier bedrijf of zelfs een soortgelijke overheidsinstelling niet zouden nastreven.

3) Bepaalde overheidsinstellingen zijn door opname in de begroting onderhevig aan parlementaire controle terwijl andere onderworpen zijn aan bijv. een vorm van departementale accountantscontrole. Het is echter ook mogelijk dat overheidsinstellingen aan een vorm van controle ontsnappen. In een dergelijk geval kan de onderneming door de houders van eigendomsrechten binnen de overheidsinstelling zelf gebruikt worden voor het realiseren van allerlei doelen.

4) Overheidsinstellingen zijn een belangrijk instrument yoor de voortbrenging van collectieve goederen. Zoals Braun aangeeft zullen de doelen van een overheidsinstelling minder nauwkeurig zijn omschreven naarmate een instelling zich meer bezighoudt met de productie van collectieve goederen. Maar ook indien er sprake is van positieve externe effecten zullen de berichtgevingscijfers veelal tekortschieten.

Hoewel doelen van overheidsinstellingen en particuliere ondernemingen veelal van elkaar zullen verschillen hoeft dat niet altijd het geval te zijn. Dit zal met name niet het geval zijn indien de overheidsinstelling alleen gebruikt wordt als een inkomstenbron.

Uit het voorgaande is duidelijk geworden dat overheidsinstellingen veelal andere doelen nastreven dan particuliere ondernemingen omdat de structuur van eigendomsrechten verschilt. Een belangrijke consequentie hiervan is dat bedrijfseconomische prestatie-analyse

552 Braun (1988, p. 24).

\$ssi Mascarenhas (1996, p. 14, p. 25). 
veelal nilet geschikt is voor "performance"-beoordeling van overheidsinstellingen. De centrale vraag in de komende hoofdstukken zal dan ook zijn hoe de "performance" van overheidsinstellingen dan wel gemeten kan worden. Gezien het grote aantal overheidsinstellingen en de grote bedragen die hierin omgaan is het van groot belang om te weten in hoeverre overheidsinstellingen de financiềle middelen efficiënt gebruiken.

Met betrekking tot het gedrag en meer in het bijzonder de "performance" van overheidsinstellingen kummen een drietal benaderingen worden onderscheiden. ${ }^{\text {SS4 }}$

De eerste onderzoeksrichting bestaat uit normatieve studies die gericht zijn op het afleiden van optimale gedragsregels voor overheidsinstellingen overeenkomstig bepaalde (vooropgestelde) doelen. Hierbij kan gedacht worden aan de in appendix 1 behandelde prijsstelling op basis van marginale-kosten, "second- and third best"-uitbreidingen daarvan en overwegingen over rechtwaardigheid, macro-economisch beleid en financiële beperkingen.

Een tweede stroming wordt gevormd door het relatief nieuwe terrein van positieve studies die ingaat op vragen met betrekking tot prikkels, bureaucratisch gedrag en eigendomsrechten. Deze studies gaan veelal uit van de mogelijkheid dat managers, regering, werknemers, consumenten etc. conflicterende belangen en doelen hebben.

Tenslotte zijn er de empirische studies die gericht zijn op het meten van een "performance $^{\text {th }}$-index zoals effectiviteit, kosten, produktiviteit of winstgevendheid.

In de opembare financiën is ten aanzien van de "performance"-meting een ontwikkeling gaande van voornamelijk normatief en theoretisch onderzoek naar positief en empirisch onderzoek, waarbij het veeleer gaat om de feitelijke prestatie van overheidsinstellingen. In dit verband kunnen een tweetal brede benaderingen worden onderscheiden, namelijk de doel-onafhankelijke benaderingen ("goal-independent"-benaderingen) versus de doelafhankelijke benaderingen ("goal-centered"-benaderingen). ${ }^{555}$ De eerste benadering maakt gebruik van algemene standaard "performance" criteria en indicatoren die voor alle overheidsinstellingen gebruikt worden, zoals bijyoorbeeld winstgevendheid en produktiviteit. Uitgangspunt is dat deze criteria een goede benadering vormen van de werkelijke doelen van een overheidsinstelling of van de doelen die de overheidsinstelling zou moeten nastreven. De tweede bemadering wijst op het belang van de werkelijke doelen van een overheidsinstelling bij het analyseren van de "performance" van een bepaalde overheidsinstelling. Aangezien de doelen per bedrijf kunnen verschillen is het volgens deze benadering noodzakelijk dat de gebruikte indicatoren en criteria de specifieke doelenstructuur van een overheidsinstelling weerspiegelt. Case study-onderzoek is dan onontkomelijk. In dit deel worden beide benaderingen onderzocht en wordt bezien in hoeverre beide benaderingen het mogelijk maken de "performance" van een netwerk te bepalen.

\footnotetext{
${ }^{554}$ Marchand, Pestieau en Tulkens (1984, pp. 3-4).

sss Lioukas (1991, p. 3).
} 


\section{HOOFDSTUK 13. Doel-onafhankelijke en doel-afhankelijke benaderin- gen}

\subsection{Inleiding}

In dit hoofdstuk staat in de eerste plaats de vraag centraal in hoeverre de "performance" van een overheidsinstelling kan worden bepaald met behulp van doel-onafhankelijke benaderingen ("goal-independent"-benaderingen). Daartoe wordt achtereenvolgens ingegaan op de "indicatoren"-methode en de kwantitatieve benadering. Vervolgens wordt in het kader van de doelafhankelijke benaderingen ingegaan op de kwalitatieve benadering.

\subsection{Kan de "performance" worden bepaald met de "indicatoren"-methode?}

Veel onderzoek naar overheidsinstellingen maakt gebruik van allerlei soorten indicatoren. Kenmerkend voor deze methode is dat niet de doelen van overheidsinstellingen worden onderzocht maar dat met behulp van deze indicatoren bijvoorbeeld de productie of de kosten worden geschat. In de empirische literaturur worden een aantal conventionele indicatoren van efficiëntie onderscheiden, namelijk partiêle en totale produktiviteit van productiefactoren, gemiddelde kosten en rendement op kapitaal en andere financiële ratio's. Parris, Pestieau en Saynor onderscheiden een drietal vanouds gebruikelijke indicatoren: indicatoren voor de financiele "performance" (rendement, winstcijfers, verlies e.d.), partiële produktiviteit en verschillende informele maatstaven voor de tevredenheid van consumenten (bijvoorbeeld gebruikt door consumentenorganisaties). Zij stellen: "(..) that such indicators could very well indicate nothing meaningful as to the actual performance of public enterprise" "In deze paragraaf worden de voor belangrijkste indicatoren die gebruikt worden kort weergegeven.

\section{Produktiviteit:}

Een methode die het al aanwezige empirische materiaal beter wenst te benutten meet de produktiviteit van de overheid en maakt daartoe gebruik van verhoudingsgetallen/ratio's. ${ }^{357}$ Onder produktiviteit wordt verstaan: de verhouding nussen geleverde produkten en de daarvoor ingezette middelen (personen, materiaal, kapitaal). Het onderzoek maakt een onderscheid tussen intermediaire en finale producenten. Allereerst kan de vraag worden gesteld of niet kan worden voortgebouwd op het systeem van productiemeting zoals het C.B.S dat publiceert. De productie van bedrijven in de marktsector wordt volgens dit systeem gemeten door het berekenen van de productiewaarde, dat will zeggen de marktwaarde van alle voor de verkoop aan consumenten of producenten bestemde goederen en diensten, die vervolgens gecorrigeerd wordt voor inflatie. De bepaling van de productiewaarde van overheidsinstellingen is echter veel moeilijker omdat marktprijzen hier veelal ontbreken en de productie moeilijk eenduidig is vast te stellen. Op zijn hoogst worden administratieve prijzen gehanteerd die echter geen afspiegeling vormen van de kosten en derhalve niet als waarderingsgrondslag voor de productie kunnen dienen. Derhalve wordt de waarde van de productie bij de overheid in de nationale rekeningen gelijkgesteld aan de waarde van de ingezette middelen. Voor 1989 werd de productie van

\footnotetext{
55s Parris, Pestieau en Saynor (1987, p. 135),

5s: De Groot en Goudriaan (1991, pp. 9 e.v.).
} 
de Nederlandse overheid (Rijk + Overige Publiekrechtelijke Lichamen (OPL)) gemeten door de sallarissen en sociale lasten. $\mathrm{Na} 1981$ zijn er een antal veranderingen doorgevoerd in het C.B.S.-systeem.

De totale productie van Rijk en OPL bestaat (bij wijze van definiëring) uit:

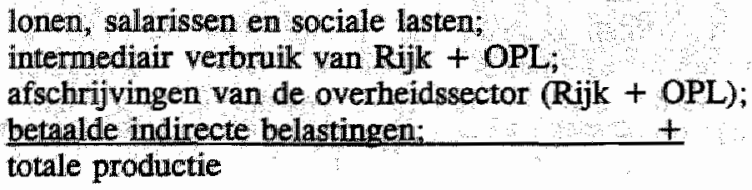

De netto toegevoegde waarde van de sector $\mathrm{Rijk}+\mathrm{OPL}$ bestaat uit de totale productie verminderd met het intermediaire verbruik en de afschrijvingen. Het bezwaar van dit systeem is dat wij feitelijk niet de output meten maar de input. Goudriaan et al. proberen de productie te meten met behulp van proces-, produkt-, en effektindicatoren. $\mathrm{De}$ onderwijsproductie wordt dan bijvoorbeeld bepaald door als indicator het aantall leerlingen of studenten te nemen. Vervolgens worden allerleil ratio's gebruikt om een beter beeld te krijgen van de produktiviteit van de overheidsinstelling.

Een nadeel van deze methode is dat productie-indicatoren veelal moeilijk zijn vast te stellen. Hierbij kan gedacht worden aan indicatoren voor collectieve goederen en externe effecten. Indien er al een indicator kan worden aangewezen zijn de meningen erover veelal verdeeld. Een tweede bezwaar is dat de productie dient te worden afgezet tegen bepaalde doelen. Het gaat ons er voor een belangrijk deel om in hoeverre de door de betreffende organisatie gestelde doelen bereikt worden. Vanuit de Public Choice-benadering kan nog een derde bezwaar worden aangevoerd. Actoren bij overheidsorganisaties hebben er veelal weinig belang bij dat de productie gekwantificeerd wordt. Datzelfde geldt voor de doelen. Indien indicatoren gebruikt worden wordt het risico gelopen dat enerzijds actoren hierop anticiperen en gaan handelen overeenkomstig de indicatoren en anderzijds dat niet de werkelijke productie en doelen gemeten worden maar een schijnproductie. ${ }^{558}$ De meeste van dergelijke "performance" studies maken gebruik van indicatoren die weinig zeggen over de werkelijke "performance" van een overheidsinstelling. Vaak wordt gebruik gemaakt van traditionele indicatoren zoals arbeidsproduktiviteit en rendement op kapitaal. Dergelijke factoren kunnen relevant zijn maar kunnen ook tot verkeerde conclusies leiden over de "performance" van een overheidsinstelling.

Pestieau tenslotte merkt op, dat het bezwaar van dit soort produktiviteitsindicatoren die gebruikt worden als maatstaf voor efficièntie is, dat zij berekend worden op basis van marktprijzen zonder acht te slaan op de onderliggende productiefunctie. Dit impliceert dat zij alleen een juist beeld geven indien de prijzen de werkelijke waarde van goederen en productiefactoren weerspiegelen. ${ }^{559}$ Kopp wijst er op dat het mogelijk is dat de produk-

\footnotetext{
558. Stel bijvoorbeeld dat een universiteit haar produktie meet door als indicator het anntal studenten te nemen dat slaagt voor bepaalde tentamens. Overeenkomstig de gerealiseerde produktie worden vervolgens bijvoorbeeld de budgetten verdeeld. Betrokkenen kunnen dan een prikkel hebben om tentamens gemakkelijker te maken. Hierdoor zullen wellicht meer studenten slagen voor examen. De met de indicator gemeten produktie neemt toe. Toch kan niet gezegd worden dat de produktie van de betreffende universiteit werkelijk toeneemt.
}

${ }^{559}$ Pestieau (1989, p. 299). 
tiviteit van een bepaalde productiefactor toeneemt, terwijl er een verlies in efficientie kan zijn. ${ }^{560}$ Ook is het mogelijk dat de produktiviteit onveranderd blijft terwijl de efficièntie verbeterd. 561

\section{Gemiddelde kosten}

Een tweede benadering is gericht op het vergelijken van de kosten van bedrijven. Daartoe wordt een schatting gemaakt van een kostenfunctie, inclusief een dummy variabele die het verschill weergeeft tussen publieke en private bedrijven. Deze benadering berust op de vergaande veronderstelling dat of de publieke of de private sector efficiënt is zonder te differentiëren naar sectoren en bedrijven. Voorbijgegaan wordt aan de mogelijkheid dat bedrijven in beide sectoren inefficiënt zijn.

\section{Financiële ratio's}

Een derde benadering die zich bezighoudt met de analyse van overheidsinstellingen maakt gebruik van financiële ratio's die zijn ontleend aan de financiële rekenkunde en de financiële verslaglegging van private bedrijven. Deze ratio's kunnen echter niet blindelings worden toegepast en dienen met veel voorzichtigheid te worden geïnterpreteerd. Overheidsinstellingen opereren vaak in imperfecte markten en streven bovendien allerlei bijkomende doelen na die niet terug te vinden zijn in deze ratio's.

De conclusie luidt dan ook dat het in de praktijk niet mogelijk is de "performance" van een overheidsinstelling te meten met behulp van indicatoren. Er wordt te weinig aandacht besteed aan de doelen van de overheidsinstelling en dan met name aan de bijkomende doelen. Deze zijn soms wel de belangrijkste zoals in het geval van de Nederlandse Spoorwegen (N.S.) en de Nationale investeringsbank (N.I.B.)

13.3 In hoeverre kan de "performance" van een overheidsinstelling worden verklaard door de "performance approach"?

Zoals beschreven in appendix 2 probeert de "performance benadering" de mate van efficiëntie van overheidsbedrijven te bepalen. Tulkens onderscheidt ten aanzien van deze benadering een viertal fasen in het onderzoeksproces. Teneinde de "performance" van een overheidsinstelling te bepalen attribueert deze benadering in de eerste plaats doelen aan overheidsinstellingen. Deze doelen worden afgeleid door middel van een welvaartseconomische analyse. De tweede stap is het voorzien in een rechtvaardiging voor deze attributie van doelen. Vervolgens moeten deze doelen gemeten worden met behulp van zorgvuldig geformuleerde indicatoren. Tenslotte dienen de waargenomen waarden van de indicatoren vergeleken te worden met een best presterende onderneming. ${ }^{562}$ De best presterende onderneming is het relatiepunt waarmee onderzochte overheidsinstellingen vergeleken kunnen worden.

Ten aanzien van de attributie van doelen maakt Pestieau een onderscheid tussen een viertal doelen die overheidsinstellingen nastreven, namelijk efficiëntie, rechtvaardigheid,

\footnotetext{
300 Kopp (1981, pp. 477 e.v.).

561 Thiry en Tulkens (1989, p. 24).

562 Pestieu, Marchand en Tulkens (1984, pp. 25-27).
} 
financieel evenwicht en macro-economische doeleinden. ${ }^{563}$ Deze doelen maken onderdeel uit van het algenene overheidsbeleid. Ten aanzien van efficiëntie maakt Pestieaw een onderscheid tussen technische en prijsefficiërntie en allocatieve efficiëntie. Pestieau geeft aan dat deze soorten van efficiëntie met elkaar samenhangen.

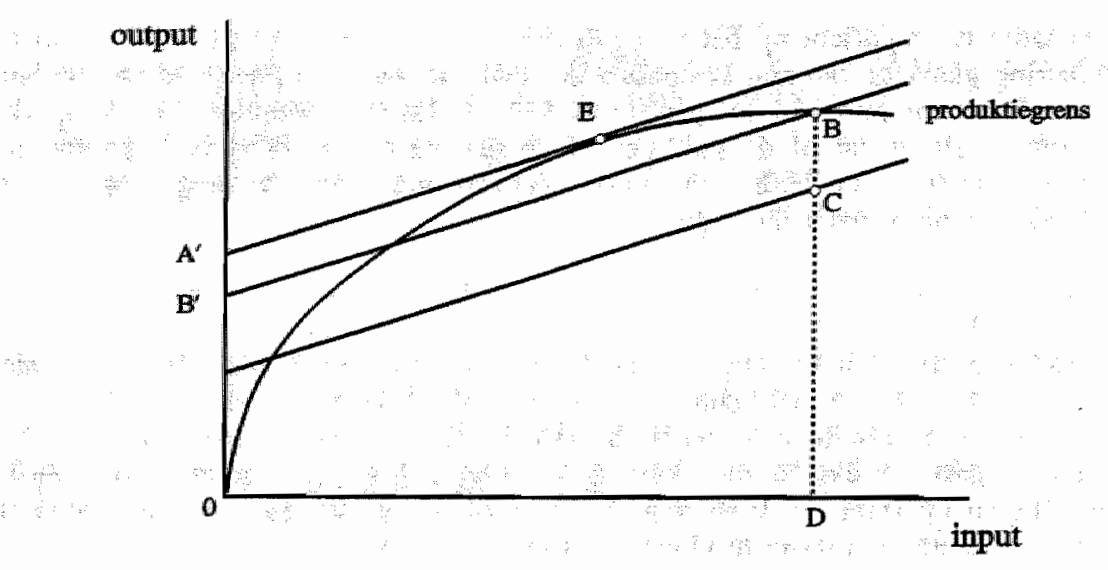

Figuur 13.1 Overheidsinstellingen en technische en allocatieve efficiëntie ${ }^{564}$

In Figuur 13.1 is weergegeven dat éen produetiefactor gebruikt wordt om één consumptiegoed voort te brengen. De curve $\mathrm{BO}$ is de productiemogelijkhedencurve, in dit geval ook wel "best practice frontier" genoemd. In de figuur wordt de technische efficiëntie gemeten door $\mathrm{CD} / \mathrm{BD}$. Input-output-combinatie $\mathbf{C}$ is minder technisch efficiënt als punt $\mathbf{B}$. In punt $B$ hoeft er geen sprake te zijn van een Pareto-efficiênte allocatie. De allocatieve efficiëntie wordt gemeten door $\mathrm{OB}^{\prime} / \mathrm{OA}^{\prime}$ indien punt $\mathrm{E}$ allocatief efficiènt is en $\mathrm{B}$ de gerealliseerde productie is. Of punt $B$ ook allocatief efficiënt is hangt af van de relatieve prijzen van de het consumptiegoed en de productiefactor, van de vraag of in dit punt de maximale winst wordt verwezenlijkt en van de indifferentiecurve. Dit wordt weergegeven door de isowinstlijnen waarbij $A^{\prime} E$ een hogere winst oplevert dan $B^{\prime} B$. Zowel punt $B$ als punt $A$ zijn technisch efficiënt. Alleen punt $E$ is in dit geval allocatief efficiënt.

De tweede doelstelling, rechtvaardigheid heeft vooral betrekking op behoud van werkgellegenheid en de effecten van het prijsbeleid van de overheidsinstelling op de verdeling van het reèle inkomen in de economie. Een derde doelstelling is die van financieel evenwicht. Veel overheidsinstellingen hebben in werkelijkheid tekorten. De vraag rijst dan of dit komt door mismanagement of door hoge vaste kosten. Macro-economische doelen hebben betrekking op uiteenlopende doelen zoalls werkloosheid, inflatie en tekorten op de betalingsbalans.

Pestieau vermeldt een aantal gevolgen van een dergelijke combinatie van doelen. ${ }^{55}$

1. Er bestaat een "trade-off" tussen verschillende doeleinden. Het nastreven van het ene

\footnotetext{
563 Pestieau (1989, pp. 293-305).

.54. Bron: Pestieau (1989, p. 298).

stas T.a.p., pp. 298-299.
} 
doel gaat veelal ten koste van een ander doel. Pestieau vermeldt dat er vaak een conflict zal zijn tussen efficiëntie en non-allocatieve doelen. Derhalve dient uiteindelijk cen evenwichtig doelenpakket te worden nagestreefd. Volgens Pestiean is de technische efficièntie het enige doel dat het nastreven van andere doelen miet belet. Dit is echter niet juist. Indien een overheidsinstelling technisch inefficiënt produceert kan er sprake zijn van een "public enterprise rent" die voor allerlei bijkomende doelen kan worden gebruikt.

2. Een bedrijf kan om tweëerlei redenen inefficiënt zijn. Doel van het bedrijf kan zijn dat zij non-allocatieve doelen moet realiseren. Dit zal gepaard gaan met technische inefficientie. Voorts is het mogelijk dat het bedrijf eigen doelen nastreeft. Het mastreven van mon-allocatieve doelen of eigen bijkomende doelen door de overheidsinstelling bemoeilijkt het toezicht.

3. Voorts noemt hij het probleem van de prestatie-evaluatie, De vraag rijst in hoeverre een bepaald doel gerealiseerd is. Theoretisch gezien zou voor iedere doelstelling een indicator moeten worden opgesteld. Vervolgens zouden deze indicatoren moeten worden samengevoegd tot een multi-criteria-variabele. Pestieau wijst erop dat de ontwikkeling van een dergelijke variabele gezien de huidige stand van de economische wetenschap en de beschikbare kennis niet haalbaar is. Efficiëntie kan gemeten worden terwijl de bepaling van de andere doelen slechts ad hoc plaatsvindt. Coelli en Perelman merken op: "The single-output production function has long been regarded as one of the principle limitations of the econometric approach to technical efficiency measurement. If one wished to investigate efficiency in a multiple-output industry using econometric methods one ustually either: (a) aggregates outputs into a single index of output (..., bijvoorbeeld totale ontuangsten); or (b) attempts to model the technology using a dual cost function".560 Voor de eerste benadering moeten de prijzen van produkten te bepalen zijn, hetgeen bij overheidsinstellingen vaak niet het geval is. Voor de tweede benadering is het nodig dat uitgegaan wordt van de veronderstelling van kostenminimalisatie. Ook deze veronderstelling doet zich bij overheidsinstellingen vaak niet voor. In recent empirisch onderzoek wordt veel aandacht besteed aan de vraag hoe toch meerdere doelen geanalyseerd kunnen worden. ${ }^{567}$ Hoewel de nodige vorderingen zijn geboekt is nog veel onderzoek nodig.

Naast de wijze waarop de doelen worden bepaald valt op dat de prestatie van een overheidsbedrijf vergeleken wordt met een ander bedrijf. De in appendix 2 genoemde DOLS-methode is in empirisch onderzoek bijvoorbeeld door verschillende ecomomen gebruikt voor het schatten van een productiegrens (bijvoorbeeld Pestiean en Jansen ${ }^{568}$ ). Met deze techniek kan een productiefunctie van het Cobb-Douglas-type worden afgeleid. Door de constante in de productiefunctie te verhogen wordt een productiemogelijkhedenciurve opgesteld. De constante wordt verhoogd met de hoogste restterm die afkomstig is van het meest efficięnte (overheids)bedrijf, zodat tenminste én waarneming zich op de productiemogelijkhedencurve bevindt. ${ }^{569}$

Een belangrijk kenmerk van deze benadering is dat de prestatie wan het ene bedrijf wordt vergeleken met de prestatie van een ander bedrijf. Ook Pestieau erkent dat dit één van de

$\$ 66$ Coelli en Perelman (1996, p. 1).

567 Zie voor een overzicht: Coelli en Perelman (1996).

s.s. Vergelijk Jansen (1993, p. 19).

Pestieau en Tulkems (1990, p. 9). 
zwakheden van deze benadering is ${ }^{570}$ Indien de prestatie van het bedrijf waarmee vergeleken wordt verandert, wijzigt ook de prestatie van de te onderzoeken overheidsinstelling. Voorts hebben veel overheidsinstellingen de vorm van een monopolie en kunnen daarom niet vergeleken worden met andere bedrijven. Volgens Pestieau kan dit worden opgelost door gebnuik te maken van intertemporele en internationale vergelijkingen.

\subsubsection{Is de kwantitatieve benadering goed genoeg?}

Zoals Backhaus aangeeft schiet deze benadering op een aantal punten tekort. ${ }^{571}$ In paragraaf A.2 wan appendix 1 is reeds gewezen op een aantal bezwaren die tegen de normatieve benadering, meer in het bijzonder tegen het afleiden van doelen van welvaartsfuncties, kumnen worden aangevoerd. De best-presterende-onderneming-benadering is gebaseerd op het toewijzen van algemene beleidsdoelen. In werkelijkheid zijn overheidsinstellingen echter zeer verschillend en geschikt voor de uitvoering van de meest diverse beleidsdoelen. Daarom weerspiegelen prestatie-indicatoren van een algemene soort, gebaseerd op welvaartseconomie, miet het doel van een specifieke overheidsinstelling. Met andere woorden, op grond van de welvaartseconomie worden algemene doelen afgeleid, terwijl de vraag die beantwoord dient te worden is wat de doelen van een bepaalde overheidsonderneming zijn. De "performance approach" schiet hier dan ook tekort. Een ander punt van kritiek is dat op grond van de welvaartseconomie de doelen van een overheidsinstelling op een bepaalde wijze zouden moeten zijn, maar dat de overheidsinstelling in werkelijkheid misschien wel geheel andere doelen nastreeft en ze om een geheel andere reden kan zijn opgericht.

Mogelijk zitten er bijwoorbeeld tal van politieke actoren achter en zijn de doelen van de overheidsinstelling feitelijk geheel anders. Vanuit de "performance approach" bezien is de instelling dan onlogisch bezig, maar gezien het krachtenveld van actoren maximaliseert zij haar nut. Voorts dient beseft te worden dat efficiëntie op zich zelf echter zelden een doel is van overheidsinstellingen. Het is veel meer een voorwaarde voor het bereiken van een doel. Daar komt nog bij dat veel van de gebruikte indicatoren niet de werkelijke doelen van overheidsinstellingen weerspiegelen. In paragraaf 13.2 is hier reeds op ingegaan. Verder kan als bezwaar tegen de kwantitatieve benadering worden aangevoerd dat zij het verschijinsel privatisering nauwelijks kan verklaren. Pestieau suggereert bijvoorbeeld dat privatiseringen irrationeel zijn. $^{572}$

Tenslotte kan nog worden opgemerkt dat de kwantitatieve benadering de prestatie van overheidsinstellingen probeert te meten zonder daarbij uit te gaan van een op het verklaren van de "performance" gerichte politiek-economische theorie. Een dergelijke theorie zoals in Deel 2 behandeld is, is nodig om te begrijpen dat overheidsinstellingen sterk verschillend zijn. Wat en goede "performance" is voor de ene overheidsinstelling hoeft geen goede "performance" te zijn voor een ander.

\subsection{In hoeverre kan de doelbenadering worden gebruikt?}

In de vorige paragraaf zijn een aantal bezwaren genoemd van de kwantitatieve benade-

\footnotetext{
sto Pestieau (1989, p. 300).

574. Vergelijk: Backhaus (1994, pp. 280-287 e.v.)

572 Pestieau (1989).
} 
ring. Een belangrijk bezwaar was dat de werkelijke doelen van de overheidsinstelling niet worden onderzocht. De vraag rijst of een doel-afhankelijke benadering uiteindelijk meer mogelijkheden biedt.

Om de effectiviteit en de efficièntie van een organisatie te bepalen is de "doel-benadering" de meest gebruikte. Matteson en Ivancevich stellen: The idea that organizations as well as individuals and groups, should be evaluated in terms of goal accomplishment has widespread appeal. The goal approach reflects purposefuliness, rationality and achievement - the fundamental tenets of contemporay Westem Societies" ${ }^{* 13}$

Deze doel-benadering heeft, zoals vaak gesteld wordt, echter ook een aantal bezwaren:

1. Voor organisaties met weinig tastbare doelen, waaronder veel overheidsinstellingen zoals bijvoorbeeld universiteiten, is het moeilijk om te bepalen in hoeverre het doel bereikt is.

2. Organisaties streven vaak meerdere doelen na die elkaar voor een deel uitsluiten. Het ene doel gaat veelal ten koste van een ander doel.

3. Vaak bestaat er geen officiële verzameling van doelen die door alle leden van de organisatie wordt nagestreefd. Veelal zal er slechts tot een bepaalde hoogte consensus bestaan over de gemeenschappelijke doelen.

4. Het is denkbaar dat een organisatie het officiële doel bereikt maar desalniettemin als inefficiënt en ineffectief wordt beschouwd. Een bedrijf slaagt er bijvoorbeeld in het officiële doel van $15 \%$ jaarlijkse omzetgroei te halen, maar bereikt dit slechts door milieuvervuilende productie, door een daling van de winst, door het nemen van ongehoorde risico"s of bijvoorbeeld door slecht personeelsbeleid.

De doelbenadering kan bij de "performance-analyse" dan ook alleen worden toegepast indien aan dergelijke bezwaren wordt tegemoet gekomen.

\subsection{Evaluatie en de beleidsnetwerkbenadering}

In dit onderzoek staat de "performance" van een netwerk centraal. In de literatuur over beleidsnetwerken is de nodige aandacht besteed aan het beoordelen van het succes en het falen van besluitvormingsprocessen op bepaalde beleidsterreinen. ${ }^{574}$ Een methode die wordt gebruikt om beleidsprocessen binnen netwerken te evalueren houdt in dat de ex ante-doelen van actoren binnen het netwerk als jjkpunt worden genomen. Proces en resultaat worden dan in samenhang beoordeeld. Een aantal problemen doen zich voor:

1. Ex ante doelstellingen hebben een statisch karakter. Actoren passen binnen een beleidsproces hun doelen aan;

2. Meetproblemen: beschikken actoren die aan een interactieproces deelnemen wel over een gezamenlijke probleemdefiniëring? Zijn de geformuleerde doelen niet symbolisch?

3. De belangen van actoren die niet deelnemen aan het interactieproces kunnen geschaad worden. Of dit het geval is wordt in deze vorm van evaluatie niet onderzocht.

Daarnaast kan als beoordelingsmaatstaf van het functioneren van beleidsnetwerken gebruilk

\footnotetext{
53 Matteson en Ivancevich (1987, p. 18).

574 Pröpper (1996).
} 
worden gemaakt van ex post-evaluatie. Achteraf worden betrokkenen am hun oordeel gevraagd. Daarmee worden bovengenoemde problemen voorkomen. Deze benadering brengt echter weer andere bezwaren met zich mee, zoals:

1. Actoren kunnen achteraf rationalisaties bedenken om hun eigen falen te verhullen;

2. De uitspraken van de verschillende actoren leiden niet meteen tot één ijkpunt. Dit bezwaar kan door de onderzoeker worden tegengegaan door de diverse uitspraken te aggregeren tot een oordeel op collectief niweau. Met behulp van en win-win-criterium kam vervolgens worden beoordeeld of actoren een uitkomst tot stand brengen waarbij iedereen erop vooruitgaat of waarbij verliezers kunnen worden gecompenseerd. Ook is het mogelijk om actoren gezamenlijk tot een oordeel te laten komen over het proces en de beleidsuitkomst;

3. Belangrijke groepen actoren kunnen van de besluitvorming zijn uitgesloten. Dit bezwaar kan overwonnen worden door in bij de evaluatie hier expliciet aandacht aan te besteden.

Beide benaderingen hebben nadelen die ertoe leiden dat de genoemde bezwaren verbonden aan de doelbenadering miet of slechts gedeeltelijk het hoofd worden geboden. Daar komt bij dat in dit onderzoek nadrukkelijk de "performance" centraal staat en niet alleen de uitkoms van beleidsprocessen.

\subsection{Wat wordt verstaan onder de kwalitatieve benadering?}

Teneinde de bezwaren verbonden aan de "best practice"-benadering, de doelbenadering en meer specifiek de beleidsnetwerkbenadering te ondervangen oppert Backhaus een kwalitatieve benadering gebaseerd op "public choice" theorie ${ }^{575}$ De kwalitatieve benadering kan worden opgevat als een exponent van de doelbenadering. Zij vraagt zich af in hoeverre en tegen welke kosten de doelen van de eigenaren van de organisatie zijn gehaald. Deze benadering heeft de theoretische studie van Olson en de empirische studie van Braun als uitgangspunt. De basis voor deze theorie werd gelegd door Olson. ${ }^{576}$ Olson stelt dat overheidsinstellingen meestal technisch inefficiënt zijn. Onder inefficiënt wordt hier verstaan: inefficiënt volgens de "performance"-analyse-benadering (met de beschikbare productiefactoren kan niet meer geproduceend worden). De kosten van een overheidsinstelling liggen veelal hoger dan die van een gelijksoortig particulier bedrijf. Zoals in hoofdstuk 4 is uiteengezet wordt deze inefficiëntie veroorzaakt doordat overheidsinstellingen vooral ook collectieve goederen en externe effecten voortbrengen. $\mathrm{Zij}$ volgt uit de definitie van een collectief goed. In het geval van collectieve goederen kan niemand van het gebruik worden uitgesloten (niet-exclusiviteit) en worden preferenties niet kenbaar gemaakt: Daarnaast zijn collectieve goederen niet geschikt voor splitsing in individueel leverbare eenheden waardoor de output niet te meten valt. Deze colectieve goederen en externe effecten worden vaak voortgebracht naast de goederen die een overheidsinstelling in het kader van de primaire doelstelling voortbrengt. Tenslotte geldt dat er zich problemen voordoen bij de marginale kostenberekening. Indien het goed er eenmaal is zijn de marginale kosten gelijk aan nul. Op deze gronden is "performance"analyse niet goed mogelijk. Productiefuncties voor collectieve goederen en externe effecten kunnen niet of heel moeilijk worden vastgesteld.

Backhaus merkt op dat de opvatting van Stigler en daarmee die van de Chïcago school.

${ }^{575}$ Backhaus (1994, pp. 280 e.v.).

${ }^{576}$ Olson, in: Moss ed. (1973, pp. 355 e.v.). 
hiermee niet in strijd is. ${ }^{57}$ Stigler stelt dat slechts gesproken kan worden van inefficientie indien een Pareto-werbetering mogelijk is. Maar bij overheidsinstellingen kan niet gesproken worden van inefficiëntie, aangezien het niet bekend is wat de maatregelen ter verbetering zouden kunnen zijn. Met andere woorden: eigen aan overheidsinstellingen is dat zij voor een belangrijk deel andere doelen nastreven dan particuliere ondernemingen. Dit is niet per definitie Pareto-inefficiënt. Indien meer van het ene doel wordt bereikt met: als kosten minder van een ander doel, dan is de toename van de productie die ontstaat niet een toename (of afname) van efficiëntie maar een toename van productie ${ }^{578} \mathrm{De}$ Public Choice benadering gaat er derhalve vamuit dat overheidsinstellingen Paretooptimaal worden gerund. Gegeven de nagestreefde doelen is geen betere werkwijze mogelijk omdat er nog geen beter alternatief bekend is.

De empirische studie van Braun is vooral gericht op het bepalen van de doelen van overheidsinstellingen, vergeleken met particuliere bedrijven. ${ }^{579}$ Met betrekking tot die doelen worden dertien hypothesen opgesteld. Belangrijk voor ons onderzoek is onder andere de eerste hypothese inhoudende dat naarmate een instelling zich meer bezig houdt met de voortbrenging van collectieve goederen haar doelen minder precies omschreven zullen zijn. Braun geeft vervolgens aan in hoeverre (particuliere) ondernemingsplanningstechnieken gebruikt kunnen worden. Indien doelen duidelijk omschreven zijn zullen dergelijke planningstechnieken beter toepasbaar zijn.

Beide studies leiden tot de conchusie dat doelen van overheidsinstellingen veelal vaag zijn. "Performance"-analyse gebruikt voor particuliere bedrijven zal veelal niet bruikbaar zijn voor de "perfomnance"-bepaling van overheidsinstellingen. Hoewel de doelen vaag zijn is het desalniettemin mogelijk ze zodanig te verduidelijken dat ook de "performance" van overheidsinstellingen kan worden gemeten, zij het dat hiervoor andere methoden gebruikt dienen te worden.

Voorts maakt de "public choice"-benadering bij de "performance"-analyse van een overheidsinstelling onderscheid tussen de primaire, eigenlijke doelen en de discretionaire politieke doelen van een overheidsinstelling. ${ }^{580}$ Bij een eigenlijk doel van een overheidsinstelling kan gedacht worden aan de elektriciteitsproductie van een elektriciteitsbedrijf. Bij bijkomende doelen kan gedacht worden aan inkomensherverdeling door interne subsidiëring en bevorderen van de werkgelegenheid in een bepaalde regio. De kwalitatieve benadering gaat er vanuit dat de prestatie van overheidsinstellingen politiek bepaald is. De eigenlijke doelen oftewel de standaardactiviteiten moeten op een "acceptatieniveau" worden vervuld. Dit acceptatieniveau is politiek bepaald. De doelen van de principalen kunnen in die zin beschouwd worden als een restrictie. De agenten streven op grond van hun eigendomsrechten eigen doelen na (analoog aan het bureaucratiemodel van Niskanen). De "performance" van een overheidsinstelling moet nu voornamelijk beoordeeld worden op grond van het al dan niet bereiken van de overige discretionaire politieke doelen. ${ }^{581}$ Deze discretionaire ruimte wordt gebruikt voor allerlei activiteiten (die een particulier bedrijf niet zou verrichten), die eveneens op grond van een "rent-seeking" -

\footnotetext{
$m$ Stigler (1976, p. 214).

578 T.a.p., p. 213.

5789 Braun (1988).

Backhaus (1994, pp. 282-285).

sal Backhaus (1989, p. 367).
} 
proces worden ingevuld. Verder kan bekeken worden of de gederfde winst, de "public enterprise rent", die bij winstmaximalisatie verkregen had kumnen worden opweegt tegen de bijkomende nagestreefde doelen. De gederfde winst vormt de alternatieve kosten. Het eigen vermogen van een overheidsinstelling had immers ook geinvesteend kunnen worden in obligaties met het bijbehorende rendement.

Deze doelen worden door middel van een "public choice"-analyse afgeleid van het observeerbare gedrag van de overheidsinstelling. Een ander kenmerk van de "public choice"benadering is dat zij uitgaat van een samenstel van personen, die, uitgaande van bepaalde (principaal-agent-) relaties, allen bepaalde doelen nastreven ${ }^{582}$ Door positieve en empirische analyse kunnen deze concrete beleidsdoelen worden vastgesteld, waartegen dan vervolgens de "performance" van publieke instellingen kan worden geschat.

Overigens zijn er binnen de public choice benadering meerdere min of meer gelijke benaderingen ontwikkeld om de "performance" van overheidsinstellingen te meten. Een voorbeell hiervan is de methode van "effectiveness measurement". 583 De benadering bestaat sterk vereenvoudigd weergegeven uit de volgende stappen:

1. Maak duidelijk welke inspanning in uren of eenheden geleverd is.

2. Bepaal de mate waarin de overheidsinstelling de beoogde cliënten bereikt.

3. Bepaal de mate warin de consumenten van de goederen en diensten die de overheidsinstelling voortbrengt enerzijds deze goederen en anderzijds de overheidsinstelling waarderen.

4. Bepaal het uiteindelijke resultaat (effecten) dat bereikt wordt ten gevolge van de inspanningen van de overheidsinstelling en relateer dat aan de doelen.

Aangezien deze methode niet wezenlijk afwijkt van de kwalitatieve benadering wordt in het vervolg de nadruk vooral op deze laatste methode gelegd.

\subsection{In hoeverre biedt de kwalitatieve benadering een antwoord op de tegen de doelbenadering gerezen bezwaren?}

De kwalitatieve benadering probeert dan ook zoveel mogelijk tegemoet te komen aan de hiervoor in paragraaf 13.4 genoemde bezwaren die zijn gerezen tegen de doelbenadering. $\mathrm{Z}_{\text {ij }}$ doet dit door bij de analyse met een aantal zaken rekening te houden:

Allereerst is als aanvulling op en nast de doelbenadering de systeembenadering van belang. De organisatie kan gezien worden als een netwerk van actoren die ondering afthankelijk zijn en die ook weer verbonden is met allerlei andere netwerken. Het is van belang te weten hoe en waarom mensen in de organisatie en binnen toezichthoudende organen hun werkzaamheden verrichten. Met de systeemtheorie kan het gedrag van individuen en groepen in de organisatie worden verklaard. De systeembenadering benadrukt dat: ${ }^{584}$

\footnotetext{
582 Mueller (1989, pp. 1-3).
}

s83 Baakman en Van Mierlo (1991, pp. 131-147), vergelijk ook: Van der Har in: Wijchers, Kerklaan en Mastenbroek (eds) (1992, pp. 178-179) en Van Mierlo (1995, p. 12).

584 Vergelijik: Etzioni (1971, pp. 35-36). 
a. Het uiteindelijk blijven voortbestaan van een overheidinstelling afhankelijk is van de vaardigheden van die instelling om zich aan te passen aan haar omgeving (cliênten, departement e.d.).

b. Om te blijven voortbestaan de aandacht van het mamagement gericht moet zijn op het totalle input-output-proces.

De kwalitatieve benadering beoogt een vergaande analyse van de organisatie, waardoor ook aan dergelijke "systeem"-aspecten uitgebreid aandacht wordt geschonken.

In de tweede plaats meent de kwalitatieve benadering dat het mogelijk is om de alternatiewe kosten te memen als de kosten van de doelen. Vaak zal het tot op zekere hoogte mogelijk zijn om te onderzoeken in hoeverre de (vage) doelen bereikt zijn. Hierbij dient bedacht te worden dat de doelen niet altijd vaag zijn. $\mathrm{Ze}$ zijn voor betrokkenen vaak glashelder, maar veelal is het niet de bedoeling dat ze door iedereen besproken worden. Om deze doelen te kunnen bepalen zullen gerichte vragen moeten worden beantwoord. Tegen de bereikte doelen worden vervolgens de kosten afgezet van deze mate van doelbereiking. Een vergelijkende benadering is dan niet nodig.

In de derde plaats maakt het op grond van deze analyse niet uit dat het ene doel ten koste gaat van een ander. Wel is het belangrijk een schatting te maken van het relatieve bellang van de doelen.

In de vierde plaats meent de kwalitatieve benadering dat door naar de doelen van de dragers van eigendomsrechten te kijken en door het feitelijke gedrag van een overheidsinstelling te analyseren het mogelijk is om een goed beeld van de doelen van een overheidsinstelling te krijgen.

Het vierde genoemde bezwaar tenslotte is ondervangen door de schatting van het relatieve belang van de doelen. Daarvoor zullen wel de juiste vragen moeten worden beantwoord. Het is denkbaar dat bijvoorbeeld het milieu en het personeels- en werkgelegenheidsbeleid naast de winst als doelen van de organisatie moeten worden aangemerkt. Indien de door de kwalitatieve benadering voorgestelde analyse wordt gevolgd, worden ook dergelijke doelen als ontsluierde doelen van de organisatie opgevat.

Op grond van deze aanvullingen van de doelbenadering door de kwalitatieve benadering is het mogelijk om ook bij overheidsinstellingen een "performance" analyse uit te voeren waarbij de doelen van de organisatie als uitgangspunt worden genomen.

\subsection{In hoeverre zijn de bezwaren die zijn gerezen tegen de kwalitatieve benadering van belang?}

Ten aanzien van de kwalitatieve benadering zijn een aantal vragen gerezen waarop hier kort zal worden ingegaan.

In de eerste plaats zijn vragen gerezen bij de benadering van Pareto-efficiëntie die door de kwallitatieve benadering gevolgd wordt. Zoals uiteengezet in paragraaf A.2.3.2 (appendix 1 ) is de Virginia-benadering (Virginia politieke economie) evenwel zonder meer verdedigbaar. ${ }^{585}$ Hierbij moet wel worden benadrukt dat deze benadering niet zodanig moet

sas Vergelijk ook: Buchanan (1969) en Twllock (1967, pp. 224-232). 
worden uitgelegd dat rationele individuen dan ook antomatisch kiezen voor de meest efficiênte instituties en andere restricties: Zoals aangegeven in voorgaande hoofdstakken kunnen er verscheidene redenen zijn waarom dit niet het geval hoeft te zijn. Hierbij kan, zoals ook vermeld in paragraaf A.2.3.2, gedacht worden aan het ontbreken van informatie bij individuen over de hoogte van de transactiekosten (alternatieve kosten) van alternatieve instituties. Met behulp van de kwalitatieve benadering kunnen deze alternatieve instituties worden geanalyseerd.

Een tweede vraag heeft betrekking op het volgende. Zoals opgemerkt gaat deze benadering uit van de veronderstelling dat overheidsinstellingen per definitie Pareto-optimaal functioneren. Deze veronderstelling lijkt de kwalitatieve benadering automatisch een eventuele normatieve werking te ontnemen. Zij houdt immers in dat niet bekend is of en zo ja hoe het beter zou kumen. Dit is evenwel geen belangrijk bezwaar. De normatieve benaderingen hebben zich voomamelijk bezig gehouden met de vraag hoe een overheidsinstelling zich zou moeten gedragen. In de praktijk gedragen zij zich echter veelal volstrekt anders. Volhouden dat overheidsinstellingen niet efficiënt $z$ ijon op grond van dergelijke abstracte modellen heeft dan veel weg van een illusie. Zinvoller is het er vanuit te gaan dat overheidsinstellingen efficiënt zijn, gegeven de vele beperkingen die er in de werkelijkheid zijn. Met behulp van een dergelijke analyse zouden eventueel ook aanbevelingen kunnen worden gedaan over de wenselijkheid van privatisering, dat wil zeggen over institutionele veranderingen en het algemeen functioneren van een overheidsinstelling.

Tenslotte is het mogelijk een andere redenering te volgen. Indien er vanuitgegaan wordt dat een overheidsinstelling Pareto-efficiënt opereert, in de zin dat geen beter alternatief bekend is, impliceert dit in dat geval dat een punt op het productiemogelijkhedenvlak (van alle doelen) wordt bereikt. De "performance" is optimaal indien de doelfunctie raakt aar de productiemogelijkhedencurve, die gegeven alle beperkingen bereikbaar is ("feasibility curve"). Indien dat niet het geval is, is de "performance" niet optimaal en voor verbetering vatbaar. Dit betekent evenwel ook dat de doelen van de eigenaren niet altijd bereikt zullen worden. In dat geval ontstaat een methodologisch probleem en is het mogelijk dat onderzoek naar het feitelijke gedrag van een overheidsinstelling miet de doelen van de eigenaren oplevert. Backhaus voert derhalve de redelijke veronderstelling in dat overheidsinstellingen gegeven alle restricties, Pareto-efficiënt opereren. ${ }^{586}$ Hierdoor kunnen de doelen van de overheidsinstelling worden afgeleid uit het gedrag van die instelling.

\subsection{In hoeverre is het wenselijk de door Jansen voorgestelde benadering te gebrui- ken?}

Jansen heeft geprobeerd om te komen tot een synthese van de kwantitatieve en de kwalitatieve benadering (ten dele in verband met de hiervoor geschetste bezwaren van de behandelde benaderingen). ${ }^{587}$ Enerzijds onderzoekt hij de doelen van een overheidsinstelling zelf. Uitgaande van de door Backhaus voorgestelde procedure meet hij de prestatie van een drietal overheidsinstellingen. Anderzijds maakt hij onder meer gebruik van productiefuncties. Met behulp van deze productiefuncties vergelijkt hij vervolgens de technische efficiẻntie van een overheidsinstelling en de technische efficiëntie van een gelijksoortig bedrijf. Het verschil in efficiëntie is dan een maatstaf voor het streven naar

\footnotetext{
5s6 Vergelijk ook: Samuelson $(1947)$.

s87 Jansen (1993, pp. 19-26).
} 
bijkomende doelen. Deze benadering heeft als voordeel dat een goed beeld gevormd wordt van een overheidsinstelling. De met de kwantitatieve benadering gevonden prestatie kan worden vergeleken met de door middel van de kwalitatieve benadering gevonden "performance". Bij deze benadering kunnen echter ook een aantal kanttekeningen geplaatst worden. In de eerste plaats is vergelijking van sen instelling met een gelijksoortige andere organisatie vaak weinig zinwol, omdat de doelen van beide verschillen. In de tweede plaats meet een productiefunctie in de praktijk met name de basisactiviteit (vervoer van passagiers e.d.) en gaat deze methode in die zin voorbij aan bijkomende doelen waar het ons in het kader van de "performance" schatting van overheidsinstellingen nu juist om te doen is. Dat een overheidsinstelling bijkomende doelen nastreeft en veelal technisch inefficiënt is, is immers bekend. Of zoals Perrow ten aanzien van én van deze bijkomende doelen stelt: "The particularistic criteria are likely to be negatively related to performance - the more these particularistic criteria are used, the poorer the performance" "s88 Hiermee komt een derde kanttekening overeen inhoudende dat deze synthese-benadering zich vooral bezig houdt met prestatie-analyse. Bij de "performance"analyse zijn wij echter niet alleen in de prestatie geïnteresseerd maar in de gehele wijze van functioneren van een overheidsinstelling.

\subsection{Conclusie}

Ondanks de bezwaren van de genoemde benaderingen kan desainiettemin worden geconstateerd dat er de nodige voortgang is geboekt bij de bepaling van de "performance" van specifieke overheidsinstellingen. Samenvattend kunnen een tweetal benaderingen worden onderscheiden. De "performance"-benadering meet de "performance" door het maximaliseren van een doel/welvaartsfunctie, gegeven het budget. De kwalitatieve benadering beziet gegeven de doelen de kosten oftewel het budget, dat gevormd wordt door de "public enterprise rent". In die zin kan gesproken worden van dualiteit. Uit dit hoofdstuk kan worden geconcludeerd dat de kwalitatieve benadering waarschijnlijk de meeste kans op succes biedt. In het vervolg van dit deel wordt deze benadering dan ook verder uitgewerkt. Aangegeven wordt hoe met behulp van de kwalitatieve benadering een overheidsinstelling onderzocht kan worden. Vervolgens worden in de hoofdstukken 15, 16 en 17 het Rijksmuseum, MEGA Limburg en de Belastingdienst onderzocht.

sss Penrow (1986, pp. 8-9). "Particularism means that inelevant criteria (.. ), in contrast to wniversalistic criteria (competence is all that counts), are employed in choosing employees." 


\section{Hoofdstuk 14. Onderzoeksprotocol}

\subsection{Inleiding}

In voorgaande hoofdstukken is een theorie geschetst van overheidsinstellingen. Vervolgens moet de theorie worden toegepast. Dit geschiedt aan de hand van een achttal hypothesen. Door de beantwoording van deze hypothesen wordt duidelijk hoe de "performance" van een netwerk in de praktijk kan worden bepaald.

\subsection{Hypothesen en methode van onderzoek}

Op grond van het verrichte onderzoek is inzicht verkregen in de factoren die de "performance" van een netwerk bepalen en het keuzegedrag van actoren binnen een netwerk beïnloeden. Empirisch onderzoek is nodig om de verschillende verbanden en de invloed van de verschillende factoren in de praktijk te bepalen.

In dit empirische deel worden daartoe de volgende 8 hypothesen onderzocht:

Hypothese 1:

De doelen van een netwerk kunnen worden bepaald door een combinatie van de interviewmethode, de "revealed preference" methode en een analyse van de verdeling van eigendomsrechten.

Hypothese 2:

Een netwerk dat wordt gekenmerkt door een bepaalde verdeling van eigendomsrechten kan slechts een bepaald pakket van goederen en diensten (op een optimale wijze) voortbrengen.

Hypothese 3:

De alternatieve kosten vormen de kosten van de bijkomende doelen van een netwerk.

Hypothese 4:

Indien de omgeving van een netwerk verandert moeten, teneinde een optimale "performance" te realiseren, ook de verhouding van eigendomsrechten, de principaal-agentverhoudingen, de besluitvorming en de transacties binnen het netwerk an de gewijzigde omstandigheden worden aangepast:

Hypothese 5:

De "performance" van een netwerk kan worden bepaald met behulp van de kwalitatieve benadering.

Hypothese 6:

Met behulp van de resultaten van een kwalitatieve analyse is het mogelijlc om aanbevelingen en voorspellingen te doen.

Hypothese 7:

De ontwikkelde netwerkbenadering is ook bruikbaar voor de analyse van particuliere organisaties. 
Hypothese 8:

Indien een netwerkorganisatie gewijzigde doelen wil bereiken zijn een groot aantal wijzigingen van het netwerk nodig.

Deze hypothesen worden door middel van case study-onderzoek aan de hand van een zestiental vragen onderzocht. Deze zestien stappen vormen een verdere uitwerking van het geschetste netwerkmodel Het gaat daarbij onder meer om het bepalen van de doelen van de dragers van eigendomsrechten van de overheidsinstelling (doelfuncties). Uiteindelijk kan voortbouwend op de eerste vijftien stappen en met in achtneming van het relatieve belang van de doelen de "performance" vastgesteld worden in termen van inputs en outputs. Dit geschiedt door de "public enterprise rent" als restrictie/kosten te beschouwen van de doelen.

Het is belangrijk om te onderkemen dat case study-onderzoek voor de analyse van de 8 hypothesen en meer algemeen voor de analyse van netwerken essentieel is. In het algemeen wordt tegen dit soort onderzoek een aantal bezwaren aangevoerd. Allereerst wordt vaak het gebrek aan generaliseerbaarheid genoemd. Verder doet de onderzoekssituatie zich maar eénmaal voor en is herhaling niet mogelijk. Voorts wordt wel aangevoerd dat de selectiecriteria van door middel van case study-onderzoek onderzochte instellingen onduidelijk zijn. In dit onderzoek wordt desalniettemin voor case study-onderzoek gekozen. Een drietal instellingen worden onderzocht, namelijk het Rijksmuseum, de N.V. MEGA Limburg/N.V. PLEM en de Belastingdienst. De reden dat voor deze vorm van onderzoek wordt gekozen is dat zoals opgemerkt netwerken sterk van elkaar kunnen verschillen. Geen enkel netwerk is hetzelfde. Met name de doelen van verschillende netwerken zullen sterk van elkaar verschillen. Daartoe moet de situatie steeds van geval tot geval worden bekeken en zijn geen algemene uitspraken over alle overheidsinstellingen mogelijk. Het gebrek aan generaliseerbaarheid is dan ook geen probleem maar eigen aan de gevolgde benadering. Hetzelfde geldt voor het niet kunnen herhalen van een bepaalde situatie. Juist omdat elk netwerk in de loop van de tijd veranderd moet steeds opnieuw de werkelijke situatie worden bezien. Ook het probleem van het op arbitraire gronden selecteren van te onderzoeken instellingen wordt hier niet groot geacht. Dit onderzoek sluit namelijk aan op reeds eerder verricht case study-onderzoek. Getracht is om een stap verder te gaan door enerzijds meer gecompliceerde instellingen te onderzoeken en anderzijds deze te onderzoeken instellingen meer diepgaand te analyseren. Bovendien kan naar verwachting elk netwerk met het opgestelde analysekader worden onderzocht.

Nadat het duidelijk is waarom de overheid ervoor kiest invloed te hebben binnen de organisatie kan het analyse-kader worden toegepast. In de komende paragrafen en hoofdstuk 15 tot en met 17 worden de geformuleerde hypothesen door het beantwoorden van de volgende vragen onderzocht:

\subsection{Overheidsinvloed: waarom is de betreffende instelling een overheidsinstelling?}

Voordat de "performance" van een netwerk met het ontwikkelde analysekader wordt onderzacht moet het duidelijk zijn waarom de instelling een overheidsorganisatie is. In paragraaf 7.1 is aangegeven dat op grond van de economische theorie van beschikkingsrechten een klassieke onderneming kan ontstaan indien de totale productie door teamproductie kan toenemen. Hierdoor kan er een meetprobleem ontstaan ten aanzien van het bepalen van de individuele marginale produktiviteit van werknemers. Een andere genoemde voorwaarde is dat de marginale produktiviteit van de individuele productiefactoren het best kan worden gemeten door het registreren van de input. In deze fase dient te worden weergegeven in hoeverre de organisatie aan deze eisen voldoet en waarom zij gerund wordt als een overheidsinstelling. In dit verband dienen ook de taken 
en functies van de verschillende afdelingen te worden geschetst. Tenslotte moet worden onderzocht op welke wijze de overheid invloed uitoefent.

\section{4:4 Structuur-analyse; welke doelen kunnen worden bereilkt?}

Zoals in het vorige hoofdstuk is aangegeven dient de verdeling van de drie categorieen van eigendomsrechten binnen overheidsinstellingen te worden onderzocht. Savas stelt in dit verband dat een viertal vragen moeten worden beantwoord: ${ }^{589}$

1. Wie is de "arranger?" De "arranger" selecteert, wijst de producent aan en geeft hem de bevoegdheid om te handelen.

2. Wie is de producent? De producent levert de goederen en diensten aan de consument.

3. Wie is de consument? Wie neemt de goederen en diensten die door de overheidsinstelling worden voortgebracht af?

4. Wie is degene die betaalt? Het gaat er hierbij om wie de goederen en diensten die door de producent geleverd worden aan de consumenten betaalt:

Een belangrijke ontwikkeling die met name de laatste jaren nog eens versterkt is, is dat deze zaken niet meer allemaal voorbehouden zijn aan éen actor. Degene die toezicht heeft op de productie hoeft bijvoorbeeld niet de sponsor te zijn. $\mathrm{Nu}$ is er altija wel een bepaalde verdeling van eigendomsrechten over verschillende actoren geweest. De vraag is welke actoren nu precies welke eigendomsrechten bezitten. Zoals is benadrukt in hoofdstuk 7, kunnen de houders van eigendomsrechten binnen het netwerk overheidsinstelling worden beschouwd als de eigenaren. Zij zijn in staat het besluitvormingsproces bìnnen het netwerk overheidsinstelling te beinvloeden en zij beinviloeden derhalve het keuzegedrag. Uit de anallyse van de eigendomsrechtenverdeling binnen overhelldsinstellingen kunnen vervolgens doeleinden worden afgeleid, waarbij het ons met name gaat om de (veelal vage) discretionaire politieke doelen. ${ }^{590}$ Zoals in hoofdstuk 6 tot en met 12 is benadrukt kunnen met een bepaalde institutionele structurur slechts bepaalde doelen worden nagestreefd. Het is dan ook van groot belang te weten hoe de verdeling van eigendomsrechten er uitziet. De vraag die dan ook centraal staat is welke doelen gerealiseerd kunnen worden gegeven de structurur van de organisatie/de verdeling van eigendomsrechten. In het kader van de structuuranalyse dienen, zoals is aangegeven in hoofdstuk 7, de volgende vragen te worden beantwoord : ${ }^{591}$

\section{Naar aanleiding van het recht op gebruik van een zaak (usus):}

1) Wie houdt toezicht op het aankoopbeleid ("inputs") en de prestaties van de productiefactoren ("input performance")?

2) Wie houdt toezicht op de productieresultaten ("output performance") ?

\footnotetext{
589 Savas $(1987$, p. 58$)$

$\$ 90$ Backhans (1994, pp. 278-279).

sos T.a.p., pp. 16-17.
} 
3) Wie registreert en houdt toezicht op het productieproces?

4) Wie houdt toezicht op de omvang en samenstelling van het team van producenten?

Naar aanleiding van het recht op yruchtgebruik (usus fructus):

4a) Wie maakt aanspaak op de winst?

Naar aanleiding van het recht om de vorm van een zaak te veranderen of te verhandelen (abusus):

5) Wie heeft het recht de organisatie te wijzigen, te verkopen of te liquideren?

Beantwoording van deze vragen maakt het duidelijk welke actoren binnen het netwerk verschillende eigendomsrechten houden. Hier wordt kort ingegaan op de verschillende eigendomsrechten en op de vraag hoe bepaald kan worden welke actoren deze eigendomsrechten houden.

Het recht op het gebruik van een zaak:

Ad.1. Toezicht op de input en registratie van de "input performance": Wie houdt toezicht op het aankoopbeleid en de prestaties van de productiefactoren?

In deze fase van het structuuronderzoek gaat het met name om de vraag welke actoren binnen het netwerk beslissen over de input. Daarbij kan, voortbouwend op hetgeen daarover reeds eerder is opgemerkt in hoofdstuk 6, onderscheid worden gemaakt tussen principalen en agenten.

Zoals Jansen ${ }^{592}$ ook aangeeft ontbreekt er een uniforme wettelijke regeling voor de vaststelling van begrotingen van overheidsinstellingen. Hierdoor is het toezicht op het aankoopbeleid van overheidsinstellingen verspreid over verschillende principalen. Welke principalen en agenten bevoegd zijn kan per overheidsinstelling verschillen en is voor een belangrijk deel afhankelijk van de juridische vormgeving van een overheidsinstelling.

De regeling met betrekking tot het financiële toezícht bepaalt voor een belangrijk deel wie beslist welke inputs er worden aangeschaft. De actoren die toezien op het functioneren van de overheidsinstelling zien eveneens toe op de produktiviteit van de productiefactoren. Jansen beschrijft als voorbeeld de mogelijkheid dat overheidsinstellingen gedwongen worden produkten te kopen bij binnenlandse toeleveranciers. Dit kan gepaard gaan met hogere kosten. De houders van een gebruiksrecht zullen ook op deze produktiviteit van productiefactoren en de kosten daarvan toezien. Vaak zal het zo zijn dat er een Ministeriele instructie, bijvoorbeeld in de vorm van een K.B. is uitgevaardigd, waarbij de Minister gemachtigd wordt toezicht uit te oefenen op de aankoop van productiefactoren. Naast de eventuele goedkeuring van de begroting van een overheidsinstelling door de Staten-

592 Jamsen (1993, p. 28) 
Generaal zal de directie van een overheidsinstelling aan het begin van het jaar, op grond van de Ministeriële instructie, als een vorm van externe machtiging vaak een werkplan ter goedkeuring moeten voorleggen aan de bevoegde minister. Dit werkplan zal veelal tevens een kostenraming bevatten. Jansen beschrijft dat dit bijvoorbeeld bet geval was bij DSM ${ }^{593}$ Vaak keurt een Minister een dergelijke aanvraag slechts goed na raadpleging van één of meer adviesorganen. Voorts kan de Minister aangeven dat de directie bepaalde bestellingen pas mag doen na een specifieke Ministeriële machtiging. Daarnaast is er binnen de meeste overheidsinstellingen een stelsel van interne machtiging. Deze regels regelen de procedures van aankopen en investeringen binnen de overheidsinstelling en bepalen onder meer wie bevoegd is daarover beslissingen te nemen. De stelsels van interne en externe machtiging houden verband met elkaar. Een wijziging van de externe machtiging zal veelal tot een wijziging van de interne machtiging leiden, bijvoorbeeld door grotere bevoegdheden voor de directie. Voor bepaalde belangrijke projecten zal de toestemming van de directie nodig zijn, terwijl voor andere alleen de toestemming van bijvoorbeeld de chef van de financiële afdeling of de afdeling inkoop nodig is.

\section{ad.2. Toezicht op de output en registratie van de output "performance": wie houdt toexicht op de productieresultaten?}

De houders van het gebruiksrecht van overheidsinstellingen, veelal de Staten-Generaal en de Minister indien deze gemachtigd is, zien tevens toe op de productieresultaten. Jansen merkt op dat, aangezien beloningen dienen te worden gerelateerd aan de productieprestaties, beloningen slechts effectief zijn indien de individuele bijdragen aan de productie effectief kunnen worden vastgesteld. ${ }^{994}$ Indien de individuele bijdrage niet juist wordt gemeten, zijn de beloningssystemen inefficiënt. Het is van belang dat de actoren bekend zijn die toezicht houden op de productieresultaten, aangezien zij bepaalde doelen hebben die zij met behulp van hun eigendomsrechten zullen trachten te realiseren. Zij zullen dan ook toezien op eventuele beloningssystemen. Vaak zal de directie ramingen van de productie en dienstverlening vermelden in de begroting, die goedgekeurd moet worden door het parlement. Voor het vaststellen van de productieresultaten kunnen veelal verschillende indicatoren gekozen worden (produktiviteit, toegevoegde waarde, bedrijfsresultaat etc.), die zoals opgemerkt een beperkt beeld geven van de "performance" . De politieke actoren, met name het parlement, zullen toezicht uitoefenen op het aldus gemeten productieresultaat. Zoals opgemerkt kan de Staten-Generaal hiervoor de Minister gemachtigd hebben. Veelal zullen de gevonden productieresultaten op enigerlei wijze bepalend zijn voor de beloning van het personeel. Het is duidelijk dat de keuze van een bepaalde productieindicator de hoogte van de beloning zal beïnvloeden. Een Ministerie zal veelal niet rechtstreeks ingrijpen in het loonbeleid van een overheidsinstelling. Vaak geldt een c.a.o., waarin op enigerlei wijze de beloning van het personeel gebonden zal zijn aan de prestatie van de werknemers.

Naast de feitelijke productie van een overheidsinstelling zijn er zoals we gezien hebben veelal allerlei bijkomende doelen, waaronder bijvoorbeeld de realisering van externe effecten. We dienen ons dan ook af te vragen wie op deze bijkomende doelen toeziet.

59s Jansen (1993, p. 54).

sol Jansen (1993). Vergelijk cok: Simon (1989, pp. 10-11). 
Overheidsinstellingen zijn betrokken bij tal van externe effecten. Hierbilj valt te denken aan milieuverontreiniging door elektriciteitscentrales en de verspreiding van wetenschappelijke kennis door universiteiten. In het navolgende worden de drie voor ons vooral van belang zijnde categorieën van externe effecten, zoals die zich kunnen voordoen bij overheidsinstellingen, nader bezien. De houders wan gebruiksrechten zien eveneens toe op deze exterme effecten. Vaak streven de houders van gebruiksrechten positieve externe effecten als eển van de bijkomende doelen na.

De eerste categorie heeft betrekking op externe effecten op milieugebied. Hierop is in hoofastuk 2 reeds ingegaan. De publieke eigenaren moeten een afweging maken tussen enerzijds de winst en anderzijds het milieu. Het milieubeleid kan immers leiden tot lagere winst bij overheidsinstellingen. Beantwoord moet dan ook worden wie bevoegd is om de tarieven en bijvoorbeeld een dienstregeling van de overheidsinstelling vast te stellen. Vaak zal de verantwoordelijke Minister hiertoe bevoegd zijn. Hiermee zal hij mede invloed kunnen witoefenen op de externe milieueffecten.

Een tweede categorie van exterme effecten zijn de invloeden die uitgaan van de verspreiding van wetenschappelijke kennis. De regering kan een overheidsinstelling gebruiken als een instrument voor het realiseren van doelen in het kader van het technologie- en innovatiebeleid. Overheidsinstellingen kunnen als bijkomend doel een optimalle omvang van onderzoek en ontwikkeling realiseren voor de instelling zelf maar ook voor de bedrijfstak of voor de samenleving. Vaak zal de Raad van Commissarissen van een overheidsinstelling, indien aanwezig, toezicht uitoefenen op deze externe effecten, omdat zij bijvoorbeeld over het recht beschikken om de exploitatiebegroting goed te keuren.

Een derde categorie van externe effecten zijn de invloeden die uitgaan van overheidsinstellingen door hun activiteiten op de kapitaalmarkt. Doordat overheidsinstellingen vaak beschikken over impliciete of expliciete overheidsgaranties, kunnen zij gemakkelijker geld lenen, onder meer, indien zij daartoe toestemming hebben, op de kapitaalmarkt. Dit kan onder omstandigheden leiden tot "crowding out". Dit impliceert dat productiefactoren niet worden benut voor hun meest rendabele aanwendingen, hetgeen een efficiënte allocatie verstoort. Jansen merkt op dat de dalende welvaart beschouwd kan worden als een negatief extern effect. Veelal is de toegang van een overheidsinstelling tot de kapitaalmarkt beperkt waardoor deze effecten door de overheid in de hand gehouden kunnen worden. ${ }^{595}$ Onderzocht moet worden wie toezicht uitoefent op de kapitaalmarktactiviteiten van een overheidsinstelling. Veelal zullen de bevoegde ministers, waaronder de Minister van Financiën hierop toezien. Uiteindelijk zijn zij verantwoording schuldig aan het parlement.

\section{ad.3. Wie houdt toexicht op het productieproces?}

Zoals in het vorige hoofdstuk is aangegeven kan het productieproces en de organisatiestructuur van overheidsinstellingen verschillende vormen aannemen. Jansen wijst erop dat zij bijwoorbeeld de vorm kunnen aannemen van een bureaucratie. ${ }^{5 \% 6}$ In een bureaucratie is de bestuurlijke informatievoorziening erop gericht dat de principalen en de directie de benodigde informatie verkrijgen waardoor zij in de gelegenheid worden gesteld om

\footnotetext{
598: Haririan (1989, p. 48).

596 Jansen (1993, p. 34).
} 
thoezicht uit te oefenen op het productieproces. Zoals dat in het kader van de principalagent-verhoudingen binnen het netwerk is behandeld kan de directie het productieproces beirmloeden met behulp van een straf- en beloningsstelsel. Bij een beloningsstelsel kan gedacht worden aan een vorm van prestatieloon. Vaak is het straf- en beloningsstelsel geregeld in een reglement, waarin de dienstvoorwaarden zijn neergelegd. Veelal zullen materiële en immaterièle straffen worden onderscheiden en is aangegeven welke chefs bevoegd zijn om bepaalde straffen op te leggen. Vaak zal hierbij tevens een beroepsmogelijkheid zijn ingesteld. De instelling waarbij beroep kam worden ingesteld zal uiteindelijk toezien op het productieproces.

\section{ad.4. Wie houdt toezicht op de omvang en de samenstelling van het team van producenten?}

Dit recht kan in handen zijn van de betreffende Minister maar zal vaak tot bepaaide hoogte zijn gedelegeerd aan actoren binnen de instelling zelf. Jansen merkt op: "Delegatie van het toezicht op de samenstelling en de omvang van het team wan producenten aan de directie van het overheidsbedriff dient ter vermijding van conflicten in de sfeer van de arbeidsverhoudingen. De werknemers vormen immers een electoraal potentieel'.597. Wie in de praktijk toeziet op de omvang en samenstelling van het personeel van een overheidsinstelling hangt voor een belangrijk deel af van het karakter van de betreffende overheidsinstelling en de aard van het dienstverband. ${ }^{598}$ Veel werkmemers bij overheidsinstellingen worden benoemd in ambtelijke dienst. Behoort de instelling tot het Rijk, zoals het Rijksmuseum gedurende de jaren tachtig, dan is de Kroon bevoegd om personeel aan te stellen. Art. 7 van het ARAR bepaalt dat de aanstelling van personeel in een vast dienstverband in schaal 12 of hoger van bijlage B van het BBRA 1984 gebeurt door de Kroon, terwijl aanstelling in lagere schallen door of namens de Minister van het betreffende Ministerie geschiedt. De benoeming in ambtelijke dienst bij de provincie geschiedt op grond van de Provinciewet door de Provinciale Staten. Deze kunnen desgewenst deze bevoegdheden delegeren. De aanstelling van werknemers in ambtelijke dienst bij de gemeente geschiedt op grond van de Gemeentewet door de Gemeenteraad. Ook hier geldt dat de Gemeenteraad deze bevoegdheid kan delegeren, tenzij dit bij de wet verboden is. In de praktijk zal per instelling moeten worden onderzocht wie de eigenaar is van dit recht.

\section{Het recht op vruchtgebruik (usus fructus):}

\section{ad.4a. Aanspraak op de winst}

Centraal staat hierbij de vraag wie het recht heeft op de winst. Vaak zal het recht op de winst geregeld zijn in de statuten. Van belang hierbiji is hoe de afschrijvingen mogen worden bepaald. Vaak mag een gedeelte van de winst worden gereserveerd. Indien er een algemene vergadering van aandeelhouders is zal deze veelal gemachtigd zijn de winstbestemming te bepalen. Jansen merkt op dat een overheidsinstelling zijn winst te hoog of te laag kan weergeven in zijn externe verslaggeving. Een te hoge weergave heeft tot doel een gunstig beeld van het bedrijf in de publieke opinie te creëren. Indien de winst te laag

597 Monsen en Walters (1983, pp, 45-47).

${ }^{598}$ Korteweg-Wiers (et al.) (1988, hoofdstuk 4). Zie ook: Korteweg-Wiers (1992). 
wordt weergegeven gaat dit gepaard met stille en geheime reserves. Jansen ${ }^{59}$ geeft in zijn onderzoek aan dat directies van overheidsinstellingen door het creëren van stille en geheime reserves proberen aanspraken op de winst van de kant van belangenorganisaties, zoals valkbonden, tegen te gaan. Stille reserves blijken wit de gepubliceerde balans, maar de omvang echter niet. Deze reserves ontstaan door het versneld afschrijven van durrzme productiemiddelen. In tegenstelling tot stille reserves blijken geheime reserves niet uit de gepubliceerde balans. Geheime reserves ontstaan doordat de vaste activa te laag worden gewaardeerd of doordat veemd vermogen te hoog wordt weergegeven.

Actoren kunnen op verschillende manieren proberen om aanspraak te maken op de winst. Veelal bestaan er binnen een overheidsinstelling allerlei winstdelingsregelingen. Vaak kummen de politiek verantwoordelijke minister, de directie en het personeel zich een deel van de winst van de overheidsinstelling toeëigenen in de vorm van dividenden, tantièmeis en premies. Het recht op dividend en tantièmes kan bij overheidsinstellingen zijn vastgelegd in de statuten of in arbeidscontracten. De wijze waarop de winstuitkering is geregeld beïnvloedt niet alleen de stijl van bedrijfsvoering maar ook de arbeidsprestaties. Zo kan een tantième-regeling voor het hogere kader tot gevolg hebben dat het netwerk meer nadruk legt op het doel inkomsten voor de overheid te verwerven. Dit komt omdat leidinggevenden in dat geval belang hebben gekregen bij het realiseren van zo hoog mogelijke winst: Zoals ook Jansen opmerkt is het denkbaar dat in het geval van een winstdelingsregeling het niet realiseren van winst door de overheidsinstelling madelige invloed heeft op de arbeidsprestaties.

Naast dergelijke winstdelingsregelingen komt het bij overheidinstellingen ook voor dat de salarièring gekoppeld wordt aan de omzet. Empirisch onderzoek naar de relaties tussen salariëring, omzet en winst bij overheidsinstellingen ontbreekt. ${ }^{600}$ Ramanadham constateert dat het hogere kader van overheidsinstellingen relatief lagere inkomens ontvangen. Het lagere kader ontvangt in vergelijking met het bedrijfsleven daarentegen een hogere beloning. Hierbij moet echter niet alleen gekeken worden naar de salarisstructuur maar ook naar de genoemde winstdelingsregelingen. Door de vrijstelling van bijvoorbeeld dividend- en tantièmebelasting voor het leidinggevend personeel van overheidsinstellingen ontvangen zij in feite een onzichtbare overdracht van baten van de Rijksoverheid. Om het gedrag van overheidsinstellingen te kumnen voorspellen moet de aandacht worden gevestigd op de beloningsstimuli bij de diverse organisatievormen van overheidsinstellingen. ${ }^{602}$ De beperking van de tantiemes leidt ertoe dat de directie (en het personeel) gaat streven natar autonomie om haar eigen doeleinden te realiseren.

Indien dergelijke winstdelingsregelingen ontbreken kunnen actoren proberen zich een deel van de winst toe te eigenen door gebruik te maken van allerlei, vanuit de overheidsinstelling bezien, kostenverhogende activiteiten als spaarregelingen. ${ }^{603}$ Op grond van art. 5 wan de Bedrijvenwet van 1928 maakte de Minister van Financiën aanspraak op de winst

\footnotetext{
s9 Jansen ( 1993 , pp. 35 e.v).

T.a.p. p. 36

601 Ramanadham (1991, p. 14).

Davies en Brucato (1987, p, 10),

${ }^{609}$ Ramanadham (1991, p. 108).
} 
van een staatsbedrijf. ${ }^{604}$ Teneinde te voorkomen dat deze winst naar het Rijk stroomt; kan deze tot op bepaalde hoogte worden omgezet in kosten.

Een andere wijze waarop aanspraak op de winst plaats vindt is door "rent seeking". Vaak neemt "rent seeking" de vorm aan van een overdracht van middelen van de overheidsinstelling naar de betrokkenen. Jansen noemt als voorbeeld van een dergelijke ondoorzichtige transfer van baten de voorkeur van de directie van de NV Nederlandse Spoorwegen om bij kleine prijsverschillen met buitenlandse bedrijven orders te plaatsen bij de Nederlandse wagonindustrie ${ }^{605}$ In paragraaf 10.3 is reedis aangegeven dat ook bureaucratische inefficiëntie ("slack") als een vorm van vruchtgebruik kan worden beschouwd. De kosten van deze bureaucratische inefficiëntie is de "public enterprise rent" gederfide winst die ontstaat doordat allerlei bijkomende doelen worden nagestreefd. De vraag die beantwoord moet worden is dan ook wie hierover kan beschikken.

Tenslotte $\mathrm{kan}$, zoals uiteengezet in hoofdstuk 7, ook de opbouw van eigen vermogen door toevoeging aan reserves worden beschouwd als een vorm van vruchtgebruik. De vraag die beantwoord dient te worden is in hoeverre het aan een overheidsinstelling is toegestaan om de winst die zij in een bepaalde periode maakt zelf te houden. Künneke onderscheidt ten aanzien van het recht op eigen vermogen een drietal mogelijkheden, namelijk het recht op eigen vermogen in onbeperkte omvang, het recht op eigen vermogen in beperkte omvang en het ontbreken van een recht op eigen vermogen. ${ }^{606}$ Zoals aangegeven in hoofdstuk 7 kan gesteld worden dat een organisatie met een onbeperkt recht op eigen vermogen meer prikkels heeft om de technische efficièntie te verbeteren dan een organisatie die dit recht niet heeft. Een organisatie die dit recht niet heeft zal meer prikkels hebben om alleriei bijkomende doelen na te streven. Dit is de enige manier om zich alsnog een deel van de "public enterprise rent" toe te eigenen.

Het recht om de vorm of inhoud van een zaak te veranderen of te verhandelen (abusus):

\section{Ad.5. Wie heeft het recht om de organisatie te wijzigen, te verkopen of te liquideren?}

In de theorie van de eigendomsrechten wordt onder dit recht met name het recht van verhandelbaarheid verstaan. Künneke geeft aan dat dit recht ook bij overheidsinstellingen vaalk bestaat. Hij wijst op de reorganisatie van de elektriciteitssector, waarbij veel gemeenten hun gasbedrijf hebben verkocht. In het algemeen is de gedachte dat personen die een dergelijk recht bezitten niet alleen rekening zullen houden met de huidige opbrengsten maar ook met toekomstige kosten en baten. Indien en dergelijk recht ontbreekt zullen instmaximaliserende individuen geneigd zijn de goederen volledig te gebruiken, hetgeen ten kaste kan gaan van de efficiëntie. Dit argument is bij overheidsinstellingen minder van belang. Publieke eigenaren zullen, ook als zij het goed niet zouden kunnen verhandelen, veelal niet alleen naar maximale winst streven. Het is dan ook niet waarschijnlijk dat toekenning van het recht op verhandelbaarheid van overheidsinstellingen op een soortgelijke wijze als bij een particulier bedrijf de technische efficiëntie zal vergroten.

${ }^{604}$ Artikel 5 (1j en 2f), Bedrijvenwet, Wet van 21 juli 1927, Stb. 249.

Jansen (1993, p. 208) Vergelijk ook Backhaus (1994, p. 286).

Künneke (1991, pp. 128-129). 
Voor dit onderzoek is een rümere opvatting van dit recht dan ook meer relevant. Zoals opgemerkt in hoofdstuk 7 geeft Künneke aan dat het recht op toegang tot de kapitaalmarkt als een bepaald facet van dit recht kan worden geinterpreteerd. Een overheidsinstelling die toegang heeft tot de kapitaalmarkt zal hiervoor delen van de overheidsinstelling in onderpand geven. Een gevolg hiervan is dat de bundel van eigendomsrechten van een overheidsinstelling hierdoor impliciet gewijzigd wordt. Een tweede belangrijk gevolg van de toegang van een overbeidsinstelling tot de kapitalmarkt heeft betrekking op de vergroting van efficiêntieprikkels. Particulieren zullen alleen bereid zijn kredieten te verlenen aan overheidsinstellingen die zelfstandig en zonder garantieverlening door de publiekrechtelijke eigenaar vreemd vermogen op de kapitaalmarkt kunnen aantrekken, indien deze een zekere mate van winstgevendheid hebben. Hoewel een overheidsinstelling niet snel failliet zal gaan is het duidelijk dat het niet nakomen van vorderingen grote invloed kan hebben op de organisatie als geheel. De conclusie is derhalve dat overheidsinstellingen die geen toegang hebben tot de kapitaalmarkt minder blootgesteld zullen zijn aan efficientieprikkels. Voor dit onderzoek is het dan ook van belang te weten of een overheidsinstelling toegang heeft tot de kapitaalmarkt. Indien dit het geval is kan hieruit als doel onder meer worden afgeleid dat de overheidsinstelling relatief meer naar winst en technische efficiëntie zal streven.

\section{Conclusie}

Na de uitvoering van een structuuranalyse is het duidelijk wie welke bevoegdheden heeft. Uit het recht om toezicht uit te oefenen op de aankopen en de prestaties van de productiefactoren kan bijvoorbeeld als doelstelling het realiseren van een bepaald rendement worden afgeleid. Een ander doel kan bijvoorbeeld het streven naar conjuncturele stabiliteit zij̄n. Ook wit de andere eigendomsrechten kunnen op deze wijze doeleinden worden afgeleid. Indien de politieke actoren bijvoorbeeld de onderneming een recht op de winst toekennen kan dit tot doel hebben de continuitteit van de onderneming te bevorderen. Daartoe dienen ook beleidsdocumenten te worden geanalyseerd.

\subsection{Hoe kan de ontsluierde "performance" van een overheidsinstelling worden geanalyseerd?}

De kwalitatieve benadering tracht de doelen te relateren aan de houders van de eigendomsrechten. Er zijn in dat geval twee methoden om een individuele doelstellingsfunctie af te leiden. De eerste methode is de interviewmethode. Individuele actoren worden in dat geval gevraagd naar hun preferenties. De tweede methode is de "revealed preference" methode. Doelen worden afgeleid uit het feitelijke keuzegedrag van individuen. De interviewmethode heeft als voordeel dat zij relatief eenvoudig is. Daar staat tegenover dat de resultaten minder betrouwbaar kunnen zijn. Individuen hebben geen prikkel om hun werkelijke voorkeuren weer te geven. Dit probleem doet zich niet voor bij de "revealed preference" methode. Een probleem van deze methode is evenwel dat het niet eenvoudig is uit het feitelijke keuzegedrag van individuen de doelstellingen af te leiden. Dit hangt onder andere af van het grote aantal mogelijke doelen en van de randvoorwaarden die ten grondslag kunnen hebben gelegen aan het keuzegedrag.

\section{Interviewmethode}

Door middel van de interviewmethode, aangevuld met documentenonderzoek, wordt onderzocht welke actoren welke doelen nastreven. Zij moeten dan aangeven hoeveel zij aan welk doel zouden besteden en hoe belangrijk dat doel voor hen is. Bijwoorbeeld actor 1 vindt werkgelegenheid erg belangrijk en besteedt zijn thele budget hieraan. Actor 2 vindt juist de arbeidsomstandigheden binnen de overheidsinstelling het belangrijkst en zou het 
totale budget hieraan besteden. Het gaat derhalve on de mate waarin actoren de doelen kannen bepalen.

Stap 2 heef vervolgens betrekking op het afleiden van het belang van de diverse actoren. Dat will zeggen dat de invloed van die actoren op het beleif en de doelen moet worden bepaald. In de literatuur is hier het nodige onderzoek naar verricht Tannenbaum heeft bijwoorbeeld onderzoek verricht naar de invloedsverdeling binnen organisaties met de zogenaamde "control graph". 607 Hij vraagt leden van een organisatie op een vijfpuntschaal aan te geven, hoeveel invloed bepaalde leden of posities in de organisatie hebben.

Patchen geeft aan dat de "control graph" een aantal bezwaren kent. ${ }^{\text {"s }}$ Beschikbaar onderzoek wijst erop dat mensen op verschillende hiërarchische niveaus verschillende opvattingen hebben over de invloed uitgeoefend op elk hierarchisch niveau. Verschillen in oordelen over de mate van invloed van actoren worden onder andere veroorzaakt doordat de aard van de bijdragen van de verschillende individuen in de verscheidene stappen van het besluitvormingsproces verschillen en doordat een beslissing in wezen vaak gemeenschappelijk is. De verschillende participanten kunnen van mening verschillen over de mate van invioed van de verschillende actoren.

Om deze problemen te ondervangen is het waarsehijnijk verstandiger de verschillende acties van de verschillende actoren in het hele besluitvormingsproces en de reacties van anderen hierop te onderzoeken. Op grond van dergelijke informatie kan de onderzoeker het relatieve belang van elke actor ten aanzien van de uitkomsten van elke stap in het besluitwormingsproces schatten. Eventueel kan hij actoren in het bedrijf vragen dit (ook) te doen. Hierbij sluit de benadering van Backhaus aan die, zoals wordt aangegeven in paragraaf 14.6 , het relatieve belang van de doelen raamt door een diepgaande analyse van de verdeling van eigendomsrechten (machtsverdeling). Uit een dergelijke analyse blijkt dat bijvoorbeeld actor 1 over veel bevoegdheden beschikt (bijvoorbeeld de directeur van het bedrijf) en actor 2 over weinig bevoegdheden.

\section{2. "Revealed Preference" Methode}

De tweede methode die gevolgd wordt is de "revealed preference" methode. Deze methode is oorspronkelijk ontwikkeld door Paul Samuelson als onderdeel van de theorie van het consumentengedrag. ${ }^{69}$ Mansfield vat deze theorie als volgt samen: "The theory of revealed preference assumes the following. First, if a market basket is purchased when this market basket is more expensive than another market basket it must also be purchased when it is no more expensive (...). Second, if one market basket is chosen over a second and the second is chosen over a third, the first must be chosen over the third. This is the assumption of transitivity. Third, given any market basket, it is assimed that there exists some budget line that will lead the consumer to buy it". 610 Het gebruik van de "revealed preference" methode is niet beperkt gebleven tot het consumentengedrag. Deze benadering wordt grotendeels gevolgd door de public-choice-benadering. Onder de veronderstelling van Pareto-efficiëntie is het mogelijk om uit het kenbare gedrag en de gemaakte keuzes van een overheidsinstelling de doelen af te leiden. Onderzoeksmethoden zijn de

on Tannenbaum (1968, pp. 73 e.v.).

Patchen (1974, p. 215).

(609) Vergelijk: Samuelson (1947) en Samuelson (1948, pp. 243 e.v.).

${ }^{\text {Bid }}$ Mansfield (1982, pp. 72-73). 
structuur-analyse en documentenonderzoek. Uitgangspunt van deze benadering is dat de doelen afgeleid uit het gedrag van een overheidsinstelling de doelen van de actoren zijn (dus efficiënt). In paragraaf 8.5 is reeds ingegaan op de vraag in hoeverre deze methode te gebruiken is. De conclusie was dat het niet altijd maar wel vaak zo zal zijn dat de eigenaren wan een overheidsinstelling er in slagen hun doelen te bereiken. Het is derhalve raadzaam om de "revealed preference" benadering te combineren met de interviewmethode teneinde de doelen van de houders van eigendomsrechten en daarmee de doelfunctie van de overheidsinstelling te achterhalen. In het navolgende wordt kort ingegaan op de "revealed preference" -methode.

5.

Gedurende deze fase wordt getracht de kenbaar gemaakte beleidsdoelen te verzamelen en te analyseren met behulp van (beleids)documenten. Deze analyse bevestigt of weerlegt de met de structuranalyse gevonden doeleinden en omvat de volgende procedure: ${ }^{611}$

5a. Het verzamelen en definiëren van de kenbaar gemaakte doeleinden in documenten en verklaringen van de bij de overheidsinstelling betrokken principalen. Het gaat daarbij vooral om de doelen van de verantwoordelijke ministers en de directie van de overheidsinstelling. Deze kunnen gevonden worden in beleidsdocumenten, financiële verslagen, kamerstukken en statuten.

5b. Het verzamelen en definiëren van de doeleinden, die zijn gevonden in niet-officiële documenten. Hierbij kan gedacht worden aan notulen van vergaderingen en briefwisselingen maar ook aan door medewerkers van de betreffende overheidsinstelling op eigen titel gepubliceerde boeken.

5c. Het vergelijken van de doeleinden zoals gevonden in de structurranalyse met de doelen gevonden door middel van stap $5 \mathrm{a}$ en $5 \mathrm{~b}$.

5d. Het samenstellen van een lijst met doeleinden, die als volgt wordt onderverdeeld:

d1. Doeleinden gevonden met de analyse van de kenbaar gemaakte doeleinden.

d2. Doeleinden gevonden met de structuuranalyse.

d3. Doeleinden gevonden met beide analyses.

Onduidelijk geformuleerde wettelijke en statutaire doeleinden voor overheidsinstellingen bevorderen het streven naar een mate van vrijheid om eigen beleidsdoeleinden te verwezenlijken. De kwalitatieve prestatie-analyse stelt deze bijkomende doeleinden vast.

Vervolgens kan de op deze manier opgestelde lijst worden gebruikt voor de volgende stappen.

6. Bepaal de reeks van doelen.

7. Bepaal de mate waarin deze doelen zijn verwezenlijkt.

8. Bepaal de mate waarin de verwezenlijking van de doelen fundamenteel en continu is.

9. Bepaal de "public enterprise rent" en zet de mate waarin de doelen zijn verwezenlijkt af tegen deze "public enterprise rent".

GII Backhaus (1994, p. 286). 
10. (Facultatief: Schets een zodanig scenario voor privatisering/verzelfstandiging van de activiteiten waarbij alle doelen worden gerealiseerd).

\section{ad. 9 Het bepalen van de kosten van de overheidsinstelling}

De kosten van een overheidsinstelling kunnen veelal worden onderscheiden in een aantal verschillende categorieên. Naast subsidies is met name de "public enterprise rent" van belang. Dit is de winst die de overheidsinstelling derft, omdat deze allerlei bijkomende doelen nastreeft. De "public enterprise rent" kan op een tweetal wijzen worden vastgesteld, te weten enerzijds door middel van de methode van het fictief privatiseren van de overheidsinstelling en anderzijds via de methode van Jansen en Meijer. ${ }^{6 i 2}$

\section{A. De methode van het fictief privatiseren}

De "public enterprise rent" kan gevonden worden door de overheidsinstelling fictief te verzelfstandigen en meer financiële zelfstandigheid te geven. Het accent ligt daarbij op externe verzelfstandiging. De overheidsinstelling wordt dan zelf verantwoordelijk voor haar contimü̈teit en zal prijzen moeten rekenen die meer de kosten weerspiegelen. Om de "public enterprise rent" te bepalen dient een verlies- en winstoverzicht opgesteld te worden waarin precies staat aangegeven hoeveel arbeid en kapitaal en hoeveel voorraden mu gebruikt worden en hoeveel in het geval van privatisering, hoe groot de omzet zou kunnen zijn etc. Vervolgens kan worden bezien hoe groot de kostenverschillen zijn. De vraag rijst wat voor een prijs een dergelijke geprivatiseerde instelling zal rekenen. In principe zal de prijs gelijk moeten worden gesteld aan de marginale kosten (vergelijk appendix 1). Door vervolgens de winst van het geprivatiseerde bedrijf te vergelijken met die van de overheidsinstelling kan de "public enterprise rent" worden bepaald. Stel het fictieve bedrijf maakt een winst van 10 miljoen gulden. We weten tevens dat de overheidsinstelling een verlies maakt van bijvoorbeeld 5 miljoen gulden. De kosten van de overheidsinstelling bestaan echter niet alleen uit deze 5 miljoen. Hier moet de potentiële winst bij worden opgeteld die de overheidsinstelling had kunnen maken, indien het een particulier bedrijf was geweest. Dus:

"Performance" overheidsinstelling in guldens:

5 miljoen (verlies)

+10 miljoen (winst eventuele verzelfstandigde fictieve overheidsinstelling)

"gederfde winst": Verlies van 5 miljoen +10 miljoen gulden waarbij de winst van de fictieve overheidsinstelling is genomen nadat er al vennootschapsbelasting over is geheven.

Een belangrijk probleem van deze benadering is dat de prijsvorming van een geprivatiseerde instelling beïnvloed wordt door allerlei uiteenlopende factoren waaronder de marktstructuur en de mate van concurrentie. Indien de geprivatiseerde overheidsinstelling met veel concurrentie geconfronteerd wordt zal de winst klein zijn. De "public enterprise rent" kan dan kleiner lijken dan zij in werkelijkheid is. Dit zal zich bijvoorbeeld voordoen indien de overheidsinstelling een monopolie heeft.

\section{B. Een rendementscriterium}

De kosten die gemaakt worden voor het bereiken van de verschillende doelen vormen de

6i2 Jansen (1993, p. 42). 
restrictie. Deze restrictie oftewel het budget kan van overheidsinstelling tot overheidsiastelling verschillen. Hiter wordit er vamuit gegaan dat deze bestaat uit a. de "public enterprise rent" en b. de kosten van het eigenlijke doel.

$b=b(p 1 D 1+p 2 D 2+\ldots+p n D n)$

Het gaat er nu om hoe de kosten van de bijkomende doelen, de "public enterprise rent" bepaald kunnen worden: Bij de tweede methode ter bepaling van de "public enterprise rent $^{\text {th }}$ kan worden uitgegaan van een rendementscriterium. ${ }^{6}$ Verondersteld wordt dat het rendement van een overheidsinstelling in principe minimaal gelijk moet zijn aan het rendement op staatsobligaties, omdat anders de overheid het geld beter kan uitlenen en de rente kan gebruiken voor aanvullende doelen.

Dit kan als volgt worden toegelicht. Stel bijvoorbeeld dat de volgende situatie zich voordoet:

Norm:

- Rendement op staatsobligaties, $9 \%$.

Feitelijke winst: $\quad$ - Bijvoorbeeld 0 .

Eigen vermogen: - bijvoorbeelld F. 100 miljoen.

Stel dat het rendement op staatsobligaties $9 \%$ bedraagt. De winst van een overheidsinstelling is gelijk aan 0 en het eigen vermogen F. 100 miljoen bedraagt. De overheidsinstelling zou nu een winst moeten behalen van tenminste het obligatierendement van $9 \%$ of negen miljoen gulden. De winst is 0 , derhalve bedraagt de gederfde winst of "public enterprise rent" negen miljoen.

Hoewel de voorkeur uitgaat naar de eerste methode omdat deze veel meer informatie verschaft over de overheidsinstelling is het vooralsnog niet duidelijk of met deze methode de "public enterprise rent" eenduidig kan worden vastgesteld. Bij de privatisering zullen wellicht bepaalde keuzes gemaakt dienen te worden die tot bepaalde hoogte subjectief zullen zijn. De voordelen van de tweede methode zijn dat enerzijds snel een beeld verkregen kan worden van de "public enterprise rent" en anderzijds dat de methode van het fictief privatiseren beter beoordeeld kan worden. Derhalve wordt bij de vaststelling van de "public enterprise rent" de laatste benadering gevolgd.

\subsection{Hoe kan het relatief belang van de doelen worden vastgesteld?}

Het relatieve belang van de doelen kan worden bepaald door een analyse van de principaal-agent-relatie en een analyse van de instelling's eigen verklaring voor zijn "performance" en de reactie van de principalen op die verklaring. Deze methode gaat er van uit dat uit de wisselwerking tussen de verklaring van de bedrijfsprestaties door de bestuurders van de overheidsinstelling en de reacties van de principalen hierop, het relatieve gewicht van de verschillende doeleinden valt af te leiden. De analyse bestaat uit een vijftal stappen. ${ }^{614}$

11. In de eerste plaats dienen de benoemingen van personen in toezichthoudende instanties

\footnotetext{
.613 Jansen (1993, p. 42).

${ }^{614}$ Backhaus, (1994, pp. 283 e.v.).
} 
en in het management van de overheidsinstelling te worden geanalyseerd ${ }^{\text {tis }}$ Vaak zal de algemene vergadering van aandeelhouders beschikken over het recht om de leden van de Raad van Commissarissen te benoemen. Ook hierbij is het van belang wie in de Raad van Commissarissen benoemd worden en in hoeverre daar wijzigingen in optreden. Voorts ils het van belang te weten hoe de directie wordt benoemd en door wie. Vaak zal het zo zijn dat de algemene vergadering van aandeelhouders de directieleden benoemt, terwijl de Raad van Commissarissen het recht heeft eén of meer personen aan te bevelen, Jansen merkt op dat regeringen veelal de directies en de leden van de toezichthoudende organen benoemen en herbenoemen. Deze bevoegdheid is ook vaak gedelegeerd aan de betrokken ministers. In het geval van overheidsinstellingen met een N.V.-vorm oefent de raad van commissarissen toezicht uit en dient het management van advies.

12. In de tweede plaats kunnen de principalen indien zij ontevreden zijn over de wijze van functionereo van een overheidsinstelling de beschikbare beleidsvrijheid in een overheidsinstelling beëindigen. De doelen van de overheidsinstelling worden dan eveneens veranderd. Dit zullen zij alleen doen als het eigenlijke doel van de overheidsinstelling voor hen het belangrijkste is of indien het mogelijk is om de door hen nagestreefde doelen op een andere wijze beter te realiseren, bijvoorbeeld door het tot stand brengen van meer beleidsvrijheid in een andere overheidsinstelling. Expliciete beleidswijzigingen en yerschuivingen in doelen tuissen verschillende actoren dienen te worden verklaard. Backhaus stelt dat dergelijke verschuivingen ontevredenheid met de "performance" van de actor die een bepaalde taak moet uitvoeren impliceert. Tegelijkertijd drukt het tevredenheid uit met betrekking tot de "performance" van de actor die de betreffende taak ontvangt. Door een dergelijke verschuiving van taken en bevoegdheden is het mogelijk dat de doelen van een overheidsinstelling veranderen.

13. In de derde plaats dienen impliciete beleidswijzigingen en verschuivingen, die niet publiekelijk worden bediscussieerd of gedocumenteerd, te worden geanalyseerd. Jansen merkt op dat impliciete beleidswijzigingen kunnen worden vastgesteld aan de hand van statistische discontinuiteiten in tijdreeksen, aangezien deze discontinuïteiten veelal duiden op een beleidswijziging. Voorts kunnen impliciete beleidswijzigingen ontdekt warden door wijzigingen in het gedrag van een overheidsinstelling die niet corresponderen met de doelen zoals die zijn weergegeven in officiële documenten zoals jaarverslagen.

14. In de vierde plaats moeten verschillen tussen datgene wat de houders van eigendomsrechten zeggen in officiele beleidsdocumenten en het werkelijke gedrag te worden vastgesteld. Dergelijke verschillen kunnen wijzen op ceremoniele "performance". In het geval van ritueel gedrag ontstaat er een versehil tussen het door de overheidsinstelling gepresenteerde beleid en de werkelijke beleidsuitwoering. Dit kan onder meer worden veroorzaakt door het gebruik van planningsmethoden. Indien het gebruik van planningssystemen als "management by objectives" en "planning programming budgetting systems" onder druk worden ingevoerd kan dit leiden tot ritueel gedrag. 616 Voor de vorm wordt het beleid uitgevoerd, maar feitelijk handelen de verantwoordelijke actoren overeenkomstig de traditionele gedragspatronen. ${ }^{617}$

lsos Jansen (1993, pp : 48-49).

${ }^{616}$ T.a.p., pp. 49-50.

6ry Braun (1988, pp. 327 e.v.). 
15. Tenslotte dient de mate waarin activiteiten niet worden bediscussieerd maar wel gewoon worden uitgevoerd te worden vastgesteld. Met de analyse van de financiële administratie kunnen de niet ter discussie staande beleidsactiviteiten worden achterhaald. Jansen ${ }^{618}$ noemt als voorbeeld van dergelijke beleidsactiviteiten het reclame- en garantiebeleid.

\section{Reclame}

Net als bij particuliere bedrijven kunnen overheidsinstellingen proberen om door middel van reclame hun afnemers te bereiken. Hierbij kan gedacht worden aan uitgaven voor publiciteit en advertentiedoeleinden. Daarnaast is reclame voor een overheidsinstelling om een aantal redenen nog van extra belang. Overheidsinstellingen hebben, vooral als er sprake is van dalende gemiddelde kosten, belang bij een uitbreiding van de omzet. Een hogere omzet onder omstandigheden van een naturlijk monopolie leidt tot een volledige benutting van de schaalvoordelen. Het maken van reclame kan dan een middel zijn om de prijs dichter bij de marginale kosten te stellen, zonder dat daarvoor subsidies nodig zijn. ${ }^{619}$ Bovendien vormt reclame voor de regering en voor de actoren in het management van de overheidsinstelling een middel om het electoraat via de bedrijfsprestaties te beinvloeden. Door de presentatie van goede resultaten kunnen ministers proberen om hun populariteit te vergroten en herverkiezing te verzekeren. Door de directies van overheidsinstellingen wordt reclame gebruikt om zich te verzekeren van subsidies door de overheid. Omdat zowel de principalen als de agenten daar belang bij hebben bestaat bij overheidsinstellingen een prikkel om meer aandacht te besteden aan reclame dan bij particuliere ondernemingen het geval is. Overheidsinstellingen zullen zoals reeds eerder is uiteengezet vaker verlieslijdend zijn. Het reclamebeleid van de directie zal zich dan ook vooral richten op het benadrukken van het belang van de bijkomende doelen. ${ }^{620}$

\section{Garanties}

Garanties vormen eển van de vele beleidsinstrumenten van de overheid. ${ }^{621}$ Een belangrijk kenmerk van garanties is dat deze niet op de begroting vermeld worden. Zij komen pas op de begroting tot uitdrukking indien de verplichting tot het nakomen van de garantie zich inderdaad voordoet. Het verlenen van garanties kan zowel voor de overheid als voor de overheidsinstelling diverse voordelen hebben. Zo kunnen overheidsinstellingen door dergelijke garanties tegen gunstige voorwaarden geld lenen. ${ }^{622}$. Meer in het algemeen kan gesteld worden dat het verlenen van garanties door de overheid inhoudt dat bepaalde financiële voorrechten worden toegekend aan bepaalde actoren. Voor de overheid zal het vaak aantrekkelijk zijn om overheidsinstellingen garant te laten staan omdat de kosten van toezicht door dergelijke instellingen veelal lager zijn dan de kosten van het toezicht door ambtenaren bij de overheid. Dat komt enerzijds omdat directieleden van overheidsinstellingen over meer informatie kunnen beschikken, bijvoorbeeld omdat zij zitting hebben in de directies van dochterondernemingen en in de Raden van Commissarissen van particu-

\footnotetext{
GI Jansen (1993, pp. 50-52).

6.19 Vogelsang (1990, pp. 327 e.v.).

T.a.p. p. 62.

621 Jansen (1993, pp. 51-52).

Aharoni (1986, pp. 118 e.\%.).
} 
liere ondernemingen. Anderzijds hebben de directies van overheidsinstellingen die zich garant stellen in tegenstelling tot ambtenaren een belang bij toezicht omdat riskante activiteiten van de betreffende organisatie waarvoor de overheidsinstelling garant staat belangrijke gevolgen kan hebben voor de eigen instelling.

De doelfuncties van de overheidsinstelling zullen vooral wijzigen indien sprake is van impliciete of expliciete beleidswijzigingen, veranderingen in de eigendomsrechtenverdeling en verandering in de individuele doelvoorkeuren van relevante actoren. Het relatieve belang kan worden vastgesteld aan de hand van enerzijds archiefonderzoek en anderzijds door het afnemen van interviews met de houders van eigendomsrechten.

\subsection{Hoe kan de "performance" van een overheidsinstelling worden samengevat?}

16. Het samenvatten van "performance"-schattingen in termen van inputs en outputs

Deze samenvatting moet laten zien wat de kosten zijn van de bereikte doelen. De kosten zijn de gederfde winst, die in geval van winstmaximalisatie gerealiseerd zou zijn (de "public enterprise rent"). Daarnaast bestaan de kosten veelal uit administratieve kosten en kosten voor de gebruikte productiefactoren. De precieze kostencategorieën verschillen veelal per overheidsinstelling en zullen dan ook per instelling geanalyseerd moeten worden. De bijkomende doelen zullen gefinancierd worden door de "public enterprise rent". Voorts kan worden bezien wie profiteert van het bestaan van een overheidsinstelling en wie betaalt.

Tenslotte moet in een conclusie een samenvatting worden gegeven van de voorgaande stappen. Voorts kan een vergelijking worden getrokken met andere onderzochte overheidsinstellingen. Verder kunnen concrete aanbevelingen gedaan worden. Hierbij kan aansluiting worden gezocht bij recente verslagen en (organisatiekundige) rapporten over een overheidsinstelling.

\subsection{Toelichting van de onderzoeksmethode}

\subsubsection{De selectie van de te onderzoeken overheidsinstellingen}

In de komende hoofdstukken worden de resultaten van het case study-onderzoek naar de "performance" van een drietal overheidsinstellingen weergegeven. Er zijn een aantal redenen waarom voor deze drie instellingen is gekozen. Zoals aangegeven verschillen overheidsinstellingen qua doelen en "performance" van particuliere ondernemingen. Die verschillen zijn het grootst voor overheidsinstellingen die collectieve en quasi-collectieve goederen voortbrengen. Binnen de categorie van instellingen die collectieve of quasicollectieve goederen voortbrengt is gekozen voor een drietal instellingen die recentelijk te maken hebben gehad met een reorganisatie. De reden hiervoor is dat, aangezien het in dit onderzoek gaat om het onderzoeken en verklaren van de "performance" van overheidsinstellingen, het van belang is te bezien in hoeverre deze herstructureringen een tekortschietende "performance" weerspiegelen. Op grond van deze gedachtengang is gekozen voor:

-Het elektriciteitsbedrijf MEGA-Limburg/NV PLEM

-Het Rijksmuseum

-De Rijksbelastingdienst 
Zowel een elektriciteitsbedrijf zoals MEGA-Limburg/NV PLEM als het Rijksmuseum zijn organisaties waar de overheid zeggenschap heeft en waarvan de goederen en diensten ook door naar winst strevende particuliere ondernemingen kunnen worden geleverd. Het zijn conform de in dit onderzoek gebruikte definitie overheidsinstellingen die quasi-collectieve goederen voortbrengen. Onder quasi-collectieve goederen worden goederen verstaan die in principe wel voor levering via de markt in aanmerking komen maar waarvan om verschillende, soms politieke redenen wordt afgezien. Met betrekking tot de Belastingdienst lijkt het minder duidelijk dat ook hier sprake is van een overheidsinstelling zoals hier gedefinieerd. Toch kan, uitgaande van deze definitie, ook de Belastingdienst als een overheidsinstelling worden beschouwd. De belastinginning zou eventueel ook door particuliere organisaties kunnen worden verricht. Hierbij kan een parallel worden getrokken met de verplichte ziektekostenverzekering, waarbij de inning geschiedt door particuliere bedrijven. Net als de inning van verzekeringspremies kunnen ook belastingen geind worden door particuliere instellingen. Een ander voorbeeld is de B.T.W., zij het dat hier slechts een deel van de inning door het bedrijfsleven geschiedt.

\subsubsection{De onderzoeksperiode}

In verband met de reorganisaties die bij de geselecteerde instellingen eind jaren tachtig zijn doorgevoerd is het Rijksmuseum onderzocht over de periode 1970-1990, waarbij het accent ligt op de periode 1980-1990. Eerdere statuten en beleidsdocumenten, bijvoorbeeld oprichtingsstatuten, worden meegenomen voor zover relevant voor een beter begrip van de "performance" in deze periode. Voor de Belastingdienst was vooral informatie beschikbaar vanaf 1980. Verder liep het reorganisatieproces van de Belastingdienst door tot 1993, reden waarom voor deze instelling is gekozen voor de onderzoeksperiode 19801993. Ook het reorganisatieproces van MEGA Limburg ging begin jaren negentig voort. Op grond hiervan is in overleg met de betrokkenen binnen deze organisatie gekozen voor de periode 1970-1992.

\subsubsection{De onderzoeksbronnen}

Het onderzoek is uitgevoerd gedurende de tweede helft van 1993 tot en met eind 1996. De nadruk lag daarbij op uitgebreid archiefonderzoek en verder zijn een aantal aanvullende interviews afgenomen. De bij de interviews gebruikte vragenlijsten waren opgesteld volgens het stramien aspecten, indicatoren, vragen. Bij het Rijksmuseum zijn gesprekken gevoerd met de (voormalig) directeur prof. dr. H.W. van Os, de Secretaris mevr. M. Verberne, het hoofd van de afdeling Algemene en Financiële Zaken dhr. drs. D. Elders en met dhr. M.C.W. Veen en dhr. E. Stender, hoofd van het archief. Bij de N.V. PLEM zijn gesprekken gevoerd met dhr. drs. C.H.A. van Balveren en dhr. drs. W.J. Timmermans. Verder zijn voor het onderzoek bij de Belastingdienst een aantal oriënterende gesprekken gevoerd met medewerkers van de afdeling Planning en Control van het Ministerie van Financiën, namelijk dhr. Mr. V. van Kommer en Mr. J.C.F. Muizelaar. Verder zijn de diverse archieven geraadpleegd en is materaal verzameld uit het archief van de Tweede Kamer. Vooral voor het onderzoek naar de Belastingdienst is veel gebruik gemaakt van Tweede Kamerstukken. Voorts is gebruik gemaakt van een aantal rapporten van de Algemene Rekenkamer. Tenslotte is ook contact opgenomen met de DAD's van Financiën en OC\&W. Voor het onderzoek naar de N.V. PLEM is ook gebruik gemaakt wan rapporten van de Provinciale Staten van de provincie Limburg en van een aantal gemeenten, terwijl voor het onderzoek naar het Rijksmuseum gebruik is gemaakt van onderzoeksrapporten van IKON Beleidsconsulenten. 


\subsection{Conclusie}

In dit hoofdstuk is een onderzoekprotocol uitgewerkt waarin is verwoord hoe de ontwikkelde netwerkbenadering en meer in het bijzonder de "performance" van een netwerk in de praktijk kan worden onderzocht. Een achttal hypothesen zijn geformuleerd die worden onderzocht door de beantwoording van een zestiental vragen. In de volgende hoofdstukken worden met behulp van de ontwikkelde methodiek case studies uitgevoerd naar het Rijksmuseum, MEGA Limburg en de Belastingdienst. 


\section{Deel 3. Sectorstudies}

\section{Hoofdstuk 15. Het Rijksmuseum}

\subsection{Inleiding}

Het Rijksmuseum Amsterdam ressorteerde gedurende de periode 1970-1990 onder het Ministerie van Welzijn, Volksgezondheid en Cultuur (WVC). In 1994 is dit Ministerie gesplitst in enerzijds het Ministerie van Volksgezondheid, Welzijn en Sport (VWS) en anderzijds het Ministerie van Onderwijs, Cultuur en Wetenschappen (OC\&W) waarbij de cultuurafdeling verhuisde naar $O C \& W$. Hierdoor is het museum afhankelijk van de culturpolitiek en het cultuurbeleid van de overheid. In dit hoofdstuk wordt het Rijksmuseum onderzocht aan de hand van de in het vorige hoofdstuk uitgewerkte benadering. Bronnen bestaan onder meer uit jaarverslagen, statuten en beleidsnota's, organisatieonderzoeken, circulaires, accountantsrapporten, briefwisselingen en interviews. In aanvulling op hetgeen in hoofdstuk 2 is opgemerkt wordt kort aangegeven waarom het Rijksmuseum functioneert als een overheidsinstelling. In paragraaf 15.3 wordt een overzicht gegeven van de organisatie en funeties van het Rijksmuseum. In paragraaf 15.4. en verder wordt de "performance" van het Rijksmuseum geanalyseerd. Tenslotte wordt in paragraaf 15.14. een conclusie gegeven ten aanzien van de "performance"..

\subsection{Waarom is het Rijksmuseum een overheidsinstelling?}

In hoofdstuk 2 is hier reeds uitgebreid op ingegaan. Aangegeven is dat een tweetal redenen met name van belang zijn. In de eerste plaats zijn allocatie-overwegingen van belang voor de politieke actoren. Politieke actoren hebben een reeks van mogelijkheden om hun doelen te bereiken. Indien de belastingen erg hoog zijn en dienovereenkomstig de "excess burden" daarvan, wordt het aantrekkelijker hun doelen op kunstgebied te bereiken door middel van musea. Dit komt dan de efficiëntie ten goede. In de tweede plaats dient het feitelijke doel gezocht te worden in het voorzien in rents, die door de eigenaren van het Rijksmuseum worden gebruikt om allerlei doelen na te streven. Deze doelen kunnen verband houden met het corrigeren van marktgebreken maar ook zijn er andere doelen zoals het overhevelen van middelen van de belastingbetaler naar liefhebbers van kunst. Het bestaan en het opereren van het Rijksmuseum moet dan ook verklaard worden door een "public choice" proces waarbij de werkelijk magestreefde doelen kunnen verschillen van de door de regering in officiële documenten weergegeven doelen. De "public enterprise rent" wordt door de eigenaren van het Rijksmuseum gebruikt voor het nastreven van een reeks van (bijkomende) doelen. Het is dan ook van belang deze doelen te onderzoeken en te analyseren wat de kosten van deze doelen zijn. De conclusie zou dan kunnen zijn dat de mate waatin de doelen bereikt worden het daaraan bestede geld rechtvaardigt of dat dit niet het geval is en naar andere instrumenten gezocht moet worden. Het is dan denkbaar dat een alternatieve verdeling van eigendomsrechten noodzakelijk is.

\subsection{De organisatie van het Rijksmuseum}

\subsubsection{De organisatie van het Rijksmuseum}

Het Rijksmuseum bezit een collectie bestaande uit kunst- en historische voorwerpen. $\mathrm{Zij}$ beschikt over medewerkers en financiële middelen en verricht als onderdeel (dienst) van het Ministerie van WVC activiteiten ten behoeve van het publiek. Het Rijksmuseum kan 
dan ook gezien worden als (onderdeel van) een netwerk. In dat netwerk is het Ministerie van WVC de principaal, onder meer via de Directie Musea, Monumenten en Archieven en is het Rijksmuseum de agent. Dit netwerk kan als volgt worden weergegeven.

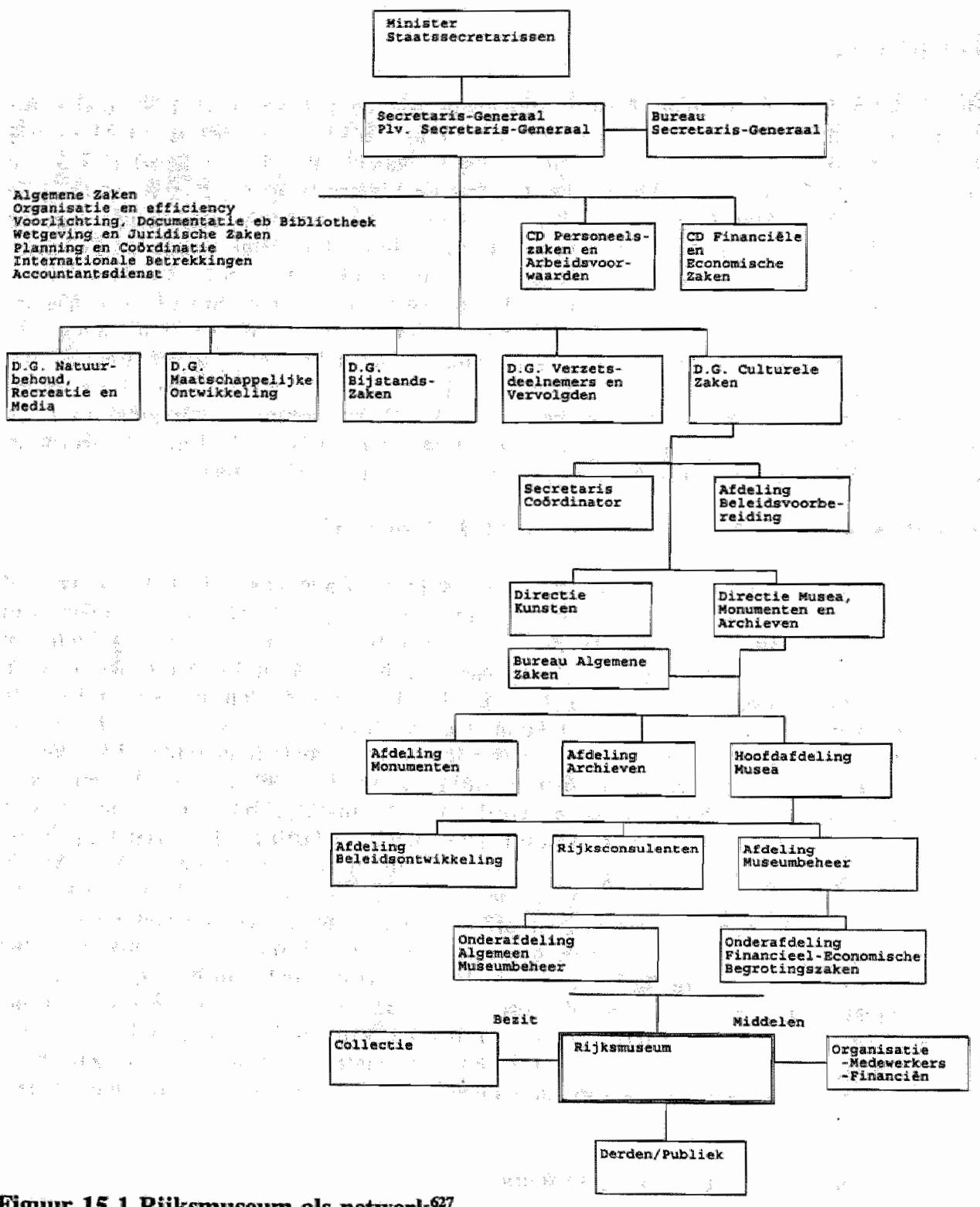

Figuur 15.1 Rijksmuseum als netwerk ${ }^{627}$

627 Bron: IKON Beleidsconsulenten (1987a), Rapport Organisatie Rijkssmuseum, p. 10. Situatie gedurende de periode 1970-1990. Organisatie van het Ministerie van WVC zoals weergegeven in de verschillende Accountansrapporten wan de departementale Accountantsdienst van het Ministerie van WVC, 1983-1990. 
De beleidsverantwoordelijkheid is als volgt geregeld. De Hoofdafdeling Musea is belast met het coördineren van het beleid met betrekking tot de musea, meer in het bijzonder de Rijksmusea. De afdeling Beleidsontwikkeling houdt zich vooral bezig met het ontwikkelen van het overheidsbeleid ten aanzien van de musea op de lange termijn, terwijl de Afdeling Museumbeheer zorgt voor het operationele management binnen de Hoofdafdeling Musea.

Het Rijksmuseum is een non-profit organisatie. Ten aanzien van de finameiering van de kosten kan gesteld worden dat middelen waarover het museum kan beschikken zijn yastgelegd in begrotingen, met daarin onder andere de geschatte entreegelden. In die zin vormt de schatkist van de overheid de grootste financielle bron. Het personeel, de gebouwen, restauratie en tentoonstellingen worden voor een belangrijk deel op deze manier gefinancierd. Naast de subsidiëring door de overheid worden er echter ook schenkingen gedaan. Voorts zijn entreeinkomsten van belang en worden inkomsten verkregen wan sponsors. Elke afdeling krijgt een budget toegewezen voor de diverse activiteiten en functies die zij witoefenen.

\subsubsection{Afdelingen en diensten van het Rijksmuseum}

De organisatiestructuur van het Rijksmuseum Amsterdam zoals die gold gedurende de onderzoeksperiode kan worden weergegeven met het volgende organogram.

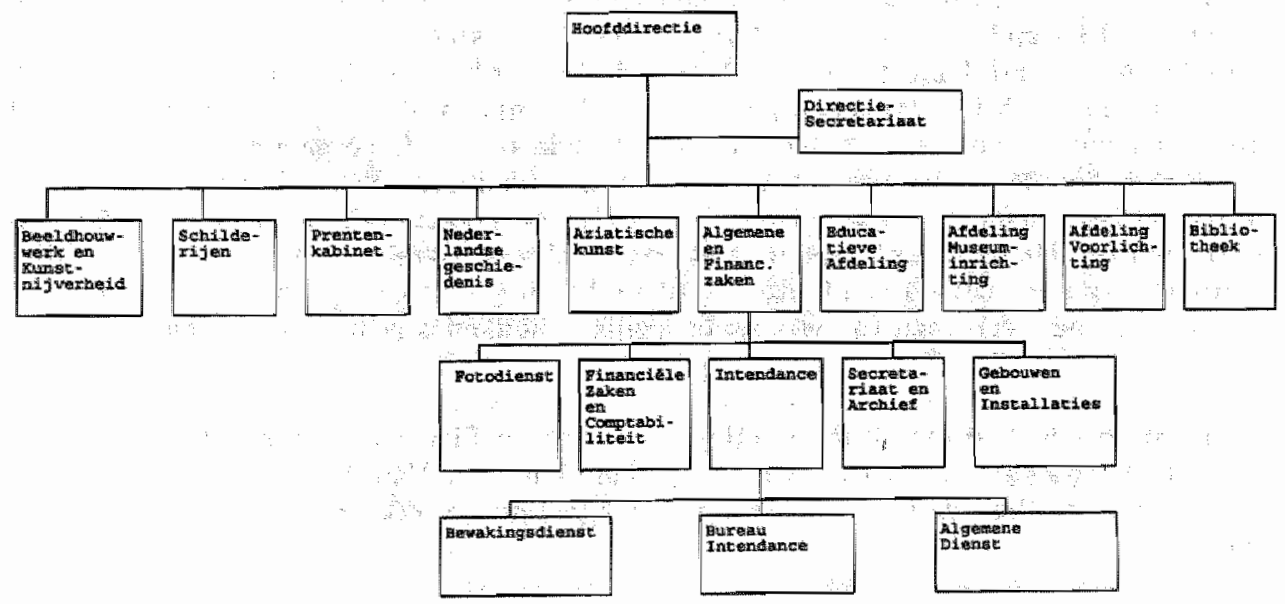

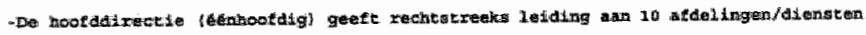

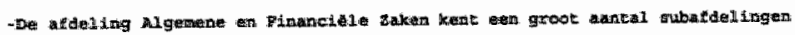

\section{Figuur 15.2 Organisatieschema Rijksmuseum ${ }^{628}$}

De organisatie van het Rijksmuseum was samengesteld uit een vijftal groepen. De eerste groep bestond uit de verzamelafdelingen. De collectie werd beheerd door een vijftal afdelingen, te weten: ${ }^{629}$

${ }^{628}$ Brop: IKON Beleidsconsulenten (1987a), Rapport organisatie Riiksmuseum, p. 18.

629 Ministerie van Welzijn, Volksgezondheid en Cultuur, Verslag van de Hoofddirecteur over het jaar 1990. Riiksmuseum te Amsterdam, Hoofdstuk 2 en 3. 
* Schillderijen;

* Beeldhouwkunst en kunstnijverheid;

*Aziatische kunst;

* Nederlandse geschiedenis;

*Prentenkabinet.

Bij het onderbrengen van de collectie zijn verschillende criteria gehanteerd. Onder andere is gekeken naar de aard van de objecten, het geografisch gebied van herkomst en naar cultuurhistorische kenmerken. De belangrijkste oorzaak waarom de collectie in de betreffende afdelingen was ondergebracht ligt evenwel in de historische ontwikkeling van het Rijksmuseum. De afdelingen Beeldhouwkunst, Schilderkunst, Prentenkabinet en Nederlandse geschiedenis werden geleid door een Directeur. De afdeling Aziatische kunst werd geleid door een afdelingshoofd. Zij rapporteerden rechtstreeks alan de hoofddirectie.

\section{Functies en taken van de verzamelafdelingen}

De vijf genoemde verzamelafdelingen vervulden een aantal taken. Een belangrijke functie van het Rjjksmuseum is het beheer van de collectie. Onder beheer wordt het identificeren, inventariseren en classificeren van de collectie verstaan, alsmede het bewaren van de collectie. ${ }^{630}$ Een andere belangrijke functie heeft betrekking op het onderhouden van de kunstobjecten. Daarbij moet onder andere gedacht worden aan de restauratie van kunst, de verzorging van het in bruikleen geven aan andere musea, de conservatoire behandeling van de aanwinsten en het conserveren van het oude bezit. Het organiseren van tentoonstellingen behoorde verder ook tot de taak van de afdelingen. Naast de praktische aspecten die bij het organiseren van belang zijn, is het ook noodzakelijk contact te leggen met andere musea. Hierbij werd veel overleg gepleegd met betrekking tot de noodzakelijke coördinatie van het aambod van kunst. Tenslotte kan nog de functie van het verrichten van onderzoek en het verzorgen van wetenschappelijke publikaties genoemd worden.

De tweede groep bestond uit de afdeling Algemene en Financiële Zaken. Het hoofd van de afdeling rapporteerde rechtstreeks aan de hoofddirectie. Van de 350 medewerkers die op 6 november 1986 werkzaam waren, werkten 271 medewerkers of $75 \%$ op deze afdeling. ${ }^{631}$

\footnotetext{
${ }^{630}$ IKON Beleidsconsulenten (1987a, p. 20).

${ }^{6311}$ T.a.p., p. 27.
} 


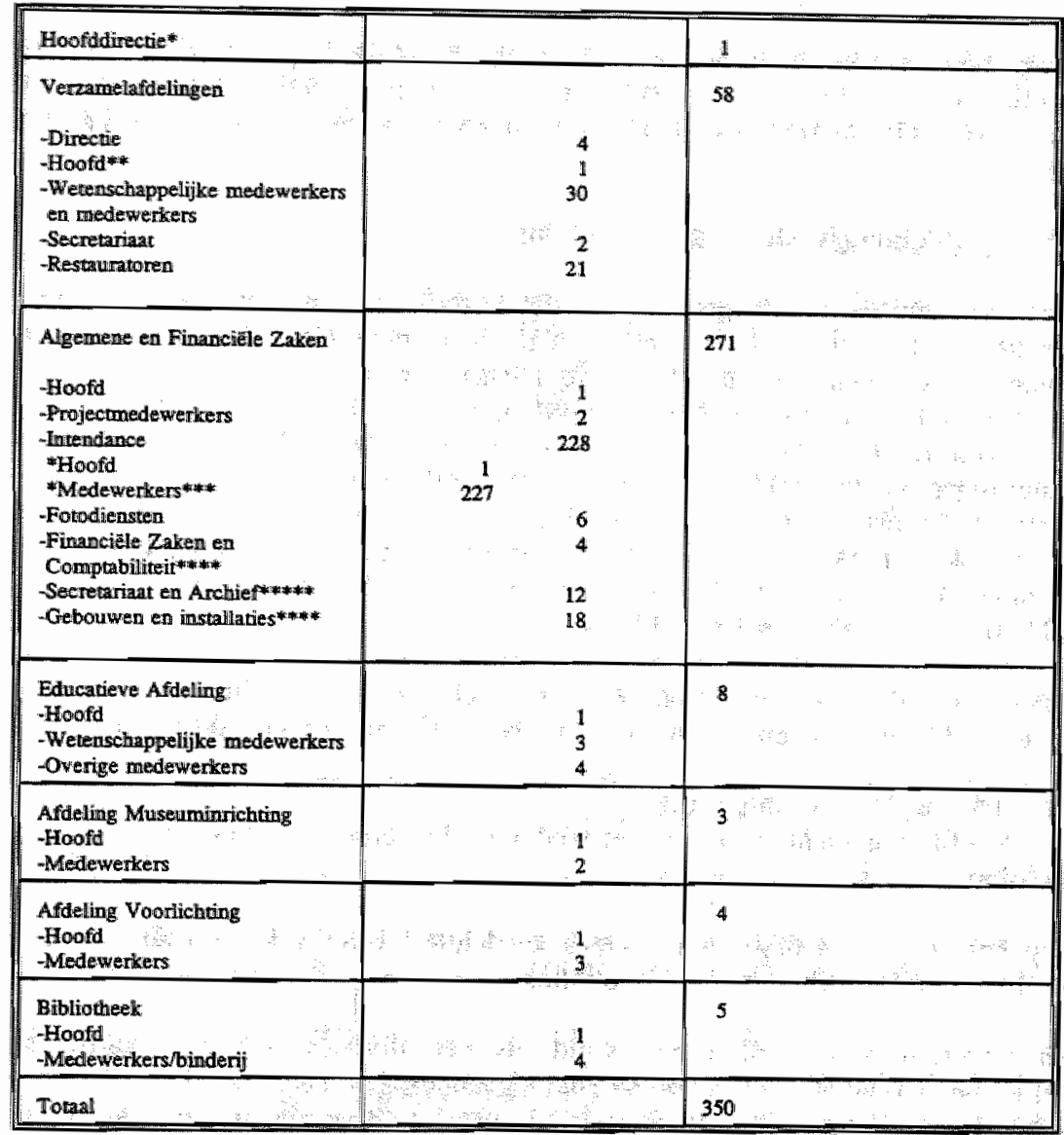

* Formatie en bezetting per 06-11-1986, exclusief medewerkers contractmanagement

* Betreft (fingerendi) hoofd Aztatische Kunst

* Betreft alle medewerkers, inclusief chefs/hoofden van (sub)afdelingen binnen de intendance

** Benref alle medewerkers, inclusief chefs/hoofder

**** Inclusief chefs/hoofden, directiesecretaris, bode, telefoon- en transportdienst

\section{Figuur 15.3 Personele bezetting}

Functies in het kader van de algemene en financièle taken.

De verrichte taken liggen op het terrein van het algemeen beheer en voorts werden ondersteunende activiteiten verricht. De taken op het gebied van het algemeen beheer bestonden vooral uit financieel-economische zaken, personele zaken en secretariaatswerkzaamheden. De ondersteunende werkzaamheden bestonden onder meer wit het onderhouden van het gebouw. Daarbij kan ook gedacht worden aan het vervangen en onderhouden van alle apparatuur en installaties. Voorts diende het gebouw soms te worden heringericht en diende de tuin te worden onderhouden. Andere taken die onder deze categorie vielen waren de bewaking en beveiliging en de verschillende serviceverlenende taken. 
De derde groep bestaat uit de Educatieve Afdeling en Afdeling Voorlichting. De Educatieve Afdeling bestond uit 8 formatieplaatsen, terwijl de Afdeling Voorlichting 4 formatieplaatsen kende. De hoofden van beide afdelingen rapporteerden rechtstreeks aan de hoofddirectie.

\section{Functies Educatieve Afdeling en Afdeling Voorlichting}

Beide afdelingen verrichtten taken gericht op de bezoekers van het Rijksmuseum. Daarnaast verrichtte de Educatieve Dienst een aantal meer specifieke taken ten behoeve van het onderwijs. Deze taken van de Educatieve Dienst zijn belangrijk, onder meer in verband met de doelstellingen van het Rijksmuseum. Een eerste belangrijke taak was het begeleiden van bezoekers. Daaronder vielen twee soorten van begeleiding: begeleiding in permanente opstellingen en begeleiding in tentoonstellingen. In de tweede plaats onderhield de Educatieve Dienst externe contacten, bijvoorbeeld onderwijscontacten. In de derde plaats viel ook het aanbieden van project-pakketten en de kunstkrant van het Rijksmuseum onder de Educatieve Dienst. Hiermee probeerde het Rijksmuseum het museum aantrekkelijk te maken voor het publiek.

De vierde groep bestond uit de Afdeling Museuminrichring. De afdeling werd geleid door een afdelingshoofd die eveneens rechtstreeks rapporteerde aan de hoofddirectie.

\section{Functies van de Afdeling Museuminrichting}

De taken van deze afdeling hielden vooral verband met de verzorging van de inrichting van de publieksruimten

De vijfde groep bestond uit de bibliotheek. Deze verrichtte bibliotheektaken ten behoeve van andere afdelingen en ten behoeve van het publiek.

De beschreven structuur kan worden aangeduid als een divisiestructuur, waarbij de verschillende afdelingen relatief veel zelfstandigheid genoten. $\mathrm{Na} 1985$ werd steeds meer gewerkt aan interne verzelfstandiging. In die periode werd contractmanagement als vorm van zelfbeheer ingevoerd en werd op grond van een organisatie-onderzoek van IKONbeleidsconsulenten de organisatiestructuur de facto gewijzigd. De juridische wijziging had pas begin negentiger jaren plaats. De nieuwe organisatiestructuur kan als volgt worden weergegeven. 


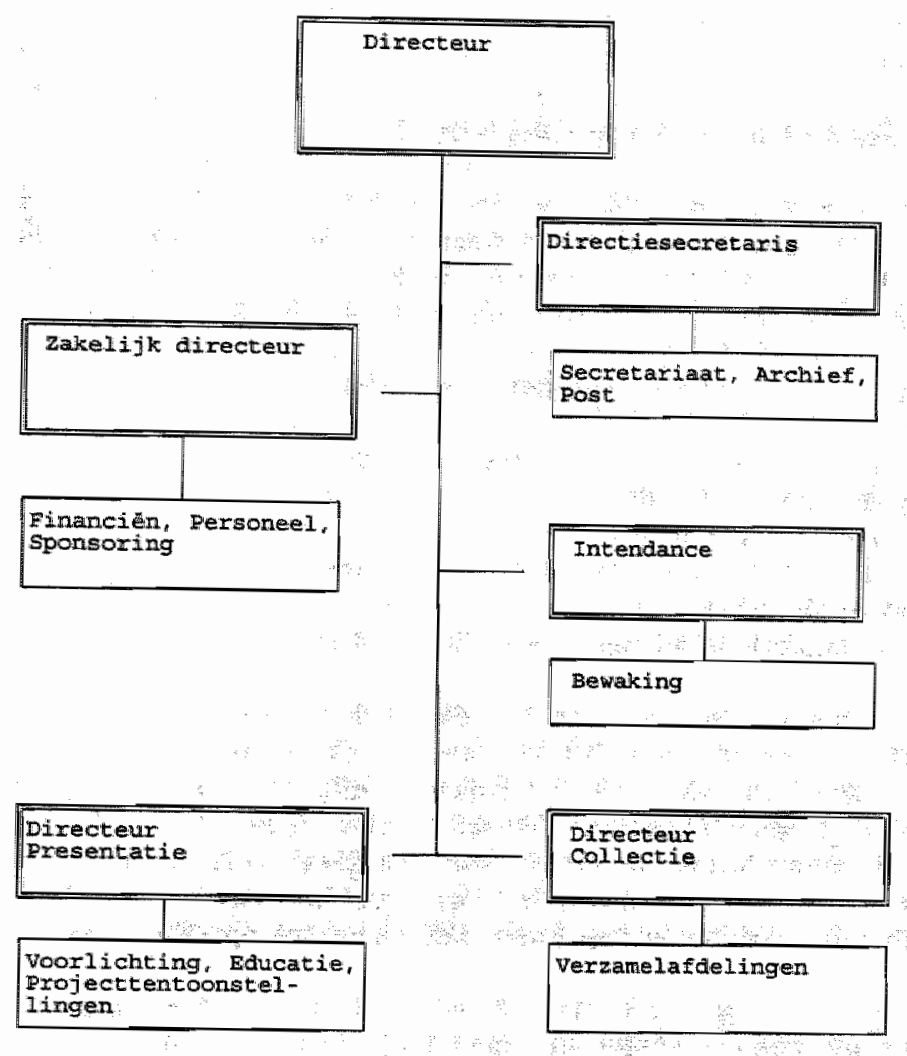

Figuur 15.4 De organisatiestructuur na $1990^{632}$

De organisatiestructuur zoals die zich na 1990 verder heeft ontwikkeld is opgebouwd uit een tweetal sectoren, namelijk de sector Behoud en Beheer en de sector Presentatie. De verzamelafdelingen vallen onder de sector Behoud en Beheer (Collecties). Financiën en Personeel vallen onder een zakelijk directeur, verder is er een directiesecretaris en tenslotte is de afdeling intendance belast met de bewaking. Begin jaren ${ }^{-90}$ is een verdere reorganisatie doorgevoerd met het doel verschillende rijksmusea, waaronder het Rijksmuseum (extern) te verzelfstandigen. Per 1 juli 1995 is het Rijksmuseum Amsterdam daadwerkelijk verzelfstandigd en functioneert sindsdien als stichting.

\section{Communicatiestructumur}

Mede omdat de taken en verantwoordelijkheden van werknemers binnen de organisatie niet altijd duidelijk geregeld waren (met uitzondering van de intendance na reorganisaties in het begin van de jaren '80) was de communicatiestruchur verre van optimaal. Dit kwam vooral door de snelle groei van het Rijksmuseum na 1945. Sinds 1976 zijn nieuwe

632 Vergelijk ook: IKON Beleidsconsulenten (1987b), Rapport uitwerking organisatie Rijksmuseum, bijlagen. 
vormen van overleg ingesteld en werd aan al bestaande vormen een grotere frequentie toegeikend.

\subsection{Structuur-analyse: welke doelen kunnen worden bereikt?}

In deze paragraaf wordt de verdeling van eigendomsrechten binnen het Rijksmuseum onderzocht. De houders van eigendomsreehten zijn in staat het besluitvormingsproces te beïnvloeden en bepalen de doelen van het Rijksmuseum. Zoals uiteengezet in hoofdstuk 15 dienen in het kader van de structuuranalyse de volgende vragen beantwoord te worden:

1) Wie hield toezicht op het aankoopbeleid (inputs) en de prestaties van de productiefactoren (input performance)?

2) Wie hield toezicht op de productieresultaten (output performance)?

3) Wie hield toezicht op de externe effekten?

4) Wie hield toezicht op het productieproces?

5) Wie hield toezicht op de omvang en samenstelling van het team van producenten?

6) Wie maakte aanspraak op de winst?

7) Wie had het recht de organisatie te wijzigen, te verkopen of te liquideren?

In het algemeen kan gesteld worden dat de rijksregels die gelden voor het financiële, personele en (administratief-) organisatorische beheer van de rijksdienst gedurende de onderzoeksperiode ook van toepassing waren op het Rijksmuseum. Deze regels maken deel uit of zijn gebaseerd op de Comptabiliteitswet, het ARAR, het BBRA, het AOB; het reisbesluit, de departementale voorschriften inzake de administratieve organisatie en de voorschriften die te maken hebben met het financiële beheer van het personeelsbestand, waarbij gedacht kan worden aan de voorschriften in het geval van het opvullen van een vacature.

\subsubsection{Het recht op het gebruik van een zaak}

\subsubsection{Wie hield toezicht op het aankoopheleid en de prestaties van de productiefactoren?}

In deze fase van het structuuronderzoek gaat het met name om de vraag welke actoren beslissen over de input van het Rijksmuseum. Hierbij kan gedacht worden aan de aanschaf en verkoop van kunstwerken en aan het aantrekken van personeel. De regeling met betrekking tot het financielle toezicht bepaalt voor een belangrijk deel wie beslist welke inputs er worden aangeschaft. Daarbij kan onderscheid gemaakt worden tussen principalen en agenten.

Het Rijksmuseum maakte gedurende de onderzoeksperiode deell uit van het Ministerie van WVC en ressorteerde, zoals is aangegeven in Figur 15.1. onder de Directie Musea, Monumenten en Archieven (MMA). Ten aanzien van de financiële informatievoorziening zijn op het Ministerie en binnen het Rijksmuseum een aantall actoren vooral van belang, te weten de hoofddirecteur van het Rijksmuseum, de Rekenplichtige, het Hoofd van de hoofdafdeling Musea, het Hoofd van de onderafdeling Museumbeheer, Financieeleconomische en Begrotingszaken ( $\mathrm{Mu} / \mathrm{FZ}$ ), het Hoofd van de Centrale Directie Financieel Economische Zaken (CDFEZ), de Departementale Accountantsdienst, de Algemene 
Rekenkamer en de Centrale Accountantsdienst op het Ministerie van Financièn. ${ }^{632}$ De financièle informatievoorziening liep via het Ministerie waarbij de Comptabiliteitswet van toepassing was. Eens in de vier jaar stelde het Rijksmuseum een beleidsplan op. ${ }^{63 *}$ Dit beileidsplan had een kwalitatief karakter. Daarnaast moest jaarlijks een begroting worden ingediend die vergezeld diende te gaan van een activiteitemplan voor dat jaar. Een activiteitenplan is een begroting van activiteiten en van de daarvoor benodigde middelen in het jaar $\mathrm{t}-1$ en kan worden opgevat als een operationalisering van het beleidsplan. Hierbij moet bedacht worden dat het Ministerie weliswaar een beleidsplan en een activiteitemplan eiste, maar dat indien hieraan geen gehoor werd gegeven, daar geen sanctie op stond. Tot halverwege de jaren tachtig werd hieraan dan ook herhaaldelijk niet voldaan. Daarnaast wordt sinds 1990 een bestedingsplan opgesteld. Dit is de bijgestelde en goedgekeurde begroting in het jaar t. Het vormt een werkplan voor het Rijksmuseum. Het jaarverslag vormt tenslotte een afsluiting van de begrotingscyclus en vormt de verantwoording en evaluatie van het bestedingsplan in het jaar $t+1$. De externe verantwoording door het Rijksmuseum gebeurde door middel van een tweetal overzichten, namelijk het financieel overzicht en de verantwoording begrotingsuitgaven en middelen. Deze overzichten hadden onder meer als functie om CDFEZ inzicht te geven in de begrotingsontwangsten en -uitgaven. Bovendien dienden zij om verantwoording af te leggen, overeenkomstig de Comptabiliteitswet, aan de Algemene Rekenkamer (AR) en de Centrale Accountantsdienst (CAD) van het Ministerie van Financiën. Verder vormden deze overzichten een middel om zich ten opzichte van CDFEZ te verantwoorden voor het gebruik van de rekening-courant-middelen. De rol van de Algemene Rekenkamer is geregeld in de artikelen 45 tot en met 82 van de Comptabiliteitswet, terwijl de artikelen 24 e. $v$. betrekking hebben op de positie van de rekenplichtigen ${ }^{635}$ Binnen de hoofdafdeling Musea is de Afdeling Beleidsontwikkeling vooral belast met het bepalen van het beleid en de Afdeling Museumbeheer met de uitwerking. Beide zijn uit dien hoofde nauw betrokken bij het zorgen voor een optimale toewijzing van middelen over de verschillende musea.

Het Rijksmuseum diende derhalve overeenkomstig bovenstaande procedure een conceptbegroting in. De uiteindelijke begroting werd door het Ministerie en het parlement vastgesteld. De uiteindelijk door het Ministerie van WVC ter beschikking gestelde kredieten konden worden onderscheiden naar personele en materiële kredieten en kredieten voor aankopen en produktvernieuwing. Gedurende de jaren zeventig en tachtig kreeg het Rijksmuseum een tweetal budgetten waarover het zelfstandig kon beschikken, namelijk het materièle budget en het aankoopbudget. Daarnaast betaalde het Ministerie van WVC de salarissen van het personeel van het Rijksmuseum. Het totale krediet inclusief personeelskosten bedroeg in 1985 bijwoorbeeld F. 28,7 miljoen gulden en in 1992 f. 31.561 .928 ,(dit was in 1985 ongeveer een derde van het totale aan de rijksmusea verstrekte krediet; waarmee het Rijksmuseum Amsterdam de grootste was).

Het Rijksmuseum was bevoegd om betalingen en aanschaffingen te doen ten laste van de

633 Vergelijk ook: De Secretaris-Generaal van het Ministerie vam Welzijn Volksgezondheid en Culturur, circulaire AD/ADS-U 5206, Functie en taken van de Accountantsdienst, 19 december 1983.

634 Hoofddinecteur Cultuurbeheer, Circulaire MMA/B-U2941 van de aan de Hoofden van de Instellingen ressorterende onder de Hoofddirectie Culturbeheer $i_{0}, 16$ augustus 1988 , p. 2. Dit was de situatie eind jaren ' 80 .

${ }^{635}$ De rekenplichtige is degene die de Minister van WVC op grond van art. 24 wan de Comptabilliteitswet 1976 heeft aangewezen om namens hem ontvangsten en betalingen te doen en gelden te bewaren: CDPZ/RP U 78142 
toegewezen kredieten. De verantwoordelijkheden en bevoegdheden van het management i.c. de hoofddirecteur van het Rijksmuseum was vastgelegd in de Instructie Hoofden van Dienst van 1953. Hierin werd echter niet systematisch ingegaan op de verantwoordelijkheden ten aanzien van de financièle verslaglegging. In het algemeen gold dat zollang de aankopen binnen de begroting bleven het Rijksmuseum zelf tot bepaalde hoogte kon bepalen welke aankopen zij deed. Deze transacties waren evenwel gebonden aan strakke regels. Het ging hierbij om de zogenaamde comptabele voorschriften zoals de Comptabiliteitswer en het Besluit Taak Centrale Afdeling FEZ, maar ook om voorschriften van andere departementen. Hierbij moet vooral gedacht worden aan de voorschriften en normen van het Rijks Inkoop Bureau, het Reísbesluit 1971, de Reisbeschikking Nederland, de Reisbeschikking Buitenland, het Verplaatsingskostenbesluit 1962 en de bijbehorende Verplaatsingskostenbeschikking. Voor aankopen van duurzame goederen en van geautomatiseerde systemen golden daarnaast speciale procedures. Deze procedures voorzien in een preventieve beoordeling door het Ministerie van WVC, meer in het bijzonder door de hoofdafdeling Musea, CDFEZ, de Centrale Dienst Organisatie en Efficièntile (CDOE) en de afdeling Gebouwen, Materiaal, Energie en Interne Dienst (GMEID). De roll van GMEID is voor een deel vastgelegd in de Beschikking Normering Aanschaffingen. In de kredietbrieven wordt vermeld dat alle aanschaffingen boven $F$. 1.500 ,- door GMEID goedgekeurd moesten worden.

Daarnaast controleerde het Ministerie achteraf of het cumulatieve totaal van de uitgaven niet hoger is dan het krediet per kostenpost. Bij overschrijdingen werd het Rijksmuseum verzocht om de kredieten bij te sturen. Indien het totale krediet werd overschreden moest het Rijksmuseum de budgethouder verzoeken om een verhoging van het krediet. deze procedure verschilde dus niet van de algemene departementale begrotingsprocedures. De hoofddirecteur Cultururbeheer stelde in dit verband in zijn circulaire van 16 augustus 1988: "De essentie daarvan is dat ik de instellingen zoveel mogelijk ruimte wil verschaffen om zelfstandig te kunnen opereren. Anderzijds verwacht $i k$ van $u$, dat $u$ mij informatie aanlevert met betrekking tot uw plannen en de realisatie daanvan. Deze informatie moet mij voldoendie inzicht geven in uw beleidsvoormemens en prestaties, zodat het mij mogelijk is op hoofdlijnen te sturen en te toetsen, om over het beleid verantwoording af te leggen aan de departementsleiding, minister (t.b.v. diens verantwoording aan het parlement) en om richtlijinen van die kant in te passen in uw beleidsvoomemens". 636

Uit de verschillende regelingen blijkt dat de politieke actoren binnen het Ministerie over het recht om toezicht op het aankoopbeleid te houden beschikten. Door dit recht nemen zij een zeer sterke positie in en zijn zij in staat hun doelen na te streven.

Indien de aandacht gericht wordt op het management van het Rijksmuseum over deze periode, dan kan onderscheid gemaakt worden tussen de controle op de aankoop van de inputs en de controlle op de prestaties van de productiefactoren. Met betrekking tot de aankoop van goederen (inputs) bestiond er binnen het Rijksmuseum relatief weinig controle. Geconstateerd kan worden dat iedere afdeling binnen het Rijksmuseum een eigen directeur had die voor een belangrijk deel verantwoordelijk was voor het aankoopbeleid. De aankopen hoefden niet duidelijk te worden verantwoord aan de directeur, wel moest binnen het budget dat aan iedere afdeling werd toegekend, worden gebleven. Indien een afdelling buiten het budget dreigde te komen moest er wel overleg worden gepleegd. Het Rijksmuseum kende bovendien geen vaste procedure voor de behandeling van inkomende facturen. De Departementale Accountantsdienst had de nodige bezwaren tegen de wijze waarop het Rijksmuseum toezag op de aankoop van inputs. Zo merkte zij in bet accountantsrapport over 1984 op: "De autorisatie van de betalingen - door of namens het Hoofd

${ }^{636}$ Hoofddirecteur Cultuurbeheer, Circulaine MMA/B-U-2941, 16 augustus 1988, p. 1. 
van Dienst als bedoeld in de Comptabiliteitswet art. 76 c.a.- hebben wij niet of slechts sporadisch aangetraffen. De competenties van de functionarissen dienen door de Hoofddrecteur in een delegatielijst te worden vastgelegd. Een en ander met inachtneming wan doelmatig te verwezenlijken contraletechnische onderscheidingen "637. Deze delegatielijst; waarin werd aangegeven welke functionaris tot welk bedrag bevoegd was bestellingen te doen en wie bevoegd was te betalen nota's te controleren en te fiatteren, is halverwege de jaren tachtig onder druk van de accountantsdienst alsnog ingevoerd.

Een extra probleem dat zich voordeed bij het voeren van een efficiênt beleid ten aanzien van de aankoop van inputs was dat niet geschoven mocht worden tussen budgetten, bijvoorbeeld tussen het materiële en het personele budget. Dit kon leiden tot een niet efficiënte allocatie van middelen. Vaak werden er in verband met het personeelsgebrek met name gedurende het begin van de jaren tachtig noodgedwongen dure tijdelijke arbeidskrachten ingehuurd ten laste van het materiële budget omdat het miet mogelijk was om de formele formatie ten laste van dit materiële budget uit te breiden.

Ook de controle van het management op de prestatie van het personeel was beperkt. De Accountantsdienst merkte hierover op: "Wij hebben onvoldoende inzicht kunnen werkrijgen of en in hoeverre binnen het Rijksmuseum controle wordt uitgeoefend op het doelmatig functioneren van medewerkers. Dit wordt mede veroorzaakt doordat:

- de taak-en functie-omschrijvingen geactualiseerd moeten worden;

- er niet altijd een duidelijke afbakening is van bevoegdheden en verantwoordelijkheden;

- een adequate verantwoording van ingezette middelen (personeel, materieel etc.) ontbreekt ${ }^{\text {t' }}$. In het Rijksmuseum werden wel persoonsbeoordelingen gehouden. Opgemerkt wordt dat de scores hoger liggen dan bij andere musea en rijksinstellingen op het gebied van de kunst. Aangegeven wordt dat dit terecht kan zijn, maar dat het ook een vertekend beeld kan geven omdat er niet objectief beoordeeld wordt. ${ }^{63}$ De Algemene Rekenkamer geeft aan dat de controle op de productieresultaten beperkt was. Zo vonden er soms ook geen personeelsbeoordelingen plaats. Eind jaren tachtig moest de functieWaardering die in het kader van het ARAR plaatsvindt meer duidelijkheid brengen in de vervulling van de diverse taken van het Rijksmuseum. ${ }^{640}$ Tot 1988 fungeerde de Secretaris-Generaal als het bevoegde gezag in het kader van de beoordelingsvoorschriften. Per 1 september 1988 beslist de Directeur-Generaal respectievelijk de Plv. Secretaris-Generaal als hoogste interne instantie over bezwaren tegen een personeelsbeoordeling. Instellingen die vallen onder de Kaderregeling Experimenten Contractmanagement of de proefneming P-budgettering vallen hier niet onder. Voor deze instellingen is het hoofd van de betreffende dienst als beoordelingsautoriteit aangewezen. ${ }^{641}$

Naast de controle op de aanschaf van inputs en de controle op de prestatie van het

637 Accountantsdienst van het Ministerie van WVC, Rapport NR. AD/C 85.3138, inzake de financiele verantwoording over 1984 van het Riksmuseum te Amsterdam, 1986, p. 7.

638 Accountantsdienst van bet Ministerie van WVC Rapport NR. AD/C 85.3138, inzake het onderzoek naar de financielle verantwoording over 1984 van het Rijksmuseum te A.dam, 1985 , p. 4 .

${ }^{639}$ Brief van de personeelsconsulent aan de Hoofddirecteur van het Rijksmuseum, 5-1-1976.

400 Aigemene Rekenkamer, Rijksmusea, Tweede Kamer, vergaderjaar 1987-1988, 20697, nirs. 1-2, pp. 22 24.

541 De Minister van Welzijn, Volksgezondheid en Culturr, het Hoofd van de Centrale Directie Personeelszaken, CDPZ U 48131, Aanwiizing bevoegd gezagen beoordelingsautariteit, 29 augustus 1988. 
personeel is ook de aanschaf van kunstobjecten van belang voor de beoordeling van de vraag wie het gebruiksrecht heeft. De bedragen voor kunstaankopen waarboven departementale machtiging modig was, waren vastgelegd in $1969 .{ }^{642}$ Per 1 juni 1984 is het bedrag voor de aankoop van een kunstobject waarboven departementale machtiging nodig is verhoogd tot f: $25.000,-{ }^{643}$

Tenslotte kan nog worden opgemerkt dat ook het door het Rijksmusenm gebruikte gebouw eigendom was van de Staat der Nederlanden en in beheer was bij de Rijksgebouwendienst, hetgeen onderdeel is van het Ministerie van Volkshuisvesting Ruimtelijke Ordening en Milieu (VROM). Alleen het kleine onderhoud aan het gebouw werd zoals weergegeven in paragraaf 15.3 .2 , door het Rijksmuseum zelf verricht. Voor de overige activiteiten die betrekking hebben op het gebouw is de Rijksgebouwendienst medeverantwoordelijk. De Rijksgebouwendienst zorgde voor het onderhoud van het gebouw en bepaalde welke zalen werden verbouwd en vernieuwd. Geld daarvoor was afkomstig van de Rijksgebouwendienst. Het Rijksmuseum was daarvoor dus afhankelijk van het Ministerie van VROM. Ook de beveiliging van het gebouw werd geregeld door de Gebouwendienst. Laan en Vollebergh stellen in dit verband:"64 "Daamaast geldt voor de museale gebouwen dat de afhankelijkheid van de Rijksgebouwendienst (...) sterke beperkingen oplegt aan het management van de musea". Belangrijk is in dit verband op te merken dat het contact met de Rijksgebouwendienst niet door het Rijksmuseum maar door de Centrale Directie Bedrijfsvoering en Facilitaire Ondersteuning (CDBFO) voorheen Centrale Directie Algemene Zaken (CDAZ) genoemd, werd onderhouden. ${ }^{645}$ Deze centrale directie hield zich onder meer bezig met het beheer van gebouwen waarin WVCafdelingen zijn ondergebracht. $\mathrm{Zij}$ trad op als adviseur en belangenbehartiger van deze afdelingen waaronder het Rijksmuseum, fungeerde als adviseur van de Hoofddirecteur Cultururbeheer (HCB), waarbij het vooral gaat om de verdeling van middelen en tenslotte onderhield zij de contacten met de Rijksgebouwendienst die uiteindelijk verantwoordelijk is voor de huisvesting van de overheid. De procedure was voor het Rijksmuseum nogall omslachtig. Voor nieuwbouw, onderhoud, bouwkundige veranderingen e.d. moest het Rijksmuseum zich wenden tot het Ministerie, deze mam contact op met de RGD, die vervolgens een aannemer inhuurde om de betreffende activititeiten te verrichten. Deze procedure was enerzijds omslachtig en anderzijds konden er zich belangentegenstellingen voordoen tussen de verschillende actoren. Het Rijksmuseum had hier dan ook slechts beperkt invloed op terwijl de besluitvormingslijnen lang waren. $\mathrm{Na}$ de verzelfstandiging per 1 juli 1995 heeft het Rijksmuseum zeIfstandig contact met de Rijksgebouwendienst. Er is sprake van een huurovereenkomst. De CDBFO treedt desgewenst als adviseur voor het Rijksmuseum op. Ook na de verzelfstandiging zal het gebouw eigendom blijven van de Staat der Nederlanden. Dit vraagstuk is ook aan de orde gekomen bij de behandeling van het wetsvoorstel over de verzelfstandiging in de Tweede Kamer, meer in het

\footnotetext{
642 De Minister van Welzijn, Volksgezondheid en Cultur namens deze het Hoofd van de Directie Musea, Monumenten en Archieven, aan de onder het ministerie van WVC ressorterende Rijksmusea, O.K.N.151901, Machtigingsprocedures, 6 oktober 1969.

${ }^{643}$ De Minister van Welzijin, Volksgezondheid en Cultuur namens deze het Hoofd van de Dürectie Musea, Monumenten en Archieven, aan de onder het ministerie van WVC ressorterende Rijksmusea, MU/BA-U11807 1, Machtigingsprocedures, 1 mei 1984.

Laan en Vollebergh (1994, pp. 6-7).

${ }^{645}$ Projectbureau voor verzelfstandiging van rijksmuseale instellingen (PMZ), Over de relatie CDBFO en verzelfstandigde (rijks)museale instellingen, PMZ 210, 30 augustus 1993.
} 
bijzonder bij de schriftelijke behandeling door de Vaste Commissie voor Cultuur. De Tweede Kamer-fracties hebben in dit verband diverse vragen gesteld met betrekking tot het verslag. ${ }^{646}$ Het antwoord was dat het gebouw van het Rijksmuseum tot het nationale culturele erfgoed behoort en derhalve ook in de toekomst niet in eigendom wordt overgedragen.

Na 1985 werden in het kader van het op grond van de Kaderregeling Experimenten Contractmanagement W.V.C. ingevoerde zelfbeheer een aantal bevoegdheden ten aanzien van het toezicht op de aankoop en de prestaties van inputs overgedragen aan de directeur van het Rijksmuseum. Er kwamen meer mogelijkheden om zelf kleine bouwprojecten te regelen met de RGD, in samenwerking met de Centrale Directie Algemene Zaken. Bovendien konden taken gedelegeerd worden ten aanzien van het nemen van beslissingen over de manier waarop het klein onderhoud en het schoonmaken van het gebouw zou plaatsvinden. voorts werd het mogelijk zelf te beslissen over de vervanging van kapitaalgoederen en over de reparatie en uitbreiding van kapitaalgoederen. Voorts kon de directeur beslissen over de aankoop van gebruiksgoederen en over het afvoeren van overcompleet materiaal. ${ }^{647}$ Deze ontwikkeling moet gezien worden als een overgang naar de door het Ministerie beoogde interne en externe verzelfstandiging. Geleidelijk werden een aantal bevoegdheden overgedragen aan het Rijksmuseum, hetgeen uiteindelijk zou leiden tot volledige zelfstandigheid en vergaande overdracht van bevoegdheden per 1 juli 1995. De overdracht halverwege de jaren tachtig was nog beperkt. In het eerste convenant dat getekend werd op 24 februari 1986 is het aantal taakstellende activiteiten nog gering. Het ligt in de bedoeling deze langzamerhand uit te breiden. Door invoering van het contractmanagement worden op grond van artikel 16 van de Kaderregeling Experimenten Contractmanagement nieuwe eisen gesteld aan de jaarstukken. In verband met de beperkte omvang van het eerste convenant is er voor gekozen vooralsnog geen tweede jaarverslag op te stellen gebaseerd op de Kaderregeling. Het jaarverslag is dan ook onveranderd gebaseerd op de Instructie Hoofden van Dienst Rijksmusea uit 1953. De hoofddirecteur wees er op dat contractmanagement de zelfstandigheid van het Rijksmuseum weliswaar bevorderde en de noodzaak ten aanzien van machtigingsprocedures verminderde, maar anderzijds ook problemen met zich meebracht. Zo was de organisatie van het Rijksmuseum niet afgestemd op deze nieuwe zelfstandigheid. Verder meende het museum dat door het Ministerie centraal beheerde budgetten voor onder meer opleidingen en uitzendkrachten beter en efficiënter door het Rijksmuseum zelf konden worden beheerd, terwijl ook werd gevonden dat het Ministerie zich te veel bleef bemoeien met de overgedragen bevoegdheden.

\section{Conclusie}

Het recht om toezicht uit te oefenen op de aanschaf van inputs en de prestaties van de productiefactoren lag uiteindelijk bij het parlement, terwijl het feitelijke toezicht lag bij het Ministerie. De inzet van materiële middelen was minder aan regels onderworpen dan de inzet van personeel en de huisvesting. Gedurende de onderzoeksperiode kreeg het Rijksmuseum steeds een eigen materieel budget, terwijl het personele budget besteed werd

646 Directie Beleidszaken Cultuurbeheer, Brief aan de Directeur van het Rijksmuseum, hierbil gevoegd de reacties op vragen en antwoonden van Tweede Kamerfacties in de bijdragen voor het verslag, 1 december 1992, vraag 14, p. 3. De procedure bestond uit: eerst schriftelijke behandeling door de Vaste Commissie voor Cultuur (verslag), vervolgens reactie door de minister (Nota naar amieiding van het versiag) en tenslotte plenaire mondelinge behandeling. Vervolgens dezelfde procedure in Eerste Kamer.

647 Kadlerregeling Experimenten Contractmanagement W.V.C. 1985, artikel 11.6e tot en met $11.12 \mathrm{e}$. 
door bet Ministerie van W.V.C. en de huisvesting bekostigd werd door het Ministerie van V.R.O.M. Toch bleven er ook aan het eind van de jaren tachtig nog tal van regels bestaan die het niet goed mogelijk maakten zelf de inzet van inputs te bepalen. Door de toepassing van het kasstelsel, hetgeen inhoudt dat uitgaven en inkomsten worden verantwoord op het moment dat zij feitelijk plaatsvinden, was het niet mogelijk af te schrijven op kapitaalgoederen. Als een machine was afgeschreven waren er geen fondsen beschikbaar om haar te vervangen. Dit moest bimnen het bestaande budget hetgeen de nodige problemen met zich meebracht. Een ander probleem dat bleef bestaan was dat op grond van het kasstelsel overgebleven middelen zoals aangegeven niet of slechts beperkt mochten worden meegenomen naar het volgende jaar. Het was mogelijk dat daarom bedrijfsmatig gezien minder rendabele uitgaven werden gedaan.

\subsubsection{Wie hield toexicht op de productieresultaten?}

In de vorige paragraaf is reeds ingegaan op de prestaties van de inputs (personeel). De controle op de output was veel minder duidelijk geregeld. De vraag rijst allereerst wat onder de productie van het Rijksmuseum verstaan dient te worden. De productie bestond enerzijds uit de verrichte onderhoudswerkzaamheden. Elke afdeling beschikte over een restauratie-atelier. Anderzijds bestond de productie van het Rijksmuseum uit de gehouden tentoonstellingen. Derhalve dient bezien te worden wie de verantwoording had over de gekozen onderwerpen en de getoonde kunstvoorwerpen. Deze onderwerpen werden geruime tijd van te voren bekend gemaakt. De grote tentoonstellingen werden al meer dan een jaar van te voren bekend. Het management was bevoegd hierover zelfstandig beslissingen te nemen. Dit bood hen dan ook de mogelijkheid zelfstandig bepaalde doelen tha te streven. Ten gevolge van het gefragmenteerde beleid en de daaruit voortvloeiende afstemmingsproblemen, zowel binnen het Ministerie als tussen het Ministerie en het Rijksmuseum was het Ministerie inhoudelijk slechts beperkt betrokken bij het Rijksmuseum. In de praktijk beperkt het Ministerie zich tot het financiele beleid en de personeelsformatie vam het Rijksmuseum. Zoals in het IKON-rapport wordt geconstateerd had de beleidscyclus door gebrek aan sturing door het Ministerie een ongecoördineerd karakter. ${ }^{648}$ Het beleid en de doelstellingen waren veelal impliciet, terwij1 de beleidsontwikkeling een ad hoc karakter had. Dit leidde ertoe dat de verschillende afdelingen en individuen binnen het Rijksmuseum relatief grote invloed uit konden oefenen. Een probleem hiervan was voorts dat de doelen van deze individuen konden verschillen en dat er geen centraal beleid was dat voldoende coördineerde.

\subsubsection{Wie hield toezicht op de externe effecten?}

Via de begroting had het Ministerie invloed op de mate waarin externe effecten werden voortgebracht en kon zij deze ook controleren. Aan de kunst worden in het algemeen een tweetal positieve externe effecten toegekend (hoewel deze door anderen worden ontkend). ${ }^{649}$ De eerste categorie positieve externe effecten bestaat uit de invloeden die uitgaan van de verspreiding van kennis van kunst en cultuur en van de vergroting van wetenschappelijke kennis voor de huidige generatie. Daarbij staat een zo groot mogelijke toegankelijkheid centraal. De tweede categorie betreft het behoud van de kunstwerken voor latere generaties zodat ook zij met deze kunst hun voordeel kunnen doen. In dit

${ }^{648}$ IKON Beleidsconsulenten (1987a, pp. 37-38).

649 Vergelijk: Grampp (1989, p. 250). 
kader is de functie van behoud en beheer van belang. Daarnaast kan het door het Rijksmuseum verrichte onderzoek (op het gebied van restauratie, echtheid van de kunstwerken etc: ) een positief extern effect opleveren. Deze kenmis is ook voor andere bedrijven, instellingen en overheid beschikbaar. Door middel van de begroting was het Ministerie in staat (indirect) invloed uit te oefenen en toe te zien op de gerealiseerde externe effecten. Dit blijkt dwidelijk uit de door het Ministerie gedurende de periode 1970-1990 genomen en in paragraaf 15 12,4. genoemde maatregelen. Het Ministerie streefde blijkbaar andere doelen na dan het management van het Rijksmuseum. Door middel van wijzigingen in het verstrekte budget kon zij het Rijksmuseum dwingen de hoeveelheid voortgebrachte externe effecten te wijzigen en in die zin hield zij hier indirect toezicht op.

\subsubsection{Wie hield toezicht op het productieproces?}

Het Rijksmuseum werd gekenmerkt door hiërarchische verhoudingen en een functionele organisatie. De bureaucratische organisatievorm verstrekte het Ministerie van WVC en de directie de benodigde informatie om toezicht uit te oefenen op het productieproces. Met betrekking tot de formele relatie tussen het Rijksmuseum en het Ministerie van WVC kan worden geconstateerd dat het Ministerie van WVC de eindverantwoondelijke was ten aanzien van het beleid van het Rijksmuseum, waaronder de financiën, het personele beleid en de organisatie van het museum. Het Rijksmuseum verzorgde de beleidsvoorbereiding en -uitwoering. De relatie met het Ministerie verliep via verschillende afdelingen binnen WVC, te weten via de Beleidsafdeling MMA/DGCZ, via de Stafafdelingen CDFEZ, CDPZ, CDAZ, CDOI en via de afdeling Voorlichting. Deze afdelingen hadden elk verschillende bevoegdheden en verantwoordelijkheden in de verschillende fasen van de beleidswoorbereiding, -vaststelling en -uitvoering. Het Ministerie stuurde evenwel niet of nauwelijks inhoudelijk. Omdat ook het beleid impliciet was hadden individuen in de organisatie de mogelijkheid invloed uit te oefenen op de te verrichten activiteiten. De bevoegdheden waren geconcentreerd bij de Hoofddirectie en de Directie van het Rijksmuseum. De uitvoering vond evenwel plaats door de verschillende afdelingen en onderafdelingen. Omdat er onvoldoende samenhang was tussen verantwoordelijkheden en werkelijke bevoegdheden was het niet altijd duidelijk wie waarvoor verantwoordelijk was en hoe de gezagsverhoudingen liepen. De afdeling Algemene en Financiële Zaken was feitelijk zeer belangrijk (qua taken en personeelsomvang) maar formeel nevengeschikt. Tentoonstellingen werden veelal georganiseerd door meerdere afdelingen waardoor het probleem van onderlinge afstemming nog groter werd en competentieproblemen konden ontstaan. Met betrekking tot het tentoonstellingsbeleid kan dan ook opgemerkt worden dat de verschillende afdelingshoofden vaak zelf konden beslissen wat zij in bepaalde ruimtes wilden laten zien. Een belangrijke reden, naast de bovengenoemde, waarom de afzonderlijke afdelingen grote invloed hadden was de relatief grote "span of control" vạ de hoofddirectie, hetgeen ook blijkt uit Figuur 15.3. Een andere reden had te maken met de specifieke deskundigheid waar de verschillende afdelingen over konden beschilken. Voorts waren de taken van de verzamelafdelingen en de afdeling Algemene en Financiële Zaken divers en niet altijd logisch op elkaar afgestemd. ${ }^{650}$ Het gevolg was dat het toezicht op het productieproces sterk versnipperd was. Bij de intendance waar in de jaren ' 80 ongeveer $70 \%$ van het totale personeel werkzaam was zijn ma een aantal reorganisa-

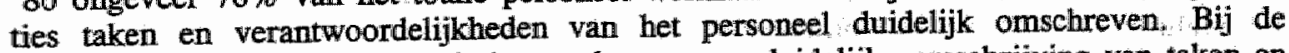
overige afdelingen was veel minder sprake van een duidelijke omschrijving van taken en

650 IKON Beleidsconsulenten (1987a, $p_{n} 47$ ). 
verantwoordelijkheden.

$\mathrm{Na} 1986$ werd een begin gemaakt met de introductie van contractmanagement, als vorm van interne verzelfstandiging. De bedoeling hiervan was dat aan het Rujksmuseum een budget zou worden toegekend en dat de directie in ruil daarvoor haar contractverplichtingen moest nakomen. Omdat het aantal taakstellende bepalingen zeker in de eerste convemanten nog beperkt was, werd het moeilijker voor het Ministerie om toezicht uit te oefenen op het productieproces, mochten zij dit al willen. Eind jaren 80 werd er een organisatiestructuurwijziging doorgevoerd, waarbij de verschillende afdelingen die voorheen relatief zelfstandig waren, ondergebracht werden in een tweetal grote afdelingen. Het gevolg en ook het doel daarvan was dat de directie meer grip kreeg op de organisatie en ook beter controle kon uitoefenen op het productieproces. Begin jaren " 90 werd door het kabinet en het Ministerie van WVC gestreefd naar externe verzelfstandiging, waarbij het management van het Rijksmuseum, meer in het bijzonder de directie, zelf volledig toezicht houdt op het productieproces. Dit is gerealiseerd per 1 juli 1995. Het Ministerie kan nu in principe geen invloed meer uitoefenen op het productieproces. Concluderend kan over de periode 1970-1990 gesteld worden dat het Ministerie niet intensief toezicht hield op het productieproces. Aanvankelijk was het toezicht op het productieproces zeer verspreid. In een aantal stappen is getracht deze versnippering te verminderen door de invoering van duidelijke taakomschrijvingen en duidelijker gezagstricturen.

\subsubsection{Wie hield toexicht op de omvang en samenstelling van het team van produ- centen?}

Teneinde inzicht te krijgen in de verdeling van deze eigendomsrechten wordt in de eerste plaats een overzicht gegeven van de ontwikkelingen op personeelsgebied gedurende de onderzoeksperiode. Hilendoor wordt duidelijk welke problemen met name speelden en hoe bepaald werd wanmeer personeelsuitbreiding noodzakelijk was. Vervolgens wordt aangegeven wie bevoegd was de omvang van het personeelsbestand te bepalen en wie toezicht hield op de samenstelling.

\subsection{Personele ontwikkelingen gedurende de periode 1970-1990: een overzicht.}

De eerste helft van de jaren ' 70 werd gekenmerkt door de instelling van een Dienstcommissie in 1970 , het instellen van vacaturestops en door bezuinigingen op het personeelsbudget. ${ }^{\text {52 }}$ In combinatie met de instelling van een vijfurige werkweek voor het bewakingspersoneel leidde dat ertoe dat er in 1976 bij vele afdelingen sprake was van onderbezetting. Dit gold met name voor de Beveiligingsdienst, de restauratie-ateliers van de afdelingen Beeldhouwkunst en Kunstnijverheid, voor de afdeling Nederlandse Geschiedenis, de afdeling Inrichting en voor de Educatieve Dienst. Eind jaren "70 kwam hierin geen verandering, ondanks de uitbreiding van de bewakingsdienst met 11 formatieplaatsen. Regelmatig moest worden overgegaan tot sluiting van delen van het museum. Met name de 19 de eeuwse schilderkunst werd niet of nauwelijks tentoongesteld. Vantevoren was het vaak niet duidelijk hoeveel zaalwachters er waren waardoor het eveneens onzeker was of een bepaalde afdeling geopend zou zijn. Als oplossing werd dan ook aangedrongen op uitbreiding van het aantal formatieplaatsen bij de bewakingsdienst: Als belangrijkste

${ }^{651}$ Rijksmuseum Amsterdam, Beleidsnota van het Riiksmuseum, Amsterdam, oktober 1983, p. 89.

${ }^{652}$ Vergelijk: Rijksmuseum te Anasterdam, Verslagen van de Hoofddirecteur over de jaren 1971 en 1972 , Ministerie van CRM. 
redenen van het personeelstekort bij de bewakingsilienst worden genoemd het uitfaseren wan losdienstverbanders, de vermindering van het aantal ingezette gewetensbezwaarde dienstplichtigen en het onnustbarende ziekteverzuim. Er deden zich eind jaren 70 binnen het Rijksmuseum een aantal wijzigingen op het gebied van het personeelsbeleid voor. Twee uitbreidingsplaatsen waarvoor in 1978 toestemming was verleend door het Ministerie werden ingevuld. Een directiesecretaris werd benoemd terwijl de andere plaats werd toegevoegd aan de Intendance. Voorts werden een aantal personen bevorderd. Toestemming werd verder verkregen voor een reorganisatie binnen de bewakingsdienst. Hierdoor kon binnen de bewakingsdienst een middenkader worden gecreëerd. In 1980 werd de formatie van de bewakingsdienst met drie plaatsen uitgebreid. Desalniettemin bleef de onderbezetting bij deze dienst een dusdanig probleem dat ook in 1980 regelmatig zalen gesloten werden. Met ingang van 1 september 1980 werd de Centrale Meldkamer operationeel, terwijl een begin werd gemaakt met de plaatsing van nieuwe bewakingsapparatuur. Ook gedurende het begin van de jaren tachtig werden regelmatig delen van het Rijksmuseum gesloten in verband met deze personele onderbezetting. ${ }^{653} 1982$ werd gekenmerkt door een aantal personele ontwikkelingen. In de loop van het jaar werd het restrictieve vacaturebeleid ingevoerd waardoor ontstane vacatures in beginsel niet meer vervuld konden worden. Op aandringen van het management van het Rijksmuseum werd bereikt dat het restrictieve vacaturebeleid niet zou gelden voor het bewakingspersoneel van het Rijksmuseum.

Gedurende de jaren 1983 tot en met 1986 werd personeellsbestand bij de overheid en dus ook bij het Rijksmuseum met jaarlijks $2 \%$ verminderd (de zogenaamde $4 \times 2 \%$-operatie). Voor de personeelsveminderingsoperatie werd voor het Rijksmuseum uitgegaan van 317 personen waardoor geen gedwongen ontslagen nodig waren. Door de onderbezetting bij de bewakingsdienst, met name ook door de $2 \%$ reductie, moesten opnieuw afdelingen worden gesloten. In 1983 werd het Rijksmuseum op maandag gesloten, hetgeen een positief effect op de werkdruk van de bewakingsdienst had. ${ }^{64}$ Een tweetal belangrijke ontwikkelingen speelden in 1984 en latere jaren een rol. Enerzijds is er een ontwikkeling in de richting van contractmanagement. Anderzijds wordt nagedacht over een wijziging van de organisatiestructuur. Sinds het rapport van de commissie Vonhoff werd gestreefd naar verbetering van het management en de efficièntie binnen het openbaar bestuur. In dit verband werd door het Ministerie van Binnenlandse Zaken een Projectgroep OrganisatieDiagnose ingesteld die onderdelen van het rijk doorlichtte. Op voorstel van de SecretarisGeneraal van het Ministerie van WVC werd ook het Rijksmuseum doorgelicht. De hoofddirecteur van het Rijksmuseum stemde hier mee in. Al in de concept-beleidsnota van 1985 werd een integraal organisatie-onderzoek wenselijk geacht. In 1986 werd aan IKON Belleidsconsulenten B.V. opdracht gegeven een dergelijk organisatie-onderzoek uit te voeren. Het rapport van de Projectgroep Organisatie-Diagnose, neergelegd in het rapport "Bevindingen, Organisatiedoorlichting bij het Rijksmuseum te Amsterdam" speelde daarbij eveneens een rol. Een tweede belangrijke ontwikkeling vormde de invoering van zelfbeheer. Bij sommige van de dienstonderdelen van WVC, waaronder het Rijksmuseum, werd zoals al werd opgemerkt in paragraaf 15.4.1.1., contractmanagement. (een vorm van zelfbeheer) als experiment ingevoerd. Er werd een contract opgesteld (convenant) tussen de Secretaris-Generaal en de hoofddirecteur van het Rijksmuseum. Er kwamen voor de directie grotere bevoegdheden en verantwoordelijkheden met betrekking tot de financiën en het personeel. Tenslotte $\mathrm{kan}$ mog vermeld worden dat per 1 augustus 1986 een ar-

${ }^{659}$ Rijksmuseum te Amsterdam, Yerslag van de Hoofddirecteur over het jaar 1981, Ministerie van CRM, p. 10.

${ }^{654}$ Rijksmuseum te Amsterdam, Verslag vam de Hoofddirecteur over het jaar 1983, Ministerie van WVC, p. 11. 
beidstijdverkorting van 5\% werd doorgevoerd voor die sectoren van het Rijksmuseum waarvoor een werktijd gold van 40 uur per week. ${ }^{655}$

In 1987 werd het contractmanagement, waarmee in 1986 geëxperimenteerd was, definitief ingevoerd. Halverwege de jaren ' 80 bleef grote onzekerheid bestaan over de afslankingsen privatiseringsprocedures. Als gevolg van het restrictieve vacaturebeleid ontstonden bovendien op tall van plaatsen in de organisatie vacatures. ${ }^{656}$ De Dienstcommissie had overwegende bezwaren tegen de op grond van het IKON-rapport voorgestelde functie Hoofd Beleidsstaf. Hieronder zouden zowel de afdeling Financiële Zaken als de afdeling Personeelszaken ressorteren. De directie was hier wel voorstander van. Dit probleem werd als zijnde een conflict in de zin van art. 127 f ARAR voorgelegd aan de Minister. Door dit conflict was de invoering van de nieuwe organisatiestructuur, gebaseerd op het IKON-rapport, in 1988 nog niet haalbaar. Belangrijk is voorts dat Minister Brinkman bekend maakte dat een onderzoek gestart zou worden naar de mogelijkheid van externe verzelfstandiging van de Rijksmusea. Dit onderzoek vond begin 1989 plaats. ${ }^{657} \mathrm{De}$ combinatie van hoofddirecteurschap en voorzitterschap van de te vormen sector Kunstmusea en -diensten stuitte op bezwaren van de Dienstcommissie.

Het probleem van de functie Hoofd Beleidsstaf werd opgelost door aan de beleidsstaf de functie van Financieel-economisch manager toe te voegen, waardoor personele en financiële aspecten gescheiden konden blijven. Voorts werd er een directeur voor de Sector Presentatie aangetrokken. ${ }^{658}$ De formatieve sterkte bleef in 1990 onveranderd. Aan het einde van de onderzoeksperiode was het ziekteverzuim bij de Intendance relatief groot. Dit werd voor een deel opgevangen door uitzendkrachten en $65+$ ers in de bewakingsdienst in te zetten. In verband met de specifieke aspecten ten aanzien van het genereren van middelen en de relatie met de Rijksmuseum Stichting werd de Fotodienst onder de nieuwe functie van Financieel-economisch manager gebracht. ${ }^{.69}$

\subsection{Wie zag toe op de omvang wan het team van producenten?}

Het overzicht van de personele ontwikkelingen over de onderzoeksperiode zoals geschetst in de vorige paragraaf maakt duidelijk dat het Rijksmuseum niet vrij was zelf te bepalen hoeveel mensen in dienst zouden worden genomen. Het personeelsbeleid van het Rijksmuseum was formeel gecentraliseerd binnen het Ministerie van WVC. Dit beleid was verder onderworpen aan de richtlijnen van het Ministerie van Binnenlandse Zaken. In dit verband waren ondermeer het Formatiemodel Binnenlandse Zaken, de Ambtenarenwet en het ARAR van belang. Voor uitbreiding van het team van producenten c.q. het aantal formatieplaatsen was toestemming nodig van de Secretaris-Generaal van het Ministerie van WVC. Ook reorganisaties moesten goedgekeurd worden door het departement, meer in het bijzonder door de Secretaris-Generaal. De rijksregelingen zoals die golden op het

\footnotetext{
${ }^{165}$ Rijksmuseum Amsterdam, Jaarverslag van de Hoofddirecteur over 1985 , Ministerie van WVC, p. 13.

${ }^{656}$ Rijksmuseum Amsterdam, Jaarverslag van de Hoofddirectewr over 1987 , Ministerie van WVC, pp. 1011.

${ }^{657}$ Rijksmuseum Amsterdam, Verslag van de Hoofddirecteur over het jaar 1988, Ministerie van WVC, p. 8.

${ }^{658}$ Rijksmuseum Amsterdam, Verslag van de directie over het iaar 1989, Ministerie van WVC, p. 4.

${ }^{659}$ Rijksmuseum Amsterdam, Verslag van de directie over het iaar 1990, Ministerie van WVC, pp " 8-10.
} 
departement van WVC waren hierop van toepassing. Zoals aangegeven stelde het Rijksmuseum gedurende de periode $1970-1990$ herhaaldelijk voor het aantal formatieplaatsen, bijwoorbeeld bij de bewakingsdienst en de afdeling Inrichting, te vergroten. Het Ministerie had evenwel eigen doelen en zette die ook door. Dit leidde tot herhaldelijke reducties van personeel door onder andere de $4 \times 2 \%$-operaties in de jaren 80 en de $3 \%$-reductie voor het overheidspersoneel, waaronder het Ministerie van WVC, over de periode 1987 tot en met $1990{ }^{660}$ Deze bezuinigingen op het personeel hadden voor het Rijksmuseum grote gevolgen. Er was grote onzekerheid over de formatie, vacatures werden traag ingevuld en het formatieve bestand was bovendien weinig flexibel. Als reactie op de bezuinigingen op de personeelsformatie sloot het Rijksmuseum herhaaldelijk bepaalde afdelingen van de tentoonstellingsruimten. Ook over de mogelijkheden personeel aan te stellen ten laste van derden diende altijd contact op te worden genomen met CDPZ. Het management van het Rijksmuseum was dan ook nauwelijks in staat een flexibel personeelsbeleid te voeren. Uitzonderingen waren het verrichten van enkele diensten en het uitbesteden van diensten op declaratiebasis. ${ }^{661} \mathrm{Om}$ toch aan voldoende personeel te komen maakte het Rijksmuseum gebruik van tijdelijk personeel ten koste van het materièle budget en verder werden vrijwilligers aangetrokken. Waren de bevoegdheden op het personele vlak tot midden jaren tachtig gering, eind jaren tachtig kwam hier veramdering in. Dit hield enerzijds verband met de reorganisatie van het Ministerie van WVC en anderzijds met de genoemde Kaderregeling Experimenten Contractmanagement.

Per 1 januari 1989 en formeel per 1 januari 1990 werd een grondige herziening van de personele functie op het Ministerie van WVC doorgevoerd. Deze decentralisatie vloeide voort uit het decentralisatiebeleid zoals dat ten aanzien van de gehele Rijksdienst werd gevoerd. Doel van deze reorganisatie was de taken op het terrein van het personeelsbeleid en -beheer zoveel mogelijk te decentraliseren. Een deel van de personele functie is gedecentraliseerd naar de Directoraten-Generaal en de verschillende diensten. Deze organisatie-onderdelen gingen ook over eigen personeelsafdelingen beschikken terwijl op centraal niveau de Centrale Dienst Personeelsmanagement (CDPM) werd opgericht. In een brief werd door het Ministerie (CDPM) aangegeven wat de nieuwe taak zou zijn van de Secretaris-Generaal, waarbij datgene wat bepaald was bij het Koninklijk Besluit van 18 oktober $1988^{662}$ onverminderd van kracht zou zijn. Aangegeven werd dat de SecretarisGeneraal belast was met het vaststellen van de hoofdlijnen van het personeelsbeleid en met de hoofdlijnen van de uitvoering hiervan. Zijn taak is onder meer het vaststellen van de formatie vanaf schaal 14 van bijlage B van thet BBRA. Verder kan hij straffen uitdelen op grond van het ARAR $^{663}$ en het Arbeidsovereenkomstenbesluit $(A O B)^{664}$ en houdt

600 Secretaris-gemeraal van het ministerie van Welzijn, Volksgezondheid en Cultuur, brief aan de medewerkers van het ministerie van WVC, personele afslanking, 18-09-1986.

661 Brief van het ministerie van W.V.C. aan de Hoofden van de onder de Hoofddirecteur ressorterende Diensten, 21 februari 1989.

${ }^{662}$ Stb. 1988, 499, houtende een regeling van de functie en verantwoordelijkheden van een Secretaris-Generaal.

669 Stb. 1931, 248.

664 Stb. $1931,354$. 
hii zich bezig met gevoelig liggende zaken op het terrein van het personeelsbeleid $66^{65}$ De Centrale Directie Personeelszaken is belast met het vaststellen van de formatie voor functies tot schaal 14 van Bijlage B van het BBRA 1984. De Directeur-Generaal is belast met de uitwoering van het beleid. Het Rijksmuseum werd gerekend tot de contractdiensten. Het vanaf 1986 afgesloten convenant had echter weinig invloed op de bepaling van de formatieve sterkte. Deze geschiedde nog steeds door het Ministerie. Artikell $11.1 \mathrm{e}$ van de Kaderregeling Experimenten Contractmanagement W. V.C. bepaalde: Het opstellen van formatieplannen en het maken van doartoe strekkende orgaan- en functiebeschrijvingen en het inrichten van de formatie van de dienst (worden opgedragen aan de directeur, JFK) met inachtneming en gebruikmaking wan:

a. de BBRA functiewaarderingsmethodiek;

b. de vastgestelde topformatie en sleutelposities;

c. de personeelsbegroting qua aantallen en budget;

d. de door de Secretaris-Generaal met het Ministerie van Binnenlandse Zaken afgesproken randvoorwatirden en de door de Secretaris-Generaal voor het departement vastgestelde randvoorwaarden".

Elke Directeur-Generaal kan besluiten ook na 1989 bevoegdheden bij het hoofd van een dergelijke dienst te leggen, hetgeen ook bij het Rijksmuseum gebeurde. De beslissingsbevoegdheid van de hoofddirecteur van het Rijksmuseum blijkt uit het feit dat hij de mutatieformulieren ondertekent. Aangegeven wordt dat de verschillen tussen contractdiensten en overige diensten per 1 januari 1989 gering zijn, aangezien bij de decentralisatie van de personeelsfunctie binnen het Ministerie met de ervaringen binnen de contractdiensten rekening is gehouden. Vermeld wordt: "Omdat de personele bevoegdheden per 1 januar 1989 bij de directeur-generaal/plv. secretaris-generaal liggen, worden ook bij de contractdiensten de bevoegdheden namens de directeur-generaal/plv. secretaris-generaal uitgeoefend. Het voornaamste verschil in de personele functie tussen contractdiensten en overige diensten is dat in convenanten taakstellende elementen zijn opgenomen waar het gaat om prestaties en personele begrotingsmiddelen die daarvoor beschikbaar worden gesteld". ${ }^{660}$ De bevoegdheden ten aanzien van het personele beleid van de contractdiensten zijn dus gedelegeerd door de Directeur-Generaal/plv. Secretaris-Generaal. Een ander verschil is dat er voor contractdiensten sehuifmogelijkheden bestaan tussen de verschillende budgetten.

\subsection{Hoe was het toezicht op de samenstelling van het team van producenten geregeld?}

Bevoegdheden op het terrein van het personeelsbeleid waren slechts in beperkte mate gedelegeerd aan het Rijksmuseum. Het hoofd Algemene Zaken was belast met de uitvoering van het door het Ministerie vastgestelde personeelsbeleid. De samenstelling van het team van producenten werd bepaald door de juridische organisatiestructuur die niet veranderd kon worden zonder instemming van het Ministerie. Volgens deze organisatiestructurur was er een hoofddirecteur met daaronder een aantal afdelingshoofden die ten opzichte van elkaar nevengeschikt zijn. Ook waren er een aantal ondersteunende diensten.

Voorts is van belang wie bevoegd was om wijzigingen in benoemingen aan te brengen.

645 Brief van het hoofd van CDPZ aan de Hoofden van Dienst, CDPZ-U-51400, taken en bevoegdheden personele functie 1989,19 december 1988 , pp. 1-2.

${ }^{666}$ Centrale Directie Persomeelszaken, Brief van het hoofd van CDPZ aan de Hoofden van Dienst, CDPZU-51400, taken en bevoegdheden personele functie 1989 , 19 december 1988; p. 2. 
Hierbij moet onderscheid gemaakt worden tussen de verschillende niveaus in de organisatie. Op grond van artikel 7 ARAR gold dat aanstelling geschiedt door de Kroon indien het gaat om een vaste aanstelling met een salaris van minimaal schaal 12 van bijlage $B$ van het BBRA 1984. ${ }^{667}$ In de overige gevallen gebeurde de aanstelling door of namens de Minister van het Ministerie van WVC. Dit betekent dat onder meer de benoeming van een nieuwe hoofddirecteur door de Kroon moest worden goedgekeurd. Ook de functiewaarderingen werden door WVC bepaald. Dit leidde tot problemen bij de versterking van met name het zakelijk management. Laan en Vollebergh stellen in dit verband: "Versterking van het zakelijk management is nauwelijks mogelijk als gevolg van een te lage inschaling bij WVC ${ }^{\prime \prime} .{ }^{668}$ Verder nam de Minister van WVC de uiteindelijke beslissing in lang durende of belangrijke zaken, ook ten aanzien van het personeelsbeleid. Ten aanzien van de lagere niveaus kon een afdelingshoofd iemand voorstellen. In de meeste gevallen werd deze dan ook aangenomen. Dit neemt niet weg dat formeel het departement, meer in het bijzonder de Secretaris-Generaal namens de Minister bevoegd was personeel aan te stellen. Dit bleek ook uit de in paragraaf 15.4.1.5.1. genoemde vacaturestop die in de jaren '70 en ' 80 herhaaldelijk werden ingesteld, waardoor bestaande vacatures niet vervuld konden worden. Het advies van de Minister van Binnenlandse Zaken was vereist als de formatie door de aanstelling wijziging ondergaat. De Rijksmusea hadden wel de bevoegdheid om bij vacatures voor lager ingeschaald personeel, zoals bewakings- en ondersteunend personeel, de werving en selectie onafhankelijk van het Ministerie te regelen. Opgemerkt kan worden dat het departement nauwer betrokken was bij ontslag dan bij benoemingen. Indien een afdelingshoofd bijvoorbeeld meende dat een werknemer niet goed functioneerde werd dit overlegd met de hoofddirecteur. Indien werd gekozen voor gedwongen ontslag werd dit verder afgehandeld door het departement, met uiteindelijk de Secretaris-Generaal als bevoegde functionaris. Hij tekende stukken ten aanzien van ontslag niet op verzoek: ${ }^{69}$ In het algemeen werd als volgt te werk gegaan. Het Rijksmuseum stuurde een mutatieformulier of een ander document naar de Centrale Directie Personeelszaken op het departement. Veelal gebeurde dit pas na eerst overleg te hebben gevoerd met CDPZ. In 1988 wees deze Directie het Rijksmuseum erop dat het noodzakelijk was dat er bij hen een door de hoofddirecteur getekende schriftelijke verklaring aanwezig was, waarin deze aangaf wie namens hem bevoegd was de mutatieformulieren of daarmee overeenkomende documenten te tekenen en verder moest zijn aangegeven wie hiertoe alleen bevoegd was bij verhindering, en in hoeverre de rechten van deze functionaris beperkt waren ${ }^{670}$ Wijzigingen in de tekenbevoegdheid dienden in het vervolg direct te worden doorgegeven. Het hoofd Algemene en Financiële Zaken werd aangewezen bij afwezigheid van de hoofddirecteur.

Zoals opgemerkt in de vorige paragrafen werden er balverwege de jaren tachitig belangrijke wijzigingen doorgevoerd door de invoering van zelfbeheer. Deze wijziging liet onverlet dat het Ministerie de formatieve sterkte ook na 1986 bepaalde. Zij leidde er echter well toe dat de verdeling van bevoegdheden inzake het toezicht op de samenstelling van het personeel veranderde. Jaarlijks werd onder verantwoordelijkheid van het hoofd

667 Vergelijk pun 5 voor de verdeling van de werknemers van het Rijksmuseum naar salarisschaall.

668 Laan en Vollebergh $(1994$, p. 8$)$.

669 Brief van het hoofd vali CDPZ aan de Hoofden van Dienst, CDPZ-U-51400, taken en bevoegdhedlen personele functie 1989,19 december 1988 , p. 2.

670 Brief van de Centrale Directie Personeelszaken asn de Hoofden van Dienst, ten aanxien van de machtiging ondertekening mutatieformulieren, 23 november 1988. 
van het Rijksmuseum een contract opgesteld. Dit contract was onderdeel van de reguliere begrotingscyclus. Voor de opstelling van het contract maakte het departement de randvoorwaarden duidelijk door onder meer de begrotingsaanschrijving en personeelscirculaires. Bij het opstellen wan het contract werd door de directeur van het Rijksmuseum overleg gepleegd met de betrokken centrale directies over de taakstelling, de voor die taakstelling benodigde productiemiddelen als personeel, materieel en huisvesting, het budgettaire kader, de over te dragen bewoegdheden en de informatieverstrekking tijdens de uitvoering. Op grond hiervan werd een contract opgesteld dat bestond uit drie delen, te weten: 671

-een planning van de output/activiteiten;

-een vertaling van de geplande output naar benodigde middelen;

-de afspraken over delegatie van bevoegdheden op organisationeel, personeels-, materieelen huisvestingsgebied en op het gebied van de informatievoorziening en het financiële beheer.

De vaststelling van een convenant gebeurdle voor 1 november van elk jaar door ondertekening door de Secretaris-Generaal en medeondertekening door de directeur van het Rijksmuseum. Door de convenanten ontstonden er meer mogelijkheden voor het Rijksmuseum om zelf te bepalen in welke combinatie de inputs werden ingezet. In de Kaderregeling was bepaald dat het niet toegestaan was middelen te verschuiven van het materiële (M-budget) naar het personele budget (P-budget). Het was toegestaan om van het personele naar het materiële budget te verschuiven tot maximaal $10 \%$ van het materiële budget. Wel moest de directeur een dergelijk voornemen melden bij het hoofd van de Centrale Directie Financiële en Economische Zaken. Indien deze daar geen bezwaar tegen had kon de directeur deze verschuiving doorvoeren. Verder werd het budget voor opleidingen en uitzendkrachten onder het materiële budget gebracht. Het budget voor gratificaties viel onder het personele budget. Voor de contract-diensten gold niet langer het preventieve toezicht van CDPZ. Dit werd vervangen door achteraf te toetsen in hoeverre aan het contract was voldaan. Werving en selectie van interne en externe sollicitanten tot en met hoofdgroep IV, uitgezonderd schaal 12, werden gedelegeerd aan de directeur van het Rijksmuseum. Ook de bevoegdheid personeel aan te stellen in tijdelijke en vaste dienst, alsmede het in dienst nemen op arbeidsovereenkomst voor functies tot en met hoofdgroep $\Gamma$, uitgezonderd schaal 12 , werden overgedragen aan de directeur. Daarbij moest wel binnen de vastgestelde formatie gebleven worden. Verder werd het toekennen van periodieke salarisverhoging en het onthouden ervan een zaak van de directeur, terwijl ook het bevorderen van personeel aan hem werd overgedragen. Hij trad dan ook op als beoordelingsautoriteit.

Voor 1 april volgend op het convenamtjalar stuurde de directeur van het Rijksmuseum de jaarstukken naar de Secretaris-Generaal die ze verspreidde over de Directeur-Generaal, de betrokken hoofden van de Centrale Directies en het hoofd van de Accountantsdienst. De jaarstukken bevatten een jaarverslag en de jaarrekening, waarin het Rijksmuseum verantwoording aflegt voor het gevoerde beleid. Hierin wordt aangegeven in hoeverre de convenantsverplichtingen zijn gerealiseerd.

\section{Conclusie}

Gedurende de jaren tachtig werden er weliswaar een aantal wijzigingen doorgevoerd ten aanzien van de verdeling van dit eigendomsrecht, toch is deze herziening nog vrij beperkt. De formatie ligt vast, terwijl het sturen op kwaliteit, oftewel het bepalen van de

${ }^{671}$ Vergelijk artikel 3 Kaderregeling Experimenten Contract Management WVC. 
samenstelling van het personeelsbestand, eveneens slechts beperkt mogelijk is. Opgemerkt wordt: "Sturen op kwaliteit beweegt zich nu tussen zeer smalle marges en is een kwestie wan de lange adem. Het hoeft geen betoog dat de huidige praktijk tot een aanienlike verspilling van middelen leidt, die bij slagwaardig operenen voor museale doelen had kumnen worden ingezet. Het is daarom van belang dat de musea de beschikking krijgen over een eigen personeelsbudget en over de formatiewe mogelijkheden die in de private sector gebruikelijk zijn". ${ }^{672}$ In de beleidsnota uit 1991 wordt in dit verband opgemerkt: Er worden derhalve steeds meer personeelstaken en -bevoegdheden naar het instellingsniveau gebracht. Het gaat hier, voor de goede orde, om personeelsmanagement (de wijze van omgaan met mensen en middelen) en niet om personeelsbeleid (het kader waarbinnen dit alles moet plaatsvinden) 673

\subsection{Het recht op vruchtgebruik (usus fructus)}

\subsubsection{Wie maakte aanspraak op de winst?}

Op grond van de theorie van de eigendomsrechten kan de verwachting worden uitgesproken, dat indien de winst moet worden afgedragen aan de publiekrechtelijke eigenaren, dit kan leiden tot een verminderd belang bij het streven naar technische efficiëntie Het gaat er daarbij om of een overheidsinstelling exploitatie-overschotten tot stand kan brengen. Indien een overheidsinstelling daarentegen een eigen vermogen mag hebben en dit naar eigen goeddunken mag gebruiken, kunnen efficiëntiewinsten ontstaan. Het recht op eigen vermogen biedt de overheidsinstelling de mogelijkheid zelf de continuiteit te waarborgen. Indien dit recht van vruchtgebruik aan het bedrijf is toegekend is het in het belang van de overheidsinstelling om een zekere mate van efficiêntie te realiseren. De vraag rijst dan ook of aan het Rijksmuseum een dergelijk recht is toegekend.

Het Rijksmuseum werd gesubsidieerd door het Ministerie van WVC Via de begroting werden inkomsten en uitgaven vastgelegd. Het is van belang daarbij onderscheid te maken tussen enerzijds gedane giften en anderzijds de entreeprijzen. Giften werden niet geraamd in de begroting. Zij werden juridisch gedaan aan de Staat der Nederlanden. Vervolgens werden zij per suppletoire begrotingswet toegevoegd aan de begroting van het Rijksmuseum. Dit werd zichtbaar bij de afrekening aan het einde van het jaar. Veelal werd dit geld gegeven voor het doen van specifieke aankopen. Het is daarbij van belang te onderkennen dat kunstwerken die met de giften werden aangekocht eigendom werden van de Staat der Nederlanden en dus niet van het Rijksmuseum. De collectie is dus van het rijk, die deze in bruikleen heeft gegeven aan het Rijksmuseum, terwijl daarnaast bepaalde onderdelen van de collectie in bruikleen zijn gegeven door de gemeente Amsterdam en verschillende stichtingen.

Daamaast zijn de entreegelden van belang. Deze werden ontvangen, beheerd, verwerkt en afgedragen door het Bureau Intendance. Sinds 1986 is de controle van de kassauitkomsten bij Financiële Zaken ondergebracht, zodat gecontroleerd kan worden of de uitkomst van het bureau Intendance overeenkomt met de bevindingen van de afdeling Financiële Zaken. De procedure was verder als volgt. Entreegelden werden wel begroot. De opbrengsten uit entreegelden van het normale museale bezit dienen te worden verantwoord onder de middelen. Daarbij werd uitgegaan van de gemiddelde entree-inkomsten. De opbrengst van

672 Rijkssmuseum Amsterdam, Ondernemimgsplan 1989, 31 maart 1989, p. 16.

673 Rijksmuseum Amsterdam, Zorg voor de nationale schatkamer, beleidsnota van het Rijksmuseum 1991 1999, september 1991 , p. 63 . 
entreegelden voor 1990 werd bijwoorbeeld berekend op basis van het totale gemiddelde bezoek in de jaren 1984-1988 en de gemiddelde bezoeken verdeeld over de bestaande tarieven. ${ }^{674}$ Hiervoor gold halverwege de jaren " 80 de afspraak met Financiën dat van de inkomsten boven de F, 8,3 miljoen $50 \%$ mocht worden gehouden. Indien in de begroting van het Rijksmuseum bijvoorbeeld 15 miljoen gulden was opgenomen aan uitgaven en 5 miljoen aan entree-inkomsten dan werd dus 10 miljoen overgemaakt naar het Rijksmuseum. Vielen de entree-inkomsten tegen dan kwam dit voor rekening van het Ministerie van Financiën terwijl meevallers eveneens voor rekening (in dit geval ten goede) kwamen van het Ministerie van Financiën. Dit verklaart ook waarom her Rijksmuseum nauwelijks een prikkel had om de entree-inkomsten te vergroten. Hierbij dient wel bedacht te worden dat entreeprijzen werden bepaald door het Ministerie van WVC en niet door het Rijksmuseum zelf. Eind jaren tachtig werd mede op grond hiervan de regel ingevoerd dat meevallende entree-inkomsten, bijvoorbeeld hier F. 6 miljoen in plaats van F. 5 miljoen, door het Rijksmuseum besteed mochten worden. ${ }^{675}$ Dit is eên van de redenen waarom het management van het Rijksmuseum meer gewicht is gaan toekennen aan de bereikbaarheid. $\mathrm{Na} 1$ juli 1995 kan het Rijksmuseum zelf de toegangsprijzen vaststellen. Bij de behandeling van het verslag in de Tweede Kamer is aan de orde gekomen of dit niet kan leiden tot onbeperkte prijsstijging. Dit zal niet het geval zijn omdat het Rijksmuseum afhankelijk is van de bekostiging door het rijk dat deze subsidiëring baseert op de beleidsuitgangspunten die in overleg met de Tweede Kamer zijn vastgesteld. Overigens kunnen opbrengsten uit extra heffingen op entreegelden voor bijzondere tentoonstellingen (bezit van buitenaf) wel buiten de begroting om op een derdenrekening worden geboekt. Uitgaven voor een bijzondere tentoonstelling worden dan van deze derdenrekening afgeboekt. ${ }^{676}$ Opbrengsten uit verkopen van catalogi en affiches van het normale museale bezit dienen ten gunste van de middelen te worden geboekt.

Tenslotte kan nog de behandeling van sponsorgelden worden genoemd. Bijdragen van sponsors moeten altijd gekoppeld zijn aan een specifiek doel. Opbrengsten uit sponsorgelden kunnen buiten de begroting om op een derdenrekening geboekt worden. De uitgaven voor het specifieke doel kumnen op de derdenrekening in mindering worden gebracht. Indien de uitgaven groter zjjn dan de ontvangen sponsorgelden dienen deze uitgaven op grond van art. 34 lid 3 van de Comptabiliteitswet alsnog ten laste van de begroting te worden gebracht. ${ }^{677}$ In het algemeen geldt dat zolang de mogelijkheid van verrekening met derden aanwezig blijft, deze ontvangen sponsorgelden op een derdenrekening mogen blijven staan. Indien echter blijkt dat geen verrekening meer zal plaatsvinden dan dienen deze middelen te worden overgeboekt naar het middelen-artikel van de begroting van het dan lopende dienstjaar.

Geconstateerd kan worden dat het Rijksmuseum ook niet bevoegd was er eigen vermogen op na te houden. Er waren een aantal uitzonderingen hierop in de vorm van een aantal fondsen. De omvang van deze fondsen was evenwel relatief gering. Een voorbeeld

${ }^{674}$ Rijksmuseum Amsterdam, Activiteitenplan 1990, hoofdstuk 2 Algemene bedrijfsvoering, p. 3.

675 Vergelijk: Ministerie van WVC, brief van het hoofd van het Burean Financiele en Economische Aangelegenheden aan de Hoofden van de onder de Hoofddirecteur Cultuurbeheer ressorteremde diensten, tem aanzien ran boeking van inkomsten, d.d. 21 februari 1989.

676 Vergelijk artikel 34 van de Comptabiliteiltswet.

677 Ministerie van WVC, Brief van het ministerie van W.V.C. aan de Hoofden van de onder de Hoofddirecteur Cultuurbeheer ressonterende Diensten, 21 februari 1989. 
daarvan vormen de drie fondsen welke door J.W. Edwin von Rath bij testamemt in 1934 werden gelegateerd (f. $95.000_{\text {, }}$ - in 1987 ) en het F.G. Waller-fonds. Voor het beheer vam dergelijke fondsen was veelal een reglement opgesteld, waarbij de hoofddirecteur van het Rijksmuseum als beheerder werd aangewezen. Meestal werden deze fondsen belegd in nationale schuld en waren de opbrengsten van deze fondsen bestemd voor de aankoop van kunstwerken. Om de wijze van belegging van deze fondsen te wijzigen was nadrukkelijk toestemming van het Ministerie van W.V.C. nodig. ${ }^{678}$ Het onderbrengen van deze middelen in een stichting was alleen mogelijk met toestemming van het Ministerie van WVC.

Het Rijksmuseum maakte gedurende de onderzoeksperiode geen winst. In dit verband is het van belang aandacht te besteden aan de vraag wie aanspraak maakte op middelen die niet besteed waren in een jaar en woorts of er verkapt winst werd gemaakt.

Reserveringen en afschrijvingen waren in strijd met de Comptabiliteitswet. Met betrekking tot verplichtingen die niet tot besteding zijn gekomen in een jaar gold volgens art. 12 van de oude Comptabiliteitswet dat het mogelijk was dergelijke gelden mee te nemen naar het volgende jaar. Artikel 12 van de Comptabiliteitswet 1976 was evenwell in 1988 verval len. $\mathrm{Om}$ in dat jaar eveneens een exogene bijtelling te kunnen bewerkstelligen dient aan een aantal woorwaarden te worden voldaan. 880 In de eerste plaats moet er niet alleen een verplichting zijn maar moet er ook werkelijk sprake zijn van overblijven van de middelen. Verschuiving naar andere begrotingsposten is niet toegestaan. In de tweede plaats moet het niet besteden van de middelen buiten de macht van de rekenplichtige liggen. Laan en Vollebergh stellen in dit.verband: "De verplichting dat overschotten aan het eind van het jaar terugvloeien naar de schatkist lewert de bekende "december uitgavenhausse" op. De laatste jaren zijn deze eisen weliswaar enigszins versoepeld door middel van talrijke ad hoc regelingen, maar deze vergen veel departementaal en interdepartementaal overleg en bovendien een aanzienlijke informatiebehoefte" 681

Ten aanzien van de vraag of er verkapt winst werd gemaakt is voorts de Rijksmuseum Stichting van belang. De Rijksmuseum Stichting is bînnen het Rijksmuseum gevestigd en heeft als doel de belangen van het Rijksmuseum te dienen, meer in het bijzonder met het oog op de uitbreiding van de verzameling Schilderijen. ${ }^{682}$ De stichting die geleid wordt door een directeur, probeert dit doel te verwezenlijken door de verkoop van onder meer reproducties en prentbriefkaarten. Het werd het Rijksmuseum toegestaan middelen over te hevelen naar de Rijksmuseum Stichting, waardoor verkapt vermogen werd aangehouden voor bepaalde doelen (aankoopbeleid, relatief riskante projecten etc.). Voor aankopen werd veelal gebruik gemaakt van deze stichting. Deze stichting is gevestigd binnen het

\footnotetext{
678 Vergelijk bijwoorbeeld: Ministerie van WVC, brief van de minister van W.V.C., namens deze het Hoofd van de Hoofdafdeling Beheer-MMA, 19 janwari 1988, over de wiiziging in de belegging van de fondsen I.W. Edwin vom Rath.
}

679 Vergelijk de circulaire DBC-U-6565, wan de Hoofddirecteur Culturbeheer an de Algemeen Directeur wan het Rijksmuseum, 16 oktober, 1989 .

680 Het Hoofd van de Centrale Directie Financiêle en Economische Zaken, Richtlijin ten aanzien van begrotingsuitvoering en verantwoording 1987,1987 , p. 11.

681 Laan en Vollebergh $(1994$, p. 8$)$

Vergelijk artikel 2 van de statuten van de Rijksmuseum-Stichting. 
Rijksmuseum en heeft tot doel de belangen van het Rijksmuseum te bevorderen, meer in het bijzonder door uitbreiding van de verzameling van het Rijksmuseum. De belangenverwevenheid tussen Rijksmuseum en Rijksmuseum Stichting blijkt onder andere ook uit de accountantsrapporten van de accountantsdienst van het Ministerie van WVC. In het accountantsrapport naar de financièle verantwoording over 1983 van het Rijksmuseum spreekt de accountantsdienst expliciet van deze belangenverwevenheid. Voorts vermelidt zij dat middelen worden overgedragen van het Rijksmuseum naar de Rijksmuseum Stichting. Dit gebeurde vooral indirect. In de eerste plaats heeft de Rijksmuseum Stichting een aantal ruimten in gebruik binnen het Rijksmuseum onder meer voor de verkoop van reproducties en prentbrieflkaarten. Voor het gebruik van deze ruimten alsook voor de verwarming en verlichting ervan wordt geen vergoeding betaald. In de tweede plaats gaat de gehele opbrengst van de fotodienst van het Rijksmuseum naar deze stichting. ${ }^{63 i}$ In miil daarvoor is een werknemer van de Rijksmuseum Stichting werkzaam in het fotoarchief van het Rijksmuseum. De Accountantsdienst heeft hier de nodige bezwaren tegen. Zij stelt:" "Er bestaat een nawwe band tussen het Rijksmuseum en de Rijksmuseum Stichting. Vanwege de belangenvenwevenheid kunnen er voor het Rijksmuseum ook nadelige consequenties zijn die wij niet kumnen beoordelen omdat ons geen inzage wordt gegeven in de administratie c.q. jaarrekening wan de Stichting. Wij achten het noodzakelijk voortaan inzage te krijgen in de administratie van deze Stichting. Zo gaat de gehele opbrengst van de fotodienst van het Rijksmuseum naar deze Stichting zonder dat hiervoor een redelijke verklaring wordt gegeven" In 1985 geeft de Rijksmuseum Stichting aan dat haar totale inkomsten ongeveer F. 270.000,- bedragen en de totale uitgaven ongeveer F. 96,500,-. Het Rijksmuseum merkt op dat de netto-winst die door de Rijksmuseum Stichting wordt behaald uitsluitend gebruikt wordt voor de uitbreiding van het kunstbezit door het Rijksmuseum. Dit gebeurt of door medefinanciering van aankopen of door volledige financiering waarbij de stichting het eigendom van het kunstobject verwerft en dit vervolgens aan het Rijksmuseum in bruikleen geeft. ${ }^{65}$ Het Rijksmuseum biedt bovendien permanente huisvesting aan het Koninklijk Oudheidkundig Genootschap en de Stichting Cultururgeschiedenis Nederlanders Overzee. Deze instellingen dragen niet bij in de kosten (energie, schoonmaak e.d.).

Naast de verkapte "winst" die wordt overgeheveld naar de Rijksmuseum Stichting en beide andere stichtingen is het van belang de aanspraken te onderzoeken van de werknemers, door het analyseren van hun beloning. De rechtspositie en de bezoldiging wordt op grond van artikel 109 van de Grondwet van 1983 bepaald bij wet. Met behulp van artikel 125 van de Ambtenarenwet van 1929 wordt de bezoldiging van het rijkspersoneel vastgesteld bij Algemene Maatregel van Bestuur, te weten het Bezoldigingsbesiuit burgerlijke rijksambtenaren 1984 (BBRA). ${ }^{68}$

\footnotetext{
683 Accountantsdienst, Accountantsrapport Nr. AD/C 84. 3101, inzake het onderzoek naar de financiële verantwoording over 1983 van het rijksmuseum te Amsterdam, pp. 1-5.
${ }^{684}$ Accountantsdienst van het Ministerie van WVC, Rapport NR. AD/C 84.3101, inzake het onderzoek naar de financiele verantwoording over 1983 van het Rijksmuseum te A'dam, 19 maart 1985, p. 1.

685 De Hoofddirectuer van het Rijksmuseum, brief betreffende steunstichtingen, gericht aan de directeurgeneraal woor Culturele Zaken, 25 februari 1986.

6366 Zie ook de gewijzigde ambtenarenwet, Wet van 26 september 1984 , Staatsblad 461 , Tweede Kamer, vergadejiaar $1981,16955$. 


\begin{tabular}{|l|l|l|l|}
\hline & \multirow{2}{*}{\begin{tabular}{l} 
Werkelijke bezetting \\
\cline { 3 - 4 }
\end{tabular}} & $30-06-1984$ & Begrotingssterkte \\
\cline { 3 - 4 } & 967,7 & 1984 & 1985 \\
\hline Rijksmusea & 293 & 1051,5 & 1051,5 \\
\hline $\begin{array}{l}\text { Rijksmuseum Am- } \\
\text { sterdam }\end{array}$ & 1 & 303 & 303 \\
\hline schaal 18 & 4 & 1 & 1 \\
\hline schaal 15 & - & 4 & 4 \\
\hline schaal 14 & - & - & \\
\hline schaal 13 & 6 & - & - \\
\hline schaal 12 & 17 & 5 & 6 \\
\hline schaal 11 & 8,5 & 25,5 & 24,5 \\
\hline schaal 10 & 52,7 & 2 & 1 \\
\hline schaal 5-9 & 203,8 & 53 & 54 \\
\hline schaal 1-4 & 212,5 & 212,5 \\
\hline
\end{tabular}

\section{Tabel 15.1 Overzicht van het personeel naar salarisschaal (BBRA 1984) ${ }^{687}$}

In Tabel 15.1 is het overzicht van het personeel naar salarisschaal weergegeven. Welke salarisschaal geldt voor een werknemer wordt op grond van artikel 5 lid 2 van het BBRA 1984 bepaald door rekening te houden met de aard en het niveau van de functie die door de ambtelijke werknemer wordt uitgevoerd. Dit wordt bepaald met behulp van functiewaardering. Op grond van artikel 7 BBRA wordt een jaarlijkse periodieke verhoging toegekend. Daarnaast zijn er in het BBRA 1984 bepalingen opgenomen over allerlei toelagen zoals een toelage voor de waarneming van een hogere functie en over de vakantie-uitkering.

Het gaat er hierbij met name om in hoeverre de beloning van het personeel verschilt van de beloning die betaald zou zijn in het geval van een marktconform loongebouw. Er zijn hierover gedurende de onderzoeksperiode geen bronnen te vinden. De vraag in hoeverre de werknemers extra beloond worden kan het beste beantwoord worden door te kijken naar de totstandkoming van de CAO-Rijksmusea. Door de Minister gestelde randvoorwaarden voor de totstandkoming van de CAO hielden in dat de overgang naar een CAO voor de overheid budgettair neutraal zou verlopen en voor het personeel gelijkwaardige arbeidsvoorwaarden zou opleveren ${ }^{688}$ Het beleid van de Minister hield vooral een nettonetto-garantie in. Niemand zou er netto op achteruit mogen gaan. De hoofddirecteur Cultuurbeheer wees erop dat deze twee zaken bijna tegenstrijdig waren. Voor personeelsleden waarvoor het loongebouw lager uitvalt wordt omdat zij er netto niet op achteruit mogen gaan geen opbrengst gecreëerd terwijl personeelsleden die er met een marktconform loongebouw op vooruit gaan niet gekort worden. Er konden binnen het

687 Tweede Kamer, Riikssbegroting van het Ministerie van WVC, vergaderjaar 1984-1985, 18600, hoofdstuk XVI, ar. 3, p. 34.

688 Hoofddirecteur Cultuurbeheer, Brief van 14 oktober 1993 van de hoofddirecteur Cultuurtueheer (HCB). dhr. C. van 'tt Veen aan de Directeur-Generaal woor Culturele Zaken, dhr, I. Vriezen, p. 2. 
Rijksmuseum in dit verband een viertal categorieên werknemers worden onderscheiden: ${ }^{699}$

1. De werknemers die zich onder het loongebouw bevinden en in dat loongebouw geplaatst worden zodra de CAO van kracht wordt. Zij gaan er dus op vooruit.

2. De werknemers die zich voor de in werkingtreding van de CAO en daarna in het loongebouw bevinden:

3. Werknemers die zich boven het loongebouw bevinden en waarvoor een netto-nettogarantie is afgegeven. Deze werknemers blijven daar tot aan het natuurlijke verloop.

4. De werknemers die zich thans in het loongebouw bevinden maar die er op basis van het bestaande ambtelijke perspectieven uitgroeien. Deze groep is vrij groot en zou uiteindelijk $40 \%$ van het totale aantal werknemers kunnen uitmaken.

Pas op lange termijn vinden besparingen plaats, namelijk indien werknemers die behoren tot de categorie garantiegevallen het Rijksmuseum verlaten. Voor de beoordeling van de vraag in hoeverre de werknemers bij het Rijksmuseum beter beloond werden gedurende de jaren '70 en " 80 dan indien zij deel zouden uitmaken van een particulier museum is het van belang te weten in hoeverre de marktconforme $\mathrm{CAO}$, dus bezien op de lange termijn (zonder de compensaties), afwijkt van de ambtelijke beloning. Door de invoering van een zuiver marktconform loongebouw zou ca $50 \%$ van de medewerkers er op achteruitgaan. Op de lange termijn treedt door de CAO een besparing per jaar op van 3,4 miljoen gulden. Dat betekent dat de werknemers van het Rijksmuseum in 1993 dit bedrag kregen boven de beloning die gegeven zou zijn in de marktsector. Dit was ongeveer $17,3 \%$ van de jaarlijkse personeelskosten ${ }^{690}$ Het is redelijk om aan te nemen dat dit ook gedurende de periode 1970-1990 het geval was.

15.6 Wie had het recht om de organisatie van het Rijksmuseum te wijzigen, te verkopen of te liquideren?

De vraag rijst wie het recht heeft de organisatie te wijzigingen of te verkopen. Zoals in hoofdstuk 6 is opgemerkt geeft Künneke aan dat de mogelijkheid voor een onderneming om vermogen op de kapitaalmarkt aan te trekken als een vorm van dit recht dient te worden aangemerkt. Aan het Rijksmuseum is dit recht niet toegekend. Op grond van artikel 39 van de Comptabiliteitswet was daarvoor machtiging door de wet vereist. Dit eigendomsrecht was dan ook in handen van de Kroon en was niet overgedragen aan het Rijksmuseum.

Een belangrijk deel van het Rijksmuseum is de collectie. Ten aanzien van de verkoop van kunstwerken door het Rijksmuseum kan worden geconstateerd dat zodra een kunstwerk eenmaal was toegevoegd aan de collectie deze behoorde aan de Staat der Nederlanden.

${ }^{689}$ T.a.p., pp. 2-3.

${ }^{690}$ Kostenverdeelstaat 1993, de personeelskosten voor 1993 bedroegen F. 19.611.000,-. Vergelijk ook: Accountantsdienst, Controlerapport Nr. AD/C 3280.93.15, inzake het onderzoek naar de financielle yerantwoording over 1993 van het Riikssmuseum te Amsterdam, Rijswijk, 21 november 1994. 
Verkoop ervan was niet mogelijk zonder toestemming van het Ministerie van WVC. 691 Ten aanzien van bruiklenen kan worden opgemerkt dat op grond van artikel 12 van de Instructie Hoofden van Dienst Rijksmusea departementale machtiging nodig was voor kunstobjecten die voor een periode van maximaial zes maanden in bruikleen werden afgestaan. Het departement meende echter dat alleen departementale machtiging nodig was voor echt kostbare stukken. Zij bepaalde dat per 1 juni 1984 alleen nog departementale machtiging nodig was voor bruiklenen van korte termijn naar het buitenland, waarvan de verzekeringswaande F. 500.000 ; - of hoger is. Verder kan worden opgemerkt dat ongeveer $20 \%$ van de schilderijencollectie zich buiten het Rijksmuseum bevond. De Rekenkamer constateert dat er geen actieve controle was op de staat van deze objecten. $^{692}$

Het recht om de organisatie te wijzigen ligt bij het Ministerie van WVC, meer specifiek de Secretaris-Generaal. Alleen het Ministerie is bevoegd, bijvoorbeeld door wijziging van de formatie of door wijzigingen in het budget, om de organisatiestructuur aan te passen. Voor het doorvoeren van reorganisaties zoals bet volledig afstoten van taken, het uitbesteden en het overdragen van taken aan verzelfstandigde organisaties (bijvoorbeeld een N.V.) gelden een aantal regelingen. Voorafgaand aan de verzelfstandiging van diensten werd een onderzoek verricht door interdepartementale ambtelijke werkgroepen. De Interdepartementale begeleidingscommissie Privatisering (IBP) vervalt een adviserende en coördinerende rol bij het onderzoek door deze werkgroepen. Uiteindelijk worden de onderzoeksresultaten, voorzien van een advies van de IBP, aan de Minister van WVC, die het vervolgens aan de Ministerraad aanbiedt voor besluitvorming. Zij beslist over de verder te nemen stappen. Dit proces kan zich herhalen totdat de Ministerraad definitief beslist over het al dan niet privatiseren van de betreffende dienst, i.c. het Rijksmuseum. Op grond van art 105 ARAR is voor beslissingen over belangrijke aangelegenheden die van algemeen belang zijn voor de rechtstoestand van de ambtenaren overleg nodig tussen de Minister van Binnenlandse Zaken en de Centrale Commissie van Georganiseerd Overleg. Verder is overleg nodig met de Bijzondere Commissie van de Rijksdienst. Beide commissies zijn samengesteld uit vertegenwoordigers van de centrales van overheidspersoneel. In de circulaire van 13 februari 1978 is bepaald op welke wijze in het kader van reorganisaties overleg moet worden gevoerd. ${ }^{693}$ Ook in deze circulaire is aangegeven dat overleg met de centrales van overheidspersoneel nodig is. Bepaald is: "De centrales dienen in een zodanig stadium van de besluitvorming worden betrokken, dat hun standpunten bij het nemen van een beslissing mede kunnen worden overwogen " Met de centrales wordt bij reorganisaties alleen overleg gevoerd over personele aspecten. De dienstcommissie kan ook advies geven over de politieke of inhoudelijke wenselijkheid van de reorganisatie. Uiteindelijk moesten ingrijpende wijzigingen in de organisatiestructuur zoals de verzelfstandiging per 1 juli 1995 geregeld worden per wet. Dit recht berust derhalve bij regering en parlement.

69» De Minister van Welzijn, Volksgezondheid en Cultuur namens deze het Hoofd van de Directie Musea, Monumenten en Archieven, aan de onder het ministerie van WVC ressorterende Rijksmusea, MU/BA-U118071 , Machtigingsprocedures, 1 mei 1984.

692 Algemene Rekenkamer, Rapport Rijksmusea, Tweede Kamer, vergaderjaar 1987-1988, 20697, nrs. 1-2, p. 36 .

693 Minister van Binnenlandse Zaken, Onderwerpen van overleg bil reorganisatjes en dergeliike, 13 februari 1978.

694 Ministerie van Binnenlandse Zaken, Directoraat-Generaal voor Overheidspersoneelsbeleid, Directie Overheidspersoneelszaken, Nota personele aspecten wan privatisering, mei 1985 , paragraaf 2.2 .1 . en 2.2 .2 . 
Uit de verdeling van eigendomsrechten kunnen een aantal doelen worden afgeleid.

Het toezicht op het aankoopbelleid berust in verband met de begrotingsprocedure bij het parlement. In allerlei regelingen was het concrete toezicht gelegd bij het Ministerie van WVC. Doelen die hieruit afgeleid kunnen worden houden verband met het meer of minder inzetten van inputs. De overheid bepaalde met behulp van dit recht dat er vergeleken met de marktsector te veel personeel werd ingeschakeld en dat kunstobjecten niet verkocht konden worden (pas na departementale goedkeuring). Groot belang werd gehecht aan het culturele erfgoedkarakter van de kunstcollectie. In de jaren ' 80 begon het Ministerie gedeeltes van dit recht over te hevelen naar het Rijksmuseum. Het Ministerie beoogde mede dat hierdoor minder inputs zouden worden ingezet. Hierdoor konden minder bijkomende doelen zoals werkgelegenheid worden nagestreefd.

Het toezicht op de productieresultaten is voornamelijk in handen van het management van het Rijksmuseum, meer in het bijzonder van de hoofddirecteur. Onder andere omdat doelstellingen veelal impliciet waren konden ook andere werknemers invloed uitoefenen op de productieresultaten. Derhalve is de conclusie gerechtvaardigd dat dit recht voor een belangrijk deel in handen is van het management en voor het overige verspreid is over de diverse afdelingen. Dit impliceert enerzijds dat de Hoofddirectie met behulp van dit recht een aantal doelen kon verwezenlijken. Met het oog op de presentatie- en behouds- en beheersfunctie streefde zij naar een zo groot mogelijke collectie en een zo goed mogelijke reputatie van het Rijksmuseum. De overige werknemers die invloed kunnen uitoefenen zullen enerzijds doelen nastreven als een zo groot mogelijke collectie van kunstvoorwerpen voor de afdeling waarvoor zij werken, meer personeel en in het algemeen het belangrijker maken van die betreffende afdelingen. Anderzijds kunnen doelen gelegen zijn in het bevorderen van de eigen positie in de organisatie. Hierbij kan gedacht worden aan promotie, hogere salarissen, meer verlof en arbeidstijdverkorting en minder werkdruk.

Het recht toezicht uit te oefenen op de externe effecten is zoals uiteengezet indirect geconcentreerd bij het Ministerie. Het Ministerie streefde tal van bijkomende doelen na. Eind jaren " 80 is het Ministerie minder gewicht gaan toekennen aan de door het Rijksmuseum gecreeerde externe effecten en dienovereenkomstig is zij begonnen met het terugbrengen ervan. Minder nadruk wordt gelegd op de doelstelling dat iedereen tegen zo laag mogelijke prijzen toegang moet krijgen tot het Rijksmuseum terwijl juist meer de nadruk wordt gelegd op budgettaire doelen als bezuinigen.

\section{Het recht toezicht uit te oefenen op het productieproces}

Het toezicht op het productieproces is sterk verspreid. Dit leidt er toe dat individuen in de organisatie in staat zijn hun doelen na te streven. Mogelijke doelen zijn ook hier gelegen in vergroting van hun bevoegdheden, individuele doelen als het veilig stellen van werkgelegenheid e.d.

Het toezicht op de omvang en de samenstelling is voornamelijk in handen van het Ministerie. Het voornaamste doel dat hieruit kan worden afgeleid is dat een relatief groot personeelsbestand werd aangehouden. Voorts valt op dat de Hoofddirectie van het Rijksmuseum relatief laag beloond werd, terwijl per saldo het personeel van het Rijksmuseum beter beloond werd dan in de marktsector. Ook voor dit recht geldt dat eind jaren ' 80 veranderingen in de doelen zijn opgetreden, terwijl een bescheiden gedeelte van dit 
recht is overgeheveld naar het Rijksmuseum. Het doel hiervan was het verminderen van het streven naar bijkomende doelen, minder personeel (gedeeltelijke personeelstops), minder promoties en meer technische efficièntie.

Het recht op de winst is minder van belang aangezien het Rijksmuseum geen winst maakt maar juist is aangewezen op middelen van het rijk. Aangegeven is echter dat het personeel per saldo een hogere beloning krijgt dan het geval zou zijn in de marktsector. Dit kan worden gezien als een claim op de winst. Het doel dat hieruit kan worden afgeleid is dan ook dat werknemers een relatief hoge beloning krijgen.

Het recht om de organisatie te verkopen is niet toegekend. Het recht om de organisatie te wijzigen is zoals uiteengezet in handen van het parlement en het Ministerie. Hieruit kan worden afgelleid dat met name de politieke actoren in staat zijn met dit eigendomsrecht hun doelen na te streven. Het Rijksmuseum had geen toegang tot de kapitaalmarkt, hetgeen impliceert dat het streven naar technische efficiëntie beperkt was. Het Rijksmuseum kon bovendien niet zelfstandig kunstobjecten verkopen. Eén en ander impliceert dat: de eigenaren van dit recht groot belang hechten aan het culturele erfgoed karakter van de collectie.

\subsection{Het analyseren van de ontsluierde "performance" van het Rijksmuseum}

15.8.1 Welke doelen worden kenbaar gemaakt in documenten en welke doelen worden door de bij het Rijksmuseum betrokken principalen genoemd?

Bij het totstandkomen wan het beleid van het Rijksmuseum zijn, zoals gemeld, actoren binnen een tweetal instanties van belang. De actoren binnen het Ministerie van WVC houden zich bezig met de beleidsvaststelling en controle op de beleidsuitwoering. De leiding en medewerkers van het Rijksmuseum houden zich met name bezig met beleidsvoorbereiding en beleidsuitvoering.

\subsubsection{Beleid van het Ministerie van WVC}

In deze paragraaf wordt ingegaan op het kunstbeleid van de overheid en doelstellingen van de overheid/politieke actoren zoals die in officiele documenten zijn terug te vinden.

Het kunstbeleid en de betreffende wetgeving vallen onder het Ministerie van Welzijn, Volksgezondheid en Cultuur. Door dit Ministerie wordt het kunstbeleid in de Kunst- en Museumnota opgesteld. Oorspronkelijk was het de bedoeling dat deze wetsvoorbereidende nota's zouden aangeven hoe het inhoudelijk beleid zou worden ingepast in de Kaderwet Specifiek Welzijn. Deze wet is echter ingetrokken. Beide nota's en de parlementaire behandeling van de wet geven nu een beeld van de doelen van de regering en het parlement. Het kunstbeleid omschrijft de doelstellingen ten aanzien van de cultuur. Aangezien de musea onder cultuurbehoud vallen, zijn de doelstellingen ook vam toepassing op het Rijksmuseum. Voor ons zijn. verder met name de museumnota's van belang; In verband met de veranderingen op museaal, economisch, maatschappelijk en bestuurlijk gebied is 
het beleid zoals neergelegd in de nota "Naar een nieuw museumbeleid" uit 1976 halverwege de jaren " 80 geactualiseerd. Dit is gebeurd in ce Concept-Museumnota en de Museumnota van 1985 . Beide zullen hier worden gebruikt aangezien ze tezamen een goed inzicht geven in de doelen van het departement.

\section{Overheidsimploed}

Uitgangspunt voor het kunstbeleid is lang de bekende stelling van Thorbecke geweest: "Kunst is geen regeringszaak", die hij nog eens bevestigde tijdens een redevoering in de Tweede Kamer op 15 september 1862 . De bemoeienis van de rijksoverheid met de musea bleef tot ver in de twintigste eeuw beperikt tot een klein aantal rijksmusea. Musea werden vooral opgericht door particulieren en niet door de overheid. De nieuwe rijksmusea die werden gesticht in de periode tot 1940 waren vooral het gevolg van schenkingen en legateringen door particulieren van collecties en behuizingen aan de staat. De rijksoverheid stuurde niet maar volgde op afstand. Desondanks is de directe centrale bemoeienis bij de aankoop van kunstwerken en musea sterk toegenomen. Het subsidie-instrument is het belangrijkste instrument voor het Ministerie. Het is echter niet het enige instrument. Sinds de jaren '80 zijn de marktvernimende stimulerende maatregelen zoals het aankoopbeleid van de overheid en rentesubsidies an consumenten aan de subsidiemaatregelen toegevoegd. De overheid probeert steeds minder de enige financier te zijn. Sponsoring moet meer de aandacht krijgen. Het subsidie-instrument is aan het einde van de jaren ' 80 meer taakstellend. Hierbij moet gemeld worden dat de overheid zich niet alleen laat leiden door overwegingen van prestige, populariteit, maatschappelijk en economisch rendement om de cultuur te bevorderen. In de Museumnota van 1976 werd duidelijk de richting waarin het beleid zich zou moeten ontwikkelen aangegeven. ${ }^{69}$ Sedert enkele decennia worden de woorden van Thorbecke dan ook anders geilnterpreteerd. Halverwege de jaren " 80 leek de overheid zich weer meer terughoudend ten opzichte van de kunst te willen opstellen. Zo schreef de Minister van WVC in de begroting vam 1985: "Ik constateer dat cultutur-(...)-in ons land althans, niet het onderwerp of voorwerp is van het cultuurbeleid' en zelfs miet van de overheidszarg in een ruimer verband. Hiermee is een praktische en een principielle overweging gemoeid. De praktische luidt dat de overheid weliswaar op allerlei deelterreinen van de cultuur een rol vervult en ook te vervullen heef, maar dat het haar comperentie te boven gaat, de cultuur als zodanig te sturen. Principiele overweging is de overheid zich in deze geen taak behoort toe te kennen" "697. Politici mogen zich wilet inhoudelijk met kunst bemoeien. Het is aan deskundigen om advies te geven en een oordeel te vellen. De jaren ' 80 stonden in het teken van het terugtreden van de overheid. Onder deze noemer zijn er flinke verschuivingen zichtbaar in het beleid van de overheid. Rond $1980 \mathrm{lag}$ het accent sterk op de interngerichte reorganisatie van de overheid. Hierbij valt te denken aan reorganisatie van de rijksdienst e.d. . Na 1983 is de nadruk komen te liggen op het externe, inhoudelijke functioneren van de overheid. Dit heeft ook belang-

695 Tweede Kamer, Nota Naar een nieuw museumbeleid, van het Ministerie van Cultuur, Recreatie en Maatschappelijk Werk, zittingsjaar 1976-1977, ar. 14290, nrs. 1-2, 21-21977.

696 Minister van Welzijn, Volksgezondhedd en Cultunr (WVC), Nota Museumbeleid, Tweede Kamer, Vergaderjaar 1984-1985, 19066, ars 1-2, p. 3.

697 Tweedle Kamer der Staten-Generaal (vergaderjaar 1984-1985), Rijksbegroting van WVC, 18600, hoofdstuk XVI, nr. 2, p. 76. 
rijke consequenties gehad voor het cultuurbeleid, meer in het bijzonder voor het museumbeleid. In de concept-Nota Museumbeleid wordt als doelstelling van musea genoemd: Musea vormen belangrijke instrumenten voor het cultuurbehoud en de cultuuroverdracht. In de Nota wordt het fundamentele verband tussen hun behouds- en presentatiefuncties en -taken gelegd en wordt de betekenis van het educatieve beleid voor en van de musea onderkend en benadrukt, evenals het belang van hun gerichtheid op een breed publiek" 698

Bij het museumbeleid van de Rijksoverheid kan onderscheid gemaakt worden tussen de verantwoordelijkheid van de Rijksoverheid voor het museale bestel als geheel en de verantwoordelijkheid van het $\mathrm{Rijk}$ voor museale instellingen. Met betrekking tot het museale bestel als geheel kan weer onderscheid gemaakt worden tussen sectorale en bovensectorale aspecten. De sectorale aspecten (volkenkunde, cultuurhistorie e.d.) komen aan bod in sectornota's. Bij de bovensectorale aspecten kan gedacht worden aan conservering, educatie, deskundigheidsbevordering en automatisering. Ook deze aspecten worden in afzonderlijke nota's behandeld. Naast de verantwoordelijkheid voor het bestel als geheel is het rijk ook verantwoordelijk voor afzonderlijke musea van nationaal belang; waaronder het Rijksmuseum Amsterdam. In dit verband is de Museumnota 1976 van betekenis, waarin het beleid van de overheid wordt geschetst. Bij het museumbeleid wordt de Minister bijgestaan door de afdeling III van de Monumentenraad, de Rijkscommisie voor de Musea en de Commissie van Advies voor de Natuurhistorische Musea. In het Kunstbeleid zijn een tweetal categorieën doelstellingen te onderscheiden, namelijk culnurinhoudelijke en bestuurlijke doelen.

\section{Cultururinhoudelijke doelstellingen:}

In het kader van de cultuurinhoudelijke doelstellingen kunnen een drietal categorieên onderscheiden worden: ${ }^{699}$

1) Behoud van kunst.

2) Het toegankelijk maken hiervan, de publiekstaak. ${ }^{700}$

3) Het bevorderen van deelneming aan de culturur.

4) Overige doelen:

\section{ad.1) Behoud en vernieuwing van culturele waarden}

In dit verband zijn het ontwikkelen en in stand houden van culturele waarden en het bewaren en overdragen van het natuurlijke en culturele erfgoed met het oog op een menswaardig leefklimaat voor de toekomst van belang. Verder wordt het extra stimuleren van

6s Concept-Nota Museumbeleid, maart 1985, p. 3. Zie ook de definitieve nota Museumbeleid, Tweede Kamer der Staten-Generaal (vergaderjaar 1984-1985), 19066, nrs. 1-2.

699 Tweede Kamer der Staten-Generaal (vergaderjaar 1984-1985), Rijksbegroting van WVC, 18600 hoofdstuk XVI, nr. 2 ; pp. 76-77.

${ }^{700}$ Minister van Welzijn, Volksgezondheid en Culturur (WVC), Concept-Nota Museumbeleid, maart 1985, $p$, 11. In de definitieve nota Museumbeleid wordt onderscheid gemaakt tussen de behoudtaak en de publiekstaak, nota Museumbeleid, Tweede Kamer, vergaderjaar 1984-1985, 19066, nrs. 1-2. 
culwurvernieuwing, hetgeen kan bijdragen aan een meer leefbare maatschappij met een rechtvaardige verdeling van materiële en immateriële goederen, belangrijk geacht. In de begroting van WVC van 1985 wordt dit doel genoemd en wordt opgemerkt dat het culturele erfgoed bedreigd wordt: ${ }^{701}$

Het gaat daarbij met name om conservering en restauratie. De behoudsfunctie wordt gezien als uitgangspunt voor de presentatiefunctie. Zonder een goed onderhouden collectie geen presentatie. Voor een goede wijze van conservering en restauratile is kwallitatieve en kwantitatieve inventarisatie essentieel. Geconstateerd wordt dat de condities waaronder kunst in de Nederlandse musea bewaard wordt vaak bedroevend zijn. ${ }^{702}$

ad.2) Het toegankelijk maken van cultuur: de presentatiedoelstelling.

In de Concept-Nota Museumbeleid staat vermeld: "Het is de wens van de rijksoverheid de participatie van het publiek aan de cultuur te stimuleren".

(samen met punt 3 "merit good"-aspect). Geconstateerd wordt dat veel musea hieraan bijdragen. Daar staat, zoals in paragraaf 15.4 .1 .5 .1 . is opgemerkt, tegenover dat vanwege budgettaire redenen musea sinds het begin van de jaren ' 80 op maandag gesloten zijn.

Ook het toerisme wordt steeds belangrijker geacht. In de begroting wordt gesteld: ${ }^{704}$ Dat ons cultureel erfgoed ook een zeer aantrekkelijk aanbod vormt in recreatieve en toeristische zin wordt in toenemende mate beseft. Om deze waarde zo goed mogelijk te benutten, met name ten aanzien van het inkomend toerisme vindt structureel overleg plaats met het ministerie van Economische Zaken en het Nationaal Bureau voor Toerisme". Het Nederlands Research Institunt voor Recreatie en Toerisme heeft het onderzoeksrapport "Erfgoed-toeristisch goed" gepresenteerd over de toeristisch-economische betekenis van monumenten en musea in Nederland met als belangrijkste conclusie dat de aanwezige toeristische mogelijkheden onvoldoende worden benut. ${ }^{705}$

De Minister probeert het museumbezoek te vergroten door een aantal maatregelen, waaronder de participatie in de Stichting Museum Jaarkaart van alle rijksmusea en de bevordering van de samenwerking door musea, onder meer door bruikleengeving van kunst over en weer. De Minister streeft naar een indemniteitsclausule, waarbij de overheid zich garant stelt voor schade aan bruiklenen uit een ander land. Dit heeft voor de musea het voordeel dat zij dan geen verzekeringspremies hoeven te betalen. De musea worden dan minder gedwongen om zich bij tentoonstellingen te beperken tot de eigen collectie. Daarnaast acht de Minister het van groot belang dat nieuwe inzichten worden gepresenteerd. Dat geldt met betrekking tot de inhoud maar ook ten aanzien van nieuwe wijzen van presentatie en publieksbegeleiding. Opvallend is dat de Minister probeert te komen tot een duidelijke afbakening van de taken en verantwoordelijkheden van de

\footnotetext{
701 T.a.p. p. 80 .
}

702 De Minister van Welzijn, Volksgezondheid en Cultuur (WVC), Concept-Nota Museumbeleid, t.a.p, p. 15.

${ }^{703}$ T.a.p., p. 16.

70\%. T.a.p., p. 81 .

${ }^{705}$ Nederlandls Research Instinut voor Recreatie en Toerisme, Rappont "Erfgoed: Toeristisch goed!", in opdracht van W.V.C. en E.Z., november 1983. 


\section{ad.3) Het bevorderen van deelneming aan de cultuur}

Het bevorderen van de mogelijkheden van de bevolking om in culturele waarden te participeren. Deze doelstelling is een verbreding van de tweede. Het gaat hier niet alleen om vergroting van de toegankelijkheid van de voorzieningen, maar ook om persoonlijke ontwikkeling en bewustwording, vergroting van het inzicht in de samenleving en de afstemming van de voorzieningen op belangen en verlangens van de mensen.

\section{ad.4) Verschillende andere genoemde doelen worden genoemd, te weten ${ }^{706}$}

Ter bevordering van de kwaliteit van musea is het van groot belang dat medewerkers goed gekwalificeerd zijn. In dit verband wordt ook overleg gevoerd met universiteiten; meer in het bijzonder over museologie en vakdidactiek. De Minister will voorts de deskundigheid van het aanwezige personeel bevorderen door middel van cursussen, symposia, en publikaties. Daarnaast wil de Minister de gegevens met betrekking tot bet beheer en de documentatie van de collectie van de verschillende musea zoveel mogelijk op elkaar afstemmen, onder meer met behulp van automatisering. Daartoe heeft de door WVC gesubsidieerde stichting "Murdoc" een systeem voor museale automatisering ontworpen. Dit systeem wordt door de rijksmusea gebruikt. Deze stichting begeleidt tevens het automatiseringsproces van de rijksmusea.

Verder wordt onderzoek belangrijk geacht. Doel daarvan is vooral ook de effectiviteit van maatregelen in de toekomst te vergroten. In dit verband wordt met andere instellingen door het Ministerie onderzoek verricht naar de musea.

Ook wordt de betekenis van musea voor het onderwijs van groot belang geacht. Geconstateerd wordt dat sinds het begin van de jaren 70 deze doelstelling belangrijker is geworden. Voorts werd opgemerkt dat de spreiding van de presentatie van met name moderne kunst een belangrijk doel was. De drie grote steden vervullen op cultureel gebied een bijzondere rol, hetgeen gezien kan worden als een vervulling van de rijkstaak.

Tenslotte kan als doelstelling nog de beloning van het personeel genoemd worden. Dit is niet alleen een doel van de politieke actoren ten opzichte van het Rijksmuseum maar ten opzichte van alle ambtenaren. ${ }^{707}$ Het recht op bezoldiging is steeds ruimer geweest dan de geleverde tegenprestatie. Een aantal redenen kunnen hiervoor worden aangevoerd. De belangrijkste zijn de gedachte dat ambtenaren zich volledig aan hun taak moeten kunnen wijden en dus niet allerlei bijbanen nodig moeten hebben en daarnaast het idee dat de staat ten opzichte van zijn personeel een voorbeeldfunctie voor particuliere werkgevers te vervullen heeft.

Eind jaren tachtig en begin jaren negentig legt de overheid steeds meer de nadruk op interne en later ook op externe verzelfstandiging. De beoogde budgetfinanciering wan instellingen leidt ertoe dat de overheid eisen stelt aan de prestaties van de instellingen,

\footnotetext{
706 Minister van Welzijn, Volksgezondheid en Cultur, Concept-Nota Museumbeleid, maart 1985, p. 12 ev.. Vergellijk ook de definitieve Nota Museumbeleid, Tweede Kamer der Staten-Generaal (vergaderjaar 1984-1985), 19066, nis. 1-2, pp. $13 \mathrm{ev.}$

707 Vergelijk in dít verband bijvoorbeeld het rapport van de staatscommissie-Kranenbürg uit 1958 over de status van ambtenaren.
} 
maar geeft de instellingen ook een grotere autonomie met name bij het management. Dit geldt ook voor het Rijksmuseum. De eisen die de doelen van het Ministerie aan het eind van de jaren tachtig weerspiegelen zijn met name:

\section{- Kwaliteit}

Het begrip kwaliteit moet num worden opgevat. De gedachte is dat kunst en cultuur de kwaliteit van het bestaan bevorderen. Kwaliteit wordt nadrukkelijk gezien als een criterium voor overheidssteun. $\mathrm{Zij}$ heeft dan meer de betekenis van professionele degelijkheid. In het algemeen leeft het idee dat indien over de kwaliteit positief geoordeeld wordt, de mate wan publieke belangstelling miet maatgevend mag zijn. Uitgaande van de kwaliteitsnorm bij de subsidiëring van het aanbod, moet de overheid de gevestigde en nieuwe kunstwormen meer gelijke kansen geven. Bescherming van het kwetsbare speelt een rol bij de handhaving en versterking van onze nationale culturele identiteit.

\section{- Aanbod}

Eind jaren ' 80 en begin jaren ' 90 wordt ook nadrukkelijk gewezen op het belang van een regionaal evenwichtig gespreid aanbod. Pluriformiteit van het aanbod wordt gezien als een belangrijk uitgangspunt bij de subsidiëring, maar de overheid hoeft niet te bevorderen dat iedere stroming thaar deel krijgt. Bij de beleidsafweging zijn de genoemde kwaliteitsoverwegingen en de afweging van middelen in het kader van de begrotingsprocedure ook bepalend.

\section{- Publiekswerving}

Eind jaren '80 leeft meer en meer het idee dat van alle gesubsidieerde producenten mag worden verwacht dat zij an actieve publiekswerving doen en dat zij proberen hun marktpositie te versterken. Indien bepaalde voorzieningen bekostigd kumnen worden via entreegelden en andere ontvangsten zal de ruimte voor de meer kwetsbare zaken toenemen.

De genoemde kwaliteitsgedachte met betrekking tot het aanbod laat onverlet dat de gesubsidieerde instelling alles moet doen om zoveel mogelijk betalende bezoekers te trekken. Meer en meer wordi er naar gestreefd alle gesubsidieerde instellingen een duidelijke taak te geven bij de publiekswerving. Hierbij wordt ingezien dat de norm die door de overheid gehanteerd wordt niet voor iedere aanbieder van kunst gelijk hoeft te zijn. De aard van de kunstvormen speelt hierbij ook een rol.

\section{Bestuurliike doelstellingen:}

De bestuurlijke uitgangspunten en doelstellingen zijn veelal een afgeleide van in 1977 ingediende wetsvoorstellen inzake de reorganisatie van het binnenlands bestuur en de welzijnssector. Hierbij kan gedacht worden aan reorganisatie, decentralisatie, samenhang tussen welzijnssectoren, democratische beleidsvoorbereiding en planning ${ }^{708}$ Daarnaast is het onderzoeksrapport "Zorg voor het museum" uit 1983 van belang hetgeen als een synthese van de inzichten op bestuurlijk terrein gezien kan worden. Ten aanzien van de

${ }^{708}$ IKON Beleidsconsulenten (1987a, p. 265). 
bestuurlijke doelstellingen zijn met name een tweetal zaken van bellang. Enerzijds worden musea vanaf 1990 niet meer gelijktijdig gefinancierd door het departement van WVC en lagere overheden gezamenlijk. Er vindt in deze een duidelijke scheiding plaats, waarbij de door het Ministerie gesubsidieerde musea aan een aantal criteria moeten voldoen. ${ }^{700}$ Daarnaast wordt er gestreefd naar interne en externe verzelfstandiging.

\subsubsection{Beleid van het Rijksmuseum}

Voor 1985 waren de doelen van het Rijksmuseum in feite niet vastgelegd in een door de beleidsdirectie goedgekeurd beleidsplan (nota). De Accountantsdienst merkt op dat het jaarlijks door de hoofddirecteur opgestelde verslag te veel een overzicht is van verrichte activiteiten en een opsomming van aanwinsten en te weinig een kwantitatieve weergave is van de bedrijfsmatige en financiële activiteiten. De doelen worden niet duidelijk weergegeven. Het Rijksmuseum heeft geprobeerd door middel van het opstellen van een beleidsnota hierin verandering te brengen. Uit de beleidsnota van 1985 en de jaarverslagen van het Rijksmuseum blijkt dat het Rijksmuseum zich ten doel stelde voor een nationaal en internationaal publiek een volledig overzicht te geven van de Nederlandse kunst en geschiedenis vanaf de middeleeuwen en belangrijke aspecten van Europese en Aziatische kunst te tonen ${ }^{710}$ Hieruit kunnen een aantal doelstellingen worden afgeleid. Een eerste doelstelling heeft betrekking op het bewaren, beheren, conserveren en restaureren en kan worden aangeduid als de conserverende doelstelling. Daarnaast is er een kunsthistorische en/of historische doelstelling waarbij het wetenschappelijk onderzoeken en bewerken centraal staat. Voorts is er een verzameldoelstelling die betrekking heeft op de verwerving van kunstwerken. Deze verzameldoelstelling is drieledig. $\mathrm{Zij}$ is gericht op het invullen van lacunes, zij is gericht op verbetering van de kwaliteit en zij is gericht op het verkrijgen van aansluiting bij hoofdstedelijke collecties. ${ }^{71}$ Tenslotte kan een externe publieksdoelstelling worden onderscheiden. Deze doelstelling beoogt kunst toegankelijk te maken hetgeen zich onder andere vertaalt in het organiseren van tentoonstellingen. ${ }^{72}$ Een andere doelstelling van het Rijksmuseum heeft betrekking op het bevorderen van de werkgelegenheid. Dit is gedeeltelijk een intermediair doel, nodig om andere doelen te bereiken en gedeeltelijk een doel in zichzelf. Daarnaast vormen goede arbeidsvoorwaarden een doel voor de directie van het Rijksmuseum. Dit bleek ook uit het door het Rijksmuseum gevoerde beleid in de periode 1970-1990.

Het beleid van het Rijksmuseum ten aanzien van de doeleinden was veelal impliciet. Voorts gold, mede ten gevolge van het ontbreken van sturingsmiddelen van WVC, dat de beleidsontwikkeling, -vaststelling en -uitvoering voor een deel ongepland geschiedde. Bij het verrichtten van activiteiten bestond daardoor relatief veel ruimte voor eigen interpretatie van actoren.

\footnotetext{
${ }^{709}$ T.a.p., p. 6. Een drietal criteria worden genoemd die unhouden dat musea slechts voor subsidiëring in aanmerking komen indien zij van national belang zijin.

${ }^{710}$ Beleidsnota van het Rijksmuseum, Amsterdam, maart 1985, pp. 2-3.

711 Rijksmuseum Amsterdam, Concept-beleidsnota, Amsterdam, oktober 1983, p. 19.

712 [KON Beleidsconsulenten (1987a, p. 41).
} 


\subsubsection{Welke doeleinden worden genoemd in niet-officiële documenten?}

De in niet-officiele documenten gevonden doelen wijken niet af van de officiële doelen. Hierbij kan gedacht worden aan de diverse circulaires van het departement, redevoeringen van de directeur van het Rijksmuseum gedurende deze periode en de correspondentiewisseling tussen het Ministerie en het management en binnen het Rijksmuseum zelf. Zo wordt opgemerkt dat het Rijksmuseum oog heeft voor het belang van het presenteren van haar kunstcollectie. ${ }^{713}$. In onder meer het Groot Beraad wordt uitgebreid gesproken over het belang van de presentatie en over de aan te brengen verbeteringen. Zo werd gesteld: "Enerzijds kan gesteld worden dat het Rijksmuseum een nationale taak heefi in het geven van een brede presentatie, en dat de beperkingen van het huidige gebouw niet de grenzen van de presentatie zouden moeten bepalen, maar dat een nieuwbouw wellicht de oplossing voor dit probleem biedt. Anderzijds kan men kiezen voor een grotere, over alle perioden evenwichtige, selectie, waarbij ook de rest van het bezit in studiecollecties toegankelijk zou moeten blijven. Vooral in het laatste geval zou men door periodieke wijzigingen in de opstellingen kunnen inspelen op nieuwe kunsthistorische inzichten". ${ }^{714}$ Ook het belang van het organiseren van tentoonstellingen werd door het management gezien als een belangrijk doel ${ }^{715}$ Verder werd ook het doel van het zoveel mogelijk instandhouden van de werkgelegenheid genoemd. Het management probeerde de vermindering van de werkgelegenheid ten gevolge van de bezuinigingsoperaties van het Ministerie op het personeelsbestand, zo beperkt mogelijk te houden ${ }^{716}$ Daarbij wijst het management onder meer op het structurele personeelstekort bij de bewaking, hetgeen een optimaal functioneren van het Rijksmuseum in de weg staat. In het Groot Beraad werd ingegaan op het belang van het behoud en beheer van kunst. Aangegeven werd dat het ruimtegebrek moet worden aangepakt; aangezien dit het Rijksmuseum ernstig hinderde. ${ }^{71}$. Verder werd gesteld dat het publiek te weinig prioriteit heeft in het Rijksmuseum. ${ }^{718}$ Ook wordt de spreiding van het kunstbezit als doel genoemd. Voor zover het Rijksmuseum twintigste eeuwse kunstobjecten verzamelt doet het dat op gebieden die het Stedelijk Museum laat liggen. ${ }^{719}$ Verder worden het educatieve doel en het belang van wetenschappelijk onderzoek genoemd, alsmede het grote belang van het Rijksmuseum voor het Nederlandse culturele bezit. ${ }^{720}$

713 De Minister van Welzijn, Volksgezondheid en Culturu, namens deze het Hoofd van de Hoofdafdeling Bebeer-MMA a:i:, MMA/B-24631, brief aan de Voorzitter van de Nederlandse Gidsen, Organisatie Quidor, toegang groepen en gidsing in een aantal rilksmusea, 24 juni 1987.

${ }^{714}$ T.a.p., pp. 2-3. Vergelijk ook het verslag over het Groot Beraad op 16 december 1980.

${ }^{715}$ De Directeur van het Rijksmuseum, Nieuwiaarswoord over 1986, 31 december 1986.

${ }^{716}$ Hoofddirecteur Rijksmuseum, Bekendmaking, 2 december 1986.

717 De Directeur van het Rijksmuseum, Nieuwiaarswoord over 1986, 31 december 1986.

${ }^{718}$ Filledt Kok (1985, p. 2).

${ }^{719}$ Het Groot Beraad, Het Rijksmuseum en de presentatie van de 19de-eeuwse kunst, 2 november 1983, p. 2.

720 Praatpapier, dienstverlening, ten behoeve van het Groot Beraad van 11 december 1981. 
15.8.3 Een overzicht van de doeleinden

De doelen van het Rijksmuseum kunnen als volgt worden weergegeven.

\begin{tabular}{|c|c|c|c|c|c|}
\hline Doelen & $\begin{array}{l}\text { Doeleinden } \\
\text { gevonden } \\
\text { met analyse } \\
\text { kenbaar ge- } \\
\text { maakte doe- } \\
\text { len }\end{array}$ & Ministerie & $\begin{array}{l}\text { mamage- } \\
\text { ment }\end{array}$ & $\begin{array}{l}\text { Doeleinden } \\
\text { strue- } \\
\text { turranalyse }\end{array}$ & $\begin{array}{l}\text { Doeleinden } \\
\text { gevonden met } \\
\text { beide analyses }\end{array}$ \\
\hline $\begin{array}{l}1 . \\
\text { Bewaren }\end{array}$ & $x$ & 8 & $x$ & $x$ & $x$ \\
\hline $\begin{array}{l}2 . \\
\text { Toegankelijk maken } \\
\text { en presentatie }\end{array}$ & $x$ & $x$ & $\mathrm{xx}$ & 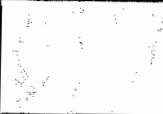 & \\
\hline $\begin{array}{l}\text { 3. } \\
\text { Bevorderen cultuur- } \\
\text { deelname en publie- } \\
\text { kswerving }\end{array}$ & $\mathrm{x}$ & $\therefore \quad 8$ & 4 & $\mathrm{x}$ & $x$ \\
\hline $\begin{array}{l}4 . \\
\text { Wetenschappelijk } \\
\text { onderzoek }\end{array}$ & $\mathrm{x}$ & $x$ & $x+4$ & $\mathrm{x}$ & $x$ \\
\hline $\begin{array}{l}\text { 5. } \\
\text { Verzameldoelstel- } \\
\text { ling }\end{array}$ & $x$ & $x$ & $x$ & $\mathrm{x}$ & 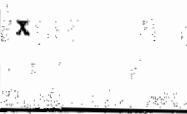 \\
\hline $\begin{array}{l}6 . \\
\text { Werkgelegenheid }\end{array}$ & 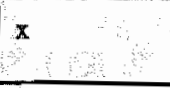 & 8 & $\mathrm{x}$ & $\mathrm{x}$ & $\mathrm{x}$ \\
\hline $\begin{array}{l}\text { 7. } \\
\text { Educarieve functie }\end{array}$ & $x$ & $x$ & $x$ & $x$ & $x$ \\
\hline $\begin{array}{l}8 . \\
\text { Culturele } \\
\text { erfgoed }\end{array}$ & $\mathrm{x}$ & $\mathbf{x}$ & $\mathbf{x x}$ & $x$ & $x$ \\
\hline $\begin{array}{l}9 . \\
\text { Bevorderen regio- } \\
\text { naal } \\
\text { evenwichtig ge- } \\
\text { spreid aanbod }\end{array}$ & $x$ & $x$ & & & \\
\hline $\begin{array}{l}\text { 10. } \\
\text { Beloning personeel }\end{array}$ & & $x$ & & $x$ & $x$ \\
\hline $\begin{array}{l}11 . \\
\text { Bevorderen } \\
\text { kunstmarikt A'dam }\end{array}$ & & & $x$ & $x$ & $x$ \\
\hline $\begin{array}{l}12 . \\
\text { Bewordering toe- } \\
\text { risme }\end{array}$ & & $x$ & 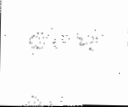 & $x$ & $x$ \\
\hline
\end{tabular}

Tabel 15.2 De gevonden doelen van het Rijksmuseum 


\subsection{Het bepalen van de reeks van doelen}

Het Rijksmuseum houdt zich vooral bezig met de bescherming van het culturele erfgoed. In dit verband kan onderscheid gemaakt worden tussen het conserveren van de kunstvoorwerpen, de presentatie en de educatie. Het eigenlijke doel van het Rijksmuseum is het bewaren van kunstwerken. Dit is het belangrijkste doel van het Rijksmuseum en wordt zowell door de politieke actoren als door het management nagestreefd. Als bijkomende doelen kunnen de presentatie van kunstwerken, het bevorderen van cultuurdeelname, het verrichten van wetenschappelijk onderzoek, het verzamelen van kunstwerken, de bevordering van de werkgelegenheid en tenslotte de categorie overige doelen worden aangemerkt. Bij deze categorie kan gedacht worden aan salariswensen, arbeidlsomstandigheden etc.. Opvallend is dat zowel politieke actoren als het management tal van doelen zeggen na te streven. Indien het feitelijke beleid en de bijbehorende eigendomsverhoudingen geanalyseerd worden valt op dat de overbeid als principaal er naar streeft te bezuinigen op het Rijksmuseum. Dit leidt er toe dat aan vrijwel alle doelen minder besteed wordt. De overheid stelt zich steeds meer op het standpunt dat de presentatie van kunst aan het publiek belangrijk is en dat de bewaarfunctie te veel wordt geaccentueerd. Het Rijksmuseum moet volgens de principaal meer afhankelijk worden van de bijdragen van bezoekers en sponsors. Budgetten worden verminderd, waaronder het budget voor kunstaankopen.

\subsection{In hoeverre zijn deze doelen verwezenlijkt en is deze verwezenlijking continu?}

In paragraaf 15.9 is beschreven welke doelen door het Rijksmuseum werden nagestreefd. Om de "performance" te bepalen moeten de doelen van de eigenaren vergeleken worden met de feitelijke doelrealisatie. Een belangrijk probleem hierbij is dat de doelen niet duidelijk zijn afgebakend. Ze zijn vaag geformuleerd, waardoor het moeilijk te beoordelen is in hoeverre deze doelen gerealiseerd zijn. ${ }^{721}$ In het IKON-rapport wordt in dit verband opgemerkt: "Doelstelling Rijksmuseum levert maximale ruimte voor subjectieve interpretatie $o p "$. De Algemene Rekenkamer heeft eind jaren tachtig een onderzoek verricht naar de sterke en zwakke punten en de wijze waarop het Rijksmuseum zijn taken uitvoerde. De resultaten hiervan sluiten veelal aan bij de bevindingen zoals verwoord in deze paragraaf en kunnen als volgt worden samengevat. ${ }^{22}$

\begin{tabular}{|l|l|l|l|l|l||}
\hline Collectiebeheer & & Publieksgerichtheid & & Publieke belangstelling & \\
\hline registratie & + & tentoonstellingsbeleid & + & $\begin{array}{l}\text { ontwikkeling bezoekersaantal- } \\
\text { len }\end{array}$ & + \\
\hline conservering & - & "public relations"-activiteiten & + & Wetenschappel. doelstelling & \\
\hline restauratie & - & $\begin{array}{l}\text { bereikbarheid museum (o.a. } \\
\text { locatie) }\end{array}$ & ++ & studie, lezingen, publikaties & + \\
\hline
\end{tabular}

sterke en zwakke kanten (naar kwaliteit, kwantiteit e.d.):

t* * raim voldoende

4 : voldoendile

t. - voldoende/orvoldoende

$\because$ onvoldoende

- ruim onvoldoende

\section{Tabel 15.3 De wijze van functioneren van het Rijksmuseum}

${ }^{721}$ IKON Belleidsconsulenten (1987a, p. 41).

722. Algemene Rekenkamer, Rijksmusea, Tweede Kamer der Staten-Generaal, Tweede Kamer der StatenGeneraal, vergaderjaar $1987-1988,20697$, wrs. 1-2. Zie onder meer pp. 45-47. 
Overigens zijn deze aanduidingen niet onomstreden. De Algemene Rekenkamer gaf bijwoorbeeld aan dat de conservering van de kunstobjecten grote achterstanden kent, terwijl het Rijksmuseum meende dat dat wel meevalt. De aanduidingen voldoende, onwoldoende moeten dan ook worden opgevat als een indicatie, waarmee vooral de positie van het Rijksmuseum ten opzichte van andere rijksmusea wordt aangegeven, In het vervolg van deze paragraaf wordt ingegaan op de verschillende doelen van het Rijksmuseum en de mate waarin deze doelen zijn gerealiseerd.

\section{Bewaren van kunst en het culturele erfgoed}

De zorg voor het behoud van de verzameling is het uitgangspunt van de museale activiteiten. ${ }^{723}$ Ten aanzien van de bewaarfunctie kan onderscheid worden gemaakt tussen het bewaren van kunst en de conservering en restauratie ervan.

Het grootste deel van de collectie van het Rijksmuseum wordt in het museum zelf bewaard, zij het dat delen van de collectie langdurig aan andere musea ter beschilkking worden gesteld. Slechts een deel van de collectie wordt tentoongesteld, het meeste wordt bewaard in een aantal depots. Daarnaast is voor kunst waarvan het wenselijk is dat zij toegankelijk is, naast de vaste opstelling een studiecollectie ingesteld. De laatste decennia is steeds getracht om de bewaarcondities van op zalen tentoongestelde kunst zo optimaal mogelijk te maken. Daartoe wordt met het oog op de beveiliging maar ook steeds meer in verband met de bewaarfunctie gebruik gemaakt van vitrines. Dit is niet altijd even goed te combineren met het doel van het tentoonstellen van kunstwerken aan het publiek. Het Rijksmuseum is steeds bezig om de conservatie zo veel mogelijk te verbeteren. De studiecollectie is in het leven geroepen als een soort tussenvorm tussen enerzijds de vaste opstelling en anderzijds de depots. Het doel van de studiecollectie is: "(..) om te voldoen aan de behoefte van een specifieke publieksgroep van specialisten, studenten, handelaars, verzamelaars etc., om een zo groot mogelijk deel van het museale bezit te kannen bestuderen". ${ }^{724}$ Op 13 september 1974 is het souterrain voor de studiecollectie in gebruik genomen. Deze ruimte is voorzien van air-conditioning en voldoet in die zin aan goede bewaaromstandigheden. Door het groeien van de collectie en de veranderde opvattingen over de mate waarin de collectie tentoongesteld diende te worden, zijn in het Rijksmuseum steeds meer depots ingericht. De bewaarcondities in deze depots laten nogal eens te wensen over. Hierbij kan gedacht worden aan de klimatologisehe omstandigheden, de toegankelijkheid van de depots waardoor het verhuizen van kunstvoorwerpen binnen het Rijksmuseum risico's met zich meebracht, terwijl voorts thet gebrek aan numte binnen de depots een rol speelde.

Met betrekking tot de conservatie en restauratie van kunst kan worden opgemerkt dat veelal met conservatie wordt volstaan. Dit geldt met name voor de kunst die niet voor expositie in aanmerking komt. Welke handelingen verricht dienen te worden werd voornamelijk bepaald door de conservator en de restaurateur. In het Rijksmuseum waren in het midden van de jarem tachtig een zevental restauratie-ateliers. Veel van deze ateliers zijn destijds ingesteld in verband met de toenemende groei van de collectie. Vaak zijn ze ongelukkig gelegen. Voor diverse afdelingen bestaan achterstanden in conservering en restauratie. Dit was in de jaren ' 80 vooral het geval voor het Rijksprentenkabinet, de afdeling Nederlandse Geschiedenis en de afdeling Beeldhouwkunst en Kunstnijverheid. Nadruk ligt op het zoveel mogelijk bijscholen van het personeel ten einde op de hoogte te

223 Rijksmuseum, Concept-beleidsnota, olktober 1983, p. 36.

T24 T.a.p., p. 39. 
blijven van de ontwikkelingen op hun vakgebied. Gedurende de onderzoeksperiode werd herhaaldelijk gewezen op de achterstand in onderhoud en de slechte omstandigheden waaronder de kunst bewaard werd. In de beleidsnota "Deltaplan voor Cultururbehoud" wordt geconstateerd dat er een grote achterstand bestaat in het onderhoud van het culturele erfgoed. In deze beleidsnota wordt de totale achterstand geschat op vier miljard gulden. ${ }^{725}$ Deze bedragen zijn echter niet eenduidig. In 1989 nog werden de achterstanden op het gebied van conservering en restauratie die binnen de rijksmusea bestonden geschat op F. $116.936 .000,-$, hetgeen dan nogal aan de lage kant is. ${ }^{726}$ De achterstand in conservering en restauratie voor het Rijksmuseum wordt geschat op F, 20.498.000,-, terwijl geschat wordt dat voor het inhalen van deze achterstand 216 mensjaren zouden zijn gemoeid.

Ook een betrouwbare registratie van kunstvoorwerpen ontbrak gedurende de onderzoeksperiode. De Accountantsdienst merkt in dit verband op: "Daarbij gevoegd het feit, dat in het verleden, door tal wan omstandigheden - welke per afdeling verschillen - delen van de verzameling niet of onvoldoende zijn geilnwentariseerd, is thans nog naunelijks sprake van een adequaat beheer wan de verzameling (kunst)voonwerpen". ${ }^{72}$. Eind jaren '80 werd hieraan wel gewerkt. De achterstand was echter aanzienlijk. De kosten van de achterstand, inclusief de achterstand in de fotoregistratie werden geschat op F. 1.210.100, - Om de achterstand in te lopen zouden 3.100 mensjaren nodig zijn. Gezien de omvang van het personeelsbestand kon dit slechts geleidelijk plaatsvinden. Tot aan halverwege de jaren tachtig werd er weinig gestructureerd gewerkt aan het automatiseringsproces. Hierin kwam eind jaren tachtig verandering. Begin 1988 werd een beleidscommissie automatisering collectiebeheer ingesteld. Deze had als doel de werkzaamheden te verrichten die nodig zijn om te komen tot een centraal beheerssysteem en anderzijds diende zij de algemene beleidslijn uit te zetten. Voor de uitwerking hiervan werd het Bureau IMC ingeschakeld. ${ }^{728}$ De kosten voor de invoering van een centraal collectiebeheersysteem werden geraand op F. $1.472 .000,-.729$

\section{Toegankelijk en begrijpelijk maken van kunst: de presentatiefunctie}

De mogelijkhedien om kunst te bewaren en te presenteren werden in belangrijke mate bepaald door de ruimte in het gebouw, die een constante beperking vormde. Door het grote aantal bezoekers werd de behoefte aan nieuwe nimte ook steeds groter. Bij de Minister was in 1969 al een uitbreidingsplan ingediend, hetgeen werd onderzocht door de RGD en nader bezien werd door het Ministerie. Naast het gebrek aan ruimte werd begin jaren " 70 herhaaldelijk gewezen op de toenemende slijtage en vervuiling die het groeiende bezoekersaantal met zich meebracht.

\footnotetext{
${ }^{725}$ Ministerie van Welzijn, Volksgezondheid en Caltuur, Deltaplan voor Cultuurbehoud. Tweede Kamer, vergaderjaar, 1990-1001, 21965.
}

${ }^{726 i}$ De Werkgroep Financiële en Bedrijfseconomische Aspecten Verzelfstandiging Rijksmusea, Concept Eindrapport, april 1989 , paragraaf 5.2 .

727 Accountantsdietst, Rapport NR. AD/C 85.3138, inzake het onderzoek naar de verantwoording over 1984 van thet Rijksmuseum te A'dam, p. 5.

${ }^{728}$ Bureau IMC, Informatieplan Collectiebeheer Riiksmuseum Amsterdam, augustus/september 1989.

${ }^{729}$ T.a.p. p. 27. 
Om het probleem van het gebrek aan ruimte voor opslag en behoorlijke presentatie op te lossen werden herhaaldelijk commissies in het leven geroepen. Ten behoeve van het onderzoek naar het uitbreidingsplan werd een werkgroep ingesteld. Ferst in 1974 waren alle leden van de hiertoe ingestelde werkgroep benoemd en kon zij met haar werkzaamheden beginnen. Een andere werkgroep was begonnen met het opstellen van een procedureplan en met het analyseren van de opzet van een nader onderzoek, teneinde het uitbreidingsplan te actualiseren. De leden van deze werkgroep werden aangewezen door de Rijksgebouwendienst, de afdeling Organisatie en Efficiency van het Ministerie, de Hoofdafdeling Musea, de afdeling Gebouwen, Aanschaffingen en Vervoer en verder nam de hoofddirecteur zitting. Allen waren formeel aangewezen door de Minister van CRM. Het Hoofd van de afdeling Geschiedenis van het Rijksmuseum trad op als secretaris. Halverwege de jaren '70 verstrekte het Ministerie een extra krediet waardoor de inrichting van een paar extra zalen mogelijk was. In 1976 voltooide de door het Ministerie van Volkshuisvesting en Ruimtelijke Ordening ingestelde Studiegroep Uitbreiding Rijksmuseum een inventarisatie van de huidige en toekomstige behoefte aan ruimte tot het jaar 2000. Hieruit werd geconcludeerd dat de behoefte aan uitbreidingsnuimte de huidige omvang van het Rijksmuseum evenaarde. Het management wees herhaaldelijk op de toenemende verpaupering van het Rijksmuseum, veroorzaakt door de geringe financiële armslag, de onderbezetting van de afdeling Inrichting en door de slijtage veroorzaakt door het grote aantall bezoekers.

De behoefte aan ruimte was zelfs zo groot dat deze niet via aanbouw kon worden gerealiseerd zoals oorspronkelijk werd gedacht, te meer daar het pand belangrijke monumentale waarde heeft voor de gemeente Amsterdam. Daarom werd gezocht naar een ander pand,

bij voorkeur in de buurt van het Rijksmuseum. Eind jaren "70 werden een aantal voorzieningen getroffen die het ergste gebrek aan ruimte moesten opvangen. De hoofddirecteur stelde dat het gebouw dermate vol was dat zelfs fundamenteel onderhoud, in verband met onvoldoende vervangende ruimte, niet meer goed kon worden uitgevoerd. De directie had het voomemen een knelpuntennota op te stellen met als belangrijk doel in de toekomst te kumen beschikken over het pand waarin voorheen het Veiligheidsinstituut gevestigd was. De uitbreiding van het eigen gebouw bleek in het begin van de jaren ' 80 in verband met de bezuinigingen veelal niet mogelijk, terwijl verbeteringen aan het gebouw slechts op beperkte schaal werden gerealiseerd. Halverwege de jaren ' 80 werd een begin gemaakt met een aantal renovaties. In 1986 werd overeenkomstig de plannen een deel van het woormalige Veiligheidsinstiturut gehuurd om als opslagplaats dienst te doen. Dit zorgde wel voor extra druk op het materiële krediet. In 1987 werd de restauratie van het restaurant die in 1986 begonnen was afgerond. Verder werden de meest noodzakelijke veranderingen doorgevoerd met betrekking tot de brandweervoorschriften. De nog steeds niet toereikende brandvoorzieningen bleven evenwel een probleem. Het werd duidelijk dat binnen het museum bijna geen goede opslag voor de kunst gevonden kan worden. Het gebruik van het veiligheidsmuseum bood uitkomst.

De periode overziend kan geconstateerd worden dat veel inspanningen zijn geleverd om beter in staat te zijn de kunst op een verantwoorde manier te bewaren en daarnaast om ook zoveel mogelijk kunst op een goede manier te kunnen presenteren. Door budgettaire beperkingen is dit echter maar beperkt verwezenlijkt. Per 1 januari 1983 was het Rijksmuseum op maandag gesloten, terwijl de bezuinigingen ertoe hebben geleid dat regelmatig afdelingen werden gesloten voor het publiek. Daarnaast speelde mee dat het Rijksmuseum in deze sterk afhankelijk was van andere instellingen, waaronder de Rijksgebouwendienst. Alle inspanningen die geleverd zijn om de bewaarde kunst toegankelijk te maken voor het publiek impliceren niet dat het de bedoeling is van het Rijksmuseum om alle bewaarde kunst te tonen. Zoals zij stellen: "Aangezien de callectie bij lange na niet meer (zoals in 1885 het geval was) in zijn geheel getoond kan worden. 
hetgeen overigens ook niet de bedoeling is, is in de loop der jaren een groot aantal depots ontstaan". ${ }^{730}$ Dat het niet wenselijk wordt geacht alle aanwezige kunst tentoon te stellen houdt niet alleen verband met de beschikbare ruimte maar vooral ook met de conservatie ervan. In het beleidsplan staat vermeld: "Bewaren in voor het publiek toegankelijke tentoonstellingsnumten, zeker in een zo oud gebouw als het Rijksmuseum levert uit een oogpunt van conservatie van de tentoongestelde voorwerpen een conflictsituatie op ${ }^{\text {"7. }}{ }^{731}$

\section{Educatieve doelstelling}

De educatieve doelstelling is nauw verwant met de doelstelling van het toegankelijk maken van het Rijksmuseum. De activiteiten in het kader van de educatieve doelstelling zijn er op gericht bezoekers een zo groot mogelijk nut te laten hebben van hun museumbezoek. Deze doelstelling was voornamelijk opgedragen aan de Educatieve Dienst in samenwerking met de verzamelafdelingen. De activiteiten liggen op een drietal gebieden, namelijk de bezoekvoorbereiding, de bezoekbegeleiding en de ontwikkeling van museumeducatieve disciplines. Zij bestonden vooral uit rondleidingen en informatieverstrekking in geschreven of gedrukte vorm. Daarnaast werd steeds meer geprobeerd door middel van geautomatiseerde informatiesystemen inzicht te geven in de collectie. Ten aanzien van de bezoekbegeleiding werd meer in het bijzonder gewerkt aan verbeteringen, onder meer door het ontwikkelen van een algemene inleidende audio-visuele presentatie.

\section{Bevorderen cultururdeelname en publiekswerving}

Het bezoek aan het Rijksmuseum bestaat voor ongeveer twee derde uit individueel bezoek en voor een derde uit groepsbezoek. Naar schatting is ongeveer $80 \%$ van de bezoekers uit het buitenland afkomstig. Na 1973 werd er in de jaren ' 70 en begin van de jaren ' 80 geen onderzoek gedaan naar het totale bezoek (motivering van bezoekers om te komen, eerste bezoek, vervolgbezoek etc.). Wel werden deelpopulaties onderzocht. Een aantal knelpunten worden gesignaleerd zoals het onvoldoende verschaffen van informatie aan het publiek over de inrichting van het gebouw, het onvoldoende toegankelijk zijn van het gebouw en het ontbreken van voldoende faciliteiten. Het Rijksmuseum probeerde de aandacht van het publiek te trekken door het verzenden van persberichten en door persoonlijk contact met vertegenwoordigers van de media, het verzenden van een tentoonstellingsagenda en door het verspreiden van tentoonstellingsaffiches over ongeveer 2400 ophangadressen.

Het Rijksmuseum rekende sterk gesubsidieerde entreeprijzen. Zou het Rijksmuseum kostendekkend hebben moeten opereren in bijvoorbeeld 1985 dan zou de totale opbrengst F. 24.687.211,- hebben moeten zijn, in plaats van F. 5.587.757,-. Dit betekent dat F. 19.099.454,- werd besteed aan lagere entreeprijzen. Dit komt in feite neer op een herverdeling van inkomen omdat met name de hogere inkomensgroepen musea bezoeken. Uit de verschillende documenten kan worden opgemaakt dat het doel van het Rijksmuseum is het aantal bezoekers iets boven het miljoen te houden en het aantal Nederlandse bezoekers te vergroten. Gezien het bezoekersaantal eind jaren tachtig is het doel van tenminste één miljoen bezoekers bereikt.

\footnotetext{
T30 T.a.p., p. 36

73 T.a.p., p. 37.
} 
Ten aanzien van het wetenschappelijk onderzoek kan onderscheid worden gemaakt tussen enerzijds de inventarisatie en anderzijds de documentatie en wetenschappelijke bewerking.

De wijze waarop de inventarisatie en het administratieve beheer plaatsvindt is voor een belangrijk deel historisch gegroeid. Elke afdeling gebruikt een eigen inventarisatiesysteem voor het vastleggen van de gegevens over de kunstvoorwerpen. Bovendien zijn door allerlei omstandigheden delen van de verzameling niet of onvoldoende geinventariseerd. Het uniformeren van de verschillende inventarissystemen zou naar de mening van de directie zeer arbeidsintensief zijn. De oplossing werd vooral gezocht in de automatisering van het administratieve beheer. In dit verband is door het management van het Rijksmuseum in 1981 het "Beleidsplan van automatisering van de museale informatieverzorging" opgesteld. Het invoeren van gegevens in een computer zou meteen betekenen dat aok de achterstanden in de inventarisatie worden aangepakt. ${ }^{732}$

De documentatiewerkzaamheden zijn op grond van historisch gegroeide omstandigheden beperkt tot het (kunst)historisch beschrijven van kunstvoorwerpen. Daarnaast wordt getracht zoveel mogelijk gegevens te verzamelen over de objecten (in boeken, door wetenschappelijke correspondentie, e.d.). De toegankelijkheid van deze gegevens is nogal beperkt. Dit is met name het geval ten aanzien van de niet-gepubliceerde collectieonderdelen. Voor een belangrijk deel is alleen via de conservatoren informatie te verkrijgen. Er bestonden in het begin van de jaren ' 80 aanzienlijke achterstanden in het documentatiewerk. Teneinde een goed toegankelijk en uniform documentatiesysteem voor het gehele Rijksmuseum op te zetten werd een geautomatiseerd systeem essentieel geacht.

Het wetenschappelijke werk in het Rijksmuseum kan onderscheiden worden in:

1. Het bestuderen van afzonderlijke objecten.

2. Het bestuderen van samenhangende categorieën objecten en collectie-onderdelen.

3. Het bestuderen van onderlinge verbanden tussen de collectie-onderdelen. ${ }^{733}$

Het objectgerichte onderzoek vindt vooral zijn neerslag in artikelen en tijdschriften, waaronder het bulletin van het Rijksmuseum en bezitscatalogi. In verband met de achterstanden in inventarisatie en in verband met de omvang van de collectie is op verschillende gebieden wan het objectgerichte wetenschappelijke onderzoek een achterstand ontstaan. Per afdeling verschilt de mate waarin bezitscatalogi zijn opgesteld. Het bezit aan schilderijen is goed gecatalogiseerd. Bij de beeldhouwkunst, prenten en Aziatische kunst is dat slechts tot bepaalde hoogte het geval.

Op grond van het onderzoek waarbij zoveel mogelijk de verschillende kunstvoorwerpen met elkaar in verband worden gebracht vinden presentaties, publikaties en tentoonstellingen plaats. Dit soort onderzoek vindt voornamelijk plaats ten behoeve van tentoonstellingen en dan vooral in samenwerking met andere musea en universiteiten.

Ten aanzien van de derde categorie wordt opgemerkt dat onderzoek waarbij dwarsdoorsneden van de totale collectie van het Rijksmuseum aan de orde komen in de jaren ' 80 veelal nog een utopie is. Getracht werd met behulp van tentoonstellingen hier toch nog

${ }^{732}$ Rijksmuseum, Concept-beleidsplan, Amsterỉam, oktober 1983, p. 24.

733 Rijksmuseum Amsterdam, Concept-beleidsnota van het Rijksmuseurn, Amsterdam, oktober 1983, p. 32. 
iets te bereiken. ${ }^{734}$

De conclusie die ten aanzien van het verrichte wetenschappelijke onderzoek werd getrokken luidde dat de kwantiteit van het wetenschappelijke werk op alle niveaus voor verbetering vatbaar was, of zoals werd gesteld: "De dagelijkse beslommeringen van de wetenschappelijke medewerkers terzake van het beheer en behoud van de collectie, de correspondentie, de presentatie, de bemoetenis met uitlenen van kunstwerken aan derden etc. vergt zoveel tijd, dat aan het wetenschappelijke werk, te beginnen met het objectgerichte onderzoek, slechts mondjesmaat wordt toegekomen". ${ }^{735}$

\section{Verzameldoelstelling}

In verband met de steeds verder gaande bezuinigingen werden herhaaldelijk grote vraagtekens bij de realisering van dit doel gesteld. De bijdrage van het Ministerie ten behoeve van de aankoop van kunst werd gedurende meerdere jaren bevroren en viel steeds meer in het niet bij de gedane schenkingen. Het management achtte de budgetten voor het voeren van een aankoopbeleid volstrekt ontoereikend. ${ }^{736}$ Er konden onvoldoende lacunes in de collectie worden opgevild terwijl bovendien het onvoldoende mogelijk was de kwaliteit te verbeteren. Gevreesd werd dat voorwerpen die bij uitstek in de verzameling van het Rijksmuseum thuishoren, voor het Rijksmuseum en voor Nederland verloren zouden gaan. In dit verband werd opgemerkt: "Een continue stroom van substantiêle middelen is onontbeerlijk om een verzamelbeleid, dat aan alle aspecten van de collectie recht kan doen wedervaren, gestalte te geven en om op de kunstmarkt (veilingen!) slagvaardig te kunnen optreden. Nimmer dient wit het oog te worden verloren dat een representatieve verzameling als die wan het Rijksmuseum geen storende ernstige lacunes mag vertonen en dat iedere gemiste kans er toe leidt, dat de collectie - relatief gezien - aan kwaliteit inboet $^{17}{ }^{737}$ Om toch zoveel mogelijk de verzameldoelstellingen te realiseren werd meer gebruilk gemaalkt van het in bruikleen nemen van objecten. Dit werd alleen acceptabel geacht indien de duur van het bruikleen voldoende lang is, minimaal drie jaar met stilzwijgende verlenging, en tevens het eerste recht van koop verworven wordt. Belangrijke delen van de collectie zijn in bruikleen van de gemeente Amsterdam. Daarnaast heeft het Rijksmuseum de collecties van het Koninklijk Oudheidkundig Genootschap (K.O.G.), de Stichting Cultururgeschiedenis van de Nederlanders Overzee (C.N.O.) en van de Vereniging Vrienden der Aziatische Kunst in langdurig bruikleen:

\section{Bevorderen yan een tegionaal evenwichtig gespreid aambod}

Een ander doel dat in het kader van de verzameldoelstelling werd nagestreefd betrof het verkrijgen van zoveel mogelijk aanshiting bij de andere hoofdstedelijke collecties. Daarbij werd in de jaren ' 80 vooral ook gelet op het aankoopbeleid van het Stedelijk Museum. Het Stedelijk Museum voerde voor kumstobjecten uit de periode 1900-1940 een selectief aankoopbeleid. Om te voorkomen dat er hiaten zouden vallen probeerde het

\footnotetext{
734 T.anp, p. 34.

735 T.a.p., P. 34.

736 Rijksmuseum Amsterdam, Concept-beleidsnota, Amsterdam, oktober 1983, p. 21.

T37 T.a.p., Pp. $21-22$.
} 
Rijksmuseum ten aanzien van zijn verzamelbeleid zoveel mogelijk rekening te houden met het verzamelbeleid van het Stedelijk Museum. Daarom is bijvoorbeeld ook kunstnijverheid uit de Art-Déco-periode aangekocht en werd bovendien niet voor elke verzamelafdeling dezelfde tijdsgrens aangehouden. ${ }^{738}$

Volgens de Rekenkamer was de mate waarin musea samenwerkten en het aanbod van kunst op elkaar afstemden nogal beperkt. Zij stelt: "Er was nauwelijks sprake van samenwerking. Elk museum had een eigen depot en een eigen registratie van kunstvoorwerpen die kwalitatief vaak verschilden. Voor een deel is dit ontbreken van samenwerking verklaarbaar omdat de verzamelgebieden van de musea elkaar niet of slechts in geringe mate overlappen. Ook als er wel sprake was van gelijksoortige collecties was er geen intensief bruikleenverkeer tussen de rijksmusea en ook geen sprake van een gecoördineerd aankoopbeleid. Zo vond er tussen RM Amsterdam en RM Mauritshuis onvoldoende afstemming plaats ten aanzien van aankopen voor wat betreft negentiende eeuwse Nederlandse schilderkunst" ".739

\section{Kunstmarkt Amsterdam}

Het Rijkmuseum kende verschillende faciliteiten. Bepaalde werken van het Rijksprentenkabinet waren bijvoorbeeld slechts onder toezicht in een aparte zaal in te zien. Ook was het mogelijk depots te bezoeken, zij het dat ook dit slechts onder toezicht mogelijk was. Een andere faciliteit die door het Rijksmuseum werd aangeboden was dat mensen een oordeel konden vragen over in hun bezit zijnde kunstwerken. Verder werden er symposia, wetenschappelijke congressen en vergaderingen in het Rijksmuseum gehouden. Hierbij traden de gemeente Amsterdam en de Staat der Nederlanden veelal gemeenschappelijk als gastheer op. Daarnaast konden officiele bezoekers uit binnen- en buitenland voor of tijdens openingstijd de collectie bezoeken. Ook is in dit verband de studiecollectie van belang. Een belangrijke taak was het voorzien in informatie die vanuit de gehele wereld gevraagd werd. Dit gebeurde schriftelijk, telefonisch of mondeling aan de informatiebalie. Daarnaast werd medewerking verleend aan filmploegen die voor allerlei doeleinden opnamen maakten in het Rijksmuseum.

\section{Werkgelegenheid}

Hiervoor is reeds uitgebreid ingegaan op het personeelsbeleid en de ontwikkeling van het personeelsbestand. Er was sprake van een structureel tekort aan personeel, gegeven de in de jaren " 70 en " 80 bestaande infrastructuur. Het management streefde met name naar uitbreiding van het aantal formatieplaatsen. Daarbij werd de nadruk gelegd op het uitbreiden van de verzamelafdelingen waar een middenkader gecreëerd moest worden, op de uitbreiding van de afdeling inrichting, mede omdat het door de bezuinigingen op het materiële budget steeds minder mogelijk was werk uit te besteden, op de uitbreiding van het foto-atelier en tenslotte op de vergroting van de bewakingsdienst waar zoals beschreven gedurende de jaren '70 en ' 80 een structureel tekort aan personeel bestond. Dit personeelstekort werd in de jaren " 80 nog verergerd door de bezuinigingen van de overheid op personeelsgebied. Door de $4 \times 2 \%$-operatie in de jaren tachtig verdwenen er 29 banen in het Rijksmuseum (eind 1987). Dit ging zonder gedwongen ontslag. Ook voor de nabije toekomst werd een verdere inkrimping verwacht in plaats van de door het Rijksmuseum gewenste uitbreiding.

${ }^{738}$ T.a.p., p. 21.

739. Algemene Rekenkamer, Rijksmusea; Tweede Kamer der Staten-Generaal, vergaderjaar 1987-1988, 20697 , nrs. $1-2$, p. 16 . 
Was de formatieve sterkte in 1986 nog 350 werknemers, in 1991 bedroeg dit nog 340,5 . Hiervan waren in 199160 personen werkzaam in deeliijd. Gemiddeld 25 personen waren op grond van de WSW als erkend gewetensbezwaarde of als stagiair(e) werkzaam.

In 1996 waren er 366 formatieplaatsen. In paragraaf 15.14. wordt hier verder op ingegaan en wordt aangegeven in hoeverre er sprake was van verborgen werkloosheid.

\section{Beloning personeel}

Zoals in paragraaf 15.5.1 behandeld is, ligt de bezoldiging van het personeel boven datgene wat het in de marktsector zou ontvangen.

\subsection{Wat zijn de kosten wan de doelen van het Rijksmuseum?}

In deze paragraaf wordt onderzocht wat precies de omvang is van het budget c.q. wat precies de kosten zijn waarmee de doelen kunnen worden nagestreefd. Dit "budget" bestaat uit de "public enterprise rent".

Gedurende de periode 1970 tot 1990 was het Rijksmuseum juridisch niet gerechtigd eigen vermogen aan te houden. Ook het vormen van afzonderlijke fondsen werd zoveel mogelijk tegengegaan. De collectie van het Rijksmuseum (inclusief kunstwerken die opgeslagen zijn) kan echter worden opgevat als activa van het museum (niet juridisch). Een particuliere instelling zou hier een marktrendement over wensen te behalen. Zoals in hoofdstuk 15 is aangegeven kan het obligatierendement worden beschouwd als alternatieve kosten. Onlangs is de externe verzelfstandiging van het Rijksmuseum afgerond. Dit heeft erin geresulteerd dat het Rijksmuseum sindsdien zal functioneren als een zelfstandige stichting. Het is hierbij van belang te constateren dat de collectie niet werd overgedragen aan de stichting. Aan de stichting is slechts het behoud en beheer en de presentatiefunctie overgedragen. Indien de collectie als wezenlijk bestanddeel van het museum wordt gezien kan worden geconcludeerd dat de verzelfstandiging slechts beperkt is geweest. De collectie maakt als niet verzelfstandigd onderdeel deel uit van het museum. Met andere woorden: De collectie is niet geprivatiseerd, het beheer wel.

De vraag rijst hoe de "public enterprise rent" over de onderzoeksperiode, meer in het bijzonder over de jaren ' 80 , berekend kan worden. Dit kan door enerzijds de waarde van de collectie als eigen vermogen te nemen. De collectie was zoals opgemerkt gedurende de onderzoeksperiode gedeeltelijk van het Rijk en gedeeltelijk van de gemeente Amsterdam. Dit is ook vanaf 1 juli 1995 het geval, zij het dat de collectie in bruikleen is gegeven aan het Rijksmuseum. Toch kan de collectie van het Rijksmuseum als eigen vermogen worden gezien van het Rijksmuseum, gezien als netwerk, aangezien het Rijksmuseum de collectie exploiteert. De collectie valt uiteen in enerzijds voorwerpen met een artistieke/kunsthistotische waarde en anderzijds voorwerpen met een historische waarde. De collectie kan onderscheiden worden naar de vijf verzamelafdelingen. Het deel van de collectie dat beheerd wordt door de afdeling schilderijen bestaat uit ongeveer 5000 werken ${ }^{740}$ Hiervan wordt ongeveer $90 \%$ gevormd door schilderijen terwijl de resterende $10 \%$ vooral miniaturen en pastels zijn. De verzameling bestaat vooral uit Nederlandse meesters, waarbij de nadruk ligt op de $17 \mathrm{e}$ eeuw. Daarnaast bezit het Rijksmuseum ongeveer 200 schilderijen van buitenlandse meesters. De afdeling beeldhouwkunst en kunstnijverheid omvat ongeveer 30.000 voorwerpen, variërend van de $12 \mathrm{de}$ eeuw tot circa 1920. De nadruk ligt op de periode $1500-1800$. Naast Nederlandse beeldhouwkunst beschikt het

${ }^{740}$ Rijksmuseum, Beleidsnota van het Rijksmuseum, Amsterdam, maart 1985, hoofdstuk 2. 
Rijksmuseum ook over Franse, Duitse, Italiaanse en in mindere mate Engelse en Spaanse beeldhouwkunst en kunstnijwerheid. De afdeling Nederlandse Geschiedenis omvat ongeveer 17.000 objecten, waaronder 9.000 historiepenningen. De belangrijkste onderdelen van de collectie zijn afkomstig van de grote handelscompagnieèn zoals de VOC en WTC. Het Rijksprentenkabinet beschikt over ongeveer 950.000 prenten en ongeveer 50.000 tekeningen. Het overgrote deel van de collectie heeft betrekking op de $15 \mathrm{e}$ tot en met de $19 \mathrm{e}$ eeuw. De afdeling Aziatische kunst tenslotte beschikt over ongeveer 3.000 kunstwoorwerpen, waarvan 1.350 in bruikleen zijn verkregen van de Vereniging van Vrienden der Aziatische Kunst. De nadruk ligt op de kunst van Oost-Aziê.

De collectie is derhalve zeer omvangrijk en heterogeen samengesteld. Halverwege de jaren tachtig maakte de Accountantsdienst bezwaar tegen het ontbreken van een (volledig) systeem van registratie van kunstwoorwerpen. Hierdoor was er ook nauwelijks controle op vervreemding (onder meer ook door werknemers) mogelijk. Het management van het Rijksmuseum geeft aan hierin verandering te willen brengen maar merkt ook op door het ontbreken van mankracht onvoldoende mogelijkheden hiertoe te hebben. ${ }^{741}$ Dit maakt het moeilijk de waarde ervan te bepalen. Als hulpmiddel voor het bepalen van de waarde zou het op zich redelijk zijn om de verzekeringswaarde van de collectie te hanteren. Aangezien de collectie van de overheid is, en deze haar bezittingen niet verzekert, zijn ook dit soort gegevens echter niet beschikbaar. Misschien dat de overheid in de toekomst van haar standpunt haar eigendom niet te verzekeren afwijkt, Uit de diverse gevoerde gesprekken werd duidelijk dat de waarde van de collectie van het Rijksmuseum voor de betrokken actoren geen onderwerp van discussie was. Daar komt nog bij dat de bepaling van de waarde van kunst een probleem is. Wat is bijvoorbeeld de "Nachtwacht" waard? Veel kunstwerken zijn lang geleden verworven en het is vaak onduidelijk wat de tegenwoordige waarde is. Zelfs taxaties van kunstwerken doox deskundigen kunnen ver afwijken van de uiteindelijke veilingprijs. Dat het bepalen van de waarde van de collectie woor het management niet onomstreden was blijkt ook uit het feit dat in het rapport van het belastingadviesburean Moret Gudde Brinkman uit 1988 bleek dat het management geen gegevens had verstrekt over de waarde van de collectie van het Rijksmuseum. ${ }^{722}$ Eind jaren tachtig wordt in het kader van de verzelfstandiging geprobeerd toch tot een waardebepaling van de verschillende collecties te komen. Alle rijksmusea hebben daartoe een reële schatting gemaakt van de waarde van de collectie De totale waarde van de collectie van alle rijksmusea bij elkaar komt uit op ongeveer 30 miljard gulden. De waarde van de collectie van het Rijksmuseum wordt geschat op 10 miljard gulden.

Naast de waarde van de collectie is de waarde van het gebouw van belang. Na de verzelfstandiging per 1 juli 1995 betaalt het Rijksmuseum huur. Daarvoor was dat niet het geval. Het gebouw was echter wel in gebruik en kon dus niet verkocht worden. Dit betekent dat het obligatierendement op de waarde van het gebouw ook gezien moet worden als een "public enterprise rent". Eventueel had ook de hurwwarde na de verzelfstandiging genomen kunnen worden. Deze hurwaarde van de gebouwen wordt vastgesteld door de Domeinen op basis van een advies van een extern taxateur. De huur wordit yoor zover mogelijk vastgesteld door een marktvergelijking uit te voeren, waarbij rekening wordt gehouden met de bestemming van de gebouwen. Deze huwrwaarde heeft dan ook als nadeel dat niet altijd de markthuurprijs weerspiegeld wordt. Op grond van

\footnotetext{
741 Accountantsdienst, Rapport NR. AD/C 86.3138, inzake het onderzoek naar de financielle verantwoording over 1985 van het Rijksmuseum te A'dam, 12 september 1986
}

742 Moret Gudde Brinkman belastingadviseurs, Riiksmuseum als omzetbelastingplichtig ondernemer; "sGravenhage, 28 oktober 1988, p. 15. 
gegevens met betrekking tot 1989 wordt de vervangingswaarde van het gebouw van het Rijksmuseum geschat op F. $301.401 .000,-743$ Naast de waarde van de gebouwen is ook de vervangingswaarde van de in gebruik zijnde terreinen van belang. Deze worden geraamd op F. 26.250.000, aan het eind van 1988. Tenslotte is voor de bepaling van het eigen vermogen ook de vervangingswaarde van de inventaris relevant. Deze bedroeg eind $1988 \mathrm{~F} .3 .423 .000$,-. In het ondernemingsplan 1989 wordt eem totale waarde van de technische en kantoorinventaris van F. 25 milloen genoend.

Het eigen vermogen kan nu berekend worden door de waarde van de collectie, van het gebouw, het terrein en de inventaris bij elkaar op te tellen. $Z \mathrm{ij}$ bedraagt dus totaal $\mathrm{F}$. 10.352.651.000,- aan het eind van $1988^{744}$ Voor de jaren hiervoor zijn geen gegevens beschikbaar. Teneinde de waarde van het eigen vermogen voor eerdere jaren te bepalen, moet dit eigen vermogen verminderd worden met de prijsstijging en de toevoegingen aan de collectie.

Naast het eigen vermogen is het van belang te weten hoe groot de winst was. Deze winst was steeds negatief. Het tekort bestond uit de subsidies van het rijk. Deze subsidie bestond uit het door het Ministerie toegekende bedrag min de entreegelden en de giften.

Tenslotte moet de vraag beantwoord worden in hoeverre de behandeling van de omzetbelasting van belang is. In een onderzoek uit 1988 is bezien in hoeverre de rijksmusea belastingplichtig zijn voor de omzetbelasting. In dit rapport wordt uitgebreid ingegaan op de Wet op de omzetbelasting 1968, de bijbehorende jurisprudentie en de diverse Europese richtlijnen. ${ }^{745}$ In 1988 werd door het Rijksmuseum Amsterdam geen omzetbelasting afgedragen. Per saldo ontving het Rijksmuseum in $1986 \mathrm{f} .21 .000$,-, terwijl in 1987 per saldo f. 37.697,- werd ontvangen van de fiscus. Dit is echter geen subsidiëring indien gelet wordt op het bedrag aan omzetbelasting dat afgedragen en gevorderd zou kunnen worden indien zowel de ontvangsten van het Rijksmuseum als de kosten, de aankoop van kunst en de aankoop van boeken onder het $6 \%$-tarief zouden worden gebracht. Volgens de berekening van het belastingadviesbureau Moret Gudde Brinkman zou het Rijksmuseum in dat geval per saldo f. 422.647 , in 1986 en f. 415.013 , in 1987 aan omzetbelasting hebben kumnen terugvorderen van de fiscus. ${ }^{746}$ Dit zou pas anders zijn indien het Rijksmuseum onder het $20 \%$-tarief zou worden gebracht. In dat geval zou in 1986 per saldo $\mathrm{f}, 28.179$,- en in $1987 \mathrm{f} .81 .832$,- aan omzetbelasting moeten worden afgedragen. Het is onduidelijk onder welk tarief het Rijksmuseum eventueel gebracht zou moeten worden. Eén en ander is reden om bij de berekening van de "public enterprise rent" de afdracht van omzetbelasting buiten beschouwing te laten, te meer daar de behandeling van de B.T.W. na verzelfstandiging niet veranderd is.

De berekening van de "public enterprise rent" na 1981 is weergegeven in Tabel 15.4.

743 Werkgroep Financiele en Bedrijfseconomische Aspecten Verzelfstandiging Rijksmusea, Concept eindrapport, 21 april 1989, paragraaf 3.

744 Per 31 december 1988.

745 Moret Gudde Brinkman belastingadviseurs, Rijksmusea als amzetbelastingplichtig ondernemer, "sGravenhage, 28 oktober 1988 .

${ }^{746}$ T.a.p., bijlage B 3. 


\begin{tabular}{|c|c|c|c|c|c|c|}
\hline Taar. & $\begin{array}{l}\text { nendement: } \\
\text { op stanis- } \\
\text { obligaties }\end{array}$ & $\begin{array}{l}\text { winsti yan het } \\
\text { Rijksmingeumi } \\
\text { (subsidie van bet } \\
\text { rijk - entreegel- } \\
\text { Gan (incl. kosten } \\
\text { RGD) -schenkin- } \\
\text { gen) }\end{array}$ & $\begin{array}{l}\text { prijsstij- } \\
\text { ging }\end{array}$ & $\begin{array}{l}\text { toevoeging and de } \\
\text { collectie } \\
\text { (betrostigid door } \\
\text { tijk + schenlkin } \\
\text { genl) }\end{array}$ & $\begin{array}{l}\text { Eigen Venmogen an } \\
\text { geot linde ran hat jaar } \\
\text { (gebouw }+ \text { colliectie) }\end{array}$ & 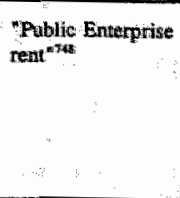 \\
\hline 1982 & $10,08 \%$ & F. $21.693,301,=$ & $5,5 \%$ & F. $845.044=$ & F. $9448.800,000 n_{n}=$ & F. $974.420 .757_{n}$ \\
\hline 1983 & $8,61 \%$ & F. 19.994 .419 & 2,8 & F. $1.258 .587, *$ & P. 9.714 .600 .900 & F. 856.420 .397 \\
\hline 1984 & $8,16 \%$ & F. $28.975 .661^{*}$ & 3.38 & F. $11.389 .188,{ }^{*}$ & F. $10.047,0000,0000_{1}$ & F. $848.807390^{4}$ \\
\hline 1985 & $7,34 \%$ & F. 20.968 .519 & 2.85 & F. $1.136 .0222_{*}^{*}$ & F. $10.329 .000,000$. & F. 779.119065. \\
\hline 1986 & $6,35 \%$ & F. 20.628 .954 & $0 \%$ & F. 2.109 .083$, & 10.331.000,000,- & F. $676.643 .690^{-}$ \\
\hline 1987 & $6.39 \%$ & $F_{2} 21.776 .320$ & $-0,5 \%$ & F. 988.966; - & F. $10280,000,000 ; \mathrm{m}$ & F. $678.671,000=$ \\
\hline 1988. & $6,35 \%$ & F. 19.330 .000 & $0,7 \%$ & F. $1.085 .0988^{-}$ & F. $10.325,65,11000,-$ & F. $676.727,0000$ \\
\hline 1989 & $7,21$. & F. 22.294 .430 & $1,1 \%$ & P. 4.795 .331 :- & F. 10.471331 .000 & F, $777,278.0000_{n}=$ \\
\hline 1990 & $8,93 \%$ & $F, 23.125 .287$ & $2,5 \%$ & F. 3.217 .158$, & F. $10.736,331.000$ - & F. 981.8800000. \\
\hline
\end{tabular}

*De uitzonderlijk grote toevoeging van kunst aan de collectie in 1984 is het gevolg van de aankoop van twee schilderijen in 1984. Deze aankoop werd gefinancierd door midddel van schenkingen ("fund raising") en een renteloze lening van WVC.

\section{Tabel 15.4 De "public enterprise rent"749}

Voor 1982 waren minder gegevens beschikbaar. Een schatting van de "public enterprise rent $^{\prime \prime}$ voor deze periode is weergegeven in Bijlage 5 , waarbij derhalve moet worden opgemerkt dat deze berekening minder nauwkeurig is dan na 1981 . Wordt de gehele periode bezien dan kan worden opgemerkt dat de prijsstijging van 1971 tot en met 1980 $69,8 \%$ bedroeg. De "public enterprise rent" steeg van $F, 357,52$ miljoen aan het eind van 1970 tot $F .861,28$ miljoen. Dit is een stijging van $140,9 \%$. De prijsstijging gedurende de periode eind 1980 tot en met eind 1990 bedroeg $20,4 \%$. De "public enterprise rent" steeg. van F. 861,28 miljoen tot F. 981,88 miljoen, een stijging van ongeveer $14 \%$. Ook indien rekening gehouden wordt met de prijsstijging kan geconstateerd worden dat gedurende de

747 prijsindexcijfer van de gezinsconsumptie.

${ }^{748}$ Cijfers zijn afgerond.

749 De tabel is gebaseerd op een aantal bronnen. Voor het rendement op staatsobligaties is tor en met 1983 uitgegaam van de rente op de nieuwste drie langstlopende staatsobligaties, zoals vermeld in de jaarverslagen wan de Nederlandsche Bank. Vanaf 1984 is uitgegaan van de rente op de wijf langstlopende staatsobligaties, aangezien de Nederlandsche Bank dan aileen deze categorie vermeldt. Het verlies van het Rijksmuseum. wordt als volgt berekend. De subsidiëring aan personeelskosten en het materiele budget is bekend uit de diverse accountantsrapporten. Deze zijn echter slechts beschikbaar over de periode vanaf 1983. Yoor de periode voor 1983 is gebruik gemaakt van begrotingscijfers, In het verlies van het Rijksmuseum zijn ook de kosten voor de hnisvesting die gemaakt zijn door de RGD opgenomen. Deze cijfers zijn afkomstig van de Rijksgebouwendienst, Bouwburo Rijksgebouwendienst Rijksmuseum Amsterdarn, brief van $F$. Veltmeijer van 21 januari 1997. Vergelijk ook: Werkgroep Financiele en Bedrijfseconomische Aspecten Verzelfstandiging, Concept-eindrapport, 21 april 1989, bijlage 4. De cijfers over de prijsstijging zijin afkomstig uit de jaarverslagen van De Nederlandsche Bank over de periode 1970-1990. Het eigen vermogen is berekend per eind 1988 . Vervolgens is teruggerekend waarbij rekening is gehouden met de inflatie en de jaarlijkse toewoeging. 
jaren "70 de "public enterprise rent" fors toenam. Het betrof hier niet alleen een nominale maar ook een reële toename. In de jaren ' 80 deed zich echter een reële afname van de "public enterprise rent" voor. Zoals aangegeven was dit overeenkomstig de doelstellingen van de politieke actoren.

15.12 Wat is het relatieve belang van de doelen: een analyse van de wisselwerking tussen de eigen verklaring van het Rijksmuseum voor zijn "performance" en de reactie van de principalen op deze verklaring

\subsubsection{De ontwikkeling van de organisatiestructuur van de toezichthoudende instan- ties}

De benoemingen in toezichthoudende organen waren voor het Rijksmuseum als onderdeel van het departement minder van belang. Veel belangrijker was de reorganisatie die eind jaren ' 80 is doorgevoerd op het departement. Een en ander kan als volgt worden verduidelijkt. Op grond van artikel 26 van de Comptabiliteitswet 1976 was de Minister verplicht het uitoefenen van de administratie van het Rijksmuseum te controleren. Deze controle werd namens de Minister uitgeoefend door de Accountantsdienst en ook gedeeltelijk door CDFEZ. Vanaf 1983 wordt de controle volledig uitgeoefend door de Accountantsdienst. Het personeel van CDFEZ werd dienovereenkomstig naar de Accountantsdienst overgeplaatst. ${ }^{750}$ Gedurende de onderzoeksperiode werden verder ingrijpende interne reorganisaties doorgevoerd binnen het Ministerie. In paragraaf 15.3. is de organisatie van het Rijksmuseum beschreven. Daarbij is uiteengezet dat het Rijksmuseum deel uitmaakte van een netwerk. In dit verband is kort de organisatie van het Ministerie van WVC beschreven. Dit was echter de organisatie zoals die gold tot halverwege de jaren tachtig. 'De organisatie van de directie Musea, Monumenten en Archieven (MMA) is eind jaren tachtig gewijzigd. Verder werd er, zoals bij de bespreking van de eigendomsrechtenstructuur is aangegeven, in de jaren ' 80 gewerkt aan zelfbeheer van de diensten, aan budgettering en aan decentralisatie van de personeelsfunctie. ${ }^{751}$ De reorganisatie van de directie MMA is in dit verband met name van belang, aangezien zij de instantie was die toezicht hield op onder meer het Rijksmuseum en aangezien de aanleiding voor deze reorganisatie met name de tekortschietende efficiëntie van de rijksmusea (diensten) en de budgettaire situatie van het Rijk was, waardoor middelen herschikt werden.

In het kader van de reorganisatie van de Directie Musea, Monumenten en Archieven (MMA) stelde de Secretaris-Generaal van het Ministerie van WVC op 12 mei 1986 de Stuurgroep Organisatie Musea, Monumenten en Archieven (SOM) in. Ten behoeve van deze Stuurgroep werden een aantal werkgroepen ingesteld. De hoofddirecteur van het Rijksmuseum was voorzitter van de werkgroep Kunstmusea en -diensten. Een medewerker van de directie MMA werkte ten behoeve van de werkgroep voor een deel van de werktijd in het Rijksmuseum. De reorganisatie bestond met name uit de volgende vier wijzigingen: ${ }^{752}$

\footnotetext{
${ }^{750}$ De Minister van WVC, Brief aan de Directeuren-Generaal van het ministerie van WVC. AD/ADSU4506, 15 april 1093.

${ }^{751}$ Minister van $\mathrm{WVC}_{\mathrm{y}}$ Begroting van de Directie Musea, Monumenten en Archieven (MMA) 1986, bijlage bij nota MMA/FEA-U-445 van 13 mei 1985 , p. 3.

752 Directeur-Generaal Culturele Zaken, U 2359, Reorganisatie MMA, brief aan de Secretaris-Generaal en Plaatsvervangend Secretaris-Generaal, 11 maart 1986.
} 
1. De MMA-diensten zoals de rijksmusea werden gehergroepeerd in een aantal sectoren; waaronder een sector Kunstmusea en -diensten, een sector Cultuurhistorische musea en diensten, een sector Volkenkunde/Natuurlijke Historie en een Rijksdienst voor de Monumentenzorg. Deze sectoren werden binnen de lijnorganisatie geplaatst.

2. De directie MMA werd omgevormd tot een staf-directie organisatie, overeenkomstig het secretariemodel, zoals weergegeven in Figur 15.5.

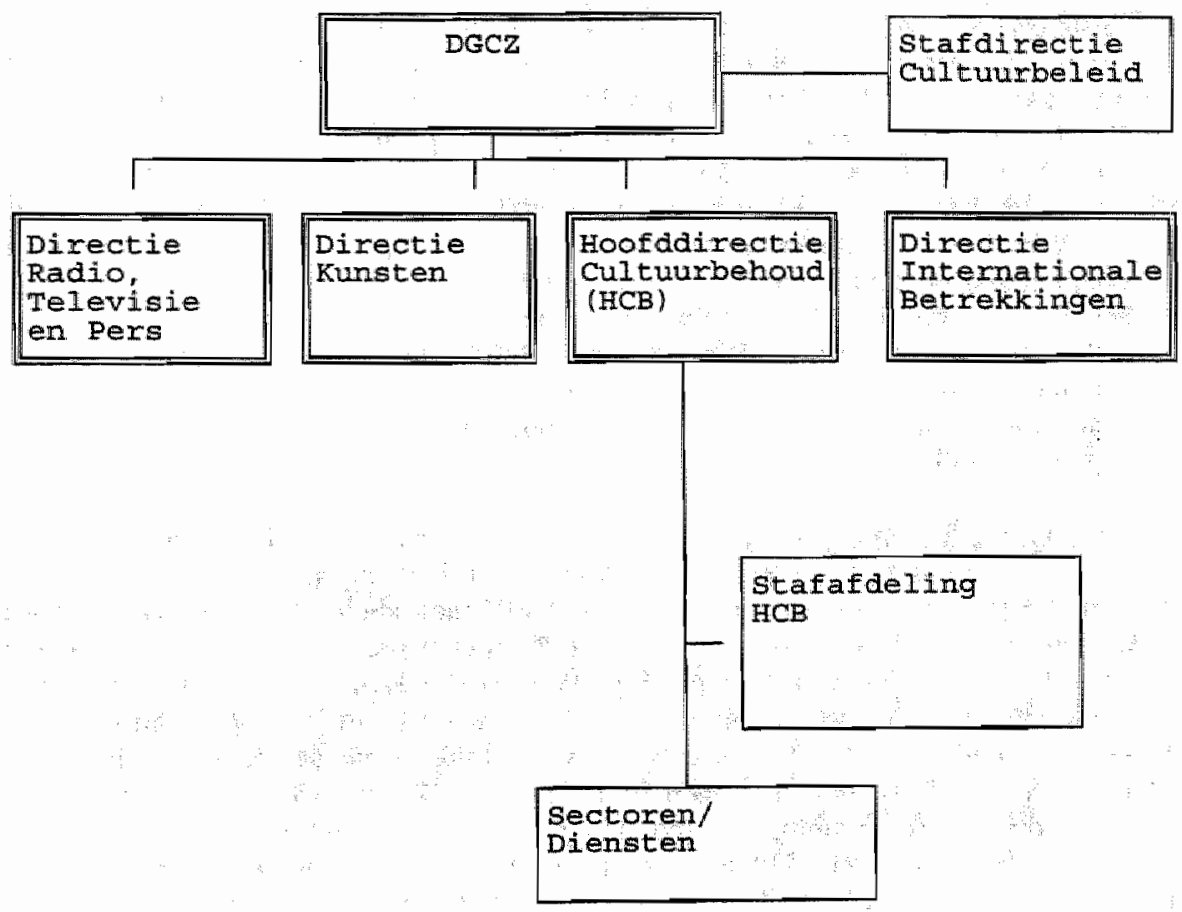

Figuur 15.5 De organisatie van de Directie Musea, Monumenten en Archieven na de reorganisatie.

3. De MMA-directies kregen zelfbeheer.

4. De uitwerking van punt 1 tot en met 3 was opgedragen aan DGCZ.

Het doel van deze reorganisatie was vooral om de Diensten effectiever en efficiënter te laten functioneren. De regelgeving zoals die gold tot halverwege de jaren tachtig maakte directe sturing van de productieprocessen binnen het Rijksmuseum door de overheid onmogelijk. Anderzijds was het voor het Rijksmuseum niet mogelijk besluiten te nemen over de inzet van middelen (materieel, personeel) zonder toestemming van de beleids- en centrale directies. De coördinatie- en besluitvormingslijnen waren echter dermate lang dat het voor het Rijksmuseum niet mogelijk was flexibel op veranderingen in te spelen. Het Ministerie was van mening dat de taken van het Rijksmuseum en de andere musea onvoldoende gerealiseerd werden. Bovendien veranderden de doelen van de principalen gedurende de jaren zeventig en tachtig. De overheid zou met name het behoud en beheer moeten financieren terwijl bijkomende doelen als tentoonstellingen, educatieve functie e.d. 
meer door het Rijksmuseum zelf gefinancierd moesten worden. Aan deze bijkomende doelen werd minder belang gehecht. De gedachte is dat met dezelfde middelen meer tot stand gebracht moest kumnen worden.

\subsubsection{Voorts zijn de expliciete beleidswijzigingen en verschuivingen in doelen tussen de verschillende actoren relevant}

Sinds het begin van de jaren zeventig werd er mede vanwege de verslechterende economische situatie bezuinigd op de exploitatiebegroting van het Rijksmuseum. In verband met de bestedingsbeperking moesten tal van activiteiten ingekrompen worden. Bovendien werden er zoals in paragraaf 15.4.1.5. is aangegeven herhaaldelijk personeelsstops en vacaturestops afgekondigd, waardoor opengevallen plaatsen niet vervuld konden worden. Dit leverde met name ten aanzien van de bewakingsdienst problemen op en leidde er toe dat veelvuldig delen van het Rijksmuseum voor het publiek gesloten waren. Deze verandering in het beleid van het kabinet leek aanvankelijk slechts tijdelijk. Achteraf blijkt het een wezenlijke beleidsverandering te zijn geweest waarbij de overheid steeds meer probeent te bezuinigen op de musea door het verminderen van budgetten en het vergroten van bijdragen van het publiek. De bezuinigingen hadden grote invloed op met name de publieksfunctie van de rijksmusea. Dat uitte zich bijvoorbeeld in de sluiting van het Rijksmuseum gedurende één dag in de week per 1 januari 1983 en de herhaaldelijke verhoging van entreeprijzen. Het ingevoerde contractmanagement sluit aan bij deze beoogde terugtred van de overheid.

Vanaf 1987 werkt het Rijksmuseum aan een wijziging van haar organisatiestructuur. Deze wijziging diende om ervoor te zorgen dat de voornamelijk vanwege historische redenen gegroeide organisatie werd aangepast aan de grotere zelfstandigheid. Deze ontwikkelingen werden voor een groot deel gestuurd door de politiek, met name door haar bevoegdheden ten aanzien van het vaststellen van de begroting. Een tweetal expliciete beleidswijzigingen kunnen worden onderscheiden gedurende de periode 1970-1990. In het begin van de jaren "70 werd er bezuinigd op het Rijksmuseum, naar verluidt vanwege de verslechterende situatie. Gezien de vrij forse bezuinigingen in 1971 en 1972 rijst het vermoeden dat het hier niet alleen om macro-economische redenen gaat. De overheid wil steeds meer de "public enterprise rent" verlagen. Dit impliceert dat zij minder subsidies verleent aan het Rijksmuseum. Deze middelen kan zij gebruiken voor belastingverlaging en andere doelen. Aangezien begin jaren ' 70 de belastingen niet verlaagd zijn, is het waarschijnlijk dat andere doelen zijn nagestreefd, waaronder inkomensnivellering. Deze inkomensnivellering is zowel nagestreefd via belastingmaatregelen als door middel van specifieke uitgaven.

Een tweede verandering is dile begin jaren '80. Er wordt dan expliciet gestreefd naar een terugtreden van de overheid. Er wordt opnieuw bezuinigd. Niet alleen met het oog op de moeilijke economische omstandigheden maar ook in verband met het genoemde terugtreden van de overheid. Kabinetten streven naar denivellering. Het is ook voor deze beleidswijziging waarschijnlijk dat het uiteindelijk gaat om een verdeling van de "public enterprise rent". Door het bezuinigen op de subsidie aan musea kunnen de belastingen omlaag en kunnen staatsobligaties eerder worden afgelost of hoeven er minder staatsobligaties te worden uitgegeven. Ontwikkelingen die corresponderen met deze beleidsverandering zijn de invoering van contractmanagement en het onderzoek naar externe verzelfstandiging eind jaren ' 80 . De organisatiewijziging na 1987 , gebaseerd op een door het Ministerie goedgekeurd statuut, is dus in die zin een gevolg van de beleidsverandering door politieke actoren aan het begin van de jaren ' 80 . Zij moet gezien worden als een amtwoord van het management op de gewijzigde omstandigheden. Gedwongen door de bezuinigingen is het management van het Rijksmuseum genoodzaakt bepaalde prioriteiten te leggen. De directie legt daarbij begin jaren ' 80 de prioniteit bij behoud en beheer boven 
de doelstelling van toegankelijkheid.

15.12.3 Analyse van impliciete beleidswijzigingen die niet publiekelijk werden bediscussieerd

Impliciete beleidswijzigingen kunnen enerzijds worden afgeleid uit de ontwikkeling van het bezoekersaantal gedurende de onderzoeksperiode en anderzijds uit de wijzigingen in de "public enterprise rent".

\subsubsection{De ontwikkeling van de bezoekersaantallen en de belangrijkheid van doelen}

Voor de analyse van de impliciete beleidswijzigingen van het Rijksmuseum zijn vooral de bezoekersaantallen van belang. Deze bezoekersaantallen weerspiegelden de discussie tussen het Ministerie van WVC en het management van het Rijksmuseum over de vraag in hoeverre het accent moest liggen op het zoveel mogelijk bevorderen van deelname aan de cultuur of juist op het doel van het bewaren van kunst. De ontwikkeling van de bezoekersaantallen kan als volgt worden weergegeven.

\begin{tabular}{|l|l|l|l|l||}
\hline jaar & $\begin{array}{l}\text { bezoekersaan- } \\
\text { tallen }\end{array}$ & $\begin{array}{l}\text { betalende bezoe- } \\
\text { kers }\end{array}$ & $\begin{array}{l}\text { niet-betalen- } \\
\text { de bezoekers }\end{array}$ & entreeopbrengst \\
\hline 1970 & 1.130 .035 & 714.576 & 415.459 & F. $586.923,50$ \\
\hline 1972 & 1.317 .240 & 824.158 & 493.082 & F. $1.216 .638,80$ \\
\hline 1974 & 1.285 .352 & 697.437 & 587.915 & F. $1.128 .924,-$ \\
\hline 1976 & 1.407 .022 & 724.540 & 682.482 & F. $1.021 .519,90$ \\
\hline 1978 & 1.071 .427 & 707.369 & 364.058 & F. $1.988 .349,61$ \\
\hline 1980 & 1.078 .106 & 719.226 & 358.880 & F. $1.985 .477,80$ \\
\hline 1982 & 999.180 & 767.405 & 231.775 & F. $2.351 .726,-$ \\
\hline 1984 & 1.013 .654 & 768.574 & 245.080 & F. $4.938 .429,50$ \\
\hline 1986 & 937.942 & 703.760 & 234.182 & F. $4.172 .959,-$ \\
\hline 1988 & 916.493 & 701.685 & 214.808 & F. $4.153 .919,50$ \\
\hline 1990 & 1.021 .239 & 873.205 & 148.034 & F. $4.850 .524,25$ \\
\hline
\end{tabular}

\section{Tabel 15.5 De ontwikkeling van bezoekersaantallen}

Het aantal bezoekers nam gedurende de eerste helft van de jaren '70 fors toe. Getracht werd om dit op te vangen door de openingstijden te verruimen, met name van de schilderijenafdeling of van alle afdelingen bij toerbeurt, in die zin dat het museum ook eén of meer avonden per week en in het bijzonder zondagmorgen wordt opengesteld. ${ }^{753}$ Aan de

${ }^{753}$ Rijksmuseum Amsterdam, Verslagen van de Hoofddirecteur over de jarep 1971 en 1973 . Mimisterie vain CRM. 
andere kant begon zich ook een andere ontwikkeling af te tekenen. Onder druk van het departement werd er minder de nadruk gelegd op het aantal bezoekers en meer op de entree-ontvangsten. Met ingang van 1 jamuari 1972 werden de entreeprijzen op werkdagen verhoogd van $F 1$, - tot $F .2$,- en op zaterdagen en zondagen van $F .0,50$ tot $F$. 1,-. De jaarkaarten stegen in prijs van F. 2,- tot F. 10,-. Door deze stijging in de entreeprijzen nam de recette fors toe. In juli 1974 berichtte het Ministerie dat de entreeprijzen van de rijksmusea met ingang van 1 januari 1975 verhoogd dienden te worden. Dit betekende voor het Rijksmuseum een prijsverhoging met $50 \%$. De hoofddirecteur en de directie hadden hiertegen principiële bezwaren. Zoals reeds eerder is aangegeven stelde de directie zich op het standpunt dat een bezoek aan het Rijksmuseum voor iedereen betaalbaar moest zijn. Mede in verband met de publiciteit die hieraan in de media werd gegeven werd het voorstel uiteindelijk ingetrokken. In 1975 steeg het bezoekersaantal met ongeveer $10 \%$. Dit was tot dan toe het hoogste bezoekersaantal uit de geschiedenis van het Rijksmuseum. Het aantal niet-betalende bezoekers begon vanaf 1976 af te nemen, voomamelijk door het door het Ministerie gevoerde beleid van prijsverhoging, maar ook door het verminderde binnenlandse dagbezoek aan Amsterdam. ${ }^{755}$ In 1977 verminderde het aantal bezoekers met $12 \%$. Een en ander werd geweten aan een aantal factoren waaronder het verrichten wan te weinig publicitaire activiteiten. Opvallend is evenwel vooral de forse afname wan de niet-betalende bezoekers. ${ }^{756}$ Het aantal bezoekers daalde in 1978 met nog eens $12 \%$. Ook deze daling werd vooral geweten aan de daling van het toeristische bezoek aan Amsterdam. Andere redenen waren het ontbreken van een publiektrekkende tentoonstelling en het ontbreken van activiteiten op publicitair gebied. Als redenen voor dit laatste werd de afwezigheid wegens ziekte van het Hoofd van de afdeling Voorlichting genoemd. ${ }^{757}$ Begin jaren ' 80 zette de daling van het aantal niet betalende bezoekers door. Deze daling werd onder meer veroorzaakt door het afschaffen van de gratis enturee op woensdagen. Andere redenen zijn vooral gelegen in het herhaaldelijk sluiten van zalen en de stijging van de entreeprijs met F. 1,- per 1 juli 1982. De totale opbrengst daalde van F. 2.511.492,40 in 1981 tot F. 2.351.726,- in 1982. Aangezien deze middelen naar het Rijk gingen (ingecallculeerd via de begroting) vroeg de hoofddirecteur zich af of de door het Rijk genomen maatregelen verstandig waren. Ook de entreeprijsstijging in 1983, ditmaal yan $F, 4,50$ tot $F, 6,50$ per bezoeker, droeg bij aan de daling van het aantal niet betalende bezoekers. Het management vond deze stijging van de entreeprijs onwenselijk, doch, zoals ook in de vorige paragraaf werd geconstateerd, minder erg dan het opofferen van behouds- en beheerstaken. Een andere reden voor de daling van het aantal bezoekers werd veroorzaakt door de eerder gememoreerde sluiting van het museum op maandag. De hoofddirecteur stelde het Ministerie voor de toegangsprijs van het Rijksmuseum te bepalen naar rato van het percentage gesloten afdelingen van het museum. Dit om te voorkomen dat een situatie ontstaat waarbij de prijs steeg, het museum éen dag in de week gesloten was en bovendien regelmatig delen van het museum gesloten zouden zijn. Dit zou naar de

754 Rijksmuseum Amsterdam, Verslag yan de Hoofddirecteur over het iaar 1975 , Ministerie van CRM, p. 12.

795 Rijksmuseum Amsterdam, Verslag yan de Hoofddirectear over het laar 1976, Ministerie van CRM. Vergelijk ook de concept-beleidsmota van het Rijksmuseum; Amsterdam; oktober 1983, p. 55.

${ }^{756}$ Rijksmuseum Amsterdam, Verslag van de Hoofddirecteur over het jaar 1977, Ministerie van CRM, pp. 8-9.

757 Rijksmuseum Amsterdam, Verslaz van de Hoofddirecteur over her jaar 1978, Ministerie van CRM, pp. 10-11. 
mening van het museum tot een aanzienlijke aantasting van de presentatiefunctie leiden. ${ }^{78}$ In 1986 daalde het aantal bezoekers met $11 \%$ tot 937.942 personen. Eén en ander werd voornamelijk veroorzaakt door de sterke daling van het aantal Amerikaanse toeristen. Dit had als gevolg dat het in het convenant genoemde taakstellende bedrag van F. 4.250 .000 ,- niet gehaald werd. Aan entreegelden werd namelijk een bedrag van $F$. 4.172.959,- geïnd. ${ }^{759}$ Eind jaren ' 80 stabiliseerde het aantal bezoekers zich op ongeveer én miljoen. Het aantal niet betalende bezoekers nam verder af: ${ }^{760}$

Indien naar de ontwikkeling van het aantal bezoekers gedurende de periode 1970-1990 wordt gekeken valt een belangrijke impliciete verandering in de doelen op. In de jaarverslagen en de beleidsnota's legt het management de nadruk op het zo toegankelijk mogelijk zijn van het museum. In de concept-beleidsnota van 1983 stelt de directie van

het Rijksmuseum bijvoorbeeld: "Er dient naar gestreefd te worden de geestelijke en materiële drempels die belemmerend werken op de lust om het Rijksmuseum te bezoeken te elimineren. Zo dient het museum in zijn geheel toegankelijk te zijn, dient de toegangsprijs voor niemand een drempel te vormen en dienen de mogelijkheden voorhanden te zijn om een gevarieerd presentatie- en tentoonstellingsbeleid te kunnen verwezenlijken ". 761 . De entreeprijzen dienen zo laag mogelijk te zijn en het aantal niet betalende bezoekers moet niet beperkt worden. In tegenstelling tot datgene wat door het management maar ook door het Ministerie wordt gesteld, wordt er echter geleidelijk aan gedurende de onderzoeksperiode steeds meer de nadruk gelegd op het meer kostendekkend functioneren en minder op het bereiken van een zo groot mogelijk publiek. Het management kiest zoals ze zelf aangeeft als het moet voor het behoud en beheer van kunst boven de presentatie en bereikbaarheid ervan. Zoals het zelf stelt: "Voor de keuze gesteld waar de prioriteiten moeten liggen, acht het Rijksmuseum, opdat de collectie in fysieke zin en de daarbij behorende kennis za goed mogelijk aan het nageslacht worden overgedragen, het behoud en beheer van de verzameling van groter belang dan de dienstverlening in het algemeen en de toegankelijkheid van de collectie ${ }^{1 .}{ }^{762}$ Deze impliciete wijziging van de doelen blijkt ook uit de ontwikkeling van de "public enterprise rent", zoals weergegeven in paragraaf 15.12. In de jaren' 80 trad er reèel gezien een daling op, terwijl er gedurende een aantal jaren zelfs sprake was van een nominale daling.

\subsubsection{De ontwikkeling van de "public enterprise rent"}

Indien wordt gekeken naar de cultuuruitgaven, de totale overheidsuitgaven en de "public enterprise rent" van het Rijksmuseum als percentage van het nationale inkomen valt het volgende op:

${ }^{758}$ Rijksmuseum Amsterdam, Verslagen van de Hoofddirecteur ower de jaren 1981 en 1983, Ministerie van WVC, p. 11 .

759 Rijksmuseum Amsterdam, Nederlandse Riiksmusea 1986, Ministerie van WVC, p. 10.

${ }^{760}$ Rijksmuseum Amsterdam, Verslagen wan de directie over her jaar 1989 en 1990 , Ministerie van WVC, p. 77 .

761 Rijksmuseum, Concept-beleidsnota; Amsterdam, oktober 1983, p. 60. Vergelijk ook de definitieve beleidsmota van maart 1985 , p. $58 \mathrm{ev}$.

762 Rijksmuseum, Concept-beleidsnota, Amsterdam, oktober 1983, p. 92. 


\begin{tabular}{|l|l|l|l|l|l|l|l|l|l|}
\hline & 1982 & 1983 & 1984 & 1985 & 1986 & 1987 & 1988 & 1989 & 1990 \\
\hline $\begin{array}{l}\text { Netto } \\
\text { nationalal } \\
\text { inkomen }\end{array}$ & 330,62 & 342,39 & 358,56 & 375,99 & 385,44 & 386,46 & 401,2 & 420,3 & 452,45 \\
\hline $\begin{array}{l}\text { Uitgaven } \\
\text { voor cultuur } \\
\text { uitgedrukt } \\
\text { in NNI }\end{array}$ & 0,51 & 0,55 & 0,52 & 0,56 & 0,52 & 0,46 & 0,49 & 0,46 & 0,44 \\
\hline $\begin{array}{l}\text { Public } \\
\text { enterprise } \\
\text { rent van } \\
\text { bet } \\
\begin{array}{l}\text { Rijksmuseum } \\
\text { in NNI }\end{array}\end{array}$ & 0,29 & 0,25 & 0,24 & 0,21 & 0,18 & 0,18 & 0,17 & 0,18 & 0,22 \\
\hline $\begin{array}{l}\text { Totale } \\
\text { overheids- } \\
\text { uitgaven } \\
\text { in NNI }\end{array}$ & $69,3 \%$ & $70,3 \%$ & $68,7 \%$ & $67,3 \%$ & $67,1 \%$ & $66,4 \%$ & $66 \%$ & $62 \%$ & $62,5 \%$ \\
\hline
\end{tabular}

Tabel 15.6 De uitgaven voor cultuur, "public enterprise rent" en netto nationaal inkomen ${ }^{763}$

In Tabel 15.6 is weergegeven dat niet alleen de culturuitgaven in het algemeen als percentage van het netto nationaal inkomen dalen maar ook de "public enterprise rent" van het Rijksmuseum. ${ }^{754}$ Dit wordt niet met zoveel woorden door de politieke actoren bediscussieerd. De "public enterprise rent" van het Rijksmuseum uitgedrukt als percentage van het nationale inkomen, dalen echter sneller gedurende de jaren ' 80 dan de totale overheidsuitgaven. Dit impliceert dat het beleid van de overheid om de kunstsector te ontzien veranderd is. De "public enterprise rent" van het Rijksmuseum daalt ook meer dan de totale uitgaven voor cultuur. Blijkbaar kiezen de principalen voor andere bestedingsmogelijkheden en is er sprake van een impliciete beleidswijziging. Dit is opmerkelijk omdat in de diverse stukken van het departement de indruk wordt gewekt dat het Rijksmuseum ontzien wordt.

\section{Conclusie}

Uit de impliciete wijziging van de doelen bleek dat de Minister zich steeds meer concentreerde op het behoud van de collectie, terwijl bijkomende doelen, voor zover bekostigd door de overheid, werden verminderd. Het relatieve belang van deze doelen werd minder.

15.12.4 Zijn er verschillen tussen datgene wat de houders van eigendomsrechten zeggen en datgene wat zij werkelijk doen?

Aan de hand van een beschrijving van het gevoerde beleid gedurende de periode 19701990 kan inzicht worden gekregen in het verschil tussen datgene wat de eigenaren zeggen

76. De cijfers over het mationale inkomen zijn afkomstig uit: Centraal Planbureau, centraal economische lamen over 1982-1990, "s-Gravenhage, 1982-1990. De cijfers over de overheidsuitgaven zijn afkomstig uit de diverse Milljoenennota's.

764. T.a.p., 90. 
na te streven (zie de beschrijving van de doelen) en hetgeen werkelijk is nagestreefd.

\section{De periode 1970-1975}

Het management stelde zich op het standpunt dat het Rijksinuseum voor ledereen bereikbaar diende te zijn tegen een zo laag mogelijke prijs. De kunst zoals die door het Rijksmuseum beheerd wordt, werd gezien als een "merit good". Het is goed voor de gebruiker en derhalve dient de kennismaking met deze kunst bevorderd te worden. Centraal stond het bezoekersaantal. In principe diende dit aantal zo groot mogelijk te zijn waarbij het weinig uitmaakte of de bezoekers al dan niet betalend waren. De enige beperkingen vormden de muimte die het gebouw biedt en de aanwezigheid van voldoende budgetten voor bewaking, onderhoud en schoonmaakwerkzaamheden. Daarom werd er bij het Ministerie herhaaldelijk op aangedrongen de budgetten niet te beperken maar juist uit te breiden, opdat de kwaliteit van de dienstverlening door het Rijksmuseum en de kwaliteit van de collectie gewaarborgd blijven.

Het Ministerie streefde er, mede in verband met de verslechterende economische situatie, naar de entreegelden te verhogen en de mate van subsidiëring te beperken. Het ging er daarbij niet om dat er zoveel mogelijk mensen komen maar dat er zoveel mogelijk betalende bezoekers komen. De uitbreiding van het gebouw en faciliteiten werd opgeschort en de begroting voor het Rijksmuseum werd fors verminderd. In de periode 19701975 werd wel een werkgroep geinstalleerd die de uitbreiding van het gebouw c.q. van de nuimte waarover het museum kan beschikken onderzocht. Daarnaast kwam de Minister met voorstellen om de entreeprijzen in 1975 fors te verhogen. Dit impliceerde dat het Ministerie de subsidies aan het museum will verlagen. $\mathrm{Zij}$ kende meer gewicht toe aan technische efficiëntie dan het management van het Rijksmuseum. Dit was ook een reden waarom zij de afdeling Organisatie en Efficiency van het Ministerie onderzoeken liet verrichten. Indien dit wordt bezien in het kader van rentseeking" kan geconstateerd worden dat het management van het Rijksmuseum een zo groot mogelijke "publie enterprise rent" wenst. Deze wil zij] onder meer gebruiken voor lage prijzen, relatief meer werkmemers, uitbreiding van faciliteiten en indien gewenst arbeidstijdverkorting.

Het Ministerie wil daarentegen de "public enterprise rent" verminderen door het bezuinigen op de begroting en hogere entreeprijzen, door het opschorten van de uitbreiding van het gebouw en overige faciliteiten en door het instellen van een vacaturestop. Dit moet er toe leiden dat het Rijksmuseum technisch efficiënter wordt. $\mathrm{Zij}$ tracht het aantal bijkomende doelen (zoals werkgelegenheid) terug te brengen. Dit impliceert dat zij minder belang becht aan een eventueel "merit good" karakter van kunst.

Toch worden bezuinigingen door het rijk niet steeds doorgezet, ondanks dat zij dat gezien haar bezit aan eigendomsrechten zou kunnen doen. Er was een vacaturestop ingesteld maar hier zijn wel een aantal uitzonderingen op gemaakt. De aangekondigde stijging van de entreeprijs voor 1975 ging niet door. De begroting werd teruggebracht, maar dit kon nog wel redelijk worden opgevangen door het verminderen van de variabele kostem. Voorts is het aantal niet betalende bezoekers over de periode 1970-1975 aanzienlijk toegenomen. Opvallend is verder dat het Rijksmuseum enerzijds steeds weer wijst op de gebrekkige behuizing en anderzijds het aantal niet betalende bezoekers laat toenemen, hetgeen wordt toegestaan door het Ministerie.

De conclusie die hieruit getrokken kan worden is dat ook het Ministerie en de politieke actoren wel oog hebben voor het speciale karakter van de dienstverlening door het Rijksmuseum. Zij moeten evenwel een afweging maken nussen tal van bestedingsmogelijkheden, waarbij gezien de economische problemen de musea niet de voornaamste prioriteit hebben. $\mathrm{Zij}$ overwegen geen interne of externe verzelfstandiging maar kiezen voor het. zoveel mogelijk opschorten van nieuwe activiteiten totdat betere tijden aanbreken. 
Gedurende deze periode bleef de begroting veelal bevroren. Zo nu en dan werden door het Ministerie extra kredieten verstrekt. Het management probeerde de bevriezing van de begroting op te vangen door in te teren op variabele posten zoals onderhoud.

Zoals in de vorige paragraaf is aangegeven stegen de oplbrengsten van de entreegelden van ruim 1 miljoen gulden in 1976 tot bijna 2 miljoen gulden in 1980 . De gesignaleerde tegenstelling tussen het Ministerie en het management van het Rijksmuseum deed zich ook in de periode 1976-1980 voor. Dat het management nog steeds streefde naar bijkomende doelen zoals bijvoorbeeld werkgelegenheid en minder oog had voor technische efficiëntie bleek bijvoorbeeld uit haar streven naar uitbreiding van het aantal formatieplaatsen bij de bewakingsdienst. Door gebrek aan personeel moesten regelmatig onderdelen van het museum worden gesloten. Dit gebrek aan bewakingspersoneel werd geweten aan het teruglopen van het aantal ingezette dienstplichtigen, invoering van arbeidstijdverkorting en vooral aan het hoge ziekteverzuim. Aangezien het bezoekersaantal gedurende deze periode is teruggelopen en het gebouw verder niet vergroot is rijst de vraag of in plaats van nog meer personeel aan te trekken het niet beter is eerst intern orde op zaken te stellen. Zo doet zich de merkwaardige situatie voor dat het van te voren niet duidelijk was welke zaalwachters verschijnen, waardoor het onzeker is welke delen van het museum geopend zijn. $^{765}$ Hieraan moet worden toegevoegd dat er met name aan het eind van de periode gestreefd werd naar verbetering (waarschijnlijk mede omdat steeds meer duidelijk wordt dat de verdere uitbreiding van de bewakingsdienst niet gerealiseerd kon worden), zoals bijvoorbeeld de modernisering van de beveiliging en de opening van een meldkamer.

Het Ministerie bleef streven naar vergroting van de technische efficiëntie en bezuinigingen op de uitgaven voor musea. Dit probeerde het te realiseren door bevriezing van de begroting, formatiestops en verplichtingenstops. Hierdoor had het Rijksmuseum steeds minder mogelijkheden bijkomende doelen na te streven. Dit streven van het Ministerie naar een situatie waarin het Rijksmuseum steeds meer door middel van entree-opbrengsten en schenkingen haar eigen continuitteit dient te waarborgen was de eerste stap op weg naar interne en mogelijk externe verzelfstandiging.

Samenvattend kan gesteld worden dat ook in de periode 1976-1980 het Rijksmuseum een belangrijke rol toekent aan kunst als "merit good" en daarom een zo groot mogelijk publiek wil bereiken. Het Ministerie vindt dit doel blijkbaar minder belangrijk, hoewel dit nergens met zoveel woorden gezegd wordt, en wil derhalve haar bijdragen verminderen. Omdat zij als principaal beschikt over het recht te beslissen over de input is haar positie dermate sterk dat zij ook in staat is haar bijdragen te verminderen.

\section{De periode $1981-1985$}

De keuzes zoals die door het Ministerie en het management van het Rijksmuseum gedurende deze periode gemaakt zijn bevestigen de standpunten zoals die reeds eerder zijn aangegeven. Het Ministerie wenste het streven naar technische efficiëntie te bevorderen en het streven naar bijkomende doelen te verminderen. Zij zag kunst minder als een goed met belangrijke externe effecten. Zij legde de nadruk op het behoud van de huidige collectie en niet op de uitbreiding ervan. Ook de presentatie achtte zij blijkbaar van ondergeschikt belang.

Het management van het Rijksmuseum zag zoals vermeld de door het Rijksmuseum beheerde kunst als onderdeel van het nationale culturele erfgoed dat aan iedereen

\footnotetext{
${ }^{765}$ Verslag van de Hoofddirecteur over het jaar 1979, Rijksmuseum te Amsterdam, Ministerie van CRM, pp. 7-9.
} 
toebehoort en zij trachtte ondanks de bezuinigingen zo goed en zo kwaad als het ging haar doelen te bereiken. De restricties die het Ministerie oplegde gingen steeds verder: Gedwongen door de door het Ministerie voorgestelde personeelsreducties met $2 \%$ per jaar legde zij prioriteit bij de doelstelling behoud en beheer omdat het prijsgeven van behoudsen beheerstaken ernstige gevolgen zou hebben voor het nageslacht, terwijl beperking van de fysieke toegankelijkheid weliswaar voor de huidige generatie voelbaar is, maar minder zwaarwegende consequenties heeft voor de toekomst. Indien zij een keuze moet maken kiest zij voor het handhaven van behouds- en beheerstaken en verhoging van entreeprijzen boven het handhaven van prijzen met tegelijkertijd vermindering van de behouds- en beheerstaken. Desalniettemin tracht het Rijksmuseum de stijging van entreeprijzen tegen te gaan door het voorstel bezoekers te laten betalen naar rato van gesloten delen van het museum.

Aan het einde van de periode werd een begin gemaakt met de invoering van contractmanagement, dat als een vorm van interne verzelfstandiging kan worden gezien. Dit komt overeen met de doelen van de politieke actoren zoals deze zich gedurende de laatste decennia hebben ontwikkeld. Mede gezien deze ontwikkelingen wil het management van het Rijksmuseum een integraal onderzoek naar de organisatiestructuur laten verrichten.

\section{De periode 1986-1990}

Zoals ook al in eerdere periodes is aangegeven hechtte het Ministerie minder belang aan het speciale karakter van de kunst dan het management (zonder dat dit in officiële verslagen zo werd gesteld) en derhalve beoogde zij een grotere mate van kostendekking. Eén en ander maakte een grotere mate van zelfstandigheid van het Rijksmuseum waarschijnlijk.

De periode 1986-1990 werd dan ook gekenmerkt door twee reeds eerder genoende ontwikkelingen. In het kader van de interne verzelfstandiging kreeg het Rijksmuseum meer bevoegdheden. Een andere belangrijke ontwikkeling was het onderzoek naar een geschikte organisatiestructuur die uiteindelijk resulteerde in de IKON-rapporten en de daarop gebaseerde organisatorische wijzigingen.

Beide ontwikkelingen staan niet los van elkaar. Mede door het ingevoerde zelfbeheer was het belangrijk ook de organisatiestructuur te herzien. Deze twee ontwikkelingen hebben ook invloed gehad op de doelstellingen van het management van het Rijksmuseum. Zij zijn meer gewicht gaan toekennen aan de bereikbaarheid en minder aan andere doelen (waaronder werkgelegenheid, bijvoorbeeld bij de bewakingsdienst). Daarvoor was het nodig ervoor te zorgen dat niet langer delen van het museum gesloten zouden zijn. Opvallend is dat de personele problemen bij de bewakingsdienst nu wel opgelost kunnen worden, waardoor het ook mogelijk werd de openingstijden te verruimen.

Aan het einde van de periode werd onderzoek verricht naar externe verzelfstandiging. Dit sluit aan bij de ontwikkelingen zoals deze zich vanaf 1970 voordeden. Als motief voor de externe verzelfstandiging van rijksmusea wordt de vergroting van het maatschappelijk draagvlak genoemd. Het is de bedoeling dat rijksmusea minder in zichzelf gericht zijn en zich meer richten op de wensen en behoeften van het publiek. ${ }^{766}$

Op 30 juni 1994 werden de Protocollen van Overdracht voor de verzelfstandiging van de eerste zes rijksmusea ondertekend (het Rijksmuseum valt hier nog niet onder). In plaats van de "instructie aan de directeur", op grond waarvan de Minister instructies kon geven aan de directeur van het Rijksmuseum, zijnde een hiërarchisch ondergeschikte, zijn er nu overeenkomsten met zelfstandige culturele ondernemingen. Naast de protocollen van

766 D'Ancona (1994), Staatscourant 124, p. 5. 
eigendom werden de beheersovereenkomsten en de hurrovereenkomsten ondertekend. De verzelfstandigingswet werd met algemene stemmen door de Eerste en Tweede kamer aanvaard. Voorts ondersteunde het kabinet het voorstel van de Minister van Volkshuisvesting om $\mathbf{5 0}$ miljoen extra te steken in de verbetering van de museale gebouwen. Verder werd er; buiten veramtwoordelijkheid van de Minister, met instemming van het personeel een nieuwe c.a. o. vastgestell.

Het Rijksmuseum is per 1 jull 1995 gaan functioneren als een stichting. De werknemers zijn niet langer ambtenaren. Voorts is er een Raad van Toezicht ingesteld, die toeziet op het functioneren van de directie. De Rijksdienst Beeldende Kunst is belast met de inspectie van de beheersovereenkomst.

Opvallend is dat de externe verzelfstandiging niet eenzijdig door de overheid is verordonneerd maar dat de rijksmusea zelf ook voor externe verzelfstandiging waren. Aanvankelijk was het voor de rijksmusea vooral een streven om te ontsnappen aan de knellende regelgeving, geleidelijk aan werd ook meer aandacht gericht op de positieve kanten van de verzelfstandiging. De bedoeling was dat sponsors en bedrijfsleven geleidelijk de rol van de overheid zouden ovememen. Het effect van de externe verzelfstandiging is dat de verhouding tussen de overheid als principaal en het Rijksmuseum als agent meer gekenmerkt wordt door tweezijdigheild. Er geschiedt nog het een en ander per beschikking en voorts blijft de staat, zoals aangegeven, eigenaar van de gebouwen en de collectie.

Anderzijds kan het Rijksmuseum zich mu meer richten op de maatschappij en minder op ambtelijke regels en verordeningen.

Zoals reeds eerder opgemerkt bestaat er een verschil tussen datgene wat de politieke actoren in beleidsdocumenten en -nota's zeggen te willen en wat zij in de praktijk doen. In beleidsdlocumenten wordt steeds vermeld dat zij veel waarde toekennen aan de kunst: $\mathrm{Zij}$ zeggen te streven naar de bevordering van de bewaarfunctie, de presentatiefunctie, $z$ ij] beogen de educatieve functie uit te breiden en willen de deelname aan de cultuur bevorderen. Door het gevoerde financiële beleid moet evenwel op vrijwel alle terreinen een stap teruggedaan worden. Tarieven van entreekaarten stijgen, middelen voor uitbreiding van het gebouw zijn vele jaren niet aanwezig, het aankoopbudget wordt beperkt en gedurende een aantal jaren worden er vacaturestops afgekondigd. Hierdoor komt er weinig terecht van de door de politieke actoren geformuleerde doelen. Opvallend is dat de ingediende begroting sterk verschilt van de uiteindelijk toegewezen middelen. Het verschil is herhaaldelijk bijna $100 \%$.

\subsubsection{De mate waarin activiteiten niet worden bediscussieerd maar wel gewoon worden uitgewoerd}

Opvallend is dat de waarde van de collectie niet wordt bediscussieerd noch de uitbreidingen ervan. Elk jaar wordt de collectie uitgebreid. Aangezien de collecties van de diverse rijksmusea eind jaren tachtig op ruim dertig miljard gulden wordt geschat is dit opmerkelijk. Voor de uitbreiding van de collectie werd gedurende een groot deel van de jaren tachtig een vast bedrag van F. 750.000 ,- beschikbaar gesteld door WVC. Daarnaast werden schenkingen gebruikt voor het aankopen van kumstwerken. In het aankopen van kunstwerken was het Rijksmuseum in grote mate vrij. Dit werd nauwelijks inhoudelijk getcetst door het Ministerie. Hieruit kan worden afgeleid dat het doel van het instandhouden en uitbreiden van het culturele erfgoed van Nederland van groot belang werd geacht. Naast de niet-bediscussieerde stijging van de waarde van de collectie valt verder op dat de uitgaven voor de musea onderling weinig verschoven. De uitgave aan het Rijksmuseum 
ten opzichte van de totale netto-uitgaven aan alle musea blijft ongeveer gelijk. ${ }^{767}$

Dat wil overigens niet zeggen dat er geen belangrijke verschuivingen van de uitgaven zijn geweest tussen de verschillende overheden.

\subsubsection{Conclusie ten aanzien van het relatief belang van de doelen}

De doelen vam het Rijksmuseum zijn gedurende de onderzoeksperiode geleidelijk veranderd. Dit is vooral gebeurd onder druk van het Ministerie van WVC. De behoudsfunctie is meer tegen het licht gehouden. Vooral vanuit de politiek is verder de madruk gelegd op duidelijke selectiecriteria bij collectievorming. Dit gold niet alleen voor het Rijksmuseum maar ook voor de andere rijksmusea. Budgetten voor de aankoop van kunstobjecten werden bevroren, waardoor deze relatief onbeduidend werden. Daarbij is het opvallend dat er zowel vanuit de politiek als het management van het Rijksmuseum weinig oog is voor het bepalen van de waarde en samenstelling van de collectie. Het Ministerie dringt hier well steeds meer op aan. Grote nadruk werd gelegd op het behoud van de al aanwezige kunst. Steeds meer blijkt dat de overheid de functie van het behouden van kunst tot de primaire overheidsverantwoordelijkheid rekent. Ook ten aanzien van de publieksfunctie doen zich veranderingen voor. Aanvankelijk werd de educatieve taak benadrukt en werd er naar gestreefd om een zo groot mogelijk publiek te bereiken. Onder druk van het departement is dit doel steeds meer veranderd. Meer en meer wordt gemeend dat de musea waaronder het Rijksmuseum zich in eerste instantie moeten richten op publiek dat al geînteresseerd is in kunst en bereid is een prijs te betalen. De gedachte is dat de publieksfunctie kan worden overgelaten aan een verzelfstandigd Rijksmuseum.

\subsection{Vaststellen van de "performance" in termen van baten en kosten.}

De analyse tot dusver geeft aan dat het Rijksmuseum technisch inefficiënt produceert. Dit impliceert dat middelen in de zin van de "public enterprise rent", worden besteed aan andere doelen. Verschillende actoren proberen zich middelen toe te eigenen door een proces van "rentseeking". In de vorige paragrafen zijn de gerealiseerde doelen en de kosten van deze doelen weergegeven. In de periode 1980-1990 slagen politieke actoren erin de "public enterprise rent" te beperken. De tarieven gaan omhoog, het budget voor de aankoop van kunstwerken wordt beperkt. Er wordt minder gewicht toegekend aan het culturele erfgoedkarakter van de kunst. De vrijkomende middelen worden in het kader van het macro-economische beleid besteed aan andere doelen, waaronder aflossing van obligaties en schatkistpapier en belastingverlaging.

\subsubsection{De "performance" van het Rijksmuseum}

Het grootste deel van het budget bestaat in de periode 1970-1990 uit de jaarlijkse toelage van het Ministerie van WVC. Het budget werd met name gebruikt voor het bereiken van een tweetal doelen, namelijk voor de bewaarfunctie en voor de presentatie van kunst en culturur. De totale kosten van de doelen zijn echter veel hoger, aangezien er sprake is van een omvangrijke "public enterprise rent" "Hoewel aangegeven is dat bij de berekening met name ten aanzien van de jaren '70 (Bijlage 5), een slag om de arm moet worden gehouden is het wel duidelijk dat deze zeer aanzienlijk is. $\mathrm{Zij}$ wordt enerzijds gebruikt om de entreeprijzen laag te houden. Anderzijds wordt de "public enterprise rent" gebruilkt om een aantal kunstwerken in Nederland te houden, als onderdeel van het culturele erfgoed.

767 Van Puffelen (1993, p. 90). Dit geldt indien alleen gekeken wordt naar het Rijk, maar ook indien alle overheidsuitgaven bezien wordem. 
Geconstateerd kan worden dat het Rijksmuseum Amsterdam een aantal doelen nastreeft. Wordt uitgegaan van 1988 dan kan geconstateerd worden dat de doelen bij elkaar per saldo F. 676,727 miljoen kostten (de entreegelden werden grotendeels afgedragen aan het departement). In dit hoofdstuk is aangegeven aan welke doelen dit bedrag werd besteed en in hoeverre deze doelen werden gerealiseerd. ${ }^{76}$

\section{Doelen 3,2,7 en 12}

Een deel van het budget werd besteed aan de publieksfunctie. Om kostendekkend te zijn had het Rijksmuseum in 1988 F. 21,94 miljoen aan entreeopbrengsten en andere ontvangsten hebben moeten realliseren. In werkelijkheid bedroegen de ontvangsten ongeveer F, 4,8 miljoen. Dit betekent dat in 1988 van de 676,727 miljoen $F, 17,17$ miljoen werd besteed aan het bevorderen van het bezoek van het publiek door relatief lage entreeprijzen en door de vrijstelling van allerlei categorieẻn. Dit bedrag werd dus besteed aan doel 2 , het toegankelijk maken en de presentatie, doel 3 , het bevorderen van de cultuurdeelname, en aan doel 12, het bevorderen van het toerisme. Ook de educatieve functie kan hieronder worden gebracht. Hierbij kan dan nog worden opgemerkt dat voor het organiseren van tentoonstellingen en de permanente presentatie een bedrag van F. 1.667.749, besteed werd. In totaal werd aan de publieksfunctie ongeveer 23,5 miljoen gulden van de "public enterprise rent" besteed. Voor een particulier museum zou het uitgesloten zijn geweest tegen zulke lage entreeprijzen zo'n omvangrijke collectie te tonen. Deze "rents" worden dus overgeheveld naar de liefhebbers van kunst. Een gedeelte van de salarissen van het personeel kan ook tot deze categorie doelen worden toegerekend. Van de ongeveer 340 werknemers waren naar schatting ongeveer 160 personen werkzaam ten behoeve van de publieksfunctie. ${ }^{769}$ De totale materiele en personele kosten bedroegen F. 21,94 miljoen. Een en ander impliceert dat ongeveer $160 / 340$ deel, dus F. 10,3 miljoen, van deze kosten gemaakt werden voor de publieksfunctie. De totale kosten gemaakt voor de publieksfunctie kunnen dan worden geschat op F. 33,8 miljoen.

\section{Doel 4}

Aan wetenschappelijk onderzoek werd in 1988 F. 343.500,- besteed. Daarnaast werden een gedeelte van de algemene en personeelskosten hieraan besteed, Omgeslagen over de 30 wetenschappelijke medewerkers bedraagt dit ongeveer $F, 1,4$ miljoen. Dit doel kostte per saldo dan ook ongeveer F. 1,7 miljoen.

\section{Doelen 5 en 9}

Voor de aanschaf van kunstwerken werd in 1988 num 1 miljoen gulden besteed. Dit bedrag varieerde nogal gedurende de jaren tachtig, vooral door de verschillende omvang van de schenkingen. Het management merkt herhaaldelijk op dit bedrag veel te weinig te vinden. $\mathrm{Zij}$ meent dat het aankoopbudget minimaal $\mathrm{F} .10$ miljoen moet bedragen.

\section{Doel 6}

De werkgelegenheid in het Rijksmuseum was naar schatting ongeveer 4 mensen groter dan strikt noodzakelijk. Dit kan berekend worden door de veranderingen na 1995 te

\footnotetext{
${ }^{768}$ Eén en ander exclusief de kosten van het gebouw.

769 Educatieve afdeling 8 personen, afdeling museuminrichting 3, verzamelafdelingen ongeveer 7 (exclusief restauratie en wetenschappelijke medewerkers) en een deel van de intendance.
} 
analyseren. Aan de ene kant ging een gedeelte van de "overhead" van het Ministerie naar het Rijksmuseum waardoor er mensen bijkwamen, terwijl anderzijds de formatie werd beperkt. De overhead van de Ministeries van WVC, VROM, Financiën en Binnenlandse Zaken die werd overgedragen thaar het Rijksmuseum bedroeg ongeveer 30 personeelsleden $^{70}$ Voor de verzelfstandiging waren er ongeveer 340 werknemers werkzaam in het Rijksmuseum. Na de verzelfstandiging was dat 366 . Aangenomen dat er niet bezuinigd kon worden op de overhead, hetgeen onwaarschijnlijk is, betekent dit dat er per saldo ongeveer 336 mensen nodig waren, in plaats van de 340 , om dezelfde activiteiten te verrichten. Er waren ongeveer 4 mensen meer werkzaam in het Rijksmuseum dan strikt noodzakelijk. Vermenigvuldigd met F. 94.990,- (gemiddeld inschalingsniveau van deze plaatsen) betekent dit dat er in het Rijksmuseum maximaal een kleime vierhonderdduizend gulden aan het doel van het bevorderen van de werkgelegenheid besteed werd. Aangezien het waarschijnlijk is dat bij het overdragen van taken aan het Rijksmuseum ook op de "overhead" bezuinigd kan worden (er zijn niet werkelijk 30 mensen meer nodig) is het doel van de werkgelegenheid voor 1988 niet erg bellangrijk. De belangrijkste reden hiervoor was dat door de verschillende bezuinigingsoperaties het personeelsbestand al aanzienlijk was tenuggebracht. Voor de jaren 70 was dit doel dus meer van bellang. Gegeven de omvang van de "public enterprise rent" was dit doel echter duidelijk van ondergeschikte betekenis.

\section{Doelen 1,8 en 9}

Het belangrijkste doel blijkt het culturele enfgoed te zijn. Het grootste deel van het bedrag werd besteed aan dit doel. Weergegeven met de doelen van Tabel 15.2 betekent dit dat het grootste deel werd besteed aan doel 8 , het culturele erfgoed, doel 9 , het bevorderen wan een gespreid aanbod en doel 1 , het bewaren van kunst.

Aan het doel van het collectiebeheer werd in 1988 een bedrag van F. 259.750,- besteed. Indien ook de salarissen van de restaurateuren hieronder worden gebracht bedragen de kosten ongeveer F. 1,25 miljoen, hetgeen gezien de omvang van de collectie bescheiden is. Op grond van de beleidsnota "Deltaplan voor Cultuurbehoud" is het duidelijk dat het doel van het onderhoud duidelijk tekortschoot. Door het gebrek aan onderhoud nam de waarde van de collectie relatief af. Naar schatting gaat het hier gemiddeld om éen procent: van de waarde van de collectie per jaar. Het betreft in 1988 circa honderd miljoen gulden. Er werd weliswaar veel kunst bewaard, maar deze kunst werd onvoldoende onderhouden. Het Rijksmuseum had onvoldoende prikkels om hiervoor te zorgen, terwijl de overheid/WVC niet of nauwelijks controleerde of dit wel goed gebeurde. Dit betekende dat ook het doel van het behoud van het culturele erfgoed onvoldoende werd gereallseerd. Voor een betere controle was het essentieel dat beter in kaart zou worden gebracht hoe groot de collectie is en waar zich de verschillende onderdelen van de collectie bevinden. Dat dit gedurende de onderzoeksperiode niet gebeurde blijkt zoals vermeld ook uit de bevindingen van de Departementale Accountantsdienst die stelde: De interne verplaatsingen worden niet geregistreerd, zodat niet zonder meer duidelijk is vast te stellen waar een object zich bevindt. Evenmin kan worden vastgesteld of de collectie nog compleet is ${ }^{n}$. ${ }^{771}$

770 Werkgroep Financiele en Bedrijfseconomische Aspecten Verzelfstandiging Rijksmusea, Eindrapport, april 1989, Tabel 2. Gezien de grootte van het Rijksmuseum zou ongeveer $30 \%$ van de "overhead" voor de rijksmusea naar het Rijksmuseum gaan.

71 Departementale Accountantsdienst, Rapport Nummer AD/C 84.3101, 19 maart 1984, inzake het onderzoek naar de financielle verantwoording over 1983 van het Rijksmuseum. 
Oolk de werknemers kregen een deel van de "public enterprise rent". In paragraaf 15.5.1. is opgemerkt dat gerekend over 1993 de werknemers in totaal F. 3,4 miljoen extra ontvingen, vergeleken met hetgeen zij aan salaris zouden verdienen indien zij CAO-lonen zouden ontvangen. Passen we dit toe op 1988 dan kan worden geconstateerd dat werknemers ongeveer F. 2,4 miljoen meer ontvingen dan werknemers in de marktsector.

\section{Doel 11}

De ondersteuning van Amsterdam als kunstmarkt. Ook van dit doel is het erg moeilijk te taxeren hoeveel het kost. Het gaat er hierbij om dat de kunsthistorische kennis, de kennis van restauratie van kunstwerken en dergelijke in Nederland aanwezig is. Een deel van de salarissen van de restaurateurs en van het archiefpersoneel en een deel van de algemene kosten en van de huisvestingskosten moet onder dit doel worden gebracht. De kosten kunnen worden geschat op F. 1 miljoen. Hierbij moet bedacht worden dat ook kosten zoals gemaakt ten behoeve van de publieksfunctie en de behouds- en beheersfunctie voor een deel onder dit doel gebracht kunnen worden.

Aan het doel van het culturele erfgoed werd verreweg het grootste deel van de "public enterprise rent" besteed. De beleidsnota die in 1991 werd opgesteld heette dan ook niet voor niets "Zorg voor de nationale schatkamer". Aan het bijeenhouden van de kunstcollectie werd per jaar ruim F, 500 milloen besteed.

\subsubsection{Hoe moet de "performance" van het Rijksmuseum worden beoordeeld?}

De vraag is 'of het Rijksmuseum zodanig functioneerde dat zij op deze wijze zo goed mogelijk haar doelen kon bereiken, onder meer de behouds- en de publiekstaak. Voor het beoordelen van de "performance" : van het Rijksmuseum is vooral het beoordelen van de mate waarin het doel van het culturele erfgoed/nationale schatkamer (doel 8) werd gerealiseerd van belang, afgezet tegea de kosten ervan. Zoals beschreven in paragraaf 15.10 liet het nastreven van de behoudstaak veel te wensen over. De collectie was voor een deel van de onderzoeksperiode ondergebracht in ruimtes die daarvoor niet geschikt waren, de registratie van de collecties was slechts beperkt gerealiseerd, waardoor nawwelijks te controleren viel waar welk object zich bevond en in welke staat het verkeerde. Ook waren er grote achterstanden in de restauratie van kunstobjecten. De omvang van de collectie nam weliswaar steeds meer toe, maar het onderhioud ervan was tot halverwege de jaren tachtig onvoldoende. Dit werd ook ingezien door het Rijksmuseum, die trachtte een en ander te verbeteren. De doelen van de politieke eigenaren veranderden geleidelijk gedurende de jaren "70 en "80. Eind jaren " 80 was het doel van de eigenaren om te komen tot een flexibel en slagvaardig museum, dat zelf ook zou zorgen voor inkomsten. De organisatiestructuur was echter niet afgestemd op het nastreven van de nieuwe doelen, onder meer omdat het Rijksmuseum nauwelijks mogelijkheden had zelf veranderingen door te voeren en met handen en voeten gebonden was aan de wetgeving (met name de comptabiliteitswet) en de vele departementale regelingen. Ten aanzien van de "performance" merkt het Rijksmuseam op: "Het bovenstaande maakt duidelijk dat de drie productiefactoren (personeel, materieel en huisvesting JFK) tot de competentie van verschillende beheerseenheden horen. De museumdirectie krijgt nauwelijks inzicht in de kosten van personeel en huisvesting. Zij kan derhalve nooit de integrale kostprijs van haar activiteiten berekenen en zodoende trachten zo efficiënt mogelijk te werken.

Verschuivingen tussen posten voor personeel en materieel zijn niet mogelijk. Besparingen die ontstaan door een uitgekiend personeelsbeleid komen alleen de schatkist ten goede. 
Personeelsbesparende diepte-investeringen zijn mu voor nuseumdirecties niet aantrekkelijk, aangezien de winst op het personeelsbudget niet gecompenseerd wordt door een hoger bedrag aan materiële middelen. Ook het uitbesteden van taken die efficiënter exter kunnen worden uitgevoerd wordt hierdoor niet gestimuleerd. Integendeel, voor elk van de drie onderscheiden factoren zal de museumdirectie trachten "haar budget" te maximaliseren. En dat is, op de lange duur, zowel voor het museum als voor het Rijk waarvan zij deel uitmaakt een kostenverhogende manier van werken. De beheersregels van het Rijk zijn nu eenmaal niet ontworpen voor bedrijfsmatige onderdelen van de overheid. Zij blijven moeilijk te verenigen met het bedrijfsmatig karakter van bijvoorbeeld de Rijksmusea. Wanneer de Rijksmusea functioneren in een "gewone" bedrijfsmatige omgeving waar men zelf de zeggenschap heeft over de inzet van materieel, personeel en huisvestingsmiddelen, zouden veel van de problemen die zij nu ondervinden in de bedrijfsvoering kunnen worden opgelost zonder dat de wetgever daarvoor grote sommen geld extra behoeft te voteren. De frictiekosten die de huidige regelgeving oproept, kunnen bij de verzelfstandiging worden besteed aan museale taken". 772

Uitgaande van de doelen van de politieke eigenaren werd het Rijksmuseum eind jaren ' 80 dan ook met een aantal problemen geconfronteerd:

-het toezicht op het behoud van de collectie door de principalen was duidelijk onvoldoende;

-het Rijksmuseum was niet in staat zelf een afweging te maken tussen de verschillende inputs, onder meer omdat veelal niet geschoven mocht worden tussen de verschillende onderdelen van het budget;

-het toezicht op het productieproces was onvoldoende. Door de spreiding van dit eigendomsrecht over verschillende actoren hadden de chefs van de verschillende afdelingen in feite een grote zelfstandigheid;

-het toezicht op de productieresultaten was feitelijk nauwelijks aanwezig. Enerzijds omdat de productie van het Rijksmuseum zich moeilijk duidelijk laat definiëren en anderzijds omdat het Ministerie zich beperkte tot het sturen op afstand en het houden van toezicht op de inputs. Ook het management was echter onvoldoende in staat toezicht te houden op de resultaten;

-het Rijksmuseum kon slechts in zeer beperkte mate zelf haar inkomsten vaststellen. Aangezien overschotten aan het eind van het jaar in principe (uitzonderingen daargelaten) teruggingen naar het Ministerie van Financiên, had het Rijksmuseum een prikkel om deze middelen op te maken, hetgeen ertoe kon leiden dat uitgaven werden gedaan die op zich niet nodig of niet rendabel waren. Verder mocht het Rijksmuseum niet afschrijven en reserveren waardoor het niet mogelijk was te komen tot een realistische kostprijs; -het parlement had het recht het Rijksmuseum te wijzigen en eventueel te verkopen. Dit was één van de oorzaken van het tekortschieten van de controle op onder meer de collectie. Aandeelhouders zouden (afhankelijk van de spreiding van de eigendomsrechten) een prikkel hebben om hun bedrijf te controleren en na te gaan of het eigen vermogen wel goed wordt beheerd. Bij het Rijksmuseum was dat duidelijk minder het geval; -het Rijksmuseum had weinig prikkels om het aantal betalende bezoekers te vergroten, aangezien entree-ontvangsten tot eind jaren " 80 naar het Ministerie van Financiën gingen; -omdat het rijksmuseum geen recht had op de winst had zij geen prikkel om te investeren in de collectie en de andere activa. De reden hiervoor is dat zij zelf niet zou profiteren van deze investeringen.

Het werd steeds meer duidelijk dat de doelen van de eigenaren aan het eind van de jaren tachtig op een beter wijze en tegen lagere kosten bereikt konden worden. Na 1990 is derhalve de organisatie gewijzigd en is het Rijksmuseum extern verzelfstandigd. In dit

72 Rijksmuseum Amsterdam, Ondernemingsplan 1989, 31 maart 1989, pp. 18-19. 
verband zijn onder meer de volgende maatregelen genomen.

-het Rijksmuseum kan zelf de hoogte van de entreeprijzen bepalen;

-het Rijksmuseum mag reserveren en afschrijven op activa:

-de salarissen van de werknemers zijn geregeld in een c.a.o;

-de kosten die eerst door de afzonderlijke Ministeries werden gemaakt zijn overge-

heveld naar het Rijksmuseum, die nu een subsidie krijgt waarin zowel het materi-

ele als het personele budget zit, terwijl ook de huur van het gebouw hieruit

betaald dient te worden;

-thet Rijksmuseum $\boldsymbol{z}$ iet zelf toe op de omvang en samenstelling van het personeel;

-het Rijksmuseum kan zelf bepalen welke inputs aangeschaft worden;

-het Rijksmuseum heeft een huurcontract met de RGD.

Hoewel het buiten het bereik ligt van dit onderzoek is het interessant te bezien of deze maatregelen ertoe zullen leiden dat de doelen zoals de eigenaren die eind jaren ' 80 hadden beter zullen worden gerealiseerd. Of dit zal gebeuren hangt vooral af van de vraag of het culturele erfgoed beter zal worden onderhouden of tegen lagere kosten. In feite is het toezicht op de inputs door het Ministerie vervangen door een controle op de output. In de contracten met het Rijksmuseum worden tegenwoordig drie soorten outputs onderscheiden, te weten behoud en beheer, de collectiesamenstelling en de presentatie. Of het doel van het culturele erfgoed beter bereikt zal worden hangt vooral af van de mate waarin het departement erin slaagt het behoud en beheer van de collectie in de contracten te formuleren als een duidelijk omschreven outputdoel, dat duidelijk gecontroleerd kan worden. Daarnaast moeten er voldoende sancties zijn. Voor het beoordelen van de vraag of te verwachten is dat de (gewijzigde) doelen door de gewijzigde organisatie- en eigendomsrechtenstructuur beter gerealiseerd kunnen worden en tegen lagere kosten gaat het er dan ook voorall om of de controle op de outputs beter is te realiseren dan het vroegere toezicht op de inputs. Dit is waarschijnlijk het geval. Het Rijksmuseum heeft, mede onder druk van het Ministerie, veel gedaan aan het inventariseren van de collectie, onder meer met behulp van automatisering. Het Ministerie heeft nu meer inzicht in de samenstelling van de collectie en de staat ervan en kan door middel van contracten ook gemakkelijker eisen stellen aan het Rijksmuseum. Dit geldt niet alleen voor het doel van het culturele erfgoed maar ook voor de overige doelen. Bovendien heeft het Rijksmuseum er nu meer belang bij te investeren in de collectie, aangezien zij het recht heeft op de winst die met het gebruik van de collectie wordt gemaakt.

\subsection{Conclusie}

Het onderzoek zoals neergelegd in dit hoofdstuk laat zien dat het voor het bepalen van de "performance". essentieel is te weten welke doelen worden nagestreefd en wat de alternatieve kosten van deze doelen zijn. Het onderzoek in dit hoofdstuk laat dan ook duidelijk zien dat elk ander door de eigenaren nagestreefde doelenpakket een andere eigendomsrechtenstruetuur vereist. De organisatie- en eigendomsrechtenstructuur van het Rijksmuseum was sinds de jaren 70 nauwelijks veranderd. De doelen van de eigenaren echter wel. Dit leidde tot frictie en het niet meer bereiken van een voor de eigenaren aanvaardbare "performance". Het onderzoek laat zien dat het, voordat wordt overgaan tot privatisering, van groot belang is te weten wellke doelen worden nagestreefd en hoe de huidige "performance" moet worden ingeschat. Afhankelijk van deze doelen kan bepaald worden welke eigendomsrechten moeten worden overgeheveld. 


\section{Hoofdstuk 16. Het elektriciteitsbedrijf N.V. MEGA-Limburg (N.V. Provinciale Limburgse Elektriciteitsmaatschappij)}

\section{1 Inleiding}

In dit hoofdstuk wordt met behulp van de kwalitatieve benadering de "performance" van de N.V. PLEM geanalyseerd. De onderzoeksperiode loopt tot de fusie met Limagas in 1990, waarbij de nadruk zal liggen op de jaren tachtig. Het onderzoek beperkt zich dan ook tot de elektriciteitsproductie en -distributie. De gasdistributie door Limagas wordt niet onderzocht, tenzij dit voor een goed begrip van de wijze van functioneren van de PLEM noodzakelijk is. Na de bepaling van de doelen en de mate waarin deze zijn gerealiseerd wordt wederom de "public enterprise rent" bepaald. Vervolgens wordt ingegaan op het relatief belang van de doelen. In paragraaf 16.12 .1 . worden tenslotte de doelen afgezet tegen de kosten ervan en wordt verder ingegaan op de "performance". In paragraaf 16.12.2. wordt een verband gelegd tussen de "performance" van de PLEM en de ontwikkelingen na 1990. Uitgaande van de bevindingen bij de N.V. PLEM wordt ingegaan op de mogelijke effecten van toekomstige veranderingen in de elektriciteitssector.

\subsection{De ontwikkeling van N.V. SVM naar N.V. PLEM}

Vanaf het begin van de jaren tachtig van de vorige eeuw begon geleidelijk aan de elektriciteitsvoorziening in Nederland op gang te komen. De elektriciteitsbedrijven hadden in het begin geen nutsfunctie maar waren voornamelijk kleinschalige ondernemingen die door particulieren, meer in het bijzonder door banken en industriëlen, werden opgezet. Het doel dat werd nagestreefd was het zoveel mogelijk maximaliseren van de winst.. Deze situatie bleef bestaan tot omstreeks de Eerste Wereldoorlog en voor de "Maatschappij tot Verkoop van den Electrischen Stroom der Staatsmijnen in Limburg" (SVM), die als voorloper van de N.V. PLEM op 3 september 1909 werd opgericht, zelfs nog langer. ${ }^{772}$ In 1917 verwierf de provincie Limburg 95\% van alle aandelen, terwijl de overige aandelen in particuliere eigendom bleven. Besloten werd om de SVM om te zetten in een N.V. ${ }^{773}$ Teneimde te voldoen aan wettelijke bepalingen werden ook enige aandelen uitgegeven aan de gemeente Geleen. Vanaf de oprichting van de Stroomverkoopmaatschappij in 1909 tot 1954 functioneerde de PLEM alleen als distributiebedrijf. Sindsdien verzorgt zij ook de elektriciteitsproductie in Limburg. Onder druk van regeringsplannen zijn in 1987 de productie-afdelingen van de PLEM en de PNEM samengevoegd in een gezamenlijke dochteronderneming EPZ. ${ }^{774}$ Gezien de gekozen structuur van de NV EPZ als dochtermaatschappij is de PLEM formeel echter niet alleen een distributiebedrijf.

16.3 De organisatie van de elektriciteitssector in Nederland en van de PLEM

\subsubsection{De organisatie van de elektriciteitssector in Nederland}

De productiebedrijven zijn in Nederland aangesloten bij de N.V. Samenwerkende

\footnotetext{
772 Timmermans (1993, voorwoord).

773 T.а.p., pp. $26-30$.

T/4 In 1989 is ook de PZEM toegetreden: Aandelenverhouding $1 / 3: 1 / 3: 1 / 3$.
} 
Elektriciteitsproductiebedrijven (SEP). In het begin van de jaren zeventig was de SEP nog voornamelijk een coötdinerend orgaan op het terrein van de opwekking van elektriciteit en voor de uitbreiding van productievermogen. Ten gevolge van veranderde doelstellingen van de politiek werd de rol van de SEP steeds belangrijker. Zij kreeg een belangrijke taak bij de planning van de bouw van elektriciteitsopwekkingsvermogen en de uitvoering van het beleid. Naast de SEP werkten de elektriciteitsbedrijven in Nederland samen in een aantal andere instellingen, waaronder de N.V. Gemeenschappelijke Kernenergiecentrale Nederland (G.K.N.), de Vereniging van Exploitanten van Elektriciteitsbedrijven in Nederland (V.E.E.N.), de Vereniging van Exploitanten van Gasbedrijven in Nederland (VEGIN) en de Vereniging van Exploitanten van Stadsverwarmingsbedrijven in Nederland (VESTIN), de N.V. tot Keuring van Elektrotechnische Materialen (K.E.M.A.) en de Vereniging van Directeuren van Elektriciteitsbedrijven in Nederland (V.D.E.N.) ${ }^{775}$ Begin jaren negentig gingen de VEEN, VEGIN en VESTIN op in EnergieNed. Samenvoeging van de verschillende genoemde instellingen werd in de jaren tachtig niet wenselijk gevonden omdat elke van de bestaande instellingen een specifieke taak had binnen de energievoorziening. Zo houdt de G.K.N zich bezig met bet beheer en de exploitatie van de kerncentrale te Dodewaard. Alle met het koppelnet verbonden openbare productiebedrijven zijn aandeelhouder. De V.E.E.N. is het coördinerend orgaan met betrekking tot de verhouding tussen de elektriciteitsbedrijven, de gebruikers en de centrale overheid. Vrijwel alle elektriciteitsbedrijven in Nederland zijn hierbij aangesloten. Aan het einde van de jaren tachtig werd er niet alleen bij de PLEM maar in de gehele Nederlandse elektriciteitssector, een scheiding doorgevoerd van de productiesector en de distributiesector. De V.E.E.N. wordt dan steeds meer het vertegenwoordigende orgaan van de distributiesector terwijl de SEP de productiesector representeert. De K.E.M.A. is een dienstvetlenend orgaan waarvan 34 elektriciteitsbedrijven aandeelhouder waren en is met name belast met het uitvoeren van keuringen en met de behandeling van zaken die ten behoeve van andere gemeenschappelijke instellingen gezamenlijk moeten worden verricht. Alle elektriciteitsbedrijven kunnen gebruik maken van de diensten van de K.E.M.A.. De V.D.E.N. tenslotte verleent bijstand en ondersteuning aan het geheel van de elektriciteitsvoorziening, meer in het bijzonder ten behoeve van de K.E.M.A.

\subsubsection{De ontwikkeling van de elektriciteitssector in de jaren tachtig}

Begin jaren tachtig is er in Nederland een bezinning op de gewenste structuur van de elektriciteitsvoorziening op gang gekomen. Door de Commissie Concentratie Nutsbedrijven (COCONUT) werd een onderzoek verricht naar de vereiste ontwikkelingen van de organisatie in de sectoren elektriciteit, gas en water. ${ }^{76}$ Zij vroeg het organisatiebureau Krekel, Van der Woerd en Wouterse (KWW) in dit verband een onderzoek te verrichten naar de mate van concentratie en herstructurering die nodig was in de elektriciteitssector. Deze commissie bracht een rapport uit waarin zij adviseerde om te komen tot één landelijk elektriciteitsproductie en -transportbedrijf, het vormen van provinciale regionale distributiebedrijven, een bepaalde minimumomyang van distributiebedrijven, meer bemoeienis van de Rijksoverheid en grotere horizontale integratie tussen bedrijven voor gas, water en elektriciteit. In het door het kabinet ingenomen standpunt kwam het meeste hiervan terug. De behoefte aan een landelijk productiebedrijf werd beklemtoond. De productiebedrijven reageerden met het door de V.E.E.N. en de Raad van Commissarissen van de SEP aangehangen SEP-plus-model. Dit plan hield globaal in dat de rol van de SEP

\footnotetext{
${ }^{775}$ Tweede Kamer (1991), Memorie van Toelichting, 22160, nr. 3, pp. 3 e.v.

${ }^{776}$ N.V. Provinciale Limburgse Elektriciteitsmaatschappij, Jaarverslag over 1981, 1982, p. 12.
} 
zou toenemen en dat de planning van nieuw opwekkingsvermogen meer gecentraliseend zou worden uitgevoerd. De zelfstandigheid van de afzonderlijke deelnemers diende echter wel gehandhaafd te blijven. De PLEM meende dat dit plan in combinatie met de reeds ingevoerde Landelijke Economische Optimalisatie en met de beoogde pooling van productiekosten, een beter alternatief was. De in de S.E.P. samenwerkende bedrijven besloten in fasen over te gaan tot pooling van de productiekosten per 1 december 1986.

De Minister van Economische Zaken gaf in de Memorie van Toelichting bij de begroting van het Ministerie van Economische zaken voor 1984 aan voorstander te zijn van een landelijk bedrijf voor productie en transport. De S.E.P. stelde zich opnieuw op het standpunt dat door het SEP-plus-model de doelen van de Minister bereikt konden worden. Het essentiële verschil vormde het al dan niet zelfstandig voortbestaan van de elektriciteitsbedrijven. Bij de behandeling van de begroting in het parlement bleek dat de regering inmiddels was afgestapt van haar voornemen om te komen tot een landelijk bedrijf voor productie en transport. Uit de Memorie van Toelichting bij de begroting van Economische Zaken van 1985 blijkt dat de regering er nu naar streefde het aantal productiebedrijven te verminderen tot drie à vijf. De minister wilde dit realiseren door de bouw van nieuw productievermogen alleen toe te staan aan bedrijven die een bepaald minimum vermogen hadden. Tevens werd een beleidsmatige scheiding voorgestaan tussen productie en distributie.

De N.V. PLEM speelde op deze ontwikkelingen in door samenwerking met andere bedrijven na te streven. Zo werd de samenwerking tussen PLEM, Limagas en het Waterleidingbedrijf geintensiveerd door de benoeming van een secretaris voor het samenwerkingsverband van deze bedrijven. Aan het einde van 1984 besloot de Raad van Commissarissen van de PLEM op voorstel van de Directie om besprekingen te beginnen met de Directies van PZEM en PNEM over mogelijke samenwerking op het gebied van de productie. Naast een scheiding van productie en distributie achtte de regering een reorganisatie van de distributie steeds meer noodzakelijk. Hierbij werd een horizontale integratie van gas, elektriciteit en water beoogd, teneinde te komen tot een betere afstemming van het energiebeleid in de verschillende sectoren en tot kostenbesparing en om een meer gerichte dienstverlening aan verbruikers te realiseren. PLEM en Limagas voerden besprekingen over de mogelijke gevolgen van deze regeringsvoornemens. Voor de verlaging van de elektriciteitstarievem en de totstandbrenging van de horizontale integratie leek de uutkering van wimsten aan de eigenaren van de bedrijven één van de grootste problemen. De omvorming van de Nederlandse elektriciteitsvoorziening kreeg in 1985 steeds meer vorm. $\mathrm{Zij}$ werd gekenmerkt door:

1. Beleidsmatige scheiding tussen productie en distributie.

2. Vermindering van het aantal elektriciteitsproductiebedrijven tot drie à vier.

3. Omvorming van de SEP van coördinerend tot meer leidinggevend orgaan.

4. Horizontale integratie in de distributiesector van gas, elektriciteit en warmte in combinatie met een vermindering van het aantal bedrijven.

Over de reorganisatie van de elektriciteitssector rees binnen de SEP verschil van mening over de mate waarin de SEP zich met de uitvoering moet bezighouden. De PLEM meende dat alleen zaken met een strikt landelijk karakter bij de SEP moesten worden ondergebracht. De afzonderlijke bedrijven dienden zoveel mogelijk zelfstandig de taken van het productiebedrijf uit te voeren. Met betrekking tot het pool-systeem meende de PLEM dat alleen productiekosten die veroorzaakt waren door landelijk genomen besiuiten in aanmerking dienden te komen voor vereffening. Begin 1986 werd een compromis bereikt dat inhield dat enerzijds het systeem vam pooling van productiekosten verder ging 
dan door de PLEM wenselijk werd geacht, anderajds bleef de zelfstandigheid van de afzonderlijke bedrijven in redelijke mate behouden. Het behouden van voordelen voor afzonderlijke regio's, bijvoorbeeld door het voeren van een goede bedrijfsvoering waardoor de tarieven laag konden blijven, bleef een belangrijk element.

De regering publiceerde in 1985 het voorontwerp van een Elektriciteitswet. Hierop werd door de elektriciteitssector de nodige kritiek geuit. Om niet gedwongen te worden besloten de betrokken landelijke organisaties V.E.E.N., V.E.G.I.N. en V.E.S.T.I.N. zelf de nodige stappen te nemen op het gebied van schaalvergroting en horizontale integratie Een eerste stap was het instellen van een Inventarisatiecommissie Reorganisatie Distributiesector. In overleg met bestuurscolleges en Directies heeft deze commissie aanbevelingen gedaan. De Minister heeft in een brief aan de Tweede Kamer zijn standpunt bekend gemaakt. Duidelijk was dat de plannen van de overheid verstrekkende gevolgen konden hebben voor de structuur van de energiedistributie van de PLEM.

In 1986 werd het ontwerp voor een nieuwe Elektriciteitswet behandeld door de Tweede Kamer. Dit ontwerp beoogde zoalls aangegeven vergaande uitbreiding van bevoegdheden van de Minister van Economische Zaken ten aanzien van de elektriciteitsvoorziening en verder beoogde de Minister een absolute scheiding van productie en distributie. De elektriciteitsbedrijven hebben hiertegen krachtig stelling genomen, aangezien het wetsontwerp essentieel afwijkt van de organisatievorm die de SEP-deelnemers zelf voorstaan en die ten grondslag heeft gelegen aan de Overeenkomst van Samenwerking (OVS) van de SEP. De absolute scheiding van productie en distributie zou tot een algehele pooling van productiekosten leiden. Dit zou voor de PLEM, nog meer dan door de samenwerking in SEP-verband tot mu toe, tot een verdere stijging van de kosten leiden.

In 1986 was het proces om op vrijwillige basis te komen tot schaalvergroting en horizontale integratie inmiddels aanzienlijk gevorderd. De V.E.E.N., V.E.G.I.N. en

V.E.S.T.I.N. besloten op grond van het rapport van de inventarisatiecommissie een. landelijke Stuurgroep in te stellen, de zogenaamde commissie Brandsma. Deze Stuurgroep heeft vervolgens een aantal regionale commissies ingesteld die als taak kregen de reorganisatie van de distributie verder uit te werken; vitgaande van een aantal vastgestelde uitgangspunten. Voor Limburg werd de Regionale Commissie Limburg (RCL) ingesteld met vertegenwoordigers van de negen in Limburg werkzame Gemeentelijke Energiebedrijven (GEB"s) en de PLEM en Limagas. De commissie heeft een zelfstandig voorzitter en secretaris. De commisie adviseerde over te gaan tot een fusie van PLEM, Limagas en alle GEB's met minder dan 30.000 verbruikersadressen, ütgezonderd die van Maastricht en Heerlen. De Stuurgroep besprak de bevindingen van de commissie met de V.E.E.N., V.E.G.I.N. en V.E.S.T.I.N, en in oktober 1987 met de Minister van Economische Zaken.

Eind 1986 werd het door de SEP aan de Minister van EZ voorgelegde elektriciteitsplan door hem goedgekeurd. In de loop van 1987 werd de productiesector van de PLEM met de productiesector van de PNEM samengevoegd in de zelfstandige dochtermaatschappij de NV Elektriciteitsproductiemaatschappij Zuid-Nederland (EPZ). ${ }^{\text {m }}$ Op 22 mei 1987 werd de SEP een meer zelfstandig instituut door de ondertekening van de nieuwe Overeenkomst. van Samenwerking tussen SEP en SEP-deelnemers. Ook bij andere elektriciteitsbedrijven in Nederland werd een scheiding tot stand gebracht tussen productie en distributie. Alleen

${ }^{7}$ N.V. PLEM en N.V. PNEM, Eindnota samenwerking PLEM en PNEM op het gebied van de productie van electrische energie, 25 april 1986, bijlage. Vergelijk ook: Raad van Commissarissen, Notitie samenwerking PLEN/PNEM op het gebied van de productie van elektrische energie, 4 november 1986. 
de PZEM heeft nog geen definitieve keuze gemaakt.

In het in 1988 verschenen elektriciteitsplan gaat de productiesector er vanuit dat in de komende jaren steeds meer decentraal elektriciteitsproductievermogen tot stand zal komen en dat voorts een aanzienlijke energiebesparing gerealiseerd zal worden. $\mathrm{Na}$ het bereiken van een compromis tussen de Minister van EZ en de SEP is begin 1989 de Tweede Kamer akkoord gegaan met het voorstel van een nieuwe Elektriciteitswet. Tussen aan de ene kant de producenten, verenigd in de SEP, en aan de andere kant de distributiebedrijven, verenigd in de VEEN ontstond verschil van mening over de mogelijkheid van import van stroom. De productiesector was hiertegen en werd in deze gesteund door de Minister van EZ en de Tweede Kamer. De Elektriciteitswet beoogde enerzijds het aantal bedrijven in de distributiesector verder te reduceren (concentratie) en beoogde anderzijds de distributie van de diverse energievormen regionaal in een bedrijf te integreren (horizontale integratie). ${ }^{778}$ Dit heeft in 1990 geleid tot een fusie van Limagas en PLEM tot MEGA LIMBURG.

\subsubsection{De organisatie van de PLEM}

De topstructuur van de PLEM was van oudsher gebaseerd op een functionele indeling met onderscheid tussen techniek en economie. ${ }^{79}$ Begin jaren tachtig is deze functionele indeling nog verder doorgevoerd door het instellen van een drietal sectoren, zoals weergegeven in Figuur 16.1. Kenmerkend voor deze organisatiestructuur was dat voor zaken, die vanuit een bepaalde sector besproken moesten worden met een andere sector, overleg nodig was met de bedrijfsdirecteur van die andere sector en vaak ook met de directeur (het Directieteam). Dit leidde ertoe dat erg veel onderwerpen aan de orde moesten komen in de Directievergadering. Een ander probleem was dat iedere afdeling rapporteerde aan de directeur, dit ondanks het feit dat de grootte van de afdelingen sterk uiteenliep. ${ }^{780}$

In 1984 werd de structuur van de sector Economie gewijzigd. Een zelfstandige afdeling Bestuurlijke Informatievoorziening (BI) werd opgericht. Het gebouwenbeheer werd ondergebracht bij de afdeling Bouwkunde, voortaan afdeling Gebouwen en Terreinen geheten. Onderdelen van de huisdrukkerij, bibliotheek en magazijn kantoorbenodigdheden zijn ondergebracht bij de afdeling JZ/A\&C, in het vervolg aangeduid als Algemene en Juridische Zaken. Per 1 oktober 1985 werd een nieuwe structuur voor de afdeling Algemene en Juridische Zaken ingevoerd. In verband met de voorgenomen fusie met de NV PNEM werd gewerkt aan een formatieplan voor de sector Productie. In verband met de komende veranderingen werd ook de organisatie van andere afdelingen nader bezien.

Naast de genoemde communicatieproblemen stelden ook de in de vorige paragraaf genoemde veranderingen die eind jaren tachtig werden doorgevoerd extra eisen aan de organisatie. Enerzijds ging het hierbij om het scheiden van de productie- en distributietaak van de PLEM. Dit werd gerealiseerd door het onderbrengen van de productietaak van de PLEM in EPZ. In 1989 werd in het managementteam opgemerkt: "De NV PLEM is met het afstoten van de productie-eenheden in een dochter-NV een ander type bedrijf geworden dat nu als hoofdtaak heeft de betrouwbare en efficiënte doorlevering van electriciteit aan

778 Vergelijk ook de jaarverslagen van de N.W. PLEM over de periode 1985-1992.

779 N.V. PLEM, Een anzet tot de systematische ontwikkeling yan het sociaal beleid bij de NV PLEM, juni 1978, p. 12 ev.

${ }^{780}$ Raad van Commissarissen, Notulen vergadering no. 5/88, 6-12-1988, bijlage. 
de gebruikers". ${ }^{782}$ Anderzijds ging het om horizontale integratie die op grond van de Elektriciteitswet van 1989 moest worden doorgevoerd. Deze wijzigingen leidden er ook toe dat nieuwe eisen gesteld werden aan de organisatie. Opgemerkt werd: "De omzetting van een wat traditioneel ingesteld bedriff naar een modeme, commerciële en klantgerichte organisatie is de inzet van het project "Horizon".

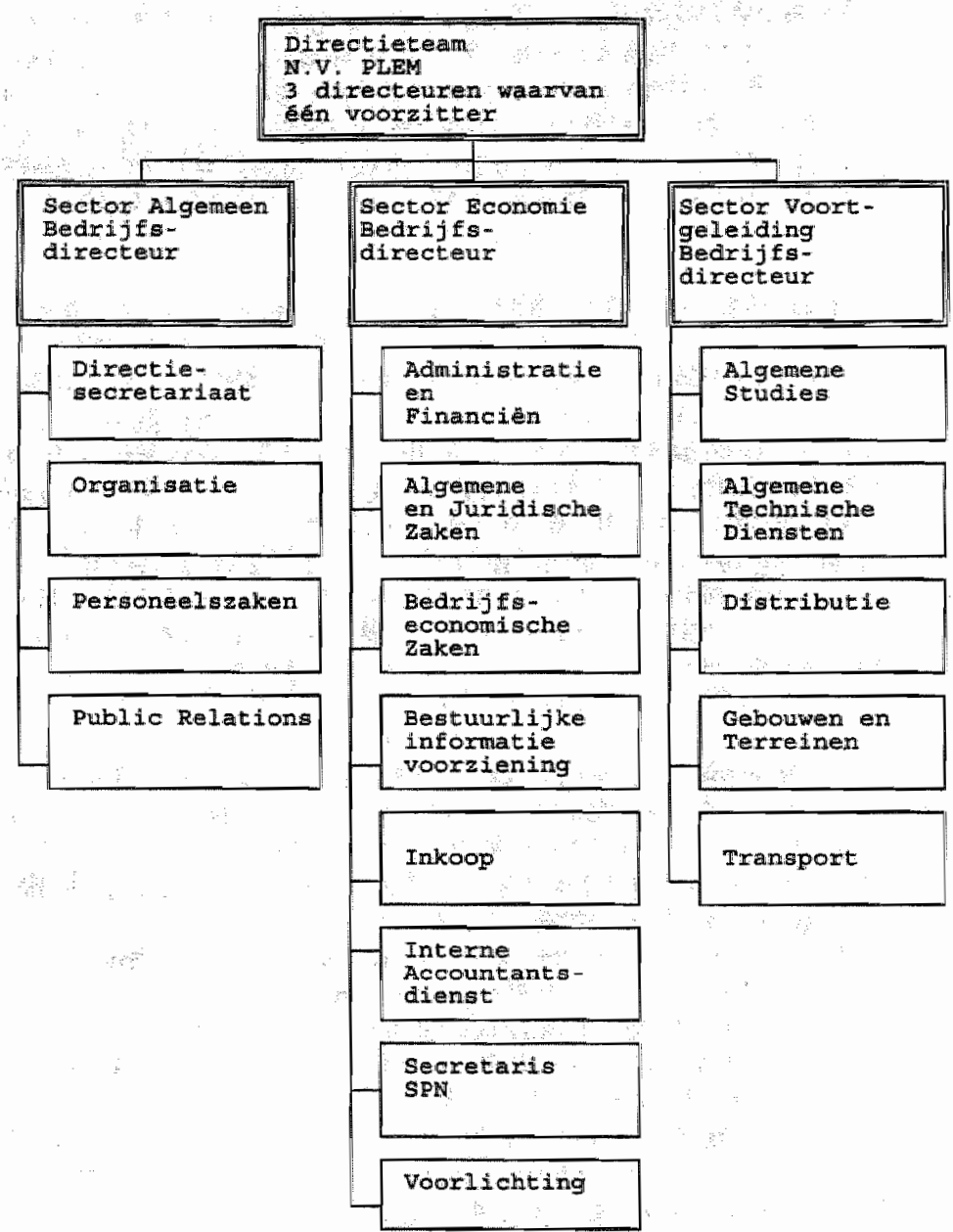

Figuur 16.1 De organisatiestructuur van de N.V. PLEM voor 1 november 1988.

Eind 1988 werd om deze verandering te bereiken een eerste organisatieverandering doorgevoerd. Deze bestond uit het samenvoegen van de sector Voortgeleiding en de

781 Managementteam N.V. PLEM, Notitie project "Horizon", 30-01-1989, punt 1.

782 T.a.p., punt 1. 
sector Algemeen, waardoor een tweetal sectoren resteerden: 73

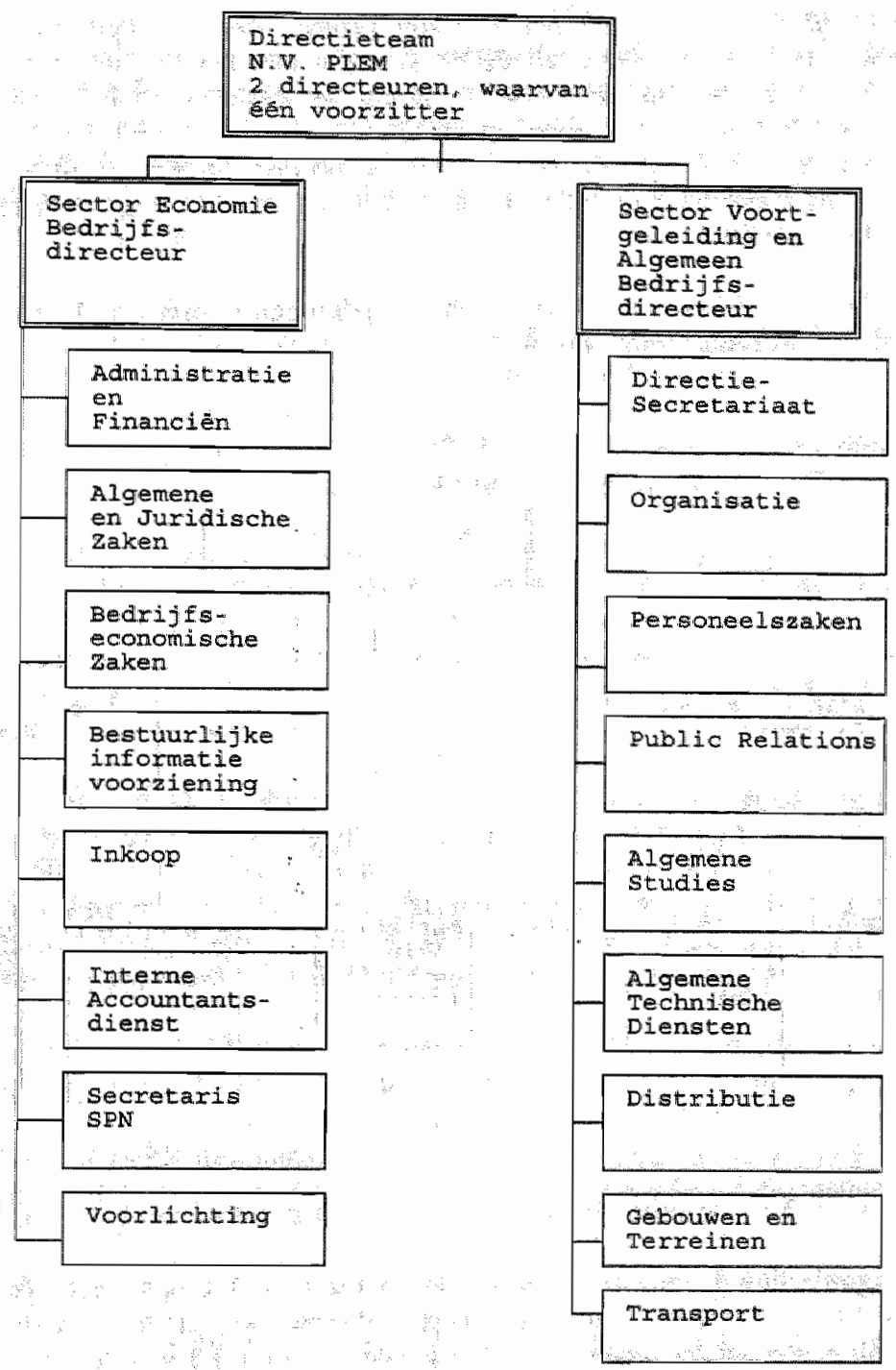

\section{Figuur 16.2 De organisatiestructuur van de N.V. PLEM na 1 november 1988}

Het project Horizon ging veel verder en diende ter aanpassing van de organisatiestructuur aan de gewijzigde amstandigheden, terwijl ook de definitieve invoering van budgettering werd beoogd, De Directie erkende dat de voor de uitvoering van het project Horizon bestaande bedrijfsstructuur in combinatie met de bestaande bedrijfsculltuur verkokering tussen de verschillende afdelingen en sectoren in de hand werkte. Geconstateerd wordt dat deze situatie gegroeid is omdat zoals door de voorzitter van de Directie werd opgemerkt:

${ }^{783}$ Raad van Commissarissen, Notulen wan vergadering no. 5/88, 6-12-1988, bijlage 2. 
"(..) wij als monopolisten gewend waren om - van binnenuit kijkend - de meest gewenste structuren te kiezen". Of dat wel in het belang van de klant was, speelde daarbij niet de belangrijkste rol". ${ }^{784}$ Met het Horizon project werd beoogd om de organisatie fundamenteel te berzien. Het strategische plan dat aan het project Horizon ten grondslag lag kende een viertal doelstellingen, te weten het nastreven van de laagste tarieven, er zijn voor de klant, goed werk leveren en tenslotte in Limburg bekend staan als betrouwbaar; energiek en vitaal. Om dit te bereiken diende ook de bedrijfscultuur te veranderen. Deze moest meer resultaatgericht worden, terwijl ook meer klantgericht en praktischer gewerkt diende te worden.

Om dat te bereiken werden een aantal wijzigingen doorgevoerd, waarvan het resultaat als volgt kan worden weergegeven: ${ }^{785}$

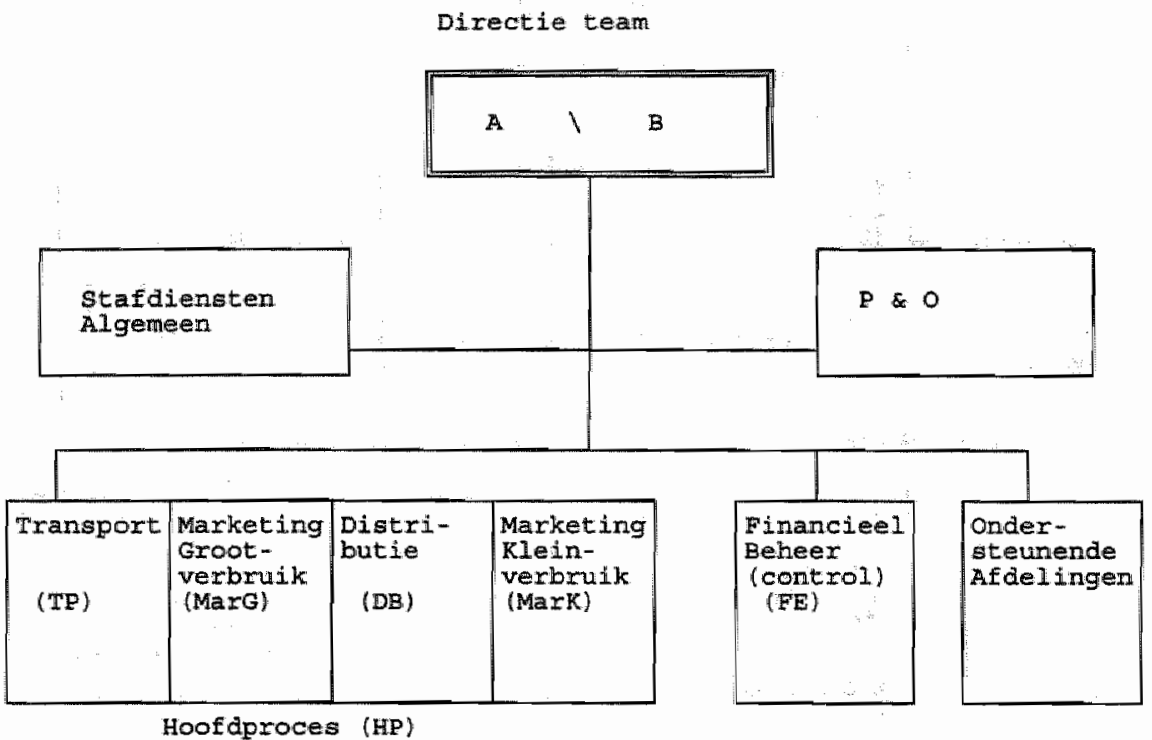

Figuur 16.3 De organisatieveranderingen ten gevolge van het project Horizon

De organisatiewijziging hield in dat de sectoren werden opgeheven en dat er een Directieteam kwam bestaande uat een tweetal directeuren. Tussen beide directeuren is een verdeling van aandachtsgebieden doorgevoerd. Tot 1988 werkten de afdelingen binnen het primaire proces (transport, inkoop, distributie en verkoop) van de PLEM in belangrijke mate zelfstandig. De organisatiewijziging ten gevolge van het Horizonproject hield vooral ook in dat er tussen deze afdelingen, met name tussen. Transport (TP), Distributie (DB), Bedrijfseconomische Zaken (in- en verkoop van elektriciteit) en Voorlichting (VO, service) een grote mate van samenwerking tot stand werd gebracht. Eén van de twee directeuren kreeg dit primaire proces tot zijn aandachtsgebied. De afdelingshoofden

\footnotetext{
${ }^{784}$ N.V PLEM, Horizontaal, eerste editie, 13 oktober 1988. De redactie van dit blad wordt gevormd door de projectgroep "PR + communicatie", bestaande uit ondermeer de voorzitter van de directie.

${ }^{785}$ Managementteam, 89.046, Notulen, 30-01-1989, bijlagen.
} 
binmen dit primaire proces kunnen met deze directeur steeds op ad hoc basis overleg voeren over de lopende zaken.

Binnen dit hoofdproces werden een aantal organisatjewijzigingen doorgevoerd. Zo kwam er een nieuwe afdeling Marketing, die zich bezig hield met alles wat zich op de energiemarkt kan afspelen, zoals de in- en verkoop van energie, de voorlichting en service en het stellen van tarieven. Hierbij werd onderscheid gemaakt tussen de afdeling Marketing Grootverbruik (MarG) (grootverbruikers, giganten, GEB's e.d.) en de afdeling Marketing Kleinverbruik (MarK), waarbij de grens kwam te liggen bij een aansluitwaarde van 63 ampère.

De afdeling Voorlichting (VO) werd omgevormd tot de afdeling Marketing Kleinverbruik (MarK). Daarbij was het de bedoeling dat het marketingbeleid centraal zou worden ontwikkeld en decentraal zou worden uitgevoerd. Contacten met de kleinverbruikers zouden vooral op rayonniveau plaatsvinden. Het was de bedoeling dat ook de afdeling public Relations (PR) na 1990 bij de afdeling MarK zou worden gevoegd.

De bestaande afdeling Bedrijfseconomische Zaken (BEZ) werd omgevormd tot de afdeling Marketing Grootverbruik (MarG). Binnen de afdeling Marketing Grootverbruik (MarG) werd een Bureau voor Energie- en Milieutechniek opgericht dat een aparte status kreeg. ${ }^{786}$ Dit bureau met circa 6 medewerkers kreeg als taak onderzoek te doen naar technische ontwikkelingen en nieuwe toepassingen, het verrichten van haalbaarheidsstudies en de begeleiding van projecten.

De andere directeur kreeg vooral de financiën en het personeelsbeleid als aandachtsgebied. Ook op dat gebied werden belangrijke wijzigingen doorgevoerd. De afdeling Administratie \& Financiën werd vervangen door de afdeling Financiën en Economie (FE), waarbij de nadruk meer dan voorheen lag op beleidsondersteuning en het verstrekken van adviezen aan het management. Verder werd de afdeling Organisatie met de Afdeling Personeelszaken samengevoegd tot de afdeling Personeelszaken en Organisatie (PO).

Zoals is weergegeven in Figuur 16.3 zijn er daarnaast een aantal ondersteunende afdelingen. Deze afdelingen zijn verdeeld over beide directeuren, waarbij de afdeling Algemene Technische Diensten tot het aandachtsveld van de directeur behoorde die met name toezag op het primaire proces, terwijl afdelingen als Bestuurlijke Informatievoorziening (BI), Algemene en Juridische zaken (AJZ) en Gebouwen en Terreinen (GT) tot het aandachtsterrein van de andere directeur gerekend werden.

De stafdiensten werden eveneens verdeeld over beide directeuren, waarbij de directeur die belast was met het primaire proces, de afdeling Public Relations voor zijn rekening nam. terwijl de andere directeur met name aandacht besteedde aan het Directie-secretariaat (DS) en de Interne Accountantsdienst (IAD). Benadrukt moet worden dat het hierbij ging om een verdeling in aandachtsvelden, belangrijke beslissingen werden steeds gezamenlijk genomen. Of zoals in de notulen van de Raad van Commissarissen werd opgemerkt: "De directie zal als team leiding geven aan deze drie hoofdprocessen. primair proces, $P$. en $O$. proces (Personeel en Organisatie, JFK) en financieel-economisch proces" ${ }^{787}$ Bovendien kan iedere directeur, ongeacht de specifieke aandachtsvelden binnen de PLEM, extern bepaalde taken verrichten (denk aan VEEN-onderhandelingsdelegatie voor tarieven,

\footnotetext{
${ }^{786}$ Raad van commissarissen, Notulen van vergadering no, $5 / 88,6$ december $1988,10 . \mathrm{a}$
}

787 T.a.p., punt 10.a. 
Werkgeversvereniging Energiebedrijven (WEB), e.d.).

De hiervoor genoemde organisatiewijzigingen gingen formeel grotendeels per 1 juli 1989 in. Het totale project Horizon werd eind 1989 afgerond, waarbij alle overige voorgestelde wijzigingen ingevoerd werden. Ook na 1990 werden nog een aantal organisatieveranderingen doorgevoerd. De organisatiestructuur zoals die gold voor $1993 \mathrm{kan}$ als volgt worden weergegeven:

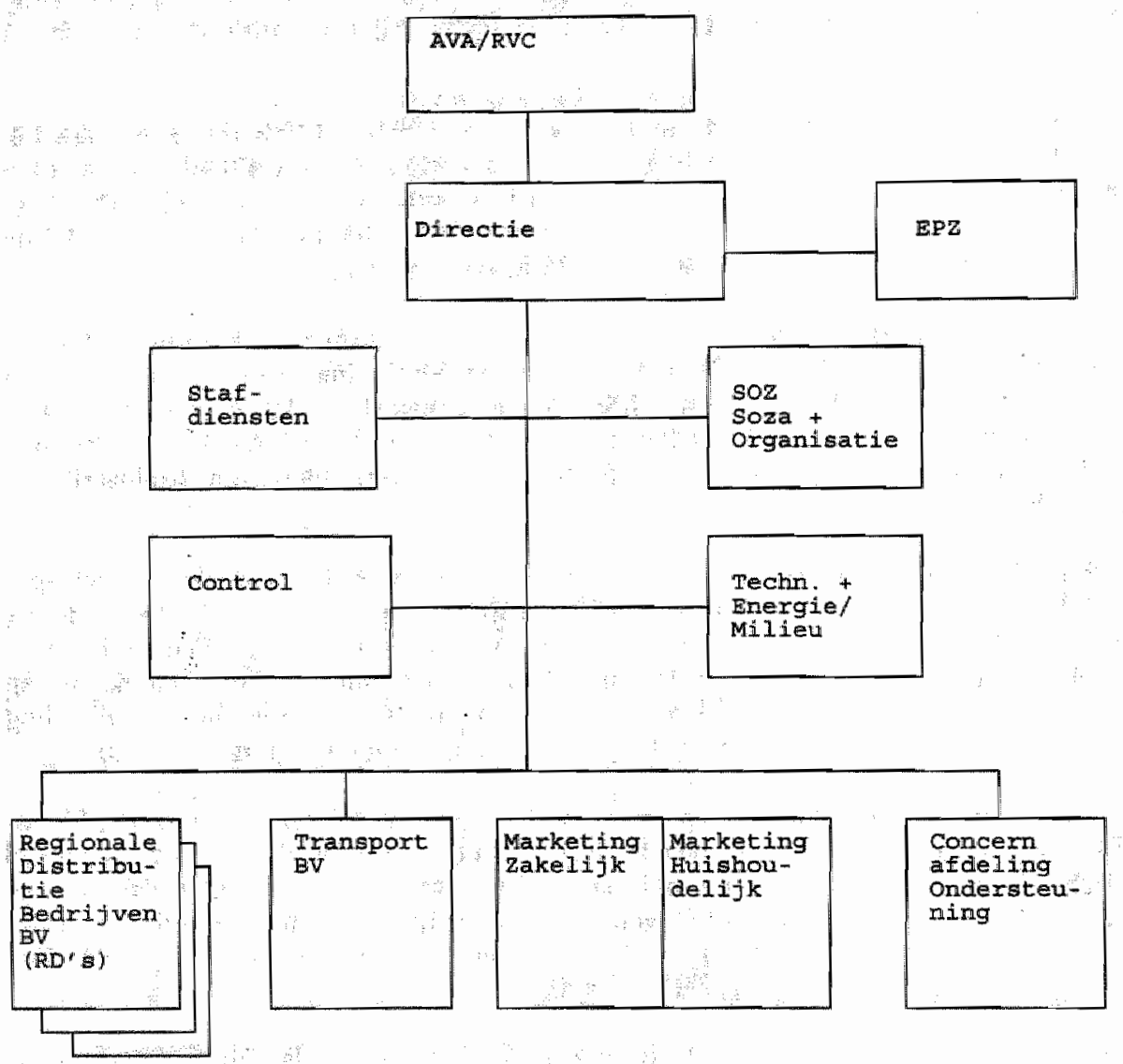

Figuur 16.4 De organisatiestructuur van de N.V. PLEM in 1992

Ook Figuur 16.4 betreft slechts een momentopname. In verband met de ingrijpende organisatieveranderingen in de elektriciteitssector in Europees verband werden ook halverwege de jaren negentig opnieuw organisatieveranderingen voorbereid. Aangezien in dit hoofdstuk de periode 1970-1990 centraal staat wordt er hier niet verder op ingegaan.

16.4 Structuur-analyse: welke doelen kunnen worden bereikt?

1) Wie hield toezicht op het aankoopbeleid en de prestaties van de productiefactoren?

2) Wie hield toezicht op de productieresultaten? 
3) Wie hield toezicht op het productieproces?

4) Wie hield toezicht op de omvang en samenstelling van het team van producenten?

5) Wie maakte aanspraak op de winst?

6) Wie had het recht de organisatie te wijzigen, te verkopen of te liquideren?

\subsubsection{Het recht op het gebruilk van een zaak}

\subsubsection{Wie hield toezicht op het aankoopbeleid en de prestaties van de productie- factoren?}

De PLEM was een NV en kan dus als rechtspersoon zelfstandig deelnemen an het economische verkeer. Het juridische eigendom van de PLEM ligt bij de aandeelhouders. De aandelen luidden op naam. Artikel 6 lid 2 van de statuten bepaalt: Houders van aandelen kunnen slechts zijn Nederlandse publiekrechtelijke lichamen of naamloze vennootschappen of besloten vennootschappen met beperkte aansprakelijkheid, waarvan de aandelen uitsluitend in handen zijn van Nederlandse publiekrechtelijke lichamen".788 Hiervan waren er 3493 in handen van de Provincie Limburg en 7 in handen van de Gemeente Geleen. Volgens artikel 6 van de statuten mogen de aandelen alleen in bezit zijn van publiekrechtelijke instellingen.

Vanaf 1977 is de PLEM een structuurvennootschap. Dientengevolge zijn de bevoegdheden van de Algemene Vergadering van Aandeelhouders beperkt, om te voorkomen dat deze direct ingrijpt in het ondernemingsbeleid. De Algemene Vergadering van Aandeelhouders bij de PLEM heeft sindsdien verschillende taken, waaronder de goedkeuring van de jaarrekening en het bepalen van de winstbestemming voor zover deze niet geregeld is in de statuten. Ook voor enkele andere bestuurshandelingen is toestemming vereist van de Algemene Vergadering van Aandeelhouders. Directiebesluiten die naast de goedkeuring van de Raad van Commissarissen tevens onderworpen zijn aan de goedkeuring van de Algemene Vergadering van Aandeelhouders hebben op grond van artikel 16 van de statuten onder meer betrekking op deelneming in andere bedrijven en de uitgifte, verkrijging of intrekking van aandelen of schuldbrieven ${ }^{789}$ Tenslotte zijn aan de Algemene Vergadering van Aandeelhouders binnen de door de wet en de statuten geldende grenzen, alle bevoegdheden toegekend die niet aan de Directie of anderen behoren. ${ }^{790}$

Omdat de PLEM een structururvennootschap is zijn belangrijke bevoegdheden van de Algemene Vergadering van Aandeelhouders overgedragen aan de Raad van Commissarissen. De Raad van Commissarissen van de PLEM bestond tot de statutenwijziging in 1977 uit 12 personen. De nieuwe statuten traden op 15 maart 1978 door het verlijden van de notariele akte in werking. Bij de statutenwijziging is het aantal commissarissen op 13 gesteld. De benoeming van de commissarissen is niet gewijzigd. Op grond van artikel 17 van de statuten moeten 7 personen door de overheid worden benoemd, te weten door de Gedeputeerde Staten van de Provincie Limburg, die allen op grond van artikel 17 lid 5

${ }^{788}$ Artikel 6 lid 2 van de statuten vam september 1987.

789 Artikell 16 van de statuten van september 1987.

790. Artikel 31 van de statuten van september 1987. 
van de statuten voorzitter of lid van de Provinciale Staten van Limburg moeten zijin. Verder moeten 6 commissarissen door coöptatie worden benoemd door de zittende leden van de Raad zelf. De statuten bepalen dat van deze 6 door coöptatie benoemde commissarissen er 2 burgemeester of gemeenteraadslid van een Limburgse gemeente moetten zijn en 2 een functie moeten vervullen bij een bedrijf dat in Limburg gevestigd is. Aangezien in een structuurvennootschap commissarissen op grond van artikel 158 boek 2 BW door coöptatie worden benoemd was voor de benoeming van commissarissen door de overheid ontheffing nodig door de Minister van Justitie. De Algemene Vergadering van Aandeelhouders en de ondernemingsraad hebben een zogenaamd geclausuleerd veto-recht. Op grond van 158 lid 4 boek 2 BW en artikel 17 van de statuten doet de Raad van Commissarissen aan de Algemene Vergadering van Aandeelhouders en de ondernemingsraad mededeling van het bestaan van een vacature binnen de Raad. De Raad van Commissarissen geeft aan beide colleges aan wie zij wenst te benoemen. De Algemene Vergadering van Aandeelhouders en de Ondernemingsraad kunnen bezwaar maken. Belangrijkste gronden zijn de ongeschiktheid van de voorgedragen persoon, het in geval van benoeming niet naar behoren samengesteld zijn van de Raad van Commissarissen en sinds de wijziging van het BW op 1 augustus 1987 het niet behoorlijk naleven van wettelijke voorschriften met betrekking tot de benoeming. ${ }^{791}$ In dat geval gaat de benoeming niet door tenzij de SER op verzoek van de Raad van Commissarissen het bezwaar ongegrond verklaarde. Voor het benoemen van commissarissen die van overheidswege worden benoemd heeft naast de Algemene Vergadering van Aandeelhouders, de Directie en de ondernemingsraad ook de Raad van Commissarissen een recht van aanbeveling.

De Raad van Commissarissen houdt toezicht op het beleid van de Directie en de algemene gang van zaken. De bevoegdheden van de Raad van Commissarissen zijn enerzijds wettelijk geregeld en zijn anderzijds verder uitgewerkt in de statuten.

De wettelijke bevoegdheden van de Raad van Commissarissen kunnen naar een drietal categorieën worden onderscheiden, te weten:

1. artikel $162 \mathrm{BW}{ }^{79}$ Benoeming en ontslag van bestuurders;

2. artikel $163 \mathrm{BW}$. De vaststelling van de jaarrekening. Deze categorie is nadrukkelijk van belang. Artikel 25 bepaalt" "(..) Jaarlijks binnen vijf maanden na afloop wan het boekjaar der vennootschap (...), worden door de directie een balans en een winst- en verliesrekening met een toelichting opgemaakt en ter vaststelling overgelegd aan de raad wan commissarissen". "Fen belangrijke in 1977 doorgevoerde verandering van de statuten is dat op grond van artikel 25 van de statuten de vaststelling van de jaarrekening dient te geschieden door de Raad van Commissarissen in plaats van door de Algemene Vergadering van Aandeelhouders, zoals dat voorheen het geval was.

Eên en ander was overeenkomstig de structuurvennootschapsbepalingen in de wet. Het bestuur stelt de jaarrekening op en legt deze voor aan de Raad van Commissarissen ter

\footnotetext{
791 Op 1 augustus 1987 is het BW ten aanzien van commissarisbenoemingen bij structuurvennootschappen op en tweetal punten gewijzigd. De behandeling van bezwaren vindt niet langer door de SER plaats maar door de Ondernemingskamer van het Gerechtshof te Amsterdam en er is de genoemde bezwaargrond toegevoegd.
}

792 Boek 2 BW. Dit is de juridische situatie zoals die gold gedurende de jaren tachtig.

793 Artikel 25 van de statuten van september 1987 . 
vaststelling. Na vaststelling van de jaarrekening wordt deze op grond van artikel 27 van de statuten naar de Algemene Vergadering van Aandeelhouders gestuurd (en vanaf 1977 op grond van artikel 27 van de statuten ook naar de ondernemingsraad). De Algemene Vergadering van Aandeelhouders moet op grond van artikel 28 van de statuten de jaarrekening wel goedkeuren. Doet zij dit niet dan is de situatie niet geheel duidelijk. Heeft zij bezwaren die verband houden met titel 8 dan was een procedure op grond van artikel $999 \mathrm{ev}$. Rv. denkbaar. Indien evenwel de bezwaren van de Algemene Vergadering niet gebaseerd waren op titel 8 , art. 335 boek 2 BW e.v., biedt de wet geen oplossing. De Algemene Vergadering van Aandeelhouders heeft in principe geen bevoegdheid een commissaris te ontslaan. Eventueel zou de Algemene Vergadering van Aandeelhouders de ondernemingskamer van het gerechtshof te Amsterdam kamnen vragen een commissaris te ontslaan. Dit was echter slechts mogelijk op grond van de in artikel 161 lid 2 genoemde gewichtige redenen (vergelijk ook artikel 20 lid 5 van de statinten) en was alleen voor incidentele gevallen van toepassing. Overigens gold dit niet voor overheidscommissarissen". Deze konden ook ontslagen worden door degene die met benoeming is belast.

3. artikel $164 \mathrm{BW}$. Goedkeuring van belangrijke bestuursbesluiten en bestuurshandelingen waaronder ontslag van een aammerkelijk aantal werknemers, wijziging van arbeidsvoorwaarden en financiële deelneming in andere vennootschappen. Om te bepalen wie het recht op het toezicht op de inputs heeft is ook deze categorie van belang. In artikel $164 \mathrm{f}$ boek 2 BW werd opgemerkt dat de Raad van Commissarissen onder meer moest goedkeuren: "Investeringen welke een bedrag gelijk aan ten minste een vierde gedeelte van het geplaatste kapitaal met de resenves der vennoatschap volgens haar balans met toelichting vereisen". Gedurende de periode dat de goedkeuring van de Raad van Commissarissen niet is verkregen heeft het besluit geen rechtskracht.

Bij de PLEM heeft de Raad van Commissarissen ook bevoegdheden die niet bij wet zijn geregeld maar in de statuten vermeld staan (met name artikel 15 lid 2 ). Deze bevoegdheden zijn onder andere goedkeuring van overeenkomsten en transacties waarmee een waarde gemoeid is die boven een door de Raad van Commissarissen te bepalen bedrag gaat, goedkeuring van investerings- en financieringsplannen alsook van een herziening daarvan, goedkeuring van overnames van andere nutsbedrijven, het overnemen van distributiebedrijven, de goedkeuring voor het voeren van juridische processen en het vaststellen van algemene arbeidsovereenkomsten voor zover deze niet door een collectieve arbeidsovereenkomst (CAO) worden geregeld. Verder vermelden de statuten dat de Raad: van Commissarissen goedkeuring moet verlenen aan: "Het vasistellen en wijzigen van de tarieven en de algemene voonwarden woor levering van elektriciteit". ${ }^{794}$

De Raad van Commissarissen heeft het recht op toezicht op alle belangrijke activiteiten. Belangrijke bestuursbeslissingen moeten door haar worden goedgekeurd. Daarmee heeft de Raad van Commissarissen grote bevoegdheden, die echter niet zo ver gaan dat zij zich actief met het ondernemingsbeleid kan bemoeien. Zij kan bestuursbesluiten afkeuren maar kan in principe het bestuur niet opleggen wat er dan wel moet gebeuren. Dat belangrijke maatregelen die betrekking hebben op de input door de Raad van Commissarissen moeten worden goedgekeurd, blijkt bijvoorbeeld uit de procedure rond het begin jaren tachtig gestarte nieuwbouwproject. Pas na goedkeuring van het nieuwe gebouw en de bijbehorende budgetten door de Raad van Commissarissen kon begonnen worden met de bouw (afgezien van de benodigde vergunningen).

Met de beschrijving van de bevoegdheden van de Raad van Commissarissen en van de

794 Artikel 15 lid $2 \mathrm{j}$ van de statuten van september 1987. 
Algemene Vergadering van Aandeelhouders is voor een belangrijk deel tevens aangegeven wat de bevoegdheden van het besturur zijn. De taak van het bestuur is het voorbereiden en het uitvoeren van het beleid, terwijl de Raad van Commissarissen belast is met het goedkeuren van het beleid en het controleren van de uitvoering. Artikel 129 boek 2 BW vermeldde als taak van het bestuur: "Behoudens beperkingen volgens de statuten is het bestuur belast met het besturen wan de vennootschap". De beperkingen in de statuten van de PLEM gingen vrij ver. Voor allerlei belangrijke maatregelen die het bestuur wilde nemen was toestemming nodig van de Raad van Commissarissen en de Algemene Vergadering van Aandeelhouders. Het is belangrijk dat de Raad van Commissarissen voor meer dan de helft benoemd werd door de Gedeputeerde Staten van de provincie Limburg. Dit hield in dat zij door hun invloed op de samenstelling van de Raad van Commissarissen, invloed konden uitoefenen op het gebruiksrecht. Dit werd nog versterkt door de eisen die aan de overige door coöptatie te benoemen commissarissen werden gesteld. Zij moesten voor een belangrijk deel zitting hebben in organen van gemeenten. Deze commissarissen maakten dus deel uit van het openbaar bestuur en waren uit dien hoofde verplicht verantwoording af te leggen over de wijze waarop zij als commissaris functioneerden.

Binnen de hiervoor beschreven beperkingen kon het bestuur van de PLEM en het personeel aankopen doen. Binnen de PLEM zijn bij de verwerving van goederen en diensten in het algemeen een tweetal functies betrokken, namelijk de afdeling die voor het uitvoeren van haar plannen bepaalde inputs nodig heeft (de gebruiker) en de afdeling Inkoop. Voor de inkoop van goederen is naast technische ook commerciële kennis onmisbaar. Er was binnen de PLEM een streven naar een functionele takkverdeling waarbij de commerciële inbreng vooral door de afdeling Inkoop (Inkooporgaan) verzorgd werd. Deze afdeling was commercieel ingesteld maar heeft ook een technische oriëntatie. Er is ten aanzien van de inkoop sprake van een zowel organisatorische als geografische centrale verwerving van de inputs. Deze afdeling Inkoop ressorteerde onder de $\mathrm{Be}$ drijfsdirecteur Economie. ${ }^{795}$ Ten aanzien van de bevoegdheid inputs aan te schaffen wordt opgemerkt: "Ter wille van een juiste coördinatie is het in beginsel aan Inkoop voorbehouden om het bedriff op het gebied van de verwerving te binden. Inkoop kan dit echter alleen doen wanneer hiertoe door de gebruikende afdeling een verzoek is gedaan. Voorts zijn er een aantal bestelsystemen ontwikkeld in het kader waarvan de opdrachtverlening tot stand komt door een combinatie van handelingen door Inkoop en door de gebruikersfunctie. Ook zijn er gevallen (b.v. bij storingen), waarin de gebruiker opdracht kan verlenen" ${ }^{796}$ In het algemeen gold dat de gebruiker een bepaalde behoefte aan goederen signaleert, de technische eisen specificeert en vervolgens samen met de afdeling Inkoop afspreekt welke bedrijven bij een aanbesteding zullen worden betrokken. De gebruiker analyseert ook de ontvangen offertes en bepaalt uiteindelijk samen met de afdeling Inkoop welke leverancier wordt gekozen. De gebruiker zorgt op deze wijze vooral voor de technische inbreng, terwijl de afdeling Inkoop zoals opgemerkt vooral het commerciële gedeelte van de verwervingsprocedure, waaronder de eigenlijke verwervingsactiviteiten, voor haar rekening nam. De mate waarin de inbreng van de afdeling Inkoop en van de gebruiker vereist was, kon per input en per transactie verschillen. Daarbij speelt een rol of het om een standaard produkt gaat of juist om maatwerk, om een eerder gekocht produkt of om een eerste aankoop, en $00 \mathrm{k}$ of het gaat om een lange verbintenis of om een eenmalige aanschaf. Gaat het om routine-aankopen dan treedt de afdeling Inkoop meer op de voorgrond. In dit verband wordt onderscheid gemaakt tussen de speciale en de routine-procedure. Van welke procedure gebruik gemaakt moest worden,

\footnotetext{
${ }^{795}$ N.V. PLEM, Handleiding voor de verwerving van goederen en diensten, 1 oktober 1984, p. 4.

${ }^{796}$ T.a.p., p. 8.
} 
werd door de gebruiker aangegeven, waarbij hij gebruik kon maken van een checklist. Opgemerkt werd: "Deze vereenvoudigde werkwijze leent zich vooral voor de aanschaf van die goederen, welke in een repeterende behoefte voorzien en warnan de besteleisen voor geruime tijd vastliggen ${ }^{\text {. }}{ }^{797}$ Een belangrijk verschil tussen beide procedures was dat de bij de speciale procedure opgegeven lewerancier bindend was, dat wil zeggen dat de afdeling Inkoop hier niet van afweek zonder nader overleg met de gebruiker, terwijl de afdeling Inkoop wel kon afwijken van de bij een routine-procedure opgegeven leverancier. ${ }^{798}$

Verder was voor elke afdeling bepaald wie welke bevoegdheden heeft, dat wil zeggen welke functionaris bevoegd was welke goederen via de afdeling Inkoop aan te schaffen. Veelal was de afdelingschef en/of één of meer andere functionarissen bevoegd tor het goedkeuren van aanvraag- en bestelverzoeken bij de afdeling Inkoop alsook van de facturen en ontvangstcontrolemeldingen. ${ }^{799}$ In een aantal gevallen zijn binnen de betreffende afdeling aanvullende afspraken gemaakt.

Naast deze wijze van verwerving zijn er ook verwervingscategorieën die niet door de afdeling Inkoop werden behartigd (hoewel de afdeling Inkoop onder omstandigheden wel hierbij betrokken kan worden). Het gaat hierbij onder meer om de verwerving van geldsmiddelen, accountantsdiensten, verzekeringen, diensten van de PTT, diensten van organisatiebureaus, notariêle bemiddelingen en stroominkopen. Deze aankopen en dienstverrichtingen zijn aan bepaalde afdelingen binnen de PLEM en later MEGA Limburg opgedragen. Daarnaast kan de Directie een afdeling of een werknemer met de verwerving van speciale projecten belasten (de boww van een nieuwe vleugel aan het gebouw e.d.) of bepaalde taken van een afdeling incidenteel overhevelen naar de afdeling Inkoop.

Voor de normale loop van het inkoopproces gold voor het doen van de uiteindelijke bestellingen de volgende regel:" Als regel worden uitgaande orders tot $F$. 50:000,- in het kader van de procuratieregeling getekend door HIN Bij diens afwezigheid parafreert plv. HIN. en geschiedt ondentekening door het betreffende $A H$. Is deze laatste eveneens niet aanwezig, dan tekent het qua afdeling meest verwante dan aanwezige $A H$. Boven het genoemde bedrag zijn twee handtekeningen vereist. De ondertekening vindt dan plaats door het hoofd van de betreffende gebruikersafdeling en $H W$. Bij afwezigheid van HIN parafeert piv. HIN. en tekent eerst het betreffende $A H$, vervolgens het qua afideling meest verwante dan aanwezige $A H{ }^{800}$ Dit is dus de situatie waarbij de betreffende afdeling niet zelfstandig goederen mag verwerven. Naast de hiervoor beschreven verwervingsprocedure middels offerte-aanvragen werden een aantal andere procedures onderscheiden waarbij de belangrijkste de aanbesteding van grote werken is. De procedure hiervoor verschilde niet veel van die van de speciale procedure. De beslissing aan welke aannemer de opdracht gegeven zal worden werd genomen door het Hoofd van de betreffende

797 T.a.p., p. 21.

798 N.V. PLEM, De verwerving van goederen en diensten (concept) deel il (inkoopmanual), september 1983, p. 31.

799 T.a.p., p. 62 . Zỉe ook het rapport: Projectgroep verwerving van goederen en diensten, Rapport definitiestudie, oktober 1987, pp. 8 e.v.

${ }^{800}$ T.a.p., p. 33. Hierbij staat HIN voor Hoofd Inkoop, en AH voor afdelingshoofd. 
bedrijfisafdeling en het Hoofd van de afdeling Inkoop. ${ }^{801}$

\section{Conclusie}

Concluderend kan ten aanzien van dit eigendomsrecht gesteld worden dat dit recht verspreid is over de Directie enerzijds en de provincie anderzijds door middel van de bevoegdheden van de Raad van Commissarissen. Het bestur is tot bepaalde mate autonoom en kan zelf beslissen over de aanschaf van de inputs en ziet zelf toe op de prestatie. Voor belangrijke beslissingen is evenwel goedkeuring van de Raad van Commissarissen nodig. Het bestuur is belast met de dagelijkse ondermemingsleiding. Zuj kan een zelfstandig beleid voeren op het niveau van de operationele planning. De strategische planning vindt plaats in samenwerking met de Raad van Commissarissen en de Algemene Vergadering van Aandeelhouders.

\subsubsection{Wie hield toezicht op de productieresultaten?}

De Directie van de PLEM controleerde het personeel, terwijl de Raad van Commissarissen de Directie controleerde, waarbij zoals in de vorige paragrafen is opgemerkt de jaarrekening een belangrijke rol speelde. De Raad van Commissarissen beziet in hoeverre de productieresultaten overeenkomstig haar doelen zijn. Zoals aangegeven in paragraaf 16.3.3 was er sprake van een hiërarchische organisatie, waarbij hogere niveaus veelal aanwijzingen konden geven aan lagere niveaus. De Directie van de PLEM en tegenwoordig MEGA Limburg heeft de mogelijkheid om door middel van een straf- en beloningsstelsel invloed uit te oefenen op het personeel. In de $\mathrm{CAO}$ werden verschillende disciplinerende straffen vermeld, die door de Directie kunnen worden opgellegd. Straffen die genoemd werden waren: $\$ 02$

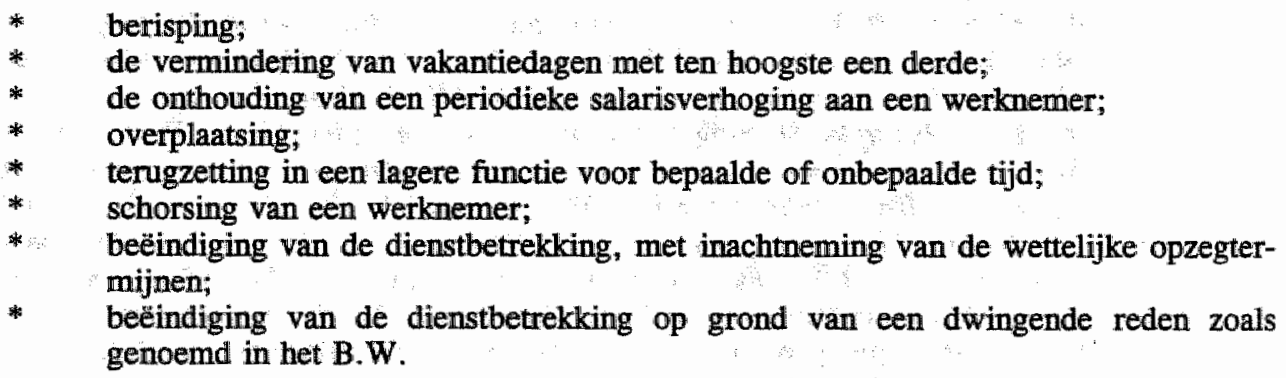

Een straf werd pas opgelegd nadat de werknemer in de gelegenheid was gesteld zich te verantwoorden. Tegen de strafoplegging stond beroep open bij een college van beroep. Dit college bestaat uit 5 leden en 5 plaatsvervangende leden. Van de leden en de plaatsvervangende leden werden er 2 benoemd door de Werkgeversvereniging Elektriciteitsbedrijven en 2 door de gezamenlijke Werknemersorganisaties die partij bij de CAO zijn. Deze 4 benoemen vervolgens het vijfde lid en het plaatsvervangend lid, die tevens fungeren als voorzitter en plaatsvervangend voorzitter. Leden van dit college mochten geen banden hebben met de N.V. PLEM. Het college kan zelf de beslissing nemen, die naar zij tmeent, genomen had moeten worden. Tegen een beslissing van het college staat

${ }^{801}$ N.V. PLEM, De verwerving van goederen en diensten, deel II, inkoop-manual, september 1983, p. 41.

802 Zie bijwoorbeeld de Collectieve Arbeidsovereenkomst elektriciteitsbedrijven in N.V.-vorm, november 1978, Hoofdstuk 22. 
Naast het opleggen van straffen had de Directie de mogelijkheid werknemers te belonen of deze beloningen juist aan een werknemer te onthouden. In de $\mathrm{CAO}$ 's was bepaald: "De salariëring van de werknemers geschiedt voorshands volgens de ondernemingsgewijs geldende regelingen " ${ }^{803}$ Speciale vergoedingsregelingen golden voor het volgens rooster verrichten van ploegendiensten en onregelmatige diensten, het in opdracht verrichten van overwerk en het in opdracht verrichten van werkzaamheden, niet zijnde overwerk, in do eigen tijd van de werknemer. ${ }^{304}$

Een en ander was geregeld in de salarisregeling van de NV PLEM en een bijbehorende salaristabel. ${ }^{805}$ Deze salaristabel is opgedeeld in achttien salarisklassen, terwijl ledere salarisklasse is opgebouwd ait een aantal periodieken. Artikel 2 van de salarisregeling bepaalde dat iedere functie door de Directie overeenkonstig de regeling Functiewaardering NV PLEM in één van deze salarisklassen wordt ingedeeld, die verblijfsklassen worden genoemd. Eind jaren tachtig werden alle functies op deze wijze, overeenkomstig de regeling Functiewaardering N.V. PLEM, opnieuw ingedeeld Het doel van deze functiewaardering was mede tot een meer objectief beloningssysteem te kromen. In overleg met de ondernemingsraad is gekozen voor de Integrale Methode voor Functieclassificatie van het organisatiebureau Klijnveld, Bosboom en Hegener (KBH), onder meer omdat met dit systeem de nodige ervaring was opgedaan bij verschillende elektriciteitsbedrijven en andere nutsbedrijven. De procedure bij de indeling van functies was globaal als volgt. Het afdelingshoofd diende zijn voorstel in bij de Directie. De Directie ontving van de toetsingscommissie haar standpuntbepaling. Uiteindelijk bepaalde de Directie de definitieve indeling in een bepaalde verblijfsklasse.

Het belonings- en sanctiesysteem van de PLEM was zoveel mogelijk op dit functiewaarderingssysteem afgestemd In de salarisregeling was bepaald dat elke werknemer jaarlijks per 1 januari een periodieke verhoging ontvangt. De Directie had de mogelijkheid een werknemer geen periodieke verhoging toe te kennen, één en ander overeenkomstig artikel 27 WEB/CAO (akkoord hierover bereikt tussen Werkgeversvereniging Energiebedrijven (WEB) en vakorganisaties). Artikel 3 van de salarisregeling bepaalde: "De directie kan een periodieke verhoging onthouden indien er naar zijn oordeel sprake is van aantoonbaar onvoldoende functioneren. Dit oordeel dient gebaseerd te zijn op een schriftelijk vastgelegde motivering, welke aan de betreffende werknemer uiterlijk vóór 1 november voorafgaand aan de in lid 1 genoemde datum (1 januari JFK) schriftelijk is kembaar gemaakt".80"

In dit verband wordt opgemerkt: "In de gegeven situatie - immers voor 1 november zal er nog geen directiebesluit zijn - is het raadzaam een dergelijk voomemen wan het afdelingshoofd in samenwerking met de afdeling $P$ en $O$ te behandelen"." verder de mogelijkheid om ingeval van uitstekend functioneren, meerdere periodieken toe te kennen. De overgang binnen de aanvangsklassen naar een hogere klasse (binnen het

803 Collectieve arbeidsovereenkomst elektriciteitsbedrijven in N.V.-vorm, november 1978, hoofdstuk 5.

804. T.a.p., artikel 40.

205 NV PLEM Salarisregeling, Hoofdstuk F, 01-01-1990.

206 Vergelijik ook. N.V. PLEM, Regeling Functiewaardering N.V. PLEM ${ }^{1988 .}$

807 NV PLEM, Salarisregeling. Hoofdstuk F, 01-01-1990, artikel 3 lid 3.

${ }^{808}$ Hoofd afdeling Personeel en Organisatie, Notitie voor de afdelingshoofden, 25-09-1989, punt 6. 
aan de betreffende verblijfsklasse verbonden voortraject van aanvangsklassen) geschiedde indien de Directie meende dat er sprake was van een goede functie-uitoefening, terwijl de overgang van de categorie van aanvangsklassen naar de verblijfsklassen plaatsvond indien er naar het oordeel van de Directie sprake was van volledige en volwaardige uitoefening van de functie. ${ }^{809}$ Bij bevordering van een werknemer waardoor deze werd ingedeeld in een hogere verblïfsklasse, ontving deze tevens een periodieke verhoging. Daamaast was bepaald dat een werkmemer in aanmerking komt voor een uitloopperiodiek (indien hij de hoogste periodiek in zijn verblijfsklasse reeds bereikt heeft) indien hij de leeftijd van 51 jaar heeft bereikt, terwijl een werknemer voor een tweede uitloopperiodiek in aanmerking komt indien hij de leeftijd van 56 jaar heeft bereikt. Ook deze regeling was onderdeel van het straf en beloningsstelsel. Zij gold alleen indien de Directie van mening was dat de betreffende werknemer zijn of haar functie goed had vervuld. Verder was bepaald dat in uitzonderlijke situaties, ter beoordeling aan de Directie, de beide uitloopperiodieken ook gelijktijdig konden worden toegekend. Verder had de Directie de mogellijkheid extra beloningen toe te kennen. Artikel 7 bepaalde in dit verband: "Ingeval van naar het oordeel wan de directie buitengewone werkomstandigheden, werkzaamheden of prestaties van bijzondere aard kan de werknemer een extra beloning in de vorm van een gratificatie of een geschenk worden toegekend" 810 De richtlijnen gratificatie-beleid bleven daarbij van kracht. Tijdens de salarisprocedure 1989/1990 werd daarbij opgemerkt: "Voorop staat dat gratificaties het best kunnen worden toegekend ommiddellik aansluitend aan de te honoreren prestatie of omstandigheden": 811 Ook indien er sprake was van belastende werkomstandigheden, die niet pasten binnen het bij de NV PLEM gebruikte functiewaarderingssysteem, kon aan een werknemer een extra vergoeding worden toegekend.12 Tenslotte had de Directie onder bepaalde omstandigheden de mogelijkheid het salaris niet uit te betalen. Bepaald was: "De directie behoudt zich het recht voor om over de tijd gedurende welke de werknemer in strijd met zijn verplichtingen opzettelijk nalaat zijn betrekking te verwullen, hem zijh salaris niet uit te betalen, met dien verstande dat elk ingetreden half uur zal worden verrekend voor een half uur. De berekening van het in te houden salaris geschiedt op basis van het per uur genoten salaris" 813

\subsubsection{Wie hield toezicht op het productieproces?}

Het toezicht op het productieproces was toegekend aan de Raad van Commissarissen en in mindere mate aan de Directie. In de regel vond het toezicht op het productieproces vooraf plaats, in de zin dat bepaalde activiteiten, waaronder investeringen slechts mochten worden uitgevoerd na goedkeuring door de Raad van Commissarissen en de Directie. Eén

809 NV PLEM, Salarissegeling, Hoofdstuk F, 01-01-1990, artikel 3, lid 6.

$\$ 10$ T.a.p., artikel 7.

${ }^{811}$ Hoofd afdeling Personeel en Organisatie N.V PLEM, Notitie voor de afdelingshoofden, 25-09-1989, punt 5.

812 N.V. PLEM, Regeling vergoeding belastende werkomstandigheden, maart 1989, artikel 1, Bij belastende werkomstandigheden kan bijvoorbeeld gedacht worden aan geluidshinder, stank etc.

${ }^{813}$ NV PLEM, Saliarisregeling, Hoofdstuk F, 01-01-1990, artikel 9, lid 1. 
en ander was als volgt geregeld. ${ }^{814}$ Met betrekking tot het productieproces kon onderscheid gemaakt worden tussen enerzijds de plammingsfase en anderzijds de beheersingsfase. Tujdens de planningsfase werd het bedrijfsplan opgesteld en goedgekeurd door Directie en Raad van Commissarissen. Hierdoor werd aan de afdelingen aangegeven welke taken zij moesten verrichten. ${ }^{815}$ Vervolgens werden tijdens de beheersingsfase de betreffende activiteiten meer gedetailleerd geraamd, gerealiseerd en eventueel bijgestuurd ten opzichte van het bedrijfsplan. Tijdens de beheersingsfase werd in overleg met de Raad wan Commissarissen de oorspronkelijke taakstelling aangevuld en werd indien nodig het bedrijfsplan herzien.

Een investeringsplan maakte onderdeel uit van het bedrijfsplan. De investeringen in het bedrijfsplan waren door de Directie impliciet goedgekeund. Op grond van de goedkeuringsbepalingen van de PLEM was een hernieuwde goedkeuringsaanvraag nodig tijdens de beheersingsfase. Toestemming van de Directie was namelijk vereist voor:

-aankoop van transportmiddelen;

-investeringsprojecten die meer dan F. 10.000,-kostten;

-onderhoudsprojecten waarmee meer dan F. 5.000;- is gemoeid;

-aankoop of ruil van grond.

Eind jaren tachtig zijn een aantal wijzigingen doorgevoerd, waardoor hernieuwde goedkeuring alleen vereist is voor belangrijke afwijkingen ten opzichte van het bedrijfsplan en waardoor afdelingshoofden ruimere bevoegdheden kregen. ${ }^{816}$ Belangrijk is daarbij of het budget zoals is opgenomen in het bedrijfsplan al dan niet overeenstemt met de raming. In dit verband werd opgemerkt: "Wijkt de nieume raming af van het oorspronkelijk goedgekeurde budget, dan gelden uiteraard meer beperkte bevoegdheden voor de afdelingshoofden en de door hen aangewezen medewerkers" " ${ }^{17}$ "Met betrekking tot budgettering werd opgemerkt: De projectgroep wil benadrukken dat het een stuurmechanisme en een delegatiemodel is, met het doel het dragen van verantwoordelijkheden door ieder op zijh eigen plaats te vermimen, te ondersteunen en te beheersen. Bij het dragen hoort ook het afleggen van verantwoordelijkheid". Het gaat daarbij nadrukkelijk om door middel van wederzijdse communicatie tussen de verschillende niveaus, de output en het resultaat te verbeteren.

Het onderhoudsplan, dat eind jaren tachtig werd geintroduceerd, maakte anders dan het investeringsplan geen deel uit van het bedrijfsplan. Er werd wel zoveel mogelijk een gelijke behandeling van investerings- en onderhoudskosten nagestreefd. Het toezicht op het productieproces vooraf kan nu als volgt worden weergegeven:

\footnotetext{
\$114 Natities ter bespreking in sectoroverteg Voortgeleiding en Economie, 880848, Notitic bepalingen rond verantwoordelijkheden yoor de administratieve afhandeling van investerings-en onderhoudsproiecten, 2-31988, pp. 1-3.
}

815 Notities ter bespreking in het sectoroverleg Voortgeieiding en Economie, 872885, Wiiziging goedkeuringsbepalingen en -procedures ten aanzien van investeringen en onderhoud, 2-3-1988.

\$16 T.a.p., pp. 1-2.

${ }^{117}$ T.a.p., p. 3.

${ }^{818}$ Projectgroep Budgettering van de PLEM, Budgetteren bil de PLEM. 27-12-198:, p. 1. 


\begin{tabular}{|c|c|c|c|c|c|}
\hline \multirow{3}{*}{$\begin{array}{l}\text { Bevoegde } \\
\text { functionaris }\end{array}$} & \multicolumn{4}{|c|}{ Investeringen } & \multirow{3}{*}{ Onderhoud } \\
\hline & \multicolumn{2}{|c|}{ Specifieke projecten } & \multicolumn{2}{|c|}{ Niet specifieke projecten } & \\
\hline & $\begin{array}{l}\text { raming } \\
\leq \\
\text { budget }\end{array}$ & $\begin{array}{l}\text { raming } \\
> \\
\text { budget }\end{array}$ & $\begin{array}{l}\text { bindende aan- } \\
\text { bieding. }\end{array}$ & $\begin{array}{l}\text { geen (binden- } \\
\text { de) aanbieding }\end{array}$ & \\
\hline $\begin{array}{l}\text { Door het be- } \\
\text { treffende } \\
\text { Afdelings- } \\
\text { hoofd } \\
\text { aangewezen } \\
\text { medewer } \\
\text { ker(s) }\end{array}$ & $\begin{array}{l}<F \\
10,000\end{array}$ & $-\cdots \operatorname{los}^{2}$ & $\begin{array}{c}3 \\
\vdots \\
\vdots\end{array}$ & $\begin{array}{c}<F, 5.000,- \\
\end{array}$ & $<$ F. 5,000 \\
\hline $\begin{array}{l}\text { Afdelings- } \\
\text { hoofd }\end{array}$ & $\begin{array}{l}\text { alle pro- } \\
\text { jecten }\end{array}$ & $\begin{array}{l}\text { afwijking < } \\
10 \% \text { of } \\
\text { F. } 25.000 \text {; } \\
\text { van het budget } \\
\text { in het bedrijfs } \\
\text { (investerings- } \\
\text { plan) }\end{array}$ & alle projecten & F. 50.000 ,- & $\mathrm{F}_{\mathrm{s}} 50.000^{-}$ \\
\hline Directie & 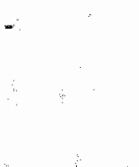 & $\begin{array}{l}\text { afwijking }> \\
10 \% \text { of } F \\
25.000, \text { van } \\
\text { het bedrijfs- } \\
\text { plan }\end{array}$ & 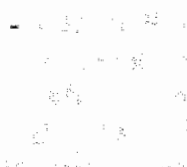 & F. 50,000, & F. 50.000 \\
\hline
\end{tabular}

Tabel 16.1 Bevoegdheidsverdeling ten aanzien van het productieproces: investeringen en onderhoud ${ }^{819}$

Het was niet toegestaan om zonder goedkeuring vooraf verplichtingen aan te gaan of daadwerkelijke uitgaven te doen, anders dan in Tabel 16.1 vermeld.

Goedkeuring yooraf was slechts in uitzonderingsgevallen niet vereist. Deze hadden vooral betrekking op storingen die onmiddellijk verholpen moesten worden. Onderhoud of wijzigingen die gelijktijdig met de storingen werden doorgevoerd moesten achteraf door middel van een overzicht van de uitgevoerde werkzaamheden en van de daarmee gepaard gaande kosten, worden verantwoord.

Dit systeem van voorafgaande goedkeuring werd eind jaren tachtig verder geconcretiseerd. In een drietal afdelingen werd begonnen met budgettering, namelijk bij de afdelingen Personeelszaken (PZ), Transport (TP) en Gebouwen en Terreinen (GT) ${ }^{820}$ Met de invoering werd beoogd: "Wij willen naar een situatie waarin afdelingen zich verantwoordelijk weten voor de financiële en technische resultaten van het met elkaar afgesproken personeelsbeleid". Dit systeem van budgettering werd op grond van dit project in de hele organisatie ingevoerd, als onderdeel van een systeem van planning,

\footnotetext{
819 Notities ter bespreking in het sectoroverleg Voortgeleiding en Economie, 872885, Wiiziging goeclkeuringsbepalingen en -procedures tten aanzien van investeringen en onderhoud, $2-3-1988$, p. 4.
}

820 N.V. PLEM, Horizontaal, eerste editie, 13 oktober 1988, p. 2. 
budgettering en "control". Zoals vermeld in paragraaf 16.3.3. werd als gevolg van het project Horizon aan het eind van de jaren tachtig de afdeling FE opgericht, die zich vooral bezig hield met deze planning, budgettering en beheersing ("control"). Na het opstellen van een plan, worden de kosten van de activiteiten geraamd in een budget. Dit budget wordt vervolgens aan de afdelingen beschikbaar gesteld die het voor de afgesproken activiteiten gebruiken. Dit wordt door de Directie gevolgd en waar nodig wordt bijgestuurd. Dit proces kon door de Directie en afdelingshoofden worden bijgestuurd aangezien er sprake was van een hiërarchische organisatie, waarin hogere niveaus opdrachten kunnen geven aan lagere. De verschilende stappen van planning, budgettering en uitvoering moesten beheerst worden, de zogenaamde "control"-functie. Dit systeem van planning, budgettering en "control" stelde het management in staat te sturen op hoofdlijnen. Dit had als belangrijk voordeel dat meer gedelegeerd kon worden naar lagere niveaus. Het bracht wel met zich mee dat hogere eisen gesteld moest worden aan de communicatie tussen de verschillende niveaus in de organisatie.

\subsubsection{Wie hield toezicht op de omvang en samenstelling van het team van produ- centen?}

\subsection{Wie zag toe op de omvang van het team van producenten?}

Ten aanzien van het recht toe te zien op de omvang en samenstelling van het team van producenten kan onderscheid gemaakt worden tussen de benoeming van het bestuur van de PLEM en de rest van het personeel.

Artikel 8 lid 1 van de statuten bepaalde: "De vennootschap wordt bestuurd door een directie bestaande uit één of meer directeuren, onder toezicht van de raad van commissarissen". ${ }^{821}$ Lid 2 bepaalde: "Het aantal directeuren wordt bepaald door de raad van commissarissen". Zoals aangegeven in paragraaf 16.3.3. kende de PLEM gedurende de jaren zeventig en tachtig een Directieteam bestaande uit een drietal directeuren, waarvan één fungeerde als voorzitter. Dit waren de in de statuten genoemde directeuren. Daarnaast was er een bedrijfsdirecteur voor de sector Algemeen, voor de sector Economie en voor de sector Voortgeleiding. Eind jaren tachtig werd een statutenwijziging doorgevoerd waarbij zoals in paragraaf 16.3.3 is opgemerkt, een Directieteam van twee directeuren werd ingevoerd. Op grond van artikel 162 boek 2 BW en artikel 9 van de statuten werden bestuurders benoemd door de Raad van Commissarissen. ${ }^{822}$ Artikel 162 bepaalde verder: "(..) deze bevoegdheid kan niet door enige bindende voordracht worden beperkt. Hij geeft de algemene vergadering van aandeelhouders kennis van een voorgenomen benoeming van een bestuurder van de vennootschap; hij ontslaat een bestuurder niet dan nadat de algemene vergadering over het voorgenomen ontslag is gehoord". Hoewel de Algemene Vergadering van Aandeelhouders op de hoogte gesteld moest worden stond hierop geen sanctie. Ontslag was slechts mogelijk indien eerst de Algemene Vergadering van aandeelhouders daarover was gehoord. Artikel 9 lid 3 van de statuten bepaalde: "(..) In geval van een voorgenomen ontslag met of zonder voorafgaande schorsing, zal de betrokken directeur door de raad van commissarissen in de gelegenheid worden gesteld te worden gehoord in de algemene vergadering van aandeelhouders die over het voorgenomen ontslag wordt gehoord. (...)" ${ }^{823}$ Anders dan bij de benoeming stond hier bij

821 Artikel 8 lid 1 van de statuten van juni 1981.

82 Artikel 9 lid 1 van de statuten wan september 1987.

823 Artikel 9 lid 3 van de statiten van september 1987. 
ontslag wel een sanctie op. Onvrijwillig ontslag zonder raadpleging van de Algemene Vergadering van Aandeelhouders is vermietigbaar. Dit laat echter onverlet dat de Raad van Commissarissen miet gebonden was aan het oordeel van de Algemene Vergadering van Aandeelhouders.

Ten aanzien van de omvang van het personeelsbestand kan worden opgemerkt dat elk jaar door de PLEM een formatieplan werd opgesteld. ${ }^{824}$. Het formatieplan werd per afdeling opgemaakt, in samenwerking met de afdeling Organisatie. Uitgaande van de feitelijke bezetting werd aangegeven hoeveel medewerkers in mensjaren uitgedrukt de afdeling in het betreffende jaar nodig had en welke opleiding en ervaring voor deze functies nodig was, Dit formatieplan werd door de Directie ingediend bij de Raad van Commissarissen. Op grond van de uit te voeren taken en activiteiten werd bepaald welke soorten functies en welke aantallen werknemers per saldo nodig waren. Deze ideale formatie kon in verband met het in het verleden ontstane personeelsbestand afwijken van de werkelijke formatie. Naast deze formatieve sterkte waren er ook werknemers die boven de formatie uitgingen, zoals zij die voor bepaalde tijd in dienst waren, mensen in opleiding en schoolverlaters. Beide groepen bij elkaar opgeteld vormden samen de toegestane bezetting. De omvang van de toegestane bezetting moest dus worden goedgekeurd door de Raad van Commissarissen. Naast deze feitelijke bezetting stonden er ook mensen op de loonlijst van de PLEM die niet actief waren, zoals werknemers met wachtgeld en werknemers die gebruik maakten van de "60-jarigen regeling". In de Nota "Op weg naar personeelsplanning" werd verder opgemerkt. ${ }^{.25}$ "Een eenmaal vastgesteld formatieplan geldt woor het komende jaar. Binnen de goedgekeurde formatie mag een openwallende plaats opnieuw worden bezet. De toegestane bezetting mag in principe niet stijgen hetzij dat op grond van een medische of sociale indicatie noodzakelijk is (..). Ad hoc wijzigingen van het formatieplan gedurende het lopende jaar zullen alleen in uitzonderingsgevallen dienen plaats te vinden en behoeven de goedkeuring van de directie".

Op basis van de door de Raad van Commissarissen goedgekeurde bezetting konden derhalve vacatures worden opgevuld. Eind jaren tachtig werd er bij het benoemen van personeel en de invulling van vacatures een zogenaand vier-stappen-model gevolgd. ${ }^{26}$ In de eerste plaats werd nadnukkelijk bezien of het mogelijk was om een werknemer te herplaatsen. Het ging daarbij vooral om werknemers die op grond van een keuringsbesluit van het $A B P$ niet meer geschikt waren voor hun oude functie maar wel geheel of gedeeltelijk voor een andere functie en om werknemers die in verband met organisatorische redenen hun baan verloren hadden. In de HPZ-OR-commissie (hoofd personeelszaken-ondernemingsraad-commissie) moest melding worden gemaakt van deze aanstelling. ${ }^{27}$ Indien er geen herplaatsing mogelijk was, was het mogelijk dat het afdelingshoofd met een voorstel kwam. Het afdelingshoofd moest in dat geval aantonen dat de door hem voorgedragen kandidaat in aanmerking kwam voor de vacante functie. Ook hier gold dat in de HPZ-OR-commissie melding gemaakt moest worden van deze aanstelling. Indien herplaatsing niet mogelijk was en ook de afdelingschef niet met een voorstel

${ }^{824}$ Personeel en Organisatie, Vrijban. intern vacatureblad NV PLEM, eerste uitgave van 9 januari 1989.

825 Afdeling Personeelszaken van de N.V. PLEM, Nota "Op weg naar personeelsplanning", 1 januari 1989 , bijlage 2.

${ }^{26}$ Raad van commissarissen, Personeelsbestand NV PLEM, 1989, p. 8. Zie ook: Afdeling Personeelszaken, Nota "Op weg maar personeelsplanning", 1 januari 1989, pp. 9-10.

${ }^{827}$ Afdeling Personeelszaken, Nota "Op weg maar personeelspanming", 1 januari 1989, p. 10. 
kwam, werd als derde stap overgegaan tot interne werving. Dit gebeurde door opname van de vacature in een vacaturekrant. De afdelingshoofden en de afdeling Personeelszaken stelden samen een lijst op met vacatures die binnen éen à twee jaar te verwachten zijn. De vierde stap tenslotte was de externe werving. Een belangrijke wijziging in het vacaturebeleid in de jaren tachtig was dat vacatures niet meer min of meer automatisch extern geplaatst worden, maar dat eerst intern wordt gezocht naar geschikte kandidaten. Slechts indien er geen geschikte kandidaten binnen de PLEM werkzaam waren en er ook geen herplaatsbare werknemers waren, werd gezocht naar externe kandidaten.

De procedure was verder als volgt. De personeelsconsulent stelde samen met het afdelingshoofd een lijst op van te verwachten vacatures. Deze lijst werd ter kennisgeving gestuurd aan de betreffende directeur. Er was een personeelsplanningsgroep die bestond uit het betreffende afdelingshoofd, de personeelsconsulent, de chef arbeidsvoorwaarden, de opleidingsfunctionaris en de chef $\mathbf{P V O}$, die optrad als voorzitter van de planningsgrcep. Het doel van de planningsgroep was zorg te dragen voor de juiste invulling van de vier stappen. Indien er verschil van mening bestond binnen de planningsgroep over de toepassing van het vier-stappen-beleid, werd het door de planningsgroep opgemaakte verslag via het hoofd van de afdeling Personeelszaken toegezonden aan de statutair directeur, met het verzoek een uitspraak in deze te geven. Verder was bepaald dat indien extern geworven werd woor functies met verblijfsklasse 9 of hoger, de toestemming van de statutair directeur nodig was. De wervings- en sollicitatieprocedure werd verder afgehandeld door het afdelingshoofd en de personeelsconsulent. ${ }^{828}$ Het hiervoor beschreven vier-stappen-plan was in principe ook van toepassing op de benoeming van afdelingshoofden. Een belangrijk verschil was dat voor deze functies het initiatief door de Directie genomen moest worden. Tenslotte kan nog worden opgemerkt dat bij de benoeming van managers inspraak van het personeel mogelijk was. Deze inspraak varieerde van afspraken per situatie tot een inspraakprocedure. Sinds 1991 werd ook gewerkt met inspraak voor middel-managementfuncties, waarbij per vacante functie een inspraakcommissie wordt samengesteld, die bestaat uit 3 à 4 medewerkers van de betreffende afdeling. ${ }^{829}$

\subsection{Hoe was het toezicht op de samenstelling van het team van producenten geregeld?}

Uit het voorgaande bleek reeds dat de Raad van Commissarissen uiteindelijk de omvang en de samenstelling van het personeelsbestand van de PLEM bepaalden. Zij beslisten over de toegestane formatie, hetgeen was ingevuld met het in paragraaf 16.4.1.2. genoemde functiewaarderingssysteem. Ten aanzien van de samenstelling kan nog worden opgemerkt dat ook de beloning hierop invioed heeft. Op grond van artikel 135 boek 2 BW wordt de bezoldiging van bestuurders, behoudens statutaire afwijkingen, bepaald door de Algemene Vergadering van Aandeelhouders. Bij de PLEM was dit overgedragen aan de Raad vam Commissarissen. Artikel 11 van de statuten bepaalde: "Het salaris en de overige arbeidsvoorwaarden van een directeur worden vastgesteld door de raad van commissaris$\operatorname{sen}^{+1830}$

228 T.a.p., pp. 11-15.

829 Raad van Bestuur, Notitie aan de leden wan de Ondernemingsraad, Inspraakprocedure MEGA Limburg, 02-07-1992, pp. 1-3.

830 Arikel 11 van de statuten van september 1987. 
Dit recht kan worden opgevat als het recht om de onderneming te leiden. De PLEM was een rechtspersoon en had het recht tot op zekere hoogte zelfstandig in de zin van onafhankelijk van de Algemene Vergadering van Aandeelhouders het ondernemingsbeleid vast te stellen. Omdat de PLEM een structururvennootschap was, was dit recht voor cen belangrijk deel overgeheveld van de Algemene Vergadering van Aandeelhouders naar de Raad van Commissarissen. Het was slechts in beperkte mate overgedragen aan de Directie. Het bestuur regelde de dagelijkse gang van zaken met als belangrijke controle de bepaling dat de Raad van Commissarissen de jaarrekening vaststelde en dat de Algemene Vergadering van Aandeelhouders de jaarrekening diende goed te keuren.

\subsection{Het recht op vruchtgebruik (usus fructus)}

\subsubsection{Hoe werd de winst verdeeld gedurende de onderzoeksperiode?}

De verdeling van de winst kan als volgt in een tabel worden weergegeven.

\begin{tabular}{|c|c|c|c|}
\hline 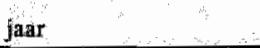 & winst & dividend & reservering \\
\hline 1970 & F. 1,6 miljoen $^{83}$ & $\begin{array}{l}\text { F. } 375.000,-(\text { in procent } \\
\text { eigen vermogen }=0,5 \%)\end{array}$ & F. 1,225 miljoen \\
\hline 1974 & - F. 1 miljoen & F. 375,00, $-(0,3 \%)$ & - F. 1.375.000, \\
\hline 1978 & F. 14,819 miljoen & F. $6000000,-(0,1)$ & F. 14,219 miljoen \\
\hline 1982 & F. 13,95 millioen & $\begin{array}{l}\text { F. } 3,937 \text { miljoen } \\
(0,7 \%)\end{array}$ & F. 10,013 miljoen \\
\hline 1984 & F 13,089 miljoen & 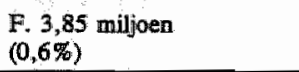 & F. 9,239 miljoen \\
\hline 1986 & F. 3,6 miljoen & $\begin{array}{l}\text { F. } 3,413 \text { miljoen } \\
(0,5 \%)\end{array}$ & F. 187,000 \\
\hline $\begin{array}{l}1988 \\
\end{array}$ & F. 9,8 miljoen & $\begin{array}{l}\text { F. } 3,5 \text { miljoen } \\
(0,5 \%)\end{array}$ & F. 6,295 miljoen \\
\hline 1990 & F, 28,4 miljoen & $\begin{array}{l}\text { F. } 17,9 \text { milfoen } \\
(2 \%)\end{array}$ & F. 10,5 milljoen \\
\hline
\end{tabular}

\section{Tabel 16.2 De verdeling van de winst ${ }^{832}$}

Gedurende de onderzoeksperiode valt op dat de winst nogal fluctueert Verder valt op dat de dividenduitkeringen relatief laag waren, hetgeen de vraag doet rijzen wat met de rest van de winst gebeurde. Hierbij dient bedacht te worden dat dotaties aan de voorzieningen, overeenkomstig de Wet op de Jaarrekening, vanaf 1975 niet meer ten laste van de winst maar ten laste van de exploitatie geschieden. Deze toevoegingen aan de voorzieningen zijn in Tabel 16.2 niet opgenomen. De reservering en fondsvorming gedurende de onderzoeksperiode kan als volgt worden weergegeven:

\footnotetext{
831. Verschillen tussen de winst en de som van dividend en ingehouden winst zijn het gevolg van afrondingen.
}

\$92 De cijfers zijn afgerond. 


\begin{tabular}{|c|c|c|c|c|c|c|c|c|}
\hline Jar. & 1975 & 1980 & 1985 & 1986 & 1987 & 1988 & 1989 & 1990 \\
\hline $\begin{array}{l}\text { Totale bedrag aan } \\
\text { reserves en voor- } \\
\text { ziemingen aan het } \\
\text { eind van het be- } \\
\text { treffende jaar }\end{array}$ & 175.505 & 539.358 & 656.964 & 654.344 & 623.348 & 641,285 & 689.241 & 772.442 \\
\hline $\begin{array}{l}\text { Reserves: statu- } \\
\text { tail' reserve fonds }\end{array}$ & 1.593 & -3 & - & - & - & - & - & - \\
\hline $\begin{array}{l}\text { Vernieuwings- } \\
\text { reserve }\end{array}$ & 103.325 & 395.509 & 501.614 & 543.173 & 549.780 & 562.006 & 593.992 & $\vdots$ \\
\hline Algemene reserve & 40.786 & 80.237 & 85.297 & 55.772 & 56.775 & 59.892 & 75.854 & 768.047 \\
\hline Dividendreserve & 836 & 10.012 & 15.000 & 15.000 & 12.825 & 15.000 & 15000 & - \\
\hline $\begin{array}{l}\text { Voorzieningen: } \\
\text { pensioenverplich- } \\
\text { tingen }\end{array}$ & 812 & 670 & 449 & 399 & 167 & 154 & 130 & 130 \\
\hline $\begin{array}{l}\text { Fonds voor } \\
\text { deelneming in } \\
\text { kemenergiecen- } \\
\text { trales en in het } \\
380 \mathrm{kV} \text {-net }\end{array}$ & $\begin{array}{r}12.639 \\
1\end{array}$ & 19.151 & 19.414 & - & - & - & - & - \\
\hline Assurantiefonds & 15.356 & 28.178 & 32.032 & 25.000 & 4.804 & 4.233 & 4.265 & 4.265 \\
\hline
\end{tabular}

Bedragen . F. 1.000

\section{Tabel 16.3 De verdeling van het vermogen over reserves en voorzieningen ${ }^{838}$}

De niet door de PLEM uitgekeerde winst werd gebruikt voor het realiseren van een aantal reserves. Verder werden een aantal voorzieningen gecreěerd. In de jaren zeventig werden middelen voornamelijk toegevoegd aan de statutaire reserve en aan het Fonds voor deelneming in kernenergiecentrales en in het 380-kV-net. Voorts was er een Fonds

833 Naast de in de tabel genoemde reserves en voorzieningen bestaan of bestonden er nog enige andere fondsen die van minder financieel belang waren of die later in de wel genoemde fondsen zijn opgegaan zoals: amovering centrales, fonds koersrisico vreemd geld en fonds voor het verkabelen van laagspanningsnetten.

${ }^{834}$ In 1977 overgeboekt naar de algemene reserve.

835 Sinds 1976 word deze reserve overeenkomstig de in de Wet op de Jaarrekening gebruikte terminologie, aangeduid als berwaarderingsreserve.

836 Ingestell met ingang van 1976.

337 Beëindigd met ingang van 1986.

${ }^{838}$ Exclusief de egalisatiebijdragen van de SEP (vergoedingen van de SEP voor uitbreiding capaciteit en andere investeringen). Bedragen zijn afgerond. 
assurantie eigen risico. Er bestond een algemene reserve die sinds 1971 bestaat vit de reserves voor bijzondere doeleinden (hier aangeduid als RBD), het egalisatiefonds (EF), het Fonds voor onrendabele uitbreidingen en netverbeteringen (FUN) en het fonds voor het verkabelen van laagspanmingsnetten (FL). In 1976 werd een nieuw fonds opgericht, de diviflendreserve, ter verzekering van toekomstige dividenduitkeringen Eind jaren zeventig werd door de Algemene Vergadering van Aandeelhouders besloten het jaarlijkse bedrag dat an de dividendreserve werd toegevoegd te vergroten. De reden hiervoor was dat de herwaarderingsreserve van 1975 tot en met 1978 was opgelopen van $F$. 109 miljoen naar muim $F, 339$ miljoen, de algemene reserve gedurende die periode toenam van ruim $F .40$ miljoen tot num F. 88 miljoen en ook allerlei andere voorzieningen nog waren versterkt. Hierbil vergeleken was het rendement voor de provincie laag. In de Algemene Vergadering werd opgemerkt: "Het Provinciaal Bestuur is dan ook van mening dat van de vorengenoemde winst (..) de helf zou moeten worden toegevoegd aan de dividendresenve. Een statutenwijziging - die het mogelijk maakt een hoger dividend voor de aandeelhouders te verkrijgen - komt vervolgens wenselijk voor". 839 In afwijking van het advies van de Raad van Commissarissen besloot de Algemene Vergadering van Aandeelhouders dan ook de winstverdeling te wijzigen. Aan de Raad van Commissarissen werd opgedragen een statutenwijziging voor te bereiden waardoor het maximaal uit te keren dividend werd verhoogd. Het in 1980 geleden verlies van F. 5.614.000,- werd op grond van de statuten ten laste van de algemene reserve gebracht. Verder werd overeenkomstig de aanhangige statutenwijziging, witgaande van plaatsing van het volledige aandelenkapitaal aan de aandeelhouders, een uitkering ten laste van de dividendreserve verricht van

F. 4.988.000,- In 1981 en 1982 werd de dividendreserve weer aangevuld tot de beoogde maximale hoogte van F. 15 miljoen. In 1981 werd door de Algemene Vergadering van Aandeelhouders besloten orm een uitkering van F. 30 miljoen te verstrekken aan de aandeelhouders, naar evenredigheid van hun aandelenbezit. Deze uitkering werd gedaan ten laste van de algemene reserve en gebeurde onder de voorwaarde dat de provincie Limburg en de gemeente Geleen deze bedragen zouden gebruiken om de extra uit te geven aandelen mee te betalen. ${ }^{840}$ In verband met de oprichting van de NV EPZ in 1987 en het landelijke verrekeningssysteem werd de voorziening Fonds voor deelneming in kernenergiecentrales en in het $380 \mathrm{kV}$-net beëindigd en ten gunste van het eigen vermogen verantwoord. Het ging daarbij om ongeveer $F$. 19 miljoen. In 1990 is in verband met de fusie met Limagas eem aantal voorzieningen en reserves verdwenen. Gedurende de onderzoeksperiode werd vrijwel steeds het in de statuten maximaal toegestane dividend uitgekeerd. Opvallend is dat dit dividend weliswaar toeneemt maar als percentage van het eigen vermogen gelijkblijft. Het uitgekeerde dividend bedroeg in $19700,5 \%$ van het eigen vermogen, in $19790,1 \%$ en in $19880,5 \%$. Door de relatief lage dividenduitkering kon het eigen vermogen van de PLEM door reservering sterk toenemen.

\subsubsection{Wie maakte aanspraak op de winst?}

De PLEM had een wettelijk gegarandeerd recht op eilgen vermogen. Door winstinhoudingen konden reserves worden opgebouwd, terwijl de PLEM ook mocht afschrijven. Het recht op vruchtgebruik kwam toe aan de aandeelhouders. De winst die mocht worden uitgekeerd was echter aan een maximum verbonden, zodat gegarandeerd was dat een deel van de winst binnen de onderneming bleef. Tot de statutenwijziging van 15 maart 1977 bedroeg het maximaal uilt te keren bedrag $7,5 \%$ van het totale aandelenkapitaal van $F .5$ miljoen. Bij deze statutenwijziging werd de dividendgrens gewijzigd in een percentage

839 Algemene Vergadering van Aandeelhouders, Notulen, 22 juni 1979, p. 6.

840 Algemene Vergadering van Aandeelhouders, Notulen, vergadering gehouden op 16 april 1981, p. 2 e.v.. 
van $3,5 \%$ boven de rentevoet van de laatste in het betreffende boekjaar geplaatste langlopende staatslening. Het resterende bedrag werd toegevoegd aan het eigen vermogen. In 1981 werd opnieaw een statutenwijziging doorgevoerd die leidde tot een verdere verruiming van de dividend-uitkering ${ }^{841}$ Naar aanleiding van het besluit van de Algemene Vergadering van Aandeelhouders had de Raad van Commissarissen een statutenwijziging voorbereid waardoor het maximaal uit te keren dividend werd verhoogd. De Minister van Economische Zaken gaf het Provinciaal Bestuur van Limburg te kennen akkoord te kunnen gaan met een statutenwijziging, waarbij het aandelenkapitaal werd verhoogd van F. 5 miljoen tot F. 35 miljoen. Het maximaal uit te keren dividend bleef gehandhaafd op 3,5\% boven de rentevoet van de laatstelijk voor 31 december van het betreffende boekjaar geplaatste langlopende staatslening. Op grond van de gewijzigde statuten werden 3000 aandelen van $F$. 10.000 , à pari en naar evenredigheid van het bestaande aandelenbezit uitgegeven aan de huidige aandeelhouders. $\mathrm{Om}$ de hiervoor verschuldigde koopsom te kumnen voldoen werd zoals in de vorige paragraaf is aangegeven, F. 30 miljoen ten laste van de algemene reserve aan de aandeelhouders uitgekeerd. In het algemeen gold dat winst tot een maxi-mum van $3,5 \%$ boven de bedoelde rentevoet automatisch werd uitgekeerd. Niet uitgekeerde winst werd gereserveerd. De statuten boden de mogelijkheid om in verliesjaren de dividendreserve aan te spreken. Artikel 30 lid 3 luidde sinds de wijziging van 1981: "Mocht in enig jaar de winst niet toereikend zijn of verlies zijn geleden dan wordt de in lid 1 bedoelde dividend-uitkering aanwullend respectievelijk geheel voldaan uit de dividend-reserve, met dien verstande dat indien verlies is geleden, hetwelk niet uit een reserve bestreden of op een andere wije wordt gedelgd, in volgende jaren geen winstuitkering geschiedt zolang zodanig verlies niet is aangezuiverd". ${ }^{82}$ De voorstellen van de Directie ten aanzien van de verdeling van de winst zijn in de periode 1970-1990 steeds volledig overgenomen door de Raad van Commissarissen en door de Algemene Vergadering van Aandeelhouders.

Bij het recht op de winst is verder van belang wie de tarieven mocht bepalen. Indien de eigenaren de tarieven op een hoog niveau vaststellen neemt immers de winst toe. Voor de reorganisatie van 1987 werden beslissingen over de uitbreiding van productievermogen en het ombouwen naar andere brandstofvormen al landelijk genomen. De voordelen verbonden aan het gebruiken van goedkope brandstoffen als kolen kwamen toen nog ten goede aan de verbruikers van het betreffende energiebedrijf. Door de nieuwe Elektriciteitswet die eind 1989 in werking trad, veranderde dit. De beleidsmatige scheiding tussen productie en distributie is nu wettelijk vastgelegd. Op grond van de Overeenkomst tussen SEP en productiebedrijven leveren productiebedrijven als EPZ aan de SEP. Vervolgens kopen de productiebedrijven de hoeveelheid elektriciteit die nodig is voor de levering aan distributiebedrijven in hun voorzieningsgebied: ${ }^{843}$ Voor de ontvangen elektriciteit vergoedt de SEP aan de productiebedrijven de directe productiekosten bestaande uit de kosten voor kapitaallasten, onderhoud en bediening, en de kosten van brandstoffen. Alle vergoedingen vinden plaats op een genormeerde basis. Kosten die uitstijgen boven de normering en de kosten die geen verband houden met de directe productielkosten worden door de SEP niet vergoed. Voor de elektriciteit die zij afnemen betalen de productiebedrijven vervolgens de SEP een vergoeding op grond van het Landelijk Basis Tarief

841 Het ging om een wijziging van artikel 30 van de statuten, houdende bepalingen omtrent de dividendưtkering.

\$42 Vergelijk: Directeur van de NV PLEM, brief aan đe Minister van Economische Zaken, 17 april 1981.

843 Vergelijk ook: Tweede Kamer (1988), Nota naar aanleiding van het Eindverslag, 19591, nr. 9, paragraaf 1.3.3. 
(LBT). Deze bestaat enerzijds ulit de vaste kosten, uitgedrukt in een bedrag per $\mathrm{KW}$ en anderzijds uit de brandstofkosten, uitgedrukt in een bedrag per $\mathrm{kWh}$. Alle belangrijke investeringsbeslissingen in de productiesector gebeuren slechts met toestemming van de SEP. De financiele gevolgen van deze beslissingen worden in SEP-verband vervolgens verrekend in het LBT. Omdat de kosten die boven de normering uitgaan en de indirecte productiekosten zoals overhead, het hebben van een hoofdkantoor e.d. niet door de SEP worden vergoed moeten de elektriciteitsproductiebedrijven deze zelf dragen. De productiebedrijven rekenen de distributiebedrijven voor dit soort kosten een toeslag op het LBT. Deze toeslag wordt de Regionale Toeslag (RT) genoemd en vormt samen met het LBT het Regionale Basis Tarief (RBT). De Regionale Toeslag hangt ook af van het aandeel van het voorzieningsgebied van de PLEM in de landelijke maximale belasting. Een en ander impliceert dat het LBT woor alle productiebedrijven hetzelfde is, de Regionalle Toeslag kan echter verschillen. Het is voor de PLEM, gezien de doelstelling van zo laag mogelijke tarieven van groot belang deze Regionale Toeslag zo beperkt mogelijk te houden. De PLEM probeerde dit te realiseren door de constructie waarbij EPZ een dochteronderneming was. Via de Raad van Commissarissen werd toezicht op EPZ gehouden. Opgemerkt werd: "Daarmee wordt bewerkstelligd dat bij EPZ het besef levend blijf dat elektriciteitsproductie geen doel op zich zelf is, maar dat elektriciteit wordt geproduceerd ten behoeve van afnemers:" Ten aanzien van de tarieven moet worden opgemerkt dat tariefwijzigingen niet alleen toestemming van de Raad van Commissarissen behoeven. Alle relevante tarieven (LBT, RBT en eindverbruikerstarieven) behoeven ook goedkeuring van de Minister. In dit verband werd in de Memorie van Antwoord bij de Elektriciteitswet van 1987 opgemerkt dat de Minister van Economische Zaken enkele uitzonderingssituaties daargelaten, geen tarieven kan vaststellen. Opgemerkt werd: "Hij heeft namelijk in het algemeen slechts de bevoegdheid am tariefivorstellen die hem in alle openbaarheid door de elektriciteitssector zijn voorgelegd, goed of af te keuren". In artikel 25 lid 1 van de Elektriciteitswet 1989 zijn een beperkt aantal gronden opgenomen op grond waarvan afkeuring mogelijk is. De bedoelde voorstellen zijn afkomstig van de SEP en de elektriciteitsbedrijven. Samenvattend kan gesteld worden dat de winst van de PLEM na invoering van de Elektriciteitswet 1989 in de eerste plaats afhankelijk is van de door de VEEN voorgestelde maximum-eindverbruikerstarieven in de tweede plaats van de inkooptarieven en in de derde plats van de distributiekosten en de bedrijfsprestaties van de PLEM.

Tenslotte is ook de regeling van de belastingen relevant. De PLEM betaalde een aantal belastingen nilet, waardoor de winst hoger leek dan zij feitelijk was. Vemnootschapsbelasting moet worden betaald indien er sprake is van cen organisatie die gericht is op deelname aan het economische verkeer met behulp van arbeid en kapitaal en zich daarbijj ten doel stelt winst te behalen. Ook overheidsbedrijven die concurreren met derden en die geen overheidstaak uitvoeren zijn in principe belastingplichtig voor de vennootschapsbelasting. In artikel 2 lid 3 van de Wet op de vennootschapsbelasting 1969 werd limitatief opgesomd welke bedrijwen dat zijn. Gedurende de onderzoeksperiode verrichte de PLEM een overheidstaak en concurreerde niet met andere bedrijven. Verder viel de PLEM onder artikel 2 lid 7 , hetgeen inhield dat een $\mathrm{NV}$ die voor $100 \%$ in handen is van provincie of gemeente niet belastingplichtig is zolang zij naast het leveren van energie niet meer dan.

\footnotetext{
844 Raad van Commissarissen N.V. PLEM, 89.055.477, Relatie PLEM-EPZ N.V. Elektriciteitsprodukciemaatschappii Zuid Nederland EPZ), 08-11-1989, p. 3.

845 Tweede Kamer der Staten-Generaal (1987), Memorie van Antwoond bij het wetswoorstel Elektriciteitswet 1987, 19591 p. 19.
} 
$10 \%$ andere activiteiten verrichten. De PLEM betaalde dan ook geen vennootschapsbelasting. VNO en NCW wezen er begin jaren negentig op dat de grote activiteiten van de mutsbedrijven op het gebied van besparingsactiviteiten ertoe zouden kunnen leiden dat deze bedrijven vennootschapsbelastingplichtig worden. Er werd door hen op gewezen dat afstemming tussen de Minister van Economische Zaken en de nutssector in deze nodig was. Wel moest de PLEM omzetbelasting doorberekenen aangezien zij overeenkomstig de Wet op de omzetbelasting 1968 als ondernemer kon worden gezien. De PLEM oefende immers een bedrijf uit dat erop gericht was om door duurzame deelneming aan het economisch verkeer behoeften te bevredigen. De regering verhoogde de omzetbelasting op elektriciteit per 1 oktober 1976 van 16 tot $18 \%$. De PLEM wees daarbij op de ongelijke behandeling van elektriciteit en andere energiebronnen waaronder aardgas, aangezien de omzetbelasting op aardgas met $4 \%$ onveranderd bleef. Op 1 april 1978 werd echter ook de omzetbelasting op gas verhoogd van $4 \%$ tot $18 \%$ waardoor aan de ongelijke behandeling een einde kwam. De PLEM meende echter dat zowel gas als elektriciteit tot de primaire levensbehoeften gerekend moeten worden en daarom onder het lage tarief moeten vallen. Tenslotte kan worden opgemerkt dat geen kapitaalbelasting verschuldigd was. In de jaren tachtig was de regeling dat kapitaalbelasting van $1 \%$ werd geheven ten aanzien van het bijeenbrengen wan in aandelen verdeeld kapitaal. Op grond van artikel 37 lid $c$ zijn instellingen met een doel dat betrekking heeft op het algemeen nut en waarvan uitsluitend publiekrechtelijke lichamen aandeelhouder zijn, vrijgesteld van kapitaalbelasting.

16.6 Wie had het recht om de vorm of inhoud van een zaak te veranderen of te verhandelen (abusus)?

16.6.1 Wie had het recht om de organisatie van de NV PLEM te wijzigen, te verkopen of te liquideren?

De categorie rechten om de vorm of inhoud van een zaak te veranderen ligt bij de Algemene Vergadering van Aandeelhouders. Ten aanzien van het verkopen van de organisatie wordt in artikel 6 lid $4 \mathrm{~b}$ van de statuten opgemerkt: "Elke overdracht van aandelen behoeft de goedkeuring van de algemene vergadering van aandeelhouders, die omtrent een verzoek tot goedkeuring dient te beslissen binnen drie maanden, nadat het verzoek daartoe aan de algemene vergadering van aandeelhouders is gedaan onder opgave van het publiekrechtelijk lichaam of de vennootschap welke de aandelen wil overnemen. Indien de algemene vergadering van aandeelhouders de overdracht van aandelen goedkeurt dient zij tevens aan te geven dat de vennootschap bereid is de aandelen over te nemen danwel aan te geven welk lichaam of welke vennootschap bereid is de aandelen over te nemen". ${ }^{846}$

Verder kan ten aanzien van dit eigendomsrecht worden opgemerkt dat artikel 164 lid g boek 2 BW en dienovereenkomstig artikel 15 lid 1 sub $\mathrm{f}$ van de statuten bepaalden dat een voorstel tot wijziging van de statuten of tot ontbinding van een structuurvennootschap i.c. de PLEM goedkeuring behoefde van de Raad van Commissarissen. Dat gold evenwel alleen voor het voorstel en niet voor het uiteindelijke besluit. Dit uiteindelijke besluit behoorde als eigenaar van de vennootschap toe aan de Algemene Vergadering van Aandeelhouders, in het geval van de PLEM dus voornamelijk de Provinciale Staten van de provincie Limburg. Een wijziging van de statuten moest goedgekeurd worden door de Provinciale Staten, Verder merkt artikel 35 lid 1 van de statuten op: "Onverminderd het bepaalde in de artikelen 123, 124 en I25 Boek 2 Burgerlijk Wetboek kunnen besluiten tot

846 Artikel 6 lid 4 b van statuten van september 1987. 
wijziging van deze statuten en tot ontbinding van de vennootschap slechts worden genomen met een meerderheid van drie/vijfde van de geldig uitgebrachte stemmen in een algemene vergadering van aandeelhouders, waarin tenminste drie/vijfde van het geplaatste kapitant is vertegenwoordigd". 847

Op grond van artikel 35 lid 3 was voor een besluit tot wijziging van de statuten of tot ontbinding van de vennootschap tevens voorafgaande goedkeuring van de Provinciale Staten van Limburg vereist. Volgens de concessie inzake de ellektriciteitswoorziening in Limburg behoefde een wijziging van de statuten daarnaast de goedkeuring van de Minister van Economische Zaken. 48

Omdat de PLEM een structuurvennootschap was, was, zoals bij de behandeling van het gebruiksrecht al is opgemerkt, voor belangrijke besluiten de goedkeuring nodig van de Raad van Commissarissen. In 1988 deed de Directie bijvoorbeeld voorstellen aan de Raad van Commissarissen om de organisatiestructuur en werkwijze te veranderen. De Raad van Commissarissen keurde deze voorstellen in april 1989 goed. Hoewel de Raad van Commissarissen niet het recht had de statuten te wijzigen of de vennootschap te ontbinden had zij wel invloed op de organisatiestructurur.

Als een belangrijk onderdeel van het recht om de organisatic te wijzigen kan zoals in hoofdstuk 15 is aangegeven, de toegang van de PLEM tot de kapitaalmarkt worden genoemd. Omdat de PLEM een N.V. was kon zij zowel aandelen uitgeven als vreemd vermogen aantrekken en had zij dus zelfstandig toegang tot de kapitaalmarkt.

De mogelijkheid om aandelen wit te geven was beperkt door de bepaling in de statuten dat alleen publiekrechtelijke instellingen eigenaren konden zijn van de aandelen. Bovendien was op grond van artikel 164 boek $2 \mathrm{BW}$ voor de uitgifte van aandelen toestemming nodig van de Algemene Vergadering van Aandeelhouders. Dit recht kan worden gedelegeerd aan het bestuur. Artikel 164 a geeft aan dat in dat geval het bestuursbesluit waarbij dit recht is gedelegeerd, goedkeuring behoeft van de Raad van Commissarissen. Artikel 16 van de statuten van de PLEM geeft aan dat voor de uitgifte van aandelen zowel de goedkeuring van de Algemene Vergadering van Aandeelhouders als de Raad van Commissarissen nodig is: In dit verband is de aandelenfusie van PLEM en Limagas die op 6 juni 1990 plaatsvond van belang. De aandelenfusie werd mogelijk door het door de aandeelhouders in 1989 bereikte principe-akkoord. De NV MEGA Limburg is een structuurvennootschap waarvan de aandelen voor $63 \%$ in het bezit zijn van de provincie Limburg en voor $37 \%$ in handen zijn van een $66-$ tal gemeenten.

De mogelijkheid om vreemd vermogen aan te trekken was niet beperkt, zij het dat hiervoor toestemming van de Raad van Commissarissen vereist was. Voor het aangaan van geldleningen was eveneens toestemming nodig van de Algemene Vergadering van Aandeelhouders. De Algemene Vergadering van Aandeelhouders verstrekte veelal, op voorstel van de Directie, een doorlopende machtiging aan de Directie tot het aangaan van geldleningen. Bij de Algemene Vergadering van 21 juni 1989 werd bijvoorbeeld een machtiging verstrekt tot het aangaan van geldlleningen met een looptijd van maximaal eén jaar en/of tot het gebruik maken van rekening-courantkrediet tot een maximumbedrag van F. 150 miljoen. Het voorstell van de Directie aan de Algemene Vergadering moest

${ }^{847}$ Artikel 35 lid 1 van de statuten van september 1987.

${ }^{248}$ Vergelijk artikel 27 bis van de rijksconcessie inzake de elektriciteitswoorziening in Limburg.

${ }^{849}$ Algemene Vergadering van Aandeelhouders, Notulen, 21 juni 1989, p. 3 ev. 
worden goedgekeurd door de Raad van Commissarissen Voor het lenen op de kapitaalmarkt was toestemming nodig van de Algemene Vergadering van Aandeelhouders. Met name in de jaren zeventig werd in verband met de gedane investeringen, herhaaldelijk een beroep gedaan op de kapitaalmarkt. De financiering mam daarbij veelal de vorm aan van een onderhandse lening. Over de periode 1975-1979 werden de investeringen geraamd op F. 976 miljoen. Een groot deel van dit bedrag werd op de kapitaalmarkt middels onderhandse leningen geleend. Eind 1977 bedroeg het total van de onderhandse leningen, te onderscheiden naar verschillende nog resterende looptijden $F, 983,199.000,-$. De uitgifte van obligaties was tot 1974 niet aantrekkelijk in verband met de daaraan verbonden kosten. Het lenen in het buitenland was niet mogelijk in verband met bezwaren van DNB. De rentedaling vergemakkelijkte de financiering. In $1988 \mathrm{kwam}$ de PLEM als eerste nutsbedrijf in Nederland met een Medium Term Note-programma van maximaal F. 200 miljoen. Deze Medium Term Notes zijn door de voortgaande liberalisatie van de kapitaalmarkt vanaf 1988 mogelijk. Inclusief de Medium Term Notes heeft de PLEM in 1988 voor F. 138 miljoen aan langlopende leningen opgenomen. Aan het eind van 1988 bedroeg de langlopende schuld per saldo F. 566 miljoen. Het totale bedrag aan kasgeldleningen bedroeg F. 31 miljoen. De toegang tot de kapitaalmarkt van de PLEM leidde ertoe dat de PLEM relatief meer streefde naar efficiëntie, aangezien schuldeisers alleen bereid zullen zijn te lenen indien het bedrijif voldoende rendabel is.

Tenslotte zou ook het recht on goederen (eigemdom van de PLEM) te verkopen tot dit recht gerekend kunnen worden. Voor de verkoop van onroerende goederen die een bepaalde waarde te boven gaan en voor het sluiten van overeenkomsten die een door de Raad van Commissarissen te bepalen bedrag te boven gaan is overeenkomstig artikel 15 lid $2 \mathrm{f}$ en $\mathrm{g}$ toestemming modig van de Raad van Commissarissen. In het algemeen gold verder dat goederen, waarvan besloten is dat ze niet langer door het bedrijf gebruikt zullen worden, verkocht zullen worden door de afdeling Inkoop. 850

\section{Conclusie}

Gedurende de onderzoeksperiode was de provincie door middel van haar invloed in de Algemene Vergadering van Aandeelhouders en Raad van Commissarissen houder van de meeste eigendomsrechten. Geleidelijk aan werden er steeds meer landelijke resticties opgelegd, op grond waarvan de PLEM moet opereren. In de Memorie van Antwoord bij de Elektriciteitswet 1987 werd opgemerkt: "In lijn met de noodzaak van de besluituorming op landelijk niveau over de grootschalige elektriciteitsproductie, treedt er een zekere verschuiving op van de zeggenschap van de lagere overheden naar de centrale overheid. Daarnaast dient de overheid (zowel de centrale als de lagere overheid) aan de sector meer ruimte te laten voor een bedrijfsmatig opereren ${ }^{351}$ De provincie kon door haar aandelen vooral de besluitvorming binnen de PLEM bepalen.

\subsection{Welke doelen kunnen uit de verdeling van eigendomsrechten worden afgeleid?}

Tijdens de Algemene Vergadering van Aandeelhouders in 1977 werden de statuten ingrijpend gewijzigd. De doelen van de vemnootschap en haar maatschappelijke taakstelling werden opnieuw geformuleerd. Meer nadruk werd gelegd op de bevordering van het

850 N.V. PLEM, De verwerving van goederen en diensten, deel II inkoop-manual (concept), september 1983 , p. 49.

85: Tweede Kamer der Staten-Generaal (1987), Memorie van Antwoord met betrekking tot de Elektriciteitwet 1987, 19591, p. 110. 
welzijn van de medewerkers. Bij de PLEM werden 7 van de 13 commissarissen benoemd door de Gedeputeerde Staten van de provincie Limburg. Dit betekende dat de aandeelhouders overwegende invloed hadden binnen de onderneming. Zij konden met behulp wan hun bevoegdheden erop toezien dat uiteindelijk zoveel mogelijk hun doelen werden nagestreefd.

Het toezicht op het aankoopbeleid berustte voor een belangrijk deel bij de Raad van Commissarissen. Belangrijke besluiten over de aanschaf van materialen en over het doen van investeringen moesten door de Raad van Commissarissen worden goedgekeurd. In de Handleiding voor de verwerving van goederen en diensten werden een tweetall doelen. genoemd op het gebied van de aanschaf van inputs, namelijk: 852

- Het zorg dragen dat de voor het bedriff benodigde goederen en diensten in de juiste kwaliteit, in de juiste haeveelheid, op de juiste plaats en op de juiste tijd ter beschikking stiaan;

-Het verkrijgen van een maximale tegenwaarde voor alle aan de verwerving bestede uitgaven ".

Deze eigendomsrechtenverdeling was op deze wijze geregeld om ervoor te zorgen dat de provincie Limburg invloed kon uitoefenen op de verwerving van imputs en daarmee op de economische ontwikkeling van de regio. De provincie streefde ernaar zoveel mogelijk aankopen te doen binnen Nederland en meer in het bijzonder binnen de provincie zelf. In dit verband werd opgemerkt: "(..) geringe prijsverschillen alléén (dienen JFK) geen aanleiding te vormen opdrachten buiten onze grenzen te plaatsen". ${ }^{55}$. De provincie streefde ernaar dat bedrijven buiten de provincie Limburg, waarbij orders geplaatst werden, ook weer tegenorders bij Limburgse bedrijven plaatsten. Bovendien kon de provincie op deze manier proberen de technologische ontwikkeling van het bedrijfslewen in de provincie Limburg te verbeteren. Tenslotte biedt dit eigendomsrecht de provincie de mogelijkheid te streven naar een efficiënte elektriciteitsvoorziening met zo laag mogelijke tarieven. In dit verband werkte de PLEM onder meer samen met het Rijksinkoopbureau (RIB) en andere (semi-)overheidsbedrijven. ${ }^{854}$

\section{Het toezicht op de productieresultaten}

De Directie controleerde het personeel en de Raad van Commissarissen de Directie, onder meer met behulp van de jaarrekening. De Raad van Commissarissen besliste over de salarisregeling, de Directie zag toe op de naleving hiervan en was bevoegd straffen en beloningen op te leggen. De Raad van Commissarissen bezag in hoeverre de productieresultaten overeenkomstig haar doelen waren. De doelen, die uit deze verdeling van dit eigendomstecht kunnen worden afgeleid, hebben dan ook betrekking op de door de provincie gewenste "output". De provincie wilde er met haar eigendomsrecht voor zorgen dat er ook onrendabelle aansluitingen gerealiseerd werden, er voldoende geïnvesteerd werd in het milieu; bijvoorbeeld door het treffen van allerlei milieumaatregelen in de centrales. en ten behoeve van de distributie en zij beoogde netverliezen zoveel mogelijk te beperken. De functie-omschrijvingen waren hierop afgesternd. Indien een werknemer goed functioneerde kon de Directie daar een extra beloning tegenover stellen.

\footnotetext{
852 N.V. PLEM, Handleiding voor de verwerving yan goederen en diensten, 1 oktober 1984, p. 2.

853 T.a.p., p. 5 .

84 T.a.p. p. 6.
} 
Commissarissen en was in beperkte mate gedelegeerd aan de directie, afdelingschefs en overige personeelsleden. Door middel van dit recht had de Raad van Commissarissen de mogelijkheid te bepalen welke activiteiten in het productieproces zouden worden verricht en de wijze waarop, wat voor onderhoud werd uitgevoerd en welke investeringsprojecten zouden worden doorgevoerd. Dit recht gaf de Raad van Commissarissen de mogelijkheid te zorgen voor een efficiènt productieproces, waardoor een redelijk rendement en lage elektriciteitsprijzen gerealiseerd konden worden. Ook kon zij met dit recht ervoor zorgen dat extra geinvesteerd werd in schone productieprocessen en kon zij de techmologische ontwikkeling van de PLEM verbeteren. Verder kon zij met dit recht toezien op de veiligheid van het productieproces van de PLEM.

Eind jaren tachtig werd budgettering ingevoerd. Dit hield zoals opgemerkt in dat eerst een plan werd opgesteld waarvan nauwkeurig de realisatie gevolgd werd. Lagere niveaus kregen bepaalde bevoegdheden maar moesten ook verantwoording afleggen. Opgemerkt werd: "Het resultaat is een verdiepte beleving van het belang van afweging van kosten en baten, naast uiteraard allerlei effecten naar binnen en naar buiten van meer flexibiliteit, meer nemen en dragen van verantwoordelijkheid en meer produkt- en/of klantgerichtheid" ${ }^{\text {"8ss }}$ Het doel dat uit deze bevoegdheidsverdeling kan worden afgeleid is dan ook het streven naar efficiëntie en het bevorderen van klantgerichtheid.

\section{Het toezicht op de omvang en de samenstelling van het personeelsbestand}

De Directie werd benoemd door de Raad van Commissarissen, die haar ook kon ontslaan. De provincie Limburg had door dit recht de mogelijkheid bestuurders te benoemen die haar doelen nastreefden. Het ging daarbij vooral om doelen als de economische ontwikkeling van de regio Limburg, het bevorderen van de werkgellegenheid en het zorgen voor een goede beloning van het personeel. Het recht om toe te zien op de omvang en samenstelling van het personeelsbestand behoorde eveneens toe aan de Raad van Commissarissen. $\mathrm{Zij}$ keurde het formatieplan goed en bepaalde de toegestane bezetting. Binnen die vastgestelde formatie kon de Directie personeel aannemen. Daarmee kon de provincie bepalen hoeveel personeel ingehuurd zou worden en op welke terreinen. Het ging daarbij niet alleen om het aanstellen van werknemers in vaste dienst, maar ook om werknemers in tijdelijke dienst en bijvoorbeeld schoolverlaters.

\section{Het recht op de winst}

Uit het recht winst slechts gedeeltelijk te hoeven uitkeren kan als doel worden afgeleid dat de PLEM efficiēnt probeerde te werken. De PLEM had op het eerste gezicht weinig belang bij het zo laag mogelijk houden van de tarieven. Lage tarieven leidden immers tot een lagere winst. Dat de tarieven toch erg laag waren kwam gedeeltelijk omdat de Minister van Economische Zaken hierop invloed had. Tariefsverhogingen moesten worden goedgekeurd door het Ministerie van Economische Zaken. ${ }^{856}$ Eind jaren tachtig kon het Ministerie van EZ invloed uitoefenen op de tarieven op grond van de Elektriciteitswet 1989 en door middel van haar invloed in de SEP (via de berekening van de elektriciteitstarieven aan de elektriciteitsproductiebedrijven). In 1981 merkte de Minister van Economische Zaken bij de statutenwijziging die de grotere dividenduitkering mogelijk

${ }^{255}$ Projectgroep Budgettering van de PLEM, Budgetteren bif de RLEM, december 1988, p. 4.

${ }^{856}$ N.V. Provinciale Limburgse Elektriciteitsmaatschappij, Jaarverslag 1974, 1975, p. 12. 
moest maken op: "Ik heb er goede nota van genomen dat de voorgestelde dividendverhoging geen aanleiding zal vormen voor tariefsverhoging, alsook dat de verhoogde dividenduitkering in principe voor 10 jaar zal gelden". ${ }^{857}$ Ook de Directie zelf noemde herhaaldelijk het doel van het zo laag mogelijk houden van de tarieven. De reden hiervan was dat zoals hiervoor vermeld, de provincie grote invloed had in de Raad van Commissarissen die de Directie benoemde. Voor de provincie waren lage tarieven voor burgers en bedriffsleven van groot belang. De directeur van de PLEM merkte in 1989 op: "Toch wilden wij bij de goedkoopsten bliven horen. Waarom? De kleingebruiker kan niet van leverancier veranderen, maar grootgebruikers zijn wel in staat om al of niet in Limburg te produceren. Solvay heeft bijvoorbeeld een chloorjabriek bij Roermond en een in Antwerpen. Het gaat dan vaak om fracties van centen per $\mathrm{kWh}$, maar het is goed voor de Limburgse werkgelegenheid in zijn totaliteit als we de goedkoopste zijn. Dit kan bedrijven aantrekken". ${ }^{858}$ De aandeelhouders benoemden bestuurders die eveneens $00 \mathrm{~g}$ voor deze doelen hadden (onder meer ook door de in de statuten geregelde benoemingswijze van de commissarissen). Bovendien werden de tarieven door de Raad van Commissarissen bepaald en (uiteindelijk) niet door de Directie.

\section{Het recht om de organisatie te verkopen}

Voor een wijziging van de statuten was toestemming nodig van de Provinciale Staten van Limburg, de Minister vam $\mathrm{EZ}$ en van de Raad van Commissarissen en de Algemene Vergadering van Aandeelhouders. Daarmee was de verdeling van bevoegdheden vastgelegd. Deze kon niet veranderd worden zonder toestemming van deze drie groepen van actoren. Daardoor konden ook de doelen, die met deze verdeling van bevoegdheden nagestreefd konden worden, niet gemakkelijk gewijzigd worden. Een ander belangrijk facet van dit recht betrof het recht om te lenen op de kapitaalmarkt. Dit recht was vastgelegd in de statuten. Om te lenen op de kapitaalmarkt was toestemming nodig van de Algemene Vergadering van Aandeelhouders. Uit dit recht kan als doel het nastreven van efficiëntie worden afgeleid.

\section{Conclusie}

Er zijn een drietal actoren te onderscheiden binnen de NV PLEM, namelijk de aandeelhouders, het bestuur en de Raad van Commissarissen. De aandeelhouders zijn met name gebaat bij de winst (het recht op vruchtgebruik). Het bestuur heeft op grond van de bestaande informatie-asymmetrie de mogelijkheid eigen doelen na te streven, waaronder het aanwenden van een zo groot mogelijk deel van de "public enterprise rent". Hierbij valt te denken aan arbeidsomstandigheden en -voorwaarden en werkgelegenheidsbevordering. De commissarissen beschikken met name over een gedeelte van het gebruiksrecht en het recht om de organisatie te wijzigen. De doelen van de commissarissen kunnen verschillen. De 7 commissarissen die door Gedeputeerde Staten van de provincie Limburg benoemd zijn zullen de belangen van de provincie nastreven. De 2 commissarissen die tevens een functie in het Limburgse bedrijfsleven vervullen zullen de belangen van dit bedrijfsleven behartigen. De 2 commissarissen die burgemeester of wethouder van cen gemeente zijn zullen vooral de belangen van hun gemeente behartigen. Tenslotte is het

\footnotetext{
857 De Minister van Economische Zaken, voor deze de Directeur-Generaal van Energie, brief aan de N.V. Provinciale Limburgse Elektriciteits-Maatschappil, E 381/L/479/EEK, ten agnzien van de door de PLEM voorgestelde statutenwiiziging, 28 april 1981.
}

858. N.V. PLEM, De Werkgever, nummer 19, 5 oktober 1989. 
Ministerie van Economische Zaken en het parlement van groot belang. Zij hebben grote invloed op de orgamisatie van de elektriciteitsvoorziening in Nederland en daarmee ook op de PLEM.

\subsection{Het analyseren van de ontsluierde "performance" van de NV PLEM}

16.8.1 Welke doelen werden kenbaar gemaakt in documenten en welke doelen werden door de bij de PLEM betrokken principalen genoemd?

\subsubsection{Beleid van regering en parlement en meer in het bijzonder van het Ministe- rie van Economische Zaken}

Zoals aangegeven in paragraaf 16.5 .2 en 16.6.1 beschikte thet Ministerie van Economische zaken over een beperkt eigendomsrecht binnen de PLEM (met name het recht om de organisatie te wijzigen, het beïvloeden van de winst door het mede bepalen van elektriciteitsprijzen e.d.). Daamaast konden regering en parlement door middel van wetgeving de organisatie van de elektriciteitssector in Nederland verregaand bepalen.

Volgens de Oriënteringsmota Ruimtelijke Ordening en later ook op grond van de Elektriciteitswet 1989 kunnen structuurschema's opgesteld worden teneinde een beleid op langere termijn te kunnen voeren ten aanzien van voor het ruimtelijke beleid rellevante onderwerpen waarvoor het Rijk in belangrijke mate verantwoordelijkheid draagt. Eén van deze onderwerpen betreft de elektriciteitswoorziening. De Ministers van Economische Zaken en VROM boden op 10 jull 1975 aan de Tweede Kamer het ontwerp-structuurschema 1975 aan. In dit schema werd het bellang van de elektriciteitsvoorziening afgewogen tegen de effecten op milieu en ruimte, De PLEM stond grotendeels positief tegenover dit structuurschema. De plannen leken voor Limburg een beperkt effect te hebben en waren deels ook al gerealiseerd. In de jaren zeventig werd grote nadruk gelegd op de continuïteit van de levering van elektriciteit. Dit verklaarde ook, naast de ontwikkeling van het elektriciteitsverbruik, waarom in de jaren tachtig veelal sprake was van een landelijke overcapaciteit. Eind jaren tachtig werd het belang van de continuitteit relatief minder en werd geleidelijk aan meer de nadruk gelegd op efficiëntie en klantgerichtheid.

Zoals opgemerkt in paragraaf 16.3 .2 is er in 1987 een convenant gesloten tussen de Minister van Economische zaken en de organisaties van distributiebedrijwen, namelijk de VEEN, VEGIN en VESTIN, over concentratie en horizontale integratie van de verschillende energiebronnen in één bedrijf. $\mathrm{Op}$ de branche-organisaties rustte een inspanningsverbintenis terwijl de Minister voor ondersteunende wetgeving zou zorgen. In een voorontwerp wan een dergelijke wet vermeldde de Minister een aantal hoofddoelstellingen, waaronder het voeren vam een energiebesparingsbeleid, zowel door de elektriciteitsbedrijven zelf als ten aanzien van de verbruikers. De branche-organisaties waren het niet eens met dit ontwerp. $\mathrm{Zij}$ meenden dat de vermelde doelstellingen wel tot hun taak behoren maar zij achten het onjuist één en ander op deze wijze in een wet te regelen.

In de Elektriciteitswet van 1989 werden een aantal belangrijke zaken geregeld die dienden om de productie en distributie efficiënter te maken. Belangrijk in dit verband is de reeds genoemde scheiding die werd doorgevoerd tussen productie en distributie. Efficiëntie werd ook nagestreefd door het bevorderen van de concurrentie in de energiesector. Dit gebeurde onder meer door het vergroten van de ruimte voor decentrale opwekking, door invoering van een standaardregeling voor de teruglevering van elektriciteit aan het net en verder is er sprake van een transportverplichting. In artikel 13 lid 1 van de Elektriciteitswet is bepaald dat distributiebedrijven "horizontaal kunnen winkelen", dat wil zeggen 
dat zij bij andere productiebedrijven kunnen inkopen. In verband met de pooling van de productiekosten waardoor de prijsverschillen kleiner zijn geworden, blijkt dit in de praktijk nauwelijks te gebeuren. Bovendien wordt horizontaal winkelen tegengegaan door de transportkosten die dit met zich mee zou brengen. ${ }^{859}$ In artikel 13 lid 2 van de Elektriciteitswet van 1989 is bepaald dat ook bijzondere groepen grootverbruilkers onder bepaalde omstandigheden horizontaal kunnen winkelen. Ten behoeve van het centrale plannings- en voorzileningssysteem en de efficiëntie werd op een aantal punten de vrijheid van de marktpartjjen echter beperkt. Zo werd er een leveringsverbod van producenten aan verbruikers ingevoerd, werd bepaald dat de brandstofinkoop plaatsvond door de SEP en dat de vermogensplanning landelijk plaatsvindt. Op grond van de Elektriciteitswet is er verder sprake wan een leveringsplicht en heeft de SEP een alleenrecht op de import van stroom. Tenslotte is er zoals opgemerkt, sprake van een actieve pooling van productiekosten en is er toestemming van de SEP nodig voor de bouw van opwekkingsvermogen groter dan 25 Megawatt (MW).

Zoals vermeld werd bij de behandeling van de Elektriciteitswet zijn de doelen van de horizontale integratie het verbeteren van de dienstverlening aan het publiek en het bevorderen van de efficiëntie. Voorts zal de PLEM/MEGA Limburg zich meer bezighouden met energiebesparing en milieubeheer. Door organisatieveranderingen probeerde de PLEM zich zo goed mogelijk aan te passen aan de veranderde omstandigheden. Het doel van regering en parlement was de efficientie van de elektriciteitsector te verhogen en de mogelijkheid van winstneming door lagere overheden uit elektriciteitsbedrijven tegen te gaan. Bij de behandeling van het Elektriciteitswetsontwerp in het parlement werd door de Minister in de nota naar aanleiding van het eindverslag opgemerkt: ${ }^{860}$ "Inwerkingtreding wan dit nieuwe systeem heeft als gevolg dat de mogelijkheid voor de zogenaamde winstneming uit elektriciteitsbedrijven vervalt. Met winstneming in deze zin is bedoeld het leggen van een opslag op de elektriciteitstarieven die groter is dan een redelijke vergoeding voor het geinvesteerde kapitaal. Een en ander gebeurt om inkomsten te verwerven voor de dekking van algemene uitgaven bij de lagere overheden".

De Elektriciteitswet impliceert verder een aantal doelen van regering en parlement, namelijk:

* De totale welvaart moet worden gemaximaliseerd.

* Elektriciteitsbedrijven blijven financieel zelfstandig.

* De winsten moeten beperkt blijven.

* Interne subsidiëring tussen verschillende groepen verbmikers moet zoveel mogelijk vermeden worden.

Deze doelen blijken ook uit de in het Elektriciteitsplan gestelde criteria op grond waarvan de SEP productie-uitbreidingen van distributiebedrijven die groter zijn dan 25 Megawatt (MW) mag weigeren. Deze criteria gelden overeenkomstig artikel 15 lid 4 onder $f$ van de Elektriciteitswet van 1989. Deze criteria zijn:

* de beperking van de invloed op het milieu;

* energiebesparing;

859 Tweede Kamer der Staten-Generaal (1988), Nota naar aanleiding van het eindverslag ten aanzien van de: Elektriciteitswet 1989, 19591, nr. 9, p. 5.

860 T.a.p., p. 24. 
zo laag mogelijke kosten van de totale elektriciteitsvoorziening.

Hoewel het belang van een efficiênte distributie en meer klantgerichtheid steeds belangrijker wordt blijft de Minister van Economische Zaken ook aan het eind van de jaren tachtig oog houden voor het belang van continue levering. Zo merkte hij op: " $k$ ben overigens: wel van oordeel dat het kunnen beschikken over elektriciteit zo belangrijk is in onze samenleving, dat het alleen maar in speciale gevallen verantwoord is van levering aan bepaalde verbruikers af te zien ${ }^{* 61}$ Een zo goed mogelijke elektriciteitsvoorziening staat centraal.

In de Memorie van Toelichting bij het ontwerp van de Elektriciteitswet 1987 werd het belang van een wettelijke regeling van de tarieven benadrukt. Het doel hiervan was het voorkomen dat misbruik gemaakt zou worden van de monopoliepositie. Opgemerkt werd: "Met een wettelijke regeling zal kunnen worden bereikt dat het tariefsysteem de efficiëntie in de sector bevordert en dat op den dutur winstneming wit de tarieven verdwijnt. Dit laatste kan door de gemiddelde kosten te laten dekken door de gemiddelde opbrengsten $^{\mathrm{m}} .862$ Ook het belang van lage elektriciteitstarieven voor grootverbruikers werd belangrijk gevonden. In de memorie van antwoord bij het Elektriciteitswetsontwerp 1987 werd opgemerkt: "(...) nog voor de publikatie van het voorontwerp, (voorontwerp van wet wit $1985 \mathrm{JFK}$ is inderdaad met de gedachte gespeeld om aan de groep bijzondere grootverbruikers hoe dan ook altijd met het buitenland concurrerende tarieven te garanderen, ongeacht het niveau van de productiekosten van elektriciteit in ons land" "Dit is uiteindelijk niet in de Elektriciteitswet van 1989 opgenomen, met name omdat dit zou leiden tot afwenteling van kosten op andere groepen verbruikers, maar geeft wel een beeld van het belang dat aan grootverbruikers werd toegekend. Tijdens de behandeling van de Elektriciteitswet in het parlement werd verder bijvoorbeeld opgemerkt: "Het $L B T$ bieat ook, in hoofdzaak als uitwloeisel van het bestaande brandstoffenpakket voor de stroomproductie, in combinatie met de dollar-gevoeligheid daarvan, onvoldoende stabiliteit aan de gebruikers die op de internationale markt moeten concurreren met gebruikers van stroom die hun prijs veel meer dan hier het geval is vooruit kunnen berekenen. Ook voor de elektriciteitssector is het van belang zulke klanten te behouden uit een oogpunt van kostendekking. Biedt men geen adequaat tarief dan zal men za'n afnemer kunnen verliezen". 864 . Weliswaar is het uitgangspunt dat elke deelmarkt (grootverbruikers, kleinverbruikers) zijn eigen kosten moet opbrengen, dit neemt niet weg dat uitzonderingen mogelijk zijn. In artikel 28 lid 2 van de Elektriciteitswet is bepaald dat de SEP in overleg met een distributiebedrijf kortingen op het tarief kunnen verlenen aan een bijzondere grootverbruiker. Een dergelijke grootverbruiker zal veelal ook stroom kunnen importeren, zodat de distributiebedrijwen sneller geneigd zijn een korting te accepteren. De VEEN heeft overigens geconstateerd dat in bepaalde gevallen juist kleinverbruikers gesubsideerd werden. Doel van de Elektriciteitswet van 1989 is evenwel geen onderlinge

861 T.a.p., p. 13.

862 Tweede Kamer der Staten-Generaal (1986), Memorie van Toellichting bij het Wetsontwerp Elektriciteilswet 1987, p. 2.

863 Twreede Kamer der Staten-Generaal (1987), Memorie van antwoord bii het Wetsontwerp Elektrïciteitswet 1987,19591, pp. $3-4$.

864 T.a.p., p. 15 . 
subsidiëring van verbruikersgroepen. ${ }^{865}$ Een ongestoorde elektriciteitsvoorziening tegen zo laag mogelijke kosten stond centraal.

Ook doelen op andere gebieden zoals milieu, ruimtelijke ordening en veiligheid werden genoemd. Deze doelstellingen vormen randvoorwaarden voor de Elektriciteitswet 1989 maar zijn hier niet in opgenomen. De Minister van EZ merkte in dit verband op" "Inderdaad spelen milieufactoren (...) een belangrijke rol". Deze moesten afgedwongen worden via de millieuwetgeving en de Wet op de Ruimtelijke Ordening. ${ }^{866}$ In meil 1989 verscheen het Nationaal Milieubeleidsplan waarin enerzijds het milieubeleid op de langere termijn werd geschetst en waarin anderzijds meer concrete doelen voor de periode 1990 1994 waren opgenomen. In het Beleidsplan Energiebesparing en Stromingsenergie (B.E.S.) beoogde de Minister van EZ met name windenergie te subsidièren. Beoogd werd de CO2-uitstoot in 1994/1995 te stabiliseren op het niveau van de uitstoot van 1989/1990. Het geven van subsidies werd gezien als een tijdelijke stimulans, centraal stond het zoveel mogelijk scheppen van marktcondities die leiden tot besparingsinvesteringen.

Her Wetsontwerp Energiedistributie, dat mede gebaseerd is op voorstellen van de branche-organisaties VEEN, VEGIN en VESTIN, voorziet in een vergaande concentratie en integratie in de distributiesector. Het wetsontwerp is in mei 1996 aangenomen door de Tweede Kamer en zal naar verwachting eind 1996 worden behandeld door de Eerste Kamer. De wet heeft als doel te zorgen voor een doelmatige organisatie van de distributie van elektriciteit, gas of warmte tegen zo laag mogelijke kosten. Het wetsvoorstel Wet energiedistributie noemde in artikel 2 lid 1 als doelen: ${ }^{867}$

thet op betrouwbare wijze zorg dragen voor de distributie van energie tegen zo laag mogelijke kosten.

thet bevorderen van de veiligheid bij het gebruik van toestellen en installaties door verbruikers van energie

-het bevorderen van een doelmatig gebruik van energie door het distributiebedrijf zelf alsook door de verbruikers van energie. Het bevorderen van energiebesparing werd ook benadrukt in de Nota Energiebesparing, waarin de rol van de distributiebedrijven, vooral ook ten aanzien van de kleinverbruikers, werd benadrukt. ${ }^{868}$

De distributiebedrijven behielden op grond van het wetsontwerp het monopolie over de fysieke distributie van energie. Dit geldt alleen voor de levering van energie ten behoeve van de openbare voorziening. In artikel 26 van het wetsontwerp zijn verschillende uitzonderingen opgenomen, die inhouden dat bepaalde afnemers zogenaamde "shoppingsmogelijkheden" hebben. Gezien de ontwikkelingen in de distributiesector in de jaren negentig was het ontwerp weinig ingrijpend en beperkte het zich met name tot het regelen van een aantal actuele zaken zoals het wettelijk onderbouwen van de Milieuaktieplan(MAP-)toeslag. Deze MAP-gelden werden in de jaren negentig namelijk op vrij grote schaal ingezet voor allerlei zaken waar ze niet voor bedoeld waren, zoals bodemsanering en tal van op zich al rendabele projecten. De bedoeling van de Minister van Economische Zaken was een wettelijk plafond van de MAP-toeslag in te voeren van $2,5 \%$ en aan te

T.a.p., p. 90 .

866 Tweede Kamer der Staten-Generaal (1987), 19591, Memorie van Antwoord bij het Wetsontwerp Elektriciteitswet 1987,19591 p. 29.

${ }^{867}$ T.a.p., p. 10. Vergelijk ook: het Voorstel van Wet (22160, nrs. 1-2).

${ }^{868}$ Tweede Kamer der Staten-Generaal (1990), Nota Energiebesparing, 21570, nrs. 1-2, pp. 5 e.v. 
geven waar deze middelen well en niet voor gebruikt mochten worden. Het milieudoel is in dit verband van groot belang. Verdere horizontale integratie wordt nagestreefd, zodat distributiebedrijven ook de ontwikkeling van bijvoorbeeld duurzame energiebronnen, energiebesparing, afvallverbranding e. 0 . kunnen bevorderen. Tijdens de parlementaire behandeling van het wetsontwerp werden verder nog als doelen genoemd het verlagen van de distributiekosten, het vergroten van de service aan en het bevorderen van een geïntegreerde benadering van de verbruiker. Tijdens de parlementaire behandeling werd ook de nodige aandacht geschonken aan de gevolgen voor het personeel. Daarbij ging het om de financiële gevolgen voor de werknemers maar ook om het aantal banen in de elektriciteitssector. Duidelijk was dat het aantal banen door de herstructurering zou verminderen maar gedwongen ontslagen werden niet nodig geacht.

\subsubsection{Beleid van de Directie van de NV PLEM}

De energievoorziening werd in de jaren tachtig meer en meer een algemeen probleem. Dat dwong elektriciteitsbedrijven tot een grotere bewustwording van hun nutsfunctie. Naast technische en economische factoren vormen overwegingen ten aanzien van de gevolgen voor het milieu, de maatschappelijke aanvaardbaarheid, de grondstoffensituatie en dergelijke belangrijke toetsstenen van het beleid. Instellingen die voor andere belangen opkomen dienden voldoende nuimte te krijgen om vamuit hun invalshoek voorstellen te doen. De overheid formuleerde het energiebeleid in hoofdlijnen en woog dienovereenkomstig de verschillende belangen tegen elkaar af. Het management van de PLEM meende dienovereenkomstig dat de elektriciteitssector slechts een beperkte rol speelde in het bepalen van het energiebeleid van de overheid.

In 1988 stantte de PLEM het project Horizon. Doel was het vinden van een geschikte organisatiestructuur. Ondersteund door een extern organisatie-adviesbureau resulteerde dit in een strategisch plan. De hoofddoelstellingen zoals vermeld in dit plan wraren:

-hoge mate van klantgerichtheid;

lage tarieven;

-kwaliteit en betrouwbaarheid;

-meer resultaat- en werkgerichte instelling.

De reorganisatie van de organisatie van de NV PLEM die in het kader van het Project Horizon werd doorgevoerd werd in 1989 afgerond. Voor de PLEM zijn sindsdien efficiëntie, zorg voor het milieu en klantgerichtheid de hoofddoelstellingen.

In de statuten van MEGA Limburg wordt het doel als volgt omschreven: ${ }^{870}$

Ten algemene nutte werkzaam te zijn op het gebied van de openbare energievoorziening in Limburg en voor zover dienstig en mogelijk ook daarbuiten, op het gebied van de zorg voor een schoon en gezond milleu, daaronder mede begrepen een doelmatig en spaarzaam gebruik van energie, alsmede op het gebied van de communicatiesystemen".

In het jaarverslag over 1992 worden een aantal doelstellingen genoemd die grotendeels

869 Vergelijk: Tweede Kamer der Staten-Generaal (1992), Memorie van Antwoord bij het ontwerp Wet
Energiedistributie, 22160, nr. 5, p. 2. Dit is op grond van de Elektriciteitswet ook al mogelijk.

870 Statuten van MEGA LIMBURG 1992. 
ook al golden voor de PLEM, namelijk:"871

* de koop, het transport, de verdeling. de verkoop en de levering van energie en het aanleggen, overnemen en exploiteren van de daartoe nodige werken;

* het produceren van elektriciteit en het stichten, overnemen en exploiteren van de daartoe nodige werken;

* het bevorderen van en het geven van voorlichting over een doelmatig en spaaraam gebruik van energie,

* het venwerken van afval:

* het aanleggen, beheren en exploiteren van centrale antenne-installaties en kabelnetten en daarbij behorende werken.

Deze doelen zijn ook van belang in de periode 1970-1990, meer in het bijzonder gedurende de jaren tachtig. Naast de elektriciteitsproductie en distributie moest zoveel mogelijk voldaan worden aan andere behoeften op het gebied van de openbare nutsvoorziening. Het gaat daarbij dus niet alleen om de behoeften die samenhangen met de voorziening in elektriciteit en gas.

Naast deze doelen werden in de jaarverslagen over de onderzoeksperiode nog verschillende andere doelen genoemd zoals het in overweging nemen van milieubelangen, waaronder het doelmatig en spaarzaam gebruik van energie en het verwerken van afval. In dit verband werkte de PLEM eind jaren tachtig en begin jaren negentig aan een millieubeleidsplan (Bedrijfsmilieuaktieplan, B-MAP). Opgemerkt werd: "Als energiebedrïf-nieuwestijl dient de PLEM energiebezuiniging en milieuvriendelijke energile-opwekkings-projecten op lokale en regionale schaal te stimuleren". ${ }^{872}$ In dit plan werd uitgebreid ingegaan op de noodzaak de uitstoot van bepaalde stoffen terug te dringen en het doelmatig verbruik van energie te bevorderen. ${ }^{873}$ Tal van nieuwe initiatieven zijn in dit plan opgenomen, waaronder klein- en grootschalige investeringen in warmte-/krachtprojecten en stortgasprojecten. Verder is een bedrag aan aanloopkosten geraamd in verband met de afvalverbrandingsinstallatie Zuid-Nederland. Ook de werkgelegenheid en goede arbeidswoorwaarden binnen de PLEM werden belangrijk geacht. Overigens werd midden jaren zeventig het doel van energiebesparing door verbruikers en door de Directie zelf steeds belangrijker gevonden. Ook de milieueffecten werden reeds gedurende de onderzoeksperiode steeds meer in overweging genomen. Verder werden de belangen van de afnemers, medewerkers en aandeelhouders genoemd, terwijl bij het bereiken van de doelstellingen rekening gehouden moest worden met het welzijn van de Nederlandse bevolking en, voor zover dat in haar vermogen lag, met de in die samenleving bestaande opvattingen omtrent hetgeen ethisch en democratisch aanvaardbaar was.

\subsubsection{Het beleid van de Provincie Limburg}

De doelen van de provincie Limburg kunnen worden gevonden door te kijken naar de doelen en besluiten van de Raad van Commissarissen, door de notullen van de Algemene

771 MEGA Limburg, Jaarverslage over 1992, 1993, p. 7.

872 N. V. Provinciale Limburgse Elektriciteitsmaatschappif, Een hanteerbare oplossing voor afvalverwerking in Limburg, januari 1990 , p. 1 .

${ }^{873}$ Vergelijlk ook: Afdeling Marketing, Op weg naar morgen, het energie en milieuplan VEEN, VEGIN en VESTIN, 22-06-1989, pp. 3-4. 
Vergadering van Aandeelhouders te onderzoeken en door analyse van documenten van de provincie zelf en van de vergaderingen van Provinciale Staten en Gedeputeerde Staten.

Voor de energievoorziening in Nederland is met name het beleid van de landelijke overheid van belang en minder dat van de provincie. Het beleid van de provincie is vooral van belang omdat $\mathrm{zij}$ grootaandeelhouder was van de PLEM waardoor zij overwegende invloed uit kon oefenen, gegeven de vaak wettelijk vastgelegde restricties van regering en parlement. Gegeven deze restricties kon de provincie het beleid van de PLEM in hoge mate bepalen. De vermelde doelen van de Directie zijn dan ook grotendeels gelijk aan de de doelen van de provincie. Dit blijkt ook uit de gesprekken die gevoerd zijn tussen de provincie (6e afdeling provinciale Griffie) en de PLEM (Directie).

Het belang van het milieu en de verwerking van afval kreeg veel aandacht. Halverwege de jaren tachtig werd het probleem van de zure regen genoemd en werd bezien in hoeverte maatregelen genomen moesten worden. ${ }^{874}$ Eind jaren tachtig is de provincie bezig om de afvalverwerking in de provincie te structureren, waarin ook de PLEM een belangrijke rol zou moeten spelen. ${ }^{875}$ Opgemerkt werd: "Provincie en PLEM zijn het erover eens dat de PLEM een stimulerende rol kan spelen bij de realisatie van een integraal plan voor de vuilverwerking in Limburg. Door het onnwikkelen van cancrete plannen door de PLEM wordt de haalbaarheid van een provinciaal beleid bevorderd" ${ }^{876}$ In dit verband werd gewerkt aan een afvalstoffenplan, dat gekoppeld was aan een Milieubeleidsplan. Dit Provinciale afvalstoffen plan (PAP II, voor de periode 1990-1993) werd op 16 maart 1990 door Provinciale Staten vastgesteld. Ook het belang van energiebesparing door warmte/kracht-koppeling wordt door de provincie benadrukt. In het kader van een provinciaal milieubeleidsplan werd onderzoek gedaan naar de mogelijkheden van energiebesparing en opwekking van schone energie. Gedeputeerde Staten maakten duidelijk aan de PLEM dat indien doorlevering via een eigen verbinding de voorkeur geniet boven doorlevering via het openbare net, hiervoor een vergunning zal worden gegeven. ${ }^{877}$ Uit overleg tussen de regering en de Gedeputeerde Staten van Limburg over de Perspectievennota Zuid-Limburg bleek dat werkgelegenheid en de ontwikkeling van de provincie Limburg belangrijke provinciale doelen waren. Daarbij speelde ook mee dat de regionale werkloosheidscomponent in het Herstructureringsgebied Zuid-Limburg van 1978 tot 1983 weliswaar afnam, maar daarna weer licht toenam. De werkgelegenheidsontwikkeling bleef dan ook een bron van zorg voor de provincie Limburg. Verder waren ook de zekerheid van de elektriciteitswoorziening en de continuitteit ervan van belang. Een ander doel dat van belang werd geacht was public relations. Opgemerkt werd: "Een goede relatie met de leveranciers past overigens geheel in onze opvattingen inzake Public

874 Vergelijk bijvoorbeeld: Bureau Planning en Ontwikkeling van de Provincie Limburg, brief aan het Hoofd van de afdeling Economische Zaken en Werkgelegenheid van de provincie Limburg. Milieubelasting door zure regen, 22 maart 1984.

875 Vergelijk: Hoofd afdeling Bodem, Provincie Limburg, BR 55509, onderzoek naar de bestuutliikorganisatorische vormgeving van de toekomstige afval werwerkingsstructuur, 22 februari 1989.

876 Verslag DT-bespreking, Nr. 31/88, Aantekeningen naar aanleiding van het gesprek over afvalverwerking met de provincie op 15-9-1988, 19-9-1988, p. 2 .

877 Gedeputeerde Staten, BN 10011, brief aan Nederlandse Energie Ontwikkelingsmaatschappij b.v., Standpunt GS ten aanzien van doorlevering elektriciteit uit warmte/kracht-koppeling in de industrie, 2 april 1985. 
Relations. PR beoogt goodwill te kweken bij allen, waarmede het bedrijf verkeent.

\subsubsection{Welke doelen werden genoemd in niet-officiële documenten?}

De doelen die werden genoemd in niet-officiele documenten verschillen niet van de in officiele documenten genoemde doelen. Eén van deze doelen is het zoveel mogelijk matigen van de elektriciteitstarieven. Bij de statutenwijziging van 1981 werd de mogelijkheid om dividend uit te keren vergroot. De Minister merkte in dit verband op " Ik heb er goede nota van genomen dat de voorgestelde dividendverhoging geen aanleiding zal wormen voor tariefsverhoging (...) . $^{\prime 70}$ De Directie en de Raad van Commissarissen benadrukken eveneens het belang van zo laag mogelijke elelktriciteitsprijzen. Ook de provincie gaf aan tariefstijging zoveel mogelijk te willen voorkomen. Zo stelde de vertegenwoordiger van de provineie in de Algemene Vergadering van 19 juni 1987: "...) anaangenaam verrast te zijn geweest door de recente perspublicaties over komende tariefsverhogingen, maar dat wit de toelichting van de directie duidelijk is geworden dat deze verhogingen aan externe oorzaken te wijten zijn". In 1989 werd in de vergadering van de Raad van Commissarissen nog uitgebreid aandacht besteed aan het belang van lage tarieven, ook na de reorganisatie van 1987 en de Elektriciteitswet van $1989^{881}$

Het streven naar winst wordt niet benadnukt. Tijdens de Algemene Vergadering van Aandeelhouders van 1987 werd opgemerkt: "Helaas is het netto-resultaat lager dan in 1985. Het streven van een nutsbedrijf is echter meer gericht op een kostendekkende exploitatie dan op winstmaximalisatie ${ }^{\text {882 }}$ Naast de winst voor de provincie als eigenaar werd ook het recht op de winst door de PLEM zelf benadrukt. Bij de Algemene Vergadering van Aandeelhouders van 12 juni 1990 stelde de gemeente Gelleen voor de winstuitkering te verhogen, omdat dit de laatste keer was dat de aandeelhoudersvergadering van de PLEM hierover kon beslissen. De provincie Limburg (en dus de algemene vergadering van aandeelhouders) wees dit af, omdat een ruimere winstuitkering in strijd zou zijn met de statutaire bepalingen ten aanzien van de winstbestemming en het gebruik van de winst. Bovendien zou dit in strijd zijn met de afspraken die in het kader van de fusie met Limagas waren gemaakt. ${ }^{8183}$

Ook het doel van het bevorderen van de werkgelegenheid en van de economische ontwikkeling van de provincie Limburg werden herhaaldelijk genoemd. Bij de fusie tussen de PLEM en Limagas kwam bijvoorbeeld de vraag aan de orde of dit geen banen zou kosten. In de Provinciale Staten werden dienaangaande vragen gesteld. De Directie merkte op: "Het samengaan wan beide ondernemingen zal zeker leiden tot zinvalle nieuwe taken, en dus werkgelegenheid, op bepaalde gebieden. Ook buj soortgelijke fusies elders in

${ }^{878}$ N.V. PLEM, Handleiding voor de venwerving van goederen en diensten, 1 oktober 1984 , p. 8.

${ }^{879}$ De Mimister van Economische Zaken, voor deze de Directeur-Generaal van Energie, brief gericht aan de NV Provinciale Limburgse Elektriciteitsmatschappij, E 381/IV/479/EEK 2481, statutenwijziging, 28 april 1981 .

Algemene Vergadering van Aandeelhouders, Norulen, 19 juni 1985, p. 4.

881 Raad van Commissarissen, 89.166, Relatie PLEM-EPZ, 8 november 1989, paragraaf 1 e.v.

882 Algemene Vergadering van Aandeelhouders, nonulen, 17 juni 1987, p. 7.

883 Algemene Vergadering van Aandeelhouders, Notulen, 12 junj 1990. 
den lande heeft de praktijk uitgewezen dat er nieuw werk is geschapen door nieuwe taikgebieden. Een gekwantificeerd overzicht is op dit moment echter noch niet te geven, dit hangt af wan de komende ontwikkelingen"."

Tenslotte werd ook het milieudoel en het belang van energiebesparing, zowel door de PLEM zelf als door de verbruikers benadrukt. In de Management Team-vergadering werd bijwoorbeeld opgemerkt: "ALs nutsbedrijf heeft de PLEM reeds gedurende langere tijl aandacht geschonken aan energiebesparing. Na de energiecrisis wan de 70 -er jaren zim diverse werkgroepen actief geweest om wit een oogpunt van besparing op schaarse fossiele brandstoffen, binnen het eigen bedrijf maatregelen ten behoeve wan energiebesparing te realiseren. Daamaast werd incidenteel bij klanten een doelmatig energiebeleid gestimuleerd. Thans dient de enrgievoorziening geplaatst te worden in het licht van een verantwoord milieubeheer". 855 De PLEM wilde ook bijdragen aan energiebesparing en een gezond millieu door te investeren in waterkracht. ${ }^{836}$

\subsubsection{Een overzicht van de doeleinden}

Eén en ander kan als volgt in een tabel worden samengevat:

\begin{tabular}{|c|c|c|c|c|c|c|}
\hline Doelen & $\begin{array}{l}\text { Doeleinden } \\
\text { gevonden met } \\
\text { analyse kenbaar } \\
\text { gemaakte doelen }\end{array}$ & $\begin{array}{l}\text { Minister van } \\
\text { EZ }\end{array}$ & $\begin{array}{l}\text { Provincie } \\
\text { Limburg }\end{array}$ & Directie & $\begin{array}{l}\text { Doeleinden } \\
\text { structurur- } \\
\text { analyse: }\end{array}$ & $\begin{array}{l}\text { Doeleinden } \\
\text { gevonden } \\
\text { met beide } \\
\text { analysis }\end{array}$ \\
\hline $\begin{array}{l}1 . \\
\text { Efficiēnte elektrici- } \\
\text { teits- en gas (na de } \\
\text { fusie met Lima- } \\
\text { gas) voorziening }\end{array}$ & $x$ & $x$ & $\mathrm{x}$ & $x$ & $x$ & $\mathrm{x}$ \\
\hline $\begin{array}{l}2 . \\
\text { Redelijk } \\
\text { rendement }\end{array}$ & $\mathrm{x}$ & $\therefore$ & $x$ & $x$ & $x$ & $x$ \\
\hline $\begin{array}{l}3 . \\
\text { Voorlichting }\end{array}$ & $\mathrm{x}$ & $\mathrm{x}$ & & $x x$ & & \\
\hline $\begin{array}{l}4 . \\
\text { Beworderen } \\
\text { economische ont- } \\
\text { wilkkeling regio }\end{array}$ & $x$ & 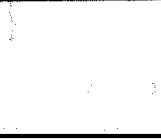 & $x$ & $\mathrm{x}$ & $x$ & $x$ \\
\hline $\begin{array}{l}5 \\
\text { Milieu }\end{array}$ & $x$ & 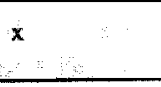 & $x$ & $\mathrm{x}$ & $x$ & $x$ \\
\hline $\begin{array}{l}\text { 6. } \\
\text { Werkgelegenheid }\end{array}$ & $x \quad=$ & $\mathrm{x} \quad \therefore \quad$ & $x$ & $x$ & $\begin{array}{l}x \\
x \\
\end{array}$ & $x$ \\
\hline $\begin{array}{l}7 . \\
\text { Technologie }\end{array}$ & $x$ & $x$ & $x$ & $\mathrm{x}$ & $x$ & $x$ \\
\hline $\begin{array}{l}8 . \\
\text { Afvalwerwerking }\end{array}$ & $x$ & $x$ & $x$ & $x x$ & $x$ & $x$ \\
\hline
\end{tabular}

824. Algemene Vergadering van Aandeelhouders, Nonulen, 21 juni 1989; $\mathrm{p} 7$.

8.5 Management Team, 90.164, Het milieubeleidsplan van de PLEM, 12-02-1990.

8866 Algemene Vergadering van Aandeethouders, Notulen, 15 juni 1983, p. 2 ev. 


\begin{tabular}{|c|c|c|c|c|c|c|}
\hline Dodelen & $\begin{array}{l}\text { Doeleinden } \\
\text { gevoriden met } \\
\text { analyse kenbaar } \\
\text { gemaakte doelen }\end{array}$ & $\begin{array}{l}\text { Ministeir van } \\
E Z\end{array}$ & $\begin{array}{l}\text { Provincie } \\
\text { Limburg }\end{array}$ & Directie & $\begin{array}{l}\text { Doeleinden } \\
\text { structuur- } \\
\text { analyse: }\end{array}$ & $\begin{array}{l}\text { Doeleinden } \\
\text { gevonden } \\
\text { met beide } \\
\text { analyses }\end{array}$ \\
\hline $\begin{array}{l}9 . \\
\text { Kabelnetwerken }\end{array}$ & $x$ & $x$ & 3 & $\mathrm{x}$ & & \\
\hline $\begin{array}{l}\text { 10. } \\
\text { Belloning wari het } \\
\text { personeel }\end{array}$ & $\begin{array}{lll}x & \\
x & \end{array}$ & & & $x$ & $x$ & $x$ \\
\hline $\begin{array}{l}\text { 11. Lagere tarteven } \\
\text { (subsiditiering) } \\
\text { groot- en kleinver- } \\
\text { bruiters }\end{array}$ & $x$ & $x$ & 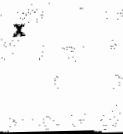 & $x$ & $\mathrm{x}$ & $x$ \\
\hline $\begin{array}{l}12 . \\
\text { Yoozzien in ontex } \\
\text { dabele } \\
\text { aansluitingen }\end{array}$ & $x$ & $x$ & $x$ & $x$ & $x$ & $x$ \\
\hline $\begin{array}{l}13 \\
\text { Zorgen voor een } \\
\text { zekere elektriciteirs- } \\
\text { voorzilening }\end{array}$ & $x$ & $x$ & $x^{x}$ & $x$ & $x$ & $x$ \\
\hline $\begin{array}{l}14 . \\
\text { Schoon } \\
\text { leefmilieu: het ver- } \\
\text { werken van eigen } \\
\text { afval en het ver- } \\
\text { minderen van } \\
\text { schadelijke produc- } \\
\text { tieprocessen }\end{array}$ & $x$ & $x$ & $x$ & $x$ & $x$ & $x$ \\
\hline $\begin{array}{l}15 . \\
\text { Veiligheid }\end{array}$ & $x$ & $x$ & $x$ & $x$ & $x$ & $x$ \\
\hline $\begin{array}{l}16 . \\
\text { Verbruikstimulering } \\
\text { besparing }\end{array}$ & $x$ & $x$ & $x$ & $x$ & $\mathrm{x}$ & $x$ \\
\hline
\end{tabular}

Tabel 16.4 De gevonden doelen van de NV PLEM

In bovenstaande tabel is aangegeven welke eigenaren welke doelen trachtten te realiseren. De conclusie is dat alle zestien doelen voor de PLEM van belang zijn, zij het dat bepaalde doelen door zowel de provincie, de Directie als de centrale overheid werden nagestreefd, terwijl andere alleen door de Directie en bijvoorbeeld de provincie werden nagestreefd. Indien dit het geval was kan dit een aanwijzing zijn voor bepaalde belangentegenstellingen tussen bijvoorbeeld de Directie en het Rijk.

\subsection{In hoeverre zijn deze doelen verwezenlijkt en is deze verwezenlijking continu?}

\section{Zorgen voor een (technisch) efficiënte elektriciteitsvoorziening}

Onder dit doel wordt verstaan het zo efficiënt mogelijk voorzien in de vraag naar elektriciteit tegen zo gering mogelijke netverliezen. De inkoop van elektriciteit bedroeg in 
1989 F. 496,1 miljoen. ${ }^{897}$ Dit bedrag bestaat voor F. 204,1 miljoen uit het basistarief en F. 292 miljoen uit brandstofkosten. De afzet van elektriciteit steeg met 4,4\% tot 6.205.444 MWh. Van de geleverde elektriciteit is het grootste deal afkomstig van inkoop. Slechts een relatief klein gedeelte van de gedistribueerde elektriciteit wordt door de PLEM zelf geproduceerd. Om te bezien in hoeverre deze distributie van elektriciteit door de PLEM efficiënt gebeurde moet vooral gelet worden op de netverliezen, de aanschaf van productiefactoren en de reorganisatie in de elektriciteitssector.

De netverliezen vertonen gedurende de onderzoeksperiode een licht dalende tendens. De PLEM probeerde deze netverliezen zoveel mogelijk te beperken. Deze stabiliseerden zich op ongeveer $3 \%$. Gedurende de onderzoeksperiode werden allerlei maatregelen genomen om de netverliezen te beperken. In 1990 werd ter beperking van de netverliezen en ter verbetering van de stabiliteit van het spanningsniveau bijvoorbeeld een plan opgesteld voor het opstellen van condensatorbatterijen in het $150 \mathrm{kV}$-en $10 \mathrm{kV}$-net. Verder werd in 1990 een studie uitgevoerd naar de belastbaarheid en betrouwbaarheid van het $10 \mathrm{kV}$ transportnet.

De PLEM streefde verder naar een efficiënte bedrijfsvoering door het volgen van regels bij de aanschaf van goederen en de verwerving van diensten ("inputs"). Bij de aanschaf van goederen werd een afweging gemaakt tussen enerzijds de veiligheid van de voorziening en anderzijds een zo laag mogelijke prijs. "In samenhang hiermede geldt als regel dat woor bestellingen tenminste twee en bij voorkeur drie offertes beschikbaar zijn".88: Verder werd zoveel mogelijk gestreefd naar het beperken van de kosten van de verwerving van goederen. Een groot aantal aandachtspunten werden in dit verband gevolgd, zoals het zich comcentreren op zaken die de grootste geldswaarde vertegenwoordigden, het afwegen van lease tegenover eigen aanschaf, het afwegen van het zelf voortbrengen van de goederen tegenover uitbesteden en bet realiseren van quantumkortingen en bonusafspraken. ${ }^{889}$

Ten derde en het meest belangrijk zijn de doorgevoerde reorganisaties in de elektriciteitssector en meer in het bijzonder bij de PLEM. Hïerbij stond bevordering van de efficiëntie centraal. In de jaren zeventig en de eerste helft van de jaren tachtig werden binnen de elektriciteitssector een aantal afspraken gemaakt. Zo werd met de PGEM en de PZEM een optimaliseringsprogramma gerealiseerd waardoor voortaan de totale productie zo economisch mogelijk over de beschikbare capaciteit werd verdeeld. Dit leidde in 1976 tot een lagere productie. Desondanks stegen de brandstofkosten met $F$. 18 miljoen als gevolg van de veel hogere brandstofprijs. Belangrijk was de landelijke "pooling" van elektriciteitsproductieinstallaties. Onder "pooling" wordt het koppelen van de verschillende elektriciteitscentrales door middel van onderlinge transportverbindingen verstaan. Dit heeft in de eerste plaats als belangrijk voordeel dat minder reservecapaciteit nodig is, zonder dat dit ten koste gaat van de bedrijfszekerheid. In de tweede plaats kunnen de kosten verder omlaag door landelijk alleen die centrales te gebnuiken die de laagste kosten hebben (Landelijke Economische Optimalisatie LEO). In de derde plaats kunnen regionale verschillen in de vraag gebruikt worden om het verschil tussen piekvraag en vraag in de niet-piekperiode te verkleinen.

${ }^{837}$ N.V. Provinciale limburgse Elektriciteitsmaatschappij; Jaarverslag over 1989, 1990, p. 14.

28s N.V. PLEM, Handleidiag voor de verwerving van goederen en diensten, 1 oktober 1984, p. 10.

899 T.a.p.., p. 12 
Verder werd door het afscheiden van de productie en de distributie en door schaalvergroting en horizontalle integratie de efficièntie verbeterd. In een rapport van Orionconsult B. V. werd gesteld dat hierdoor jaarlijkse nationale besparingen op de vaste kosten van de elektriciteitsproductie van vijftig tot zestig miljoen gerealiseerd konden worden. Hoewel deze voordelen niet automatisch werden doorgegeven aan de distributiebedrijven door lagere tarieven, profiteerde de PLEM via EPZ hier wel van. De Directie constateerde dat de PLEM ook na de invoering van het Landelijk Basistarief (LBT) nog steeds zeer lage tarieven hanteert. Ten aanzien van de efficiëntie van de PLEM merkte zij op: De destijds veelgehoorde suggestie dat de Nederlandse elektriciteitsbedrijuen minder efficiênt werken dan die in het buitenland, lijkt dan ook onjuist te zijn". ${ }^{\text {. }} 9$

Naast het bevorderen van een efficiênte distributie door de PLEM, was ook de regeling van de teruglewertarieven van belang. Indien er een erg hoge prijs betaald wordt voor door bedrijven teruggeleverde elektriciteit, die zij decentraal hebben opgewekt, kan dat leiden tot decentrale productie-uitbreiding. Indien dit leidt tot onderbezetting van de bestaande productiecapaciteit van $\mathrm{EPZ}$ en de hierop afgestemde distributie-infrastructurur kan dit, te meer daar EPZ veelal gebruik maakt van grote opwekkingseenheden, ten koste gaan van de efficiëntie. Een te lage terugleverprijs kan aan de andere kant betekenen dat mogelijkheden voor warmtekrachtkoppeling onvoldoende worden benut, waardoor onvoldoende energiebesparing en efficièntie wordt bereikt. Op grond van artikel 42 van de Elektriciteitswet van 1989 komt er een Standaardregeling tot stand. De werkwijze daarbij is dat EnergieNed (hierin zijn begin jaren negentig de VEEN, VEGIN en VESTIN samengegaan) overeenstemming over deze Standaardregeling bereikt met de belangenorganisaties van het bedrijfsleven en de Vereniging van Afvalverwerkers. In de Standaardregeling staan de verschillende tarieven en varianten vermeld waaruit degene die teruglevert kan kiezen. Deze varianten houden in dat gekozen kan worden voor teruglevering gedurende een langere of een kortere termijn. Tenslotte bevat de Standaardregeling ook afspraken over de regeling van aansprakelijkheid voor schade, de procedure die gevolgd moet worden bij geschillen en over het verstrekken van gegevens. ${ }^{892}$

\section{Zorgen voor een redelijk Iendement}

Het streven naar een redelijk rendement diende vooral ter verbetering van de vermogenspositie. Gedurende de onderzoeksperiode was de winst van de PLEM, zoals weergegeven in paragraaf 16.5 .1 , veelal positief. De winst als percentage van het eigen vermogen kan als volgt worden weergegeven.

${ }^{890}$ Orionconsuit B.V., Elektriciteitsbedrijuen in Nederlland, Amhem, 1986.

\$1 Algemene vergadering van aandeelhouders, Notulen, 17 juni 1987 , p. 8.

892 N.V. Samenwerkende Elektriciteitsproduktiebedrijven (SEP) en Vereniging van Energiedistributiebedrijven in Nederland (EnergieNed), Interformatie, Maandelijkse uitgave, augustus 1993, p. 4. 


\begin{tabular}{|l|l|l|l|}
\hline jaar & winst & $\begin{array}{l}\text { eigen vermogen (aan } \\
\text { delenkapitaal + reserves) } \\
\text { inclusief voorzieningen }\end{array}$ & $\begin{array}{l}\text { winst als percentage } \\
\text { van het eigen vermogen }\end{array}$ \\
\hline 1970 & F. 1,6 miljoen & F. $87.291 .000,-$ & $1,8 \%$ \\
\hline 1974 & - F. 1 miljoen & F. $132.737,000,-$ & $-0,8 \%$ \\
\hline 1978 & F. 14,8 miljoen & F. $481.959 .000,-$ & $3 \%$ \\
\hline 1982 & F. 13,96 miljoem & F. $637.980 .000,-$ & $2,2 \%$ \\
\hline 1984 & F. 13 miljoen & F. $664.067 .000,-$ & $1,9 \%$ \\
\hline 1986 & F. 3,6 miljoen & F. $795.563,000,-$ & $0,5 \%$ \\
\hline 1988 & F. 9,8 miljoen & F. $771.398 .000,-$ & $1,2 \%$ \\
\hline 1990 & F. 28,4 miljoen & F. $1.098 .152 .000,-$ & $2,6 \%$ \\
\hline 1991 & F. 22,6 miljoen & F. $1.130 .856 .000,-$ & $1,9 \%$ \\
\hline 1992 & F. 12,2 miljoen & F. $1.125 .395,000,-$ & $1 \%$ \\
\hline
\end{tabular}

\section{Tabel 16.5 De winst als percentage van het eigen vermogen}

Een aantal boekhoudkundige maatregelen beinvloedden de winst. Zo werd voor 1971 de centrale afgeschreven in 25 jaar en de apparatuur in 12,5 jaar, terwijl vanaf 1971 de afschrijvingstermijn van de centrale/machines gesteld werd op 15 jaar. In 1973 werd de wijze van berekening van het resultaat gewijzigd. Het verschill tussen de calculatorische en werkelijk betaalde rente werd ten gunste van het resultaat gebracht, waardoor de cijfers over 1972 zijn gewijzigd. Met betrekking tot het in 1975 geleden verlies van $F$. 2,3 miljoen moet wel worden bedacht dat dit gedeeltelijk veroorzaakt werd door een wijziging in de berekening van het resultaat. Zoals opgemerkt in paragraaf $16.5,1$. werden op grond van de Wet op de Jaarrekening dotaties aan voorzieningen niet meer uit de winst voldaan maar ten laste van de exploitatie gebracht waardoor de winst lager werd. $\mathrm{Na}$ de verliezen behadi in 1974 en 1975 steeg het resultaat in 1976 weer, met name als: gevolg van de doorwerking van de in 1975 doorgevoerde tariefsverhogingen en de personeelsstop, de sterke stijging van de afzet en de doorberekening van de veel hogere brandstofprijs. De vraag deed zich voor wat een redelijk rendement was. In de jaarverslagen werd opgemerkt dat de in 1973 behaalde winst ten bedrage van $4,1 \%$ van het eigen vermogen (inclusief voorzieningen) onvoldoende werd geacht, met name ook met het oog op de financiering van grote geplande investeringsprogramma's. Om toch een redelijk rendement te behalen werd een verhoging van de elektriciteitstarieven enerzijds en stringente kostenbewaking anderzijds onontkomelijk geacht. Deze kostenontwikkeling in combinatie met de doelstelling van de eigenaren noodzaakte tot een stijging van de basistarieven met ongeveer $8 \%$. Deze verhoging werd door de Minister van Economische zaken goedgekeurd en werd per 1 januari 1975 ingevoerd. Achteraf werd deze tariefsverhoging te beperkt geacht, aangezien het interen op het eigen vermogen mede in verband met de geplande investeringen ongewenst werd gevonden. Met het oog op het bedrijfsresultaat werden de basistarieven in 1977 niet verhoogd. Blijkbaar werd in de jaren zeventig een winst van $4,1 \%$ te laag geacht, terwijl een winst van $8,8 \%$ aan de hoge kant gevonden werd. De winst daaide in het tweede helft van de jaren zeventig, onder meer door wijziging van de afschrijvingstechniek (waardering op de actuele waarde van de duurzame productiemiddelen), stijgende personeelskosten door algemene loonmaatregelingen en uitbreiding van het personeelsbestand, toename van de rentekosten en sterke 
stijging van de brandstofkosten, onder meer door de grotere omzet. Dit leidde tot een verlies van $F .5,6$ miljoen in 1980 . Om de tarieven zo laag mogelijk te houden werd gestreefd naar kostenmatiging. In 1981 werd geconstateerd dat een einde was gekomen aan de ontwikkeling dat nieuwe eenheden qua investering per $\mathrm{kWh}$ steeds goedkoper werden, waardoor voorheen oudere eenheden noodgedwongen naar het reservevermogen moesten worden overgeheveld. Bovendien hadden de bouw van koleneenheden boven de sterkte en de afnemende groei van de vraag geleid tot overcapaciteit. Op grond van deze ontwikkeling werd verwacht dat de Clauscentrale langer zou kunnen produceren waardoor langere afschrijvingstermijnen gerechtvaardigd waren. Besloten werd de afschrijvingstermijn van de eenheden $A$ en $B$ te verlengen van 15 tot 18 jaar waardoor de winst hoger werd en de tarieven zo lagg mogelijk konden blijven. Door deze maatregel werd het geraamde verlies in 1981 van $F, 7$ miljoen gewijzigd in een winst van F. 6,6 miljoen. In de jaarrekening over 1986 werden een aantal veranderingen ingevoerd in verband met het per 1 januari 1987 geïntroduceerde landelijke verrekeningssysteem van de directe productiekosten en de oprichting van de NV Elektriciteitsproductiemaatschappij Zuid-Nederland. Hierdoor daalde het eigen vermogen met F. 91,7 miljoen. Omdat investeringen nu niet meer in het jaar van aanleg maar gedurende 20 jaar worden afgeschreven steeg het eigen vermogen aan de andere kant met F. 85,3 miljoen. De winst daalde in 1986 tot

F. 3,6 miljoen door de veranderde afschrijvings-en waarderingspolitiek en de daling van de stroomopbrengsten door dalende brandstofkosten. De toename van de winst aan het eind van de jaren tachtig werd vooral gerealiseerd door verlenging van de afschrijvingstermijnen van productiemiddelen in de transport, transformatie- en distributiesfeer, van 20 tot 25 jaar. Door de VDEN zijn voorstellen gedaan om tot uniforme landelijke afschrijvingstermijnen te komen. Verder daalde de gemiddelde inkoopprijs in 1988 van 5,05 cent tot 4,4 cent. In 1990 en 1991 daalde de winst licht, vooral ook in verband met de kosten van de herstructurering van de energiedistributiesector, waaronder kosten voor vervroegde uittreding, kosten van verhuizing van personeelsleden en overname van de GEB's. De totale kosten worden geraamd op ruim F, 25 miljoen. Door synergie, en integratievoordelen dienen deze kosten te worden terugverdiend. Opvallend is dat in de jaren tachtig door de Directie en de Raad van Commissarissen miet wordt gesteld dat de winst te laag is. Dit ondanks dat de winst lager was dan in het begin van de jaren zeventig. Dat de winst lager was heeft zoals opgemerkt ook te maken met de gewijzigde afschrijvingssystematiek. Dit impliceert desondanks dat het streven naar winst in de jaren tachtig minder belangrijk werd geacht dan in de jaren zeventig. Dit kwam enerzijds door de toename van het eigen vermogen ten opzichte van het vreemd vermogen, waardoor het reserveren van winst minder belangrijk werd en anderzijds door de grotere nadruk op efficiënte productie en lage tarieven. De Minister van Economische Zaken stelde zich op het standpunt dat $4 \%$ een passende vergoeding was voor het eigen vermogen van distributiebedrijven, althans dat bij de vaststelling van de tarieven hier van werd uitgegaan. Indien echter werd afgeschreven op basis van vervangingswaarde zou een rendement van $0 \%$ voldoende zijn ${ }^{893}$ De Elektriciteitswet van 1989 , beoogde nadrukkelijk om de winstneming uit de elektriciteitssector door de lagere overheid in Nederland met zo'n F. 200-250 miljoen te verminderen. Aangezien de PLEM sinds de tweede helft van de jaren zeventig afschreef tegen de actuele of vervangingswaarde kan geconstateerd worden dat de winst hier vanaf 1980 steeds boven lag. Ook de dividend-uitkering als percentage van het eigen vermogen lag steeds boven de $0 \%$ (Tabel 16.2). Dit percentage steeg tot $1 \%$ in 1980 en daalde daarna weer tot $0,6 \%$ in 1989 .

\footnotetext{
893 Tweede Kamer (1987), Memorie van antwoord met betrekking tot de Elektriciteitswet van 1987, 19591, p. 90 .

854. T.a.p., p. 3.
} 
Gedurende de jaren tachtig werd de organisatiestructuur van de afdeling voorlichting licht gewijzigd. In 1988 bestond zij uit een drietal secties, te weten:

-Sectie Voorlichting

-Sectie Boilerbeheer en Administratie

-Sectie Service

Zoals in paragraaf 16.3 .3 is aangegeven werd de afdeling Voorlichting ten gevolge van bet project Horizon omgevormd tot de afdeling Marketing Kleinverbruik (MarK). Daarbij werd onderscheid gemaakt tussen marktonderzoek, promotie, produktmanagement en voorlichtingsvoorbereiding en boilerbeheer. De taken waren in hoofdhijnen dezelfde gebleven. Met betrekking tot het voorlichtingsdoel kan onderscheid gemaakt worden tussen een drietal subdoelen.

\section{Voorlichting}

De NV PLEM hield zich bezig met groepsvoorlichting aan onder meer onderwijsinstellingen, besturen van woningbouwverenigingen, installateurs en particulieren die voor de reorganisatie van 1978 individueel werden bezocht. ${ }^{895}$ De doelen van het geven van voorlichting zijn voornamelijk het verbeteren van het image van het bedrijf, thet geven van voorlichting over een veilig gebruik van elektriciteit, het besteden van aandacht aan de milieuproblematiek en het bevorderen van een doelmatig gebruik van elektriciteit, met name in de jaren zeventig ook om te voorkomen dat een verkeerd beeld zou ontstaan van elektriciteit (te duur, milieuvervuilend, e.d.). Verder werd voorlichting gegeven over nieuwe toepassingsmogelijkheden waarop aandacht gevestigd moest worden.

\section{Verkoop en Verhuur}

Sinds 1973 vindt niet langer promotie plaats van de verkoop van heetwatertoestellen. De NV PLEM brengt deze toestellen wel onder de aandacht van klanten, maar dan voornamelijk om er voor te zorgen dat door de KEMA goedgekeurde toestellen worden gekocht, al dan niet via de PLEM. De nadruk ligt daarbij dus niet op het stimuleren van de afzet van deze toestellen alswel op het in goede banen leiden van de verkoop van veilige kwaliteitstoestellen.

\section{Technische serviceverlening}

Het primaire doel van de technische serviceverlening is het zorgen voor het goed functioneren van de verhuurde heetwatertoestellen. Hierbij werd kostendekking nagestreefd.

\section{Het bevorderen van de economische ontwikkeling in de regio Limburg}

De ontwikkeling van de economie in de regio Limburg werd vooral bevorderd door enerzijds het plaatsen van orders bij het Limburgse bedrijfsleven en anderzijds door het rekenen van vrijwel de laagste tarieven in Nederland.

In de jaren zeventig werd meer in het bijzonder bij de investeringen in de Clauscentrale,

895 Vergelijk in dit verband: Hoofd afdeling Voorhichting en Serviceverllening, Bns/Ge 8-1-1973, Notitie voor alle medeweetkers van de afdeling Voorlichting en Serviceverlening, Maastricht, 8-01-1973. 
nadrukkelijk rekening gehouden met het belang van de provincie Limburg: Met de bij verschillende opdrachten betrokken bedrijven zoals Stork en Balcke/Dür werd afgesproken welk bedrag an de orders minimaal in Limburg besteed zou worden. In de notulen van de Algemene Vergadering van Aandeelhouders werd gesteld: "De Voarzitter (...) dankt de directie voor de inspanningen, die zij doet om zoveel mogelijk orders in Limburg te plaatsten c.q. te doen plaatsen". ${ }^{896}$ In 1977 werd bij het vertrek van de voorzitter van de Raad van Commissarissen opgemerkt:" "Tenslotte heeft hij een voortdurende zorg aan de dag gelegd voor de Limburgse industrie, waarbij hij een directie naast zich wist, die ter zake ook zeer alent is". ${ }^{897}$ In de in 1984 opgestelde handleiding voor de verwerving van goederen werd gesteld: "Ter bevordering van de werkgelegenkeid in onze regio zal bij grote opdrachten welke noodzakelijkerwijs buiten onze provinciegrenzen worden geplaatst, getracht worden de betreffende leverancier te bewegen om voor de toelewering wan onderdelen, alsook voor de montage ter plaatse waar mogelijk gebruik te maken van regionaal gevestigde firma's. Zo dit niet het geval is, kan ernaar gestreefd worden dat aan de regionale industrie zogenaamde compensatie-opdrachten worden verstrekt". ${ }^{898} \mathrm{Om}$ de industrie te stimuleren werden er verder speciale tarieven voor grootverbruikers gerekend. De PLEM heeft geprobeerd door het bevorderen van efficiëntie en kostemmatiging deze tarieven zoveel mogelijk te verlagen. Verder werd samen met verschillende bedrijven in de regio gezocht naar mogelijkheden tot decentrale opwekking via bijvoorbeeld warmtekrachtkoppelingsinstallaties. Tot eind jaren tachtig was de PLEM relatief vrij in het bepalen van haar elektriciteitsprijzen. Dit veranderde met de SEP-Overeenkomst van Samenwerking (OVS) waardoor regels an de berekening van elektriciteitsprijzen werden gesteld. Zoals opgemerkt in paragraaf 16.5 .2 werd op grond van de nieuwe Overeenkomst van Samenwerking een uniform landelijk basistarief (LBT) als basis voor de prijsstelling voor de berekening van de elektriciteitsprijzen gehanteerd. Door verschillen per bedrijf in overige kosten van productie en distributie konden kleine regionale verschillen in elektriciteitsprijzen blijven bestaan. Het LBT leidde voor de PLEM tot kostenverhogingen. Omwille van een verantwoorde klantbenadering en een stabiel tariefbeleid werden deze kosten pas per 1 mei 1987 doorberekend. De PLEM trachtte verdere elektriciteitsprijsstijgingen te voorkomen door het doorvoeren van kostenbesparingsmaatregelen.

\section{Milieu}

Doelstelling 5 geeft aan dat de belangen van natuvar en milieu in overweging moeten worden genomen. In de jaarverslagen worden deze herhaaldelijk genoemd. Begin jaren zeventig speelde het milieu wel een rol, maar deze was relatief bescheiden. Met het oog op het milieu werd door de PLEM diversificatie nagestreefd, daarbij werd ook gedacht aan kernenergie. ${ }^{89}$ Vanaf 1974 komen er meer milieu-onderzoeken en worden alternatieve energiebronnen met het oog op de toekomst meer van belang geacht en op kleine schaal al toegepast. Vanaf 1977 wordt het tegengaan van milieuvervuiling en het verwerken van afval, veroorzaakt door het productieproces van de PLEM, belangrijker. De

\footnotetext{
896 Algemene Vergadering van Aandeelhouders, Notulen, vergadering gehouden op 23 juni 1976, p. 5.

897 Algemene Vergadering van Aandeelhouders, Notulen, 14 juni 1977, p. 9 e.v..

${ }^{998}$ N.V. PLEM, Handleiding voor de verwerving van goederen en diensten, 1 olktober 1984 , p. 5.

899 Vergelijk: N.V. Provimciale Limburgse Elektriciteirsmaatschappiy, Jaarverslagem over 1972 en 1973.
} 
belangen van natur en milieu worden dan steeds meer in owerweging genomen: 900 Verschillende technieken werden toegepast om de elektriciteitsproductie schoner te maken. De drie kolenstokende bedrijven in Nederland, de PLEM, de PGEM en de PNEM, richtten in 1982 de Vliegas Unie BV op om oplossingen te vinden voor de bij het gebruik van kolen vrijkomende reststoffen. Voor kleinere productie-eenheden leverde de zogenaamde wervelbedverbrandingstechniek een mogelijke oplossing. Reden waarom de PLEM medewerking verleende aan een onderzoek hiernaar. Voorts werd een haalbaarheidsonderzoek uitgebracht naar de bouw van waterkrachtcentrales in de Maas. een tiental plaatsen leken geschikt met een totaal vermogen van 56 à 65 Megawatt (MW). Een gedetailleerde studie naar een waterkrachtcentrale bij Heel werd uitgevoerd. Aan het einde van de periode werd er meer nadruk gelegd op het milieu. De Directie zag wel in dat elektriciteitstarieven invloed hebben op het verbruik en daarmee op het milieu, maar de tarieven werden niet in de eerste plaats gesteld met het oog op deze milieueffecten. In 1989 stelde de Directie bijvoorbeeld aan de Raad van Commissarissen voor de elektriciteitstarieven over de gehele linie te verlagen. De redenen hiervoor waren de ruimere opbrengst van de verkoop van elektriciteit en het goede resultaat. De mogelijke negatieve effecten daarvan op de energiebesparing moeten dan maar door middel van andere maatregelen tegengegaan worden. ${ }^{\text {901 }}$

Ook de regering benadrukte de milieudoelstelling. Zoals aangegeven in paragraaf 16.8.1.1 verscheen in mei 1989 het Nationaal Milieubeleidsplan waarin de overheid haar doelen verwoorde ten aanzien van het milleubeleid. De distributiesector is bij vrijwel alle in het NMP besproken onderwerpen betrokken. In het verlengde van het Nationaal Milieubeleidsplan-Plus en de Nota Energiebesparing van het Ministerie van Economische Zaken is door de overheid dan ook een belangrijke verantwoordelijkheid op milieugebied gelegd bij de energie-distributiebedrijven.

De activiteiten van de distributiebedrijven ten behoeve van het milieu zijn door de leden van de landelijke verenigingen VEEN, VEGIN en VESTIN verwoord in het Milieu-ActiePlan (MAP) dat verscheen in 1990. In het begin 1990 verschenen rapport Naar een integraal milieu-actieplan en in het MAP werden duidelijke doelen omschreven voor de gehele distributiesector. ${ }^{902}$ Doelen waren onder andere het verminderen van de emissie van $\mathrm{SO}_{2}$ en $\mathrm{NO}_{\mathrm{x}}$ met $51 \%$ in 2000 terwijl de $\mathrm{CO}_{2}$ uitstoot op langere termijn beperkt diende te worden tot het niveau van 1985 . In het NMP werd een reductie van $11 \%$ ten opzichte van het referentiescenario genoemd. ${ }^{903}$ Verder diende bijvoorbeeld het warmtekracht-vermogen toe te nemen. Deze doelen waren gebaseerd op de cijfers bij ongewij-

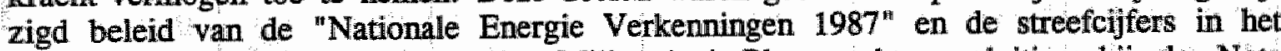
"Nationaal Milieubeleidsplan". Het Milieu-Actie-Plan zocht aansluiting bij de Nota Energiebesparing van het Ministerie van EZ en het NMP Plus van het Ministerie van VROM. De distributiebedrijven dienden mee te werken aan de uitvoering van deze doelen. Regionale bedrijven hebben op grond daarvan eigen Bedrijfs-Milieu-Actieplannen (B-MAP) ontwikkeld. In het in november 1990 door MEGA Limburg vastgestelde

900 N.V. Provinciale Limburgse Elektriciteitsmaatschappij, Jaarverslag over 1977, 1978.

son Algemene Vergadering van Aandeelhouders, Notulen, 21 juni 1989, p. 4.

902 VEEN, VEGIN en VESTIN, Stuurgroep Integraal Milieubeleidsplam Energiedistributiesector, Naar een integraal milieu-actieplan van de Energiedistributiesector (MAP), 25 januari 1990, p. 13.

${ }^{903}$ Het ging hierbij om het kolen-middenscenario van bet Energiecentrum voor de Nationale Economische Verkenmingen 1987 (NEV 1987). 
Bedrijfs-Milieuactieplan werden als doelen opgenomen het bevorderen van energiebesparing en het bewerkstelligen van een vermindering van de emissie van schadelijke stoffen. Met het oog op de vermindering van de CO2-uitstoot toonde het B-MAP dat tot het jaar 2000 jaarlijks een vermindering van 691 kiloton $\mathrm{CO} 2$ bereikt kan worden. De besparing van energie wordt nagestreefd door onder andere het actief stimuleren van woningisolatie en door het plaatsen van energiezuinige cy-ketels. Een speciaal bureau werd ingesteld dat tot taak heeft de subsidie-aanvragen die in het kader van door de overheid in samenwerking met nutsbedrijven ingestelde subsidieregelingen worden ingediend, te hehandelen. Een van de buitengewone lasten in 1990 werd gevormd door de kosten van F. 15 miljoen die werden gemaakt voor activiteiten verricht in het kader van het Milieu-Actieplan. Hierbij moet wel bedacht worden dat de feitelijke uitvoering van het MAP pas in 1991 begon en dus buiten de onderzoeksperiode valt. Deze middelen werden uit de bedrijfsreserves opgenomen in een voorziening en werden dus niet uit MAP-opslagen bekostigd. Het MAP-geld loopt in principe tot 2000. Dit betekent dat de kosten voor MEGA Limburg in ieder geval ongeveer F. 1,5 miljoen per jaar bedroegen. In het door MEGA Limburg opgestelde B-MAP werd voor de komende 10 jaar een bedrag in de orde van grootte van F. 1,1 milljard bestemd voor allerlei investeringsprojecten op het gebied van waterkracht, biogas, warmtekracht en isolatie. ${ }^{904}$ De meeste van deze activiteiten waren min of meer kostendekkend. Daarnaast waren er op grond van het B-MAP een aantal projecten die kosten voor MEGA Limburg met zich meebrachten. Deze projecten waren onder andere de vervanging van bestaande $\mathrm{CV}$-ketels en de ombouw op aardgas.

De totale kosten per jaar voor MEGA Limburg bedroegen F. 1,7 miljoen. Fen aantal van deze activiteiten vonden ook voor 1990 al plaats, zij het dat ze niet specifiek als zodanig verwoord werden. Belangrijke zaken als vervanging van ketels, advisering en voorlichting gebeurden ook al voor 1990 , terwijl ook geïnvesteerd werd in waterkracht en stortgas.

Sinds de fusie met Limagas in 1990 verzorgt MEGA Limburg ook de gasdistributie. Door middel van toeslagen op de gasprijzen werd getracht het energieverbruik te verminderen. Begin jaren negentig werd door de overheid een energieheffing ingevoerd en werd tevens een MAP-toeslag berekend. Dit kan als volgt worden geillustreerd:

\begin{tabular}{|l|l|l|l|l|l|}
\hline \multirow{2}{*}{\begin{tabular}{l} 
jaar \\
\cline { 3 - 6 }
\end{tabular}} & 1991 & 1 januari & 1 juli & 1 januari & 1 juli \\
\hline $\begin{array}{l}\text { Prijs zonder } \\
\text { heffingen }\end{array}$ & $\mathrm{ct} / \mathrm{m} 3$ & 44,2 & 46,4 & 43,2 & 40,2 \\
\hline $\begin{array}{l}\text { Energiehef- } \\
\text { fing }\end{array}$ & $\mathrm{ct} / \mathrm{m} 3$ & 0,424 & 0,972 & 0,881 & 4,156 \\
\hline Subtotaal & $\mathrm{ct} / \mathrm{m} 3$ & 44,624 & 47,372 & 44,081 & 44,356 \\
\hline $\begin{array}{l}\text { MAP-toe- } \\
\text { slag }\end{array}$ & $\mathrm{ct} / \mathrm{m} 3$ & 0,20 & 0,45 & 0,43 & 0,40 \\
\hline Totaal & $\mathrm{ct} / \mathrm{m} 3$ & 44,824 & 47,822 & 44,511 & 44,756 \\
\hline
\end{tabular}

Tabel 16.6 Gasprijs voor kleinverbruikers

904 Directie van MEGA Limburg, 90.031.141, brief aan de Minister van Economische Zaken ten aanzien van het Beleidsplan energiebesparing en stromingsenergie (B. E. S.)/Waterkracht, 22 maart 1990. 
Op 1 januari bedroegen energieheffing en MAP-toeslag gezamenlijk 1,311 cent. Op 1 juli 1992 ging het om 4,556 cent per m3. In 1992 werd aan kleinverbinikers $988.896 .000 \mathrm{~m} 3$ afgezet; zodat deze heffingen ongeveer F. 29 miljoen opleverden.

\section{Verbruikstimulering/besparing}

Vanaf het begin van de oprichting streefde het bedrijf naar groei door stimulering van het verbruik. Dit was nodig voor het verkrijgen van een gezond bedrijf. Hierdoor kon ook de laagst mogelijke kostprijs worden gerealiseerd. De PLEM constateerde dat deze doelstelling veranderd was. In 1977 merkte de vertrekkende voorzitter van de Raad van Commissarissen op: "De tijd wan de propaganda voor het elektriciteitsverbruik is voorbij. De nadruk ligt duidelijk op een zo verantwoord mogelijk verbruik" s0.5 In de discussies over milieu en energievoorraden werd ook steeds meer de rol van elektriciteit ter discussie gesteld. De PLEM achtte gezien de nieuwe ontwikkelingen verbruikstimulering niet langer gewenst. Zolang er geen duidelijk energiebeleid van de overheid was meende de PLEM evenwel dat het niet aan de elektriciteitsbedrijven was om maatregelen te nemen ter vermindering van het verbruik. Derhalve werden de verbruikstimulerende maatregelen beperkt en werd meer het accent gelegd op voorlichting en service. De naam van de afdeling verbruikstimulering werd dan ook gewijzigd in afdeling Voorlichting.

Eind jaren tachtig werd energiebesparing vooral ten behoeve van het milieu als onderdeel van een beleid van duurzame ontwikkeling gezien. De PLEM onderschreef de doelstelling van de regering ten aanzien van de energiebesparing en ondersteunde deze onder andere door haar bijdragen aan de KEMA inzake onderzoek naar energiebesparing, door subsidies aan het Stafbureau Isolatieplan Limburg (SPIL) en door deelname aan de coördinerende werkzaamheden van de provinciale stuurgroep energie. Verder werd geadviseerd aan de industrie en kleinverbruikers en voorts werd middels de binnen de PLEM werkzame stuurgroep energiebesparing en en aantal commissies een actief energiebesparingsbeleid gevoerd. Kleinverbruikers werden door advisering en voorlichting gestimuleerd zuinig om te gaan met elektriciteit. Door bijvoorbeeld spaarlampacties en het stimuleren van de aankoop van energiezuinige apparatuur werd getracht een voor de klant en voor de PLEM optimaal afnamepatroon te bereiken.

Naast energiebesparing probeerde de PLEM door het ontwikkelen van duurzame energiebronnen de inkoop van de SEP te beperken. Deze duurzame energiebronnen zijn al geschetst bij de behandeling van de milieudoelstelling. Strikt genomen was er in het geval van deze alternatieven veelal geen sprake van energiebesparing als wel van een lagere afname van de SEP door de ontwikkeling van nieuwe bronnen van elektricitteit. Doelen van de PLEM voor de periode na 1990 waren onder andere het bouwen van een waterkrachtcentrale te Borgharen, het gebruiken van stortgas en het realiseren van extra warmtekrachtvermogen. Indien al deze maatregelen daadwerkelijk zouden worden uitgevoerd zal in het jaar 2000 tussen de 1313,2 en 1710,5 GWh per jaar minder van de productiebedrijven worden afgenomen. In primaire energie uitgedrukt is dit een besparing van 219,4 tot 316,9 miljoen $\mathrm{m3}$ aardgasequivalenten per jaar. De PLEM beoogde op grond van een afweging van enerzijds de kosten en anderzijds de effectiviteit een prioriteitenvolgorde op te stellen.

Tenslotte kan worden opgemerkt dat energiebesparing, meer in het bijzonider sinds de Elektriciteitswet van 1989, niet negatief hoeft te zijn voor de PLEM. Indien verbruikers besparen is er sprake van een financieel neutrale situatie voor de PLEM. Zij verkoopt in

905 Algemene Vergadering van Aandeellhouders, Notulen, vergadering van 14 juni 1977, pp. 10 e.v.. 
dat geval minder stroom en koopt minder in van de SEP. Voor distributiebedrijven bestaat wel een prikkel om decentraal vermogen op te bouwen. De PLEM kan een afweging maken tuissen inkoop bij de SEP en eigen productie (tot 25 Megawatt (MW), daarboven is toestemming van de SEP nodig). Wanneer dit goedkoper is dan inkoop behaalt de PLEM financiele voordelen. ${ }^{90 \%}$

\section{De werkgelegenheid moet worden gestimuleerd.}

Na een geleidelijke toename van de werkgelegenheid gedurende de periode van 1970 tot 1977 nam de werkgelegenheid tussen 1978 tot 1981 vrij snell toe. In 1981 was er door de Raad van Commissarissen een personeelsplafond van 1634 medewerkers vastgesteld ${ }^{900}$ Het plafond werd in 1982 verhoogd met 11 werknemers tot 1.645 medewerkers. Dat de werkgelegenheid als een belangrijk doel werd gezien blijkt ook uit het doorvoeren van arbeidstijdverkorting en de inschakeling van schoolverlaters boven de sterkte. In verband met de resultaten van de PLEM werd in de jaren daarna meer de nadruk gelegd op kostenmatiging, ook ten aanzien van de personeelskosten. De formatie werd slechts. beperkt uitgebreid tot 1.649 medewerkers eind 1986. De ontwikkeling van de werkgelegenheid bij de N.V. PLEM kan als volgt in een tabel worden weergegeven.

\begin{tabular}{|c|c|c|c|}
\hline jaar & $\begin{array}{l}\text { aantal personeelsle- } \\
\text { den }\end{array}$ & jaar & $\begin{array}{l}\text { aantal personeelsle- } \\
\text { den }\end{array}$ \\
\hline 1976 & 1.422 & 1984 & 1.596 \\
\hline 1977 & 1.463 & $+\quad$ & 1.620 \\
\hline 1978 & 1.482 & 1986 & 1.634 \\
\hline 1979 & 1.504 & $1987 *$ & 1.142 \\
\hline 1980 & 1.558 & 1988 & 1.112 \\
\hline 1981 & 1.602 & 1989 & 1.137 \\
\hline 1982 & 1.602 & 1990 & $\begin{array}{l}1.926^{*} * \\
\text { alleen Plem: } 1.089\end{array}$ \\
\hline 1983 & 1.600 & 1991 & 1.965 \\
\hline
\end{tabular}

In 1987 en 1988 gingen 538 personen over van de PLEM naar EPZ. Inclusief Limagas

Tabel 16.7 De ontwikkeling van de werkgelegenheid gedurende de jaren zeventig en tachtig

Op 1 november 1987 gingen 505 medewerkers over naar EPZ, terwijl in 1988 nog eens

\footnotetext{
906 Dit gebeurde op 2 manieren:

1. inzet wkc. Linme;

2. invoeren van een systeem van piekregulering, "peakshaving", door middel van het afschakelen van vernogen bij grote bedrijven (w.o. DSM, ENCD). Dit werd in afzonderlijke contracten geregeld.
}

907 Raad van Commissarissen, Personeelshestand NV PLEM, 1989, P. 34. 
33 medewerkers van de bedrijfsbescherming werden overgeheveld naar EPZ. Dit leidde ertoe dat het personeelsplafond voor de PLEM eind 1987 1.107 personeeisleden bedroeg. De Directie had in 1986 aan de Raad van Commissarissen met het oog op de personeelskosten, toegezegd zeer terughoudend te zallen zijn bij de vervulling van vacatures. De Directie voerde daartoe per 1 februari 1987 een personeelsstop in, terwijl vacatures alleen nog bij hoge uitzondering met externe kändidaten opgevuld mochten worden. Ondanks het in dienstnemen van een veertigtal nieuwe werknemers bleef het totale aantal medewerkers door een combinatie van natuurlijk verloop en de genomen maatregelen toch beneden het plafond. Op 1 maart 1988 kwamen er 15 medewerkers van het Gemeentelijk Energiebedrijf Brunssum (GEB) in dienst bij de PLEM, het plafond steeg daardoor naar 1.122 medewerkers (mensjaren). In 1989 was dat ongeveer 1.139. Vanaf 1 maart werd ook proefgedraaid met een nieuw systeem van formatie- en personeelsplanning, zoals beschreven in paragraaf 16.4.1.4.1. Dit systeem werd eind 1988 ingevoerd. ${ }^{908}$ Door dit systeem was het beter mogelijk het personeelsbestand te beheersen, waardoor het mogelijk werd de personeelsstop op te heffen en voor een aantal vacatures weer extern te werven. Eind 1988 had de PLEM 1.112 medewerkers in dienst. ${ }^{909}$ Dit kwam overeen met 1.099 mensjaren ${ }^{910}$ Hierbij wordt de normale gemiddelde arbeidsprestatie gesteld op ongeveer 1560 uur per jaar. Eind jaren tachtig volgde de fusie tussen PLEM en Limagas. In 1991 waren 1.965 werknemers werkzaam bij Mega-Limburg, terwijl dat in 1992 was teruggelopen tot $1.8999^{911}$ De periode overziend valt in de eerste plaats op dat de formatie in aantallen medewerkers nogal kon schommelen doordat werknemers meer in deeltijd werkten, door de invoering van arbeidstijdverkorting en bijvoorbeeld door medewerkers die afgekeurd waren voor een oude functie maar wel herplaatsbaar zijn (waardoor er dus tijdelijk twee mensen in dienst zijn voor één functie). Daarom werd in de formatieplanning gewerkt met mensjaren.

Ten aanzien van het werkgelegenheidsdoel deden zich eind jaren tachtig een tweetal veranderingen voor. Enerzijds werd steeds meer de nadruk gelegd op het werven van interne kandidaten, anderzijds werd veel meer de nadruk gelegd op kostenbeheersing. De Directie merkte dit als volgt op: "De forse groei van het aantal medewerkers van het laatste decennium is niet alleen te verklaren door externe oorzaken of ontwikkelingen zoals de uitbreiding van het net of meer aansiuitingen e.d. Het heeft zeker zoveel van doen met een cultuur c.q. mentaliteit, waarin het economisch denken niet altijd centraal stond en waarin aspecten als het voorkomen van een hoge werkdruk en een positieve waardering door de omgeving van het hebben van een groot aantal medewerkers een rol spelen. Uw Raad (Raad van Commissarissen JFK) weet dat wij bezig zijn met een cultuurverandering. (...) Hoofden van afdelingen gaan het geleidelijk als een witdaging ervaren am met minder medewerkers dezelfde taken te blijven doen. Men gaat bovendien ervaren dat motivatieproblemen, verstarring en ontevredenheid voor een gedeelte weggenomen kunnen worden door interne doorstroming". ${ }^{912} \mathrm{Na}$ het afstoten van de productiekant van de PLEM naar

\footnotetext{
908 Vergelijk: Afdeling Personeelszaken van de N.V. PLEM, Nota Op weg naar Personeelsplanning, 1 jamuari 1989.

909 Raad van Commissarissen, Personeelsbestand NV PLEM, 1989, p. 12.

910 T.a.p., p. 12.

911 T.a.p., p.46.

912 T.a.p., p. 5.
} 
EPZ verrichtte de PLEM feitelijk alleen nog de distributie. 13 Er waren toen nog een kleine 1200 werknemers in dienst van de PLEM (los van EPZ). In de vergadering van de Raad van Commissarissen werd opgemerkt: "Nu de PLEM nog witsluitend een elektriciteitsdistributiebedriff is, is een totaal personeelsbestand wan 1140 personen wellicht aan de ruime kant". ${ }^{14}$ De voorzitter van de Raad van Commissarissen stelde in dit verband: "Wat betreft het aantal mensen dat thans bij de PLEM werkt, moet bedacht worden dat dit aantal enigszins zal toenemen door het overnemen van gemeentelijke bedrijuen. Bij de te voeren onderhandelingen walt niet wit te sluiten dat in een aantal gevallen soms meer mensen worden overgenomen dan om bedrijfseconomische redenen strikt noodzakelijk zal zijh. Toch zal op termijn ook hier een aantal besparingen kunnen worden bereikt" 915 Verder kan worden opgemerkt dat in Tabel 16.7 zoals aangegeven alleen gekeken is naar het aantal werknemers bij de PLEM zelf. Voor het werkgelegenheidsdoel was de band met EPZ natuurlijk wel van belang. Door een rechtstreekse relatie met de elektriciteitsproductie kon de PLEM toezien op de handhaving van productie-eenhedien in Limburg. Dit is van belang in verband met de omvangrijke werkgelegenheid die de productiesector in Limburg opleverde. 916

Tenslotte dient aangegeven te worden hoeveel werknemers de PLEM in de jaren tachtig te veel in dienst had. Een indicatie hiervan kan worden afgeleid uit de volgende tabel.

\begin{tabular}{||l|l|l|l|l|}
\hline Jaar & $\begin{array}{l}\text { Verkoop elektrici- } \\
\text { teit in 1.000 kWh }\end{array}$ & $\begin{array}{l}\text { Aantal personeelsle- } \\
\text { den }\end{array}$ & $\begin{array}{l}\text { Verkoop elektriciteit } \\
\text { per werknemer in } \mathrm{kWh}\end{array}$ & $\begin{array}{l}\text { Toename in pro- } \\
\text { centen }\end{array}$ \\
\hline 1975 & 3.472 .534 & 1.431 & $2.426 .648,5$ & \\
\hline 1980 & 4.492 .723 & 1.558 & $2.883 .647,6$ & $18,8 \%$ in 5 jaar \\
\hline 1985 & 5.566 .599 & 1.620 & 3.436 .172 & $19,2 \%$ in 5 jaar \\
\hline 1987 & 5.817 .195 & 1.142 & 5.093 .866 & $48,4 \%$ \\
\hline 1989 & 6.195 .167 & 1.137 & $5.448 .695,7$ & $2,2 \%$ \\
\hline 1990 & 6.560 .425 & 1.089 & $6.024 .265,4$ & $10,5 \%$ \\
\hline 1991 & 6.748 .206 & $1.110^{918}$ & $6.079 .464,9$ & $0,9 \%$ \\
\hline 1992 & 7.174 .731 & 1.072 & $6.692 .846,1$ & $10 \%$ \\
\hline
\end{tabular}

Tabel 16.8 De distributie van elektriciteit per werknemer

\footnotetext{
913 Zij veritichtte zoals aangegeven nog wel kleinschalige opwek, namelijk wkc. Linne, stortgascentrales en wkk-koppeling.
}

${ }^{914}$ Raad van Commissarissen, Notulen van de vergadering no. 5/88, 6 december 1988, paragraaf 10.6 .

915 T.a.p. paragraaf 10.b.

${ }^{916}$ In dit kader zorgde de directie ook voor vervangende/aanvullende werkgelegenheid door de bouw wan de proefcentrale kolenvergassing te Bruggenum.

917 Stijging door afstoten van de produktie.

918 De vermelde aantallen personeelsteden over 1991 en 1992 zijn gebaseerd op schattingen, angezien de PLEM vanaf 1991 geen onderscheid meer makt tussen personen in dienst bij het PLEM-onderdeel en personen in dienst bij het Limagas-onderdeel. 
Uit Tabel $16.8 \mathrm{kan}$ worden afgeleid dat in de jaren 1990-1992 de hoeveelheid gedistribueerde elektriciteit per werknemer sterk toenam. Dit was niet zozeer te wijten aan schaaleffecten (meer elektriciteit verkocht, relatief minder mensen nodig) alswel aan de reorganisatie die werd doorgevoerd. In principe kon de in 1992 per werknemer gedistribueerde elektriciteit ook al in 1989 worden voortgebracht. Indien dat zou zijn gebeurd dan waren er in 1989980 werknemers in plaats van de aanwezige 1.137 personen nodig. Dit zou betekenen dat de PLEM in 1989 ongeveer 150 werknemers te veel in dienst had. Gezien de doorgevoerde integratie met Limagas lijkt het waarschijnlijk dat er ook synergievoordelen zijn behaald, die niet zonder een fusie bereikt hadden kunnen worden. Daar staat tegenover dat MEGA Limburg ook in 1992 personeelsleden in dienst had, die op economische gronden niet strikt noodzakelijk waren. Het is interessant een vergelijking te trekken met een soortgelijk distributiebedrijf om te zien of er verschillen zijn. Voor een vergelijking leent de PNEM zich het best, aangezien dit bedrijf gedurende de jaren tachtig steeds zeer lage tarieven rekende. De PNEM haalde in 1990 een omzet van ruim 1,8 miljard gulden met een personeelsbestand van 2.603. MEGA Limburg haalde in 1990 met 1.926 werknemers een omzet van ruim F. 1,2 miljard. Omgerekend zou MEGA Limburg $0,679.2 .603$ werknemers moeten hebben of 1.768 . Dit is 158 minder dan MEGA Limburg in werkelijkheid had. Hiervan zouden op grond van de in 1990 bestaande personeelverdeling (gas, elektriciteit) ongeveer 90 personen te veel werkzaam zijn bij de PLEM. Ook hier geldt echter dat ook de PNEM als nutsbedrijf het werkgelegenheidsdoel nastreefde, zodat deze 90 personen een te laag aantal weergeven. Daar staat tegenover dat de PNEM aanzienlijk meer elektriciteit distribueerde dan de PLEM, waardoor de schaal groter was. De distributie van gas was echter minder. Natuurlijk dient bij een vergelijking van de PLEM en de PNEM wel in het oog gebouden worden dat zowel de elektriciteitsproductie als de samenstelling van het personeel verschilde waardoor deze vergelijking slechts een grove indicatie geeft. $\mathrm{Zo}$ is de reservecapaciteit, die er in verband met het verschillende verbruik tijdens dal- en " piekuren op na wordt gehouden, per bedrijf verschillend. Hierdoor was er ook verschil in de behoefte aan personeel. Een voorzichtige schatting is dan ook dat de PLEM ongeveer 100 personen te veel in dienst had. Dit correspondeert ook redelijk met de daling van het aantal werknemers aan het begin van de jaren negentig.

Tenslotte kan worden opgemerkt dat de PLEM in de jaren tachtig in het algemeen geen extra nadruk legde op het aanstellen van minderheden, waaronder bijvoorbeeld gehandicapte werknemers. Met ingang van 1 juli 1986 is de Wet arbeid gehandicapte werknemer (WagW) ingevoerd, op grond waarvan de PLEM voor ongeveer $6 \%$ van het personeelsbestand gehandicapte of gedeeltelijk arbeidsongeschikte werkmemers in dienst moest nemen. In werkelijkheid was dat voor de PLEM in 1988 ongeveer $2 \%$ van het personeelsbestand. Ook het percentage vrouwen was met 60 werknemers of $5 \%$ van het personeelsbestand laag. Het betrof bovendien voomamelijk functies op lager tot middelbaar niveau. ${ }^{919}$

\section{Beloning van het personeel}

Gedurende de onderzoeksperiode was het personeelsverloop van de PLEM slechts ongeveer $1 \%$. De reden die hiervoor werd genoemd was dat de PLEM goed betaalde en een ruim sociaal beleid voerde. ${ }^{220}$ De vraag is hoe goed de beloning van het personeel was. Werknemers van de PLEM bezaten geen ambtenarenstatus omdat zij niet onder de

919 T.a.p., p. 17.

920 N.V. PLEM, De werkgever, nummer 19, 5 oktober 1989. 
Ambtenarenwet 1929 (Stb. 530) vielen. Gedurende de jaren zeventig en tachtig werden CAO's afgesloten tussen de WEB en de werknemersorganisaties. In 1993 was dat de CAO energie- en distributiebedrijven zoals die per 1 januari 1992 van kracht was. Deze CAO werd afgesloten tussen de Werkgeversvereniging Energie en Nutsbedrijven (WENB) en de werknemersorganisaties, waaronder ook de ambtenarenbonden. De CAO kende een wachtgeldregeling die naw aansloot bij de ambtelijke wachtgeldregeling. Ook de ziektekostenregeling sluit in een aantal gevallen aan bij de ambtelijke ziektekostenregelingen (IZA of IZR). De PLEM was overigens op grond van artikel B3 van de Algemene Burgerlijke Pensioenwet (Stb. 1986, 540) wel bij het Algemeen Burgerlijk Pensioenfonds aangesloten.

De salariëring van het personeel, zoals die onder andere op grond van de diverse CAO's tot stand kwam, kan als volgt worden weergegeven.

\begin{tabular}{|c|c|c|c|c|c|}
\hline jaar & $\begin{array}{l}\text { aantal } \\
\text { personeelsseden }\end{array}$ & salarissen & $\begin{array}{l}\text { sociale lasten en overi- } \\
\text { ge personeelskosten }\end{array}$ & totaal & $\begin{array}{l}\text { gemiddelde kosten per } \\
\text { personeelslid. }\end{array}$ \\
\hline 1976 & 1.422 & 44.546 & 26.100 & 70.646 & F. $49.700,-$ \\
\hline 1978 & 1.482 & 56.232 & 25.635 & 81.867 & F. $55.200,-$ \\
\hline 1980 & 1.558 & 65.222 & 27.945 & 93.167 & F. 59.800 , \\
\hline 1981 & 1.602 & 67.903 & 29.772 & 97.675 & F. $61.000,-$ \\
\hline 1982 & 1.602 & 70.056 & 31.413 & 101.469 & F. $63.300,-$ \\
\hline 1983 & 1.600 & 69.991 & 34.901 & 104.892 & F. $65.600,-$ \\
\hline 1984 & 1.596 & 72.042 & 34.612 & 106.654 & F. $66.800,-$ \\
\hline 1985 & 1.620 & 79.809 & 29.478 & 109.287 & F. $67.500,-$ \\
\hline 1986 & 1.634 & 86.375 & $14.222 *$ & 110.597 & F. $67.664,-$ \\
\hline 1987 & 1.142 & 64.015 & 17.558 & 81.573 & F. $71.429,-$ \\
\hline 1988 & 1.112 & 60.798 & 15.556 & 76.354 & F. $68.664,-$ \\
\hline 1989 & 1.137 & 62.640 & 13.976 & 76.616 & F. $67.384,-$ \\
\hline $\begin{array}{l}1- \\
990= \\
* * *\end{array}$ & $\begin{array}{l}1.926 \\
\text { alleen } \\
\text { PLEM: } \\
1.089\end{array}$ & $\begin{array}{l}120- \\
.738 \\
62.688\end{array}$ & $\begin{array}{l}15.452 \\
15.552\end{array}$ & $\begin{array}{c}136.290 \\
78.240\end{array}$ & $\begin{array}{l}\text { F. } 70.763,- \\
\text { F. } 71.845,-\end{array}$ \\
\hline
\end{tabular}

* De stijging van de post salarissen en de daling van de post sociale lasten en overige personeelskosten wordt met name veroorzaakt door de per 1 juni 1985 ingevoerde maatregelen van de overheid op het terrein van de AOW/AWW-premie voor ambtenaren. Het personeel betaalt per 1 juni 1985 deze premie zelf, hiertegenover stond als compensatie een stijging van de salarissen.

Tabel 16.9 Salarissen, sociale lasten en gemiddelde kosten per personeelslid ${ }^{221}$

${ }^{921}$ Bron: N.V. Provinciale Limburgse Elektriciteitsmaatschappij, Jaarverslag 1985, 1986, p. 56. 
Om te beoordelen in hoeverre de beloning van het personeel van de PLEM relatief te hoog lag en er dus sprake was van "rentseeking" moet een vergelijkingsmaatstaf gevonden worden. Deze kan gevonden worden door de beloning van het personeel van de PLEM met dat van Limagas te vergelijken. De werknemers van de PLEM ontvingen in 1990 gemiddeld genomen F. 71.845 ,- per werknemer, terwijl Limagaspersoneel gemiddeld ongeveer F. 69.354,- per werknemer ontving. Het verschil tussen deze twee bedragen vermenigvuldigd met het aantal werknemers van de PLEM van 1.089 levert een bedrag op van F. 2.711.827,8. Dit is het bedrag dat de PLEM vergeleken met Limagas in 1990 te veel betaalde. Het probleem van deze analyse is dat de werkzaamheden verschilden en mogelijk ook de prestatie van het personeel. Het is in dit verband van belang om nog eens naar de PNEM te kijken. In 1990 had de PNEM 2.603 personen in dienst die

F. 181.563.000,- ontvingen. ${ }^{922}$ Gemiddeld genomen ontving een werknemer derhalve

F. 69.751,4. Betrekken we dit bedrag op de PLEM dan betekent dit dat de PLEM per saldo F. 2.279.930,- meer betaalde aan beloning voor het personeel. Daarbij dient bedacht te worden dat ook de PNEM als nutsbedrijf waarschijnlijk een beloning van het personeel nastreefde die beter was dan op bedrijfseconomische gronden noodzakelijk. Het totale bedrag dat aan dit doel werd besteed ligt dan ook hoger.

Naast de beloning in geld kende de PLEM nog een aantal regelingen die voordelig konden zijn voor het personeel. Zo kende de PLEM diverse (bedrijfs)spaarregelingen en waren er beperkte mogelijkheden voor het personeel om via de PLEM voor privedoeleinden goederen te verwerven. Het was mogelijk om via de PLEM bepaalde elektrische buishoudelijke apparaten (gereedschappen, lampen e.d.) en bepaalde magazijnvoorraadartikelen aan te schaffen. Ook was het mogelijk om bij de vaste leveranciers van de PLEM via de PLEM bepaalde goederen, zoals geluidsapparatuur en boormachines, aan te schaffen. Het personeel kan onder omstandigheden ook gebruik maken van tijdelijke kortingen van leveranciers. Ook overcomplete goederen van de PLEM, zoals auto's en kantoormeubilair kunnen door het personeel worden aangeschaft. Door deze en andere mogelijkheden zijn voor het personeel (beperkte) voordelen te behalen. ${ }^{23}$

Een andere wijze waarop de PLEM het personeel bevoordeelde was het verstrekken van leningen aan het personeel in het kader van de personeelsregeling voor het treffen van isolatiemaatregelen. Verder werden er leningen verstrekt voor het financieren van personenauto's, terwijl in 1989 er ook nog leningen uitstonden in het kader van de voormalige Eigen Bouwregeling Personeel. Op 1 januari 1989 bedroeg het bedrag aan uitstaande leningen F. 1.963.000,-. In 1989 werd F. 745.000,- verstrekt aan leningen aan het personeel en werd F. 891.000,-afgelost zodat per 31-12-1989 het saldo van uitstaande leningen F. 1.817.000,- bedroeg. Dit betekent dat in 1989 gemiddeld F. 1.890 .000 ,uitstond aan leningen aan het personeel, 924 Gegeven een rentestand van $7,21 \%$ werd derhalve $\mathbb{F}$. 136.269,- als voordeel aan het personeel verstrekt.

\footnotetext{
922 Hierbij dient wel bedacht te worden dat de PNEM in 1989 zowel elekniciteit, gas en water distribueerde en ook op een aantal andere terreinen actief was.

${ }^{923}$ N.V. PLEM, Handleiding voor de wenwerving wan goederen en dienstem, liktober 1984, p. 60 .

${ }^{924}$ Namelijk: F. $1.963 .000,=+$ F. $1.817,000,-12$.

925 Vergelijk Tabel 17.13. over de omvang van de "public enterprise rent".
} 
Gedurende de onderzoeksperiode en met name in de jaren zeventig wordt ook de bouw van kerncentrales nog gezien als een belangrijk middel om de technologische positie van Limburg en Nederland in het algemeen te verbeteren. De Directie en ook de provincie Limburg zagen de nodige perspectieven in deze richting, mede in verband met de in de jaren zeventig nog verwachte sterke toename van de vraag naar elektriciteit. De samenvoeging van de productie van elektriciteit van PLEM en PNEM werd wel gezien als een voorwaarde voor de exploitatie van kerncentrales. De gemeente Geleen keerde zich tegen kernenergie en stelde voor in de statuten van EPZ op te memen dat EPZ geen stroom door middel van kerncentrales zou opwekken. ${ }^{926}$ Dit amendement werd verworpen omdat de provincie Limburg hier niets voor voelde. Zij vond dat mede in verband met technologieoverwegingen de bouw van kerncentrales niet uitgesloten moest worden.

Jaarlijks werd geïnvesteerd in de transport en distributie van elektriciteit. In 1989 werd bijvoorbeeld in Borgharen de eerste van een nieuwe generatie middenspanningsschakelinstallaties in bedrijf genomen. In Maasbree werd het $1000 \mathrm{e} 10 \mathrm{kV}$-compactstation geplaatst. Samen met de gemeente Heerlen en het NV Nutsbedrijf Heerlen werd een renovatieproject openbare verlichting doorgevoerd ter besparing van energie. Verder werden in 1989 184 nieuwe $10 \mathrm{kV}$-transformatorstations in bedrijf gesteld. Voorts werd 105 kilometer middenspanningsnet en 165 kilometer laagspanningsnet gelegd en werd 24,6 kilometer bovengronds laagspanningsnet gedemonteerd. Ook in 1990 werd hierin geilnvesteerd. Er werden 177 nieuwe $10 \mathrm{kV}$-transformatorstations in bedrijf genomen. Verder werd 94 kilometer nieuw $10 \mathrm{kV}$-middenspanningsnet en 150 kilometer laagspanningsnet aangelegd. Er werd 16,1 kilometer bovengronds laagspanningsnet verwijderd:

Andere technologische vernieuwingen die werden doorgevoerd waren de bouw en ontwikkeling van nieuwe installaties en pompen. In 1992 vond er bijwoorbeeld een testprogramma plaats voor de nieuwe Rendamax-absorptie-waterpomp voor het provinciehuis. Dit project werd door MEGA-Limburg in samenwerking met het Provinciaal Bestuur en de Gasunie gefinancierd. Voorts kan gedacht worden aan warmtekrachtinstallaties, onderzoek naar de verdere bouw van waterkrachtcentrales, de bouw van stortgascentrales. Bovendien vond er in 1992 onderzoek plaats naar de mogelijkheden van het plaatsen van gasexpansieturbines in de gasontvangststations van MEGA-Limburg.

\section{Het yerwerken van afval}

Eind jaren tachtig stond in het teken van een herstructurering van de afvalverwerking in de Provincie Limburg. De provincies zijn wettelijk verplicht om een Provinciaal Afvalstoffenplan (PAP) op te stellen en uit te voeren en deze regelmatig aan te passen. In dit plan ontwikkelde de provincie haar afvalstoffenbeleid. Eén onderdeel daarvan is het verwerken en verbranden van afval. De provincie werkte eind jaren tachtig aan het tweede Afvalstoffemplan (PAP II). Op grond van een onderzoek van de Grontmij uit 1988 naar de halbare schaalgrootte is een voorkeursplan afgeleid. ${ }^{927}$ Dit plan hield in dat afval op twee plaatsen centraal verzameld en gescheiden moet worden waarna het

\footnotetext{
926 Algemene Vergadering van Aandleelhouders, Notulem, 18 december 1986, p.3.

927 Grontmij, Schaalgrootte-onderzoek ten behoeve van de afvalverwerking in Limburg, De Bilt, augustus 1988.
} 
brandbare gedeelte op eén centrale lokatie werd verbrand. Vervolgens worden de reststoffen op twee lokaties gestort. ${ }^{928}$ Teneinde dit plan verder uit te werken hebben Gedeputeerde Staten op 30 augustus 1988 besloten tot het instellen van een onderzoek naar de bestuurlijk-organisatorische vormgeving van de toekomstige afvalverwijderingsstructuur. ${ }^{929}$ Een drietal mogelijkheden werden overwogen, namelijk de instelling van een schap, een "private-partnership"-constructie en een semi-overheidsbedrijf zoals de PLEM. De PLEM was voorstander van de laatste variant, te meer daar het zichzelf een rol toekende bij de afvalverwijdering. Verder werd een onderzoek naar de tarieven voor de afvalverwerking opgedragen aan de Grontmij. De provincie overwoog de tarieven zodanig vast te stellen dat deze sturend werkten en dus niet alleen de kosten weerspiegelden. Verder werd en haalbaarheidsstudie voor een verbrandingsinstallatie in MiddenLimburg uitgevoerd. Dit gebeurde in overleg met de PLEM, waarbij ook de mogelijkheid van het benutten van de vrijgekomen warmte voor het opwekken van stroom moest worden onderzocht. De PLEM geeft eind jaren tachtig aan voor zichzelf een taak te zien op het gebied van de afvalverwerking. ${ }^{930}$ In opdracht van de PLEM heeft de KEMA een onderzoek uitgevoerd naar de haalbaarheid van de bouw van een verbrandingsinstallatie te Buggenum, waarbij de verbrandingswarmte wordt gebruikt voor de productie van elektriciteit. ${ }^{931}$ Het ging daarbij vooral om het bepalen van de verbrandingskosten per aangeleverde ton afval, afgezet tegen de baten van de afzet van de opgewekte elektriciteit. De geproduceerde elektriciteit zou worden afgevoerd via het bestaande $150 \mathrm{kV}$-station te Buggenum. ${ }^{932}$ Op 16 maart 1990 werd het tweede Provinciale Afvalstoffenplan (PAP II) door de Provinciale Staten vastgesteld. Een van de conclusies van dit plan was dat het nodig was een afvalverbrandingsinstallatie te bouwen. Dit moest een zogenaamde overheids nv worden met $60 \%$ van de aandelen in handen van de provincie en $40 \%$ in handen van de gemeenten. Deze overheids nv die dus voor $100 \%$ in handen van de overheid is, heeft een aantal werkmaatschappijen voor verbranding, storten, nazorg en scheiding, terwijl de gemeenten verantwoordelijk blijven voor inzameling en overslag. De bedoeling was dat de PLEM, PZEM en de PNEM gezamenlijk de organisatie van de afvalverbranding in Zuid-Nederland zouden verzorgen, overeenkomstig het door de provincies Limburg, Noord-Brabant en Zeeland gezamenlijk ontwikkelde afvalbeleid. ${ }^{933}$ In het B-MAP is de afvalverbranding als investeringsproject opgenomen. In 1992 is de N.V. Afvalverbranding Zuid-Nederland (AZN) opgericht. MEGA-Limburg participeert hierin voor $40 \%$, terwijl DELTAN en PNEM deelnemen voor respectievelijk 20 en $40 \%$. Het Milieu Effect Rapport is begin 1993 verschenen. De bedoeling is het bouwen en

\footnotetext{
928 Verslag FMT-1-bespreking, nr. 01189, Stand yan zaken provinciaal afvalverwerkingsplan met betrekking tot het initiëren van een haalbaarheidisstudie, 09-01-1991.
}

929 Hoofd afdeling Bodem, Provineie Limburg, Br 55509, Bestuurlijk-organisatorische wormgeving toekomstige afvalverwilideringsstructuur, 22 februari 1989.

930 Verslag DT-bespreking, Nr. 31.88, Aantekeningen naar aanleiding van het gesprek over afvalverwerking op 15-9-1988 met de provincie, 19-9-1988, p. 2.

931 NV KEMA, 88-1205 vWU/AK, Begeleiding haalbaarheidsstudie afvalverbranding Midden-Limburg, 30 november 1988, pp. 3-4.

932 N.V. Provinciale Limburgse Elektriciteitsmaatschappij, Een hanteerbare oplossing voor affalverbranding in Limburg, januari 1990, pp. 1-2.

9333 Vergelijk ook: Management Team, Concept persbericht met betreklking tot voorbereiding om te komen tot een NV afvalverbranding Zuid-Nederland, 5 april 1990. 
exploiteren van een tweetal afvalverbrandingsinstallaties. Aan de ene kant zal afval uit de drie Zuidelijke provincies worden verwerkt en aan de andere kant wordt er naar gestreefd de vrijkomende energie optimaal te benutten. De exploitatie zal door middel van de te hanteren tarieven kostendekkend zijn. ${ }^{994}$

Het aanleggen, beheren en exploiteren van centrale antenne-installaties en kabelnetten en daarbij behorende werken

Eind jaren tachtig was de PLEM niet actief op deze markt. Wel overwoog zij dat te worden. Daarbij werden een drietal mogelijkheden voor participatie in kabelnetten onderscheiden: ${ }^{935}$

1. Door het verwerven van bestaande en nieuw aan te leggen kabelnetten in de provincie Limburg, eventueel in samenwerking met de PTT.

2. Het aanleggen en onderhouden van kabelnetten door de PLEM (waarbij de PLEM om praktische redenen ook de juridische eigendom verwerft), terwijl de economische eigendom en het te voeren beleid ten aanzien van de programmering bij de betreffende gemeente ligt.

3. Een derde mogelijkheid is het (daarnaast) ter hand nemen van andere telematicadiensten, eventueel in samenwerking met de PTT. Hierbij kan gedacht worden aan een geïntegreerd datanet voor de industrieèn in bijvoorbeeld Zuid-Limburg.

Centraal stond daarbij voor de PLEM dat geen marginale projecten, waarbij door het toekennen van premies en andere subsidies nog net enig rendement gehaald kan worden, zullen worden aangegaan. Ook is het niet de bedoeling van de PLEM om een aantal kleine kabelnetmaatschappijen te exploiteren. Voor zover de PLEM actief wil worden wil zij dat vooral grootschalig doen, eventueel in samenwerking met de PTT. Voor de keuze van éen van bovengenoemde strategieën werden miet alleen de te behalen rendementen van belang geacht. Ook de toekomstverwachting ten aanzien van de gehele telematicasector, de plannen van de overheid en de bedrijfsstrategie van de PLEM zelf zijn relevant.

Na een uitgebreide analyse bleek dat het opzetten van afzonderlijke projecten voor de PLEM nauwelijks rendabel zou zijn. De te verwachten rendementen lagen op ongeveer 9 à $11 \%$ in 15 jaar, terwijl de PLEM zelf vermogen moest aantrekken tegen 7 à $8 \%$ met een looptijd van 20 jaar. Eind jaren tachtig rees dan ook de vraag of het niet beter was om bestaande CAI-bedrijven in onder andere Brunssum, Kerkrade en Venlo over te nemen, te meer daar deze benadering ook gevolgd is door de PNEM. De gemeenten zouden in dat geval machtiginghouder blijven. $\mathrm{Zij}$ nemen de beslissingen over de te hanteren tarieven, de door te geven programmapakketten en de besteding van de winsten. De PLEM zou dan evenals de PNEM het op gang brengen van samenwerking tussen de verschillende gemeenten kunnen stimuleren.

Zoals opgemerkt speelde ook het beleid van de overheid een belangrijke rol bij de overwegingen van de PLEM actief te worden in deze sector. Eind jaren tachtig was het telecommunicatiebeleid van de overheid nog volop in discussie. De regering heeft haar

934 FMT 4, Bedriifsplan 1991/B-MAP, 8-10-1990, pp. 1-3.

935 Vergelijk: Verslag DT-bespreking, nr. 41/88, met betrekking tot de vraag of de PLEM moet toetreden tot deze markt, 5-12-1988. 
standpunt in verschillende rapportages, waaromder vooral het rapport van de commissie Zegveld, neergelegd, terwijl ook de parlementaire behandeling van de ontwerp-wet op de telecommunicatie-voorzieningen inzicht geeft in de standpunten van de politiek. Samengevat kan worden gesteld dat de overheid eind jaren tachtig streefde naar én glasvezelnet (IBCN, integrated broadband communication network) voor heel Nederland en Europa, waarbij alle communicatie als telefoon, televisie en computerverkeer van én en dezelfde kabel gebruik maakt. Belangrijk daarbij is dat de PTT de wettelijke bevoegdheid krijgt om kabelnetten over te nemen. De reden hiervoor is dat de politieke partijen meenden dat kabeltelevisie met de openbare PTT-telecommunicatie-infrastructuur geintegreerd diende te worden. ${ }^{936}$ In deze visie zou de PTT na een overgangsperiode beheerder worden van een geïntegreerde lokale telecommunicatie-infrastructum, waarin de voorheen zelfstandige kabeltelevisienetten worden opgenomen. Dit regeringsstandpunt werd kamerbreed gedragen. Verwacht werd evenwel niet dat de PTT onmiddellijk alle kabelnetten zou overnemen, aangezien dit zeer grote investeringen met zich mee zou brengen, zonder dat hier direct evenredig baten tegenover zouden staan. Deze situatie leidde eind jaren tachtig echter wel tot onzekerheid bij de PLEM en bestaande kabelexploitanten over de vraag of nieuwe investeringen nog wel lonend zouden zijn.

\section{Voorziening in onrendabele aansluitingen}

In 1970 was met de onrendabele huisaansluiting een bedrag van F. 224.000, gemoeid. Dit werd voor F. 105.000 ,- betaald uit het Fonds voor onrendabele uitbreidingen en netverbeteringen en voor F. 88.000 ,- door belanghebbenden en gemeenten. Zoals in paragraaf 16.5.1 werd opgemerkt werd dit Fonds voor onrendabele uitbreidingen en netverbeteringen begin jaren zeventig onder de algemene reserve gebracht. De onrendabele netaansluiting werd voor het eerst ten laste van het resultaat gebracht. Voorheen werden deze kosten ten laste gebracht van een tweetal fondsen die gevoed werden uit het overschot, voor zover aanwezig. De reden van de wijziging was de gewijzigde opvatting dat netverbetering beschouwd diende te worden als noodzakelijk onderhoud en daarom niet afhankelijk mocht zijn van de vraag of er exploitatieoverschotten aanwezig waren. Het bedrag dat voor dit doel bestemd was liep in de jaren zeventig en tachtig op. In 1988 werd F. 2.000.000,- geinvesteerd in het verbeteren van de voorzieningen voor de levering van elektriciteit in zogenaamde onrendabele gebieden en het verkavelen van bovengrondse netten. ${ }^{937}$ In 1989 werd F. 1.000.000, - geïnvesteerd.

\section{Lagere tarieven}

De kosten voor de elektriciteitsbedrijven in Nederland en dientengevolge ook de in rekening gebrachte elektriciteitsprijzen, zijn door de olie- en gasprijsstijgingen in de jaren zeventig sterk toegenomen. In West-Duitsland, België en Frankrijk is met behulp van aanwezige waterkracht, kernenergie en kolen een veelal autonoom beleid gevoerd. De prijs van kolen werd in Duitsland bijvoorbeeld zodanig gesubsidieerd dat de prijs gebracht werd op wereldmarktniveau. In Nederland is de prijs van de brandstoffen van groot belang aangezien ongeveer $70 \%$ van de totale kosten werd gevormd door de brandstofkosten. In verband met het gebruik van dure brandstoffen nam de invoer van relatief

936 Notitie voor de directeur, 8808294, Kabeltelewisie en de PLEM, 9-11-1988.

937 N.V. Provinciale Limburgse Elektriciteitsmaatschappij, Raad van Commissarissen 88.-057, Bedrilfsplän 1989, 24 november 1988; p. 50. 
goedkope stroom toe. Op korte termijn is dit gunstig, op lange termijn kan dit ten koste gaan van de werkgelegenheid bij de bedrijfstak en toeleveranciers. Na 1985 trad een daling op in de Nederlandse elektriciteitstarieven. Per kwartaal word de gasprijs aangepast aan de gemiddelde olieprijs over het voorgaande halfjaar. Door de daling van de olieprijzen en hieraan gekoppeld de gasprijzen, en ook door de dalling van de kolenprijzen was de elektriciteitsprijs in $198625 \%$ lager dan in 1985 . Deze daling zette zich door waardoor de Nederlandse tarieven in 1989 lager waren dan die in bijvoorbeeld Belgie, West-Duitsland en ook Frankrijk,

De PLEM hanteerde verschillende tarieven voor de verschillende doelgroepen. Grootverbruikers betaalden gemiddeld genomen minder dan de helft van het kleinverbruikerstarief met als doel bevordering van de economische ontwikkeling in de regio.

\begin{tabular}{|l|l|l|l|l|l|l|}
\hline jaar & $\begin{array}{l}\text { openbare } \\
\text { verlichting }\end{array}$ & kleinverbruik & $\begin{array}{l}\text { en gros" } \\
\text { afnemers }\end{array}$ & $\begin{array}{l}\text { individuele } \\
\text { contracten } \\
\text { grootverbruik }\end{array}$ & $\begin{array}{l}\text { overig } \\
\text { grootver- } \\
\text { bruik }\end{array}$ & totaal \\
\hline 1975 & 15,15 & 13,09 & 7,82 & 6,28 & 8,24 & 8,64 \\
\hline 1980 & 18,05 & 18,9 & 12,15 & 10,42 & 13,41 & 13,33 \\
\hline 1985 & 35,40 & 21,76 & 14,92 & 12,37 & 16,94 & 15,37 \\
\hline 1986 & 32,07 & 17,39 & 10,86 & 8,18 & 12,66 & 11,69 \\
\hline 1987 & 33,11 & 16,92 & 10,82 & 7,64 & 12,32 & 11,38 \\
\hline 1988 & 32,89 & 16,66 & 10,57 & 6,68 & 12,11 & 10,95 \\
\hline 1989 & 30,28 & 17,10 & 10,57 & 7,02 & 12,63 & 11,38 \\
\hline 1990 & 29,56 & 17,26 & 11,00 & 7,55 & 12,95 & 11,71 \\
\hline 1991 & 25,89 & 16,27 & 10,19 & 7,30 & 12,61 & 11,29 \\
\hline 1992 & 25,80 & 15,81 & 9,97 & 7,81 & 12,14 & 11,10 \\
\hline
\end{tabular}

in $\mathrm{ct} / \mathrm{kWh}$

*exclusief de korting op basis van de restitutieregeling grootverbruikers

\section{Tabel 16.10 Elektriciteitstarieven in centen per $\mathrm{kWh}^{938}$}

Hierdoor was er sprake van een degressieve tariefstelling. Dit bleef gedurende deze periode onveranderd. Wel werden uniforme tariefstijgingen doorgevoerd. Door de sterke stijging van de olieprijs tussen 1979 en eind 1982 steeg de $\mathrm{kWh}$-prijs voor kleinverbruikers van 12 cent tot 20,5 cent. In 1982 trad een daling van de elektriciteitsprijs tot 17,5 cent op, met name veroorzaakt door de daling van de olieprijs en de overgang op kolen van de eenheden 4 en 5 van de Maascentrale. In 1981 maakten de brandstofkosten inmiddels $80 \%$ van de opwekkosten van de PLEM uit. In 1982 daalde dit tot $70 \%$. De basistarieven zijn sinds 1976 nauwelijks gestegen. Per 1 april 1984 werden de basistarie-

938. Cijfers ontleend aan de diverse jaarverslagen over deze periode. 
ven voor grootverbruikers verlaagd met $4 \%$ en voor kleinverbruikers met $2 \%$. Met ingang van 1 maart 1985 werd opnieuw een verlaging met $2 \%$ voor alle verbruikers toegepast. Deze verlaging was mogelijk door de relatief efficiënte bedrijfsvoering, het grote aandeel van steenkool als brandstof en door de import van stroom. Naast de wijze waarop de tarieven werden gesteld was ook de restitutie-regeling voor grote stroomverbruikers, die was ingesteld door de overheid, van belang. In verband met de, op grond van budgettaire redenen van de overheid, grotere inzet van aardgas en de moeilijke positie van de grootverbruikers kregen per 1 juli 1982 bedrijven die meer dan 30 miljoen $\mathbf{k W h}$ per jaar gebruikten met een bedrijfstijd van tenminste 4500 uur, een voordeel van rond 4 cent per kWh. In 1983 kwamen bijvoorbeeld 17 bedrijven in Limburg hiervoor in aanmerking. $\mathrm{Zij}$ ontvingen in totaal F. 61,5 miljoen aan restitutie. Deze regelling gold tot medio 1987.939 Gezien de daling van de Nederlandse elektriciteitstarieven onder die van andere Europese landen werd continuering van de maatregel niet nodig geacht. Eén en ander leidde er in combinatie met de reorganisatie in de elektriciteitssector toe dat de tarieven van de PLEM bij de kleinverbruikers en bij de grootverbruikers met de tarieven van enige andere elektriciteitsbedrijven tot de laagste van Nederland behoorden. Dit ondanks de tariefverhoging per $1 \mathrm{mei} 1987$, die het gevolg was van de invoering van het Landelijk Basistarief (LBT). ${ }^{940}$

Het voordeel voor de provincie Limburg kan als volgt worden weergegeven. De Regionale Toeslagen voor de 4 elektriciteitsproductiebedrijwen in 1989 waren:

$\begin{array}{ll}\text {-EPON } & \text { F. } 36,0 \text { per } \mathrm{kW} \\ \text {-EPZ } & \text { F. } 23,5 \text { per } \mathrm{kW} \\ \text {-EZH } & \text { F. } 36,0 \text { per } \mathrm{kW} \\ \text {-UNA } & \text { F. } 41,5 \text { per } \mathrm{kW}\end{array}$

Bij een belasting van de provincie Limburg van 850.000 a $900.000 \mathrm{~kW}$ leverde dit een kostenvoordeel voor Limburg ten opzichte van andere provincies op van $F$. 11 à 16 miljoen per jaar. De PLEM stelde zich ten doel dit lage prijspeil te behouden, hetgeen zij kon bewerkstelligen door haar invloed in EPZ. Door de lage prijzen van EPZ behoorden de eindverbruikerstarieven van de PLEM tot de laagste van Nederland. Ten opzichte van het landelijk gemiddelde bedroeg het voordeel per categorie:

\section{Grootwerbruik $500 \mathrm{~kW} \quad 2500$ uur: 1 cent/kWh goedkoper (ongeveer $8 \%$ ) \\ 2. Grootwerbruilk $1000 \mathrm{~kW} 4000$ uur: $0,5 \mathrm{ct} / \mathrm{kWh}$ goedkoper (ongeveer $5 \%$ ) \\ 3. Kleinverbruik $3000 \mathrm{kWh} \quad: 0,7 \mathrm{ct.kWh}$ goedkoper (ongeveer $4 \%$ )}

Bij de berekening van het bedrag van F. 11 tot 16 miljoen moet wel in gedachten worden gehouden dat de PLEM de tarieven boven de marginale kosten stelde. In die zin was er geen sprake van lage tarieven. Slechts vergeleken met andere distributiebedrijwen waren de tarieven van de PLEM laag. In paragraaf 16.12 .1 wordt nader ingegaan op de vraag wat de kosten van dit doel waren. Opvallend is dat de VEEN constateerde dat kleinverbruikers in een aantal gevallen werden gesubsidieerd. Daarom zouden er kostenver-

\footnotetext{
999 Algemene Vergadering van Aandeelhouders, Notulen, 20 juni 1984, p. 7, vergelijk ook PLEM, Jaarverslaz over 1983, 1984, p. 10.

940 Algemene Vergadering van Aandeelhouders, Notulen, 21 juni 1989, p. 4.

94. EPON (NV Elektriciteits-Maatschappij Oost-Nederland), EZH (NV Elektriciteitsbedrijf Zuid-Holland), UNA (NV Energieprođuktiebedrijf U.N.A.)
} 
schuivingen moeten plaatsvinden van kleinverbruikers naar grootverbruikers. De Minister van Economische Zaken was het hier in principe mee eens. De kosten gemaakt voor een verbruikersgroep moesten worden goedgemaakt in de tarieven voor die groep. De centrale doelstelling met betrekking tot de tarieven was zoals eerder opgemerkt dan ook vooral het zo laag mogelijk houden hiervan.

\section{Zekerheid van de elektriciteitsvoorziening}

Dit doel speelde vooral in de jaren zeventig. Door de oliecrisis bleek de kwetsbaarheid van de Nederlandse elektriciteits- en (meer algemeen) energievoorziening. Daarbij speelde vooral de overschakeling op aardgas een rol. De PLEM duidde het aardgasbeleid van de overheid evenwel aan als grillig. ${ }^{942}$. In het begin van de jaren zeventig werd het gebruik van aardgas voor de opwekking van elektriciteit gestimuleerd. In verband met de verminderde economische bedrijvigheid en de energiecrisis heeft de Minister van Economische Zaken in 1974 een energienota opgesteld. De nota beoogde enerzijds de afremming van de groei van het energieverbruik en anderzijds het vergroten van de zekerheid van de energievoorziening. In verband met de situatie in Iran werd gewezen op de noodzaak tot beperking van het energieverbruik. ${ }^{943}$ In de tweede helft van de jaren zeventig werd een aardgasstop-op-termijn voor elektriciteitscentrales afgekondigd. Tot 1985 werd een daling van het aardgasverbruik beoogd. De PLEM was het in grote lijnen eens met deze Energienota maar plaatste wel kanttekeningen bij de beoogde grote afhankelijkheid van aardolie $(52 \%)$ in 1985 en bepleitte de bouw van een drietal kernenergiecentales van elk 1000 Megawatt (MW). Daarnaast was energiebesparing van belang, enerzijds te realiseren door elektriciteitsprijsstijging en anderzijds door voorlichting. Nog meer nadruk moest worden gelegd op rendementsverbetering. Het brandstofinzetplan (BIPC) diende zo goed mogelijk in deze bezuiniging op aardgas te voorzien. Vlak na de inwerkingtreding van het plan moesten de elektriciteitscentrales, voornamelijk vanwege budgettaire redenen van de Rijksoverheid, juist weer meer aardgas gebruiken. Besloten werd dat verschillende centrales in Nederland zouden worden omgebouwd op kolen waaronder de Maascentrale. Vooruitlopend op de landelijke pooling kwamen de kosten en baten hiervan voor rekening van alle S.E.P.-deelnemers. De reden voor deze overschakeling op het stoken van kolen was vooral gelegen in het kostenaspect (elektriciteit opgewekt met kolen is goedkoper dan met olie en gas) en minder in het veiligstellen van de elektriciteitsopwekking door diversificatie, hoewel dit wel een rol speelde. In het TESIN-tapport dat de elektriciteitsbedrijven ter voorbereiding van de Maatschappelijke Discussie Energie hebben gepubliceerd werd gesteld dat economische gevolgen, zekerstelling van de energievoorziening en de gevolgen voor het milieu een rol moeten spelen. In de begin 1982 verschenen nota "Visie op het energiebeleid" gaf de Vereniging voor Directeuren van Elektriciteitsbedrijven in Nederland (VDEN) aan dat het beleid onder andere gebaseerd diende te zijn op de beperking van de vraag naar energie en de spreiding van de brandstoffen waarbij olie/gas, kolen en uraan ieder een gelijk deel voor hun rekening dienden te nemen. Dit beleid diende niet alleen ter vergroting van de zekerheid van de elektriciteitsvoorziening maar ook ter bereiking van eerder genoemde doelen als de vergroting van de werkgelegenheid en de versterking van de economie.

\footnotetext{
942 N.V. Provincialle Limburgse Elektriciteitsmaatschappij, Jaarverslag over 1983, 1984, pp. 10-13.

943 N.V. Provinciale Limburgse Elektriciteitsmaatschappij, Jaarverslag over 1978, 1979, p. 9.
} 


\section{Continue levering}

Dit doel was gedurende de onderzoeksperiode en zeker in de jaren zeventig landelijk gezien en ook voor de PLEM éen van de belangrijkste doelen. In het jaarverslag over 1992 werd gesteld: De belangrijkste primaire taak van MEGA Limburg is het bieden van een veilige en zo mogelijk ongestoorde levering van gas en elektriciteit". ${ }^{44}$ Belangrijk daarbij was de grote onzekerheid met name in de jaren tachtig over de toekomstige vraag naar elektriciteit. Prognoses uit het begin van de jaren zeventig moesten herhaaldelijk naar beneden worden bijgesteld. Dit werd vooral veroorzaakt door de tegenvallende economische groei, de sterke stijging van de brandstofprijzen en het grotere belang dat werd toegekend aan elektriciteitsbesparing en aan het milieu. De Minister van Economische Zaken gaf in zijn brief van 17 juli 1978 aan de Tweede Kamer bijvoorbeeld aan dat voor het garanderen van een continue levering van elektriciteit vanaf eind jaren tachtig vrijwel het gehele Nederlandse productievermogen van 14.500 Megawatt (MW) vervangen zou moeten worden. Dit bleek in de praktijk mee te vallen door de verlenging van de gebruiksduur van de centrales. $\mathrm{Om}$ een continue levering te kunnen waarborgen werd de mogelijkheid van kernenergie benadrukt. Het kabinet volgde in dit verband het advies van de Voorlopige Algemene Energieraad voor het houden van een "brede maatschappelijke discussie" over kernenergie. Een en ander leidde er toe dat in de jaren tachtig landelijk een aanzienlijke overcapaciteit bestond. Het bestaan van deze overcapaciteit werd vaak niet als zodanig erkend. Zij zou gerechtvaardigd zijn gezien het grote belang van een gegarandeerde levering van elektriciteit en de onzekere ontwikkeling van de toekomstige vraag. Om storingen zoveel mogelijk tegen te gaan was er een storingsdienst. Na 1990 werden de storingsdiensten van de PLEM en Limagas samengevoegd. Eind 1992 werd deze geïntegreerde dienst operationeel.

Schoon leefmilieu: het verwerken van afval en het verminderen van schadeliike productieprocessen

Voor de rechtstreeks geloosde stoffen golden speciale regelingen zoals vastgelegd in de hinderwet- en lozingsvergunningen. De storting en verwerking van bedrijfsafval door derden was geregeld in de Regeling voor de afvoer van afval via derden.445 Hierbij werd onderscheid gemaakt tussen enerzijds chemische afvalstoffen en afgewerkte oliën, waarop de Wet chemische afvalstoffen van toepassing was, en anderzijds het huishoudelijke en industriele afval van de PLEM. De regeling bepaalde dat elke afdeling in principe zelf verantwoordelijk was voor de interne verzameling, opslag en verpakking van bij haar werkzaamheden vrijgekomen afvalstoffen. ${ }^{946}$ Pas indien de stoffen werden overgedragen aan een andere daartoe bevoegde afdeling of aan het afnemende bedrijf eindigde deze verantwoordelijkheid. De inzameling, verwerking, e.d. per afdeling vindt plaats aan de hand van werkinstructies, terwijl de afdeling Inkoop de commerciële kant van de afvoer van de afvalstoffen behartigde. Zij zorgde, in overleg met de afvoerende afdeling, voor de contracten met de afnemers en controleerde of de afnemer bevoegd was om de afvalstoffen in ontvangst te nemen. De veiligheidsdienst adviseerde aan de afdelingen met betrekking tot de veiligheidsaspecten van de afvoer van de afvalstoffen. De Regeling afvoer van afval via derden was niet van toepassing op vliegas. Voor de verwerking van

\footnotetext{
MEG MA Limburg, Jaarverslag over 1992, 1993, p. 31.

945 N.V. PLEM, Regeling voor de afvoer wan afval via derden, 4 juli 1986.

246 T.a.p., artikel 2
} 
deze stoffen bestond rechtstreeks contact tussen de afdeling Bedrijfswoering Centrales en de Vliegasunie. ${ }^{947}$

Zoals bij veel bedrijven ontbrak eind jaren tachtig bij de PLEM een integrale millieuzorg die alle milieufacetten en bedrijfsonderdelen omvatte. Op grond van een door het Ministerie van VROM opgestelde Nota Bedrijfsinterne Milieuzorg moeten grote bedrijven zoals de PLEM, die een bepaald extra risico voor het milleu vormen, in 1995 beschikken over een integraal intem milieuzorgsysteem. ${ }^{948}$ Medio 1993 werd daartoe een commissie ingesteld die tot taak had de bedrijfsinterne afvalstromen te inventariseren. Deze commissie moest er voor zorgen dat Limburg vanaf 1995 overeenkomstig de Nota van het Ministerie van VROM, de beschikking heeft over een Bedrijfsintern Milieuzorgsysteem (BIM). Hierin zijn maatregelen op het gebied van energiebesparing en energiebeheer door de PLEM uitgewerkt. Verder wordt hierin aandacht besteed aan de vermindering van de negatieve effecten op het milieu van het productieproces van de PLEM. Het gaat hierbij vooral om het gebruik van allerlei altematieve materialen en om de inzameling en verwerking van gebruikte kabels, transformatorolie en lampen. Tenslotte kan het bedrijfsleven begeleid worden bij de invoering van dergelijke systemen In dit verband werd gesteld: "De milieuzorg moet dus geintegreerd worden in de bedrijssvoering, met interne voorlichting, opleiding en controles, met interne en externe rapportage en periodieke doorlichting wan het systeem (de milieu-audit) ".949

\section{Veiligheid}

Elektriciteitsproductie- en ook -distributiebedrijven moeten voldoen aan strenge veiligheidsvoorschriften. Veelal wordt aan deze eisen voldaan en wordt het niet nodig geacht specifiek aandacht te besteden aan de veiligheid. In jaarverslagen en vergaderingen van bijvoorbeeld de Raad van Commissarissen werd hier dan ook weinig aandacht aan besteed. Pas indien er zich een situatie voordeed waarbij de veiligheid in gevaar werd gebracht kreeg dit doel weer hoge prioriteit. De PLEM controleerde de installaties en leidingen aangezien deze na verloop van tijd vervangen moeten worden.

Bepaalde installaties en leidingen hebben een gegeven afschrijvingsduur. In dit verband werd in 1991 bijwoorbeeld vastgesteld, dat de 35 jaar oude schakelinstallatie van Lutterade niet meer voldeed aan de eisen op het gebied van betrouwbaarheid, hetgeen reden was deze te vervangen. Na 1990 had MEGA Limburg ook een lekzoekdienst. De werknemers bij deze dienst controleren jaarlijks een gedeelte van het gasnet, teneinde eventuele gaslekken en zwakke plekken op te sporen. In 1990 is door deze dienst ongeveer 1572 kilometer gecontroleerd.

\subsection{Wat zijn de kosten van de doelen van de NV PLEM?}

De kosten kunnen worden onderscheiden in een tweetal categorieen, namelijk:

1) kosten elektriciteitsproductie

2) public enterprise rent

947 T.a.p., artikel 7.

948 Management Team, 794, Bedrijfsinterme Milieuzarg; 28-11-1989, p. I.

949 T.a.p., p. 1. 
Een gedeelte van de gederfde winst wordt gevormd door de kosten van de elektriciteitsproductie, zoals vermeld in de jaarrekening van de PLEM. Een ander gedeelte van de public enterprise rent" bestaat uit lagere opbrengsten, bijvoorbeeld door het rekenen van gunstige tarieven voor het Limburgse bedrijfsleven.

\subsubsection{De kosten van de elektriciteitsproductie}

Ten aanzien van de kosten van de PIEM wordt uitgegaan van 1989 omdat de PLEM in 1990 gefuseerd is met Limagas, waardoor de kosten in dat jaar grote veranderingen laten zien. De kosten van de N.V. PLEM bestonden in 1989 uit de kosten van de inkoop en van de eigen opwekking van elektriciteit, de personeelskosten, de afschrijvingen en de kosten uit besteed werk, materialen en andere externe kosten.

Met de inkoop van 6.391.373 MWh elektriciteit, grotendeels van EPZ, was in 1989 een bedrag van F. 496.148,000,- gemoeid. 950 De kosten van uitbesteed werk, materiaalkosten en andere externe kosten bedroegen $\mathrm{F}, 37.103 .000,-$. De personeelskosten bedroegen F. $76.916 .000,-$ Er werd voor een bedrag van F. 65.549.000,- afgeschreven. Deze afschrijvingen kwamen als volgt tot stand:

Afschrijving op basis van vervaardigingsprijs: $\quad$ F. 53.864 .000 ,Aanvullende afschrijvingen tot actuele waarde: F. 15.369.000,-

Vrijgevallen bijdragen:

Afschrijving immateriele vaste activa:
F. 69.233.000,-

F. $5.459 .000,-$

F. 1.775:000,-

F. $65.549,000$,

De kosten van de bijdragen aan de KEMA en de VEEN waren per saldo

F. 6.975.000,-. De totale door de PLEM in 1989 gemaakte kosten bedroegen derhalve F. 682.691.000,-

\subsubsection{De bepaling van de "public enterprise rent"}

Zoals reeds vermeld in paragraaf 15.2 .3 is de "public enterprise rent" gelijk aan het verschil tussen de feitelijke winst en het obligatierendement op het eigen vermogen van een overheidsinstelling. Het eigen vermogen per 31-12-1989 bedroeg F. 719.846.000,Uitgaande van een obligatierendement op staatsleningen van $7,21 \%$ en een winst van F. 19,9 miljoen" $^{951}$, is de "public enterprise rent" gelijk aan F. 32.000 897,--. Rekenen we de voorzieningen ook tot het eigen vermogen dan bedraagt de "public enterprise rent" F. $40.854 .200,-$

\footnotetext{
950 N. V. Provinciale Limburgse elektriciteitsmaatschappij, Jaarverslag over 1989,1990 , p. 24 e. ...

951 In de analyse is uitgegaan van het netto-bedrijfsresultaat zoals vermeld in de vennootschappelijke winsten veriliesrekening over 1989 .
} 


\begin{tabular}{|c|c|c|c|c|c|c|}
\hline Jaar & $\begin{array}{l}\text { Rendement } \\
\text { op } \\
\text { staats- } \\
\text { obligaties }\end{array}$ & $\begin{array}{l}\text { Winst van } \\
\text { de NV } \\
\text { PLEM }\end{array}$ & $\begin{array}{l}\text { Eigen } \\
\text { Vermogen }\end{array}$ & $\begin{array}{l}\text { Public } \\
\text { Enterprise } \\
\text { rent (1) }\end{array}$ & $\begin{array}{l}\text { Eigen } \\
\text { vermogen inclu- } \\
\text { sief aanvullende } \\
\text { reserves }\end{array}$ & $\begin{array}{l}\text { Public } \\
\text { enterpri- } \\
\text { se rent } \\
\text { (2) }\end{array}$ \\
\hline 1970 & $8,01 \%$ & 1,6 & 73,72 & 4,3 & 87,3 & 5,39 \\
\hline 1974 & $9,82 \%$ & -1 & 107,9 & 11,6 & 132,7 & 14,0 \\
\hline 1978 & $7,74 \%$ & 14,8 & 438,1 & 19,1 & 482,0 & 22,5 \\
\hline 1980 & $10,21 \%$ & $-5,6$ & 490,8 & 55,7 & 544,4 & 61,2 \\
\hline 1981 & $11,56 \%$ & 6,6 & 530,6 & 54,7 & 584,5 & 61,0 \\
\hline 1982 & $10,08 \%$ & 14 & 585,5 & 45,0 & 638,0 & 50,3 \\
\hline 1983 & $8,61 \%$ & 14,8 & 611,4 & 37,8 & 669,0 & 42,8 \\
\hline 1984 & $8,16 \%$ & 13,1 & 608.7 & 36,6 & 664,1 & 41,1 \\
\hline 1985 & $7,34 \%$ & 14,5 & 636.9 & 32,2 & 759,8 & 41,3 \\
\hline 1986 & $6,35 \%$ & 3,6 & 648.9 & 37,6 & 795,6 & 46,9 \\
\hline $\begin{array}{l}1987 \\
*\end{array}$ & $6,39 \%$ & 13 & 653.4 & 40,5 & 748,7 & 46,5 . \\
\hline $\begin{array}{l}1988 \\
*\end{array}$ & $6,35 \%$ & 9,8 & 671.9 & 32,8 & 771,4 & 39,2 \\
\hline 1989 & $7,21 \%$ & 19,9 & 719.8 & 32.0 & 842,6 & 40,9 \\
\hline $\begin{array}{l}1990 \\
*\end{array}$ & $8,93 \%$ & 28,4 & 857.0 & 48,1 & $1.098,2$ & 69,7 \\
\hline 1991 & $8,74 \%$ & 22,6 & 863.6 & 52,9 & $1.130,9$ & 76,2 \\
\hline 1992 & $8,10 \%$ & 12,2 & 859.7 & 57,4 & $1.125,4$ & 79,0 \\
\hline
\end{tabular}

bedragen in miljoenen guldens

* Winst exclusief de winst van EPZ

Tabel 16.11 De "public enterprise rent"

Over 1989 waren de geschatte kosten respectievelijk:
1) Kosten elektriciteits- en gasdistributie:
F. 682.691.000,-
2) "Public Enterprise Rent":
F. $40.854 .200,-$

Hierbij dient bedacht te worden dat, zoals in het begin van de vorige paragraaf reeds is aangegeven, deze twee kosten niet bij elkaar opgeteld kunnen worden omdat ze elkaar gedeeltelijk overlappen. 
16.11 Wat is het relatieve belang van de doelen: een analyse van de wisselwerking tussen de eigen verklaring van de NV PLEM voor zijn "performance" en de reactie van de principalen op deze verklaring

\subsubsection{Een analyse van de benoemingen van personen in toezichthoudende instanties en in het management van de NV PLEM.}

Uit de benoemingen van personen in de Raad van Commissarissen en in de Directie blijken geen conflicterende belangen en doelen. Gedurende de onderzoeksperiode werden regelmatig vacante plaatsen in de Raad van Commissarissen opgevuld. De Algemene Vergadering heeft bet recht een aanbeveling te doen maar heeft hier vrijwel nooit gebruik van gemaakt. In de notulen van de Algemene Vergadering van Aandeelhouders gehouden op 12 juni 1990, werd bijvoorbeeld aangegeven dat een aantal plaatsen in de Raad van Commissarissen vacant kwamen in verband met periodiek aftreden van twee gewone leden en één door de Gedeputeerde Staten van Limburg aangewezen lid. De Algemene Vergadering maakte geen gebruik van haar recht tot het doen van een aanbeveling voor deze vacatures en maakte geen bezwaar tegen de herbenoeming van de twee commissarissen door de Raad van Commissarissen en tegen de herbenoeming van de commissaris door Gedeputeerde Staten. Uit de notulen van de Algemene Vergadering van Aandeelhouders blijkt dat dit gedurende de onderzoeksperiode vrijwel steeds het geval was. ${ }^{952}$ De Algemene Vergadering van Aandeelhouders oordeelde veelal positief over de samenwerking met de Directie en met de Raad van Commissarissen. Bij de Buitengewone, Vergadering van Aandeelhouders gehouden op 6 juli 1990, waarbij ingestemd werd met de aandelenfusie van Limagas en PLEM en de totstandkoming van het Energiebedrijf Limburg (EBL, de voorloper van MEGA Limburg) waarbij de PLEM voorlopig nog zou functioneren als werknaatschappij van EBL en uiteindelijk zou ophouden te bestaan, werd bijvoorbeeld gesteld: "De voorzitter spreekt veel waardering en lof uit voor het voortreffelijk werk van de PLEM in het belang van de samenleving "., terwijl namens de provincie werd opgemerkt: "(De vertegenwoordiger van de provincie Limburg JFK) dankt Raad van Commissarissen, directie en medewerkers voor de voortreffelijke wijze waarop zij de energievoorziening hebben gediend". ${ }^{53}$ :

Ook de door de provincie benoemde commissarissen werden over het algemeen herbenoemd. Er deden zich bij de benoeming van deze door de provincie benoemde commissarissen wel meer wijzigingen voor. Deze hadden vooral te maken met veranderingen in de samenstelling van Provinciale Staten ten gevolge van verkiezingen, bijvoorbeeld ondat commissarissen niet herkozen werden als lid van de Provinciale Staten. In 1987 deelden de Gedeputeerde Staten bijvoorbeeld mee aan de Algemene Vergadering van de PLEM dat drie leden niet langer deel zouden uitmaken van de Raad van Commissarissen "in verband met de gewijzigde samenstelling van Provinciale Statem. Drie nieuwe leden werden voorgesteld. ${ }^{954}$

\footnotetext{
952 Vergelijk de notulen van de algemene vergaderingen, gehouden gedurende de jaren zeventig en tachtig, bijvoorbeeld op 25 augustus 1970,13 juni 1975, 23 juni 1976, 14 juni 1977, 16 april 1981, 25 juni 1982, 15 juni 1983, 20 juni 1984, 19 juni 1985, 23 december 1986,17 jumi 1987, 22 juni 1988, 21 juni 1989 en de notulen van de buitengewone algemene vergadering van aandeelhouders gehouden op 6 jull 1990 .
}

953 Buitengewone Vergadering van Aandeelhouders van de PLEM, Notulen, 6 juli 1990, gehouden te Maastricht.

954 Voorzitter Gedeputeerde Staten van Limburg, brief aan de Algemene Vergadering van Aandeelhouders van de PLEM, BQ 6275, Vacatures Raad van Commissarissen, 13 mei 1987. 
Ook uit de benoemingen van personen in de Directie zijn geen aanwijzingen gevonden van uiteenlopende doelen. Wel kon de pensionering van een directeur voor de Raad van Commissarissen een reden zijn de organisatiestructuur van de Directie te heroverwegen, vaak in verband met eerder uitgevoerde reorganisatie-onderzoeken. In werband met het bereiken van de pensioengerechtigde leeftijd van de technisch directeur per 1 juli 1981 bijvoorbeeld, heeft de Raad wan Commissarissen zich bezig gehouden met de Directiestructurur van de PLEM.

\subsubsection{Een analyse van de expliciete beleidswijzigingen en verschuivingen in doelen tussen de verschillende actoren}

De verandering in de doelen van de eigenaren van de PLEM liep parallel met de verandering in het belang van de doelen, zoals die gedurende de periode in de jaarverslagen en andere officiële documenten werden vermeld. $\mathrm{Al}$ in de jaren zeventig rees de vraag of de organisatie op een aantal punten gewijzigd moest worden. In 1981 werd overleg gevoerd door een commissie uit de Raad van Commissarissen met de Directie, staf en ondernemingsraad over de door de Raad gewenste structuurwijzigingen. Hierbij werd teruggegrepen op het door Moret en Limperg eind jaren zeventig gehouden organisatie-onderzoek. Meer in het bijzonder werd gewerkt aan de taakverdeling van de Directie. Door de Directie werden voortbouwend op de nota "Een aanzet tot de systematische ontwikkeling van het sociaal beleid bij de NV PLEM", een aantal beleidswoorstellen voorbereid en verder werd een aanzet gegeven om te komen tot een eigentijdse stijl van leidinggeven. ${ }^{955}$ Gecombineerd met de in 1982 vastgestelde beleidsnota van de Directie met betrekking tot de topstructuur leidde dit in 1983 tot een aantal belangrijke wijzigingen in die structuur Door de invoering van het sectoroverleg in de drie bedrijfssectoren Productie, Voortgeleiding en Economische Zaken werd de communicatiestructuur verbeterd. Ook de organisatiestructuur van de sector Productie werd aangepast. Een aantal reorganisatieprocessen werden in het kader van de nota ter hand genomen. Doel was de efficiëntie in de organisatie te verbeteren. Per 1 januari 1984 zijn naast de twee statutaire directeuren drie bedrijfsdirecteuren benoemd voor Economie, Voortgeleiding en Productie. In 1985 verlieten een tweetal directeuren de PLEM (in verband met VUT en ziekte). Naar aanleiding hiervan is door de Raad van Commissarissen besloten een driehoofdige statutaire Directie in te stellen. Zoals in paragraaf 16.3.3. beschreven is, is de organisatie van de PLEM eind jaren tachtig op een aantal punten veranderd. Deze organisatieverandering impliceerde een verschuiving van de doelen. De voor de reorganisatie ten gevolge van het project Horizon bestaande organisatiecultuur werd wel omschreven als hiërarchisch, met zowel horizontaal als verticaal grote afstanden, met weinig onderlinge coördinatie en waarbij iedereen zijn eigen taakgebied had. Er bestond wel het streven de goedkoopste van Nederland te zijn, maar als monopolie van de elektriciteitsvoorziening lag de nadruk vooral ook op zekerheid en continuitteit van de elektriciteitsvoorziening. Er werd in het algemeen niet erg kritisch op de kosten gelet. Deze organisatieculturur weerspiegelde enerzijds duidelijke verhoudingen, anderzijds werden vernieuwingen er door tegengehouden. De organisatie was weinig klantgericht. De reorganisatie eind jaren tachtig beoogde dit te veranderen. De klant moest snel antwoord krijgen, de organisatie moest flexibeler en efficiënter worden. Centraal staat wat de klant van de PLEM verwacht. Goede voorlichting en milieubewustzijn zijn ook van belang. Uit onderzoek naar het beeld van de klanten van de PLEM, bleek dat zij redelijk tevreden waren over de mate van serviceverlening. De vraag voor de PLEM was dan ook hoe deze dienstverle-

\footnotetext{
955 N.V. PLEM, Een aanzet tot de systematische ontwikkeling van het sociaal beleid bii de NV PLEM, juni 1978 , p. 3 e.v.
} 
ning van de PLEM efficiënter geraliseerd kon worden. Daartoe werden zoals beschreven in paragraaf 16.3.3 de drie sectoren die vaak naast en tegen elkaar inwerkten, opgeheven en werd de communicatiestructuur vereenvoudigd. Hierdoor moeten competentieverschillen tussen techniek en commercie/economie tot het verleden behoorden. Uit het opnemen van het marketingbeleid in het hoofdaandachtsgebied van de Directie bleek het belang dat toegekend wordt aan klantgerichtheid. De invoering van budgettering geeft de Directie de gelegenheid meer de nadruk te leggen op efficiëntie. Door deze efficiëntie konden de tarieven laag gehouden worden. Met het nieuwe bureau voor Energie en Milieutechniek kan beter worden ingespeeld op nieuwe ontwikkelingen op milieugebied, zoals de invoering van warmtekrachtkoppeling, afvalverwerking e.d. Deze verschuiving in belangrijkheid van de doelen blijkt ook uit de doelen die genoemd worden in de jaarverslagen gedurende de onderzoeksperiode.

16.11.3 Analyse van impliciete beleidswijzigingen die niet publiekelijk werden bediscussieerd

\subsubsection{De ontwikkeling van de "public enterprise rent"}

Indien wordt gekeken naar de "public enterprise rent" van de PLEM als percentage van het nationale inkomen en van de totale overheidsuitgaven valt het volgende op:

\begin{tabular}{|l|l|l|l|l|l|l|l|l|l|}
\hline jaar & 1982 & 1983 & 1984 & 1985 & 1986 & 1987 & 1988 & 1989 & 1990 \\
\hline $\begin{array}{l}\text { Netto natio- } \\
\text { naal inkomen }\end{array}$ & 330,62 & 342,39 & 358,56 & 375,99 & 385,44 & 386,46 & 401,2 & 420,3 & 452,45 \\
\hline $\begin{array}{l}\text { "public en- } \\
\text { terprise rent" } \\
\text { van de } \\
\begin{array}{l}\text { PLEM uitge- } \\
\text { drukt in NNI }\end{array}\end{array}$ & 0,015 & 0,013 & 0,011 & 0,011 & 0,012 & 0,012 & 0,009 & 0,010 & 0,015 \\
\hline $\begin{array}{l}\text { "Public en- } \\
\text { terprise rent" } \\
\text { uitgedrukt in } \\
\text { totale over- } \\
\text { heidsuitgaven }\end{array}$ & 0,022 & 0,018 & 0,017 & 0,016 & 0,018 & 0,018 & 0,015 & 0,016 & 0,0246 \\
\hline $\begin{array}{l}\text { Totale over- } \\
\text { heidsuitgaven } \\
\text { in NNI }\end{array}$ & $69,3 \%$ & $70,3 \%$ & $68,7 \%$ & $67,3 \%$ & $67,1 \%$ & $66,4 \%$ & $66 \%$ & $62 \%$ & $62,5 \%$ \\
\hline
\end{tabular}

Tabel 16.12 De uitgaven voor cultuur, "public enterprise rent" en netto nationaal inkomen

Uit Tabel 16.12 blijkt dat de "public enterprise rent" uitgedrukt als percentage van het nationale inkomen gedurende de onderzoeksperiode afneemt en in 1990 weer toeneemt. Opvallend is dat de "public enterprise rent" uitgedrukt als percentage van de totale overheidsuitgaven eveneens daalt in het begin van de jaren tachtig en later weer toeneemt. Bij de toename in 1990 moet wel bedacht worden dat de PLEM in dat jaar fuseerde met Limagas, zodat een vertekend beeld ontstaat. Eén en ander impliceert dat de principalen gedurende de periode tot 1990 blijkbaar minder gewicht toekenden aan de door de PLEM 
gerealiseerde bijkomende doelen dan aan de met de overheidsuitgaven gerealiseerde doelen. Onder druk wan de economische situatie en de herijking van de overheidsuitgaven gedurende de jaren tachtig kiezen de principalen voor alternatieve bestedingsmogelijkheden. Net zoals bij het Rijksmuseum is er blijkbaar sprake van een impliciete beleidswijziging van de overheid. De Rijksoverheid beoogde, mede door de Elektriciteitswet van 1989, minder nadruk te leggen op doelen als continuïteit (monopolie e.d.), zekere levering van elektriciteit en werkgelegenheid dan in de jaren zeventig en meer op efficièntie en klantgerichtheid. Deze beleidswijziging en de OP grond daarvan door de overheid en de PLEM doorgevoerde reorganisatie van de elektriciteitsvoorziening, verklaren de relatieve daling van de "public enterprise rent".

\subsubsection{De ontwikkeling van het eigen vermogen}

De vermogenspositie van de PLEM laat de volgende ontwikkeling zien:

\begin{tabular}{|l|l||l|l|}
\hline 1970 & $10,4 \%$ & 1986 & $38 \%$ \\
\hline 1975 & $15,8 \%$ & 1987 & $41 \%$ \\
\hline 1980 & $27,4 \%$ & 1988 & $45,7 \%$ \\
\hline 1981 & $28,9 \%$ & 1989 & $42,2 \%$ \\
\hline 1982 & $33 \%$ & 1990 & 40,5 \\
\hline 1983 & $35 \%$ & 1991 & $38,4 \%$ \\
\hline 1984 & $36 \%$ & 1992 & $39,4 \%$ \\
\hline 1985 & $38 \%$ & & \\
\hline
\end{tabular}

\section{Tabel 16.13 De vermogenspositie van de PLEM (EV/VV)}

Gedurende de periode valt duidelijk op dat de verhouding eigen vermogen/vreemd vermogen na een daling in 1970 sterk toeneemt. Dit komt enerzijds door de wijziging in de toegepaste afschrijvingsmethode. In 1970 stelde de vertegenwoordiger van de gemeente Geleen: "(...)refereert aan de in het jaanerslag vermelde noodzaak tot verbetering van de vermogenspositie. Door de overgang tot afschrijving op vervangingswaarde wordt hieraan tegemoet gekomen, omdat het nu mogelijk wordt de normale vervangingsinvesteringen uit de afschrijuingen te financieren. In het kader van het streven naar verbetering van de vermogenspositie is de verhoging van het maximum dividend echter onlogisch, omdat daardoor een grotere claim van aandeelhouders op de winst wordt gelegd".957 Het doel om het eigen vermogen te vergroten betekende ook dat het van belang werd geacht een 956 Bron: N.V. PLEM, Jaaryersiagen over 1970-1990, met name jaarverslag over 1979, p. 51 , en over
1990 , p. 57 .

957 Algemene Vergadering van Aandeelhouders, Notulen, vergadering van 25 augustus 1970, p. 7. 
redelijk winstniveau te bereiken en anderzijds de dividenduitkering laag te houden:

Hierdoor kon het eigen vermogen gedurende de jaren zeventig en tachtig sterk toenemen. Deze toename van het recht op eigen vermogem (die zich dus feitelijk voordeed) impliceerde tevens het toenemende belang van het streven naar efficientie, aangezien zonder een behoorlijke efficiëntie een redelijk winstniveau moeilijk te bereiken was. Ook de samenstelling van de reservering weerspiegelde een wijziging van de doelen. De ingehouden winst werd voornamelijk toegevoegd aan de algemene reserve en diverse voorzieningen, waaronder in de jaren zeventig, het fonds ten behoeve van het opwekken van kernenergie. Doel was onder meer het bevorderen van de technologische ontwikkeling van Limburg. Later werd dit fonds opgeheven, dit weerspiegelde dat minder de nadruk werd gelegd op grootschalige productie door kerncentrales en meer op kleinschalige opwekking (ook noodgedwongen omdat de PLEM op grond van de Elektriciteitswet geen productiemaatschappij meer was), de bevordering van warmtekrachtkoppeling en elektriciteitsdistributie. Daarmee werd niet alleen de nadruk gelegd op de eigenlijke doelstelling (een continue en veilige energievoorziening) maar ook op het milieudoel.

\subsubsection{Zijn er verschillen tussen datgene wat de houders van eigendomsrechten in officièle documenten zeggen en datgene wat zij in werkelijkheid doen?}

Evenals in het vorige hoofdstuk kan een analyse van het gevoerde beleid gedurende de onderzoeksperiode inzicht geven in het verschil tussen datgene wat de eigenaren zeggen na te streven en hetgeen werkelijk is gebeurd.

\section{De periode 1970-1975}

Er kan een duidelijk onderscheid gemaakt worden tussen de Algemene Vergadering van Aandeelhouders en de Raad van Commissarissen als principaal en eigenaar en het management van het bedrijf als agent. Begin jaren zeventig werd geleidellijk de doelstelling van verbruiksstimulering verlaten. Verbruiksstimulering werd in verband met het milieu en de energievoorraden niet langer wenselijk geacht. De PLEM meende dat zolang er geen duidelijk beleid van de overheid was, het niet aan de elektriciteitsbedrijven was om maatregelen ter beperking van het elektriciteitsverbruik te nemen. Wel werd de verbruiksstimulering beperkt en werd meer de nadruk gelegd op service en voorlichting. Het bedrijf streefde naar een redelijk rendement op het eigen vermogen en dit rendement werd in 1973 onvoldoende geacht. Derhalve moesten naast strikte kostenbewaking de elektriciteitstarieven verhoogd worden. Meer voorlichting werd gegeven over een doelmatig en veilig gebruik van elektriciteit. In het Structuurschema elektriciteitsvoorziening 1975 werd bijgevolg de betekenis van de elektriciteitsvoorziening afgewogen tegen de effecten op milieu en ruimte.

In de periode 1970-1975 stegen de tarieven ter compensatie van de stijgingen van de brandstofprijzen. Het doel was het zich aanpassen aan de gewijzigde situatie op de brandstofmarkten en niet zo zeer het woeren van een wezenlijk ander beleid. Gezien het milieu en een stabiele elektriciteitsvoorziening werd kernenergie als een goed alternatief gezien. Hierwoor werden de nodige middelen gereserveerd. Aan het begin van de periode was de politiek in deze dezelfde mening toegedaan. Aan het einde van de periode neemt de politiek steeds meer afstand van kernenergie terwijl de PLEM en de SEP hier voorstander van blijven.

De periode $1976-1980$

De overheid, zijnde de principal, verhoogde het omzetbelastingstarief op gas van $4 \%$ tot 
18\%. Elektriciteit werd al met het hoge btw-tarief belast. Een van de redenen voor de overheid om een hoog btw-tarief toe te passen was dat de schaarste aan fossiele brandstoffen door deze belasting beter weerspiegeld werd. De PLEM meende dat het hier ging om een primaire levensbehoefte en dat het lage tarief dus meer voor de hand lag. De elektriciteitstarieven waren ten gevolge van de stijgende brandstofprijzen toch al sterk gestegen. Hoge btw-tarieven konden dan ook als aanvullende maatregelen gezien worden. De PLEM wees erop dat grootverbruikers door de stijging van de elektriciteitsprijzen nu slechter af waren dan in het buitenland. Waren deze in 1974 nog $15 \%$ lager dan in WestDuitsland, in 1977 zijn ze $25 \%$ hoger. Het gevolg is dat de productie door deze bedrijwen steeds meer naar het buitenland werd verlegd waar bedrijven konden beschikken over relatief goedkopere stroom wit bruinkool, kemenergie of goedkoop Nederlands aardgas. De PLEM riep daarom op of het standpunt inzake kernenergie te herzien of het aardgasbeleid te veranderen. Opvallend is dat de basistarieven voor groot- en klleinverbruikers vanaf 1975 lange tijd niet meer gewijzigd zijn.

Het Ministerie maakte bezwaar tegen de wijze van doorberekening. Bij stijgende brandstofiprijzen ontstaan volgens EZ te hoge additionele inkomsten voor elektriciteitsbedrijven. In overleg tussen het Ministerie en een delegatie van bedrijven werd uiteindelijk overeenstemming bereikt. De overheid wenste minder tariefstijging teneinde de prijzen voor elektriciteitsbedrijven relatief laag te houden. Dit is echter wel in strijd met de invoering van het hoge btw-tarief op elektriciteit in de jaren zeventig. De elektriciteitsbedrijven willen daarentegen met het oog op het winstniveau hogere prijzen. Voorts streefden zij aan het eind van de periode zo veel mogelijk naar kostenmatiging.

Het management van de PLEM benadrukte dat de elektriciteitsbedrijven de verantwoordelijkheid hebben voor de zekerheid van de voorziening en de efficiëntie van de bedrijfsvoering. Daamaast hebben andere instanties andere belangen die zij kunnen inbrengen. De overheid diende tenslotte de verschillende belangen tegen elkaar af te wegen. Op grond van deze belangenafweging bepaalde zij het energiebeleid. De overheid als principaal zal derhalve niet alleen op de efficiëntie en zekerheid van de voorziening letten maar ook op bijkomende doelen zoals bijwoorbeeld de milieuaspecten en de maatschappelijke aanvaardbaarheid. De PLEM constateerde dat door deze belangenafweging de invloed van de elektriciteitsbedrijven meer beperkt was. Het nutskarakter van de PLEM maakte evenwel dat ook zij zich bezig hield met bijkomende doelen zoals het geven van voorlichting over en het bevorderen van energiebesparing (door middel van voorlichting, een isolatieprogramma e.d.). Hoewel dit bedrijfseconomisch ongewenst was wordt hier toch voor gekozen omdat het maatschappelijke belang zwaarder woog dan het bedrijfseconomische belang. Door verhoogde bedrijfsefficiëntie moest de balans in evenwicht gehouden worden. Daarnaast werd op vrijwillige basis gewerkt aan het beter garanderen van de leveringszekerheid van elektriciteit door reorganisatie van de elektriciteitssector.

\section{De periode $1981-1985$}

Een belangrijke ontwikkeling sinds 1970 was de sterke toename van de brandstofkosten. Het elektriciteitstarief bestond in 1981 inmiddels voor $80 \%$ uit brandstofkosten en voor $20 \%$ uit vaste kosten. Hiermee leek ook het belang van schaalvoordelen en dalende gemiddelde kosten (het natuirlijk monopolie-argument) van minder belang te zijn geworden. Dit bevestigde de eerder vermelde redenen voor het bestaan van de PLEM. De PLEM kan gezien worden als een door de overheid ingesteld provinciaal monopolie. De redenen voor het instellen van een dergelijk monopolie hielden naast het beperkt houden van de winsten vooral verband met een public choice-proces. Met de gederfde winst werden bijkomende doelen nagestreefd zoals bevordering van de economische ontwikkeling van de regio Limburg en het bevorderen van energiebesparing. 
Ten aanzien van de reorganisatie van de energievoorziening in Nederland stelde de overheid zich op het standpunt dat er niet alleen een landelijk productiebedrijf diende te komen maar ook meer overheidsbemoelenis. De elektriciteitsbedrijven waren hier niet voor en wilden daarentegen de samenwerking in het kader van de SEP intensiveren De plannen van de Minister zouden er toe leiden dat de elektriciteitsbedrijven hun zelfstandig voortbestaan zouden verliezen. Dit standpunt werd midden jaren tachtig door de regering verlaten. Voorgesteld werd het aantal bedrijven aanzienlijk terug te brengen. Door wijzigingen in de organisatiestructuur die leiden tot centralisatie zouden de afzonderlijke bedrijven waaronder de PLEM minder in staat zijn bijkomende doelen na te streven. Daar staat tegenover dat een aantal van deze doelen door de SEP als geheel kan worden nagestreefd. Ook binnen de PLEM ontstond er verschil van mening over de reorganisatie van de bedrijfstak. De PLEM verwachtte dat een vergaand systeem van pooling van productiekosten en centralisatie voor de regio Limburg zou leiden tot hogere tarieven, aangezien de PLEM vrijwel de laagste tarieven van Nederland hanteende. Daarom stelt zij zich op het standpunt dat de zelfstandigheid van de afzonderlijke elektriciteitsbedrijven zo weinig mogelijk ingeperkt moest worden. Binnen de PLEM werd een compromis bereikt. Dit akkoord was door de ontwikkelingen in de politiek echter meteen al achterhaald.

Een andere belangrijke ontwikkeling sinds het begin van de jaren zeventig betrof de vermuiming van de winstuitkering aan de aandeelhouders, onder andere door verhoging van het aandelenkapitaal tot F. 35 miljoen. Het recht op vruchtgebruik komt daardoor meer nadrukkelijk toe aan de aandeelhouders, hoewel de dividenduitkering laag bleef. Aan het einde van de periode 1981-1985 werd de zelfstandigheid van de PLEM geleidelijk verminderd. Uitbreiding van het productievermogen werd voortaan expliciet geregeld door de SEP.

\section{De periode $1986-1990$}

De elektriciteitsbedrijven waaronder de PLEM probeerden onder druk van de politiek op vrijwillige basis te komen tot schaalvergroting van de productie en samenbundeling van de distributie van elektriciteit, gas en warmte (horizontale integratie). De Minister van EZ beoogde met het ontwerp van een nieuwe Elektriciteitswet zijn invloed op de elektriciteitsvoorziening aanzienlijk te vergroten. De elektriciteitsbedrijven waren hier fel tegen aangezien het zal leiden tot een algehele pooling van productiekosten, die zoals hiervoor gemeld, volgens de PLEM sterk kostenverhogend zou zijn. Bovendien zou de zelfstandigheid van de elektriciteitsbedrijven belangrijk beperkt worden. In een aantal in de vorige paragrafen genoemde stappen werd de elektriciteitssector in Nederland gereorganiseerd. Het doel van de horizontale integratie was de efficientie en de dienstverlening aan hat publiek te vergroten. Voorts werd het takenpakket van het in 1990 opgerichte energiebedrijf verbreed, waaronder energiebesparing, communicatiesystemen, milieubeheer. Op 6 juli 1990 vond de fusie plaats tussen PLEM en Limagas. Belangrijke doelen zijn klantgerichtheid, goede energievoorziening voor de provincie Limburg, milieu en energiebesparing.

\section{Conclusie}

De beschrijving van het werkelijk gevoerde beleid maakt duidelijk dat er een verschil bestaat tussen datgene wat de politieke actoren zeggen na te streven en datgene wat zij in de praktijk doen. Einde jaren zeventig stond de nutsfunctie centraal. Elektriciteitsbedrijven zijn nutsbedrijven die op grond van hun monopoliepositie verantwoordelijk zijn voor de toename van de welvaart en een continue en zekere levering van elektriciteit. 
In de jaren tachtig wordt het belang van de doelen die met de "public enterprise rent" worden nagestreefd minder, zonder dat dit in officiële documenten als zodanig wordt gesteld. Dit blijkt ook uit de ontwikkeling van de "public enterprise rent" uitgedrukt alls percentage van het eigen vermogen.

\begin{tabular}{|l|l|l|l|}
\hline jaar & $\begin{array}{l}\text { "public enterprise } \\
\text { rent" als } \\
\text { percentage van het } \\
\text { eigen vermogen }\end{array}$ & jaar & $\begin{array}{l}\text { "public enterprise } \\
\text { rent" als percentage } \\
\text { van het eigen } \\
\text { vermogen }\end{array}$ \\
\hline 1979 & $7,1 \%$ & 1985 & $5 \%$ \\
\hline 1980 & $11,3 \%$ & 1986 & $5,8 \%$ \\
\hline 1981 & $10,3 \%$ & 1987 & $6,2 \%$ \\
\hline 1982 & $7,6 \%$ & 1988 & $4,9 \%$ \\
\hline 1983 & $6,1 \%$ & 1989 & $4,4 \%$ \\
\hline 1984 & $6 \%$ & 1990 & $5,6 \%$ \\
\hline
\end{tabular}

\section{Tabel 16.14 De "public enterprise rent" als percentage van het eigen vermogen}

Ondanks het toenemende belang van de matiging van kosten door een meer efficiënte productie en distributie wordt door de Directie en het Ministerie van Economische Zaken niet gesteld dat de bijkomende doelen minder belangrijk worden geacht. Gemeend werd dat het nastreven van efficiëntie en marktgerichtheid juist nodig zijn om het eigenlijke doel, een goede elektriciteitsvoorziening, zo optimaal mogelijk te realiseren. Uit de tabel blijkt echter dat bijkomende doelen relatief minder belangrijk werden.

\subsubsection{De mate waarin activiteiten niet worden bediscussieerd maar wel gewoon} worden uitgevoerd

Gedurende de onderzoeksperiode is zoals opgemerkt vooral de toename van het eigen vermogen opvallend. Dit beleid werd nauwelijks bediscussieerd, maar wel gewoon uitgevoerd, Geleidelijk aan werd het bedrag aan winst dat elk jaar als dividend mocht worden uitgekeerd eveneens vergroot. Toch was de dividenduitkering door de PLEM erg laag, ook vergeleken met beurs-NV's (exclusief bank- en verzekeringswezen), zonder dat dit tussen de verschillende actoren steeds onderwerp van discussie was. Eén en ander kan als volgt worden weergegeven: 


\begin{tabular}{|l|l|l|l|l|l|l|}
\hline jaar & 1981 & 1982 & 1983 & 1984 & 1985 & 1986 \\
\hline $\begin{array}{l}\text { Eigen vermogen beurs-N.V.'s per } \\
\text { ultimo boekjaar in mld. guldens }\end{array}$ & 78,1 & 84,7 & 97,6 & 114 & 107,1 & 101,7 \\
\hline Dividend in mln. guldens & 3.235 & 3.328 & 3.824 & 4.724 & 5.484 & 5.623 \\
\hline $\begin{array}{l}\text { Dividend in \% van het eigen ver- } \\
\text { mogen van beurs-N.V.'s }\end{array}$ & 4,1 & 3,9 & 3,9 & 4,1 & 5,1 & 5,5 \\
\hline $\begin{array}{l}\text { Dividend in eigen vermogen van } \\
\text { de PLEM in \% }\end{array}$ & 0,93 & 0,67 & 0,68 & 0,63 & 0,58 & 0,53 \\
\hline
\end{tabular}

\section{Tabel 16.15 Dividend van de PLEM en van beurs-N.V.'s vergeleken ${ }^{958}$}

Terwijl de dividenduitkering van beurs-N.V.'s nog een licht stijgende tendens vertoont, daalde de toch al lage dividenduitkering van de PLEM, uitgedrukt in percentage van het eigen vermogen, nog verder. Van de relatief lage winst werd weinig uitgekeerd aan de aandeelhouders, Een groot gedeelte van de winst werd ingehouden. Hieruit kan worden afgeleid dat het voor de PLEM aantrekkelijk was om te streven naar efficiëntie, aangezien de voordelen daarvan voor een belangrijk deel konden worden gereserveerd.

\subsubsection{Conclusie ten aanzien van het relatief belang van de doelen}

De doelen van de PLEM zijn gedurende de onderzoeksperiode geleidelijk veranderd. Vooral het Ministerie van Economische Zaken speelde daarbij een belangrijke rol. Begin jaren zeventig waren met name verbruiksstimulering, continuiteit en zekerheid belangrijke doelen, terwijl in de jaren tachtig (daarnaast) geleidelijk de nadruk kwam te liggen op besparing van elektriciteit, een doelmatige en milieuschone opwekking en distributie en klantgerichtheid.

\subsection{Het vaststellen van de "performance" in termen van baten en kosten}

De analyse tot dusver geeft aan dat de NV PLEM net als het Rijksmuseum technisch inefficiênt produceerde. Dit impliceert dat middelen werden besteed aan andere doelen. Op grond van voorgaande analyse zijn de gerealiseerde bijkomende doelen en de kosten van deze doelen bekend. In deze paragraaf zal één en ander kort worden samengevat.

\subsubsection{De "performance" van de NV PLEM}

Zoals is aangegeven in paragraaf 16.8.3 streefde de PLEM een aantal doelen na. Uitgaande van 1989 kan worden geconstateerd dat de bijkomende doelen in totaal

F. 40.854.200,- kostten. Ingegaan is op de vragen in hoeverre de verschillende doen zijn gerealiseerd en wat het relatieve belang van de doelen was. Net zoals bij het

Rijksmuseum worden in deze paragraaf de bijkomende doelen op een globale wijze afgezet tegen de "public enterprise rent".

958 Bron: Tweede Kamer der Staten-Generaal (1988), Nota naar aanleiding van het Eindverslag (Ellektrici: teitswet 1987), 19591, nr. 9, P. 69. 
Doel 1 en 2, en ook doel 15, voor zover een particulier bedrijf dat niet zou nastreven, kunnen tot het eigeniijke doel worden gerekend. Een groot gedeelte van de bedrijfskosten van F. 682.691.000,- zijn voor dit eigenlijke doel gebruikt. Echter niet volledig omdat een gedeelte van bijvoorbeeld de materiaalkosten en personeelskosten gebruikt zijn voor bijkomende doelen. Doel 2 betreft een redelijk rendement. Gedurende de onderzoeksperiode was de Raad van Commissarissen en cok de Directie in het algemeen redelijk tevreden over het behaalde winstniveau. Blijkbaar werd een winst van 2 à $3 \%$ van het eigen vermogen redelijk gevonden. In 1989 was dit F. 19,9 miljoen, hetgeen lag boven het door de Minister van Economische Zaken redelijk gevonden winstniveau.

De bijkomende doelen zijn de doelen 3 tot en met 16. Deze doelen kostten per saldo ongeveer F. 40.854.200, -

\section{Doel 3. Voorlichting}

De ten behoeve van doel 3 gemaakte kosten bestaan vooral uit de kosten van het met de voorlichting belaste personeel. Op de afdeling voorlichting werkten in de jaren tachtig ongeveer 50 werknemers. Bij dit bijkomende doel gaat het evenwel vooral om de voorlichting aan de bevolking en niet zo zeer om de serviceverlening door monteurs, service die ook een particulier bedrijf zou verlenen. In totaal gaat het naar schatting om een kleine 20 werknemers. Gegeven de gemiddelde kosten per personeelslid van F. 67.385 ,- in 1989 bedroegen de voor dit doel gemaakte kosten ongeveer F. 1.347.700,-.

Doel 4. Het bevorderen van de economische ontwikkeling van de provincie Limburg en doel 11. Lage tarieven

Beide doelen hebben betrekking op het zo laag mogelijk houden van de elektriciteitstarieven, met name voor bedrijven, teneinde het bedrijfsleven te stimuleren en extra bedrijven aan te trekken, maar ook voor de kleinverbruikers. Bij de beschrijving van de realisatie van de doelen is aangegeven dat verschillende tarieven gerekend werden voor groot- en kleinverbruikers. De vraag is welk bedrag besteed werd aan lagere tarieven.

Om te beoordelen in hoeverre de PLEM efficiênt opereerde moet in de eerste plaats worden onderzocht wat de welvaartsverliezen zijn. Deze geven een indicatie van de mate van allocatieve inefficièntie van de productie door de PLEM. Hierbij gaat het om het verschil tussen de feitelijke tarieven van de PLEM en de tarieven op grond van gelijkstelling aan de marginale kosten. Om de welvaartsverliezen te berekenen wordt de volgende formule gebruikt:

$\mathrm{W}=0,5 \cdot \mathrm{p} \cdot \mathrm{q} \cdot \mathrm{E}(\mathrm{dp})^{2}$

waarbij:

$\mathrm{W}=$ welvaartsverlies

$\mathrm{p} . \mathrm{q}=$ de omzet van de PLEM

$\mathrm{E}=$ de prijselasticiteit van de vraag

$\mathrm{dp}=\mathrm{p}-\mathrm{p}_{\mathrm{me}} / \mathrm{p}$

Om het welvaartsverlies te kunnen berekenen hebben we dus gegevens nodig over de marginale kosten en de prijselasticiteit van de gevraagde hoeveelheid. De Braekeleer heeft 
een berekening gemaakt van de marginale kosten van de elektriciteitsproductie en distributie in Nederland, terwijl ook de VEEN hier onderzoek naar heeft verricht. ${ }^{959} \mathrm{Op}$ basis daarvan kan de volgende tabel worden opgesteld.

\begin{tabular}{|l|l|l|l|}
\hline & $\begin{array}{l}\text { marginale produc- } \\
\text { tiekosten }\end{array}$ & $\begin{array}{l}\text { marginale kosten } \\
\text { van de distributie }\end{array}$ & $\begin{array}{l}\text { totale marginale } \\
\text { kosten }\end{array}$ \\
\hline kleinverbruik & F. 0,0517 & F. 0,0721 & F. 0,12 \\
\hline grootverbruik & F. 0,0517 & F. 0,0176 & F. 0,07 \\
\hline
\end{tabular}

Tabel 16.16 De marginale kosten van elektriciteitsproductie en -distributie $\mathrm{e}^{960}$

Er zijn zoals ook wordt aangegeven door de Braekeleer geen recente gegevens over de verschillende elasticiteiten voor groot- en kleinverbruikers in Nederland. Hij maakt een schatting van een onder- en bovengrens van de verschillende elasticiteiten en komt daarbij in 1987 op de volgende cijfers uit:

\begin{tabular}{|l|l|l|l|}
\hline & ondergrens & bovengrens & gemiddeld \\
\hline $\begin{array}{l}E_{\mathrm{i}} \text { Kleinverbrui- } \\
\text { kers/laagspanning }\end{array}$ & $-0,12$ & $-0,8$ & $-0,45$ \\
\hline $\begin{array}{l}\mathrm{E}_{\mathrm{j}} \text { Grootverbrui- } \\
\text { kers/hoogspanning }\end{array}$ & $-0,5$ & $-1,05$ & $-0,75$ \\
\hline
\end{tabular}

\section{Tabel 16.17 De verschillende prijselasticiteiten van de gevraagde hoeveelheid ${ }^{961}$}

Er van uitgaande dat deze elasticiteiten ook gelden voor de afnemers van de PLEM in 1989 kunnen de welvaartsverliezen voor klein- en grootverbruikers voor 1989 eenvoudig worden berekend:

In 1989 werd aan kleinverbruikers 1.365.901 MWh geleverd tegen 17,01 cent per $\mathrm{kWh}$. Het welvaartsverlies was toen:

$\mathrm{W}=0,5 \cdot 0,45 \cdot((0,1701-0,12) / 0,1701)^{2}=0,0195$

Dat wil zeggen dat het welvaartsverlies voor kleinverbruikers $1,95 \%$ van de omzet bedroeg. De omzet was 1.365.901 MWh . 17,01 cent en bedroeg dus F, 232.339.760,Het welvaartsverlies bedroeg derhalve F. 4.530 .625 ,- .

Aan grootverbruikers en "en gros" gemeenten werd 4.839.543 MWh geleverd tegen gemiddeld genomen 9,45 cent per $\mathrm{kWh}$. Het welvaartsverlies was:

\footnotetext{
959 De Brakeleer (1990, pp. 240-244).

960 Brow: T.a.p., p. 244.

961 Bron: T.a.p., PP. 267-268. Vergelijk ook: Amhemse Instellingen (1987) en VEEN (1989, pp.96 e.v.).
} 
$0,5 \cdot 0,75 \cdot((0,0945-0,07) / 0,0945)^{2}=0,025$

Dit betekent dat het welvaartsverlies gelijk was aan $2,5 \%$ van de omzet. De omzet bedroeg $4,839.543 \mathrm{MWh} .9,45$ cent en was derhalve gelijk aan F. $457.336 .810,-$. Het welvaartsverlies was dus F. 11.433.420,--

Per saldo bedroeg het welvaartsverlies over 1989 F. 15:964.046,--

De Braekeleer constateert:

"Voor Nederland blijkt dat de grootste welvaartsverliezen optreden bij grootverbruikers": Dit was te verwachten gezien de gebruikte elasticiteiten. Verder merkt hij op: "De welvaartsverliezen die optreden bij de kleinverbruikers zijn zelfs verwaarloosbaar klein". ${ }^{962}$

\section{Wie ging er op vooruit en wie er op achteruit door de tariefstelling van de PLEM?}

Een probleem van voorgaande analyse is dat de elektriciteitssector tot bepaalde hoogte te maken heeft met dalende gemiddelde kosten. Prijsstelling gelijk aan de gemiddelde kosten zou verliezen opleveren en dat gebeurt in de praktijk niet, te meer daar de PLEM een redelijke winst nastreeft. Zoals beschreven is in hoofdstuk 4, zou een elektriciteitsbedrijf als de PLEM in theorie tarieven gebaseerd op de Ramsey-rule moeten rekenen. De vraag is dan ook hoe hoog deze Ramseyprijzen zouden zijn.

Boiteux heeft uitgaande van de ideeën van Ramsey de inverse elasticiteitsregel opgesteld en deze toegepast op elektriciteitstarieven. De prijs dient daarbij, om het verlies te dekken, zodanig af te wijken van de marginale kosten als het omgekeerde van de prijselasticiteit van de vraag, vermenigvuldigd met de "markup" die voldoende is om het nutsbedrijf kostendekkend te laten zijn.

Of voldaan is aan de Ramsey norm kan nu als volgt worden berekend:

De prijs-kostenmarge van goed i en j (de procentuele afwijking van de marginale kosten van consumentengroepen met de gerekende prijs) luidt:

$\mathrm{m}_{\mathrm{i}}=0,1701-0,12 / 0,1701=0,295$

$\mathrm{m}_{\mathrm{j}}=0,0945-0,07 / 0,0945=0,259$

Vermenigvuldigd met de gegeven elasticiteiten levert dit op:

$\mathrm{m}_{1} \cdot \mathrm{E}_{1}=0,295 \cdot 0,45=0,133$

$\mathrm{m}_{\mathrm{j}} \cdot \mathrm{E}_{\mathrm{j}}=0,259 \cdot 0,75=0,194$

Hieruit volgt dat de Ramsey norm blijkbaar niet gevolgd wordt want $m_{i}, E_{i}$ is ongelijk aan $m_{j} . E_{j} .633$ Uit $m_{i} . E_{i}<m_{j} . E_{j}$ volgt dat gemiddeld genomen grootverbruikers waarschijnlijk worden gediscrimineerd ten opzichte van kleinverbruikers.

\footnotetext{
962 De Braekeleer (1990, p. 277).

$963 \mathrm{~m}_{\mathrm{j}} / \mathrm{M}_{\mathrm{J}}=1,14, \mathrm{E}_{\mathrm{j}} / \mathrm{E}_{\mathrm{i}}$ zou bier ook gelijk aan moeten zijin. Dit is nier het geval.
} 


\section{Conclusie}

Geconcludeerd kan worden dat de PLEM een welvaartsverlies leed van ongeveer $\mathrm{F} .15$ miljoen. Dit is het verschil tussen de prijsstelling van de PLEM en de prijsstelling gelijk a an de marginale kosten. Dit welvaartsverlies is vergeleken met de omzet niet erg hoog. Opvallend is dat de "public enterprise rent" aanzienlijk groter is. Dit komt vooral omdat bij een prijsstelling gelijk aan de marginale kosten de winst ongeveer 0 zou zijn of zelfs kleiner dan 0. Maar in dat geval zou de overheid niet investeren, omdat zij geld moet lenen tegen een rente van ongeveer $7 \%$. Zij zal alleen investeren indien zij tenminste deze $7 \%$ haalt. Het welvaartsverlies zoals hierwoor berekend zou dan veel groter zijn, namelijk de "public enterprise rent". Het verschil tussen beide is de prijs voor het stellen van lage tarieven. Dit bedraagt ongeveer F. 40,8 miljoen min F. 15 miljoen oftewel $F$. 25,8 miljoen. Dit is hoger dan gemiddeld genomen in andere voorzieningsgebieden in Nederland, aangezien de tarieven daar veelal hoger liggen. De kosten van de doelen 3 en 11 kunnen derhalve geschat worden op F. 25 miljoen. Dit correspondeert ook met de bevindingen bij andere elektriciteitsbedrijven. De PLEM was aammerkelijk goedkoper dan deze bedrijven, zoals genoemd ca. F. 11 tot F. 16 miljoen. Maar ook deze bedrijven stelden zich ten doel lage tarieven voor klein- en grootverbruikers te rekenen. Tellen we dit bij elkaar op dan is F. 25 miljoen een redelijke schatting.

\section{Doel 5. Milieu en doel 16. Energiebesparing.}

Het milieudoel werd eind jaren tachtig steeds belangrijker. Zoals opgemerkt werden in 1989 de nodige voorbereiding getroffen met de bouw van een waterkrachtcentrale bij Linne, die medio 1990 in bedrijf kwam. De PLEM verwachtte door de veranderde brandstofprijzen gedurende de periode dat deze centrale in bedrijf was een exploitatieverlies te zullen lijden van $\mathbb{F} .17,2$ miljoen. Hiervoor werd een voorziening getroffen. In 1989 werd nog gesproken over een afschrijvingstermijn van 25 jaar op basis van historische kosten, terwijl later werd gesproken over afschrijving in 40 jaar. ${ }^{964}$ Het veriles over 1989 bedroeg all naar gelang de termijn warop de waterkrachtcentrale in bedrijf zou zijn F. 430,000,- tot F. 688.000 ,-. Verder werd als gevolg van het project Horizon een Bureau Energie en Milieutechnologie opgericht, voomamelijk met medewerkers die binnen de PLEM al soortgelijke werkzaamheden verrichtten. Dit bureau zou ongeveer 6 medewerkers hebben. De personeelskosten daarvan bedragen circa

F. $460.000,-$ Na 1990 werden de uitgaven voor het milieu meer gespecificeerd. Tot 1990 was dat veel minder het geval. Daar komt nog bij dat de meeste milieuactiviteiten begonnen per 1990 , zoals de genoemde waterkrachtcentrale te Lime, een stortgascentrale, e.d. Eind jaren tachtig werd op veel gebieden hiermee een begin gemaakt door het opstellen van plannen en de uitvoering daarvan. Bovendien werden veell milieuactiviteiten, zoals het bevorderen van warmte/-kracht en de bouw van windturbines gestimuleerd door overheidssubsidies, die dus niet of slechts gedeeltelijk ten koste kwamen van de PLEM. De totale kosten die de PLEM in 1989 ten behoeve van dit doel maakte liggen naar schatting tussen F. 1.000.000,- en F. 1.500.000,-.

\section{Doel 6. Het bevorderen van de werkgelegenheid in de provincie Limburg}

Zoals in paragraaf 16.9 is aangegeven waren er eind jaren tachtig meer werknemers in dienst dan strikt noodzakelijk, hoewel mede door personeelstops er al behoorlijk bezui-

964 Vergelijk: N.V. Provinciale limburgse elektriciteits-maatschappij, Raad van Commissarissen 88-057, Bedriifsplan 1989, 24 november 1988, p. 2 . 
nigd was op het personeelsbestand. Eind jaren tachtig werd opgemerkt dat de PLEM ondanks de daling meer mensen in dienst had dan op economische gronden strikt noodzakelijk was. Mede in verband met de reorganisatie die werd doorgevoerd leek het niet verstandig om de onzekerheid nog meer te vergroten door mensen te ontslaan. Een probleem hierbij is dat dit niet gekwantificeerd werd. Door de begin jaren negentig uitgevoerde reorganisatie werd er gesnoeid in het persomeelsbestand. In paragraaf 16.9. is aangegeven dat op strikt bedrijfseconomische gronden er circa 1.037 werknemers nodig waren, in plaats van de aanwezige 1.137. Dit betekent dat de PLEM in 1989 ongeveer 100 werknemers meer in dienst had dan noodzakelijk was. Gelet op de kosten per werknemer van ongeveer F. 76.616,- bedroegen de kosten van dit doel voor de PLEM F. $7.661 .600,-$.

\section{Doel 7. Technologische ontwikkeling}

In 1989 werd onder meer geïnvesteerd in de verbetering van de elektriciteitsvoorziening van Sittard en omgeving en werd F. 1.343.000,- uitgetrokken voor de verbetering van de elektriciteitsvoorziening in het gebied Maasbracht-Merum-Roermond. Zoals reeds vermeld werd er verder geïnvesteerd in de distributie door verbetering van het elektriciteitsnet. Deze investeringen behoren voor een groot deel tot het normale investeringsprogramma wan een elektriciteitsbedrijf en werden niet zozeer verricht om de technologische ontwikkeling van Limburg te verbeteren (technologische ontwikkeling gezien als bijkomend doel) door een geavanceerde elektriciteitsvoorziening, hoewel dat wel heeft meegespeeld.

\section{Doel 8. Afvalverwerking}

Dit doel werd eind jaren tachtig steeds belangrijker. Gewerkt werd aan een afvalverbrandingsinstallatie. Verder werd zoals al is verantwoord bij het milieudoel, een afvalstortcentrale bij Linne voorbereid. Deze centrale kwam najaar 1990 in bedrijf.

\section{Doel 9. Kabelnetten}

Zoals aangegeven werd eind jaren tachtig vooral onderzocht welke strategie de PLEM ten aanzien van deze markt het best kon volgen. De kosten bleven dan ook beperkt tot hooguit F. 150.000,- à 200.000 ,- Wel werd geỉnvesteerd in de aanleg van telecommunicatieverbindingen binnen de PLEM zelf.

\section{Doel 10. Beloning personeel}

In paragraaf 16.9 is een raming gegeven van het bedrag dat de PLEM meer aan het personeel betaalde dan op strikt bedrijfseconomische gronden noodzakelijk was. Uitgaande van 1990 werd dit bedrag becijferd op ongeveer F. 2.500:000,-. Hierboven komt dan nog het bedrag van de verstrekte leningen en het bedrag dat andere bedrijven als Limagas en de PNEM zelf aan dit doel besteden. Het bedrag in 1989 kan dienovereenkomstig geschat worden op ca. 3,5\% van de totale personeelskosten oftewel ongeveer F. 2,7 miljoen.

\section{Doel 12. Het voorzien in onrendabele aansluitingen}

Zoals opgemerkt in paragraaf 16.9 werd in 1989 ongeveer F. 1.000 .000 ,- geïnvesteerd ten behoeve van dit doel. 
Bij het doel van een zekere elektriciteitsvoorziening gaat het om de kosten die gemaakt zijn voorzover uitgaande boven de eisen zoals die in het algemeen gesteld mogen worden. Deze doelen kunnen samen genomen worden, aangezien de overheid de elektriciteitsvoorziening, met name in de jaren zeventig, probeerde veilig te stellen door het gebnuiken van aardgas en diversificatie. Eind jaren zeventig en gedurende de jaren tachig werd het doel van de zekerheid van de elektriciteitsvoorziening minder belangrijk. Het gaat daarbij niet om een goede en continue elektriciteitsvoorziening, hetgeen onder het eigenlijke doel valt, maar om extra matregelen die genomen worden om de elektriciteitsvoorziening ook tijdens een energieboycot op gang te kunnen houden. Eind jaren zeventig gebruikte de PLEM voor een belangrijk deel weer steenkool en werd dit doel, in ieder geval voor de PLEM, minder belangrijk, te meer daar deze in 1989 voornamelijk distribueerde.

\section{Doel 14. Schone productieprocessen}

De PLEM moest net zoals andere bedrijven aan de milieuwetgeving voldoen. Zo diende zij de eisen zoals omschreven in de hinderwet- en lozingsvergunningen in acht te nemen. De gedachte dat de PLEM als nutsbedrijf hier meer aan diende te doen dan een particulier bedrijf leefde wel, hetgeen ook blijkt uit de stappen die in de distributiesector werden genomen om te komen tot een integraal milieuzorgsysteem. Het grootste deel van deze kosten zou ook door een volledig particulier bedrijf gemaakt zijn. De kosten van schone productieprocessen van de PLEM, opgevat ais bijkomend doel, zijn eind 1989 nog beperkt.

\section{Doel 15: Veilige en continue levering}

Aan het begin van deze paragraaf is reeds ingegaan op doel 15, een veilige en continue voorziening van elektriciteit. Tot bepaalde hoogte behoort het zorgdragen voor een continue gegarandeerde levering tot het eigenlijke doel. In Nederland is echter grote nadruk gelegd op dit doel door middel van de oprichting van monopolies, in eigendom van de overheid. Het resterende gedeelte van de "public enterprise rent" werd voor dit doel gebruikt.

\section{Conclusie}

Het grootste deel van de kosten bestaan uit de kosten voor gas- en elektriciteitsdistributie. Het budget bestaande uit de "public enterprise rent" werd voor een groot deel gebruikt voor bet bereiken van een drietal doelen. In de eerste plaats werd ongeveer de helft van het budget gebruikt voor het rekenen van lage tarieven. Voorts werd ongeveer $18 \%$ gebruikt voor het realiseren van het werkgelegenheidsdoel en tenslotte werd een kleine $30 \%$ gebruikt voor het bereiken van de overige doelen, waaronder de zekerheid van de elektriciteitsvoorziening.

\subsubsection{Hoe moet de "performance" van de NV PLEM worden beoordeeld?}

Gedurende de onderzoeksperiode is er sprake van een verschuiving in de belangrijkheid van de doelen. In de jaren zeventig lag het accent op de veiligheid en zekerbeid van een continue levering. De efficiëntie was hieraan ondergeschikt. Dit was niet alleen het geval voor de PLEM maar voor de gehele elektriciteitssector in Nederland. In de jaren tachtig komt het accent meer op de efficiëntie van de elektriciteitsvoorziening te liggen. Het 
verbeteren van de concurrentiepositie door lage tarieven wordt steeds belangrijker. De organisatiestnuctuur zoals die gold in de jaren zeventig voldeed niet meer. De elektriciteitsdistributiesector kende een aantal knelpunten; waardoor de concurrentie in de sector beperkt was. Belangrijk was dat de import van elektriciteit niet was toegestaan. Horizontaal winkelen door distributiebedrijven was niet zinvol in verband met de kosten van de pooling. Verder was er voor distributiebedrijven sprake van moeizame toegang tot transport- en distributienetwerken waardoor levering door bedrijven buiten het eigen gebied moeilijk werd. Productiebedrijven mochten niet rechtstreeks leveren aan de klant of aan distributiebedrijwen en de exportmogelijkheden van productiebedrijwen waren beperkt. Ook regels ten aanzien van de zelfopwekking leiden tot een beperking van de concurrentie. Zo was er ook voor zelfopwekkers sprake van moeizame toegang tot distributie- en transportnetten, terwijl de tariefstructuur samen met de afnameverplichting tot een onjuiste waardering van decentraal vermogen en import leidde. 965 Om de veranderde doelen te realiseren was een reorganisatie van de elektriciteitssector onontkomelijk. Deze werd in de jaren tachtig doorgevoerd. Deze reorganisatie leidde ertoe dat de elektriciteitssector als geheel efficiënter werd, terwijl regionale verschillen in tarieven kleiner werden. De distributie werd ook steeds grootschaliger. Het cumulatief marktaandeel van de 5 grootste distributiebedrijven steeg tot ruim $80 \%$ Het doel van de continuitteit bleef belangrijk, daarnaast kreeg de PLEM als distributiebedrijf extra doelen toegewezen. Naast de distributie van ellektriciteit en gas was de PLEM ook actief op het gebied van de distributie van informatie. Verder werd zij begin jaren negentig actief op het gebied van de afvalverbranding, begon zij op kleine schaal elektriciteit op te wekken met behulp van waterkrachtcentrales en kwam er steeds meer nadruk te liggen op de milieudoelstelling. De PLEM voerde een actief energiebesparingsbeleid, productieprocessen binnen de PLEM moesten schoner worden, terwijl warmtekrachtkoppeling gestimuleerd werd. In dit hoofdstuk is verder aangegeven wat de kosten van de doelen waren, meer in het bijzonder is 1989 onderzocht. Hieruit bleek dat het belangrijkste doel van de PLEM het zoveel mogelijk laag houden van de tarieven was, meer nog dan van andere elektriciteitsdistributiebedrijven. Dit doel kon alleen bereikt worden door matiging van de kosten, te meer dalar de PLEM ook andere doelen nastreefde zoals goede arbeidswoorwaarden en het verschaffen wan werkgelegenheid. Bovendien werd halverwege de jaren tachtig het bedrag van de winst dat als dividend werd uitgekeerd vergroot, zodat minder gereserveerd kon worden. Om toch winst te kunnen blijven inhouden was het van belang de efficiëntie verder te vergroten. Door de reorganisatie maar ook door de lage brandstofkosten realiseerde de PLEM, evenals de andere Nederlandse elektriciteitsdistributiebedrijven, elektriciteitstarieven die tot de laagste in Europa behoren. De Nederlandse elektriciteitssector werd ook als zeer betrouwbaar beoordeeld, aangezien zij de elektriciteitswoorziening in de jaren tachtig steeds kon garanderen.

Hoewel buiten de tijdsafbakening van dit hoofdstuk vallend, rijst de vraag naar de ontwikkeling in de jaren negentig. In de jaren negentig bleef de continuïteit van de elektriciteitsdistributie en efficiëntie belangrijk, maar werd daarnaast klantgerichtheid, vooral ook door de toenemende openheid van de energiemarkt, steeds belangrijker. ${ }^{956}$ Zoals al vaker gesignaleerd vereist een ander doelenpakket een andere eigendomsrechtenverdeling en een andere organisatiestructuur. Om het gewijzigde doelenpakket te realiseren was het opnieuw nodig de elektriciteitssector te reorganiseren.

965 Amdersen Consulting (1993, p. 36).

966 T.a.p., paragraaf 1.4 
Künneke onderscheidt een wiertal mogelijke scenario's voor de Nederlandse elektriciteitssector. ${ }^{967}$ Het eerste scenario houdt in dat de huidige structurur van de Nederlandse elektriciteitssector behouden moet blijven, het tweede beoogt verticale integratie en het ontstaan van maximaal vier en minimaal 1 elektriciteitsbedrijf. Eventueel kan het Rijk de rol van eigenaar overnemen van de lagere overheden. Het derde scenario benadrukt het handhaven van de verticale desintegratie en het bevorderen van verdere schaalvergroting en verzelfstandiging. Het tariefbeleid kan bijvoorbeeld worden overgeheveld naar de distributiebedrijven. Het vierde scenario beoogt het behouden van de verticale desintegratie en privatisering van productiebedrijven. In een later stadium zouden ook de elektriciteitsbedrijven geprivatiseerd kunnen worden. De bepaling van de meest wenselijke schaalgrootte wordt aan de bedrijven zelf overgelaten.

Aangezien de energiedistributiebedrijven begin jaren negentig allemaal nog overheidsinstellingen waren, staat bij de reorganisatie de vraag centraal of privatisering wenselijk is. In het eindverslag werd opgemerkt: "Dit neemt echter niet weg, (...), dat een doelmatige, zekere, veillige kostenbewuste en ook voor het milieubeheer verantwoorde elektriciteitsvoorziening ook zou moeten kunnen ploatsvinden, wanneer de productiesector op grotere afstand van de overheid en wellicht ook van de SEP opereert. Een gelijkwaardige positie van de productiebedrijven ten opzichte van de SEP is derhalve een minimumvereiste, evenals de mogelijkheid om zelf import-contracten af te sluiten, $(. ..){ }^{968}$ Halverwege de jaren negentig werd bij de behandeling van de Wet Energiedistributie ingegaan op de wenselijkheid van privatisering. In dit verband werd in 1996 in het parlement opgemerkt: "Bij deze energiedistributiebedrijven is er echter geen sprake van privatisering. De overheid zit immers nog in alle situaties in de rol van aandeelhouder". Verder werd opgemerkt: "Er heeft schaalvergroting plaatsgevonden maar dat is ook het enige. De gemeenten en provincies zijn net als vroeger nog aandeelhouder. De schaal is alleen groter geworden".969 Het is dan ook van belang te weten in hoeverre de doelen van de eigenaren in 1996 zodanig zijn dat privatisering wel gewenst is. Voor het beantwoorden van de vraag welke van de vier door Künneke genoemde scenario's het best kan worden nagestreefd is het essentieel te weten in hoeverre er nog schaalvoordelen te behalen zijn in de elektriciteitssector.

Gedurende de eerste decennia van deze eeuw ontstonden er regionale netwerken. Doordat het niet mogelijk of zeer kostbaar was om stroom over grote afstanden te vervoeren was hier sprake van kleine natuurlijke monopolies. Mede om de mogelijke negatieve effecten van deze natuurlijk monopolies tegen te gaan stelde de overheid vervolgens tal van juridische monopolies in. Geleidelijk veranderde werd de markt steeds groter en verdween het natuurlijk monopoliekarakter. Zoals reeds aangegeven in hoofdstuk 2 is de omvang van de minimale efficiênte schaal in de jaren tachtig en negentig niet geheel duidelijk, dit geldt zowel voor de elektriciteitsproductie als voor de -distributie. Wel is het duidelijk dat de minimaal efficiënte schaal in de jaren tachtig door afzonderlijke bedrijven veelal niet werd bereikt. In dit verband werd ten aanzien van de distributiesector opgemerkt: "Een vergroting van de gemiddelde omvang van het distributiebedrijf leidt tot schaalvoordelen.

${ }^{967}$ Künnelke (1992, hoofdstuk 5)

968 Tweede Kamer der Staten-Generaal (1987), Eindverslag opgemaakt ten aancien van openbare beraadslaging over hell wetsvoorstel voot een nieuwe Elektriciteitswet, opmerkingen van de CDA-fractie, p. 4.

969 Tweede Kamer der Staten-Generaal (1996), Behandeling wetsvoorstel Regels op het gebied van de distributie van eleltriciteit, gas en warmte (Wet energiedistributie), 22160,3723, commentaar van de heer Remkes van de VVD. 
Hierbij kan gedacht worden aan effecten als relatieve vermindering van overheadkosten, administratiekosten en kosten voor netaanleg, netbewaking en netonderhoud". ${ }^{970}$

In de jaren tachtig is door Orionconsult B.V. onderzoek verricht naar het optimale aantal productiebedrijven in Nederland. ${ }^{971}$ De optimale schaal werd geschat op ongeveer 3.500 Megawatt (MW) zodat ongeveer 4 bedrijven in Nederland zouden overblijven. Voor de distributiesector kwam de Commissie Concentratie Nutsbedrijven op basis van eerder genoemde advies van het organisatiebureau Krekel, Van der Woerd en Wouterse (KWW) tot de conclusie dat voor distributiebedrijven de minimale omvang bestond uit 100.000 verbruikersadressen. In landelijke gebieden zou een kleine afstand tussen distributiebedrijf en verbruikers moeten blijven bestaan door middel van gedecentraliseerde verbruikerskantoren die minimaal een omvang van 10.000 verbruikersadressen zouden moeten hebben. In de jaren negentig ging de schaalvergroting in de distributiesector steeds verder. In 1995 waren er nog ongeveer 35 bedrijven over (van de oorspronkelijke 150), terwijl dat er begin 1996 nog 30 zijn. ${ }^{972}$ Voor de distributiebedrijven zou dat aantal gezien de ontwikkelingen van de laatste jaren, waarschijnlijk op een tiental komen te liggen. In tegenstelling tot datgene wat tijjens de debatten in de Tweede Kamer bỉj de behandeling van de wetsontwerpen van de Elektriciteitswet en de Energiedistributiewet werd opgemerkt, was er dus in Nederland nationaal gezien geen sprake van een matururlijk monopolie. Maar ook regionaal was dat, anders dan de Minister van Economische Zaken kennelijk meende, niet het geval. Zo merkte hij op: "Als ik gelijk krijg en distributiebedrijven steeds meer in een marktwerkingssituatie komen en hun natuurlijke monopolie verliezen, heb ik er eerlijk gezegd steeds minder behoefte aan on dwingend te beschrijven wat hun "activiteitenran$\mathrm{ge}^{\prime \prime}$ zal moeten zijn.".973 Overheidsingrijpen had meer te maken met de bijkomende doelen die blijkbaar van veel belang werden geacht.

Indien de overheidsbelemmeringen worden weggehaald tendeert de markt, zoals grotendeels al is gebeurd, vanzelf naar het optimale aantal. Dit zal in de toekomst waarschijnlijk in de beurt liggen van een tweetal productiebedrijven en een tiental distributiebedrijven. Ten aanzien van de distributiebedrijven werd in de Memorie van Antwoord met betrekking tot het wetsontwerp van de Wet Energiedistributie opgemerkt: "Een uniforme optimale schaalgrootte bestaat niet. Het moge duidelijk zijn dat een optimaal aantal aansluitingen in een stedelijk gebied anders is dan een optimaal aantal aansluitingen in een landelijk gebied. Er is thans een ontwikkeling gaande die inhoudt dat grotere bedrijven overgaan tot het instellen van werkmaatschappijen of districtskantoren. Zo profiteen men van de schaalvoordelen, terwijl men toch dicht bij de verbruiker staat ${ }^{n}{ }^{974}$ Verder werd gesteld: "Er is overigens thans een tendens tot verdergaande schaalvergroting. De distributiebedrijven noemen behalve efficiency-voordelen ook een versterking van hun positie in Europees verband als reden voor de verdergaande concentratie".

Door de grotere concurrentie onderling en in Europees verband zullen de tarieven verder

970 Tweede Kamer der Staten-Generaal (1991), Memorie van Toelichting met betrekking tot het wetsontwerp van de Wet energiedistributie, 22160 , ar. 3 , p. 7 .

971 Orionconsult B.V., Elektriciteitsbedriiven in Nederland, Amhem, 1986.

972 Tweede Kamer der Staten-Generaal (1996), Behandeling wetsvoorstel Regels op het gebied van de distributie van elektriciteit gas en warmte (Wet energiedistributie), 22160,3730 , commentaar van de Minister Wijers van EZ.

${ }^{973}$ T.a.p., p. 3732.

974 Tweede Kamer der Staten-Generaal (1992), Memorie van Antwoord, 22160, nr. 5, pp. 7.8. 
kumnen dalen. Het wegnemen van de restricties betekent echter wel dat de bijkomende doelen niet meer kunnen worden gerealiseerd door de PLEM/MEGA Limburg. Of zoals in het Voorlopig Verslag werd opgemerkt: (...) omdat distributiebedrijven zonder een zekere exclusieve positie de hwn toevertrouwde maatschappelijke nutsfunctie niet naar behoren kunnen vervullen ". 975 . Dit betekent dat de overheid en meer in het bijzonder de provincie deze doelen op een andere wijze moet nastreven Gezien het feit dat lagere tarieven een belangrijke doelstelling waren voor de PLEM, is het denkbaar dat privatisering positieve effecten heeft. Een probleem hierbij is dat Europese regelgeving voor de toekomstige elektriciteitsvoorziening van groot belang is. De Europese Commissie heeft aan het begin van 1992 voorstellen gedaan voor regelgeving die beoogden een goed functionerende Europese energiemarkt tot stand te brengen. In Europees verband wordt getracht hierover consensus te bereiken. Dit impliceert wel dat de reorganisatie niet voor ieder afzonderlijk bedrijf positief hoeft te zijn. Het is denkbaar dat de "performance" van sommige bedrijven verslechtert, terwijl die van andere verbetert. Künineke heeft onderzocht in hoeverre door de toegang tot het elektriciteitsnetwerk verbetering van de "performance" van de elektriciteitssector is te verwachten. ${ }^{976}$ Een tweetal mogelijkheden moeten daarbij worden onderscheiden. Bij vrije toegang ("open access") wordt de monopoliepositie van overheidsbedrijven doorbroken door hen te verplichten hun leidingnetwerk open te stellen voor doorvoer van elektriciteit door derden. De doorvoerverplichting is niet gekoppeld aan de beschikbare capaciteit van het netwerk. Het is in dat geval denkbaar dat de beschikbare capaciteit onvoldoende is. Indien dat het geval is wordt de elektriciteit naar rato doorgevoerd, waarbij dus de zekerheid en continuitteit van de levering in gevaar komt. In Europees verband staat het zogenaamde "third party access" voorop. Er wordt in dat geval alleen toegang tot het netwerk gegeven indien er voldoende capaciteit aanwezig is. De zekerheid van de elektriciteitswoorziening komt dan niet in gevaar. De elektriciteitsproductiebedrijven verliezen de door de SEP gegarandeerde afnamezekerheid, terwill de SEP bovendien geen verzorgingsverplichting meer afgeven, waardoor distributiebedrijven zelf zodanige contracten moeten afsluiten met productiebedrijven dat zij steeds aan de vraag kunnen woldoen.

Minister Wijers probeert de elektriciteitsproductiebedrijven te bundelen in een groot ellektriciteitsmonopolie, waarvan de overheid eigenaar is (vergelijk scenario 3). In feite worden de regionale monopolies vervangen door een landelijk monopolie. Dit zou volgens Wijers door de schaalvergroting tot extra besparingen kunnen leiden van $F$. 180 miljoen. Of deze besparingen ook werkelijk gerealiseerd worden is twijfelachtig. De liberalisering van de Europese elektriciteitsmarkt verloopt traag. Eind juni 1996 hebben de Europese Ministers een compromisvoorstel aangenomen waardoor in $200631 \%$ van de markt een open markt kan worden genoemd. Bovendien kunnen op grond van de voorgaande analyse vraagtekens gesteld worden bij de te behalen besparingen en schaalvoordelen. Het heeft er veel van weg dat de overheid het bedrag van de "public enterprise rent" waarover zij nu, via de provincies kan beschikken, niet wil opgeven. Indien er een overheidsmonopolie komt is de kans groot dat de elektriciteitstarieven niet of slechts licht zullen dalen. Het voordeel voor de overheid van een overheidsmonopolie is dat, net zoals de regionale monopolies dat deden, weer bijkomende doelen kunnen worden nagestreefd: Blijkbaar meent de politiek dat de bijkomende doelen niet op een goedkopere wijze kumnen worden

\footnotetext{
975 Tweede Kamer (1991), Voorlopig Verslag ten anzien van de Wel energiedistributie, vergaderjaar 19911992,22160, nr. 4, p. 10 .

${ }^{976}$ Künneke (1992).

977 T.a.p., pp. 3-4.
} 
Of het totalle doeleapakket van de PLEM/MEGA Limburg goedkoper gerealiseerd kan worden hangt er vooral vanaf of de grotere concurrentie daadwerkelijk tot stand komt. De eerste drie door Künneke genoemde scenario's belemmeren in meer of mindere mate de toekomstige concurrentie, waardoor het mogelijk is dat tarieven niet zullen dalen. Een overheidsmonopolie zal zeker indien de liberalisering van de Europese markt traag verloopt, weinig prikkels hebben om de tarieven veel lager te stellen dan nu het geval is. Het vierde scenario, door Künneke aangeduid als actief anticiperend beleid, biedt de meeste garantie dat voldoende concurrentie ontstaat. Hierbij dient wel bedacht te worden dat indien in Nederland een tweetal productiebedrijven resteren en de concurrentie in Europees verband onvoldoende gestimuleerd wordt, (ook hier) het gevaar van collusie ontstaat. Om ervoor te zorgen dat de tarieven werkelijk omlaag gaan verdient het aanbeveling een groot aantal concurrentieprikkels in de Nederlandse elektriciteitsvoorzieming in te bouwen. Hierbij kan gedacht worden aan de introductie van bedrijven op de beurs of het verkopen van aandelen aan andere ondememingen, het geven van de mogelijkheid aan alle verbruikers om stroom bij een ander bedrijf te kopen, ook in het buitenland, het aan distributiebedrijven geven van de mogelijkheid om onbeperkt stroom te produceren, terwijl ook particulieren en bedrijven onbeperkt zelf mogen produceren voor het openbare net, zij het dat dan wel concurrerende prijzen gerekend moeten worden. Door dit soort concurrentiebevorderende bepalingen kumnen de tarieven dalen. Hientegen is wel aangevoerd dat indien de Nederlandse markt geopend wordt en de buitenlandse niet, buitenlandse aanbieders een eenzijdig voordeel behalen. Op zich hoeft dit geen bezwaar te zijn aangezien dit leidt tot verdere tariefsdaling. De overheid zou voorlopig een pakket andelen in de elektriciteitsbedrijven kannen houden, teneinde hierop toe te zien en om overnames die tot vermindering van de concurrentie kunnen leiden, tegen te gaan. Zo'n regeling is ook vrij normaal. Bij de privatisering van de PTT in 1989 werd in de statuten van de nieuwe N. bijvoorbeeld een blokkeringsregeling opgenomen. In Frankrijk wordt bij de privatisering van het electronicaconcern Thompson SA een soortgelijke strategie gevolgd. Door het houden van een zogenaamd gouden aandeel, zou de overheid verkoop van onderdelen van de elektriciteitsbedrijven kunnen voorkomen en zou zij eventueel kunnen verbieden dat een aandeelhouder meer dan $10 \%$ krijgt. Uitvoering van dit scenario zal hoogstwaarschijnlijk leiden tot verdere tariefdaling. Indien de overheid de overige bijkomende doelen tegen minimaal dezelfde kosten weet te realiseren kan de "performance": van MEGA Limburg verbeteren.

\subsection{Conclusie}

Net als bij thet Rijksmuseum valt op dat de verdeling van de eigendomsrechten en de organisatiestructuur dienen om de doelen van de eigenaren uit te voeren. Bij de PLEM zijn de doelen gedurende de onderzoeksperiode verschoven van de grote nadruk op het belang van continue en zekere levering in de jaren zeventig, waarvoor een monopolie en overheidsinvloed noodzakelijk werd geacht, naar een grotere madruk op efficiëntie, lage tarieven en klantgerichtheid. Om deze doelen te bereiken was het noodzakelijk om ook de organisatie te veranderen. Aan het eind van dit hoofdstuk is ingegaan op de vraag of de "performance" verder verbeterd kan worden. Aangegeven is dat dit er voomamelijk vanaf hangt of door de door te voeren reorganisatie de concurrentie werkelijk toeneemt, waardoor de tarieven omlaag kunnen Daarnaast moeten de toekomstige kosten van de overige bijkomende doelen in overweging worden genomen. Indien de werkgelegenheid bij MEGA Limburg daalt rijst de vraag wat de kosten zijn van alternatieven hiervoor. terwijl vooral ook de hoge graad van zekerheid en continuitteit van de elektriciteitsvoorziening niet te veel mogen worden aangetast. 


\section{Hoofdstuk 17. De Belastingdienst}

\subsection{Inleiding}

In dit hoofdstuk wordt aan de hand van de zestien vragen ingegaan op de "performance" van de Belastingdienst. De doelstellingen van de Belastingdienst worden onder andere in beleidsnota's en Rijksbegrotingen geformuleerd. In tegenstelling tot de analyse van het Rijksnuseum wordt de "performance" van de Belastingdienst onderzocht gedurende de periode 1980 tot en met 1992. De redenen hiervoor zijn dat er weinig materiaal beschikbaar was over eerdere jaren en dat gedurende de periode 1990-1993 een organisatiewijziging is doorgevoerd en het van belang is om te bezien hoe de "performance" zich verhoudt met de reorganisatie. Voor zover relevant voor het onderzoek is in een aantal gevallen ook gekeken naar de cijfers over 1993.

\subsection{Waarom is de Belastingdienst een overheidsinstelling?}

Evenals het Rijksmuseum Amsterdam en de N.V. PLEM is de Belastingdienst een overheidsinstelling. Enerzijds heeft de overheid overwegende invloed, anderzijds verricht zij activiteiten die ook door particuliere bedrijven kunnen worden verricht. Zo zouden de de activiteiten van de Belastingdienst ook kunnen worden verricht door een geprivatiseerde Belastingdienst of eventueel meerdere particuliere bedrijven, zoals dat ook bij de verplichte ziektekostenverzekering gebeurt. ${ }^{973}$ In Mexico spelen bijvoorbeeld commerciele banken een belangrijke rol bij de inning van belastingen. Voor de $20 \mathrm{e}$ eeuw gebeurde de inning van belastingen in de meeste landen zelfs voornamelijk door particuliere agenten die naar winstmaximalisatie streefden. ${ }^{974}$ In de geschiedenis zijn een drietal redenen aangevoerd voor de inning van belastingen door particulieren en meer specifiek voor "tax farming".

In de eerste plaats zou de inning en eventueel ook de heffing door particulieren de kosten voor de overheid kunnen verminderen. Bij de Belastingdienst is de inning (de invordering) de taak van de ontvanger, terwijl de heffing (het vaststellen van de belastingschuld) bij de Belastingdienst de taak van de inspecteur is. Bij particuliere heffing en inning heeft de overheid geen omvangrijk bureaucratisch apparaat meer nodig dat zich hiermee bezighoudt. Stella meent dat de administratiekosten van de overheid weliswaar lager zijn bij "tax farming" maar dat deze kosten gedragen zullen worden door de particuliere sector. Indien de particuliere sector een omvangrijk bureaucratisch apparaat heeft, zoals bij ons de overheid, hoeft particuliere heffing en inning en meer specifiek "tax farming" niet voordeliger te zijn. Daar komt bij dat de overheid bij ons toe moet zien op de uitvoering van de wetgeving. Om er op toe te zien dat de belastingwetgeving op een eerlijke wijze

973 Burgess en Stern (1993, p. 801).

974 Een in de literatuur veell besproken vorm van inning door particulieren is "tax farming." Stella omschrijft dit alls: "Tax farming is a system wherein the right to collect certain taxes owed the state is auctioned off to the highest bidder. The famer then keeps whatever revenue is collected. A winning bidder wishing to maximize profit will operare at the point where private marginal revenue equals private marginal cost. Tax farming represents a private sector solution to the tax collection problem". Stella (1993, pp. 217. 225). Vergelijk ook: Jensen, Toraa en Toma (1994, p. 57). Hoewel sommigen menen dat "tax farming" ook tegenwoordig en in de toekomst nog goede mogellikheden heeft menen anderen waaronder Stella dat dat niet het geval is. Vergelijk bijvoorbeeld: Azabou en Nugent (1988, pp. 684-705). 
wordt uitgevoerd is veel controle van de overheid nodig, zowel op het geinde bedrag als op het proces van inning en heffing. ${ }^{959}$ Dit is vooral het geval indien de inning vergaand gedelegeerd is en controle moeilijk wordt. Bovendien is belastingbetaling niet vrijwillig zodat er geen sprake is van marktwerking waarbij de innende instantie slechts optreedt als bemiddelaar. "Consequently one can not depend on the market to generate an apropriate outcome". ${ }^{\text {.75 }}$ Bovendien is het denkbaar dat particuliere innende instanties misbruik zullen maken van de grote hoeveelheid informatie die zij ter beschikking krijgen. Of er werkelijk problemen ontstaan bij de controle van een eventuele particuliere inner en/of heffer hangt vooral af van het gebruikte systeem van inning en aanslag. In Nederiand is bij de inkomsterbelasting aangesloten bij het bronnenstelsel ${ }^{977}$ De aanslag vindt daarbij op een subjectieve wijze plaats, in de zin dat inkomen aan een bron moet worden toegerekend. Er is alleen van inkomen sprake indien het inkomen voortvloeit uit één van de in de wet genoemde bronnen (winst uit ondermeming, inkomsten uit arbeid, inkomsten uit vermogen, inkomsten in de vorm van periodieke uitkeringen en winst uit aanmerkelijk belang). De waardestijging van de bron wordt niet gezien als inkomen. In principe wordt bij dit systeem rekening gehouden met de persoonlijke omstandigheden van de belastingplichtige. Van Schie, Van Smeden en De Kam merken op: "Het wettelijke inkomensbegrip wil de individuele draagkracht benaderen en daarbij aansluiten bij de maatschappelijke opvattingen over inkomen. Aldus is het een "praktisch, empirisch begrip" dat in de loop der jaren ten behoeve van de inkomstenbelastingheffing als draagkrachtbelasting is gevormd". ${ }^{\text {st8 }}$ Op de toepassing van het bronnenstelsel is in Nederland op veel manieren inbreuk gepleegd. Hierbij kan gedacht worden aan de invoering van de aanmerkelijkbelangregeling in 1941 en het in 1914 geschrapte voorschrift dat de bron duurzaam moet zijn. $\mathrm{Nu}$ is het in verband met de controle van een eventuele particuliere instelling belangrijk te bedenken dat het ook mogelijk is om op grond van objectieve criteria belastingen te heffen. Een voorbeeld van dergelijke belastingen zijn accijnzen en de b.t.w: maar ook de inkomstenbelasting zou in principe op grond van meer objectieve criteria geheven kunnen worden. Een voorbeeld hiervan vormt het inkomensbegrip dat in de vermogensvergelijkingstheorie wordt gebruikt. Het inkomensbegrip is dan rumer. Onder inkomen wordt de toename van vermogen verstaan vermeerderd met de consumptie in de betreffende periode. ${ }^{979}$ Indien mu gekozen wordt voor het opleggen van aanslagen op grond van objectieve criteria, dan is verdere delegatie mogelijk. Ook het opleggen van aanslagen zou dan door bijwoorbeeld een bank kunnen gebeuren. Het probleem van het controleren van de particuliere instelling is dan veel minder groot evenals de kosten.

Een tweede reden voor met name "tax farming" is dat het recht om bepaalde belastinggelden te innen dat aan "tax farms" wordt verleend kan dienen als onderpand voor leningen die door de "tax farmer" aan de overheid werden verstrekt. Dit argument was vooral belangrijk in de tijd dat er nog geen of imperfecte geld- en kapitaalmarkten bestonden. Dit argument impliceert dus niet dat particuliere inning efficiënter was dan inning door de overheid. Stella zet vraagtekens bij dit argument voor het bestaan van " $\operatorname{tax}$

975 Stella (1993, p. 219).

976 T.a.p.,p. 219

977 Fuisting (1902).

978 Van Schie, Van Smexten en De Kam (1995, p. 85).

979 Zie: Van Schie, Van Smeden en De Kam (1995, p. 85). Vergelijk ook: Simons (1938, pp. 41 e.v.) en Haig (1921). 
farming". Opgemerkt wordt: "If foreign commercial banks cannot enforce loan contracts it is difficult to see how they could enforce tox obligations. Thus, the argument for tox farming as simply a substitute for collateral would appear to have little relevance for modern developing countries":980

Een derde reden, die kort is besproken in hoofdstuk 2, had betrekking op het kenmerk van dalende gemiddelde kosten. Aangegeven is in hoeverre dit kenmerk bestaat. Door verbetering van de transportmogelijkheden, door het op grote schaal bijhouden wan gegevens van burgers en door automatisering is het voor één instelling mogelijk van honderden miljoenen burgers gelden te innen, terwijl dit wroeger veel kostbaarder was. Dit zou een verklaring kunnen zijn waarom vroeger "tax farming" en in het algemeen inning door particulieren heel veel voorkwam, terwijl dat tegenwoordig met uitzondering van enige ontwikkelingslanden niet het geval is. In dit licht kan ook het door Stella genoemde derde argument gezien worden. Dit houdt in dat "tax farming", afgezet tegen de wensen van de bellastingbetaler, tot overinning leidt. Dat wil zeggen dat de inning wordt gemaximaliseerd en niet zozeer de economische welvaart. "Tax farming generates the maximum amount of revenue because it gives the farmer profit-maximizing incentives to moximize net revenue collected is to maximize profit". ${ }^{981}$ Indien dit het doel van de overheid is, is "tax farming" de aangewezen wijze van inning. Stella merkt op: "Such an institution may be preserved either because it represents the best option among available technologies - that is, it is a second-best solution - or because the government has an objective function that does not appropriately value citizens' preferences". ${ }^{982}$ Dit argument houdt in feite in dat particuliere inners van belastingen (in dit geval "tax farms") het door hen gekochte recht zullen gebruiken om zoveel mogelijk belastinggeld te innen. Door gebrek aan competitie, bijvoorbeeld omdat éen "tax farm" het volledige recht krijgt om een bepaalde belasting te innen, maakt de "farmer" veel winst, zijn de belastingopbrengsten zeer hoog en dienovereenkomstig ook de welvaartsverliezen. Hetzelfde geldt in meer of mindere mate voor andere particuliere besturingsstructuren

De drie genoemde redenen en de problemen die de particuliere heffing en inning met zich mee zouden brengen zijn tevens redenen waarom in de praktijk veel ontwilkkelde economieën belastinggelden innen door middel van een belastingdienst die in handen is van de overheid en daar meestal deell van uitmaakt. Belastingheffing door particuliere instellingen zou leiden tot grote welvaartsverliezen, overinning van belastinggelden en hoge "monitoring costs" ${ }^{n}$ voor de overheid. De overheid zou bij particuliere heffing en inning op naleving van de belastingwetgeving moeten blijven toezien omdat enerzijds belastingbetaling niet vrijwillig gebeurt en er dus geen sprake is van een marktmechanisme en anderzijds omdat de overheid dient toe te zien op een rechtvaardige uitvoering en naleving van de wetgeving. Een andere reden voor de overheid om zelf de inning van belastinggelden ter hand te nemen is dat de overheid naast het doel van de inning andere doelen nastreeft zoals het in dienst nemen van extra personeel en het kwijtschelden van belastingschulden van bijzondere categorieên belastingbetalers.

De belastingadministratie verricht een groot aantal verschillende werkzaamheden. Gedacht kan worden aan de interpretatie van belastingwetgeving, het uitgeven van richtlijnen maar ook aan de inning van belastinggelden. Taken van de Belastingdienst die niet voor velerlei

\footnotetext{
${ }^{980}$ T.a.p., p. 220.

981 T.a.p., p. 220.

${ }_{982}$ T.a.p. p. 220.
} 
interpretatie vatbaar zijn zouden eventueel geprivatiseerd kumen worden, in de betekenis: dat de particuliere sector hier meer bij betrokken zou kunnen worden. Gedacht kan: worden aan de huidige activiteiten van de werkgever die bepaalde belastingen die de werknemer verschuldigd is inhoudt en verder aan de omzetbelasting. Activiteiten zoals de interpretatie van belastingwetgeving en het bepalen van de aanslag zouden zich minder lenen voor privatisering, aangezien de "monitoring costs" voor de overheid dan erg hoog zouden worden.

Eén en ander is reden voor de overheid om zelf de belastingadministratie te verzorgen. Duidelijk is dat dit op verschillende wijzen mogelijk is. Gedacht kan worden an een in hoofdstuk 1 omschreven publiekgeörienteerde onderneming, maar ook aan een zelfstandig bestuursorgaan of een N.V. Welke structurur de overheid zal kiezen en welke factoren hierbij vooral een rol spelen is ook aan de orde gekomen in paragraaf 11.2. bij de behandeling van de interne organisatiestructuur van overheidsinstellingen.

Aan het ene uiteinde bevindt zich de Belastingdienst met een U-vormige organisatiestructuur. De Belastingdienst verricht in dat geval uitwoerende taken; terwijl de beleidstaken zijn ondergebracht bij beleidsafdelingen yan het Mimisterie van Financiën. De Belastingdienst kan echter ook intern verzelfstandigd zijn bỉnnen het Ministerie. Dit doet zich voor in een situatie waarbij de Belastingdienst beleid en beheer combineert en waar zelfstandig personele en financiële functies worden uitgevoerd. Het Ministerie stuurt op afstand door middel van een dienstbegroting, managementcontract en managementsrapportage. De planning, beheersing en supervisie vanuit de top is nog wel aanwezig, maar minder intensief dan bij een U-vormige organisatie. Er kan gedeeltelijk worden gewerkt met prijsafspraken in de vorm van een prestatiebegroting. De derde mogelijkheid betreft die warbij de Belastingdienst in beperkte mate extern is verzelfstandigd. Gedacht kan worden aan het onderbrengen van de Belastingdienst in een $\mathrm{N}$. V. De directie van de Belastingdienst kan bijvoorbeeld zelfstandig opereren bij het verwerven van nieuwe klanten. Toch is de verzelfstandigingsgraad beperkt. Het Ministerie moet in principe de begroting en de rekening van de dienst goedkeuren. Tenslotte kan de Belastingdienst volledig extern verzelfstandigd zijn. Daarbij kan zoals opgemerkt gekozen worden voor het verzelfstandigen van de inning maar ook van de heffing. Eến vorm van externe verzelfstandiging is zoals aangegeven "tax farming". De externe verzelfstandiging kan vorm worden gegeven door het afsluiten van een meerjarig contract met één of meerdere particuliere ondernemingen die verantwoordelijk worden voor de belastinginning. Het Ministerie is niet langer planner, beheerser en toezichthouder, zij is slechts marktpartij. De te leveren prestaties worden in een contract gespecificeerd evenals de te betalen prijs. In hoofdstuk 11 is aangegeven dat de keuze tussen de verschillende varianten voor een belangrijk deel afhangt van de mate van "asset specificity". Ten aanzien van de Belastingdienst doet zich een tamelijk hoge graad van "asset specificity" voor. De Belastingdienst maakt gebruik van ambtelijke deskundigheid die zijn effectiviteit mede ontleent aan kennis van de doelgroep. Voorts is de Bellastingdienst afhankelijk van wetgeving en dient zij over specifieke fiscaal-juridische kennis te beschikken, te meer daar zij met de andere Directoraten-Generaal op haar beurt de Minister van Financiên adviseert over wijzigingen van de belastingwetgeving. Anderzijds zijn veel van de activa van de Belastingdienst, zij het met het nodige waardeverlies, vervangbaar. Hierbij kan met name gedacht worden aan menselijke "know how". Hoewel derhalve in eerste instantie een U-vormige organisatiestructuur het meest geëigend lijkt, zijn gezien de mate van "asset specificity" ook minder stringente vormen van overheidsinvloed mogelijk, bijvoorbeeld een divisionele structuur (M-vorm) of een beperkt extern verzelfstandigde dienst. Dit neemt niet weg dat de mate van "asset specificity" (met name het nauwe contact met de wetgever en de genoemde "monitoring costs") van de Belastingdienst een belangrijke reden is waarom de Belastingdienst functioneert als een overheidsinstelling. Naast deze factor zijn er ook andere redenen waarom de Belastingdienst een overheidsinstelling is. Met name kan hierbij 
gedacht worden aan een "rentseekingsproces" "waarbij politieke actoren trachten de (gederfde) winst te verdelen. Tenslotte hebben ook culturele en historische factoren invloed uitgeofend op de mate waarin de overheid afstand bewaart tot de belastingheffing. Aan het eind van het hoofdstuk wordt verder ingegaan op de besturingsstructuur van de Belastingdienst.

\subsection{De Belastingdienst als netwerk}

De Belastingdienst maakt deel uit van een extern netwerk van een groot aantal actoren. Daarbij gaat het niet alleen om belastingplichtigen maar ook om de Staten-Generaal, de Minister van Financiën en de Algemene Rekenkamer.

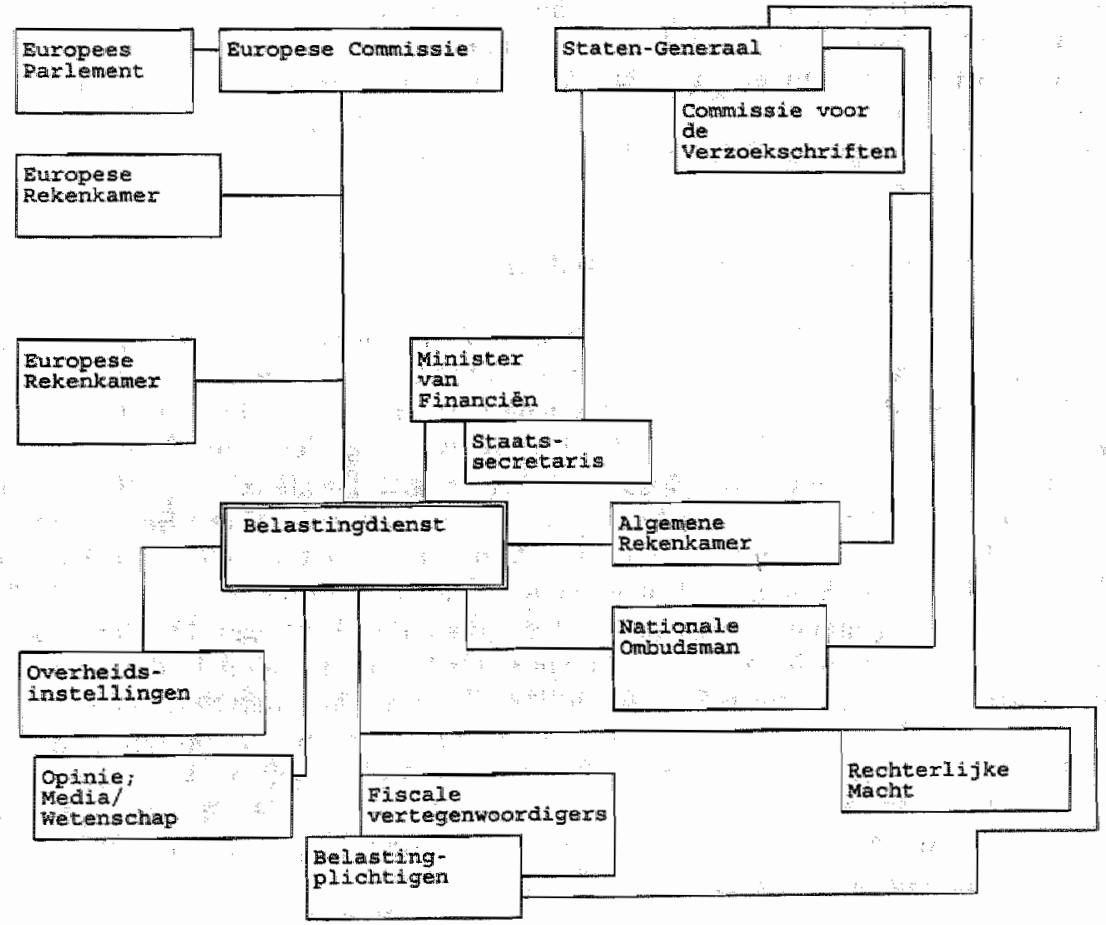

Figuir 17.1 De Belastingdienst als onderdeel van een extern netwerk ${ }^{983}$

De Minister van Financiën is zoals Van Kommer en Muizelaar opmerken opdrachtgever wan de Belastingdienst. Hij legt verantwoording af aan het parlement. De wetgever bepaalt de begroting en controleert de Belastingdienst. Zij beoordeelt de wijze van functioneren van de Belastingdienst en let daarbij nadrukkelijk op de opbrengsten en kosten en daarmee op de efficiëntie en effectiviteit. ${ }^{984}$ Daarnaast bepaalt de overheid als wetgever de inhoud van de fiscale wetgeving. De Belastingdienst zorgt voor de uitvoering

983 Bron: Van Kommer en Muizelaar $(1995$, p. 7$)$, Voor een meer uitgebreide beschrijving van het netwerk. zie pp. 7-12.

${ }^{984}$ T.a.p. p. 8. 
van de fiscale wetgeving, maar ook van verschillende niet-fiscale wetten zoals de Landbouwheffing, de Wet Algemene Bepalingen Milieuhygiëne en de Premies wolksverzekeringen ten behoeve van de sociale fondsen. De Belastingdienst dient bij de uitwoering van deze wetgeving rekening te houden met rechtsbeginsellen als rechtsgelijkheid en rechtszekerheid. Naast de Minister van Financiën, de Kroon en de Staten-Generaal zijn verschillende andere instanties van belang. Zo wordt de Staten-Generaal in haar controlerende taak ondersteund door verschillende instellingen. Op grond van artikel 76 van de Comptabiliteitswet controleert de Algemene Rekenkamer de ontvangsten en uitgaven van het Rijk, terwijl op grond van de Wet Nationale Ombudsman van 1981 ledere burger eventuele klachten kan voorleggen aan de Nationale Ombudsman. In het kader van de Europese eenwording worden ook Europese instellingen zoals de Europese Commissie en de Europese Rekenkamer steeds meer van belang. De Belastingdienst int verschillende belastingen zoals een deel van de omzetbelasting bij invoer, douanerechten en landbouwheffingen die Nederland afdraagt aan Europa. Samenwerking met andere overheidsinstellingen heeft tenslotte betrekking op het verstrekken van gegevens aan onder meer gemeenten en Ministeries om misbruik van overheidsregelingen tegen te gaan. Ook de samenwerking met buitenlandse Belastingdiensten is geintensiveerd..$^{985}$

\subsection{De interne organisatie van de Belastingdienst}

Aansluitend bij de voorgaande analyse wordt in deze paragraaf ingegaan op de interne organisatie van de Belastingdienst. De ongeveer 30.000 werknemers van de Belastingdienst werken verspreid over het hele land. Slechts een relatief klein gedeelte werkt op het Ministerie van Financiën. De politieke leiding is in handen van de Minister van Financiën en de Staatssecretaris, die speciaal belast is met fiscale zaken. De ambtelijke leiding van de Belastingdienst is in handen van de Directeur-Generaal der Belastingen. Dit is één van dé vier Directeuren-Generaal op het Ministerie van Financiën. De DirecteurGeneraal wordt bijgestaan door zijn plaatsvervanger, zeven stafdirecties, twee staffunctionarissen van de Rijksaccountantsdienst en tot 1987 door de dienst van de Waarborg. De Belastingdienst had verder acht regionale directies. Onder deze regionale directies vielen een groot aantal inspecties; ontvangkantoren, bureaus van de rijksaccountantsdienst en overige diensteenheden zoals de kantoren van de waarborg en de posten douane en accijnzen. Er waren ongeveer 350 plaatselijke eenheden. Verder omvat de Belastingdienst de Fiscale inlichtingen en opsporingsdienst te Haarlem en de Directie automatisering rijksbelastingen te Apeldoorn. Het organogram van de Belastingdienst in 1986 kan als volgt worden weergegeven.

${ }^{285}$ T.a.p., p. 12. 


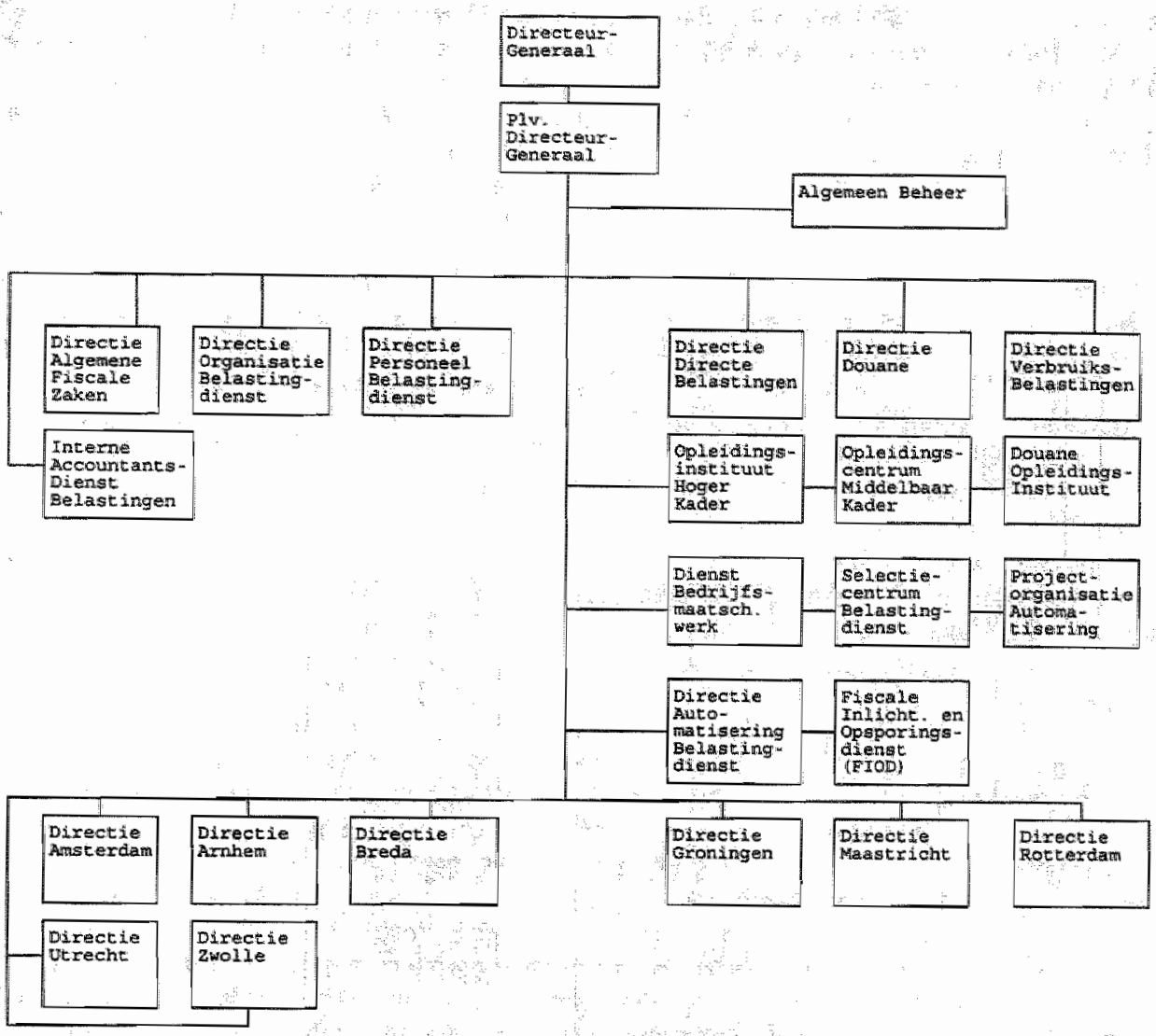

Figuur 17.2 Organogram van de Belastingdienst in 1986

De organisatie laat zich gedurende de jaren zeventig en tachtig het best omschrijven als een u-vormige organisatie. Er was sprake van gecentraliseerd gezag, in combinatie met een functionele afdelingsvorming naar soort belasting. Een nadeel van deze structuur was enerzijds dat het voor de belastingplichtige veel werk met zich meebracht: Voorts was het voor hem vaak niet duidelijk bij wie hij terecht moest met een probleem. Voor elke belasting was een andere afdeling bevoegd. Anderzijds waren er tevens nadelen voor de Belastingdienst zelf. Er was relatief veel sprake van dubbel werk, hetgeen weinig efficiënt was. Daamaast werd de organisatiestructur gekenmerkt door een scheiding tussen heffing, inning en controle. De heffing vond zoals opgemerkt plaats door inspecteurs, de inning door de ontvanger en de controle door de Rijksaccountantsdienst. Dit had als nadeel dat er veel tijd tussen inning en heffing en uiteindelijk tussen controle en heffing kon liggen. Dit had als nadeel dat na de behandeling door een belastinginspecteur een ontvanger zich in het probleem diende te verdiepen. Voorts was het aantal hiërarchische schakels relatief hoog waardoor de informatievoorziening vertraging opliep. Bovendien werd de centrale directie te veel belast met detailinformatie waardoor het gevaar dreigde dat zij te weinig toekwam aan algehele strategische planning. Een ander probleem was dat bij de definiëring van de subdoelstellingen binnen de diverse afdelingen het probleem bestond van het nastreven van eigen doelen (opportunisme).

Om deze problemen het hoofd te bieden is na 1988 in een aantal fasen een reorganisatie 
(de zogenaamde HABO-operatie, dat wil zeggen Herstructurering en Automatiseringsoperatie Belastingdienst Organisatie) doorgevoerd, die de grootste was die ooit binnen de Rijksdienst is uitgevoerd.

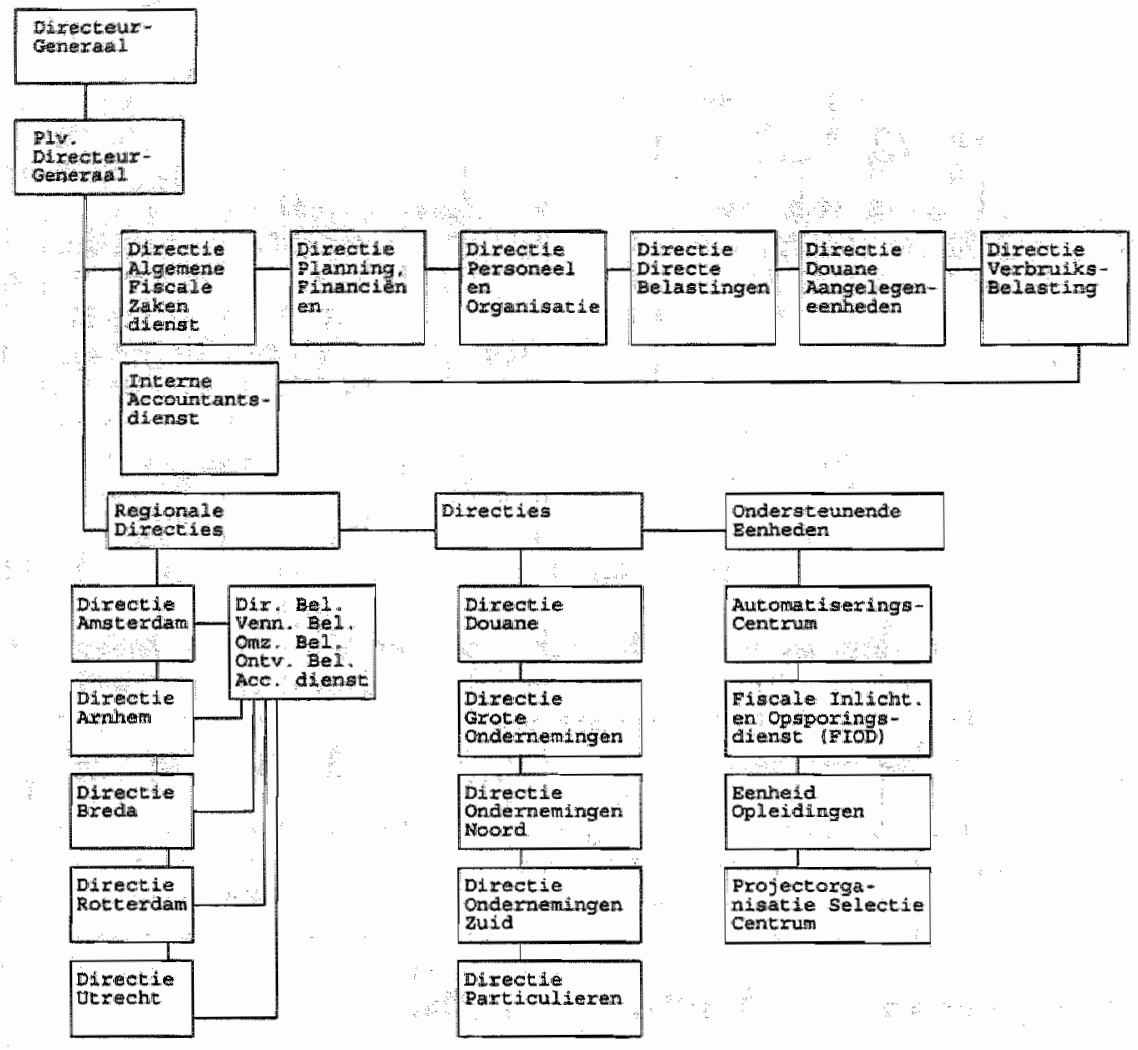

\section{Figuur 17.3 Organogram van de Belastingdienst in 1990}

In 1988 en 1989 werd een begin gemaakt, terwijl de herstructurering zelf in 1990, 1991 en 1992 werd gerealiseerd. Deze reorganisatie werd voornamelijk geïnitieerd door de Belastingdienst zelf. De reden hiervoor is mede dat de Belastingdienst op grond van de diverse wetten de belastingen int. Hoe zij dit dient te doen is in deze wetten niet omschreven. Deze reorganisatie is in een drietal fasen doorgevoerd. De eerste fase ging in op 1 januari 1990, de tweede op 1 januari 1991 terwijl de derde fase op 1 juni 1992 formeel is afgerond (en voor het grootste deel van de Belastingdienst reeds 31 december 1991). De reorganisatie wordt gekenmerkt door een aantal elementen. In de eerste plaats werden de verschillende afdelingen doelgroepgewijs ingedeeld. Als hoofidoelgroepen werden genoemd: grote ondernemingen, ondernemingen, partiealieren en degenen die contact hebben met de douane. Per 1 januari 1989 werden vijf nieuwe directies ingestell, namelijk particulieren, grote-ondernemingen, ondernemingen-Noord, ondernemingen-Zuid en de douane.

$\$ 86$ Vergelijk ook: Koster en Muizelaar (1992, p. 13). 
Meer specifiek zijn in dit verband een tweetal belangrijke veranderingen doorgevoerd. Enerzijds bestaat er nu een hoofdstructuur met afzonderlijke eenheden voor particulieren, ondememingen, grote ondermemingen en douane. Deze eenheden worden bestuurd door de genoemde vijf directies. Aan de andere kant is de regionale bestuurlijke structuur vervangen door directies per doelgroep. De verantwoordelijkheid voor de directie is overgedragen aan de desbetreffende directeuren. De Belastingdienst wordt geleid door een relatief kleine top en vijf directies waaronder 101 eenheden vallen.

Een andere wijziging is dat sinds de reorganisatie ook de heffing, inning en controle geïntegreerd plaatsvinden, niet in éen persoon maar in éen team. Een eenheid bestaat uit 10 à 11 teams met 20 à 25 personen. Een team houdt zich bezig met een beperkt aantal branches (bijvoorbeeld tandartsen, huisartsen). Voorts bevat zij zowel inners, heffers als controleurs. In één dossier wordt dan ook informatie gevonden over inkomsten-, loon- en vennootschapsbelasting. In het jaarverslag over 1988 werd hierover opgemerkt: "De integratie houdt in dat aanslagregeling, controle en inning - de hoofdprocessen - en de toepassing van de verschillende belastingwetten per belastingplichtige binnen een eenheid worden verricht. Dit laatste betekent dat de huidige inspecties (aanslagregeling en controle) en de bureaus van de rijksaccountantsdienst (controle grote ondernemingen) ophouden te bestaan ${ }^{\text {. }}{ }^{987}$ Hierdoor kan de belastingplichtige in het vervolg bij éen loket terecht voor alle belastingzaken.

Een verdere verandering is dat een aantal taken zijn overgeheveld naar de directies. Vooral de stafdirecties kregen te maken met de gevolgen van de versterking van de besturing via de lijn en de overheveling van bevoegdheden. Dit had vooral gevolgen voor de stafdirectie Organisatie, de stafdirectie Personeel en de stafdirectie Douane van de Belastingdienst. Uitvoerende taken werden van deze stafdirecties overgeheveld naar de nieuwe directies. Verder werd de directie Organisatie omgevormd tot de directie Planning, Financiën en Control. De directie Personeel zal zich voortaan vooral bezig houden met strategisch personeelsmanagement en organisatie-ontwikkeling. De Directie Douane geeft leiding aan de verschillende douane-districten. De nieuwe Directies particulieren, grote ondernemingen en ondernemingen (Noord en Zuid) hebben taken overgenomen van de acht bestaande directies. Verder zijn ook het Centraal Bureau Motorrijtuigenbelasting en de Centrale Betalingsadministratie onder de Directie particulieren geplaatst.

Hierbij aansluitend vindt de controle nu meer in de lijn plaats. Gesteld wordt: "Centraal staat verder versterking van de sturing via de lijn en het realiseren van zo zelfstandig mogelijke eenheden binnen de Belastingdienst". ${ }^{988}$ Voorts wordt gestreefd naar een meer klantgerichte wijze van werken. Dit houdt verband met het doel van de herstructurering, te weten het ontwikkelen van een meer flexibele organisatie die beter op veranderingen, waaronder ook maatschappelijke veranderingen, kan inspelen.

Eén en ander overziend kan worden opgemerkt dat na 1988 en vooral gedurende het begin van de jaren negentig geleidelijk aan een M-vormige organisatiestructuur is ingevoerd. De lagere niveaus hebben relatief meer autonomie ontvangen. Hierdoor is minder opwaartse en neerwaartse communicatie binnen de Belastingdienst nodig. Voorts krijgt het topmanagement meer de handen vrij on zich met het strategische beleid bezig te houden. Bezien vanuit de transactiekostenbenadering impliceert het meer beleidsmatig

987 Belastingdienst, Jaarverslag over 1988, Den Haag, 1989, p. 8.

388 T.a.p., p. 8. 
runnen van de verschillende afdelingen dat er minder gevaar is voor opportunistisch gedrag dan bij de u-vormige organisatiestructuur zoals deze voor 1988 gold. Tevens functioneren de directies meer als winstcentra, waardoor relatief eenvoudiger een koppeling kan worden gelegd tussen de doelstellingen van de divisies en die van de organisatie als geheel. Dit wordt ook gerealiseerd doordat de Directeur-Generaal managementcontracten afsluit met de directies. Zij sluiten veryolgens contracten met de eenheden, die op hun beurt weer contracten sluiten met de teamleider.

\subsection{Structuur-analyse: welke doelen kunnen worden bereikt?}

1. Wie hield toezicht op het aankoopbeleid en de prestaties van de productiefactoren?

2. Wie hield toezicht op de productieresultaten?

3. Wie hield toezicht op het productieproces?

4. Wie hield toezicht op de omvang en samenstelling van het team van producenten?

5. Wie had het recht de organisatie te wijzigen, te verkopen of te liquideren?

\subsubsection{Het recht op het gebruik van een zaak}

\subsubsection{Wie hield toezicht op het aankoopbeleid en de prestaties van de productie-} factoren?

Het Directoraat-Generaal der Belastingen is belast met het besturen van de uitvoering van de fiscale en niet-fiscale wetgeving, voor zover opgedragen aan de Belastingdienst. De dagelijkse leiding is in handen van de Directeur-Generaal. Zoals aangegeven in Figuur 17.2 en 17.3 geeft de Directeur-Generaal leiding aan een zestal stafdirecties, waarvan een aantal dient ter fiscaal-technische ondersteuning en een aantal een bestuursondersteunende taak hebben. Deze stafdirecties hebben in de eerste plaats een voorwaardenscheppende functie ten behoeve van de Belastingdienst. In de tweede plaats helpen ze bij de voorbereiding van de strategische besluitvorming en in de derde plaats adviseren zij aan de Directeur-Generaal en de Directieraad. De fiscaal-technische directies zijn de Directie Algemene Fiscale Zaken (AFZ), de Directie Douane-Aangelegenheden (DA), de Directie Directe Belastingen (DB) en de Directie Verbruiksbelastingen. Deze directies adviseren vooral over de uitvoering van bestaande wetten en bij de totstandkoming van nieuwe. De bestuursondersteunende directies zijn de Directie Planning, Financiën en Control (PFC) en de Directie Personeel en Organisatie van de Belastingdienst (POB). Deze directies helpen de Directeur-Generaal bij het besturen van de Belastingdienst. Belangrijk is dat de Belastingdienst zelf verantwoordelijk is voor de uitvoering van de fiscale en relevante niet-fiscale wetgeving.

In de jaren 80 was het begrotingsproces als volgt. ${ }^{989}$ De voorbereiding van de begroting begon met het versturen van de interne begrotingsaanschrijving in novernber/december door CDFEZ aan elk relevant dienstonderdeel (de budgethouders). Deze begrotingsaanschrijving diende als uitwerking van de rijksbegrotingsvoorschriften en de technische

${ }^{989}$ T.a.p., pp. 55-57. 
begrotingsaanschrijving die door Financiën-II aan alle Ministeries werd toegezonden ${ }^{990}$ Deze begrotingsaanschrijving diende vooral om ervoor te zorgen dat de afzonderlijke afdelingen van het Ministerie hun voorstellen zodanig presenteerden dat de ambtelijke en politieke top een prioriteitenafweging kon maken. In dit verband werd uitvoerig overleg gevoerd tussen CDFEZ en de beleidsdirecties. CDFEZ beziet wat de financiële gevolgen zijn van de voorstellen en toetst de voorstellen aan de meerjarencijfers, die door CDFEZ werden bijgehouden en bewaakt. Indien de meerjarencijfers werden overschreden diende in principe steeds voor voldoende dekking te worden gezorgd. Het standpunt van CDFEZ werd vervolgens opgenomen in het begrotingsrapport. Dit rapport werd vervolgens voorgelegd aan de Minister en de Staatssecretaris. Na goedkeuring door beide bewindslieden werden de stukken ingediend bij Financiën-II. De concept begroting van het Ministerie stond dan vast. Vervolgens overlegde CDFEZ met de Inspectie der Rijksfinanciën. Voorts werd overlegd tussen de Secretaris-Generaal, die belast is met de ambtelijke leiding van het Ministerie van Financiën en de Directeur-Generaal van de Rijksbegroting (het DG/SG-overleg). De uitkomst van dit overleg moet worden goedgekeurd door de Minister en de Staatssecretaris. Indien dit gebeurd was werd de ontwerp-begroting opgesteld. Deze ontwerp-begroting moet conform het budgetrecht door het parlement worden goedgekeurd. Vervolgens vindt de begrotingsuitvoering plaats. Dit gehele proces van beleidsvoorbereiding en uitvoering werd tenslotte afgerond door het afleggen van verantwoording. De verantwoording van de Belastingdienst aan de Tweede Kamer vindt vooral plaats door de toelichting op de geintegreerde slotwet/rekening van hoofdstuk

IX B, hetgeen onderdeel uitmaakt van de begroting van het Ministerie van Financiën. Bij deze slotwet wordt door de Algemene Rekenkamer haar Rapport gevoegd. De Tweede Kamer vormt dan ook mede op grond hiervan, haar oordeel over het door de Belastingdienst gevoerde beleid en beheer.

Begin jaren '80 werden een aantal bestuurlijke instrumenten ontwikkeld. Deze waren:

-Systeem van jaarplanning en jaarrapportage tussen eenheid en regionale directie enerzijds en regionale directie en Ministerie anderzijds.

-Budgettering: de regionale directie kreeg kredieten toegewezen die zij naar eigen inzicht over de diensten verder kon verdelen.

\section{Jaarplancyclus}

Het toenemende gebruik van budgettering leidde ertoe dat door de Belastingdienst halverwege en aan het eind van de jaren tachtig veel nadruk werd gelegd op het verbeteren van de financiële administratie en de interne controle. Deze operatie paste ook binnen de operatie Comptabel Bestel die binnen de gehele overheid werd doorgevoerd. Zo werd in het midden van de jaren ' 80 de jaarplancyclus geïntroduceerd: De bedoeling hiervan was een duidelijke afweging mogelijk te maken tussen enerzijds de diverse opgedragen taken en anderzijds de verschillende mensen en middelen. Dit hield een stelsel in van (meerjarige) beleidsplannen en verantwoordingsverslagen over de uitvoering van het fiscale proces. Doelen van deze operatie waren onder andere het verbeteren van de begrotingspresentatie, een goede inrichting van de administratieve organisatie, een betrouwbare financiële verantwoording en een goede accountantscontrole.

Met ingang van 1990 is de jaarplancyclus verder uitgewerkt met behulp van geïntegreerde

990 Het Ministerie van Financiën heeft op grond van de Comptabiliteitswet een verantwoordelijkheid voor de Rijksbegroting en de coördinatie van het budgettaire beleid, ook wel Financiën-II taak genoemd. 
meerjarige Bedrijfsplanien en Beheersverslagen." Het Beheersverslag Belastingdienst dient als intern verantwoordingsverslag van de Directeur-Generaal aan de Minister en Staatssecretaris en kan worden gezien als de afronding van het planiings-, uitwoerings- en "control"-proces. Het wordt ter kennisname gestururd aan de leden van het parlement. De Beheersverslagen werden ingevoerd in yerband met het steeds belangrijker worden vam budgettering maar ook door de toegenomen publieke aandacht voor het belleid en de uitvoering van de taken door de Belastingdienst. Het Beheersverslag is ook ingevoerd in verband met de wijziging van de Comptabiliteitswet 1976 die in 1991 bij de Eerste Kamer in behandeling was. Deze vijfde wijziging verplichtte Ministeries om de financiële verantwoording an te villen met een toereikend verslag over het uitgevoerde beleid ten aanzien van misbruik-en oneigenlijk gebruik van wet- en regelgeving.

\section{Budgettering budgetcyclus}

In 1983 werd in samenwerking met de lokale directies een begin gemaakt met budgettering, vooral met betrekking tot de materiële uitgaven zoals huisvesting, personeelsontwikkeling, bureaukosten en automatiseringskosten. Doel van deze budgetsystemen is vooral de administratieve vastlegging te verbeteren en meer inzicht te krijgen in de kosten op het regionale niveau. Decentralisatie van bevoegdheden op het organisatorische, personele en financiële vlak werd beoogd door het toekennen van regionale en lokale budgetten. In augustus 1986 werd een Financieel Informatieplan (FIP) vastgesteld waarin werd uitgegaan van een decentraal financieel beheersconcept voor het Ministerie van Financiën. Bepaald werd dat de Centrale Directie Financieel Economische Zaken (FEZ) de functie kreeg van controller, terwifl de beleidsdirecties de rol van budgethouder kregen. Bij de Belastingdienst fungeert de Directeur-Generaal als budgethouder. Voor de uitvoering van de begroting kent CDFEZ budgetten toe aan budgethouders. Daarbij geldt dat budgetten alleen kunnen worden toegekend indien er op de begroting een bedrag voor gereserveerd is. In principe kon CDFEZ ex-ante toezicht uitoefenen. ${ }^{939}$ De mate waarin er bestedingsvrijheid bestond voor de budgethouders/Belastingdienst hing vooral af van de mate waarin de voorstellen tijdens de begrotingswoorbereiding voldoende gedetailleerd waren onderbouwd. Indien dat niet het geval was kon CDFEZ meer toezicht houden op de besteding van de middelen.

Daarbij werd onderscheid gemaakt tussen beheers- en beleidsuitgaven. De beleidsuitgaven werden ook voor 1986 al decentraal beheerd. De decentralisatie van de financiële functie geschiedt doordat de budgethouders zelf het beheer voeren over een toegewezen kasverplichtingen budget voor apparaats- en programma-uitgaven. Door de decentralisatie van de financiêle functie kreeg de Directeur-Generaal der Belastingen meer taken. bevoegdheden en verantwoordelijkheden. Geleidelijk aan werd het ex-ante toezicht door CDFEZ steeds meer vervangen door ex-post toezicht. Hierdoor werden ook hogere eisen gesteld aan de verantwoording en de rapportage door de budgethouder over het gevoerde financiele beheer. Belangrijk is verder dat bij de toekenning van het budget ook bepaald werd in hoeverre er tussen budgetten of delen daarvan geschoven mocht worden. Bepaald

991 Directoraat-Generaal der Belastingen, Beheersverslag Belastingdienst over 1991, Den Haag, 1992, woorwoord. $M$ en $O$-beleid staat voor het beleid geticht op de bestrijding wan misbruik en oneigenlijk gebruik van fiscale wet- en regelgeving.

992 Belastingdienst, Jaarverslag over 1984, Den Haag, 1985, p. 69.

999 Tra.p., p. 58 : 
was: "Als een verschuiving consequenties heeft voor begrotingsbedragen op artikelniveau, is altijd vooraf de toestemming van CDFEZ nodig". Belastingdienst rapporteerde als budgethouder maandelijks per toegekend budget. Dit geschiedde met behulp van budgetoverzichten. In dit soort overzichten werden taakstellings- en realisatiecijfers aan elkaar gerelateerd. Gedurende de jaren " 80 werd ook de Belastingdienst herhaaldelijk geconfronteerd met bezuinigingen. In principe werden ombuigingen ingevuld tijdens de begrotingsvoorbereiding. Indien dit pas geschiedde na de begrotingsuitvoering werden de budgetten naar beneden bijgesteld. Daarbij was het aan CDFEZ om erop toe te zien dat de budgethouder voldoende maatregelen namen om de ombuigingstaakstelling ook daadwerkelijk te realiseren. Dit hele proces van begrotingsuitvoering werd voortdurend geëvalueerd. In dit verband werd regelmatig overleg gevoerd met de budgethouders. Daarbij werd ook bezien in hoeverre bijvoorbeeld een verschil tussen begroting en rekening incidenteel of structureel van aard was.

De invoering van budgettering bij de Belastingdienst stond overigens niet op zichzelf. Ook elders op het Ministerie van Financiën en op andere Ministeries werd hiermee een begin gemaakt. Zo werd in 1987 begonnen met een aantal experimenten in zelfbeheer, door het instellen van een drietal proeftuinen. ${ }^{995}$ Dit had ook gevolgen voor de Belastingdienst. De Belastingdienst werkte verder aan decentralisatie van de beheerskosten door contractmanagement en aan de hiervoor genoemde jaarplancyclus. In 1992 was de situatie zodanig dat de Directeur-Generaal der Belastingen binnen het Ministerie van Financiën optrad als budgethouder ten aanzien van de materiële en personele uitgaven. Voor zover budgetten niet werden gezien als directie-overschrijdend (dit was wel het geval voor automatisering en betalingsverkeer) werden de budgetten doorgedecentraliseerd naar de directies en eenheden. Voor de personele budgetten gold dit eveneens, met uitzondering van de salarissen en de wachtgelden. Er werd naar gestreefd om de salarisbudgetten in 1993 te decentraliseren. De Centrale Directie Financieel-Economische Zaken (FEZ) ziet er tenslotte op toe dat begrotingsartikelen niet overschreden worden. Belangrijk is in dit verband te onderkennen dat het budgetrecht van de Tweede Kamer niet wordt aangetast door de decentralisatie.

Vervolgens is het voor een goed inzicht in de verdeling van dit recht van belang te weten hoe de budgettering binnen de Belastingdienst plaatsvond. De Directeur-Generaal gaf in een beleidskaderbrief het beleidskader aan. Uitgaande van deze beleidskaderbrief en de beleidskaderbrieven van de regionale directeurs stelden de eenheden vervolgens jaarplannen op. Deze jaarplannen werden daarna op het niveau van de regionale directies samengevoegd tot jaarplannen per directie. Vervolgens werd in het najaar overleg gevoerd tussen de centrale directie van de Belastingdienst en de regionale directies over de uiteindelijke hoogte van de budgetten. Vervolgens kenden de regionale directeuren budgetten toe aan de onder hen vallende eenheden. Er zijn binnen de Belastingdienst in die zin dus een groot antal budgethouders. Deze budgetten werden op kasbasis toegekend. Verplichtingen konden slechts worden aangegaan voorzover daarvoor binnen het toegekende budget ruimte is. Bepaald is verder dat verschuivingen tussen kostensoorten zijn toegestaan indien dat voor de uitvoering noodzakelijk is. In het jaarverslag over 1984 werd opgemerkt: "De ermee opgedane erwaringen zijn positief. Verschuivingen tussen

T.a.p., p. 58

995 Tweede Kamer (vergaderjaar 1987-1988), Decentraal begrotingsbeheer, 20200, hoofdstuk IX B, nr. 21, p. 241 . 
kostensoorten binnen de begroting hebben geleid tot een meer effectieve besteding van geldien. 996 Verder was bepaald dat onvoorziene ontwikkelingen binnen het toegekende budget moesten worden opgevangen. Indien dit niet mogelijk is moet het binnen het budget van de regionale directie worden gecompenseerd. Slechts in uitzonderlijke situaties kon een regionale directeur een verzoek bij het Ministerie indienen voor aanvulling van het budget. In de praktijk dienden in dat gevall andere regionale directies bij te dragen.997 Verder was bepaald dat periodiek gerapporteerd werd van decentraal niveau naar regionale directies en het centrale niveau. Voorts werden de gerealiseerde uitgaven maandelijks verwerkt in de begrotingsboekhouding van CDFEZ. Voorzover aanschaffingen niet plaatsvinden met behulp van het systeem van budgettering worden deze op central niveau verricht. Voor deze uitgaven werden van te voren bestedingsplannen opgesteld, die de toegestane begrotingsruimte niet mochten overtreffen. De voorgenomen uitgaven werden vervolgens aan deze plannen getoetst.

In 1991 werd vervolgens de eerste stap gezet met het invoeren van contractmanagement. In het Beheersverslag over 1991 werd opgemerkt: "Het invoeren van contractmanagement moet worden gezien als een logisch siuitstuk van de decentralisatie, het streven van integratie van beleid en middelen en van de verzakelijking van de planning-en controlcyclus". Mede met het doel managementcontracten te kumnen afsluiten met de lagere niveaus werden begin jaren 90 door de directies en eenheden jaarplannen opgesteld. Met behulp van deze plannen werd in samenwerking met de doelgroepdirecties een meerjarenbeleidsplanning voor de gehele Bellastingdienst opgezet. ${ }^{99}$ Door de verdere ontwikkeling van dit meerjarenbeleid (meer strategisch karakter) kwam de nadruk van de jaarplannen van directies en eenheden op operationeel vlak te liggen. Dit maakte het ook beter mogelijk om managementcontracten af te sluiten met de lagere niveaus. Bij de jaarplancyclus 1991 is een begin gemaakt met managementcontract binnen de Belastingdienst door het sluiten van een contract tussen de Directeur-Generaal en een enige doelgroepdirecteuren. In 1992 werden contracten afgesloten met de directie Douane en de FIOD. In dit verband werd opgemerkt: "In de (...) af te sluiten contracten zullen met name doelstellingen inzake de te verrichten taken met betrekking tot het primaire proces worden opgenomen, gerelateerd aan zaken als budgetten en formaties. Het contractmanagement zal geleidelijk worden ingevoerd. Voor de jaarplancyclus 1993 wordt (een beperkte) invoering voor alle directies nagestreefd". ${ }^{1000}$ In 1992 werden contracten afgesloten met wrijwel alle divisies voor planjaar 1993. Dit leidde ertoe dat met ingang van januari 1993 het Budgetsysteem Belastingdienst (BSB) door alle budgethouders van de Belastingdienst wordt gebnuikt. Verder is in 1993 de opbouw van de Centrale Concern-administratie (CCA) voltooid. Deze organisatie is onderdeel van de Centrale Betalingsadministratie en voert de grootboekadministratie van de Belastingdienst. De ondersteuning van BSB is éen van de taken van de Centrale Concern-administratie. Voorts zijn de uitvoerende taken ten aanzien van de financiele verantwoording van de Belastingdienst van het Ministerie overgedragen naar de CCA. Het toenemende gebruik van budgettering leidde ook tot een aantal aanpassingen van het begrotingsproces. Zo werd de begrotingsuitvoering maande-

\footnotetext{
996 Belastingdienst, Jaarverslag over 1984, Den Hasg, 1985, p. 13.

997 Tweede Kamer (wergaderjaar 1987-1988), 20200, hoofdstuk IX B, nr. 21, p. 137.

998 Directoraat-Generaal der Belastingen, Beheerswerslag Belastingdienst 1991, Den Haag, 1992, p. 4.

999 Zie ook: Gerritser (1992, p. 206).
}

${ }^{1000}$ Directoraat-Generaal der Belastingen, Beheersverslag Belastingdienst 1991, Den Haag, 1992, p. 65. 
lijks gevolgd terwijl in 1993 voor het eerst een Budget- en Formatiebrief werd opgesteld waarin budgettaire kaders waren opgenomen waaraan budgetaanvragen van de divisies werden getoetst. Ook werden kaders opgesteld voor taakstellende integrale personeelsbudgetten.

Ten aanzien van het gebruiksrecht moet voorts worden opgemerkt dat ook de door de Belastingdienst gebruikte gebouwen eigendom waren van de Staat der Nederlanden. Deze waren in beheer bij de Rijlksgebouwendienst, hetgeen, zoals al is opgemerkt in hoofdstuk 16, onderdeel uitmaakt van het Ministerie van Volkshuisvesting Ruimtelijke Ordening en Milieu (VROM). ${ }^{1001}$ Alleen het kleine onderhoud aan het gebouw werd door de Belastingdienst zelf verricht. Voor de overige activiteiten die betrekking hebben op het gebouw is de Rijksgebouwendienst medeverantwoordelijk. Net als bij het Rijksmuseum zijn in de huisvestingskosten van de Belastingdienst niet de kosten voor de aanschaf en de huur van de gebouwen begrepen. Deze komen ten laste van de Rijksgebouwendienst. De Belastingdienst was daarvoor dus athankelijk van het Ministerie van VROM. De Belastingdienst zelf betaalde voornamelijk de kosten voor brandstof, gas, licht, water en het schoonhouden van het gebouw. Sinds het Meerjarenprogramma Investeringsprojecten Rijkshuisvesting 1988-1992 en het Meerjarenprogramma Projecten Rijkshuisvesting 1989-1993 vindt overleg plaats over alle huisvestingsprojecten op het niveaw van de Ministerraad. Verder vindt in het kader van de begrotingsprocdure overleg plaats over de prioriteiten die aan de huisvesting worden toegekend. Ten behoeve van de coördinatie en uitvoering van het huisvestingsbeleid werd een Projectbureau Huisvesting ingesteld. Dit bureau was belast met het inventariseren van de huisvestingsbehoeften van de verschillende eenheden en directies. Vervolgens werd een prioriteitenlijst opgesteld. Deze werd door de verantwoordelijke directeur, te weten de directeur Ondernemingen-Zuid, voorgelegd aan de Directieraad. Nadat de Directieraad een beslissing heeft genomen onderhandelen de directeur Ondernemingen-Zuid en het hoofd van het projectburean met de Rijksgebouwendienst. Het gaat daarbij vooral om de wijze van financiering en de planning van de projecten. Vervolgens wordt door het projectbureau en de Rijksgebouwendienst samengewerkt bij de uitvoering van de huisvestingsprojecten. Tenslotte kan nog worden opgemerkt dat het Ministerie van Financiën bijdroeg aan de financiering van projecten; onder andere ten behoeve van de Belastingdienst. Hiertoe werden middelen overgeboekt van het Ministerie van Financiën naar het Ministerie van VROM. Deze mutaties werden verantwoord in de desbetreffende begrotingswetten. Deze toenemende betalingen door het Ministerie van Financiën nemen evenwel niet weg dat de Minister van VROM verantwoordelijk blijft voor de huisvesting van de Rijksdienst.

Tenslotte was aok de controle van het management op de prestatie van het personeel beperkt. Belangrijk hierbij is de personeelsbeoordeling. Met dit instrument wordt een beeld verkregen van het functioneren van de betreffende ambtenaar. In het jaarverslag over 1981 werd in dit verband opgemerkt: "Na de invoering in 1973 van het (nieuwe) Beoordelingsvoorschrift Rijksbelastingdienst zijn de beoordelingen echter vervlakt". ${ }^{1002}$ In 1981 werd hierover een studie afgerond. In deze studie werd onderscheid gemaakt tussen het bevorderingsbeleid ten aanzien van leidinggevende functies en van degenen die meer "solitaire" functies vervullen zoals in de aanslagregeling of bij de controle ent invordering. In 1981 werd ook begonnen met het opzetten van een systematischer systeem van functiebeschrijvingen, profielschetsen en functie-eisen. Bij het aantrekken van personeel diende reeds zoveel mogelijk rekening te worden gehouden met interne

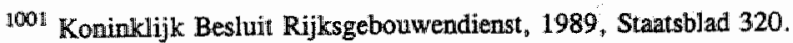

1002 Belastingdienst, Jaarverslag over 1981, Den Haag, 1982, p. 79. 
doorstroming naar functies van middelbaar en hoger niveau. Overwogen werd het systeem van personeelsbeoordeling te vervangen door een systeem van functioneringsgesprekken. In het jaarversiag over 1982 werd hieromtrent opgemerkt: "(..) met name de waarde wan het hwidige beoordelingssysteem moet worden afgewogen tegen de gedachte een aantal personeelstaken, waaronder een deel van de benoemingen, in handen te leggen wan de plaatselijke hoofden van dienst". ${ }^{1003}$ In overleg met de personeelssectoren van de directies werden in 1983 enige taken op het gebied van de personeelswoorziening, de vorming en opleiding en de rechtspositie verschoven van het Ministerie van Financiën naar directies en plaatselijke eenheden. In het jaarverslag over 1982 wordt in dit verband opgemerkt: "Dit beleid past in een bestuursopvatting waarin plaatselijke en regionale eenheden ruimte wordi gelaten woor enige differentiatie. Ter bescherming wan de rechtspositie wan de ambtenaar hoort dan echter als corrigerend integratiemechanisme een nog in te stellen intern beroepsrecht"

\section{Conclusie}

Het recht om toezicht te houden op de aanschaf van inputs lag evenals bij het Rijksmuseum bij het parlement. Feitelijk werd het toezicht uitgeoefend door het Ministerie van Financien (CDFEZ). Gedurende de jaren tachtig werd geleidelijk budgettering ingevoerd terwijl begin jaren negentig gebruik werd gemaakt van managementcontracten. Bevoegdheden werden steeds meer overgedragen naar de Belastingdienst zelf.

\subsubsection{Wie houdt toezicht op de productieresultaten?}

Met betrekking tot het toezicht op de output binnen de belastingdienst kan worden opgemerkt dat de beoordeling en de sturing van de resultaten van de eenheden sinds de reorganisatie plaats vindt op hoofdlijnen. Daarbij wordt gekeken naar de prestaties en de doelen die in een jaar worden nagestreefd. De hoofden van de eenheden zien hier vooral op toe. Wordt de gehele onderzoeksperiode bezien dan kan worden gesteld dat het toezicht op de input door de Minister en de Staten-Generaal steeds meer vervangen werd door toezicht op de output. Deze controle op de output was zeker in het begin van de onderzoeksperiode minder duidelijk geregeld. Dit kwam onder andere tot uiting doordat de productie feitelijk niet gemeten werd. Toezicht hierop was behalve voor direct betrokkenen moeilijk te realiseren. Begin jaren " 90 werd getracht de bestuurlijke informatievoorziening verder te verbeteren. Dit gebeurde onder meer door het gebruik van kengetallen. In 1991 werd daartoe een begin gemaakt met het project kengetallen Belastingdienst. Dit project werd uitgevoerd in overleg met de Centrale Directie Financieel-Economische Zaken en het Directoraat-Generaal van de Rijksbegroting. Het doel was beter in kart te brengen hoe de ontwikkeling was van de productiviteit van de Belastingdienst. Voorts werd een begin gemaakt met het gebruik van kengetallen in de bestuurlijke informatievoorziening, terwijl in 1992 een begin werd gemaakt met het doorlichten van bepaalde onderdelen van de materiële uitgaven. Zo werden de huisvestingsuitgaven geanalyseerd. De resultaten van dit soort onderzoek worden meegenomen bij het nemen van beslissingen over de budgettoedeling en bij de begrotingsvoorbereiding IX-B 1994. In dat jaar verscheen in dit verband een "plan van aampak doorlichtingen 1992 " en een "rapport inventarisatie doorlichtingen/audits binmen de Belastingdienst" ${ }^{\mathrm{HI}}$. Zo werden doorlichtingen gehouden met betrekking tot de bestuurlijke processen van het portefeuille-

${ }^{1003}$ Belastingdienst, Jaarverslag over 1982, Den Haag, 1983 , p. 65

${ }^{1004}$ Belastingdienst, Jaarverslag over 1982, Den Haag, 1983, p. 66. 
houderschap, de bezwaarschriftenbehandeling en het toepassen van het entiteitenbegrip. De directie ging meer dan voorheen sturen op hoofdlijnen. Daartoe was ook informatie op hoofdlijnen nodig.

Naast het toezicht op de productie gaat het er bij dit recht om wie thet beloningssysteem bepaalt. Net als het Rijksmuseum zijn de werknemers van de Belastingdienst ambtenaren. De bezoldiging is geregeld in het Bezoldigingsbesluit Burgerlijke Rijksambtenaren (BBRA 1984). Het BBRA 1984 is op voorstel van de Minister van Binnenlandse Zaken tot stand gekomen, aangezien onder dit Ministerie het Directoraat-Generaal Management en Personeelsbeleid valt. Het is met ingang van 1 januari 1984 in werking getreden. Naar aanleiding van dit Besluit werd in 1987 voor de Belastingdlienst het Ambtenarenreglement Belastingdienst ingevoerd. Er bestaat een overgangstemijn van vier jaar. De beloning van het personeel vond evenals bij andere departementen in principe dus niet plaats overeenkomstig de prestatie en de resultaten van de Belastingdienst. Binnen de overheid bestond eind jaren ' 80 en begin jaren ' 90 de tendens meer de nadrik te leggen op de prestatie. Dit geschiedde door het toekennen van extra beloningen. Tot 1 april 1993 was de Minister van Binnenlandse Zaken verantwoordelijk yoor het personeelsbeleid van de Rijksoverheid, terwijl dit na deze datum alleen nog voor de sector Rijk het geval is. Hij heeft in het Bezoldigingsbesluit Burgerlijke Rijksambtenaren 1984 (BBRA) en het Algemeen Rijksambtenaren Reglement (ARAR) een aantal regelingen aangaande extra beloningen opgenomen. Het gaat daarbij bijvoorbeeld om zeer goede dienstvervulling en om het behouden van werknemers. Ten aanzien van dat laatste werd opgemerkt: "Een goed functioneren van de overheidsdienst vergt een zowel kwalitatief als kwantitatief goede bezetting van ook die functies, waarvoor het personeel op de arbeidsmarkt schaars is. Derhalve is het noodzakelijk in de beloning de mogelijkheden te scheppen om adequaat op arbeidsmarktverhoudingen in te spelen" ${ }^{1005}$ Meer differentiatie in beloning moet worden aangebracht in verband met arbeidsmarktverhoudingen. Hierbij is de gedachte dat de op functiewaardering gebaseerde interne beloningsverhoudingen niet te veel doorkruist moeten worden. Zo besloot de Ministerraad op 27 februari 1987 dat de categorieên accountants-, automatiserings- en financieel-economisch personeel bij alle Ministeries en de categorie fiscaal deskundigen bij het Ministerie van Financiën in aanmerking kunnen komen voor extra beloningen overeenkomstig de artikelen $18 \mathrm{~b}$ en $22 \mathrm{a}$ van het BBRA

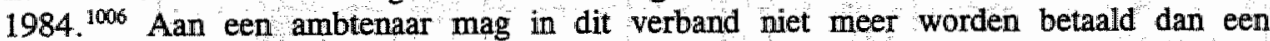
bepaald bedrag, in 1987 F. 20.000 ,- bruto. Om de interne beloningsverhoudingen niet te verstoren mag de extra toelage in prineipe niet uitgaan boven het maximumsalaris van de naasthogere schaal. Het bevoegde gezag, bij de Belastingdienst de Minister van Financiën, bepaalt wie binnen deze categorieën daadwerkelijk in aanmerking komt voor een extra beloning. Groepen van ambtenaren die in aanmerking komen voor de toekenning van extra beloningen worden, na overleg met de Minister van Bímnenlandse Zaken en de andere betrokken Ministers, door de Ministerraad aangewezen, waarna de Minister van Financièn tot toekenning kan overgaan. De Minister is bevoegd aan afzonderlijke ambtenaren extra beloningen te verstrekken. In principe dient de Minister jaarlijks schriftelijk te rapporteren aan de Minister van Binnenlandse Zaken, die zorgt voor de interdepartementale afstemming. Binnen deze regels heeft het Directoraat-Generaal der Belastingen de vrijheid om eigen beleid met betrekking tot extra belonen te ontwikkelen. Zo werd begin jaren ' 90 een begin gemaakt met de invoering van beloningsdifferentiatie.

${ }^{1005}$ Tweede Kamer (vergaderjaar 1987-1988), circulaire AB87/U1667 van het Ministerie van Binnenlandse Zaken, 20220, hoofdstuk IX B, ni: 21, p. 251

${ }^{1005}$ Tweede Kamer, vergaderjaar 1987-1988, 20200 hoofdstuk IX B, ar. 21, circulaire AB87/U1668 van het Ministerie van Binnenlandse Zaken, p. 250. 
Wel werd opgemerkt dat de effecten zich moeilijk laten bepalen. ${ }^{1007}$ Het personeel bleek hier veelal positief tegenover te staan. In 1991 werd het beloningsinstrument Belastingdienst ingevoerd. Hierdoor werd het mogelijk om met behulp van een op te maken basisbeoordeling op een objectievere wijze beloningdifferentiatie toe te passen.

De Algemene Rekenkamer heeft onderzoek verricht naar het gebruik van dit instrument door een aantal Ministeries. ${ }^{1008}$ Hienuit bleek dat de Belastingdienst in 1993

F. 14.875.000,- besteedde aan extra beloningen, hetgeen neerkwam op $F$. 484,43 per volledige baan. Dit was relatief laag vergeleken met andere onderzochte delen van de overheid, zoals het Ministerie van Economische Zaken en het Ministerie van Welzijn, Volksgezondheid en Sport (resp. F. 651,72 en F. 713,34). Maar ook valt op dat het Ministerie van Financiën aanzienlijk meer uitbetaalt aan extra beloningen, namelljk $F$. 2.631 , - per volledige baan. Het bleek bij de Belastingdienst niet mogelijk om aan te geven hoe de extra beloningen waren verdeeld over de salarisschalen, aangezien voor $32 \%$ hiervan de verdeling onbekend was. Bij het Ministerie van Financiën werden relatief veel extra beloningen toegekend aan ambtenaren in de hoogste schalen. ${ }^{1009}$ Dit hield vooral verband met de toekenning in verband met arbeidsmarktknelpunten. Het gebruik van de diverse beloningsartikelen bij het Ministerie van Financiën en de Belastingdienst was als volgt:

\begin{tabular}{|c|c|c|c|c|c|c|}
\hline \multirow{2}{*}{ Ministerie } & \multicolumn{6}{|c|}{ beloningsartikel f 1.000} \\
\hline & $\begin{array}{l}12 \mathrm{a} \\
\text { BBRA } \\
\text { (gratifica- } \\
\text { ties bij } \\
\text { bijzondere } \\
\text { prestaties) } \\
\quad\end{array}$ & $\begin{array}{l}12 \mathrm{~b} \\
\text { BBRA } \\
\text { (toelagen } \\
\text { wegens } \\
\text { zeer } \\
\text { goede of } \\
\text { uitste- } \\
\text { kende } \\
\text { functie- } \\
\text { vervil- } \\
\text { ling) }\end{array}$ & $\begin{array}{l}18 \mathrm{~b} \\
\text { BBRA } \\
\text { (toelagen } \\
\text { om rede- } \\
\text { nen van } \\
\text { werving } \\
\text { en be- } \\
\text { houd) }\end{array}$ & $\begin{array}{l}22 \mathrm{a} \\
\text { BBRA } \\
\text { (uitkeringen } \\
\text { orn redenen } \\
\text { wan } \\
\text { werving en } \\
\text { behoud) }\end{array}$ & $\begin{array}{l}79 \\
\text { ARAR } \\
\text { (gratificaties } \\
\text { bij loffelijke } \\
\text { dienstver- } \\
\text { richting) }\end{array}$ & Totaal \\
\hline $\begin{array}{l}\text { Ministerie van } \\
\text { Financien }\end{array}$ & 826 & 19 & 0 & 2.714 & 388 & 3.947 \\
\hline Belastingdienst & 12.666 & 268 & 0 & 1.595 & 0 & 14.529 \\
\hline
\end{tabular}

Tabel 17.1 Bij de Belastingdienst in 1993 toegepaste beloningsartikelen

Het is opvallend dat bij de Belastingdienst vooral beloningen op grond van art $12 \mathrm{a}$ BBRA belangrijk zijn. Het betrof dus vooral uitkeringen op grond van goed functioneren en minder op grond van arbeidsmarktknelpunten. Aangezien de beloning op grond van arbeidsmarktknelpunten bij de Belastingdienst een relatief minder belangrijke rol speelde is het denkbaar dat bij deze dienst ambtenaren in hogere schalen relatief minder profiteer-

1007 Belastingdiensi, Jaarverslag over 1990, Den Haag, 1991, p. 37.

loos Tweede Kamer (vergaderjaar 1995-1996), Extra beloninged, Rapport Algemene Rekenkamer, 24657, ins. $1-2$.

${ }^{1009}$ Schaal 16-20 ontving 9,5\% van de bruto-salarissen, maar meer dan $23 \%$ van de extra beloningen. 
den dan bij het Ministerie van Financiën. Het aantal gevallen van cumulatie van beloning bleek bij de Belastingdienst relatief beperkt. Wel bleek dat extra beloningen woor een belangrijk deel een structureel karakter hebben. De Algemene Rekenkamer constateerde dat in $64 \%$ van de onderzochte dossiers de betreffende ambtenaren de extra beloning minimaall vijf jaar achtereen ontvingen. Volgens de Staatssecretaris van Financiën was dit geen automatisme maar een bewijs van uitstekend functioneren ${ }^{1010}$

\subsubsection{Wie houdt toezicht op het productieproces?}

De Belastingdienst kent een zestal hoofdprocessen, namelijk bestandsbeheer, heffing, toezicht op de nakoming van niet-fiscale regelgeving, opsporing, inning en dienstverlening. ${ }^{1011}$ Verder zijn er een aantal processen die dienen ter ondersteuning van de hoofdprocessen. Het gaat hierbij vooral om financiên, personeel en organisatie, huisvesting, onderzoek en ontwikkeling, en communicatie. Door de vrij sterke centralisatie van beslissingsbevoegdheid en regelgeving waren de uitvoeringsprocessen op de verschillende vestigingen relatief uniform. Bij die uitvoering zijn een drietal zaken met name van belang. In de eerste plaats moeten de uitvoeringsprocessen binnen de Belastingdienst effectief zijn. Dit houdt in dat uitvoerende eenheden flexibel moeten kunnen inspelen op veranderingen. Dit houdt ook in dat hogere bestuurlijke niveaus sturen op afstand. Dat wil zeggen dat zij wel sturen, maar daarbij wel de nodige terughoudendheid in acht nemen Daarnaast dienen de processen binnen de Belastingdienst beheersbaar en bestuurbaar te blijven. In de derde plaats probeert de Belastingdienst te zorgen voor een goede besturing. Zij tracht in dit verband te zorgen voor voldoende kwaliteit van de besluitvorming, verantwoording en controleerbaarheid; waardoor enerzijds de politiek en anderzijds de Directeur-Generaal ook daadwerkelijk zijn verantwoordelijkheid kan dragen.

In de jaren tachtig is om beter aan deze aandachtspunten te voldoen overgeschakeld van een strikt hiërarchisch besturingssysteem op een meer collegiale bestuursvorm. Er is een Directieraad ingesteld die bestaat uit de (plv) Directeur-Generaal en de 5 divisiedirecteuren. Door deze Raad worden de doelen bepaald en wordt afgestemd tussen de verschillende delen van de Belastingdienst. Formeel is de Directeur-Generaal der Belastingen eindverantwoordelijk. Hij kan op de manier waarop het productieproces binnen de Belastingdienst plaatsvindt en dan vooral op de resultaten van dat proces door de politiek (Staatssecretaris, Minister, Staten-Generaal) worden aangesproken. In de praktijk bepaalt de Directeur-Generaal de beleidsmatige en budgettaire kaders. Verder kent elke divisie een divisieraad die voor de divisie een soortgelijke functie vervult als de Directieraad voor de Belastingdienst in zijn geheel. De directies (divisies) zijn verantwoordelijk voor het resultaat en zijn volledig verantwoordelijk voor de vormgeving en uitvoering van de bedrijfsprocessen. ${ }^{1012}$ De operationele doelen van de Belastingdienst op het gebied van het fiscaal-technische beleid, het fiscale beleid en de productie worden op divisieniveau vertaald in bedrijfsprocessen. De lokale eenheden zijn vervolgens verantwoordelijk voor een juiste uitvoering van de bedrijfsprocessen. Daarbij is het wel de bedoeling dat er landelijk gezien de nodige uniformiteit bestaat. De eenheden dienen binnen bepaalde algemene kaders te blijven. De afzonderlijke eenheden zijn dan ook relatief zelfstandig en

1010 T.a.p., p. 12.

${ }^{1011}$ Van Kommer en Muizelaar (1995, p. 49).

1012 Directoraat-Generaal der Belastingen, Beheersverslag Belastingdienst 1991, Den Haag, 29 april 1992, p. 54. 
hebben eigen bevoegdheden. Om ook inderdaad deze verantwoordelijkheid te kunnen dragen zijn zoals opgemerkt bevoegdheden gedecentraliseerd. Daarbij gaat het onder meer om bevoegdheden op het terrein van financiën, personeel en organisatie. Het streven is integraal management op eenheidniveau mogelijk te maken. De hoofden van deze eenheden zijn zelf verantwoordelijk woor een goede afhandeling en zien hier op toe. Van Kommer en Muizelaar merken dienaangaande op: "De hoofden van de eenheden dragen integrale verantwoordelijkheid voor de behandeling van de fiscale zaken en voor het functioneren van de eenheid". ${ }^{1013}$ "Om dit mogelijk te maken is gekozen voor een platte organisatie met korte besluitvormings- en communicatielijnen. In dit verband merken zij op: "Beslissingen worden door verantwoordelijke managers ("de lijn") genomen en niet door ondersteunende functionarissen ("de staf"). Ten aanzien van het productieproces wordt verder gesteld: "Beheersing van de operationele processen gebeun binnen de eenheden. Daartoe worden continu productiegegevens geproduceerd en getoetst. Over afwijkingen ten opzichte van planningen wordt aan de directies gerapporteerd ("management by exception"), mede ten behoeve van de door de Belastingdienst als geheel af te leggen verantwoording". ${ }^{1014}$ Ook de informatievoorziening werd hierop afgestemd. De Belastingdienst trachtte de informatievoorziening en daarmee de bedrijfsbesturing door de Directieraad te verbeteren door het verbeteren van het informatiemanagement en door het sluiten van informatiecontracten. In deze contracten is bepaald welke gegevens met welke frequentie door welk bestuurlijk niveau dient te worden aangeleverd. Met deze informatie worden vervolgens onder andere kengetallen opgesteld, waarmee inzicht kan worden verkregen in de productie van de Belastingdienst. In 1993 werd in dit verband de informatiebehoefte in kaart gebracht die nodig is in verband met de bedrijfsbesturing.

Wordt het productieproces meer inhoudelijk bezien, dan kan worden geconstateerd dat dit proces van groot belang was om de overschakeling van correctie naar preventie te kunnen maken. Hierdoor kwam meer nadruk te liggen op klantgerichtheid. Net als bij productiebedrijven wordt meer de nadruk gelegd op just-in-time-management: Hieronder wordt verstaan het op tijd leveren, het op een goede wijze afleveren van zaken en het voorraadbeheer. De integrale besturing van de goederenstroom werd net als bij dit soort bedrijven veel belangrijker. Allerlei logistieke principes bleken ook voor de Belastingdienst van belang. Zo werd veelal (ook nog in 1993) pas na de binnenkomst van een aangifte bepaald welke activiteiten moeten worden verricht. Moet er bijvoorbeeldl een boekenonderzoek plaatsvinden of niet. Om een snelle afhandeling te realiseren is het wenselijk om van te voren al een idee te hebben welke activiteiten moeten worden verricht. Dit moet zodanig geschieden dat aangiften die diepgaand moeten worden onderzocht, pas binnenkomen indien er voldoende capaciteit beschikbaar is. De gedachte is meer dan voorheen dat het aanhouden van een grote voorraad vermeden moet worden. De Belastingdienst probeert het binnenkomen van aangiften en de afhandeling steeds meer te synchroniseren. Dit diende onder andere te gebeuren door het verder vereenvoudigen van het proces. Naast het bevorderen van de "compliance" door grotere klantgerichtheid heeft de Belastingdienst echter ook andere taken zoals het toezien op de naleving van de bestaande wetgeving. Deze taken kunnen strijdig zijn met het snel afdoen van aangiften. Ook in de jaren negentig werd verder gewerkt aan de verbetering van het productieproces. Zo werd voor de eenheden Ondernemingen een blauwdruk opgesteld voor de inrichting van het administratieve proces in de jaren "90 en het jaar 2000. Hieruit bleek dat het niet mogelijk was om alle doelen meteen al te realiseren. Daarom koos de Belastingdienst

\footnotetext{
${ }^{1013}$ Van Kornmer en Muizelaar (1995, p. 36).

1014 T.a.p., p. 37.
} 
wöor een groeimodel, dat flexibel kon inspelen op evenuele veranderingen.

Tenslotte moet nog worden opgemerkt dat in het kader van de herstructurering aan het begin van de jaren negentig het portefewillehouderschap werd ingesteld. Dit hield in dat de Directeur-Generaal de bevoegdheid voor het vaststellen van het door de Belastingdienst te yoeren beleid met betrekking tot én bedrijfsproces of eén belastingmiddel delegeerde aan een portefeuillehouder, in de praktijk eén van de directies. ${ }^{1016}$ Dit is bijvoorbeeld gebeurd bij de vennootschapsbelasting en de invordering. Het doel van het instellen van het portefeuillehouderschap is het bevorderen van doelmatige commumicatie, coóndinatie en taakverdeling ten aanzien van de verschillende belastingmiddelen en bedrijsprocessen. Het betreft onder meer de communicatie en coordinatie tussen de directies op het ministerie en de doelgroepdirecties". Dit portefeuillehouderschap heeft betrekking op een viertal terreinen. In de eerste plaats gaat het om het organiseren en bewaken van het landelijke fiscale overleg. Daarnaast is de portefeuillehouder het aanspreekpunt voor aan de ene kant het Ministerie en aan de andere kant de eenheden. Verder is de portefeuillehouder belast met het toezicht op de automatiseringssystemen voor het betreffende belastingmiddel of het proces en de bijbehorende administratieve regelingen. In de vierde plaats houdt de portefeuillehouder zich bezig met de regelgeving op uitvoerend gebied. Ten aanzien van de vraag wie toezicht hield op het productieproces werd opgemerkt: "Het portefeuillehouderschap tast overigens de eigen bevoegdheid en (lijn-jverantwoordelijkheid die de doelgroepdirecties hebben ten aanzien wan het resultaat en de kwaliteit van het primaire proces niet aan ${ }^{\prime \prime}{ }^{1017}$. Het portefeuillehouderschap past in de toenemende decentralisatie van taken bij de Belastingdienst. Zij beoogt door het toewijzen van de primaire verantwoordelijkheid voor een bepaald werkterrein zoals een bepaalde belasting, de rechtszekerheid en rechtsgelijkheid te bevorderen. In 1993 werd de conclusie getrokken dat het instrument van het portefeuillehouderschap nuttig is en zich goed ontwikkelt. De samenwerking tussen de verschillende portefeuilles werd meer ingevuld, onder meer door afstemmingsoverleg.

Concluderend kan over de periode 1970-1990 gesteld worden dat de Belastingdienst aanvankelijk gekenmerkt werd door een hiërarchische besturingsstructuur. Toezicht werd ook uitgeoefend door het Ministerie. Geleicelijk aan veranderde dit door de reorganisatie, het toenemende gebruik van budgettering en de invoering van contractmanagement waardoor het toezicht op het productieproces voomamelijk werd uitgeoefend door de Belastingdienst zelf en dan vooral door resultaatverantwoordelijke directies en eenheden.

17.5.1.4 Wie houdt toezicht op de omvang en samenstelling van het team van producenten?

\subsection{Wie zag toe op de omvang van het team van producenten?}

De omvang van het personeel werd begin jaren tachtig bepaald door het parlement, aangezien het parlement de begroting diende goed te keuren. Toezicht werd gehouden door het Ministerie. Gedurende de jaren tachtig en negentig werd door de politici

1015 Zie ook: Koster en Verstegen (1991).

${ }^{1016}$ Directoraat-Generaal der Belastingen, Beheersverslag Belastingdienst 1991, Den Haag, 29 april 1992, p. 16. Vergelijk ook: Dirrectoraat-Generaal der Belastingen, Beleidsverslag 1992, Den Haag, april 1993, p. 21.

${ }^{1017}$ T.a.p., p. 16. 
herhaaldelijk gebruik gemaakt van dit recht. Onder invloed van de politiek liep de formatie bij de Belastingdienst in 1996 terug tot 28.676. Deze was in 1989 nog 31.552. Ook investerings- en personeelsplannen moesten worden aanvaard door Ministerraad. In januari 1983 aanvaardde de Ministerraad bijwoorbeeld het investerings- en personeelsplan 1983-1987. Dit plan geeft aan wat de gevolgen van het door de Belastingdienst beoogde beleid zijn voor de personele en materiële begroting. Het kabinet ging accoord met het extra beslag op de middelen dat uit het plan voortvloeide. Indien er zich binnen de Belastingdienst tegenvallers voordoen in de zin dat yoor het bestaande takenpakket meer mensen nodig zijn, moet de Belastingdienst dat zelf compenseren. Doordat de betrouwbaarheid van de formatieciffers toenam verbeterde ook de personeelsplanning halverwege de jaren 80 . Dit werd voornamelijk gerealiseerd door toenemende automatisering waardoor uifgebreide bezettingsoverzichten konden worden opgesteld. Hierdoor verbeterde de betrouwbaarheid van de doorstroom- en verloopprognoses. ${ }^{2018}$ Bovendien kreeg de personeelsplanning de beschikking over vermoedelijke begrotingsformaties voor een periode van vier jaar.

In 1988 is het Bedrijfs- en Personeelsplan 1989-1992 opgesteld, waarvan het Sociaal Beleidskader onderdeel uitmaakte. De doelen, ontwikkelingen en de personele consequenties worden hierin geschetst. Het Sociaal Beleidskader Belastingdienst voorziet in een zogenaamd flankerend beleid dat dient om de overgang van de oude naar de nieuwe structuur te vergemakkelijken. Het Sociaal Beleidskader Belastingdienst is gebaseerd op het Sociaal Beleidskader Rijksoverheid. Het wijkt hier echter op een aantal punten vanaf. De werkingsduur van het Sociaal Beleidskader Belastingdienst is langer en bovendien is het breder toepasbaar. Daarom was toestemming van de Ministerraad nodig. Op 19 oktober 1988 werd met de Bijzondere Commissie voor georganiseerd overleg overeenstemming bereikt ower dit Bedrijfs- en Personeelsplan en het daarbij behorende Sociaal Beleidskader Belastingdienst. Deze overeenstemming werd in een convenant neergelegd. Hierin werd aangegeven welke maatregelen nodig zijn om de gevolgen op te vangen van de reorganisatie, de invoering van de Oort-wetgeving, de afslanking van de Rijksdienst en de toenemende automatisering. Bepaald werd dat tot en met 1992 een werkgelegenheidsgarantie werd gegeven aan het personeel. Verder werd een wervingsstop ingevoerd. Aan de andere kant konden nu functies en personen binnen de Belastingdienst verplaatst worden. Hierdoor kon de herstructurering en de afslankingsoperatie doorgang vinden.

Het overzicht van de personele ontwikkelingen maakt duidelijk dat de Belastingdienst gedurende de jaren tachtig, net als het Rijksmuseum, niet vrij was om zelf te bepalen hoeveel mensen in dienst zouden worden genomen. Begin jaren ' 80 werd een getrapte formatievaststelling doorgevoerd. Het Ministerie van Financiën stelde de verdeling van de personeelsformatie vast per regionale directie en per dienstvak. De regionale directie verdeelt verder. Eind jaren tachtig en begin jaren negentig werden een aantal taken op personeelsgebied gedecentraliseerd. Het ging daarbij in de eerste plaats om het opstellen van algemene kaders voor het beleid inzake de formatie, de rechtspositie en de arbeidsomstandigheden. Het formatiebeheer en het beheer over de personeelsuitgaven gedecentraliseerd. In dit verband werd de Belastingdienst belast met het voorbereiden van de personele begroting, het verdelen van deze middelen over de verschillende divisies en andere budgethouders en tenslotte met het controleren van de personele uitgaven. De regelgeving bevat vooral hoofdlijnen. Daardoor is het mogelijk deze verder in te vullen al naargelang de lokale situatie. Het beheer over de formatie werd weliswaar gedecentrallseerd, dat nam niet weg dat de Belastingdienst niet vrij was zelf de optimale formatie te bepalen. Met ingang van 1 januari 1993 zijn echter alle personeelsuitgaven gedecen-

1018 Belastimgdienst, Jaarwerslag over 1984, Den Haag, 1985, p, 72. 
traliseerd naar de directies evenals het formatiebeleid.

\subsection{Hoe was het toezicht op de samenstelling van het team van producenten geregeld?}

Vanaf 1983 is geprobeerd om bij de Belastingdienst te komen tot een minder centraal personeelsbeheer. Het plaatselijk management werd verantwoordelijk voor de indeling van personeel in eenvoudig en minder eenvoudig administratief werk. Verder kwam de werving van administratief personeel in nauw overleg tussen directie en eenheden tot stand. Dit maakt het mogelijk om de ontplooiingsmogelijkheden van het personeel beter te laten aansluiten bij de behoeften. Enerzijds kunnen mensen kiezen voor eenvoudige functies. $\mathrm{Zij}$ hoeven dan niet of weinig extra interne opleidingen te volgen. Anderzijds is er plaats voor schoolverlaters die moeilijker taken ambiëren maar daar dan wel een aanvullende interne opleiding voor moeten volgen. Een tweede belangrijke verandering is dat het personeel meer invloed kreeg op de standplaatstoewijzing en later ook op de functietoedeling. De regionale directies hadden verder ook een rol bij de beschrijving van functies. Bijzonder voor de Belastingdienst is de grote nadruk op de verticale doorstroming van het personeel. Indien interne tests met succes zijn afgelegd en interne opleidingen worden gevolgd is doorstroming naar andere of hogere functies mogelijk. ${ }^{1019}$ Het gevolg hiervan is een van oorsprong zeer omvangrijk opleidingsapparaat hetgeen een belangrijke functie vervult binnen de Belastingdienst. Bij het bepalen van de geschiktheid van interne sollicitanten voor leidinggevende functies werd in de jaren ' 80 steeds meer gebruik gemaakt van functiebeschrijvingen en profielschetsen. De ervaring was dat dergelijke functiebeschrijvingen en profielschetsen belangrijk konden bijdragen aan een goede vervulling van deze vacatures. Halverwege de jaren ' 80 werd dit systeem verder ontwikkeld. In 1986 werd er voor de hoogste functies binnen de Belastingdienst een systeem van loopbaanplanning opgezet. Dit hield in dat binnen de Belastingdienst geselecteerd werd op personeel dat in de toekomst een managementfunctie zou kunnen bekleden. Geselecteerd personeel werd vervolgens vanaf een vroeg stadium begeleid. Er werd een adviseur aangetrokken die dit systeem van management development verder worm moest geven. Zijn taak was wooral het bijhouden van een langere termijn planming van managementfuncties die beschikbaar komen en van de voor deze functies beschikbare kandidaten.

Een belangrijk probleem bij de decentralisatie van taken bleek in 1988 de wirwar van regels op het terrein van het personeelsbeleid te zijn. Uitgaande van de algemene voor de centrale overheid geldende regels werd een eigen regeling voor de Belastingdienst opgesteld. Begin jaren ' 90 vond op personeelsgebied decentralisatie en deregulering plaats. Het uitgangspunt van het decentralisatiebeleid was dat gedecentraliseerd wordt, tenzij er belangrijke redenen zijn waarom bepaalde taken op centraal of divisie-niveau uitgevoerd moesten worden: In overleg met het Ministerie van Binnenlandse Zaken is in 1990 de decentralisatie van het beheer van de formatie begonnen. Voorheen konden alleen bepaalde personeelscategorieën solliciteren naar een functie. $\mathrm{Na} 1990$ maakte een lokale manager de functie-eisen van een vacature bekend, vervolgens kon iedereen binnen de Belastingdienst hiernaar solliciteren. Verder werd onderzocht in hoeverre bepaalde regels op personeelsgebied verder beperkt konden worden.

Voorts is van belang wie bevoegd was om wijzigingen in benoemingen aan te brengen. In

1019 Huizenveld, in: Van der Valk (1985). 
1986 werd een experiment gehouden met zelfbeheer. ${ }^{1020} 19$ personeelstaken werden van het departement van Financiën overgeheveld maar drie lokale eenheden. Besloten is om per december 1987 een twaalftal taken over te dragen aan de (lokale) hoofden van dienst. Het ging daarbij onder meer om:

* verlenen van ontslag op eigen verzoek of wegens het bereiken van de pensioengerechtigde leeftijd;

* verlenen van toestemming om te werken in deeltijd;

* toekennen van gratificaties;

* aanstellen in vaste dienst;

* toekennen van studiefaciliteiten, met inbegrip van de tegemoetkoming in de studiekosten. ${ }^{1021}$

De meeste van deze taken werden in de praktijk reeds door lagere organen vervuld. Begin jaren negentig werd dit verder uitgewerkt door de Belastingdienst zelf dit soort zaken te laten regelen. Daarnaast kreeg de dienst de mogelijkheid om zelf personeel aan te nemen en te ontslaan.

\section{Conclusie}

Net als bij het rijksmuseum werden er gedurende de jaren tachtig weliswaar een aantal wijzigingen doorgevoerd ten aanzien van de verdeling van dit eigendomsrecht, maar de herziening was nog vrij beperkt. De formatie wordt bepaald door de Staten-Generaal terwijl de Belastingdienst slechts in beperkte mate zelfstandig de samenstelling wan het personeelsbestand kon bepalen. Begin jaren negentig werd het personeelsbeleid verder gedecentraliseerd waardoor de Belastingdienst meer vrijheid kreeg om te bepalen wie zij in dienst nam of wie zij ontsloeg.

\subsection{Het recht op vruchtgebruik, wie maakt aanspraak op de winst?}

De Belastingdienst is zoals opgemerkt onderdeel van het Ministerie van Financiën en maakt geen winst. Het recht op de winst is dan ook niet aan de Belastingdienst toegekend. Ook werden er geen reserveringen en afschrijvingen toegepast. De reden hiervoor was dat reserveringen en afschrijvingen in strijd waren met de Comptabiliteitswet.

Om te bezien of de werknemers verkapt aanspraak maakten op de winst is het belangrijk om de aanspraken van de werknemers te onderzoeken. In 1988 kwam het loopbaan- en bezoldigingsreglement Belastingdienst tot stand. Veel verspreide regelingen werden in éen reglement opgenomen. In paragraaf $\mathbf{1 7 . 1 0}$ wordt hier verder op ingegaan.

17.7 Wie heeft het recht de organisatie van de Rijksbelastingdienst te wijzigen, te verkopen of te liquideren?

Het parlement beschikt net als bij het Rijksmuseum over dit recht. De reorganisatie die is uitgevoerd gedurende de jaren 1990-1992 is door het parlement goedgekeurd. Het parlement is ook degene die beslist over eventuele verdere privatisering. Wel werd herhaaldelijk overleg gepleegd met de Bijzondere Commissie voor georganiseerd overleg

${ }^{1020}$ Belastingdienst, Jaaryerslag over 1986, Den Haag, 1987, p. 61.

${ }^{102.1}$ Belastingdienst, Jaarverslag over 1987, Den Haag, 1988, p. 43. 
ower de veranderingen binnen de Belastingdienst. In verband met de herstructurering en de eigen rol van het management is ook overlegd over de medezeggenschap:

Zoals reeds herhaaldelijk opgemerkt kan ook de mogelijkheid voor een onderneming om vermogen op de kapitaalmarkt aan te trekken als een vorm van dit recht worden aangemerkt. Dit recht was aan de Belastingdienst niet toegekend. Net als bij het Rijksmuseum was hiervoor op grond van artikel 39 van de Comptabiliteitswet machtiging door de wet vereist. Dit eigendomsrecht was dan ook in handen van de Kroon en was niet overgedragen aan de Belastingdienst.

\subsection{Welke doelen kunnen uit de verdeling van eigendomsrechten worden afgeleid?}

\section{Het gebruiksrecht}

Uit de verdeling van het gebruiksrecht en de veranderingen daarin kan worden afgeleid dat de bestrijding van fraude belangrijker is geworden. Gedurende de jaren "70 constateerde de Belastingdienst dat de belastingmoraal mede door de hoge belastingen begon te veranderen. Dat hield ook verband met de regelgeving, die vaak moeilijk te handhaven was. ${ }^{1022}$ Hierbij kan gedacht worden aan de tweeverdienersregeling en de reiskostenaftrek. Een betere aanpak van de fraude werd steeds noodzakelijker, wilde de Belastingdienst niet te maken krijgen met dalende belastingopbrengsten. Daartoe diende de organisatie te veranderen. Door de organisatiewijziging en het veranderde toezicht op het productieproces en de productieresultaten begin jaren " 90 werd het beter mogelijk om fraude te bestrijden. Van Kommer en Muizelaar merken in dit verband op: "De geîntegreerde en doelgroepgerichte aanpak maakt landelijke acties die op een specifiek onderdeel van de aangifte zijn gericht, zoals huurwaardeforfait, reiskostenvergoedingen en buitengewone lasten, gemakkelijker uitwoerbaar. Datzelfde geldt voor landelijke brancheacties en minder traditionele vormen van onderzoek, zoals korte bedrijfsbezoeken (de zogenoemde "waarnemingen-ter-plaatse") en bezoeken aan beginnende ondernemers $(\ldots).)^{n !} 1023$

Voorheen was de Belastingdienst georganiseerd naar belastingmiddel en naar de verschillende stappen in het proces (inning gelden, controles ed.). Dit had tot gevolg dat afzonderlijke eenheden geen totaal beeld hadden van een belastingplichtige, waardoor fraude vergemakkelijkt werd, Bovendien was de Bellastingdienst weinig flexibel, amdat elke eenheid slechts verantwoordelijk was voor een deel van het proces. Dit verbeterde door de reorganisatie waardoor afzonderlijke belastingmiddelen en processtappen werden samengevoegd (particulieren, grote ondernemingen e.d.).

Naast de toename van de mogelijkheid om de fiscale fraude te bestrijden kan uit de verdeling en de wijziging van dit eigendomsrecht worden afgeleid dat het belang van het voorkomen van overtredingen ("compliance") van de fiscale en andere wetgeving is toegenomen, terwijl het belang van de correctie van deze wetgeving daarentegen is afgenomen. De besturing van de Belastingdienst is veranderd. Er kwam een meer collegiale besturing met een Directieraad en divisieraden. Ook kregen lokale eenheden meer bevoegdheden en verantwoordelijkheid. Het doel hiervan was de medewerkers van de Belastingdienst meer te betrekken bij het nastreven van de doelstellingen van de Belastingdienst. Dit had ook hiermee te maken dat de doelen van de Belastingdienst veranderden. Het bevorderen van de "compliance" werd veel belangrijker. Dit was noodzakelijk om voldoende belastingopbrengst te realiseren. De organisatiestructuur en

${ }_{1022}$ Vergelijk in dit verband: Algemene Rekenkamer, Jaarwerslag over 1989.

1023 Van Kommer en Muizelaar (1995, p. 24). 
ook de -cultuir was hier echter nog onvoldoende op afgestemd. Om de nieuwe doelen te kumnen halen moest het personeel meer betrokken worden bij het nastreven ervan.

De wijziging van dit eigendomsrecht reflecteerde ook het grotere belang dat gehecht werd aan klantgerichtheid: en het behalen van resultaten. Aanvankelijk was de Belastingdienst een $\mathrm{min}$ of meer centraal geleide bureaucratische organisatie die traag werkte. Klantgerichtheid was van minder belang aangezien burgers toch well betaalden. De omgeving van de Belastingdienst wijzigde zich echter aanzienlijk, terwijl de Belastingdienst daar onvoldoende op kon reageren. Niet veranderen zou grote risico"s opleveren voor de belastingopbrengsten en zou de toch al verslechterende belastingmoraal verder verslechteren. Om dit tegen te gaan werd er meer nadruk gelegd op het resultaat. In plaats van ambtelijk en risicomijdend werd de verdeling van dit eigendlomsrecht gericht op een Belastingdienst die naar buiten gericht en dienstverlenend was. De Directeur-Generaal bepaalt de algemene beleids- en budgettaire kaders. De directies zijn verantwoordelijk voor het te behalen resultal Eén en ander wordt ook weerspiegeld in de veranderingen in het productieproces. Daarbij werd nadrukkelijk gebruik gemaakt van logistieke principes. De nadruk kwam te liggen op een snellere afdoening van aangiften en voorraadbeheer. De instroom van angiften diende beter te worden afgestemd op de beschikbare capaciteit binnen de Belastingdienst. Meer belang werd gehecht aan het vertrouwen van de burgers in de Belastingdienst. Getracht werd dit vertrouwen te vergroten teneinde daarmee de "compliance" te vergroten. Door de gewijzigde logistieke processen kunnen angiften en bezwaarschriften snel worden afgehandeld. Daartoe werden de logistieke processen binnen de Belastingdienst verbeterd. Documentenstromen en ook geldstromen dienden zo goed mogelijk te worden beheerst. Daarom wordt veel gewerkt met voorlopige aanslagen.

Tenslotte kan uit het instellen van het portefeuillehouderschap worden afgeleid dat de Belastingdienst probeerde om de rechtszekerheid en rechtsgelijkheid door de decentralisatie van taken niet in gevaar te brengen.

\section{Het recht op het toezicht op de omvang en de samenstelling van het personeel}

De omvang van het personeelsbestand moest worden goedgekeurd door het parlement. De overheid kon er hierdoor voor zorgen dat meer personeel werd aangetrokken dan strikt noodzakelijk was voor het bereiken van de door de Belastingdienst nagestreefde doelen. De toenemende decentralisatie van taken op personeelsgebied diende om de efficièntie te bevorderen. De Belastingdienst kon meer dan voorheen zelf de samenstelling van haar personeelsbestand bepalen en kon deze dus ook sneller aanpassen aan gewijzigde omstandigheden. Zo zette de Belastingdienst meer mensen in woor het verrichten van onderzoek. Wel bleef het parlement ook hier invloed behouden. Het door de overheid gevoerde beleid dat erop neer komt dat minderheidsgroepen op de arbeidsmarkt extra aandacht moeten krijgen bij thet aantrekken van overheidspersoneel werd ook door de Belastingdienst nagevolgd.

\section{Conclusie}

De wijziging van de verdeling van eigendomsrechten binnen de Belastingdienst weerspiegelt het toenemende belang van het toezicht houden op de output en het minder belangrijk worden van de controle op de input. 


\subsection{Het analyseren wan de ontsluierde "performance" van de Rijkssbelastingdienst}

17.9.1 Welke doelen worden kenbaar gemaakt in documenten en welke doelen worden door bij de Rijksbelastingdienst betrokken principalen genoemd.

\subsubsection{Beleid van regering en parlement en meer in het bijzonder van het Ministe- riè van Financiën}

Omdat de Belastingdienst onderdeel is van het Ministerie van Financiën, is in de begroting elk jaar een hoofdstuk te vinden over de Belastingdienst (hoofdstuk IX B). In deze begrotingen worden verschillende doelen genoemd. Het primaire doel van de Belastingdienst dat genoemd wordt is het realiseren van belastinginkomsten voor de overheid. Daarbij gaat het om de heffing, de controle en de inning op grond van de diverse belastingwetten, de douanewetgeving en de heffing van de premies voor de volkswerzekering. De premies voor de volksverzekeringen kunnen in economische zin als belastingen worden beschouwd. Onder belasting wordt dan verstaan: volgens algemene normen aan de overheid verschuldigde bedragen, zonder dat hiertegenover in het individuele geval een direct aanwijsbare tegenprestatie staat.

In het investerings- en personeelsplan 1983-1987 dat in januari 1983 door de Ministerraad werd aangenomen werden verschillende doelen genoemd. ${ }^{1024}$ Belangrijke doelen waren het verbeteren van de dienstveriening aan het publiek, het verbeteren van de doelmatigheid; het beter bestrijden van de fraude en het verbeteren van de invordering. Om de efficiëntie te verbeteren werd automatisering nagestreefd.

In 1990 was de Belastingdienst volop bezig met de herstructurering. Het doel van de herstructurering was om de hoofddoelstelling van de Belastingdienst beter dan voorheen te kunnen verwezenlijken. Deze hoofddoelstelling heeft naar haar aard een meerjarig karakter. Zij kan worden gesplitst in de kwaliteit van de heffing, van de controle en van de invordering. In de Rijksbegroting worden zij uitgesplitst als: ${ }^{1025}$

-het verhogen van de controledichtheid;

-selectiviteit en differentiatie in de aanpak van individuele zaken;

-de beheersing van de werkprocessen, doorlooptijden en voorraden;

-het verbeteren van de dienstverlening en de doelmatigheid van de organisatie;

-het optimaliseren van de (meerjaren-)planning en controle in de vorm van periodieke uitvoeringsrapportages en jaarverslaglegging. Deze planning en controle diende om de realisatie van de doelen goed te kunnen volgen en om indien nodig tijdig bij te kunnen sturen.

Een doel dat veelvuldig wordt genoemd heeft betrekking op het opsporen van fiscale fraude door het uitwoeren van een adequaat fraudebestrijdingsbeleid. Eind jaren "70 werd onderzoek naar het misbruik en oneigenlijk gebruik van belastingen verricht: Dit onderzoek werd neergelegd in het Rapport Van Bijsterveld. ${ }^{1026}$ Mede op grond van dit rapport werd meer aandacht besteed aan de fraudebestrijding. Intensiveringen van dit beleid

1024 Ministerie van Financiẽn, Investerings- en personeelsplan 1983-1987, Den Haag, 1983

${ }^{1025}$ Tweede Kamer der Staten-Generaal (vergaderjaar 1990-1991), 21800, hootdstuk IXB, nr. 2, p. 28.

1026 Tweede Kamer der Staten-Generaal, Rapport Van Bijsterveld, Handelingen vergaderjaar 1979-1980, $16180, \mathrm{nr}^{\circ} 1$. 
werden geregeld in de diwerse Fraudenota's en bijvoorbeeld in het fiscale deel van het Fraudeplan 1992. ${ }^{1027}$ In de nota Fraude-bestrijding in de directe belastingen en de omzetbelasting, die door de toenmalige Minister en Staatssecretaris in 1982 aan de Tweede Kamer werden aangeboden, werden al een groot aantal maatregelen genoemd die dienden om de preventie van overtredingen te bevorderen. Gewezen wordt op het belang van goede voorlichting, dienstverlening en het verbeteren van de informatievoorziening. In deze en andere nota's wordt groot belang gehecht aan het verbeteren van de "compliance $^{\text {"1 }}$. Vanaf 1996 kunnen een aantal aanvillende maatregelen worden genomen (additioneel aan het fraudeplan). Deze hebben onder andere betrekking op het uitvoeren van meer branche-onderzoeken, het verder uitbouwen van waarnemingen ter plaatse en een verdere verbetering van het clientenbestand.

Voorts wordt het doel van de dienstverlening aan het publiek en meer in het algemeen van het verbeteren van de relatie met de belastingplichtigen genoemd. Daarbij gaat het vooral om woorlichting aan het publiek en om het bevorderen van de klantvriendellijkheid. De Belastingdienst streeft ernaar dat de dienstverlening voldoet aan een aantal concrete kwaliteitseisen op het terrein van procedures, bereikbaarheid, beschikbaarheid, goede externe communicatie en beginselen van behoorlijk bestuur. Een goede dienstverlening dient om de "compliance" te vergroten en te behouden. ${ }^{1028}$

Een ander doel van de Belastingdienst heeft betrekking op het bevorderen van een rechtvaardige inkomensverdeling. ${ }^{1029}$ Zoals elke overbeidsinstelling is ook de Belastingdienst gebonden aan allerlei wettelijke bepalingen. Daarnaast beschikt zij over een zekere mate van (interpretatie-) vrijheid. Een doel dat de Belastingdienst met deze eigen beslissingsbevoegdheid nastreeft is het bevorderen van de verdeling van inkomen. Dit houdt ook verband met de "excess burdens" van de verschillende belastingen. Wel moet worden opgemerkt dat dit doel niet met zoveel woorden genoemd werd in begrotingen. Het kan hier wel impliciet uit worden afgeleid, bijwoorbeeld gelet op hetgeen vermeld wordt inzake het beleid ten aanzien van kwijtschelding en oninbaarheid van belastingen. De Belastingdienst heeft namelijk een bepaalde vrijheid om bedragen kwijt te schelden. In de jaren ' 80 waren de directeurs van de acht regionale directies belast met een aantal taken met een uitvoerend karakter, zoals:. ${ }^{1030}$

- het kwijtschelden van toegepaste verhogingen;

-het kwijtschelden van belastingschuld omdat de belastingplichtige deze niet kan betalen; -het doen van een aanbod tot schikking.

Een ander belangrijk doel betreft het bevorderen van de werkgelegenheid als macroeconomisch doel. ${ }^{1034}$ Het gaat daarbij om het bevorderen van de nationale werkgelegenheid door onder meer het stimuleren van de werkgelegenheid in bepaalde sectoren van de

1027. Vergelijk bijvoorbeeld: Tweede Kamer der Staten-Generaal (Handelingen 1983-1984), "Nota Frande-bestrijcling in de directe belastingen en de omzetbelasting", $17050,17 \$ 22$, ar. 3, in 1982 door de Staatssecretaris aan de Tweede Kamer gezonden. Fraudeplan 1992, Bijlage 14 bij de begroting van 1993, Hoofdstuk $9 \mathrm{~B}$.

1028 Rijksbegroting (1990-1991, pp. 115).

1029 Stiglitz en Brown (1988, p. 485).

${ }^{1090}$ Belastingdienst, Jaarverslag over 1981, Den Haag, 1982, p. 12.

1031 Ministerie van Financiën, Rijksbegroting, Hoofdstuk 4, pp. 113 
economie. Dit gebeurt onder andere door het op een bepaalde manier interpteteren van richtlijnen en wetten, door het niet gelijkelijk toepassen van de fraudebestrijding en door bij de invordering bepaalde grote bedrijven die in financiële moeilijkheden verkeren te ontzien.

Verder kan uit de diverse parlementaire stukken het doel van het bevorderen van de werkgelegenheid bij de Belastingdienst zelf worden afgeleid. Bij de behandeling van de doelen van overheidsinstellingen is opgemerkt dat overheidsbedrijven vaak gebruikt worden voor bet creëren van werkgelegenheid. Dat geldt ook voor de Belastingdienst. Ook het doel van het bevorderen van goede arbeidsomstandigheden is van belang. Met betrekking tot het personeelsbeleid worden een tweetal doelstellingen genoemd, namelijk individualisering en flexibilisering van het loopbaan- en opleidingsbeleid en decentralisatie van personeelstaken. Tenslotte wordt ook gewezen op het belang van het houden van toezicht op in- uit- en doorvoer van goederen. ${ }^{1032}$

\subsubsection{Beleid van de Directeur-Generaal van de Belastingdienst}

Uit de jaarverslagen die betrekking hebben op de onderzoeksperiode en uit de vele verschenen nota"s blijkt dat de hiervoor omschreven doelen eveneens worden genoemd door de directie van de Belastingdienst. In het jaarverslag over 1990 werden als doelen genoemd: : 1033

* Het tegengaan van de achterstanden bij de invordering en het tegen

gaan van oninbaar geleden bedragen;

* Het handelen moest meer kwaliteitsbewust en resultaatsgericht worden;

* Het tijdig afdoen van voorrangsposten;

* Het tijdig afdoen van bezwaarschriften:

* Het verbeteren van de wijze van functioneren van de organisatie;

* Het intensiveren van de fraudebestrijding door het verhogen van de controledichtheid.

Vanaf 1990 worden door de Belastingdienst meerjarige bedrijfsplannen en beheersverslagen uitgegeven. In het bedrijfsplan 1990-1994 is de permanente opdracht van de Belastingdienst opgenomen. Deze staat eveneens vermeld in het jaarverslag over 1988 en houdt: in: "De Belastingdienst woert de wetgeving die haar is opgedragen zo doeltreffend en doelmatig wit en streeft in zijn handelen naar handhaving van rechtszekerheid en rechisgelijkheid. Respect voor en dienstverlening aan het publiek zijn aan het handelen onlosmakelijk verbonden". ${ }^{1034}$ De daarbij horende strategische doelstelling luidt: "Het onderhouden en versterken van de bereldheid van belastingplichtigen tot zoveel mogelijk wrijwillige nakoming (compliance) van de (fiscaal-)wettelijke verplichtingen". In het bedrijfsplan 1990-1994 wordt deze doelstelling onderverdeeld in een aantal externe en interne hoofddoelstellingen. De externe hoofddoelstellingen richten zich op de primaire (preventieve, correctieve, innende en dienstverlenende) taken van de Belastingdienst. De

1002 Bedrijfisplan 1994-1997, pp. 14 e.v.

${ }^{4033}$ Belastingdienst, Jaarverslag over 1990, Den Haag, 1991, p. 20 ;

3034 Directoraia-Generaal der Belastingen, Jaarverslag over 1988, Den Haag, 1989, woord vooraf. Vergelijk ook: Tweede Kamer der Staten-Generaal (1990), Bedriffoplan Belastingdienst 1990-1994, aangeboden aan de Tweede Kamer op 13 juni 1990 bij brief nr. PFC90/632, Den Hiaag, 1990. 
interne doelstellingen hebben vooral betrekking op de bedrijfswoering en de organisatorische en personele aspecten daarvan. ${ }^{103}$

De vermelde hoofddoelstellingen van externe aard zijn: $^{1036}$

* Versterking van controlerende activiteiten. Dit hoult in dat er een controledichtheid van eens in de vijf jaar bereikt moet worden voor de omzetbelasting en loonbelasting en eens in de zes jaar voor de inkomstenbelasting en de vemnootschapsbelasting.

* Verbetering van de kwaliteit van de uitvoering van de primaire taken (heffing, controle en inning). Dit moet bereikt worden door selectie en differentiatie in de aanpak van individuele zaken.

* Resultaatgericht handelen waarbij meer in het bijzonder aandacht wordt geschonken aan:

-De beheersing van de achterstand bij de invordering en dus van het bedrag dat elk jaar wordt kwijtgescholden of oninbaar blijkt te zijn.

-Het tijdig afdoen van met name bezwaarschriften, voorrangposten en de voorlopige aanslagregeling.

-De hulp- en dienstverlening aan het publiek.

De hoofddoelstellingen van interne aard zoals die genoemd worden in het bedrijfsplan zijn:"

* Het verhogen van de doeltreffendheid en de slagvaardigheid door middel van de herstructurering van de organisatie, zoals beschreven in paragraaf 17.4 .

* Het verbeteren van het doelmatig functioneren van de organisatie door steeds de kosten en baten tegen elkaar af te wegen. Verder moest er naar gestreefd worden om de niet-inzetbaarheid terug te dringen.

In het bedrijfsplan 1990-1994 worden verder als doelen genoemd:

* Aanpassing van geautomatiseerde systemen;

* Goede interne en externe voorlichting;

* Informatisering werkprocessen;

* Anticiperen op de EG-ontwikkelingen;

* Versterken van de administratieve organisatie en de interne controle.

In de beheersverslagen komen een groot aantal van deze doelstellingen terug. Zo wordt het uitvoeren van controle alls een belangrijk doel genoemd. Door het uitvoeren van strikte controles worden niet alleen wanbetalers gepakt, maar krijgen andere belastingbetalers ook eerder de neiging om hun belastingformulieren goed in te vullen. Ook in het

${ }^{1035}$ Directoraat-Generaal der Belastingen, Beheersverslag Belastingdienst 1991, Den Haag, 1992, p. 3. Vergelijk ook: Tweede Kamer der Staten-Generaal, Bedrififsplan 1992-1996, op 30 mei 1991 aangeboden aan de Tweede Kamer bij brief mr. PFC91/814, Den Haag, 1991.

${ }^{1036}$ Uitgegaan is van het Beheersverslag over 1991. Directoraar-Generaal der Belastingen, Beheersverslag Belastingdienst 1991, Den Haag, 1992, pp. 3-4. Vergelijk ook: Directeur-Generaal der Belastingen, Beleidskaderbrief (BKB) 1991, brief van de Directeur-Generaal der Belastingen aan de hoofden van directies en eenheden van de Belastingdienst, aangeboden aan de Tweede Kamer der Staten-Generaal op 30 mei 1991 bij brief nr. PFC91/814, Vergelijk ook: Directoraat-Generaal der Belastingen, Bedrijfsplan 1993-1997, Den Haag, 1992. 
Bedrijfsplan / Beleidskader 1992-1996 wordt dit doel genoemd. In diverse verslagen werd het doel van de fraudebestrijding vermeld. ${ }^{1037}$ Verder werd in het Beheersverslag Belastingdienst 1991 uitgebreid ingegaan op het belang van voorlichting en communicatie. ${ }^{1038}$ De communicatie- en dienstverleningsdoelstelling worden uitgewerkt in een viertal doelen, te weten goede voorlichting aan interne en externe doelgroepen, het verbeteren van de dienstverlening, het vergroten van de efficiëntie en effectiviteit en tenslotte het benadrukken van de identiteit van de Belastingdienst.

Voorts wordt vermeld dat het doel van de herstructurering die aan het begin van de jaren negentig werd doorgevoerd hierin gelegen was dat de dienstverlening aan bet publiek zou verbeteren en dat de effectiviteit zou worden verhoogd. ${ }^{1039}$ Met de afronding van de reorganisatie van de Belastingdienst op 1 juni 1992 werd een periode afgesloten die gekenmerkt werd door grootschalige aanpassingen in de werkwijze en de daaraan gekoppelde automatisering, door omvangrijke herhuisvestingsoperaties en door een hernieuwde toedeling en bijscholing van personeel. Naast de hiervoor genoemde doelstellingen kwamen een aantal nieuwe onderwerpen aan de orde, waaronder:

* (internationale) gegevensuitwisseling;

* rulings (afspraken, afgegeven door Belastingdienst/Grote Ondernemingen te Rotterdam);

*. ontwikkeling productiviteitsgetallen;

* fraudegevoelige of moeilijk uitvoerbare elementen in de fiscale wetgeving;

* administratieve lasten bedrijfsleven.

Op het gebied van de dienstverlening is het steeds belangrijker geworden dat de Belastingdienst de belastingbetalers voldoende informeert. Door de problemen die het invullen van belastingformulieren voor burgers met zich meebrengt is het verstrekken van informatie steeds belangrijker geworden. Verder wordt herhaaldelijk het doel van de werkgelegenheid genoemd. Goede voorzieningen en opleidingsmogelijkheden voor het personeel worden van groot belang geacht. Door het wegvallen van de Europese binnengrenzen en de verplichte inkrimping werd het moeilijk om de aangestelde werknemers in dienst te kunnen houden. Verder heeft de Belastingdienst als overheidsinstelling ook nog de verplichting om minderheidsgroepen binnen de arbeidsmarkt in dienst te nemen. Ook valt op dat de Belastingdienst steeds meer naar internationalisering toewerkt. Dit vooral ook in verband met het Verdrag van Maastricht en de daaruit volgende consequenties. De doelstellingen die inspelen op de eenwording van Europa krijgen, hoewel nog zwak, gedurende de onderzoeksperiode meer aandacht. Tenslotte wordt er ook extra aandacht geschonken aan de huisvesting. De doelstelling die in dit verband vermeld wordt is het zorgdragen voor een adequate huisvesting binnen de kaders van een doeltreffende en doelmatige taakuitoefening van de Belastingdienst en een doelmatig voorraadbeheer van de Rijksgebouwendienst.

1037 Vergelijk bijvoorbeeld: Directoraat-Generaal der Belastingen, Beleidsverslag 1992, Den Haag; april 1993, p. 15 .

${ }_{1038}$ Directoraat-Generaal der Belastingen, Beheerswerslag Belastingdienst 1991, Den Haag, 29 april 1992, pp. $57-61$.

1039 Belastingdienst, Jaarverslag over 1990, Den Haag, 1991, p. 9. 


\subsubsection{Welke doelen worden genoemd in niet officiële documenten?}

Niet-officiële doelen werden wooral gevonden in artikelen in kranten en in door medewerkers van de Belastingdienst gepubliceerde boeken. ${ }^{1040}$ Van Kommer en Muizelaar noemen een aantal kerntaken van de Belastingdienst. Deze sluiten aan bij de hiervoor genoemde in officiële documenten gevonden doelen. Genoemd worden de heffing, inning en controle van rijksbelastingen, de opsporing van fiscale fraude, de controle van en toezicht op de doorstroom van goederen, de heffing en inning van premies voor de volksverzekering en overige werkzaamheden zoals de heffing en inning van andere heffingen ${ }^{1041}$ De uitvoering wan de wetgeving dient gepaard te gaan met respect voor het publiek en een goede dienstverlening. Verder wordt het bevorderen van de "complian$\mathrm{ce}^{\text {" }}$ genoemd. Deze laatste doelstelling kan worden opgevat als de strategische doelstelling van de Belastingdienst en vormt een uitwerking van de taakopdracht van de Belastingdienst. De Kam, directeur Planning, Financiën en Control van de Belastingdienst, en Van den Berg noemen in een artikel in Openbaar Bestuur eveneens deze doelen. ${ }^{1042}$ Als strategische doelstelling wordt door hen het versterken van de bereidheid tot nakoming van wettelijke verplichtingen genoemd, de zogenaamde "compliance". Deze doelstelling werd vertaald in operationele doelstellingen voor een drietal beleidsterreinen, te weten ten aanzien van het fiscaal-technische beleid, het fiscale beleid en het beleid met betrekking tot de productie van de Belastingdienst. Bij het fiscaal-technische beleid gaat het om het nemen van maatregelen waardoor de heffings- en inningswetten op een correcte wijze worden uitgevoerd. Het fiscale beleid heeft betrekking op het bereiken van de doelen die de wetgever heeft met die wetgeving. De Belastingdienst probeert de kwaliteit van het fiscaal-technische beleid te verbeteren door het verbeteren van het opleidingsniveau van het personeel, door het afstemmen van de uitvoering op de omvang van de fiscale belangen en door het verbeteren van de interne communicatie. ${ }^{1043}$ Met betrekking tot het beleid ten aanzien van individuele belastingplichtigen en doelgroepen worden een drietal kritische succesfactoren voor het overheidshandelen genoemd. In de eerste plaats is de snelheid van afhandelen van groot belang, in de tweede plaats de zorgvuldigheid van afhandelen en in de derde plaats dient de mate van aandacht voor een belastingaanslag te variëren met het fiscale belang en het risico ervan. Tenslotte is het beleid met betrekking tot de omvang van de productie van groot belang. De juiste uitvoering van de wetgeving dient immers om ontvangsten voor de overheid te genereren. Allerlei doelen worden in dit verband gesteld. Zo moeten aanslagen binnen een bepaalde tijd worden afgehandeld en mag de achterstand in de invordering niet hoger zijn dan 6,5\%. Tenslotte noemen zij nog een aantal ondersteunende doelen zoals een dienstverlenende instelling en het zorgen voor goede scholing van het personeel. Ook Koster en Muizelaar gaan in op de doelen van de

1040 Vergelijk: V. Kommer en Muizelaar (1995).

1041 T.a.p., p. 14. Mr. J.C.F. Muizelaar was hoofd van de afdeling Particulieren, directie Flanning, Financiën en Control, Ministerie van Financiën. Vergelijk ook: Gerritsen (1992, pp. 206-207) en Gerritsen en Breukelen (1992, pp. 2-3). Drs. E. Gerritsen RA was hoofd van de directie Planning, Financiën en Control en werd na 1 april 1992 plv. directeur FEZ, ministerie van Financiën, drs. M.C.J. van Breukelen. was plv. directeur Planning. Financièn en Control van de Belastingdienst.

${ }^{1042}$ De Kam en Van den Berg (1992, p. 21). Vergelijk ook De Kam en Van Wuijitswinkel (1993, pp. 238239). Drs. R.J.M. van Wujitswinkel was eveneens werkzaam bij de Directie Planning, Financiën en Control van het Directoraat-Generaal der Belastingen.

1043 T.a.p., p. 22. 
Belastingdienst. ${ }^{1044} \mathrm{Zij}$ noemen als doelen het op tijd leveren van de door de Belastingdienst werrichte diensten, het toezien op de rechtmatigheid, de betrouwbaarheid en de efficiency.

\subsubsection{Een overzicht van de doeleinden}

De gevonden doelen kunnen als volgt in een tabel worden weergegeven:

\begin{tabular}{|c|c|c|c|c|c|}
\hline Doelen & $\begin{array}{l}\text { Doeleinden } \\
\text { gevonden } \\
\text { met analyse } \\
\text { kenbaar } \\
\text { gemaakte } \\
\text { doelen }\end{array}$ & Ministerie & $\begin{array}{l}\text { Belasting- } \\
\text { dienst }\end{array}$ & $\begin{array}{l}\text { Doeleinden } \\
\text { structuur- } \\
\text { analyse }\end{array}$ & $\begin{array}{l}\text { Doeleinden } \\
\text { gevonden } \\
\text { met beide } \\
\text { analyses }\end{array}$ \\
\hline $\begin{array}{l}1 . \\
\text { Belastingontvangst }\end{array}$ & $x$ & $x$ & $x$ & $\mathrm{x}$ & $x$ \\
\hline $\begin{array}{l}2 . \\
\text { Uitvoering milieu- } \\
\text { heffingen }\end{array}$ & $\mathrm{x}$ & $x$ & $\mathrm{x}$ & & \\
\hline $\begin{array}{l}3 . \\
\text { Automatisering }\end{array}$ & $\mathrm{x}$ & $x$ & $x$ & & \\
\hline $\begin{array}{l}4 . \\
\text { Bestrijden fraude }\end{array}$ & $\mathrm{x}$ & $x$ & $x$ & $x$ & $\mathrm{x}$ \\
\hline $\begin{array}{l}5 . \\
\text { Communicatie- en } \\
\text { dienstverlening }\end{array}$ & $\mathrm{x}$ & $x$ & $\mathrm{x}$ & & \\
\hline $\begin{array}{l}6 . \\
\text { Verbeteren } \\
\text { "compliance" }\end{array}$ & $x$ & $x$ & $x$ & $x$ & $\mathrm{x}$ \\
\hline $\begin{array}{l}7 . \\
\text { Nationale } \\
\text { werkgelegenheid }\end{array}$ & $\mathrm{x}$ & $\mathrm{x}$ & $\mathrm{x}$ & $x$ & $x$ \\
\hline $\begin{array}{l}8 . \\
\text { Het bevorderen } \\
\text { van de werkge- } \\
\text { legenheid bij de } \\
\text { Bellastingdienst } \\
\text { zelf. }\end{array}$ & & $x$ & $x$ & $\mathrm{x}$ & $x$ \\
\hline $\begin{array}{l}9 . \\
\text { Het personeels- } \\
\text { verloop } \\
\text { tegengaan }\end{array}$ & $x$ & $x$ & $x$ & 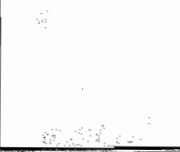 & 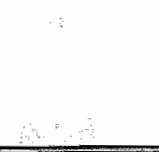 \\
\hline
\end{tabular}

${ }^{1044}$ Koster en Muizelaar (1992, p. 14). 


\begin{tabular}{|c|c|c|c|c|c|}
\hline Doelen & $\begin{array}{l}\text { Doeleinden } \\
\text { gevonden } \\
\text { met analyse } \\
\text { kenbaar } \\
\text { gemaakte } \\
\text { doelen }\end{array}$ & Ministerie & $\begin{array}{l}\text { Belasting- } \\
\text { dienst }\end{array}$ & $\begin{array}{l}\text { Doeleinden } \\
\text { structuux- } \\
\text { analyse }\end{array}$ & $\begin{array}{l}\text { Doeleinden } \\
\text { gevonden } \\
\text { met beide } \\
\text { analyses } \\
\end{array}$ \\
\hline $\begin{array}{l}10, \\
\text { Beloning en goede } \\
\text { arbeidsomstan- } \\
\text { digheden } \\
\text { personeel }\end{array}$ & $x+3$ & \begin{tabular}{l:l}
$\mathbf{x}$ & \\
\hdashline
\end{tabular} & $x$ & 8 & \\
\hline $\begin{array}{l}11 . \\
\text { Toezicht doorvoer }\end{array}$ & $x$ & $x$ & $\mathrm{x}$ & $x$ & $x$ \\
\hline $\begin{array}{l}12 . \\
\text { Internationalise- } \\
\text { ring } \\
\text { belastinginning }\end{array}$ & $x$ & $x$ & $x$ & & \\
\hline $\begin{array}{l}13 \\
\text { Verbeteren } \\
\text { human capital" }\end{array}$ & $\mathrm{x}$ & , & $\mathrm{x}$ & & \\
\hline $\begin{array}{l}14 . \\
\text { Rechtvaardige } \\
\text { inkomensverde- } \\
\text { ling }\end{array}$ & & & $x$ & $\mathrm{x}$ & . \\
\hline $\begin{array}{l}15 . \\
\text { Waarborg } \\
\end{array}$ & $x$ & $x$ & $\mathrm{x}$ & $\mathrm{x}$ & $\mathbf{x}$ \\
\hline $\begin{array}{l}16 . \\
\text { Bevorderen werk- } \\
\text { gelegenheid } \\
\text { minderheden }\end{array}$ & x & $x$ & $\mathrm{x}$ & $x$ & $x$ \\
\hline $\begin{array}{l}17 \\
\text { Onderzoek }\end{array}$ & & & $x$ & $\mathrm{x}$ & \\
\hline $\begin{array}{l}18 . \\
\text { Huisvesting }\end{array}$ & $x$ & $x$ & $x$ & $x$ & \\
\hline
\end{tabular}

Tabel 17.2 De gevonden doelen van de Belastingdienst

17.10 In hoeverre zijn deze doelen verwezenlijkt en is deze verwezenlijking continu?

1. Belastingontvangst

\subsection{De ontwikkeling van het functioneren van de Belastingdienst}

Uit zowel de structuuranalyse als uit de officiële en inofficiële documenten blijkt dat de primaire doelstelling van de Belastingdienst het zo doeltreffend en doelmatig mogelijk uitvoeren van de aan haar opgedragen belastingwetgeving is. Een indruk van de wijze van 
werken van de Belastingdienst kan verkregen worden door te kijken naar een combinatie van factoren als werkaanbod, opbrengsten van belastingen en de formatie. Gedurende de jaren tachtig steeg de totale opbrengst en het werkaanbod, terwijl de formatie verminderde. De totale opbrengsten bestonden uit belastingen, premies en bijvoorbeeld schoolgeld en landbouwheffingen, zoals weergegeven in Tabel 17.3.

\begin{tabular}{|c|c|c|c|c|c|c|}
\hline Belasting & 1980 & 1984 & 1988 & 1990 & 1991 & 1992 \\
\hline $\begin{array}{l}\text { Kostprijs- } \\
\text { verhogende } \\
\text { belastingen }\end{array}$ & 38.419 & 44.761 & 55.451 & 59.635 & 63.353 & 67.566 \\
\hline $\begin{array}{l}\text { Bellastingen op } \\
\text { inkomen, winst } \\
\text { en vermogen }\end{array}$ & 51.828 & 49.159 & 62.872 & 76.623 & 88.176 & 85.803 \\
\hline Totaal-generaal & 90.247 & 93.920 & 118.366 & 136.323 & 151.557 & 153,467 \\
\hline $\begin{array}{l}\text { Premieheffing } \\
\text { volks- } \\
\text { verzekeringen }\end{array}$ & 35.048 & 52.508 & 58.281 & 47.032 & 54.506 & 59.625 \\
\hline $\begin{array}{l}\text { Gemeentelijke } \\
\text { onroerende- } \\
\text { zaakbelasting } \\
\text { ilows }\end{array}$ & 1.723 & 2.484 & 2.795 & 3.082 & 3.257 & 6.640 \\
\hline Schoolgeld & 85 & 134 & 9 & s & - & - \\
\hline Waarborg & 3 & 5 & . & - & 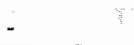 & - \\
\hline $\begin{array}{l}\text { Ruil- en herver- } \\
\text { kavelingsrente }\end{array}$ & 36 & 48 & 46 & 64 & 111 & 97 \\
\hline $\begin{array}{l}\text { Landbouw- } \\
\text { heffing }\end{array}$ & 24 & 26 & 73 & 82 & 82 & 103 \\
\hline $\begin{array}{l}\text { Overige: } \\
\text { waaronder } \\
\text { milieulieffingen }\end{array}$ & 45 & 174 & 135 & 139 & 160 & 67 \\
\hline $\begin{array}{l}\text { Totaal overige } \\
\text { middelen }\end{array}$ & 36.964 & 55.379 & 68.498 & 50.596 & 58.391 & 60.294 \\
\hline $\begin{array}{l}\text { Totaal door de } \\
\text { Belastingdienst } \\
\text { geinde } \\
\text { bedragen }\end{array}$ & 127.211 & 153.705 & 186.864 & 186.919 & 209.948 & 213.761 \\
\hline
\end{tabular}

Tabel 17.3 Belastingopbrengsten op kasbasis (in miljoenen guldens) ${ }^{1046}$

De Belastingdienst was begin jaren '80 van mening dat er onvoldoende efficiënt gewerkt werd. Het investerings- en personeelsplan 1983-1987 was er dan ook op gericht de efficiëntie van de dienst te verbeteren. Dit werd op een drietal manieren nagestreefd. Tot

1045 Eind 1988 besloot het kabinet dat de onroerende zaakbelastingen door de gemeenten per 1993 zelf uitgevoerd moeten worden. Dit werd in 1990 door het parlement goedgekeurd.

104.5 Bron: Belastingdienst, Jaarversllagen 1978-1993, Den Haag. 
bepaalde hoogte kon de efficiëntie worden vergroot door het wijzigen van administratieve procedures. Begin jaren ' 80 werden in dit verband een aantal administratieve procedures vereenvoudigd. Meer heil werd verwacht van toenemende automatisering van de administratie die steeds meer werd doorgevoerd. ${ }^{1047}$ Ten derde kon de efficientie verbeterd worden door de inwerkingtreding van bepaalde wettelijke voorzieningen. Hierbij kan gedacht worden aan de invoering van een sofi-nummer, terwijl ook gedacht kan worden aan Wet ketenaansprakelijkheid. Hoofdaannemers kunnen op grond van deze wet in bepaalde gevallen aansprakelijk worden gesteld voor het niet-afdragen van belasting en premies door onderaannemers.

Uit Tabel 17.3 blijkt dat eind jaren ' 80 de geïnde bedragen inderdaad toenamen. Dit was voor een belangrijk deel te danken aan de toegenomen economische groei, maar ook efficientieverbetering speelde een rol. Eind jaren ' 80 werd bijvoorbeeld het aangiftebiljet inkomstenbelasting/vermogensbelasting verbeterd. In 1990 bleken de belastingopbrengsten achter te blijven bij de ramingen. Uit het Onderzoek Herstructurering Belastingdienst dat in 1990 werd gehouden bleek dat de productie van de Belastingdienst en daarmee de belastingopbrengst niet verminderde door de herstructurering. ${ }^{1048}$ Ook uit vervolgonderzoeken, die in 1991 en 1992 werden afgerond, bleek wederom dat de productie tijdens de herstructurering op peil was gebleven. In dit rapport werden een aantal aanbevelingen gedaan met betrekking tot het management, de bestuurlijke informatie en de automatisering en decentralisatie van bevoegdheden. ${ }^{1049}$ Het rapport met de resultaten van het derde en laatste onderzoek werd eind 1992 aan de Tweede Kamer aangeboden. ${ }^{1050}$ De belangrijkste conclusies zijn positief. Wel werd aambevolen om, mede met het oog op een evenwichtige personele bezetting, de werkverdeling tussen en binnen de divisies nader te evalueren. Ook werd aangeraden om extra inspanningen te verrichten op de gebieden van opleiding en automatisering. ${ }^{1051}$

\subsection{De prestatie van de Belastingdienst}

De vraag is nu in hoeverre dit doel van het zo goed en efficiënt mogelijk realiseren van belastingopbrengsten werd bereikt. Het gaat daarbij om het bepalen van het belastingbedrag, maar ook om de inning en de eventuele invordering indien niet tijdig betaald wordt. Om een beter inzicht te krijgen in de inkomstenverwerving door de Belastingdienst kan de belastinginning worden benaderd als een productieproces. Heyndels en Vuchelen stellen dat de bruto-productiviteit van de belastingambtenaren, hetgeen kan worden gedefinieerd als de totale belastingopbrengst gedeeld door de ingezette middelen in de vorm van het

${ }^{1047}$ Belastingdienst, Jaarverslag over 1983, Den Haag, 1984, p. 29.

1048 Tweede Kamer, Herstructureringsonderzoek Belastingdienst, op 14 juni 1990 bij brief nr. PFC90/1334 door Belastingdienst aangeboden aan de Tweede Kamer, Den Haag, 1990.

${ }_{1049}$ Tweede Kamer, Rappont vervolgonderzoek herstructurering Belastingdienst, op 3 april 1991 bij brief nr. PFC91/539 aangeboden aan de Tweede Kamer, Den Haag, 1991.

1050 De drie onderzoeken naar de herstructurering van de Belastingdienst werden uitgevaerd in een samenwerkingsverband van een onderzoeksteam uit de Belastingdienst en twee externe adviesbureaus, namelijk Moret Ernst \& Young Regsiteraccountants en Coopers \& Lybrand Managementconsultants.

1051 Tweede Kamer (1992-1993), Rapport derde onderzoek herstructurering Belastingdienst, p. 7. 
aantal ambtenaren, inzicht geeft in de administratieve efficiẽntie. ${ }^{1052}$ In deze paragraaf wordt een andere benadering gevolgd. Met betrekking tot de productiviteit van de Belastingdienst kan worden opgemerkt dat in 1992 de Belastingdienst gestart is met de ontwikkeling van kengetallen die inzicht kunnen geven in de ontwikkeling van de productiviteit. Onder productiviteit wordt bij dit soort kengetallen de verhouding tussen ingezette middelen en gerealiseerde productie verstaan. Als productie van de Belastingdienst wordt aangemerkt: voorlopige en definitieve aanslagen, verwerkte aangiften, navorderingen en naheffingen, veldtoetsen, dwangbevelen en een aantal meer specifieke douane producten. Hierbij werd gebruik gemaakt van wegingsfactoren, omdat niet elk van de genoemde producten even zwaar weegt. ${ }^{1053}$ Verder wordt in het beleidsverslag over 1992 opgemerkt dat omdat er geen marktprijzen bestaan voor de producten van de Belastingdienst, er gebruik wordt gemaakt van een andere factor, te weten de bewerkingstijd per stuk. Vergelijk Figuur 17.4:

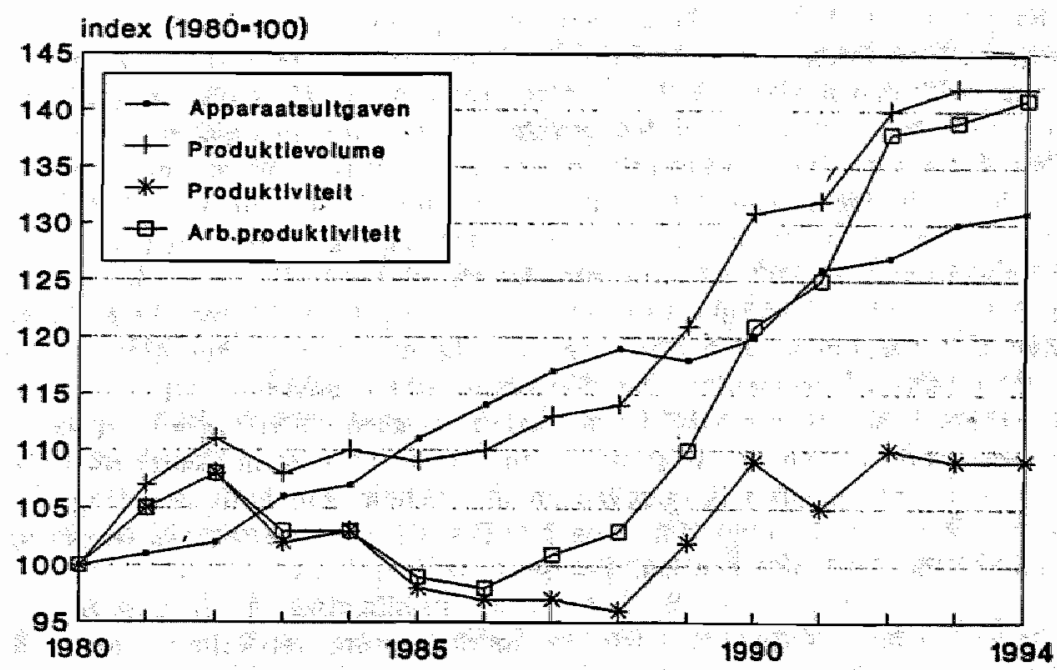

\section{Figuur 17.4 Productiviteit van de Belastingdienst ${ }^{1054}$}

De voor inflatie gecorrigeerde apparaatsuitgaven en het productievolume vertonen gedurende de onderzoeksperiode een stijging. Het productievolume wordt bepaald door het voortgebrachte aantal per product te vermenigvuldigen met de bewerkingstijd per product. Vervolgens worden deze gesommeerd. In het beleidsverslag wordt verder opgemerkt dat de weergegeven productiviteit wordt gedefinieerd als het productievolume gedeeld door de voor inflatie gecorrigeerde uitgaven. Indien de productiviteit zoals weergegeven in Figuur 17.4 een stijgend verloop vertoont wil dit zeggen dat de uitgaven

${ }^{1052}$ Heyndels en Vuchelen (1987).

los; Tweede Kamer (vergaderjaar 1993-1994), Begroting van het Ministerie van Financiën, 23400, hoofdlstuk IXB, nr. 2, p. 122. Vergelijk ook: Directoraat-Generaal der Bellastingen, Beleidsverslag 1993, Den Haag, april 1994, p. 9 e.v.

1054 Bron: Tweede Kamer der Staten-Generaal (vergaderjaar 1993-1994), Ontwikkeling Belastingdienst, 23400, hoofdstuk DXB, nr. 2, p. 122. 
relatief minder snel stijgen dan het productievolume. In 1993 steeg de productiviteit bijvoorbeeld met ongeveer $4,5 \%$. Deze stijging was het gevolg van een toename van het productievolume met $6 \%$ en de voor inflatie gecorrigeerde apparaatsuitgaven met $1,8 \%$. De arbeidsproductiviteit steeg gedurende de periode aanzienlijk. Vooral indien miet de formatie wordt genomen (voor 1993) maar de werkelijke bezetting minus de niet-inzetbare cursisten. In het beleidswerslag 1992 worden een aantal kanttekeningen bij deze benadering geplaatst. In de eerste plaats wordt de onderzochte periode te kort geacht voor een trendanalyse. Verder is het niet gezegd dat de kwaliteit van de productie constant is terwijl ook de omgeving niet stabiel is. De samenleving is constant in beweging, terwijl ook de uit te voeren wetgeving steeds verandert. Hierdoor moet de Belastingdienst kosten maken waardoor een vertekend beeld ontstaat van de productiviteit. In de derde plaats kunnen kantrekeningen worden geplaatst bij de wegingsfactoren. Deze zijn afkomstig van tijdmetingen bij een aantal eenheden in 1990. Deze eenheden waren toen nog bezig om zich aan te passen aan de wijzigingen in organisatie en taken. Tenslotte worden een aantal producten geselecteerd. Bij het benoemen van de productie van de Belastingdienst moeten keuzes gemaakt worden. Zoals de Belastingdienst zelf opmerkt: "Met de benoeming van producten wordt een model van de werkelijkheid gecreëerd". (...) Een ander model, dat wil zeggen de benoeming van andere producten, leidt tot een andere productiviteitsontwikkeling". ${ }^{055}$ Dat de wijze waarop de productie wordt bepaald van groot belang is blijkt ook uit de bevindingen van het Sociaal en Cultureel Planbureau (SCP). ${ }^{1056}$ Het SCP vindt met name voor de jaren negentig lagere cijfers. Met inachtneming van deze kanttekeningen kan gesteld worden dat dat de Belastingdienst er in geslaagd is de afgelopen jaren een geleidelijke productiviteitsstijging te realiseren. Ook de arbeidsproductiviteit is toegenomen. Een deel van de stijging van de arbeidsproductiviteit wordt veroorzaakt door het wegvallen van douane-taken ten gevolge van het wegvallen van binnengrenzen. Deze taken maakten namelijk veelal geen onderdeel uit van de indicatoren waarmee de productiviteit wordt gemeten. In Figuur 17.4 komt voorts tot uiting dat het werkaanbod de laatste jaren is opgevangen met behulp van automatisering. Hierbij kan gedacht worden aan de invoering van het Fiscaal nummer en de invoering van de geautomatiseerde voorlopige aanslagregeling.

Heyndels en Vuchelen gebruiken zoals opgemerkt een andere definitie van productiviteit. Zij delen de totale belastingopbrengst door het aantal ambtenaren. In een onderzoek uit 1987 geven zij aan dat er belangrijke verschillen bestaan in productiviteit tussen verschillende landen. Zo zou de productiviteit in de V.S. achtmaal hoger zijn dan in een gemiddeld Europees land. ${ }^{1057}$ Uit dit onderzoek trekken zij de conclusie dat er belangrijke schaalvoordelen optreden bij de belastinginning (vergelijk ook hoofdstuk 2). Zij stellen:

"Een toename van de belastingopbrengst gaat gepaard met een uitbreiding van het aantal ambtenaren. Deze uitbreiding is minder belangrijk dan de toeriame van de belastingopbrengst (de elasticiteit van de tewerkstelling ten opzichte van de belastingopbrengst ligt tussen de .53 en .63). Dit impliceert dat een toename van de belastingopbrengst gepaard gaat met een aanzienlijke opvoering van de productiviteit". ${ }^{1058}$

$\mathrm{Zij}$ constateren dat er een duidelijke positieve relatie bestaat tussen de omvang van de belastingopbrengsten en de productiviteit van belastingambtenaren, de zogenaamde

1055 Directoraat-Generaal der Belastingen, Beleidsverslag over 1992, Den Haag, aprill 1993, pp. 11-12.

1056 De Haring eit al (1995).

1057 Heyndels en Vuchelen (1987).

1058 Heyndels en Vuchelen (1987). 
statische schaalvoordelen. Op grond van hun onderzoek menen zij dat er geen sprake is van dynamische schaalvoordelen. "Een snelle toename van de belastingopbrengst gaat niet gepaard met een snelle groei van de productiviteit ${ }^{\text {th }}$.

\section{Uitvoering milieuheffingen/milieubeleid}

Begin jaren " 90 besloot het kabinet om de uitwoering van de Wet Algemene Bepalingen Milieuhygiëne (WABM) met ingang van 1 juli 1992 op te dragen aan de Belastingdienst (voorheen uitgevoerd door het Ministerie van VROM). De uitvoering werd voorlopig geconcentreerd bij de eenheid Grote Ondernemingen Rotterdam, terwijl de coördinatie geschiedde vanuit de directie Grote Ondernemingen. Verwacht werd dat ook de uitvoering van nog in te voeren milieuheffingen aan de Belastingdienst zouden worden opgedragen.

In het kader van het Arbeidsomstandighedenbeleid werd de nodige aandacht besteed aan de bedrijfsinterne milieuzorg. Begin jaren ' 90 hebben de meeste eenheden een lokaal millieuzorgplan opgesteld en vervolgens ingevoerd. Het gaat daarbij vooral om het gescheiden houden van afval en om het doelmatig gebruik van energie en materialen. ${ }^{1059}$

Verder streefde de Belastingdienst, voortbouwend op het Nationaal Milieubeleidsplan plus, naar energiebesparing. Dit werd neergelegd in het Energie Aktie Plan. ${ }^{1060}$ Het doel was om in 2000 ten opzichte van 1989 een besparing te bereiken van $17 \%$. Eenheden zetten daartoe energiewerkplannen op, terwijl alle gebouwen van de Belastingdienst een energiecoördinator kregen: Met ingang van 1994 werd hier ook in de managementcontracten aandacht aan besteed.

Voorts besloot de Ministerraad dat departementen een operationeel vervoerplan dienden te ontwikkelen. Met behulp van dergelijke vervoerplannen moet het autogebruik worden verminderd. Binnen de Belastingdienst waren in 199272 eenheden betrokken bij het ontwikkelen van zulke lokale vervoerplannen. In 1992 waren er inmiddels 12 gereed.

\section{Automatisering}

Een belangrijk middel om de efficiëntie van de Belastingdienst te bevorderen is automatisering, hetgeen ook als een belangrijk doel wordt genoemd. Op verschillende terreinen werd gestreefd naar automatisering.

Begin jaren 80 werd een douane-automatiseringssysteem ontwikkeld (het zogenaamde SAGITTA-automatiseringsproject). Er werd een afzonderlijke afdeling opgericht, het Centraal Bureau Douane, die dit systeem beheert. Dit bureau ressorteert onder de Directeur Automatisering Rijksbelastingen te Apeldoorn. Door automatisering konden belangrijke verbeteringen gerealiseerd worden bij de dowaneprocedure bij de inwoer wan goederen. De gegevens met betrekking tot de aangifte kunnen geautomatiseerd worden aangeleverd. Vervolgens wordt bezien welke heffingen van toepassing zijn. In E.G.-

1059 Directoraat-Generaal der Belastingen, Beheersverslag Belastingdienst 1991, Den Haag, 29 april 1992, p. 49.

1060 Directoraat-Generaal der Belastingen, Energle Aktie Plan, Den Haag, 1991. 
verband werd in de jaren ' 80 onderzocht of het mogelijk was de informatiestromen tussen de lidstaten onderling en tussen de lidstaten en de Europese Commissie te automatiseren. Begin 1986 werd de eerste fase van het Sagitta-project, te weten de automatisering van de debiteurenadministratie in gebruik genomen. Eind 1989 werd het Sagitta-automatiseringssysteem formeel in gebruik genomen. In 1990 werd reeds $30 \%$ van de invoeraangiften op elektronische wijze bij de douane ingediend.

Ook ten aanzien van de belastingheffing en -inning streefde de Belastingdienst automatisering na. In het Beleidsplan automatisering 1981 werd aangegeven hoe automatisering werder kon worden ingevoerd bij de Belastingdienst. ${ }^{1061}$ In latere jaren werd dit beleidsplan bijgesteld. Door de invoering van het sofi-mummer konden de loonbetalingskaarten, die voorheen handmatig werden verwerkt geautomatiseerd worden verwerkt, waardoor de efficiëntie sterk verbeterde en tenuggaven sneller kunnen worden uitbetaald. Ook bij de controle werd begin tachtiger jaren een geantomatiseerd systeem operationeel. Door deze automatisering konden controleresultaten van boekenonderzoeken per branche en bijvoorbeeld per regio snel worden geraadpleegd.

In het investerings- en personeelsplan 1983-1987 werd de nadruk gelegd op het belang van de kantoorautomatisering. Op grond van dit plan kwam jaarlijks gemiddeld ruim 40 miljoen vrij voor lokale automatiseringsprojecten. Door deze middelen konden tekstverwerkende systemen worden geinstalleerd en konden ontvangkantoren worden voorzien van automatiseringsapparatuur. Daardoor konden zij beter achterstallige belastingschulden bewaken (in het oog houden). Ter bevordering van de automatisering is in 1983 éénmalig 215 miljoen gulden toegekend. Naast het automatiseringsbeleidsplan 1983-1987 kwam in 1983 het Projectenplan Automatisering Lokale Administraties Rijksbelastingdienst 19831987 gereed. In dit plan werd aangegeven welke activiteiten in de toekomst met behulp van kantoorautomatisering verricht zouden worden en hoe deze projecten zouden worden uitgevoerd. ${ }^{1062}$ Verder werd ook, onder bepaalde voorwaarden, het doen van aangifte per computer ingevoerd.

In 1985 werd een infrastrategieplan opgesteld. Dit plan werd verder uitgewerkt in het automatiseringsbeleidsplan. Onderscheid wordt gemaakt tussen een tiental functionele informatiegebieden, zoals het beheer van relaties, heffing, serviceverlening en bedrijfsbesturing. Voor elk van deze gebieden werden informatie-plannen opgesteld die weer de basis vormden voor de ontwikkeling van geautomatiseerde informatiesystemen. Verschill lende informatiesystemen werden halverwege de jaren ' 80 ontwikkeld, zoals het beheer van relaties, heffing douane (Sagitta) en heffing particulieren.

De Belastingdienst stelde jaarlijks een Informatie- en Automatiseringsbeleidsplan (IABP) op. In dit plan werd aangegeven hoe automatisering een rol kon spelen bij het vergroten van de efficiëntie binnen de Belastingdienst. Het plan werd jaarlijks aan de Tweede Kamer gezonden. Zo verseheen in 1988 het Informatie- en automatiseringsplan 1989 1993, waarin het automatiseringsbeleid overeenkomstig voorgaande beschrijving gevoerd werd. ${ }^{1063}$ Het beleid werd voortgezet, niet gewijzigd. Wel was aanpassing nodig aan een aantal wijzigingen waammee de Belastingdienst geconfronteerd werd, zoals de Oort-

\footnotetext{
${ }^{1061}$ Belastingdienst, Beleidsplan automatisering 1981, Den Haag, 1982.

${ }^{1062}$ Belastingdienst, Prolectenplan automatisering lokale administraties riiksbelastingdienst 1983-1987, Den Haag, 1983.
}

1063 Belastingdienst, Informatie-en automatiseringsplan 1989-1993, Den Haag, december 1988. 
operatie en de nieuwe Invorderingswet. Bij de automatisering werd in hoge mate standaardisatie nagestreefd. Het ging daarbij niet alleen om de apparatuur maar ook om de software. ${ }^{1064}$ Gedurende de reorganisatie van de Belastingdienst werden 110 projecten uitgevoerd in verband met de automatisering van de Belastingdienst (operatie Tislan, Technische infrastructuur.Local Area Network). In het onderzoek Herstructurering Belastingdienst werd geconstateerd dat het budget voor automatisering onvoldoende was om de herstructuring te ondersteunen. ${ }^{105 s}$ Derhalve werden in 1990 extra middelen ter beschikking gesteld. Sinds 1990 zijn de afzonderlijke (doelgroep-)directies in eerste instantie zelf verantwoordelijk voor de automatisering en het informatiseringsbeleid. Met behulp van de informatiseringsplannen van deze directies werd in 1990 een Informatie- en automatiseringsbeleidsplan opgesteld. ${ }^{1066}$ Er werden voor de uitvoering extra middelen ter beschikking gesteld. Met medewerkers op lokaal niveau is meer voorlichting gegeven over de ontwikkelingen in de automatisering. Ook begin jaren ' 90 werd gewerkt aan de verdere automatisering van de verschillende belastingen. In 1990 werd bijyoorbeeld het informatiesysteem Beheer van Relaties operationeel. Met behulp van dit systeem werd het beheer van gegevens wan belastingplichtigen verbeterd. ${ }^{1067}$ De doelen op het gebied van de automatisering werden begin jaren. 90 vermeld in de automatiseringsbijlage bij de ontwerp-begroting van het Ministerie van Financiën.

De Staatssecretaris van Financièn vroeg in oktober 1987 aan de werkgroep Priwatisering van de Directie Automatisering Rijksbelastingen (DAR) te onderzoeken in hoeverre het wenselijk was om deze Directie te privatiseren. Op 14 maart 1988 werd aan de Stalatssecretaris het eindrapport aangeboden. Dit rapport bevatte de aanbeveling de DAR niet te privatiseren en gaf de voorkeur van een nader te onderzoeken vorm van interne verzelfstandiging. De voorstellen van de werkgroep werden in december 1988 door de Ministerraad aanvaard. Besloten werd de Directie Automatisering Rijksbelastingen om te vormen tot een op bedrijfseconomische leest geschoeid facilitair bedrijf.

Door de toenemende betekenis van automatisering bij de gegevensverwerking worden ook steeds hogere eisen gesteld aan de geautomatiseerde gegevensverwerking. Het gaat daarbij om de hogere eisen die aan de computerprogramma's en -apparatuur gesteld moeten worden, maar ook om de verdeling van bevoegdheden binnen het informatiesysteem. In dit verband werd geinvesteerd in informatiebeveiliging, terwijl de introductie in 1993 van het Handboek informatiemanagement de beheersing beoogde te vergroten.

\section{Het bestriiden van fraude}

\subsection{De ontwikkeling van de fraudebestrijding.}

In het Rapport Van Bijsterveld werd onderzoek naar het misbruik en oneigenlijk gebruik van belastingen neergelegd. ${ }^{068}$ Op grond van dit rapport werd een beleid ontwikkeld

1064 Belastingdienst, Jaarverslag over 1988, Den Haag, 1989, p. 43.

${ }^{1065}$ Bellastingdienst, Eerste Onderzoek Herstructurering Bellastingdienst, Den Haag, 1990.

${ }^{1066}$ Belastingdienst, Informatie- en automatiseringsbeleidsplan Belastingdiënst 1991-1995. Den Haag, 1990.

${ }^{1057}$ Belastingdienst, Jaarverslag over 1991, Den Haag, 1992, p. 39.

1068 Tweede Kamer der Staten-Generaal, Rappon Van Bijsterveld naar misbruik en oneigenliik gebruik van belastingen, Handelingen vergaderjaar 1979-1980, 16180, nr. 1 . 
dat beoogde de fraude intensiever te bestrijden. In de eerste plaats diende daartoe onderscheid gemaakt te worden tussen verschillende aangiften. Gelijke gevallen dienden op gelijke wijze te worden behandeld, terwijl ongelijke gevallen op ongelijke wijze moesten worden afgehandeld. Daardoor was het beter mogelijk meer aandacht te besteden aan belangrijke angiften. In de tweede plaats diende de controle te worden verbeterd door het vaker verrichten van boekenonderzoeken. In de derde plaats diende de gegevensuitwisseling tuissen de Belastingdienst en derden en binnen de Belastingdienst te worden verbeterd. De Belastingdienst probeerde de fraude door het nemen van een aantal concrete maatregelen te bestrijden. In de Nota "Fraudebestrijding in de directe belastingen en de omzetbelasting" wordt aangegeven dat bij de fraudebestrijding een drietal sporen moeten worden gevolgd. ${ }^{1069}$ In de eerste plaats dient de toetsing van aanslagen aan de wetgeving instand gehouden te worden en waar mogelijk te worden verbeterd. In de tweede plaats dient in samenwerking met andere overheidsorganen krachtig te worden opgetreden tegen fraudeurs. Tenslotte dient voldoende voorlichting te worden gegeven. Eén van de doelen van de voorlichting was het tegengaan van belastingfraude. In de Nota "Fraudebestrijding in de directe belastingen en de omzetbelasting" wordt vermeld dat er waarschijnlijk een positief verband bestaat tussen fraudebestrijding en adequate voorlichting.

De fraudebestrijding werd verder uitgewerkt in de "Fraudenota $1986 "{ }^{1070}$ In deze nota werden verschillende maatregelen aangekondigd. Belangrijk was vooral het voomemen om bestuurders van rechtspersonen hoofdelijk aansprakelijk te stellen voor de nietnakoming van belastingbetaling van die rechtspersoon en verder de inwoering van renterenseignering voor natuurlijke personen. Dit hield in dat banken informatie over rente op spaartegoeden van burgers doorgeeft aan de fiscus. De fraudebestrijding bleek belemmerd te worden door de functionerende organisatiestructuur. Na de herstructurering werd de Nota Fraudebeleid 1992 opgesteld. Landelijke acties waren nu beter mogelijk. Ook de uitbreiding van de renseignering voor dividenden was in dit verband van belang.

Bij de fraudebestrijding was vooral ook de controle van grote betekenis. Controle gebeurt op verschillende manieren. In 1992 is in de horeca bijvoorbeeld geëxperimenteerd met het waarnemen ter plaatse. Controle geschiedt echter voornamelijk door het controleren van de boekhouding. Een boekenonderzoek vindt plaats indien een aanslagregelend ambtenaar bij het behandelen van een aangifte onjuistheden vermoedt of indien een aangifte aan de beurt is voor een periodieke controle. In ernstiger zaken kan de inspecteur de Rijksaccountantsdienst een onderzoek laten instellen. Ongeveer $10 \%$ van alle boekenonderzoeken werden verricht door de Rijksaccountantsdienst. In 1981 stelde de Belastingdienst bijvoorbeeld 110.000 boekenonderzoeken in voor de omzetbelasting, de loon- en inkomstenbelasting en de vennootschapsbelasting. Bij een dergelijk boekenonderzoek wordt niet alleen de aangifte onderzocht maar wordt ook bezien of de daaraan ten grondslag liggende administratie aanvaardbaar is. Controles vergden steeds meer tijd. Van 1975 tot 1981 steeg het gemiddeld aantal werkdagen bij boekenonderzoeken voor de inkomstenbelasting van 7,9 tot 12,1 . Bij de onderzoeken voor de vennootschapsbelasting bleek dit te zijn opgelopen van 9 tot 13,1 werkdagen. De belangrijkste reden van deze toename is de diepgaandere controle die nodig was om de fraude te bestrijden.

Belangrijk is te onderkennen dat met de controle niet alleen een correctieve maar ook een

\footnotetext{
1069 Tweede Kamer, Ministerie van Financiên (Handelingen vergaderjaar 1983-1984), Nota "Fraudebestriiding in de directe belastingen en de omzetbelasting", 17050/17522, nr. 3. In 1982 door de Staatssecretaris aan de Tweede Kamer gezonden.
}

1070 Tweede Kamer der Staten-Generaal, Handelingen vergaderjaar 1986-1987, 17050, nr. 64. 
prewentieve werking wordt beoogd. Daarvoor is het essentieel dat de kans dat iemand die fraudeert ook werkelijk gepakt wordt aanzienlijk is. Begin jaren ' 80 bleek steeds meer dat de pakkans te gering was geworden ${ }^{1071}$ Herdoor verminderde de preventieve werking die van controlebeleid uitgaat. De controledichtheid, het aantal controles op het totale aantal te controlleren aangiften, was te ver teruggelopen en was volgens de Belastingdienst gedaald onder een aanvaardbaar niveau. ${ }^{1072}$ De Belastingdienst beoogde de pakkans onder meer te vergroten door de uitbreiding van het personeel dat belast was met de controle. Het personeelsbestand van de Rijksaccourtantsdienst werd uitgebreid, terwijl ruim 1.200 controlerende ambtenaren werden toegevoegd aan de overige controlerende afdelingen, waarvan ongeveer 1.000 in de periode tot 1987. Andere maatregelen die genomen werden hadden betrekking op het verbeteren van de opleiding, het verbeteren van de coördinatie en de samenwerking in de controle, het vergroten van het aantal controlevormen en de verbetering van de selectie van de te controleren aanslagen. 1073 Voorts beoogt de Belastingdienst de administratieve verplichtingen van ondernemers aan te scherpen. Het ging daarbij vooral om het kunnen afdwingen van de zogenaande boekhoudverplichting. Controle vindt ook plaats door middel van zogenaamde renseigneringsacties. Deze acties houden in dat door landelijk gecoördineerde operaties gegevens worden verzameld over de bedrijven in een bepaalde branche. Deze acties worden voorbereid en geëvalueerd door een projectgroep waarin alle geledingen van de Belastingdienst zijn opgenomen. Verder werd in de jaren ' 80 intensiever samengewerkt met de Bedrijfsverenigingen, vooral ten aanzien van de Wet Ketenaansprakelijkheid. Op grond van de Instructie Informatieverschaffing kreeg de Belastingdienst de mogelijkheid, teneinde fraude en misbruik van regelingen tegen te gaan, om op eigen initiatief informatie te verstrekken aan overheidsorganen. Verder werd vanaf 1984 steeds meer geprobeerd om de controle-onderzoeken van de verschillende afdelingen beter te coördineren. In 1984 werden door de Belastingdienst en de Procureurs-Generaal bij de Gerechtshoven nieuwe richtlijnen opgesteld met betrekking tot de opsporing en vervolging van fiscale delicten in het kader van de Algemene Wet Inzake Rijksbelastingen. Deze richtlijnen traden op 1 februari 1985 in werking. In de richtlijnen is ondermeer bepaald dat teneinde de vervolgingscapaciteit zo goed mogelijk te benutten, er regelmatig overleg zal plaatsvinden tussen een vertegenwoordiger van de regiomale directie der rijksbelastingen, een vertegenwoordiger van de FIOD en de Officier van Justitie. Beoogd werd hierdoor de werkwijze van het opsporingsapparaat te verbeteren en de duur van de onderzoeken te verkorten. Besloten is dat tot strafrechtelijke vervolging wordt overgegaan indien het bedrag van te weinig geheven belasting groter is dan F. $50.000,-$. Indien sprake is van recidive wordt de grens gelegd bij F. $5.000,-$. Het doel van de Belastingdienst was om uiteindelijk eens in de vijf à zes jaar een onderzoek te verrichten. Dit zou in 1990 bereikt moeten worden. Om dit te bereiken werd door automatisering tot en met 1991 nog eens zo' $\mathrm{n} 2.000$ werknemers vrij gemaakt voor controlewerkzaamheden. Door de verhoging van de controledichtheid kon ook een belangrijke bijdrage worden geleverd aan het beleid van het kabinet om in de kabinetsperiode van 1986-1990 éen miljard gulden extra aan belastingmiddelen te realiseren door middel van intensivering van de fraudebestrijding. Meer concreet moest deze extra belastingopbrengst bereikt worden door de verstrekking van informatie over rentebetalingen door banken aan de Belastingdienst, de invoering van de Wet bestuurdersaamsprakelijkheid en meer inzet van personeel. De fraude werd verder

107. Rapport Bijsterveld, Nota Fraudebestrilding in de directe belastingen en de omxetbelasting, Den Haag, 1982 , in 1982 aangeboden aan de Tweede Kamer.

1072 Belastingdienst, Jaarverslag over 1982, Den Haag; 1983, p. 60.

1073 T.a.p., p. 68. 
tegengegaan door het per 1 januari 1987 in werking treden van de Wet bestuurdersaansprakelijkheid (WBA) en de Wet bestururdersaansprakelijkheid bij faillissement (WBF). Door deze wetten konden bestuurders van rechtspersonen hoofdelijk aansprakelijk worden gesteld voor schulden van de betreffende rechtspersoon aan de fiscus en bedrijfswerenigingen. Door de genomen maatregelen werd bij de vennootschapsbelasting in 1988 al de geplande controledichtheid voor 1989 bereikt. ${ }^{1074}$

Ook begin jaren negentig werden nog tal van maatregelen genomen om het controlebeleid aan te scherpen. Het Landelijk systeem boekenonderzoek werd ingevoerd, waardoor de resultaten van boekenonderzoeken konden worden gemeten en geanalyseerd. Verder werd meer gebruik gemaakt van automatisering en werden de mogelijkheden op dit gebied uitgebreid. Er functioneerde verder begin jaren '90 een Coördinatiegroep Constructiebestrijding (CCB), Eenheden konden verdachte constructies aan de CCB voorleggen. De CCB kon dan advies geven over de toelaatbaarheid ervan, waarna de betreffende eenheid zelf de zaak verder afhandelt. Ook was het mogelijk dat de eenheid de zaak voorlegde aan é̉n van de CCB-projectgroepen. $\mathrm{Na}$ toestemming van een plan van aanpak kon de betreffende projectgroep vervolgens zelf zorgen voor de landelijke coördinatie van de bestrijding. ${ }^{1075}$ Begin 1991 is verder het Meerjarenplan Controlebeleid 1991-1996 vastgesteld: Overeenkomstig dit plan werden een groot aantal maatregelen genomen om de controle te verbeteren. Deze maatregelen varieerden van het vergroten van het aantal portable p.c.'s tot het ontwikkelen van diverse computerprogramma's. In de Fraudenota 1992 en het daarop gebaseerde Plan van Aanpak Fraudenota 1992 werden maatregelen vermeld die pasten binnen het door het kabinet gevoerde beleid, zoals bijvoorbeeld verwoord in de Miljoenennota, ${ }^{1076}$ op het gebied van de sociale en fiscale fraude. ${ }^{1077}$ In het beleidsverslag 1992 werd opgemerkt: "De voorgenomen fiscale maatregelen zullen moeten leiden tot een structureel hogere belastingopbrengst die wan $f 285$ miljoen in het jaar 1993 zal oplopen tot $f 940$ miljoen in 1995 en volgende jaren". ${ }^{1078}$ In het Beleidsverslag 1993 werd opgemerkt dat de in het Fraudeplan 1992 aangekondigde maatregelen in combinatie met de aanvullende fraudetaakstelling 1993 en de rente-renseignering voor niet-natuurlijke personen een structureel hogere belastingopbrengst moeten opleveren van F. 285 miljoen in $1993, F .780$ miljoen in 1994, F. 1.380 in 1995 en ongeveer F. 2.200 miljoen in 1996 en volgende jaren. ${ }^{1079}$

Het beleid van de Belastingdienst om de controle te verscherpen was in die zin succesvol dat de controledichtheid toenam en dat er minder uren nodig waren voor een onderzoek. Begin jaren " 90 bedroeg de totale geintegreerde controledichtheid voor alle belastingen 1:7,7, hetgeen wil zeggen dat een belastingplichtige eens in de 7,7 jaar werd gecontro-

${ }^{1074}$ Belastingdienst, Jaarverslag over 1988, Den Haag, 1989, woord vooraf.

1075 Directoraat-Generaal der Belastingen, Beheersverslag Belastingdienst 1991, Den Haag, 29 april 1992, p. 8.

1076 Zie bijlage 22 bij de Miljoenennota 1993.

1077 Directoraat-Generaal der Belastingen, Nota "Intensivering en bestrijding misbruik en oneigenlijk gebnik, maatregelen op fiscail terrein (Fraudenota 1992), Den Haag, juni 1992, zie bijlage 14 bij hoofdstuk LXB van de Rijksbegroting 1993, Tweede Kamer 22800.

${ }^{1078}$ Directoraat-Generaal der Belastingen, Beleidsverslag 1992, Den Haag, april 1993, p. 15.

1079 Directoraat-Generaal der Belastingen, Beleidswerslag 1993, Den Haag, april 1994, p. 27. 
leerd. In 1992 werd gestreefd naar eens in de zes jaar. Voor de Loon- en Omzetbelasting werd gestreefd naar een controledichtheid van eénmaal in de vijf jaar. Voor de vennootschapsbelasting was dat eens in de zes jaar. Dit bleek in 1991 niet gerealiseerd. Dit kwam vooral doordat het te controleren bestand groter was dan verwacht, terwijl anderzijds de nodige investeringen gedaan moesten worden in verband met de reorganisatie (personeel moest opleidingen volgen etc.). Een dichtheid van 1:7 leek de Belastingdienst het hoogst haalbare. ${ }^{1080}$ Was de doelstelling van controledichtheid voor 1991 nog per belastingmiddel gedefinieerd, na 1991 werd door de nieuwe eenheden niet meer gestuurd op controledichtheid per belastingmiddel maar per entiteit, dat wil zeggen per cluster van belastingplichtigen met gezamenlijke economische activiteiten. Op grond daarvan is in het Bedrijfsplan / Bedrijfskader 1991-1996 een controledichtheidsdoelstelling per entiteit gegeven. ${ }^{1081}$ Deze bedroeg in $19911: 7,7$. Het streven was dit zodanig te verbeteren dat de aldus gemeten controledichtheid uiteindelijk 1:6 zou zijn. In 1993 was de controledichtheid per economische entiteit verbeterd tot 1:7.1082

\subsection{De opsporing}

Indien een eenheid bij de Belastingdienst op grond van de controle bepaalde onregelmatigheden ontdekt kan worden overgegaan tot opsporing. Indien overtredingen zijn begaan op fiscaal gebied worden veelal administratieve boeten opgelegd. Afhankelijk van de zwaarte van het fiscale vergrijp kan overgegaan worden tot strafrechtelijke vervolging. In principe bepaalt de eenheid van de Belastingdienst waar een bepaald vergrijp wordt geconstateerd zelf of tot strafrechtelijke vervolging moet worden overgegaan. Daarbij dienen zij zich onder meer te baseren op de Leidraad Administratieve Boeten 1984. Hierin worden aan inspecteurs richtlijnen gegeven in welke gevallen volstaan kan worden met administratieve boeten en in welke gevallen strafrechtelijke vervolging gewenst is. Indien een eenheid kiest voor strafrechtelijke vervolging meidt zij de zaak aan bij de Fiscale Recherche of eventueel de Douanerecherche. In $1991 \mathrm{kwam}$ de helft van de aangemelde zaken inderdaad voor een strafrechtelijk onderzoek in aanmerking. De conclusie kan worden getrokken dat het opgespoorde financiële nadeel ongeveer gelijk bleef of licht toenam (fiscaalrechtelijk nadeel). In 1991 werd door een werkgroep binnen de Belastingdienst het rapport "Randwoorwaarden fiscaal-strafrechtelijk fraudebestrijdingsbeleid" uitge-

bracht. ${ }^{1083}$ De voorstellen van deze werkgroep dienden als uitgangspunt voor het opstellen van de "Beleidsrichtlijnen opsporing en vervolging van fiscale delicten voor eenheden particulieren". Deze richtlijnen dienen om het fraudebestrijdingsbeleid van de eenheden te stroomlijnen en te verbeteren. De transactie, aanmeldings- (onder welke omstandigheden een functionaris bij de Belastingdienst een zaak moet aanmelden voor beoordeling of vervolging) en vervolgingsrichtlijnen werden aangeboden aan de Tweede Kamer en werden gepubliceerd in de Staatscourant. Het is de bedoeling om in overleg met het Ministerie van Justitie met behulp van deze richtlijnen fiscale recherchecapaciteit toe te delen aan de eenheden. Het rapport "Randvoorwaarden fiscaal-strafrechtelijk fraudebestrijdingsbeleid ${ }^{\text {" }}$ vormde verder het uitgangspunt voor regionale uitvoeringsplannen

${ }^{1080}$ Directoraat-Generaal der Belastingen, Beheersverslag Belastingdienst 1991, Den Haag, 1992, p. 36.

1081. Directoraat-Generaal der Belastingen, Bedrijfsplan / bedriifskader 1992-1996, Den Haag, 1992.

1082 Directoraat-Gemeraal der Belastingen, Produktieverslag over 1993, Den Haag, april 1994, tabel 14. Vergelijk ook: Directoraat-Generaal der Belastingen, Beleidsverslag 1992, Den Haag, April 1993, p. 46.

1083 Directoraat-Generaal der Belastingen, Rapport "Randwoorwaarden fiscaal-strafrechtelijk fraudebestrildingsbeleid", Den Haag, 1991. 
fraudebestrijding die in 1992 werden opgesteld.

De samenwerking met de politie werd steeds belangrijker. In 1992 werd $18 \%$ van de capaciteit van de Fiscale Recherche en $31 \%$ van de capaciteit van de Douane Recherche in samenwerking met de politie gebruikt voor de bestrijding van de georganiseerde misdaad. In 1992 zijn verder 23 medewerkers (18 formatieplaatsen) bij de bureaus Financiële Ondersteuning (BFO's) van de politie geplaatst. Voor de jaren tot 1999 werd de nadruk gelegd op verdere bestrijding van de fraude. Dit diende te geschieden door het verschuiven van personeel van de Divisie Particulieren naar de Divisie Grote Ondernemingen. Dit was mogelijk in verband met de invoering van het InkomstenBelastingSysteem (IBS). Verder werd een snellere behandeling beoogd en diende het niveau van de dienstverlening door onder andere automatisering te worden verbeterd. ${ }^{1084}$

\section{Communicatie- en dienstverlening}

Bij de communicatiedoelstelling werd door de Belastingdienst onderscheid gemaakt tussen de in- en externe voorlichting, het bewaken van de eigen identiteit, het bijdragen aan de effectiviteit en efficiëntie en het verbeteren van de dienstverlening. ${ }^{1085}$ Gedurende de onderzoeksperiode werd hier de nodige aandacht aan besteed. In het jaarverslag over 1981 wordt bijvoorbeeld opgemerkt:" ${ }^{1085}$ "Sedert enkele jaren legt de Belastingdienst meer accent op de verplichting tot het geven van voorlichting en informatie aan het publiek. Dit is temeer noodzakelijk omdat onze zich emanciperende samenleving steeds meer de discussie met overheidsorganen aangaat. Men wil weten hoe de overheid/de Belastingdienst handelt". Voorlichting dient vooral om burgers duidelijk te maken dat met de belastinggelden de overheidsuitgaven worden gefinancierd. Voorlichting gebeurt vooral door voorlichting in de aangifteperiode voor de inkomstenbelasting, door bezoeken van ambtenaren aan wijk- en buurtcentra en bejaardentehuizen en door mondelinge voorlichting op de inspecties der directe belastingen. Verder wordt gebruik gemaakt van advertentiecampagnes, televisiespots en folders. Teneinde goede externe voorlichting te kunnen geven was ook de interne voorlichting van groot belang. Per 1 augustus 1982 functioneert er in dit verband een eigen afdeling Voorlichting van de Belastingdienst. Deze afdeling kreeg als taak het verbeteren van de in- en externe voorlichting voor de hele Belastingdienst. Ook werd door belastingambtenaren geholpen bij de aangifte. In februari 1985 werd de belastingtelefoon ingevoerd. Het aantal belastingplichtigen dat geholpen werd bij het invullen van hun aangifte daalde geleidelijk gedurende de jaren ' 80 en begin jaren '90. Vulde in 1985 slechts $35 \%$ van alle particulieren zelf zijn belastingformulieren in, in 1993 was dit percentage opgelopen tot $55 \% .^{1087}$ Dit was volgens de directie van de Belastingdienst mede het gevolg van het gevoerde voorlichtingsbeleid waardoor minder hulp nodig was. ${ }^{1088} \mathrm{De}$ telefonisch verstrekte informatie nam echter toe. In 1992 en 1993 steeg het aantal belastingplichtigen dat telefonisch informatie aanzienlijk tot ongeveer 1 miljoen. Hierdoor was voor de voorlichting veel mankracht nodig. In verband met de ingewikkeldheid van de belastingwetgeving werd bovendien een eventuele reductie

${ }^{1034}$ Ministerie van Financièn, Miljoenennota 1995, Hoofdstuk DX-B.

1085 Directoraat-Gemeraal der Belastingen, Beheersverslag Belastingdienst 1991, Den Haag, 29 april 1992, p. $5 \%$.

${ }^{1086}$ Belastingdienst, Jaarverslag over 1981, Den Haag, 1982, voorwoord.

${ }^{1087}$ Directoraat-Generaal der Belastingen, Beleidsverslag 1993, Den Haag, april 1994, pp. 62-63.

${ }^{1088}$ Belastingdienst, Jaarverslag over 1990, Den Haag, 1991, p. 40 e.v. 
moeilijk geacht.

Ook het jaarverslag werd als een belangrijk middel gezien om voorlichting te geven aan het publiek. In 1988 introduceerde de Belastingdienst een eigen huisstijl, die diende om de grote verschillen in naamgeving en taalgebruik tegen te gaan. Hierdoor moest de herkenbaarheid bij het publiek toenemen. Bovendien zou standaardisatie van informatiedragers leiden tot besparingen. Voorts was het de bedoeling dat de communicatie met de belastingplichtigen door de nieuwe huisstijl zou verbeteren. In het jaarverslag over 1988 werd met betrekking tot de nieuwe huisstijl opgemerkt: "De sleutelwoorden daarbij zijn: zakelijk, integer en betrouwbaar" ${ }^{1089}$ Alle formulieren van de Belastingdienst zijn onderzocht. Met ingang van 1 januari 1992 wordt gebruik gemaakt van een nieuw standaard-aanslagbiljet, dat de bestaande veertig verschillende soorten aanslagbiljetten ging vervangen. ${ }^{1050}$ Begin jaren "90 werd de implementatie van de huisstijlnormen grotendeels gedecentraliseerd naar de directies.

Verder probeerde de Belastingdienst haar dienstverlening aan het publiek te verbeteren door verzoekschriften e.d. zo snel mogelijk af te doen. Het doel was om alle verzoekschriften inclusief het verzenden van de beschikking binnen twee maanden af te doen. In 1991 lukte dit met $89 \%$ van de verzoekschriften. In 1992 was dit verder verbeterd tot 92\%. De overige correspondentie diende overeenkomstig het klachtenstatuut binnen én maand te worden afgedaan. Dit mocht maximaal twee maanden zijn indien contact met derden nodig was. Omdat realisatie van deze doelstelling moeilijk bleek te zijn werd deze heroverwogen. Verder stelde de Belastingdienst zich in het kader van de bereikbaarheid ten doel dat eenheden telefonisch bereikbaar zijn tussen 08.00 en 17.00. Dit doel werd zoveel mogelijk nagekomen. Dit neemt echter niet weg dat de telefonische bereikbaarheid van de Belastingdienst in 1992 onvoldoende werd geacht. Zowel door technische maatregelen als door maatregelen in de sfeer van de communicatie en organisatie werd getracht de telefonische bereikbaarheid te verbeteren.

Tenslotte probeerde de Belastingdienst de interne communicatie te verbeteren. In dit verband werd een managementinformatiebulletin uitgegeven (Belasting Management), bedoeld woor leidinggevenden in de Belastingdienst. Verder verscheen in 1984 een tijdschrift (BelastingWERK) voor alle medewerkers van de Belastingdienst. Tenslotte werd in 1984 BelastingNieuwsdienst geïntroduceerd. Dit blad was bedoeld om de dienst of bepaalde afdelingen op de hoogte te houden van bepaalde ontwikkelingen. Het verschijnt bijwoorbeeld na belangrijke wetswijzigingen. Tenslotte werden videobanden gebruikt om het personeel te informeren over bepaalde ontwikkelingen. In 1990 werd een telefonische informatielijn voor het personeel ingesteld, waar werknemers terecht konden met vragen over de herstructurering. In 1990 werd ook het blad BelastingWERK gewijzigd. Meer ruimte kwam beschikbaar voor specifieke artikelen.

\section{Verbeteren "compliance"}

Van "compliance" kan worden gesproken indien door belastingplichtigen voldaan wordt aan een aantal voorwaarden. In de eerste plaats moeten belastingplichtigen tijdig gegevens verstrekken en betalingen doen. Bovendien moeten de verstrekte gegevens en de gedane

10B9 Belastingdienst, Jaarverslag over 1988, Den Haag, 1989, p. 44.

${ }^{1090}$ Belastingdienst, Jaarversiag over 1991, Den Haag, 1992, p. 29. 
betalingen volledig zijn. In de derde plaats moeten de verstrekte gegevens juist zijn. De "compliance" is voor de Belastingdienst belangrijk omdat belastingen naar hun aard onvrijwillige owerdrachten zijn. ${ }^{1092}$ Gedurende de gehele onderzoeksperiode probeerde de Belastingdienst de bereidheid van het publiek om vrijwillig hun fiscale verplichtingen na te komen ("compliance") te vergroten, hoewel zich hier verschillende problemen voordeden. Begin jaren ' 80 werden de inspecties bijvoorbeeld geconfronteerd met steeds ingewikkelder wetgeving. Die wetgeving werd bovendien steeds verder verfijnd, enerzijds omdat de regering en het parlement de lasten van de belastingen zo evenwichtig mogelijk probeerde te spreiden en anderzijds omdat de Belastingdienst besparende constructies zoveel mogelijk wilde tegengaan: ${ }^{1093}$ Dit gebeurde vooral door reparatiewetgeving.

De Belastingdienst probeerde de "compliance" vooral te verbeteren door het verbeteren van de relatie met het publiek ${ }^{1094}$ Getracht werd het taalgebruik in formulieren en correspondentie meer te laten aansluiten bij dat van belastingplichtigen. Zoals vermeld is verder geprobeerd om de opzet van belastingformulieren doelmatiger te maken. Verder werd met allerlei maatschappelijke organisaties samengewerkt teneinde de relatie met het publiek te verbeteren Aan het Nederlands Centrum voor Buitenlanders werd bijvoorbeeld geld en middelen gegeven met als doel de voorlichting over belastingen aan buitenlanders te verbeteren. ${ }^{1095}$ Voorts verschenen een groot aantal folders, brochures, toelichtingen en informatiebrieven, voor een deel gericht op speciale groepen.

Verder probeerde de Belastingdienst de relatie met het publiek te verbeteren door zelf correct te handelen. De dienst trachtte dit te doen door de bedrijfswoering en de dienstverlening aan het publiek te verbeteren. ${ }^{1056}$ Belangrij]k was in dit verband het streven om aangiften en bezwaarschriften zo snel mogelijk af te handelen. ${ }^{1097}$ In 1986 was van alle voorrangsaangiften die voor 1 april waren ingediend ruim $98 \%$ op 30 november afgedaan, terwijl dit $79 \%$ was voor de voorrangsaangiften die na 1 april waren ingediend. Ingezien werd dat dit voor individuele gevallen desalniettemin te lang kon duren. In 1988 werd $99,3 \%$ afgedaan voor 1 oktober. In 1991 was dat licht gedaald tot $98,5 \%$. Een verbetering was de per 1 april 1987 ingevoerde wettelijke regeling voor rentevergoeding. Eind jaren ' 80 werd veel aandacht gegeven aan het project Beheer van Relaties. Het doel hiervan was het registreren van belastingplichtigen uniform te maken. De registratie moest voor alle onderdelen van de Belastingdienst bruikbaar zijn. Eind 1990 werd dit systeem ingevoerd. Ook werd geprobeerd om zoveel mogelijk van te voren contact op te nemen met een belastingplichtige indien van de aangifte of het bezwaarschrift werd afgeweken. ${ }^{1098}$

1091 Directoraat-General der Belastingen, Beleidswerslag 1993, Dea Haag, april 1994, p. 11.

1092 Belastingdienst, Jaarverslag over 1991, Den Haag, 1992, p. 13.

1093 Belastingdienst, Jaarverslag Belastingdieast over 1991, Den Haag, 1982, p. 27.

1094 Belastingdienst, Jaarverslag over 1982 Den Haag, 1983, pp. 16 e.v.

${ }^{1095}$ Belastingdienst, Jaarverslag over 1982, Den Haag, 1983, p. 20.

1096 Belastingdienst, Jaarverslag over 1991, Den Haag, 1992, p. 13.

${ }^{1097}$ Belastingdienst, Jaarverslag over 1988, Den Haag, 1989, woord vooraf:

1098 Belastingdienst, Jaarverslag over 1991, Den Haag, 1992, p. 13. 
Begin jaren " 90 onderzocht de Belastingdienst bet effect van haar handelen en meer in het bijzonder van het fraudebeleid op de "compliance". 1099 Nadrukkelijk werd onderzocht wat het effect is van het fraudebeleid op de "compliance". In 1991 werd het Meerjarenbeleidsplan inzake de inkomstenbelasting uitgebracht. ${ }^{100}$ In dit plan werden een aantal maatregelen uiteengezet die zouden moeten leiden tot het verder verbeteren van de "compliance" bij de inkomstenbelasting. Deze maatregelen hadden enerzijds ten doel het functioneren van de Belastingdienst zelf te verbeteren zoals het vergroten van de snelheid. van afdoening van aangiften e.d. Anderzijds beoogde de Belastingdienst door een fraudebeleid het ontbreken van "compliance" zoveel mogelijk tegen te gaan. Tenslotte kan de Belastingdienst, indien zij merkt dat belastingplichtigen niet aan de genoemde criteria voldoen, de "compliance" afdwingen. Verschillende maatregelen kunnen in dit verband genomen worden. Eén van de maatregelen vormt de toepassing van artikel 31 van de Algemene Wet Rijksbelastingen. Met de bepalingen inzake de richtige heffing zijn in enige honderden gevallen constructies bestreden. Op grond van deze bepalingen wordt door de fiscus geen rekening gehouden met bepaalde rechtshandelingen indien belastingbesparing het voornaamste motief voor deze handelingen was. Andere maatregelen zijn het treffen van invorderingsmaatregelen of het opleggen van een boete.

Vanaf 1991 is de Belastingdienst gaan schatten hoe groot de niet-nakoming van de belastingplichtigen is. Deze niet-nakoming is in Figuur 17.5 geillustreerd.

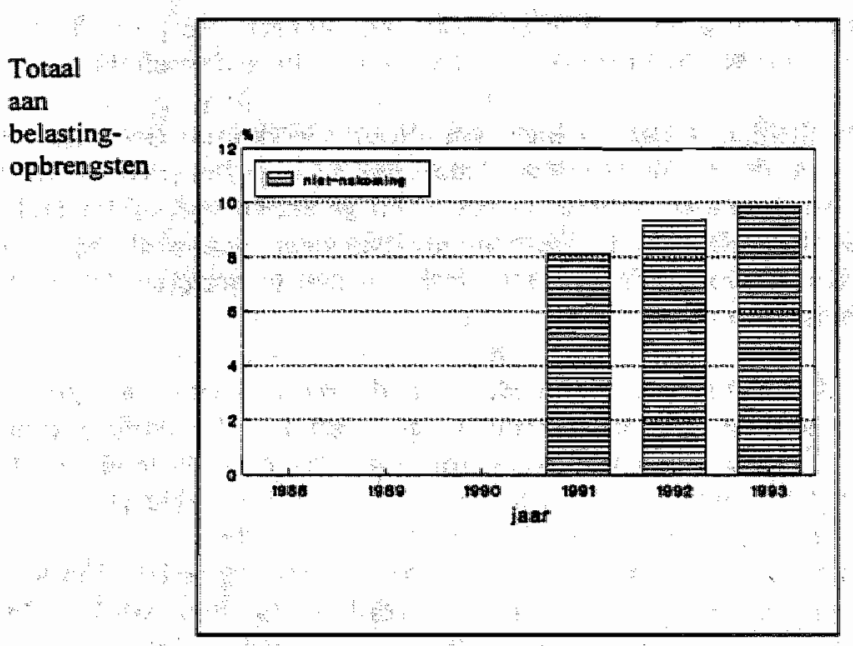

Figurur 17.5 Geconstateerde niet-nakoming ${ }^{1101}$

\footnotetext{
1099 Tweede Kamer, notitie hoofdlijnen yan het onderzoeksproject "Compliance/Non-compliance, atangeboden aan de Tweede Kamer bij brief nur. PFC91/1610, Den Haag, 1991.

${ }^{1100}$ Directoraat-Generaal der Belastingen, Meeriarenbeleidsplan AWR, Den Haag, 1991.

1101 Bron: Directoraat-Generaal der Bellastingen, Beleidsverslag 1993, Den Haag, april 1994, pp. 11-12, voetnoot 4 , In de weergegeven index van geconstateerde niet-nakoming gaat het onder andere om het totaal bedrag aan belastingopbrengsten ten gevolge van aangebrachte correcties, het totale bedrag aan niet-betwiste invorderingsachterstand en oninbaar afgeboekte bedragen en kwijtscheldingen (van IB, LB, VpB en OB).
} 
Vanaf 1991 is de geconstateerde niet-nakoming toegenomen. Ging het in 1991 nog om ongeveer $8 \%$, in 1993 was dit gestegen tot bijna $10 \%$. In het beleidsverslag wordt er op gewezen dat dit kan komen door een toename van de niet-nakoming door bijvoorbeeld een andere houding van belastingplichtigen, maar ook doordat de Belastingdienst actiever geworden is op dit gebied en dit beter in kaart is gaan brengen dan woorheen. Ook wordt benadrukt dat deze index nog verdere verfijning behoeft.

\section{Nationale werkgelegenheid/economische groei}

De Belastingdienst was betrokken bij het zoveel mogelijk bevorderen van een aantrekkelijk vestigingsklimaat. $\mathrm{ZO}_{\mathrm{O}}$ is de eenheid Grote Ondernemingen Rotterdam sinds 1993 het centrale aanspreekpunt voor buitenlandse bedrijwen die overwegen in Nederland te investeren. In het Beleidsverslag over 1993 werd opgemerkt: "Deze eenheid is, met inachtneming van het voor alle belastingplichtigen geldende beleid, verantwoordelijk voor de totstandkoming wan afspraken voor alle fiscale aspecten van een voorgenomen investering door eien nog niet in Nederland gevestigde onderneming. De bedoeling is dat deze potentielle investeerders zich op "ëen loket" verzekerd weten wan een snelle en goede begeleiding;" . ${ }^{1102} \mathrm{Er}$ wordt samengewerkt met het Commissariaat voor buitenlandse investeringen in Nederland (CBIN) dat onder het Ministerie van Economische Zaken valt. In 1993 werden ongeveer 25 zaken behandeld waarvan in ongeveer de helft van de gevallen ook werkelijk afspraken werden gemaakt. Verder heeft de Belastingdienst de vrijheid om binnen door het Ministerie gegeven grenzen belastingschuld kwijt te schelden.

In paragraaf 14 wordt hier verder op ingegaan. Voorts werkte de Belastingdienst mee aan het vermindleren van de administratieve belastingdruk op het bedrijfsleven. Door de Staatssecretaris is een brede commissie in het leven geroepen met onder andere vertegenwoordigers van de Belastingdienst. Deze commissie deed aanbevelingen om binnen de bestaande fiscalle regelgeving zodanige verbeteringen aan te brengen dat de administratieve lastendruk vermindert.

Tenslotte kan worden opgemerkt dat gedurende de reorganisatie op grote schaal werd geinvesteerd in huisvesting. Daarbij bestaan volgens het Rijkshuisvestingsplan belangrijke multipliereffecten. ${ }^{1103}$ Het multipliereffect van de bouw in Nederland wordt geschat op 1,2 à 2,6 . Via de rijkshuisvesting gaan impulsen naar economie en werkgelegenheid. Bovendien leveren deze uitgaven een bijdrage aan bouwtechnische innovatie, voorzover zij gepaard gaat met nieuwe technieken, materialen en bouwprocedes. Verder wordt opgemerkt dat de Gebouwendienst de architectuur bevorderd. Gesteld wordt: "Zo kan via het opdrachtgeverschap van de Rijksgebouwendienst een beleid, dat de rijksoverheid ten aanzien van de architectur $m$ van de (...) gebouwde omgeving voorstaat, ook direct in daden worden omgezet en kan het rijk een woorbeeldfunctie hebben". Deze uitgaven werden grotendeels betaald via de Rijksgebouwendienst, maar werden wel ten behoeve van de Belastingdienst besteed.

\section{Het bevorderen van de werkgelegenheid bij de Belastingdienst zelf}

${ }^{1102}$ Directoraat-Generaal der Belastingen, Beleidsverslag 1993, Den Haag, april 1994, p. 26.

1103 Tweede kamer der Staten-Generaal (vergaderjaar 1988-1989), Riikshuisvestingsplan, 20891, nrs. 1-4, p. 17. 


\subsection{De formatie}

Zoais reeds opgemerkt was één van de doelen van het investerings- en personeelsplan 1983-1987 het verbeteren van de efficiëntie. Het plan bestond vooral hieruit dat door verbetering van de doelmatigheid 3.000 werknemers minder nodig zouden zijn. Daar stond tegenover dat door beleidsintensiveringen in de planperiode ongeveer 3.850 mensen extra nodig zouden zijn. Halverwege de jaren ' 80 werd een groot aantal ambtenaren geconfronteerd met reorganisaties. Daarbij ging het ondermeer om de reorganisatie van het dienstvak van de registratie en successie, de herstructurering van de douane en reorganisaties bij de ontvangkantoren. Hierdoor werden functies opgeheven en werden werknemers overgeplaatst. In de jaren " 80 werd verder deeltijdarbeid op ruimere schaal ingevoerd. In 1981 verviel de voorwaarde dat alleen gewerkt kon worden in deeltijd indien men een verzorgende taak in een gezin of samenlevingsverband had. Wel moet het persoonlijk belang worden afgewogen tegen de wijze van functioneren van de betreffende afdelingen bij toepassing van deeltijdarbeid. Eind 1981 waren er ongeveer 1000 vrouwen die in deeltijd werkten, waarvan $65 \%$ vier dagen werkten en de rest voor halve dagen. Verder werkten 30 mannelijke werknemers vier dagen in de week. In de jaren ' 80 liep dit aantal verder op.

In 1985 omwatte de formatie 31.572 mensjaren. Vanaf 1986 werd door het kabinet een geleidelijke en beperkte personeelsreductie van de Belastingdienst nagestreefd. Deze reductie moest gepaard gaan met automatisering, waardoor de wijze van functioneren niet zou hoeven te verslechteren. Per 1 april 1988 gold er een personeelwervingsstop. Hierdoor was de bezetting bij met name de administratieve afdelingen aan de krappe kant. In 1988 is in dit verband het Bedrijfs- en Personeelsplan 1989-1992 opgesteld, waarin de gevolgen voor het personeelsbestand werden uiteengezet. Op 19 oktober 1988 is in overleg met de Bijzondere Commissie voor georganiseerd overleg over het Bedrijfs- en Personeelsplan een convenant opgesteld. In dit convenant is een werkgelegenheidsgarantie opgenomen tot en met 1992 . Hier staat tegenover dat het personeel eventueel een andere functie of standplaats moet accepteren. Later werd een werkgelegenheidsgarantie voor alle personeelscategorieèn afgegeven tot 1 juli 1994.

Begin jaren ' 90 nam de formatieve sterkte af. De reden hiervan was enerzijds gelegen in de afslankingsdoelstelling en anderzijds in het afstoten van taken. Bij het afstoten van taken moet vooral gedacht worden aan het wegvallen van de binnengrenzen, het afstoten van de Onroerend-goedbelasting en de Oort-wetgeving. De Belastingdienst wilde in 1990 het totale personeelsbestand terugbrengen van 31.049 arbeidsplaatsen in 1990 naar 29.942 arbeidsplaatsen in 1995. In 1991 werd het noodzakelijk geacht deze doelstelling aan te scherpen, te meer daar de bezetting eind 199129.052 bedroeg. De Belastingdienst wilde het personeelsbestand in 1995 verder teruggebracht hebben tot 27.778 arbeldsplaatsen. Hierbij speelt ook een rol dat door het wegvallen van de Europese binnengrenzen in 1992 bij de douane veel mensen overbodig werden. Hierdoor kwam per 1 januari 1993 het werk van 1.400 dowane-ambtenaren te vervallen. Het bestaande personeel bleef gegarandeerd van een baan door het niet opvullen wan vacatures en het niet opleiden van nieuw personeel. Voorts werden werknemers overgeplaatst naar de Westelijke douane districten of naar andere functies binnen de Belastingdienst. In dit verband werd de vrijwillige uitstroom van personeel gestimuleerd. ${ }^{1104}$ Tenslotte waren er door de overheveling per 1 januari 1992 wan de inning van de onroerend-goedbelasting naar de gemeenten bij de Belastingdienst 650 deurwaarders minder nodig. Eén en ander leidde ertoe dat de formatie

1104 Belastingdienst, Jaarverslag over 1991, Den Haag, 1992, p. 33. 


\subsection{De bezetting}

De formatie kon afwijken van de feitelijke bezetting. Deze was als volgt:

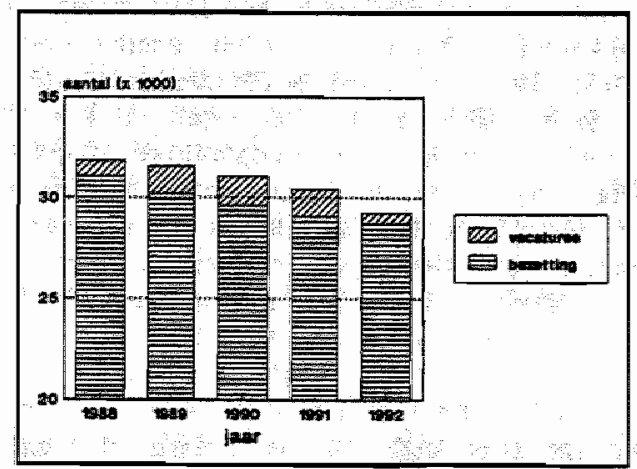

\section{Figuur 17.6 Formatie en bezetting ${ }^{1105}$}

De bezetting verschilde veelal van de toegestane formatie. Hiervoor waren een antal redenen. ${ }^{1106}$ In het kader van de herstructurering werd de personeelsformatie ingekrompen. Om deze inkrimping zonder gedwongen ontslagen te kunnen opvangen werd op formatieplaatsen soms gewerkt met uitzendkrachten. Een andere reden was dat de instroom soms iets lager was dan gepland, terwijl de uitstroom soms iets hoger was. Tenslotte was op grond van het personeelsbudget in 1990 geen volledige bezetting toegestaan.

In de Beleidskaderbrief 1991 werden de doelstellingen vermeld inzake de formatie en de bezetting. ${ }^{1107}$ Genoemd werden:

* De organisatiestructurr, de bedrijfsmiddelen, het functiegebouw en de formatie moeten steeds zijn afgestemd op de bedrijfsdoelstellingen van de Belastingdienst.

* De bezetting moet steeds in overeenstemming zijn met de formatie.

* De kwaliteit van de medewerk(st)ers moet steeds zijn afgestemd op de functieeisen en functioneringseisen die aan hen gesteld worden.

Hoewel er een werkgelegenheidsgarantie gold nam de Belastingdienst wel uitstroombevorderende maatregelen. Voor het bevorderen van uitstroom van personeel naar andere overheidsorganisaties functioneerden lokale werkgelegenheidscommissies. Ook met betrekking tot de douane en de deurwaarderij werden maatregelen genomen om de overtalligheid tegen te gaan.

\footnotetext{
${ }^{1105}$ Bron: Directoraat-Generaal der Belastingen, Beleidsverslag over 1993, Den Haag, april 1994, p. 68.

${ }^{1.106}$ Belastingdienst, Jaarverslag over 1990 , Den Haag, 1991, p. 70.

1107 Directoraat-Generaal der Belastingen, Beleidskaderbrief 1991, Den Haag, 1992.
} 
Wat bij de Belastingdienst ook opvalt is dat het verloop aanzienlijk is. Dit komt enerzijds doordat er veel doorstroming van het personeel naar het bedrijfsleven plaatsvindt en anderzijds door de VUT-regeling. De VUT-maatregelen hadden grote invloed op de Belastingdienst aangezien het vervangen van een ervaren kracht per saldo (aantrekken, opleiden e.d.) ongeveer 6 tot 8 jaar duurde. In 1983 verlieten bijvoorbeeld 1.359 medewerkers de Belastingdienst, waarvan 510 gebruik maakten van de VUT-regeling. Het gaat hier om $4,4 \%$ van het totale personeelsbestand van de Belastingdienst. Bij administrateurs, hoofdassistenten en taakhoofdassistenten was het verloop groter dan $10 \%$. Daarbij moet wel worden bedacht dat bijvoorbeeld de categorie van de administrateurs vrij gering van omvang is. De Belastingdienst ving dit verloop op door het aanstellen van mensen van buiten de Belastingdienst. Het verloop nam in 1984 toe tot $5 \%$, met name door de invoering per 1 juli 1984 van de mogelijkheid om met 40 dienstjaren met vUT te gaan. Hiervan maakten 228 ambtenaren gebruik; terwijl 496 ambtenaren om VUT-ontslag vroegen bij het bereiken van de leeftijd van 61 jaar. ${ }^{1108}$ In het jaarverslag over 1986 werd ten aanzien van het verloop opgemerkt: "Vamwege het nog steeds zorgbarende vertrek van ervaren krachten naar elders, lukt het maar heel langzaam om de kwalitatieve personeelsbezetting te verbeteren. In de sectoren van accountants, inspecteurs en automatiseringsdeskundigen kunnen de aantallen met moeite worden gehandhaafd. De ervaring neemt door het verloop echter nog steeds af". ${ }^{1100}$ Ook aan het einde van de jaren ' 80 bleef het grote verloop een belangrijk probleem, dat slechts met grote opleidings- en wervingsinspanningen het hoofd kon worden geboden. In 1989 daalde mede door het door de Belastingdienst gevoerde beleid het verloop tot 3,85\%.1110 Dit was voor een belang. rijk deel ook te danken aan de vermindering van het aantal VUT-gerechtigden.

Hierbij dient bedacht te worden dat het verloop bij veel organisaties in het bedriffsleven eveneens rond de 4 a $5 \%$ ligt. Op zich is dit niet verontrustend hoog. Het probleem voor de Belastingdienst was echter dat bepaalde categorieën ervaren personeel moeilijk te vervangen waren. Het verloop bleek vooral een probleem bij de categorie inspecteurs en accountants. Meer specifiek baarde vooral het verloop onder inspecteurs bij de vennootschapsbelasting zorgen. Ervaren personeel dat naar het bedrijfsleven vertrok moest veelal worden vervangen door nieuw en onervaren personeel, waardoor het functioneren van de Belastingdienst in het geding kwam. Verder bleek het verloop in de randstad groter dan in de rest van het land. Er werden verschillende redenen genoemd voor het verloop. Een belangrijke reden was de hogere beloning in het bedrijfsleven voor met name de categorieën inspecteurs en accountants. Verder speelde ook de secundaire bezoldiging een rol. Er waren in dit verband duidelijke verschillen met het bedrijfsleven. Voorts was de secundaire bezoldiging niet gerelateerd aan de verschillen in geleverde prestatie. Verder was het carrièreperspectief, de werksituatie en ontevredenheid over de kwaliteit van het afgeleverde werk van belang. ${ }^{111}$ Het belangrijkste gevolg van het verloop van het personeel was dat ervaring verloren ging waardoor belastinginkomsten werden gederfd. De werkgroep Exodus schatte de inkomensderving op 545 miljoen gulden per jaar. In het rapport implosie werd de inkomstenderving zelfs op ongeveer anderhalf miljard gulden

${ }^{1108}$ Belastingdienst, Jaarverslag over 1984, Den Haag, 1985, p. 74.

${ }^{1109}$ Belastingdienst, Jaarverslag over 1986, Den Haag, 1987, woord wooraf.

${ }^{1110}$ Belastingdienst, Jaarverslag over 1989 , Den Haag, 1990, p. 87.

1111 Directie Personeel/Organisatie belastingdienst (1987, p. 5). 
geschat. Door de mindere kwaliteit van het controleapparaat werd de fraude bijvoorbeeld minder bestreden. Hierbij werd well opgemerkt dat fraude niet alleen bestreden werd door inspecteurs en accountants maar ook door controleurs en commiezen. Getracht werd om het verloop terug te dringen door het nemen van diverse maatregelen. Zo werd de Arbeidsmarktknelpuntentoelage (AMK)-regeling van artikel 22a BBRA 1984 toegepast. In 1991 werd, teneinde het verloop tegen te gaan, aan $2,1 \%$ van het personeelsbestand eem AMK-toelage toegekend. In 1992 werd aan 567 ambtenaren of $2 \%$ van het personeelsbestand een toelage toegekend. Verder trachtte de Belastingdienst de personele omvang van het controleapparaat te vergroten en de inhoud van het werk aantrekkelijker te maken. Dit diende onder meer te geschieden door middel van het verminderen van de werkdruk en het verbeteren van de informatievoorziening.

Naast het vertrek van personeel was verder ook het ziekteverzuim van belang. Het kabinet maakte begin jaren ${ }^{3} 90$ plannen bekend om het ziekteverzuim te verminderen. De Belastingdienst ontwikkelde in dit verband een drie-stappenplan. Het was de bedoeling dat de eenheden vanaf 1992 beter in staat zouden zijn om het ziekteverzuim in de hand te houden: ${ }^{112}$ Er werd voor 1992 gestreefd naar een maximaal ziekteverzuim van $7,5 \%$. In 1992 was dit in werkelijkheid 7,4\%, terwijl in 1993 het ziekteverzaim verder gedaald was tot $7,2 \%$.

\section{Beloning en goede arbeidsomstandigheden personeel}

In 1988 kwam het loopbaan- en bezoldigingsreglement Belastingdienst tot stand, waarin veel tot dan toe verspreide regellingen werden opgenomen. De beloning van het personeel $\mathrm{kan}$ als volgt in een tabel worden weergegeven:

\begin{tabular}{|l|l|l|}
\hline Jaar & 1991 & 1992 \\
\hline Salarissen & 1.491 .022 & 1.546 .333 \\
\hline $\begin{array}{l}\text { Overwerk en toeslagen onregelmatige } \\
\text { dienst }\end{array}$ & 31.132 & 27.119 \\
\hline Toelagen en uitkeringen & 9.969 & 22.736 \\
\hline $\begin{array}{l}\text { Uitzendkrachten en ander vervangend } \\
\text { personeel op formatieplaatsen }\end{array}$ & 26.353 & 18.011 \\
\hline Sociale lasten & 328.327 & 362.954 \\
\hline Totale personele uitgaven & 1.886 .803 & 1.977 .153 \\
\hline Gratificaties & 3.804 & 4.172 \\
\hline $\begin{array}{l}\text { Gratificaties beloningsdifferentiatie en } \\
\text { gepresteerde arbeid }\end{array}$ & 5.031 & - \\
\hline Premiespaarregeling Rijksambtenaren & 1.114 & 1.067 \\
\hline
\end{tabular}

1112 Belastingdienst, Jaarverslag over 1991, Den Haag, 1992, p. 35. 


\begin{tabular}{|l|l|l|}
\hline Jaar & 1991 & 1992 \\
\hline Tegemoetkoming in de studiekosten & 3.851 & 3.117 \\
\hline Kantine-activiteiten & 12.514 & 11 \\
\hline Kosten kinderopvang & 1.539 & 3.355 \\
\hline Langdurig zieken & 24.974 & 18.194 \\
\hline $\begin{array}{l}\text { Non-activiteitswedden, wachtgelden en } \\
\text { uitkerings-regeling } 1966\end{array}$ & 5.422 & 8.510 \\
\hline Sociale lasten & 6.157 & 4.693 \\
\hline Overige uitgaven & 149 & 7 \\
\hline Totaal overige uitgaven personeel & 64.555 & 43.115 \\
\hline Totaal & 1.951 .358 & 2.020 .268 \\
\hline
\end{tabular}

. F. 1.000,-

Tabel 17.4 De beloning van het personeel in 1991 en 1992

Per saldo namen de uitgaven voor personeel in 1992 toe tot 2.020 miljoen gulden. Deze stijging werd vooral veroorzaakt door algemene salarismaatregelen.

Welke salarisschaal geldt voor een werknemer wordt op grond van artikel 5 lid 2 van het BBRA 1984 en het loopbaan- en bezoldigingsreglement Belastingdienst bepaald door rekening te houden met de ard en het niveau van de functie die door de ambtelijke werknemer wordt uitgevoerd. ${ }^{114}$ Dit wordt bepaald met behulp van functiewaardering; In 1988 was de waardering van functies op grond van het BBRA 1984 grotendeels voltooid. Op grond van artikel $7 \mathrm{BBRA}$ wordt een jaarlijkse periodieke verhoging toegekend. Daamaast zijn er in het BBRA 1984 bepalingen opgenomen over allerlei toelagen zoals een toelage voor de waarneming van een hogere functie en over de vakantie-uitkering.

Het gaat er nu met name om in hoeverre de beloning van het personeel verschilt van de beloning die betaald zou zijn in het geval van een marktconform loongebouw. Uit het rapport implosie bleek dat met name de categorie inspecteurs en accountants in vergelijking met het bedrijfsleven te laag beloond werd. ${ }^{115}$ In 1990 ging het dus om ruim 1.800 werknemers. Zoals reeds opgemerkt betaalde de Belastingdienst niet naar prestatie maar naar rang. In verband met het verloop onder accountants en inspecteurs doen veel vam deze functionarissen werk dat eigenlijk door een functionaris in een hogere tang zou moeten worden verricht. Verder zijn er wachttijden voordat het maximumsalaris van een bepaalde schaal wordt bereikt en voordat iemand benoemd werd in een hogere rang. Dienovereenkomstig werd in het rapport van de commissie "Exodus" opgemerkt dat teamleiders die zijn ingeschaald in schaal 12 werk doen van een hoger niveau. Zo bleek

1113 Vanaf 1992 opgenomen onder de materiêle uitgaven.

11.4 Bron: Directoraat-Generaal der Belastingen, Jaarverslag over 1989. Den Haag, 1990. De cijfers geven de situatie weer per 31 december van het betreffende jaar.

1115 Directie Personeel/Organisatie van de Belastingdienst, wrerkgroep "exodus? „1987, p. 13) 
In 1985 dat van de 413 hoofdinspecteursplaatsen er slechts 108 waren bezet door werknemers met deze rang; terwijl van de 155 hoofdaccountantplaatsen er 48 werden bezet door medewerkers met deze rang. ${ }^{116}$ Pas na een groot aantal jaren konden deze werknemers ook daadwerkelijk deze rang krijgen. Te lage inschaling kwam dus herhaaldelijk voor. Tenslotte bleek uit de pakketvergelijking uit 1986 dat verschillende categorieen werknemers bij de Rijksoverheid vergeleken met het bedrijfsleven werden onderbetaald. Hoeveel dit gemiddeld bij de Belastingdienst was kan worden bepaald aan de hand van de volgende tabel:

\begin{tabular}{|c|c|c|c|c|c|c|c|}
\hline $\begin{array}{l}\text { Sector \&unctieni- } \\
\text { weau }\end{array}$ & 1 & 2 & 3 & 4 & 5 & 6 & 7 \\
\hline $\begin{array}{l}\text { Gemiddeld } \\
\text { netto beschikbaar } \\
\text { inkonen (NBD) in } \\
\text { guidens Rijksowerheid }\end{array}$ & 23.360 & 24.465 & 26.245 & 30.299 & 34.952 & 43.859 & 57.195 \\
\hline $\begin{array}{l}\text { Gemiddeld } \\
\text { metto beschilkbaar } \\
\text { inkomen (NBI) } \\
\text { marktsector }\end{array}$ & 22,495 & 23.318 & 27.126 & 34.109 & 40.698 & 51.385 & 75,105 \\
\hline $\begin{array}{l}\text { Aantal medewerkers } \\
\text { van de Belastingdienst } \\
\text { (bezetting) }\end{array}$ & 415 & 5.208 & 14.059 & 6.412 & $4: 405$ & 1.233 & 673 \\
\hline $\begin{array}{l}\text { Bedrag aan NBI } \\
\text { betaald door de Be- } \\
\text { lastingdienst in mil- } \\
\text { joenen guldens }\end{array}$ & 9,7 & 127,41 & $\begin{array}{c}368,9 \\
;\end{array}$ & 194,3 & 153,9 & 54 & 38,5 \\
\hline $\begin{array}{l}\text { Bedrag dat door ees } \\
\text { particuliere onderne- } \\
\text { ming zou zijn betaald } \\
\text { in miljoenen guldens }\end{array}$ & 9,3 & 121,4 & $381, \mathbb{1}$ & $218_{n} 7$ & 179,27 & 63,4 & 38,5 \\
\hline $\begin{array}{l}\text { Door ce Bellasting- } \\
\text { dienst werd minder } \\
\text { betaald in miljoenen } \\
\text { gutdens }\end{array}$ & 65 & & & & & & \\
\hline
\end{tabular}

Tabel 17.5 De beloning van personeel bij de Belastingdienst en in het bedrijfsleven $^{1117}$

De pakketvergelijking van 1986 ging uit van een zevental functies. De functies bij de overheid en in het bedrijfsleven werden vervolgens op grond van de zwaarte van de functie en in mindere mate de inhoud daarvan, ingedeeld in deze zeven categorieën. In Tabel 17.5 zijn de werknemers van de Belastingdienst eveneens in deze zeven functies gerubriceerd. Dit is gedaan door te kijken naar de aard van de functie en door te kijken naar de verdeling van het personeel van de Belastingdienst over de achttien schalen van het BBRA. Uit Tabel 17.5 blijkt dat de Belastingdienst. gemiddeld ongeveer $6,4 \%$ minder betaalde dan in het bedrijfsleven gebeurde. Uit de pakketvergelijking bleek voorts dat bij

\$116. T.a.p., p. 13 .

${ }^{1117}$ De tabel geeft de beloningswerschillen aan het eind van 1986. Zij is gebaseerd op: Bakkenist, Spits en Co Adviseurs (1986c; p. 1). Uitgegaan wordt van $\mathrm{NBI}$ actief personeel. 
de Rijksoverheid de schalen 11 en hoger een achterstand in netto besteedbaar inkomen hebben van $20 \%$, terwijl dit voor specialisten nog hoger ligt: ${ }^{112 \%}$ In 1989 ging het bij de Belastingdienst om ongeveer 3.300 werknemers terwijl het in 1991 om 3.840 werknemers ging, hetgeen slechts gedeeltelijk blijkt uit Tabel 17.5. Met name ervaren accountants en fiscalisten konden in het bedrijfsleven $50 \%$ meer bruto salaris verdienen. Het verschil in beloning lag in werkelijkheid dan ook hoger dan de genoemde $6,4 \%$. In de jaren tachtig werd getracht om het verloop tegen te gaan door het nemen van maatregelen in de sfeer van prestatieverlof, extra periodieken, waarnemingstoeslagen en gratificaties. Omdat deze maatregelen blijkbaar tekortschoten werd in 1987 een arbeidsmarktkmelpuntentoeslag van circa twee miljoen gulden toegekend aan inspecteurs en accountants. Zoais opgemerkt in paragraaf 17.5.1.2. werden bowendien extra beloningen toegekend. In 1993 ging het om $\mathbb{F}$. 12.666.000,- en een arbeidsmarktknelpuntentoeslag ten bedrage van F. 1.595.000,Door dit soort maatregelen nam het verschil in beloning af tot maar schatting gemiddeld ongeveer $6 \%$.

\section{Toezicht doorvoer}

Eind jaren "70 veranderde het karakter van de douanewerkzaamheden. Voorheen ging het vooral om de toepassing van fiscale maatregelingen, waarbij gedacht kan worden aan het heffen van invoerrechten, accijnzen en omzetbelasting bij invoer. Begin jaren 80 was de douane ook belast met de uitvoering van allerlei niet-fiscale maatregelen en het controleren daarvan. Daarbij ging het gedeeltelijk om financièle regelingen zoals landbouwheffingen en gedeeltelijk om controle en toezicht op allerlei matregelen, zoals regelingen inzake de volksgezondheid en in- en uitvoerverboden of beperkingen. Met betrekking tot de douane bestaan intensieve contacten met andere EG lid-staten. De meeste douanemaatregelen worden in Europees verband vastgesteld. Daarmaast is er een toenemende harmonisatie van allerlei administratieve voorschriften. De douane dient nadrukkelijk de belangen van het verkeer in het oog te houden. In het jaarverslag over 1981 werd opgemerkt: "De doucine dient voortdurend in het oog te houden dat een stroeve gang van zaken bij de uitvoering wan de donanetaken sterk belemmerend werkt voor handel en verkeer. Primair is daarom de aandacht gericht op een flexibele aanpassing wan de werkmethoden ${ }^{m 119}$ Op grond hiervan werd begin jaren '80 bepaald dat de inlevering van aangiften voor in-, uit- en doorvoer niet meer diende te geschieden bij woor het handelswerkeer vaak ongunstig gelegen ontvangkantoren maar bij de posten douane en accijnzen. In het jaarverslag over 1982 werd dienaangaande opgemerkt: "De verschuiving bracht het vaststellen met zich mee van nieuwe streefformaties voor de personeelsbezetting van alle dowaneposten en van de ontwangkantoren die bevoegd waren om inwoerrechten en accijnzen af te handelen " 120 Op 1 oktober 1982 werd de Algemene wet inzake de douane en de accijnzen ingrijpend gewijzigd. ${ }^{1121}$ De wijzigingen waren vooral nodig in verband met de E.G.-harmonisatie van de dowanewetgeving en leiden tot belangrijke veranderingen in de dagelijkse douanepraktijk. Binnen de douane deden zich in de jaren tachtig vooral drie belangrijke ontwikkelingen voor. Naast harmonisatie van wetgeving in

\footnotetext{
${ }^{1118}$ Bakkenist, Spits en CO Adviseurs (1986c, p. 1.).

41197 Belastingdienst, Jaarverslag van de Bellastingdienst ower 1981, Den Haag, 1982, p. 48.

${ }^{1120}$ Belastingdienst, Jaarverslag over 1982, Den Haag, 1983, p. 46.

${ }^{1121}$ Algemene wet inzake de dowane en de accijuzen van 1962, wijziging van kracht op 1 oktober 1982.
} 
Europees verband was er bij de douane een accentverschuiving naar allerlei niet-fiscale regelingen (agrarische regelingen e.d.), terwijl ook de automatisering steeds duidelijker haar intrede deed. Eind jaren tachtig werd het eerder genoemde Sagitta-project afgerond. Daarnaast waren de veranderingsprocessen binnen de Belastingdienst van belang. Deze veranderingen bestonden vooral uit gewijzigde managementinzichten binnen de Belastingdienst die ook invlloed hadden binnen de douane. Er werd een Beleidsgroep douane opgericht die ten doel had voorstellen te formuleren om het functioneren van de douane, gegeven deze ontwikkelingen, ook in de toekomst zo goed mogelijk te kunnen verzekeren. Naar aanleiding van de voorstellen van deze beleidsgroep werd een slotmemorandum Douane opgesteld ${ }^{1122}$ Dit memorandum beoogde de douane-structuur beter af te stemmen op het in de jaren ' 80 sterk gewijzigde takenpakket. Met ingang van 1990 functioneert de douane met een nieuwe organisatiestructuru. Er werd een Directie Douane ingesteld waaronder een negental douane districten ressorteren. Binnen deze districten waren er 48 douaneposten, een laboratorium en de Centrale Douaneadministratie. Doel van deze herstructurering was vooral het vergroten van de duidelijkheid en het inspelen op de herstructurering van de rest van de Belastingdienst. ${ }^{1123}$

Begin jaren negentig werd de douane geconfronteerd met de gevolgen van de voltooiing van de interne markt per 1 janwari 1993. Bij de kleine doorlaatposten werd bijvoorbeeld gebruik gemaakt van flexibele bezetting. Dit betekende dat deze posten slechts een aantal uren per dag en op onregelmatige tijdstippen bezet waren. Binnen de douane vervielen er ten gevolge van het wegvallen van de Europese binnengrenzen ongeveer 1400 banen. ${ }^{1124}$

\section{Internationalisering belastinginning}

Internationalisering van de belastinginning heeft enerzijds betrekking op internationale regelgeving en afspraken die invloed hebben op de Nederlandse belastinginning en anderzijds op samenwerking tussen de diverse nationale Belastingdiensten.

De invloed van internationale regelgeving, meer in het bijzonder van de Europese Unie, werd gedurende de periode steeds groter: $Z o$ heft en int de Belastingdienst de eigen middelen voor de Europese Unie. Daarbij kan gedacht worden aan een deel van de omzetbelasting bij invoer, landbouwheffingen en douanerechten die worden afgedragen aan de Europese Unie. Gedurende de onderzoeksperiode deden zich met name in dit verband verband grote veranderingen voor. Begin jaren $\$ 80$ begonnen de richtlijnen van de Europese Gemeenschap een steeds belangrijker rol te spelen. Per 1 januari 1981 werd de achtste richtlijn ingevoerd. Deze verschafte een regeling voor de teruggave van buitenlandse omzetbelasting. ${ }^{1125}$ Eind 1991 aanvaardde de Raad van Ministers (ECOFIN) van de EG een wijziging op de zesde richtlijn. Deze wijziging had eveneens betrekking op de omzetbelasting en hield in dat tot 1991 in een overgangsperiode bij de heffing en inning van omzetbelasting rekening gehouden wordt met de gevolgen van het wegvallen van de

\footnotetext{
${ }^{1122}$ Belastingdienst, Slotmemorandum Douane, Den Haag, 1986.

${ }^{1123}$ Belastingdienst, Jaarverslag over 1990, Den Haag; 1991, p. 29.

${ }^{1124}$ Belastingdienst, Jaarverslag over 1991, Den Haag, 1992, woord vooraf, wergelijk ook: p. 27.

${ }^{1125}$ Belastingdienst, Jaarverslag van de Belastingdienst over 1981, Den Haag, 1982, p. 43.
} 
Europese fiscale binnengrenzen. Door het wegvallen van de binnengrenzen in Europa controleert de douane in principe niet meer aan de grenzen. Om ervoor te zorgen dat elke lidstaat de juiste bedragen aan B.T.W. afdraagt is besloten om een administratief controlesysteem op te zetten. Met ingang van 1 januari 1993 moeten ondernemers derhalve bij hun belastingadministratie een overzicht inleveren over de waarde van de goederen die zij hebben geëxporteerd. Binnen de Belastingdienst is in dit verband de projectorganisatie Intra Communautaire Transacties (ICT) opgericht. Deze projectorganisatie hield zich ook bezig met het opzetten van een nieuw systeem van informatieverzameling. Dit omdat het belangrijkste document met gegevens over de in- en uitvoer, namelijk het douanedocument, na 1992 verdween. Verder heeft de Staatssecretaris een commissie opgericht waarin het bedrijfsleven en de Belastingdienst overleggen over eventuele uitvoeringsproblemen die zich naar aanleiding van de gewijzigde regelgeving kunnen voordoen. Eén en ander leidde ertoe dat de Centrale Eenheid Intra Communautaire Transacties (ICT) werd opgericht. Deze eenheid fungeert als aanspreekpunt inzake de omzetbelasting voor de andere lidstaten.

Ook bij de accijnzen had het wegvallen van de binnengrenzen per 1 januari 1993 gevolgen. Na die datum gaf de douane geen verklaring meer af dat goederen een lidstaat hebben verlaten. Er werd een nieuw systeem opgezet om toch een zekere controle in stand te houden. Dit mondde in 1992 uit in de "horizontale Accijns-Richtlijn". Verder werd het in EG-verband overeengekomen geleidedocument in Nederland ingevoerd. Besioten werd yerder dat de verschillende lidstaten zelf kunnen bepalen in hoeverre zij de Belastingdienst in hun land bij de controle op de stroom van documenten willen inschakelen. ${ }^{1126}$ Uit onderzoek van het Economisch Instituut voor het Midden- en Kleinbedrijf bleek overigens dat de voordelen van het verdwijnen van douaneprocedures groter waren dan de kosten van nieuwe administratieve procedures. Per saldo trad een lastenverlichting voor het bedrijfsleven op van 500 miljoen gulden.

Naast de omzetbelasting en de accijnzen deden zich ook op een aantal andere terreinen veranderingen voor. Ten gevolge van de Europese eenwording werd bijvoorbeeld met ingang van 1 januari 1993 de Bijzondere Verbruiksbelasting vervangen door de Belasting van personenauto's en motorrijwielen (BPM).

Naast de gewijzigde Europese regelgeving werkten de verschillende nationale belastingdiensten ook meer samen. Teneinde belastingfraude en het ontgaan van belastingen te voorkomen werd steeds meer informatie uitgewisseld tussen belastingdiensten. Dat gebeurde niet alleen indien fraude werd vermoed, maar ook in het algemeen ter controle van belastingaangiften. Verder werden verzoeken om informatie afgehandeld op het terrein van de douanebijstand, de internationale fiscale rechtshulp en de invorderingsbijstand. ${ }^{112 \pi}$ Getracht werd de tijd die nodig was voor het afhandelen van buitenlandse verzoeken om informatie te verkorten. De bevoegdheid tot het uitwisselen van informatie is binnen het Ministerie van Financiën gelegd bij de Directeur-Generaal der Belastingen.

\section{Verbeteren "human-capital"}

Het opleidingsbeleid van de Belastingdienst kenmerkt zich door:

${ }^{1126}$ Directoraat-Generaal der Belastingen, Beheersverslag Belastingđienst 1991, Den Haag, 29 april 1992, p. 21.

${ }^{1127}$ Directoraat-Generaal der Belastingen, Beleidsverslag 1993, Den Haag, april 1994, p. 23. 
1. -het verzorgen van functiegerichte opleidingen;

2. -het zorgen voor voldoende opleidingscapaciteit;

3. het zoveel mogelijk professionaliseren van de opleidingseemheden;

4. - het versterken wan de opleidingsfunctie in de regionale directies;

5. - het ervoor zorgen dat het lesmateriaal voldoende van kwaliteit is.

In de eerste plaats wordt het verzorgen van functiegerichte opleidingen benadrukt. Functiegericht opleiden wil zeggen dat de opleiding zo goed mogelijk bij de taken die in het kader van een bepaalde functie moeten worden uitgevoerd past. Het gaat daarbij niet alleen om fiscaal-juridische kennis, maar ook om sociale vaardigheden en managementvaardigheden. Begin jaren 90 namen de gegeven opleidingen ten gevolge van de herstructurering fors toe. In verband met de Oont-operatie en de nieuwe Invorderingswet vonden bovendien omvangrijke bijscholingsoperaties plats.

In de tweede plats wordt gewezen op het belang van voldoende opleidingscapaciteit. Omdat geschikte vooropleidingen in het bestaande onderwijssysteem nog onvoldoende aanwezig zijn en omdat het personeelsbeleid sterk gericht is op doorstroming verricht de Belastingdienst veel eigen opleidingsactiviteiten. Een belangrijke belemmering begin jaren 80 was het vertrek van vakmensen naar functies buiten de Belastingdienst. De opleidingscapaciteit was dan ook volledig benut om extra vakmensen voor de aanslagregeling beschikbaar te krijgen. In 1981 bedroegen de totale opleidingskosten voor het personeel zoals weergegeven op de begroting ongeveer F. 15,3 milloen. In werkelijkheid waren de opleidingskosten veel hoger, gelet ook op de ongeveer 6000 belastingambtenaren die deel namen aan een vijftigtal opleidingen. Daarmee waren 600.000 werkdagen oftewel ongeveer $9 \%$ van de capaciteit van de dienst gemoeid. De Belastingdienst stelde zich ten doel dit beslag op de capaciteit, ondanks de steeds zwaarder wordende eisen tengevolge van maatschappelijkeontwikkelingen, niet verder te laten toenemen en op termijn zo mogelijk te beperken: ${ }^{1128}$

Voor het opleiden van medewerkers beschikt de Belastingdienst over diverse opleidingsinstituten. Zo werden er begin jaren ' 80 een negental Regionale Opleidingsinstituten Belastingdienst (ROB's) opgezet voor met name het vernieuwen en verbeteren van de opleidingen op lager en middelbaar niveau. Met deze instituten werd beoogd de opleidingen beter af te stemmen op het werk en bovendien de opleidingen dichter bij de lokale diensteenheden te brengen waardoor sneller op de veranderingen in de opleidingsbehoefte kon worden ingespeeld. Ook voor andere categorieén werknemers werden beroepsgerichte opleidingen opgezet of werden de bestalande opleidingen verbeterd. Per 1 september 1982 is een nieuw instituut voor de inspecteursopleiding opgericht. Ook werd meer aandacht besteed aan de training in sociale, communicatieve en managementwaardigheden. In het jaarverslag over 1983 werd opgemerkt: "De in 1981 begonnen planmatige vernieuwing van alle opleidingen is in 1982 en 1983 onverminderd voortgezet en zal tot een zodanige verhoging van kwaliteit en doelmatigheid leiden, dat met hetzelfde capaciteitsbeslag ook nietowe opleidingswensen gehonoreerd kunnen worden". ${ }^{1129}$ In 1984 werd het Opleidingsinstituut Financiën opgericht. Hierdoor werd de capaciteit van de Belastingdienst om intern managementtrainingen te verzorgen aanzienlijk vergroot. Naast het volgen van eigen opleidingen waren er op grond van de Studiefaciliteitenregeling Rijkspersoneel ook studiefaciliteiten voor het personeel. Onder bepaalde voorwaarden werden faciliteiten gegeven om algemeen vormende opleidingen (HAVO, VWO e.d.), bedrijfsadministratieve en bijvoorbeeld fiscale en economische studies (buiten de Belastingdienst) te volgen.

${ }^{1128}$ Bel astingdienst, Jaarverslag over 1981, 1982, Den Haag. p. 80 .

${ }^{1.129}$ Belastingdienst, Jaarverslag over 1983 , Den Haag, 1984, p. 75. 
Daarnaast beschikt de Directie Automatisering Rijksbelastingen over een eigen opleidingsinstiturt. Naast opleidingen op lager en middelbaar niveau worden ook her- en bijscholingscursussen op het terrein van de automatisering gegeven. Verder leidt het Opleidingscentrum Belastingdienst controleurs en adjunct-controleurs op. Begin jaren tachtig werd de controleursopleiding vernieuwd. Dit is onder meer gerealiseerd door part-time docenten te vervangen door full-time docenten, terwijl voorts de cursusduur verlengd is tot drie jaar. Ook de opleiding tot adjunct-controleur werd halverwege de jaren "80 vernieuwd. Voorts kent de Belastingdienst het Douane-Opleidingsinstituut. Hier wordt onder andere het eerste jaar van de assistenten-opleiding en de vooropleiding tot verificateur verzorgd. Het Opleidingsinstituut Financien is met name bestemd voor het opleiden van inspecteurs, hoofden van de afdeling controle en ontvangers. Tenslotte is in 1986 de Opleiding Topmanagement Belastingdienst ingesteld. In het kader van deze opleiding wordt veel aandacht besteed aan het trainen van managementvaardigheden.

In de derde plaats wordt veel belang gehecht aan voldoende professionalisering. Teneinde de kwaliteit van het opleidingsapparaat te waarborgen zijn docenten van binnen de Belastingdienst aangetrokken. Daarnaast zijn externe deskundigen ingehuurd zoals docenten sociale vaardigheden, managementtrainers en bedrijfskundigen. Verder waren er in 1984 tien onderwijskundigen aangetrokken.

Voorts wordt erop gewezen dat de ROB's mede ten doel hebben gehad om taken te verschuiven van het departement naar de regionale directies. Er werd sinds 1985 gewerkt met contractmanagement, aanvankelijk nog experimenteel. In een contract werden doelen geformuleerd. De realisatie van deze doelen was de verantwoordelijkheid van het management van het opleidingsinstituut. Achteraf werd getoetst in hoeverre de doelen gerealiseerd waren.

Tenslotte werd er veel geünvesteerd in lesmateriaal. Het lesmateriaal werd zoveel mogelijk aangepast aan nieuwe onderwijskundige inzichten, veranderde wetgeving en de eisen van de samenleving. Ook werd steeds meer gebruik gemaakt van audio-visuele middelen. ${ }^{1130}$

Eind jaren " 80 verscheen de notitie Kader voor de nieuwe opleidingsstruetuur. ${ }^{1131}$ De opleidingscapaciteit van de Belastingdienst zou niet langer verspreid moeten zijn over verschillende regio's, maar zou moeten worden geconcentreerd in êen instituut, dat dus in het vervolg zou moeten zorgen voor alle interne opleidingen. Voorts moesten er jaarplannen komen waarin beschreven zou worden welke activiteiten verricht worden en wat de gewenste prestaties zijn. Sinds 1990 functioneert de opleiding als een facilitair bedrijf. In 1993 zijn verantwoordelijkheden voor de personeelsontwikkeling meer dan voorheen bij het lijnmanagement gelegd. Het lijnmanagement bepaalt nu in overleg met de ambtenaar welke opleidingen gevolgd moeten worden en wanneer. Het doel hiervan is ervoor te zorgen dat de kwaliteit van de medewerkers zo goed mogelijk wordt afgestemd op de functie- en functioneringseisen. ${ }^{1132}$

\section{Rechtvaardige inkomensverdeling}

De Belastingdienst heeft de mogelijkheid om regelgeving uit te leggen en eventueel regelingen te treffen indien de uitvoering van een bepaalde regeling tot ongewenste

${ }^{1130}$ Belastingdienst, Jaarverslag over 1984 "Den Haag, 1985, p. 78.

${ }^{1131}$ Belastingdienst, Notitie Kader voor de nieuwe opleidingsstructuur, Den Haag, 1988.

1132 Directoraat-Generaal der Belastingen, Beleidsverslag 1993, Den Haag, april 1994, p. 70. 
effecten zoul leiden In 1981 werd bijvoorbeeld met de Nederlandse Sportfederatie gesproken over de fiscale positie wan deze sector. Een probleem dat zich voordeed was dat sportverenigingen in bepaalde gevallen loonbelasting en premies moesten inhouden, omzetbelasting moesten voldoen over kantine-omzetten en vennootschapsbelasting moesten afdragen over kantinewinsten. Met de Federatie werden regelingen getroffen over onder meer de heffing van de omzetbelasting en de heffing van vennootschapsbelasting. Ook op andere gebieden beschikte de Belastingdienst over een zekere vrijheid om regelingen te treffen Bij de vitvoering van de WIR leidden het grote aantal uitsluitingsbepalingen tot een toename van vooroverleg tussen Belastingdienst en ondernemers. Hierbij deden zich de nodige meningsverschillen voor. Ook werd een toenemend aantal gevallen voorgelegd an de administratieve rechter. Hierbij speelde ook een rol dat de WIR veelvuldig gewijzigd werd. Met betrekking tot de omzetbelasting deed zich het probleem voor dat het bepalen van het tarief dat op nieuwe producten moet worden toegepast vaak met de nodige moeilijkheden gepaard ging. ${ }^{1133}$

Verder heeft de Belastingdienst, meer precies de ontvanger, de mogelijkheid uitstel van betaling te verlenen. Hoewell dat wettelijk niet vereist is verleent de ontvanger indien er een bezwaarschrift loopt tegen de aanslag bijvoorbeeld veelal uitstel van betaling. Ook betalingsmoeilijkheden kunnen een reden zijn om betalingsuitstel te verlenen. Bij betalingsuitstel is door de belastingplichtige rente verschuldigd, tenzij het om een aanslag gaat van minder dan F. 1.200,-. In prineipe hoeft deze discretionaire bevoegdheid de Belastingdienst dus niets te kosten. Dit is het geval indien de door belastingplichtigen te betalen rente minimaal gelijk is aan de rente op staatsobligaties. In 1984 betaalden belastingplichtigen bijvoorbeeld $9 \%$ rente, terwijl de rente op staatsobligaties $8,16 \%$ bedroeg. Dit impliceert dat het betalingsuitstel de Belastingdienst geen geld kostte. Daarbij moet wel overwogen worden dat met het betalingsuitstel voor de Belastingdienst ook kosten gemoeid waren. Zo leverde het betalingsuitstel meer werk op omdat één en ander in de gaten gehouden moest worden. Indien betaling van de belasting in verband met de financiële situatie redelijkerwijs niet kan worden verlangd kan de regionale directeur op verzoek kwijtschelding verlenen. $\mathrm{Na}$ kwijtschelding vervalt de belastingschuld definitief. De kwijtscheldingsbedragen per soort belasting kunnen als volgt worden weergegeven:

${ }^{1133}$ Belastingdienst, Jaarverslag over 1981, Den Haag, 1982, p. 30 en p. 43. 


\begin{tabular}{|c|c|c|c|c|c|c|c|c|c|}
\hline Jaar & $\begin{array}{l}\text { Inkombstea- } \\
\text { ea } \\
\text { wermagens- } \\
\text { belasting }\end{array}$ & $\begin{array}{l}\text { Moworiy- } \\
\text { wrigente- } \\
\text { lastings } \\
\end{array}$ & $\begin{array}{l}\text { Premien } \\
\text { hefffing } \\
\text { (cohien) }\end{array}$ & $\begin{array}{l}\text { Omber } \\
\text { bellasting }\end{array}$ & $\begin{array}{l}\text { Loon- } \\
\text { betasting }\end{array}$ & $\begin{array}{l}\text { Premiehef } \\
\text { fing (venk- } \\
\text { gewers) }\end{array}$ & $\begin{array}{l}\text { Overige } \\
\text { heffingiger } \\
\text { (scheol } \\
\text { geid) }\end{array}$ & $\begin{array}{l}\text { Onnoe } \\
\text { rewie } \\
\text { zati } \\
\text { bellusting }\end{array}$ & Tocisil \\
\hline 1978 & 50.931 & 374 & 15.483 & 2.721 & 280 & 271 & 29 & 1.347 & 71.435 \\
\hline 1980 & 46.493 & 338 & 17.865 & 2.431 & 418 & 521 & 58 & 1,641 & 69.765 \\
\hline 1982 & 51.716 & 718 & 22,537 & $2+890$ & 253 & 414 & 99 & 2.850 & 81.477 \\
\hline 1984 & 50,317 & 1.080 & 25,786 & 16.182 & 1.880 & 1.897 & 366 & 11,036 & 108.544 \\
\hline 1986 & 36.418 & 689 & 25.706 & 13.418 & 1.134 & 1.862 & 221 & 19.462 & 98.910 \\
\hline 1987 & 32.324 & 181 & 21.279 & 7.463 & 781 & 1.217 & 17 & 16.814 & 80.076 \\
\hline 1988 & 26.575 & 108 & 23.479 & 2.666 & 814 & 1.885 & 6 & 14.611 & 70.144 \\
\hline 1989 & 22.490 & 52 & 18.884 & 5.477 & 675 & 1.254 & 8 & 12,670 & 61.510 \\
\hline$\$ 990$ & 18.846 & 59 & 15.090 & 6.339 & 386 & 830 & 8 & 7.911 & 49.469 \\
\hline 1991 & 15.185 & 8 & 10.269 & 3.342 & 538 & 1,248 & 0 & 5.502 & 36,092 \\
\hline
\end{tabular}

Tabel 17.6 Kwijtgescholden bedragen ${ }^{135}$

Begin jaren " 80 liep het bedrag aan kwijtscheldingen duidelijk op. De belangrijkste reden van deze toename was de verslechterde economische situatie. In 1981 werd

F. $75.956,000$, kwijtgescholden op een totale opbrengst van F. 130,173 miljard aan belastïngen, premies volksverzekeringen, schoolgeld etc. In 1983 werd een bedrag van ongeveer 100 miljoen gulden kwijtgescholden. In het jaarverslag over 1983 werd over kwijtschelding opgemerkt: "In 1983 zijn voorbereidingen getroffen om de voorlichting over kwijtschelding van belastingen te verbeteren. Dit omdat de indruk bestond, met name ook verwoord in het parlement, dat het publiek niet voldoende op de hoogte was van de gang van zaken rond kwijtscheiding ".1136 Blijkbaar vond het parlement dat burgers onvoldoende op de hoogte waren van de mogelijkheden die bestonden ten aanzien van de kwijtschelding van belastingschulden. Hierdoor nam in de jaren daarna het totale bedrag aan kwijtschelding toe De werkgroep Inkomensbeleid/Kwijtscheldingsbeleid waarin vertegenwoordigers van de Ministeries van Binnenlandse Zaken, Sociale Zaken en Werkgelegenheid, Binnenlandse Zaken en Financiën zitting hadden, bracht in 1987 een rapport uit over het kwijtscheldingsbeleid. Dit rapport werd integraal aanvaard door het kabinet. Het hield onder meer in dat het kwijtscheldingsbeleid niet wezenlijk afwijkt van het inkomensbeleid. 1137 Verder moest onderzocht worden in hoeverre hoge huur of het aanvragen van huursubsidie invloed heeft op het al dan niet aanvaarden van kwijtscheldingsverzoeken. Voorts moet het beleid van de verschillende departementen die betrokken zijn bij het inkomens- of kwijtscheldingsbeleid beter op elkaar worden afgestemd. Omdat bleek dat het toekennen van de bevoegdheid tot het verlenen van kwijtschelding de

\footnotetext{
1134 Vanaf 1986 inclusief kwijtgescholden vennootschapsbelasting.

1135 Zie voor 1992 Tabel 18.14

${ }^{1136}$ Belastingdienst, Jaarverslag over 1983, Den Haag, 1984, p. 65

${ }^{1137}$ Belastingdienst, Jaarverslag over 1087, Den Haag, 1988, p. 37.
} 
afdoening van kwijtscheldingsverzoeken aanzienlijk versnelde is besloten om met ingang van 1 april 1988 deze bevoegdheid voor alle belastingen aan de ontvanger toe te kennen. Bovendien werd de procedure vereenvoudigd. Niet langer moet een kwijtscheldingsformulier aan de directeur kwijtschelding worden gericht maar aan de ontvanger. In 1988 daalde het bedrag aan kwijtschelding tot 70 miljoen gulden. Het kwijtscheldingsbeleid werd aangepast en verduidelijkt. In 1988 verscheen in dit verband een handleiding kwijtschelding particulieren waardoor meer duidelijkheid ontstond. Begin jaren 90 deed zich een verdere daling voor tot 27 miljoen in 1992. Als redenen worden genoemd een strikt invorderingsbeleid, het wegvallen van de werkzaamheden voor de onroerend goedbelasting en het geven van meer voorlichting aan het publiek ten aanzien van het kwijtscheldingsbeleid.

Naast de bedragen die werden kwijtgescholden waren er ook belastingschulden die oninbaar bleken. Begin jaren " 80 namen deze bedragen toe, vooral ook in verband met de moeilijke economische sinuatie. Deze oninbaar gebleken bedragen kunnen als volgt worden weergegeven:

\begin{tabular}{|c|c|c|c|c|c|c|c|}
\hline Jatar & $\begin{array}{l}\text { Inkomsten- en } \\
\text { vermogensbellas } \\
\text { ting }\end{array}$ & $\begin{array}{l}\text { Wemnoot- } \\
\text { schapsbelas- } \\
\text { ting }\end{array}$ & $\begin{array}{l}\text { Omzet- } \\
\text { belasting }\end{array}$ & Looubelasting & $\begin{array}{l}\text { Premies } \\
\text { Yolksverzekerin- } \\
\text { gen }\end{array}$ & $\begin{array}{l}\text { Overige } \\
\text { nass }\end{array}$ & $\begin{array}{l}\text { Touaal } \\
\text { n13ss }\end{array}$ \\
\hline 1978 & 143,9 & 44,9 & 167,7 & 77,1 & 144,3 & 13,2 & 591,3 \\
\hline 1980 & 197,0 & 100,3 & 292,0 & 183,0 & 302,7 & 18,4 & $1.093,4$ \\
\hline 1982 & 335,6 & 247,2 & 695,3 & 612,4 & $930 ; 9$ & 26,5 & 2.847 .9 \\
\hline 1984 & $641 ; 1$ & 334,6 & 780,0 & 237,3 & 501,0 & 48,4 & $2.542,4$ \\
\hline 1985 & 601,8 & 250,0 & $1.188,0$ & 230,1 & 575,0 & 55,6 & $2.900,5$ \\
\hline 1986 & 499,3 & 256,5 & 737,6 & 208,4 & 488,1 & 49,7 & 2.239 .6 \\
\hline 1987 & 406,2 & 365,3 & 506,0 & 144,7 & 404,4 & 44,0 & $1.870,5$ \\
\hline 1988 & 342,1 & 251,4 & 401,6 & 110,6 & 339,0 & 38,8 & $1.483,5$ \\
\hline 1989 & 307,8 & 330,0 & 411,8 & 133,5 & 352,0 & 37.5 & $1.572,7$ \\
\hline $1990^{\circ}$ & 287,4 & 161,9 & 339,9 & 78,8 & 247,7 & 30,4 & $1.146,1$ \\
\hline 1991 & 203,6 & 132,7 & 264,5 & 99,7 & 215,0 & 30,2 & 945,5 \\
\hline${ }_{1100}^{1992}$ & 266,5 & 234,5 & 435,9 & 102,2 & 445,2 & 43,4 & $\int_{1.44}^{1.527 .9}$ \\
\hline
\end{tabular}

Tabel 17.7 Oninbare bedragen ${ }^{1142}$ in miljoenen gulden

1.38 Zoals motorrijtuigenbelasting, onroerende zaakbelasting en schoolgeld.

${ }^{1339}$ Eventuele verschillen in sornmering zijn het gevolg van afronding.

${ }^{1140}$ Inclusief kwijtgescholden bedragen.

${ }^{1141}$ oninbaar $=$ f. $1.488 .000 .000,-$, kwijtschelding $=$ f. $27.000,000,--$

1142 Bron: Belastingdienst, Jaarverslag over 1981, Den Haag, 1982, p. 61. 
In 1982 bleek ruim drie miljard gulden van de belasting- en premieschuld niet inbaar te zijin. Dit was ongeveer $2,1 \%$ van de totale belasting- en premieontvangsten. ${ }^{1143}$ Volgens de Belastingdienst werd ongeveer de helft van dit bedrag veroorzaakt door faillissementen. De Belastingdienst probeerde deze oninbare bedragen op verschillende wijzen terug te dringen. Eén van de methoden was het automatiseringsproject loonbelasting aan het begin van de jaren tachtig. In het jaarverslag over 1981 wordt dienaangaande vermeld: "De strakkere procedures in dit systeem hebben geleid tot een zeer sterke stijging van her aantal naheffingsaanslagen loonbelasting en premieheffing ". ${ }^{114}$ In de oninbare bedragen zijn verder ook de administratieve boetes in verband met de niet tijdige afdracht (van veelal 10\%) en ten gevolge van gebleken onjuistheden (van maximaal 100\%) opgenomen. Halverwege de jaren ' 80 nam het totale oninbare bedrag af doordat het aantal faillissementen verminderde en door de verdere invoering van lokale automatisering. Door de automatisering kon nauwkeurig aangegeven worden wat de oorzaken waren van oninbaarheid zodat preventieve maatregelen genomen konden worden. Ook werd binnen de Belastingdienst meer samengewerkt tussen de verschillende dienstvakken. Hierdoor kon bij de invordering de kwijtschelding en het oninbare gedrag dalen. Mede door de forse toename van de ontvangsten daalde het percentage aan oninbaar geleden of kwijtgescholden belastingen en premies tot $1,4 \%$ van de netto-ontvangsten in 1986 , terwijl dit in 1985 nog 1,9\% was. Mede door de reorganisatie die vanaf 1987 werd doorgevoerd nam het oninbare bedrag verder af tot 1,4 miljard gulden in 1988. Door deze maatregelen maar ook door de sterke stijging van de ontvangsten daalde het oninbare en kwijtgescholden bedrag in 1987 verder tot $1,1 \%$ van de netto-ontvangsten. In 1991 was het oninbare gedrag verder gedaald tot 1.146 miljoen, een halvering ten opzichte van 1986. Naar aanleiding van een onderzoek van de Algemene Rekenkamer is het beleid inzake de oninbaarheid van belastingen op een aantal punten bijgesteld. Duidelijker dan voorheen zijn situaties beschreven waarin kan worden besloten dat een vordering oninbaar is, terwijl ook een procedure ingesteld is die vergezeld gaat van voldoende interne controle. ${ }^{1145}$ Het oninbaar geleden bedrag was in 1991 gedaald tot 946 miljoen gulden. In 1992 steeg dit bedrag tot 1.488 miljoen gulden. Als reden wordt de beleidskeuze genoemd waardoor faillissementsposten sneller oninbaar werden geacht. Deze keuze werkte ook nog door in 1993.

Tenslotte wordt het doel van het realiseren van een rechtvaardige inkomensverdeling nagestreefd door de opzet van het Nederlandse loon- en inkomstenbelastingstelsel, zoals kort uiteengezet in paragraaf 17.2. De huidige belastingwetgeving is gebaseerd op het gelijkheids- en draagkrachtbeginsel, waardoor belastingplichtigen met een wat betreft omvang gelijk belastbaar inkomen ongeacht de samenstelling daarvan aan een gelijke fiscale behandeling worden onderworpen. Dit leidde ertoe dat bij de belastingheffing wordt gekeken naar het totale inkomen, zonder daarbij onderscheid te maken naar aard en oorsprong van de samenstellende inkomensbestanddelen (het zogenaamde synthetische inkomensbegrip). Door de verfijning van de wetgeving was een relatief groot deel van de bevolking belastingplichtig voor de inkomstenbelasting (begin jaren tachtig circa $35 \%$ of 5 miljoen mensen). Mede hierdoor werd er een aanzienlijke werkdruk, op de betreffende afdelingen van de Belastingdienst gelegd, hetgeen aanzienlijke uitvoeringskosten met zich

${ }^{1143}$ Belastingdienst, Jaarverslag over 1982, Den Haag, 1983, p. 57.

1144 T.a.p., p. 62.

1145 Vergelijk ook: Directoraat-Generaal der Belastingen, Financielle Verantwoording 1991, Den Haag, 1992, pp. 60/65. 
meebracht. ${ }^{1146}$

\section{Waarborg}

De dienst van de Waarborg behoorde ook tot de Belastingdienst. Deze dienst hield in dat alle gouden, zilveren en platina voorwerpen die in Nederland in de handell werden gebracht voorzien moesten worden van een rijksstempel, dat het edelmetaalgehalte van deze voorwerpen garandeerde. Voor een dergelijke keuring was een waarborgrecht verschuldigd, hetgeen diende om zoveel mogelijk de kosten te dekken. Op grond van de Waarborgwet 1950 controleerden werkmemers van de Waarborg bijvoorbeeld of winkels en veilingen de regeis van deze wet ook daadwerkelijk naleefden. Eind 1981 werkten bij de Waarborg 71 personen, die verspreid waren over zeven kantoren. In 1981 werden 10.671 voorwerpen aangeboden en bedroeg de opbrengst van het waarborgrecht $\mathbb{F}$. $3.424 .000,-$ In 1986 was dit opgelopent tot F. 6:130.000,-

In 1984 nam de Ministerraad een principebesluit tot privatisering. Op 21 november 1984 werd een projectgroep Privatisering Waarborg ingesteld die de privatisering van de waarborg moest voorbereiden. De gedachte was dat de waarborg het best onder het beheer van de belanghebbenden kon functioneren. Daarbij diende wel zoveel mogelijk rekening te worden gehouden met de belangen van het personeel. Ondertussen werd een herstructurering van de Dienst van de Waarborg doorgevoerd. Een aantal kantoren werd gesloten. De Waarborg zou uiteindelijk beschikken over een drietal kantoren te Amsterdam, Arnhem en Rotterdam. Een viertal werknemers werden overgeheveld naar de Belastingdienst. Daardoor resteerden er eind 198468 werknemers op 66 voltijdsfuncties. In maart 1986 bereikten het Ministerie van Financiën en de Federatie Goud en Zilver overeenstemming over voorwaarden die aan de overdracht van de Dienst Waarborg zou worden gesteld. Het wetsvoorstel tot privatisering werd in 1986 goedgekeurd door de Tweede Kamer en eind jamuari 1987 door de Eerste Kamer. Per 1 maart 1987 is de Dienst van de Waarborg dan ook geprivatiseerd. Ongeveer een kwart van de werknemers trad in dienst van de nieuwe Waarborg Platina, Goud en Zilver N.V., terwijl de rest van het personeel ervoor koos de dienstbetrekking bij de Belastingdienst, zij het in een andere betrekking, te continueren. Teneinde de privatisering te laten slagen werden zij het eerste jaar geplaatst bij deze N.V.. Het aantal kantoren werd door de geprivatiseerde onderneming teruggebracht tot eén kantoor te Gouda.

\section{Bevorderen werkgelegenheid minderheden}

Het Rijk heeft zich als doel gesteld om meer vrouwen in te huren. Dit beleid werd ondersteund door de Belastingdienst. De Belastingdienst voerde een personeelsbeleid waarin mannen en vrouwen gelijke kansen hebben. Dit leidde ertoe dat in vrijwel alle functies vrouwen werkzaam waren. In totaal waren binnen de Belastingdienst eind 1981 4.054 vrouwen werkzaam op een totaal personeelsbestand van 29.883 . Het beleid van de Belastingdienst was erop gericht dat meer vrouwen bij de Belastingdienst zouden gaan werken, terwijl bovendien de vrouwen die er al werkten meer ontplooiingsmogelijkheden moesten krijgen. ${ }^{1147}$ Een projectgroep binnen de Belastingdienst stelde voor om het aantal vrouwen op $25 \%$ van het totale personeelsbestand te brengen. Dit vond zijn weerslag in het rapport "Naar een emancipatiegericht personeelsbeleid bij de Belasting.

11.46 Tweede Kamer der Staten-Generaal, (vergaderjaar 1980-1981), Deelrapport 7, heroverweging groei Belastingdienst, 16625 , nr. 12, pp. 15 e.v.

${ }^{2147}$ Belastingdienst, Naar een emancipatiegericht personeelsbeleid bij de Belastingdienst, Den Haag, 1987. 
dienst". De Belastingdienst probeert zoveel mogelijk de ideeën in dit rapport uit te voeren. In 1990 constateerde de Belastingdienst: "De Belastingdienst kent geen evenwichtige verdeling van mannen en vrotwen over alle functies. Om dat evenwicht wel te bereiken zullen meer prouwen moeten doorstromen naar de middelbare en hogere functies". 1148 Volgens cijfers wan de Belastingdienst bedroeg het aantal vrouwen in de salarisschalen 1 tot en met 5 en de jeugdschalen in $199014,5 \%$, in de schalen 6 tot en met $118,3 \%$ en in de schalen 12 tot en met $180,4 \%$. Om deze percentages te verhogen gollden met ingang van 1990 een aantal voorrangsbepalingen voor vrouwen. Zo werden bij gelijke geschiktheid vrouwen aangenomen, werd de mogelijkheid om in deeltijd te werken verruimd, terwijl de helft van de plaatsen in start-opleidingen werd gereserveerd voor vrouwen. In het Beheersverslag over 1991 werd echter geconstateerd dat het aantal vrouwen weinig was toegenomen. ${ }^{149}$ Het aantal vrouwen in schaal 1 tot en met 5 was gestegen tot $15,3 \%$, van 6 tot en met 11 tot $9 \%$ en van 12 en hoger tot $0,5 \%$. Dat de toename beperkt bleef werd door de directie geweten aan de vacaturestop en de geringe door- en instroommogelijkhedien. Besloten werd een meer decentraal beleid te voeren. Zoals ook in het jaarverslag over 1991 werd benadrukt bleef de doelstelling evenwel gehandhaafd. ${ }^{1150}$ In 1992 en 1993 was het aantal vrouwen in de verschillende schalen licht gestegen. Het totale aantal vrouwen steeg van 25 naar $26 \%$. Het doel van het Rijk is om ervoor te zorgen dat in $199530 \%$ van het personeelsbestand uit vrouwen bestat. Dit werd in 1993 nog niet bereikt. Wel was er een geleidelijke toename van vrouwelijke werknemers. Deze toename leidde ook tot meer deeltijdbanen, Dat betekende ook dat er meer kosten gemaakt moesten worden, aangezien deeltijdwerkers meestal wel een eigen werkplek hebben.

Eind jaren ' 80 werd er ook meer nadruk gelegd op het bevorderen van de werkgelegenheid voor etnische minderheden bij de Belastingdienst. Op grond van het Beleidsplan Werkgelegenheid voor etnische minderheden bij de rijksoverheid (EMO-plan) was het de bedoeling orn wan 1987 tot 19901.500 mensen uit etnische groepen extra aan te nemen bij de Rijksoverheid ${ }^{151}$ Voor de Belastingdienst betekende dit dat er 95 allochtonen per jaar moesten worden aangenomen. In verband met de wervingsstop was dit niet volledig haalbaar. Wel probeerde de Belastingdienst $z 0$ goed mogelijk dit beleid te verwezenlijken door in elk geval voor $50 \%$ van de instroom allochtonen en gehandicapten aan te nemen. Van september 1987 tot 1 januari 1989 zijn er 40 allochtonen aangenomen. In 1990 werden overeenkomstig het banenplan Molukkers 61 Molukkers in dienst genomen. Op grond van het EMO (Etnische Minderhedenbeleid Overheid)-plan 2 werden nieuwe doelen opgesteld. Per jaar wilde de Belastingdienst tot en mell 199580 allochtonen aannemen. Dit aantall werd verdeeld over de directies naar rato van hun budget. In 1992 bedroeg de instroom 130 allochtonen, terwijl dit in 1993170 was. De doelen werden dus ruimschoots gehaald.

Op grond van de Wet gehandicapte werknemers (WAGW) ${ }^{1152}$ streefde de overheid er

${ }^{1448}$ Belastingdienst, Jaarverslag over 1990, Den Haag, 1991, p. 36.

"149" Directoraat-Generaal der Belastingen, Beheersverslag Belastingdienst 1991, Den Haag, 29 april 1992, p. 49.

1150 Directoraat-Generaal der Belastingen, Jaarverslag over 1991, Den Haag, 1992, pp. 37 e.v.

115L Beleidsplan Werkgelegenheid voor etrische minderheden bij de rijksoverheid (EMO-plan), 1986.

1152 Wet gehandicapte werknemers. (WAGW), 1 juli 1986. 
tenslotte naar om het aantal gehandicapte werknemers te vergroten tot minimaal $5 \%$ van het personeelsbestand in 1993. Bij de Belastingdienst bleek dit 3,5\% te zijn. Daarom werd in overleg met de Bijzondere Commissie een beleid gevoerd dat dit percentage moest verhogen. Dit moest gebeuren door het op grotere schaal aannemen van gehandicapten, maar ook door het zoveel mogelijk reüntegreren van langdurig zieken en het voorkomen van arbeidsongeschiktheid.

\section{Onderzoek}

Begin jaren 90 gaf de Belastingdienst steeds meer aandacht aan het ontwikkelen van de onderzoeksfunctie (R\&D-functie). Daarbij ging het niet zozeer om het doorlichten van de organisatie en het verrichten van audits die met het oog op de controlfunctie werden uitgevoerd, alswel om onderzoeksmatige soorten van beleidsevahuatie. Er werd in overleg met de stafdirecties en doelgroepdivisies een Beleidsplan Onderzoek en Ontwikkeling opgesteld. De onderzoeken die werden uitgevoerd hadden betrekking op een breed terrein. Belangrijk waren vooral ramingsonderzoeken naar de verschillen tussen ramingen en realisaties van bepaalde belastingopbrengsten, onderzoeken naar de kwaliteit van het functioneren van de Belastingdienst, beleidsevaluatie-onderzoeken en onderzoeken naar de "compliance". In het beleidsverslag 1992 werd gesteld: "Uit het grate aantal uitgevoerde en in uitwoering zijnde onderzoeken en studies (...) blijkt dat het belang van de facilitaire $R \& D$-functie, als ondersteuning van het politieke besluitvormingsprocies en de bedrijfsprocessen van de Belastingdienst, algemeen erkenning heeft gevonden". ${ }^{1153}$

\section{Huisvesting}

Elk jaar werd door zowel de RGD als door de Belastingdienst zelf geinvesteerd in de huisvesting van thet personeel. Tot bepaalde hoogte zijn deze kosten gebruikelijk voor een orgamisatie. Ten gevolge van variabele werktijden, deeltijdarbeid, arbeidstijdverkorting e.d. blijkt de gemiddelde bezetting van veel organisaties gedaald te zijn tot $40 \%$. Nelissen merkt op: "Dit percentage is binnen de Belastingdienst wellicht nog lager als gevolg van het feit dat er veel ambulante medewerkers in dienst zijn. Dit zijn voornamelijk de deurwarders en controle-ambtenaren. ${ }^{1154}$ Gemiddeld wordt landelijk ongeveer

F. 22.000,- per werkplek per jaar uitgegeven aan facility-management. ${ }^{1155}$ Bij de Belastingdienst was dit ongeveer F. 24.000,-. Dit had dus grotendeels te maken met de aard van de functies.

\subsection{Wat zijn de kosten van de doelen van de Rijksbelastingdienst?}

In deze paragraaf wordt ingegaan op de kosten van de doelen. Het gaat ons met andere woorden om het budget waarmee de in de vorige paragraaf gevonden doelen worden nagestreefd. Als kosten worden niet alleen de perceptiekosten aangemerkt maar ook de maatschappelijke kosten. Deze maatschappelijke kosten bestaan uit de bijkomende kosten van de belastingheffing.

${ }^{1153}$ Directoraat-Generaal der Belastingen, Beleidsverslag 1992, Den Haag, april 1993, p. 74.

1154 K.T.H. Nelissen, Flexibel $\mathrm{m}^{2}$ gebruik binnen de Belastingdienst, afstudeerscriptie, Belastingdienst, Projectbureau huisvesting/ Hogeschool Holland, 1993, p. 3.

1155 Bij facilities moet gedacht worden aan de hwisvesting maar ook aan energie, schoonmaak, beveiliging, meubilair, apparanur etc. 


\subsubsection{De perceptiekosten}

Allereerst zijn de apparaatsuitgaven of perceptiekosten van belang. Perceptiekosten zijn de kosten van heffing, inning en controle (de vitvoeringskosten). ${ }^{\text {ISs }}$ Deze uitgaven betreffen de personele en materiële uitgaven van de Belastingdienst. De uitgaven gedaan door de Rijksgebouwendienst zijn hierin niet begrepen. Hoe hoog mogen de perceptiekosten zijn? Uiteindelijk is dit een politieke keuze. Het rapport van de commissie-Haks spreekt van maximaal vijf à tien procent. In Tabel 17.8 zijn de uitgaven van de Belastingdienst uitgewerkt naar uitgavenpost.

\begin{tabular}{|c|c|c|c|c|c|c|}
\hline & 1980 & 1984 & 1988 & 1990 & 1992. & 1993 \\
\hline $\begin{array}{l}\text { Totale personeelskasten } \\
\text { (algemeen beheer }+ \\
\text { Belastingdienst) }\end{array}$ & 1.582 .506 & 1.697 .763 & 1.816 .389 & 1.876 .721 & 1.977 .153 & 2,048379 \\
\hline $\begin{array}{l}\text { *Algemeen Be- } \\
\text { beer }^{1159}\end{array}$ & 25.402 & 28.897 & 33.875 & 100 & & 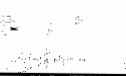 \\
\hline $\begin{array}{l}\text { - Personeel } \\
\text { Belastingdienst }\end{array}$ & 1.557 .104 & 1.668 .866 & 1.782 .514 & $1.876,721$ & 2.020 .268 & 2.048 .379 \\
\hline -sallarissen & 1.087 .592 & 1.136 .097 & 1.402 .012 & 1.459 .023 & 1.546333 & 1.590 .271 \\
\hline -aandeel in sociale lasten & 452.219 & 513,024 & 347922 & 321,905 & 362.954 & 354410 \\
\hline Materiële kosten & 179.963 & 339.197 & 459.574 & 604.998 & 760.858 & 799,460 \\
\hline huisvesting & 28.761 & 36.517 & 36.043 & 40.838 & 52.407 & 54.208 \\
\hline Kosten opleiding personeal & 12.341 & 19.983 & 21.001 & 24.794 & 32.292 & 43158 \\
\hline $\begin{array}{l}\text { Rente } \\
\text { belastingschulden }\end{array}$ & $\because$ & $-\quad$ & -8 & $-2 \cdot$ & $1,178.031$ & 1.183 .422 \\
\hline $\begin{array}{l}\text { Totaal ten laste van het } \\
\text { Mimisterie van Financiën }\end{array}$ & 1.762 .469 & 2.036 .960 & $2,275.962$ & 2.481 .720 & 3.904 .252 & 4.052 .625 \\
\hline $\begin{array}{l}\text { Huisvestingskosten bekostigd } \\
\text { door het Ministerie van } \\
\text { VROM"161 }\end{array}$ & 58.400 & 58.400 & 72.000 & 136,000 & 200.000 & 200,000 \\
\hline Totaal: & 1.820 .869 & 2.095 .360 & 2.347 .962 & $2,617,720$ & 4.104 .252 & 4.252 .625 \\
\hline
\end{tabular}

\section{Tabel 17.8 Uitgaven van de Belastingdienst ${ }^{1162}$}

${ }^{1158}$ Rapport van de Commissie verruiming eigen middelen lagere overheden, $1992, \mathrm{p}, 35$.

1159 Uitgaven op kasbasis ten laste van de begroting van het Ministerie van Financién, zoals vermeld in de jaarverslagen van de Belastingdienst over de onderzoeksperiode.

1160 Vanaf 1990 in verband met reorganisatie bij persomeelskosten Belastingdienst genomen.

${ }^{1151}$ De bedragen die betaald werden door de RGD zijn geschat op grond van de gegevens zoals opgenomen in het Rijkshuisvestingsplan 1 en 2. In 1991 betaalde de RGD bijvoorbeeld F. 6.400 per werkplek. Van de totale uitgaven van de Belastingdienst was ongeveer $5 \%$ besternd woor huisvesting.

1162 Bedragen in duizenden guldens. 
Gemiddeld genomen bedroegen de perceptiekosten ongeveer $1,2 \%$, hetgeen voorall ook gelet op de norm van de Commissie Haks niet erg hoog is.

De uitgaven van de Belaistingdienst bestonden in 1984 voor circa $81 \%$ uit personeelskosten. Dat was iets minder dan de $82 \%$ in 1983 . Dit kwam vooral door de overheveling van de portikosten naar de begroting van het Ministerie van Financiën en door de toenemende kosten die gemaakt werden voor automatiseringsapparatuur. De materiële uitgaven namen in 1990 toe met 87 miljoen gulden tot F. 605 miljjoen. Dit kwam enerzijds door de ook in dat Jaar toenemende kosten van automatisering en anderzijds omdat de Belastingdienst sinds 1989 aan de banken een vergoeding betaalt voor de kosten van het betalingsverkeer. ${ }^{1163}$ Ook in 1991 namen de materiële kosten toe. Dit was vooral het gevolg van de kosten die in verband met de herstructurering extra gemaakt moesten worden voor automatisering. Verder werden door de Belastingdienst hogere kosten gemaakt voor huisvesting en voor het onderhoud van de gebouwen, terwijl ook de prijzen voor porti, het schoonmaken van de gebouwen, het betalingsverkeer en het openbaar vervoer stegen. ${ }^{1164}$

Bij deze kosten moeten de kosten die door andere departementen werden gemaakt worden opgeteld. Het gaat hierbij vooral om de portikosten en de huisvestingskosten. Tot en met 1983 kwamen de portikosten vrijwel geheel ten laste van het Ministerie van Verkeer en Waterstaat. Het ging hier om een bedrag van ongeveer F. 47 miljoen. Met ingang van 1984 komen de portikosten ten laste van de begroting van de Belastingdienst. De Belastingdienst heeft tegelijkertijd een bezuinigingsoperatie doorgevoerd om de portikosten terug te dringen Desondanks is de post portikosten die voor rekening van het Ministerie van Financiën komt fors toegenomen. De huisvestingskosten werden voor het grootste deel gedragen door het Ministerie van Volkshuisvesting, Ruimtelijke Ordening en Milieu. In 1984 gaf dit Ministerie ongeveer 58,4 miljoen gulden uit aan huisvestingskosten ten behoeve van de Belastingdienst. Hiervan was 23,1 miljoen voor nieuw-, aan- en verbouw van huisvestingsruimten, 10,3 miljoen werd betaald aan huren en aan onderhoud, terwijl F. 25.000.000 werd besteed aan exploitatie en eerste inrichting. Ten behoeve van de herstructurering van de Belastingdienst verstrekte het Rijk voor de periode 1988-1992 210 miljoen gulden aan de Rijksgebouwendienst. De huisvestingsoperatie die vanaf 1988 in verband met de herstructurering van de Belastingdienst werd doorgevoerd werd voltooid op 1 juli 1992 . Het betrof ongeveer 200 projecten waarmee ongeveer $F$. 650 miljoen gemoeid was. ${ }^{1165}$

Met betrekking tot de perceptiekosten moet tenslotte worden aangetekend dat een gedeelte van de kosten van belastinginning in Nederland niet door de Belastingdienst maar door de burgers wordt gedragen. Werkgevers dragen de in te houden loombelasting en sociale premies af aan de Belastingdienst. Daamaast dragen ondernemers de in rekening gebrachte BTW af. Deze bijkomende kosten van het bedrijfsleven lopen op tot ruim 7 miljard gulden. Volgen wij deze onderzoeken dan kunnen we constateren dat de perceptiekosten gesaldeerd met de bijkomende kosten in Nederland in 1991 circa 9,7 miljard bedragen. ${ }^{1160}$ Andere onderzoekers menen dat deze kosten hoger zijn. Volgens Allers bedragen de kosten voor het bedrijfsleven bijwoorbeeld ongeveer 8 miljard. Daarnaast

\footnotetext{
${ }^{1163}$ Belastingdienst, Jaarverslag over 1990; Den Haag, 1991, p. 17.

1164 Belastingdienst, Jaarverslag over 1991, 1992, Den Haag, p. 50.

${ }^{1165}$ Directoraat-Generaal der Belastingem, Beleidsverslag 1992, Den Haag, april 1993, p. 71.

${ }^{1160}$ Rapport van de Commissie Haks, 1991, p.87
} 
maken burgers kosten doordat zij tijd vrij moeten maken om belastingaanslagen in te vullen en omdat belastingalmanakken moeten worden gekocht en advies moet worden ingewonnen. Al met al kumnen deze kosten becijferd worden op ongeweer 2 miljard gulden. ${ }^{1161}$ Per saldo bedroegen de kosten van de inning van belastingen inclusief de door de Belastingdienst gemaakte kosten in 1994 volgens hem ongeveer 13 miljard gulden.

\subsubsection{De bepaling van de "public enterprise rent"}

De "public enterprise rent" kan mu berekend worden door te bepalen hoe hoog de winst of het verlies van de Belastingdienst gedurende de onderzoeksperiode was. Verder moet worden bepaald hoe groot het eigen vermogen was. De Rjksbelastingdienst functioneert ongeveer net zoals het Rijksmuseum gedurende de onderzoeksperiode. Zij kreeg een budget toegewezen dat door het parlement werd goedgekeurd. Dat betekent dat er dus feitelijk een verlies werd geleden. Zoals aangegeven in tabel 17.8 werd in 1984 door de overheid ongeveer twee miljard gulden betaald ten behoeve van de Belastingdienst.

Naast de kosten zijn er ook opbrengsten. De Belastingdienst verrichtte werkzaamheden waarvoor betaald werd. In Tabel 17.9 zijn de opbrengsten weergegeven. Deze ontvangsten bestaan aan de ene kant uit de aan derden doorberekende kosten en anderzijds uit de niet-bellastingopbrengsten. $\mathrm{Bij}$ deze niet-belastingopbrengsten moet gedacht worden aan administratieve boeten, vervolgingskosten en de heffings- en invorderingsrente. De remte op belastingschulden bestond enerzijds uit de invorderingsrente en anderzijds uit de heffingsrente. De invorderingsrente bedroeg in $1991 \mathrm{~F}, 206,4$ miljoen De ontvangen heffingsrente bedroeg in dat jaar F. 474,5 miljoen. Deze werd tot 1991 gesaldeerd opgenomen in de belastingontvangsten. Tabel 17.9 geeft dan ook een vertekend beeld omdat de ontwangen rente op belastingschulden vanaf 1991 geheel werd meegeteld, terwijl dat voor 1991 niet het geval was. 


\begin{tabular}{|c|c|c|c|c|c|c|}
\hline$\omega_{n}$ & 1987 & 1988 & 1989 & 1990 & 1991 & 1992 \\
\hline $\begin{array}{l}\text { Verkoop } \\
\text { formulieren }\end{array}$ & 2.526 & 2.530 & 1.950 & 1.444 & 1.065 & 1.496 \\
\hline $\begin{array}{l}\text { Geconsigneerdle } \\
\text { gelden }\end{array}$ & 386 & 433 & 1.144 & 672 & 17 & 5.109 \\
\hline Legesgelden & 4.713 & 7.176 & 6.956 & 2.505 & 6.593 & 8.139 \\
\hline $\begin{array}{l}\text { Rente belasting- } \\
\text { schulden }\end{array}$ & 86.349 & 117.799 & 119.232 & 162.268 & $\begin{array}{l}68- \\
0.847^{1162}\end{array}$ & 961.219 \\
\hline $\begin{array}{l}\text { Kosten van ver- } \\
\text { volging }\end{array}$ & 86222 & 88.460 & 86.025 & 70.997 & 78.517 & 102.800 \\
\hline $\begin{array}{l}\text { Boetes en } \\
\text { dergelijke }\end{array}$ & 9.518 & 16.124 & 9.796 & 10.398 & 8.213 & 6.779 \\
\hline $\begin{array}{l}\text { Administratieve } \\
\text { boeten }\end{array}$ & -8 & - & - & - & $\begin{array}{l}190.610 \\
1163\end{array}$ & 167.908 \\
\hline $\begin{array}{l}\text { Ontvangen ver- } \\
\text { goeding } \\
\text { yoot diverse } \\
\text { werkzaamheden } \\
\text { (premieheffing } \\
\text { wolksverzekerin- } \\
\text { gen, OGB, etc.) }\end{array}$ & 350.516 & 322.564 & 369.664 & 370.416 & 431.281 & 490.916 \\
\hline $\begin{array}{l}\text { Bijdragen } E G \text { in } \\
\text { de inningskosten } \\
\text { douane }\end{array}$ & 192.600 & 220.600 & 248.400 & 253.143 & 331.253 & 327.000 \\
\hline Totaal & 732.830 & 775.686 & 843.167 & 871.843 & 1.728 .396 & 2.071 .358 \\
\hline
\end{tabular}

Tabel 17.9 Verschillende Opbrengsten ${ }^{1165}$ ( $x$ duizend)

Verder werden opbrengsten gegenereerd door het rekenen van tarieven voor de werkzaamheden die betrekking hadden op de dwanginvordering van belastingschulden. Deze werden aan de belastingschuldige doorberekend. Tenslotte is ook de post diverse

\footnotetext{
1162 Bij de rente op belastingschulden ging het tot 1991 alleen om de ontvangen invorderingsrente. De heffingsrente werd opgevat als belastingopbrengst. Met ingang van 1991 werten beide beschouwd als belastingopbrengst waardoor deze post aanzienlijk toenam. Daar staat echter tegenover dat de Belastingdienst in 1991810 miljoen gulden aan heffings- en invorderingsrente moest vergoeden.
}

${ }^{1163}$ Met ingang van 1991 zijn de administratieve boeten geboekt als afzonderlijke opbrengstpost. Voorheen werden administratieve boeten gezien als belastingopbrengsten en dus niet als zodanig geboekt als opbrengst.

1164 Vergelijk: Besluit 88/376. EEG, 24 juni 1988, art. 2, lid 3. Toepassing van dit Besluit vond plaats in de verordeningen $\mathrm{nr}$. $1552 / 89$ en $1553 / 89$ van 29 mei 1989 . De Belastingdienst ontving $10 \%$ van de opbrengst van invoerrechten.

1165 Cijfers antleend aan jaarwerslagen over de periode 1980-1992 en de beheers- en produktieverslagen. 
ontwangsten wan belang. ${ }^{166}$ Het gaat hierbif onder meer om de opbrengst wan voor het publiek verkrijgbaar gestelde stukken, legesgelden en geconsigneerde gelden waarvan het recht op uitkering is vervallen. Verder zijn ook administratieve boetes van belang. In Tabel 17.9 is eveneens vermeld wat de opbrengsten uit aan derden doorberekende kosten zijn. Deze opbrengsten moeten voor het berekenen van de "public enterprise rent" op de uitgaven van de Belastingdienst in mindering worden gebracht. De inkomsten van de Belastingdienst bedroegen ongeveer een half miljard gulden.

Zoals bij de analyse van het gebruiksrecht is aangegeven worden de uitgaven en inkomsten van de Rijksbelastingdienst in een begroting geraamd. Deze twee zijn in principe steeds aan elkaar gelijk: De bepaling van het eigen vermogen is moeilijker. Aangezien de Rijksbelastingdienst onderdeel is van het Ministerie van Financiën wordt net als bij het Rijksmuseum in de jaren tachtig geen balans met daarop het eigen vermogen opgesteld. De reden hiervoor is dat de Rijksbelastingdienst geen eigenaar is van de door haar gebruikte activa. Deze activa behoren net als bij het Rijksmuseum toe aan de overheid. Voor het bepalen van de "public enterprise rent" kan de waarde van deze activa echter well als eigen vermogen van de Belastingdienst worden genomen. De reden is dat de Rijksbelastingdienst deze activa gebruikt, waarvoor geld betaald moet worden. Dit geld kan niet op een andere wijze besteed worden, bijvoorbeeid door staatsobligaties te kopen. Het zijn dus alternatieve kosten. Om het eigen vermogen te kumen bepalen moet dan ook de waarde van de door de Rijksbelastingdienst gebruikte gebouwen en grond worden bepaald.

Om de waarde van de gebouwen te kunnen bepalen moet het aantal $\mathrm{m}^{2}$ kantoorruimte en de prijs daarvan in kaart worden gebracht. Deze waarde wordt geraamd met behulp van cijfers uit de Rijkshuisvestingsplannen, de Beheersverslagen en de rijksbegrotingen. De waarde van de kantoomuimte die beheerd wordt door de Rijksgebouwendienst en de waarde van de gebouwen die in gebruik zijn bij de Belastingdienst zijn weergegeven in Tabel 17.10 .

1166 Vergelijk Rijksbegroting 1991, hoofdstuk DXB. 


\begin{tabular}{|c|c|c|c|c|c|}
\hline : & $\begin{array}{l}\text { Onderhoudskosten } \\
\text { per jaar totale } \\
\text { yoorraad RGD } \\
\end{array}$ & $\begin{array}{l}\text { In percentage } \\
\text { vam de ver- } \\
\text { vangings- } \\
\text { waarde van } \\
\text { de voorraad } \\
\end{array}$ & $\begin{array}{l}\text { Waarde totale } \\
\text { voorralad Rijks- } \\
\text { gebouwendienst } \\
\text { in miljarden } \\
\text { guldens (een } \\
\text { gedeelie hiervan } \\
\text { wordt door de Ge- } \\
\text { bouwendienst } \\
\text { gehururd) }\end{array}$ & $\begin{array}{l}\text { Aantal } \mathrm{m}^{2} \\
\text { in gebruik } \\
\text { bij de } \\
\text { Belasting- } \\
\text { dienst } \\
\text { "16s }\end{array}$ & $\begin{array}{l}\text { Waarde eigen } \\
\text { vermogen } \\
\text { Belastingdienst }\end{array}$ \\
\hline 1980 & F. $86,000,000$ & 0,83 & $\begin{array}{l}10,3121 \\
14,85^{1169}\end{array}$ & 780.000 & 1,8711 miljard \\
\hline 1982 & $\mathrm{~F} \quad 1000000,000$ & 0,88 & $\begin{array}{l}11,3631 \\
16,36 \\
\end{array}$ & 770.000 & 2,06 miljard \\
\hline 1984 & F. 132.000 .000 & 1,1 & $\begin{array}{l}12 / \\
17,28\end{array}$ & 800.000 & 2,178 miljard \\
\hline 1986 & F. $125,000,000$ & 0,965 & $\begin{array}{l}12,953 / \\
18,65\end{array}$ & 830.000 & 2,3499 miljard \\
\hline 1988 & F. $86.000 .000,-$ & 0,62 & $13,87 / 20^{1170}$ & $\begin{array}{l}820.000 \\
(=12,6 \%) \\
\end{array}$ & 2,52 miljard \\
\hline 1990 & F. $105,000,000$, & 0,60 & 19,6 & 768.000 & 2,37 miljard \\
\hline 1991 & F 115.000 .000 - & 0,70 & 19,4 & 745,000 & 2,294 miljard \\
\hline 1992 & F. 96.000 .000 ,- & 0,8 & 19,2 & $\begin{array}{l}707.000 \\
(=11,3 \%)\end{array}$ & 2,172 miljard \\
\hline 1993 & F. 90.000 .000 & 0,8 & 19 & $\begin{array}{l}695.000= \\
(11.2 \%)\end{array}$ & 2,128 milljard \\
\hline
\end{tabular}

Tabel 17.10 De waarde van de kantoorruimte die in gebruik is bij de Belastingdienst $^{171}$

Op landelijk niveau neemt de totale behoefte aan kantoorruimte door de diverse Ministeries af. Dit houdt verband met de inkrimping van de omvang van het overheidspersoneel. Bovendien werd begin jaren "90 door de politiek geprobeerd het gebruik van kantoorruimte terug te dringen. Dit probeerde zij te realiseren door het invoeren van een Normeringsnota in 1992 en door het voeren van een reductiebeleid van $10 \%$ per werknemer. Het was

1167 Van de kantoormimte van 6.5 miljoen $\mathrm{m}^{2}$ die de RGD beheerde in 1988 is $85 \%$ eigendom en wordit 15\% gehuurd. In 1993 beheerde de RGD ongeveer 3.800 gebouwen met een bruto vloeroppervlakte van 6,2 miljoen $\mathrm{m}^{2}$. Hiervan was $75 \%$ in eigendom, $19 \%$ gehuurd en $6 \%$ geleased.

1168 Schatting gebaseerd op gegevens in het Rijkshuisvestingsplan.

${ }^{1169}$ Het tweede bedrag is de waarde van de voorraad inclusief de grond.

${ }^{1170}$ Inclusief grond en BTW. Vergelijk: Tweede Kamer, vergaderjaar 1988-1989, 20891, ars 1-4, p. 38 .

1171 Bron: Tweede Kamer der Staten-Generaal (vergaderjaar 1988-1989), 20891, nrs. 1-4, Rijkshuiswestingsplan, pp. 10 e.v., het Meerjarenprogramma (MPR) 1989-1993, en Tweede Kamer der Staten-Generaal (vergaderjaar 1992-1993), 20891, nr. 8, Rijkshuiswestingsplan 2. 
de bedoeling dat de totale kosten voor de beschikbare ruimte per ambtenaar met $10 \%$ zou afnemen. ${ }^{1172}$ In het Rijkshuisvestingsplan 2 werd geconstateerd dat de totale kosten waren afgenomen met $5 \%$. Er waren namelijk ook opwaartse kosteneffecten die veroorzaakt werden door het toegenomen ruintegebruik ten gevolge van deeltijdarbeid en de voorbeeldfunctie van het Rijk. Bovendien ontstond er steeds meer behoefte aan andere, dat wil zeggen betere of elders gevestigde, huisvesting. Eind jaren " 80 werkten het Ministerie van Financiën en de RGD samen aan het nader invullen van dit landelijke beeld. Bij de Belastingdienst hadden vooral de reorganisatie begin jaren " 90 en de afslanking van het personeelsbestand grote gevolgen. De Belastingdienst bestond uit 260 lokale eenheden. Daarbij moet gedacht worden aan ontvangkantoren voor de invorderingtaken, inspecties voor de heffingstaken en aan bureaus voor de Rijksaccountantsdienst. De Bellastingdienst inclusief de douane was gevestigd op ongeveer 400 adressen. Door de reorganisatie werd het aantal organisatorische eenheden teruggebracht tot ongeveer 92 . Om dit te realiseren was een omvangrijke huisvestingsoperatie noodzakelijk Deze werd in een drietal fasen uitgevoerd in respectievelijk 1989, 1990 en 1991. Op grond van de Normeringsnota kan worden geschat dat per werknemer binnen de Belastingdienst gemiddeld circa $23,75 \cdot \mathrm{m}^{2}$ bruto: vloeroppervlakte beschikbaar is (of circa $13,5 \mathrm{~m}^{2}$ functioneel muttige oppervlakte) ${ }^{1173}$ Daarbij dient wel bedacht te worden dat door allerlei factoren vaak maar gedeeltelijk aan de norm voldaan wordt. Dit komt vooral omdat de Belastingdienst een organisatie is die steeds onderhevig is aan verandering en die moet reageren op allerlei ontwikkelingen. Bovendien leidt een vermindering van personeel slechts op wat langere termijn tot een reductie van het bruto vloeroppervlak. Aangezien de Belastingdienst niet aangeeft hoeveel vloeroppervlak jaarlijks in gebruik is, wordt gebruik gemaakt van een schatting met behulp van de normen voor vloergebruik, gerelateerd aan de personeelsomvang. In 1988 lag het gebruikte vloeroppervlakte per werknemer dan ook circa $10 \%$ hoger $\left(26,10\right.$ bvo resp $\left.14,8 \mathrm{~m}^{2}\right)$. Dat de Belastingdienst in 1992 minder kantoorruimte gebruikte dan in 1988 kwam niet alleen door de 10\%-operatie en de reorganisatie maar ook door de aandacht die het Projectbureau huisvesting begin jaren ' 90 besteedde aan een efficiënter gebruik van de beschikbare kantoorruimte. ${ }^{1174}$ Eên van de mogelijke oplossingen werd gezocht in het gebruik van gecombineerde werkplekken. Ondanks de reductie in gebruikte kantoormimte verminderden de huisvestingskosten echter niet. Dit kwam voor een belangrijk deel door de reorganisatie-ontwikkelingen. Daarnaast werd in het algemeen de opwaartse druk bij de huisvestingskosten ten gevolge van de maatschappelijke ontwikkelingen en de voorbeeldfunctie van het Rijk geschat op $5 \%$ in de periode 1988-1992. De huisvestingskosten voor het Rijk bedroegen in 1991 jaarlijks gemiddeld $\mathrm{F}, 356,-$ per $\mathrm{m}^{2}$ en $\mathrm{F} .11 .200$,- per formatieplaats.

Ten behoeve van het Rijkshuisvestingsplan 2 is een inventarisatie gehouden van de ruimtebehoefte en het -aanbod bij onder meer de Belastingdienst. Uit onderzoek bleek dat bepaalde sectoren binnen de Belastingdienst te maken hadden met ruimtegebrek, terwijl andere sectoren juist te maken hadden met werkplekken die niet of nauwelijks gebruikt werden. Illustratief is een onderzoek naar het Central Belastinggebouw te Amersfoort

${ }^{1172}$ Tweede Kamer, vergaderjaar 1992-1993, 20891, nrs. 7-8, Riikshuisvestingsplan 2, p. 7.

${ }^{1173}$ Rijksgebouwendienst, Directie Advisering \& Onderzoek, Ministerie van Volksgezondheid, Ruimtelijke Ordening en Milieu, Normeringsnota, 1992. Vergelijk ook: K.T.H. Nelissen, Flexibel m² gebruik binnen de Belastingdienst, afstudeerscriptie, Hogeschool Holland, studierichting Management. Facillitaire Dienst, 1993, hoofdstuk 2 en 3 .

1174 Vergelijk in dit verband bijvoorbeeld: Belastingdienst, Projectbureau huisvesting, Facility management; inwoering bil de Belastingdienst, 1993. 
waaruit bleek dat bepaalde teams geconfronteerd werden met gebrek aan kantoormuimte terwijl andere juist te maken hadden met nauwelijks gebruikte werkplekken. ${ }^{1175}$ Vooral de bezettingsgraden van deurwaarders, veldwerkers en deeltijdwerkers waren relatief laag. Binnen de Belastingdienst ging het daarbij om ruim 9.000 personen. Ook bij de douane bleek dat zich in een aantal regio's tekorten voordeden, terwijl andere regio's juist geconfronteerd werden met overschotten. Dat in Tabel 17.10 het onderhoudsbudget begin jaren ' 90 nauwelijks toenam, terwijl het percentage van de wervangingswaarde wel steeg heeft vooral te maken met de situatie waarin de Nederlandse vastgoedmarkt verkeerde, Eind 1992 bedroeg de leegstand in de kantorensector ongeweer 3 miljoen $\mathrm{m}^{2}$. In 1991 daalde bovendien het transactievolume op de kantorenmarkt van $700.000 \mathrm{~m}^{2}$ tot 560.000 $\mathrm{m}^{2}$, terwijl zich in 1992 een verdere daling voordeed. Ook de vraag naar grotere pandem liep terug. Zo daalde de omzet in projecten groter dan $5.000 \mathrm{~m}^{2}$ met ongeveer $50 \%$. Met behulp van de gegevens over de waarde van de totale voorraad van de RGD en over het aantal $\mathrm{m}^{2}$ dat in gebruik was bij de Belastingdienst kan verwolgens de waarde van het eigen vermogen worden bepaald.

Met deze informatie over het eigen vermogen en de winst en met de gegevens over het rendement op staatsobligaties uit de vorige twee hoofdstukken kan de "public enterprise rent" bepaald worden. De berekening hiervan na 1981 is weergegeven in Tabel 17.11.

\begin{tabular}{|l|l|l|l|l||}
\hline Jaar & $\begin{array}{l}\text { Rendement op } \\
\text { staatsobligaties }\end{array}$ & $\begin{array}{l}\text { Verlies van de } \\
\text { Rijksbelasting- } \\
\text { dienst }\end{array}$ & $\begin{array}{l}\text { Eigen vermogen aan } \\
\text { het einde van het } \\
\text { jaar }\end{array}$ & $\begin{array}{l}\text { "Public enterprise } \\
\text { rent" }\end{array}$ \\
\hline 1980 & $10,21 \%$ & 1.259 .169 & 1,8711 miljard & 1.450 .208 \\
\hline 1981 & $11,56 \%$ & 1.274 .021 & 1,958 miljard & 1.500 .365 \\
\hline 1982 & $10,08 \%$ & 1.347 .557 & 2,06 miljard & 1.555 .205 \\
\hline 1983 & $8,61 \%$ & 1.421 .692 & 2,128 miljard & 1.604 .912 \\
\hline 1984 & $8,16 \%$ & 1.416 .760 & 2,178 miljard & 1.594 .484 \\
\hline 1985 & $7,34 \%$ & 1.396 .225 & 2,347 miljard & 1.568 .494 \\
\hline 1986 & $6,35 \%$ & 1.472 .077 & 2,345 miljard & 1.620 .984 \\
\hline 1987 & $6,39 \%$ & 1.580 .995 & 2,445 miljard & 1.737 .235 \\
\hline
\end{tabular}

1175 Nelissen (1993, inleiding). 


\begin{tabular}{|l|l|l|l|l|}
\hline Jaar & $\begin{array}{l}\text { Rendemem op } \\
\text { staatsobligaties }\end{array}$ & $\begin{array}{l}\text { Verlies van de } \\
\text { Rijksbelasting- } \\
\text { dienst }\end{array}$ & $\begin{array}{l}\text { Eigen vermogen aan } \\
\text { het einde van het } \\
\text { jaar }\end{array}$ & $\begin{array}{l}\text { "Public enterprise } \\
\text { rent }\end{array}$ \\
\hline 1988 & $6,35 \%$ & 1.572 .276 & 2,52 miljard & 1.732 .296 \\
\hline 1989 & $7,21 \%$ & $1.599,532$ & 2,475 miljard & 1.777 .979 \\
\hline 1990 & $8,93 \%$ & 1.745 .877 & 2,37 miljard & 1.957 .518 \\
\hline 1991 & $8.74 \%$ & 1.588 .970 & 2,294 miljard & 1.789 .465 \\
\hline 199 & 8,1 & 1.537 .982 & 2,172 miljard & 1.713 .914 \\
\hline
\end{tabular}

F. 1.000,-

Tabel 17.11 De "public enterprise rent"

Uit Tabel 17.11 blijkt dat de "public enterprise rent" eind jaren ' 80 ongeveer twee miljard gulden bedroeg. Begin jaren 90 nam deze duidelijk af.

\subsection{Wat is het relatieve belang van de doelen}

\subsubsection{Een analyse van de ontwikkeling van de accountantsdiensten}

De verantwoording van de Belastingdienst werd gecontroleerd door de Interne Accountantsdienst Belastingen (IAB) en de Departementale Accountantsdienst Financièn (DAF). Bij de financiële verantwoording was allereerst de accountantsverklaring van de Interne Accountantsdienst van de Belastingdienst van belang. De interne accountantsdienst van de Belastingdienst draagt op grond van het Besluit Taak Departementale Accountantsdienst zorg voor de controle op de financiele verantwoording van de Belastingdienst (interne controle) en valt rechtstreeks onder de Directeur-Generaal. Dit gebeurt binnen het kader van de accountantscontrole van het hele Ministerie van Financiën. In 1985 werden Regionale Interne Accountantsdiensten (RIA's) ingesteld, die onderdeel uitmaakten van de regionale directies. De RIA's verrichten onderzoeken bij de eenheden van de Belastingdienst, naar de inkomsten- en uitgavenstroom. De Interne Accountantsdienst Rijksbelastingen zorgde voor de coórdinatie van deze instellingen. Doel van deze regionale instellingen was om vanaf 1990 overeenkomstig het Actieplan Accountantscontrole 1986 1990 bij de financiele verantwoording een accountantsverklaring voor de gehele Belastingdienst te kunnen afgeven. 1178 Er kwam echter nogal wat kritiek op de hierarchische structuur van de RIA's (als onderdeel van de regionale directies) door onder andere de Algemene Rekenkamer en de Vaste Commissie voor Financiên van de Tweede Kamer. Reden waarom de RIA's dan ook werden samengevoegd tót eén dienst onder leiding van de directeur van de Interne Accountantsdienst Belastingen, die weer direct onder de Directeur-Generaal der Belastingen valt. De Interne Accountantsdienst gaf over 1988 voor het eerst een goedkeurende accountantsverklaring af over de uitgavensitroom. Aangezien

1176 Voor 1987 gedeeltelijk gebaseerd op schattingen op grond van jaarverslagen.

117 De uitgaven en de ontvangsten vanaf 1991 zijn op dezelfde madier berekend als voor 1991.

1178 Belastingdienst, Actieplan Accountaniscomtrole 1986-1990, Den Haag, 1985. 
de Belastingdienst een herstructurering doorvoerde probeerde de Accountantsdienst enerzijds haar organisatie hier zo goed mogelijk op af te stemmen en anderzijds zich constructief op te stellen door rekening te houden met deze reorganisatie. De heffende eenheden waren nog niet aan accountantscontrole onderworpen, waardoor nog geen volledig oordeel over de ontvangstenstroom kon worden gegeven. In 1990 vond voor het eerst een volkomen accountantscontrole plaats. Dit leidde ertoe dat de Interne Accountantsdienst een goedkeurende verklaring aflegde bij de financiële verantwoording van de Belastingdienst. De Interne Accountantsdienst speelde dan ook een belangrijke rol in thet yerantwoordingsproces. In het Beheersverslag over 1991 werd opgemerkt: "Norm voor de inspanningen is dat verantwoorden geen doel op zich kan zijn, maar aantoonbaar moet bijdragen aan het beter laten functioneren van de Belastingdienst als geheel ${ }^{\text {in }}{ }^{1179} \mathrm{De}$ bevindingen van de interne Accountantsdienst worden voor zover relevant opgenomen in halfjaarlijkse managementletters aan de Directeur-Generaal der Belastingen en aan de orde gesteld in het Audit Committee Belastingdienst. ${ }^{180}$ Begin jaren '90 kreeg de Interne Accountantsdienst, overeenkomstig het Besluit Taak Departementale Accountantsdienst, naast de controletaak ook steeds meer een adviserende taak. Verder werd begin jaren ' 90 gewerkt aan het versterken van het administratieve organisatie/interne controle (AO/IC) op de eenheden. Alle eenheden moeten beschikken over een handboek $\mathrm{AO} / \mathrm{IC}$, dat regelmatig geactualiseerd moet worden. Verder voeren de meeste doelgroepdirecties AO/IC-audits uit. In samenwerking met de Interne Accountantsdienst Belastingen (IAB) is in die zin gewerkt aan het verder verbeteren van de interne controle waardoor een betrouwbare financiële verantwoording gegarandeerd moet zijn. Het systeem van de bestuurlijke informatievoorziening is verder verbeterd door onder andere het bevorderen van de deskundigheid, het vaststellen van standaardrapportages en het gebruik van kengetallen.

Ook werd vanaf 1991, overeenkomstig het verzoek van de Algemene Rekenkamer, steeds meer inzicht gegeven in de uitgevoerde beleidsondersteunende en evaluerende onderzoeken Naast de controle door de Interne Accountantsdienst Belastingen (IAB) vond voortvloeiend uit het Besluit Taak Departementale Accountantsdienst ook controle plaats door de Departementale Accountantsdienst Financiën. De controle richt zich voornamelijk op de controle van de financiële verantwoording. De aanpak die door de accountantsdiensten wordt gevolgd is vastgelegd in accountantscontroleprogramma's die elk halfjaar worden geëvalueerd.

Uit de ontwikkeling in de structuur van de interne accountantscontrole kan worden afgeleid dat de controle op de imput steeds meer vervangen werd door een controle op de output. Daartoe was het belangrijk dat de accountantsdienst ook daadwerkelijk elk jaar aangeeft of de door de Belastingdienst gepresenteerde cijfers betrouwbaar zijn. Duidelijk is voorts dat de controle achteraf belangrijker wordt. Voorheen was het van te voren duidelijk wat er ging gebeuren. De accountantsdienst bekeek dan ook voornamelijk of de Belastingdienst zich hieraan had gehouden. Begin jaren negentig krijgt de Belastingdienst steeds meer vrijheid om zelf yorm te geven aan de productie. Een betere controle is dan voor de principalen noodzakelijk.

1179 Directoraat-Generaal der Belastingen, Behersverslag Belastingdienst 1991, Den Haag, 1992, voorwoord.

${ }^{1.380}$ Directoraat-Generaal der Belastingen, Beleidsverslag over 1992, Den Haag, april 1993, p. 10. 
17.12.2 Een analyse van de expliciete beleidswijzigingen en verschuivingen in doelen tussen verschillende actoren

\section{0-1985}

Begin jaren " 80 vond er een herbezinning plaats door de Belastingdienst over de effectiviteit en de doelmatigheid van haar taakuitoefening. De herbezinning had betrekking op het gehele functioneren van de Belastingdienst. Niet alleen werd gekeken naar bijvoorbeeld de aanslagregeling, de controle, de invordering en de voorlichting maar ook de bestuursstijl, de procedures en de communicatie werden bezien. Beseft werd dat nieuwe werkmethoden nodig waren om de doelen te kunnen realiseren. Overeenkomstig het plan fraudebestrijding bleken een drietal doelstellingen te worden benadrukt. Er moest meer nadruk worden gelegd op de fraudebestrijding, de invordering en de dienstverlening. In het jaarverslag over 1983 werd opgemerkt: "Gestreefd zal moeten worden naar een accentverschuiving van aanslagregeling naar controle, intensivering van invordering, voorlichting en hulpverlening, stroomlijning van de administratieve processen door het installeren van kantoorautomatiseringsapparatuur en meer interne en externe samenwerking ". ${ }_{1181}$ Omdat de pakkans onvoldoende werd geacht werd vooral aan de fraudebestrijding grotere prioriteit toegekend. Er werd in dit verband intensief samengewerkt met andere opsporingsorganen. Daarnaast probeerde de Belastingdienst de efficiëntie te verbeteren door middel van automatisering. Hiervoor werden in het investerings- en personeelsplan 19831987 extra middelen uitgetrokken.

\section{$\underline{1985-1990}$}

Ook in de tweede helft van de jaren '80 werd intensief gewerkt aan het verbeteren van de wijze van functioneren van de Belastingdienst. Enerzijds werd steeds verder automatisering doorgevoerd, terwijl anderzijds meer nadruk kwam te liggen op de heffing, invordering en vooral de controle. Om de effectiviteit te vergroten werd in 1987 begonnen met een omvangrijke reorganisatie. Beoogd werd de organisatie meer in te richten naar duidelijk te onderscheiden groepen van belastingplichtigen. In het jaarverslag over 1986 werd opgemerkt: "Een andere structuur wordt ook noodzakelijk geoordeeld opdat de Belastingdienst goed toegenust een aantal maatschappelijke ontwikkelingen tegemoet kan treden, zoals de roep om betere bestrijding van de belastingfraude en het toenemend beroep op individuele rechisbescherming ". "1182 Belangrijk was ook de operatie-Oort. De Commissie tot vereenvoudiging van de loon- en inkomstenbelasting (commissie-Oort) presenteerde in 1986 ingrijpende voorstellen om het aantal schijven te beperken en het aantal aftrekposten te verminderen. Een andere belangrijke wijziging was dat vanaf het midden van de jaren ' 80 de Belastingdienst haar personeelsbestand geleidelijk en beperkt moest inkrimpen. Dit werd opgevangen door verdere efficiëntieverbetering. De grotere nadruk op de controle leidde er ook toe dat het bedrag aan niet-inbare belasting- en premieschulden daalde. In 1988 daalde dit bijvoorbeeld met $25 \%$ tot 1,4 miljard gulden.

1990-1992

Gedurende de jaren 1990-1992 had de Belastingdienst te maken met een groot aantal veranderingen zoals de inwoering van de Oort-wetgeving in 1990 (loonbelasting) en 1991 (inkomstenbelasting) en de herstructurering van de Belastingdienst. Het onderzoek Her-

119.1 Belastingdienst, Jaarwerslag over 1983, Den Haag, 1984, p. 17.

1182 Belastingdienst, Jaarverslag over 1986, Den Haag, 1987, p. 9. 
structurering Belastingdienst constateerde zoals opgemerkt dat de productie voldoende gewaarborgd kon worden om de opbrengsiten te garanderen. Wel deden zich een aantall knelpunten voor. De formatie was eind jaren ' 80 geleidelijk afgeslankt en de opleidingscapaciteit werd onvoldoende geacht om medewerkers snel te kunnen opleiden. Uit onderzoek naar de personeelsformatie moest blijken of een herschikking van personeel nodig was. Ook het budget voor automatisering werd onvoldoende geacht om de herstructuring te ondersteunen. Derhalve werden extra middelen ter beschikking gesteld. Het doel van de herstructurering was vooral het zorgen voor een betere dienstverlening aan het publiek en het verhogen van de effectiviteit. Beoogd werd verder door de herstructurering de controle en fraudebestrijding effectiever te maken. In het Beheersverslag over 1991 werd opgement: "De Belastingdienst beoogt met de herstructurering op een structurele wijze invulling te geven aan de wens tot het verhogen van de effectiviteit en efficiency van de vitvoering van de opgedragen taken op de gebieden heffing, controle en inning". "1183 In het Beheersverslag 1992 werd verder opgemerkt: "Beleidsmatig heeft in 1992 de intensivering wan de bestrijding wan misbruik en oneigenlijk gebruik van fiscale regels een belangrijk aandachtspunt gevormd ${ }^{m}$. ${ }^{184}$. Verder werd met de herstructurering beoogd de Belastingdienst flexibeler te maken, zodat sneller op veranderingen, bijvoorbeeld in Europees verband kon worden ingespeeld. Tenslotte werd het doel van de "compliance" als hoofddoelstelling genoemd. ${ }^{1185}$ De gedachte van deze doelstelling was dat door het bevorderen van de "compliance" de fraude zou worden verminderd.

\section{Na 1991}

$\mathrm{Na}$ de afronding van de herstructurering van de Belastingdienst werd de nadruk gelegd op de vernieuwing van processen binnen de Belastingdienst en anderzijds op het veranderen van de organisatiecultuur. Deze vernieuwing van processen had vooral betrekking op het vernieuwen van de "klantbehandeling". In dit verband wordt gewezen op het belang van het tijdig afhandelen van bezwaarschriften. De Belastingdienst probeert dit te bereiken door meer in de "actualiteit te werken". Dit tracht de dienst te bereiken door de heffing en inning van belastingen nauwer te laten aansluiten op het moment waarop het belastbare feit zich voordoet en op de fiscal relevante situatie van de belastingplichtige. Dit leidt ook tot een verstrakking van het uitstelbeleid. Verder moet de kwaliteit van de controle en heffing hierdoor worden verbeterd, waardoor misbruik en oneigenlijk gebruik worden teruggedrongen. Het veranderen van de organisatiecultuur tenslotte beoogt het verbeteren van de dienstverlening an het publiek Door deze verbetering van de dienstverlening moet de "compliance" toenemen

\footnotetext{
1183 Directoraat-generaal der Belastingen, Beheersverslag Belastingdienst 1991, Dem Haag, 1992, p. 5.

1184 Directoraat-Generaal der Belastingen, Directie Planning, Financiën en Control, Beheersverslag Belastingdienst 1992. Den Haag, april 1993, voorwoord.

${ }^{1185}$ Directoraat-Generaal der Belastingen, Beheersverslag Belastingdienst 1991, Den Haag, 29 april 1992, p. 15.

${ }^{1186}$ Directoraat-Generaal der Belastingen, Bedriffsplan Belastingdienst 1993-1997, bij brief nr. PFC92/673 op 4 juni 1992 aangeboden aan de Tweede Kamer.
} 
17.12.3 Analyse van impliciete beleidswijzigingen die niet publiekelijk werden bediscussieerd

Een eerste indruk van een impliciete beleidswijziging kan verkregen worden door te kijken naar de ontwikkeling van het bedrag dat elk jaar wordt kwijtgescholden of oninbaar is.

\begin{tabular}{|l|l|l|l|}
\hline jaar & $\begin{array}{l}\text { Kwijtgescholden en } \\
\text { oninbare belastingen } \\
\text { (in duizenden guldens) }\end{array}$ & $\begin{array}{l}\text { Belastingopbrengst } \\
\text { (in miljoenen } \\
\text { guldens) }\end{array}$ & $\begin{array}{l}\text { Kwijtgescholden en } \\
\text { oninbare belasting in } \\
\text { percentage van de be- } \\
\text { lastingopbrengst }\end{array}$ \\
\hline 1980 & 1.163 .134 & 127.211 & $0,91 \%$ \\
\hline 1982 & 2.929 .382 & 136.934 & $2,14 \%$ \\
\hline 1984 & 2.650 .957 & 149.299 & $1,78 \%$ \\
\hline 1986 & 2.338 .554 & 163.368 & $1,43 \%$ \\
\hline 1987 & 1.950 .673 & 172.819 & $1,13 \%$ \\
\hline 1988 & 1.553 .637 & 179.637 & $0,86 \%$ \\
\hline 1989 & 1.634 .186 & 179.362 & $0,91 \%$ \\
\hline 1990 & 1.195 .610 & 186.919 & 0,64 \\
\hline 1991 & 981.630 & 209.948 & $0,47 \%$ \\
\hline 1992 & 1.527 .850 & 213.761 & $0,71 \%$ \\
\hline \hline
\end{tabular}

Tabel $17.12 \mathrm{Kw}$ wijgescholden en oninbare bedragen als percentage van de belastingopbrengst

Door het kwijtschelden en het oninbaar lijden van belastingen hoeven de betreffende belastingplichtigen minder belasting te betalen. Het doel van het verdelen van inkomen wordt evenwel miet benadrukt door de Belastingdienst. Toch zijn hier grote bedragen mee gemoeid. In de jaren tachtig namen deze bedragen aanzienlijk toe, hetgeen zoals opgemerkt ook te maken had met de moeilijke economische situatie. Uit Tabel 17.12 blijkt dat het bedrag aan kwijtschelding en oninbare belastingen niet alleen in absolute bedragen maar ook afgezet tegen de belastingopbrengst aanzienlijk afneemt. Dit weerspiegelt de verandering in de doelstellingen van de Belastingdienst. Minder nadruk werd gelegd op het doel van verdeling van inkomen en meer op het bereiken van meer efficiëntie.

Naast de oninbare en kwijtgescholden bedragen blijkt ook uit de ontwikkeling van de achterstanden bij de invordering een impliciete beleidsverandering. 


\begin{tabular}{|l|l|l|l|}
\hline jaar & $\begin{array}{l}\text { Achterstanden } \\
\text { bij de invorde- } \\
\text { ring (in miljoe- } \\
\text { nen guldens) }\end{array}$ & $\begin{array}{l}\text { Belastingop- } \\
\text { brengst } \\
\text { (in miljoenen } \\
\text { guldens) }\end{array}$ & $\begin{array}{l}\text { Achterstanden bij de } \\
\text { invordering in percen- } \\
\text { tage van de belasting- } \\
\text { opbrengst }\end{array}$ \\
\hline 1981 & 15.862 & 130.173 & $12,2 \%$ \\
\hline 1983 & 15.963 & 143.223 & $11,1 \%$ \\
\hline 1985 & 16.420 & 154,481 & $10,6 \%$ \\
\hline 1986 & 16.272 & 163.368 & $9,9 \%$ \\
\hline 1987 & 15.001 & 172.819 & $8,7 \%$ \\
\hline 1988 & 15.226 & 179.637 & $8,5 \%$ \\
\hline 1989 & 15.140 & 179.362 & $8,4 \%$ \\
\hline 1990 & 14.346 & 186.919 & $7,7 \%$ \\
\hline 1991 & 14.128 & 209.948 & $6,7 \%$ \\
\hline 1992 & 14.504 & 213.761 & $6,8 \%$ \\
\hline
\end{tabular}

Tabel 17.13 Achterstanden in de invordering uitgedrukt als percentage van de belastingopbrengsten

Terwijl de belastingopbrengsten gedurende deze periode stegen, daalden de achterstanden in de invordering aanzienlijk. Ging het begin jaren tachtig uitgedrukt in percentage van de belastingopbrengst nog om ruim $12 \%$ van de belastingopbrengst, in 1992 was dat gedaald tot bijna $7 \%$. Deze daling was vooral het gevolg van een aantal maatregelen waaronder de invoering van de nieuwe Invorderingswet 1990 op 1 juni 1990 . Deze verving de Wet op de invordering van "s Rijks directe belastingen van 1845 en de invorderingsbepalingen in de verschillende heffingswetten. Tegelijk met de nieuwe Invorderingswet trad de Leidraad Invordering 1990 in werking. Behouden blewen het voorrangsrecht, dat een belastingvordering heeft boven andere schuldeisers, en het bodemrecht, inhoudende dat de ontvanger van de Belastingdienst zich onder bepaalde voorwaarden kan verhalen op goederen van derden die zich bij de belastingschuldige bevinden. Belangrijkste veranderingen waren de versterking van de positie van de belastingplichtige, de vergroting van de doelmatigheid en versterking van de positie van de ontvanger. ${ }^{1187}$

Eén en ander weerspiegelt de impliciete wijziging van het belang van het doel van de herverdeling. De achterstanden bij de invordering werden teruggebracht. De mogelijkheden om uitstel toe te kennen werden verminderd.

Een indruk van een andere impliciete verschuiving kan verkregen worden door de "public enterprise rent" van de Belastingdienst te vergelijken met de ontwikkeling van het nationale inkomen en meer specifiek met de belastingopbrengst.

${ }^{1187}$ Directoraat-Generaal der Belastingen, Beheerswerslag Belastingdienst 1991, Den Haag, 29 april 1992, p. 40 . 


\begin{tabular}{|l|l|l|l|l|l|l|l|}
\hline & 1982 & 1984 & 1986 & 1988 & 1990 & 1991 & 1992 \\
\hline $\begin{array}{l}\text { Netto nationaal } \\
\text { inkomen }\end{array}$ & 330,62 & 358,56 & 385,44 & 401,2 & 452,45 & 478,05 & 498,4 \\
\hline $\begin{array}{l}\text { "Public enter- } \\
\text { prise rent" van } \\
\text { de belasting- } \\
\text { dienst (in } \\
\text { NNI) }\end{array}$ & $0,47 \%$ & $0,44 \%$ & $0,42 \%$ & $0,43 \%$ & $0,43 \%$ & $0,37 \%$ & $0,34 \%$ \\
\hline $\begin{array}{l}\text { "Public enter- } \\
\text { prise rent" van } \\
\text { de Belasting- } \\
\text { dienst uitge- } \\
\text { drukt in belas- } \\
\text { tingopbrengst }\end{array}$ & $1,14 \%$ & $1,04 \%$ & $0,99 \%$ & $0,93 \%$ & $1,04 \%$ & $0,85 \%$ & $0,80 \%$ \\
\hline
\end{tabular}

\section{Tabel 17.14 De "public enterprise rent" en het netto nationaal inkomen ${ }^{1189}$}

Uit Tabel $17.14 \mathrm{kan}$ worden afgeleid dat de "public enterprise rent" uitgedrukt als percentage van het netto nationaal inkomen in de jaren tachtig een lichte daling vertoont. Gedurende het begin van de jaren negentig treedt een forse daling op. Dit geldt ook voor de "public enterprise rent" uitgedrukt in percentage van de belastingopbrengst. Blijkbaar worden aan de bijkomende doelen van de Belastingdienst minder middelen besteed. Om welk doel gaat het dan vooral? Het belangrijkste bijkomende doel van de Belastingdienst is het zorgen voor een rechtvaardige uitvoering van wetgeving. Aan dit doel zijn minder middelen besteed. Een impliciete beleidswijziging is dat minder belang werd toegekend aan dit bijkomende doel. Dit had waarschijnlijk echter ook te maken met de operatie-Oort waardoor minder aan dit bijkomende doel hoefde te worden besteed.

\subsubsection{De mate waarin activiteiten niet worden bediscussieerd maar wel gewoon worden uitgevoerd}

Opvallend is dat de overige belastingontvangsten van de Belastingdienst sterk toenemen. Het gaat daarbij bijvoorbeeld om rente op belastingschulden, bijdragen van de E.G. in de inningskosten van de douane en de kosten van vervolging. Zonder dat hierop in de jaarverslagen en Beheersverslagen nadrukkelijk wordt ingegaan nemen dit soort ontvangsten begin jaren " 90 aanzienlijk toe. In 1987 ging het daarbij nog om ruim 700 miljoen gulden, terwijl dit bedrag in 1992 was opgelopen tot bijna 1,4 miljard gulden. Eén en ander is in Tabel 17.15 weergegeven:

11189 De "Public enterprise rent" is berekend overeenkomstig de periode voor 1991 , Vergelijk tabel 18.21 .

1189 Bedragen zijn afgerond. 


\begin{tabular}{|l|l|l|l|}
\hline Jaar & $\begin{array}{l}\text { Ontvangsten van de Be- } \\
\text { lastingdienst in duizenden } \\
\text { guldens }\end{array}$ & $\begin{array}{l}\text { Belastingop- } \\
\text { brengsten in } \\
\text { miljoenen gul- } \\
\text { dens }\end{array}$ & $\begin{array}{l}\text { Ontvangsten Belas- } \\
\text { tingdienst in \% } \\
\text { belastingopbrengst }\end{array}$ \\
\hline 1987 & 732.830 & 172.819 & $0,42 \%$ \\
\hline 1988 & 775.686 & 179.637 & $0,43 \%$ \\
\hline 1989 & 843.167 & 179.362 & $0,47 \%$ \\
\hline 1990 & 871.843 & 186.919 & $0,47 \%$ \\
\hline 1991 & 1.267 .410 & 209.948 & $0,6 \%$ \\
\hline 1992 & 1.388 .239 & 213.761 & $0,65 \%$ \\
\hline
\end{tabular}

Tabel 17.15 De ontwikkeling van de inkomsten van de Belastingdienst

Uit Tabel 17.15 blijkt dat niet alleen de ontvangsten toenemen maar ook de ontvangsten uitgedrukt als percentage van de geïnde belastingen. Deze ontwikkeling werd in beleidsverslagen en begrotingen feitelijk niet bediscussieerd maar werd wel gewoon doorgevoerd. Het is blijkbaar de bedoeling om de Belastingdienst meer kostendekkend te maken.

Een tweede activiteit die gewoon wordt uitgevoerd en waar weinig over wordt gediscussieerd is de eerlijke uitvoering van de belastingwetgeving. Hoewel de Belastingdienst dit doel niet expliciet noemt, geeft zij wel veelvuldig aan dat een eerlijke uitvoering van de fiscale wetgeving voor haar essentieel is. Dit blijkt ook uit het overzicht van de doelen zoals dat gegeven is in paragraaf 17:10. Veel van deze doelen hebben indirect ten doel de burgers te beschermen tegen willekeur. In dit verband huldigt de Belastingdienst het principe dat iedere burger gelijk is voor de wet.

\subsubsection{Conclusie ten aanzien van het relatief belang van de doelen}

Gedurende de onderzoeksperiode wordt het bevorderen van de "compliance" steeds belangrijker. Dit komt omdat de belastingen in de jaren ' 80 erg hoog zijn met hoge "excess burdens". Bovendien verslechtert de belastingmoraal. Dit leidt ertoe dat de nadruk komt te liggen op de realisatie van belastingontvangsten. Daarnaast verandert het relatief belang van de controle achteraf van overtredingen. Meer nadruk wordt gelegd op preventie. Verder valt op dat de "public enterprise rent" begin jaren negentig afneemt. Ook het doel wan de verdeling van inkomen wordt duidelijk minder belangrijk. Verder blijkt de Belastingdienst steeds meer kostendekkend te gaan opereren.

\subsection{Het vaststellen van de "performance" in termen van baten en kosten}

\subsubsection{De "performance" van de Belastingdienst}

In paragraaf 17.10 zijn een groot aantal doelen aan de orde gekomen die worden genoemd door de Belastingdienst en de Staten-Generaal. Deze doelen kunnen gedeeltelijk tot het eigenlijke doel van de Belastingdienst, namelijk de inning van belastinggelden, gerekend worden. Een aantal van de vermelde doelen moeten echter als bijkomende doelen beschouwd worden, in de zin dat een particulier bedrijf ze niet zou nastreven. Derhalve worden in deze paragraaf de behandelde doelen in een aantal categorieën ondergebracht. 
Het eigenlijke doel: Doel $1,2,3,4,5,9,11,12,13 \mathrm{en} 15$

(belastingontvangst, uitvoeren milieuheffingen, automatisering, fraudebestrijding, communicatie, personeelsverloop, toezicht doorvoer, verbeteren "human capital" en Waarborg).

In 1991 bedroegen de uitgaven van de Belastingdienst nuim F. 3,6 miljard. Gecorrigeerd voor renteuitgaven op belastingschulden ging het om ruim 2,8 miljard gulden. Het grootste deel van deze uitgaven werden gebruikt om het eigenlijke doel te realiseren. Uit paragraaf 17.10 . waarin is ingegaan op de mate waarin de doelen zijn gerealiseerd; kan worden opgemaakt dat de inning van belastingen verbeterd is. Zo tekenden de resultaten van het anti-fraudebeleid zich duidelijk af. Gedurende de onderzoeksperiode verbeterde bijvoorbeeld de controledichtheid buj de inkomsten-, vennootschaps- en omzetbelasting aanzienlijk. Verder verbeterde de productiviteit, hoewel hier wel enige kanttekeningen bijgezet kunnen worden. Vooral de wijze waarop de productie gemeten en gewogen wordt beinvloedt vanzelfsprekend in hoge mate dit soort kengetallen. Verder verbeterde ook de communicatie en de dienstverlening. In plaats van een hiërarchische en tamelijk bureaucratische organisatie werd de Belastingdienst flexibeler en meer klantgericht. Ook de achterstanden in de invordering werden teruggedrongen. Bedroeg de achterstand in 1985 nog 16,42 miljard of $9,6 \%$, in 1991 was dit gedaald tot 14,128 miljard of $6,3 \%$. Gelet op de meerjarendoelstelling van de Belastingdienst van $7,5 \%$ was deze dus ruimschoots gerealiseerd. Het eigenlijke doel werd beter gerealiseerd. Vervolgens rijst de vraag hoe het zit met de kosten van deze mate van doelrealisering. In dit verband is de uitgaven/inkomsten-ratio van belang. In Tabel 17.16 wordt een overzicht gegeven voor de periode 1980-1992. Hierdoor wordt cen indruk gekregen van de toename van de kosten van het eigenlijke doel. Verreweg het grootste deel van de kosten werd namelijk voor het eigenlijke doel gebruikt.

\begin{tabular}{|l|l|l|l|l|l|l|}
\hline jaar & 1980 & 1984 & 1988 & 1990 & 1991 & 1992 \\
\hline $\begin{array}{l}\text { Uitgaven in } \\
\text { miljarden } \\
\text { guldens }\end{array}$ & 1,8 & 2,095 & 2,35 & 2,6 & 2,9 & 2,93 \\
\hline $\begin{array}{l}\text { Belastingontvang- } \\
\text { sten in miljarden } \\
\text { guldens }\end{array}$ & 127,11 & 153,7 & 186.9 & 186,9 & 209,9 & 213,7 \\
\hline $\begin{array}{l}\text { Uitgaven in \% van } \\
\text { de belastinginkom- } \\
\text { ten }\end{array}$ & $1,43 \%$ & $1,36 \%$ & $1,25 \%$ & $1,4 \%$ & $1,36 \%$ & 1,36 \\
\hline
\end{tabular}

Tabel 17.16 De uitgaven-/ontvangst-ratio in getallen ${ }^{\text {i19o }}$

Uit Tabel 17.16 blijkt dat de uitgaven-/inkomsten-ratio een lichte daling vertoonde gedurende de onderzoeksperiode. De conclusie is dan ook dat het eigenlijke doel beter werd gerealiseerd tegen verhoudingsgewijs ongeveer dezelfde kosten.

De bijkomende doelen

Naast het eigenlijke doel probeerde de Belastingdienst andere doelen te bereiken. In 1991

${ }^{1190}$ De uitgaven $*$ inkomsten-ratio verschilt iets van die in Tabel 18.15. omdat in Tabel 18.24 alle inkomsten en belastingontvangsten zijn gerekend en tevens is gecorrigeerd yoor rente op belastingschulden. 
bedroegen de ontvangsten, berekend overeenkomstig de periode voor 1991 , ruim 1,2 miljard gulden. De uitgaven die bekostigd werden door het Rijk bedroegen een kleine 2,9 miljard. Per saldo bedroegen de uitgaven ongeveer 1,54 miljard. Het eigen vermogen in dat jaar bedroeg 2,172 miljard. Aangezien de obligatierente $8,74 \%$ bedroeg had de Belastingdienst een winst behoren te maken van bijna 190 miljoen. Dientengevolge was er dus een "public enterprise rent" ten bedrage van bijna 1,8 miljard gulden. Deze "public enterprise rent" ontstond grotendeels omdat de Belastingdienst feitelijk verlies leed. Dit kwam niet zozeer doordat de uitgaven in verhouding met een particulier bedrijf te hoog waren maar omdat de Belastingdienst de kosten van de activiteiten die zij verrichtte niet in rekening bracht aan de belastingbetaler. $\mathrm{Zij}$ zou bijvoorbeeld iedere belastingbetaler premies kunnen laten betalen.

De bijkomende doelen van de Belastingdienst hingen gedeeltelijk samen met de hiervoor genoemde doelen. Het is niet altijd mogelijk om een strikte scheiding aan te brengen. In deze paragraaf worden de bijkomende doelen, waaraan dus ongeveer 1,8 milljard werd besteed, voor het vergroten van het inzicht in een aantal belangrijke doelen samengevat.

\section{Rechtmatigheid in enge zin: bezwaarschriften en procedures (onderdeel doel 1 en doel 6)}

Een belangrijk doel van de Belastingdienst is naast het innen van belastinggelden het uitvoeren van de belastingwetgeving. In dit verband werd groot belang gehecht aan het doel van de rechtmatigheid. Onder het doel van de rechtmatigheid wordt verstaan dat de Belastingdienst zorgt dat burgers op een eerlijke manier worden behandeld. Duidelijk is dat met het nastreven van rechtmatig handelen veell kosten zijn gemoeid. Burgers moeten tegen een belastingaanslag beroep kunnen instellen. De Belastingdienst moet dan ook regelmatig bezwaarschriften in behandeling nemen en moet regelmatig procederen. In Nederland is de procedure bij de verschillende belastingwetten als volgt. De Belastingdienst legt een burger een belastingaanslag op. Deze aanslag heeft het karakter van een beschikking. Indien een burger het met deze aanslag niet eens is kan hiertegen bij de Belastingdienst een bezwaarschrift worden ingediend. Indien dit bezwaarschrift niet wordt gehonoreerd kan vervolgens veelal in beroep worden gegaan bij de Belastingkamer van het Gerechtshof. In Nederland wordt geen gebruik gemaakt van een niet-formele rechtsgang zoals arbitrage. Vervolgens kan nog in cassatie worden gegaan bij de Hoge Raad. Daarnaast bestaat de mogelijkheid dat belastingplichtigen in het geheel niet willen betalen of proberen om de belasting te ontwijken of te ontduiken. De Belastingdienst besteedt in dit kader veel aandacht aan het bestrijden van fraude en oneigenlijk gebruik en aan het verminderen van achterstanden in de invordering. Voorts tracht zij de "compliance" te verbeteren. In het jaarverslag over 1981 werd in dit verband opgemerkt: "Van de Belastingdienst mag worden verwacht dat met de daarvoor beschikbare middelen al datgene wordt gedaan om tot een goede uitvoering van de wetgeving te kamen. Rechtwaardigheid en doelmatigheid staan in die uitvoering vaak met elkaar op gespannen voet. In dat spanningsveld moet de dienst dan ook zijn beleid bepalen. In ieder geval moet de dienst erwoor waken dat weerstanden tegen de belastingheffing onnodig worden vergroot". 1191 Duidelijk is dat met het nastreven van rechtmatig handelen veel kosten zijn gemoeid. De Belastingdienst moet regelmatig bezwaarschriften in behandeling nemen en moet regelmatig procederen. Daar komt nog bij dat deze hele procedure ook de "compliance" beinvloedt. Indien burgers menen dat zij onterecht worden behandeld of indien er sprake is van willekeur, zoals dat in de middeleeuwen bij de inning door allerlei feodale heersers vaak het geval was, zal de bereidheid mee te werken sterk afnemen. Die

${ }^{1191}$ Belastingdienst, Jaarverslag over 1981, Den Haag, 1982, voorwoord. 
"compliance" wordt natururlijk ook sterk beïnloed door de hoogte van de belastingen en de daarmee gepaard gaande "excess burdens". Deze nadruk op rechtmatigheid leidt echter wel tot veel kosten voor de Belastingdienst.

Wat zijn nu de kosten van dit doel? Van deze kosten wordt uiteindelijk ongeveer $20 \%$ gedragen door de Belastingdienst. De totale kosten van het oplossen van geschillen op belastinggebied worden geraamd op ongeveer 10 tot $20 \%$ van de perceptiekosten. 1192 De perceptiekosten in Nederland bedroegem in 1991 zoals opgemerkt ongeveer F. 2,92622 miljard gulden. Gaan we uit van $15 \%$ dan betreft het een bedrag van ongeveer $\mathbb{F} .440$ miljoen. Hiervan werd $20 \%$ door de Belastingdienst gedragen. ${ }^{1193}$ Het gaat dan om ongeveer 88 miljoen gulden. Hierbij aansluitend trachtte de Belastingdienst de "compliance $^{\prime \prime}$ (doel 6) te verbeteren. Andere doelen droegen eveneens bij aan de "compliance", terwijl de bevordering van de "compliance" diende om de inning van belastingmiddelen ook in de toekomst te realiseren.

\section{Nationale werkgelegenheid en economische groei: doel 7}

In paragraaf 17.10 is op het doel van het bevorderen van de nationalle werkgelegenheid en economische groei ingegaan. Naar schatting werd elk jaar 50 miljoen gulden aan dit doel besteed.

\section{Werkgelegenheid bij de Belastingdienst: doel 8}

Bij het doel van het bevorderen van de werkgelegenheid bij de Belastingdienst gaat het er vooral om in hoeverre er verborgen werkloosheid bestaat bij de Belastingdienst. Zou een particulier bedrijf met andere woorden minder personeel in dienst hebben? Begin jaren tachtig was dit het geval. Halverwege de jaren tachtig en begin jaren negentig werd er echter fors bezuinigd op de personeelsformatie. Bedroeg de formatie in 198432.600 personen, in 1994 was dit gedaald tot 29.000 , een afname van $11 \%$. In 1995 moest dit verder zijn teruggebracht tot 27.778 werknemers. Deze afname hield verband met de afslankingsopdrachten wan de verschillende kabinetten en met het afstoten van taken. In 1991 waren er 29.052 medewerkers werkzaam bij de Belastingdienst, terwijl de formatie 30.415 bedroeg. Deze 29.052 medewerkers ontvingen ruim 1,9 miljard gulden. Dit is

F. $67.167,8$ gemiddeld per werknemer. In principe zou een particulier bedrijf de doelstelling van 1995 al in 1991 behaald kunnen hebben. Temeer daar de automatiseringsoperatie ook al eerder uitgevoerd had kunnen worden dan aan het begin van de jaren megentig. Indien wordt uitgegaan van 27.778 werknemers dan waren er 1.274 werknemers op bedrijfseconomische gronden niet strikt noodzakelijk. Vermenigvuldigd met het gemiddelde salaris per werknemer bedroeg dit F. 85,6 miljoen. In werkelijkheid zijn deze kosten hoger, aangezien deze werknemers ook allemaal een werkplek moesten hebben. Gaan we zoals reeds vermeld uit van F. 24.000,- per werkplek, dan zijn de totale kosten ongeveer 120 miljoen gulden.

1192 Bron: Cijfers afkomstig van een bijeenkomst met Prof, dr. Santos Pastor op 23 januari 1997 aan de Uniwersiteit maastricht. Vergelijk ook: Estrada en Pastor (1996, p. 7, Pp. 11-13).

1193 Vergelijk: Pastor (1995, p. 4, pp. 6-8). Het gaat om cijfers uit andere Europese landen. Er wordt hier vanuit gegaan dat deze ook op Nederland van toepassing zijn. 
Gezien het verloop van bepaalde categorieèn personeel zoals inspecteurs, accountants en automatiseringspersoneel kan worden afgeleid dat deze groepen in het bedrijfsleven beter beloond worden. Daar staan echter groepen tegenover die bij de Belastingdienst een hoger salaris ontvangen. Dat bleek bijvoorbeeld ook bij de privatisering van de Dienst der Waarborg per 1 maart 1987 . Een kwart van de werknemers ging over naar de nieuwe N.V., terwijl de rest van het personeel ervoor koos om bij de Belastingdienst te blijven werken. In paragraaf 17.10 is een globale becijfering gemaakt van de verschillen in beloning tussen werknemers bij de Belastingdienst en in het bedrijfsleven. Uitgaande van de pakketvergelijking werd aangegeven dat werknemers bij de Belastingdienst gemiddeld ongeveer $6 \%$ lager beloond werden. Gegeven de uitgaven aan salarissen, toelagen en dergelijke bij de Belastingdienst, in 1991 ten bedrage van F. 1,9 miljard, ging het dus om 124,5 miljoen gulden.

\section{Rechtvaardige inkomensverdeling: doel 14}

Voor doel 14, het bevorderen van een rechtvaardige inkomensverdeling, werden eveneens kosten gemaakt. Het is echter moeilijk te bepalen hoe hoog deze kosten zijn. Dat ligt er ook aan in hoeverre de "excess burdens" ten gevolge van de belastingheffing worden gezien als kosten van dit doel. Duidelijk is dat een groot deel van de welvaartsverliezen ten gevolge van belastingen worden veroorzaakt om herverdeling mogelijk te maken. Het gaat hierbij echter niet zozeer om de uitvoering van belastingwetgeving maar om het opstellen en bepalen van wetgeving, waar de Belastingdienst weinig invloed op heeft. De Belastingdienst heeft evenwel slechts beperkte mogelijkheden om de herverdeling te bevorderen: $\mathrm{Zij} \mathrm{kan} \mathrm{bijvoorbeeld} \mathrm{regels} \mathrm{op} \mathrm{een} \mathrm{bepaalde} \mathrm{wijze} \mathrm{toepassen.} \mathrm{Dit} \mathrm{leidt} \mathrm{tot}$ "excess burdens". Het is echter moeilijk te bepalen hoe hoog deze welvaartsverliezen zijn, temeer daar de Belastingdienst zelf terughoudend is in het verstrekken van dit soort informatie.

Indien ook de kwijtschelding en de oninbaarheid van belastingen wordt gezien als een facet van dit doel, dan kan worden geconstateerd dat een particulier bedrijf een prikkel heeft om deze kwijtschelding en de oninbaarheid van belastingen zoveel mogelijk tegen te gaan. In 1991 ging het per saldo om 981,6 miljoen gulden. Dit was aanzienlijk minder dan gedurende de jaren tachtig, toen het om ruim 2 miljard gulden ging. Ook een particulier bedrijf zall niet ontkomen aan kwijtschelding en oninbaarheid van belastingen. Dat neemt niet weg dat deze aanzienlijk lager zouden liggen. Gezien de ontwikkelingen van de oninbaarheid en kwijtschelding van belastingen na 1992 zou dit bedrag zo'n 500 miljoen kunnen bedragen. Dit doel kostte in 1991 dientengevolge een kleine 500 miljoen guiden.

\section{Werkgelegenheid voor minderheden: doel 16}

Het doel van het bevorderen van werkgelegenheid voor minderheden werd door het Rijk nagestreefd. De Belastingdienst beoogde eveneens aan dit beleid inhoud te geven. Dit doel bracht kosten met zich mee. Vooral omdat door dit beleid meer in deeitijd werd gewerkt, terwijl meer gebruik werd gemaakt van arbeidstijdverkorting. Hierdoor had de Belastingdienst meer werknemers waardoor ook meer kantoorruimte nodig was, aangezien in de praktijk weinig gebruik werd gemaakt van de mogelijkheid om werkplekken te delen. Dit was vooral het gevolg van het aanstellen van meer vrouwen. Van de vrouwen werkten ongeveer $40 \%$ vier dagen of minder. In 1982 werkten bijvoorbeeld $33 \%$ van de vrouwen halve dagen en $65 \%$ van de vrouwen vier dagen in de week. Bij de mannen lag het 
percentage dat vier dagen of minder werkte op ongeveer $7 \%$. In 1991 waren er 23.592 mannen werkzaam en 7.717 vrouwen. Indien van de mannen $7 \%$ vier dagen werkte en de rest 38 uur dan werd er $52.846+833.741$ uren per week gewerkt door mannen. Gemiddeld is dit 37,58 uur per man. Indien van de vrouwen $40 \%$ vier dagen in de week werkte dan werkten zij $98.777+175.947$ uren. Per vrouw werd dus 35,6 uur per week Om dit aantal uren door mannen te laten werken zouden er dus 7.310 mannen nodig zijn. Dit betekent dat er doordat vrouwen meer in deeltijd werken 406 vrouwen extra in dienst genomen moesten worden. Deze werknemers kregen ook een werkplek, aangezien het delen van werkplekken nog niet was ingeburgerd. Vermenigvuldigd maal: $\mathrm{F}$; 24.000 betekent dit dat ongeveer 10 miljoen gulden aan dit doel besteed werd. Het betreft hier een voorzichtige schatting. Duidelijk is wel dat de kosten van dit doel relatief gering waren.

\section{Onderzoek: doel 17}

Binnen de Belastingdienst werd gedurende de onderzoeksperiode steeds meer aandacht besteed aan het verrichten van onderzoek. Met behulp van begrotingen en jaarverslagen kunnen de kosten hiervan worden geraamd op 35 miljoen gulden.

Rechtvaardige uitvoering van belastingwetgeving en tegengaan van willekeur en hoge bellastingen: rechtmatigheid in ruime zin (onderdeel doel 14)

Bij het doel van de rechtmatigheid is aangegeven dat de Belastingdienst kosten maakt voor het afhandelen van bezwaarschriften en voor het voeren van procedures. Daarnaast heeft de overheid als taak om ervoor te zorgen dat de belastingwetgeving op een eerlijke manier wordt uitgevoerd. Hiervoor is controle door de overheid nodig. Het gaat daarbij zowell om controle op het geinde bedrag als om controle op het proces van inning. Een particulier bedrijf zou dus weliswaar een winst maken van bijna 190 miljoen gulden, daarnaast zou de overheid kosten moeten maken in de controlesfeer. Dat de overheid bij een particulier bedrijf veel kosten zou moeten maken voor het controleren van de uitvoering komt vooral ook door het, zoals opgemerkt in paragraaf 17.2 , in Nederland bij de inkomstenbelasting gehanteerde bronnenstelsel. Er wordt rekening gehouden met persoonlijke omstandigheden. Subjectieve criteria worden gehanteerd. De keuze voor dit stelsel leidt ertoe dat een particuliere instelling moeilijk te controleren zou zijn. Hierdoor zou de winst yoor de overheid en de Belastingdienst gezamenlijk feitelijk lager zijn dan de genoemde 190 miljoen, waardoor ook de "public enterprise rent" dus kleiner is. Tenslotte dient bedacht te worden dat het doel van het bronnenstelsel is om rekening te houden met ieders draagkracht. De kosten die gemaakt worden om de Belastingdienst te controleren en meer in het bijzonder om de Belastingdienst als overheidsinstelling te laten functioneren, zijn dan ook gedeeltelijk an het doel van de herverdeling van inkomen toe te rekenen.

\section{Welvaartsverliezen tegengaan (onderdeel doel 6)}

Verder heeft de overheid de Belastingdienst opgericht om monopoliewinsten die door een particulier bedrijf behaald zouden kunnen worden tegen te gaan. Mede in verband met de (statische) schaalvoordelen zou een particulier bedrijf, bijvoorbeeld in de vorm van een "tax farm", veel winst kunnen maken waardoor de welvaartsverliezen groot zouden zijn. De prijzen liggen dan boven de marginale kosten. De. Belastingdienst doet dit niet en lijdt daardoor een verlies. Een deel van de kasten van de Belastingdienst dient dan ook om deze welvaartsverliezen tegen te gaan. 
17.13.2 Conclusie: hoe moet de "performance" van de Rijkssbelastingdienst worden beoordeeld?

Samenvattend kan een global overzicht worden gegeven van het deel van de "public enterprise rent" dat aan elk doel werd besteed:

\begin{tabular}{|l|l|}
\hline Bijkomend doel & $\begin{array}{l}\text { percentage van de "public enterprise } \\
\text { rent dat hieraan besteed werd }\end{array}$ \\
\hline Rechtmatigheid & $4,9 \%$ \\
\hline Werkgelegenheid Belastingdienst & $2,8 \%$ \\
\hline $\begin{array}{l}\text { Nationale welvaart en economische } \\
\text { groei }\end{array}$ & $6,7 \%$ \\
\hline Beloning personeel & $-6,9 \%$ \\
\hline Werkgelegenheid minderheden & $27,4 \%$ \\
\hline Rechtvaardige inkomensverdeling & $0,6 \%$ \\
\hline Onderzoek & $2 \%$ \\
\hline $\begin{array}{l}\text { Eerlijke uitvoering belastingwet- } \\
\text { geving }\end{array}$ & $33,5 \%$ \\
\hline Welvaartsverliezen tegengaan & $29 \%$ \\
\hline Totaal & $100 \%$ \\
\hline
\end{tabular}

Tabel 17.17 De besteding van de "public enterprise rent"1194

De "public enterprise rent" wordt voor het grootste deel besteed aan een drietal doelen. In de eerste plaats wordt bijna $28 \%$ besteed aan het doel van een rechtvaardige inkomensverdeling Het tweede belangrijke bijkomende doel is dat van een eerlijke uitvoering van de belastingwetgeving. Hoewel, zoals opgemerkt, de Belastingdienst dit doel niet expliciet noemt, geeft zij wel veelvuldig aan dat een eerlijke uitvoering van wetgeving voor haar erg belangrijk is. Tenslotte is het doel van het voorkómen van welvartsverliezen van groot belang, Door de schaalvoordelen die zich voordoen is het voor een efficiënte allocatie belangrijk dat de prijs yoor de belastinginning niet te hoog wordt gesteld. Daardoor lijdt de innende instantie, in dit geval de Belastingdienst wel automatisch een verlies Dit verlies dient derhalve om de welvaartsverliezen in de economie tegen te gaan. Uit het onderzoek naar de Belastingdienst blijkt vooral dat de doelstelling van de Belastingdienst in de jaren ' 80 veranderde. De eigenlijke doelstelling, te weten de inning van belastinggelden, werd belangrijker. Dit kwam vooral ook doordat er zich belangrijke wijzigingen voordeden in de omgeving. Het aantal belastingbetalers steeg, de belastingmoraal verslechterde, terwijl bovendien de wetgeving steeds gecompliceerder werd. Verder bleek de Belastingdienst te statisch om goed op deze en andere veranderingen te kunnen inspelen. Door de ingewikkeldheid van de belastingwetgeving werd het bovendien moeilijker om de Belastingdienst te kunnen controleren. Bovendien nam de herverdeling van middelen door de kwijtschelding en oninbaarheid van belastingen dusdanige proporties aan dat gevreesd werd voor dalende belastingopbrengsten. Teneinde het gewijzigde

1194 De bedragen zijn geschat op grond van paragraaf 18.10 en de begrotingem, beheers- en produktieverslagen. 
doelenpakket ook te kunnen realiseren moesten een groot aantal aspecten van het netwerk worden veranderd. Het ging daarbij miet alleen om het wijzigen van de organisatiestructurur maar ook om het om-en bijscholen van personeel, het ontwikkelen van nieuwe informatiesystemen die nodig waren om de transactiekosten te verminderen, terwijl ook de organisatiecultuur en de relaties binnen het netwerk moesten worden gewijzigd. Deze conclusie is ook relevant voor andere overheidsorganisaties die bestuurstechtelijke taken uitwoeren, zoals allerlei inspecties, de gemeentelijke sociale diensten en allerlei sociale werzekeringsinstellingen. Een wijziging van de doelstelling; in het geval van de Belastingdienst gepaard gaande met een verschuiving van correctie naar preventie, maakt alleen kans van slagen indien de verschillende delen van het netwerk simultaan worden gewijzigd. De verschillende wijzigingen zullen bovendien steeds op elkaar moeten worden afgestemd. Hieruit volgt ook dat de reorganisatie van de Belastingdienst formeel in 1992 was afgesloten, maar in werkelijktheid ook na 1992 zal voortgaan. Duidelijk is dat deze verdere wijzigingen de "performance" zullen beinvloeden.

Tenslotte rijst de vraag of de "performance" verbeterde. Opgemerkt is dat het eigenlijke doel beter werd gerealiseerd (in de zin van sneller, effectiever e.d.) tegen verhoudingsgewijs ongeveer dezelfde kosten. De kosten van de bijkomende doelen bedroegen in 1989 bijna 1,8 miljard, in 1990 werd een piek bereikt van bijna 2 miljard guiden In 1991 en 1992 daalde dit tot ongeveer 1,7 miljard gulden. De kosten van de bijkomende doelen daalden dus met ongeveer 100 a 200 miljoen gulden. In hoeverre veranderde de realisering van de bijkomende doelen? Duidelijk is dat met name aan de herverdeling van middelen minder aandacht werd besteed. In 1989 werd hieraan nog ruim 1,6 miljard besteed, terwijl dit in 1991 sterk terugliep. In 1992 ging het echter weer om ruim 1,5 milljard. De relatief lage perceptiekosten in 1991 worden dan ook vooral veroorzaakt door de daling van het kwijtgescholden en oninbare bedrag. Het doel van de eerlijke uitvoering wan de belastingwetgeving werd niet minider belangrijk maar kon iets goedkoper worden gerealiseerd. De reden hiervan ligt niet alleen in de betere interne organisatie en vooral informatiestructuur maar waarschijnlijk ook in de eind jaren tachtig uitgevoerde operatieOort, waardoor de belastingwetgeving enigszins vereenvoudigd werd, waardoor het voor de Belastingdienst goedkoper werd om deze op een eerlijke wijze uit te voeren. Het doel van het tegengaan van welvaartsverliezen is voor zover kon worden nagegaan niet veranderd, noch de kosten daarvan.

\section{Alternatieven voor de Belastingdienst}

Afrondend en aansluitend bij paragraaf 17.2 is het gewenst om te analyseren of er betere alternatieven zijn voor de in 1992 geldende organisatiestructuur. Allereerst kan de in 1991 bestaande organisatiestructurur van beperkte interne verzelfstandiging verder wotden uitgewerkt. Dit zou kunnen door zelfbeheer door middel van flexibilisering van beheersregels of daarnaast door het invoeren van een agentschap. ${ }^{1195}$ Gerritsen en Wuijtswinkel geven een overzicht van de voor- en nadelen van de invoering van deze interne verzelfstandigingvarianten voor de Belastingdienst. ${ }^{196}$ In beide gevallen blijft de minister verantwoordelijk.

In het geval van flexibilisering van beheersregels krijgt de Belastingdienst meer vrijheid om met behulp van eigen budgetten zelf de formatie te bepalen en middelen aan te

\footnotetext{
1195 Werkgroep Beheersregels, Verder bouwen aan beheet, Rapport Herowerweging werkgroep beheersregels, Den Haag, 1991 .

119\% Gerritsen en Wuijtswinkel (1993, p. 17).
} 
schaffen. Aangezien het doel van de eerlijke wijze van uitvoering bij de verdere invoering van deze variant door de democratische controle geen gevaar loopt en de grotere flexibiliteit de efficiëntie kan verhogen zou dit kumnen leiden tot verbetering van de "performan$\mathrm{ce}^{\mathrm{n}}$. Wel lijkt het waarschijnlijk dat de herverdeling van middelen dan verder afneemt. Aangezien de Belastingdienst geen eigen prijzen kan rekenen en de reserveringsmogelijkheden beperkt zijn, zal het doel van het verminderen van de welvaartsverliezen er niet op achteruit hoeven gaan. De welvaartsverliezen zouden zelfs kunnen afnemen door de Belastingdienst meer kostendekkend te laten opereren. Hierdoor worden de "excess burdens" van de subsidie die door de overheid aan de Belastingdienst wordt verstrekt en die uit belastinggelden wordt bekostigd lager.

Een agentschap gaat verder dan het hiervoor genoemde zelfbeheer, dat zoals aangegeven al voor een belangrijk deel bij de Belastingdienst is ingevoerd. Een agentschap kan net als een staatsbedrijf een eigen vermogensbeheer voeren. Er dient dan een balans en een resultatenrekening te worden opgesteld. Of invoering van een agentschap aanbeveling verdient, hangt zoals ook Gerritsen en Wuijtswinkel benadrukken, af van de vraag of de bedrijfsvoering van de Belastingdienst hierdoor verder zal verbeteren. Zij menen dat dit niet of zeer beperkt het geval zal zijn, aangezien de Belastingdienst geen commerciële activiteiten ontplooit. Zij rekenen geen prijzen en hebben dan ook niet zoveel aan een recht op eigen vermogen en een eigen verslaglegging van het gebruik daarvan. Dit zou echter veranderd kunnen worden door wel prijzen te rekenen, ongeveer vergelijkbaar met de premies voor de verplichte ziektekostenverzekering. De inning van belastingen zal dan waarschijnlijk efficiënter worden. Daar staat tegenover dat de bijkomende doelen minder belangrijk zullen worden. De controle op een eerlijke wijze van uitvoering van de belastingwetgeving kan nog wel gerealiseerd worden door het verder verbeteren van de informatievoorziening binnen de Belastingdienst. De herverdeling van middelen zal verder verminderen, terwijl de welvaartsverliezen kunnen toenemen. De Belastingdienst zal prijzen in rekening brengen. Indien deze prijzen de marginale kosten overstijgen kunnen welvaartsverliezen ontstaan. Daar staat tegenover dat de "excess burdens" van het door de overheid verstrekte budget wegvallen. Of per saldo op dit punt een verbetering ontstaat hangt af van de hoogte van de gerekende prijzen.

Tenslotte kan gekozen worden voor externe verzelfstandiging. Hierbij kan zoals opgemerkt in paragraaf 17.2 onderscheid worden gemaakt tussen de verzelfstandiging van de aanslagregeling en van de inning. Problemen doen zich vooral voor bij de verzelfstandiging van de heffing. Het gaat er daarbij vooral om of de herverdeling, de eerlijke uitvoering van belastingwetgeving en de welvaartsverliezen niet te veel achteruitgaan of op een andere goedkopere wijze kunnen worden gerealiseerd. Twee varianten kunnen worden onderscheiden. In de eerste plaats kan de Belastingdienst worden omgezet in een zelfstandig bestuursorgaan (functionele decentralisatie). Of er problemen ontstaan bij de bijkomende doelen hangt vooral af van hetgeen in de instellingswet is bepaald. In een dergelijke wet wordt namelijk bepaald welke taken worden overgedragen aan de betreffende instelling en in hoeverre de minister controlemogelijkheden houdt. In principe gaat de instelling van een zelfstandig bestuursorgaan in meer of mindere mate gepaard met een vermindering van de ministeriële verantwoordelijkheid. De minister is niet of minder verantwoordelijk voor de uitvoering door de Belastingdienst. De gedachte is dat door het sturen op hoofdlijnen door de minister met behulp van bijvoorbeeld richtlijnen en daarnaast grotere zelfstandigheid voor de Belastingdienst, de Belastingdienst beter beheersbaar en bestuurbaar kan worden. Zij kan dan een betere afweging maken tussen de baten en kosten van haar handelen. Daar staat tegenover dat er belangentegenstellingen kunnen ontstaan tussen de verantwoordelijke minister en de Belastingdienst. De Belastingdienst krijgt meer vrijheid om minder aandacht te besteden aan de eerlijke uitvoering van belastingwetgeving en de andere bijkomende doelen. Dat de Belastingdienst minder 
aandacht aan de eerlijke wijze van uitvoering van de belastingwetgeving kan besteden komt omdat de minister niet meer de mogelijkheid heeft om in the grijpen op detailniveau. Dit is vooral een probleem omdat de Nederlandse inkomstenbelasting zoals opgemerkt aansluit bij de bronnentheorie. Of een zelfstandig bestuursorgaan een verbetering van de "performance" oplevert ligt dan ook enerzijds aan de wijze waarop én en ander is geregeld in de instellingswet en anderzijds aan de vraag of ook de heffing geprivatiseerd wordt. In theorie is het echter mogelijk de politieke sturing te verbeteren, terwijl eweneens het functioneren en de flexibiliteit toeneemt: Of die politieke sturing inderdaad verbeterd is echter zeer de vraag aangezien de verschillende Directoraten-Generaal op het Ministerie van Financiën nauw met elkaar zijn verbonden.

Tenslotte zou de Belastingdienst kumen worden omgezet in een stichting of een $\mathbb{N} . V$. of een B.V. Problemen ontstaan ook hier vooral bij het verzelfstandigen van de heffing. Het eigenlijke doel zal dan waarschijnlijk, afhankelijk van de definitieve opzet, beter en goedkoper worden gerealiseerd, daar staat tegenover dat de bijkomende doelen minder belangrijk zullen worden. Dienovereenkomstig zal ook de "public enterprise rent" afnemen. Aangezien zo'n N.V. prijzen/premies zal rekenen kunnen er welvaartsverliezen ontstaan. Bovendien zal de herverdeling sterk verminderd worden. Tenslotte ontstaan in verband met het in hoofdlijnen gehanteerde bronnenstelsel, zoals gememoreerd in paragraaf 17.2, vooral problemen bij de eerlijke uitvoering van de fiscale wetgeving. Temeer daar de belastingwetgeving in Nederland ondanks de Oort-operatie nog steeds gecompliceerd is en controle van een particulier bedrijf veel kosten met zich mee zou brengen.

Eén en ander overziend verdient het aanbeveling om verder te gaan met de invoering van flexibele beheersregels. Ook de omvorming tot een zelfstandig bestuursorgaan moet overwogen worden. Daarbij is het wel essentieel dat goed uitgewerkt wordt welke bevoegdheden wel en welke niet worden overgedragen. Tenslotte is het de moeite waard om meer onderzoek te verrichten naar een systeem waarbij de inning wordt uitgevoerd door én of meerdere particuliere ondernemingen en de heffing geschiedt door een volledig intern verzelfstandigde Belastingdienst.. 


\section{Hoofdstuk 18. Slotbeschouwing}

\subsection{Samenvatting van het onderzoek}

In dit onderzoek is enerzijds getracht om te komen tot een theoretisch beter onderbouwde analyse van de "performance" van overheidsinstellingen en is anderzijds met behulp van deze theoretische kennis de "performance" van een aantal overheidsinstellingen in de werkelijkheid onderzocht. Het onderzoek was dienovereenkomstig gebaseerd op een tweetal centrale vragen, te weten:

1. Hoe kan de "performance" van een overheidsinstelling op theoretische wijze worden verkllaard?

2. Hoe kan de "performance" van een specifieke overheidsinstelling worden bepaald?

Het onderzoek bestaat dan ook uit een theoretisch en een empirisch deel. Het gaat met andere woorden om de vragen, wat doen overheidsbedrijven nu werkelijk, hoe doen zij dat en hoe goed doen zij dat.

In hoofdstuk 1 is een afbakening van het onderzoek gegeven. In dit wordt ingegaan op een aantal voor het onderzoek belangrijke begrippen als "performance", efficiëntie en overheidsinstellingen. In dit onderzoek staat de "performance" centraal. Daarbij gaat het niet alleen om de productie van een bedrijf, maar ook nadrukkelijk om de activiteiten die plaatsvinden in het productieproces en om de uiteindelijke effecten. Daarbij gaat het niet alleen om de mate van efficiëntie, maar ook om de effectiviteit van de instelling.

Vervolgens is in deel 2 aan de hand van een aantal deelvragen een analyse gegeven van de factoren die in het algemeen de "performance" van overheidsinstellingen bepalen. Uit de analyse kan worden afgeleid wanneer voor een overheidsinstelling wordt gekozen en wanneer voor bijvoorbeeld privatisering. Hoewel hiermee inzicht is gekregen in de bestaansredenen van een overheidsinstelling is nog niet duidelijk hoe de "performance" van dit soort instellingen kan worden geanalyseerd.

Vervolgens wordt in hoofdstuk 3 een begin gemaakt met het ontwikkelen van een netwerkmodel van overheidsinstellingen. Daarbij wordt uitgegaan van de industriêle organisatiebenadering van het structuur-gedrag-resultaat-paradigma. Benadrukt is dat niet wordt uitgegaan van eenvoudige causale relaties. Een groot aantal factoren bleken van belang te zijn. Het voornaamste verschil met particuliere ondernemingen houdt verband met het gedrag van overheidsinstellingen.

In hoofdstuk 4 is daarom ingegaan op de welvaartseconomie. Een belangrijk deel van de zogenaamde "public enterprise economics" houdt zich bezig met de vraag hoe overheidsinstellingen zich zouden moeten gedragen. De conclusie is dat dergelijke normatieve economie weinig inzicht geeft in het werkelijke gedrag en de "performance" van een overheidsinstelling. Dit laat onverlet dat de welvaartseconomie grote verdiensten heeft woor de economie. Benadrukt is slechts dat gelet op de centrale vraag de welvaartseconomie als normatieve theorie de "performance" van een overheidsinstelling in de praktijk onvoldoende kan verklaren.

Vervolgens wordt in hoofdstuk 5 onderzocht of het gedrag en de "performance" van overheidsinstellingen net grotendeels een resultante is van de wensen van de burgers. 
Hoofdstuk 5 ligt in het verlengde van hoofdstuk 4. Werd in hoofdstuk 4 de welvaartseconomie op een normatieve wijze benaderd, in hoofdstuk 5 wordt de welvaartseconomie opgevat als een positieve theorie. In werkelijkheid zal het politieke proces veelal niet leiden tot een welvaartsoptimum. Politici kunnen tot bepaalde hoogte eigen doelen nastreven. Vervolgens rijst de vraag of dat beleid ook werkelijk door overheidsinstellingen wordt uitgevoerd. Dit blijkt lang niet altijd zo te zijn. De uitvoering van het beleid kan eveneens gezien worden als een politiek proces. Dit houdt ondermeer verband met het bestaan van asymmetrische informatie. De conclusie is dan ook dat het politieke proces grote invloed heeft op het gedrag en de "performance" van een overheidsinstelling, maar dat daarnaast ook andere factoren van belang zijn. Ook het beleid van de actoren binnen overheidsinstellingen moet worden onderzocht. De vraag is welke factoren dit gedrag beinvloeden.

Daartoe wordt in hoofdstuk 6 en verder het netwerkconcept uitgewerkt. Overheidsinstellingen moeten worden gezien als netwerken van actoren. Daarbij kan onderscheid gemaakt worden tussen een intern en een extern netwerk. Een intern netwerk wordt gevormd door de actoren binnen de overheidsinstelling, terwijl een extern netwerk daarnaast ook actoren in toezichthoudende organen bevatten. Duidelijk is dat er een groot aantal actoren bestaan bininen een netwerk. Teneinde het gedrag en de "performance" te kunnen verklaren dient dit aantal te worden ingeperkt tot de actoren die vooral invloed hebben op het gedrag.

Daarom wordt in hoofdstuk 7 ingegaan op de theorie van de eigendomsrechten. Aangegeven is dat de verdeling van eigendomsrechten grote invloed kan hebben op het gedrag en de "performance". Bij eigendomsrechten gaat het om een verdeling van bevoegdheden. Actoren die bepaalde bevoegdheden hebben zijn beter in staat hun doelen na te streven. Belangrijke vragen zijn dan: wie beschikt of beschikken over het recht op gebruik van een zaak, wie beschikt over het vruchtgebruik en wie heeft het recht om de zaak te veranderen. Vaak zullen meerdere actoren delen van deze bundels van eigendomsrechten bezitten. In dit verband is een parallel getrokken met het machtsvraagstuk in de organisatietheorie.

Vervolgens rijst de vraag hoe het besluitwormingsproces binnen een netwerk eruit ziet. Verschillende soorten besluitvormingsprocessen kunnen worden onderscheiden. De mate waarin de eigenaren van de organisatie de overheidsinstelling kunnen beheersen hangt voor een belangrijk deel af van de aard van het besluitvormingsproces binnen een netwerk. De wijze watrop de besluitvorming platsvindt hangt af van een aantal factoren, waaronder de mate waarin de doelen door meerdere actoren worden gedeeld en de mate waarin de verschillende outputs kunnen worden gemeten.

Naast de verdeling van eigendomsrechten en het besluitvormingsproces zijn ook de relaties en interacties binnen een netwerk van belang. In dit kader is ingegaan op de principaal-agent-theorie. De belangrijkste vraag in dit verband is hoe de relaties binnen een netwerk de "performance" en het gedrag van het netwerk kunnen beinvloeden. In hoofdstuk 10 wordt ook het bureaucratiemodel van Niskanen bezien en wordt onderzocht wat de gevolgen van dit soort modellen zijn voor het gedrag van publieke instellingen. Tenslotte worden de transacties binnen deze netwerken geanalyseerd met behulp van transactiekosten-economie. Onderzocht wordt in boeverre de transactiekosten-benadering gecombineerd kan worden met de gevolgde netwerkbenadering en wat de effecten zijn van het bestaan van transactiekosten op het gedrag van overheidsinstellingen. Tenslotte worden met behulp van de netwerkbenadering conclusies getrokken met betrekking tot het gedrag en de "performance" van overheidsinstellingen.

In het empirische deel wordt aan de hand van acht hypothesen geanalyseerd hoe de "performance" van een publiek netwerk in de praktijk bepaald kan worden. Het onder- 
zoek naar de hypothesen vond plaats door de beantwoording van zestien vragen. Daartoe werd enerzijds onderzocht in hoeverre de verbanden zoals weergegeven in deel 2 in werkelijkheid een rol spelen en werd anderzijds geanalyseerd hoe de versehillende delen van het netwerk in de praktijk bepaald kumnen worden (eigendomsrechten, transactiekosten, principaal-agent-verhouding e.d.). Aangegeven is dat de kwalitatieve benadering goed bruikbaar is om de verschillende delen van een netwerk in kaart te brengen. $\mathrm{Zij}$ geeft duidelijk aan hoe bepaald kan worden wie welke eigendomsrechten heeft en hoe de principaal-agentverhoudingen liggen. Bovendien incorporeert zij de transactiekostentheorie aangezien de transactiekosten van een overheidsinstelling deel uitmaken van de alternatieve kosten. Indien goed toegepast geeft deze benadering een goed inzicht in de "performance". Om te onderzoeken in hoeverre de netwerkbenadering in de praktijk kan worden gebruikt en of zij inderdaad een goed inzicht geeft in de "performance" van een overheidsinstelling zijn case studies uitgevoerd naar het Rijksinuseum, MEGA Limburg en de Belastingdienst.

Teneinde de "performance" van het Rijksmuseum te bepalen was het gelet op de waarde van de collectie vooral belangrijk om vast te stellen in hoeverre het doel wan het bewaren van het culturele erfgoed was gerealiseerd. Vervolgens moesten de kosten van deze mate van doelrealisering worden vastgesteld. Gedurende de onderzoeksperiode bleek dat het bewaren van het culturele erfgoed door het Rijksmuseum veel te wensen overliet. Omdat de collectie slecht gehuisvest was, kon vaak niet worden gecontroleerd waar een bepaald stuk uit de collectie zich bevond en wat de kwaliteit daarvan was. Tevens groeide de collectie fors, waardoor de problemen zich verder aanscherpten Eind jaren tachtig veranderden ook de doelen van de eigenaren. Het Rijksmuseum zou moeten worden omgevormd tot een flexibele organisatie. In verband met de geldende wettelijke bepalingen (Comptabiliteitswet) en de departementale regels kon het Rijksmuseum zich evenwell niet aampassen aan de gewijzigde doelen en de verandering in de omgeving. Eén en ander was reden om het Rijksmuseum geleidelijk te privatiseren. Tal van rechten werden overgedragen. Zo mocht het Rijksmuseum zelf zijn entreeprijzen vaststellen en kreeg het een eigen budget: Tegelijkertijd werd de controle op de input steeds meer vervangen door controle op de output. Deze en andere veranderingen leiden ertoe dat de "performance" verbeterde. De samenstelling van de collectie werd beter in kaart gebracht, het bewaren van kunst werd als ến van de outputs gespecificeerd in contracten, terwijl voorts de kosten werden verminderd.

Bij MEGA Limburg bleek de "public enterprise rent" vooral gebruikt te worden voor het rekenen van lage elektriciteitsprijzen, voor het aanstellen van meer werknemers en yoor het zorgen voor een veilige en zekere levering van elektriciteit. Gedurende de onderzoeksperiode verschoven de doelen. In de zeventiger jaren lag de nadruk op een weilige en zekere levering van elektriciteit. Een monopolistische marktvorm werd hiervoor noodzakelijk geacht. Aan het eind van de jaren tachtig en gedurende het begin van de jaren negentig kregen andere doelen meer nadruk, zoals efficiëntie, lage tarieven en het zo goed mogelijk tegemoet komen aan de wensen van de klanten. Bovendien werden ook de gevolgen van de Europese integratie steeds duidelijker. Om de veranderde doelen te kunnen realiseren en om beter te kunnen opereren in de gewijzigde omgeving bleek het noodzakelijk om de organisatie te wijzigen. Of en in hoeverre door de organisatiewijziging de "performance" verbetert hangt vooral af de ontwikkelingen in de omgeving en hangt voorts af van de mate waarin de concurrentie zal toenemen, waardoor de tarieven verder verlaagd kunnen worden. Verder gaat het erom of de secundaire doelen zoals het bevorderen van de werkgelegenheid gerealiseerd kumen worden tegen lagere kosten. Tenslotte mag het doel van de veilige en zekere levering niet te veel verslechteren.

Ook de Belastingdienst trachtte een hele reeks doelen te realiseren. Duidelijk is dat het 
eigenlijke doel neerkwam op de heffing en inning van belastingen ten behoeve van de overheid: Daarnaast werden verschillende bijkomende doelen nagestreefd. In hoofdstuk 18 wordt aangegever dat het grootste deel van de "public enterprise rent" wordt besteed aan een drietal doelen, te weten de verdeling van inkomen, de eerlijke uitvoering van belastingwetgeving en het zoveel mogelijk beperken van de welvaartswerliezen. Gedurende de jaren tachtig deden zich vooral problemen voor bij het eigenlijke doel. Door de verslechterende belastingmoraal, de gecompliceerde wetgeving en de toename van het aantal belastingbetalers werd steeds meer gevreesd voor een daling van het bedrag aan geinde belastingen. Bovendien nam de herverdeling van middelen, mede door de moeilijke economische situatie aan het begin van de jaren negentig, extreme vormen aan. Begin jaren tachtig ging het om ruim 3,5 miljard gulden, waarvan echter wel een belangrijk deel werd veroorzaakt door faillissementen. De reorganisatie aan het begin van de jaren negentig zorgde ervoor dat de inning efficiënter werd. Bovendien werden de bijkomende doelen op een acceptabel niveau verricht. De verdeling van inkomen nam weliswaar af, maar de rechtvaardige uitvoering van de belastingwetgeving kon mede door de Oortwetgeving goedkoper worden gerealiseerd. De realisatie van het doel van het laag houden van de welvaartsverliezen veranderde niet, aangezien geen prijzen werden gerekend. Tenslotte wordt in hoofdstuk 17 ingegaan op alternatieve besturingsstructuren voor de Belastingdienst. Aangegeven wordt dat verdere invoering van flexibele beheersregels aanbeveling verdient. Ook de oprichting wan een zelfstandig bestuursorgaan dient overwogen te worden, waarbij veel afhangt van de in de instellingswet op te nemen bepalingen en over te dragen bevoegdheden. Meer in het bijzonder gaat het erom of alleen de inning of ook de heffing wordt verzelfstandigd. Vooral bij de heffing zijn bij een eventuele verzelfstandiging; in verband met het in het Nederlandse Inkomstenbelastingstelsel in hoofdlijnen toegepaste bronnenstelsel, problemen te verwachten. Gelet op het doel van de rechtvaardige uitvoering van de belastingwetgeving zal de minister verantwoordelijk moeten blijven en zal hij dus ook, bij wijze van uitzondering, moeten kunnen ingrijpen. Een bezwaar van de Belastingdienst in de vorm van een zelfstandig bestuursorgaan is wel dat de regels waaraan deze besturingsstructuur moet voldoen nog weinig duidelijk zijn. Indien alsnog wordt besloten om de Belastingdienst om te vormen tot een dergelijk zelfstandig bestuursorgaan dient dit dan ook verbeterd te worden.

\subsection{Welke conchusies kunnen uit het onderzoek worden getrokken?}

\section{Uit het onderzoek kunnen een aantal conclusies worden getrokken.}

Een eerste conclusie is dat de "performance" van een overheidsinstelling goed kan zijn terwijl de instelling toch technisch inefficiënt produceert. Indien naar alle doelen wordt gekeken is het in dat geval niet mogelijk de welvaart te vergroten.

Een tweede conclusie heeft betrekking op de eisen die de politieke actoren stellen. Indien de doelen van de politieke actoren teveel verschillen van die van de andere belangrijke actoren, met name van het management van een overheidsinstelling, is het waarschijnlijk dat zij hiet tevreden zullen zijn over de resultaten van de instelling. In dat geval kunnen zij verschillende strategieën volgen. In de eerste plaats kunnen politieke actoren gaan streven naar privatisering. Door privatisering en door tegelijkertijd hun doelen te verwezenlijken in andere bedrijven en met andere instellingen en beleidsinstrumenten slagen zij er beter in hun doelen te realiseren. Een tweede mogelijke strategie is het wijzigen van de eigendomsrechtenstructuur. Dit kan gerealiseerd worden door een reorganisatieproces met onder andere fundamentele wijziging van de organisatiestructuur. Bij de drie onderzochte instellingen is gedurende de onderzoeksperiode een dergelijk reorganisatieproces doorgevoerd. In het geval van het Rijksmuseum was er sprake van wrijving tussen het ministerie 
van WVC en het Rijksmuseum. Door de organisatie te veranderen werd de eigendomsrechtenstructuur gewijzigd. Hierdoor werd de relatief grote zelfstandigheid van de verschillende afdelingen binnen het Rijksmuseum verkleind, waardoor de verantwoordelijke actoren minder invloed konden uitoefenen op de doelbepaling. Voorts werden personele wijzigingen doorgevoerd, waardoor de doelfuncties van individuele actoren veranderden. Een derde strategie is het beïnvloeden van de verschillende actoren door middel van het besluitvormingsproces, onder andere met behulp van financiële subsidies.

Een derde conclusie heeft betrekking op de grootte van overheidsinstellingen en de belangrijkheid van actoren (gedefinieerd als de mate waarin een actor beschikt over machtsbromen c.q. eigendomsrechten). In met name kleinere bedrijven is het aantal voor de doelbepaling relevante actoren beperkt. In dat geval is het mogelijk dat er een principaal-agent relatie ontstaat tussen bijvoorbeeld politici en management van het bedrijf. In het gehanteerde denkkader betekent dit; dat na uitgebreid onderzoek, een groot belang zal worden toegekend aan een tweetal actoren. Indien dit het geval is kan onder bepaalde voorwaarden, zoals geschetst in hoofdstuk 10 , ook het bureaucratiemodel van Niskanen worden gebruikt.

Een vierde conclusie die getrokken kan worden heeft betrekking op de verhouding van werknemers met andere actoren. Indien het doel van werknemers en andere actoren te veel verschilt neemt het risico van ziekteverzuim en ontevredenheid toe. Werknemers hebben niet de mogelijkheid hun doelen, waaronder zaken als goede werkomstandigheden en salarissen, eenzijdig op te leggen. In theorie is het dus mogelijk dat de instelling een goede "performance" heeft maar ontevreden personeel. Indien externe actoren, waaronder vakbonden, ontevreden zijn over het beleid van het bedrijf kunnen zij proberen de doelen van de overheidsinstelling te wijzigen via het lobbyen bij politieke actoren of via het onder druk zetten van het management in onderhandelingen, bijvoorbeeld via de media. Deze conclusie komt overeen met de conclusie die Bulder, Leeuw en Flap trekken in hun onderzoek naar de effecten van reorganisaties van publieke netwerken op het sociale kapitaal en de prestatie. ${ }^{1204}$ Deze sociale netwerken zijn zoals opgemerkt van invloed op de "performance". Indien een reorganisatie er toe leidt dat deze sociale netwerken uit elkaar vallen is het mogelijk dat de "performance" verslechtert in plaats van verbetert. Zij merken in dit verband op: "Thus the unintended outcome of an organizational reform that focuses on increasing efficiency, effectiveness and customer satisfaction, may be that these in fact deteriorate". ${ }^{205}$.

Verder moet worden opgemerkt dat het onderzoek een conceptueel kader levert waarmee het gedrag van instellingen binnen de collectieve sector kan worden geanalyseerd. Indien bijvoorbeeld de marktstructuir wordt gewijzigd kan met behulp van het schema in Figuur 12.1 worden geanalyseerd wat het gevolg hiervan is voor het gedrag en de "performan$\mathrm{ce}^{*}$. Hetzelfde geldt voor een groot aantal veranderingen. Dit heeft als voordeel dat een groot aantal sinuaties hiermee verklaard kunnen worden. Belangrijk is echter well dat de belangrijkheid van de verschillende factoren per netwerk verschillen en dus ook van geval tot geval moeten worden onderzocht.

Een volgende conclusie is dat grote besparingen bereikt kunnen worden indien met name instellingen met veel overheidssteun zoals Fokker, Daf e.d. of instellingen met hoge

1204 Bulder, Leeuw en Flap (1996, pp. 261 e.w.).

12005 T.a.p., p. 262. 
alternatieve kosten op deze wijze worden onderzocht. In het geval van Fokker zou zijn gebleken dat de doelen van de eigenaren niet gericht waren op winstmaximallisatie maiar op bijkomende doelen als werkgelegenheid, goede arbeidswoorwaarden e.d.. Dit lijkt waarschijnlijk aangezien Folker er in slaagde om ten tijde van het faillissement in korte tijd grote efficiêntiewinsten te bereiken. Dit was stellig ook eerder mogelijk geweest. Blijkbaar was dit echter niet de primaire doelstelling. Op zich hoeft dit niet erg te zijn. Het is echter wel een goede zaak indien het parlement en het publiek hier zicht op hebben. Hetzelfde doet zich nu in feite voor met KPN. Wat zijn de doelen van de eigenaren? Is dit winstmaximalisatie, hoge omzetgroei e.d. of juist het zoveel mogelijk instandhouden van oude privileges. Indien dat laatste het geval is zall bijvoorbeeld onvoldoende gesneden worden in de organisatie en het personeelsbestand om maximale winit te bereiken. Allerlei bijkomende doelen worden nagestreefd, hetgeen op zich, gegeven de doelen wan de eigenaren, evenwel efficiènt kan zijn. Het is duidelijk is dat het de winstontwikkeling niet ten goede zal komen.

Tenslatte is de geschetste en toegepaste kwalitatieve benadering niet alleen bruikbaar voor de analyse van het functioneren van overheidsinstellingen. In iets gewijzigde vorm kunnen ook hele beleidsprocessen, van beleidsontwikkeling tot beleidsuitvoering door bijwoorbeeld een overheidsinstelling, geanalyseerd worden. Ook allerlei regelingen zoals nieuwe wetten, het gebruik wan convenanten en bijvoorbeeld milieu-effectrapportages. zouden geanalyseerd kunnen worden. Onderzocht moet dan worden wat de doelen zijn van degenen die dergelijke regels opstellen, in hoeverre deze doelen behaald worden en wat de kosten van deze doelen zijn.

In het empirische deel zijn verder door middel van de beantwoording van zestien wragen een achttal hypothesen onderzocht. In dit verband worden de volgende conclusies getrokken:

\section{Hypothese 1:}

In hoofdstuk 14 zijn een aantal problemen genoemd die zich voordoen bij het bepalen wan de doelen van een netwerk. Uit het onderzoek bleek zoals ook weergegeven in paragraaf 13.7 dat de kwalitatieve benadering tegemoet komt aan de tegen de doelbenadering aangevoerde bezwaren. Veel overheidsinstellingen hebben vage doelstellingen. Deze doelen kunnen slechts door een gecombineerde aanpak worden gedetermineerd. Daarbij is vooral ook een analyse van de uit het uiteindelijke keuzegedrag blijkende doelen van belang. De door deze methode ontdekte doelen dienen vergeleken te worden met de door de houders van eigendomsrechten genoemde doelen en de doelen die met de bestaande verdeling van eigendomsrechten kunnen worden nagestreefd. Vervolgens moeten de baten van de verschillende doelen worden afgezet tegen de kosten ervan.

\section{Hypothese 2:}

Uit de case studies blijkt dat een netwerk dat wordt gekenmerkt door een bepaalde verdeling van eigendomsrechten, indien het streeft naar een optimale "performance", slechts een bepaald goederempakket kan realiseren. Indien de verdeling van eigendomsrechten verandert, bijwoorbeeld omdat de minister taken will afstoten, veranderen ook de doelen van het netwerk.

Hypothese 3:

Uit het onderzoek blijkt dat het noodzakelijk is om de alternatieve kosten als uitgangspunt 
te nemen. Dit vloeit voort uit de gevolgde instinationele benadering, waarbij het niet alleen gaat om het eigenlijke doel maar om alle doelen van de organisatie. Uit het onderzoek bleek bijvoorbeeld dat het Rijksmuseum een aantal doelen kon realiseren. Dit. betekende dat de ingezette middelen niet voor andere doelen gebruikt konden worden. De overheid kon het geld bijwoorbeeld niet uitlenen en daardoor rente ontvangen. Deze gederfde winst vormen de kosten van de door de het Rijksmuseum voortgebrachte goederen en diensten.

\section{Hypothese 4:}

Uit de netwerkbenadering kan worden afgeleid dat een institutionele analyse moet worden gevolgd. Zoals Buchanan en Tullock aangeven functioneren instituties, in dit geval publieke netwerken, gegeven alle beperkingen efficiënt. Dat neemt niet weg dat indien de omgeving verandert het netwerk zich om een optimale situatie te behouden zal moeten aampassen. Dat betekent niet alleen een aanpassing van de verdeling van eigendomsrechten maar ook meer algemeen van de relaties tussen actoren, de aard van de transacties en van de besluitworming bininen het netwerk.

\section{Hypothese 5:}

De "performance" van een netwerk kan het beste kan worden onderzocht met de kwalitatieve benadering. Het blijkt mogelijk te zijn om in de praktijk aan te geven wie de eigenaren zijn, welke doelen deze eigenaren hebben, wat het relatief belang is van de doelen, welke principaal-agent-relaties er bestaan en wat de (transactie-) kosten van deze doelen zijn. Hierdoor wordt een goede indruk gekregen in de wijze van functioneren van de betreffende instelling. Deze conclusie sluit goed aan bij recente ontwikkelingen binnen dit vakgebied. Een aantal onderzoeken van de Algemene Rekenkamer naar de doelmatigheid van instellingen en regels vertoont bijvoorbeeld overeenkomsten met de kwalitatieve benadering. 1206 $^{2}$ Veel bestuurskundig onderzoek was sterk gericht op de effectiviteit. Dit. soort onderzoek schiet in die zin tekort dat effectiviteit op zich weinig zegt. Het is denkbaar dat een doel gehaald wordt maar dat de kosten bijvoorbeeld $100 \%$ hoger zijn dan noodzakelijk. Ook binnen dit vakgebied wordt steeds meer beseft dat ook de kosten in overweging moeten worden genomen.

\section{Hypothese 6:}

In de loop der tijd doen er zich binnen een netwerk en in de omgeving van een netwerk allerlei ontwikkelingen voor. Vaak blijken er slechts tot op bepaalde hoogte binnen een netwerk veranderingen mogelijk. De vraag rijst waarom geen efficientere institutie tot stand komt. In hoofdstuk 4 is opgemerkt dat de reden dat deze (efficiënte) instituties niet tot stand komen bijvoorbeeld te maken heeft met het ontbreken van informatie bij individuen over de hoogte van de transactiekosten (alternatieve kosten) van alternatieve instituties. Het is aan economen om deze alternatieve instituties te analyseren en zo een belangrijke bijdrage te leveren aan het bereiken van efficientiewinsten. Het gaat er dan om instituties met elkaar te vergelijken en on te bezien in hoeverre er verbeteringen mogelijk zijn door het netwerk te wijzigen. Daartoe dient de netwerkbenadering. Het opgestelde netwerkmodel kan bijwoorbeeld gebruikt worden bij het beoordelen van de

1206 Vergelijk bijwoorbeeld het rapport naar het functioneren wan de Rijksmusea. 
vraag of en vooral hoe overgegaan moet worden op een andere besturingsstructurur. Daartoe kunnen uit het model eenvoudig een aantal vragen worden afgeleid die in elk geval beantwoord moeten worden, wil de "performance" er door privatisering daadwerkelijk op vooruitgaan. In de volgende paragraaf worden een aantal van dit soort vragen genoemd.

\section{Hypothese 7:}

Een andere conclusie die getrokken kan worden is dat de kwalitatieve benadering en de geschetste netwerkbenadering ook van toepassing kunnen zijn op particuliere organisaties. In de eerste plaats streven steeds meer particuliere organisaties ook allerlei bijkomende doelen na. Denk bijvoorbeeld aan het toenemende belang van het milieu. De verschillende onderdelen van het netwerk zullen wel afwijken van die van een publiek netwerk en daarmee zal ook de uitkomst van de kwalitatieve analyse verschillen. Het lijkt de moeite waard om bijwoorbeeld een concern als Philips eens te onderzoeken met deze benadering. In de tweede plaats kan de ontwikkelde benadering gezien worden als een integratie van een drietal belangrijke benaderingen van de onderneming, te weten de aandeelhouderswaardetheorie, de managementtheorie en de ondernemerstheorie. ${ }^{1207} \mathrm{Bij}$ de aandeelhouderswaardetheorie staan de aandeelhouders centraal. Bij de managementtheorie ligt het zwaartepunt bij het management en bij de ondernemerstheorie tenslotte ligt het zwaartepunt bij de werkenden in een bedrijf. Uit de netwerkbenadering blijkt heel duidelijk dat de mate waarin de ene of de andere groep actoren domineren per netwerk kan verschillen.

\section{Hypothese 8 .}

Voorts valt op, zoals opgemerkt in de vorige paragraaf, dat de doelstellingen van de drie onderzochte overheidsinstellingen gedurende de onderzoeksperiode veranderde. De conchusie die getrokken kan worden is dat indien een organisatie de gewijzigde doelstellingen wil realiseren een groot aantal wijzigingen nodig zijn in het netwerk. Deze conclusie sluit goed aan bij de bevindingen van Miller en Friesen en meer recentelijk De Kam en Van den Berg. ${ }^{1208}$ Indien de doelen gewijzigd worden dienen eveneens de werschillende onderdelen van het netwerk opnieuw daarop te worden afgestemd. Eigendomsrechten moeten worden aangepast, informatiesystemen gewijzigd. Vaak zullen ook de relaties binnen het netwerk en de organisatiecultuur moeten worden aangepast.

Uit het empirische onderzoek blijkt ook dat er nog een aantal problemen zijn die verder overwonnen moeten worden. Het gaat daarbij vooral om het in de toekomst beter kwantificeren van het relatief belang van de doelen en de kosten van de verschillende doelen. Dat heeft niet alleen met dit soort onderzoek te maken, maar ook alles met de verslaglegging door de overheid. Deze verslaglegging dient verder verbeterd te worden. Het is belangrijk dat elke overheidsorganisatie in een financieel verslag duidelijk aangeeft welke doelen zij nastreeft, in welke mate deze doelen gerealiseerd worden, wat de kosten van die activiteiten en die mate van doelrealisering zijn en hoe dat opgesplitst kan worden per doel. Hierdoor krijgt de overheid veel meer inzicht in de kosten van bepaalde doelen en is veel beter parlementaire controle mogelijk. Het parlement is dan ook beter in staat om prioriteiten aan te geven. Het is duidelijk dat de eigenaren van een overheidsinstelling

1207 De Jong (1997, pp. 164-167).

${ }^{1208}$ Miller en Friesen (1984). De Kam en Van den Berg (1992, p. 26). 
hier lang niet altijd baat bij zullen hebben. De cijfers die overheidsinstellingen vermelden in een financieel verslag dienen dan ook minimaal onderworpen te worden aan accountantscontrole.

\subsection{Een toepassing: privatisering en privatiseringsschema's}

In dit onderzoek wordt een theoretische en empirische verklaring van de "performance" van een overheidsinstelling gegeven. Daarbij is steeds uitgegaan van een positieve benadering. Hoewel strikt genomen buiten de probleemstelling van dit onderzoek vallend is het voor een goed inzicht in de ontwikkelde benadering van belang om een stap verder te gaan. Met name in bijvoorbeeld Oost- maar ook in West-Europa is het vraagstuk van privatisering van groot belang. Al snel wordt met name in Oost-Europese landen gedacht dat de beste privatisering een volledige verzelfstandiging is, dus zonder dat er invloed van de overheid blijft. Deze gedachtengang is sterk gebaseerd op het idee dat overheidsinstellingen inefficiënt zijn en dat hier zo snel mogelijk iets aan gedaan moet worden. Gezien het verleden van veel Oost-Europese landen, die veelal nog steeds te maken hebben met een omvangrijke bureaucratie, is dit alleszins begrijpelijk. Dit neemt echter niet weg dat deze landen het risico lopen zichzelf hiermee in grote problemen te brengen. Een verkeerd uitgevoerde privatisering hoeft de "performance" niet te verbeteren maar kan deze aanzienlijk verslechteren. Dit leidt dan niet tot bezuinigingen door de overheid maar tot faillissementen, werkloosheid, lagere productie en uiteindelijk minder overheidsinkomsten. Hoewel wellicht minder extreem doet dit zich ook voor in West-Europese economieën. Denk bijvoorbeeld aan de privatisering van de sociale zekerheid. Daarom rijst de vraag over welke zaken tenminste duidelijkheid moet bestaan en over welke zaken in ieder geval een beslissing moet worden genomen teneinde te komen tot een optimale privatisering. De vragen die beantwoord moeten worden hangen naw samen met de vragen die gesteld moeten worden in verband met het onderzoek naar de "performance" van een overheidsinstelling, aangezien "performance"-verbetering wordt beoogd, gegeven de nieuwe doelen van de politieke actoren.

Het volgende privatiseringsschema kan daarbij worden gevolgd: ${ }^{2009}$

\subsection{1.}

Welk soort economisch beleid wordt gevoerd door de regering van een land? Deze vraag is essentieel aangezien dit beleid grote invloed zal hebben op de mate van succes van de privatisering. Een goed voorbeeld is Duitsland. De Treuhand stond voor de opdracht Oost-Duitse staatsbedrijven te verkopen/privatiseren. Tegelijkertijd werden de lonen in Oost-Duitsland op het West-Duitse niveau gebracht. Het is dan essentieel om te weten welke doelen de geprivatiseerde onderneming moet nastreven. Indien dit onder meer is de werkgelegenheid binnen deze bedrijven op peil te houden dan zall dat betekenen dat de privatisering vrijwel gedoemd is te mislukken, tenzij de overheid op grote schaal bijspringt. Het is dan nog maar de vraag indien alle kosten worden afgewogen, of er sprake is van een verbetering van de "performance".

\subsection{2.}

Inventariseer welke behoeften er bestaan bij het publiek (de doelgroep waaraan de

${ }_{1209}$ Zie ook: Commissie Sint (1993, pp. 2 e.v.). Vergelijk ook: Mitchell en Zeldes (1996, paragraaf 2) en Wallin (1997, pp. 11 e.w.). 
goederen en diensten door de overheid worden geleverd) en wat de bestaande problemen zijn. Wat zijn de oorzaken van die problemen? Welke overheidsinstellingen moeten worden geprivatiseerd? In dit verband kunnen een tweetal selectiecriteria worden onderscheiden. Enerzijds kan gekeken worden naar de contante waarde van de netto geaggregeerde baten voor de consument en anderzijds naar het rendement op eeuwigdurende staatsleningen. Beesley en Littlechild noemen als selectiecriterium een positieve contante waarde van de geaggregeerde netto baten voor de consument. Bij netto baten gaat het om besparingen zoalls de prijsverlaging voor de consument en de lagere belasting in verband met de verminderde subsidies. Voorts zijn de effecten met betrekking tot de productie en bijvoorbeeld de kwaliteit van de beschikbare goederen en de innovatie van belang. ${ }^{210}$ De gedachte is nu, dat de overheidinstellingen die na privatisering tot de hoogste netto baten voor de consumenten en andere besparingen leiden geprivatiseerd zouden moeten worden. ${ }^{1211}$ Een alternatief selectiecriterium is het rendement op eeuwigdurende staatsleningen. Volgens deze benadering moeten overheidsinstellingen die een winst behalen die lager ligt dan het rendement op eeuwigdurende staatsleningen geprivatiseerd worden.

Bij de beshuitvorming maakt de overheid dan een afweging tussen enerzijds de lagere rentelasten op de staatsschuld en anderzijds de gederfde inkomsten uit het geprivatiseerde bedrijf. Daarbij dient ook gekeken te worden naar de door de overheidsinstelling voortgebrachte externe effecten.

\subsection{3.}

Met behulp van kwantitatieve gegevens moet een schatting gemaakt worden van de omvang van de doelgroep. De relevante markt moet met andere woorden systematisch in kaart worden gebracht.

\subsection{4.}

De volgende vraag luidt: welke doelen moet de geprivatiseerde organisatie nastreven? Daarbij dienen de voorgaande twee punten in overweging te worden genomen.

\subsection{5.}

Welke randvoorwaarden zijn er bij die doelstelling? Mag de geprivatiseerde onderneming bijvoorbeeld onbeperkt snijden in het personeelsbestand en bijwoorbeeld onbeperkt onrendabele onderdelen sluiten of moet zij aan allerlei randvoorwaarden voldoen.

\subsection{6.}

Stel een werkopdracht op waarin nauwkeurig is aangegeven wat de verwachtingen zijn die ten grondslag liggen aan de privatisering. Daarin moeten in elk geval de voorgaande vijf punten zijn opgenomen. Verder moeten structuur- en prestatiespecificaties zijn opgenomen. De structuurspecificaties bepalen binnen welke structuur de dienst geleverd moet. worden. Het gaat daarbij vooral om de aard van het productieproces. Het gaat er hierbij om zo nauwkeurig mogelijk te bepalen welke werkmethode de geprivatiseerde instelling

${ }^{1210}$ Curwen (1986, p. 198).

${ }^{1211}$ Beesley en Littlechild (1983, pp. 9 e.v.). 
moet volgen en welke middelen zijn voorgeschreven? Hoeveel personeelsleden en wat voor soort personeelsleden moeten na privatisering worden ingezet of zijn er geen beperkingen op dit punt? Bij de prestatiespecificatie gaat het erom welke prestatie wordt verlangd van de geprivatiseerde instelling. Hierbij kan onderscheid gemaakt worden tussen output- en outcomefactoren. Indien een elektriciteitsproductiebedrijf wordt geprivatiseerd gaat het niet alleen om het specificeren van de elektriciteitsproductie maar ook om het zo duidelijk mogelijk in kaart brengen van de bijkomende doelen die de geprivatiseerde onderneming ook moet voortbrengen. Hoeveel moet de geprivatiseerde onderneming investeren in millieuschone technieken, in hoeverre moet zij bijdragen aan de ontwikkeling van de regio etc. De werkopdracht moet zodianig zijn geformuleerd dat de doelstellingen zo goed mogelijk kunnen worden gerealiseerd. $\mathrm{Zij}$ dient er mede toe om de transactiekosten in de toekomst zoveel mogelijk te verminderen. De toekomstige besturingsstructuur kan worden gezien als een agent met de overheid als principaal. Het is dan van belang dat beide partijen precies weten waar ze in de toekomst aan toe zijn. Bovendien is de overheid met behulp van een duidelijke werkopdracht beter in staat cle geprivatiseerde instelling in de toekomst te controleren.

\subsection{7.}

Gelijktijdig met stap 6 moet de optimale besturingsstructuur bepaald worden. Dit kan een particuliere onderneming zijn maar ook allerlei andere vormen zijn mogelijk. Hier is het onderscheid van Savas, zoals behandeld in hoofdstuk 2, van belang "Welke goederen worden door de instelling voortgebracht? Het ene goed vereist een andere eigendomsrechtenverdeling dan een ander goed. Duidelijk is dat er meerdere doelen/goederen zijn. Van groot belang is de vraag in hoeverre de voortbrenging van het goed duidelijk gespecificeerd kan worden. In hoeverre is dit goed geregeld in de bestaande juridische regelgeving? Kan het goed dat op grond van de regelgeving moet worden voortgebracht duidelijk gemeten worden of juist niet? Hierbij kan gedacht worden aan de WAO. De wettelijke regel was dermate dubbelzinnig geformuleerd dat het beroep erop niet te voorspellen bleek. Verder is de vraag van belang in hoeverre er duidelijke kwaliteitsnormen bepaald kunnen worden. Bij het bepalen van de beste besturingsstructuur moet bedacht worden dat een overheidsinstelling ook vervangen kan worden door meerdere van de in hoofdstuk 2 genoemde besturingsstructuren. Het eigenlijke goed wordt bijvoorbeeld voortgebracht door een B.V, terwijl de bijkomende doelen op contractbasis worden nagestreefd door een ander bedrijf.

\subsection{8.}

Hierbij is ook de mate van specificiteit van belang. In hoofdstuk 11 is aangegeven dat indien de mate van specificiteit hoog is, externe verzelfstandiging moeilijker wordt.

\subsection{9.}

Vervolgens moet onderzocht worden wat de verwachte kosten wan woortbrenging door de betreffende besturingsstructuur zullen zijn. ${ }^{1212}$ Dit kan per overheidsactiviteit verschillen. Het is mogelijk dat er op grond van punt 7 meerdere besturingsstructuren zijn geselecteerd. Vervolgens moet bezien worden in hoeverre deze besturingsstructuren kunnen voldoen aan de specificaties zoals opgenomen in de werkopdracht en wat de kosten van de voortbrenging door een bepaalde combinatie van besturingsstructuren zijn. Tenslotte moet een keuze worden gemaakt voor een bepaalde variant.

${ }^{1212}$ Zie ook: Verma (1996, pp. 59-60). 
Vervolgens moet de optimale juridische structuur worden bepaald. Indien bijvoorbeeld op grond van de analyse van punt 7,8 en 9 wordt gekozen voor privatisering dan moet nog worden bepaald voor welke juridische vorm wordt gekozen. Kan de geprivatiseerde instelling het best functioneren als een stichting, een vereniging of als een beursgenoteerde N.V.? Tevens moet de waarde van de overheidsinstelling worden bepaald. Jansen ${ }^{1213}$ stelt dat de waarde van de overheidsinstelling gelijk is aan de som van de intrinsieke waarde van de vaste activa en de rentabiliteitswaarde. Dit bedrag moet dan vanzelfsprekend wel worden verminderd met de contante waarde van de kosten. Bij deze kosten kan gedacht worden aan de kosten van toekomstig onderhoud, de kosten van de aandelenuitgifte en de eventuele kosten die het gevolg zijn van het nemen van milieu-

maatregelen. ${ }^{1214} \mathrm{De}$ intrinsieke waarde kan worden bepaald door het verschil te nemen tussen enerzijds de actuele waarde van de vaste activa en anderzijds de voorzieningen en verplichtingen. De rentabiliteitswaarde is gelijk aan de contante waarde van de bestaande en de toekomstige winstgevendheid van een overheidsinstelling. De contante waarde kan worden bepaald door de rentabiliteit van één of meer soortgelijke bedrijven in de betreffende bedrijfstak als discontovoet te nemen.

\subsubsection{1.}

Voorts moet onderzocht worden welke eigendomsrechten, gegeven de doelen moeten worden overgeheveld naar het bedrijf. De vragen zijn dan:

\subsubsection{1.}

In hoeverre moet het toezicht op de aankoop van de inputs en de controle op de prestatie ervan worden overgeheveld? Indien de overheidsinstelling zelf kan beslissen welke inputs worden gekocht zonder daarbij langdurig te moeten wachten op de besluitvorming door het parlement zal dat de slagkracht al snel ten goede komen. Hetzelfde geldt voor het toezicht op de prestatie van de productiefactoren. De overheidsinstelling kan dan zelf een afweging maken tussen verschillende soorten machines, tussen machines en kapitaal e.d. Of dit recht moet worden overgedragen hangt echter grotendeels van de doelen af. Indien de overheidsinstelling zelf toeziet op de aankoop van inputs zou zij deze bijvoorbeeld ook. in het buitenland kunnen kopen. Ook zou zij bijvoorbeeld kunnen beslissen op grote schaal te moderniseren waardoor veel mensen ontslagen zullen worden. Dit kan volledig. ingaan tegen datgene wat met de privatisering werd beoogd. Ook is het denkbaar dat bepaalde elgendomsrechten wel worden overgedragen en andere niet, waardoor de "performance" niet verbeterd, maar juist verslechterd. Neem bijvoorbeeld een bedrijf dat voortaan zelf mag beslissen welke productiefactoren worden aangeschaft, maar niet het recht heeft om winst te maken. Het is denkbaar dat de inputs dan nog steeds in te grote hoeveelheden en verkeerde samenstellingen zullen worden aangeschaft, zeker indien er ook sprake is van subsidiëring.

\subsubsection{2.}

In hoeverre moet het toezicht op de productieresultaten worden overgedragen?

\footnotetext{
1213 Jansen (1993, p. 46).

${ }^{1214}$ Curwen (1986, p. 201).
} 
In hoeverre moet het recht op het toezicht op het productieproces worden overgedragen?

\subsubsection{4.}

In hoeverre moet de instelling, gegeven de doelen zelf kunnen bepalen hoeveel mensen zij in dienst neemt en wie zij in dienst neemt? Het is van groot belang dat het van te voren volstrekt duidelijk is wie dit recht krijgt en in hoeverre dit spoort met de doelstellingen van privatisering.

\subsubsection{5.}

In hoeverre krijgt de overheidsinstelling het recht op de winst; kan zij er een vermogen op nahouden en heeft zij toegang tot de kapitaalmarkt? Indien het overheidsbedrijf het recht krijgt een eigen vermogen op te bouwen is het van groot belang dat er ook prikkels bestaan die ertoe leiden dat dit wermogen efficiënt wordt besteed. Indien de overheid een aantal andere rechten behoudt maar wel dit recht overdraagt kan het goed zijn dat, zoals opgemerkt in hoofdstuk 6, het gebruik van de (verkapte)winst onvoldoende gecontroleerd wordt door het Ministerie. In dat geval kan deze winst gebruikt worden door het management voor allerlei eigen doelen. De "performance" gaat er dan op achteruit, in plaats van op vooruit zoals beoogd was.

\subsubsection{6.}

Wie krijgt het recht de geprivatiseerde instelling te wijzigen, te verkopen of zelfs te liquideren? Wie krijgt bijvoorbeeld de aandelen? Worden deze verhandelbaar? Komt er een beursnotering? Aandelen kunnen worden uitgegeven op de beurs of na inschrijving. Bij inschrijving kunnen een tweetal methoden worden onderscheiden. De eerste methode houdt in dat belangstellenden kunnen inschrijven tegen een vaste prijs. De tweede methode maakt gebruik van het tender systeem. De inschrijvers geven dan van te voren aan hoeveel aandelen zij willen kopen en tegen welke prijs. Daarbij moet bedacht worden dat indien de nieuwe eigenaren van dit eigendomsrecht menen dat beëindiging van het bedrijf of bijvoorbeeld splitsing in onderdelen en verkoop van die onderdelen voor hen gunstiger is, dit tegen de bedoeling van de overheid kan ingaan. Dit zal bijvoorbeeld het geval zijn indien hierdoor een groot aantal arbeidsplaatsen verloren gaan of indien een bepaalde industrietak hierdoor verdwijnt. Voor de nieuwe eigenaren kan dit evenwel zeer winstgevend zijn, bezien vanuit de politieke eigenaren worden de doelen niet gehaald en is er sprake van verslechtering van de "performance". Het bedrijf betaalde bijvoorbeeld eerst lonen en belastingen terwijl ook de werknemers belasting betaalden. Daar staat tegenover dat nu de overheid minder belasting moet betalen, maar wel meer geld kwijt is aan uitkeringen. Tevens zal zij de andere bijkomende doelen op een andere manier moeten realiseren, hetgeen duurder kan zijn.

\subsubsection{2.}

Vervolgens moet bezien worden of en in hoeverre de wijziging van het netwerk/privatisering gepaard moet gaan mett voordelen? Hierbij kan gedacht worden aan een (te) lage uitgifteprijs van aandelen maar ook aan de vraag of de huisvesting en de grond moet worden geschonken aan de te privatiseren instelling. In hoeverre dergelijke voordlelen 
moeten worden toegekend hangt vooral af van de doelen die de politieke actoren hebben met de privatisering.

\subsubsection{3.}

De volgende vraag die gesteld moet worden is in hoeverre de "public enterprise rent" moet en kan worden beperkt. Stel bijwoorbeeld dat de geprivatiseerde onderneming nog slechts de helft van de doelen en mate van doelrealisering realiseert. Indien de "public enterprise rent ${ }^{n}$ met een derde wordt teruggebracht doet het bedrijf het slechter. De bijkomende doelen kosten meer geld.

\section{3 .14 .}

Hiermee verwant is de vraag in hoeverre de doelen, indien gekeken wordt naar de gehele economie, goedkoper voortgebracht. Indlien de geprivatiseerde overheidsinstelling de helft van de doelen voor een vijfde van de kosten voortbrengt $(10 \%$ van de oorspronkelijke kosten) lijkt dat een indrukwekkende werbetering. Indien echter de overheid ook nog $30 \%$ van de andere doelen wil realiseren en de voortbrenging van deze doelen door andere instellingen, subsidies etc. alleen kunnen worden gerealiseerd tegen het dubbele van de orrspronkelijke kosten, verslechterd per saldo de "performance". Concreet moet vaststaan hoe de resterende doelen zullen worden gerealiseerd. Eén en ander kan met een eenvoudig aan hoofdstuk 2 ontleend voorbeeld geillustreerd worden. Stel de overheid geeft aan een bedrijf een subsidie van 10 . Het bedrijf betaalt 80 aan loon, terwijl de werknemers en het bedrijf per saldo 40 betalen aan belastingen aan de overheid. Per saldo ontvangt de overheid dus 30. Stel nu dat de politieke actoren besluiten de overheidsinsteling volledig te privatiseren. Het geprivatiseerde bedrijf ontslaat vervolgens $3 / 4$ van het personeel en halveert de productie. De betaling aan lonen daalt dienovereenkomstig tot 20 , terwijl de belastingbetaling afneemt tot 15 . De overheid betaalt vervolgens de werkloze werknemers een uitkering van 20. Dit betekent dat de overheid er per saldo 35 op achteruit is gegaan. Dit geldt niet alleen voor het doel van de werkgelegenheid maar kan voor elk doel gelden. Natuurlijk is dit slechts een eenvoudig voorbeeld. Zo rijst de vraag of deze mensen werkloos blijven of dat zij binnen een redelijke termijn een baan zullen vinden, zonder dat anderen daardoor werkloos worden. Ook kan het zo zijn dat op de langere termijn de economische groei door de modernisering toeneemt, waardoor er op lange termijn wel een duidelijke verbetering gerealiseerd wordt. Dit voorbeeld impliceert dan ook niet dat er niet geprivatiseerd moet worden. Het geeft aan dat nauwkeurig moet wordlen afgewogen hoe de verschillende doelen het best gerealiseerd kunnen worden, welke marktstructuur daarvoor nodig is en welke eigendomsrechten daarvoor moeten wordlen overgedragen.

\section{3 .15 .}

Een van de belangrijkste punten bij privatisering is de tijdsafbakening daarvan. Er moet duidelijk bepaald worden in hoeveel tijd de overheidsinstelling geprivatiseerd moet worden. De snelheid van privatisering wordt voor een belangrijk deel bepaald door de vraag welke eigendomsrechten moeten worden overgedragen. Stiglitz benadrukt dat alleen al de aankondiging van privatisering het gedrag van managers en werknemers kan verandleren. Hij stelt: "In cases where the managers do not divert resources to their own benefit, workers may effectively seize control of the firm and exercise it for their own benefit. Capital is depleted, withe the firm's profits going to pay wages rather than being 
reinvested in the firm". ${ }^{215}$ Verder merkt hij op: "Key employees leave, and effort is reduced, or at least diverted, as employees focus their intention on seeking jobs elsewhere or entrenching themselves within the firm". Door de aankondiging van privatisering kan de "performance" van de overheidsinstelling negatief worden beïnvloed. Op grond van dit soort overwegingen zou een snel uitgevoerde privatisering met een duidelijke planning de voorkeur verdienen.

\subsubsection{6.}

Voorts moet worden bepaald hoe de nieuwe besturingsstructuur aan middelen komt. Gebeurt dit via de markt of verstrekt de overheid ook subsidies. De vraag is in het laatste gevall welke financieringsmogelijkheden er zijn? Daarbij kan gedacht worden aan input-, proces- of outputfinanciering. De financieringsmogelijkheid hangt voornamelijk af de vraag of de output meetbaar is en of we inzicht hebben in de technologie (het productieproces). ${ }^{1216}$

In dit onderzoek is vanuit een institutionele analyse ingegaan op de "performance" van owerheidsinstellingen. Het ging er om in hoeverre instituties goed functioneren en uiteindelijk of er verbeteringen mogelijk zijn. Door het volgen van deze zestien stappen is het in principe mogelijk om de besturingsstructuur inderdaad zodanig te wijzigen dat een "performance"-verbetering gerealiseerd wordt.

1.215 Stiglitz (1994, p. 182).

1216 Van Gemerden (1987). 


\section{Appendix 1. De Normatieve benadering}

\section{Inleiding}

In deze appendix wordt ingegaan op de normatieve benadering. Aandacht wordt besteed aan de vraag welke doelen een overheidsinstelling zou moeten nastreven en de vraag welke prijzen een overheidsinstelling zou moeten rekenen.

\section{A.1 Welke doelen zou een overheidsinstelling op grond van de normatieve benadering moeten nastreven?}

In de literatuur is veel aandacht besteed aan de normatieve theorie van overheidsinstellingen en meer in het bijzonder aan de doelen van overheidsinstellingen. Het gaat daarbij om de beantwoording van de vraag welke doelen overheidsinstellingen zouden moeten nastreven. Deze doelen worden veelal afgeleid van een welvaartseconomische benadering. De onderliggende veronderstelling is dat de overheid een welvartsfunctie maximaliseert met daarin het nut van alle individuen in een land. Hieruit worden vervolgens doelen afgeleid voor een overheidsinstelling. In theorie kunnen een reeks van doelen worden onderscheiden.

\section{A.2 Levert de maximalisatie van een welvaartsfunctie een juist beeld op van het feitelijke gedrag van een overheidsinstelling?}

Er kunnen een aantal bezwaren worden aangevoerd tegen het concept van het maximaliseren van een welvaartsfunctie. Hierna worden een tweetal categorieèn vragen behandeld. In de eerste plaats de vraag of een welvaartsfunctie in de praktijk gebruikt kan worden en anderzijds de vraag of een dergelijke welvaartsfunctie wel datgene oplevert wat in dit deel (hoofdstukken $2-12$ ) beoogd wordt, namelijk het verklaren van het feitelijke gedrag van een overheidsinstelling.

\section{A.2.1 Is het in werkelijkheid mogelijk en zinvol om gebruik te maken van welvaarts- functies?}

In de literatuur is veel geschreven over het opstellen van welvaartsfuncties. Veel van deze literatuur is gericht op het consumentengedrag en derhalve slechts beperkt te gebruiken voor het affeiden van een doelfunctie voor een overheidsinstelling. Hier zal kort worden ingegaan op de mogelijkheid om met behulp van een welvaartsfunctie doelen af te leiden voor een overheidsinstelling. Met betrekking tot het bepalen van doelen van organisaties merkt Simon op: "Either we must explain organizational behavior in terms of the goals of the individual members of the organization or we must postulate the existence of one or more organization goals, over and above the goals of the individuals" ${ }^{1217}$

In het geval van de normatieve benadering wordt in feite de laatste methode gevolgd. Door middel van de maximalisering van een welvaartsfunctie worden doelen geattribueerd

${ }^{1217}$ Simon $(1976$, p. 257$)$. 
aan een overheidsinstelling. In een dergelijke welvaartsfunctie is het mut van alle individuen in een samenleving opgenomen. Indien het gezamenlijke nut van meerdere individuen bepaald moet worden ontstaat het probleem dat het belang van de eén kan botsen met het belang wan een ander. De vraag rijst dan ook hoe de welvaart van het ene individu moet worden afgewogen tegen de welvaart van een ander individu. Hiervoor zijn in principe een tweetal mogelijkheden. ${ }^{1218}$ De eerste methode is die van de interpersonele (of intrapersonele) mutswaardering In dat geval bepaalt een externe actor aan welk doel een hoger nut wordt toegekend. Dit impliceent dat deze actor vaststelt aan de welvaart van welk individu een groter belang moet worden gehecht. De tweede methode is die van de interpersonele nutsvergellijking. Deze methode houdt in dat de behoeftebevrediging die een bepaald individu van een bepaald doel ondervindt wordt afgewogen tegen de bevrediging die een ander imdividu van dat goed ondervindt: ${ }^{1219}$ Essentieel hierbij is de wijze waarop het individuele nut gemeten wordt. Van den Doell merkt op dat interpersonele nutsvergelijking alleen mogelijk is indien in de eerste plaats kan worden bepaald hoeveel van het ene doel voor een individu gelijkwaardig is aan een bepaalde hoeveelheid van een ander doel en indien in de tweede plaats kan worden vastgesteld wat de verhouding is tussen het nut van het ene en het nut van een ander individu. ${ }^{1220}$

De vraag rijst allereerst op wat voor een schaal het eerste aspect van interpersonele nutsvergelijking kan worden gemeten. ${ }^{1221}$ In het algemeen kan onderscheid worden gemaakt tussen de ordinale en de cardinale methode. Volgens de ordinale methode is het nut niet in absolute zin meetbaar, terwijl dat in het geval van kardinaal nut wel het geval is. Een schaal is ordinaal indien alleen gewicht mag worden toegekend aan het groter of kleiner zijn van de getallen. Doelenpakketten worden slechts gerangschikt naar voorkeur met behulp van de nutsfunctie. Dit impliceert dat elke monotoon stijgende transformatie van de nutsfunctie ook bruikbaar is: In het geval van de cardinale meetmethode wordt gebruik gemaakt van een interval of ratio meetschaal. In het geval van een ratioschaal kan er worden gedeeld en vermenigvuldigd. Het cijfer 10 impliceent een vijf maal zo hoog nut als het cijfer 2, uitgaande van een mulpunt. Indien er wordt gemeten op intervalniveau betekent dit dat gelijke afstanden op een schaal een gelijk nut impliceren. Er kan evenwel niet vermenigvuldigd worden. Wel kunnen er lineaire bewerkingen worden toegepast. Riker en Ordeshook merken op dat voor het bepalen van de vraag hoe de welvaart die voortvloeit uit het ene doel zich verhoudi met de welvaart zoals die voortwloeit uit een ander doel, het noodzakelijk is nut te meten op rationiveau. Daarnaast moet voor interpersonele nutsvergelijking voldaan worden aan het tweede hierboven vermelde criterium. ${ }^{1222}$ Ookk hier doen zich problemen woor. ${ }^{1223}$

De vraag rijst hoe de welvaartsfunctie van de overheid (en met behulp dalarvan de

${ }^{1218}$ Hennipman (1977, hoofdstuk 2, pp. 152-172).

1219 Vergelijk ook: Van den Doel $(1978$, p. 56$)$

1220 T.a.p., pp. 56-57.

${ }^{1221}$ Vergelijk: Harsanyi in: Arrow en Scitowsky (1972, pp. 46 e.v.).

1222 Riker en Ordestook (1973).

${ }^{1223}$ De zogenaamde "old new welfare economics" benadrukte bijvoorbeeld dat interpersonele vergelijkingen van nut onmogelijk waren. Zie voor eem overzicht: Stiglitz in: Auerbach en Feldstein (eds.) (1987, pp. 991 e.v.). 
attributie van doelen aan een overheidsinstelling) in de praktijk bepaald kan worden. In de literatuur zijn verschillende wegen bewandeld teneinde dit probleem op te lossen.

De Bergsoniaanse welvaartstheorie tracht te komen tot een maatschappelijke welvaartsfunctie vanuit een collectief perspectief. ${ }^{122}$ De maatschappelijke welvaart (of het behaalide nut van de eigenaren van de overheidsinstelling) is afhankelijk van de door alle individuen te consumeren hoeveelheden van de goederen en diensten, van de door hen te verrichten arbeidsinspanning en van mogelijk aanwezige andere factoren die de welvaart van de individuen beïnvloeden ${ }^{225}$ Omdat deze benadering uitgaat van het collectief laat zij zich niet in met het vraagstuk van nutsmeting en nutsvergelijking. Met betrekking tot de Bergsoniaanse welvaartsfunctie merkt Bös op: "It is often argued that the Bergsonian welfare function should be abandoned because it is a purely normative concept which requires far-reaching assumptions on individual utilities, namely cardinal utilities which can be compared interpersonally". Er zijn dan ook drie bezwaren gerezen tegen dit type welvaartsfuncties. In de eerste plaats blijft het noodzakelijk om de verlangens van individuen mee te wegen teneinde te komen tot een welvaartsfunctie. In de tweede plaats heeft Arrow aangegeven dat indien de keuzesituaties twee of meer alternatieven betreffen en indien de preferenties van individuen voldoende divers zijn, er geen unieke en transitieve algemene welvaartsfunctie kan worden opgesteld, tenzij een deel van de samenleving de rest haar wil oplegt. ${ }^{227}$ Ten derde en hiermee verwant besteedt deze benadering geen aandacht aan de manier waarop collectieve keuzes tot stand komen.

De vraag rijst dan ook of het mogelijk is op een andere wijze welvaartsfuncties op te stellen. Pigou, die kan worden aangemerkt als de grondlegger van de welvaartstheorie, is van mening dat welvaart kan worden gemeten op cardinaal niveau cq. op rationiveau. Pigou omschrijft het als volgt: The one obvious instrument of measurement available in social life is money. Hence, the range of our inquiry becomes restricted to that part of social welfare that can be brought directly or indirectly into relation with the measuringrod of money. This part of welfare may be called economic welfare" ${ }^{\prime 228}$ Het meten van welvaart wordt derhalve gerealiseerd door alle produkten te vermenigvuldigen met hun prijs. Vervolgens worden deze bedragen bij elkaar opgeteld en wordt de totale welvaart van een individu gevonden. Daarbij wordt 0 ook inderdaad opgevat als een nulpunt. Welvaart wordt in dat geval gemeten met geld als meeteenheid. In die zin is ook aan het tweede criterium voor interpersonele nutsvergelijking voldaan. Er wordt immers vanuitgegaan dat het hebben van een zelfde geldinkomen voor elk individu een zelfde welvaart oplevert, ongeacht de omstandigheden waarin de personen zich bevinden. De Pigouviaanse welvaartstheorie beschouwt het maatschappelijke nut dan ook als de som van het individuele nut, waardoor een welvaartsfunctie kan worden afgeleid met de vorm:

$\mathrm{W}=\mathrm{U} 1+\mathrm{U} 2+\ldots+\mathrm{Un}$.

Voorts maakt Pigou onderscheid tussen de totale welvaart en de economische welvart: Alleen de laatste kan volgens hem gemeten worden door middel van geld. De economische welvaart is dan ook slechts een ondercleel van de totale welvaart. Indien de economische welvaart wordt gemeten zegt dat op zich nog niets over de totale welvaart. Volgens

\footnotetext{
1224 Bergson (1938, pp. 7-25):

1225 Vergelijk ook: Hartog (1973, pp. 22-23).

1226 Bös (1994, p. 83).

$1227 \mathrm{Vgl}$. Arrow, in: Arrow en Scitowsky (1969, p. 150 en pp. 167-168).

1228: Pigou (1932, p. 11). Vergelijk ook: Pigou (1912, pp. 4 ew.).
} 
Pigou maakt dit geen verschil omdat de interesse niet uitgaat naar de totale welvaart maar naar de welvaart zoals deze wordt beinvloed door politici, andere individuen etc.. ${ }^{1229}$ Desalniettemin kan worden verondersteld dat het effect van bijwoorbeeld een beleidsmaatregel van de overheid op de totale welvaart en de economische welvaart waarschijnlijk equivalent zijn qua richting. Eên en ander tenzij er expliciet bewijs is van het tegendeel. ${ }^{1230}$ De Pigouviaanse welvaartstheorie is op een aantal punten bekritiseerd. ${ }^{1231}$ In de eerste plaats wordt geen rekening gehouden met het consumentensurplus. Ten tweede hebben verschillende bedragen voor verschillende individuen terschillende betekenissen. Aangezien het niet mogelijk is het nut te meten op rationiveau is het niet mogelijk te komen tot een welvaartsfunctie.

Vogelsang merkt op dat in de theorie verschillende welvaartsfuncties kunnen worden onderscheiden waarbij in de meest eerivoudige het consumenten- en producentensurplus is opgenomen en wordt uitgedrukt in monetaire eenheden. Het producentensurplus wordt daarbij veelal gelijkgesteld aan de winst. Hierbij wordt veelal geabstraheerd van inkomenseffecten, hetgeen impliceert dat de goederen gekenmerkt worden door relatief lage inkomenselasticiteit van de vraag en dat de goederen een relatief klein deel uitmaken van het budget. Een belangrijke beperking van deze benadering is dat honderd gulden woor het ene individu evenveel nut oplewert als honderd gulden voor een ander individu. Dit is onrealistisch aangezien met name distributieve doelen (door rechtstreekse of interne subsidiëring) van groot belang zijn bij overheidsinstellingen. ${ }^{1232}$ Hoewell dergelijke welvaartsfuncties niet aangeduid worden als Pigouviaans zijn zij well gebaseerd op een Pigouviaanse benadering van het nutvraagstuk. Met de distributieve doelen wordt rekening gehouden door een gewicht toe te kennen aan de verschillende onderdelen van een welvaartsfunctie. Verschillende gewichten kunnen bijwoorbeeld worden toegekend aan het nut van de verschillende individuen. De overheid kan bijvoorbeeld in de welvaartsfunctie door middel van een parameter een hoog nut toekennen aan het nut van een groep consumenten met een laag inkomen, waarbij de parameters worden gewaardeerd op grond van de prioriteit die de betreffende groep heeft voor de overheid. Per saldo sommeren alle gewichten tot één. Ook kan de overheid bijwoorbeeld een bepaalde parameter toekennen aan de winst van een overheidsinstelling, dit in verband met de marginale kosten van overheidsfondsen. ${ }^{1233}$ Ook hier is evenwel geen sprake van interpersonele nutswergelijking. Veeleer is er sprake van interpersonele nutswaardering. Ook op de door Vogelsang geschetste wijze is het onmogelijk om tot een welvaartsfunctie te komen die in de praktijk bruikbaar is.

Volgens de Paretiaanse welvaartstheorie kan welvaart dan ook alleen ordinaal gemeten worden. Nutswaardering levert dan weinig of geen inzicht op in de welvaart van groepen. ${ }^{1234}$ In dat geval kan aan een goederenpakket wel een hoger nut worden toegekend,

1229 T.a.p. . pp. 12-13

1230 T.a.p., pp. 14 e.v.

${ }^{1231}$ Hartog $\left(1981, p p .7 \mathrm{e}_{\mathrm{n}} \mathrm{v}\right)$.

1232 Koers (1.995, pp. 34 e.v.)

1233 Vergelijk bijvoorbeeld: Vogelsang (1990, paragraaf 3.2.), inzake Government Objectives for the Public Enterprise.

1234 Pareto (1971, pp. 110 e.v.). 
maar kan niet gezegd worden hoeveel meer nut een pakket oplevert.

Tegenwoordig is de Paretiaanse visie de meest gangbare, of zoals Henipman stelt: sindsdien is volgens het in vakkringen sterk overheersende gevoelen de ommogelijheld van interindividuele vergelijkingen, evenzeer een onomstorelijke waarheid, die nauwelijks toelichting of bewijs behoef, als tevoren de omgekeerde mening" ${ }^{235}$ Dat welvaart overigens veelal op ordinaal niveau wordt gemeten heeft ook te maken met het principe van Occam's razor. Vooronderstellingen die niet nodig zijn om tot een bepaald resultaat te komen moeten worden weggesneden. In het consumentengedrag is het veelal voldoende uit te gaan van individueel nut, gemeten op ordinaal niveau. Voor de welvaartstheorie is het in de praktijk evenwel een groot bezwaar dat geen weivaartsfunctie kan worden opgesteld. ${ }^{1236} \mathrm{Er}$ is op verschillende wijzen getracht het meten van welvaart op cardinaal niveau mogelijk te maken. ${ }^{1237}$ Voorbeelden hiervan zijn de "expected utility theory" van Von Neumann en Morgenstern en de methode van Van Praag. Hier worden kort beide benaderingen vermeld en zal worden aangegeven in hoeverre deze benaderingen het mogelijk maken om alsniog een welvaartsfunctie op te stellen.

Von Neumann en Morgenstern hebben een methode voor nutsmeting ontwikkeld. ${ }^{1238}$ Deze methode is verder uitgewerkt door McKenna. ${ }^{1239}$ De expected utility theory tracht welvaart te meten op intervalniveau en maakt daarbij gebruik van interviews ${ }^{1240}$ Het doel van de "expected utility theory" is het vergelijkbaar maken van verschillende alternatieve acties, waarbij het niet van te voren duidelijk is wat de precieze uitkomsten van deze acties zullen zijn. Deze theorie maakt derhalve deel uit van het vakgebied van "economics of uncertainty". De "expected utility theory" gaat er vanuit dat een bepaalde actie niet automatisch leidt tot een bepaald resultaat maar dat de kansen op de verschillende uitkomsten wel bekend zijn. Mc Kenna geeft een axiomatisehe onderbouwing van de expected utility theory. Het eerste axioma houdt in dat individuen in staat zijn de verschillende alternatieven te ordenen. Voorts moeten de kansverdelingen op de verschillende uitkomsten in een ordening kunnen worden ondergebracht. Het derde axioma stelt dat de verschillende uitkomsten in een loterij met behulp van een standaardloterij kunnen worden omgezet in een loterij met uiterste uitkomsten. Het vierde axioma houdt in dat twee loterijen die met betrekking tot een element van elkaar verschillen, gelijk worden gewaardeerd indien dat betreffende element gelijk gewaardeerd wordt. Op grond van axioma vijf kan de hele loterij worden omgezet in een loterij met alleen uiterste uitkomsten. Axioma zes tenslotte geeft een beslisregel, inhoudende dat de loterij die de hoogste kans heeft verbonden aan de twee uiterste uitkomsten zal worden gekozen. Deze kans bestaat uit een sommatie van de kansen op de verschillende uitkomsten in de oorspronkelijke loterij vermenigvuldigd met de subjectieve waardering. Deze subjectieve waardering

1235 Hennipman (1977, p. 154).

1236 Vergelijk ook: Arrow, in: (1984; hoofdstulk 1, p. 25).

1237 Vergelijk bijvoorbeeld: Kaldor (1939, pp. 549-552). Hij benadrukt de mogelijkheid orn degenen die er op achteruil gaan te compenseren (ongeacht of dat werkelijk gebeurt). Vergelijk ook: Hicks (1939, Pp. 698 701).

1238 Vergelijk: Von Neumann en Morgenstem (1980, pp. 20 e.v.).

12319 McKenna (1986, Hoofdstuk 3).

1240 T.a.p., Hoofdstuk 3 Expected Utility theory, p. 19. 
staat woor een waardering van de oorspronkelijke uitkomst $y$, zodanig dat deze kan worden vervangen door een loterij in de uiterste uitkomsten: $P=\Sigma P_{i} u_{i}$.

$P$ is derhalve het verwachte nut en impliceert risico (er is immers sprake van een kansverdeling). Vervolgens kan het verwachte nut vergeleken worden met het nut van de verwachte uitkomst van een kanswerdeling (hierbij wordt aan de verwachte uitkomst een nutsniveau gekoppeld en is er geen sprake van risico). Een verschil in mutsmiveau geeft tenslotte de mate van risico-aversie weer. Terugkerend naar het meetniveau betekent dit dat $u$ gekozen wordt op een intervalschaal. ${ }^{1241}$ Indien bijvoorbeeld $u_{2}=0,7$ en $u_{3}=0,2$ betekent dat niet dat $u_{2}$ tweemaal $u_{3}$ is, maar dat $u_{2}=0,7$ in relatie tot us. Harsanyi laat zien dat indien onder andere voldaan wordt aan de axioma's van de "expected utility" theorie een sociale welvaartsfunctie kan worden opgesteld die kan worden weergegeven als de gewogen som van de individuele nutsfuncties. 1242

Terecht wijst Hartog erop dat deze benadering slechts meet op intervalniveau en daarom tekortschiet voor de welvaartstheorie. Het nut is nog steeds niet optelbaar en derhalve is interpersonele nutsvergelijking ook nog steeds onmogelijk. ${ }^{1243^{\circ}}$ Daarnaast vermeldt Hartog als tweede tekortkoming dat het mut van goederen en de positieve of negatieve preferentie ten aanzien van het memen wan risico $(=P)$ miet te scheiden zijn. ${ }^{1244}$ Hartog stelt: "Risico's zelf kunnen ook positief of negatief nut oproepen. Dat blijkt als we zient naar feitelijke gevallen waarin kansen met zekerheden worden vergeleken en voor een beslissing tegen elkaar worden afgewogen. Dit doet zich voor enerzijds bij verzekering en anderzilds bij loterij. Als iemand zich werzekert, wordt de zekerheid van een kleine schade (..) werkozen boven de kleine kans op een grote schade. Maar als men strikt actuarisch zou rekenen, zonder het risico zelf te waarderen, zou het omgekeerde het geval moeten zijn. Anders zou de werzekeringsmaatschappij immers geen winst kumnen maken, of in het geval van een onderlinge verzekering haar kosten niet goed kunnen maken. Er moet dus een aversie tegen risico in het spel zijn. Omgekeerd wordt bij het kopen van een lot de kleine kans op een grote winst verkozen boven de zekerheid van het uitsparen van geld. Actuarisch komt dat ook omgekeerd uit, anders zou een loterij woor de uitgever van de loten verlies moeten opleveren. Hier bestaat dus een voorkeur voor het gokken als zodanig. De neocardinalisten leggen zich hierbij neer en zij kunnen ook niet anders. Maar het zich neerleggen bij een onvermijdelijke vertroebeling is niet hetzelfde als het opheffen van die vertroebeling ". 1245

Derhalve kan geconstateerd worden dat ook met de benadering van Von Neumann en Morgenstern geen interpersonele nutsvergelijking mogelljk is en dus is het ook niet mogelijk een welvaartsfunctie op te stellen.

Van Praag (1968) meet de welvaart door middel van de interviewmethode met behulp van een intervalschaal. De geïnterviewden waarderen hun welvaart op een schaal van nul tot

${ }^{1241}$ T.a.p., pp. $21-26$.

1242 Vergelijk: Harsanyi (1955, pp. 309-321). Zie ook: Harsanyi (1977) en Harsanyi, in: Aumann en Hart (eds) (1994, pp. 669-707).

1243 Vergelijk ook: Lange, in: Arrow en Scitovsky (1972, p. 26).

${ }^{1244}$ Hartog (1981, pp. 130-131).

12455 T.a.p., pp. 131-132. 
en met tien. ${ }^{1246}$ Een individu geeft dan aan dat een inkomensstijging van bijwoorbeeld F. 400,- per jaar zijn welvaart vergroot van bijvoorbeeld 5 tot 6 . Van Praag geeft voorts aan dat indien het inkomen verandert ook de doelfunctie verandert. Daardoor neemt de feitelijke welvaart minder dan evenredig toe. Van Praag ontdekte dat de feitelijke stijging ongeveer $35 \%$ van de verwachte stijging bedroeg. Met deze benadering komen Van Praag en Kapteyn tot een interpersonele nutsvergelijking door ervan uit te gaan dat een bepaald cijfer, bijwoorbeeld een twee, voor elk individu een zelfide nutsmiveau oplevert. Dit is gebaseerd op de veronderstelling dat begrippen als goed, matig, etc. en een bepalild cijfer, bijvoorbeeld een 5 , voor iedereen dezelfde betekenis heeft Het probleem van deze veronderstelling is nu dat deze juist bewezen moet worden, zoals ook Hartog aangeeft. ${ }^{1247}$ Ook zij slagen er niet in het nut zodanig te meten dat een interpersonele nutsvergelijking mogelijk wordt.

\section{Conclusie}

De vraag die in deze paragraaf centraal stond was in hoeverre het mogelijk is om een sociale welvaartsfunctie op te stellen. In de theorie is dit naturilijk geen probleem. Indien voldoende veronderstellingen worden toegevoegd kan een sociale welvaartsfunctie worden afgeleid. ${ }^{1248}$ De balans opmakend kan echter ook geconstateerd worden dat het, zoals Arrow all in de vijftiger jaren liet zien, in werkelijkheid niet mogelijk blijkt te zijn een welvaartsfunctie op te stellen. ${ }^{1249}$ Het "impossibility" theorema van Arrow laat zien dat het niet mogelijk is om een sociale welvaartsfunctie op te stellen die alan de vier genoemde criteria voldoet. In dit verband merkt Woll op: "Die Axiome und damit die Folgerungen der paretianischen Wohlfahrtsökonomik und der Sozialen Wohlfahrtsfunktion sind gedanklich-logische Konstruktionen, die in der Realität kaum nachwiesbar sein düften (...) ${ }^{* 1250}$ Niet alleen Woll marar ook bijwoorbeeld Bonus en Ribhegge erkennen dit. "In der Paretianischen Wohlfahrtökonomik ist man sich spätestens seit Arrow (1951) bewusst, dass die gesellschaftlich akzeptable Aggregation individueller Nunenfunktionen zu einer konsistenten Wohlfahrtsfunktion scheitern muss"12si Hier zij benadrukt dat hiermee niets negatiefs gezegd wordt over de welvaartseconomie en het concept van sociale welvaartsfuncties. Dat de welvaartseconomie grote theoretische en didaktische betekenis heeft staat voorop. $\mathrm{Er}$ is slechts aangegeven dat het in de praktijk niet mogelijk blijkt te zijn om een acceptabele sociale welvaartsfunctie af te leiden. Het is vanzelfsprekend dan ook onmogelijk, alleen al op technische gronden, om met behulp van een welvaartsfunctie in de praktijk doelen te attribueren aan een overheiclsinstelling. De doelen van een overheidsinstelling, zoals die in empirisch onderzoek worden angetroffen kunnen dan ook nooit afkomstig zijn wan een dergelijke benadering.

\footnotetext{
1246 Van Praag (1968, pp. 52 e.w.). Vergelijk ook: Van Praag en Kapteyn (1973).

12477 Hartog (1981, p. 131).

${ }^{1248} \mathrm{Ng}(1990$, hoofdstuk 5).

1249 Arrow (1951, Hoofdstuk 5).

1250 Woll (1986, p. 760).

${ }^{1251}$ Bonus en Ribhegge (1986, p. 754).
} 


\section{A.2.2 Levert het gebruik van een welvaartsfunctie wel datgene op wat we willen weten?}

Ook indien er van wordt uitgegaan dat het wel mogelijk is om een welvaartsfunctie op te stellen levert deze benadering weinig inzicht op in de werkelijke doelen van een overheidsinstelling. Vogelsang merkt op dat de uitkomst van een dergelijk maximaliseringsproces zich niet direct laat vertalen in een doelfunctie van een overheidsinstelling. 1252 In de eerste plaats omdat het nut niet direct vertaald kan worden in voor de overheidsinstelling operationele doelen (zoals prijzen en hoeveelheden). In de tweede plaats omdat een overheidsinstelling slechts éên van de vele instrumenten is waarmee de overheid de welvaart van individuen kan proberen te maximaliseren. Daarom veronderstelt Vogelsang dat een overheidsinstelling alleen dan gebruikt zal worden indien het niet optimaal is om andere instrumenten te gebruiken. Vogelsang concludeert dat de voornaamste doelen van de overheid dan betrekking zouden hebben op (technische) efficiëntie en inkomensverdeling. Duidelijk is dat hierbij een subjectief criterium wordt gehanteerd. In feite is hier sprake van nutswaardering. Volgens Backhaus is een dergelijke benadering onjuist. ${ }^{1253}$ Hij meent dat de op grond van een welvaartsfunctie afgeleide algemeen economische doelen, zoals efficiëntie en macro-economische doelen onmogelijk automatisch kunnen worden geprojecteerd op een bepaalde overheidsinstelling. Dat een dergelijke methode inderdaad de werkelijke doelen van de overheidsinstelling oplevert is welhaast uitgesloten, of zoals Backhaus het stelt: "Whereas the typical instruments of economic policy may effect economic activity in general terms, public enterprises can be targeted to specific purposes, specific geographic areas or even specific geographic points, (..). Given this bewildering diversity, it is (almost) never possible to assign or attribute objectives to public enterprises in general, and certainly not a priori"." ${ }^{1254}$ Voorts plaatst Backhaus als kanttekening dat deze wijze van doeltoekenning niet gebaseerd is op een onderliggende theorie die een verklaring geeft van het gedrag van overheidsinstellingen. ${ }^{1255}$ Tenslotte voert hij aan dat een doel als efficiëntie, dat vaak op grond van de normatieve benadering aan een bepaalde overheidsinstelling wordt toegedicht, vrijwel nooit een doel van een overheidsinstelling kan zijn, onder meer omdat efficiëntie eerder een conditie is dan een doel, maar in feite ook omdat het de werkelijke functie van tegenwoordige overheidsin-

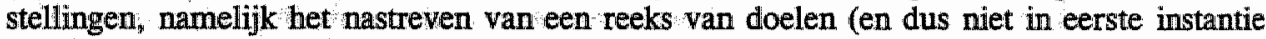
techmische efficiëntie), miskent.

De conclusie van deze paragraaf luidt dat de doelen van overheidsinstellingen in de praktijk niet worden bepaald door de maximalisatie van een welvaartsfunctie door de politieke actoren. Enerzijds omdat het niet mogelijk is om in de werkelijkheid een welvaartsfunctie op te stellen en anderzijds omdat overheidsinstellingen van elkaar verschillen en het niet mogelijk is om de algemene doelen die afgeleid worden van een eventuele welvalartsfunctie te projecteren op een specifieke overheidsinstelling.

In paragraaf A.2.3. wordt verder ingegaan op een aantal normatieve regels voor overheidsinstellingen, die gerekend kunnen worden tot de in paragraaf A.1.3 genoemde tweede categorie. Vervolgens wordt ingegaan op de vraag in hoeverre dergelijke

\footnotetext{
${ }^{1252}$ Vogelsang $(1990, \mathrm{p}, 22)$

1253 Vergelijk: Backlhaus (1994, pp. 277 e.v).

1254 T.a.p., p. 277

1255 T. 2.p.p. p. 280
} 
normatieve regels het gedrag van overheidsinstellingen kunmen verklaren en in hoeverre de onderliggende redenering ten aanzien van de aard van overheidsinstellingen realistisch is.

\section{A.2.3 Welke prijzen zou een overheidsinstelling moeten rekenen?}

\section{A.2.3.1 Enige normatieve regels voor overheidsinstellingen}

In het navolgendle wordt ingegaan op een aantal prijsstellingsregels, er vanuit gaande dat elders in de economie voldaan is aan de voorwaarden voor Pareto-optimaliteit. Het gaat dus om "first best"-prijsstellingsregels. Elders in de economie is overal sprake van prijsstelling gelijk aan de marginale kosten, er zijn geen externe effecten, terwijl voorts tén gulden in handen van het ene individu voor de samenleving als geheel evenveel gewicht heeft als één gulden in handen van een ander individu. ${ }^{1256}$

\section{Overheidsprijzen met vaste kapitaalvoorraad en variabele capaciteitsgrenzen}

Uitgaande van een overheidsinstelling met een gegeven kapitaalvoorraad en variabele capaciteitsgrenzen, bijwoorbeeld een museum, rijst de vraag welke prijs een klant zou moeten betalen voor een bezoek aan het museum en welk bezoekersaantal optimaal is. Uit de micro-economie weten we dat die situatie optimaal is waarbij de prijs gelijk is aan de marginale kosten. Deze situatie is Pareto-efficiênt aangezien in dit geval het producentenen consumentensurplus gemaximaliseerd worden.

\section{Korte of lange termijn marginale kosten}

In werkelijkheid is de situatie meer gecompliceerd indien zoals vrijwel steeds het geval is de capaciteit kan veranderen. Een museum bijvoorbeeld zou op tal van manieren de capaciteit kunnen vergroten, waaronder het ophangen van meer schilderijen en het inrichten van meer expositie- en opslagruimtes. We moeten derhalve niet alleen het optimale aantal bezoekers van het museum vinden maar ook de optimale capaciteit van de overheidsinstelling. $\mathrm{Om}$ in dit geval een optimale oplossing te vinden dient onderscheid gemaakt te worden tussen de korte en lange termijn marginale kosten, De marginale kosten op korte termijn zijn zoals bekend de kosten van het produceren van een extra eenheid terwijl de marginale kosten op de lange termijn de kapitaalkosten per periode zijn. Een en ander is weergegeven in Figur A.1 waarin de oorspronkelijke capaciteit gelijk is aan $\mathrm{q} 1$.

1256 De Jong (1958, pp. 24 e...). 


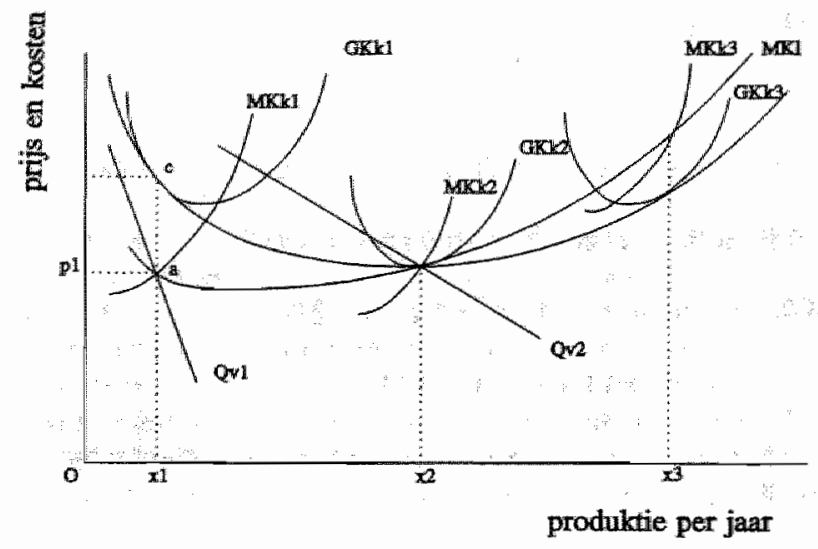

$G K k=$ korte termijn gemiddelde kosten MKk = korte termijn marginale kosten $\mathrm{GKI}=$ lange termijin gemiddelde kosten MKU =lange termijn margimale kosten

\section{Figuur A.1 De marginale kostenprijsregel ${ }^{1257}$}

Indien de prijs gelijkgesteld wordt aan $c$ is de prijs hoger dan de lange termijn marginale kosten waardoor een efficiëntieverbetering behaald kan worden door uitbreiding van de capaciteit tot het punt waarop de prijs gelijk is aan de korte en lange termijn marginale kosten. Deze regel kan worden aangeduid als de marginale kosten-prijsregel. In Figuur A.1 zou op grond van deze regel de hoeveelheid $x 2$ moeten worden voortgebracht. Door de prijs gelijk te stellen aan de korte termijn marginale kosten wordt de vraag gelijk aan het aanbod en wordt het aantal bezoekers bepaald. Door de prijs gelijk te stellen aan de lange termijn marginale kosten kan de capaciteit worden bepaald. Het probleem is derhalve niet of de prijs gelijk gesteld moet worden aan de korte of aan de lange termijn marginale kosten aangezien op grond van de marginale kosten prijsregel de prijs gelijk gesteld dient te worden aan de korte en lange termijn marginale kosten. ${ }^{1258}$

\section{Vaste capaciteit met capaciteitbeperking}

In het voorgaande werd er vanuit gegaan dat de capaciteit veranderd kan worden. Dit bleek uit de vorm van de korte termijn marginale kostencurve. Vervolgens dient onderzocht te worden wat de optimale uitkomst is indien de capaciteit vast is en er capaciteitsbeperkingen zijn. ${ }^{1259}$ In dat geval zal de marginale kostencurve niet u-vormig zijn maar de vorm hebben als weergegeven is in Figuur A.2.

${ }^{1257}$ Webb (1976, p. 20). Zie ook: Bös (1994, pp. 125-127).

1258 Vergelijkk ook: Kay (1971, pp. 367-368).

1259 Rees (1984, paragraaf 5.1.) 


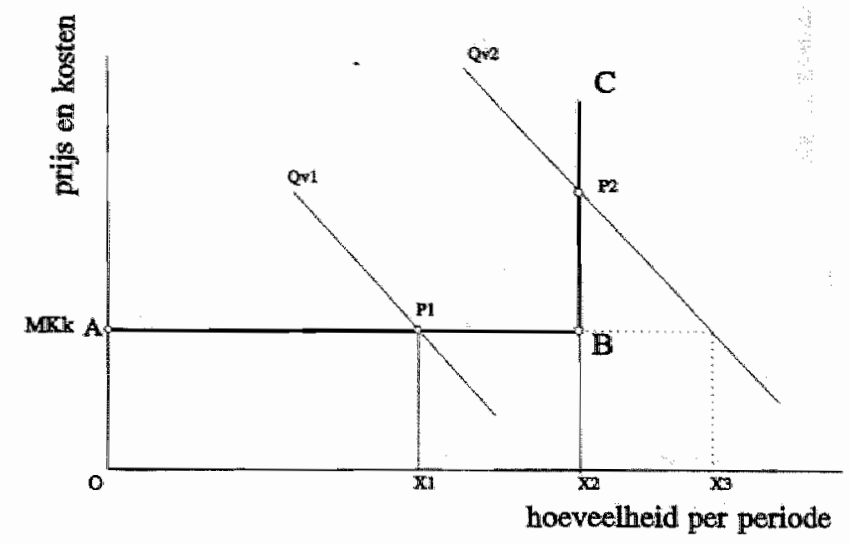

Qv =vraageurve

MKK =korte termijn marginale kosten

Figuur A.2 Overheidsinstelling met vaste capaciteit en capaciteitsgrenzen ${ }^{1260}$

In Figuur A.2 worden een tweetal vraagcurves gegeven. Indien de vraag Qv2 is wordt de capaciteitsbeperking bereikt. De prijs zal dan gelijk zijn aan p2, het punt waar de prijs gelijk is aan de marginale opportuniteitskosten BC. In het geval van de capaciteitsbeperking kan feitelijk niet meer worden gesproken van marginale kosten aangezien het niet gaat om de kosten van de laatste eenheid voortgebracht produkt, maar moet worden gesproken van marginale opportuniteitskosten, aangezien het hier gaat om de vraag hoeveel de laatste klant bereid is op te geven om nog te worden bediend door de overheidsinstelling. De prijs ligt in dat geval boven de marginale bedrijfskosten $A B{ }^{1261}$

\section{Capaciteitsgrenzen met de mogelijkheid de capaciteit aan te passen}

In Figuur A.2 werd uitgegaan van een overheidsinstelling met een vaste capaciteit. Op de lange termijn kan de capaciteit in werkelijkheid vrijwel altijd worden uitgebreid.

1260 Blankart (1980, p. 28).

126. Vergelijk ook: Henderson, in: Arrow en Scitovsky (1969, p. 543). 


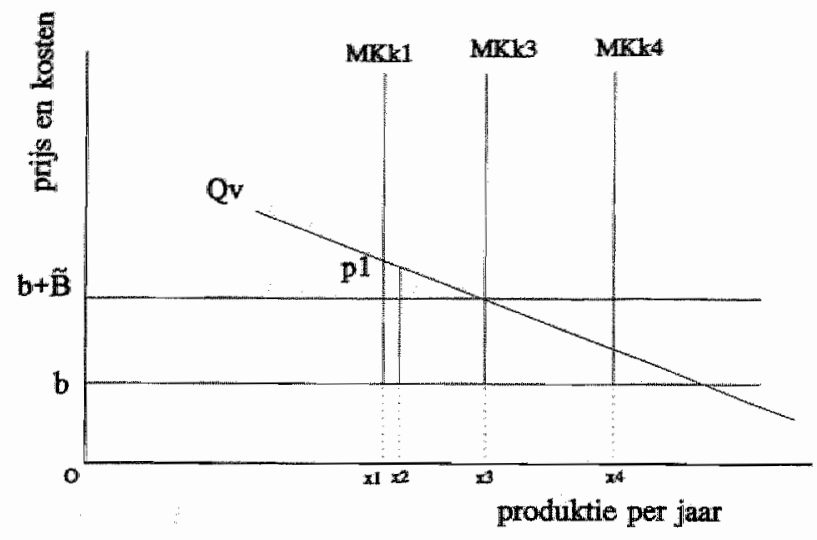

MKk $=$ korte termijn marginale kosten

MKI $=$ lange termijn marginale kosten

GKI = lange termijn gemiddelde kosten

$\mathrm{Qv}=$ vraagcurve

Figuur A.3 Overheidsinstelling met capaciteitsgrenzen en de mogelijkheid de capaciteit uit te breiden ${ }^{1262}$

In Figuur A 3 blijkt dat indien de capaciteit kan worden uitgebreid van bijvoorbeeld $x 1$ naar $\times 2$ het efficient is dit te doen. Bij p1 ligt de prijs boven de lange termijn marginale kosten, die bestaan uit enerzijds de marginale bedrijfskosten b en anderzijds de kapitaalkosten B per periode. De investeringsregel luidt dan ook dat de productie dient te worden uitgebreid tot het punt waar de consumenten bereid zijn te betalen voor deze marginale bedrijfskosten en kapitaalkosten. De prijs is dan wederom gelijk aan de korte en lange termijn marginale kosten.

\section{Ondeelbaarheid van de capaciteit: Het probleem van grote projecten}

In het voorgaande werd er op grond van de marginale kostenprijsregel vanuit gegaan dat de capaciteit zich met kleine hoeveelheden laat veranderen. Indien evenwel gekeken wordt naar grote projecten als spoorwegen, luchthavens en havens blijkt dit niet juist te zijn. De vraag rijst in de eerste plaats hoe belangrijk deze ondeelbaarheden van de capaciteit zijn. 


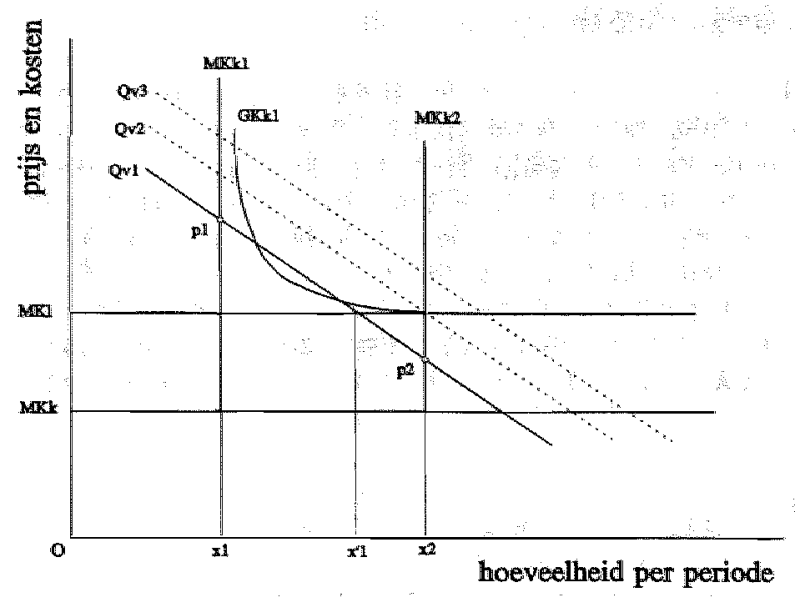

MKK = korte termijn marginalie kosten

GKk $=$ korte termijn gemiddelde kosten.

MKI = lange termijn marginale kosten

Qv $=$ vraag

\section{Figuur A.4 Ondeelbare capaciteit: grote projecten ${ }^{1263}$}

Blankart geeft aan dat dit er vanaf hangt. Als voorbeeld wordt een telecommunicatienetwerk nader bezien. Zo'n netwerk heeft een grote capaciteit die slechts tegen hoge kosten vergroot kan worden. Het zal evenwel vaak mogelijk zijn om binnen dit netwerk de capaciteit intensiever te gebruiken indien de vraag toeneemt. Het belang van dergelijke ondeelbaarheden hangt dan ook af van welk facet op een bepaald moment het belangrijkst is. In de tweede plaats dient beantwoord te worden of de marginale kosten-prijsregel gebruikt kan worden. Het probleem wordt uiteengezet in Figuur A.4 In deze figuur worden een tweetall capaciteiten onderscheiden, namelijk capaciteit $x 1$ en $\times 2$. Hiertussen bevindt zich geen andere capaciteitsmogelijkheid. Indien de vraag gelijk is aan Qv1 zal de prijs ongelijk zijn aan de korte en lange termijn marginale kosten, aangezien p1 boven de lange termijn marginale kosten en $\mathrm{p} 2$ hieronder ligt. Het probleem kan na verloop van tijd worden opgelost indien de vraag toeneemt van Qv1 naar Qv2 en Qv3. Met een capaciteit van $\times 2$ zal er aanvankelijk een verlies zijn, dat indien de vraag toeneemt verdwijnt en omslaat in winst. Het te lijden verlies zal moeten worden gefinancierd op de kapitaalmarkt, hetgeen op een competitieve kapitaalmarkt in principe mogelijk zou moeten zijn. In werkelijkheid hebben overheidsinstellingen vaak geen rechtstreekse toegang tot de kapitaalmarkt of is deze aan beperkingen onderhevig waardoor problemen kunnen ontstaan met de voorfinanciering. Daar staat tegenover dat de owerheid vaak bereid zal zijn kredieten te verstrekken. 
In paragraaf 2.2.1.1 is in het kader van de allocatiefunctie reeds kort ingegaan op het natuurlijke monopolie. Aangegeven is dat indien een overheidsinstelling in het geval van een naturilijk monopolie de prijs gelijk stelt aan de marginale kosten, er een verlies ontstaat. Verder is het bekend dat een monopolie in verband met de kostenfunctie en de schaal van de productie, wel winst kan maken. Voorts heeft een monopolie het voordeel van gecombineerde productie, in de Duitse literatuur aangeduid als "Verbundproduktion". Blankart noemt als voorbeeld hiervan het controleren van het verkeer en het beschermen van burgers. Het afzonderlijk nastreven van beide doelen zal duurder zijn dan indien beide taken gecombineerd worden. Dit kan als volgt weergegeven worden in Figuur A.5:

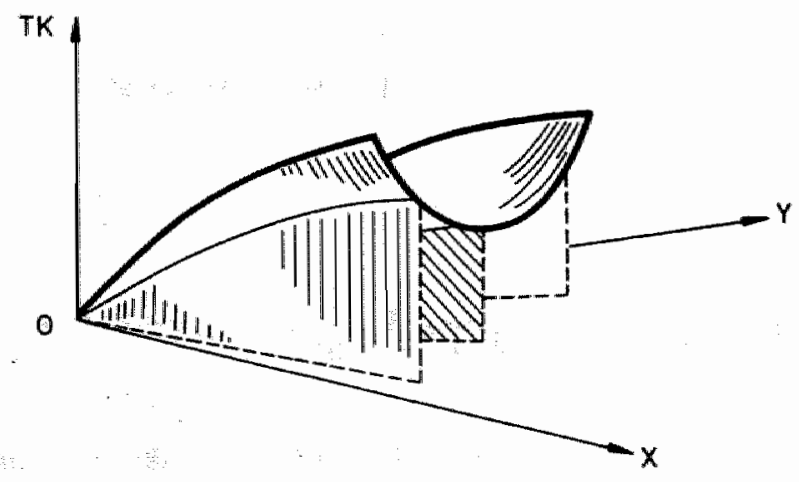

TK=toule kosten

Fuguur A.5 De voordelen van gezamenlijke productie van goederen door een bedriff (Verbundproduktion). ${ }^{1264}$

Indien in het geval van een natuurlijk monopolie de prijs gelijk wordt gesteld aan de marginale kosten ontstaat een verlies. De vraag is hoe dit verlies dient te worden betaald en in hoeverre dit gepaard gaat met inefficiënties. Aansluitend bij paragraaf 2.2.1.1 kunnen een aantal strategieen worden onderscheiden. Indien de overheid het bedrijf subsidieert zal zij belastingen moeten heffen. Belastingen gaan in de praktijk altijid in meer of mindere mate samen met "excess burdens" waardoor allocatieve verstoringen optreden. Voorts kan een subsidie er toe leiden dat een overheidsinstelling minder geprikkeld wordt om kostenefficiênt te opereren. Een tweede mogelijkheid is het hanteren van prijsdifferentiatie. Hieronder wordt verstaan een prijsstelling overeenkomstig de (verschillende) prijselasticiteit van de vraag. Dit is alleen mogelijk indien verschillende markten onderscheiden kunnen worden. Dit kan Pareto-efficiënt zijn. Een probleem in de praktijk is dat de marginale vraag beinvloed kan worden, mede aangezien het in de praktijk moeilijk is om te onderscheiden tussen verschillende groepen. Een derde mogelijkheid is om gebruik te maken van tarieven die enerzijds bestaan uit een vaste prijs en anderzijds uit een marginale prijs. Voor zover de vraag niet veranderd wordt door de vaste prijs kan dit Pareto-efficiënt zijn. Hierbij kan gedacht worden aan de gas- en elektriciteitssector. Een vierde mogelijkheid is de prijs gelijk te stellen aan de gemiddelde kosten. Dit leidt 
weliswaar niet tot een verlies maar is ook niet Pareto-efficiênt. Hoe groter de prijselasticiteit van de vraag hoe groter het verlies aan consumentensurplus zal zijn bij deze vorm van prijsstelling en hoe groter dus de inbreuk zal zijn op de allocatie. Tenslotte kan gebruik worden gemaakt van interne subsidiëring, aangezien een overheidsinstelling vrijwel altijd meer dan één goed of dienst zal aanbieden. Twee gevallen kunnen onderscheiden worden. Indien de productie van een goed gekenmerkt wordt door dalende gemiddelde kosten en de andere door stijgende gemiddelde kosten kan de eventuele winst van de laatste gebruikt worden voor het dekken van het verlies van het eerste goed. Indien de prijzen in beide markten gelijk gesteld wordt aan de marginale kosten levert dit een Pareto-efficiënte allocatie op. Een probleem ontstaat indien de productie van beide goederen gekenmerkt wordt door dalende gemiddelde kosten of indien de winst behaild op de ene markt onvoldoende is om de prijs in de andere markt te dekken. De prijs zall dan boven de marginalle kosten moeten worden gesteld waardoor een Pareto-inefficiënte situatie ontstaat. Vanuit de marktfalenbenadering kan worden aangevoerd dat interne subsidièring en "rent-seeking" de allocatie van productiefactoren verstoort. In het geval van interne subsidiëring zullen sommige prijzen boven de marginale kosten worden gesteld, terwijl de prijzen van andere goederen beneden de marginale kosten zullen liggen. Bovendien is de entree tot de markt beperkt, hetgeen met name in het geval dat er geen sprake is van een natuurlijk monopolie, de efficiëntie kan verminderen. Posner stelt: "The criticism of internal subsidization as inefficient points to a real characteristic of the device; but as a criticism it is superficial. It measures the device against an ideal standard, and of course finds it wanting. The proper comparison is other exercises of the taxing power. $A l l$ methods of taxation distort the "optimum allocation of resources,..., and there are no a priori grounds for assuming that excise taxes, such as the internal-subsidy programs imposed by regulatony agencies, produce worse misallocations than income or other taxes $^{\prime 2}$. 265 Vanwege de verstorende effecten van belastingen is het niet waarschijnlijk dat het verhogen van bijvoorbeeld inkomstenbelastingtarieven een meer efficiënte methode zou zijn dan interne subsidiëring. Indien bijvoorbeeld de vraag in hoge mate prijsinelastisch is, kan het voor de overheid aantrekkelijk zijn om een overheidsinstelling de betreffende goederen en diensten te laten voortbrengen.

De vraag wordt dan welke prijs gerekend moet worden. In dit verband wordt in de literatuur ingegaan op de Ramsey-prijsregel, ${ }^{1266}$ die verder is ontwikkeld door Baumol en Bradford. ${ }^{1267}$ De afwijking van de prijs van de marginale kosten dient gelijk te zijn aan de reciproke van de prijselasticiteit wan de vraag vermenigvuldigd met een proportionaliteitsfactor (een constante) (inverse elasticiteitsregel): ${ }^{1268}$

$$
\frac{P_{i}-G K_{i}}{P_{i}}=k \frac{1}{\eta} ; k \leq 0
$$

wawij: $\mathbf{P}_{\mathbf{i}}=$ prijs wan goed $\mathrm{i}$

$\mathbf{G K}_{\mathbf{i}}=$ lange termijn marginale kosten

$\eta$ = directe prijselasticiteit van de vraag naar goed $\mathbf{i}$.

$\mathbf{k}=$ constante

126.5 Posner $(1971$, p. 42).

${ }^{12665}$ Ramsey (1927, pp. 47 e.v).

${ }^{1267}$ Baumol en Bradford (1970, pp. 269-270). Zie ook: Atkinson en Stiglitz (1980, p. 367).

1268 Voor een uitwerking, zie Bös (1994, paragraaf 8.1.2). Vergelijk ook: Chang (1996, pp. 282 e.v.). 
Dit komt overeen met hetgeen is opgemerkt bij de prijsstelling gelijk aan de gemiddelde kosten. Deze regel houdt in dat de prijzen van goederen waarvan de vraag prijsinelastisch is meer verhoogd kunnen worden dan de prijzen van goederen waarvan de vraag relatief prijgelastisch is. ${ }^{269}$ In het geval van een hoge prijselasticiteit zal het gedrag door de prijsstelling ongelijk aan de marginale kosten meer verstoord worden en zal dienovereenkomstig het consumentensurplus meer verminderen. Een belangrijke veronderstelling die ten grondslag ligt aan de Ramsey-regel is dat de kruiselingse prijselasticiteit van de goederen 0 is. Indien dat niet het geval is kan de vraag naar een goed door een prijsstelling boven de marginale kosten aanzienlijk afwijken van de verwachte vraag waardoor de Ramsey-regel dan niet opgaat. De centrale vraag is nu vanzelfsprekend in hoeverre het management van overheidsinstellingen een reden heeft de Ramsey-regel of bijvoorbeeld de marginale prijskostenregel toe te passen.

\section{Periodieke verschuivingen van de vraag}

Verschillende markten waarin overheidsinstellingen opereren worden gekenmerkt door periodieke versehuivingen van de vraag, bijvoorbeeld in de vraag naar elektriciteit. ${ }^{1270}$ Om in de piekvraag te kunnen voorzien moeten overheidsinstellingen reservecapaciteit aanhouden, die gedurende een groot deel van de periode ongebruikt zal blijven. De vraag rijst welke prijs een overheidsinstelling moet rekenen indien er sprake is van een dergelijke marktvraag en welke capaciteit in teserve moet worden gehouden. ${ }^{1271}$ De overheidsinstelling zou kunnen overgaan tot rantsoenering. In de praktijk gaan overheidsinstellingen hier evenwel vrijwel nooit toe over en is het van meer belang in te gaan op de prijzen die de overheidsinstelling dan zou moeten rekenen, teneinde de capaciteit. te optimaliseren. Hierbij kan onderscheid gemaakt worden tussen de situatie waarin de pieklast en de gewone last aanmerkelijk van elkaar afwijken en de situatie waarbij beide minder van elkaar verschillen.

De situatie dat de basislastvraag en de piekvraag ver uiteen liggen kan als volgt in een figuur worden geillustreerd.

\footnotetext{
1269 Vergelijk ook: Bös (1994, paragraaf 8.1.) en Brown en Sibley (1986, pp. 107 e.v.).

${ }^{1270}$ Mohring (1970, pp. 693 e.v.).

${ }^{1271}$ Bioiteux (1949, pp. 321 e.v.) en Steiner (1957, pp. 570 e.v.).
} 


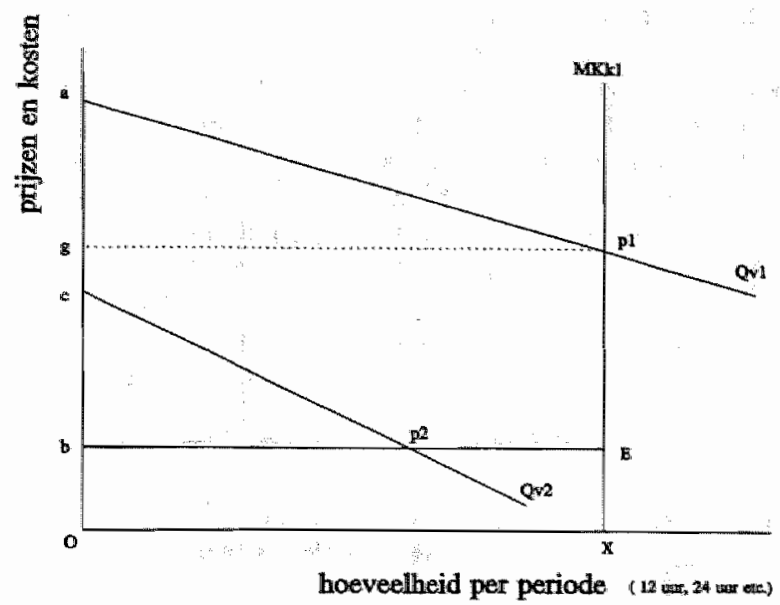

MKk = korte termijin marginale kosten

$g-b=$ kapitaallkosten in de betreffende periode

$b-a=$ marginale bedrijfskosten

Qv1 = piekvraag

Qv2 = basislastrragg

Figuur A.6 Prijsstelling indien de basislastrraag en de piekvraag ver uiteen lig$\operatorname{gen}^{1272}$

Gegeven een aantal veronderstellingen zoals constante schaalopbrengsten en een kruiselings prijselasticiteit tussen beide markten ter waarde van 0 , kan de door de overheidsinstelling te rekenen prijs worden bepaald. Uit figuur A.7 blijkt dat de vragers bereid zijn om in de piekperiode een prijs van p1 te betalen. In dat geval betalen zij de kosten van het aanhouden van een reservecapaciteit volledig. De vragers in de normale periode dragen dan ook niet bij aan de kosten van de reservecapaciteit en betalen een prijs gelijk aan de marginale kosten op de korte termijn, te weten p2. In de praktijk wordt qua prijsstelling vaak geen onderscheid gemaakt tussen beide soorten vraag. Dit heeft als belangrijk nadeel dat, indien de prijs bijvoorbeeld wordt vastgesteld op één niveau, bijvoorbeeld tussen $c$ en $b$, de vraag in de piekperiode aanzienlijk zal toenemen. De overheidsinstelling moet ex dan een grotere reservecapaciteit op nahouden. ${ }^{1273}$ Blankart merkt op dat het in dat geval bovendien niet zeker is dat door deze tariefstelling de totale kosten worden gedekt.

Indien de vraag van beide groepen niet ver uiteen ligt dienen beiden te delen in de kosten van de reservecapaciteit. ${ }^{1274}$ Webb verduidelijkt dit aan de hand van de volgende figuur.

\footnotetext{
1272 Webb (1976, p. 34).

1277 Rees (1984, pp. 70 e.v.).

$\$ 274$ Zie ook: Uri (1983, pp. 93 e. v.).
} 


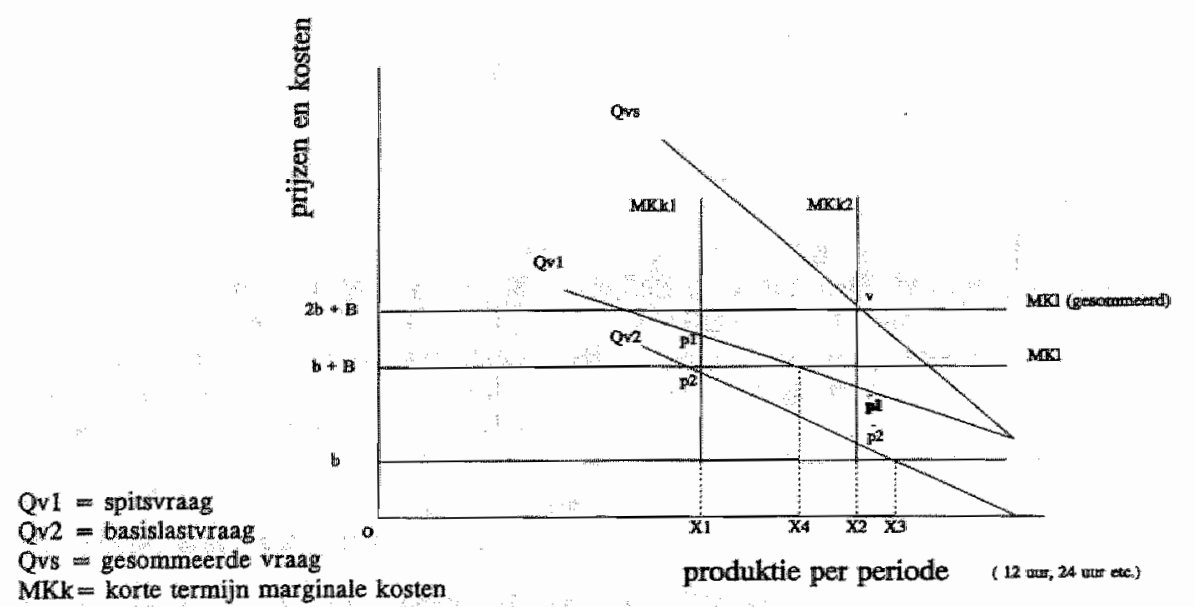

MKI = lange termifin marginale kosten

\section{Figuur A.7 Prijsstelling indien de piekwraag en de basislastvraag dicht bij elkaar liggen ${ }^{1275}$}

In Figuur A.7 geeft $\mathrm{Qv}_{1}$ de piekvraag en $\mathrm{Qv}_{2}$ de basislastvraag weer. $\mathrm{Qv}$ s staat voor de gesommeerde vraag. Indien net als hiervoor de piekvraag gelijk wordt gesteld an de lange termijn marginale kosten, is er een capaciteit nodig ter grootte van $\mathrm{X} 4$ bij een prijs van $b+B$. Indien ook in dit geval de basislastvraag gelijk zou worden gesteld aan de marginale kosten op korte termijn zou een prijs b gerekend worden terwijl een capaciteit groter dan X4 nodig is. De capaciteit is derhalve onvoldoende en er ontstaan wachtrijen. Dit kan voorkomen worden door woor de vragers in de normale periode een prijs te rekenen die boven de korte termijn marginale kosten (de bedrijfskosten) ligt. De optimale capaciteit bedraagt dan X2. Deze optimale capaciteit kan gevonden worden door de gesommeerde vraag $\left(\mathrm{Qv}_{\mathrm{s}}\right)$ gelijk te stellen aan de gesommeerde marginale kosten. Deze zijn gelijk aan $2 b+B$, aangezien dit de kosten zijn van het werkrijgen van één additionele eenheid capaciteit die gedurende de cyclus van 24 uur gebruik gebruikt wordt vermeerderd met de kosten van het gebruik van die capaciteit in elk van de subperiodes. In dat geval dragen de basislastvragers bij aan het aanhouden van reservecapaciteit $(=p 2-b)$ door het betalen yan een prijs $\mathrm{p} 2$, terwijl de piekvragers een bedrag ter hoogte van $\mathrm{p} 1-\mathrm{p} 2$ bijdragen aan de reservecapaciteit.

Vanzelfsprekend kunnen de gehanteerde veronderstellingen worden losgelaten en kan worden geanalyseerd in hoeverre de situatie hierdoor verandert. Bezien kan bijvoorbeeld worden wat voor machines het best in reserve gehouden kunnen worden en wat bijvoorbeeld het effect is van het invoeren van een kruiselingse prijselasticiteit ongelijk aan 0 . Aangezien dergelijke specificeringen geen wezenlijke veranderingen aanbrengen, wordt hierop niet verder ingegaan.

Tenslotte kan worden opgemerkt dat het hanteren van verschillende tarieven met name plaatsvindt in de elektriciteitssector. In de elektriciteitssector worden vaak een tweetal tarieven gerekend, enerzijds gebaseerd op een zogenaamde prestatieprijs (per $\mathrm{kW}$ ) en anderzijds op een arbeidsprijs (per $\mathrm{kWh}$ ). Door de betaling van een prestatieprijs verzekert de klant (het gaat hier met name om grootverbruikers) zich van een bepaald

1275 Webb $(1976$, p. 37). 
deell van de capaciteit van het elektriciteitsbedrijf terwijl de consument voor de werkelijk gebruikte capaciteit een arbeidsprijs moet betalen overeenkomstig de marginale bedrijfskosten. Het belangrijkste verschil met het voorgaande systeem is dat bij deze methode de klant van te voren moet aangeven welke hoeveelheid hij vermoedelijk zal gebruiken. Hij draagt dan ook het risico voor het verkeerd inschatten van de behoefte. De meetkosten zullen voor kleine afnemers relatief vaak erg hoog zijn, waardoor dergelijke systemen vooral voor grote en middelgrote afnemers worden toegepast. Voor kleinverbruikers wordt wel gebruik gemaakt van meer eenvoudige prijsregells zoals het hanteren van een verschillend dag- en nachttarief.

\section{A.2.3.2 "Second"- en "Thirdbest" prijsregels}

\section{Inlleiding}

Markten met volkomen en volledige mededinging komen zelden voor In dat geval heeft het geen zin dat de overheid er voor zorgt dat OP sommige plaatsen in de economie wel voldaan wordt aan de Pareto-efficiëntievoorwaarden. Indien namelijk in eén of meer markten niet meer voldaan wordt aan de optimumvoorwaarden worden ook de optimumvoorwaarden voor andere goederen en productiefactoren aangetast. De overheid beschilkt in de praktijk niet over de enorme hoeveelheid informatie die nodig is om alle gebreken te corrigeren. Indien evenwel aan één van de veronderstellingen die ten grondslag liggen aan een "first best" economie niet meer voldaan wordt is er sprake van een "second best" oplossing. Zoals vermeld in hoofdstuk 2 kan hierbij worden gedacht aan het bestaan van marktimperfecties op grond van monopolistische en oligopolistische marktvormen $_{n}$ aan externe effecten en aan onzekerheid. In dat geval zijn de prijzen in de economie ongelijk aan de marginale kosten en realiseert het marktmechanisme niet langer een Paretoefficiënte allocatie. In deze paragraaf zal verder worden ingegaan op de gevolgen hiervan voor het bestaan van overheidsinstellingen."

\section{De "second- en thirdbest"-benadering en overheidsinstellingen}

De overheid kan in het algemeen op twee manieren proberen om een inefficiënte situatie te verbeteren. In de eerste plaats kan zij proberen met behulp van belastingen en subsidies, anti-trustwetgeving en regulering alsnog een "first-best"-oplossing tot stand te brengen. De beleidmakers kumnen bijvoorbeeld trachten door middel van het subsidiebeleid of door middel van prijsregulering de prijs-hoeveelheidscombinaties van een monopolist direct te beinvloeden. De overheid kan er ook voor kiezen, onder meer omdat zij niet in staat is de prijs-hoeveelheidscombinaties van een monopolist rechtstreeks te beinvloeden, door middel van overheidsinstellingen een first-best-oplossing tot stand te brengen: Zij brengt dan zelf de Pareto-efficiënte hoeveelheid voort. Vaak zal dit niet mogelijk zijn gezien de grote hoeveelheden informatie die hiervoor nodig zijn of zall de politiek hier niet voor kiezen. Bovendien zullen er in een economie weelal meerdere inefficiënties zijn. Dan geldt in de economie dat de prijzen ongelijk zijn aan de marginale kosten en dat de schaarsteverhoudingen niet goed worden weergegeven. Deze afwijking kan gedeeltelijk worden gecorrigeerd door het prijsbeleid van overheidsinstellingen te gebruiken als instrument waarmee een "second-best" traditionele theorie van second best werd geformuleerd door Lipsey en Lancaster in 1959. ${ }^{1276}$ Volgens deze traditionele benadering van het "second-best" probleem maximaliseren politieke actoren een doelfunctie onder de veronderstelling dat zij het publieke belang nastreven. Deze doelfunctie is onderworpen aan een tweetal restrieties. De eerste

1276. Lipsey en Lancaster (1959, pp. 225-226). 
restrictie heeft betrekking op de aanwezige hulpbronnen terwijl de tweede restrictie betrekking heeft op een verstoring van de Paretiaanse eerste orde voorwaarden. Dit kan als wollgt worden weergegeven:

Sociale doelfunctie: $\quad F\left(x^{1}, x^{2}, \ldots, x^{n}\right)$

Restrictie ten aanzien van

beschikbare hulpbronnen:

$\mathrm{G}\left(\mathrm{x}^{1}, \mathrm{x}^{2}, \ldots, \mathrm{x}^{\mathrm{n}}\right)$

Second-Best restrictie: $\quad \mathrm{F} 1 / \mathrm{Fn}=\mathrm{k}$ G1/Gn, waarbij $\mathrm{k}$ ongelijk aan 1

Het prijsbeleid van een overheid zall dan zodanig worden gekozen dat een Pareto-optimum gehaald wordt, maar onder de restrictie dat de monopolist vrij is zijn eigen gedrag te bepalen. De overheidsinstelling rekent dan een prijs ongelijk aan de marginale kosten, tenzij het monopolistische bedrijf niet beïnvloed wordt door de prijsstelling van de overheidsinstelling. Een tweede belangrijk kenmerk is dat een "second-best"-oplossing inferieur is aan een "first-best"-oplossing. Dit impliceert dat de Pareto-efficiënte nutsmogelijkhedencurve niet gehaald wordt. ${ }^{1277}$ Stel dat er in een economie een drietal sectoren zijn, waarvan een tweetal particuliere sectoren, en dat het uitgangspunt een economie met volkomen mededinging is. De kruiselingse substitutie-elasticiteit van de vraag tussen de twee particuliere sectoren is 0 . Het aanbod op de derde markt wordt verzorgd door een overheidsinstelling. De goederen die verhandeld worden op de twee particuliere markten zijn substituten voor goed drie. In de uitgangssituatie stellen de drie bedrijven de prijs gelijk aan de marginale kosten.
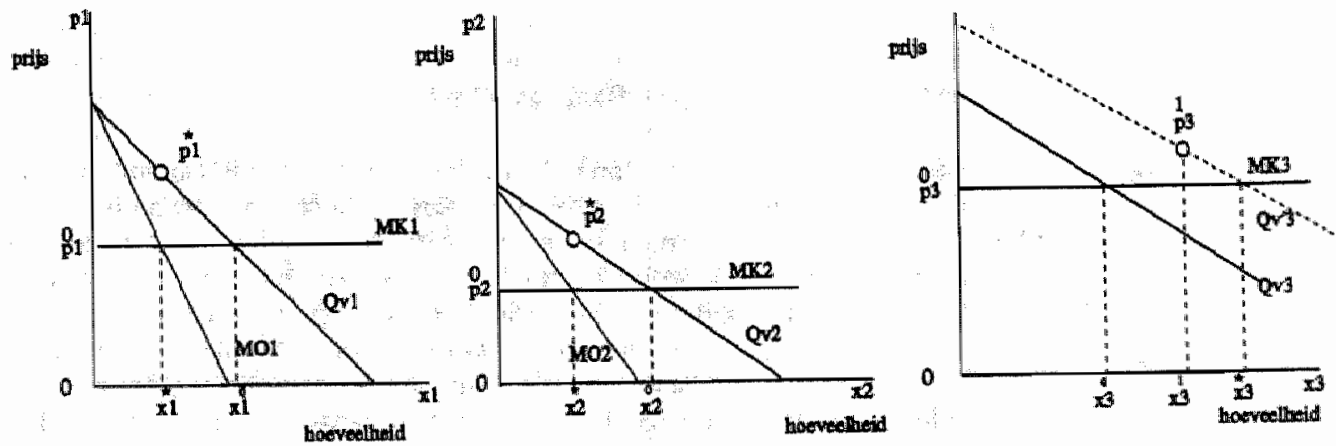

Figuur A.8 Second-best-benadering en overheidsinstellingen ${ }^{1278}$

De twee monopolisten in de particuliere sectoren stellen teneinde hun winst te maximaliseren de prijs vervolgens ongelijk aan de marginale kosten, terwijl de aangeboden

${ }^{1277}$ Rees (1984, pp. 38 e.v.). Zie ook: Bös (1994 „pp. 150-152).

1278 Vergelijk: Rees (1984, p. 40). 
hoeveelheid daalt. Aangezien de overheidsinstelling de prijs gelijk blijft stellen alan de marginale kosten zal de vraag naar goed drie toenemen (Qv"3). Door de productievermindering in de particuliere sectoren komen productiefactoren vrij die vervolgens in markt drie worden gebruikt voor de toegenomen productie van $x 3$, namelijk $x * 3-x^{\circ} 3$. De prijsratio"s zijn nu evenwel ongelijk aan de marginale kostenverhoudingen:

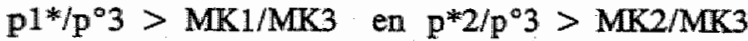

In theorie is het mogelijk door reallocatie van productiefactoren van sector drie naar de eerste twee sectoren de efficiëntie te verbeteren. Bovendien zouden de consumenten die kopen op markt én of twee consumenten van deelmarkt drie volledig kunnen compenseren en er toch nog op vooruitgaan. Omdat echter de productie in de particuliere sectoren verzorgd wordt door monopolies komt deze overdracht niet tot stand. Gesteld dat de overheid niet in staat is, bijwoorbeeld door regulering in deelmarkt eén en twee, de prijs opnieuw gelijk aan de marginale kosten te stellen, resteert het prijsbeleid van de overheidsinstelling in deelmarkt drie. Indien de overheidsinstelling de prijs verhoogt tot p $3^{0}$ zal de vraag van de overheidsinstelling dalen en zal de vraag van de particuliere sectoren stijgen. Productiefactoren zullen nu geheralloceerd worden naar de particuliere sectoren, totdat geen enkele consument er op vooruit kan gaan en geen enkele andere er op achteruit kan gaan, gegeven het gebruikte instrument. ${ }^{1279}$ Indien verder aangenomen wordt dat bedrijf 2 door middel van regulering de optimale hoeveelheid gaat produceren resteert de vraag hoe hoog de overheidsinstelling de prijs moet stellen om de Paretoinefficiëntie veroorzaakt door bedrijf 1 te corrigeren. Essentieel is daarbij het verband tussen de door beide bedrijven gekozen prijzen en hoeveelheden. Stel dat deze relatie als volgt kan worden weergegeven:

$\mathrm{x} 1=\delta 1(\mathrm{x} 2)$, waarbij $\mathrm{x} 1$ de door bedrijf 1 gekozen productie weergeeft, $\mathrm{x} 2$ de door de overheidsinstelling vastgestelde productie en $\delta 1$ de reactiefunctie is. De overheidsinstelling moet nu de prijs zodanig vaststellen dat geldt:

$\mathrm{p}^{2 *}-\mathrm{MK} 2=-\left[\mathrm{p} 1^{*}-\mathrm{MK} 1\right] \delta 1$, waarbij $\delta 1$ de reactie weergeeft van een kleine productieverandering van de overheidsinstelling.

Indien de beide voortgebrachte goederen complementen van elkaar zijn loopt de reactiefunctie stijgend en zal de overheidsinstelling de prijs lager dan de marginale kosten moeten stellen. Indien beide goederen daarentegen substituten zijn moet de overheidsinstelling de prijs hoger dan de marginale kosten stellen. Zelfs in dit voorbeeld ontstaan er woor een overheid al belangrijke problemen. Hoe zien bijvoorbeeld de marginale kostenfuncties van de particuliere bedrijven er uit, hoe hoog en hoe prijsselastisch is de vraag en in hoeverre zijn de goedenen te zien als substituten. In de gehele economie wordt dit nog moeilijker.

Op grond van de "second-best" benadering is het bekend dat het op bepaalde plekken "nastreven van "first-best" Pareto-efficiëntie terwijl er elders well Pareto-inefficiënties zijn, de efficiëntie van de economie niet hoeft te verbeteren. Een "second-best"-benadering zou hier een oplossing kunnen bieden. In de praktijk is dit niet haalbaar in verband met de grote hoeveelheid informatie die de overheid hiervoor nodig zou hebben. $\mathrm{Ng}$ stelt in dit verband: "It is clear that the informational and administrative costs of attaining a secondbest optimum are prohibitive in the real economy of multiple-distortion. The second-best solution has been termed "optimal feasible". Taking account of informational and administrative costs, it is in fact neither optimal nor feasible. ${ }^{1280}$ Verder merkt hilj op:

${ }^{1279}$ Dit voorbeeld is ontleend aan: Rees $(1984$, p. 42$)$.

${ }^{1280} \mathrm{Ng}(1977, \mathrm{p} .1)$. 
"However, if we can have all the relevant information costlessly and apply the second-best rules without significant additional costs, then we have again, (..) second-best rules for second-best worlds". "1281 Indien er sprake is van wat $\mathrm{Ng}$ informatie-overvloed (informational abundance ${ }^{1282}$ ) noemt, kunnen zoals in het voorgaande is aangegeven second-best regels worden gebruikt. In werkelijkheid bestaan er veel verstoringen waaronider informatiekosten.

Yew-Kwang $\mathrm{Ng}$ schetst daarom een alternatieve "third-best" benadering. ${ }^{1283} \mathrm{Naast}$ informatieovervloed onderscheidt hij enerzijds de mogelijkheid van informatie-armoede en anderzijds de mogelijkheid van informatieschaarste. . $^{284}$ Informatie-armoede houdt in dat er een groot gebrek bestaat aan informatie. Hierdoor is er niets bekend over de verschillen tussen prijzen en marginale kosten. Dit impliceert dat de mate van afwijking van de "second-best" en "first-best" regels niet voorspeld kan worden. Verder wordt uitgegaan van de veronderstelling dat de kans op een bepaalde positieve afwijking van de welvaartsfunctie gelijk is aan de kans op een even grote negatieve afwijking. Voorts wordt verondersteld dat de sociale welvaartsfunctie symmetrisch is, zoals is weergegeven in Fugur A.9. De conclusie is dat in het geval van informatie-armoede toch de "first-best" regels zouden kunnen worden toegepast, aangezien dat gemiddeld gezien een juiste uitkomst oplevert. Dit kan als volgt worden geillustreerd:

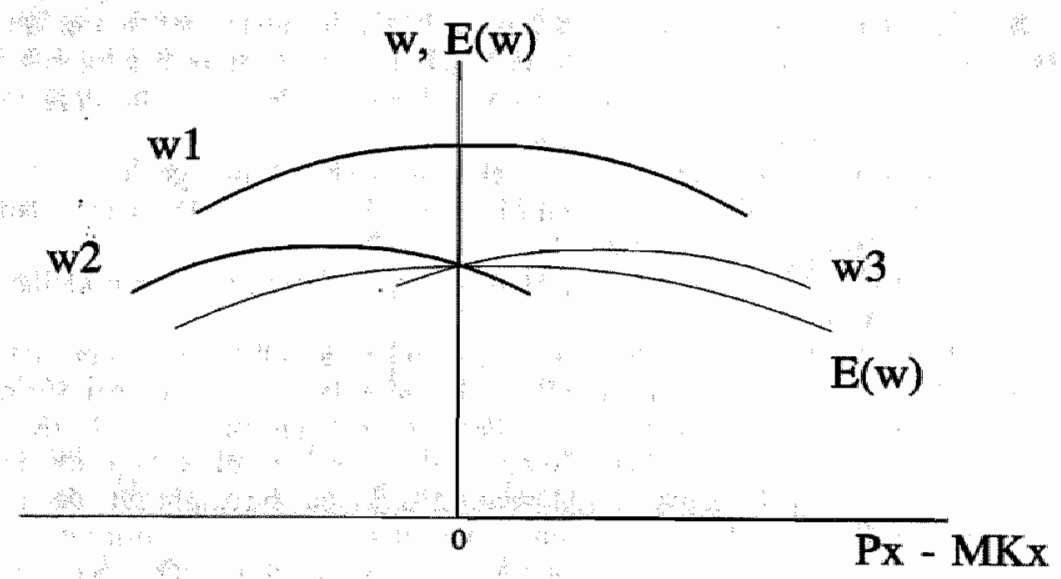

Figuur A.9 "Third best" informatie-armoede 2 12s5

1281 T.a.p., p. 3 .

1282 Dat wil zeggen perflecte informatie, de kosten van informatie zijn verwaarloosbaar.

${ }^{1283} \mathrm{Ng}(1975, \mathrm{pp}, 507-525)$, zie ook: $\mathrm{Ng}(1983, \mathrm{p}, 245)$ en $\mathrm{Ng}(1977, \mathrm{pp} .1-15)$.

1284 Vergelijk ook: Maks, in: Meijer (ed) (1995, pp. 203 e.v.).

${ }^{1285}$ Bron: $\mathrm{Ng}(1977, \mathrm{p} .5)$, vergelijk ook: Maks, in. Meijer (ed) (1995, pp. 204-205) en: McKee en West (1984, p. 249). De curves $w 1$, w2 en w3 zijn concaaf indien de helling van de vraagcurve overal kleiner is dan de helling van de marginale kostemcurve. 
Stel we bezien de elektriciteitsmarkt. In Figurar A.9 wordt het effect van de situatie op de elektriciteitsmarkt op de sociale welvaart weergegeven. Hierbij kan onderscheid gemaakt worden tussen een tweetal mogelijkheden. Indien in alle andere markten in de economie een Pareto-efficiènte allocatie wordt bereikt en dus voldaan is aan de "first best" optimum voorwaarden $\mathrm{kan}$ de sociale welvaart worden weergegeven met curve $\mathrm{w}_{1}$. Het is duidelijk dat de maximaal haalbare sociale welvaart bereikt wordt indien de elektriciteitsprijs gelijk is aan de marginale kosten $\left(\mathrm{p}_{\mathrm{x}}=\mathrm{mk}_{\mathrm{x}}\right)$. Stel nu evenwel dat er op een onbekend aantal andere markten dan de elektriciteitsmarkt niet voldaan is aan de "first best" voorwaarden. In dat geval is het niet bekend wat het effect van deze afwijkingen is op de sociale welvaart in de elektriciteitsmarkt. Het sociale welvaartsmaximum kan dan links of rechts van het maximum van $w_{1}$ liggen. Zoals weergegeven in Figuur $A .9$ kunnen mu, gegeven de voorgaande veronderstellingen, de even waarschijnlijke sociale welvaartsfuncties w, en $\mathrm{w}_{3}$ worden afgeleid. Aangezien de kans op een positieve en negatieve afwijking even groot is geeft $E(w)$ de verwachte waarde van de sociale welvaart weer. De verwachte sociale welvaart wordt gemaximaliseerd indien $p_{x}=m k_{x}$. Hieruit volgt dat in het geval van informatie-armoede de verwachte waarde van de sociale welvaartsfunctie gemaximaliseerd wordt indien in een specifieke markt voldaan is aan de first-best"-voorwaarden. Dit is ook het geval indien in andere markten geen Pareto-efficiẻnte allocatie wordt bereikt.

In het geval van informatieschaarste is er wel voldoende informatie aanwezig om een waarschijnlijkheidsverdeling op te stellen van de mate van afwijking van de prijs van de marginale kosten op een markt en daarmee van de waarschijnlijkheid van een bepaalde positieve en negatieve afwijking van de welvaartsfunctie op de elektriciteitsmarkt (in dit voorbeeld). Bovendien is er voldoende informatie aanwezig om de vorm van de sociale welvaartsfunctie te schatten. Dit kan geillustreerd worden met het volgende woorbeeld:

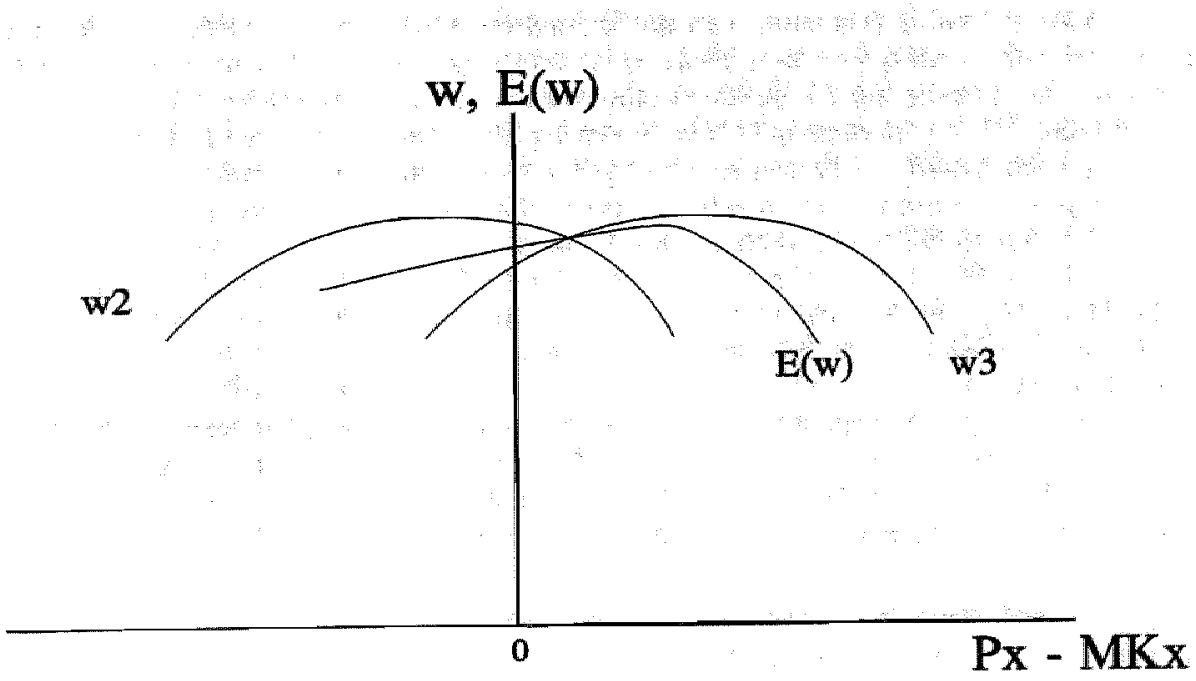

Figuur A.10 "Third-best" en informatieschaarste ${ }^{1286}$

1286. Vergelijk ten aanzien van de "third best"-benadering ook: Maks en Schinkel $(1993$, p. 4). 
Stel dat er voldoende informatie aanwezig is over de afwijking en de vorm van de welvaartsfunetie op de ellektriciteitsmarkt om de curves $w_{2}$ en $w_{3}$ te tekenen. Stel bovendien dat het mogelijk is om op grond van de aanwezige informatie te concluderen dat $w_{2}$ en $w_{3}$ even waarschijnlijk zijn. De waarschijnlijke sociale welvaartsfunctie kan nu worden weergegeven met $E(w)$. Maximalisatie van de sociale welvaart impliceert nu dat de prijs in de elektriciteitsmarkt ongelijk aan de marginale kosten moet worden gesteld. Dit is in dit geval de sociaal optimale "third best" voorwaarde.

Welke van beide benaderingen nu het best gekozen kan worden hangt natuurlijk vooral af van de vraag over welke informatie de overheid beschilkt. In dit verband kan onderscheid worden gemaakt tussen enerzijds marktspecifieke en anderzijds algemene informatie. Om een schatting van de welvaartsfunctie op de elektriciteitsmarkt te kunnen maken is in elk geval informatie nodig over de marktvraag en de kosten.

$\mathrm{Ng}$ meent dat het onder bepaalde voorwaarden redelijk (optimaal) is om de prijs/marginale kosten-ratio gelijk te stellen aan het geschatte gemiddelde van deze ratio in de economie. ${ }^{1287}$ Dit zal het geval zijn indien het goed niet in hoge mate complementair is aan of substitueerbaar is door goederen die onder monopolistische marktomstandigheden worden aangeboden. In dat geval zouden overal gelijke afwijkingen tussen prijzen en marginale kosten nagestreefd moeten worden. Dit zou alleen anders zijn indien grotere welvaartsvoordelen te behalen zijn indien een overheidsinstelling de prijs meer laat afwijken van de marginale kosten. Ng merkt op: "Since this ratio is larger than one, this third-best rule requires pricing above marginal cost. (..) However, if optimality requires not marginal-cost pricing but above marginal-cost pricing, then one may not be too far out by setting price at average-cost, unless marginal cost is very much smaller than average cost" ${ }^{\prime \prime}{ }^{1288}$

McKee en West stellen de relevantie van de "second en third best" theorieën aan de orde. $\mathrm{Zij}$ stellen dat alle verstoringen die, zoals vaak wordt gesteld, zouden moeten leiden tot een "second-best" benadering de uitkomst zijn van een door het politieke proces gekozen Pareto-oplossing. ${ }^{1289} \mathrm{Zij}$ merken op: "On reviewing the genesis of second best "distortions" we find them usually to be the result of prior transaction in the political market (at the pre - or post - constitutional level). As such, these distortions must be viewed as a part of the Paretian solution and their existence constitutes a political market, $(\ldots)$. .1290

Yew-Kwang Ng reageert hierop met te stellen dat McKee en West slechts gedeeltelijk gelijk hebben. Hij maakt onderscheid tussen politieke verstoringen, waarvoor het argument van McKee en West gedeeltelijk van toepassing is en niet-politieke verstoringen waarvoor de theorie van "second" en "third best" volledig toepasbaar is. ${ }^{1291}$

Indien het politieke proces bepaalde verstorende maatregelen treft is het waarschijnlijk dat zij second-best verbeteringen zullen tegenhouden. In zoverre klopt volgens $\mathrm{Ng}$ het argument van McKee en West. Daarnaast zijn er echter verstoringen waar de overheid niet expliciet voor gekozen heeft, bijvoorbeeld externe effecten, die niet worden gecorri-

${ }^{1287} \mathrm{Ng}(1983$, pp. 236-237). Vergelijk ook: $\mathrm{Ng}$ (1977, pp. 9-10).

${ }^{1288} \mathrm{Ng}(1977$, p. 10$)$.

${ }^{1289}$ McKee en West (1981, pp. 436-448) en McKee en West (1984, pp. 246-260).

. ${ }^{1290}$ McKee en West $(1984$, p. 250).

${ }^{1291} \mathrm{Ng}\left(1987, \mathrm{pp} .137\right.$ e.. $\left.\mathrm{V}_{\text {. }}\right)$ 
geerd in verband met administratieve redenen, niet door politieke beslissingen gecorrigeerde monopolies en niet lump sum belastingen met als doel ontvangsten te creëren: Hiervoor zouden traditionele second- en third-best oplossingen gebruikt kunnen worden.

Met betrekking tot de categorie van verstoringen die door McKee en West bedoeld worden, de zogenaamde politieke verstoringen, zijn verbeteringen die enerzijds de efficiëntie verbeteren maar anderzijds het herverdelende aspect onveranderd laten denkbaar. McKee en West behandelen als voorbeeld een eenvoudig model met daarin twee geografisch gescheiden groepen van producenten (aangediud als het Noorden en het Zuiden). ${ }^{1292} \mathrm{Er}$ is sprake van een mimimum-loon-regeling als een instrument ter bescherming van het Noorden tegen competitie van het Zuiden, waar de lonen lager zijn. Indien een overheid een dergelijk minimumloon stelsel aanneemt moet zo'n beleid volgens Mckee en West gekarakteriseerd worden als Pareto-efficiënt in de betekenis dat de economische allocatie verschuift van een staat A naar een staat B, waarin iedereen beter af is dan wel even goed af is als in staat $\mathrm{A} . \mathrm{Ng}$ wijst erop dat McKee en West uitgaran van een onjuiste opvatting ten aanzien van het Pareto-criterium. ${ }^{1293}$ Immers indien in staat $B$ iedereen beter af is en niemand slechter af is dan in staat $A$ wil dat nog niet zeggen dat er sprake is van een Pareto-efficiënte allocatie. $\mathrm{Ng}$ stelt dat bijvoorbeeld door de prijsstelling van overheidsinstellingen door middel van een second of third-bestbenadering de efficiëntie mogelijk verbeterd kan worden. In die zin is second en thirdbest beleid. ook relevant met betrekking tot verstoringen die gecreëerd zijn door het politieke proces in verband met distributieve doelen. Ng past vervolgens deze redenering toe op het voorbeeld van het minimumloonstelsel. Volgens hem kan het om redenen van efficiëntie van belang zijn, gegeven het doel van bescherming van de industrie in het Noorden, maatregelen te aanvaarden die de verstoring zoals die veroorzaakt door het minimumloon tegengaan, zonder de beschermende functie teniet te doen. In bun artikel van 1987 geven McKee en West als antwoord hierop dat $\mathrm{Ng}$ er niet in slaagt aan te geven hoe de efficiëntie kan worden verbeterd.1294 Ter illustratie nemen zij nogmaals het voorbeeld van het minimumloon. Een verbetering is alleen denkbaar door een correctie van de door het minimumloon veroorzaakte misallocatie. Indien bijwoorbeeld an het Zuiden subsidies worden gegeven zal de productie en werkgelegenheid in het Zuiden weer toenemen. Hierdoor zal het distributieve voordeel voor het Noorden weer minder worden of zelfs tenietgaan. Hierbij is evenwel voorbij gegaan aan de uitwerking op de verschillende bedrijfstakken.

Het is duidelijk dat de verschillende standpunten voor een belangrijk deel zijn terug te voeren op het verschil van inzicht ten aanzien van Pareto-efficiêntie. McKee en West menen dat indien politici kiezen voor een bepaalde situatie deze wel Pareto-optimaal moet zijn aangezien zij anders niet hiervoor gekozen zouden hebben. Zoals $\mathrm{Ng}$ het stelt:

"Given some mild assumptions about rational behaviour, if we include all issues of political, institutional, and informational feasibility, strategic behaviour, time lags etc. into the set of inviolable constraints, then it is relatively trivial that whatever a given situation is, it must already be Pareto optimal "1295 Het standpunt van McKee en West houdt dus in dat de bestaande door de politieke actoren gekozen situatie Pareto-efficiènt is aangezien het gegeven de bestaande beperkingen niet bekend is hoe het beter zou kunnen.

1.292 McKee en West (1984, p. 252).

1.293 Vergelijk bijwoorbeeld noot $\mathbb{1}$ van het artikel van Yew-Kwang $\mathrm{Ng}$ over " Political Distortions" and the Relevance of Second and Third-Best Theories" uit 1987.

1294 McKee en West (1987, pp. 146 e.v.).

$1295 \mathrm{Ng}(1987$, p. 152). 
$\mathrm{Ng}$ verzet zich tegen een dergelijke benadering van de economie. Volgens hem hoeven we al die beperkingen op onder ander politiek, institutioneel en informationeel gebied niet te accepteren. Wellicht dat beleidmakers en kiezers niet weten hoe het beter zou kunmen. Dit neemt wolgens hem niet weg dat met name economen hier een belangrijke taak hebben. Zij zouden moeten onderzoeken of er Pareto-verbeteringen mogelijk zijn en indien dat het geval is deze vervolgens duidelijk moeten maken aan het publiek en beleidmakers. Mogelijk zal de directe invloed op het beleid niet erg groot zijn, aangezien beleidmakers in werkelijkheid niet de maatschappelijke welvaart maximaliseren. Dit neemt niet weg dat de sociaal-economische optimaliseringsbenadering gebraikt kan worden als een vergelijkingsstandaard. $\mathrm{Ng}$ geeft het verschil tussen beide benaderingen verder als volgt weer:

"A utility possibility curve that ignores institutional, political, and informational constraints may be criticized as infeasible. But if we can show that the relevant feasibility cune ways inside the possibility curve, this may help to improve information availability, dismantle some institutional barriers, etc. and hence to move the utility feasibility curve closer to the possibility curve. An economist need not just be an obedient servant of the policy-maker; he can also be the serwant of the people, keeping a watchful eye on the policy-maker". 1296

Als conclusie stelt hij dat de public-choice theorie weliswaar tot bepaalde hoogte nuttig is geweest om een juist evenwicht te vinden tussen de traditionele sociaal-economische optimaliseringsbenadering en het belang van institutionele factoren, maar dat anderzijds. niet zover gegaan moet worden dat de traditionele benadering volledig over boord wordt gezet. De verschillen in beide benaderingswijzen hebben ook invloed op de keuze van de te gebruiken onderzoeksmethoden. Indien een meer normatieve werkwijze gevolgd wordt ligt een deductieve werkwijze meer voor de hand. Met behulp van een model worden aanbevelingen gedaan ter verbetering van een bepaalde situatie. Indien uitgegaan wordt van een Pareto-efficiênte allocatie zal vaak gebruik worden gemaakt van een positieve benadering waarbij eveneens empirisch (inductief) onderzoek van belang is.

Hoewel er nog wel enig verschil van mening bestaat blijkt deze kleiner dan aanvankelijk het geval leek te zijn. De benadering van McKee en West gaat duidelijk verder dan de Chicago-benadering. Volgens de Chicago-benadering is datgene wat in de werkelijkheid tot stand komt automatisch efficiënt. Of zoals Becker stelt: "Policies that raise efficiency are likely to win out in the competition for influence because they procduce gains rather than deadweight costs (... $)^{\prime \prime}{ }^{1297}$ Daarmee komt de opvatting van McKee en West in de buurt van de Virginia-benadering (Virginia politieke economie). Deze benadering van onder meer Buchanan en Tullock kan als volgt worden weergegeven: "Given the institutional setting, absence of consummated exchange is strongly suggestive that the resources involved remain in their most highly-valued uses" ${ }^{1298}$ Ook de benadering van $\mathrm{Ng}$ komt hier redelijk mee overeen. De benaderingen van McKee en West en $\mathrm{Ng}$ gaan er immers allebei vanuit dat gegeven de institutionele restricties in de economie de uitkomst efficiẻnt is. $\mathrm{Ng}$ geeft aan dat deze restricties eventueel gewijzigd kunnen worden. Dit wordt feitelijk ook door de Virginia-benadering benadrukt. Crew en Rowley merken dienaangaande op: "Institutional constraints, however, may well impede the attainment of efficiency gains potentially available within a different set of rules or constitutional

${ }^{1296}$ T.a.p., p. 153.

${ }^{1297}$ Becker (1982, p. 396). Zie ook: Crew en Rowley (1988, p. 49).

${ }^{1298}$ Crew en Rowley (1988, p. 54). Vergelijk ook: Buchanan (1969) en Tullock, (1967, pp. 224-232). 
conditions. In such circumstances, what is is not efficient if meta-level rules changes are feasible" ${ }^{\text {.2099 }}$ De vraag rijst dan of rationele individuen dan ook niet automatisch kiezen voor de meest efficiënte instituties en andere restricties. Crew en Rowley stellen in dit verband: "If changes in rules offer net gains in efficiency, surely utility maximizing individuals would already have embraced them. In our view, this inference stretches the equilibrium concept beyond acceptable limits". De reden dat deze (efficiënte) instituties niet tot stand komen heeft dan bijwoorbeeld te maken met het ontbreken van informatie bij individuen over de hoogte van de transactiekosten (alternatieve kosten) van alternatieve instituties. Economen zouden dan deze alternatieve instituties kunnen analyseren en zo een belangrijke bijdrage kunnen leveren aan het bereiken van efficiëntie-winsten, of in de woorden van Crew en Rowley: "By reducing the cost of search, political economists exogenous to the prevailing equilibrium play a productive role in political market intermediation, even when the relevant transaction cost information already exists: More creatively, the traty original political economist exercises an entrepreneurial role dedicated (...) to the design of cost-reducing institutional alternatives that will be subjected (ideally) tot a consensus-efficiency test ". ${ }^{1300}$ Dit is eveneens de benadering van efficiëntie die in dit onderzoek wordt gevolgd.

\section{Conclusie}

Al deze in paragraaf A.2.3.1 en A.2.3.2 genoemde vormen van prijsstelling zijn in feite gebaseerd op de marginale kostenprijsregel of op varianten daarvan. Vanuit verschillende kanten is kritiek geuit op de marginale kostenprijsregel. Deze kritiek varieert van het probleem van het in de praktijk meten van de marginale kosten tot meer algemene problemen als preferenties die zich kunnen wijzigen en de nadruk op marginale veranderingen. ${ }^{1301}$ Vanuit de Duitse "Gemeinwirtschaftslehre" wordt tegen de marginale kostenprijstheorie aangevoerd dat deze theorie slechts een abstract model geeft met weinig realiteitswaarde. Hiertegen zou kunnen worden aangevoerd dat alternatieve second en third best-benaderingen zijn opgesteld om aan deze bezwaren tegemoet te komen. ${ }^{1302}$ Een tweede bezwaar dat vanuit deze benadering wordt aangevoerd houdt in dat de relevante politieke groepen en actoren in het geheel niet geïteresseerd zijn in marginale kostenprijsstelling, alswel in het gebruiken van de overheidsinstelling als een instrument voor het bereiken van hun doelen. ${ }^{1303}$ Hartog stelt ten aanzien van deze benadering: "Deze vindt in Duitsland veel aanhang en leidt daar in het algemeen tot allerlei manipula-

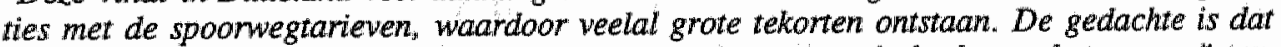
het vervoer dienstbaar moet zijn aan de rest van het economische leven, hetgeen geinterpreteerd wordt als een wenselijkheid tot gebruik van vervoentarieven als instrument van. economische politiek (b.v. lage wrachttarieven ter bevordering van de ontwikkeling van

1259 Crew en Rowley (1988, p. 54).

${ }^{1300}$ T.a.p. pp. 54-55.

${ }^{1301}$ Blankart (1980, pp. 106 e.v.).

1302 Echter, ook bij deze beriaderingen kunnen vraagtekens gezet worden bij de realiteitswaarde ervan. Zie: Koers (1995, pp. 28 e.v.).

1303 Thiemeyer (1987, pp. 108-110). 
bepaalde streken).

${ }^{1304}$ Hartog $(1973$, p. 115). 


\section{Appendix 2. De "Performance benadering"}

B.1 In hoeverre kan de "performance" van een overheidsinstelling gemeten worden met behulp van de "performance approach"?

\section{B.1.1 Wat wordt verstaan onder de kwantitatieve benadering?}

Als tweede exponent van een meer empirisch gerichte stroming is de performance approach" of kwantitatieve benadering van belang. Zij vormt in verschillende opzichten een uitbreiding van de in paragraaf 13.2 beschreven methode waarbij gebruik wordt gemaakt van indicatoren. Als grondlegger van de kwantitatieve prestatie-analyse kan M.J. Farrel worden beschouwd. ${ }^{1305}$ Hij verrichtte onderzoek naar de mate van efficiêntie van een productieproces. Hij onderzoekt daarbij kostenefficièntie, hetgeen bestaat uit enerzijds technische efficiëntie en anderzijds prijsefficiëntie. Door zijn methode wordt het mogelijk om beide vormen van efficiëntie te onderscheiden. Hij gaat bij zijn analyse uit van een eenvoudig neo-klassiek model met een productieproces waarin alleen gebruik gemaakt wordt van arbeid en kapitaal en waarbij sprake is van constante schaalopbrengsten.

De eerste stap die nodig is voor een dergelijke prestatie-analyse is het afleiden van een productiefunctie waartegen de feitelijke prestatie van een overheidsinstelling kan worden geschat. Farell meent dat een dergelijke optimale transformatiecurve moet worden afgeleid van een soortgelijk bedrijf met dezelfde technologie, dat de meeste goederen produceert met een gegeven input. Met behulp van een Farreldiagram kan dit worden toegelicht.

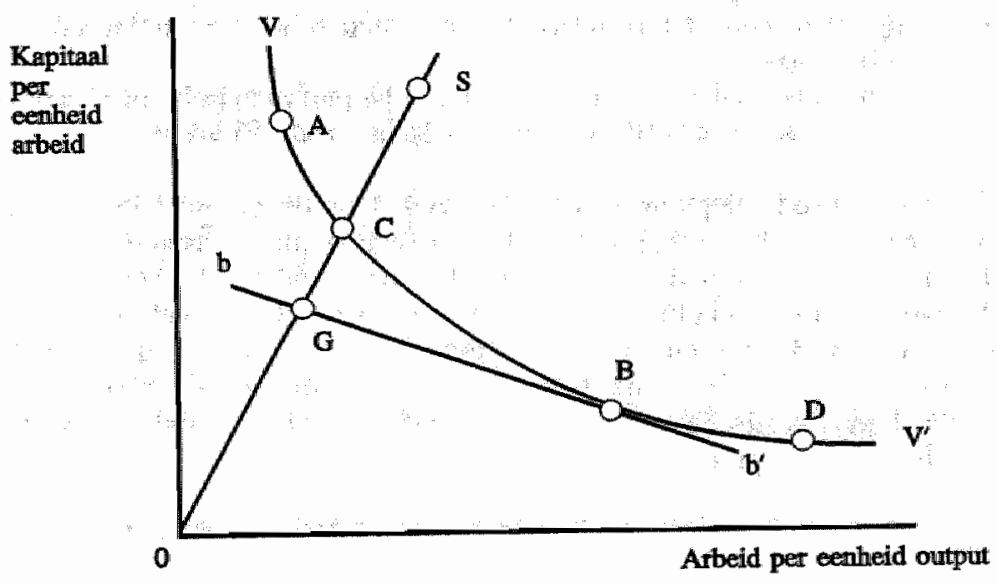

\section{Figuur B.1 Farreldiagram}

Farrel kiest als efficiëntiestandaard voor een isoquant. De punten A, B en C op de isoquant zijn technisch efficiënt. Punten beneden de $\mathrm{VV}^{\prime}$-curve zijn niet haalbaar. Punt $\mathrm{S}$ boven de isaquant is niet technisch efficiënt, noch prijsefficiềnt. Hoe kunnen we meten of punt $S$ technisch efficiënt en prijsefficiënt is? Dit kan worden bepaald door een lijn te

${ }^{1305}$ Farrel (1957, pp. 253-281). Vergelijk ook. Koopmans (ed.) (1965, pp. 33-97). 
trekken naar de oorsprong, in dit geval OS. De ratio OC/OS geeft de mate van technische efficiëntie weer. De mate van prijsefficiëntie kunnen we bepalen met de isokostenlijn bb: OG/OC geeft de mate van prijsefficièntie weer van punt $c$.

Een bellangrijk probleem hierbij is hoe de meest efficiënte productiemethode/productiefunctie oftewel de isoquant $\mathrm{VV}^{*}$ in Figuur B.1 te bepalen. Indien een bedrijf onderzocht wordt is het immers niet zonder meer bekend wat de meest efficiënte productiemethode is. Kopp merkt verder op: "The "The observed standard' is determined by those production organizations sharing a common technology that produce the greatest output from a given input set. Efficiency measures based on the observed standard are relative in the sense that individual production organizations are compared with the performance of their peer groups (een bedrijfstak met bijwoorbeeld een zelfde technologie, IFK). As the performance of the peer group changes, so will measured efficiency. Finally, the adoption of a unit isoquant necessarily implies that the technology employed by the production organizations is linear homogeneous (constante schaalopbrengsten, JFK) ${ }^{\prime}$.

De kwantitatieve benadering bouwt voort op de analyse wan Farrel. Zij beoogt de prestatie, meer in het bijzonder de technische efficiëntie, wan een overheidsinstelling te meten door middel van het schatten van een productiegrens. In de literatuur worden verschillende manieren genoemd waarop een productiegrens kan worden bepaald. Kopp geeft een overzicht van de verschillende mogelijkheden die er bestaan voor het opstellen van een "best practice" productiefunctie ${ }_{\text {." }}^{1307}$ Deze benaderingen leveren echter niet dezelfde resultaten op. Thiry en Tulkens vermelden een viertal mogelijkheden om een productiegrens op te stellen, te weten: ${ }^{1308}$

I. schatting van een productiegrens met behulp van de non-parametrische benadering; II. schatting van een deterministische parametrische productiegrens op een nietstatistische wijze;

III. statistische schatting van een deterministische parametrische productiegrens;

IV. schatting van een stochastische parametrische productiegrens.

Enerzijds kan de productiegrens worden bepaald door de parametrische methode waarbij de productiegrens wordt gespecificeerd als een functie met constante parameters zoals de Cobb-Douglas productiefunctie of de CES-functie. Anderzijds kan een productiegrens opgesteld worden met behulp van een non-parametrische benadering waarbij het niet mogelijk is de productiegrens weer te geven als een functie met constante parameters. ${ }^{1309}$ Binnen de parametrische benadering kan onderscheid worden gemaakt tussen enerzijds de deterministische parametrische productiegrens en anderzijds de stochastische parametrische productiegrens.

${ }^{1306}$ Kopp (1981, p. 482).

${ }^{1307}$ Kopp (1981, pp $477-503$ ). Onder "best practice"-onderneming wordt in het vervolg de best presterende onderneming bimmen de betreffende of een verwante bedrijfstak bedoeld.

1308 Thiry en Tulkens (1989, p. 25). Zie verder ook: Tulkens, Thiry en Palm in: Thiry en Tulkens (eds) (1988).

1309 Vergelijk: Forsund, Lovell en Schmidt (1980, pp. 5-25) en Thiry en Tulkens (1989). 
In het geval van een deterministische productiegrens geeft de geschatte functie precies de grens weer. Bij de stochastische benadering daarentegen wordt de functionele vorm van de productiegrens met een bepaalde waarschijplijkheid gespecificeerd. ${ }^{1310} \mathrm{Er}$ is met andere woorden sprake van een "random error". Thiry en Tulkens geven aan dat de stochastische parametrische benadering gebruik maakt van statistische methoden (waaronder bijvoorbeeld de methode van de kleinste kwadraten). Ook de deterministische parametrische productiegrens kan geschat worden met behulp van statistische methoden, namelijk indien de inefficiëntie op de één of andere wijze statistisch gespreid is. Indien dat niet het geval is worden niet-statistische methoden zoals lineaire programmering gebruikt.

ad I.) Kan de "performance" gemeten worden door het bepalen van een non-parametrische productiegrens?

De benadering van Farrel, zoals hierboven weergegeven, is non-parametrisch, aangezien zij niet vereist dat de productiegrens moet worden weergegeven door een functie waarvan de parameters bepaald moeten zijn. Deze benadering is later uitgewerkt door onder meer Deprins, Simar en Tulkens. ${ }^{1311}$ Een observatie is volgens deze benadering inefficiënt indien andere combinaties van inputs en outputs gevonden kunnen worden waarbij de geproduceerde hoeveelheid groter is en/of de gebruikte hoeveelheid inputs kleiner is. Dit kan worden geillustreerd met Figuur B.2:

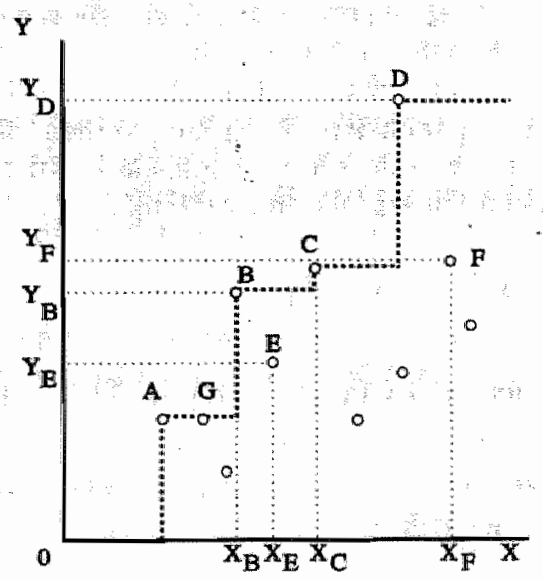

\section{Figuur B.2 Een non-parametrische productiegrens}

Stel dat wordt uitgegaan van een overheidsinstelling die één produkt voortbrengt met één productiefactor. Situatie $F$ is nu bijvoorbeeld inefficiënt aangezien $C$ en $D$ meer efficiënt zijn. Punten A, B, C en D zijn daarentegen efficiënt, aangezien er geen andere inputoutput-combinatie is die meer technisch efficiënt is.

Dit leidt er gegeven de vrije beschikbaarheid van inputs en outputs toe dat de productie-

1310 Vergelijk ook: Coell en Perelman (1996, pp. 2 e.v.).

${ }^{1311}$ Deprins, Simar en Tulkens (1984, pp. 243-267). 
grens trapsgewijs loopt. Elke tree wordt bepaald op grond van de meest efficiënte inputoutput-combinatie. Deze methode om de productiegrens te bepalen wordt de "Free Disposal Hull"-methode (FDH) genoemd. De mate van efficiëntie van bijvoorbeeld punt $\mathrm{E}$ is $\mathrm{OXB} / \mathrm{OXE}$ uitgedrukt in inputs en $\mathrm{OYE} / \mathrm{OYB}$ uitgedrukt in output.

ad. II) Kan de "performance" gemeten worden door middel van een niet-statistische schatting van een deterministische parametrische productiegrens?

Ook deze benadering gaat er vanuit dat met een aantal inputs een bepaalde hoeveelheid produkt kan worden voortgebracht. $Y_{0}$ is de werkelijke hoeveelheid van het voortgebrachte produkt, terwijl Y* de maximale hoeveelheid van het produkt voorstelt die met dezelfde hoeveelheid inputs voortgebracht had kunnen worden. De mate van technische efficiëntie kan mu worden weergegeven met de ratio:

$\mathrm{TE}=\mathrm{Y}_{0} / \mathrm{Y}^{*}$

Daarbij wordt er vanuit gegaan dat de productiegrens kan worden weergegeven met een parametrische functie $\mathrm{Y}^{*}$, bijvoorbeeld in de vorm van een Cobb-Douglas functie of een logaritmische functie: ${ }^{1312}$

$\mathrm{Y}^{*}=\mathrm{f}(\mathrm{X}, \alpha)$ of $\ln \mathrm{Y}^{*}=\ln \mathrm{f}(\mathrm{X}, \alpha)$

Indien er sprake is van technische inefficiëntie zal er een verschil bestaan tussen $Y_{0}$ en $\mathrm{Y}^{*}$. Dit kan worden weergegeven als: $\mathrm{u}=\ln \mathrm{Y}^{*}-\ln \mathrm{Y}_{0}$

Hoe kan nu de waarde van de parameters $\alpha$ bepaald worden? Stel er zijn $\mathbf{N}$ waarnemingen van inputs en outputs. De waarde van de parameters kan nu worden gevonden door het oplossen van een programmeringsprobleem, namelijk:

Minimaliseer: $\quad \sum_{k=1}^{N}\left[\ln f\left(X^{0 k} ; \alpha\right)-\ln Y^{0 k}\right]$

waarbij voor elke $N$ observaties van $k(k=1, \ldots, N)$ de vgl.: $\ln f\left(X^{0 k} ; \alpha\right)-\ln Y^{\text {rok }} \geq 0$ vervuld moet zijn.

Deze methode gaat dus uit van het minimaliseren van de eenzijdige residuen en kan worden geillustreerd met Figuur B.3.

1312 Thiry en Tulkens (1989, p. 29). 


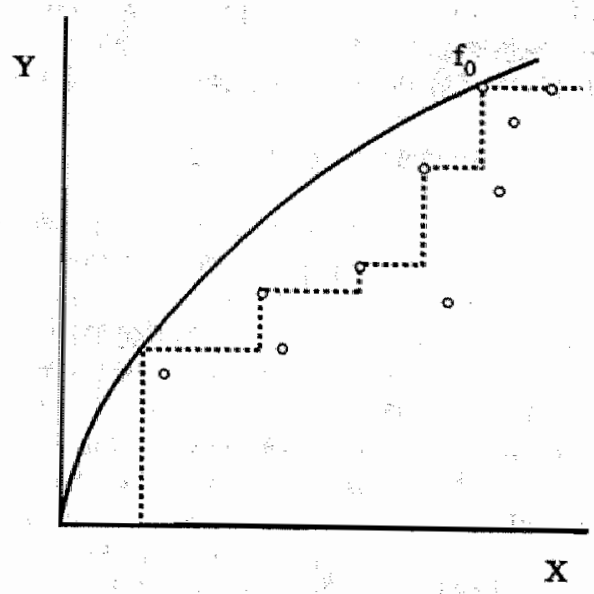

Figuur B.3 Niet statistische schatting van een deterministische parametrische productiegrens

De parameters zijn dusdanig dat er een continue productiegrens $f_{0}$ gevonden wordt. Vergeleken met de non-parametrische benadering heeft deze methode als voordeel dat de productiegrens en daarmee het bepalen van de technische efficiëntie, continu is. Met behulp van een dergelijke productiegrens kunnen allerlei kenmerken worden bepaald, zoals de schaal van de productie en de substitutie-elasticiteiten. Een belangrijk nadeel van deze methode is dat het antal observaties dat deze benadering efficiënt acht afhangt van het aantal parameters in de productiegrensfunctie. Daardoor is het aantal geobserveerde inefficiënte gevallen veel groter dan bij de non-parametrische methode.

ad. III Kan de "performance" gemeten worden door middel van een statistische schatting van een deterministische parametrische productiegrens?

Indien er van wordt uitgegaan dat verschillen in $Y^{*}$ en $Y_{0}$ uitsluitend technische inefficientie weerspiegelen, is het mogelijk om een productiegrens te schatten met behulp van statistische technieken. In de literatuur worden een drietal methoden gebruikt, namelijk de methode van de grootste waarschijnlijkheden ("maximum likelihood method"), de gecorrigeerde kleinste kwadratenmethode ("corrected ordinary least squares method (COLS)" $)$ en de verplaatste kleinste kwadraten-methode ("displaced ordinary least squares method (DOLS)").

\section{a. De methode van de grootste waarschijnlijkheden}

Zoals aangegeven bedroeg de mate van efficiëntie: $u=\ln Y^{*}-\ln Y_{0 .}$ Het is nu mogelijk om de productiegrens te schatten met behulp van de maximale waarschijnlijkheidmethode. Alleriei waarschijnlijkheidsverdelingen kunnen gekozen worden, bijvoorbeeld een exponentiële of bijvoorbeeld een log-normale verdeling.

Een belangrijk bezwaar van deze methode is dat de uiteindelijke resultaten afhangen van de gekozen verdeling van u. Het maakt nogal wat uit of je kiest voor een exponentiële verdeling of voor één van de andere mogelijke waarschijnlijkheidsverdelingen. Deprins heeft een aantal criteria opgesteld waarmee de beste statistische waarschijnlijkheidsverde- 
ling gekozen kan worden. ${ }^{1313}$ DePrins en Simar passen de deterministische methode toe in hun onderzoelk naar de spoorwegen. ${ }^{1314} \mathrm{Zij}$ laten zien dat deze methode gebruikt kan worden om informatie te krijgen over de inefficiënties in een bepaalde sector.

\section{b. De gecorrigeerde kleinste kwadratenmethode (COLS)}

De eerste stap is het bepalen van een productiefunctie door middel van de gewone minstekwadraten-methode. Hierbij wordt voorbijgegaan aan eventuele technische inefficientitie. Een gemiddelde productiefunctie wordt afgeleid. De tweede stap van deze methode houdi in dat vervolgens een verschuiving optreedt van de gemiddelde productiefunctie naar de productiegrens in $f(X, \alpha)$. Hiertoe wordt de constante in de productiefunctie verhoogd met de gemiddelde afwijking $\left(u_{v}\right)$. Thiry en Tulkens stellen: ${ }^{1315}$ "To shift from the "mean" production function to the production frontier, the mean value of $u$ should be added to the estimated OLS constant term. This mean value may be derived in an unbiased and consistent way from the central moments of the least squares residuals, when a particulier distribution is assumed for $u$. The method thus provides unbiased and consistent estimates of all the frontier parameters". Deze methode wordt daarom aangeduid als de gecorrigeerde OLS-methode. Zij wordt onder meer toegepast door Perelman en Pestieau in hun onderzoek naar de spoorwegen en de postbestelling ${ }^{1316} \mathrm{Zij}$ richten zich daarbij op productie-efficiëntie (met een gegeven input een bepaalde hoeveelheid output bereiken). Ook Lovell et al. en Grosskopf et al. volgen deze benadering. ${ }^{1317}$

Deze benadering kent een aantal bezwaren. De schatting van $u_{u}$ is gebaseerd op de waarschijnlijkheidsverdeling waarvoor gekozen is. Dienovereenkomstig is het verschil tussen de productiegrens en de gemiddelde productiefunctie hiervan afhankelijk. Bovendien is er geen garantie dat het corrigeren van de constante term van de productiefunctie er toe leidt dat de gemiddelde productiefunctie voldoende verschuif, zodat uiteindelijk alle waargenomen input-output-combinaties op of beneden de productiegrens liggen.

\section{c. De aangepaste kleinste kwadraten-methode (DOLS)}

Deze methode is verwant met de voorgaande. Deze benadering houdt in dat de constante van de gemiddelde productiefunctie (geschat door middel van OLS) zodanig wordt aangepast dat alle waarnemingen onder of op de productiegrens liggen en dat ten minste

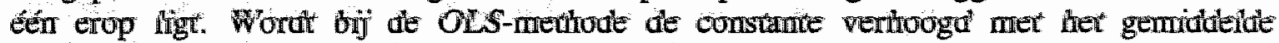
verschil tussen $\ln Y^{*}$ en $\ln Y_{0}\left(=u_{n}\right)$, bij de DOLS-methode wordt de constante aangepast met het hoogste positieve OLS-residu.

Het voordeel van deze methode is dat aan de beide genoemde bezwaren van de COLSmethode wordt tegemoet gekomen. Het belangrijkste bezwaar is echter dat er slechts éen observatie efficiënt is. Veel empirisch onderzoek binnen de kwantitatieve benadering maakt gebruik van deze methode. Gathon gebruikt bijvoorbeeld deze methode in combina-

${ }^{1313}$ Deprins (1986)

1314 DePrins en Simar $(1989$, p. 83$)$.

1315 Thiry en Tulkens $(1989$, p.33).

1316 Perelman en Pestiean (1988, pp. 432-441).

${ }^{1317}$ Grosskopf, Hayes, Taylor en Weber (1994). 
tie met de FDH-methode om de technische efficièntie in de transportsector te onderzoeken. ${ }^{131 \%}$ Omdat deze benadering in veel empiriseh onderzoek wordt gevolgd, wordt in paragraaf 13.3 verder op de voor- en nadelen en op de verdere uitwerking in de literatuur ingegaan.

ad. IV Kan de "performance" worden bepaald door middel van het schatten van een stochastische parametrische productiegrens?

Het belangrijkste verschill met de hiervoor beschreven parametrische benaderingen is dat in de productiegrens een "random error" $\mathrm{v}$ is opgenomen. ${ }^{1319}$ Als voorbeeld kan de door Thiry en Tulkens genoemde Cobb-Douglas-productiegrens dienen."1320

$$
\ln Y^{0}=\alpha_{0}+\sum_{i=1}^{M} \alpha_{i} \ln X_{i}-(u-v)
$$

Hierbij staat $u$ voor de efficiëntie en $v$ voor de standaardfout. Hierbij kan gedacht worden aan allerlei niet door het management te beïnvloeden factoren als meetfouten en niet waargenomen variabelen. Veel van de bovengenoemde methoden worden in empirisch onderzoek met elkaar gecombineerd.

Thiry en Tulkems proberen in dit verband op een andere wijze te komen tot een stochastische parametrische productiegrens. De eerste stap is het meten van technische efficièntie van de verschillende observaties met de FDH-methode. In hun onderzoek vonden zij inefficiënte combinaties die zonder meer duidelijk waren. Gedurende de tweede stap negeren zij vervolgens deze inefficiëntie, terwijl zij een parametrische productiefunctie opstellen. De parametrische functie wordt aangepast met behulp van OLS, maar alleen over de in de eerste stap gevonden efficiënte observaties. Gedurende deze tweede stap wordt op deze wijze rekening gehouden met de "random" term. Zo ontstaat een continue en parametrische grens. Door het tijdens stap 2 rekening houden met de inefficientie verbetert de schatting van de productiefunctie.

Côte tracht de efficiëmtie in de Amerikaanse elektriciteitssector te meten door middel van een stochastisch model. Hij maakt daarbij tevens gebruik van zoals hij het noemt een grootste waarschijnlijkhedenschatter. ${ }^{1321} \mathrm{Hij}$ geeft aan dat de schatting van de stachastische grens op deze wijze gebaseerd is op vergaande veronderstellingen, met name ten aanzien van de error term. Ook hij beperkt zich in zijn onderzoek tot het meten van technische effaciëntie.

B.2 Wat wordt verstaan onder de methode waarbij gebruik gemaakt wordt van een dummy variabele?

Künneke noemt een aantal bezwaren wan de benadering van het bepallen van een productiegrens. ${ }^{1322}$ Aangezien de meest efficiënte productiemethode feitelijk op én waarne-

\footnotetext{
1318 Gathon $(1989$, p. 49).

${ }^{1319}$ Vergelijk: Aigner, Lovell and Schmidt (1977, pp. 21-37).

${ }^{1320}$ Thiry en Tulkens (1989, p. 34).

${ }^{1321}$ Côte $(1989$, p. 432).

1322 Künneke (1993, pp. 183-184).
} 
ming berust, is er onvoldoende statistisch materiaal om de betrouwbaarheid van de gevonden meest efficiënte productiemethode te kunnen controleren. Voorts kan de vraag worden gesteld of het wel mogelijk is om de isoquant op deze manier naar bemeden te verschuiven. Wellicht heeft deze in werkelijkheid een andere vorm. Bovendien is het mogelijk dat verschillende producenten verschillende productietechnologieën gebruiken. Het is dan denkbaar dat de isoquanten van verschillende producenten elkaar snijden. Tegenover deze nadelen staat als voordeel dat de efficiëntie in absolute zin bepaald kan worden.

Kinnneke meent dat de nadelen van de productiegrens-benadering de voordelen overtreffen en kiest daarom voor de methode waarbij gebruik wordt gemaakt van dummy-variabelen. ${ }^{1323}$ Met behulp van deze methode is het mogelijk om een kostenfunctie of een productiefunctie op te stellen, waarbij gebruik gemaakt wordt van een dummy variabele. Hierbij worden verschillende categorieën bedrijven met elkaar vergeleken. Een productiefunctie weerspiegelt de minimale combinatie van inputs die nodig zijn om een bepaalde hoeveellheid eindprodukt voort te brengen. De punten op de productiefunctie zijn technisch efficiênt. Een kostenfunctie is in zekere zin het omgekeerde van een productiefunctie. Hierbij gaat het namelijk om minimalisatie van de productiekosten. Dit gaat verder dan technische efficiêntie. Uit alle technisch efficiënte punten moeten die punten worden gekozen waarvan de productiekosten minimaal zijn, dus rekening houdend met de prijzen van de inputs. Afwijkingen van de kostenfunctie wijzen op inefficiëntie in de zin van kostenefficiëntie. Ook in het geval er gebruik gemaakt wordt van een productiefunctie kan de mate van kostenefficiëntie bepaald worden. De punten op de isoquant zijn technisch efficient. Waar de isokostenlijn de isoquant raakt is er sprake van prijsefficientie, De richtingscoëfficiënt van beide curves moet dus aan elkaar gelijk zijn. Dat wil zeggen dat de marginale produkten van de productiefactoren gelijk moeten zijn aan de relatieve prijsverhouding van de productiefactoren. Indien er sprake is van prijsefficiëntie is er ook sprake van kostenefficiëntie. Gegeven een productiefunctie kan de mate van kostenefficiëntie alleen bepaald worden indien de prijzen van de productiefactoren bekend zijn.

Stel dat we twee categorieën waarnemingen hebben. Eén categorie van geprivatiseerde musea (categorie A) en een categorie van musea als overheidsinstellingen (categorie B). De verwachting ten aanzien van beide categorieën zou kumnen zijn dat de eerste groep bedrijuen efficiënter zijn. Met behulp van de waarnemingen van beide groepen is het nu mogelijk om een regressievergelijking in de vorm van een productiefunctie of eventueel een kostenfunctie op te stellen. Aan deze productiefunctie of kostenfunctie wordt nu een dummy variabele toegevoegd van bijvoorbeeld 1 voor categorie $A$ en 0 voor categorie $B$. De efficièntieverschillen tussen overheidsinstellingen en geprivatiseerde bedrijven blijkt mu uit de parameter behorend bij de dummy variabelen (vam 0 of 1 ).

Het voordeel van deze methode is dat de betrouwbaarheid van de resultaten statistisch bepaald kan worden. Een belangrijk nadeel van deze benadering is dat met behulp van de regressievergelijking alleen de efficientieverschillen tussen twee groepen van waarnemingen bepaald worden, niet de efficiënte in absolute termen. Met behulp van de methode met een dummy variabele wordt namelijk niet de meest efficiënte productiemethode bepaald maar de combinatie van productiefactoren die gemiddeld voor de productie van één eenheid produkt nodig is. Dan wordt slechts gekeken naar de relatieve efficiëntie!

De toevoeging van een dummy variabele zoals dat in de praktijk gangbaar is, beïnvloedt

1323 T.a.p., p. 183. 
niet de helling maar alleen de ligging wan de productiefunctie. Het is echter mogelijk dat verschillende categorieën bedrijven in verschillende mate proberen te besparen op arbeid en kapitaal. De helling van de overeenkomstige productiefuncties verandert dan.

Künneke past de methode die gebruik maakt van dummy variabelen toe. omdat het bij de eerste methode nauwelijks mogelijk is om de betrouwbaarheid van de schatting te bepalen. ${ }^{1324}$ 
Bijlagen 


\section{Bijlage 1}

Publiekgeörienteerde ondernemingen (onderdelen van Ministeries) ${ }^{1.325}$

(met een * aangeduide organisaties zijn agentschappen)

-Raad van State ${ }^{1326}$

-Algemene Rekenkamer ${ }^{1327}$

Ministerie van Algemene Zaken

-Rijksvoorlichtingsdienst (RVD) ${ }^{1328}$

-Bureau van de Wetenschappelijke Raad voor het Regeringsbeleid

Ministerie van Binnenlandse Zaken

-Binnenlandse Veiligheidsdienst

*Centrale Archief Selectiedienst

* Dienst Informatievoorziening Overheidspersoneel

- Dienst Uitvoering Ontslaguitkeringsregeling

-Centrum voor Arbeidsverhoudingen Overheidspersoneel

-Dienst Ziektekostenvoorziening Overheidspersoneel

-Landelijk Selectie- en Opleidingsinstituut Politie (LSOP)

*Gemeentelijke Basisadministratie

\section{Ministerie van Defensie}

-Ressort Secretaris-Generaal

-Ressort Defensiestaf

-Ressort DG Materieel

-Ressort Koninklijke Marine

-Resoort Koninklijke Landmacht

-Ressort Koninklijke Luchtmacht

-Ressort Koninklijke Marechaussee

*Defensie Telematica Organisatie

*Dienst Gebouwen, Werken en Terreinen

Ministerie van Economische Zaken

-Economische Controledienst

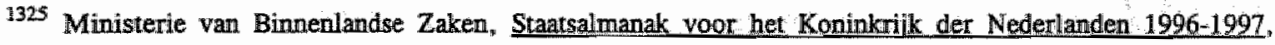
Den Haag: SDU-Uitgevers, 1996. Een overzicht is gegeven van de diensten die in de staatsalmanak zijn opgenomen en een aantal instellingen. Voor agentschappen is gebruik gemaakt van; Tweede Kamer der Staten-Generaal, vergaderjaar 1997-1998, Nota over de Toestand van 's Rijks Financién, 25600, nr. 1 , bijlage 2 .

${ }^{1326}$ Hoog College van Staat, geregeld in art. $73-75$ van de Grondwet en in de Wet op de Raad wan State van 9 maart 1962 (Stb. 88.)

${ }^{1327}$ Hoog College van Staat, geregeld in art. 76-78 van de Grondwet en in de Comptabiliteitswet ant. 39-63.

1328 In de Staatsalmanak niet aangemerkt als dienst. 
* Senter

-Bureau voor de Industriëlle Eigendlom

-Centraal Planbureau

-Centrale dienst voor In- en Uitvoer

-EVD

-InnovatieCentra Netwerk Nederland

-Staatstoezicht op de Mijnen

-Rijksgeologische Dienst

\section{Ministerie van Financiên}

-Directie Domeinen

-Dienst Domeinen

-Directies en Eenheden van de Belastingdienst.

\section{Ministerie van Justitie}

*Immigratie en Naturalisatiedienst (IND)

-Centraal Orgaan Opvang Asielzoekers (COA)

-Dienst Rechtsbijjstand en Juridische Beroepen

-Dienst Rechtspleging (DRP)

*Korps Landelijke Politiediensten (KLPD)

- Gerechtelijk Laboratorium (GL)

-Laboratorium voor Gerechtelijke Pathologie (LGP)

-Dienst Preventie, Jeugd en Reclassering

-Raad voor de Kinderbescherming

-Landelijk Bureau Inning Onderhoudsbijdragen (LBIO)

*Centraal Justitieel Incasso Bureau (CJIB)

*Dienst Justitiële Inrichtingen

waarvan:

-Dienst Individuele Beslissingen (DIB)

-Dienst Arbeid en Educatie (A \& E)

-Dienst Uitvoering, Beheer en Advisering (DUBA)

-Dienst Gerechtelijke Verzorging (GV)

-Dienst Gerechtelijke Inspectie (GI)

-Districts Psychiatrische Diensten

-Dienst Beveiligd vervoer (DBV)

-Opleidingsinstituut (DJI)

-Dienst Landelijke Bijzondere Bijstandverlening en Tijdelijke Executieve Ondersteuning (LBB/TEO)

\section{Instellingen}

-Landelijke Organisatie Slachtofferhulp

-Stichting Reclassering Nederland (SRN)

-Hall Nederland

-Landelijke Israelische Geestelijke Verzorging

-Gevangenismuseum Veenhuizen

-Landelijk Gevangenismuseum i.o.

-Centrale Raad voor Strafrechtstoepassing 
overige

-diverse penitentiaire Inrichtingen

-Rijksjeugdimrichtingen

-Rijks TBS-inrichtingen

-Parket-Generaal van het Openbaar Ministerie

Ministerie van Landbouw, Natuurbeheer en Visserii

-Algemene Inspectiedienst (AID)

-Dienst Landelijke Service bij Regelingen (LASER)

-Rijksdienst voor de Keuring van Veen en Vlees (RVV)

-Dienst Landinrichting en Beheer Landbouwgronden (LBL)

-Dienst Landbouwkundig Onderzoek (DLO)

-Staatsbosbeheer (SBB)

*Plantenziektenkundige Dienst (PD)

*Bureau Heffingen

Instellingen

-Kasteel Groeneveld

-Stichting Internationaal Agrarisch Centrum (IAC)

-STOAS

Ministerie van Onderwijs, Cultuur en Wetenschappen

-Universiteiten

-Instituut voor Nederlandse Geschiedenis (ING)

-Rijksinstituut voor Oorlogsdocumentatie (RIOD)

-Stichting Instituut voor Nederlandse Lexicologie

-Stichting Organisatie voor Strategisch Arbeidsmarktonderzoek (OSA)

*Rijksarchiefdienst

-Rijksdienst voor de Momumentenzorg

-Rijksdienst voor Oudheidkundig Bodemonderzoek

-Rijksacademie voor Beeldende Kunsten

-Nederlandse Omroepstichting (NOS)

-Nederlandse Programma Stichting (NPS)

- Nederlandse Omroepproductie Bedrijf N.V.

- Stichting Radio Nederland Wereldomroep

-Stichting Ether Reclame (STER)

-Rijkscommissie van Advies inzake opdrachten op het gebied van de literatuurhistorie

-Adviescommissie Nederlandse muziekprijs

*Centrale Financiële Instelling

Ministerie van Verkeer en Waterstaat

-Regionale Organisatie van Rijkswaterstaat

waarvan:

* Rijksdienst voor Radiocommunicatie

- Meetkundige Dienst

-Dienst Weg- en Waterbouw 
-Bouwdienst

-Adviesdienst Verkeer en Verwoer (AVW)

-Rijksdienst voor Kust en Zee

-Rjjksinstituut voor Integrail Zoutwaterbeheer en Afvalwaterbehandeling (RIZA)

-Regionale Organisatie voor Scheepvaart en Maritieme Zaken (RDR)

waarvan:

- Vaarmarkeringsdienst

-Scheepvaartinspectie

*Koniniklijk Meteorologisch Instituut

\section{Instellingen}

-Stichting Bedrijfsrestaurants en Kantines van het Ministerie van Verkeer en Waterstaat (SBK)

-Stichting Sociaal Fonds Ministerie van Verkeer en Waterstaat

-Vertegenwoordiging bij de Internationale Burgerluchtvaartorganisatie (ICAO)

Ministerie van Volksgezondheid, Welzijn en Sport

\section{Onderzoeksinstituten}

*Agentschap ten behoeve van het College ter Beoordeling van Geneesmiddelen (CBG) -Rijksinstituiut voor Volksgezondheid en Milieu (RIVM)

-Sociaal en Cultureel Planbureau (SCP)

Ministerie van Volkshuisvesting. Ruimteliike Ordening en Milieubeheer

-Inspecties van de Volkshuisvesting van de provincies

-Inspecties van de ruimtelijke Ordening van de provincies

-Staatstoezicht op de Volksgezondheid, Inspectie van de Volksgezondheid, belast met het toezicht op de Hygiëne van het Milieu

-Regionale Inspecties Milieuhygiëne

-Regionale Directies van de Rijksgebouwendienst

Instellingen

-Stichting International Water en Sanitation Centre (IRC)

-Stichting Adviesbureau Onroerende Zaken

-Stichting Advisering Besturarsechtspraak voor Milieu en Ruimtelijke Ordening i.o. 
Bijlage 2

Deelnemingen in Nederlandse ondernemingen per 31 december 1994 en $1996^{1329}$

Overheidsinstelling

Balansbedragen (in miljoenen. guldens)

-De Nederlandsche Bank N.V.

$\underline{1994}$

1995

$\underline{1996}$

-Koninklijke PTT Nederland N.V.

18.883

23.049

29.388

- N.V. Nederlandse Spoorwegen

9.375

12.087

13.662

-Koninklijke Luchtvaartmaatschappij N.V.

8.618

11.175

12.963

- N.V. DSM

1.787

1.684

1.559

1.723

1.443

-N.V. Bank Nederlandse Gemeenten

1.524

1.578

0

-N.V. Luchthaven Schiphol

1.312

1.425

1.680

- Energiebeheer Nederland B.V.

-N.V. Verenigd Streekvervoer Nederland

-Nationale Investeringsbank N.V.

1.112

1.203

1.552

501

568

1.203

426

609

568

-Koninklijke Nederlandsche Hoogovens

384

262

810

en Staalfabrieken N.V.

-Ultra-Centrifuge Nederland N.V.

-N.V. Nederlandse Gasunie

262

247

200

188

-DAF Trucks N.V.

172

155

-N.V. Noordelijke Ontwikkelingsmaatschappij

- Nederlandse Waterschapsbank N.V.

-Roccade Informatie Groep N.V.

-Nederlandse Financieringsmaatschappij voor

Ontwikkelingslanden N.V.

- N.V. SDU

-N.V. Nozema

-Nederlandse Onderneming voor Energie en Milieu B.V.

-Overige deelnemingen

$\begin{array}{rrr}146 & 165 & 189 \\ 73 & 74 & 75 \\ 71 & 82 & 96 \\ 68 & 79 & 71 \\ 67 & 78 & 77 \\ 66 & 29 & 23 \\ \frac{270}{47.613} & \frac{270}{57.402} & \frac{279}{65.497}\end{array}$

3329 Tweede Kamer der Staten-Generaal, Nota over de toestand van "s Rijksfinanciën, vergaderjaar 19951996, 24400, nr. 1, 19 september 1995, bijlage 10 en Nota over de toestand van 's Rijksfinanciën. vergaderjaar 1997-1998, 25600, nr. 1, 16 september 1998, bijlage 9 . 


\section{Bijlage 3}

\section{Zelfstandige bestuursorganen ${ }^{1330}$}

\section{Ministerie van Buitenlandse Zaken}

-Stichting Nationale Commissie Voorlichting en Bewustwording Ontwikkelingssamenwerking (NCO)

\section{Ministerie van Justitie}

-Stichtingen Bureau's voor Rechtshuip

-Stichting Rechtsbijstand/Bureau voor Rechtshulp Amsterdam

-Reclasseringsstichtingen

-Stichting Reclasering Den Haag

-Raden voor de Kinderbescherming

- Raad voor de Kinderbescherming Maastricht

-Commissie Schadefonds Geweldsmisdrijven

-Registratiekamer

- Nederlandse Orde van Advocaten (NOVA)

- Centrale Raad voor Strafrechtstoepassing

-College van Advies voor de justitiële Kinderbescherming (CVA)

-Kamers van Toezicht op het notarisambt

- Kamer van Toezicht op het notarisambt Arnhem

-Regeringscommissaris voor de Vereniging BUMA

-College van Toezicht voor de Stichting Reprorecht

-Regeringscommissaris voo de Stichting Thuiscopie

-College van Toezicht voor de Stichting ter exploitatie van naburige rechten

-Raden van Rechtsbijstand in strafzaken

-Bureau's voor consultatie

-College van toezicht op de kansspelen

-Koninklijke Notariële Broederschap

-Raden voor Rechtsbijstand

-Stichting Reclassering Nederland

- Kiesraad

-Commissie, belast met de algemene leiding en het beheer van de Dienst geneeskundige verzorging politie

-Stichting Arbeidsmarkt- en Opleidingsfonds voor de Overheid

-Landelijke Selectie- en Opleidingsinstituut Politie (LSOP)

-Stichting Administratie Indonesische Pensioenen (SAIP)

-Algemeen Burgerlijk Pensioenfonds (ABP)

-Fonds Arbeidsongeschiktheidsverzekering

- Overheidspersoneel (FAOP)

-Nederlands Bureau Brandweerexamens

-Nederlands Instituut voor Brandweer en Rampenbestrijding

-Politieregio's

-Stichting Fonds Vrijwillig Vervroegd Uittreden

1330 Tweede Kamer, vergadlerjaar 1994-1995, 24130, nr. 3, Verslag van de Algemene Rekenkamer over 1994, p. 10 e.v.. 


\section{Ministerie van Onderwijs en Wetenschappen}

- Centrale Commissie Aanmelding en Plaatsing aanstaande eerstejaarsstudenten (CCAP) Institunt voor Leerplanontwikkeling (SLO)

-Koninklijke Nederlandse Academie van Wetenschappen (KNAW)

-Instituut voor Onderzoek van het Onderwijs (SVO)

-Nederlandse Organisatie voor Toegepast Natuurwetenschappelijk Onderzoek (TNO)

-Instituat voor Toetsontwikkeling (CITO)

-Centrale Examencommissie Vaststelling Opgaven (CEVO)

-Staatsexamencommissies

-Staatsexamencommissie m.a.v.o.

- Nederlandse Organisatie voor Wetenschappelijk Onderzoek (NWO)

-Landelijke organen voor het leerlingwezen

-Stichting Vakopleiding Bouwbedrijf

-Koninklijke Bibliotheek

-Rijksuniversiteit voor Oorlogsdocumentatie (RIOD)

-OV-Studentenkaart BV

-Open Universiteit

-Openbare Uniwersiteiten

-Universiteit Utrecht

-Openbare Hogescholen

-Rijkshogeschool Uselland

-Algemene academische ziekenhuizen

-Informatie Beheer Groep

\section{Ministerie van Financiên}

-De Nederlandsche Bank NV (DNB)

-Stichting Waarborgfonds Motorverkeer

-Stichting Verzekeringskamer

-Stichting Effectenvernieuwingsbureau

-Stichting Toezicht Effectenverkeer

-CoöperatieveCentrale Raiffeisen-Boerenleenbank BA

-Stichting Medefinanciering Oververtegenwoordiging Oudere Ziekenfondsverzekerden (MOOZ)

- Waarderingskamer

\section{Mimisterie van Defensie}

-Nederlandsche Marineraad

Ministerie van Volkshuisvesting Ruimteliike Ordening en Milieu

-Huurcommissies

-Huurcommissie Amsterdam

-Reconstructiecommissie "Midden Delfland"

-Centraal Fonds voor de Volkshuisvesting

-Stichting Bureau Architectenregister

-Keuringsinstelling in het kader van de Wet Geluidhinder (Stichting ABOMA + 


\section{KEBOMA)}

-Instituut voor Mechanisatie, Arbeid en Gebouwen IMAG)

-Keuringsdienst voor Waterleidingartikelen NV (KIWA)

-Kadaster

-Stichting Waarborgfonds Eigen Woningen

-Commissie van beroep als bedoeld in art. 3 van de Wet rijonderricht motorrijtuigen 1993

-Instituut als bedoeld in art. 2 van de Wet rijonderricht motorrijtuigen 1993

-Rijksdienst woor het Wegverkeer

\section{Ministerie van Verkeer en Waterstaat}

-Commissie Binnenvaartrampenwet

-Stichting Centraal Bureau Rijvaardigheidsbewijzen (CBR)

-Stichting Nationale en Internationale Wegvervoer Organisatie (NIWO)

-Stichting Inschrijving Eigen Vervoer (SIEV)

-Raad voor de Luchtvaart

-Raad voor de Scheepvaart

-Spoorwegongevallenraad

-Facilitair Bedrijf Loodswezen B.V.

-Luchtverkeersbeveiligingsorganisatie

-HavenschapTerneuzen

-Havenschap Vlissingen

-Instantie voor het afnemen van examens en de afgifte klein vaarbewijs (ANWB-examensecretariaat)

-Instantie voor het afnemen van examens voor radardiploma's en voor de afgifte van radardiploma's (Koninklijk Onderwijsfonds voor de Scheepvaart)

-Nederlandse Loodsen corporatie (NLC)

-Regionale Loodsencorporaties

-Commissie van advies omtrent de geschiktheid als scheepsbevrachter

-Erkend particulier onderzoekingsbureau ex artikel 3 Schepenbesluit 1965 (Register

Holland)

-Instelling voor het afnemen van het examen voor de afgifte van diploma's vervoer binnenvaart (Koninklijk Onderwijsfonds voor de Scheepvaart)

-Stichting Bureau Examens voor het Beroepsvervoer

-Stichting Examens Personenvervoer

-Spoorwegpensioenfonds

- Aangemelde instantie in het kader van de Europese Randapparatuur (N.V. KEMA)

-Stichting Bureau Internationale Vaart

-Instantie voor de afgifte wan het certificaat Vervoer Gevaarlijke Stoffen (Koninklijk

Onderwijsfonds voor de Scheepvaart)

-Raad voor de Casinospelen

-Kamers van Koophandel en Fabrieken

-Kamer van Koophandel en Fabrieken voor Utrecht en Omstreken

-IJkwezen B.V.

-Octrooiraad

-Orde van Octrooigemachtigden

-Nederlands Instituut van Registeraccountants (NIVRA)

-Stichting Nederlands Instituut voor Vliegtuigontwikkeling en Ruimtevaart

-Nederlandse Onderneming voor Energie en Millieu BV (NOVEM)

-Nederlandse Orde van Accountants-administratieconsulenten (NOvAA)

-Waarborg Platina, Goud en Zilver N.V.

-Stichting Coördinatie Maritiem Onderzoek (CMO) 
-Stichting Institurut voor het Midden-en Kleinbedrijf Nederland

-Centrale Commissie voor de Statistiek

-Nederlandse Stichting voor de Exkenning van Kalibratie- en Testlaboratoria en InspectieInstellingen (NKO/STERTN/STERLAB)

-Stichting Centra voor Micro-electronica (CME)

-Stichting voor de Technische Wetenschappen (STW)

-Havenbeheerders (bedoeld in art. 12 van het Besluit voorkoming olieverontreiniging door schepen)

-Havenbeheerders (bedoeld in ant 7 Besluit voorkoming verontreiniging doar met schepen in bulk vervoerde schadelijke stoffen)

-Havenbeheerders (bedoeld in art 7 van het Besluit voorkoming olieverontreiniging door vuilnis van schepen)

-Bevoegde autoriteiten (als bedoeld in art. 1, onderdeel a van het Voorschriftenbesluit

Registerloodsen)

-Bevoegde autoriteiten (bedoeld in art. 1 , lid a, Loodsplichtbesiluit)

-Instanties (als bedoeld in art. 5 en 8 Scheepvaartverkeerswet, etc)

-Commissie van beroep voor de loodsenexamens

-Commissie voor de landelijke loodsenexamens

-Commissie voor de regionale loodsenexamens

-Examencommissie Certificaatloodsen

-Erkende installateurs en reparateurs van tachografen

-Schoolcommissies als bedoeld in art. 2.3 van de Wet op de zeevaartdiploma's en art. 3.1

Examenbesluit

-Zeevaartdiploma's

-APK-keuringsstations

\section{Ministerie van Landbouw, Natum en Visserii}

-Keuringsinstellingen voor plamtaardig uitgangs-/teeltmateriaal

-Stichting Nederlandse Algemene Keuringsdienst voor Zaaizaad en Pootgoed van Land bouwgewassen (NAK)

-Controle-instellingen voor de kwaliteit van landbouwprodukten

-Stichting Centraal Orgaan Zuivelcontrole (COZ)

-Stichting Kwaliteitsgarantie Vleeskalversector

-Rijkscommissie voor de keuring van niet-stamboekhengsten

-Commissie van Beroep (art 19 Paardenwet)

-Stichting Borgstellingsfonds woor de landbouw

-Grondkamers

-Grondkamer Zuid-Holland

-Stichting examens vakbekwaamheid Honden-en Kattenbesluit

-Stichting Uitvoering Landbouwmaatregelen

-Bureau Bijwerkingen Diergeneesmiddelen

- Groenfonds

-Staatsbosbeheer

-Organisatie ter verbetering van de Bimnenvisserij (OVB)

-Kamer voor de Binnenvisserij

-Raad voor het Kwekersrecht

-Jachtfonds

-Commissie/Bureau Beheer Landbouwgronden

-Centrale Landinrichtingscommissie

-Stichting Ontwikkelings- en Saneringsfonds voor de Landbouw

-Stichting Ontwikkelings- en Saneringsfonds voor de Visserij 
-Commissies voor de samenstelling van de rassenlijsten

-Commissie voor de samenstelling van de rassenlijst voor bosbourgewassen

- Erkende stamboekverenigingen voor paarden

-Koninklijke Vereniging "Het Nederlandsche Trekpaard" (KVNT)

-Stichting Fonds Nederlandse Veefokkerij

-Naturur- en recreatiegebied De Grevelingen

-Stichting Gezondheidszorg voor Dieren

-Stichting registratie gezelschapsdieren Nederland

Herinrichtingscommissie "Oost-Groningen en de Gronings-Drentse Veenkolonièn"

-Stichting Landelijke Mestbank

-Stichting tot Ontwikkeling van Agrarische Onderwijskunde en Scholing (STOAS)

\section{Ministerie van Sociale Zaken en Werkgelegenheid}

-Sociaal Economische Raas (SER)

-Keuringsinstellingen als bedoeld in artikel 5 van de Wet op de gevaarlijke werktuigen

-Stichting Nederlands Instituut voor Lifttechniek (Liftinstituut)

-Stichting Zeemanswelzijn Nederland

-Pensioenkamer

-Bedrijfslichamen

-Hoof sbedrijfschap Ambachten

-Emigratiebestuur

-Gemeenschappelijke Medische Dienst

-Stoomwezen B.V.

-College van Toezicht Sociale Verzekeringen

-Tijdelijk Instituut voor Coördinatie en Afstemming (TTCA)

-Erkende instelling als bedoeld in artikel 141, vijfde lid van het Veiligheidsbesluit voor

Fabrieken of Werkplaatsen 1938 (Stichting KEBOMA)

-Toeslagenfonds

-Administratiekantoren als bedoeld in de Organisatiewet Sociale Verzekering

-Gemeenschappelijk Administratiekantoor (GAK)

-Bedrijfsverenigingen

-Bedrijfsvereniging voor de Gezondheid, Geestelijke en Maatschappelijke Belangen (BVG)

-Algemeen Arbeidsongeschiktheidsfonds

-Algemeen Werkloosheidsfonds

-Arbeidsongeschiktheidsfonds

- Arbeidsvoorzieningsorganisatie

Fonds Voorheffing Pensioenverzekering

-Herkeuringscommissie Arbeidsomstandighedenwet

-Stichting Centraal Bureau voor de Grafische Bedrijven in Nederland

-Sociale Verzekeringsraad

-Sociale Verzekeringsbank

\section{Ministerie van Welzijn. Volksgezondheid en Cultuur}

-Commissie Algemene Oorlogsongevallenregeling Indonesië (CAOR)

-College ter beoordeling van geneesmiddelen

-Commissies voor Gebiedsaanwijzing

-Commissie voor Gebiedsaanwijzing Noord-Brabant

- Commissie Sanering Ziekenhuisvoorzieningen

-Praeventiefonds 
-Bedrijfsfonds voor de Pers

-Stichting Fonds voor de Ietteren

-Stichting Fonds voor de Scheppende Toonkunst

-Stichting Fonds voor Beeldende Kunsten, Vormgeving en Bouwkunst

-Stichting Fonds voor de Nederlandse Film

-Stichting Productiefonds voor Nederlandse Films

-Stichting Nederlands Literair Productie- en Vertalingenfonds

-Mondriaan Stichting

-Stichting Stimuleringsfonds voor de Architectuur

-Stichting Voorzieningsfonds voor kunstemaars (VVK)

-Nederlandse Filmkeuring

-Keuringsinstellingen Wet medische hulpmiddelen

-Kunststoffen en Rubber Instituut TNO

-Pensioen- en Uitkeringsraad (PUR)

- College voor de Bloedtransfusie van het Nederlandse Rode Kruis

-Stichting Fonds voor de Podiumkunsten

-Registratiecommissies

-Specialisten Registratie Commissie van de KNMG

-Stichting Stimuleringsfonds Nederlandse Culturele Omroepproducties

-Dienst Omroepbijdragen van de Koninklijke PTT Nederland NV

- Commissariaat voor de Media

-Stichting Centraal Administratie Kantoor Algemene Wet Bijzondere Ziektekosten

-Ziekenfondsen

-Ziekenfonds Amsterdam en Omstreken (ZAO)

-Ziekenfondsraad

- Centraal Orgaan Tarieven Gezondheidszorg (COTG)

-Stichting Uitvoering Omslagregeling Wet op de Toegang Ziektekostenverzekering (WTZ)

-Centraal College ex art. 3 van de Wet bevolkingsonderzoek op tuberculose

-Commissie ex art. 14 van het Sera- en Vaccinsbeshit

-Fonds voor bijzondere journalistieke projecten

-Nationaal Comite 4 en 5 mei

-Particuliere ziektekostenverzekeraars

-Centraal Orgaan Opvang Asielzoekers. (COA)

-Organisatie voor verstrekking van subsidiegelden voor internaten voor kinderen van

binnenschippers en kermisexploitanten

-Stichting Registratie Orgaandonatie

-Topsportfonds

-Industriefaciliteit

-Fonds voor economische structururversterking

-Stichting Innovatie Centrum Netwerk 


\section{Bijlage 4}

Een aantal voorbeelden van Publiek-Private Samenwerking (PPS) ${ }^{1331}$

-Sphinx-céramique, Maastricht

- Verbindingskanaalzone, Groningen

-Centraal Stadsgebied Amersfoort, Amersfoort

-N.V. World Trade Center, Rotterdam

-N.V. de Beurs van Koophandel, Rotterdam

-N.V. Stadsherstel Den Haag en omgeving, Den Haag

-B.V. Exploitatiemaatschappij Capelle aan de IJssel, Capelle aan de Issel

-AVR Chemie CV/BV, Rotterdam

-Stichting Stadsherstel Leeuwarden, Leeuwarden

-Stichting Nieuwe Weerdjes, Arnhem

-Stichting Project Rijnoevers Arnhem, Arnhem

-N.V. Economisch Herstel Zeedijk, Amsterdam

-N.V. Schiphol Area Development Company, Amsterdam

-N.V. MEGA Limburg, Maastricht

-Stichting Rijksmuseum (na 1995), Amsterdam

1331 Bron: Dijkstra en Iedema (1990, p. 500). Het betreft hier slechts enkele voorbeelden uit het totale aantal. 
Bijlage 5

\begin{tabular}{|l|l|l|l|l||}
\hline Jaar & $\begin{array}{l}\text { rendement } \\
\text { op staats- } \\
\text { obligaties }\end{array}$ & $\begin{array}{l}\text { prijsstij- } \\
\text { ging }\end{array}$ & $\begin{array}{l}\text { eigen Vermogen } \\
\text { aan het einde van } \\
\text { het jaar } \\
\text { (gebouw + collec- } \\
\text { tie) }\end{array}$ & $\begin{array}{l}\text { "public Enterprise } \\
\text { rent" }\end{array}$ \\
\hline 1970 & $8,01 \%$ & $3,6 \%$ & F. $4.338 .600 .000,-$ & F. $357.520 .000,-$ \\
\hline 1971 & $7,63 \%$ & $7,5 \%$ & F. $4.494 .800 .000,-$ & F. $352.950 .000,-$ \\
\hline 1972 & $7,35 \%$ & $7,8 \%$ & F. $4.831 .900 .000,-$ & F. $367.140 .000_{-1}-$ \\
\hline 1973 & $7,92 \%$ & $8 \%$ & F. $5.208 .700 .000,-$ & F. $424.530 .000,-$ \\
\hline 1974 & $9,82 \%$ & $9,6 \%$ & F. $5.625 .400 .000,-$ & F. $565.410 .000,-$ \\
\hline 1975 & $8,79 \%$ & $10,2 \%$ & F. $6.165 .500 .000,-$ & F. $554.950 .000,-$ \\
\hline 1976 & $8,95 \%$ & $8,8 \%$ & F. $7.081 .000 .000,-$ & F. $646.750 .000,-$ \\
\hline 1977 & $8,10 \%$ & $6,4 \%$ & F. $7.137 .740 .000,-$ & F. $591.160 .000,-$ \\
\hline 1978 & $7,74 \%$ & $4,1 \%$ & F. $7.430 .000 .000,-$ & F. $590.080 .000,-$ \\
\hline 1979 & $8,78 \%$ & $4,5 \%$ & F. $7.764 .400 .000,-$ & F. $698.710 .000,-$ \\
\hline 1980 & $10,21 \%$ & $6,5 \%$ & F. $8.269 .100 .000,-$ & F. $861.280 .000,-$ \\
\hline 1981 & $11,56 \%$ & $8,3 \%$ & F. $8.955400 .000,-$ & F. $1.055 .200 .000,-$ \\
\hline
\end{tabular}

De "public enterprise rent" van het Rijksmuseum over de periode 1970-1982 


\section{Literatuuropgave}

Algemene Rekenkamer, Handreiking onderzoek naar privatisering, april 1993.

Algemene Rekenkamer, Handleiding Algemene Rekenkamer (HANDAR), map 4 (Comptabiliteitswet): 14-02-1997.

Algemene Rekenkamer, Handleiding doelmatigheidsonderzoek, 2 mei 1996.

J. Andreoni, Why Free Ride? Journal of Public Economics, 37, pp. 291-304.

K.J. Arrow, A Difficulty in the Concept of Social Welfare, in: Collected Papers of Kenneth J. Arrow, Vol, 1 Social Choice and Justice, Oxford: Basil Blackwell, 1984.

KJ. Arrow, Economic Welfare and the Allocation of Resources for Invention, in: D.M. Lamberton, Economics of Information and Knowledge, Suffolk: Richard Clay Ltd, 1962.

KJ. Arrow en T. Scitovsky, Readings in Welfare Economics, London: George Allen and Unwin Ltd; 1969.

Peter Aucoin, Administrative Reform in Public Management: Paradigms, Principles, Paradoxes \& Pendulums, Governance: An International Journal of Policv and Administration, Vol. 3, No. 2, April 1990, pp. 115-137.

M. Azabou en J.B. Nugent, Contractual choice in Tax Collection Activities: Some Implications of the Experience with Tax Farming, in. Journal of Institutiona] and Theoretical Economics (JITE), vol. 144 , september 1988 , pp. 684-705.

N.A.A. Baakman en J.G.A. van Mierlo, Overheid en onderneming, een inleiding, Groningen, 1991.

Jürgen G. Backhaus, Pareto on Public Choice, Public Choice, 33/1, 1978.

Jürgen G. Backhaus, Eine Politisch-Ökonomische Theorie der Öffentlichen Unternehmung, Diskussionsbeitrage, Serie $\mathrm{A}, \mathrm{Nr}, 145$, Diskussionsbeiträge, Facultät für Wirtschaftswissenschaften und Statistik, Universität Konstanz, Juli 1980.

Jürgen G. Backhaus, Assessing the Performance of Public Enterprises: A Public Choice Approach, European Journal of Law and Economics, Vol. 11, nr. 4, 1994.

Jürgen G. Backhaus en H.G. Nutzinger, Eigentumsrechte und Partizipation, Frankfurt/Main: Haag + Herchen, 1982.

Jürgen G. Backhaus, Privatisering en nationalisering: een aanzet tot een nieuwe benadering, in: Maandschrift Economie/ jaargang 53, 1989a.

Jürgen G. Backhaus, "Privatization and Nationalization: A Suggested Approach". Annals of Public and Co-Operative Economics, 60 (3), 1989b. Also in: Decision (Indian Institute of Management, Calcutta), December, 1989.

Jürgen G. Backhaus, Public Enterprise: Forms and Functions. (Öffentliche Unternehmen: Zum Wirtschaftsrecht, den Functionen und Rechtsformen offentlicher Unternehmen). Frankfurt: Haag + Herchen 1977, pp 441; second and revised edition 1980.

Jürgen G. Backhaus (Ed) "The Economic Functions of Supreme Auditing Institutions", European Journal of Law and Economics, 1 (2), 1993. 
Jürgen G. Backhaus, Ökonomik der Sozialisierung: Masstabe und ihre Anwendung anhand eines Internationalen Vergleichs. In: Gerd Winter (Ed), Sozialisierung von Unternehmen Bedingungen und Begrundungen: Vier Rechts- und Wirtschaftswissenschaftliche Studien. Frankfurt EVA, 1976 (pp 25-188).

Jürgen G. Backhaus, Property Rights in Public Enterprise. (Neuere Ansätze zur Rechtșform offentlicher Unternehmen). Zeitschrift fur offfentliche und gemeinwirtschaftliche Unternehmen. forthcoming.

J.G. Backhaus, Die Überführung von Produktionsmitteln in Gemeineigentum, Maastricht: METEOR, 1995.

D. Badaüs, Problematik einzelwirtschaftlichen Effizienzkriteria bei öffentlichen Unternehmen, in: T. Thiemeyer, et al., Öffentliche Unternehmen und okonomische Theorie, Baden-Baden: Nomos, 1987.

P.C.M.G. Baeten, Kansen en risico's bij de introductie van produktiemeting bij steunfunctieorganisaties in Limburg, in: Beleidsanaluse, Ministerie van Financiën, 93-1.

J.S. Bain, Barriers to New Competition, Cambridge, MA: Harvard University Press, 1954.

Y. Barzel, Economic Analysis of Property Rights, Cambridge: Cambridge University Press, 1989.

K. Basu, Notes on Evolutio, Rationality and Norms, Journal of Institutional and Theoretical Economics, Vol: $152,1996$.

P. Bate, The Impact of Organizational Culture on Approaches to organizational Problem Solving, in: Organization Studies, 5,1984 .

F.M. Bator, The Anatomy of Market Failure, in: The Quarterly Joumal of Economics, 72, 1958.

W.J. Baumol en D.F. Bradford, Optimal Departures from Marginal Cost Pricing, American Economic Review, jumi, vol. 80, 1970, pp. 269-270. Vergelijk ook: A. Atkinson en J. Stiglitz, Lectures on Public Economics, London; New York: McGraw-Hill, 1980.

William J. Baumol en Wallace E. Oates, The Theory of Environmental Policy, Cambridge: Cambridge University Press, 1988.

G.S. Becker, A Theory of Competition among Pressure Groups for Political Influence, Quarterly Journal of Economics, 96, 3, 1982.

K.M. Becking en W.S.P. Fortuyn, De overheid als concurrerende werkgever, ESB, 15-2-1995.

M. Beesley en S. Littlechild, Privatization: Principles, Problems and Priorities, in: Lloyds Bank Review, 1983.

C.J. Bellone en G.F. Goerl, Reconciling Public Entrepreneurship and Democracy, Public Administration Review, Vol. 52, 1992.

J.B.J.M. ten Berge, P.B. Boorsma en A.B. Ringeling (hoofdred.), H.R.W. Gokkel (eindred.), Verklarend woordenboek Openbaar Bestuur, Alphen aan den Rijn: Samsom H.D. Tjeenk Willink, 1992 .

A. Bergson, A Reformulation of Certain Aspects of Welfare Economics, in: Quarterly Journal of Economics: $2,1938$.

J.M. Berkenbosch en J. Helleman, Mogelijkheden en voordelen van sturen op output, in: 
A.A. Berle en G.C. Means, The Modern Corporation and Private Property, Buffalo, NY: William

S. Hein \& Co., 1982 (herziene wersie van het oorspronkelijke werk uit 1932).

Y. Berrihardt en M. Canoy, Hordenlopen van monopolie naar markt, ESB, 16-7-1997, pp. 556559.

K. Bertels en D. Nauta, Inleiding tot het modelbegrip, Amsterdam: Wetenschappelijke Uitgeverij, 1974.

J. Berveling, De beleidsnetwerkbenadering: Wel gegroeid, nog niet volwassen, Beleidswetenschap 1997/2, pp. 168-173.

J.E. Biddle, Purpose and evolution in Common's Institutionalism, in: History of Political Economy, Band 22.

J. van der Bij, Dienstverlening namens de overheid, in: Openbaar Bestuur, 2, 1992.

D. Black, The Theory of Committees and Elections, Cambridge, 1971 (first edition 1958).

J.H. Blair en R.A. Pollak, Rational Collective Choice, Scientific American, 249, no. 2, August 1983.

A. Blais en S. Dion, The Budgetmaximizing Bureaucrat, Pittsburgh: University of Pittsburgh Press, 1991 .

Ch. Blankart, Why do Public Goods remain Public?, in: K.W. Roskamp (ed.), Public Finance and Public Choice, Paris, Curjas. 1980.

C.B. Blankart, Ökomomie der öffentlichen Untermehemen; eine Institutionelle Analyse der Staatswirtschaft, München: Vahlen, 1980.

C.B. Blankart en G. Knieps, What can we learn from Comparative Institutional Analysis? The Case of Telecommunications, Kyklos, Internationale Zeitschrift für Sozialwissenschaften, Vol. 42, 1989.

M. Boiteux, La Tarification des demandes en point: Application de la Théorie de la Vente au Cout Marginal, Revue Général de l'electricité, 58, Augustus, 1949.

W.Th.M. Bokkes, Privatisering belicht vamuit de transactiekostenbenadering, Proefschrift, Enschede: Universiteit Twente, 1989.

P.B. Boorsma, Naar de versoberingsstaat: rooien en snoeien in de verzorgingsstaat, Akademische rede Enschede, 1980.

P.B. Boorsma (et al.), Saneringen in de collectieve sector: mogeliike toepassingen van het profijubeginsel, mogeliikheden voor privatisering van overheidsactiviteiten, Enschede: Technische Hogeschool Twente, 1981.

P.B. Boorsma, Privatisering, (SMO-informatief), 's-Gravenhage: Stichting Maatschappij en Onderneming, 1983.

H. Bonus en H. Ribhegge, Wohlfahrtsökonomik - Werkzeug für Diktatoren oder ökonomische Grammatik? Bemerkungen zu einem neuen Buch won A. Woll, in: Journal of Instituional and Theoretical Economics (JTE), 142, 1986. 
TE. Borcherding. The Sources of Public Expenditures in the United States, 1902-1970, in: Budgets and Bureaucrats: The Sources of Government Growth, Durham, North carolina, 1977.

T.E. Borcherding, Towards a positive Theory of Public Sector Supply Arrangements, in: J.R. Prichard (ed.). Crown Corporations in Canada. The Calculas of Instrument Choice, Canada: Butterworth and Co., 1983, pp. 99-184

T.E. Borcherding, W.W. pommerehme en F. Schneider, Comparing the Efficiency of Private and Public Production: The Evidence from Five Countries, in: S.H. Baker en C.S. Elliot, Readings in Public Sector Economics, Lexington, Massachusetts: Heath, 1990.

L.E. Borge, The Bahavior of Bureaucrats and the Choice Between Single-Purpose and MultiPurpose Authorities, Public Finance Quarterly, Vol. 24, No. 2, 1996, pp. 173-191.

D. Bös en C. Seidl, Welfare Economics of the Second Best, Wien: New Yorki Springer, 1986.

Dieter Bös, Public Enterprise Economics. Theory and Application, Amsterdam: Elsevier Science Publishers BV, 1986.

Dieter Bös, Privatization: A Theoretical Treatment, Oxford: Clarendon Press, 1991

D. Bös; Pricing and Price Regulation, An Economic Theory for Public Enterprises and Public Utilities, Amsterdam: Elsevier, 1994.

J.L. Bouma, Het Beteugelen van Spelbederf; Garanties in het licht van de economische theorie van de transactiekosten, in: J.L. Bouma (ed:), Samenspel: Opstellen aangeboden aan Prof, Dr. G.F.W.M. Pikkemaat, Wolters-Noordhoff, Groningen, 1991.

M. Boycko, A. Shleifer en R.W. Vishny, Second-best Economic Policy for a Divided Government, in: European Economic Review, 40, 1996.

F. de Braekeleer, Ramseynorm en regulering van elektriciteitstarieven in België en Nederlands, proefschrift Universiteit van Amsterdam, 10 december 1990.

F. de Braekeleer en J. Hartog, Regulation of Electricity Prices in Belgium and the Netherlands; Research Memorandum, 1992.

Günther E. Braun, Ziele in Öffentlicher Verwaltung und Privatem Betrieb. Baden-Baden: Nomos, 1988, (Schriften zur Öffentlicher Verwaltung und Öffentlichen Wirtschaft, volume 76).

A. Breton en R. Wintrobe, The Equilibrium Size of a Budget Maximizing Bureau: A Note on Niskanen's Theory of Bureaucracy, Journal of Bolitical Economy, Vol. 83, No. 1, 1975.

A. Breton en R. Wintrobe, The Logic of Bureaucratic Conduct, Cambridge: Cambridge University Press, 1982 .

J.N. Breunessen en L.J. Roborgh (red), Ministeries van algemeen bestuur, Leiden: Van Mantgem \& De Does, 1989.

S.J. Brown en D.S. Sibley, The Theory of Public Utility Pricing, Cambridge: Cambridge University Press, 1986.

Y. Brozen, Entry Barriers: Advertising and Product Differentiation, in: H.D. Goldschmid (et al.), Industrial Concentration: The New Learning, Boston: Little Brown, 1974.

J.A. de Bruijn en E.F. ten Heuvelhof, Netwerkmanagement; Utrecht, 1995.

James M. Buchanan, An Economic Theory of Clubs, Economica, 1965, Vol. 32. 
James M. Buchanan en G. Brennan, The Reason of Rules. Constitutional Political Economy, Cambridge: Cambridge University Press, 1987 (first published 1985).

James M. Buchanan en G. Brennan, The Power to Tax: Analytical Foundations of a Fiscal Constitution, Cambridge: Cambridge University Press, 1980.

J.M. Buchanan, Cost and Choice, Chicago: Markham, 1969 en G. Tullock, The Welfare Costs of Tariffs, Monopolies, and Theft, Western Economic Journal, 5, 1967.

James M. Buchanan en Gordon Tullock, The Calculas of Consemt, Logical Foundations of Constitutional Democracy, Ann Harbor Paperbacks: The University of Chicago Press, 1987, first edition 1965.

J.M. Buchanan en G. Brennan, The Reason of rules. Constitutional Political Economy, Cambridge: Cambridge University Press, 1987 (first published 1985).

J.M. Buchanan, Cost and Choice, Chicago: Markham, 1969

G.N.J.A. Bukkens, M.C.E. Goyen en F.L. Leeuw, Over een doelmatige culturur gesproken, cultuur als variabele bij doelmatigheidsonderzoek, Overheidsmanagement, 1997/10.

B. Bullder, F. Leeuw en H. Flap, Networks and Evaluating Public-sector Reforms, in: Evaluation, Vol. 2(3), 1996.

R. Burgess en N. Stern, Taxation and Development, in: Journal of economic literature, wol. XXXI, 1993.

R.M. Buxbaum, Is "Network" a Legal Concept?, Journal of Institutional and Theoretical Economics, JITE, 149/4 (1993), Zeitschrift für die gesamte Staatswissenschaft.

J.E. Campos en H.S. Estahani, Why and when do Governements initiate Public Enterprise Reform? in: The World Bank Economic Review, 10(3), 1996, pp. 451-486.

R.E. Caves, Mergers, Take overs and Economic Efficiency, Foresight ws. Hindsight, International Journal of Industrial Organization; 7, 1989.

D.W. Caves en L.R. Christenson, Industrial Organization, Corporate Strategy and Structure, Iournal of Economic Litterature, 13, 1975.

D.W. Caves en C.R. Christensen, Relative Efficiency of Public and Private firms in a Competative Environment, The Case of Canadian Railroads, Journal of Political Economy, 88(5), october 1980.

Ming Chung Chang, Ramsey Pricing in a Hierarchical Structure with an Application to Networkaccess Pricing, in: Journal of Economics, Zeitschrift für Nationalökonomie, Vol. 64, no. 3, 1996, pp. 281-314.

L.R. Christensen en W.H. Greene, Economics of Scale in US Electric Power Generation, Journal of Political Economy, vol. 84, 1976.

Roger Clarke, Industrial Economics, Cambridge Massachusetts: Basil Blackwell Ltd, 1990 (first published 1985).

Ronald H. Coase, The Problem of Social Cost, in: The Journal of Law and Economics, Vol. 3, october 1960, pp. 1-44, herdrukt in: R.H. Coase, The Firm. The Market and the Law, Chicago: University of Chicago Press, 1988. 
Ronald H. Coase, The Nature of the Firm, in: Economica, New Series, Vol. IV, 1937, pp. 386405 .

Ronald H. Coase, The Nature of the Firm, in: Economica, New Series, Wol. IV, 1937, herdrukt in: G.J. Stigler en K.E. Boulding (eds.), Readings in Price Theory, London: Allen and Unwin, 1953, pp. 331-352.

Ronald H. Coase, Concluding Comment, Journal of Institutional and Theoretical Economics (JITE), 149/1, 1993.

T Coelli en S. Perelman, Efficiency Measurement, Multiple Output Technologies and Distance Functions: With Application to European Railways, Universite de Liege, University of New England, 09/05/1996.

M.D. Cohen, J.G. March en J.P. Olsen, A Garbage Can Modell of Organziational Choice, Administrative Science Ouarterly, vol. 17, nr. 1, 1972, pp. 1-25.

M. Coles en J.M. Malcomson, Contract "Theory and Incentive Compatibility, in: John D. Hey, Current Issues in Microeconomics, Hoofdstuk 5, 1989.

Commissile Sint, Verantwoord verzelfstandigen: rapportage, 1993.

Commissie Steenbergen (1985-1986), Signalen voor straks. Een nieuwe richting voor de PTT, kamerstukken 17370 , nrs. 30-31.

Commissie Swartouw (maart 1982), Rapport van de commissie Swarttouw, kamerstukken, 17370, nr. 1.

Commissie van de Europese Gemeenschappen, Richtliin nr. 90/388, EEG, 28 juni 1990 (dienstenrichtlijn).

J.R. Commons, Legal Foundations of Capitalism, Madison: University of Wisconsin Press, 1924.

J.R. Commons, Institutional Economics - Its Place in Political Economy " Madison: University of Wisconsin Press, 1934.

J. Conlisk, Why Bounded Rationality?, Journal of Economic Literature, Vol. XXXIV, june 1996, pp. 669-700.

Ph.E. Converse, The Problem of Party Distances in Models of Voting Change, in: M.K. Jennings en H. Zeigler, The Electoral Process, Englewood Cliffs NJ, 1966.

J.A.C. Conybeare, Bureaucracy, Monopoly, and Competition: A Critical Analysis of the Budgetmaximizing Model of Bureaucracy, American Political Science Review, 77, 1983.

P. Cook en C. Kirkpatrick, Privatization Policy and Performance, Hemel Hempstead: Harvester Wheatsheaf, 1995.

Richard Comes en Todd Sandler, The Theory of Externalities, Public Goods, and Club Goods; Cambridge: Cambridge University Press, 1986.

D.O. Cote, Firm Efficiency and Ownership Structure, The Case of US Electric Utilities Using Panel Data, in: Annals of Public and Cooperative Economics; No. 3, 1989.

M.A. Crew en C.K. Rowley, Toward a Public Choice Theory of monopoly Regulation, Public Choice, 57, 49-67, 1988. 
J. Cubbin en D. Leech. The Effect of Shareholding Dispersion on the Degree of Control in British Companies: Theory and Evidence, Economic Joumal, 1983.

John G. Cullis en Philip R. Jones, Microeconomics and the Public Economy: A Defence of Leviathan, Oxford: Blackwell, 1987.

P.J. Curwen, Public Enterprise: A Modern Approach, Brighton: Harvester Press, 1986.

R.M. Cyert en J.G. March, A Behavioural Theory of the Firm, Cambridge, Massachusetts: Blackwell Business, 1992 (first edition 1963).

H.P. van Dalen en O.H. Swank, Ideologie en opportunisme bij de overheidsuitgaven, in: ESB, 19-4-1995.

M. Dalton, Man who Manage: Fusions of Feeling and Theory in Administration, New York: Wiley: London: Chapman \& Hall, 1959.

A. d'Aspremont, Une Mesure Generale d'Efficacite au sens de Farrell: Application au cas de la S.T.I.B., Dissertatie, LAG Universiteit van Leuven. 1984.

D.W. Daves en C.R. Christensen, Relative efficiency of public and Private Firms in a Competative Environment: The Case of Canadian Railroads, Journal of Political Economy, 88(5), october 1980.

D.G. Davies en P.F. Brucato, Property rights and transaction costs: theory and evidence on privately owned and government-owned enterprises, Joumal of Institutional and Theoretical Economics, 143, 1987.

D.D. Davis en C.A. Holt, Experimental Economics, Princeton, New Jersey: Princeton University Press, 1993.

L. De Alessi, Implications of Property Rights for Government Investment Choices, American Economic Review, 59, March 1969, pp. 13-24.

Harold Demsetz, Information and Efficiency: Another viewpoint, Journal of Law and Economics, 12, 1965, in: D.M. Lamberton, Economies of Information and Knowledge, Suffolk: Richard Clay Ltd, 1971.

Harold Demsetz, Barriers to Entry, American Economic Review, 72, 1981.

Harold Demsetz. The Private Production of Public Goods; in: The Journal of Law and Economics, 13,1970 .

Harold Demsetz, Efficiency, Competition, and Policy, Oxford: Basil Blackwell, 1989.

Harold Demsetz en K. Lehn, The Structure of Corporate Ownership: Causes and Consequences, Journal of Political Economy, 93, 1985, pp. 1155-1177.

Harold Demsetz, The Structure of Ownership and the Theory of the Firm, Journal of Law and Economics, $1983,26$.

Harold Demzetz, The Theory of the Finm Revisited, Journal of Law, Economics and Organization, Vol. 4, ar. 1, 1988.

D. Deprins, L. Simar en H. Tulkens, Measuring Labor Efficiency in Post Offices, in: $M$. Marchand, P. Pestieau en H. Tulkens, The Performance of Public Enterprises: Concepts and Measurement, Amsterdam: Elsevier Science Publ. B.V. North Holland, 1984. 
D. Deprins, Modelling Technical Inefficiencies with Log-Linear Regression for One-Sided Residuals, Core Discussion Paper, No 8617, CORE, Université Catholique de Louvain.

D. De Prins en L. Simar, Estimating Technical Inefficiencies with Correction for Environmental Conditions, with an Application to Railway Companies, in: Annals of Public and Cooperative Economics, Vol. 60, No.3, 1989.

M. Dietrich, Transaction Cost Economics and Beyond. Towards a New Economics of the Firm. London, New York: Routledge, 1994.

J.B. Dijkstra en R.A. Iedema, PPS en het toezicht op het gebruik van privaatrechtelijke rechtspersonen, TvO, jrg. 16, nr. 20, 19-11-1990.

J. van den Doel, Demokratie en welvaartstheorie, Alphen aan den Rijn:

Samson Uitgeverij, 1978.

J. van den Doel, Democracy and Welfare Economics, Cambridge, 1979.

J. van den Doel en B.C.J. van Velthoven, Democracy and Welfare Economies, Cambridge; 1993.

S. Domberger en J. Pigott, Privatization Policies and Public Enterprise: A Survey, in: Economic Record, 64, 1957. pp 145-160.

J.A.A. van Doorn en C.J. Lammers, Moderne sociologie, Utrecht: Het Spectrum, 1959.

K. Dowding en P. John, Exiting Behavior under Tiebout Conditions: Towards a Predictive Model, Public Choice, 88, 1996, pp. 393-406.

A. Downs, An Economic Theary of Democracy, New York: Harper \& Row, 1957.

A. Downs, Inside Bureaucracy, Boston: Little Brown, 1967.

P. Dunleavy, Democracy, Bureaucracy and Public Choice, New York: Harvester Wheatsheaf, 1991.

D. Easton, A Framework for Political Analysis, Chicago: University Press, 1965.

D. Easton, A Framework for Political Analysis, Chicago: University Press, 1979.

Economic Commission for Europe, Privatization and changing Owinership in the Steel Industry, New York: United Nations, 1996:

Eerste Kamer der Staten-Generaal, (13 september 1988), Memorie van Antwoord Regels met betrekking tot de voorzieningen voor telecommunicatie (Wet op de telecommunicatievoorzieningen), vergaderjaar 1987-1988, 20369, $\mathrm{nr} .226 \mathrm{~b}$.

J.M. Enelow en M.J. Hinich, The Spatial Theory of Voting, Cambridge: CUP, 1984.

A. Etzioni, Two Approaches to Organizational Analysis: A Critique and a Suggestion, in:

J. Ghorpade, Assessment of Organizational Effectiveness, Santa Monica,CA: Goodyear Publishing, 1971.

T. Falbo, The Multi-dimensional Scaling of Power Strategies, in: Journal of Personality and Social Psychology, volume 35, 1977.

E.F. Fama, Agency Problems and the Theory of the Firm, Journal of Political Economy, 88, 1980. 
E.F. Fama en M.C. Jensen, Seperation of Ownership and Control, Journal of Law and Economics, 26, 1983.

E.F. Fama en M.C. Jensen, Agency Problems and Residual Claims, Journal of Law and Economics, 26, 1983 .

M. Farrel, The Measurement of Productive Efficiency, in: The Journal of the Roval Statistical Society, Part III, 1957, pp. 253-281.

A. Feist, Economic Measurement and Arts Bureaucrats, Boekmancahier, kwartaalschrift voor kunst, onderzoek en beleid, 8 (27), 1996, pp. 74-77.

F.R. Forsund, C.A.K. Lovell en P. Schmidt. A Survey of Fronter Produktion Functions and their Relatioship Efficiency Measurement, in: Journal of Econometrics, 13, 1980. pp 27-56.

C.J. Fox Reinventing Government as Postmodern Symbolic Politics, Public Administration Review, Vol. 56, No. 3, 1996, pp. 256-262.

H.G. Frederickson, Comparing the Reinventing Government Movement with the New Public Administration, Public Administration Review, Vol. 56, No. 3, 1996, pp. 263-270.

B.S. Frey en W.W. Pommerehne, Muses and Markets; Explorations in the Economics of the Arts, Cambridge, Massachusetts: Basil Blackwell Inc, 1989.

D. Frey en B. Schuster, Innovatieve bedrijfsculturen: op weg naar het centre of Excellence - Wat is de vereiste leidinggevende stijl van de toekomst, hoe moet de organisatiecultuur eruit komen te zien? in: PEMselect, $\mathbb{1 2}(3), 1996$, pp. 29-33.

P. Friedrich, Ordnungspolitische Rahmungsbedingungen und öffentliche Unternehmungstätigkeit, in: $T$. Thiemeyer, et al., Öffentliche Untermehmen und ökonomische Theorie, Baden-Baden: Nomos, 1987.

B. Fuisting, Grundzüge der Steuerlehre, Berlin: Heymann, 1902.

E.G. Furubotn en S. Pejovich, Property Rights and Economic Theory: A Survey of Recent Literature, Journal of Economic Literature, $10,1972$.

E.G. Furubotn en S. Pejovich, The Economics of Property Rights, Cambridge, MA: Ballinger Publisher Cambridge, 1974.

M.R. Garner, The Theory of Public Enterprise Reconsidered, in: Annales de l' Economie Publiques, Sociale et Comparative, 67(1), 1996, pp. 85-116.

H.J. Gathon, Indicators of Partial Productivity and Technical Efficiency in the European Urban Transit Sector, in: Annals of Public and Cooperative Economics, Vol. 60, No. 3, 1989.

L.J. van Gemerden, Budgetmechanisme en efficiency, in: L.J. van Gemerden (et. al.), M. Herweyer en J.A. van Selm (red.), Budgetfinanciering. een beleidsverkenning, Publicatiereeks Samenwerkingsverband Bestuurswetenschappen Noorden des Lands (SBN), nr. 7, Groningen: Universiteitsdrukkerij, december 1987 .

H.G. Frederickson, The Seven Principles of Total Quality Politics, Public Administration Times, Vol. $17(1), 1994$.

A. Gifford, Jr. en G.J. Santoni, Politicians and Property Rights, Public Choice, 33/1, 1978.

A.J.A. Godfroij en N.J.M. Nelissen (red.), Verschuivingen in de besturing van de samenleving, 
Bussem, 1993.

C. Goedhart, Hoofdliinen van de leer van de openbare financięn, Leiden: H.E. Stenfert Kroese B.V., 1975.

P.C. van Gool, De Nationale Investeringsbank sinds 1945, Amsterdam: Nederlands Instituut voor het Bank-en Effectenbedrijf, 1988.

Rene Goudriaan et al., Kosten van kwartaire diensten 1970-1983: een statistische verkenthing van kostenstructuren en voorzieningengebrik, Sociaal en Cultureel Planbureau, 's-Gravenhage: Distibutiecentrum Overheidspublikaties, 1986.

William D. Grampp, Pricing the Priceless, Art, Artist and Economics, New York: Basic Books Inc., 1989.

William D. Grampp, Rent-seeking in Arts Policy, Public Choice, no: 60, 1989.

C.M. Gray, Philistines in the cathedral? Thoughts on Economics and the Arts, Boekmancahier, kwartaalschrift voor kunst, onderzoek en beleid, 8 (27), 1996, pp, 69-72.

K. Groenveld, J.A.H. Maks en J. Muysken, Economic Policy and the Market Process Austrian and Mainstream Economics, Amsterdam: North-Holland, 1990.

T. Grondsma en J. van den Doel, Rationaliteit in het bestuurlijk proces - Een systeembenadering, in: Bestuurswetenschappen, 1975.

Hans de Groot en Rene Goudriaan, De produktiviteit van de overheid: over prestaties, personeel en uitgaven in de publieke sector. Schoonhoven: Academic Service, 1991.

H. Grossekettler, Zur Theoretischen Integration der Wettbewerbs- und Finanzpolitik in die Konzeption des ökonomischen Liberalismus, in: Jahrbuch für Neue Pollitische ökonomie, Erik: Boettcher (ed.), 10 Band, Systemvergleich und Ordnungspolitik, J.C.B. Mohr (Paul Siebeck): Tübingen, 1991

H. Grossekettler, On Böhm's Contribution to Economic Theory and Policy, Westfälische Wilhelms Universität Münster, gepresenteerd op de conferentie gewijd aan Franz Böhm, gehouden op 26 september 1995 aan de Rijksuniversiteit Limburg, opgenomen in European Journal of Law and Economics, 3 (4), 1996.

S. Grosskopf, K. Hayes, L. Taylor en W. Weber, Budget Constrained Frontier Measures of Fiscal Equality and Efficiency in Schooling, Review of Economics and Statistics, 1994.

J.H. Hagel en A.E. Roth (eds), The Handbook of Experimental Economics, Princeton: New Jersey: Princeton Uniwersity Press, 1995.

Robert M. Haig, The Federal Income Tax, New York: Columbia University Press, 1921.

Handelingen 2, Bijl. 1954/55 en 1955/56, 3816, Wet van 28 juni 1956 houdende belastingheffing van overheidsbedrijven.

J.F. Handler, Down from Bureaucracy: the Ambiguity of Privatization and Empowerment, Princeton, N.J.: Princeton University Press, 1996.

G. Hardin, The Tragedy of the Commons, Science, 162.

M. Haririan, State-Owned Enterprises in a Mixed Economy: Micro versus Macro Economic Objectives, Boulder, CO (etc.): Westview Press, 1989. 
J.C. Harsanyil, Cardinal Welfare, Individualistic ethics, and interpersonal comparison of utility, in: Journal of Political Economics, 63, 1955.

J.C. Harsanyi; Cardinal Welfare, Individualistic Ethics, and interpersonal Comparisons of Utility, in: K.J. Arrow en T. Scitovsky, Readings in Welfare Economics, London: George Allen and Unwin Ltd, 1972.

J.C. Harsanyi, Games with Incomplete Information, The American Economic Review, june, 1995.

J.C. Harsanyi, Rational Behavior and Bargaining Equilibrium in Games and Social Situations, Cambridge: Cambridge University Press, 1977.

J.C. Harsanyi, Game and Decision theoretic Models in Ethics, in: R.J. Aumann en S. Hart (eds), Handbook of Game Theory with Economic Application, vol, 1, Amsterdarn: North-Holland, 1994.

H.W.C. van der Hart, Overheidsorganisaties en hun klanten, Strategie, tactiek en uitvoering, in: L.Th.R. Wijchers, L.A.F.M. Kerklaan en W.F.G. Mastenbroek (ed), Kwaliteitsmanagement in de dienstverlening. Continue resultaatverbetering als managementstill, Deventer 1992.

O. Hart en B. Holmstrom, Theory of Contracts, in: T.F. Bewly, Advances in Economic Theory, Cambridge: Cambridge University Press, 1987.

F. Hartog, Toegepaste Welvaartseconomie, Leiden: Stenfert Kroese B.V., 1973.

F. Hartog, Toegepaste welvaartstheorie, Leiden/Antwerpen: H.E. Stenfert Kroese B.V., 1981.

C. Hassapis, Are Bureaucrats Efficient? An Application to the Provision of AFDC (Aid to Families with Dependent Children), Public Choice, 86, 1996, pp. 157-174.

T. Hatta, A Theory of Piecemal Policy Recommendations, in: Review af Economic Studies, 1977.

F.A. Hayek, The Constitution of Liberty, London: Routledge, 1990 (herdruk, gepubliceerd in 1960).

J. Heilbrun, External Benefits of the Arts, Agnostic Position no Longer Tenable, Boekmancahier, kwartaalschrift voor kunst, onderzoek en beleid; 8 (27), 1996, pp. 72-74.

S.J. Hekman, Weber, the Ideal Type, and Contemporary Social Theory, Notre Dame, Indiana: University of Notre Dame Press, 1983.

Gerrit J. van Helden, De verzelfstandiging bezien vanuit de transactiekostenbenadering, in: Nico P. Mol en Harrie A.A. Verbon, Institutionele economie, perspectieven op de verzelfstandiging van overheidsdiensten, "s-Gravenhage: VUGA Uitgeverij B.V., 1993.

A.C. Hemerijck, De politiek van de economie, in: Beleid en Maatschappii, (21), 1994/1995.

A.M. Henderson, The Pricing of Public Utility Undertakings, Manchester School, no. 3, 1947, reprinted in: KJ. Arrow en T. Scitovsky, Readings in Welfare Economics, London: Allen \& Unwin, 1969.

P. Hennipman, Welvaartstheorie en economische politiek, Alphen aan den Rijn/Brussel: Samson Uitgeverij, 1977.

J.D. Hess, The Economics of Organization; Amsterdam: North Holland; 1983.

J.D. Hey, Experiments in Economics, Cambridge, Massachusetts: Basil Blackwell,Inc., 1991. 
B. Heyndels en Jef Vuchelen, De wet van Verdoorn in de belastingadministratie, Maandschrift Economie, jaargang $51,1987$.

B. Heyndels en $J$. Vuchelen, Een internationale vergelliking van de produktiviteitsontwikkeling van de belastingambtenaren, Cemspaper nr. 216, 1987.

J.R. Hicks, The Foundations of Welfare Economics, Economic Journal, XLIX, 1939.

M.J. Hinich en P.C. Ordeshook, Plurality Maximization vs Vote Maximization: A Spatial Analysis With Variable Participation, in: American Political Science Review, Vol, 64, No, 3 , $\underline{1970 .}$

Harold Hochman en J,D. Radgers, Pareto Optimal Redistribution, in: American Economic Review, september 1969.

Harold Hochman en J.D. Rodgers, Pareto Optimal Redistribution: Reply, in: American Economic Review, 60 (5), december 1970, pp. 997-1002.

Harold Hochman en J.D. Rodgers, Redistribution and the Pareto Criterion, American Economic Review, 64 (4), september 1974.

G.M. Hodgson, The Challenge of Evolutionary Economics, Journal of Institutional and Theoretical Economics, Vol. 152, 1996, pp. 697-706.

P.J.M. Hofhuis, Doen en laten, een onderzoek naar verzelfstandiging van overheidsdiensten, Deventer: Kluwer, Instituut voor Onderzoek van Overheidsuitgaven, onderzoeksreeks nr. 6, 1983.

G. Hofstede, Management Control of Public and Non-For-Profit Activities, Accounting. Organizations and Society, 6, 3, 1981 .

R.G. Holcombe en E.O. Price III, Optimality and the Institutional Structure of Bureaucracy, Public Choice, 33/1, 1978.

P. Holl, Effect of Control Type on the Performance of the Firm in the UK, Journal of Industrial Economics, 25, 1975, pp. 257-262.

C. Hood, A Public Management for All Seasons? Public Administration, Vol. 69, 1991, pp. 3-19.

D.A. Huettner en J.H. Landon, Electric Utilities: Scale Economies and Diseconomies, Southern Economic Journal, wol. $45,1978$.

F.E. Huibers, Privatiseren van staatsbedrijven; Wanneer heeft dat zin? , ESB, 3-5-'95.

H.H. Huizenveld, Organisatie-ontwikkeling in de Belastingdienst, een procesbeschrijving, in" R.W. van der Valk, Organisatieverandering in de Rijksdienst, praktijk en perspectieven, 'sGravenhage: Staatsuitgeverij, 1985.

M. Hüther, Integrierte Steuer-Transfer-Systeme für die Bundesrepublik Deutschland, Finanzarchiv, 49 (2), 1991.

M. Hutter en G. Teubner, The Parasitic Role of Hybrids, Journal of Institutional and Theoretical Economics. (JTTE) 149/4, 1993.

R.M. Isaac, K. McCue en C. Plott, Public Goods Provision in an Experimental Environment, Journal of Public Economics, 26, 1985, pp. 67-68. 
JM. Ivancevich en M.T. Matteson, Organizational Behavior and Management, Plano, Texas: Business Publications, NNC, 1987.

RW.J. Jansen, Prestatie-onderzoek naar Nederlandse overheidsbedrijven: case-studies naar de Staatsmijnen. de N.V. Nederlandse Spoorwegen en de Nederlandse Centrale Organisatie voor Toegepast-Natuurwetengchappeliik Onderzoek, Proefschrift Maastricht, 1993, pp. 19-26.

B. Jacquillat, Desetatiser, Paris, Robert Laffont, 1985.

M.C. Jensen, Organization Theory and Methodology, in: The Accounting Review, Vol. 58, 1983.

M. Jensen W. Meckling, Theory of the Firm Managerial Behavior, Agency Cost and Ownership Structure, Iournal of Financial Economics, 3, 1976.

R. Jensen, E.F. Toma en M. Toma, Privatization of Tax Collection and the Time-Consistency Problem, in: Public Finance/Finances Publiques, Vol. 49(1), 1994.

L. Johansen, Public Economics; Amsterdam, 1965.

L.P. Jones en Mason, in: L.P. Jones et al., Public Enterprise in less Developed Countries, New York: Cambridge Uniwersity Press, 1982.

L.P. Jones et al., Public Enterprise in less Developed Countries, New York: Cambridge University Press, 1982.

L.P. Jones en Ingo Vogelsang, The Effects of Markets on Public Enterprise Conduct and vice versa, Ljubljana: International Centre for Public Enterprises, 1982.

F.J. de Jong, Concurrentieregime en prijsvorming; te behandelen aan de hand van de volgende viagen, (prae-advies van de Vereniging voor de Staatshuishoudkunde, "s-Gravenhage: Nijhoff, 1958.

H.W. de Jong, Drie benaderingen van de onderneming, ESB, 26-2-1997, pp. 164-167.

N. Kaldor, Welfare Propositions of Economics and Interpersonal Comparisons of Utility, Economic Joumal, XLIX, 1939.

P.W. de Kam en F. van den Berg, Vam correctie naar preventie, ervaringen van de Belastingdienst; in: Openbaar Bestuur, 10, 1992.

J.M. Kamensky, Role of the "Reinventing Government" Movement in Federal Management Reform, Public Administration Review, Vol. 56, No. 3, 1996, pp. 247-255.

H. Kamps, Privatiseren: ideologie of economie?, in: Financieel Overheidsbeheer, $1985 / 9$.

E. Karni, Social Welfare Functions and Fairness, in: Social Choice and Welfare, 13, 1996.

J.A. Kay, Recent Contibutions to the Theory of Marginal Cost Pricing: Some Comments, Economic Journal, June 1971.

J.A. Kay, The State and the Market: the U.K. Experience of Privatization, London Business School, Mimeo, 1987.

R.D. Mc Kelvey. Intransitivities in Multidimensional Voting Models and some Implications for Agenda Control, Journal of Economic Theory, 12, 1976.

C.J. Mc Kenna, The Economics of Uncertainty, Brighton, Sussex: Wheatsheaf Books, 1986. 
R.W. Kenney en B. Klein, The Economics of Blockbooking, Joumal of Law and Economics, Vol. 26.

J.H.M. van Kesteren en J.F.J. Vos, Pendelen tussen collectivisering en privatisering, in: Bestuurswetenschappen, nr. 2, 1996.

W.I.M. Kickert, E.H. Klein en J.F.M. Koppenjan (eds.), Managing Complex Nerworks, London 1997.

A. Klamer, The Value of Culture, Boekmancahier, kwartaaltijdschrift over kunst, onderzoek en beleid, 7 (25), 1995, pp. 298-310.

A. Klamer, The Value of Culture: On the Relationship between Economics and Arts; Amsterdam: Amsterdam University Press, 1996.

A. Klamer, Reaffirming the Value of Culture, A Replu to the Critics, Boekmancahier, kwartaaltijdschrift over kunst, onderzoek en beleid, 8 (27), 1996, pp. 78-84.

E.H. Klijn, J.F.M. Koppenjan en C.J.A.M. Termeer, Managing Networks in the Public Sector, in: Public Administration, 1995, vol. $73, \mathrm{nr}, 3, \mathrm{pP}, 437-454$.

E.H. Klijn, Regels en sturing in netwerken, Delft, 1996.

E.H. Klijn en J.F.M. Koppenjan, Beleidsnetwerken als theoretische benadering: Een tussenbalans, Beleidswetenschap 1997/2, pp. 143-167.

E.H. Klijn en J.F.M. Koppenjan, Een Netwerkbenadering van beleid: Een dupliek, BeleidswetenSchap, 1997/2, pp. 179-181.

B.A.S. Koene, Orgamizational Culture, Leadership and Performance in Context: Trust and Rationality in Organizations, Proefschrift Universiteit Maastricht, 1996.

J.F. Koers, Redenen voor het bestaan van overheidsbedrijven, Working Paper, 007, Rijksuniversiteit Limburg, Economische Faculteit, 1995.

V. van Kommer en J.C.F. Muizelaar, De Belastingdienst, profiel van een organisatie, Arnhem: Gouda Quint B.V., 1995.

J.F.M. Koppenjan, J.A. de Bruijn en W.J.M. Kickert (red.), Netwerkmanagement in het openbaiar bestuur, "s-Gravenhage, 1993.

M.J.S. Korteweg-Wiers (et al.), Hoofdliznen van het ambtenarenrechit. Alphen aan den Rijn Samsom H.D. Tjeenk Willink, "s-Gravenhage: VUGA Uitgeverij, 1988 en 1992.

T.C. Koopmans, Analysis of Production as an Efficient Combination of Activities, in: T.C. Koopmans (ed.), Activity Analysis of Production and Allocation, New York: Wiley, 1965.

R.J. Kopp, "The Measurement of Produktive Efficiency: A Consideration", in: Quarterly Journal of Economics, $97,1981$.

T.H. Koster en J.C.F. Muizelaar, Met logistiek naar een klantgerichte Belastingdienst, in: Openbaar Bestuur, 1. 1992.

T.H. Koster en M.F.G.M. Verstegen, Logistiek en administratieve organisatie, in: Financieel overheidsmanagement, 191, nrs. 5 en 8.

D.J. Kraan, Bureaucratietheorie en organisatie van de rijksdienst, Openbare Uitgaven, 24, 1992. 
D.1. Kraan, Verzelfstandiging bezien vanuit de bureaucratietheorie II: Normkostenfinanciering, in: N.P. Mol en H.A.A. Verbon, Institutionele economie en openbaar bestuur, perspectieven op de verzelfstandiging van overheidsdiensten, "s-Gravenhage: VUGA, 1993.

R.S. Kravehuk en R.W. Schack, Designing Effectiwe Performance-Measurement Systems under the Government Performance and Results Act of 1993, Public Administration Review, Vol. 56, No. 4, $1996,348-358$.

G. Kubon-Gilke, Institutional Economics and the Evolutionary Metaphor, Journal of Institutional and Theoretical Economics, Vol. $152,1996, \mathrm{pp} .723-738$.

R.W. Künneke, Invloed van EG-ontwikkelingen op de Nederlandlse markt woor gas en elektriciteit, onderzoek verricht in opdracht van het ministerie van Financiën, Universiteit Twente, Enschede, 16 april 1992.

R.W. Künneke, Verzelfstandiging bezien vamuit de property rights-theorie, in: N.P. Mol en H.A.A. Verbon, Institutionele economie en openbaar bestuur: perspectieven op de verzelfstandiging van overheidsdiensten, 's-Gravenhage: VUGA Uitgeverij BV, 1993a.

R.W. Kinneke, Op armlengte van de overheid: Een theoretisch en empirisch onderzoek naar de effekten van verzelfstandiging op de efficiëntie van openbare nutsbedrijven, Enschede: Faculteit der Besthurskunde, Universiteit Twente, $1993 \mathrm{~b}$.

R W. Konneke, Invloed van EG-ontwikkelingen op de Nederlandse markt voor gas en elektriciteit, onderzoek verricht in opdracht van het Ministerie van Financiën, Inspectie der Rijksfinanciën, Universiteit Twente, Enschede, 16 aprill 1992.

R. Laan en H. Vollebergh, Verzelfstandiging van de rijksmusea, Openbare Uitgaven, 1994, nr. 1.

I. Lakatos, Falsification and the Methodology of Scientific Research Programmes, in: I. Lakatos en A. Musgrave, Criticism and the Growth of Knowledge, Cambridge: Cambridge University Press, 1970.

O. Lange en F.M. Taylor, On the Economic Theory of Socialism, New York: McGraw-Hill Book Company, 1965.

O. Lange, The Foundations of Welfare Economics, in: K.J. Arrow en T. Scitovsky, Readings in Welfare Economics, London: George Allen and Unwin Ltd, 1972.

M. Laver en W.B. Hunt, Policy and Party Competition, New York: Routledge, 1992.

M. Laver, N. Schofield en M.G. Schmidt, Multiparty Government, Politische Vierteliahresschrift, Zeitschrift der Deutschen Vereinigung für Politische Wissenschaft, Marz 1992, p. 175.

M. Laver, Theory, Institutions and Government Formation, plenary lecture to the annual conference of the European Public Choice Society Portrush, Co Antrim, 17 april 1993.

M. Laver en K.A. Shepsle, Making and Breaking Governments: Cabinets and Legislatures in Parliamentary Democracies, Cambridge: Cambridge University Press, 1996.

J.D. Ledyard, Public Goods: A Survey of Experimental Research, in: J.H. Hagell en A.E. Roth (eds); The Handbook of Experimental Economy, Princeton, New Jersey: Princeton University Press, 1995.

D. Leech en J. Leahy, Ownership Structure, Control Type Classifications and the Performance of large British Companies, Economic Journal, 101, 1991. 
F.L. Leeuw, Doorlichting zelfstandige bestuursorganen en beleidsdoelmatigheid, Bestuurskunde; jrg. 6, nr. 6, 1997.

J. Le Grand en W. Bartlett, Quasi-Markets and Social Policy, Basingstoke and London, 1993.

Harwey Leibenstein, Allocative Efficiency vs. X Efficiency, American Economic Review, 56, 1966.

Harvey Leibenstein, X-Inefficiency Xists: Reply to an Xorcist, in: Amarican Economic Review, $68,1978$.

M.A. Levin en M.B. Sanger, Making Governments Work: How Entrepreneurial Executives Turn Bright Ideas into Real Results, San Francisco: Jossey-Bass, 1994.

S. Lindenberg, Multiple-Tie Networks, Structural Dependance, and Path-Dependency: Another Look at Hybrid Forms of Governance, Iournal of Institutional and Theoretical Economies (ITTE), Vol. 152, 1996, pp. 188-196.

Spyros Lioukas, Performance Evaluation and Managerial Goals of Public Enterprises, paper, Athens University of Economics and Business (Greece), 1991: in het kader van de conferentie over Public versus Private Enterprises: In Search for the Real Issues, gehouden aan de University of Liege-Department of Economics op 4 en 5 April 1991.

J.W. Lipford, Group Size and the Free-Rider Hypothesis: An Examination of New Evidence from Churches, Public Choice, 83, 1995, pp. 291-303.

J.W. Lipford, On "Group Size and the Free-Rider Hypothesis: An Examination of New Evidence from Churches: A Reply to Tullock, Public Choice, 88, 1996a, pD. 187-188.

J.W. Lipford, Group Size and the Free-Rider Hypothesis: A Re-Examination of Old Evidence from Churches: Reply to Zaleski and Zech, Public Choice, 88, 1996b, pp. 413-416.

R.G. Lipsey en K. Lancaster, The General Theory of Second Best, in: Review of Economic Studies, 24, 1956.

R.G. Lipsey en K. Lancaster, "The General Theory of Second best", Review of Economic Studies, Vol. 26, 1959.

C.A.K. Lovell, S. Richardson, P. Travers en $\mathbf{L}$.L. Wood, Resources and Functionings: A New View of Inequality in Australia, W. Eichhorn (ed.), Models and Measurement of Wielfare and Ine: guality, Berlin: Springer-Verlag, 1994.

L.E. Lynn, Policy Achievement as a Collective Good: A Strategic Perspectiwe on Managing Social Problems, in: B. Bozeman (ed.), Public Management: The State of the Art, San Francisco: Jossey-Bass, pp. 109-133.

J.A.H. Maks en A. van Witteloostuijn, Walras: Understood or Misunderstood, Research Memorandum, Faculteit der Economische Wetenschappen, Rijksuniversiteit Limburg RM 86-014.

J.A.H. Maks en M.P. Schinkel, Economic Policy and Market Imperfections an Analysis of Third Best Rules, Research Memorandum 93-029, Maastricht: Faculty of Economics, Limburg University, 1993.

J.A.H. Maks, Economic Theory and Competion Policy in the Netherlands; in: G. Meijer (ed), New Perspectives on Austrian Economics, London en New York: Routledge, 1995.

H.A. Mamuth, Markteconomie: Analyse en evaluatie, Utrecht, 1990 (oorspronkelijke uitgave). 
H.A. Mamuth, Markteconomie, Analyse en Eivaluatie, Utrecht, 1993.

E. Mansfield, Microeconomics, Theory and Applications, New York en London: W.W. Norton and Company, 1982.

J.G. March en I.P. Olson, Ambiguity and Choice in Organizations, Bergen, Norway: Universitetsforlaget, 1976.

M. Marchand, P. Pestieu en H. Tulkens, The Performance of Public Enterprises: Concept and Measurements; Amsterdam: North-Holland, 1984.

G. Marwell en R. Ames, Economists free ride, does anyone else? Experiments on the Provision of Public Goods, Journal of Public Economics, $15,1981$.

R.C. Mascarenhas, Searching for Efficiency in the Public Sector: Interim Evaluation of Performance Budgeting in New Zealand, Public Budgeting \& Finance, Vol. 16, No. 3, 1996, pp. 13-27.

M.T. Matteson en J.M. Ivancevich, Organizational Behavior and Management, Plano, Texas: Business Publications, INC, 1987.

L.G. Mattsson, Firms, "Megaorganizations" and Markets: A Network View, in: Journal af Institutional and Theoretical Economics, JITE, 151/4 (1995), Zeitschrift für die gesamte Staatswissenschaft.

Th.G. McGuire, Budget Maximizing Governmental Agencies: An Empirical Test, Public Choice, 36. No. 3, 1981 .

M. McKee en E.G. West, "The Theory of Second-Best:" a Solution in Search of a Problem", Economic Inquiry, Vol. 19, No. 3, 1981.

M. McKee en E.G: West, Do Second-Best Considerations affect Policy Decisions?, Public Finance/Finances Publiques, Vol. 39, No. 2, 1984.

M. McKee en E.G. West, Further Perspectives on the Theory of Second-Best, Public Finance/Finances Publiques, Vol. 42, No. 1, 1987.

M. McKee en E.G. West, Second-Best Considerations and Policy Decisions, in: Public Finance, 39,1984 .

Ian McLean, Public Choice: An Introduction, Oxford: Blackwell, 1987.

J.W. Mellink, Naar een vergelijkende prestatieanalyse van overheidsbedrijven; De Neo-Institutionele benadering. Discussiepaper naar aanleiding van het vooriaarscongres "Verzelfstandiging van overheidsdiensten" van de Vereniging voor Bestuurskunde, 26 en 27 maart 1992.

C. Menard, On Clusters, Hybrids, and Other Strange Forms: The Case of the French Poultry Industry, Journal of Institutional and Theoretical Economics (ITTE), Vol. 152 (1), 1996, pp. 154 183.

A.C. Meijdam en H.A.A. Verbon, Verzelfstandiging bezien vanuit de bureaucratietheorie 1: de grote operaties; in: N.P. Mol en H.A.A. Verbon, Institutionele economie en openbaar bestuur. perspectieven op de verzelfstandiging van overheidsdiensten, 's-Gravenhage: VUGA 1993.

J.G.A. van Mierlo, De Economische theorie van het politieke proces en de representieve democratie, een overzicht van dertig jaar theorievorming en empirisch onderzoek, in: Maandschrift Economie, jaargang 48, 1984. 
J.G.A. van Mierlo, Ambtelijke posities en rollen in verandering, Een owerzicht, in: A.F.A. Korsten, F. Kluytmans, T.W.P.M. van der Krogt en A. Sorber, Overheidsmanagement en de menseliike factor, Congrespublikatie 1991 van de Vereniging voor Bestuurskunde, 's-Gravenhage, 1991, pp. 157-181.

J.G.A. Van Mierlo, Spatial Analysis of Electoral Competition. Demand and Supply of Economic Policy in Representative Democracy, the Netherlands, 1946-1982, Delft: Eburon, Dissertatie; 1989.

J.G.A. Van Mierlo, Spatial Analysis of Electoral Competition and Demand/Supply Models of Economic Pollicy: the Case of the Netherlands: 1946-1982, Paper for the ECPR Joint Sessions of Workshops, 1990, April 2-7 at the Ruhr Universität, Bochum (BRD).

J.G.A. van Mierlo, Institutionele variëteit in de publieke sector: Een polycentrische benadering, in: N.P. Mol en H.A.A. Verbon, Institutionele economie en openbaar bestuur. Perspectieven op de verzelfstandiging van overheidsdiensten, 's-Gravenhage: VUGA, 1993.

J.G.A. van Mierlo, Learning Processes between Public and Private Organisations, Research Memorandum RM 0/94-059, Meteor, Faculty of Economics and Business Administration, Limburg University, Maastricint, December 1994. (vergelijk ook: J.G.A. van Mierlo, Wat kunen overheden en ondernemingen van elkalar leren? Een bestuurseconomisch perspectief, Research memorandum, 0/094-044, Vakgroep Algemene Economie, Rijksuniversiteit Limburg.

J.G.A. van Mierlo, Bureaucratic Entrepreneurship as Innovative Management Strategy in the Public Sector, A Public Choice-Approach. Paper voorbereid voor de 65 e jaarlijkse conferentie van de "Southers Economic Association", 18 november, 1995.

J.L. Migué en G. Bélangér. Towards a General Theory of Managerial Discretion, Public Choice, $17,1974$.

G. Miller, Bureaucratic Compliance as a game on the Unit Square, Public Choice, XXIX, 1977, pp. 37-51.

G.J. Miller en T.M. Moe, Bureaucrats, Legislators, and the Size of Government, Americam Political Science Review, 77, 1983.

Ministerie van Binnenlandse Zaken, Staatsalmanak voor het Koninkrijk der Nederlanden 19961997, Den Haag: SDU-Uitgevers, 1996.

Ministerie van Financièn, Hafir, deel 1 en 2, 1997.

Ministerie van Financiën, Directie Begrotingszaken, Aansturen op resultaak, 17 juni 1997.

Ministerie van Economische Zaken, Markt en overheid, oktober 1997.

A.P. Minkler, Property rights, Efficiency and Labor-Managed Firms, in: Anmals of Public and Cooperative Economics, 60, 1989.

E.J. Mishan, Economic Efficiency and Social Welfare, London: Allen \& Unwin Ltd., 1981.

H.A.J.F. Misset, Vaststelling der verkooporijzen en begroting van de afzet, Leiden: Stenfert Kroese N.V., 1961.

J.C. Mitchell, The Concept and Use of Social Networks, Manchester: Manchester University Press, 1969.

O.S. Mitchell en S.P: Zeldes; Social Security Privatization: A Structure for Analysis, American Economic Review, Vol. 86, no. 2, May 1996, pp. 363-367. 
T.M. Moe, The New Economics of Organization, American Journal of Political Science, $28_{*} 4$, 1984.

K.O. Moene, Types of Bureaucratic Interaction, Joumal of Public Economics, 29, 1986.

P.W. Moerland, Ieder aandeel een stem, ESB, 26-2-1997, pp. 168-170.

H. Mohring; The Peak Load Problem with increasing Returns and Pricing Constraints, American Economic Review, september 1970.

N.P. Mol, Doelmatig financieel beheer in de rijksdienst, Openbare Uitgaven, 24, 1992.

N.P. Mol en H.A.A. Verbon, Institutionele economie en openbaar bestuur. perspectieven op de verzelfstandiging van overheidsdiensten, "s-Gravenhage: VUGA Uitgeverij B.V., 1993.

$\mathbb{R}$ Molyneux en D. Thompson, Nationalized Industry Performance: Still Third Rate" in: Fiscal Studies, 8, 1987. pp. 48-82.

R.J. Monsen en K.W. Walters, Nationalized Companies: a Threat to American Business, New York: McGraw-Hill Book Company, 1983.

R. Monsen, J.S. Chin en D.E. Cooley, The Effect of Seperation of Ownership and Control an the Performance of the large Firm, Quarterly Journal of Economics, june, 1968, pp. 435-451.

R. Morck, A. Schleifer en R.W. Vishing, Management, Ownership and Marketvaluation: an Empirical Amalysis, Journal of Financial Economics, 20, 1988, pp. 292-315.

D.C. Mueller, Public Choice II, A Revised Edition of Public Choice, Cambridge: Cambridge University Press, 1989.

Richard A. Musgrawe, The Theory of Public Finance, New York: McGraw-Hill, 1959.

R.A. Musgrave en P.B. Musgrave, Public Finance in Theory and Practice, New York: McGrawHill, 1984.

Richard A. Musgrave, Public Finance in a Democratic Society, Brighton: Wheatsheaf Books, 1986, Vol. 1.

R.P. Nathan, Reinventing Government: What does it mean? Public Administration Review, Vol. 55. No. 2, March/April, 1995.

G.H.J.M. Neelen, Verzelfstandiging bezien vanuit de agencytheorie, in: N.P. Mol en H.A.A. Verbon, Institutionele economie en openbaar bestuum, perspectieven op de verzelfstandiging van pverheidsdiensten, 1993, "s Graventhage: VUGA Uitgeverij BV.

K.T.H. Nelissen, Flexible $m_{2}$ gebruik binnen de Belastingdienst, afstudeerscriptie, Hogeschool Holland, studierichting Management Facilitaire Dienst, 1993.

L.G. Neuberg. Two Issues in the Municipal Ownership of Electric Power Distribution Systems, Bell Journal of Economics, 8(1), spr. 1977, pp, 303-323.

Dick Netzer, The Subsidized Muse. Public Support for the Arts in the United States, Londlon: Cambridge University Press, 1978.

J. von Neumann en O. Morgenstern, Theory of Games and Economic Behavior, Princeton, NJ: Princeton University Press, 1947 (first edition 1944). 
David M. Newbery, Missing Markets: Consequences and Remedies, in: F. Hahn editor, The Economics of Missing Markets, Information and Games, Oxford: Clarendon Press, 1989, Hoofdstuk 10.

$\mathrm{Y}-\mathrm{K}, \mathrm{Ng}$, Non-Economic Activities, Indirect Externalities, and Third-Best Policies, Kyklos, 28, 1975 , pp. 507-525.

Y.K. Ng, Welfare Economics: Introduction and Development of Basic

Concepts, London and Basingstoke: The MacMillan Press Ltd., 1983 (first edition 1979).

Y-K Ng. Towards a Theory of Third Best, in: Public Finance, 32, 1977, pp. 1-15.

Y-K Ng, "Political Distortions" and the Relevance of Second and Third-Best Theories, Public Finance/Finances Publiques, Vol. 42, No.1, 1987.

Y-K Ng, The Role of Economists and Third-Best Policies, Public Finance/Finances Publiques, Vol. 42 , No. 1, 1987.

William A. Niskanen, Bureaucracy and Representative Govermment, Chicago: Aldine, 1971:

William A. Niskanen, The Peculiar Economics of Bureaucracy, American Economic Review, $58_{i}$ 1968.

William A. Niskanen, Bureaucrats and Politicians, Journal of Law and Economics, 18, 1975.

William A. Niskanen, A Reflection on Bureaucracy and Representative governement, in: A. Blais en S. Dion, The Budget Maximixing Bureaucrat, Appraisals and Evidence, Pittsburgh: University of Pittsburgh Press, 1991.

Frans K.M. van Nispen, Anorexia nervosa publica, een evaluatie van de grote efficiency-operatie; Bestuurswetenschappen, nr, 2, 1997.

M. Noordegraaf, Beelden wan de overheidsmanager, Bestuurskunde, jrg. 6, nr. 3, 1997.

W.D. Nordhaus, The Political Business Cycle, Review of Economic Studies, 1975, pp. 169-190.

G. Norman en M. La Manna, The New Industrial Economics, Recent Development in Industrial Orgamization, Oligopoly and Game Theory, England: Edward Elgar Publishing Ltd, 1992.

Mancur Olson, "Evaluating Performance in the Public Sector". In Milton Moss, ed., The Measurement of Economic and Social Performance, Studies in income and wealth 38 . New York. and London: Colombia University Press for the National Bureau of Economic Research, 1973.

Mancur Olson, The Logic of Collective Action: Public Goods and the Theory of Groups, Cambridge, Massachusetts: Harvard University Press, 1971.

P.C. Ordeshook, The Spatial Theory of Elections: A Review and a Critique, in: I. Budge, et al." Party Identification and Beyond, London, 1976.

P.C. Ordeshook, Game Theory and Political Theory, Cambridge: Cambridge University Press, 1986.

W. Orzechowski, Economic Models of Bureaucracy: Survey, Extensions and Evidence, in: T. Borcherding (Ed.), Budgets and Bureaucrats, Durham: Duke University Press, 1977.

D. Osborme en T. Gaebler, Reinventing Government, How the Entrepreneurial Spririt is Transforming the Public Sector, Reading MA: Addison-Wesiley Pub. Co., 1992. 
Andreas Papandreou, Externality and Institutions, Oxford: Clarendon Press, 1994.

F.A. Pappi, D. Knoke en S. Bisson, Information Exchange in Policy Networks, in: F.W. Scharpf (ed.), Games in Hierarchies and Networks, Frankfurt am Main/Boulder, CO: Campus Verlag/Westview, pp. 287-313.

V. Pareto, Manual of Pollitical Economy, London and Basingstoke: The Macmillan Press Ltd, 1971, (vertaling van de Franse editie van 1927 ).

V. Pareto, Faits et Thêories, Genève; Droz, 1976 (vertaling van: Fatti e Teorie, 1920).

Parlementaire enquetecommissie RSV. Verslag van de Werkzaamheden, deel 13, Den Haag, Staatsdrukkerij, 1984.

C.N. Parkinson, "Parkinson"s Law", The economist, november 1955, reprinted in E. Mansfield, Managerial Economics and Operations Research, New York: W.W. Norton, 4th ed., 1980.

H. Parris, P. Pestieau en P. Saynor, Public Enterprise in Western Europe, London: Croom Helm Ltd., 1987.

M. Patchen, The Locus and Basis of Influence on Organizational Decisions, Organizational Behavior and Human Performance, In: Organizational Behavior and Human Performance, Vol. 11,1974 .

J.C.L. Paul, Hiërarchie en besluitvorming, in: L.J. van Gemerden (et al.), M. Herweyer en J.A. van Selm (red), Budgetfinanciering: een beleidsverkenning, Publicatiereeks, nr. 7, Groningen: Samenwerkingsverband Bestuurswetenschappen Noorden des Lands, december 1987.

A. Peacock en I, Rizzo (eds.), Cultural Economics and Cultural Policies, Dordrecht, Boston, Londen: Kluwer Academic Publishers, 1994.

William S. Peirce, "Bureaucratic Failure", Incremental Drift from Public Goods". Cleveland: Case Western Reserve University, Department of Economics, Working Paper, nr, 32, 1977.

W.S. Peirce, Bureaucratic Failure and Public Expenditure, Quantative Studies in Social Relations, New York: Academic Press, Inc., 1981.

S. Pejovich, Towards a General Theorie of Property Rights, Zeitschrift für Nationalökonomie, Band 31, 1-2, 1971, in: E.G. Furubotn en S. Pejovich, The Economics of Property Rights, Cambridge, MA: Ballinger Publishing Company, 1974.

S. Perelman and P. Pestieu, The Performance of Public Enterprises: A Comparative Efficiency Study of Railways and Postal Services, CIRIEC Working Paper 87-05. 1987.

S. Perelman en P. Pestieau, Technical Performance in Public Enterprises, A Comparative Study of $\mathbb{R}$ ailways and Postal Services, in: European Economic Review, 32, 1988.

F.D. Perimutter en R.A. Cnaan, Entrepreneurship in the Public Sector: The Horns of a Dilemma, Public Administration Review, Jan./Feb., 1995, Vol. 55, No. 1, 1995.

Charles Perrow, Complex Organisations. A Critical Essay, New York: Random House, 1979.

Charles Perrow, Complex Organisations, A Critical Essay, New York: Random House, 1986.

P. Pestieu, Measuring the Performance of Public Enterprise: A Must in Times of Privatization, in: Annals of Public and Co-Operative Economics, 60 (3), 1989.

P. Pestieau en H. Tulkens, Assessing the Performance of Public Sector Activities, some recent 
evidence from the Productive Efficiency Viewpoint, 1990 :

A. Philips, Comment on Sappington, D. and Stiglitz J., Joumal of Policy Analysis and Management, 6 (4), 1987.

A. Picot, Contingencies for the Emergence of Efficient Symbiotic Arrangements, Journal of Institutional and Theoretical Economics (JITE), 149/4, 1993.

A.C. Pigou, Wealth and Welfare, London: MacMillan and CO, Ltd, 1912.

A.C. Pigou, The Economics of Welfare, London: Macmillan, 1932.

W.W. Pommerehne, Präferenzen fiir Öffentliche Güter. Ansätze zui Threr Erfassung, Tübingen: J:C.B. Mohr, 1987.

W.W. Pommerehne, L.P. Feld en A. Hart, Voluntary Provision of a Public Good: Results from a Real World Experiment, Kyklos, vol. 47, 1994.

Johannes Popitz, Der künftige Finanzausgleich zwischen Reich, Ländern und Gemeinden, Berlin: Verlag von Otto Liebmann, 1932.

R.A. Posner, Taxation by Regulation, The Bell Journal of Economics and Management Science, Voll. 2, no. 1, spring 1971.

R.A. Posner, Theories of Economic Regulation, The Bell Journal of Ecomomics, Autumn, nr. 5.

W.W. Powell, Neither Market nor Hierarchy! Network Forms of Organization, Research in Organizational Behavior, Vol. 12, 1990.

B.M.S van Praag, Individual Welfare Functions and Consumer Behavior, Amsterdam: NoordHollansche Uitgeverij Maatschappij, 1968.

B.M.S. van Praag en A. Kapteyn, Wat is ons inkomen ons waard, Economisch Statistische Berichten, 25 april 1973.

J.W. Pratt en R.J. Zeckhauser, Principals and Agents: An Overview, in: J.W. Pratt en R.J. Zeckhauser (ed.), Principals and Agents: The Structure of Business; Harvard Business School Press: Boston, Massachusetts, 1985.

I.M.A.M. Pröpper, Succes- en faalfactoren voor repliek: De discussie over beleidsnetwerken, Beleidswetenschap, 1997/2, pp. 174-178.

K.G. Provan en H.B. Milward, A Preliminary Theory of Network Effectiveness: A Comparative Study of Four Mental Health Systems, Administration Science Quarterly, 40, 1995, pp. 1-33.

F. van Puffelen, Cultuur, in: Instituut voor Onderzoek van Overheidsuitgaven, Jaarboek Overheidsuitgaven 1993, Schoonhoven: Academic Service, 1993.

Hilary Putnam, Mathematics, Matter and Method, Cambridge: Cambridge University Press, 1979.

D.S. Pugh en D.J. Hickson, Writers on Organization, Newbury Park, CA: Sage, 1989.

Venkata $V$. Rammanadham, The economics of public enterprise, London: Routledge, 1991.

V.V. Ramanadham (ed.), Privatization and Equity, London and New York: Routledge, 1995.

F. Ramsey, A Contibution to the Theory of Taxation, Economic Journal, maart, vol. 37, 1927. 
Organization, New York: Free Press, 1976.

H.A. Simon, Models of Man- Social and Rational Mathematics Essays on Rational Human Behavior in a Social Setring 1957.

H.A. Simon, The New Science of Decision Making, New York: Harper \& Row, 1960.

H.A. Simon, Organizations and markets, 1989.

H.A. Simon et al., Economics. Bounded Rationality and the Cognitive Revolution, Aldershot: Edward Elgar, 1992.

H.A. Simon, The New Science of Management Decision, Englewood Cliffs: Prentice-Hall, NC, 1977.

H.A. Simon, Organizations and Markets, Journal of Economic Perspectives, 5, 1991, pp. $24-44$.

Henry C. Simons, Personal Income Taxation, Chicago: University of Chicago Press, 1938.

Arend Soeteman, Norm en logica, opmerkingen over logica en rationaliteit in het normatief redeneren met name in het recht, Zwolle: Tjeenk Willink, 1981.

R.M. Steers, Introduction to Organizational Behayior, Glenview: Scott Foresman and Co, 1984.

P.O. Steiner, Peak Loads and Efficiency Pricing, Quarterly Journal of Economics, 71, November, 1957.

P. Stella, Tax Farming, in: International Monetary Fund Staff Papers, Vol. 40, 1993, pp. 217225.

F.H. Stephen en D.D. Gillanders, Ex Post Monitoring Versus Ex Ante Screening in the New Institutional Economics "Journal of Institutional and Theoretical Economics (JTE) 149/4, 1993.

B. Steunenberg, Agent Discretion, Regulatory Policymaking, and Different Institutional Arrangements, Public Choice, 86, 1996.

Th.A. Stevers, Een economische analyse van het democratisch proces, in: H. Brugmans, et al., Welvaart en Democratie, speciaal nummer van Maandschrift economie, Tilburg: Gianotten, 1968 , pp. 37-70.

G.J. Stigler. The Diwision of Labour is limited by the Extent of the Market, Journal of Political Economy, 59, 1951.

George J. Stigler, The Organization of Industry, Homewood: Irwin, 1968.

George J. Stigler en Kenneth E. Boulding, Readings in Price Theory, London: Allen and Unwin, 1953.

George J: Stigler, "The Xistence of X-Efficiency", in: American Economic Review, 66, 1976, pp. $213-216$.

J.E. Stiglitz, Pareto Efficient and Optimal Taxation and the New New Welfare Economics, in: A. Auerbach en M. Feldstein (eds.), Handbook on Public Economics, Amsterdam: Elsevier Science Publishers/North-Holland, 1987.

Joseph E. Stiglitz, Economics of the Public Sector, New York: Norton, 1988. 
J.E. Stiglitz en E.P. Brown, Economics of the Public Sector, New York, 1988.

Joseph E. Stiglitz, Whither Socialism, Cambridge, Massachusetts: The MrT Press, 1994.

D.E. Stokes, Political Models of Party Competition, in: American Political Science Review, Vol. 57, june 1963 , pp. 368-377.

T. Stratmann, Instability of Collective Decisions? Testing for Cyclical Majorities, Public Choice, 88, 1996, pp. 15-28.

R. Sugden, A Theory of Focal Points, The Economic Jourmal, 105, mei 1995.

Mo-Yin Tam en J.J. Persky, On the Distributional Implications of Public Goods, Public Choice, 33/1, 1978.

A.S. Tannenbaum, Control in Organizations, New York: McGraw-Hill, 1968.

A.S. Tannenbaum (et ali), Hierarchy in Organizations, San Francisco Jossey-Bass; 1974.

T. Thiemeyer, Öffentliche Unternehmen und Ökonomische Theorie, Baden-Baden: Nomos, 1987.

T. Thiemeyer, Öffentliche Bindung, Deregullierung, Privatisierung, in: T. Thiemeyer, et al., Öffentliche Unternehmen und okkonomische Theorie, Baden-Baden: Nomos, 1987.

B. Thiry en H. Tulkens, Productivity, Efficiency and Technical Progress: Concepts and Measurement, in: Annals of Public and Cooperative Economics, Vol. 60, No. 3, 1989.

E.A. Thompson, Book Review of Bureaucracy and Representative Govemment by W.A. Niskanen, Journal of Economic Literature, 11, 1973.

F. Thompson en W. Zumenta, Control and Controls: A Reexamination of Control Patterns in Budget Execution, Policy Sciences, 13, 1981.

P.J. Thonet en $\mathrm{O.H}$. Poensgen, Managerial Control and Economic Performance in West Germany, Journal of Industrial Economics, 20, 1979.

C.M. Tiebout, A Pure Theory of Local Expenditures, Journal of Political Economy, 64, 1956.

Thomas H. Tietenberg, Environmental and Natural Resource Economics, Third Edition, New York: HarperCollins Publishers Inc., 1992.

J. Tirole, The Theory of Industrial Organization, Cambridge: MIT Press, 1988.

R.D. Tollison en G. Tullock (eds.), The Political Economy of Rent-seeking, Deventer: Kluwer, 1987.

L.J. O'Toole, Treating Networks Seriously: Practical and Research-Based Agendas in Public Administration, Public Administration Review, Vol. 57, No. 1, 1997, pp. 45-52.

H. Tulkens, B. Thiry en A. Palm, Mésure de 1' Efficacité Productive: Méthodologies et Applications aux Sociếtés de Transports Intercommunaux de Liège, Charleroi et Verviers, in: B. Thiry en H. Tulkens (eds), La Performance Economique des Sociétés Belges de Transponts Urbains, Liège, CIRIEC, 1988.

H. Tulkens, "The Performance Approach in Public Enterprise Economics", in: Annals of Public and Co-Operative Ecomomics, 57, 1986. 
G. Tullock, The Politics of Bureaucracy, Washington, 1965.

G. Tullock, The Welfare Costs of Tariff, Monopolies, and Theft, Western Economic Journal, 5 , 1967.

G. Tullock, Economic Hierarchies, Organization and the Structure of Production, Boston, Dordrecht and London: Kluwer Academic Publishers, 1992.

G. Tullock, On "Group Size and the Free-Rider Hypothesis: Another Hypothesis", by Jody W. Lipford: Comment, Public Choice, 87, 1996, p. 185.

G. Tullock, Provision of Public Goods through Privatization, KXKLOS, Vol. 49, 1996, pp. 221224.

Tweede Kamer der Staten-Generaal (vergaderjaar 1985-1986), Kabinetsstandpunt taak en functie wan de PTT met betrekking tot informatie- en telecommunicatietechnologie, 17370 , nrs. 30-31.

Tweede Kamer der Staten-Generaal (vergaderjaar 1988-1989), Functionele decentralisatie, 21042, nr. 2 .

Tweede Kamer der Staten-Generaal (vergaderjaar 1992-1993), Memorie van Toelichting bij de wijziging van de Machtigingswet PTT Nederland N. Vi, 23192, nr. 3, p. 5.

Tweede Kamer der Staten-Generaal (vergaderjaar 1990-1991), Memorie van Toelichting, 22160, nr. 3 .

Tweede Kamer der Staten-Generaal (1995) Nota over de toestand van 's Riiksfinanciën, Den Haag: vergaderjaar $1995-1996,24400, \mathrm{nr} .1$.

Tweede Kamer der Staten-Generaal, Nota over de toestand van 's Rijksfinanciën, vergaderjaar 1997-1998, 25600, nr. 1, 16 september 1998.

Tweede Kamer der Staten-Generaal, Beheersing gedecentraliseerd personeelsbeleid, Algemene Rekenkamer, (vergaderjaar 1992-1993), 22840, nrs. 1-2.

Tweede Kamer der Staten-Generaal, (vergaderjaar 1994-1995), Verslag van de Algemene Rekenkamer over 1994, 24130, nr. 3.

Tweede Kamer (vergaderjaar 1990-1991), Regeringsstandpunt functionele decentralisatie, 19042 , nr. 4.

Tweede Kamer der Staten-Generaal, (vergaderjaar 1994-1995), 6 wijziging van de Comptabiliteitswet, 23796, Handelingen p. 2704-2718 en p. 2850-2851.

N.D. Uri, New Dimensions in Public Utility Pricing, Greenwich, Connecticut, Londion, England: Jail Press Inc.; 1983.

V. Vanberg, Institutional Evolution within Constraints; Journal of Institutional and Theoretical Economics (JTE), Vol. 152 (1), 1996, pp. 690-696.

I.S. Vavouras, Public Enterprise in the European Union: Prospects and Constraints, Annales de 1' Economie Publigue, Sociale et Cooperative, 67 (2), 1996, pp. 267-280.

P. Veen, Mensen in Organisaties; een inleiding in de organisatiepsychologie, Houten: Bohn Stafleu Van Loghum, 1992.

C. Veljanovski, Selling the State, London: Weidenfeld and Nicolson, 1987. 
B.C.J. van Velthoven, Vraag en aanbod in de politiek, ESB, 12-9-1990.

K. Verma, Covert Costs of Privatization. Lessons from the Closure of Three Public Chronic Care Hospitals in Massachusetts, Public Budgeting and Finance, Vol. 16, No. 3, 1996, pp. 49-61.

S. Vicary, Joint Production and the Private Provision of Public Goods, Journal of Public Economics, 63, 1996, pp. 429-445.

R. Visser, Organisatiecultuur als olievlek, in: Personeelsbeleid, officieel orgaan van de Nederlandse Vereniging voor Personeelsbeleid, 31(3), 1995, pp. 41-44.

R. van der Vlist, Verschillen in groepsprestaties in de Nederlandse zeevisserii, Groningen: Wolters-Noordhoff, 1970.

Ingo Vogelsang, Public Enterprise in Monopolistic and Oligopolistic Industries, Chur: Harwood Academic Publishers, 1990.

J.F.J. Vos, Organisatie van privatisering, een swsteembenadering, Groningen: wolters-Noordhoff, proefschrift Rijksuniversiteit Groningen, 1993.

P.H.J. Vrancken, Budgetfinanciering in de collectieve sector, in: L.J. van Gemerden (et. al.), M. Herweyer en J.A. van Selm (red.), Budgetfinanciering, een beleidsverkenning, Publicatiereeks Samenwerkingswerband Bestuurswetenschappen Noorden des Lands (SBN), nr. 7, Groningen: Universiteitsdrukkerij, december 1987.

Richard E. Wagner, Economic Manipulation for political Profit: Macroeconomic Consequences and Constitutional Implications, Kylos. Vol. 30, 1977 .

R.E. Wagner, Pressure Groups and Political Entrepreneurs: A Review Article, in: G. Tullock (ed.), Papers on Non-Market Decision-Making, Vol. 1, Charlottesville: Thomas Jefferson Center for Political Economy, University of Virginia, 1966.

B.A. Wallin, The Need for a Privatization Process: Lessons from Development and Implementation, Public Administration Review, Vol. 57, No. 1, 1997, pp. 11-20.

R.F. Ware, Performance of Manager-versus Owner-controlled Firms in the Food and Beverage Industry, Quarterly Review of Economics and Business, 1975.

I. Waring, Educational Vouchers: The Case for Public Choice Reconsidered, Publie Budgeting \& Finance, Vol. 16, No. 3, pp. 63-73.

A.F.P. Wassenberg, Netwerken, organisatie en strategie, Meppel: Boom, 1980.

M. Weber, The Theory of Social and Economic Organization, (transl. Parons/Henderson), New York, 1947 .

M:G. Webb, Pricing Policies for Public Enterprises, Londom: MacMillan, 1976.

J. West, E. Berman en M.E. Milakovich, Total Quality Management in Local Government, The ICMA Yearbook, Washington, DC: ICMA, 1993.

K. Wicksell, A New Principle of Just Taxation. 1896, vertaald in R.A. Musgrave and A.T. Peacock, Classics in the Theory of Public Finance, London: MacMillan, 1958.

L.Th.R. Wijchers, L.A.F.M. Kerklaan en W.F.G. Mastenbroek, Kwaliteitsmanagement in de Dienstverlening, Continue Resultaatverbetering als Managementstijl, Deventer, 1992. 
P.G. Wijckoff, The Simple Analytics of Slack-Maximizing Bureaucracy, Public Choice, 67, 1990.

HD. Van Wijk, bewerkt door W. Konijnebelt, Hoofdstukken van administratief recht, Utrecht: Lemma, 1990.

O.E. Williamson, The Vertical Integration of Production: Market Failure Considerations, in: Economic Organization, UK: The Harvester Press Publishing Group; Wheatsheap Books, 1986.

O.E. Williamson, The Economic Institutions of Capitalism. Firms, Markets, Relational Contracting, New York: Free Press, 1985.

O.E. Williamson, The Modern Corporation: Origins, Evolution, Attributes, Journal of Economic Literature, Vol. 19, december 1981.

O.E. Williamson, Credible Commitments: Using Hostages to Support Exchange, American Economic Review, 1973 .

O.E. Williamson, The Economics of Diseretionary Behavior: Managerial Objectives in a Theory of the Firm, Englewood Cliffs, NJ: Prentice Hall, 1964.

O.E. Williamson. The Evolving Science of Organization, Journal of Institutional and Theoretical Economics (JTE), 149, 1993, pp. 36-63.

J.Q. Wilson; Reinventing Public Administration, The 1994 John Gaus Lecture, Political Science and Politics, Vol. XXVII, numer 4, December 1994.

F.A.A.M. van Winden, De economische theorie van de besluitvorming, in: ESB, 1-11-1989.

U. Witt, A "Darwinian Revolution" in Economics? Journal of Institutional and Theoretical Economies, Vol. 152, 1996, pp. 707-715.

A. van Witteloostuijn, De economische theorie van marktwerking en het gedrag van organisaties, in: ESB, 31-8-1994.

Ch. Wolfe, jr., Markets or Governments, Choosing between imperfect Alternatives, Cambridge Mass., 1988.

A. Woll, Wohlfahrtsökonomik - von hohem didaktischen, aber geringem praktischen Wert, Erwiderung zu Bemerkungen von Holger Bonus und Hermann Ribhegge, in: Iournal of Instirutional and Theoretical Economics (JITE), 142, 1986.

P. A. Zaleski en C.E. Zech, Group Size and the Free-Rider Hypothesis: A Re-Examination of Old Evidence from Churches, Public Choice, 88, 1996, pp. 407-411.

S. Ziss, Contracts as Barrier to Entry: Comment, American Economic Review, Vol. 86, no. 3, May 1996. 


\section{Literatuuropgave Case Studies}

\section{Rijksmuseum}

Algemene Rekenkamer (vergaderjaar 1987-1988), Rijksmusea, Tweede Kamer, 20697, nrs. 1-2.

Accountantsdienst van het Ministerie van WVC, Rapport NR. $A D / C$ 85.3138, inzake het onderzoek naar de financiële verantwoording over 1984 van het Rijkssmuseum te A'dam, 1985.

Accountantsdienst van het Ministerie van WVC, Rapport NR. AD/C 85.3138, inzake de financiele verantwoording over 1984 van het Rijksmuseum te Amsterdam, 1986.

Accountantsdienst, Controlerapport Nr. AD/C 3280.93.15, inzake het onderzoek niar de financiële verantwoording over 1993 van het Rijksmuseum te Amsterdam, Rijswijk, 21 november 1994.

Accountantsdienst, Rapport NR. AD/C 86.3138, inzake het onderzoek naar de financiële verantwoording over 1985 yan het Rijksmuseum te A'dam, 12 september 1986.

Accountantsdienst van het Ministerie van WVC, Rapport NR. AD/C 84.3101, inzake het onderzoek naar de financiële verantwoording over 1983 van het Rijksmuseum te $\mathrm{A}$ dam, 19 maart 1985.

H. D*Ancoma, Verzelfstandiging Rijksmusea vergroot maatschappeliik draagvlak, Staatscourant 124,4 juli 1994.

Berenschot, Commissie Privatisering Musea van de Nederlandse Museumvereniging, kenmerk 2487 , onderzoeksvoorstel, Utrecht, 29 januari 1988.

Bureau IMC, Informatieplan Collectiebeheer Rilksmuseum Amsterdam, augustus/september 1989.

Centrale Directie Financiële en Economische Zaken van het Ministerie vam WVC, IFIS, Project Implementatie Financiële Informatie Systemen, Wijzigingen in Comptabiliteitswet, augustus 1988, nummer 4.

Centrale Directie Financiële en Economische Zaken van het Ministerie van WVC, conceptcirculaire van het hoofd van de Centrale Directie Financiële en Economische Zaken aan het Rijksmuseum Amsterdam. ten aanzien van nadere voorschriften inzake het aanvragen yan GTGR-gelden en het indienen van financiele verantwoording, 2 februar 1988.

Directie Beleidszaken Cultuurbeheer, Brief aan de Directeur van het Riiksmuseum, hierbij gevoegd de reacties op vragen en anrwoorden van Tweede Kamerfracties in de bijdragen voor het verslag, 1 december 1992. De procedure bestond uit: eerst schriftelijke behandeling door de Vaste Commissie voor Cultuur (verslag), vervolgens reactie door de minister (Nota n.a.w. het verslag) en tenslotte plenaire mondelinge behandeling. Vervolgens dezelfde procedure in Eerste Kamer.

J.P. Filledt Kok, verslag over het Groot Beraad, Bevindingen organisatiedoorlichting bij het Riiksmuseum te Amsterdam, 18 december 1985.

Hoofddirecteur Cultururbeheer, Circulaire MMA/B-U-2941 van de aan de Hoofden van de Instellingen ressorterende onder de Hoofddirectie Cultunibeheer i.0, 16 augustus 1988, p. 2. Dit was de situatie eind jaren " 80 .

Hoofd van de Centrale Directie Financièle en Economische Zaken, Richtlijn ten aanzien Van begrotingsuitwoering en verantwoording $1987,1987$.

IKON Beleidsconsulenten, Rapport Organisatie Rijksmuseum, maart 1987a, p. 17. 
IKON Beleidsconsulenten, Rappont ữtwerking organisatie Rijksmuseum, bijlagen, maart $1987 \mathrm{~b}$.

Ministerie van Binnenlandse Zaken, Directoraat-Generaal voor Overheidspersoneelsbeleid, Directie Overheidspersoneelszaken, Nota personele aspecten van privatisering, mei 1985.

Ministerie van Welzijn, Volksgezondheid en Cultuur, Verslag van de Hoofddirecteur over het jaar 1990. Rijksmuseum te Ainsterdam.

Minister van Welzijn, Vollksgezondheid en Culturu (WVC), Concept-Nota Museumbeleid, maart 1985, $\mathrm{p}, 11$. In de definitieve nota Museumbeleid wordt onderscheid gemaakt tussen de behoudtaak en de publiekstaak, nota Museumbeleid, Tweede Kamer, vergaderjaar 1984-1985, 19066, nrs. $1-2$.

De Minister van Welzijin, Volksgezondheid en Cultuur namens deze het Hoofd van de Directie Musea, Monumenten en Archieven, aan de onder het ministerie van WVC ressorterende Rijksmusea, MU/BA-U-11807 I, Machtigingsprocedures, 1 mei 1984.

Ministerie van Welzijn, Volksgezondheid en Cultuur, Deltaplan voor Cultururbehoud, Tweede Kamer, vergaderjaar, 1990-1001, 21965.

De Minister van Welzijn, Volksgezondheid en Cultuur namens deze het Hoofd van de Directie Musea, Monumenten en Archieven, aan de onder het ministerie van WVC ressorterende Rijksmusea, O.K.N.-151901, Machtigingsprocedures, 6 oktober 1969.

Minister van Welzijn, Volksgezondheid en Cultuur (WVC), Nota Museumbeleid, Tweede Kamer, Vergaderjaar 1984-1985, 19066, nrs 1-2.

Minister van WVC, Begroting van de Directie Musea, Monumenten en Archieven (MMA) 1986 , bijlage bij nota MMA/FEA-U-445 van 13 mei 1985 .

De Minister van Welzijn, Volksgezondheid en Cultuur, het Hoofd van de Centrale Directie Personeelszaken, CDPZ U 48131, Aanwijzing bevoegd gezag en beoordelingsautoriteit, 29 augustus 1988.

Moret Gudde Brinkman belastingadviseurs, Riiksmuseum als omzetbelastingplichtig ondernemer, "s-Gravenhage, 28 oktober 1988.

Nederlands Research Instituut voor Recreatie en Toerisme, Rapport "Erfigoed: Toeristisch goed!", in opdracht van W.V.C. en E.Z., november 1983.

Projectbureau voor verzelfstandiging van rijksmuseale instellingen (PMZ), Over de relatie CDBFO en verzelf standigde (rijks) museale instellingen, PMZ 210, 30 augustus 1993.

Rijksmuseum Amsterdam, Verslag van de directie over de jaren 1970-1995, Ministerie van WVC (voor 1983 CRM).

Rijksmuseum Amsterdam, Beleidsnota van het Rijksmuseum, Amsterdam, oktober 1983.

Rijksmuseum Amsterdam, Zorg voor de nationale schatkamer, beleidsnota van het Riiksmuseum 1991-1999, september 1991.

Rijksmuseum Amsterdam, Ondernemingsplan 1989, 31 maart 1989.

Rijksmuseum Amsterdam, Concept-beleidsnota, Amsterdam, oktober 1983.

Rijksmuseum Amsterdam, Activiteitenplan 1990, Algemene bedrijfsvoering. 
Secretaris-generaal van het ministerie van Welzijn, Volksgezondheid en Cultuur, brief aan de medewerkers van het ministerie van WVC, personele afslanking, 18-09-1986.

Secretaris-Generaal van het Ministerie van Welzijn, Volksgezondheid en Cultuur, circulaire AD/ADS-U 5206, Functie en taken van de Accountantsdienst, 19 december 1983.

Tweede Kamer, Rijksbegroting van WVC, vergaderjaar $1984-1985,18600$ hoofdstuk XVI, nr. 2 , pp. 76-77.

Concept-Nota Museumbeleid, maart 1985. Tweede Kamer, vergaderjaar 1984-1985, nota Museumbeleid, 19066, nrs. 1-2.

Tweede Kamer der Staten-Generaal (vergaderjaar 1984-1985), Riiksbegrotimg van WVC, 18600 hoofdstuk XVI, nr. 2 , p. 76.

Tweede Kamer, Nota Naar een nieuw museumbeleid, wan het Ministerie van Cultuur, Recreatie en Maatschappelijk Werk, zittingsjaar 1976-1977, nr. 14290, nrs. 1-2, 21-2-1977.

Tweede Kamer, Rijksbegroting van het Ministerie van WVC, vergaderjaar 1984-1985, 18600, hoofdstuk XVI, nr. 3 .

Werkgroep Financiêle en Bedrijfseconomische Aspecten Verzelfstandiging Rijksmusea, Eindrapport, april 1989 ,

\section{Belastingdienst}

Directoraat-Generaal der Belastingen, Actieplan Accountantscontrole 1986-1990, Den Haag, 1985.

Directoraat-Generaal der Belastingen, Jaarverslagen over de Jaren 1980-1995, Den Haag.

Directoraat-Generaal der Belastingen, Beheersverslag Belastingdienst 1991, Den Haag, 1992.

Directoraat-Generaal der Belastingen, Meerjarenbeleidsplan AWR, Den Haag, 1991.

Directoraat-Gerieraal der belastingen, Nota "Managementvisie belastimgdienst 1983-1987", Den Haag, 1982.

Directoraat-Generaal der Belastingen, Beleidsverslag 1992, Den Haag, april 1993.

Directoraat-Generaal der Belastingen, Informatie- en automatiseringsbeleidsplan Belastingdienst 1991-1995, Den Haag, 1990.

Directoraat-Generaal der Belastingen, Informatie- en automatiseringsplan 1989-1993, Den Haag, december 1988 .

Directoraat-Generaal der Belastingen, Produktieverslagen 1990-, Den Haag.

Directoraat-Generaal der Belastingen, Projectenplan automatisering locale administraties tijksbelastingdienst 1983-1987. Den Haag, 1983.

Directoraat-Generaal der Belastingen, Beleidsplan automatisering 1981, Den Haag, 1982.

Directoraat-Generaall der Belastingen, Energie Aktie Plan, Den Haag, 1991.

Directoraat-generaal der belastingen, Nota "Gegevensuitwisseling ter Bestrijding van Misbruik en Oneigenliik Gebruik", Tweede Kamer 1991-1992, 17050, nr. 146. 
Directoraat-Generaal der Belastingen, Nota "Intensivering en bestriiding misbruik en oneigenlijk gebruik, matregelen op fiscaal terrein (Fraudenota 1992), Den Haag, juni 1992, zie bijlage 14 bij hoofdstuk IXB van de Rijksbegroting 1993, Tweede Kamer 22800.

Directoraat-Generaal der Belastingen, Bedrififsplan / bedrijfskader 1992-1996, Den Haag, 1992.

Directoraat-Generalal der Belastingen, Rapport "Randvoorwaarden fiscaal-strafrechtelijk fraudebestrijdingsbeleid", Den Haag, 1991.

Directoraat-Generaal der Belastingen, Personeels- en investeringsplan 1983-1987, Den Haag, 1983.

Ministerie van Financiën, Miljoenennota 1995, Hoofdstuk IX-B, Den Haag.

Tweede Kamer der Staten-Generaal (vergaderjaar 1995-1996), Extra beloningen, Rapport Algemene Rekenkamer 24657 , nrs. 1-2.

Tweede Kamer der Staten-Generaal (vergaderjaar 1987-1988), circulaire AB87/U1667 van het Ministerie van Binnenlandse Zaken, 20200 hoofdstuk IX B, nr. 21.

Tweede Kamer der Staten-Generaal (vergaderjaar 1987-1988), circulaire AB87/U1668 van het Ministerie van Bimenlandse Zaken, 20200 hoofdstuk IX B, nr. 21 .

Tweede Kamer der Staten-Generaal (vergaderjaar 1987-1988), Het departementale begrotingsbeheer bij het Ministerie van Financiën, 20200, hoofdstuk IX B, nr. 21,.

Tweede Kamer der Staten-Generaal (1993), Begroting van het Ministerie van Financiēn, 23400, hoofdstuk IXB, nr.. 2, Fraudeplan 1992, Bijlage 14.

Tweedle Kamer der Staten-Generaal (1991), Notitie hoofdlijnen van het onderzoeksproject "Compliance/Non-compliance, aangeboden aan de Tweede Kamer bij brief nr. PFC91/1610, Den Haag.

Tweede Kamer der Staten-Generaal (Handelingen vergaderjaar 1979-1980), Rapport Van Bijsterveld naar misbruik en oneigenlijk gebruik van belastingen, $16180, \mathrm{nr} .1$.

Tweede Kamer der Staten-Generaal, (vergaderjaar 1980-1981), Heroverweging collectieve uitgaven, deelrapport 7, heroverweging groei Belastingdienst, 16625, nr. 12.

Tweede Kamer der Staten-Generaal, (vergaderjaar 1987-1988), Afslanking Rijksoverheid 19881990, 19827, nt. 40.

Tweede Kamer der Staten-Generaal (vergaderjaar 1993-1994), Ontwikkeling Belastingdienst,

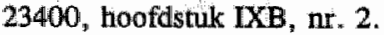

Tweede Kamer der Staten-Generaal (1991), Rapport vervolgonderzoek herstnuchurering Belastingdienst, op 3 april 1991 bij brief nr. PFC91/539 aangeboden aan de Tweede Kamer, Den Haag.

Tweede Kamer der Staten-Generaal (1990), Herstructureringsonderzoek Belastingdienst, op 14 juni 1990 bij brief nr. PFC90/1334 door Bellastingdienst aangeboden aan de Tweede Kamer, Den Haag.

Tweede Kamer (1992-1993), Rapport derde onderzoek herstrucnurering Belastingdienst, 22800, IX B, nr. 13,1992 .

Tweede Kamer der Staten-Generaal (1991), Definitieve evaluatie renterenseignering 1988, aangeboden aan de Tweede Kamer bij brief nr. PFC91/901, Den Haag. 
Tweede Kamer der Staten-Generaal (Handelingen vergaderjaar 1983-1984), Ministerie van Financiën, Nota "Fraudebestriiding in de directe belastingen en de omzetbelasting", 17050/17522, nr. 3.

\section{N.V. PLEM/MEGA Limburg}

Afdeling Marketing van de N.V. PLEM, Op weg naar morgen, het energie en milieuplan VEEN, VEGIN en VESTIN, 22-06-1989.

Afdeling Personeelszaken van de PLEM, Nota Op weg naar Personeelsplanning, 1 januari 1989.

Andersen Consulting, Concept rapport Horizon 2000, 30 september 1993.

Arnhemse Instellingen, Elektriciteit in Nederland 1986, Arnhem, 1987 en VEEN, Elektriciteitspriizen op basis van marginale kosten, deel 1 en 2, 22 maart 1989.

Directeur van de PLEM, 89.055.480, brief aan Provincie Limburg, Hoofdgroep Economie en Gemeente-Financièn, Met betrekking tot het Provinciaal Milienbeleidsplan: Resultaten onderzoek verzuring, 16 november 1989.

FMT 4, N.V. PLEM, Bedriifsplan 1991/B-MAP, 8-10-1990.

Grontmij, Schaalgrootte-onderzoek ten behoeve van de afvalverwerking in Limburg, De Bilt, augustus 1988.

Hoofd afdeling Personeel en Organisatie N.V PLEM, Notitie voor de afdelingshoofden, 25-091989.

Hoofddirecteur Cultuurbeheer, Brief aan de hoofden van de onder de Hoofddirectie Cultuurbeheer i.o. ressorterende instellingen, selectieprocedure hoofden van HCB-instellingen, 17-01-1989.

MEGA Limburg, Jaarverslag over 1990 tot en met 1995.

Ministerie van WVC, Circulaire van het Ministerie van WVC. MMA, aan de Hoofden van de instellingen ressorterende onder de Hoofddirectie Cultuurbeheer i.o., gewijd aan de begrotingsopstelling 1988, 06-08-1987.

N.V. PLEM, De verwerving van goederen en diensten, deel II, inkoop-manual, september 1983.

N.V. PLEM, Handleiding voor de verwerving van goederen en diensten, 1 oktober 1984.

N.V. PLEM, Horizontaal, eerste editie, 13 oktober 1988.

N.V. PLEM, Horizontalal, derde editie, 2 juni 1989.

N.V. PLEM, De Werkgever, nummer 19, 5 oktober 1989.

N.V. PLEM, Regeling Functiewaardering N.V. PLEM, 1988.

Tweede Kamer der Staten-Generaal, 19591, Memorie wan Antwoord met betrekking tot de Elektriciteitwet 1987, vergaderjaar 1986-1987, 25 mei 1987.

N.V. PLEM, Een aanzet tot de systematische ontwikkeling van het sociaal beleid bil de NV PLEM, juni 1978.

N.V. PLEM en N.V. PNEM; Eindnota samenwerking PLEM en PNEM op het gebied van de productie van electrische energie, 25 april 1986. 
N.V. Provinciale limburgse elektriciteits-maatschappiij, Raad van Commissarissen 88-057, Bedrifisplan 1989; 24 november 1988.

N.V. PLEM, Jaarverslagen over 1970-1990, Maastricht.

N.V. PLEM, Regeling voor de afvoer van afval via derden, 4 juli 1986.

N.V. Provinciale Limburgse Elektriciteitsmaatschappif, Een hanteerbare oplossing voor afvalverwerking in Limborg, januari 1990.

Orionconsult B.V., Elektriciteitsbedrijen in Nederland, Amhem, 1986.

Personeel en Organisatie, Vrijbaan, intern vacaturebjad NV PLEM, eerste uitgave van 9 januari 1989.

Personeel en Organisatie, Vribaan, intern vacatureblad NV PLEM, eerste uitgave van 9 januari 1989 .

Projectgroep Budgettering van de PLEM, Budgetteren bil de PLEM, 27-12-1988.

N.V. PLEM, Regeling vergoeding belastende werkomstandigheden, maart 1989, artikel 1. Bij belastende werkomstandigheden kan bijvoorbeeld gedacht worden aan geluidshinder, stank etc.

Projectgroep verwerving van goederen en diensten, Rapport definitiestudie, oktober 1987, p. 8 ev.

Provincie Limburg, Concept-eindrapport Badge Proiect, no. BN-5921, september 1989, p. 8.

Raad van Commissarissen, Notitie samenwerking PLEM/PNEM op het gebied van de productie van elektrische energie, 4 november 1986.

W.J. Timmermans, Oprichting en ontwikkeling van de Stroomverkoop Maatschappii in Limburg 1909-1933, van particulier initiatief naar openbaar nutsbedrifif, doctoraalscriptie Open Universiteit, cultuurwetenschappen, juli 1993.

Tweede Kamer, Memorie van Antwoord bii het wetsvoorstel Elektriciteitswet_1987, vergaderjaar 1986-1987, 19591, 25 mei 1987.

Tweede Kamer, Nota naar aanleiding yan het eindverslag ten aanzien van de Elektriciteitswet 1989, vergaderjaar 1987-1988, 19591, nr. 9 .

Tweede Kamer, Memorie van Toelichting bij het Wetsontwerp Elektriciteitswet 1987, Vergaderjaar 1985-1986, 19591.

Tweede Kamer, Memorie van Antwoord bij het ontwerp Wet Energiedistributie, vergaderjaar $1991-1992,22160$, nir. 5 .

Tweede Kamer, Nota Energiebesparing, 21570, vergaderjaar 1989-1990, nrs, 1-2.

Tweede Kamer, Voorlopig Verslag ten aanzien van de Wet energiedistributie, vergaderjaar 1991. $1992,22160,21$ november 1991, nr. 4.

Tweede Kamer, Memorie van Toelichting met betrekking tot het wetsontwerp van de Wet energiedistributie, 22160, vergaderjaar 1990-1991, nr. 3 .

Tweede Kamer der Staten-Generaal, 22160, Behandeling wetsvoorstel Regels op het gebied van de distributie van elektriciteit, gas en warmte (Wet energiedistributie), 50 e vergadering, 1 febnuari 
$1996,3723$.

Tweede Kamer, Eindverslag opgemaakt ten aanzien wan openbare beraadslaging over het wetswoorstel voor een nieuwe Elektriciteitswet, 24 november 1987.

Twijnstra Gudde NV, brief aan Secretaris-General van het Ministerie van Welzijn, Volksgezondheid en Cultuur, yragenliist onderzoek privatisering algemeen verzorgende functies binnen de rijksoverheid, 24 september 1985 .

VEEN, VEGIN en VESTIN, Stuurgroep Integraal Milieubeleidsplan Energiedistributiesector, Naar een integraal milieu-actieplan van de Energiedistributiesector (MAP), 25 januari 1990.

Vereniging voor Directeuren van Elektriciteitsbedrijven in Nederland (VDEN), De ontwikkeling van onze elektriciteitsvoorziening 1880-1938, deel 1, Arnhem, 1948. 
Aharoni, $Y ., 36,37,54,137$

Alchian, A. A., 56,111,112,113,114, $115,135,136$

Anow, K.J., 71,92,93,499,503

Backhaus, J.G., 61,138, 139,191,200, $202,206,219,223,504$

Bain, J.S, 68,69

Bator, F.M., 28

Baumol $_{\text {, W.J., 28,511 }}$

Becker, G.S., 522

Beesley, M., 492

Bélanger, $G_{.}, 149,150,157$

Belastingdienst, $13,22,46,64,65,66$, $67,68,69,70,72,164,188$, $207,210,226,387$ e.v.

Van den Berg, F., 68,419

Berle, A.A., 114

Bertels, K, 102

Van der Bij, J., 167

Blankart, C.B. , 21,39,510,509,513

Boiteux, M., 378

Bokkes, W.Th.M., 77,136,137,161,162, 164,177

Bonus, H., 505

Borcherding, T.E., 57,72,178,183

Bös, D., 15,501

M. Boycko, M., 104

Bradford, D.F. 512

De Braekeleer, F., 40,376,377

Braun, G. E., 144,193,202,203

Breton, A., 148,149, 151,152

Brozen, Y., 68

Buchanan, J.M., 23,90, 143,489,523

Bulder, $B_{1}, 141,487$

Buxbaum, R.M., 104, 106

Coase, R.H., $11,29,55,88,109,161$

Coelli, T., 199

Commissie Steenbergen, 20

Commissie 5 wartouw; 20

Converse, Ph.E., 97

Conybeare, J.A.C., 77,147

Côte, D. O., 531

Crew, M.A., 85,523

Cubbin, I., 133

Cyert, R.M., 80

Van Dalen, H.P., 88,99

Dalton, M., 120,172

Davis, D.D., 17,94

Demsetz, H., 23,56,68,23,71,111, $112,113,118,132,135$

Dijkstra, J B., 9

Deprins, D., 527,529

Van den Doel, J., 87,89,90,91,92,99, $100,190,500$
Downs, A., $94,95,97,143,148,152,180$

Dunleavy, $\mathbb{P}_{.,} 143$

Easton, D. 88,93

Fama, E.F., 115, 132,137

Farrel, M, 526,527,528

Feld, L.P., 25

Flap, H., 141,487

Frey, B.S, 28

Friedrich, P., 78

Friesen, P.H., 491

Funibotn, E.G, 136

Gaebler, T., 190,191

Gathon, H.J., 530

Goedhart, C., 91

Gore, A, 190

Goudriaan, R., 196

Grampp, W.D., 31

Grondsma, $T$, 88

Grossekettler, H., 23,162

Grosskopf, S., 531

Hagel, J.H., 24

Hayek, F.A., 4

Harsanyi, J.C., 157, 158,502

Hartog; F., 502,503,524

Hartog, J., 40,48

Van Helden, G.J., 57,169,178

Hennipman, P., 501

Hess, J.D., 131

Heyndels, B, 22,422,424

Hinich, M.J., 94,96,97

Hochman, H., 34

Hofstede, G., 57

Holmstrom, H., 34

Holt, C.A., 17

Hutter, M., 103,171

ledema, R.A., 9

Isaac, R.M., 24,243

Ivancevich, J.M., 201

Jansen, R.W.J., 40, 199,206,212,213, $214,215,216,217,221$, 224,492

Jensen, M.C., $118,132,137,139$

Johansen, L., 90

Jones, L.P., 56,58

Kaldor, N., 156

De Kam, P.W., 68,388,418,498

Kapteyn, A., 503

Knieps, G., 21,39

Kommer, van V., $392,406,411,418$

Kopp, R.J., 196,527

Koster, T.H., 418

Kraan, D.J., 148, 149

Künneke, R.W., $116,119,217,218,256$, $382,383,384,385,530,532,533$ 
Laan, R., 240,249,253

Lakatos, I., 9

Lancaster, K., 516

Laver, M., 98

Ledyard, J.D., 25

Leeuw, F., 141,485

Leibenstein, H., 62

Leech, D., 133

Lehn, K., 132

Lioukas, S., 80

Lipsey, R.G., 515

Littlechild, S., 490

Lovell, C.A.K., 530

Lipford, J.W., 25

La Manna, M., 63

Mansfield, E., 219

March, J.G., 80, 126

Mattsson, L.G., 105

Matteson, M.T., 201

Means, G.C., 114

McCue, K., 24

McKee, M., $520,521,522$

Mc Kelvey, R.D., 97

Mc Kenna, C.J., 501

Meckling, W., 128,132,135

Mejjdam, A.C., 148

Mellink, J.W., 41

Van Mierlo, J.G.A., 41,96,97,103, $144,180,190,191$

J.L. Migué, J.L., $147,148,154$

Miller, G., 2, 149,148,158,488

Mitchell, J.C., 105

Moe, T.M., 2,149,155

Moene, K.O., 121,127,144,149

Monsen, R.J., 44,114

Morck, R., 118,121

Morgenstern, $0 ., 157,159,162,503$, 504

Muizelaar, J.C.F., 226,391,406,411, 418

Musgrave, R.A., 15,35,44

Musgrave, P.B., $15,35,44$

Nauta, D., 102

Neelen, G.H.J.M., 135

Netzer, D., 27,30

Neuberg, L.G., 19

Von Neumann, J', $157,159,503,504$

$\mathrm{Ng}, \mathrm{Y}-\mathrm{K}, \quad 517,518,520,521,522$

Niskanen; W.A., $13,79,125,127,131$, $143,144,145,147,148,150$, $151,152,153,155,157,187$, $203,482,485$

Norman, G., 63

Oates, W.E., 28

Olson, $M_{n}, 25,77,126,143,202$

Ordeshook, P.C., $94,96,97,157,158,159$, 500
Osborne, D., 190,191

Pareto, V., 500,501

Parris, H., 195

Patcluen, M., 219

Paul, J.C.L., 124,127,128

Peirce, W.S., $87,99,107,150$

Pejovich, S., 114,136

Perelman, S., 199,530

Pestieau, P., 195, 196, 197, 198,199,200, 530

Philips, A., 56

Picot, A., 174, 175, 176

Pigou, A.C., 501

Plott, C., 24

Pommerehne, W.W., 24,25,28

Popitz, J., 5,145

Posner, R.A., 37,38,85,512

Powell, W.W., 105,131,172,173,176

Van Praag, B.M.S., 501,502,503

Putnam, H., 10

Ramsey, F., 37,75,79,378,511,512

Ribhegge, H., 503

Riker, N.H., 94,97,498

Riordan, M.H., 166

Rodgers, J.D., 34

Rogoff, K., 98,99

Roth, A.E., 24

Rowley, C.K., 85,523

Samuelson, P.A., 219

Savas, E.S., $23,45,46,47,49,50,211,491$

Saynor, P., 195

Schanze, E., 104

Scherer, F.M., 69

Schleifer, A., 106,118

Schneider, F., 24

Schofield, M., 97

Schumpeter, J.A., 36,71

Screpanti, E., 159

Shapiro, D.L., 37

Shelton, R.B., 37

Shleifer, A., 104

Simar, L., 528,531

Simon, H.A., $124,125,497$

Stella, P., 387,389

Stephen, F.H., 171

Stigler. G.J., 17,68,71, 166,202

Stiglitz, J.E. 497

Stokes, D.E., 97

Stratmann, T., 93

Swank, O.H., 98,99

Tannenbaum, A.S., 219

Teubner, G., 103,171

Thiemeyer, $T ., 83$

Thiry, B., $526,527,530,531$

Tulkens, H., 526,527,529,530,531

Tiebout, C.M., 26

Tuliock, G. , 90,147,487,522 
Veen, $\mathbf{P} ., 129$

Van Velthowen, B.C.J., 97,190

Verbon, H.A.A., 148

Vishny, R.W, 104

Vogelsang, I, 117, 120,500,504

Vollebergh, H., $240,249,253$

Vuchelen, $J_{\text {, }}, 22,422,424$

Wagner, R.E., $115,117,149$

Walters, K.W, 44

Weber, M., 433

Webb, M.G., 513

West, E.G., $520,521,522$

Wicksell, $\mathbf{K}, 90$

Williamson, $0 . \mathrm{E}_{\text {, }}, 55,56,71,119,121,163$, $164,165,166,167,170,171,173$,

183

Wintrobe, $\mathrm{R}, 148,149,151,152$

Zaleski, P.A., 25

Zamagni, S., 161

Zech, C.E., 25 
Aanbodkant, $17,26,64,73,88,95,98,100$ $138,180,184$

Aanbodmonopoliepositie, 145

Abusus, 112,116,212,217,325

Actiekanalen, 126,127

Actoren, 102, 103

"Administrative man" model, 125

Afgeleide beweringen, 10

Agentschap, 5,6,477,478,535

Algemeen Burgerlijk Pensioenfonds, 8, 353

Algemene Rekenkamer, $7,8,228,237$, $239,268,391,392,397,404,405$, $451,463,464,487$

Allocatiefunctie, $15,35,58,59,510$

Allocatieve (in)efficiency, $3,17,35$, $57,62,72,73,75,76,146,147,153$, $179,184,198,199,376,510$

Analogiemodel, 102

Appropriate set, 158

Arenamodel, 124,126,128,129

Asset specificity, $57,164,165,166,167$, $168,169,171,174,175,178,179$, 390,391

Asymmetrische informatie, $13,100,121$, $129,133,150,151,164,482$

Basislastvraag, 513,514,515

Begrensde rationaliteit, $128,164,165$

Begrotingscyclus, $100,237,250,397,401$

Beheers-en controlesysteem, 129,131 , 163,269

Beheersstructuur, 163

Bedrijfseconomisch beheer, 6

Bedrijfsprestaties, 192,222

Bedrijvenwet, 6,216

Beleidisdocumenten, $143,147,220,222$, $225,228,229,289$

Beleidsinstrument, 227,484

Beloningsstructuur, 187

Beloningssysteem, 113, 186,313,403

Beperkt (constrained) efficiênte oplossing, 17,75

Bergsoniaanse welvaartstheorie, 501

Beschikkingsrecht, $5,111,112,117,136$, $161,162,210$

Besluitvorming, $13,39,63,87,90,91,93$, $98,99,100,101,109,111,114$, $121,122,123-131,136,137,141$. $143,144,150,156,163,180,183$; $185,189,201.202,209,211,219$, $236,240,257,281,327,396,405$, $406,454,482,485,487,490,492$

Best practice (frontier), 130,131,191,
$202,206,527$

Bezuinigingsoperaties, $179,266,293,459$

Black box, 124,126, 132,150,151

Bonding costs, 135

Bounded rationality model; 125

Budgetmaximaliseringsmodel, 144,145

Bureaucratiemodel yan Niskanen, 125 , $127,131,143,145,146,148$; $150,151,152,153,157,203$, 482,485

Bureaucratiemodel van Weber, 144

Bureaucratietheorie, 127,153,187

Chicago-benadering, 523

Coalitievorming, 96,159

Coase-theorema, 29

Cobb-Douglas-productiegrens, 199,532

Collectieve goederen, $2,16,22,23,24$, $25,26,29,47,48,50,51,77$, $80,83,85,87,88,90,92,93$, $95,96,97,132,144,147,151$, $173,179,180,193,196,202$, $203,225,226$

COLS (gecorigeerde kleinste kwadratenmethode), 530,531

Comptabiliteitswet, $6,236,237,239,252$; $253,256,280,293,392,398,410$

Commissie Brandsma, 300

Commissie Concentratie Nutsbedrijven

(COCONUT), 298

Commissie Steenbergen, 20

Commissie Swartrouw, 20

Consequentiekosten, 135

Consumentensoevereiniteit, 96,97 .

Constante schaalopbrengsten, $514,525,526$

Consumentensurplus, $81,502,507,511,512$

Contractmanagement, $233,234,239,241,244$, $245,246,247,248,282,289$

Control graph, 219

Culturele erfgoed, $21,27,241,258,259,261$, $268,269,288,290,291,292,293$. $294,296,485$

Cultuurbeheer, $238,240,255$

Dalende gemiddelde kosten, $16,18,21,22$, $64,69,372,377,389,510$

Doel-onafhankelijke benadering, 194,195

Decision control, 137

Deterministische parametrische productie-

grens, $526,527,528,529,530$

Dienst der Domeinen, 116

Directe staatsdeelneming, 6

Discretionaire politieke doelen, 186,203, 211 
Diversificatie, $85,332,346,362,380$

Divisiestructurur (M-vorm), 168,234

Doelafhankelijke benadering, 195

Doelbenadering, $200,201,202,204,205$

Doelfunctie, $11,109,110,150,151,155,206$, $210,220,225,485,503,504,515$

Doeltreffend, 4

DOLS, $203,530,531$

"Double peaked preference", 92

Downsian model, 180

Dynamische schaalvoordelen, 22

Economics of uncertainty, 503

Effectindicatoren, 3

Efficięntie, $3,4,15,17,29,33,35,44,50,54$, $57,62,64,70,71,72,73,76,77,78$, $79,80,81,83,86,88,113,115,116$, $117,132,135,136,146,151,151$. $152,153,156,178,180,183,184$. $187,190,191,192,200,201,202$, $204,205,206,207,211,220,221$, $224,229,238,244,251,257,259$, $280,286,287,327,329,330,331$, $332,342,343,346,369,370,371$, $372,382,386,391,412,413,417$, $421,427,437,467,478,481,483$, $486,504,510,515,521,523,525$, $526,528,529,530$

Eigendomsrechtenbenadering, $2,76,80,81$, $109,110,111,113,185$

Eigendomsrechtenstructuur, 23,29,74,109, $113,117,118,132,156,161,180$, $189,191,192,280,296$

Elektriciteitsbedrijf Mega-Limburg, 40 , $65,67,72,225,226,297,301,311$, $312,327,333,336,348,353,356$; $357,358,363,366,368,385,386$, 485

Elektriciteitswet, $19,300,301,303,311$, $323,327,329,330,331,332,334$, $338,342,345,349,370,371,373$, 384

Entreebarrières, $17,19,21,38,63,67,68$, $69,70,72,76,174,175,185$

Entreeprijs, $21,45,81,251,252,271,281$, $283,285,287,291,294,483$

Excess burdens, $33,60,83,229,414,470$, $473,474,478,510$

Expected utility theory, 501,502

Experimentele economie, 17,24,25

Externe effecten, $16,26,28,29,30,31,32$, $40,52,57,58,83,85,88,109,153$, $154,173,179,193,196,202,206$, $212,213,214,242,257,287,490$, $505,515,520$

Feasibility curve, 206,521
Financiële externe effecten, 28,31

Financiële ratio's, 193,195,197,201

First-best-oplossing, 16,17,515

First-best-prijsstellingsregells, 518,519

First mover strategy, 55, 165

Focal points, 69

Free Disposal Hull-methode (FDH), 529

Free rider-effect, 27

Full-cost prijsregels., 69

Functionele decentralisatie, $7,8,478$

"Garbage can"-model, $124,126,128,129$

Gemeentewet; 9,215

Gemeinwirtschaftslehre, 524

Gemiddelde kosten, $17,18,21,22,37,64$, $195,197,224,333,354,372,376$, $378,389,506,508,509,510,511$. 512

"Governance" structuur, 161,162,172

Herverdelingsfunctie, $34,44,58,193$

"High powered incentives", 166

Hirschmann-Herfindahl-index, 67

Horizontale integratie, $65,70,71,298$, $299,300,301,331,333,335$, 341,373

Incentive compatibility, 134 Increasing returns to scale, 16 Indicatoren-methode, 199 Indirecte overheidsbedrijven, 4 Industriele organisatie, $12,63,481$ Informatie-asymmetrie, $145,151,189,330$ Inkomens-effect, 146,180 Inspectiekosten, 135,139 Intervalniveau, 498,501,502 Interviewmethode, $129,209,218,220,225$, Intrinsieke waarde, 6,492

Jaarplancyclus, $398,399,400$

Kaderregeling Experimenten Contractmanagement, $239,240,241,246,247$

Kapitaalmarkt, $42,59,116,117,214,218$, $220,256,259,326,327,330,388$, $411,493,509$

Kiessysteem, 92,149

Kostencurve, $16,78,79,81,152,180,506$

Kostenefficiëntie, $147,151,461,510,526,533$

Kristallisatiegraad, 106

Kunstbeleid, 259,260,261

Kunstmarkt, $267,274,275,294$

Kwalitatieve benadering, $1,4,195,202,203$, $204,205,206,207,209,210,218,220$, $297,486,487,488$

Kwaliteits(in)efficiëntie, 3 
Laffercurve, 33,84

Learning-by-doing, 164

Levenscyclushypothese van Stigler, 71,166

Limagas, $297,299,300,301,322,326,338,339$, $348,350,351,353,354,355,363$,

Logrolling, 92 $365,366,370,373,374,380$

Low powered incentives, 166

Machtsbronnen, $119,120,121,123,124,487$

Machtsgebruik, 120,121,123

Machtsgebruikstrategieẽn, $120,121,123$

Machtsmiddelen, $120,121,123,127$

Machtsverhoudingen, 88,126

Management by objectives, 223

Management-controlled firms, 114

Marginale opportuniteitskosten, 507

Markten van volkomen mededinging, 62,72 , $75,124,132,147$

Marktfalenoverwegingen, $12,16,28,30,33$, $34,35,38,42,52,56,195,512$

Marktproces, 33,186

Marktsegmentering, 32

Marktstructuur, 61,62, 63,64,67,71,72,73 $74,75,76,81,99,101,132,185$, $188,189,221,485,494$

Maximaliseringsproces, 506

Maximum likelihood method, 529

Median-voter-theorema, 95

Medium Term Notes, 327

Meerderheidsstemming, 91,93

Meerpartijenstelsel, 95, 136,139

Meertoppige-preferenties, 91

MEGA LIMBURG, 207,210,214,225,226, $227,301,311,312,326,333$, $336,3487,353,363,365,368$, $385,386,483$

Merit goods 261, 286,287

Methodologisch individualisme, 109

Middelenindicatoren, 3

Miljoenenmota, 7,430

Minimaal efficiente schaal (MES), 21,68

Ministerie van Binnenlandse Zaken, 245,247

Ministerie van Economische Zaken, 299, $329,331,332,347,347,375,398$. $402,436,478$

Ministerie van Financiên, $65,227,236,251$, $294,390,392,397,398,402$

Ministerie van OCW, 137,238

Ministerie van VROM, 239,240,270,363, 401,425

Ministerie van WVC, $30,65,229,237,241$, $242,243,246,248,251,252,252$, $258,259,280,282,291$

Model van Tiebout, 26

Monitoring costs, $135,183,389,390,391$

Monopolistische marktvorm, $70,173,190$,
$483,515,516,520$

Moral hazard, $32,33,134,176$

Multi-criteria-variabele, 199

Multidivisionele organisatiestructuur, 168,169

Multipliereffect, 31,439

Nash-evenwichten, 70

Nationalle investeringsbank, $7,33,41$

Nationalisering, $15,36,42,44$

Natururlijk monopolie, $16,17,18,19,21,22$, $29,40,226,372,383,384,510,511$,

Neo-klassieke benadering, $119,132,133,161$

Neo-institutionele benadering, $12,63,101$

Neo-institutionele economie, $12,64,101,141$

Netwerkbenadering, $84,94,103,104,107,107$, $109,127,131,132,150,161,171$, $183,201,204,209,227,482,483$, 487,488

Netwerk-model, $74,104,105,107,210$, 481,487

Netverliezen, 328,340

Nirvana-beleid, 34

Non-allocatieve doelen, 199

Non-convexiteit, 29

Non-cooperatief spel, 157

Non-parametrische benadering, $526,528,529$

Non-zero-sum-game; 96

Normatieve benadering, $12,16,19,65,75$, $76,77,78,200,206,497,504$

Normatieve welvaartstheorie, 12

Obligatierendement, $222,276,276,365$

Off-budget-activiteiten, 1,37

Omgevingsfactoren, $25,55,128$

Onderhandelingskosten; $30,56,88,90,162$, 163

Ondernemingsstaat, $33,36,86$

Open access, 385

Openbare financiën, $1,10,26,34,38,194$

Optimalliseringsbenadering, 522

Organisatiebureau Krekel, Van der Woerd en

Wouterse (KWW), 298,383

Organisatiegraad, 106

Organisatietheorie, $12,13,101,102,104$, $119,140,174,484$

Orionconsult B.V., 342,384

Overheidsbedrijven, $1,4,5,60,75,77,78$, $117,197,324,328,385,415,481$

Overheidsdeelneming, 61,538

Owner-controlled firm, 114

Outcome, $2,3,141,149,158,180$

Pakketvergelijking, 442,474

Parametrische productiegrens, 526,527 . $528,529,530,531$

Paretiaanse welvaartstheorie, $500,501,516$ 
Pareto-fficientie, $3,4,15,16,17,75,78,79,81$

$82,83,90,202,205,209,507,511$, $512,515,516,517,518,519,521$. 522

Partisan-theorie, 99

Performance benadering, 197,526

Piekvraag, $341,512,513,514$

Pigouviaanse welvaartstheorie, 499,500

Politieke of arenamodel, 124

Politiek conjunctuurcyclustheorie, 98

Pooling, 176,299,300,332,341,362,373,382

Popitz-criterium, 5,59,145

Predatory pricing, 37,70

Privatisering, $12,13,15,36,41,45,59,61$, $115,156,171,185,189,200,206$, $221,222,245,258,296,383,385$, $386,390,427,452,474,481,484$, $488,489,490,491,492,493,494$, $495,496,497,498$

Prijsleider-volger-model, 149

Productie-indicatoren, 196

Proportionaliteitsfactor, 512

Prestatie-analyse $, 197,207,220,525$

Prestatie-indicatoren, 3,200

Preventiekosten, 135, 139

Prijsdiscriminatie, 17,37

Principaal-agent-theorie, $12,13,76,102,131$, $132,148,157,185,482$

Proces-indicatoren, 3

Producentensoevereiniteit, 96,98,99,136, 144,151

Producentensurplus, $2,78,81,502$

Productiefunctie, $10,28,119,146,199,202$, $206,207,525,526,530,531$, 532,533

Productiemogelijkhedencurve, 29,198, 199,206

Produktdifferentiatie, 70

Productie- en transactiekosten, 162,167, 170,173

Public choice, $12,15,35,39,54,59,62,63$, $64,94,101,103,123,141,143$, $147,196,202,203,204,229,372$

"Public enterprise rent", 35,40,41,56,79, $138,155,156,171,173,185,199$. $204,207,210,217,220,221,222$, $225,228,229,275,276,277,278$; $280,281,282,284,285,286,290$, $291,292,293,297,330,364,365$, $366,369,370,374,375,379,381$, $385,457,459,462,463,465,468$, $472,475,476,479,483,484,494$

Publiek georienteerde ondernemingen, 8 , 536

Publiek goed, 22,26,27

Publiek-Private Samenwerking, 9,547
Q-(in)efficiency, 3

Ramsey-prijstegel, 511

Rationele actormodel, 124

Referendumdemocratie, $88,89,91,99,100$

"Regulating motive", 95

Relevante markt, $21,67,490$

Representatieve democratie, $87,88,89,93$, $94,95,99,100$

"Residual loss", 135,138

"Revealed preference" $, 4,220$

"Revealed preference"-methode, 129,209, $218,219,220$

Rijksmuseum Amsterdam, 229-297, 387

Rijn-Schelde-Verolme (R.S.V.-)concern, 128,173

Rivaliteitsgraad, 23

Rulles of thumb, 69

Samenwerkende Elektriciteitsproductiebedrijven (SEP), 297,298,299,300,301,323,324, $329,332,333,346,349,350,371$, $373,383,385$

"Satisficing", 73,76,109, 122, 125, 184

Second-best-belleid; 65

Second- en thirdbest-benadering, $91,516,521$

Second- en thirdbest-prijsregels, 518

Schaalnadelen, 19,20

Schaalvoordelen, $16,17,18,19,20,21,22$, $39,40,50,62,64,68,70,71,73$, $75,84,85,167,184,224,372,383$, $384,385,424,425,475$

Situationeel manipulatieve benadering, 121

"Slack", 54,147, 154,155, 156,189,217

Smallest distance"-hypothese, 95

Sociale welvaartsfunctie, $502,503,518$, 519,520

"Spatial theory of electoral competition", 94

Speltheorie, $63,143,149,157,159,163$

Staatsbalans, 7

Staatsbedrijwen, $4,67,489$

Stabilisatiefunctie, 15,41

Statische efficiëntie, 3

Stemparadox, 92

Stochastische parametrische productiegrens, $526,527,531$

Structuur-gedrag-resultaat-benadering, 63 e.v., 185

"Sunk costs", 64,68,119

"Symbiotic arrangement", $104,175,176$

Symmetriegraad, 106

Synergie-effecten, 84,107,177,189

Synthese-benadering, 206

Synthetisch inkomensbegrip, 454

Systeembenadering, 204

"Tax farming", 387,388,389,390 
Technische externe effecten; 28

Toetredingsbarrières $s_{\text {s }} 68$

Theorie van clubs, 23

Theorie van de eigendomsrechten, 12,13 , $62,123,217,251$

"Theory of the firm", 10,56

Third best en informatieschaarste, 195 , 519

"Throughputs", 3

Toe- en uittredingskosten, 17

Transactiekosten, $12,26,29,55,56,57,63$,

$65,71,81,90,101,102,109,113$, $122,129,131,133,134,137,159$, $161,162,163,164,165,166,167$. $168,169,170,171,173,174,175$, $178,179,181,183,185,188,189$. $191,206,395,477,482,491,523$

Transactiekosteneconomie; $12,62,101,482$

Transformatiecurve, 525

Uitbreidingshypathesen, 10,11

Unanimiteitsregels, 25

Unitaire structurur (U-vorm), 58,168

"Usus", 13,211

"Usus fructus", $111,212,215,251,320$

Variabele capaciteitsgrenzen; 507

Verborgen actie, 134

Verborgen informatie, 137

Verdelingsfunctie, $15,34,35,58,193$

Verticale integratie, $55,56,69,70,71$, $162,165,166,183,383$

Virginia-benadering (Virginia politieke economie), $3,85,205,522$

Volkomen mededinging, $3,28,54,62,72$, $79,81,124,132,147,516$

Vraagmonopoliepositie, 145

Waarschijnlijkheidsmatrix, 158

Welvaartsfunctie, $4,86,200,207,497,498$, $500,501,502,503,504,505,506$, $518,519,520$

Wettelijk monopolie, $19,21,62,67,69,185$

Wet van Verdoorn, 22

Zelfstandige bestuursorganen, $7,8,539$

Zero-sum game, 93,96,147

Ziektekostenverzekering, $22,226,387,478$ 


\section{Summary}

In the Netherlands citizens are heavily taxed by the government. These revenues are used to realize a large number of objectives. To succeed in doing, this an impressive range of public institutions are operated. Consequently, the wealth of the country depends to a considerable degree on the extent that these public institutions perform well. In recent years, more and more people have questioned whether public instinutions are performing well in the Netherlands. In this context particularly the bureaucratic procedures of a lot of public institutions are criticized. These pressures have caused a far-reaching reorganization of the Dutch welfare state. Expenditures are being cut. In the process, several public agencies have been privatized and new governance structures have been introduced in public agencies.

It is striking that these reorganization efforts are taking place in a haphazard, ad hoc way. The reason is that there is no generally accepted economic theory of public institutions. Microeconomic theory of the firm has focused particularly on modelling behavior of private enterprises. In public finance, as far as it is policy oriented, attention is especially directed at macroeconomic analysis instead of microeconomic analysis. When a microeconomic approach has been used in the theory of public finance, it has been applied almost exclusively to the study of the bureaus. Therefore, all kinds of important questions remain unanswered. For example, how should we continue. Should we go on privatizing? What should the limits of privatization be? What structural forms will work best in those organizations which remain in public sphere? In order to answer these questions, we must develop a clearer understanding of the conduct and performance of public institutions, and we must develop more effective strategies for assessing the performance of those institutions.

Because of thits, as described in chapter 1, the purpose of this dissertation is to develop a theoretical framework by which the performance of public institutions can be better understood. Based on this framework, a second objective is to examine the performance of a public institution in reality. Therefore two central questions are analyzed.

1. How can the performance of public institutions in general be explained?

2. How can the performance of a specific public institution be determined?

The first of these questions, is addressed in the theoretical section of the (chapters 2 through 12). The second question is addressed in the empirical section of the dissertation (chapters 13 through 18). Together, these chapters clarify what public institutions try to achieve, contribute to an understanding of the organizational design and operation of public institutions, and offer a methodology for assessing the performance of public agencies.

In chapter 1 the general framework for the analysis of these questions is presented. First some basic concepts of performance in a production process are introduced. It is important to realize that performance refers not only to output or production, but also to activities within the production process and the outcomes. The crucial point is that we are not only interested in the efficiency but also in the degree of effectiveness of an institution. So it is essential for us to ask how public institutions function.

Chapter 1 then operationally defines public institutions as organizations (a) in which a government has a dominant influence and (b) which produce goods and services that 
could conceivable be produced by private enterprises instead A considerable part of the Dutch economy is made up of such organizations, Section 1.3 .1 offers an analytical distinction between four different categories of public institutions. These are publicly oriented institutions, state-owned-enterprises, private corporations with dominant public influence and quasi autonomous public authorities (Quango's). However, it should be noted that these categories may entail some of the same institutions. For example, some public authorities are also private corporations like foundations and firms.

In part 2 of this dissertation a theoretical analysis of the performance of public institutions is made. This analysis indicates the factors which determine the performance of a public institution. Accordingly some subquestions are answered in chapters 2 through 11. First of all, these chapters examine why public institutions are established and why they do continue to operate. Following Richard Musgrave and in agreement with the approach by Dieter Bös, in answering these questions, three government functions are distinguished. These entail the function of allocation, of stabilization and of redistribution. Within this framework first the market failure approach is analyzed from a public choice perspective. The reasons for the government having predominant influence in this kind of organizations are further discussed. Finally, the interaction of the different functions of the government and the consequences of this interaction for the establishment of public enterprises are further delineated. Considering government objectives along with the costs of producing various goods and services make it possible to understand why governments sometimes directly supply goods and services, and at other times subsidize and regulate private firms supplying public goods. But many questions remain. To answer these questions we need a theoretical framework for analyzing the behavior and performance of public institutions.

In chapter 3 such a theory is therefore developed. The objective of this theory is to provide a general framework by which the performance of public institutions can be explaimed. As some public institutions like e.g. public enterprises have characteristics of both private enterprises and classic government agencies the theory necessarily has political, economic and organizational features. To develop a useful framework the industrial organization SCP-scheme is employed as a starting point for a theory of public institutions. However, additional complexities are introduced. This does e.g. not mean that simple one-way causal relations are assumed. On the contrary. A lot of factors are relevant and may also influence one another. A major conclusion of this section is that the main difference between private and public institutions lies in the conduct of those organizations.

Chapter 4 analyzes discrepancies between observable performance of public institutions and predictions made on the basis of welfare economics. In practice, public institutions do not behave according to normative theory. This seems partly true because governments find it impossible to develop an appropriate welfare function, and partly because of poor performance by public enterprises. This explains why normative pricing rules often are not used in practice. Of course, this does not mean that welfare economics is not an important movement in economics. It only acknowledges that welfare economics, understood as a normative theory, can not sufficiently explain performance of a public institution in practice. This forces us to ask how and by whom public sector objectives (and behavior) are determined. Are these objectives determined by the voters, the government, members of parliament or by managers of public institutions?

In chapter 5 it is examined whether the conduct and performance of public institutions can be explained by the preferences of the citizens. To explain the behavior and objectives of public institutions the influence of the political process is clearly important. Chapter 5 and 
chapter 4 are obviously related. In chapter 4 welfare economics was considered as a normative theory, whereas in chapter 5 welfare economics is looked upon as a positive theory. An important conclusion of this section is that actors on the supply side of the political process try to achieve their own objectives. Subsequently, in practice the political process will not lead to a welfare optimum, if that optimum is defined without taking political constraints and processes into consideration. Consequemtly, the question arises if the policy of politicians is really implemented by public institutions. Often this is not or only partly the case. The implementation of policy can also be considered as a political procesis, This is partly caused by the existence of asymmetric information. Accordingly, the conclusion is that the political process thas a lot of influence on the behavior and performance of public institutions although other factors are also relevant. The policy of actors within public institutions have to be examined if the performance of those institutions is to be understood.

In order to address some of these analytical problems, chapter 6 conceptualizes public institutions in terms of internal and external networks. An internal network consists of the actors within the public institution whereas an external network also entails actors from outside the public institution, especially actors within supervisory boards. From this it follows that there will often be a lot of stakeholders influencing processes within public institutions. Appreciating the impact of such forces requires that we develop a theoretic framework which is informed by literature on complex organizations, in addition to literature on neo institutional economics and public choice:

This is done in chapter 7. Property rights theory are used to analytically reduce the number of relevant actors considered in this treatment of networks by limiting analysis to those actors who really can influence the behavior of a network. Actors who own property rights of various kinds are the actors in the best position to achieve their objectives. In this respect it is important to know who has use rights, usufruct rights, and finally who has the authoritative right to change the public institution. Often, several actors possess parts of these bundles of property rights. Organizational theory is useful for helping us map the distribution of power in an institution, and understanding its impact on outcomes.

In chapter 8 the decision making process within this public networks is examined. Questions arise as to how decision making occurs within a network and how this decision making process influences orgamizational behavior and performance. Several kinds of decision making processes can be distinguished. Variation in the decision making processes is influenced by a number of factors, including the extent to which objectives are shared and the ease with which desired outputs can be measured. The degree to which the owners of the organization can control the organization depends on the character of the decision making process within a network.

Besides the distribution of property rights and the nature of decision making processes, interpersonal relations are also important. In chapter 9 interpersonal relations are described with the help of agency theory. The main question in this respect is how the relations within a network can influence the performance and behavior of the network. In section 9.4. organizational culture is discussed. The conclusion from this section is that shared understanding and values are highly important for explaining organizational performance. However; in this dissertation, the culture of an institution is not dealt with as a separate explanatory factor. It is understood as the result of other factors such as the distribution of property rights, the nature of the decision making process, and the system of interpersonal relationships found in a network. In chapter 10 relationships and culture are further examined using the bureaucracy model of Niskanen. In this chapter the 
implications of these kind of models for the behavior of public institutions are examined.

In chapter 11 the transactions within public institution-networks are analyzed using transaction cost economics. Effects of transaction costs on the behavior of public institutions are explored. Furthermore it is studied to what extent this approach can be used in case a network approach is followed.

The approach that was developed in this study makes clear that an institutional analysis should be followed. As Buchanan and Tullock indicate, public institutions function Pareto efficiently, but only in the context of several restrictions. In time different factors including the objectives of the owners and the environment will change. However, often a network only can adapt to these changes within certain limits. In chapter 4 it is indicated. that more efficient networks will not come into existence because of for example lack of information on transaction costs of alternative public networks. Therefore in this dissertation an institutional analysis is followed. How can we compare the performance of a network and consider alternative structures that will improve performance?

Several implications follow from this network approach. As mentioned, public enterprises and public institutions in general are more and more considered as redundant. This is why economists, particularly economists skilled in the neo classical tradition, argue for privatization. However, often essential differences between public and private institutions are often neglected. It is obvious that public institutions behave differently from private enterprises. This is reflected in the different objectives of their owners and also in the distinctions with respect to organizational structure and efficiency. But dissimilar behavior may not be a sign of poor performance. Private enterprises are not a suitable measurement of comparison for public institutions, particularly with regard to externalization of costs, or pursuit of all kinds of secondary abjectives. This is done in the form of off budget activities. The extent to which public institutions try to achieve such objectives varies considerable and seems only restricted by the creativity of politicians and members of the management board. The degree to which this is possible and the extent to which this actually happens can only be detected by analyzing the conduct and especially the performance of these public institutions. Thus, it appears that the performance of a network can be quite acceptable, although the network operates in a technically inefficient manner. When all objectives are examined, welfare increases seem impossible. Another implication refers to the existence of social networks within public networks. It is possible that attention is focused on efficiency, but that because of decreasing social capital, performance in fact deteriorates. Finally, the effects of all kinds of changes can be analyzed. Conclusions can be drawn with respect to the conduct and the performance of the network.

From this it follows that every network will be different and that the factors that will be most relevant for the explanation of the performance will differ from network to network. Often the performance of one institution can not meaningfully be compared with the conduct of other institutions. As a consequence, to give advice to political owners and to discuss if changes are necessary, specific networks have to be examined.

Therefore, in the empirical part of this dissertation, it is analyzed how the performance of a public network can be determined in practice. In this context it is examined to what extent the links between the different parts of a network, as described in part 2 , are really important. In addition it is studied how the different parts of the network can be determined in reality (property rights, transaction costs, principal agent relations etc.). Consequently, several empirical approaches that are used in empirical research are described in more detail. Furthermore it is indicated what the weak and strong points of these ap- 
proaches are. In this respect it is also explained why the so called "indicator approach" fails when we want to know how and how well a certain public institution performs. Obviously, this does not mean that this approach can not be used for other purposes. Nevertheless, like the quantitative approach, this approach doesn't give us much insight into the degree to which public networks succeed in reaching their objectives and what these objectives really are. The qualitative approach is scoring much better on these points. This approach indicates clearly how to determine which actor has what kind of propery rights and how to assess what kind of principal agent relations exist within a network. Besides, the qualitative approach incorporates transaction costs theory, as the transaction costs of a public institution are part of the opportunity costs. If properly used, this approach gives us correct insight in the performance. To examine to what extent the network approach can be used in reality and if the performance of a public instintion can really be determined eight hypotheses are examined. These hypotheses are studied by answering 16 questions. To do this three public institutions are examined. These three institutions have been selected because, given the central questions, they were of special interest. Each of these public institutions was confronted with a far-reaching reorganization. Therefore, it was useful to see to what extent these reorganizations were caused by poor performance.

In these case studies first it is indicated that these three institutions are indeed institutions as defined in chapter 1. This may" seem obvious for the "Dutch Rijksmuseum" and for "MEGA Limburg", but it may seem less obvious for the Dutch Tax Agency. As mentioned public institutions are institutions that produce goods and services that can also be produced by private enterprises. The principal difference is that the government chooses to have dominant influence. This is also true for the Tax Agency. In theory, it is possibile to privatize the Tax Agency and indeed in some countries taxes are levied by private firms. However, in the Netherlands the government chooses to retain dominant influence. Furthermore, each of these three public institutions were part of a network that consisted of a large number of actors and, as mentioned, each of these networks were confronted with a far-reaching reorganization. To examine if these reorganizations can be explained by the network theory of part 2 , the different parts of a network are studied in practice.

How did the Dutch "Rijksmuseum" perform during this period. To assess the performance it was especially important to determine to what extent the objective of the cultural heritage had been realized. Also, it was important to analyze the costs of this level of accomplishment of this objective. It appeared that the objective of maintenance was only reached at low level. The collection was poorly accommodated. It could not be controlled where and in what quality the art collection was. The collection grew considerably during the period of consideration, but the state of repair was lacking. Not only housing was insufficient, also the objectives of the owners changed. At the end of the eighties, the owners tried to reorganize the Dutch "Rijksmuseum" into a modern and flexible institution. However, it appeared that the museum was not able to adapt to these kind of changes, especially because of laws and department rules. Therefore, the Dutch "Rijksmuseum" was (externally) privatized. Several measures were taken in this respect. The museum, for example, was allowed to determine entry fees itself. Besides, it got it's own budget and also it's own revenues became more important. The extent to which this reorganization of the network will improve performance depends on the extent to which cultural heritage is better served against lower costs. The cultural heritage is a very important objective, as the value of the collection amounts to more than ten billion guilders and is still owned by the government. To realize this objective, control over the inputs has been replaced by control over the output. One of the outputs that is specified in contracts is the objective of maintenance of the art. It appears that the performance 
depends largely on the fact that control over the output seems better than control over the input. This is true as the museum, under pressure of the department; has made a considerable effort in making an inventory of the collection. The government is now better able to control the condition of the collection and is better equipped to see to it that the Dutch museum takes care of it in proper way. The same is true for the other objectives.

With respect to MEGA Limburg the largest part of the casts consists of costs of gas and electricity distribution. The "budget" of the public enterprise rent was especililly used for pursuing three categories of objectives. Half of the budget was used for charging lower electricity prices, approximately $18 \%$ was used for realizing more employment and finally some $30 \%$. was used for the other objectives like taking care of a certain and secure delivery of electricity. During the period the objectives shifted. In the seventies, a considerable degree of importance was attached to a certain and continuous delivery. A monopoly structure was deemed necessary, although theoretically, a trade off between competition and reliability and certainty of delivery has been postulated. At the end of the eighties and during the nineties other objectives such as efficiency, low tariffs and serving clients gained importance. Besides, also the European integration had more effects. To achieve these altered objectives, it appeared necessary to change the organization. Will this reorganization improve performance? This depends on the extent to which competition will increase and as a consequence tariffs can be reduced. Also it depends on the extent to which the secondary objectives like employment are reached against lower costs. In addition the objective of certain and contimuous delivery must not deteriorate too much.

During the period that the Dutch Tax Agency tried to pursue all kinds of objectives. Obviously, the main objective was to collect taxes for the government. Furthermore, the Tax Agency pursued several secondary objectives. The most important objectives in this respect were the distribution of income, the fair execution of Dutch tax laws and the reduction of welfare losses. These objectives conserve to explain the fact that taxes are collected by the government and not by private enterprises. During the eighties problems arose with respect to the collection of taxes. These problems were partly caused by the changed environment. Compliance for example deteriorated and the number of tax payers increased. The organization of the Tax Agency could not adapt to these changes. Therefore, it was decided to reorganize the Tax Agency. This reorganization of the Tax agency during the beginning of the nineties has improved performance. Tax collecting is realized more efficiently, while the extent to which secondary objectives are realized was acceptable for the owners. The public enterprise rent was reduced. To analyze if it is possible to further improve performance in the future, it has to be determined if taxes can be collected by private enterprises against lower costs. This will probably not be the case, as private enterprises may inflict considerable deadweight losses. Besides the objective of the fair execution of tax laws will deteriorate. A better alternative is to further increase the flexibility of the Tax Agency by transferring additional rights. Also an Independent Public Authority may be an improvement. If this is truly the case depends on the specific conditions that will be part of the law by which the authority is established. In this context it is also important that the regulation with respect to these independent authorities is simplified.

From this dissertation and the eight hypotheses that are examined it can be concluded that the performance of a specific institution can best be analyzed on the basis of a qualitative approach, such as the theory outlined before. On the basis of this approach, it appeared to be possible to determine several parts of a public network in practice. By doing this, insight can be obtained in the functioning of a certain institution. This also connects with 
recent developments in this area of research. Several studies of the Dutch court of Audit, for instance, correspond to the qualitative approach. This is also the case for a lot of management scientific research. However, the qualitative approach goes some steps further by not only analyzing effectiveness but also efficiency.

Further, it appeared that during the period of examination, the objectives of all the three institutions changed. This was partly caused by changes in the environment of the public institutions. All three institutions tried to adapt by making small adjustments. After some point, these small changes appeared to be insufficient and further changes proved not possible within the existing structure of the network in consideration. More and more the relevant actors came to the conclusion that the institution was not functioning very well. The changed objectives were not satisfactorily realized with the existing network or the owners realized their objectives against to high a cost. Therefore, ultimately, it was decided to alter the network, often because of political pressure. These changes entailed all parts of the network. Not only the property rights structure was adjusted but accordingly also the information structure, the transactions within the network and the relations were changed. After the reorganization of the network objectives were better reached against lower cost. This can be compared with the approach as described in chapter 2. Given all restrictions networks are Pareto efficient. But when the environment and the objectives change a changed network may perform better. Hence, it is important for economists to analyze how a network can be changed best. As described in paragraph 19.3 , the network approach can also be used to guide such a transition in governance structure.

Moreover, using this framework and the corresponding qualitative approach for an analysis of enterprises that are heavily subsidized by the government, for example Fokker and Nedcar, a lot of money can be saved. Often times, public institutions like these enterprises try to achieve objectives like employment, while they operate in competitive markets. It is striking to see that Fokker after going bankrupt was able to realize impressive efficiency gains. By applying this approach it is possible to warn politicians against the possible consequences of their policies of trying to reach secondary objectives with enterprises that operate in competitive markets.

Furthermore, not only public institutions, but also policy processes within the departments and all kinds of new laws and rules like the use of covenants and environmental effect reports (MER) could be analyzed. In that case also the objectives of these instruments, the extent to which they are realized and the costs of this level of accomplishment of objectives should be analyzed. It is interesting to see if better alternatives are available.

What really springs from these case studies to the eye of the impartial observer is that with this framework also private enterprises can be analyzed. Private enterprises more and more try to reach all kinds of objectives different from profit maximization or maximization of the value of the company. Examples of such objectives are the environmental objectives that are growing more important. Of course, several parts of such a network will be more or just less important than in the case of a public network. Consequently, the performance will differ.

In conclusion some improvements in the framework and the corresponding qualitative approach have to be made. These improvements have to do with better quantifying the relative importance and the costs of the various objectives. These problems are not so much characteristics of this kind of research but are mainly caused by the accounting of the government and public institutions. The way of accounting has to be improved. It is very important that public networks are forced to indicate in a financial report what their 
objectives are, how well these objectives are realized and what the costs are of this level of objective accomplishment. Finally these costs should be attributed to these objectives. By doing this, the government and ultimately parliament will get much more insight. This will improve the control by the relevant actors. Besides, parliament will be more able to weigh priorities. Of course, public institutions often will not be interested in doing this. Therefore, this financial report should at least be subjected to audit control. 


\section{Curriculum Vitae}

Jan Frank Koers werd op 4 juni 1966 geboren in Zwolle: Van 1978 tot en met 1984 volgde hij een VWO-opleiding aan het Carolus Clusius College te Zwolle. Na het VWO studeerde hij Bestuurswetenschappen. Na het behalen van het doctoraal examen heeft hij vervolgens een doctoraal examen Nederlands Recht aan de Rijksuniversiteit Groningen afgerond. Na vervulling van de militaire dienstplicht als sergeant bij de $129 \mathrm{e}$ infanteriecompagnie behaalde hij het kort hoger onderwijsprogramma Financieel-economisch overheidsbeleid aan de Open Universiteit. In 1993 trad hij in dienst van de economische faculteit van de Universiteit Maastricht. Bij de vakgroep Algemene Economie verrichtte hij promotie-onderzoek naar het functioneren van overheidsinstellingen. Voorts behaalde hij een doctoraal examen in de Algemene Economie. Sinds 1 april 1997 is hij als onderzoeker werkzaam bij de Algemene Rekenkamer in welke hoedanigheid hij zich onder meer bezighoudt met financieel beheersonderzoek.

\section{Curriculum Vitae}

Jan Frank Koers, Master's degree in Public Administration, Master's degree in Dutch Law at the University of Groningen, degree of Financial Economic Government Policy at the Open University, and Master's degree in Economics, has been a research fellow at the Section of Public Economics at the University of Maastricht. From April, 1997 he works as a researcher at the Dutch Court of Audit. 